\title{
ХИРУРГИЧЕСКИЕ БОЛЕЗНИ
}

Под редакцией Н.Ю. Байрамова

Учебник для медицинских вузов, 3-е издание, 2020

Перевод: Н.Ю. Байрамов, С.А. Алиев, М.Р. Гусейнова

Утвержден решениями Ученого Медицинского Совета Министерства здравоохранения (№ 24 от 6 декабря 2018 г.) и Министерства образования Азербайджанской Республики (№ F - 66 от 7 февраля 2019 г.).

\author{
Web site www.bck.az \\ DOI \\ ISBN 9789952536232 \\ ORCID iD https://orcid.org/0000-0001-6958-5412
}

Истанбул 2020

ISBN: 978-9952-536-30-0 


\section{Хирургические болезни}

\section{Редактор:}

Член - корреснондент НАНА, доктор медицинских наук, профессор Н.Ю. Байрамов

\section{Авторы:}

Байрамов Н.Ю., Аббасов А.Г., Асланова К.Д., Ахмедов А.М., Ахмедов Ф.Ф., Алиев Э.А., Алиев Р.Я., Алиев С.А., Алиев Т.К., Амрах А.Э., Велиев Э.А., Гасанов А.В., Гумматов А.Ф., Гапагов Ф.М., Гейбулла А.А., Гахраманова Ф.А., Гахраманова 3.Х., Зейналов Б.М., Зейналов Н.А., Зейналов С.М., Ибрагимов С.А., Ибрагимова А.А., Иманова С.С., Исазаде Э.М., Йылмаз С., Керем М., Керимов М.М., Махмудов М.Г., Мамедов Р.А., Маммедова Ш.А., Мусаев Х.Н., Намазов А.Э., Новрузов Н.Г., Омаров Т.И., Рафиев С.Ф., Рустам А.М., Рзаев Т.М., Салахова С.Ш., Сафиева А., Хыдырова Н.М., Ширинова X.H.

\section{Рецензенты:}

Доктор медицинских наук, профессор Исаев Н.Б

Доктор медицинских наук, профессор Алиев М.Я.

ISBN: 978-9952-536-23-2

ISBN: 978-9952-536-30-0

Н. Ю. Байрамов. Хирургические болезни. Учебник. 3-е издание, Истанбул. 2020. 695 стр.

\section{Перевод: Н.Ю. Байрамов, С.А. Алиев, М.Р. Гусейнова}

В учебнике представлены основные разделы частной хирургии, освещены наиболее часто встречающиеся заболевания и травмы органов брюшной полости, грудной клетки и средостения. Отдельные разделы книги посвящены хирургической эндокринологии, заболеваниям молочной железы, трансплантации, метаболической и бариатрической хирургии и хирургической реанимации, на современном уровне изложены аспекты диагностики и лечения. В отличие от классических учебников, изложение отдельных хирургических патологий представлены в 2 - х вариантах: краткое описание болезни, вопросы и ответы. Учебник предназначен для студентов лечебных факультетов медицинских вузов, хирургов и врачей смежных специальностей. Книга также может быть полезным пособием для вузов последипломнго образования. Наряду с классическим вариантом издания, учебник представлен на сайте www.bck.az и в формате “Online”.

Нуру Байрамов, 2020

ISBN: 978-9952-536-30-0 


\section{NURU YUSIF OĞLU BAYRAMOV}

\section{CORRAHI XəSTOLIKLOR III NəŞR}

Tələbələr və rezidentlər üçün dərslik

Azarbaycan Respublikası Sahiyya Nazirliyinin Elmi-Tibbi Şurasının 6 dekabr 2018 tarixli 24 saylı va Azarbaycan Respublikası Tahsil Nazirliyinin 07 fevral 2019 tarixli F-66 saylı qararı ila darslik kimi tosdiq edilmişdir.

İstanbul-2020

ISBN: 978-9952-536-23-2

$\begin{array}{ll}\text { Web site } & \text { www.bck.az } \\ \text { DOI } & \text { https://doi.org/10.25045/k.nurubay.cx-2 } \\ \text { ISBN } & 9789952536232 \\ \text { ORCID iD } & \text { https://orcid.org/0000-0001-6958-5412 }\end{array}$




\section{CORRAHI XəSTOLIKLəR}

Redaktor:

AMEA müxbir üzvü, professor, tibb elmləri doktoru N.Y. Bayramov

\section{Müəlliflər:}

Bayramov N.Y., Abbasov A.H., Aslanova K.D., Zhmədov Ә.M., Zhmədov F.F., Oliyev E.A., כliyev R.Y., Jliyev S. A., Jliyev T.Q., Zmrah A.E., Həsənov A.B., Hümmətov A.F., Xıdırova N.M., İbrahimov C.A., İbrahimova A.Ә., İmanova S.S., İsazadə E.M., Kerem M., Kərimov M.M., Qapaqov F.M., Qeybulla A.ə., Qəhrəmanova F.A., Qəhrəmanova Z.X., Mahmudov M.G., Məmmədov R.A., Məmmədova Ş.Ә., Musayev X.N., Namazov A.E., Novruzov N.H., Ömərov T.I., Rəfiyev S.F., Rüstəm Ә.M., Rzayev T.M., Salahova S.Ş., Səfiyeva A., Şirinova X.N., Vəliyev E.Ә., Yılmaz S., Zeynalov B.M., Zeynalov N.A., Zeynalov S.M.

\section{Rayçilar: \\ Professor, tibb elmləri doktoru H.B.İsayev \\ Professor, tibb elmləri doktoru M.Y.Oliyev}

ISBN: 978-9952-514-09-4

ISBN: 978-9952-536-23-2

N.Y. Bayramov. CəRRAHI XəSTəLiKLəR. Dərslik. 3-cü nəşr, 3 cilddə, İstanbul. 2020. 2130 s.

Kitabda qarın (qida bprusu, mədə, 12bb, nazik bağırsaq, yoğun bağırsaq, döz bağırsaq və anus, qaraciyər, öd yolları, mədəaltı vəzi, dalaq, periton və pylik, qarın divarı), döş boşluğu (ağciyər, plevra, divararalığı, döş qəfəsi divarı, ürək-damar), endokrin (qalxanabənzər və ətraf vəziləri, böyrəküstü vəzi) orqanların və süd vəzin cərrahi xəstəlikləri, travma, transplantasiya, metabolikbariatrik cərrahiyyə və cərrahi reanimasiya barədə məlumatlar verilmişdir. Müasir səriştəyönlü tədris proqramına və protokollara əsaslanaraq hazılanan kitabda hər bir cərrahi xəstəliklər barədə nəzəri biliklərlə yanaşı, diaqnostik yanaşmaya, diaqnostik meyarlara və müalicə yanaşmasına xüsusi yer verilmişdir.

Klassik dərsliklərdən fərqli olaraq hər bir cərrahi xəstəlik barədə məlumatlar 3 formada təqdim edilmişdir: geniş mətn (tərifi, etio-patogenezi, gedişi, ağırlaşmaları, klinikası, diaqnostikası və müalicəsi), özət (ensklopedik məlumat) və sual-cavab. Kitabda 500-ə yaxın cərrahi xəstəlik barədə mətn və özət, 4000-dən çox sual-cavab, 500-ə yaxın şəkil və 160 -a yaxın sxem yer almışdır.

Universtetlərin tibb fakultələrində Cərrahi xəstəliklər fənni üzrə təhsil alan tələbələr və rezidentlər üçün nəzərdə tutulan bu dərslikdən müəllimlər, cərrahlar və digər ixtisaslar üzrə həkimlər də istifadə edə bilər.

Dərslik klassik çap variantı ilə yanaşı www.bck.az saytında PDF və onlayın varinatlarda təqdim edilir.

(C) Nuru Bayramov, 2020

ISBN: 978-9952-536-23-2 


\section{METADATA}

Type Книга

Title Хирургические болезни

Editor Байрамов Н.Ю

Edition $\quad 3$

Authors Байрамов Н.Ю., Аббасов А.Г., Асланова К.Д., Ахмедов А.М., Ахмедов Ф.Ф., Алиев Э.А., Алиев Р.Я., Алиев С.А., Алиев Т.К., Амрах А.Э., Велиев Э.А., Гасанов А.В., Гумматов А.Ф., Гапагов Ф.М., Гейбулла А.А., Гахраманова Ф.А., Гахраманова 3.Х., Зейналов Б.М., Зейналов Н.А., Зейналов С.М., Ибрагимов С.А., Ибрагимова А.А., Иманова С.С., Исазаде Э.М., Йылмаз С., Керем М., Керимов М.М., Махмудов М.Г., Мамедов Р.А., Маммедова Ш.А., Мусаев Х.Н., Намазов А.Э., Новрузов Н.Г., Омаров Т.И., Рафиев С.Ф., Рустам А.М., Рзаев Т.М., Салахова С.Ш., Сафиева А., Хыдырова Н.М., Ширинова Х.H.

Experts Исаев Г.Б., Алиев М.Я.

Year $\quad 2020$

Pages 695

Abstract В книге изложены наиболее часто встречающиеся хирургические заболевания органов грудной клетки, средостения и брюшной полости. Рассмотрены вопросы торакальной и абдоминальной травм, эндокринной хирургии, трансплантации, метаболической и бариатрической хирургии а также хирургической реанимации. В соответствии с современной учебной программой и клиническими протоколами, большое внимание уделено вопросам диагностики отдельных хирургических заболеваний и обоснованию выбора метода лечения с учетом принципов доказательной медицины. В отличие от классических учебников, 
в книге, кроме краткого изложения текста, включающего этиологию, патогенез, клинику, диагностику и лечения каждой патологии, представлены также вопросы и ответы, что позволит повысить восприятия материала. Учебник содержит описания более 4000 вопросов и ответов.

\author{
Книга рассчитана на студентов лечебных факультетов \\ медицинских вузов, хирургов и широких кругов практических \\ врачей. Книга также может быт ценным учебным пособием для \\ вузов последипломного оброзования. Наряду с классическим \\ вариантом учебник представлен на сайте www.bck.az и в формате \\ "Online".
}

Keywords

Электронный учебник, двенадцатиперстная кишка, 3-й сегмент, живот, брюшная полость, абсцесс, аденома, надпочечники, легкие, легочно - сердечный комплекс, осложнения, реципиент, альвеол, альвеококкоз, врожденный, анус, анальный канал, аноректальная зона, анапластический, анастомоз, аномалия, аорта, аорта - коронарный, аппендицит, артерия, асцит, аутоиммунный, ахалазия, геморрой, синдром Бадди - Киари, бактериальный, бариатрический, пищевод Баррета, злокачественный, билиарный, желчные протоки, полая вена, почки, надпочечники, шея, бронхи, бронхоэктазия, бронхолитиаз, бедро, живой донор, трещина, недостаточность, хирургические болезни, ободочная кишка, многоузловой, зоб, брыжейка, критические состояния, болезнь Крона, болезнь Кушинга, селезенка, внутрисосудистое, сужение, каменный, демпинг-синдром, диабетический, диафрагма, диагностическая тактика, дифференциальная диагностика, диффузный, дисфагия, дисфункция, дискинезия, дисмоторика, средостение, дивертикул, дивертикулит, дивертикулез, донор, грудная клетка, прямая кишка, внепеченочный, экстракорпоральный, эластография, интраоперационный, эндемический, эндокринный, эндоскопический, энцефалопатия, эозинофильный, эпителоидный, этиология, эхинококк, эзофагит, пищевод, синдром Фельти, феохромоцитома, фиброзный, фистула, физиология, фокальный, фолликулярный, сосок, гинекомастия, пупок, визуализия, болезнь Грейвса, гамартома, зоб Хашимото, сердце, гемангиоэндотелиома, гемангиома, гематологический, гемигепатэктомия, гемолитический, гемоторакс, печеночный, гепатобластома, гепатопортоэнтеростомия, гепаторенальный, гепатоцеллюлярный, грыжа, гетеротопическая, гидатичный, гидроторакс, гиперальдостеронизм, гиперкортицизм, гиперпаратироеидизм, гиперспленизм, гипотиреоидизм, гиперплазия, гипертензия, Гюртле - клеточный, идиопатический, иммунологический, иммуносупрессия, внутрипротоковый, инфаркт, инфекция, внутрипеченочный, гнойный, ишемический, ишемически - реперефузионный, инконтиненция, инсулинома, инциденталома, рак, кардиоплегия, каротидный, карциноидный, карцинома, киста, классификация, кокцикодиния, колит, колоректальный, компартмент - синдром, компьютерная томография, кондилома, кортикостерома, протонный насос, криптит, лапароскопическая, лейомиома, лимфома, лимфоцитарный, печень, мальформация, магнитно - резонансная томография, масталгия, желудок, поджелудочная железа, медиастинит, средостение, медуллярный, мембранозный, метаболический, метастатический, механический, мезентеральный, мезотелиома, миастения, митральный, монитор, лечебная тактика, методы лечения, мукоцеле, полиорганная, муцинозный, тонкая кишка, неопластический, нейроэндокринный, нейрогенный, узловой зоб, обструкция, желчь, желчная колика, желчные протоки, сфинктер Одди, оксигенация, сальниковый, оппортунистическая инфекция, 
отофарингеальная, органная дисфункция, остеомиелит, болезнь Педжета, поджелудочная жеза, панкреатит, папиллярный, парапроктит, паратиреоидная, паразитарная, патогенез, перфорация, перфузия, периферический, перитонеальный, брюшина, перитонеовенозный, пилонидальный, пилоростеноз, ожирение, плевра, плевральный, плеврит, пневмоторакс, полип, полипоидный, портальный, постспленэктомический синдром, постхолецистэктомический синдром, псевдомиксома, псевдопапиллярный, псевдокистозный, псевдотуморозный, пурпура, щитовидная железа, кровотечение, гангрена, пах, гастринома, гастрит, гастроэзофагеальный рефлюкс, гастростаз, запор, неспецифический, глюкагонома, отторжение, рефлюкс, ректоцеле, ректовагинальный, релаксация, ретроперитонеальный, резекция, желтуха, семинома, сепсис, сегментарный, серозный, сфинктер, циклоспорин, сиролимус, цирроз, цистоаденокарцинома, цистоаденома, слерозирующий, холангит, тонкая кишка, шок, соматостатинома, спленомегалия, спленоз, спонтанный, струмит, шунт, талассемия, рецидивирующий, классификация, тератома, тимома, тиреотоксикоз, трансплантация, тромбоцитопенический, тромбоцитоз, тромбоз, туберкулез, трехстворчатый, третичный, ультразвуковое исследование, зоб, кольцевидный, варикоз, васкулярный, венозный, випома, вирусный, донор, хилоторакс, холангиокарцинома, холангиография, холангит, холедох, холедохолитиаз, холецистэктомия, холецистит, холестаз, язва, язвенный, обходной анастомоз, листевидный, грыжа, толстая кишка, травма, синдром Золлингера Эллисона.

\section{City \\ Истанбул}

\section{Publisher}

Type of Учебник
work

\section{URL}

\section{DOI}




\section{ПРЕДИСЛОВИЕ}

\section{Уважаемые читатели!}

Эта книга- подготовлено как учебное пособие для студентов и резидентов высших медицинских заведений, представляет собой перевод на русский язык сокращенной версии учебника «Хирургические болезни», написанный на азербайджанском языке, охватывает современную компетентно-ориетировнную программу для 4-5-6 курсов по хирургии. В учебном пособии содержатся сведения о наиболее распространенных и неотложных хирургических заболеваниях органов брюшной и грудной полости, сердечно-сосудистой системы, органов молочной железы и эндокринной системы, хирургической реанимации, травмах, трансплантации и метаболической хирургии.

В данном учебнике мы постарались уделить особое внимание некоторым аспектам интерпретации различных хирургических заболеваний.

Прежде всего, - учтены потребности современного медицинского образования. Известно, что основной целью современного медицинского образования является подготовка компетентных специалистов, а для этого необходимо поэтапно приобретать достоверные медицинские знания, умственные (клинические) и практические навыки. Основной целью обучения на университетском этапе является получение студентами медицинских знаний и овладевание умственными навыками по распространенным и неотложным заболеваниям, на этапе резидентуры усваивать знания, клинические и практические навыки по всем патологиям в области специализации, а на более поздних этапах (Непрерывное Медицинское Образование) цель состоит в улучшении знаний и навыков и освоении инноваций. По действующей программе студентам, обучающимся на 3-м курсе нашего университета, преподаются современные знания по общей хирургической патологии и некоторые общие практические навыки.

На 4-м и 5-м курсах обучение состоит в умении диагностировать распространенные и неотложные хирургические заболевания (диагностика, диагностический подход, диагностическая тактика), а на 6-м курсе - ведение пациентов с неотложными хирургическими заболеваниями (предоперационная оценка, выбор лечения и послеоперационное ведение). Имея это в виду, в книге основное внимание уделяется диагностическому подходу и тактике лечения хирургических 
заболеваний. Была предоставлена информация об этапах диагностического процесса (подозрение, уточнение, определение причины и степени тяжести).

Информация о вариантах лечения может быть полезна студентам 6 курса и резидентам.

Во-вторых, в книге представлена информация о каждом хирургическом заболевании в 2-х формах:

- Дается краткое описание болезни в форме резюме (энциклопедическая информация).

- Информация о заболевании предоставляется в форме вопросов и ответов.

В-третьих, мы попытались основывать информацию в книге на современных клинических протоколах.

B-четвертых, книга доступна на двух формах: в электронном виде, в формате PDF и в Интернете.

Мы уверены, что данное учебное пособие, подготовленное в электронной версии, будет полезна нашим студентам и резидентам для приобретения знаний и клинических навыков.

Авторы признают, что книга не лишена недостатков и будут признательны за замечания, советы и конструктивные предложения по данной книге. 


\section{СПИСОК СОКРАЩЕНИЙ}

12 п/к - двенадцатиперстная кишка

АФП - альфа-фетопротеин

АЛТ - аланинаминотрансфераза

АСТ - аспартатаминотрансфераза

ОКН - острая кишечная непроходимость

ПСХ - первичный склерозирующий холангит

СРБ - С-реактивный белок

ЭРХПГ - эндоскопическая ретроградная холангиопанкретикография

ЛнГ - локальная нодулярная гиперплазия

ГИСО - гастроинтестинальные стромальные опухоли

ИПП - ингибиторы протонной помпы

ПВЧ - папиллома-вирус человека

ГЦК - гепатоцеллюлярная карцинома

ВПХ - внутрипеченочная холангиокарцинома

ИТП - идиопатическая тромбоцитопеническая пурпура

КРР - колоректальный рак

OP - острый панкреатит

КТ - компьютерная томография

ЛА - Лос Анжелес

лД - лактатдегидрогеназа

Пж - поджелудочная железа

МЭН - множественные эндокринные опухоли

МРТ - магнитно - резонансная томография

ТК - тонкая кишка

НЭО - нейроэндокринные опухоли

ДСО - дисфункция сфинктера Одди

ПДР - панкреатодуоденальная резекция

РЭТ - позитронная эмиссионная томография

ПКА - портокавальный анастомоз

чЧХ - чрескожная чреспеченочная холангиография

ТВВ - тромбоз воротной вены

ПХС - постхолецистэктомический синдром

ЧХ - чрескожная холангиография

ФТП - функциональные тесты печен

ГЭРБ - гастроэзофагеальная рефлюксная болезнь

СПИД - синдром приобретанного иммунодефицита

ГГТ - гамма глютаминовая трансфераза

НПВС - нестероидные противовоспалительные средства

СБП - спонтанный бактериальный перитонит

ССВО - синдром системного воспалительного ответа

ТЮВПКШ - трансюгулярный внутрипеченочный порто - кавальный шунт

РГХ - рецидивирующий гнойный холангит

УзИ - ультразвуковое исследование

ВИП - вазоактивные интестинальные пептиды

НЯК - неспецифический язвенный колит

ДВС - диссеминированное внутрисосудистое свертывание 


\section{СОДЕРЖАНИЕ}

\section{Содержание}

Предсловие

Авторы

Содержание

\section{АБДОМИНАЛНАЯ ХИРУРГИЯ}

01- Хирургические заболевания пишевода (9-45)

Авторы: Н.Ю. Байрамов, А.М. Рустем, А.А. Гейбулла, А.К. Сафиева, Ш.А. Мамедова

02- Хирургические заболевания желудка и двенадцатиперстной кишки (47-82)

Авторы: Н.Ю. Байрамов, Н. А. Зейналов, З.З. Гахраманова, А.К. Сафиева, Ф.Ф. Ахмедов

03- Хирургические заболевания тонкой кишки (83-116)

Авторы: Н.Ю. Байрамов, А.М. Рустем, Б.М. Зейналов, Х.Н. Мусаев, А.К. Сафиева, Ф.А. Гахраманова

04- Хирургические заболевания толстой кишки (117-163)

Авторы: Н.Ю. Байрамов, С.А. Алиев, Э.А. Алиев, А.К. Сафиева, Ш.А. Мамедова

05- Хирургические заболевания аппендикса (165-176)

Авторы: Н.Ю. Байрамов, С.С. Салахова, А.К. Сафиева

06- Хирургические заболевания прямой кишки и анального канала (177-216)

Авторы: Н.Ю. Байрамов, С.С. Иманова

07- Хирургические заболевания печени (217-310)

Авторы: Н.Ю. Байрамов, Р.А. Мамедов, А.К. Сафиева, Ш.А. Мамедова

08- Хирургические заболевания жёлчных путей (311-377)

Авторы: Н.Ю. Байрамов, Р.А. Мамедов, А.К. Сафиева, Ш.А. Мамедова

09- Хирургические заболевания поджелудочной железы (379-415)

Авторы: Н.Ю. Байрамов, Т.И. Омаров, А.К. Сафиева, Ф.Ф. Ахмадов

10- Хирургические заболевания селезёнки (417-447)

Авторы: Н.Ю. Байрамов, Т.М. Рзаев, А.К. Сафиева, Ш.А. Мамедова

11- Хирургические заболевания брюшины (449-467) 


\section{СОДЕРЖАНИЕ}

Авторы: Н.Ю. Байрамов, С.М. Зейналов, Т.Г. Алиев, А.К. Сафиева, Ф.Ф. Ахмедов

12- Грыжи живота (469-490)

Авторы: Н.Ю. Байрамов, А.Э. Намазов, А.К. Сафиева, Ф.Ф. Ахмадов

13- Острый живот (491-504)

Авторы: Н.Ю. Байрамов, А.Б. Гасанов, Р.Й. Алиев, А.К. Сафиева, Ш.А. Мамедова

14- Желудочно-кишечное кровотечение (505-516)

Авторы: Н.Ю. Байрамов, Н. М. Хыдырова, А.К. Сафиева, Ф.А. Гахраманова

\section{ТОРАКАЛЬНАЯ ХИРУРГИЯ}

15- Хирургические заболевания лёгкого (517-552)

Авторы: Н.Ю. Байрамов, С.А. Алиев, Б.М. Зейналов, Ш.А. Мамедова

16- Хирургические заболевания плевры (553-572)

Авторы: Н.Ю. Байрамов, С.А. Алиев, Б.М. Зейналов, Ф.А. Гахраманова

17- Хирургические заболевания грудной стенки (573-582)

Авторы: Н.Ю. Байрамов, М. Г. Махмудов, Ф.А. Гахраманова

18- Хирургические заболевания средостения (583-594)

Авторы: Н.Ю. Байрамов, Н.М. Хыдырова, Ф.А. Гахраманова

19- Хирургические заболевания диафрагмы (595-600)

Авторы: Н.Ю. Байрамов, С.А. Алиев, С.Ф. Рафиев, Ш.А. Мамедова

\section{ХИРУРГИЯ СЕРДЦА И СОСУДОВ}

20- Хирургические заболевания сердца (601-628)

Авторы: Н.Ю. Байрамов, А. Амрах, Ч. Ибрагимов, Э. Валиев

21- Хирургические заболевания сосудов (629-668)

Авторы: Н.Ю. Байрамов, М.М. Каримов, Ш.А. Мамедова 


\section{СОДЕРЖАНИЕ}

\section{ЭНДОКРИННАЯ-МЕТАБОЛИЧЕСКАЯ ХИРУРГИЯ}

22- Хирургические заболевания щитовидной железы (669-696)

Авторы: Н.Ю. Байрамов, А.Ф. Гумматов, А.Г. Аббасов, Ш.А. Мамедова

23- Хирургические заболевания паращитовидной железы (697-704)

Авторы: Н.Ю. Байрамов, А.Ф. Гумматов, А.Г. Аббасов, Ш.А. Мамедова

24- Хирургические заболевания надпочечников (705-718)

Авторы: Н.Ю. Байрамов, С.А. Алиев, Н.Г. Новрузов, А.К. Сафиева, Ш.А. Мамедова

25- Ожирение. Бариатрическая и метаболическая хирургия (719-724)

Авторы: Н.Ю. Байрамов, Т.И. Омаров

\section{ДРУГИЕ ОБЛАСТИ ХИРУРГИИ}

26- Хирургические заболевания молочной железы (725-750)

Авторы: Н.Ю. Байрамов, А. Ибрагимова

27- Травмы (751-784)

Авторы :Н.Ю. Байрамов, С.А. Алиев, Ф.М. Гапагов, Ш.А. Мамедова

28- Реанимация (785-828)

Авторы: Н.Ю. Байрамов, А.М. Ахмадов, Ф.Ф. Ахмадов

29- Трансплантация органов (829-873)

Авторы: Н. Ю. Байрамов, С. Йылмаз, Р. А. Мамедов, Э. М. Исазаде, Ф. А. Гахраманова 


\section{ХИРУРГИЧЕСКИЕ БОЛЕЗНИ}

Н.Ю. Байрамов

\section{Хирургические заболевания пишевода}

Н.Ю. Байрамов, А.М. Рустем, А.А. Гейбулла, А.К. Сафиева, Ш.А. Мамедова

Перевод: Н.Ю. Байрамов, С.А. Алиев, М.Р. Гусейнова 


\section{ГАСТРОЭЗОФАГЕАЛЬНАЯ РЕФЛЮКСНАЯ БОЛЕЗНЬ}

- Гастроэзофагеальная рефлюксная болезнь - это воспалительный процесс, обусловленный часто повторяющимся забросом желудочного и дуоденального содержимого в дистальную часть пищевода.

- Основными клиническими проявлениями заболевания являются ощущение жжения за грудиной, изжога, отрыжка, а также боль, фарингит и кашель.

- С течением времени и при отсутствии соответствующего лечения возможно развитие пептических язв, кровотечений, рубцовой стриктуры пищевода и пищевода Баррета.

- Диагноз устанавливают на основе эндоскопического исследования.

- Лечение проводится медикаментозным и хирургическим методами.

\section{Вопросы и ответы по гастроэзофагеальной рефлюксной болезни}

\begin{tabular}{|c|c|}
\hline Вопросы & Ответы \\
\hline $\begin{array}{l}\text { Что такое гастроэзофагеальная } \\
\text { рефлюксная болезнь? }\end{array}$ & $\begin{array}{lr}\text { Воспалительный } & \text { процесс, } \\
\text { обусловленный } & \text { часто повторяющимся } \\
\text { забросом } & \text { желудочного } \\
\text { дуоденального } & \text { содержимого } \\
\text { дистальную часть пищевода. }\end{array}$ \\
\hline Частота встречаемости: & $\begin{array}{l}\text { Составляет 20-30\% в общей популяции, } \\
\text { в структуре заболеваний пищевода - } \\
75 \% \text {. }\end{array}$ \\
\hline Причины и факторы риска: & $\begin{array}{l}\text { - Грыжа пищеводного отверстия } \\
\text { диафрагмы; } \\
\text { - Морбидное ожирение; } \\
\text { - Приём антихолинергических } \\
\text { препаратов, кофеина, никотина; } \\
\text { - Склеродермия, заболевания } \\
\text { соединительной ткани и др.; }\end{array}$ \\
\hline
\end{tabular}




\begin{tabular}{|c|c|}
\hline & $\begin{array}{l}\text { - Травмы пищевода; } \\
\text { - Беременность. }\end{array}$ \\
\hline Патогенез: & 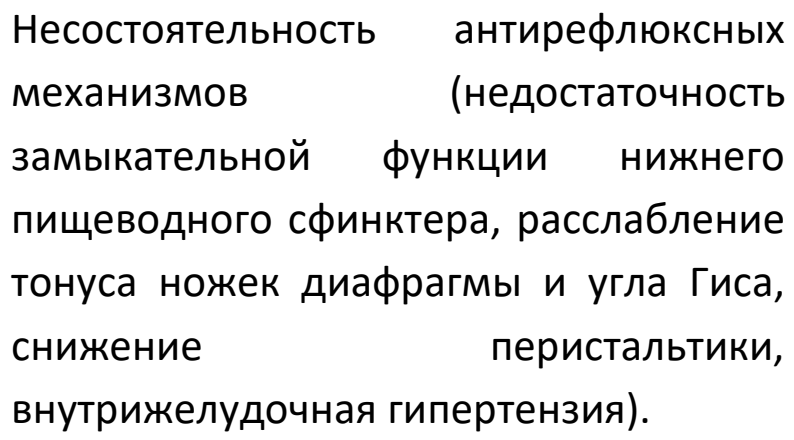 \\
\hline Особенности клинического течения: & Хроническое повторяющееся течение. \\
\hline Осложнения: & $\begin{array}{l}\text { - Пищевод Баррета; } \\
\text { - Пептическая язва; } \\
\text { - Рубцовые стриктуры; } \\
\text { - Аспирационная пневмония; } \\
\text { - Фарингит; } \\
\text { - Бронхиальная астма; } \\
\text { - Железодефицитная анемия. }\end{array}$ \\
\hline Клинические признаки: & $\begin{array}{l}\text { - Типичные признаки (изжога, } \\
\text { отрыжка); } \\
\text { - Атипичные признаки (загрудинные } \\
\text { боли, одышка, астма, хронический } \\
\text { кашель, изменение тембра голоса, } \\
\text { кровохарканье, } \\
\text { одинофагия, дисфагия). }\end{array}$ \\
\hline $\begin{array}{l}\text { У каких пациентов можно } \\
\text { заподозрить? }\end{array}$ & $\begin{array}{l}\text { У пациентов с отрыжкой и грыжей } \\
\text { пищеводного отверстия диафрагмы. }\end{array}$ \\
\hline Диагностика: & $\begin{array}{l}\text { - } \text { ЭКГ; } \\
\text { - } \text { Эндоскопическое исследование; } \\
\text { - Суточная рН-метрия; } \\
\text { - Манометрия; }\end{array}$ \\
\hline
\end{tabular}




\begin{tabular}{|c|c|}
\hline & $\begin{array}{l}\text { - Тесты с ингибиторами протонной } \\
\text { помпы. }\end{array}$ \\
\hline \multirow[t]{5}{*}{$\begin{array}{l}\text { Признаки диагностической } \\
\text { визуализации: }\end{array}$} & $\begin{array}{l}\text { При эрозивной форме - наличие } \\
\text { эрозивного эзофагита при эндоскопии; }\end{array}$ \\
\hline & Неэрозивная форма характеризуется \\
\hline & нормальной эндоскопической \\
\hline & $\begin{array}{lrr}\text { картиной; при проведении тестов с } \\
\text { ингибиторами } & \text { протонной } & \text { помпы }\end{array}$ \\
\hline & $\begin{array}{l}\text { наблюдается ремиссия клинических } \\
\text { признаков в течение } 4 \text { недель. }\end{array}$ \\
\hline $\begin{array}{l}\text { С какими заболеваниями необходимо } \\
\text { дифференцировать? }\end{array}$ & С заболеваниями коронарных сосудов. \\
\hline Диагностические критерии: & $\begin{array}{l}\text { - Повторение клинических признаков } \\
\text { 2-3 раза в неделю на протяжении 2- } \\
3 \text { месяцев; } \\
\text { - Обнаружение эзофагита во время } \\
\text { эндоскопии и рефлюкса при рН- } \\
\text { метрии; } \\
\text { - Исключение других заболеваний. }\end{array}$ \\
\hline Методы лечения: & - Консервативное - смена образа \\
\hline & $\begin{array}{l}\text { жизни, ингибиторы протонной } \\
\text { помпы и гистаминовых рецепторов; } \\
\text { • Эндоскопическое; } \\
\text { - Хирургическое. }\end{array}$ \\
\hline Показания к хирургическому лечению: & $\begin{array}{l}\text { - Неэффективность консервативной } \\
\text { терапии; } \\
\text { - Грыжа пищеводного отверстия } \\
\text { диафрагмы; } \\
\text { - Пищевод Баррета; } \\
\text { - Осложнения: рубцовые стриктуры, } \\
\text { кровотечение, перфорация. }\end{array}$ \\
\hline
\end{tabular}




\begin{tabular}{|c|c|}
\hline Методы хирургического лечения: & $\begin{array}{l}\text { - Фундопликация - по Ниссену, по } \\
\text { Тупе; } \\
\text { - Резекция пищевода. }\end{array}$ \\
\hline Методика фундопликации по Ниссену: & $\begin{array}{l}\text { Вокруг пищевода из фундального } \\
\text { отдела желудка создают муфту в виде } \\
\left.\text { манжетки (на } 360^{\circ}\right) \text {. }\end{array}$ \\
\hline Техника операции по Belsey Mark IV: & $\begin{array}{l}\text { Внутриплевральная фундопликация (на } \\
\left.240-270^{\circ}\right) .\end{array}$ \\
\hline Техника операции по Hill: & $\begin{array}{l}\text { Восстановление дугообразной связки и } \\
\text { гастропексия. }\end{array}$ \\
\hline Техника операции по Тупе: & $\begin{array}{l}\text { Неполная фундопликация } \quad \text { задней } \\
\text { стенки пищевода }\left(200^{\circ}\right) .\end{array}$ \\
\hline $\begin{array}{l}\text { Какие осложнения возникают после } \\
\text { различных вариантов } \\
\text { фундопликаций? }\end{array}$ & $\begin{array}{l}\text { - Симптом газового баллона; } \\
\text { - Стриктура пищеводно-желудочного } \\
\text { перехода; } \\
\text { - Дисфагия; } \\
\text { - Повреждение селезёнки; } \\
\text { - Перфорация пищевода; } \\
\text { - Пневмоторакс. }\end{array}$ \\
\hline Что такое симптом газового баллона? & Невозможность рвоты и отрыжки. \\
\hline Прогноз: & $\begin{array}{l}\text { При отсутствии соответствующего } \\
\text { лечения развиваются пищевод Баррета, } \\
\text { рак. }\end{array}$ \\
\hline
\end{tabular}




\section{ДИВЕРТИКУЛЫ ПИЩЕВОДА}

- Дивертикул пищевода - ограниченное мешковидное выпячивание одной или нескольких слоёв стенки пищевода.

- Внутренний слой дивертикула выстлан поверхностным эпителием.

- В образовании дивертикула важную роль играет слабость стенки и наличие препятствия в дистальном отделе.

- Дивертикулы могут располагаться в верхнем (ценкеровские), среднем и нижнем (эпифренальные) отделах пищевода.

- В начальных стадиях болезнь протекает бессимптомно, с увеличением размеров дивертикула проявляются дисфагия, изжога, отрыжка, неприятный запах изо рта.

- Возможно развитие воспаления стенки дивертикула, симптомы сдавления окружающих органов и даже перфорация.

- Диагноз основывается на данных контрастного рентгенологического или КТ исследования.

- Лечение - хирургическое (дивертикулэктомия, дистальная миотомия).

\section{Вопросы и ответы по дивертикулам пищевода}

\begin{tabular}{|c|c|}
\hline Вопросы & Ответы \\
\hline $\begin{array}{l}\text { Что представляют собой дивертикулы } \\
\text { пищевода? }\end{array}$ & $\begin{array}{l}\text { Мешковидное выпячивание одной или } \\
\text { нескольких слоёв стенки пищевода. }\end{array}$ \\
\hline Виды дивертикулов: & $\begin{array}{l}\text { • По локализации: } \\
\text { О Глоточно-пищеводный } \\
\text { (дивертикул Ценкера); } \\
\text { О Эпибронхиальные } \\
\text { (бифуркационные, } \\
\text { среднепищеводные); } \\
\text { О Эпифренальные. } \\
\text { • По механизму образования: } \\
\text { о Истинные или тракционные; }\end{array}$ \\
\hline
\end{tabular}




\begin{tabular}{|c|c|}
\hline & о Ложные или пульсионные. \\
\hline Осложнения: & $\begin{array}{l}\text { - Сдавление окружающих тканей и } \\
\text { соседних органов; } \\
\text { - Дивертикулит; } \\
\text { - Перфорация дивертикула; } \\
\text { - Формирование свищей. }\end{array}$ \\
\hline Что такое дивертикул Ценкера? & $\begin{array}{l}\text { Дивертикул, формирующийся из задней } \\
\text { стенки глотки, непосредственно над } \\
\text { входом в пищевод. }\end{array}$ \\
\hline Причины и факторы риска: & $\begin{array}{l}\text { Спазм верхнего пищеводного } \\
\text { сфинктера и дискоординация между } \\
\text { сокращениями верхнего пищеводного } \\
\text { сфинктера и глоточных мышц. }\end{array}$ \\
\hline Клинические признаки: & $\begin{array}{l}\text { - Дисфагия; } \\
\text { - Регургитация; } \\
\text { - Булькающий шум на шее при } \\
\text { проглатывании жидкости; } \\
\text { - Неприятный запах изо рта; } \\
\text { - Признаки рефлюкса. }\end{array}$ \\
\hline $\begin{array}{l}\text { У каких пациентов можно } \\
\text { заподозрить? }\end{array}$ & $\begin{array}{l}\text { У пациентов с вышеперечисленными } \\
\text { признаками и с наличием шороха при } \\
\text { пальпации на шее. }\end{array}$ \\
\hline Диагностика: & $\begin{array}{l}\text { - Контрастное рентгенологическое } \\
\text { исследование; } \\
\text { - } \mathrm{KT;} \\
\text { - Эндоскопия. }\end{array}$ \\
\hline $\begin{array}{l}\text { Признаки диагностической } \\
\text { визуализации: }\end{array}$ & $\begin{array}{l}\text { Затекание контраста в просвет } \\
\text { дивертикула. }\end{array}$ \\
\hline $\begin{array}{l}\text { Что обнаруживается при других } \\
\text { методах исследования? }\end{array}$ & $\begin{array}{l}\text { При манометрии - повышение тонуса } \\
\text { верхнего пищеводного сфинктера, }\end{array}$ \\
\hline
\end{tabular}




\begin{tabular}{|c|c|}
\hline & $\begin{array}{l}\text { дискоординация между сокращениями } \\
\text { верхнего пищеводного сфинктера и } \\
\text { глоточных мышц. }\end{array}$ \\
\hline Диагностические критерии: & $\begin{array}{l}\text { - Клиническая картина; } \\
\text { - Рентгенологические данные; } \\
\text { - Манометрические данные } \\
\text { (гипертонус верхнего пищеводного } \\
\text { сфинктера или дискординация } \\
\text { функции сфинктера и мышц глотки). }\end{array}$ \\
\hline Методы лечения: & Хирургическое. \\
\hline $\begin{array}{l}\text { Показания к хирургическому } \\
\text { лечению: }\end{array}$ & Симптоматический дивертикул. \\
\hline Виды оперативных вмешательств: & $\begin{array}{l}\text { - Миотомия; } \\
\text { - Дивертикулэктомия и миотомия; } \\
\text { • } \text { Эндоскопическая миотомия; } \\
\text { - Антирефлюксная операция. }\end{array}$ \\
\hline $\begin{array}{l}\text { Что представляет собой дивертикул } \\
\text { средней части пищевода? }\end{array}$ & $\begin{array}{l}\text { Дивертикул, расположенный в зоне } \\
\text { между грудной частью пищевода и } \\
\text { бифуркацией трахеи. }\end{array}$ \\
\hline Частота встречаемости: & Встречается наиболее часто. \\
\hline Причины и факторы риска: & $\begin{array}{l}\text { - Гранулематозные заболевания } \\
\text { средостения (туберкулёз, } \\
\text { гистоплазмоз); } \\
\text { - Лимфоаденопатии средостения; } \\
\text { - Саркоидоз. }\end{array}$ \\
\hline Клинические признаки: & $\begin{array}{l}\text { - Дисфагия; } \\
\text { - Регургитация; } \\
\text { - Загрудинная боль. }\end{array}$ \\
\hline
\end{tabular}




\begin{tabular}{|c|c|}
\hline $\begin{array}{l}\text { У каких пациентов можно } \\
\text { заподозрить? }\end{array}$ & $\begin{array}{l}\text { У пациентов с } \text { клиническими } \\
\text { признаками и перенесёнными } \\
\text { заболеваниями средостения. }\end{array}$ \\
\hline Диагностика: & $\begin{array}{l}\text { - Контрастное рентгенологическое } \\
\text { исследование; } \\
\text { - КТ; } \\
\text { - Эндоскопия. }\end{array}$ \\
\hline $\begin{array}{l}\text { Признаки диагностической } \\
\text { визуализации: }\end{array}$ & $\begin{array}{l}\text { Затекание контраста в просвет } \\
\text { дивертикула. }\end{array}$ \\
\hline Диагностические критерии: & $\begin{array}{l}\text { - Клиническая картина; } \\
\text { - Данные рентгеноконтрастного } \\
\text { исследования и КТ; } \\
\text { - Внутрипищеводная манометрия } \\
\text { (нормальный тонус нижнего } \\
\text { пищеводного сфинктера). }\end{array}$ \\
\hline Методы лечения: & $\begin{array}{l}\text { - При бессимптомном течении - } \\
\text { наблюдение; } \\
\text { - При явных проявлениях - } \\
\text { хирургическое. }\end{array}$ \\
\hline Показания к хирургической операции: & Симптоматический дивертикул. \\
\hline Виды оперативных вмешательств: & Дивертикулэктомия. \\
\hline $\begin{array}{l}\text { Что такое эпифренальный } \\
\text { дивертикул? }\end{array}$ & $\begin{array}{l}\text { Дивертикул, формирующийся над } \\
\text { нижним пищеводным сфинктером. }\end{array}$ \\
\hline Частота встречаемости: & Составляет 10\%. \\
\hline Патогенез: & $\begin{array}{l}\text { Повышение } \\
\text { давления внутрипищеводного } \\
\text { кардиопазма и стриктуры нижнего } \\
\text { отдела пищевода способствует }\end{array}$ \\
\hline
\end{tabular}




\begin{tabular}{|c|c|}
\hline & $\begin{array}{l}\text { выпячиванию слизистой оболочки в } \\
\text { виде мешковидного образования. }\end{array}$ \\
\hline Клинические признаки: & $\begin{array}{l}\text { - Дисфагия; } \\
\text { - Регургитация; } \\
\text { - Боли за грудиной. }\end{array}$ \\
\hline $\begin{array}{l}\text { У каких пациентов можно } \\
\text { заподозрить? }\end{array}$ & $\begin{array}{l}\text { У пациентов с клиническими } \\
\text { признаками и стриктурой пищевода. }\end{array}$ \\
\hline Диагностика: & $\begin{array}{l}\text { - Контрастная рентгенография; } \\
\text { - } \mathrm{KT;} \\
\text { - } \quad \text { Эндоскопия. }\end{array}$ \\
\hline $\begin{array}{l}\text { Признаки диагностической } \\
\text { визуализации: }\end{array}$ & $\begin{array}{l}\text { Затекание контраста в просвет } \\
\text { дивертикула. }\end{array}$ \\
\hline $\begin{array}{l}\text { Что обнаруживается при других } \\
\text { методах исследования? }\end{array}$ & $\begin{array}{l}\text { При манометрии - повышение тонуса } \\
\text { нижнего пищеводного сфинктера или } \\
\text { дисмоторика. }\end{array}$ \\
\hline Диагностические критерии: & $\begin{array}{l}\text { - Клинические признаки; } \\
\text { - Наличие дивертикула } \\
\text { рентгенографии и КТ; } \\
\text { - Повышение тонуса нижнего } \\
\text { пищеводного сфинктера при } \\
\text { манометрии или его дисмоторика. }\end{array}$ \\
\hline Методы лечения: & Хирургическое. \\
\hline Виды хирургической операции: & $\begin{array}{l}\text { - Дивертикулэктомия; } \\
\text { - Миотомия; } \\
\text { • Частичная фундопликация. }\end{array}$ \\
\hline
\end{tabular}




\section{СТРИКТУРЫ ПИЩЕВОДА}

- Стриктура пищевода характеризуется сужением просвета и нарушением проходимости пищевода.

- Причинами могут быть различные злокачественные (рак пищевода) и доброкачественные (врождённые клапаны, травмы, ожоги пищевода, пептические язвы сужение анастомоза и др.) заболевания.

- В зависимости от нозологических причин клиническая картина характеризуется частичной и полной непроходимостью пищевода, основным проявлением которых является острая и хроническая дисфагия.

- С течением времени развиваются различные осложнения (аспирационная пневмония, похудание).

- Диагностика основывается на данных контрастных исследований и эндоскопии. Для определения нозологической причины необходимы биопсия, КТ, эндоскопическое УЗИ, функциональные методы исследования.

- Лечение стриктуры пищевода должно быть направлено на устранение её причин. Если это невозможно применяют различные паллиативные методы восстановления проходимости пищевода (баллонная дилатация, стентирование, обходные анастомозы).

\section{Вопросы и ответы по стриктурам пищевода}

\begin{tabular}{|c|c|}
\hline Вопросы & Ответы \\
\hline Что такое стриктура? & $\begin{array}{l}\text { Сужение просвета и нарушение } \\
\text { проходимости пищевода. }\end{array}$ \\
\hline Частота встречаемости: & $\begin{array}{l}\text { Составляет 7-23\% у пациентов с } \\
\text { гастроэзофагеальной } \\
\text { болезнью. }\end{array}$ \\
\hline Клинические формы: & $\begin{array}{l}\text { - Доброкачественная; } \\
\text { - Злокачественная. }\end{array}$ \\
\hline
\end{tabular}




\begin{tabular}{|c|c|}
\hline Причины и факторы риска: & $\begin{array}{l}\text { - Доброкачественные } \\
\text { злокачественные новообразования; } \\
\text { • Фиброзные стриктуры - травмы, } \\
\text { ожоги и др.; } \\
\text { - Врождённые аномалии - клапаны } \\
\text { пищевода. }\end{array}$ \\
\hline Осложнения: & $\begin{array}{l}\text { - Аспирация в дыхательные пути; } \\
\text { - Формирование межорганных } \\
\text { свищей. }\end{array}$ \\
\hline Клинические признаки: & $\begin{array}{l}\text { - Дисфагия (в том числе } \\
\text { парадоксальная); } \\
\text { - Одинофагия; } \\
\text { - Регургитация; } \\
\text { - Похудание; } \\
\text { - Признаки осложнений; } \\
\text { - При формировании пищеводно- } \\
\text { трахеального свища - кашель во } \\
\text { время приёма пищи. }\end{array}$ \\
\hline $\begin{array}{l}\text { У каких пациентов можно } \\
\text { заподозрить? }\end{array}$ & У пациентов с клинической картиной. \\
\hline Диагностика: & $\begin{array}{l}\text { - Контрастное рентгенологическое } \\
\text { - } \text { Өсследование пищевода; } \\
\text { - Эндоскопия; } \\
\text { - КТ; } \\
\text { - Биопсия. }\end{array}$ \\
\hline Диагностические критерии: & $\begin{array}{l}\text { - Дисфагия; } \\
\text { - Наличие в анамнезе заболеваний } \\
\text { пищевода; } \\
\text { - Наличие стриктуры при контрастных } \\
\text { исследованиях и эндоскопии. }\end{array}$ \\
\hline
\end{tabular}




\begin{tabular}{|c|c|}
\hline Методы лечения: & $\begin{array}{l}\text { - Хирургическое; } \\
\text { - Баллонная дилатация; } \\
\text { - Стентирование; } \\
\text { - Радиотерапия; } \\
\text { - Химиотерапия; } \\
\text { - Эндоскопическое. }\end{array}$ \\
\hline Показания к оперативному лечению: & $\begin{array}{l}\text { Сужение просвета пищевода более чем } \\
\text { на 10-12 мм. }\end{array}$ \\
\hline Методы оперативного лечения: & $\begin{array}{l}\text { - Резекция пищевода; } \\
\text { - Эзофагоэктомия. }\end{array}$ \\
\hline
\end{tabular}




\section{ПЕРФОРАЦИЯ ПИЩЕВОДА}

- Перфорация пищевода - сквозной дефект пищеводной стенки, обусловленная различными причинами.

- В большинстве случаев возникает вследствие ятрогенных причин (зондирование желудка, эндоскопия, бужирование, стентирование, хирургические вмешательства). Также причиной перфорации пищевода могут быть баротравма, заболевания и травмы пищевода.

- Заболевание начинается острыми болями и дисфагией, за короткое время развиваются одышка и сепсис. Характеризуется тяжёлым клиническим течением, при отсутствии лечения заканчивается летальным исходом.

- Диагностика перфорации пищевода подтверждается результатами контрастного рентгенологического исследования, КТ, эндоскопия.

- K диагностическим критериям относятся клиническая картина, затекание контрастного вещества за пределы пищевода, медиастинальная эмфизема на КТ, наличие перфорации во время эндоскопии.

- Основным методом лечения является раннее хирургическое вмешательство (ушивание участка разрыва, дренирование средостения и плевральной полости, изоляция, эзофагэктомия и др.). Назначается также поддерживающая и антибактериальная терапия. По показаниям проводится стентирование пищевода.

\section{Вопросы и ответы по перфорации пищевода}

\begin{tabular}{|ll|}
\hline \multicolumn{1}{|c|}{ Вопросы } & \multicolumn{1}{c|}{ Ответы } \\
\hline Что такое перфорация пищевода? & Сквозной дефект пищеводной стенки. \\
\hline Частота встречаемости: & Перфорация шейного отдела составляет \\
& $40-60 \%, \quad$ грудного $\quad$ 40-50\%, \\
& абдоминального - 10\%. \\
\hline Причины и факторы риска: & - Ятрогенные повреждения; \\
& $\bullet$ Баротравма; \\
& - Заболевания пищевода; \\
\hline
\end{tabular}




\begin{tabular}{|c|c|}
\hline Вопросы & Ответы \\
\hline & $\begin{array}{l}\text { - Травмы пищевода; } \\
\text { - Инородные тела. }\end{array}$ \\
\hline Патогенез: & $\begin{array}{l}\text { - Внутренние факторы - травмы, } \\
\text { операции; } \\
\text { - Внешние факторы - ятрогенные } \\
\text { причины, баротравма, заболевания } \\
\text { пищевода, инородные тела. }\end{array}$ \\
\hline Особенности клинического течения: & $\begin{array}{l}\text { Характеризуется тяжелым течением. } \\
\text { При отсутствии лечения заканчивается } \\
\text { летальным исходом. }\end{array}$ \\
\hline Осложнения: & $\begin{array}{l}\text { - Абсцесс; } \\
\text { - Флегмона; } \\
\text { - Острый плеврит, перитонит; } \\
\text { - Гнойный медиастинит; } \\
\text { - Пиопневмоторакс (эмпиема); } \\
\text { - Сепсис. }\end{array}$ \\
\hline Клинические признаки: & $\begin{array}{l}\text { - Боль; } \\
\text { - Дисфагия; } \\
\text { - Одышка; } \\
\text { - Высокая температура; } \\
\text { - Кепитация, эмфизема, отёк. }\end{array}$ \\
\hline $\begin{array}{l}\text { У каких пациентов можно } \\
\text { заподозрить? }\end{array}$ & $\begin{array}{l}\text { При наличии боли и дисфагии после } \\
\text { травмы, диагностических процедур и } \\
\text { операций. }\end{array}$ \\
\hline Диагностика: & $\begin{array}{l}\text { - Контрастное рентгенологическое } \\
\text { исследование; } \\
\text { - Эндоскопия (эзофагоскопия); } \\
\text { - КТ. }\end{array}$ \\
\hline
\end{tabular}




\begin{tabular}{|c|c|}
\hline Вопросы & Ответы \\
\hline $\begin{array}{l}\text { Признаки диагностической } \\
\text { визуализации: }\end{array}$ & $\begin{array}{l}\text { - Наличие свободного газа и жидкости } \\
\text { вокруг пищевода; } \\
\text { • Вытекание контрастного вещества за } \\
\text { пределы пищевода. }\end{array}$ \\
\hline Диагностические критерии: & $\begin{array}{l}\text { - Клинические признаки; } \\
\text { - Вытекание контрастного вещества за } \\
\text { пределы пищевода; } \\
\text { - Наличие свободного газа и жидкости } \\
\text { вокруг пищевода на КТ; } \\
\text { - Наличие перфорации во время } \\
\text { эндоскопии. }\end{array}$ \\
\hline Методы лечения: & $\begin{array}{l}\text { - Хирургическое; } \\
\text { - Эндоскопическое стентирование; } \\
\text { - Консервативное - прекращение } \\
\text { орального питания, } \\
\text { антибиотикотерапия, коррекция } \\
\text { водно-электролитных нарушений. }\end{array}$ \\
\hline Показание к хирургической операции: & Наличие перфорации. \\
\hline Виды оперативных вмешательств: & $\begin{array}{l}\text { - Первичное ушивание дефекта; } \\
\text { - Дренирование; } \\
\text { - Резекция; } \\
\text { - Изоляция (диверсия, дефункция). }\end{array}$ \\
\hline Прогноз: & $\begin{array}{l}\text { Возможен летальный исход при } \\
\text { отсутствии хирургического лечения. }\end{array}$ \\
\hline
\end{tabular}




\section{ОЖОГИ ПИЩЕВОДА}

- Ожоги пищевода в большинстве случаев вызваны химическими веществами.

- Повреждения могут быть от незначительных изменений слизистой оболочки вплоть до полного некроза стенки пищевода.

- Сразу после приёма химического вещества наблюдаются сильные боли, чувство жжения, дисфагия. В течение последующих часов развиваются признаки SIRS.

- При тяжёлых ожогах могут возникать шок, перфорация, сепсис и даже летальный исход.

- В диагностике важную роль играет эндоскопия.

- $\mathrm{K}$ диагностическим критериям относятся анамнез, боли, дисфагия, ожоги на губах, языке, щеках и нёбе, характерная картина ожогов при эндоскопии.

- Лечение предусматривает проведение стабилизирующих мероприятий. При ожогах лёгкой степени проводится консервативное лечение. При перфорациях показана срочная операция (эзофагэктомия, еюностомия).

\section{Вопросы и ответы по химическим ожогам пищевода}

\begin{tabular}{|c|c|}
\hline Вопросы & Ответы \\
\hline $\begin{array}{l}\text { Что собой представляют ожоги } \\
\text { пищевода? }\end{array}$ & $\begin{array}{l}\text { Повреждение пищевода, вызванное } \\
\text { химическими веществами (кислотами и } \\
\text { щелочами). }\end{array}$ \\
\hline Клинические формы: & $\begin{array}{l}\text { - I стадия - повреждаются } \\
\text { поверхностные слои эпителия } \\
\text { слизистой оболочки пищевода; } \\
\text { - II стадия - повреждаются слизистый } \\
\text { и подслизистый слои; } \\
\text { - III стадия - повреждаются все слои } \\
\text { пищеводной стенки (перфорация). }\end{array}$ \\
\hline Причины и факторы риска: & Проглатывания кислот или щелочей. \\
\hline
\end{tabular}




\begin{tabular}{|c|c|}
\hline Вопросы & Ответы \\
\hline Патогенез: & 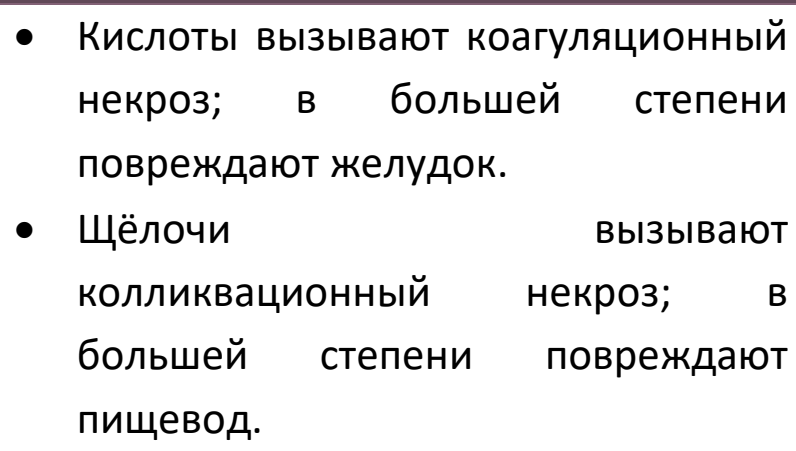 \\
\hline Особенности клинического течения: & $\begin{array}{l}3 \text { стадии: } \\
\text { - Острая некротическая стадия } \\
\text { (первые } 4 \text { дня); } \\
\text { - Стадия изъязвления и грануляции } \\
\text { (первые } 2 \text { недели); } \\
\text { - Стадия организации (бесследное } \\
\text { заживление, тонкий рубец, } \\
\text { стриктура, осложнения). }\end{array}$ \\
\hline Осложнения: & $\begin{array}{l}\text { - Шок; } \\
\text { - Перфорация; } \\
\text { - Кровотечение; } \\
\text { - Сепсис; } \\
\text { - Стриктура, малигнизация. }\end{array}$ \\
\hline Клинические признаки: & $\begin{array}{l}\text { - Гиперемия и отёк в области губ, } \\
\text { ротовой полости и глотки; } \\
\text { - Боли за грудиной; } \\
\text { - Дисфагия; } \\
\text { - Шок и признаки сепсиса. }\end{array}$ \\
\hline $\begin{array}{l}\text { У каких пациентов можно } \\
\text { заподозрить? }\end{array}$ & $\begin{array}{l}\text { Пациенты, в анамнезе которых имеется } \\
\text { проглатывание кислот или щелочей. }\end{array}$ \\
\hline Диагностика: & $\begin{array}{l}\text { - Эндоскопия; } \\
\text { - Контрастное рентгенологическое } \\
\text { исследование; }\end{array}$ \\
\hline
\end{tabular}




\begin{tabular}{|c|c|}
\hline Вопросы & Ответы \\
\hline $\begin{array}{l}\text { Признаки диагностической } \\
\text { визуализации: }\end{array}$ & $\begin{array}{l}\text { На эндоскопии - гиперемия, отёк, } \\
\text { поверхностные эрозии слизистой } \\
\text { оболочки, отторжение слизистой } \\
\text { оболочки, кровоизлияния, язвы, очаги } \\
\text { грануляции и некроз, перфорация. }\end{array}$ \\
\hline Диагностические критерии: & $\begin{array}{l}\text { - Проглатывание кислот или щелочей } \\
\text { в анамнезе; } \\
\text { - Дисфагия и боли; } \\
\text { - Различные повреждения при } \\
\text { эндоскопии. }\end{array}$ \\
\hline Методы лечения: & $\begin{array}{l}\text { - Мероприятия для стабилизации } \\
\text { состояния пациента; } \\
\text { - Консервативное лечение - при } \\
\text { ожогах І степени; } \\
\text { - Эндоскопическое лечение - при } \\
\text { ожогах II степени; } \\
\text { - Хирургическое лечение-при ожогах } \\
\text { III степени. }\end{array}$ \\
\hline Показания к хирургическому лечению: & Наличие перфорации и стриктур. \\
\hline Методы хирургического лечения: & Эзофагэктомия, эзофагостомия. \\
\hline Прогноз: & $\begin{array}{l}\text { В большинстве } \\
\text { неблагоприятен. }\end{array}$ \\
\hline
\end{tabular}




\section{ДОБРОКАЧЕСТВЕННЫЕ ОПУХОЛИ ПИЩЕВОДА}

- Пищевод Баррета - метаплазия плоскоклеточного эпителия дистальной части пищевода в цилиндрический.

- Основным патогенетическим механизмом пищевода Баррета является постоянное раздражение эпителия пищевода желудочным содержимом при гастроэзофагеальной рефлюксной болезни.

- Заболевание проявляется типичными и атипичными признаками рефлюкса; в редких случаях не прогрессирует. Однако в большинстве случаев осложняется изъязвлением стенки пищевода, кровотечением, образованием стриктур, дисплазией и раком.

- В диагностике важную роль играют эндоскопия и биопсия.

- $\mathrm{K}$ диагностическим признакам относятся признаки рефлюкса, кишечная метаплазия эпителия пищеводной стенки.

- Лечение проводится в зависимости от патоморфологических изменений: консервативное (антацидные препараты) и хирургическое (фундопликация, абляция, эзофагэктомия).

- Доброкачественные новообразования пищевода встречаются относительно редко. К ним относятся гастроинтестинальные стромальные опухоли, лейомиомы и полипы. Гемангиомы и миобластомы относятся к редким опухолям.

- Доброкачественные опухоли растут медленно, не вызывая клинических симптомов. Наиболее частым симптомом является медленно прогрессирующая дисфагия.

- Диагноз доброкачественных опухолей ставят на основании эзофагографии, эндоскопии, КТ/МРТ и эндоскопического УзИ. С целью дифференциации доброкачественных опухолей от злокачественных проводят биопсию.

- Основным методом лечения доброкачественных опухолей пищевода является хирургический. Интралюминальные опухоли, как правило, удаляются эндоскопическим методом. Симптоматические и крупные интралюминальные опухоли удаляются торакоскопическим, лапароскопическим или открытым способами. 


\section{Вопросы и ответы по доброкачественным опухолям пищевода}

\begin{tabular}{|c|c|}
\hline Вопросы & Ответы \\
\hline $\begin{array}{l}\text { Доброкачественные опухоли } \\
\text { пищевода: }\end{array}$ & $\begin{array}{l}\text { - Пищевод Баррета; } \\
\text { - Гастроинтестинальные стромальные } \\
\text { опухоли; } \\
\text { - Лейомиомы; } \\
\text { - Полипы; } \\
\text { - Гемангиомы; } \\
\text { - Гранулярные миобластомы; } \\
\text { - Кисты и др. }\end{array}$ \\
\hline Что такое пищевод Баррета? & $\begin{array}{l}\text { Метаплазия плоскоклеточного эпителия } \\
\text { пищевода в цилиндрический. }\end{array}$ \\
\hline Клинические формы: & $\begin{array}{l}\text { - Метаплазия; } \\
\text { - Высокодифференцированные; } \\
\text { - Низкодифференцированные; } \\
\text { - Аденокарциномы. }\end{array}$ \\
\hline Причины и факторы риска: & $\begin{array}{l}\text { Гастроэзофагеальная рефлюксная } \\
\text { болезнь. }\end{array}$ \\
\hline Патогенез: & $\begin{array}{l}\text { Периодическое раздражение слизистой } \\
\text { оболочки пищевода желудочным соком } \\
\text { и желчью. }\end{array}$ \\
\hline Особенности клинического течения: & $\begin{array}{l}\text { У } 1 / 3 \text { больных течение медленное, } \\
\text { стабильное, в большинстве случаев - } \\
\text { прогрессирующее. }\end{array}$ \\
\hline Осложнения: & $\begin{array}{l}\text { - Изъязвление стенки пищевода } \\
\text { - Пептическая стриктура; } \\
\text { - Дисплазия; } \\
\text { - Аденокарциномы. }\end{array}$ \\
\hline Клинические признаки: & $\begin{array}{l}\text { - В большинстве случаев } \\
\text { бессимптомное течение; }\end{array}$ \\
\hline
\end{tabular}




\begin{tabular}{|c|c|}
\hline Вопросы & Ответы \\
\hline & - Признаки рефлюкса-эзофагита. \\
\hline $\begin{array}{l}\text { У каких пациентов можно } \\
\text { заподозрить? }\end{array}$ & $\begin{array}{l}\text { У пациентов с гастроэзофагеальной } \\
\text { рефлюксной болезнью, грыжей } \\
\text { пищеводного отверстия диафрагмы, } \\
\text { стриктурой и язвенной болезнью. }\end{array}$ \\
\hline Диагностика: & Эндоскопия, биопсия. \\
\hline $\begin{array}{l}\text { Признаки диагностической } \\
\text { визуализации: }\end{array}$ & $\begin{array}{l}\text { Трансформация белого эпителия в } \\
\text { розовый. }\end{array}$ \\
\hline Гистологический анализ: & $\begin{array}{l}\text { Кишечная метаплазия эпителия (клетки } \\
\text { Гоблета). }\end{array}$ \\
\hline Диагностические критерии: & $\begin{array}{l}\text { - Признаки рефлюкс-эзофагита; } \\
\text { • Эндоскопические признаки - } \\
\text { трансформация белого эпителия в } \\
\text { розовый; } \\
\text { - Кишечная метаплазия эпителия в } \\
\text { биопсионном материале. }\end{array}$ \\
\hline Методы лечения: & $\begin{array}{l}\text { - Лечение рефлюкс-эзофагита; } \\
\text { - Устранение слизистого эпителия при } \\
\text { пищеводе Баррета: } \\
\text { о Фотодинамическая терапия; } \\
\text { О Радиочастотная деструкция; } \\
\text { о Термодеструкция; } \\
\text { О Мукозэктомия; } \\
\text { О Аргоно-плазменная коагуляция; } \\
\text { - Лечение осложнений: } \\
\text { О Дилатация; } \\
\text { О Резекция; } \\
\text { О Деструкция. }\end{array}$ \\
\hline Прогноз: & Часто развиваются осложнения. \\
\hline
\end{tabular}




\begin{tabular}{|c|c|}
\hline Вопросы & Ответы \\
\hline $\begin{array}{l}\text { Частота встречаемости других } \\
\text { доброкачественных новообразований } \\
\text { пищевода: }\end{array}$ & $\begin{array}{l}\text { Чаще } \\
\text { гастроинтестинальные } \\
\text { опухоли иромальные } \\
\text { редко - гемайомиомы, затем полипы, } \\
\text { стомы и миобластомы. }\end{array}$ \\
\hline Особенности клинического течения: & $\begin{array}{l}\text { Большинство склонны к росту, однако } \\
\text { риск малигнизации очень низок. }\end{array}$ \\
\hline Клинические признаки: & $\begin{array}{l}\text { - При интралюминальных опухолях } \\
\text { (полипы) наблюдаются обструкция, } \\
\text { дисфагия, рвота, аспирация; } \\
\text { - Интралюминальные опухоли } \\
\text { небольшого размера протекают } \\
\text { бессимптомно; при увеличении их } \\
\text { размеров >5 см наблюдаются } \\
\text { дисфагия, загрудинные боли. }\end{array}$ \\
\hline $\begin{array}{l}\text { У каких пациентов можно } \\
\text { заподозрить? }\end{array}$ & $\begin{array}{l}\text { У пациентов с клиническими } \\
\text { признаками. }\end{array}$ \\
\hline Диагностика: & $\begin{array}{l}\text { - Контрастное рентгенологическое } \\
\text { исследование; } \\
\text { - Эндоскопия; } \\
\text { - Биопсия; } \\
\text { - КТ/МРТ; } \\
\text { - Эндоскопическое УзИ; } \\
\text { - Патогистологическое исследование. }\end{array}$ \\
\hline $\begin{array}{l}\text { Признаки диагностической } \\
\text { визуализации: }\end{array}$ & $\begin{array}{ll}\text { - } & \text { При контрастном } \\
& \text { рентгенологическом исследовании - } \\
& \text { дефект заполнения; } \\
\text { - } & \text { Изменения в стенке пищевода; } \\
\text { - } & \text { При эндоскопии - наличие } \\
& \text { нормальной слизистой оболочки. }\end{array}$ \\
\hline
\end{tabular}




\begin{tabular}{|c|c|}
\hline Вопросы & Ответы \\
\hline Методы лечения: & $\begin{array}{l}\text { - Эндоскопическое - } \quad \text { при } \\
\text { интралюминальных опухолях; } \\
\text { - Хирургическое. }\end{array}$ \\
\hline Показания к хирургическому лечению: & Наличие новообразования. \\
\hline Методы хирургического лечения: & $\begin{array}{l}\text { Торакоскопический метод или } \\
\text { энуклеация опухоли открытым } \\
\text { методом. }\end{array}$ \\
\hline Что такое киста пищевода? & $\begin{array}{l}\text { Патологическая полость с жидкостью, } \\
\text { расположенная в стенке пищевода. }\end{array}$ \\
\hline Частота встречаемости: & Встречается редко. \\
\hline Клинические формы: & $\begin{array}{l}\text { - Врождённые (бронхогенные, } \\
\text { энтерогенные); } \\
\text { • Приобретённые (ретенционные). }\end{array}$ \\
\hline Осложнения: & $\begin{array}{l}\text { С ростом опухоли наблюдаются } \\
\text { симптомы сдавления соседних органов } \\
\text { (дисфагия, одышка). }\end{array}$ \\
\hline Клинические признаки: & $\begin{array}{l}\text { - В большинстве случаев протекает } \\
\text { бессимптомно; } \\
\text { • Боли в грудной полости; } \\
\text { - Дисфагия. }\end{array}$ \\
\hline Диагностика: & $\begin{array}{l}\text { - Контрастная эзофагография; } \\
\text { - КТ/МРТ; } \\
\text { - } \quad \text { Эндоскопическое УзИ. }\end{array}$ \\
\hline Методы лечения: & Хирургическое. \\
\hline Показания к хирургическому лечению: & Симптоматические кисты. \\
\hline Метод хирургического лечения: & Энуклеация кисты. \\
\hline
\end{tabular}




\section{ЗЛОКАЧЕСТВЕННЫЕ ОПУХОЛИ ПИЩЕВОДА}

- Среди злокачественных новообразований пищевода наиболее часто встречаются плоскоклеточный рак и аденокарциномы, развивающиеся из метапластического эпителия.

- К Какторам риска относятся курение, злоупотребление алкоголем, употребление пищи, содержащей нитрозамины, авитаминоз, термические и химические раздражения, вирус папилломы человека, ожоги, ахалазия, пищевод Баррета.

- На начальных этапах заболевание протекает бессимптомно. По мере прогрессирования наблюдаются дисфагия, одинофагия, похудание, кровотечение, кашель после приёма пищи, изменение тембра голоса.

- Пятилетняя выживаемость на начальных стадиях заболевания составляет 2030\%, на поздних стадиях - 0,5-1 год.

- К частым осложнениям заболевания относятся сокращение приёма пищи, аспирационная пневмония, формирование трахеобронхиальных свищей.

- Диагноз подтверждается эндоскопией и биопсией. Для определения стадии заболевания важное значение имеют эндоскопическое УзИ, КТ, ПЭТ, лапароскопия, торакоскопия.

- Лечение зависит от гистологического типа и стадии заболевания. На ранних стадиях проводится эндоскопическая мукозальная резекция, хирургическая резекция, комбинация химио- и радиотерапии. При нерезектабельных опухолях применяется стентирование, фотодинамическое лечение, химио-/радиотерапия и др.

\section{Вопросы и ответы по злокачественным опухолям пищевода}

\begin{tabular}{|ll|}
\multicolumn{1}{c}{ Вопросы } & \multicolumn{1}{c|}{ Ответы } \\
\hline $\begin{array}{l}\text { Часто встречаемая злокачественная } \\
\text { опухоль пищевода: }\end{array}$ & $\begin{array}{l}\text { Плоскоклеточный } \\
\text { аденокарцинома. }\end{array}$ \\
\hline Частота встречаемости: & $\begin{array}{l}\text { Составляет } 1,5 \% \text { всех злокачественных } \\
\text { опухолей и 7\% среди опухолей } \\
\text { желудочно-кишечного тракта. }\end{array}$ \\
\end{tabular}




\begin{tabular}{|c|c|}
\hline Вопросы & Ответы \\
\hline Клинические формы: & $\begin{array}{l}\text { - Плоскоклеточный рак; } \\
\text { - Аденокарцинома; } \\
\text { - Другие опухоли. }\end{array}$ \\
\hline Стадии заболевания: & $\begin{array}{l}\text { - I стадия - опухоль прорастает в } \\
\text { слизистую иподслизистую оболочку; } \\
\text { - II стадия - опухоль прорастает во все } \\
\text { слои пищевода, имеются единичные } \\
\text { метастазы вегионарные } \\
\text { лимфоузлы; } \\
\text { - III стадия - опухоль прорастает в } \\
\text { окружающую орган клетчатку, } \\
\text { имеются множественные метастазы } \\
\text { в регионарные лимфатические узлы; } \\
\text { І IV стадия - имеются метастазы в } \\
\text { отдалённые органы. }\end{array}$ \\
\hline Факторы риска: & $\begin{array}{l}\text { - При аденокарциноме: } \\
\text { О Пищевод Баррета; } \\
\text { о Гастроэзофагеальная рефлюкс- } \\
\text { ная болезнь; } \\
\text { О Ожирение; } \\
\text { О Табакокурение. } \\
\text { - При плоскоклеточном раке: } \\
\text { - Табакокурение; } \\
\text { - Алкоголизм; } \\
\text { - Нитрозамины; } \\
\text { - Дефицит витаминного баланса (А, С, } \\
\text { Е, рибофлавин), недостаточность } \\
\text { цинка; } \\
\text { - Постоянный приём горячей пищи и } \\
\text { напитков; } \\
\text { - Вирус папилломы человека; } \\
\text { Синдром Пламмера-Винсона; }\end{array}$ \\
\hline
\end{tabular}




\begin{tabular}{|c|c|}
\hline Вопросы & Ответы \\
\hline & $\begin{array}{l}\text { - Кератодермия; } \\
\text { - Ахалазия; } \\
\text { • Ожоги пищевода. }\end{array}$ \\
\hline Патогенез: & До конца не изучен. \\
\hline Особенность клинического течения: & $\begin{array}{l}\text { Начиная со слизистой оболочки } \\
\text { прорастает во все слои стенки } \\
\text { пищевода, } \\
\text { прогрессирует. }\end{array}$ \\
\hline Осложнения: & $\begin{array}{l}\text { - } \text { Потеря аппетита; } \\
\text { • Аспирационная пневмония; } \\
\text { • Формирование } \\
\text { пищеводнотрахеальных } \\
\text { бронхопищеводных свищей. }\end{array}$ \\
\hline Клинические признаки: & $\begin{array}{l}\text { - Начало заболевания бессимптомное } \\
\text { (доклиническая фаза); } \\
\text { - Дисфагия; } \\
\text { - Одинофагия; } \\
\text { - Отрыжка; } \\
\text { - Регургитация; } \\
\text { - Кровохарканье; } \\
\text { - Атипичные признаки - кашель, } \\
\text { охриплость голоса, } \\
\text { кровотечение. }\end{array}$ \\
\hline $\begin{array}{l}\text { У каких пациентов можно } \\
\text { заподозрить? }\end{array}$ & $\begin{array}{l}\text { У пациентов с клиническими } \\
\text { признаками, при наличии пищевода } \\
\text { Баррета, ожогов, стриктур, ахалазии в } \\
\text { анамнезе, при обнаружении опухоли, } \\
\text { сужения, свища пищевода на } \\
\text { рентгенографии или КТ. }\end{array}$ \\
\hline Диагностика: & - Эндоскопия; \\
\hline
\end{tabular}




\begin{tabular}{|c|c|}
\hline Вопросы & Ответы \\
\hline & - Биопсия. \\
\hline Диагностические критерии: & $\begin{array}{l}\text { - Дисфагия, одинофагия, похудание, } \\
\text { кровотечение, кашель после приёма } \\
\text { пищи, охриплость голоса; } \\
\text { - обнаружение опухоли на } \\
\text { эндоскопии; } \\
\text { - Определение } \\
\text { опухоли в биопсийном материале } \\
\text { (гистологическое исследование). }\end{array}$ \\
\hline $\begin{array}{l}\text { Какие методы исследования } \\
\text { необходимы для определения стадии } \\
\text { заболевания? }\end{array}$ & 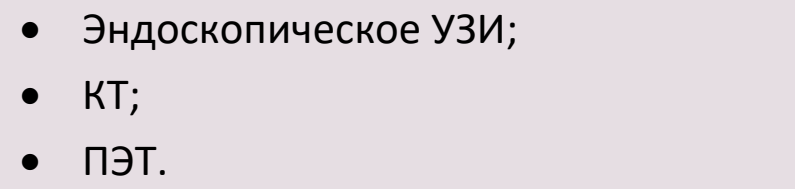 \\
\hline Методы лечения: & $\begin{array}{l}\text { - Хирургическое; } \\
\text { • Эндоскопическая } \\
\text { резекция (Т1); } \\
\text { • Химиотерапия } \\
\text { аденокарциноме; } \\
\text { - Радиотерапия } \\
\text { плоскоклеточном раке; } \\
\text { • Паллиативное: } \\
\text { О Комбинированная хими } \\
\quad \text { радиотерапия; } \\
\text { О Формирование } \\
\text { анастомозы; } \\
\text { О Стентирования пищевода; } \\
\text { О Лазерная реканализация. }\end{array}$ \\
\hline $\begin{array}{l}\text { Показания к хирургическому } \\
\text { лечению: }\end{array}$ & $\begin{array}{l}\text { При резектабельных опухолях: } \\
\text { - Отсутствие метастазов в соседних } \\
\text { органах; } \\
\text { - Отсутствие отдалённых метастазов; }\end{array}$ \\
\hline
\end{tabular}




\begin{tabular}{|c|c|}
\hline Bonpocbl & Ответы \\
\hline & $\begin{array}{l}\text { - Отсутствие тяжёлых сопутствующих } \\
\text { заболеваний. }\end{array}$ \\
\hline Методы хирургического лечения: & $\begin{array}{l}\text { - Тотальная эзофагэктомия с } \\
\text { формированием цервикального } \\
\text { анастомоза; } \\
\text { - Субтотальная эзофагэктомия с } \\
\text { формированием внутригрудного } \\
\text { анастомоза; } \\
\text { •зофагогастрэктомия } \\
\text { формированием с } \\
\text { анастомоза - при дистальных } \\
\text { аденокарциномах. }\end{array}$ \\
\hline Прогноз: & $\begin{array}{l}\text { На ранних стадиях } \\
\text { выживаемость составляет } 20-30 \% \text {, на } \\
\text { поздних -0,5-1 год. }\end{array}$ \\
\hline
\end{tabular}




\section{ДИСМОТОРИКА ПИЩЕВОДА}

- Функциональные нарушения пищевода, не связанные с органическими изменениями его мышечного слоя, называются первичными функциональными заболеваниями.

- К ним относятся дисмоторика поперечнополосатых мышц (орофарингеальная дисфагия) и дисмоторика гладких мышц (ахалазия, диффузный и сегментарный спазм пищевода, «пищевод щелкунчика»).

- Клинически функциональные заболевания пищевода проявляются острой или хронической дисфагией, болью, регургитацией, признаками аспирации.

- Диагноз подтверждается после исключения кардиологических и органических патологий. По этой причине проводится детальное обследование пациента.

- Лечение поводится консервативным (спазмолитики, дилатация) и хирургическим (миотомия) методами.

\section{Вопросы и ответы по дисмоторике пищевода}

\begin{tabular}{|c|c|}
\hline Bonpocbl & Ответы \\
\hline $\begin{array}{l}\text { Что представляет собой нарушение } \\
\text { двигательной функции пищевода? }\end{array}$ & Нарушение перистальтики пищевода. \\
\hline Клинические формы: & $\begin{array}{l}\text { - Первичные: } \\
\text { о дисмоторика } \\
\text { поперечнополосатых мышц } \\
\text { (орофарингеальная дисфагия); } \\
\text { дисмоторика гладких мышц } \\
\text { (ахалазия, диффузный и } \\
\text { сегментарный спазм пищевода, } \\
\text { «пищевод щелкунчика»); } \\
\text { Вторичные - в результате } \\
\text { заболеваний соединительной ткани, } \\
\text { эндокринной } \\
\text { метаболических заболеваний. }\end{array}$ \\
\hline
\end{tabular}




\begin{tabular}{|c|c|}
\hline Вопросы & Ответы \\
\hline Клинические признаки: & $\begin{array}{l}\text { - Загрудинные боли; } \\
\text { - Дисфагия; } \\
\text { - Одинофагия; } \\
\text { - Отрыжка; } \\
\text { - Регургитация; } \\
\text { - Кровохарканье; } \\
\text { - Атипичные признаки. }\end{array}$ \\
\hline $\begin{array}{l}\text { У каких пациентов можно } \\
\text { заподозрить? }\end{array}$ & $\begin{array}{l}\text { У пациентов с } \\
\text { признаками клиническими } \\
\text { кардиальных патологий и органических } \\
\text { патологий пищевода. }\end{array}$ \\
\hline Диагностика: & $\begin{array}{l}\text { - Контрастная рентгенография; } \\
\text { - Эндоскопия; } \\
\text { - Манометрия; } \\
\text { - } \text { рН-метрия; } \\
\text { - КТ; } \\
\text { - Эндоскопическое УЗИ; } \\
\text { - Биопсия; } \\
\text { - Тест на Н. pylori. }\end{array}$ \\
\hline Диагностические критерии: & $\begin{array}{l}\text { - Клинические признаки; } \\
\text { - Отсутствие органических патологий } \\
\text { пищевода; } \\
\text { - Дисмоторика при функциональных } \\
\text { исследованиях. }\end{array}$ \\
\hline Что такое ахалазия? & $\begin{array}{l}\text { Первичное } \\
\text { заболевание, хункциональное } \\
\text { ослаблением или полным отсутствием } \\
\text { перистальтики пищевода, повышением } \\
\text { тонуса нижнего пищеводного } \\
\text { сфинктера и отсутстие его } \\
\text { расслабления в процессе глотани. }\end{array}$ \\
\hline
\end{tabular}




\begin{tabular}{|c|c|}
\hline Вопросы & Ответы \\
\hline Частота встречаемости: & $1 / 100000-6 / 1000$ \\
\hline $\begin{array}{l}\text { Классификация по стадии } \\
\text { заболевания: }\end{array}$ & $\begin{array}{l}\text { - Iстадия-нет расширения пищевода; } \\
\text { - II стадия - есть продольное } \\
\text { расширение пищевода; } \\
\text { - III стадия-пищевод формируетодно } \\
\text { колено; } \\
\text { - IV стадия - пищевод формирует } \\
\text { несколько колен (схож с } \\
\text { сигмовидной кишкой). }\end{array}$ \\
\hline Этиология: & Неизвестна. \\
\hline Патогенез: & $\begin{array}{l}\text { Деструкция постганглионарных } \\
\text { ингибиторных нейронов в Ауэрбаховом } \\
\text { сплетении. }\end{array}$ \\
\hline Особенность клинического течения: & Прогрессирующее течение. \\
\hline Осложнения: & $\begin{array}{l}\text { - Расширение пищевода - на } \\
\text { последней стадии заболевания } \\
\text { пищевод схож с сигмовидной } \\
\text { кишкой; } \\
\text { - Аспирационная пневмония; } \\
\text { - Кандидозный эзофагит; } \\
\text { - Рак. }\end{array}$ \\
\hline Клинические признаки: & $\begin{array}{l}\text { - Парадоксальная дисфагия; } \\
\text { - Регургитация; } \\
\text { - Отрыжка; } \\
\text { - агрудинные боли; } \\
\text { - Неприятный запах изо рта. }\end{array}$ \\
\hline $\begin{array}{l}\text { У каких пациентов можно } \\
\text { заподозрить? }\end{array}$ & $\begin{array}{l}\text { - У пациентов с клинической } \\
\text { картиной; }\end{array}$ \\
\hline
\end{tabular}




\begin{tabular}{|c|c|}
\hline Вопросы & Ответы \\
\hline & $\begin{array}{l}\text { - Пациенты со стабильным весом } \\
\text { несмотря на дисфагию. }\end{array}$ \\
\hline Диагностика: & $\begin{array}{l}\text { - Контрастная рентгенография; } \\
\text { - Эндоскопия; } \\
\text { - КТ; } \\
\text { - Эндоскопическое УзИ; } \\
\text { - Манометрия; } \\
\text { - } \text { рН-метрия. }\end{array}$ \\
\hline $\begin{array}{l}\text { Признаки диагностической } \\
\text { визуализации: }\end{array}$ & $\begin{array}{l}\text { - Контрастная рентгенография - } \\
\text { сужение в дистальной части } \\
\text { (симптом «птичьего клюва» или } \\
\text { «мышиного хвоста») и расширение } \\
\text { проксимальной части без } \\
\text { перистальтики; } \\
\text { - Эндоскопия - расширенный } \\
\text { пищевод, остатки пищи, } \\
\text { кандидозный эзофагит, сужение на } \\
\text { уровне нижнего пищеводного } \\
\text { сфинктера; } \\
\text { Кт - утолщение в области } \\
\text { дистального сфинктера. }\end{array}$ \\
\hline $\begin{array}{l}\text { Что обнаруживается при других } \\
\text { методах исследования? }\end{array}$ & $\begin{array}{l}\text { - Манометрия - отсутствие } \\
\text { перистальтики пищевода или } \\
\text { наличие слабых волн сокращения, } \\
\text { повышенный тонус нижнего } \\
\text { пищеводного сфинктера (>40 мм рт. } \\
\text { ст.) с недостаточным расслаблением } \\
\text { во время глотания; } \\
\text { - рН-метрия-в норме. }\end{array}$ \\
\hline Диагностические крит & - Дисфагия; \\
\hline
\end{tabular}




\begin{tabular}{|c|c|}
\hline Вопросы & Ответы \\
\hline & $\begin{array}{l}\text { - Сужение дистальной части и } \\
\text { расширение пищевода выше } \\
\text { сужения; } \\
\text { - Отсутствие перистальтики пищевода } \\
\text { или наличие слабых волн } \\
\text { сокращения, повышенный тонус } \\
\text { нижнего пищеводного сфинктера } \\
\text { (>40 мм рт. ст.) с недостаточным } \\
\text { расслаблением во время глотания } \\
\text { (выше внутрижелудочного давления } \\
\text { на } 10 \text { мм рт. ст.); } \\
\text { Отсутствие } \\
\text { эндоскопическом УзИ или Кт. }\end{array}$ \\
\hline Методы лечения: & $\begin{array}{l}\text { - Консервативное } \\
\text { антихеликобактерная терапия, } \\
\text { блокаторы кальциевых каналов - } \\
\text { при наличии противопоказаний к } \\
\text { дилатации и хирургическому } \\
\text { лечению; } \\
\text { • Эндоскопическое: } \\
\text { О Инъекция ботулотоксина - при } \\
\text { противопоказании } \\
\text { хирургическому лечению } \\
\text { дилатации; } \\
\text { Дилатация при } \\
\text { противопоказании } \\
\text { хирургическому лечению или при } \\
\text { развитии рецидива после } \\
\text { операции; } \\
\text { Хирургическое лечение. }\end{array}$ \\
\hline
\end{tabular}




\begin{tabular}{|c|c|}
\hline Вопросы & Ответы \\
\hline $\begin{array}{l}\text { Показания к хирургическому } \\
\text { лечению: }\end{array}$ & $\begin{array}{l}\text { Неэффективность дилатации, } \\
\text { сигмообразное расширение пищевода, } \\
\text { подозрение на рак. }\end{array}$ \\
\hline Методы хирургического лечения: & $\begin{array}{l}\text { - Лапароскопическая миотомия } \\
\text { фундопликация; } \\
\text { • Эзофагэктомия. }\end{array}$ \\
\hline $\begin{array}{l}\text { Что такое диффузный и сегментарный } \\
\text { спазм пищевода? }\end{array}$ & $\begin{array}{l}\text { Функциональное заболевание, } \\
\text { характеризующееся нарушением } \\
\text { перистальтики пищевода, которые } \\
\text { возникают одновременно в различных } \\
\text { частях пищевода. }\end{array}$ \\
\hline Клинические признаки: & $\begin{array}{l}\text { - На начальных этапах течение } \\
\text { бессимптомное; } \\
\text { - Загрудинные опухоли - ночные или } \\
\text { спонтанные; } \\
\text { - Дисфагия; } \\
\text { - Регургитация. }\end{array}$ \\
\hline Диагностические критерии: & $\begin{array}{l}\text { - Переменные загрудинные боли } \\
\text { и/или дисфагия; } \\
\text { - Отсутствие органических изменений } \\
\text { пищевода на эндоскопии и КТ; } \\
\text { - Некоординированные сокращения } \\
\text { пищевода нонтрастной } \\
\text { рентгенографии; } \\
\text { - На манометрии: } \\
\text { о Некоординированные } \\
\text { сокращения нормальной или } \\
\text { слабой амплитуды; } \\
\text { О Нормальный тонус нижнего } \\
\text { пищеводного сфинктера; } \\
\text { О Нормальная рН-метрия. }\end{array}$ \\
\hline
\end{tabular}




\begin{tabular}{|c|c|}
\hline Вопросы & Ответы \\
\hline Лечение: & Как и при ахалазии. \\
\hline Что такое «пищевод Щелкунчика»? & $\begin{array}{l}\text { Двигательные нарушения, } \\
\text { характеризующиеся сильными } \\
\text { загрудинными болями, длительными } \\
\text { (>6 секунд) перистальтическими } \\
\text { сокращениями с высокой амплитудой и } \\
\text { давлением (>180 мм рт. ст.) }\end{array}$ \\
\hline Диагностические критерии: & $\begin{array}{l}\text { - Сильные загрудинные боли; } \\
\text { - Нормальная перистальтика } \\
\text { пищевода понтрастном } \\
\text { исследовании; } \\
\text { - На манометрии: } \\
\text { о Координированные } \\
\text { перистальтические сокращения с } \\
\text { высокой амплитудой (18 мм рт. } \\
\text { ст.); } \\
\text { Длительные волны сокращения } \\
\text { (6 секунд); } \\
\text { Оормальный тонус нижнего } \\
\text { пищеводного сфинктера; } \\
\text { - Нормальная рН-метрия; } \\
\text { - На эндоскопии, КТ, эндоскопическом } \\
\text { Узи и кардиологическом } \\
\text { исследовании патологии } \\
\text { выявляются. н }\end{array}$ \\
\hline Методы лечения: & Нет эффективного метода лечения. \\
\hline Методы хирургического лечения: & $\begin{array}{l}\text { Миотомия (в 50\% случаев уменьшаются } \\
\text { боли, в } 80 \% \text { - дисфагия). }\end{array}$ \\
\hline
\end{tabular}




\section{СПИСОК ЛИТЕРАТУРЫ}

- Ağayev B.A. Cərrahi xəstəliklər. Bakı 2010.

- Blackbourne LH. Surgical Recall. 4 edition, 2006, LWW, Philadelphia

- Doherty GM. Current Diagnosis and Treatment: Surgery, $13^{\text {th }}$ edition, 2010, Lang International Edition.

- Omiraslanov D.T., Qazıyev A.Y. Onkologiya. Bakı, 2010.

- İsayev H.B.Cərrahi xəstəliklərin patofizologiyası. Bakı 2005

- McNally PR. GI/Liver Secrets Plus. 4 edition. Mosby, Elsevier, 2010

- Medscape, http://www.medscape.com

- Klingensmith ME, Aziz A, Bharat A, FoxAC, Porembka MR. The Washington Manual of Surgery, $6^{\text {th }}$ edition, 2012, LWW, Philadelphia.

- Oxford Handbook of Clinical Surgery, 3d edition, 2011, Oxford Press

- UpToDate, http://www.uptodate.com

- Гостищев B.К. Общая хирургия. GEOTAR-Media, 2019 


\title{
ХИРУРГИЧЕСКИЕ БОЛЕЗНИ
}

Н.Ю. Байрамов

\section{Хирургические заболевания желудка и двенадцатиперстной кишки}

Н.Ю. Байрамов, Н. А. Зейналов, З.З. Гахраманова, А.К. Сафиева, Ф.Ф. Ахмедов

\author{
Перевод: Н.Ю. Байрамов, С.А. Алиев, М.Р. Гусейнова
}




\section{ЯЗВЕННАЯ БОЛЕЗНЬ ЖЕЛУДКА И 12-ПЕРСТНОЙ КИШКИ}

- Язва - атравматический дефект, возникающий в эпителиальном и глубоком слоях в результате трофических нарушений.

- Эрозия - дефект в эпителиальном слое.

- Пептическая язва - язва, образованная под воздействием желудочного сока (в результате дисбаланса между защитными механизмами слизистой оболочки и воздействием желудочного сока).

- Вторичные или симптоматические язвы - являются признаками или осложнением других заболеваний (эндокринные, лекарственные, стрессовые и др.)

- Первичная язва или язвенная болезнь - заболевание, характеризующееся образованием язвы в стенке желудка или 12-перстной кишки. Основной клинической и морфологической формой является язва.

○ Основной этиологической причиной является инфицирование H. Pylori, однако не исключается роль табакокурения, применения НПВС, нерегулярного питания, стресса, генетической предрасположенности и других факторов.

○ Эти факторы нарушают баланс между защитной функцией слизистой оболочки и воздействием желудочного сока, тем самым способствуя возникновению язвы.

○ Заболевание, как правило, начинается периодическими эпигастральными болями.

В редких случаях боли не наблюдаются и заболевание проявляется при развитии осложнений. В зависимости от локализации боли могут наблюдаться на голодный желудок, после еды или носить постоянный характер. Наряду с болями могут наблюдаться также изжога, тошнота и рвота.

○ Заболевание характеризуется длительным течением, при отсутствии лечения могут развиться осложнения (кровотечение, перфорация, стеноз).

○ Диагноз подтверждается на основании эндоскопического исследования.

○ Лечение в большинстве случаев консервативное: снижение секреции желудочного сока, антихеликобактерная терапия. Хирургическое лечение проводится по показаниям, при наличии осложнений и неэффективности консервативного лечения.

- Стрессовые язвы - язвы желудка и 12-перстной кишки, образующиеся в результате стрессового состояния.

- Эти язвы в большинстве случаев проявляются кровотечением, редко-перфорацией, болями.

\section{Вопросы и ответы по пептической язве}

\begin{tabular}{|ll|}
\hline \multicolumn{1}{|c|}{ Вопросы } & \multicolumn{1}{c|}{ Ответы } \\
\hline Что такое пептическая язва? & $\begin{array}{l}\text { Язва, образованная под воздействием } \\
\text { желудочного сока. }\end{array}$ \\
\hline Частота встречаемости: & $10 \%$. \\
\hline
\end{tabular}




\begin{tabular}{|c|c|}
\hline Вопросы & Ответы \\
\hline Механизм развития пептических язв: & $\begin{array}{l}\text { Нарушение баланса между защитной } \\
\text { функцией слизистой оболочки желудка и } \\
\text { повреждающими факторами. }\end{array}$ \\
\hline $\begin{array}{l}\text { Защитные механизмы слизистой } \\
\text { оболочки: }\end{array}$ & $\begin{array}{ll}\text { - } & \text { Слизь; } \\
\text { - } & \text { Регенерация эпителия; } \\
\text { - } & \text { Кровоснабжение; } \\
\text { - } & \text { Антиоксиданты и др. }\end{array}$ \\
\hline $\begin{array}{l}\text { Факторы, повреждающие слизистую } \\
\text { оболочку: }\end{array}$ & $\begin{array}{l}\text { - } \text { Соляная кислота; } \\
\text { - Жёлчь; } \\
\text { - } \quad \text { Вредная пища и др. }\end{array}$ \\
\hline $\begin{array}{l}\text { Какая бактерия играет роль в развитии } \\
\text { язвы? }\end{array}$ & H. Pylori. \\
\hline Другие этиологические факторы: & $\begin{array}{l}\text { - } \text { Гиперацидность; } \\
\text { - НПВС; } \\
\text { - Нарушение кровообращения и др. }\end{array}$ \\
\hline Осложнения: & $\begin{array}{l}\text { Боль, кровотечение, перфорация, } \\
\text { обструкция. }\end{array}$ \\
\hline Частота осложнений: & $10-30 \%$. \\
\hline Вопросы и ответы по язвеннс & й болезни 12-перстной кишки \\
\hline Вопросы & Ответы \\
\hline $\begin{array}{l}\text { В каком возрасте встречается наиболее } \\
\text { часто? }\end{array}$ & В возрасте 30-60 лет. \\
\hline $\begin{array}{l}\text { Соотношение между мужчинами и } \\
\text { женщинами: }\end{array}$ & $3: 1$ \\
\hline Частая локализация язвы: & $\begin{array}{llll}\text { Луковица } & \text { 12-перстной } \\
\text { расстоянии } & 2 \mathrm{~cm} \text { от пиши (на } \\
\text { сфинктера). } & & & \end{array}$ \\
\hline Основная причина и механизм развития: & $\begin{array}{l}\text { H. Pylori и высокая желудочная } \\
\text { кислотность. }\end{array}$ \\
\hline Другие факторы риска: & $\begin{array}{l}\text { Мужской пол, табакокурение, аспирин и } \\
\text { другие НПВС, уремия, гастринома, травмы, } \\
\text { ожоги и др. }\end{array}$ \\
\hline Жалобы: & $\begin{array}{l}\text { Боли в эпигастральной и правой } \\
\text { подрёберной области, тошнота, рвота, } \\
\text { кровотечение. }\end{array}$ \\
\hline
\end{tabular}




\begin{tabular}{|c|c|}
\hline Объективные признаки: & $\begin{array}{l}\text { Боли в эпигастральной и правой } \\
\text { подрёберной области, кровавая рвота, } \\
\text { мелена, гематохезия. }\end{array}$ \\
\hline Характерный клинический признак: & $\begin{array}{l}\text { Ночные боли, или боли, прекращающиеся } \\
\text { после приёма пищи. }\end{array}$ \\
\hline $\begin{array}{l}\text { С какими заболеваниями необходимо } \\
\text { дифференцировать? }\end{array}$ & $\begin{array}{l}\text { Острый холецистит, панкреатит, } \\
\text { заболевания, сопровождающиеся } \\
\text { желудочно-кишечными кровотечениями, } \\
\text { гастрит, инфаркт миокарда, язва желудка. }\end{array}$ \\
\hline Диагностика: & Эндоскопия. \\
\hline Принципы лечения: & $\begin{array}{l}\text { - Снижение кислотности желудка } \\
\text { (антисекреторная, антацидная терапия), } \\
\text { этиотропная терапия с целью } \\
\text { предотвращения рецидива } \\
\text { (антихеликобактерная терапия, отмена } \\
\text { НПВС и др.); } \\
\text { В основном, консервативное лечение, } \\
\text { по показаниям - хирургическое. }\end{array}$ \\
\hline $\begin{array}{l}\text { За какой промежуток времени } \\
\text { происходит заживление язвы? }\end{array}$ & В течение 2-4 недель. \\
\hline $\begin{array}{l}\text { Какие антисекреторные препараты } \\
\text { назначают? }\end{array}$ & $\begin{array}{l}\text { Ингибиторы протонной помпы и блокаторы } \\
\text { гистаминовых рецепторов. }\end{array}$ \\
\hline $\begin{array}{l}\text { По какой причине препаратами выбора } \\
\text { являются ингибиторы протонной помпы? }\end{array}$ & $\begin{array}{l}\text { Эти препараты также оказывают } \\
\text { антихеликобактерное воздействие. }\end{array}$ \\
\hline Показания к хирургическому лечению: & $\begin{array}{l}\text { - Осложнения (перфорация, стеноз, } \\
\text { массивное кровотечение); } \\
\text { - Неэффективность консервативного } \\
\text { лечения, повторяющиеся язвы. }\end{array}$ \\
\hline $\begin{array}{l}\text { Какой признак свидетельствует } \\
\text { возможности кровотечения из язвы? }\end{array}$ & $\begin{array}{l}\text { Наличие сосуда на дне язвы при } \\
\text { эндоскопии. }\end{array}$ \\
\hline
\end{tabular}

\section{Вопросы и ответы по язвенной болезни желудка}

\section{Boпросы Ответы}

В каком возрасте встречается наиболее В возрасте 40-70 лет. часто?

У кого встречается чаще? У мужчин. 


\begin{tabular}{|c|c|}
\hline Какие язвы встречаются наиболее часто? & $\begin{array}{l}\text { Дуоденальные язвы встречаются в } 2 \text { раза } \\
\text { чаще желудочных. }\end{array}$ \\
\hline Основной патомеханизм: & $\begin{array}{l}\text { Ослабление защитной функции слизистой } \\
\text { оболочки. }\end{array}$ \\
\hline Какое бывает желудочная кислотность? & $\begin{array}{l}\text { Желудочная кислотность } \\
\text { нормальной или пониженной. }\end{array}$ \\
\hline $\begin{array}{l}\text { При каких язвах желудка наблюдается } \\
\text { повышенная кислотность? }\end{array}$ & $\begin{array}{l}\text { При сочетании препилорических и } \\
\text { дуоденальных язвах. }\end{array}$ \\
\hline Факторы риска и причины: & $\begin{array}{l}\text { H. Pylori, табакокурение, алкоголь, НПВС, } \\
\text { травма, ожоги, стероиды, шок, пожилой } \\
\text { возраст. }\end{array}$ \\
\hline Частая локализация: & Малая кривизна (75\%). \\
\hline Характерные признаки: & $\begin{array}{l}\text { Эпигастральные боли, усиливающиеся } \\
\text { после приёма пищи. }\end{array}$ \\
\hline Диагностика: & Эндоскопия с биопсией. \\
\hline $\begin{array}{l}\text { С какой целью проводится биопсия язвы } \\
\text { желудка? }\end{array}$ & Для дифференциации с раком желудка. \\
\hline $\begin{array}{l}\text { С какой целью проводится повторная } \\
\text { эндоскопия спустя 4-6 недель после } \\
\text { начала заболевания? }\end{array}$ & $\begin{array}{l}\text { Для подтверждения заживления язвы и } \\
\text { исключения рака желудка. }\end{array}$ \\
\hline Лечение: & $\begin{array}{l}\text { Как и при дуоденальных язвах } \\
\text { (антисекреторная и антихеликобактерная } \\
\text { терапия). }\end{array}$ \\
\hline Показания к операции: & $\begin{array}{l}\text { - Осложнения (перфорация, стеноз, } \\
\text { массивное кровотечение); } \\
\text { - Неэффективность консервативного } \\
\text { лечения; } \\
\text { - Повторяющиеся язвы; } \\
\text { - Невозможность дифференциации с } \\
\text { раком желудка. }\end{array}$ \\
\hline Стандартная операция при язве желудка: & $\begin{array}{l}\text { Дистальная резекция желудка вместе с } \\
\text { язвой. }\end{array}$ \\
\hline
\end{tabular}




\section{ОСЛОЖНЕНИЯ ЯЗВЕННОЙ БОЛЕЗНИ}

- В клиническом течении язвенной болезни желудка и двенадцатиперстной кишки наблюдаются различные осложнения, которые встречаются у 15-30\% больных. Наиболее частыми осложнениями являются: кровотечение, перфорация и обструкция.

- Язвы 12-перстной кишки, как обычно, не малигнизируются. Считается, что язвы желудка также не малигнизируются, обнаруженные случаи рака являются изъязвлённой формой аденокарциномы (3\%).

- Язвенное гастродуоденальное кровотечение является наиболее частым осложнением (20\%) язвенной болезни, составляет 50\% кровотечений из верхних отделов желудочнокишечного тракта и является причиной смерти у $40 \%$ больных.

○ Глубокие, каллёзные язвы и язвы, расположенные на задней стенке желудка, более склонны к кровотечению.

○ Умеренные кровотечения не проявляются какими-либо серьёзными симптомами и выявляются, в основном, при исследовании кала на скрытое кровотечение. Массивное кровотечение сопровождается острой анемией и геморрагическим шоком.

○ Большинство массивных кровотечений поддаются консервативному лечению, однако часть склонна к продолжению или повторению. Несвоевременное вмешательство может привести к летальному исходу.

○ Эндоскопическое исследование подтверждает диагноз, определяет прогноз заболевания (классификация по Форресту) и даёт возможность проведения лечебных мероприятий.

○ Степень тяжести определяется по гемодинамическим и гемоконцентрационным показателям.

○ С лечебной целью первым делом проводятся поддерживающие, медикаментозные и эндоскопические гемостатические мероприятия. Продолжающиеся и рецидивирующие кровотечения требуют неотложного хирургического вмешательства (лигирование сосуда, резекция и др.)

- Перфорация - сквозной дефект в зоне язвенного кратера в результате деструкции стенки желудка или двенадцатиперстной кишки с поступлением содержимого в свободную брюшную полость.

○ В большинстве случаев у больных развивается диффузный перитонит. Иногда процесс ограничивается с образованием абсцесса брюшной полости. У ряда больных формируются межорганные свищи.

○ Заболевание, как правило, начинается острыми болями, признаками перитонита, к которым спустя несколько часов присоединяются и признаки сепсиса.

○ Без проведения лечебных мероприятий повышается вероятность летального исхода по причине диффузного перитонита.

○ Для подтверждения диагноза проводится КТ.

○ К диагностическим критериям относятся внезапно начавшаяся боль, признаки перитонита и сепсиса, наличие свободного газа в брюшной полости или экстравазация контрастного вещества на КТ. 
○ Лечение - хирургическое. Основным методом оперативного лечения является ушивание перфоративного отверстия. В отдельных случаях можно выполнить иссечение язвы и резекцию желудка.

- Пилоростеноз - воспалительно-фибротическое сужение начального отдела двенадцатиперстной кишки или пилорического отдела желудка, которое происходит в результате рубцевания хронической язвы.

○ В начальной (компенсаторной) стадии нет выраженных клинических симптомов. Сужение определяется в процессе радиологического или эндоскопического исследования.

○ По мере прогрессирования сужения возникают гипертрофия и расширение желудка, затруднение прохождения твёрдой пищи (стадия субкомпенсации), периодически наблюдается рвота.

○ В стадии декомпенсации происходит атония, острая непроходимость и возникают осложнения: рвота непереваренной пищи, дегидратация, нарушение электролитного обмена, похудание и др.

○ Диагноз ставят на основании клинической картины, данных эндоскопических и радиологических (КТ) методов исследования, а также биопсии.

О К диагностическим критериям относятся сужение и деформация пилорического сфинктера, задержка контрастного вещества, расширение желудка.

○ Лечение предусматривает проведение следующих мероприятий: коррекция водноэлектролитных и белковых нарушений, консервативные методы с целью восстановления проходимости, эндоскопическая дилатация. При неэффективности данных мероприятий возникает необходимость в хирургическом лечении (резекция, ваготомия + дренирование).

\section{Вопросы и ответы по осложнениям язвенной болезни}

\begin{tabular}{|c|c|}
\hline Boпросы & Ответы \\
\hline Что такое перфорация язвы? & $\begin{array}{l}\text { Сквозной дефект стенки желудка или 12- } \\
\text { перстной кишки в зоне язвенного кратера. }\end{array}$ \\
\hline Клинические признаки: & $\begin{array}{l}\text { Внезапно возникшая острая боль в животе } \\
\text { и развитие перитонита. }\end{array}$ \\
\hline $\begin{array}{l}\text { Чем характеризуется перфорация язвы } \\
\text { задней стенке 12-перстной кишки? }\end{array}$ & $\begin{array}{l}\text { Острый панкреатит, кровотечение из } \\
\text { гастродуоденальной артерии. }\end{array}$ \\
\hline $\begin{array}{l}\text { Чем характеризуется перфорация язвы } \\
\text { передней стенки 12-перстной кишки? }\end{array}$ & $\begin{array}{l}\text { Наличие свободного газа в брюшной } \\
\text { полости. }\end{array}$ \\
\hline $\begin{array}{l}\text { С какими заболеваниями следует } \\
\text { дифференцировать перфоративную язву? }\end{array}$ & $\begin{array}{l}\text { Острый аппендицит, острый холецистит, } \\
\text { острый панкреатит, мезентериальный } \\
\text { тромбоз, дивертикулит толстой кишки, } \\
\text { инфаркт миокарда, перфорация других } \\
\text { полых органов. }\end{array}$ \\
\hline
\end{tabular}




\begin{tabular}{|c|c|}
\hline Вопросы & Ответы \\
\hline $\begin{array}{l}\text { Наиболее характерные лабораторные } \\
\text { признаки: }\end{array}$ & $\begin{array}{l}\text { Лейкоцитоз, амилаземия, повышение } \\
\text { концентрации С-реактивного белка. }\end{array}$ \\
\hline Диагностика: & $\begin{array}{l}\text { Наличие свободного газа или } \\
\text { экстравазация контраста за пределы на } \\
\text { рентгенографии или КТ. }\end{array}$ \\
\hline Лечение: & $\begin{array}{l}\text { Срочная операция с кратковременной } \\
\text { предоперационной } \\
\text { (назогастральный зонд, мочевой катетер, } \\
\text { в/в инфузия, антибиотикотерапия). }\end{array}$ \\
\hline $\begin{array}{l}\text { Методы хирургического лечения } \\
\text { перфоративной дуоденальной язвы: }\end{array}$ & $\begin{array}{l}\text { - Ушивание перфоративного отверстия с } \\
\text { оментопластикой; } \\
\text { - Иссечение язвы, пилоропластика и } \\
\text { трункальная ваготомия; } \\
\text { - Выключение 12-перстной кишки из } \\
\text { пищеварения. }\end{array}$ \\
\hline $\begin{array}{l}\text { Варианты оперативного лечения } \\
\text { перфоративной язвы желудка? }\end{array}$ & $\begin{array}{l}\text { - При наличии перитонита - иссечение } \\
\text { перфоративной язвы, ушивание с } \\
\text { оментопластикой, биопсия. } \\
\text { - При отсутствии перитонита - резекция } \\
\text { желудка вместе с язвой. }\end{array}$ \\
\hline $\begin{array}{l}\text { О чём можно думать при сочетании } \\
\text { перфорации с кровотечением? }\end{array}$ & $\begin{array}{l}\text { Наличие зеркальных (целующихся) язв: } \\
\text { кровотечение из задней стенки, } \\
\text { перфорация передней стенки. }\end{array}$ \\
\hline $\begin{array}{l}\text { При какой локализации дуоденальной } \\
\text { язвы развивается картина панкреатита? }\end{array}$ & $\begin{array}{l}\text { При пенетрации язвы задней стенки 12- } \\
\text { перстной кишки в поджелудочную } \\
\text { железу (сильные боли опоясывающего } \\
\text { характера, повышение концентрации } \\
\text { амилазы). }\end{array}$ \\
\hline
\end{tabular}




\section{НОВООБРАЗОВАНИЯ ЖЕЛУДКА}

- Аденокарцинома - развивается из железистого эпителия слизистой оболочки желудка и является наиболее часто встречаемой гистологической формой рака.

○ Этиология до конца не изучена. К факторам риска относятся характер питания, радиация, дефицит витаминов А и С, наследственно-генетические факторы, мужской пол и некоторые предраковые заболевания (H. Pylori ассоциированный гастрит, резецированный желудок, аденоматозные полипы).

○ На ранней стадии заболевания опухоль распространяется лишь на слизистый слой желудка и, как обычно, протекает бессимптомно. Обнаруживается в процессе случайных или профилактических исследований.

- При прогрессировании заболевания опухоль распространяется на все слои желудка, окружающие и отдалённый органы, лимфатические узлы, тем самым появляются и клинические признаки.

О К клиническим признакам относятся похудание, боль, кровотечение, анемия, потеря аппетита.

○ Для диагностики используется эндоскопическое исследование (обнаружение изъязвлённой опухоли твёрдой консистенции, предрасположенной к кровотечению) с биопсией (обнаружение клеток аденокарциномы). Для определения локализации, распространённости опухоли, степени её инвазии в окружающие ткани, а также возможности оперативного лечения заболевания проводят КТ, эндоскопическое УЗИ, ПЭТ и диагностическую лапароскопию.

- При резектабельных стадиях опухоли (ранняя или поздняя резектабельная) проводят радикальную операцию (тотальная или субтотальная гастрэктомия и лимфодиссекция) с сочетанием химиорадиотерапии (тримодальная терапия) в периоперативном периоде. В поздних нерезектабельных стадиях показаны паллиативные операции в сочетании с химиорадиотерапией.

- Лимфома желудка - это лимфопролиферативное заболевание метастатического характера, развивающаяся из лимфатической ткани слизистой оболочки желудка (MALT-лимфома, диффузная B-клеточная лимфома).

○ Занимает второе место по злокачественности после аденокарцином.

○ При MALT-лимфомах высока роль инфекции H.Pylori.

○ Клиническая картина похожа на клинику аденокарциномы желудка.

○ Диагноз ставится на основе данных эндоскопии и биопсии. С целью дифференциации со вторичными лимфомами проводят иммуногистохимический анализ, общий анализ крови, биопсию костного мозга.

О Лечение, в основном, консервативное (антихеликобактерная терапия, химиорадиотерапия). Хирургическое лечение проводится по показаниям.

- Гастроинтестинальные стромальные опухоли - наиболее часто встречающиеся опухоли, исходящие из субэпителиальных тканей (к опухолям, исходящим из стромальной ткани, относятся лейомиома, лейомиосаркома, липома, липосаркома, шваннома, десмоидные опухоли и др.) 
○ Небольшие опухоли протекают как доброкачественные новообразования. Опухоли больших размеров имеют злокачественное течение.

○ Диагностика основывается на данных эндоскопии, результатах биопсии, выявлении антигена CD-117 и генетических маркеров мутации C-KIT при иммуногистохимических исследованиях.

○ Лечение направлено на радикальное удаление опухоли с последующей химиотерапией.

- Болезнь Менетрие - разновидность гипертрофического гастрита.

○ Характеризуется гипертрофией складок желудка, избыточной секрецией желудочного сока, потерей организмом белков и анемией.

○ Диагноз ставится на основании данных эндоскопии и результатов биопсии.

○ Лечение проводится с назначением антисекреторной и антихеликобактерной терапии. Хирургическое лечение проводится по показаниям.

- Карциноидные опухоли развиваются из энтерохромаффинных клеток.

○ Характеризуются разрастанием и развитием осложнений, карциноидного синдрома.

○ Диагноз ставится на основании данных эндоскопии и результатов биопсии.

○ Лечение - радикальное удаление.

- Полипы - это неопластические и неопухолевые образования, развивающиеся из эпителия слизистой оболочки. Неопластические полипы могут переродиться в злокачественные.

○ Диагноз ставится на основании данных эндоскопии и результатов биопсии.

○ Стандартное лечение - эндоскопическая полипэктомия.

\section{Вопросы и ответы по раку желудка}

\begin{tabular}{|c|c|}
\hline Вопросы & Ответы \\
\hline Частота встречаемости рака желудка: & $\begin{array}{l}\text { В общей структуре злокачественных } \\
\text { опухолей желудочно-кишечного тракта } \\
\text { занимает второе место. }\end{array}$ \\
\hline Факторы риска: & $\begin{array}{l}\text { Образ жизни: } \\
\text { - Питание (употребление копчённых и } \\
\text { консервированныхпродуктов, нитратов } \\
\text { и нитритов); } \\
\text { - Токсины - афлатоксины, алкоголь, } \\
\text { табак; } \\
\text { - Радиация; } \\
\text { - Авитаминоз (А, С). } \\
\text { Генетические факторы: } \\
\text { - Групповая принадлежность крови (І } \\
\text { группа); } \\
\text { - Семейный анамнез; }\end{array}$ \\
\hline
\end{tabular}




\begin{tabular}{|c|c|}
\hline Вопросы & Ответы \\
\hline & $\begin{array}{l}\text { - Мужской пол. } \\
\text { Предраковые заболевания: } \\
\text { • } \quad \text { Н. Руlori ассоциированный гастрит; } \\
\text { - Резецированный желудок; } \\
\text { - Хронический атрофический гастрит; } \\
\text { - Хронический } \\
\quad \text { гастрит; } \\
\text { - } \text { Аденомертрофический } \\
\end{array}$ \\
\hline Возрастная категория заболеваемости: & Возраст старше 60 лет. \\
\hline $\begin{array}{l}\text { Соотношение заболеваемости среди } \\
\text { мужчин и женщин: }\end{array}$ & Составляет 3:2. \\
\hline $\begin{array}{l}\text { Какая группа крови связана с раком } \\
\text { желудка? }\end{array}$ & I (A) Группа. \\
\hline Клинические признаки: & $\begin{array}{l}\text { - В ранней стадии протекает } \\
\text { бессимптомно; } \\
\text { - Дискомфорт в эпигастральной области; } \\
\text { - Анорексия; } \\
\text { - Похудание; } \\
\text { - Тошнота, рвота; } \\
\text { - Мелена. }\end{array}$ \\
\hline Наиболее часто встречаемы признаки: & Похудание. \\
\hline Объективные признаки: & $\begin{array}{l}\text { Анемия, мелены, наличие пальпируемого } \\
\text { образования в эпигастральной области, } \\
\text { гепатомегалия, кровавая рвота, метастазы } \\
\text { Вирхова и/или Крукенберга, увеличенные } \\
\text { подмышечные лимфоузлы. }\end{array}$ \\
\hline Что такое метастазы Вирхова? & $\begin{array}{l}\text { Метастазы рака желудка в надключичные } \\
\text { лимфоузлы. }\end{array}$ \\
\hline Что такое метастазы Крукенберга? & Метастазы рака желудка в яичники. \\
\hline Лабораторные признаки: & $\begin{array}{l}\text { У } 30 \% \text { пациентов } \text { повышается } \\
\text { концентрация онкомаркеров } \\
\text { (CEA или СА }\end{array}$ \\
\hline Верификация диагноза: & Гастроскопия с биопсией. \\
\hline $\begin{array}{l}\text { Какие методы исследования необходимы } \\
\text { для определения стадии рака? }\end{array}$ & $\begin{array}{l}\text { Эндоскопическое УЗИ, КТ грудной клетки и } \\
\text { брюшной полости, по показания ПЭТ. }\end{array}$ \\
\hline
\end{tabular}




\begin{tabular}{|c|c|}
\hline Вопросы & Ответы \\
\hline Гистологическая структура: & Аденокарцинома. \\
\hline Гистологические типы рака желудка: & $\begin{array}{l}\text { - Интестинальный (железистый); } \\
\text { - Диффузный. }\end{array}$ \\
\hline Макроскопические формы: & $\begin{array}{l}\text { - } \text { Язвенная форма (25\%); } \\
\text { - } \text { Полиповидная форма (25\%); } \\
\text { - } \text { Ранняя поверхностная форма (10-30\%); } \\
\text { - Диффузно-инфильтративная } \\
\text { (10\%); } \\
\text { - Поздний рак (35\%). }\end{array}$ \\
\hline $\begin{array}{l}\text { В каком отделе чаще всего локализуется } \\
\text { рак желудка? }\end{array}$ & На малой кривизне (70\%). \\
\hline $\begin{array}{l}\text { Какая морфологическая форма рака } \\
\text { желудка называется «кожаной } \\
\text { коробкой»? }\end{array}$ & $\begin{array}{l}\text { Диффузно-инфильтративная форма - } \\
\text { поражает все слои желудка, } \\
\text { характеризуется утолщением стенки. }\end{array}$ \\
\hline Радикальные методы лечения: & Резекция и лимфодиссекция. \\
\hline $\begin{array}{l}\text { Какая операция проводится при } \\
\text { локализации рака в антральном отделе? }\end{array}$ & $\begin{array}{l}\text { Дистальная субтотальная резекция } \\
\text { желудка. }\end{array}$ \\
\hline $\begin{array}{l}\text { Какая операция проводится при } \\
\text { локализации рака в теле желудка? }\end{array}$ & Тотальная гастрэктомия. \\
\hline $\begin{array}{l}\text { Какая операция проводится при } \\
\text { локализации рака в проксимальном } \\
\text { отделе желудка? }\end{array}$ & Тотальная гастрэктомия. \\
\hline $\begin{array}{l}\text { Показания к спленэктомии при раке } \\
\text { желудка: }\end{array}$ & $\begin{array}{l}\text { Распространение рака на селезёнку, ворота } \\
\text { селезёнки и лимфатические узлы. }\end{array}$ \\
\hline $\begin{array}{l}\text { Удельный вес нерезектабельности } \\
\text { опухоли: }\end{array}$ & Составляет 10-15\%. \\
\hline $\begin{array}{l}\text { Роль послеоперационной адъювантной } \\
\text { химиотерапии: }\end{array}$ & Пока остаётся недоказанной. \\
\hline $\begin{array}{l}\text { 5-летняя выживаемость при раке } \\
\text { желудка: }\end{array}$ & $\begin{array}{l}\text { 5-летняя выживаемость составляет } 12 \% . \\
\text { Прогноз прямо коррелирует со стадией } \\
\text { рака желудка. }\end{array}$ \\
\hline
\end{tabular}




\begin{tabular}{|c|c|}
\hline Вопросы & Ответы \\
\hline Что такое лимфома желудка? & $\begin{array}{l}\text { Лимфопролиферативное заболевание } \\
\text { локального или метастатического } \\
\text { характера, иазвивающаяся из й } \\
\text { лимфатической ткани слизистой оболочки } \\
\text { желудка }\end{array}$ \\
\hline Частота встречаемости: & $\begin{array}{l}\text { Занимает 2-ое место } \quad \text { среди } \\
\text { злокачественных опухолей желудка после } \\
\text { аденокарциномы и составляет 2-5\%. }\end{array}$ \\
\hline Клинические формы: & $\begin{array}{l}\text { - Первичная лимфома; } \\
\text { - Вторичная лимфома. }\end{array}$ \\
\hline Причины и факторы риска: & $\begin{array}{l}\text { - Инфицирование желудка H.Pylori; } \\
\text { - Аутоимунные процессы; } \\
\text { - Вирусы герпеса, Эпштейна-Барр; } \\
\text { - } \text { Энтеропатии. }\end{array}$ \\
\hline Особенности клинического течения: & $\begin{array}{l}\text { Склонна к быстрому росту и } \\
\text { метастазированию, возникновению } \\
\text { осложнений. }\end{array}$ \\
\hline Клинические признаки: & $\begin{array}{l}\text { Эпигастральная боль, похудание, потеря } \\
\text { аппетита, тошнота, рвота, скрытые } \\
\text { кровотечения. }\end{array}$ \\
\hline У каких больных можно заподозрить? & $\begin{array}{l}\text { При наличии диффузного утолщения } \\
\text { стенки желудка. }\end{array}$ \\
\hline $\begin{array}{l}\text { Какие методы исследования необходимы } \\
\text { для диагностики? }\end{array}$ & Гастроскопия с биопсией. \\
\hline Методы лечения: & $\begin{array}{l}\text { - Консервативное лечение; } \\
\text { - Химиорадиотерапия; } \\
\text { - Хирургическая операция. }\end{array}$ \\
\hline Показания к операции: & $\begin{array}{l}\text { Опухоли, не } \\
\begin{array}{l}\text { химиорадиотерапии, } \\
\text { осложнений }\end{array} \\
\text { непроходимость, перфорация). }\end{array}$ \\
\hline
\end{tabular}




\begin{tabular}{|c|c|}
\hline Вопросы & Ответы \\
\hline $\begin{array}{l}\text { Что представляют собой полипы } \\
\text { желудка? }\end{array}$ & $\begin{array}{l}\text { Неопластические и неопухолевые } \\
\text { образования, развивающиеся из эпителия } \\
\text { слизистой оболочки }\end{array}$ \\
\hline Частота встречаемости: & 2-6\% общей популяции. \\
\hline Клинические формы: & $\begin{array}{l}\text { - Гиперпластическая; } \\
\text { - Аденоматозная; } \\
\text { - Гландулярная; } \\
\text { - Гамартоматозная. }\end{array}$ \\
\hline Осложнения: & Кровотечение, малигнизация. \\
\hline Клинические признаки: & $\begin{array}{l}\text { В большинстве случаев протекает } \\
\text { бессимптомно. Могут } \\
\text { кровотечение, гастрит, язва. }\end{array}$ \\
\hline $\begin{array}{l}\text { Какие методы исследования необходимы } \\
\text { для диагностики? }\end{array}$ & Эндоскопия с биопсией. \\
\hline \multicolumn{2}{|c|}{ Вопросы и ответы по болезни Менетрие } \\
\hline Вопросы & Ответы \\
\hline Что такое болезнь Менетрие? & $\begin{array}{l}\text { Является разновидностью } \\
\text { гиперпластического гастрита. }\end{array}$ \\
\hline Причины и факторы риска: & $\begin{array}{l}\text { Этиология неизвестна. Предполагается } \\
\text { роль инфекции H.Pylori. }\end{array}$ \\
\hline Осложнения: & Кровотечение. \\
\hline Клинические признаки: & $\begin{array}{l}\text { Анемия, гипопротеинемия, похудание, } \\
\text { отёки, боль. }\end{array}$ \\
\hline $\begin{array}{l}\text { Какие методы исследования необходимы } \\
\text { для диагностики? }\end{array}$ & Эндоскопия с биопсией. \\
\hline Диагностические критерии: & $\begin{array}{l}\text { При гастроскопии обнаруживают } \\
\text { гипертрофию складок слизистой оболочки. } \\
\text { При биопсии выявляют гиперплазию сли- } \\
\text { зистой оболочки и кистозную } \\
\text { трансформацию. }\end{array}$ \\
\hline Методы лечения: & $\begin{array}{l}\text { - Консервативный; } \\
\text { - Хирургический. }\end{array}$ \\
\hline
\end{tabular}




\section{ДРУГИЕ ЗАБОЛЕВАНИЯ ЖЕЛУДКА}

\section{Вопросы и ответы по завороту желудка}

\begin{tabular}{|ll}
\multicolumn{1}{|c}{ Вопросы } & \multicolumn{1}{c}{ Ответы } \\
\hline Что такое заворот желудка? & Перекрут желудка вокруг своей оси. \\
\hline Клинические признаки: & Триада Борхарда: \\
& - Эпигастральное вздутие; \\
& - Невозможность внести зонд в желудок; \\
& - Позывы на рвоту. \\
\hline
\end{tabular}

\section{Вопросы и ответы по безоарам желудка}

\begin{tabular}{|c|c|}
\hline Вопросы & Ответы \\
\hline Что такое безоар желудка? & $\begin{array}{l}\text { Инородные тела различного состава, } \\
\text { образованные в желудке. }\end{array}$ \\
\hline Клинические формы: & $\begin{array}{l}\text { - Трихобезоар; } \\
\text { - Фитобезоар; } \\
\text { - Кандида и др. }\end{array}$ \\
\hline Причины и факторы риска: & $\begin{array}{l}\text { Покусывание волос, гастростаз, после } \\
\text { ваготомии, избыточное поедание } \\
\text { цитрусовых. }\end{array}$ \\
\hline Осложнения: & Непроходимость, кровотечение. \\
\hline Клинические признаки: & $\begin{array}{l}\text { Боль, обструкция, кровотечение и } \\
\text { перфорация. }\end{array}$ \\
\hline У каких пациентов можно заподозрить? & У пациентов с инородным телом в желудке. \\
\hline Диагностика: & Эндоскопия. \\
\hline Методы лечения: & Эндоскопическое, хирургическое. \\
\hline Показания к операции: & Кровотечение, перфорация, обструкция. \\
\hline
\end{tabular}

\section{Вопросы и ответы по дивертикулу желудка}

\section{Вопросы Ответы}

Что такое дивертикул желудка?

Клинические формы:
Выпячивание наружу всех слоёв или только слизистой оболочки стенки желудка.

- Пульсионный тип; 


\begin{tabular}{|c|c|}
\hline Вопросы & Ответы \\
\hline & - Тракционный тип. \\
\hline Особенности клинического течения: & $\begin{array}{l}\text { В большинстве случаев - бессимптомное; } \\
\text { редко наблюдается воспаление и } \\
\text { кровотечение. }\end{array}$ \\
\hline Осложнение: & Перфорация, кровотечение. \\
\hline Диагностика: & $\begin{array}{l}\text { Эндоскопическое и рентгенологическое } \\
\text { исследование. }\end{array}$ \\
\hline Методы лечения: & $\begin{array}{l}\text { - Асимптоматическое течение - } \\
\text { наблюдение; } \\
\text { - Симптоматическое течение - эксцизия. }\end{array}$ \\
\hline
\end{tabular}




\section{ПОСТГАСТРОРЕЗЕКЦИОННЫЕ СИНДРОМЫ}

- Патологические синдромы, развивающиеся после операций на желудке, делятся на 2 группы: синдромы, обусловленные морфологическими изменениями (стеноз анастомоза, язва анастомоза, синдром приводящей и отводящей петли, рефслюксгастрит, желчекаменная болезнь), и синдромы, вызываемые послеоперационными функциональными нарушениями (демпинг-синдром, диарея, гастростаз, мальабсорбция).

- Язвы анастомоза - это пептические язвы, образующиеся в области желудочнокишечного анастомоза.

○ Могут быть бессимптомными, симптоматическими (боль) и сопровождающимися осложнениями (кровотечение).

○ Наиболее информативным методом диагностики является эндоскопия. С целью определения причины проводят КТ, определение концентрации гастрина в крови, определение эффективности ваготомии.

○ Лечение направлено на проведение противоязвенной терапии, устранение причины и предотвращение осложнений.

- Синдром приводящей и отводящей петли - механическая непроходимость в приводящей или отводящей петле желудочно-кишечного анастомоза, которая характеризуется различными клиническими признаками и осложнениями.

○ Диагноз подтверждается на основании данных КТ и эндоскопии.

○ Для синдрома приводящей петли характерно расширение 12-перстной кишки, а для синдрома отводящей петли - расширение культи желудка.

○ Наиболее оптимальным способом лечения является хирургический: реконструкция анастомоза, анастомоз по Брауну (при синдроме приводящей петли), преобразование Бильрот II на анастомоз с выключенной по Ру петлёй тощей кишки и др.

- Рефлюкс-гастрит развивается вследствие заброса в культю желудка жёлчи и панкреатического сока, находящихся в дуоденальном содержимом.

○ Проявляется болью, изжогой; в большинстве случаев спонтанно проходит, редко характеризуется продолжительным течением.

○ Для диагностики применяют эндоскопическое исследования.

- Консервативное лечение включает диетотерапию и приём лекарственных препаратов (антациды, жёлчные кислоты и др.) Хирургическое лечение показано при выраженном дуоденогастральном рефлюксе. Выполняют реконструктивную операцию с формированием гастроеюнального анастомоза по Ру.

- Желчнокаменная болезнь - развивается у 20-30\% пациентов после операций на желудке.

○ Клиническая картина, диагностика и методы лечения характерны для холецистолитиаза (УЗИ, лапароскопическая холецистэктомия).

- Демпинг-синдром - симптомокомплекс нарушения гемодинамики и нейровегетативных расстройств в ответ на быструю эвакуацию желудочного содержимого в тонкую кишку после операций на желудке. 
○ В большинстве случаев проходит спонтанно, редко переходит в тяжёлую форму.

○ Диагноз основывается на характерных клинических и анамнестических данных. С целью исключения других патологий проводят эндоскопическое исследование, функциональные и гормональные исследования.

- Консервативное лечение применяют при легкой и средней степенях тяжести демпинг-синдрома (диетотерапия, медикаментозная терапия). Хирургическое лечение показано при тяжёлом демпинг-синдроме и безуспешности медикаментозной терапии (гастроеюнальный анастомоз на выключенной по Ру петле тощей кишки).

- Диарея - состояние, возникающее после операций на желудке, при котором наблюдается эпизодическая водянистая дефекация.

○ Диагноз ставится на основании клинической картины, однако необходимо исключить и другие патологии (секреторная, осмотическая, воспалительная диареи, гипертмоторика).

○ В большинстве случаев купируется консервативными мерами, в редких случаях прибегают к хирургической операции (антиперистальтический гастроэнтероанастомоз по Ру).

- Гастростаз - застой в желудке в результате нарушения эвакуации.

○ Характерным признаком является невозможность эвакуации желудочного сока или малого количества пищи (выделение более 1,5 л жидкости из назогастрального зонда, задержка контрастного вещества в желудке на 2-3 часа, расширение желудка).

○ С целью определения этиологической причины проводят эндоскопию и контрастную КТ.

○ Лечение механического застоя, как правило, хирургическое. Функциональные патологии поддаются консервативному лечению, хирургическая операция проводится по показаниям.

- Синдром мальабсорбции - развивается вследствие дефицита витаминов $\mathrm{B}_{12}, \mathrm{D}$ и железа.

○ Диагноз ставится в соответствии с показателями крови.

○ Лечение: заместительная терапия с учётом дефицита указанных элементов.

\section{Вопросы и ответы по постгастрорезекционным синдромам}

\begin{tabular}{|ll|}
\hline \multicolumn{2}{|c|}{ Вопросы } \\
\begin{tabular}{|l} 
В чём заключается суть операции \\
оментопластики?
\end{tabular} & $\begin{array}{l}\text { Перфоративное отверстие тампонируется } \\
\text { частью большого сальника, который } \\
\text { фиксируется отдельными швами к стенке } \\
\text { желудка. }\end{array}$ \\
\hline $\begin{array}{l}\text { Что такое стволовая (трункальная) } \\
\text { ваготомия? }\end{array}$ & $\begin{array}{l}\text { Пересечение ствола блуждающего нерва } \\
\text { на уровне гастроэзофагеального }\end{array}$ \\
\hline
\end{tabular}




\begin{tabular}{|c|c|}
\hline Вопросы & Ответы \\
\hline & $\begin{array}{l}\text { соединения, что способствует подавлению } \\
\text { секреторной активности желудка. }\end{array}$ \\
\hline $\begin{array}{l}\text { С какой операцией обычно сочетают } \\
\text { стволовую ваготомию? }\end{array}$ & $\begin{array}{l}\text { С дренирующими желудок операциями, } \\
\text { различными вариантами пилоропластики, } \\
\text { антрумэктомией, гастроеюностомией). }\end{array}$ \\
\hline $\begin{array}{l}\text { В чём заключается преимущество } \\
\text { селективной проксимальной ваготомии? }\end{array}$ & $\begin{array}{l}\text { В связи с сохранением дистальных } \\
\text { желудочных ветвей блуждающего нерва } \\
\text { моторная функция желудка не нарушается, } \\
\text { поэтому не возникает необходимости в } \\
\text { пилоропластике. }\end{array}$ \\
\hline $\begin{array}{l}\text { В чём заключается суть методики } \\
\text { резекции желудка Бильрот-І? }\end{array}$ & $\begin{array}{l}\text { После резекции желудка формируется } \\
\text { гастрдуоденальный анастомоз. }\end{array}$ \\
\hline $\begin{array}{l}\text { В чём заключается суть методики } \\
\text { резекции желудка по Бильрот-ІІ? }\end{array}$ & $\begin{array}{l}\text { После резекции желудка формируется } \\
\text { гастроеюнальный анастомоз. }\end{array}$ \\
\hline $\begin{array}{l}\text { Что такое операция резекции желудка по } \\
\text { Ру? }\end{array}$ & $\begin{array}{l}\text { После резекции желудка формируется } \\
\text { анастомоз на выключенной по Ру петле } \\
\text { тощей кишки. }\end{array}$ \\
\hline Что такое приём Кохера? & $\begin{array}{l}\text { Для визуализации задней стенки } \\
\text { двенадцатиперстной кишки рассекают } \\
\text { задний листок париетальной брюшины по } \\
\text { pravomu латеральному каналу. }\end{array}$ \\
\hline $\begin{array}{l}\text { После какой операции часто возникает } \\
\text { рецидив язвы? }\end{array}$ & После селективной ваготомии. \\
\hline $\begin{array}{l}\text { После какой операции уровень рецидива } \\
\text { язвы наименьший? }\end{array}$ & $\begin{array}{l}\text { После антрумэктомии и стволовой } \\
\text { ваготомии. }\end{array}$ \\
\hline
\end{tabular}




\section{ХИРУРГИЧЕСКИЕ ЗАБОЛЕВАНИЯ ДВЕНАДЦАТИПЕРСТНОЙ КИШКИ}

- Дивертикулы - представляют собой мешковидное расширение стенки двенадцатиперстной кишки.

○ Неосложнённые формы протекают бессимптомно. Частыми осложнениями являются кровотечение, перфорация, панкреатит и др.

○ Диагноз ставится на основании эндоскопических и радиологических методов исследований.

○ При бессимптомном течение показано наблюдение. При симптоматическом течении проводится консервативное лечение; при развитии осложнений возникает необходимость в хирургическом лечении: удаление дивертикул открытым или эндоскопическим способами.

- Опухоли 12-перстной кишки встречаются редко и склонны к росту и осложнениям.

○ Диагноз ставится на основании эндоскопических и патогистологических методов исследований.

○ За исключением эктопии слизистой желудка, все другие опухоли 12-перстной кишки должны быть удалены хирургическим путём. При нерезектабельных опухолях выполняют паллиативные операции или применяют химя-радиотерапию.

- Синдром верхней брыжеечной артерии (артериомезентериальная непроходимость) обусловлен сдавлением нижней горизонтальной части 12-перстной кишки верхней брыжеечной артерией, отходящей от аорты под острым углом (механический дуоденостаз).

○ Клиническая картина характеризуется резкими болями в верхней части живота и обильной рвотой с примесью жёлчи.

○ В диагностике применяют эндоскопию, рентгеноскопию (рентгенографию) и КТангиографию. Визуальными признаками являются расширение двенадцатиперстной кишки выше места сдавления, отсутствие объёмных образований и отхождение верхней брыжеечной артерии от аорты под углом $25^{\circ}$.

О Лечение, как правило, хирургическое (рассечение связки Трейца, дуоденоеюностомия).

\section{Вопросы и ответы по дивертикулам 12-перстной кишки}

\begin{tabular}{|ll|}
\multicolumn{1}{|c|}{ Вопросы } & \multicolumn{1}{c|}{ Ответы } \\
\hline $\begin{array}{l}\text { Что такое дивертикул 12-перстной } \\
\text { кишки? }\end{array}$ & $\begin{array}{l}\text { Мешковидное выпячивание стенки } \\
\text { двенадцатиперстной кишки. }\end{array}$ \\
\hline Частота встречаемости: & Составляет 5-20\%. \\
\hline Клинические формы: & $\bullet$ Пульсионный; \\
& $\bullet$ Тракционный. \\
\hline Осложнения: & $\bullet$ Воспаление (дивертикулит); \\
& - Кровотечение; \\
\hline
\end{tabular}




\begin{tabular}{|c|c|}
\hline Вопросы & Ответы \\
\hline & $\begin{array}{l}\text { - Перфорация; } \\
\text { - Обструкция; } \\
\text { - Кишечная непроходимость; } \\
\text { - } \text { Панкреатит. }\end{array}$ \\
\hline Клинические признаки: & $\begin{array}{l}\text { - Асимптоматическое течение - нет } \\
\text { клинических признаков; } \\
\text { Симптоматическое течение - боли и } \\
\text { дискомфорт в животе после приёма } \\
\text { пищи, тошнота и рвота. }\end{array}$ \\
\hline $\begin{array}{l}\text { Какие исследования необходимы для } \\
\text { уточнения диагноза? }\end{array}$ & $\begin{array}{l}\text { - } \text { Эндоскопия; } \\
\text { - Контрастная рентгенография; } \\
\text { - Контрастная КТ. }\end{array}$ \\
\hline Виды операци: & $\begin{array}{l}\text { Лапароскопическая резекция дивертикул } \\
\text { (дивертикулэктомия). }\end{array}$ \\
\hline
\end{tabular}

\section{Вопросы и ответы по доброкачественным опухолям 12-перстной кишки}

\begin{tabular}{|c|c|}
\hline Вопросы & Ответы \\
\hline Клинические формы: & 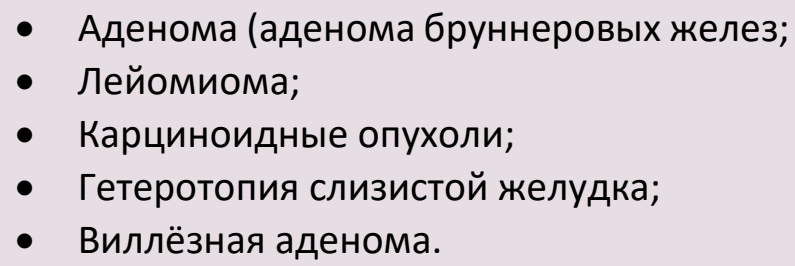 \\
\hline Осложнения: & $\begin{array}{l}\text { - Кровотечение; } \\
\text { - Обструкция (12-перстной кишки, } \\
\text { жёлчных путей); } \\
\text { - Малигнизация. }\end{array}$ \\
\hline Клинические признаки: & $\begin{array}{l}\text { - В большинстве случаев бессимптомны; } \\
\text { - При возникновении осложнений } \\
\text { наблюдается соответствующая картина. }\end{array}$ \\
\hline Диагностика: & $\begin{array}{l}\text { Эндоскопия, биопсия, КТ, эндоско- } \\
\text { пического УЗИ. }\end{array}$ \\
\hline
\end{tabular}




\begin{tabular}{|c|c|}
\hline Вопросы & Ответы \\
\hline Методы лечения: & 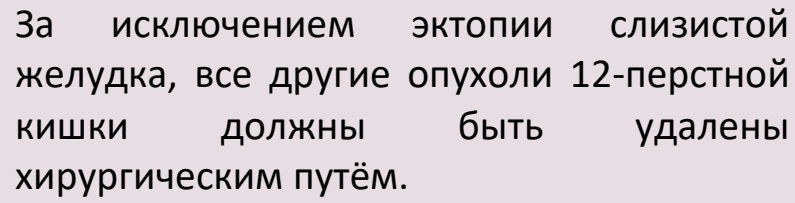 \\
\hline Виды операций: & $\begin{array}{l}\text { - Опухоли на ножке - эндоскопическая } \\
\text { эксцизия; } \\
\text { - Опухоли на широком основании - } \\
\text { хирургическая эксцизия; } \\
\text { - Малигнизация } \\
\text { панкреатодуоденальная резекция. }\end{array}$ \\
\hline
\end{tabular}

\section{Вопросы и ответы по злокачественным опухолям 12-перстной кишки}

\begin{tabular}{|c|c|}
\hline Вопросы & Ответы \\
\hline Клинические формы: & $\begin{array}{l}\text { - Аденокарцинома; } \\
\text { - Лейомиосаркома; } \\
\text { - Лимфома. }\end{array}$ \\
\hline Осложнения: & $\begin{array}{l}\text { Обструкция, кровотечение, механическая } \\
\text { желтуха. }\end{array}$ \\
\hline Клинические признаки: & $\begin{array}{l}\text { - Боль; } \\
\text { - Кровотечение; } \\
\text { - Дуоденальная непроходимость; } \\
\text { - Механическая желтуха; } \\
\text { - Наличие образования в брюшной } \\
\text { полости. }\end{array}$ \\
\hline $\begin{array}{l}\text { Какие методы исследования необходимы } \\
\text { для верификации диагноза? }\end{array}$ & $\begin{array}{ll}\text { - } & \text { Эндоскопия с биопсией; } \\
\text { - } & \text { Эндоскопическое УзИ; } \\
\text { - } & \text { КТ; } \\
\text { - } & \text { ПЭТ. }\end{array}$ \\
\hline Методы лечения: & $\begin{array}{l}\text { - При аденокарциноме, } \\
\text { лейомиосаркоме: } \\
\text { О На резектабельных стадиях - } \\
\text { панкреатодуоденальная резекция; } \\
\text { О На нерезектабельных стадиях - } \\
\text { паллиативные операции } \\
\text { сочетании с радиотерапией; } \\
\text { - При лимфоме-радио- и химиотерапия. }\end{array}$ \\
\hline Виды операций: & Панкреатодуоденальная резекция. \\
\hline
\end{tabular}


Прогноз:

5-летняя выживаемость составляет 18\%, 5летняя выживаемость после радикальной резекции - 30\%.

\section{Вопросы и ответы по синдрому верхней брыжеечной артерии}

\begin{tabular}{|c|c|}
\hline Вопросы & Ответы \\
\hline $\begin{array}{l}\text { Что подразумевается под "синдромом } \\
\text { верхней брыжеечной артерии"? }\end{array}$ & $\begin{array}{l}\text { Сдавление нижней горизонтальной части } \\
\text { 12-перстной кишки верхней брыжеечной } \\
\text { артерией, отходящей от аорты под острым } \\
\text { углом, что способствует нарушению } \\
\text { дуоденальной проходимости. }\end{array}$ \\
\hline Частота встречаемости: & $\begin{array}{l}\text { Встречается редко, наблюдается при } \\
\text { резком похудании. }\end{array}$ \\
\hline Причины и факторы риска: & Травмы и ожоги. \\
\hline Патогенез заболевания: & $\begin{array}{l}\text { Если угол отхождения верхней } \\
\text { брыжеечной артерии отаорты меньше } 25^{\circ} \\
\text { и протяженность сдавления менее } 2,5-4 \\
\text { мм, развивается картина дуоденальной } \\
\text { непроходимости. }\end{array}$ \\
\hline Особенности клинического течения: & $\begin{array}{l}\text { В большинстве наблюдений развивается } \\
\text { картина частичной или полной кишечной } \\
\text { непроходимости. }\end{array}$ \\
\hline Осложнения: & $\begin{array}{l}\text { - Продолжительная рвота, синдром } \\
\text { мальабсорбции, прогрессирующее } \\
\text { похудание; } \\
\text { - Расширение 12-перстной кишки и } \\
\text { утолщение её стенки. }\end{array}$ \\
\hline Клинические признаки: & $\begin{array}{l}\text { - Боль и вздутие живота; } \\
\text { - } \text { Рвота; } \\
\text { - } \text { Похудание. }\end{array}$ \\
\hline У каких пациентов можно заподозрить? & $\begin{array}{l}\text { - Возникновение болей в животе и рвоты } \\
\text { после еды. } \\
\text { В горизонтальном положении (на } \\
\text { правом боку) боли уменьшаются. } \\
\text { - Выявление расширения и утолщения } \\
\text { стенки 12-перстной кишки, дистальной }\end{array}$ \\
\hline
\end{tabular}




\begin{tabular}{|c|c|}
\hline Вопросы & Ответы \\
\hline & $\begin{array}{l}\text { обструкции при эндоскопии и } \\
\text { контрастной } \\
\text { (рентгенографии). }\end{array}$ \\
\hline Верификация диагноза: & КТ-ангиография. \\
\hline Лабораторные признаки: & Нет специфических изменений. \\
\hline $\begin{array}{l}\text { Признаки инструментальной } \\
\text { визуализации: }\end{array}$ & $\begin{array}{l}\text { Расширение и утолщение стенки 12- } \\
\text { перстной кишки при её дистальной } \\
\text { обструкции. }\end{array}$ \\
\hline Методы лечения: & $\begin{array}{l}\text { - В раннем периоде - консервативное } \\
\text { лечение. } \\
\text { - В позднем периоде - хирургическое. }\end{array}$ \\
\hline Виды операций: & $\begin{array}{l}\text { - Рассечение связки Трейца и } \\
\text { мобилизация двенадцатиперстной } \\
\text { кишки; } \\
\text { - Дуоденоеюностомия. }\end{array}$ \\
\hline
\end{tabular}

\section{СПИСОК ЛИТЕРАТУРЫ}

- $\quad$ Ağayev B.A. Cərrahi xəstəliklər. Bakı 2010.

- Blackbourne LH. Surgical Recall. 4 edition, 2006, LWW, Philadelphia

- Doherty GM. Current Diagnosis and Treatment: Surgery, $13^{\text {th }}$ edition, 2010, Lang International Edition.

- $\quad$ Omiraslanov Ә.T., Qazıyev A.Y. Onkologiya. Bakı, 2010.

- İsayev H.B. Cərrahi xəstəliklərin patofizologiyası. Bakı 2005

- Klingensmith ME, Aziz A, Bharat A, Fox AC, Porembka MR. The Washington Manual of Surgery, $6^{\text {th }}$ edition, 2012, LWW, Philadelphia.

- McNally PR. GI/Liver Secrets Plus. 4 edition. Mosby, Elsevier, 2010

- Medscape, http://www.medscape.com

- Oxford Handbook of Clinical Surgery, 3d edition, 2011, Oxford Press

- Sayek I. Sayek Temel Cerrahi 1-2. 4-cü baskı, 2016, Güneş Tıp Kitabevleri.

- Topçubaşov M.A. Xüsusi cərrahlıq. Bakı, 1979

- UpToDate, http://www.uptodate.com

- Гостищев B.К. Общая хирургия. GEOTAR-Media, 2019 


\section{ХИРУРГИЧЕСКИЕ БОЛЕЗНИ}

Н.Ю. Байрамов

\section{Хирургические заболевания тонкой кишки}

Н.Ю. Байрамов, А.М. Рустем, Б.М. Зейналов, Х.Н. Мусаев, А.К. Сафиева, Ф.А. Гахраманова

Перевод : Н.Ю. Байрамов, С.А. Алиев, М.Р. Гусейнова 


\section{КИШЕЧНАЯ НЕПРОХОДИМОСТЬ}

- Острая кишечная непроходимость - это срочное хирургическое состояние, при котором нарушается эвакуация содержимого кишечника.

- Непроходимость может быть механической, связанной со сужением просвета кишки (спайки, новообразования, грыжи, инвагинация, перекрут, инородные тела, гельминтозы, жёлчные камни, воспалительные заболевания кишечника, стриктуры, гематома и др.), и динамической (спастическая, паралитическая).

- Заболевание, как правило, начинается остро и характеризуется прогрессивным течением. На начальном этапе проявляются боль и рвота; в следующий, этап дегидратации, наблюдаются признаки гиповолемии; затем наступает сепсис и компартмент-синдром.

- При отсутствии соответствующего лечения наступает летальный исход.

- Имеются 4 клинические формы.

- Обструктивная форма механической кишечной непроходимости, как правило, начинается с 4-х классических признаков (вздутие, боли в животе, рвота, отсутствие дефекации и выделения газов); стадия дегидратации и сепсиса может длится несколько часов при проксимальной непроходимости и дней - при дистальной.

- При странгуляционной кишечной непроходимости, характеризующейся механической обструкцией кишечника и ишемией-некрозом, наблюдается острая боль в животе, обильная рвота, деформация и асимметрия передней стенки живота; за короткий промежуток времени наступает дегидратация, шок и сепсис в связи с некрозом кишечника.

- Паралитическая кишечная непроходимость, характеризующаяся тотальной гипотонией кишечника, наблюдается при перитоните и травмах. Проявляется постоянными тупыми и диффузными болями в животе, вздутием, рвотой, отсутствием дефекации и выделения газов.

- На поздних стадиях обструктивной и странгуляционной кишечной непроходимости на первый план выходят признаки компартмент-синдрома, сепсиса, одышка.

- Диагноз острой кишечной непроходимости ставится на основании клинической картины, данных КТ. 
- К диагностическим критериям относятся боли в животе, рвота, вздутие, отсутствие дефекации и выделения газов, наличие признаков обструкции на КТ (расширение просвета кишечника, задержка контрастного вещества, наличие странгуляции и др.). На КТ также возможно определить причину непроходимости.

- Лечение кишечной непроходимости начинается сразу же после поступления в стационар. Наряду со стабилизацией состояния пациента проводится декомпрессия кишечника с целью устранения препятствия. Хирургическое лечение - обязательно! По показаниям проводят и эндоскопические методы лечения.

\section{Вопросы и ответы по кишечной непроходимости}

\begin{tabular}{|c|c|}
\hline Вопросы & Ответы \\
\hline $\begin{array}{l}\text { Что представляет собой обструктивная } \\
\text { кишечная непроходимость? }\end{array}$ & $\begin{array}{l}\text { Механическое затруднение эвакуации } \\
\text { кишечного содержимого. }\end{array}$ \\
\hline $\begin{array}{l}\text { Частые причины кишечной } \\
\text { непроходимости: }\end{array}$ & $\begin{array}{l}\text { - Спайки; } \\
\text { - Грыжи; } \\
\text { - Новообразования. }\end{array}$ \\
\hline $\begin{array}{l}\text { Другие причины кишечной } \\
\text { непроходимости: }\end{array}$ & $\begin{array}{l}\text { - Жёлчные камни; } \\
\text { - Инвагинация; } \\
\text { - Перекрут; } \\
\text { - Внешняя компрессия; } \\
\text { - Синдром верхней брыжеечной } \\
\text { артерии; } \\
\text { - Безоар; } \\
\text { - Гематома кишечной стенки; } \\
\text { - Абсцесс; } \\
\text { - Дивертикулит; } \\
\text { - Болезнь Крона; } \\
\text { - Радиационный энтерит; } \\
\text { - Аннулярная поджелудочная железа; } \\
\text { - Дивертикул Меккеля; }\end{array}$ \\
\hline
\end{tabular}




\begin{tabular}{|c|c|}
\hline Вопросы & Ответы \\
\hline & - Стриктуры. \\
\hline $\begin{array}{l}\text { Что такое синдром верхней } \\
\text { брыжеечной артерии? }\end{array}$ & $\begin{array}{l}\text { Сдавление нижней горизонтальной } \\
\text { части 12-перстной кишки верхней } \\
\text { брыжеечной артерией, отходящей от } \\
\text { аорты под острым углом, что } \\
\text { способствует нарушению дуоденальной } \\
\text { проходимости. }\end{array}$ \\
\hline Клинические признаки: & $\begin{array}{l}\text { Резкие боли в животе, тошнота, рвота, } \\
\text { вздутие, отсутствие дефекации и } \\
\text { выделения газов, усиленные } \\
\text { перистальтические шумы. }\end{array}$ \\
\hline $\begin{array}{l}\text { Лабораторные анализы при кишечной } \\
\text { непроходимости: }\end{array}$ & $\begin{array}{l}\text { Общий анализ крови, общий анализ } \\
\text { мочи, электролиты. }\end{array}$ \\
\hline $\begin{array}{l}\text { Граница проксимальной и дистальной } \\
\text { кишечной непроходимости: }\end{array}$ & Илеоцекальный угол. \\
\hline $\begin{array}{l}\text { Отличия проксимальной и дистальной } \\
\text { кишечной непроходимости: }\end{array}$ & $\begin{array}{l}\text { При проксимальной кишечной } \\
\text { непроходимости наблюдаются сильные } \\
\text { боли, обильная рвота, ранняя } \\
\text { дегидратация в связи с нарушением } \\
\text { всасывания. }\end{array}$ \\
\hline $\begin{array}{l}\text { Классические нарушения } \\
\text { электролитного и кислотно-щелочного } \\
\text { обмена при проксимальной кишечной } \\
\text { непроходимости: }\end{array}$ & $\begin{array}{l}\text { Гиповолемия, гипохлоремия, } \\
\text { гипокалиемия, алкалоз. }\end{array}$ \\
\hline $\begin{array}{l}\text { Какая патология должна быть } \\
\text { исключена в первую очередь при } \\
\text { кишечной непроходимости? }\end{array}$ & Ущемлённая грыжа, спаечная болезнь. \\
\hline $\begin{array}{l}\text { Основной радиологический признак } \\
\text { при кишечной непроходимости: }\end{array}$ & $\begin{array}{l}\text { Расширенные петли } \\
\text { кишечника, уровень жидкости и газа. }\end{array}$ \\
\hline
\end{tabular}




\begin{tabular}{|c|c|}
\hline Вопросы & Ответы \\
\hline $\begin{array}{l}\text { Что такое полная кишечная } \\
\text { непроходимость? }\end{array}$ & $\begin{array}{l}\text { Полная закупорка просвета тонкого } \\
\text { кишечника, невозможность } \\
\text { прохождение контрастного вещества } \\
\text { дистальнее обструкции, отсутствие } \\
\text { газов в толстом кишечнике. }\end{array}$ \\
\hline $\begin{array}{l}\text { Опасность полной кишечной } \\
\text { непроходимости: }\end{array}$ & $\begin{array}{l}\text { Странгуляция петель и некроз } \\
\text { кишечника. }\end{array}$ \\
\hline $\begin{array}{l}\text { Что такое частичная кишечная } \\
\text { непроходимость? }\end{array}$ & $\begin{array}{l}\text { Неполная закупорка, частичное } \\
\text { прохождение контрастного вещества, } \\
\text { отхождение газов, наличие дефекации. }\end{array}$ \\
\hline $\begin{array}{l}\text { Какое исследование позволяет } \\
\text { дифференцировать полную и } \\
\text { частичную кишечную } \\
\text { непроходимость? }\end{array}$ & $\begin{array}{l}\text { КТ брюшной полости с оральным } \\
\text { контрастированием. }\end{array}$ \\
\hline $\begin{array}{l}\text { Первичные методы лечения } \\
\text { пациентов с кишечной } \\
\text { непроходимости: }\end{array}$ & $\begin{array}{l}\text { Прекращение питания, зондирование } \\
\text { желудка, инфузионная терапия, } \\
\text { катетеризация мочевого пузыря. }\end{array}$ \\
\hline $\begin{array}{l}\text { Лечение тотальной кишечной } \\
\text { непроходимости: }\end{array}$ & Лапаротомия и устранение причины. \\
\hline $\begin{array}{l}\text { Лечение частичной кишечной } \\
\text { непроходимости: }\end{array}$ & 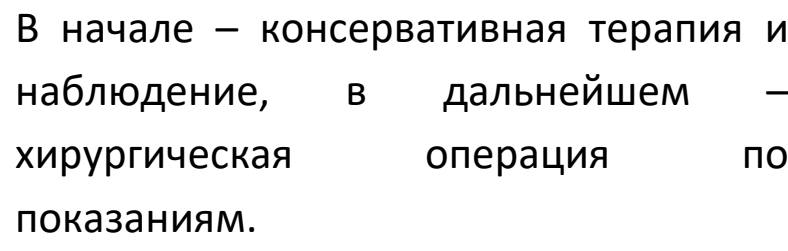 \\
\hline $\begin{array}{l}\text { Определение места обструкции во } \\
\text { время операции: }\end{array}$ & $\begin{array}{l}\text { Граница расширенной и нормальной } \\
\text { части петли кишечника. }\end{array}$ \\
\hline $\begin{array}{l}\text { Показание к хирургической операции } \\
\text { при болезни Крона: }\end{array}$ & Обструкция тонкого кишечника. \\
\hline
\end{tabular}




\begin{tabular}{|c|c|}
\hline Вопросы & Ответы \\
\hline $\begin{array}{l}\text { Возможны ли дефекация и выделение } \\
\text { газов при полной тонкокишечной } \\
\text { непроходимости: }\end{array}$ & $\begin{array}{l}\text { Возможно, из части кишечника } \\
\text { дистальнее места обструкции. }\end{array}$ \\
\hline $\begin{array}{l}\text { С какой целью проводится ушивание } \\
\text { дефекта брыжейки при резекции } \\
\text { тонкого кишечника? }\end{array}$ & $\begin{array}{l}\text { С целью предотвращения } \\
\text { возникновения внутренней грыжи. }\end{array}$ \\
\hline $\begin{array}{l}\text { Причина кишечной непроходимости у } \\
\text { пациентов, получающих } \\
\text { антикоагулянтную терапию: }\end{array}$ & Гематома стеки кишечника. \\
\hline $\begin{array}{l}\text { Частая причина тонкокишечной } \\
\text { непроходимости у взрослых: }\end{array}$ & Послеоперационные спайки. \\
\hline $\begin{array}{l}\text { Частая причина тонкокишечной } \\
\text { непроходимости у детей: }\end{array}$ & Грыжи \\
\hline $\begin{array}{l}\text { Признаки странгуляции при кишечной } \\
\text { непроходимости: }\end{array}$ & $\begin{array}{l}\text { Сильные и продолжающие боли, шок, } \\
\text { гематохезия, перитонизм, высокая } \\
\text { температура, наличие газа в воротной } \\
\text { вене, стенке кишечника и брюшной } \\
\text { полости, неконтрастируемые участки } \\
\text { кишечника, ацидоз. }\end{array}$ \\
\hline $\begin{array}{l}\text { Клинический признак, являющийся } \\
\text { показанием к операции, при } \\
\text { частичной кишечной непроходимости: }\end{array}$ & $\begin{array}{l}\text { Лейкоцитоз, высокая температура, } \\
\text { тахикардия, боли в животе. }\end{array}$ \\
\hline $\begin{array}{l}\text { Обязательные показания к операции } \\
\text { при частичной кишечной } \\
\text { непроходимости: }\end{array}$ & $\begin{array}{l}\text { Перитонизм, уровни газа и жидкости на } \\
\text { рентгенограмме. }\end{array}$ \\
\hline $\begin{array}{l}\text { Классическое выражение, } \\
\text { характеризующее кишечную } \\
\text { непроходимость: }\end{array}$ & Ожидание восхода или заката. \\
\hline
\end{tabular}




\section{Вопросы \\ Ответы}

С какими заболеваниями необходимо

- Послеоперационный

илеус (как дифференцировать паралитическую правило, проходит в течение 3-5 кишечную непроходимость? дней);

- Электролитные нарушения (гипокалиемия);

- Приём лекарственных препаратов (антихолинергические, наркотические препараты);

- Воспалительные заболевания (внутрибрюшной абсцесс, перитонит, сепсис, шок);

- Повреждения позвоночника;

- Ретроперитонеальные кровотечения. 


\section{СИНДРОМ КОРОТКОЙ кИШКИ}

- Синдром короткой кишки представляет собой тяжёлую мальабсорбцию, развивающуюся вследствие обширной резекции тонкой кишки. Как правило, наблюдается, когда после резекции остаётся менее 100-120 см тонкой кишки.

- Заболевание проявляется в первые дни после резекции тонкой кишки тяжёлой диареей (более 2 л в день), прогрессивным похуданием, стеатореей, дегидратацией, электролитными нарушениями, гипопротеинемией, слабостью. Питание усугубляет диарею.

- При отсутствии соответствующего лечения может наступить летальный исход.

- Диагноз ставится на основании клинической картины - тяжёлая диарея после обширной резекции тонкой кишки и острая мальабсорбция.

- Лечение проводится поэтапно: на ранней стадии проводят стабилизацию состояния пациента, прекращение орального питания, переход на парентеральное питание, уменьшение желудочной секреции. Следующий этап направлен на возобновление орального питания, восстановление регенерации кишечника и прекращение парентерального питания. Показаниями к хирургическому лечению являются отсутствии адаптационных механизмов (энтеропластика или антиперистальтические операции), развитие уросепсиса и печёночной недостаточности (трансплантация тонкого кишечника).

\section{Вопросы и ответы по синдрому короткой кишки}

\begin{tabular}{|ll|}
\hline \multicolumn{1}{|c|}{ Вопросы } & \multicolumn{2}{c|}{ Ответы } \\
\hline $\begin{array}{l}\text { Что собой представляет синдром } \\
\text { короткой кишки? }\end{array}$ & $\begin{array}{l}\text { Патологическая мальабсорбция, } \\
\text { развивающаяся после обширной } \\
\text { резекции тонкой кишки. }\end{array}$ \\
\hline Причины и факторы риска: & Обширная резекция тонкой кишки. \\
\hline Патогенез: & Уменьшение поверхности всасывания \\
& $\rightarrow$ диарея $\rightarrow$ потеря жидкости и \\
кишечного содержимого $\rightarrow$ острый & водно-электролитный и пищевой \\
дефицит. &
\end{tabular}




\begin{tabular}{|c|c|}
\hline Вопросы & Ответы \\
\hline Особенности клинического течения: & $\begin{array}{l}\text { Стадии диареи, адаптации и } \\
\text { стабилизации. }\end{array}$ \\
\hline Осложнения: & $\begin{array}{l}\text { - Дегидратация; } \\
\text { - Водно-электролитные нарушения; } \\
\text { - Уросепсис; } \\
\text { - Острая печёночная недостаточность; } \\
\text { - Холецистолитиаз; } \\
\text { - Нефролитиаз; } \\
\text { - Дисбактериоз. }\end{array}$ \\
\hline Клинические признаки: & 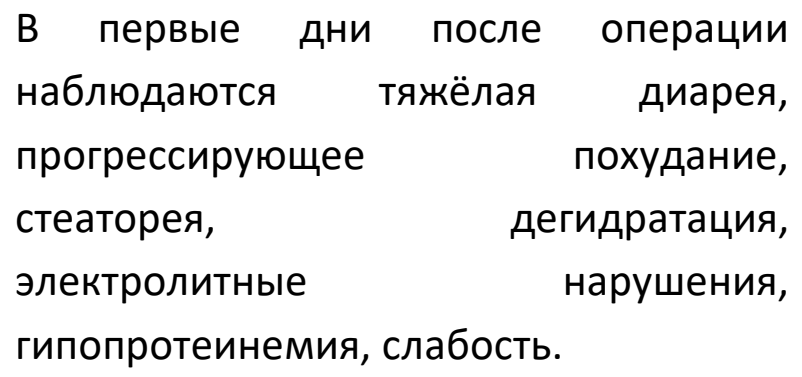 \\
\hline У каких больных можно заподозрить? & $\begin{array}{l}\text { У больных, перенёсших обширную } \\
\text { резекцию тонкой кишки. }\end{array}$ \\
\hline Лабораторные признаки: & Мальнутриция. \\
\hline Диагностические критерии: & $\begin{array}{l}\text { Тяжёлая диарея и острая мальнутриция } \\
\text { после обширной резекции тонкой } \\
\text { кишки. }\end{array}$ \\
\hline Методы лечения: & Консервативное и хирургическое. \\
\hline Показания к операции: & $\begin{array}{l}\text { Отсутствие } \\
\text { механизмов. }\end{array}$ \\
\hline Методы операции: & $\begin{array}{l}\text { - Энтеропластика; } \\
\text { - Антиперистальтические операции; } \\
\text { - Трансплантация тонкой кишки. }\end{array}$ \\
\hline
\end{tabular}




\section{СИНДРОМ СЛЕПОЙ ПЕТЛИ}

- Синдром слепой или застойной петли характеризуется увеличением микробных тел (бактерии) в тонкой кишке более $10^{5}$ млл и проявляется функциональными нарушениями и мальабсорбцией.

- В этиологии синдрома играют роль хирургические (стриктуры, дивертикулы, слепой сегмент кишки, свищи) и нехирургические (застой, иммунодефицитные состояния) патологии.

- Обычно проявляется диареей и стеатореей. По мере прогрессирования заболевания у больных развиваются авитаминоз, анемия, потеря веса.

- Для диагностики важное значение придают изучению микрофлоры кишечника и показателей мальабсорбции. Среди инструментальных методов диагностики используют КТ, эндоскопию.

- $\mathrm{K}$ диагностическим критериям относятся увеличение количества бактерий в кишечнике, признаки мальабсорбции, наличие заболеваний кишечника и исключение других причин диареи (осмотическая, воспалительная, гипермоторика).

- При лечении необходимо устранение мальабсорбции, проведение этиотропной консервативной или хирургической терапии, направленной на лечение основного заболевания.

\section{Вопросы и ответы по синдрому слепой петли}

\section{Вопросы}

Что представляет собой синдром

слепой или застойной кишки?

\section{Ответы}

Увеличение бактерий в тонкой кишке (более 105/мл), сопровождающееся функциональным нарушениями кишечника и мальабсорбцией.

\section{Причины и факторы риска:}

- Хирургические патологии:
○ Стриктуры;
○ Дивертикулы;
○ Сегмент слепой кишки; 


\begin{tabular}{|c|c|}
\hline Вопросы & Ответы \\
\hline & $\begin{array}{l}\text { ○ Свищи. } \\
\text { - Нехирургические патологии: } \\
\text { ○ Застой (склеродермия); } \\
\text { ○ Иммунодефицитные состояния. }\end{array}$ \\
\hline Патогенез: & $\begin{array}{l}\text { Нозологические причины } \rightarrow \text { ослабление } \\
\text { и подавление «антибактериальных } \\
\text { механизмов» в кишечнике } \rightarrow \\
\text { размножение бактерий } \rightarrow \text { повреждение } \\
\text { эпителия слизистой оболочки } \\
\text { кишечника, нарушение всасывания } \\
\text { пищеварения } \rightarrow \text { мальнутриция, сепсис. }\end{array}$ \\
\hline Особенность клинического течения: & $\begin{array}{l}\text { Мальабсорбция } \rightarrow \text { мальнутриция } \rightarrow \\
\text { нефролитиаз } \rightarrow \quad \text { почечная } \\
\text { недостаточность } \rightarrow \text { сепсис. }\end{array}$ \\
\hline Осложнения: & $\begin{array}{l}\text { Мальнутриция, нефролитиаз, почечная } \\
\text { недостаточность, сепсис. }\end{array}$ \\
\hline Клинические признаки: & $\begin{array}{l}\text { Признаки мальабсорбции: } \\
\text { - Диарея; } \\
\text { - Стеаторея; } \\
\text { - Мегалобластическая } \\
\text { (дефицит витамина В12); } \\
\text { - Гипокальциемия. }\end{array}$ \\
\hline $\begin{array}{l}\text { У каких пациентов можно } \\
\text { заподозрить? }\end{array}$ & $\begin{array}{l}\text { У пациентов с } \\
\text { мальабсорбции. }\end{array}$ \\
\hline $\begin{array}{l}\text { Какие методы диагностики } \\
\text { необходимы для диагностики? }\end{array}$ & $\begin{array}{l}\text { КТ, эндоскопия с биопсией, тест для } \\
\text { определения всасывания витамина } \mathrm{B}_{12} \\
\text { (тест Шиллинга), копрологический } \\
\text { анализ (определение жиров), } \\
\text { определение содержания кальция в }\end{array}$ \\
\hline
\end{tabular}




\begin{tabular}{|c|c|}
\hline Вопросы & Ответы \\
\hline & $\begin{array}{l}\text { крови и печёночного }{ }_{14} \text { С-Д-ксилозы в } \\
\text { выдыхаемом воздухе. }\end{array}$ \\
\hline Лабораторные признаки: & $\begin{array}{l}\text { Стеаторея, дефицит витамина } \text { B }_{12}, \\
\text { гипокальциемия, } \\
\text { количества бактерий в тонкой кишке. }\end{array}$ \\
\hline Диагностические критерии: & $\begin{array}{l}\text { • Признаки мальабсорбции; } \\
\text { • Бактериальная контаминация } \\
\text { тонкой кишки; } \\
\text { • Наличие патологий кишечника. }\end{array}$ \\
\hline Методы лечения: & $\begin{array}{l}\text { Консервативное (этиотропное, } \\
\text { антибактериальное, антидиарейное, } \\
\text { нутритивное) и хирургическое. }\end{array}$ \\
\hline Показания к операции: & $\begin{array}{l}\text { Наличие хирургических патологий } \\
\text { кишечника. }\end{array}$ \\
\hline Методы операций: & $\begin{array}{l}\text { Проводится соответственно конкретной } \\
\text { патологии: дивертикулэктомия, } \\
\text { фистулэктомия, устранение стриктуры, } \\
\text { удаление новообразования тонкой } \\
\text { кишки и др. }\end{array}$ \\
\hline
\end{tabular}




\section{ДИВЕРТИКУЛ МЕККЕЛЯ}

- Дивертикул Меккеля является истинным дивертикулом тонкой кишки, который формируется в результате незаращения части желточного протока, соединяющий тонкую кишку и желтое тело эмбриона.

- Обнаруживается случайно при лапаротомии или лапароскопии.

- У большинства пациентов дивертикул Меккеля протекает бессимптомно. В редких случаях наблюдается кровотечение, дивертикулит и кишечная непроходимость.

- В постановке диагноза ценную информацию даёт КТ, сцинтиграфия и лапароскопия выполняемые при поиске источника кровотечения неизвестной этиологии.

- При асимптоматическом течении показано наблюдение, при возникновении осложнений - хирургическое лечение (дивертикулэктомия).

\section{Вопросы и ответы по дивертикулу Меккеля}

\begin{tabular}{|c|c|}
\hline Вопросы & Ответы \\
\hline Что такое дивертикул Меккеля? & $\begin{array}{l}\text { Формируется при } \\
\text { желточного наращении } \\
\text { истинным дивертикулом подвздошной } \\
\text { кишки. }\end{array}$ \\
\hline Основная особенность: & $\begin{array}{r}\text { часто встречающаяся } \\
\text { желудочно-кишечного }\end{array}$ \\
\hline Типичная локализация: & 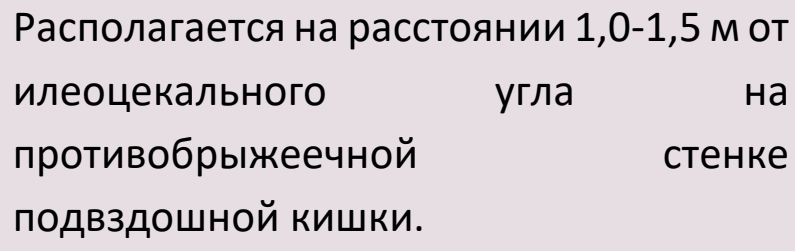 \\
\hline Является ли истинным дивертикулом? & $\begin{array}{l}\text { Состоит из всех слоёв стенки тонкой } \\
\text { кишки. }\end{array}$ \\
\hline
\end{tabular}




\begin{tabular}{|c|c|}
\hline Вопросы & Ответы \\
\hline Частота встречаемости: & 2\% среди всех аутопсий. \\
\hline $\begin{array}{l}\text { Частота встречаемости среди мужчин } \\
\text { и женщин: }\end{array}$ & У мужчин в 2 раза чаще. \\
\hline $\begin{array}{l}\text { В каком возрасте встречается } \\
\text { наиболее часто? }\end{array}$ & $\begin{array}{l}\text { Наиболее часто в возрасте 2-х лет, хотя } \\
\text { может встречаться в любом возрасте. }\end{array}$ \\
\hline Осложнения: & $\begin{array}{l}\text { Осложнения встречаются в 4\% случаев: } \\
\text { • Кишечное кровотечение - } 40 \% \text {; } \\
\text { - Кишечная непроходимость - 25\%; } \\
\text { - Дивертикулит - } 25 \% .\end{array}$ \\
\hline $\begin{array}{l}\text { С какими заболеваниями необходимо } \\
\text { дифференцировать? }\end{array}$ & Острый аппендицит. \\
\hline $\begin{array}{l}\text { Причина кровотечения из } \\
\text { дивертикула Меккеля: }\end{array}$ & $\begin{array}{l}\text { Язва, возникшая под воздействием } \\
\text { секрета эктопированной слизистой } \\
\text { желудка в стенке дивертикула. }\end{array}$ \\
\hline $\begin{array}{l}\text { Признаки кровотечения из } \\
\text { дивертикула Меккеля: }\end{array}$ & $\begin{array}{l}\text { Безболезненное кровотечение из } \\
\text { нижних отделов желудочно-кишечного } \\
\text { тракта, подвижное образование в } \\
\text { животе. }\end{array}$ \\
\hline $\begin{array}{l}\text { Частое осложнение дивертикула } \\
\text { Меккеля у взрослых: }\end{array}$ & Кишечная непроходимость. \\
\hline $\begin{array}{l}\text { Частота эктопированной слизистой } \\
\text { кишечника в дивертикуле Меккеля: }\end{array}$ & Более 50\%. \\
\hline $\begin{array}{l}\text { Какая эктопированная ткань чаще } \\
\text { наблюдается в стенке дивертикула } \\
\text { Меккеля? }\end{array}$ & $\begin{array}{l}\text { Слизистая желудка } \\
\text { двенадцатиперстной кишки, ткани } \\
\text { поджелудочной железы, слизистой } \\
\text { толстой кишки. }\end{array}$ \\
\hline $\begin{array}{l}\text { «Правило 2-х» при дивертикуле } \\
\text { Меккеля: }\end{array}$ & - Встречается у $2 \%$ населения; \\
\hline
\end{tabular}




\begin{tabular}{|c|c|}
\hline Вопросы & Ответы \\
\hline & $\begin{array}{l}\text { - Чаще встречается в возрасте до 2-х } \\
\text { лет; } \\
\text { - Соотношение мужчин/женщин - 2:1; } \\
\text { - Расположен на расстоянии 2-х фут от } \\
\text { илеоцекального угла (60-80 см); } \\
\text { - У } 1 / 2 \text { пациентов наблюдается } 2 \text { вида } \\
\text { слизистой в стенке дивертикула. }\end{array}$ \\
\hline $\begin{array}{l}\text { Что представляет собой сканирование } \\
\text { дивертикула Меккеля? }\end{array}$ & $\begin{array}{l}\text { Для определения } \text { эктопированной } \\
\text { слизистой желудка в дивертикуле } \\
\text { Меккеля проводят радиоизотопное } \\
\text { исследование (технеций, пертехнетат). }\end{array}$ \\
\hline Диагностика: & Лапароскопия или лапаротомия. \\
\hline $\begin{array}{l}\text { Тактика при случайном обнаружении } \\
\text { асимптоматического дивертикула } \\
\text { Меккеля: }\end{array}$ & Наблюдение. \\
\hline $\begin{array}{l}\text { Тактика лечения при дивертикуле, } \\
\text { осложнённом кровотечением и } \\
\text { кишечной непроходимостью: }\end{array}$ & $\begin{array}{l}\text { Хирургическая резекция, клиновидная } \\
\text { резекция дивертикула вместе со } \\
\text { стенкой кишки. }\end{array}$ \\
\hline $\begin{array}{l}\text { Как называется грыжа, при } \\
\text { ущемлении которой содержимым } \\
\text { оказывается дивертикул Меккеля? }\end{array}$ & Грыжа Литтре. \\
\hline $\begin{array}{l}\text { Какую патологию необходимо } \\
\text { исключить при позитивном тесте на } \\
\text { скрытую кровь в кале и } \\
\text { отрицательных результатах } \\
\text { колоноскопии? }\end{array}$ & $\begin{array}{l}\text { Опухоль тонкой кишки: КТ или } \\
\text { энтероклизис }- \text { контрастное } \\
\text { исследование тонкой кишки. }\end{array}$ \\
\hline
\end{tabular}




\section{БОЛЕЗНЬ КРОНА}

- Болезнь Крона - гранулематозное воспаление, характеризующееся трансмуральным поражением любого участка желудочно-кишечного тракта.

- Причины заболевания точно не установлены.

- Поражение дистальной части тонкого кишечника называется региональным или дистальным илеитом.

- Редко заболевание характеризуется бессимптомным течением, в большинстве случаев же наблюдаются длительная диарея и сильные боли.

- Для заболевания характерны периоды обострения и ремиссии, мальнутриция, кишечная непроходимость, формирование внутрибрюшных абсцессов, кишечных свищей, внекишечных осложнений и сепсиса.

- Для подтверждения диагноза, наряду с клинической картиной, возникает необходимость в проведении КТ/МРТ, эндоскопии с биопсией, генетических анализов и дифференциации с другими заболеваниями.

- $\mathrm{K}$ диагностическим критериям относятся длительная диарея, повторяющиеся абдоминальные боли, наличие заболевания в семейном анамнезе, наличие воспалительных очагов, утолщении стенки кишки, инфильтраций на КТ, гранулематозные очаги воспаления при биопсии.

- Основным методом лечения болезни Крона является консервативный (антибактериальная терапия, НПВС, стероиды, ингибиторы фактора роста опухоли). Хирургическое лечение показано при развитии осложнений.

\section{Вопросы и ответы по болезни Крона}

\begin{tabular}{|ll}
\hline \multicolumn{2}{c|}{ Вопросы } \\
Что такое болезнь Крона?
\end{tabular}




\begin{tabular}{|c|c|}
\hline Вопросы & Ответы \\
\hline Частота встречаемости: & $\begin{array}{l}\text { Среди населения Европы и США } \\
\text { составляет } 100.000: 2-9 . \\
\text { встречается среди евреев-ашкенази. }\end{array}$ \\
\hline Формы болезни Крона: & $\begin{array}{l}\text { По локализации: } \\
\text { - Илеит; } \\
\text { - Илеоколит; } \\
\text { - Колит; } \\
\text { - Перианальная форма; } \\
\text { - Другие сегменты (пищевод, } \\
\text { желудок, 12-перстная кишка и др.). } \\
\text { По степени тяжести: } \\
\text { - Бессимптомное; } \\
\text { - Лёгкое; } \\
\text { - Средней тяжести; } \\
\text { - Тяжёлое. }\end{array}$ \\
\hline Причины и факторы риска: & $\begin{array}{l}\text { Точно не установлены. Предполагают } \\
\text { роли генетических, иммунологических, } \\
\text { инфекционных и экзогенных факторов. }\end{array}$ \\
\hline Патогенез: & $\begin{array}{l}\text { Порочный } \text { круг: } \text { постоянное } \\
\text { повреждение слизистой оболочки } и \\
\text { нарушение иммунной регуляции } \rightarrow \\
\text { воспаление } \rightarrow \text { образование гранулём } \rightarrow \\
\text { повреждение слизистой оболочки. }\end{array}$ \\
\hline $\begin{array}{l}\text { Какая часть желудочно-кишечного } \\
\text { тракта поражается больше всех? }\end{array}$ & $\begin{array}{l}\text { Поражаются все отделы желудочно- } \\
\text { кишечного тракта, но в основном } \\
\text { локализуется в терминальном отделе } \\
\text { подвздошной } \\
\text { ободочная и прямая кишка. }\end{array}$ \\
\hline Особенности клиническо & - Рецидивирующее течение (75-85\%); \\
\hline
\end{tabular}




\begin{tabular}{|c|c|}
\hline Bonpocbl & Ответы \\
\hline & $\begin{array}{l}\text { - Длительная ремиссия (10-20\%); } \\
\text { - Рефрактерное течение (5\%). }\end{array}$ \\
\hline Осложнения: & $\begin{array}{l}\text { Интестинальные осложнения (20-60\%): } \\
\text { - Обструкция; } \\
\text { - } \text { Перфорация (абсцесс, наружные и } \\
\text { внутренние свищи); } \\
\text { - Аноректальные осложнения; } \\
\text { - Токсический мегаколон; } \\
\text { - Карциномы. } \\
\text { Системные осложнения: } \\
\text { - Анемия; } \\
\text { - } \text { Гепатобилиарные патологии; } \\
\text { - Увеит; } \\
\text { - Артрит, анкилозирующий спондилит } \\
\text { (болезнь Бехтерева); } \\
\text { - Узловатая эритема; } \\
\text { - Амилоидоз; } \\
\text { - Тромбоэмболизм; } \\
\text { - Цистит и др. }\end{array}$ \\
\hline Клинические признаки: & $\begin{array}{l}\text { Диарея (90\%), повторяющиеся } \\
\text { абдоминальные боли, образование в } \\
\text { брюшной полости, высокая } \\
\text { температура, анемия, аноректальные } \\
\text { патологии, усталость, мальнутриция, } \\
\text { похудание. }\end{array}$ \\
\hline У каких больных можно заподозрить? & 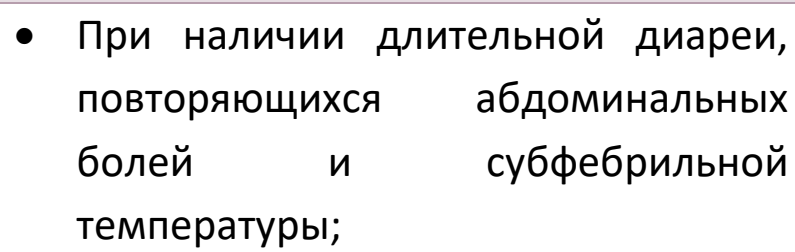 \\
\hline
\end{tabular}




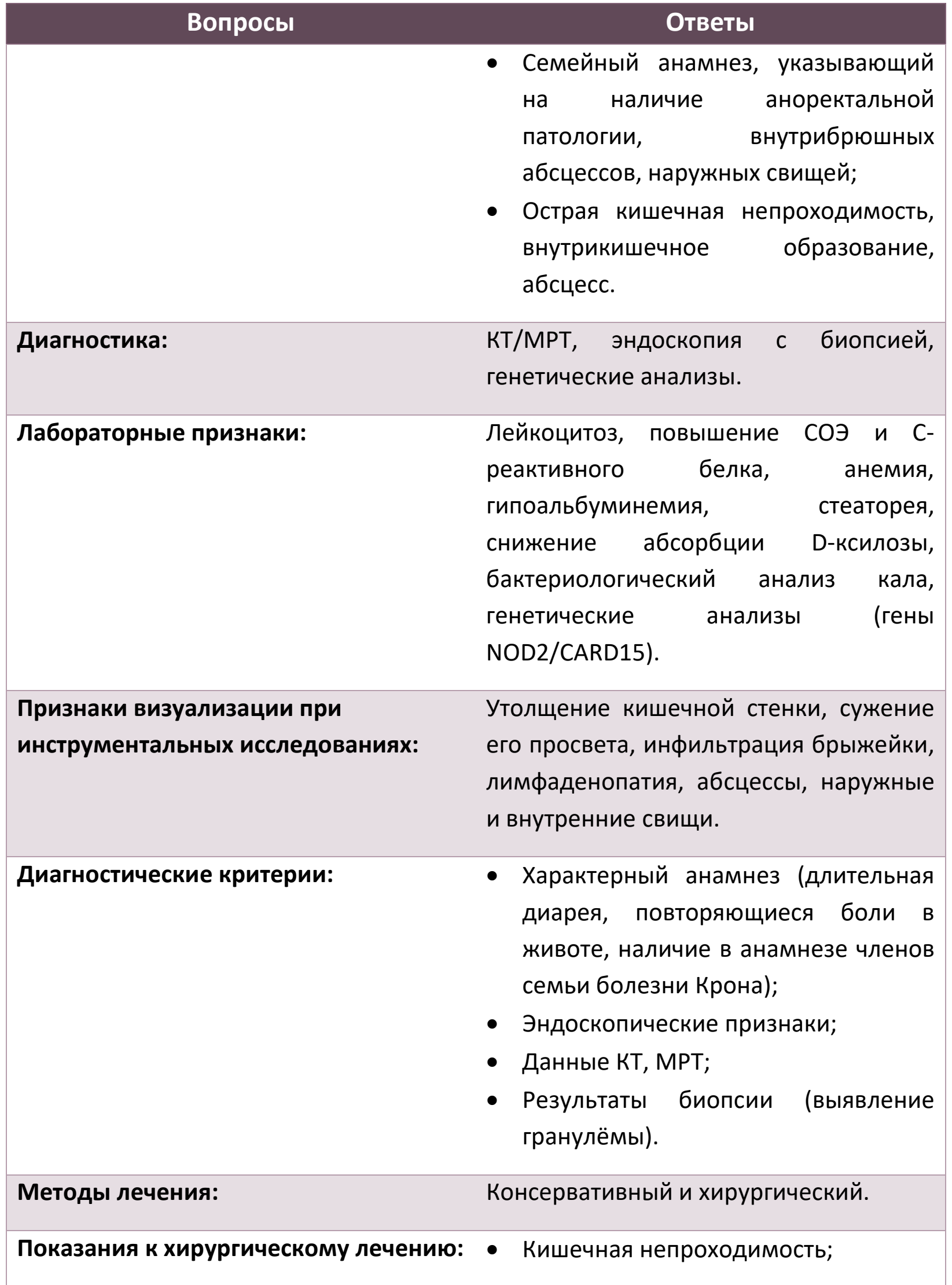




\begin{tabular}{|c|c|}
\hline Вопросы & Ответы \\
\hline & $\begin{array}{l}\text { - Перфорация (абсцесс, наружные и } \\
\text { внутренние свищи, острый } \\
\text { перитонит); } \\
\text { - Профузное кишечное кровотечение; } \\
\text { - Трудность дифференциальной } \\
\text { диагностики с неопластическими } \\
\text { процессами. }\end{array}$ \\
\hline Методы операции: & $\begin{array}{l}\text { - Резекция поражённого участка } \\
\text { кишечника; } \\
\text { - Стриктуропластика; } \\
\text { - Санация и дренирование абсцессов. }\end{array}$ \\
\hline $\begin{array}{l}\text { Характерная особенность } \\
\text { заболевания: }\end{array}$ & $\begin{array}{l}\text { Болезнь Крона - не злокачественный } \\
\text { процесс, но характеризуется } \\
\text { хроническим течением. }\end{array}$ \\
\hline
\end{tabular}




\section{ИШЕМИЧЕСКИЕ БОЛЕЗНИ ТОНКОЙ КИШКИ}

- $\mathrm{K}$ ишемическим болезням тонкой кишки относятся острая артериальная окклюзия, острая неокклюзионная ишемия, острый венозный тромбоз и хроническая артериальная ишемия.

- Острая артериальная окклюзия возникает вследствие тромбоза или тромбоэмболии.

- Сопровождается острыми и продолжительными болями в животе, некрозом кишечника, шоком, перитонитом и сепсисом.

○ Отличается высокой летальностью. Летальность без операции - 100\%.

○ Точный диагноз устанавливают при КТ-ангиографии или лапароскопии.

○ Единственным методом лечения является неотложная операция.

- Острая неокклюзионная ишемия развивается при шоке, сепсисе и аритмии.

○ Пусковым механизмом при этом является спазм сосудов малого калибра.

○ Отличается тяжёлым клиническим течением и высокой летальностью.

- Тромбоз мезентериальных вен возникает при циррозе печени, злокачественных опухолях и гиперкоагуляции.

○ Течение относительно удовлетворительное.

○ Диагноз уточняют на основании КТ-ангиографии.

○ Хирургическое лечение показано при наличии признаков некроза кишечника.

- Хроническая артериальная ишемия возникает вследствие хронической обструкции в верхней брыжеечной артерии или её главных ветвях.

○ Характеризуется болями в животе, особенно после приёма пищи.

○ Диагноз уточняется на основании КТ-ангиографии.

○ При хронической артериальной ишемии применяют реваскуляризирующие операции.

\section{Вопросы и ответы по ишемическим болезням тонкой кишки}

\begin{tabular}{|c|c|}
\hline Вопросы & Ответы \\
\hline $\begin{array}{l}\text { Что представляет собой ишемия } \\
\text { тонкой кишки? }\end{array}$ & $\begin{array}{l}\text { Сосудистое поражение тонкой кишки } \\
\text { вследствие острого или хронического }\end{array}$ \\
\hline
\end{tabular}




\begin{tabular}{|c|c|}
\hline Bonpocbl & Ответы \\
\hline & $\begin{array}{l}\text { нарушения артериального или } \\
\text { венозного кровообращения. }\end{array}$ \\
\hline Формы ишемии тонкой кишки: & $\begin{array}{l}\text { По этиологии и по клиническому } \\
\text { течению различают } 4 \text { формы: } \\
\text { • Острая артериальная окклюзия; } \\
\text { - Острая неокклюзионная ишемия; } \\
\text { - Острый венозный тромбоз; } \\
\text { - Хроническая артериальная ишемия. }\end{array}$ \\
\hline $\begin{array}{l}\text { Самая распространённая острая } \\
\text { форма: }\end{array}$ & $\begin{array}{l}\text { Острая артериальная окклюзия (60- } \\
\text { 70\%). }\end{array}$ \\
\hline $\begin{array}{l}\text { Чем отличаются острые окклюзионная } \\
\text { и неокклюзионная формы ишемии? }\end{array}$ & $\begin{array}{l}\text { Окклюзионная форма возникает } \\
\text { вследствие обструкции магистральных } \\
\text { сосудов, а неокклюзионная форма - в } \\
\text { результате ангиоспазма. }\end{array}$ \\
\hline $\begin{array}{l}\text { Причиной артериальной окклюзии } \\
\text { является тромбоз или } \\
\text { тромбоэмболия? }\end{array}$ & Тромбоэмболия. \\
\hline $\begin{array}{l}\text { Что является источником } \\
\text { тромбоэмболии? }\end{array}$ & $\begin{array}{lr}\text { Обычно левый } & \text { желудочек: } \\
\text { пристеночные } & \text { тромбы, } \\
\text { формирующиеся при } & \text { инфаркте } \\
\text { миокарда или аритмиях. } & \end{array}$ \\
\hline $\begin{array}{l}\text { Верхняя брыжеечная артерия } \\
\text { образует коллатерали с: }\end{array}$ & $\begin{array}{l}\text { С сосудами чревного ствола и нижней } \\
\text { брыжеечной артерией. }\end{array}$ \\
\hline $\begin{array}{l}\text { Показатель летальности при остром } \\
\text { мезентериальном тромбозе: }\end{array}$ & $50-90 \%$. \\
\hline $\begin{array}{l}\text { Характерный признак острого } \\
\text { мезентериального тромбоза: }\end{array}$ & Интенсивные боли в животе. \\
\hline
\end{tabular}




\begin{tabular}{|c|c|}
\hline Вопросы & Ответы \\
\hline $\begin{array}{l}\text { Чем характеризуется особенность } \\
\text { болевого синдрома? }\end{array}$ & $\begin{array}{l}\text { Острое начало, прогрессивно } \\
\text { нарастающие, некупирующиеся } \\
\text { наркотическими анальгетиками боли, } \\
\text { похожие на боли при панкреатите и } \\
\text { странгуляции. }\end{array}$ \\
\hline $\begin{array}{l}\text { Что означает несоответствии между } \\
\text { болью и состоянием живота? }\end{array}$ & $\begin{array}{l}\text { Несмотря на сильные боли в животе, на } \\
\text { ранней заболевания } \\
\text { абдоминальные признаки (перитонизм, } \\
\text { кишечная непроходимость) не } \\
\text { наблюдаются. }\end{array}$ \\
\hline Когда проходит болевой синдром? & $\begin{array}{l}\text { При развитии некроза интенсивность } \\
\text { боли может уменьшаться, но при } \\
\text { развитии перитонита - нарастает. }\end{array}$ \\
\hline $\begin{array}{l}\text { Как уточняют диагноз острой } \\
\text { артериальной окклюзии? }\end{array}$ & $\begin{array}{l}\text { В раннем периоде - на основании } \\
\text { клинической картины и ангиографии. В } \\
\text { позднем периоде - при лапаротомии по } \\
\text { поводу перитонита. }\end{array}$ \\
\hline Наиболее вероятные симптомы: & $\begin{array}{l}\text { - Внезапное начало абдоминального } \\
\text { болевого синдрома; } \\
\text { - Несоответствие между болями и } \\
\text { состоянием живота; } \\
\text { - Кровянистые выделения; } \\
\text { - Прогрессивное ухудшение } \\
\text { состояния; } \\
\text { - Перитонит и компартмент-синдром; } \\
\text { - Ацидоз, повышение уровня } \\
\text { креатинкиназы. }\end{array}$ \\
\hline Диагностика: & КТ-ангиография. \\
\hline
\end{tabular}




\begin{tabular}{|c|c|}
\hline Вопросы & Ответы \\
\hline $\begin{array}{l}\text { С какими заболеваниями следует } \\
\text { дифференцировать? }\end{array}$ & $\begin{array}{l}\text { Острый панкреатит, странгуляционная } \\
\text { кишечная непроходимость, } \\
\text { перфорация, разрыв аневризмы аорты. }\end{array}$ \\
\hline $\begin{array}{l}\text { В чём заключается лечение острого } \\
\text { артериального тромбоза? }\end{array}$ & $\begin{array}{l}\text { Срочная операция - } \\
\text { кишечника при наличии некроза, } \\
\text { формирование анастомоза или } \\
\text { энтеростомы; при отсутствии некроза - } \\
\text { реваскуляризация } \\
\text { наблюдение. }\end{array}$ \\
\hline $\begin{array}{l}\text { Причины острой неокклюзионной } \\
\text { ишемии: }\end{array}$ & Шок, септическое состояние. \\
\hline $\begin{array}{l}\text { Патогенетические механизмы } \\
\text { неокклюзионной ишемии: }\end{array}$ & $\begin{array}{l}\text { Спазм сосудов начинается с ворсин } \\
\text { кишечника и распространяется на все } \\
\text { слои его стенки вызывая ишемию и } \\
\text { некроз. }\end{array}$ \\
\hline $\begin{array}{l}\text { Почему ишемия первично начинается } \\
\text { с ворсин кишечного эпителия? }\end{array}$ & $\begin{array}{l}\text { Потому что в ворсинах имеются } \\
\text { артериовенозные шунты (капилляры } \\
\text { без прекапиллярных сфинктеров), в } \\
\text { которых при гипотензии начинается } \\
\text { спазм, вследствие чего артериальная } \\
\text { кровь поступает в венозную систему и } \\
\text { развивается ишемия в ворсинках. }\end{array}$ \\
\hline $\begin{array}{l}\text { Физиологическая роль } \\
\text { артериовенозных шунтов в ворсинах } \\
\text { кишечника: }\end{array}$ & $\begin{array}{l}\text { Регулируют кровоснабжение в } \\
\text { ворсинах: повышает во время приёма } \\
\text { пищи с целью обеспечения всасывания } \\
\text { и секреции, в остальное время - } \\
\text { снижает кровоснабжение. }\end{array}$ \\
\hline $\begin{array}{l}\text { У каких пациентов можно } \\
\text { заподозрить? }\end{array}$ & $\begin{array}{l}\text { При болях в животе неизвестной } \\
\text { этиологии у больных с высоким риском } \\
\text { заболевания, при наличии ацидоза, }\end{array}$ \\
\hline
\end{tabular}




\begin{tabular}{|c|c|}
\hline Вопросы & Ответы \\
\hline & $\begin{array}{l}\text { повышенного уровня амилазы и } \\
\text { лейкоцитозе. }\end{array}$ \\
\hline Диагностика: & $\begin{array}{l}\text { При КТ-ангиографии в магистральных } \\
\text { сосудах окклюзию не обнаруживают. } \\
\text { При эндоскопии или во время операции } \\
\text { выявляют ишемию (некроз). }\end{array}$ \\
\hline $\begin{array}{l}\text { Методы лечения неокклюзионной } \\
\text { ишемии: }\end{array}$ & $\begin{array}{l}\text { Интраартериальное } \\
\text { спазмолитиков. Пведение } \\
\text { кишечника - резекция. Характеризуется } \\
\text { высокой летальностью-90\%. }\end{array}$ \\
\hline
\end{tabular}




\section{опухоли тонкой кишки}

- Опухоли тонкой кишки могут быть первичными, формирующимися из ткани кишечника, и метастатическими.

- Среди доброкачественных опухолей наиболее часто встречаются аденома, лейомиома, липома и фиброма. Из злокачественных опухолей наблюдаются аденокарцинома, карциноид, гастроинтестинальные стромальные опухоли и лимфомы.

- Доброкачественные опухоли и опухоли малых размеров протекают бессимптомно, крупные и злокачественные опухоли характеризуются симптоматическим течением.

- Клинические проявления опухолей тонкой кишки характеризуется болями в животе, непроходимостью, перфорацией, кровотечением.

- Важную роль в диагностике опухолей тонкой кишки играют КТ, МРТ, эндоскопия, при необходимости проводится лапаротомия или лапароскопия. Гистологическую структуру опухолей определяют биопсией.

- За исключением асимптоматических липом, лечение всех опухолей тонкой кишки - хирургическое.

\section{Вопросы и ответы по опухолям тонкой кишки}

\begin{tabular}{|ll|}
\multicolumn{1}{|c|}{ Вопросы } & \multicolumn{1}{c|}{ Ответы } \\
\hline $\begin{array}{l}\text { Доброкачественные опухоли тонкой } \\
\text { кишки: }\end{array}$ & $\begin{array}{l}\text { Лейомиома, липома, лимфангиома, } \\
\text { фиброма, аденома, гемангиома. }\end{array}$ \\
\hline $\begin{array}{l}\text { Наиболее часто встречающаяся } \\
\text { доброкачественная опухоль тонкой } \\
\text { кишки: }\end{array}$ & Лейомиома. \\
\hline $\begin{array}{l}\text { Наиболее часто встречающаяся } \\
\text { злокачественная опухоль тонкой } \\
\text { кишки: }\end{array}$ & Аденокарцинома. \\
\hline
\end{tabular}




\begin{tabular}{|c|c|}
\hline Вопросы & Ответы \\
\hline $\begin{array}{l}\text { Злокачественные опухоли тонкой } \\
\text { кишки: }\end{array}$ & $\begin{array}{l}\text { - Аденокарцинома (33-50\%); } \\
\text { - Карциноид (25-44\%); } \\
\text { - Лимфома (20\%); } \\
\text { - Стромальная опухоль (17\%); } \\
\text { - Липома (8\%). }\end{array}$ \\
\hline $\begin{array}{l}\text { Какая злокачественная опухоль } \\
\text { метастазирует в тонкую кишку? }\end{array}$ & Меланома. \\
\hline $\begin{array}{l}\text { Какую опухоль тонкой кишки можно } \\
\text { определить методом диагностической } \\
\text { визуализации? }\end{array}$ & Липома. \\
\hline $\begin{array}{l}\text { Основной клинический признак } \\
\text { опухолей тонкой кишки: }\end{array}$ & Боли в животе. \\
\hline $\begin{array}{l}\text { Как можно дифференцировать } \\
\text { опухоли тонкой кишки? }\end{array}$ & Методом биопсии. \\
\hline $\begin{array}{l}\text { Предраковые состояния тонкой } \\
\text { кишки: }\end{array}$ & $\begin{array}{l}\text { Аденомы, болезнь Крона, рак толстой } \\
\text { кишки. }\end{array}$ \\
\hline $\begin{array}{l}\text { Частая локализация аденокарциномы } \\
\text { тонкой кишки: }\end{array}$ & Двенадцатиперстная кишка. \\
\hline $\begin{array}{l}\text { Чем объясняется относительная } \\
\text { редкость злокачественных опухолей } \\
\text { тонкой кишки? }\end{array}$ & $\begin{array}{l}\text { Точно не известно. Но предполагают, } \\
\text { что высокая скорость пассажа тонкой } \\
\text { кишки, кратковременный контакт с } \\
\text { канцерогенами, защитные механизмы } \\
\text { (лимфатические фолликулы, IgA, } \\
\text { регуляторы регенерации) играют } \\
\text { большую роль. }\end{array}$ \\
\hline $\begin{array}{l}\text { Чем объясняется необходимость } \\
\text { удаления доброкачественных } \\
\text { асимптоматических опухолей тонкой } \\
\text { кишки? }\end{array}$ & $\begin{array}{l}\text { Аденомы являются предраковым } \\
\text { заболеванием. Другие опухоли, за } \\
\text { исключением }\end{array}$ \\
\hline
\end{tabular}




\begin{tabular}{|c|c|}
\hline Вопросы & Ответы \\
\hline & дифференцировать \\
\hline & злокачественными. \\
\hline $\begin{array}{l}\text { Из каких клеток развивается } \\
\text { гастроинтестинальные стромальные } \\
\text { опухоли? }\end{array}$ & $\begin{array}{l}\text { Из мионейрональных пейсмекерных } \\
\text { клеток кишечника. }\end{array}$ \\
\hline $\begin{array}{l}\text { Наиболее частая локализация } \\
\text { гастроинтестинальных стромальных } \\
\text { опухолей: }\end{array}$ & Желудок и тонкая кишечник. \\
\hline $\begin{array}{l}\text { С какой опухолью невозможно } \\
\text { дифференцировать } \\
\text { гастроинтестинальные опухоли } \\
\text { методом биопсии? }\end{array}$ & Лейомиомой. \\
\hline $\begin{array}{l}\text { Диагностика гастроинтестинальных } \\
\text { стромальных опухолей: }\end{array}$ & $\begin{array}{llll}\text { Обнаружение } & \text { CD117 } & \text { антигена } & \text { или } \\
\text { мутации } & \text { C-KIT } & \text { гена } & \text { при }\end{array}$ \\
\hline & $\begin{array}{l}\text { иммуногистохимическом } \\
\text { исследовании. }\end{array}$ \\
\hline $\begin{array}{l}\text { Что представляет собой CD117 } \\
\text { антиген? }\end{array}$ & $\begin{array}{l}\text { Является частью рецептора } \\
\text { тирозинкиназы, } \\
\text { продуктом протоонкогена С-КІТ. }\end{array}$ \\
\hline $\begin{array}{l}\text { В чём заключается роль рецептора } \\
\text { тирозинкиназы и какова его } \\
\text { клиническая значимость? }\end{array}$ & $\begin{array}{l}\text { Рецептор тирозинкиназы играет } \\
\text { важную роль в росте и ангиогенезе } \\
\text { опухоли. }\end{array}$ \\
\hline $\begin{array}{l}\text { Почему гастроинтестинальные } \\
\text { стромальные опухоли склонны } \\
\text { больше к кровотечению и меньше к } \\
\text { обструкции? }\end{array}$ & $\begin{array}{l}\text { Гастроинтестинальные стромальные } \\
\text { опухоли богаты сосудами и } \\
\text { развиваются экзофитно. }\end{array}$ \\
\hline
\end{tabular}




\section{Вопросы и ответы по карциноидным опухолям}

\begin{tabular}{|c|c|}
\hline Вопросы & Ответы \\
\hline Что такое карциноидные опухоли? & $\begin{array}{l}\text { Опухоли, развивающиеся из } \\
\text { нейроэндокринных клеток (APUD-ома - } \\
\text { опухоль, синтезирующая серотонин). }\end{array}$ \\
\hline Что означает название “карциноид”? & $\begin{array}{l}\text { Карциноид - опухоль, похожая на } \\
\text { карциному. Однако по клинико- } \\
\text { гистологической особенности имеет } \\
\text { более агрессивное течение. }\end{array}$ \\
\hline Частота встречаемости: & $\begin{array}{l}\text { Составляет 0,2-1\% всех опухолей и 25\% } \\
\text { опухолей тонкой кишки. }\end{array}$ \\
\hline $\begin{array}{l}\text { Частая локализация карциноидных } \\
\text { опухолей: }\end{array}$ & $\begin{array}{l}\text { - Червеобразный отросток; } \\
\text { - Подвздошная кишка; } \\
\text { - Прямая кишка; } \\
\text { - Бронхи. } \\
\text { Редко в желудке, тощей кишке, 12- } \\
\text { перстной кишке, толстой кишке, } \\
\text { яичниках, поджелудочной железе, } \\
\text { яичках, вилочковой железе. }\end{array}$ \\
\hline Клинические признаки: & $\begin{array}{l}\text { Зависят от локализации. Обычно } \\
\text { протекает бессимптомно. } \\
\text { Характерными симптомами являются } \\
\text { кишечная непроходимость, боли в } \\
\text { животе, кровотечение, потеря веса, } \\
\text { диафорез, пеллаграподобный синдром, } \\
\text { инвагинация, карциноидный синдром. }\end{array}$ \\
\hline $\begin{array}{l}\text { Что такое пеллаграподобный } \\
\text { синдром? }\end{array}$ & $\begin{array}{l}\text { Включает в себя ЗД-комплекс: } \\
\text { - Деменция; } \\
\text { - Дерматит; } \\
\text { - Диарея. }\end{array}$ \\
\hline
\end{tabular}




\begin{tabular}{|c|c|}
\hline Вопросы & Ответы \\
\hline Что такое карциноидный синдром? & $\begin{array}{l}\text { Симптомокомплекс, обусловленный } \\
\text { продуктами, синтезированными } \\
\text { карциноидными опухолями. }\end{array}$ \\
\hline $\begin{array}{l}\text { Клинические проявления } \\
\text { карциноидного синдрома: }\end{array}$ & $\begin{array}{l}\text { - Бронхоспазм; } \\
\text { - Гиперемия лица; } \\
\text { - Диарея; } \\
\text { - Правожелудочковая } \\
\text { недостаточность. }\end{array}$ \\
\hline $\begin{array}{l}\text { Причина правожелудочковой } \\
\text { недостаточности: }\end{array}$ & $\begin{array}{l}\text { Вещества, продуцируемые } \\
\text { карциноидными опухолями, вызывают } \\
\text { воспалительный процесс и фиброз в } \\
\text { клапанах “правого сердца". }\end{array}$ \\
\hline $\begin{array}{l}\text { Частота развития карциноидного } \\
\text { синдрома у больных с карциноидной } \\
\text { опухолью: }\end{array}$ & Составляет 30\%. \\
\hline $\begin{array}{l}\text { Какое вещество, синтезируемое } \\
\text { карциноидной опухолью, является } \\
\text { причиной развития карциноидного } \\
\text { синдрома? }\end{array}$ & Серотонин и вазоактивные пептиды. \\
\hline $\begin{array}{l}\text { В чём заключается консервативное } \\
\text { лечение карциноидных опухолей? }\end{array}$ & $\begin{array}{l}\text { Внутривенное введение октреотида } \\
\text { (сандостатина). }\end{array}$ \\
\hline $\begin{array}{l}\text { В чём заключается консервативное } \\
\text { лечение диареи при карциноидном } \\
\text { синдроме? }\end{array}$ & $\begin{array}{l}\text { Применение антагониста серотонина - } \\
\text { ондансетрон (зофран). }\end{array}$ \\
\hline $\begin{array}{l}\text { Какую роль играет печень в } \\
\text { нейтрализации негативных } \\
\text { воздействий карциноидного } \\
\text { синдрома? }\end{array}$ & $\begin{array}{l}\text { При поступлении венозной крови из } \\
\text { карциноидных опухолей и других } \\
\text { вазоактивных веществ в воротную вену, } \\
\text { происходит их элиминация печенью. }\end{array}$ \\
\hline
\end{tabular}




\begin{tabular}{|c|c|}
\hline Вопросы & Ответы \\
\hline $\begin{array}{l}\text { Чем объясняется непостоянство } \\
\text { развития карциноидного синдрома? }\end{array}$ & $\begin{array}{l}\text { Если не происходит элиминации } \\
\text { продуктов карциноидных опухолей, } \\
\text { развивается карциноидный синдром. }\end{array}$ \\
\hline $\begin{array}{l}\text { Какие опухоли вызывают развитие } \\
\text { карциноидного синдрома? }\end{array}$ & $\begin{array}{l}\text { Метастазы в } \\
\text { ретроперитонеальные } \\
\text { опухоли яичников, яичек, бронхов. }\end{array}$ \\
\hline $\begin{array}{l}\text { Как происходит нейтрализация } \\
\text { серотонина в печени? }\end{array}$ & $\begin{array}{l}\text { Печень превращает серотонин в 5- } \\
\text { гидроксииндолацетатную кислоту. }\end{array}$ \\
\hline $\begin{array}{l}\text { Лабораторные маркеры } \\
\text { карциноидных опухолей: }\end{array}$ & $\begin{array}{l}\text { Повышение в крови и } \\
\text { концентрации } \\
\text { гедроконсииндолацетатной кислоты. }\end{array}$ \\
\hline $\begin{array}{l}\text { Какой стимуляционный тест } \\
\text { способствует повышению уровня } \\
\text { серотонина и развитию } \\
\text { карциноидного синдрома? }\end{array}$ & Стимуляция пентагастрином. \\
\hline $\begin{array}{l}\text { Специфическое радиологическое } \\
\text { исследование для определения } \\
\text { локализации опухоли: }\end{array}$ & Сцинтиграфия с октреотидом. \\
\hline Диагностика: & Колоноскопия, КТ. \\
\hline $\begin{array}{l}\text { Информативна ли КТ для определения } \\
\text { первичной опухоли? }\end{array}$ & $\begin{array}{l}\text { При малых размерах первичной } \\
\text { опухоли КТ неэффективна. Возникает } \\
\text { необходимость в в проведении } \\
\text { сцинтиграфии. }\end{array}$ \\
\hline $\begin{array}{l}\text { В чём заключается хирургическое } \\
\text { лечение? }\end{array}$ & $\begin{array}{l}\text { Удаление первичных опухолей } \\
\text { метастазов в } \\
\text { нерезектабельных опухолях } \\
\text { трансплантация } \\
\text { Циторедуктив } \\
\text { случаев дают положительный эффект. }\end{array}$ \\
\hline
\end{tabular}




\begin{tabular}{|c|c|}
\hline Вопросы & Ответы \\
\hline $\begin{array}{l}\text { Как проводится консервативное } \\
\text { лечение? }\end{array}$ & $\begin{array}{l}\text { Для купирования клинических } \\
\text { симптомов применяют аналог } \\
\text { соматостатина - октреотид. }\end{array}$ \\
\hline Насколько эффективен октреотид? & $\begin{array}{l}\text { В 85\% случаев уменьшается частота } \\
\text { диареи и кожных проявлений, в 10-20\% } \\
\text { способствует уменьшению размеров } \\
\text { опухоли. }\end{array}$ \\
\hline $\begin{array}{l}\text { Наиболее эффективный препарат, } \\
\text { нейтрализующий серотонин: }\end{array}$ & Ципрогептадин. \\
\hline $\begin{array}{l}\text { Как происходит нейтрализация } \\
\text { серотонина в печени? }\end{array}$ & $\begin{array}{l}\text { Печень превращает серотонин в 5- } \\
\text { гидрооксинидолацетатную кислоту. }\end{array}$ \\
\hline Прогноз: & $\begin{array}{l}\text { 5-летняя выживаемость наблюдается у } \\
\text { 2/3 пациентов. После радикальных } \\
\text { операций - } 15 \text { лет. При } \\
\text { нерезектабельных } \\
\text { интраабдоминальных опухолях - } 5 \text { лет, } \\
\text { при метастазах в печень-3 года. }\end{array}$ \\
\hline $\begin{array}{l}\text { Прогноз при метастазах в печень } \\
\text { карциноидных опухолей: }\end{array}$ & $\begin{array}{l}\text { 3-хлетняя выживаемость составляет } \\
\text { 50\%. }\end{array}$ \\
\hline $\begin{array}{l}\text { На что похожи карциноидные } \\
\text { опухоли? }\end{array}$ & $\begin{array}{l}\text { Интрамуральное образование } \\
\text { кишечника желтоватого цвета. }\end{array}$ \\
\hline $\begin{array}{l}\text { Выбор метода операции при } \\
\text { карциноиде червеобразного отростка: }\end{array}$ & $\begin{array}{l}\text { Если размер опухоли больше } 2 \text { см } \\
\text { показана правосторонняя } \\
\text { гемиколэктомия. При карциноидах } \\
\text { размером менее } 2 \text { см и без инвазии в } \\
\text { серозную оболочку } \\
\text { аппендэктомия. }\end{array}$ \\
\hline
\end{tabular}




\begin{tabular}{|c|c|}
\hline Вопросы & Ответы \\
\hline $\begin{array}{l}\text { Какие первичные карциноидные } \\
\text { опухоли отличаются высоким } \\
\text { метастазированием? }\end{array}$ & Карциноиды подвздошной кишки. \\
\hline $\begin{array}{l}\text { Подтверждается ли озлокачествление } \\
\text { карциноидных опухолей } \\
\text { гистологическим исследованием? }\end{array}$ & $\begin{array}{l}\text { Нет. Показателем озлокачествления } \\
\text { является не гистологическая структура } \\
\text { опухоли, а наличие метастазов. }\end{array}$ \\
\hline $\begin{array}{l}\text { Зависит ли степень озлокачествления } \\
\text { от размеров карциноидных опухолей: }\end{array}$ & $\begin{array}{l}\text { При карциноидах размером до } 1 \text { см } \\
\text { метастазы редкие. Метастазы обычно } \\
\text { наблюдаются при опухолях, размером } 2 \\
\text { см и более. }\end{array}$ \\
\hline $\begin{array}{l}\text { Тактика лечения при } \\
\text { нерезектабельных метастазах в } \\
\text { печень: }\end{array}$ & $\begin{array}{l}\text { Трансплантация } \\
\text { химиоэмболизация, } \\
\text { радиочастотная абляция. }\end{array}$ \\
\hline
\end{tabular}




\section{СПИСОК ЛИТЕРАТУРЫ}

\section{Ümumi adabiyyat}

- Ağayev B.A. Cərrahi xəstəliklər. Bakı 2010.

- Blackbourne LH. Surgical Recall. 4 edition, 2006, LWW, Philadelphia

- Doherty GM. Current Diagnosis and Treatment: Surgery, $13^{\text {th }}$ edition, 2010, Lang International Edition.

- Omiraslanov D.T., Qazıyev A.Y. Onkologiya. Bakı, 2010.

- İsayev H.B. Cərrahi xəstəliklərin patofizologiyası. Bakı 2005

- Klingensmith ME, Aziz A, Bharat A, Fox AC, Porembka MR. The Washington Manual of Surgery, $6^{\text {th }}$ edition, 2012, LWW, Philadelphia.

- McNally PR. GI/Liver Secrets Plus. 4 edition. Mosby, Elsevier, 2010

- Medscape, http://www.medscape.com

- Oxford Handbook of Clinical Surgery, 3d edition, 2011, Oxford Press

- Sayek I. Sayek Temel Cerrahi 1-2. 4-cü baskı, 2016, Güneş Tıp Kitabevleri.

- Topçubaşov M.A. Xüsusi cərrahlıq. Bakı, 1979

- UpToDate, http://www.uptodate.com

- Гостищев B.К. Общая хирургия. GEOTAR-Media, 2019

\section{Xüsusi adabiyyat}

- Catena F, Di Saverio S, Kelly MD, et al. Bologna Guidelines for Diagnosis and Management of Adhesive Small Bowel Obstruction (ASBO): 2010 Evidence-Based Guidelines of the World Society of Emergency Surgery. World J Emerg Surg 2011; 6:5

- Bayramov N.Y. Təcili Abdominal cərrahiyyədə müayinə və müalicə qaydaları. ISBN13 978-9952-8082-1-6, Qismət, Bakı 2009. $132 \mathrm{~s}$.

- Evaluation and management of gallstone-related diseases in non-pregnant adults.2014 May. NGC:010429. University of Michigan Health System - Academic Institution. http://www.guideline.gov 


\title{
ХИРУРГИЧЕСКИЕ БОЛЕЗНИ
}

Н.Ю. Байрамов

\section{Хирургические заболевания толстой кишки}

\author{
Н.Ю. Байрамов, С.А. Алиев, Э.А. Алиев, А.К. Сафиева, Ш.А. Мамедова
}

Перевод: Н.Ю. Байрамов, С.А. Алиев, М.Р. Гусейнова 


\section{НЕСПЕЦИФИЧЕСКИЙ ЯЗВЕННЫЙ КОЛИТ}

- Неспецифический язвенный колит представляет собой хроническое воспаление слизистой оболочки толстой кишки, которое начинается с прямой кишки и простирается на всю проксимальную часть кишечника.

- Этиология и механизм развития заболевания изучены не до конца. Однако имеется предположение о том, что в развитии болезни определённую роль играют наследственно-генетические факторы, инфекция, иммунные процессы, диета и другие внешние факторы.

- Заболевание характеризуется периодами обострения (боль, кровавая диарея, высокая температура) и ремиссии, возможно также развитие осложнений (кровотечение, токсическая дилатация, перфорация и др.)

- Диагностика основана на критериях и дифференциальной диагностике. По этой причине проводится ряд исследований (общий анализ кала, показатели воспаления, колоноскопия с биопсией, КТ и др.)

- К диагностическим критериям относятся длительная кровавая диарея (более 4-х недель), боли по всему животу, тенезмы, проктит и колит на колоноскопии, показатели воспаления на биопсии и исключение колита другой этиологии.

- Основным методом лечения язвенного колита является консервативный, который предусматривает купирование острых явлений заболевания (индукционная терапия) и профилактику его рецидивов (постоянная терапия). При развитии осложнений показано хирургическое лечение.

\section{Вопросы и ответы по воспалительным заболеваниям толстого кишечника}

\begin{tabular}{|ll|}
\multicolumn{1}{c}{ Вопросы } & \multicolumn{2}{c|}{ Ответы } \\
\hline $\begin{array}{l}\text { Что представляют собой } \\
\text { воспалительные заболевания } \\
\text { кишечника? }\end{array}$ & $\begin{array}{l}\text { Воспалительные процессы желудочно- } \\
\text { кишечного } \\
\text { этиологии. }\end{array}$ \\
\hline $\begin{array}{l}\text { Что относится к воспалительным } \\
\text { заболеваниям кишечника? }\end{array}$ & $\begin{array}{l}\text { Болезнь Крона и неспецифический } \\
\text { язвенный колит. }\end{array}$ \\
\hline
\end{tabular}




\begin{tabular}{|c|c|}
\hline Вопросы & Ответы \\
\hline Другое название болезни Крона: & $\begin{array}{l}\text { Регионарный энтерит, терминальный } \\
\text { илеит. }\end{array}$ \\
\hline $\begin{array}{l}\text { Что является причиной } \\
\text { воспалительных заболеваний } \\
\text { кишечника? }\end{array}$ & $\begin{array}{l}\text { Этиология неизвестна. Предполагают } \\
\text { роль внешних (экологических) факторов } \\
\text { и аутоиммунных процессов. }\end{array}$ \\
\hline $\begin{array}{l}\text { С какими заболеваниями следуют } \\
\text { проводить дифференциальную } \\
\text { диагностику? }\end{array}$ & $\begin{array}{l}\text { Болезнь Крона следует } \\
\text { дифференцироватьс неспецифическим } \\
\text { язвенным колитом, инфекционным } \\
\text { колитом, синдромом раздражённой } \\
\text { толстой кишки, дивертикулитом, } \\
\text { карциноидным синдромом, раком } \\
\text { толстой кишки и синдромом } \\
\text { Золлингера-Эллисона. }\end{array}$ \\
\hline $\begin{array}{l}\text { Что относится к внекишечным } \\
\text { проявлениям воспалительных } \\
\text { заболеваний кишечника? }\end{array}$ & $\begin{array}{l}\text { Анкилозирующий спондилит, афтозные } \\
\text { язвы (оральные язвы), иридоциклит, } \\
\text { гангренозная пиодермия, узловатая } \\
\text { эритема, склерозирующий холангит, } \\
\text { артрит, заболевания } \\
\text { (нефротический синдром, амилоидоз). }\end{array}$ \\
\hline
\end{tabular}

Частота встречаемости болезни Крона: 2-9/100000.

Частота встречаемости

неспецифического язвенного колита:

Какая популяция является группой риска для болезни Крона и язвенного колита?

Распространённость болезни Крона в Женщины > мужчины. зависимости от пола:

Распространённость язвенного колита Мужчины > женщины. в зависимости от пола:

10/100000.

Население семейный анамнез. средиземноморского региона, в 20\% случаев наблюдается 


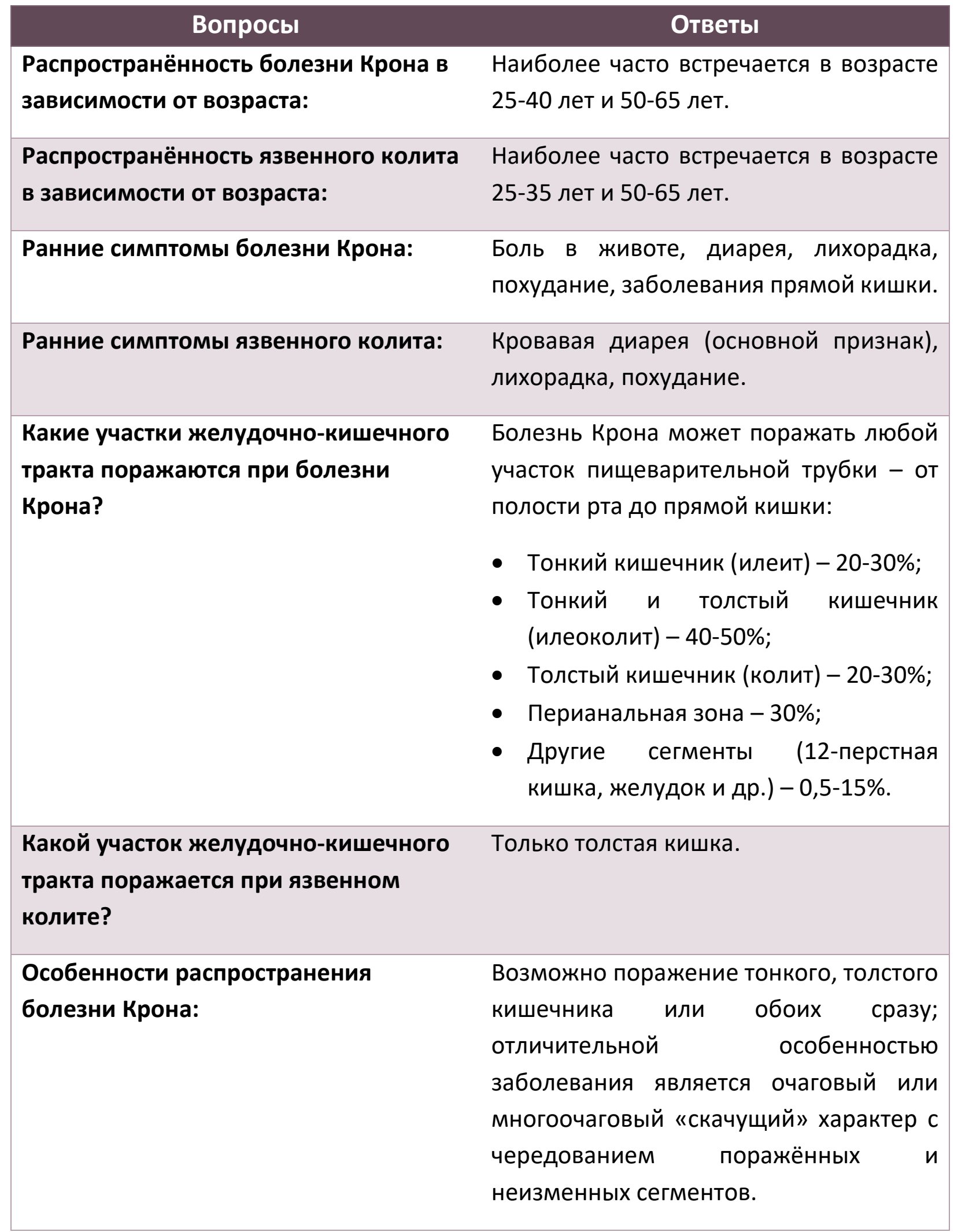




\begin{tabular}{|c|c|}
\hline Вопросы & Ответы \\
\hline $\begin{array}{l}\text { Особенности распространения } \\
\text { неспецифического язвенного колита: }\end{array}$ & $\begin{array}{l}\text { Процесс локализуется в основном в } \\
\text { прямой кишке и распространяется в } \\
\text { проксимальном направлении. }\end{array}$ \\
\hline Что такое “рефлюкс-илеит”? & $\begin{array}{l}\text { При язвенном колите происходит } \\
\text { поражение и терминального отдела } \\
\text { подвздошной кишки в связи с } \\
\text { нарушением иммунной системы тонкой } \\
\text { кишки. }\end{array}$ \\
\hline $\begin{array}{l}\text { Особенность поражения кишечной } \\
\text { стенки при болезни Крона: }\end{array}$ & $\begin{array}{l}\text { Характерно повреждение всех слоёв } \\
\text { кишечной стенки (трансмуральное } \\
\text { поражение). }\end{array}$ \\
\hline $\begin{array}{l}\text { Особенность поражения кишечной } \\
\text { стенки при язвенном колите: }\end{array}$ & $\begin{array}{l}\text { Поражается лишь слизистый } \\
\text { подслизистый слой. }\end{array}$ \\
\hline $\begin{array}{l}\text { Поражение анальной области при } \\
\text { болезни Крона: }\end{array}$ & $\begin{array}{l}\text { Составляет } 30 \% \text { и характеризуется } \\
\text { формированием абсцесса, свищей, } \\
\text { трещин, язв. }\end{array}$ \\
\hline $\begin{array}{l}\text { Поражение анальной области при } \\
\text { язвенном колите: }\end{array}$ & Встречается редко. \\
\hline $\begin{array}{l}\text { Поражение прямой кишки при } \\
\text { болезни Крона: }\end{array}$ & Наблюдается редка. \\
\hline $\begin{array}{l}\text { Поражение прямой кишки при } \\
\text { язвенном колите: }\end{array}$ & $100 \%$. \\
\hline $\begin{array}{l}\text { Особенность морфологических } \\
\text { изменений в слизистой оболочке при } \\
\text { болезни Крона: }\end{array}$ & $\begin{array}{l}\text { - Афтозные язвы; } \\
\text { - Гранулёма; } \\
\text { - Линейные язвы; } \\
\text { - Поперечные трещины; } \\
\text { - Отёк слизистой; } \\
\text { - Полное поражение - утолщение } \\
\quad \text { кишечной стенки. }\end{array}$ \\
\hline
\end{tabular}




\begin{tabular}{|c|c|}
\hline Вопросы & Ответы \\
\hline $\begin{array}{l}\text { Особенность морфологических } \\
\text { изменений в слизистой оболочке при } \\
\text { язвенном колите: }\end{array}$ & $\begin{array}{l}\text { - «Зернистая» слизистая оболочка; } \\
\text { - Язвы; } \\
\text { - Микроабсцессы в криптах; } \\
\text { - Расширение сосудов слизистой; } \\
\text { - Псевдополипоз. }\end{array}$ \\
\hline $\begin{array}{l}\text { Какие исследования необходимы для } \\
\text { диагностики болезни Крона? }\end{array}$ & $\begin{array}{l}\text { Колоноскопия с биопсией, КТ, анализ } \\
\text { кала. }\end{array}$ \\
\hline $\begin{array}{l}\text { Какие исследования необходимы для } \\
\text { диагностики неспецифического } \\
\text { язвенного колита? }\end{array}$ & $\begin{array}{l}\text { Колоноскопия с биопсией, КТ, анализ } \\
\text { кала. }\end{array}$ \\
\hline Осложнения болезни Крона: & 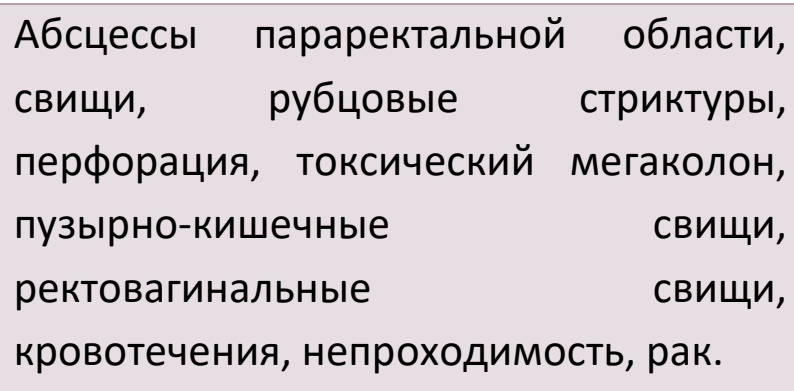 \\
\hline $\begin{array}{l}\text { Осложнения неспецифического } \\
\text { язвенного колита: }\end{array}$ & $\begin{array}{l}\text { Рак, токсический } \\
\text { перфорация толстого мегаколон, } \\
\text { кровотечения, } \\
\text { непроходимость. }\end{array}$ \\
\hline $\begin{array}{l}\text { Чем объясняется частое развитие } \\
\text { абсцессов и свищей при болезни } \\
\text { Крона по сравнению с язвенным } \\
\text { колитом? }\end{array}$ & $\begin{array}{l}\text { Трансмуральное поражение кишечной } \\
\text { стенки характерно для болезни Крона. } \\
\text { Язвенный колит характеризуется } \\
\text { поражением слизистой оболочки } \\
\text { толстой кишки. }\end{array}$ \\
\hline $\begin{array}{l}\text { Степень риска развития рака при } \\
\text { болезни Крона: }\end{array}$ & $\begin{array}{l}\text { Незначительная; наблюдается на } \\
\text { участках анастомоза кишечника. }\end{array}$ \\
\hline $\begin{array}{l}\text { Степень риска развития рака при } \\
\text { язвенном колите: }\end{array}$ & $\begin{array}{l}\text { В течение } 10 \text { лет наблюдается в 5\% } \\
\text { случаев, в последующие годы риск } \\
\text { повышается на } 1 \% \text {. }\end{array}$ \\
\hline
\end{tabular}




\begin{tabular}{|c|c|}
\hline Вопросы & Ответы \\
\hline $\begin{array}{l}\text { Как часто болезнь Крона осложняется } \\
\text { токсическим мегаколоном? }\end{array}$ & Примерно в 5\% случаев. \\
\hline $\begin{array}{l}\text { Как часто язвенный колит } \\
\text { осложняется токсическим мегако- } \\
\text { лоном? }\end{array}$ & Примерно в 10\% случаев. \\
\hline $\begin{array}{l}\text { Тактика при невозможности } \\
\text { дифференциации болезни Крона и } \\
\text { язвенного колита: }\end{array}$ & $\begin{array}{l}\text { Такое состояние принимается за } \\
\text { «смешанный колит» и проводится } \\
\text { лечение воспалительного заболевания } \\
\text { толстой кишки. }\end{array}$ \\
\hline $\begin{array}{l}\text { Показания к операции при болезни } \\
\text { Крона: }\end{array}$ & $\begin{array}{l}\text { Кишечная непроходимость, профузное } \\
\text { кровотечение, свищи, перфорация, } \\
\text { риск развития рака, абсцесс, } \\
\text { неэффективность консервативного } \\
\text { лечения, токсический мегаколон, } \\
\text { стриктуры, дисплазия. }\end{array}$ \\
\hline $\begin{array}{l}\text { Показания к операции при язвенном } \\
\text { колите: }\end{array}$ & $\begin{array}{l}\text { Токсический мегаколон, профузное } \\
\text { кровотечение, отставание в развитии, } \\
\text { перфорация толстой кишки на фоне } \\
\text { стероидной терапии, неэффективность } \\
\text { консервативного лечения. }\end{array}$ \\
\hline $\begin{array}{l}\text { Какая операция является более } \\
\text { адекватной при язвенном колите? }\end{array}$ & 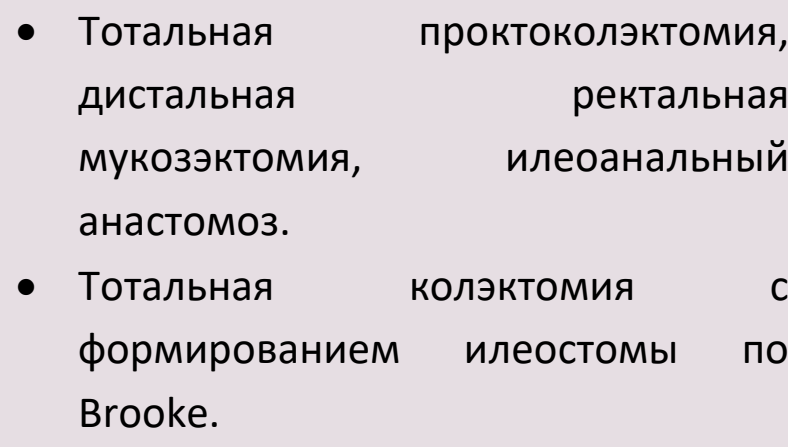 \\
\hline Что такое “токсический мегаколон”? & $\begin{array}{l}\text { Токсический пациент: сепсис, высокая } \\
\text { температура, боль в животе. }\end{array}$ \\
\hline
\end{tabular}




\begin{tabular}{|c|c|}
\hline Вопросы & Ответы \\
\hline & $\begin{array}{l}\text { Мегаколон: острое и массивное } \\
\text { расширение толстой кишки. }\end{array}$ \\
\hline Псевдополипоз обнаруживается: & $\begin{array}{l}\text { При колоноскопии у пациентов с } \\
\text { язвенным колитом: участки } \\
\text { гипертрофированной } \\
\text { толстого кишечника. }\end{array}$ \\
\hline $\begin{array}{l}\text { У каких пациентов при клизме с } \\
\text { контрастом (бариевая взвесь) просвет } \\
\text { кишки напоминает “свинцовый } \\
\text { столб”? }\end{array}$ & $\begin{array}{l}\text { У пациентов с хроническим язвенным } \\
\text { колитом. }\end{array}$ \\
\hline $\begin{array}{l}\text { Ректальное кровотечение и кровавая } \\
\text { диарея - основной признак: }\end{array}$ & $\begin{array}{l}\text { Неспецифического язвенного колита } \\
\text { (при болезни Крона встречаются редко). }\end{array}$ \\
\hline $\begin{array}{l}\text { Какие препараты используются для } \\
\text { консервативного лечения } \\
\text { воспалительных заболеваний толстой } \\
\text { кишки? }\end{array}$ & $\begin{array}{l}\text { - Аминосалицилаты (сульфасалазин, } \\
\text { месалазин); } \\
\text { - Иммуносупрессоры: азатиоприн, } \\
\text { стероидные препараты } \\
\text { (преднизолон, гидрокортизон, } \\
\text { будесонид); } \\
\text { - Антибиотики (ципрофлоксацин, } \\
\text { метронидазол); } \\
\text { - Инфликсимаб. }\end{array}$ \\
\hline Что такое инфликсимаб? & $\begin{array}{l}\text { Антитела против фактора некроза } \\
\text { опухоли (TNF). }\end{array}$ \\
\hline $\begin{array}{l}\text { Что является активным метаболитом } \\
\text { сульфасалазина? }\end{array}$ & $\begin{array}{l}\text { 5-аминосалицилат, } \\
\text { всасывается в толстой кишке. }\end{array}$ \\
\hline $\begin{array}{l}\text { Препарат, используемый для лечения } \\
\text { перианальных проявлений болезни } \\
\text { Крона: }\end{array}$ & Метронидазол. \\
\hline
\end{tabular}




\begin{tabular}{|c|c|}
\hline Вопросы & Ответы \\
\hline $\begin{array}{l}\text { Препарат, используемый для } \\
\text { достижения длительного периода } \\
\text { ремиссии у больных с } \\
\text { воспалительными заболеваниями } \\
\text { толстой кишки: }\end{array}$ & $\begin{array}{l}\text { 6-меркаптопурин, } \\
\text { месалазин. }\end{array}$ \\
\hline $\begin{array}{l}\text { Препарат, используемый при } \\
\text { обострении воспалительных } \\
\text { заболеваний толстой кишки: }\end{array}$ & Месалазин и/или стероиды. \\
\hline $\begin{array}{l}\text { Что необходимо назначить при } \\
\text { рефрактерной реакции к стероидной } \\
\text { терапии? }\end{array}$ & $\begin{array}{l}\text { Иммуносупрессанты, инфликсимаб или } \\
\text { хирургическое лечение. }\end{array}$ \\
\hline $\begin{array}{l}\text { Как отличаются азатиоприн и } \\
\text { инфликсимаб по эффективности? }\end{array}$ & $\begin{array}{l}\text { Инфликсимаб оказывает раннее } \\
\text { действие (в первые сутки), действие } \\
\text { азатиоприна отличается более поздним } \\
\text { эффектом (через недели). }\end{array}$ \\
\hline $\begin{array}{l}\text { В чём заключается отличительная } \\
\text { особенность медикаментозной } \\
\text { терапии язвенного колита? }\end{array}$ & $\begin{array}{l}\text { Клизмы с использованием стероидных } \\
\text { препаратов и 5-аминосалицилатов. }\end{array}$ \\
\hline $\begin{array}{l}\text { Что является основным показанием к } \\
\text { операции при болезни Крона? }\end{array}$ & $\begin{array}{l}\text { Рубцовая стриктура (обструкция) } \\
\text { тонкой кишки. }\end{array}$ \\
\hline $\begin{array}{l}\text { Что обнаруживается во время } \\
\text { операции, выполняемой по поводу } \\
\text { болезни Крона? }\end{array}$ & $\begin{array}{l}\text { Утолщение, } \\
\text { изменения стенки тонкой кишки, } \\
\text { укорочение брыжейки тонкой кишки, } \\
\text { наличие свищей и абсцессов. }\end{array}$ \\
\hline $\begin{array}{l}\text { Какую операцию выполняют при } \\
\text { сегментарных стриктурах тонкой } \\
\text { кишки при болезни Крона? }\end{array}$ & $\begin{array}{l}\text { Стриктуропластику (над участком } \\
\text { фиброзной стриктуры производят } \\
\text { продольный разрез и просвет кишки } \\
\text { восстанавливают поперечным швом). }\end{array}$ \\
\hline
\end{tabular}


Вопросы

Что является препаратом выбора для раннего лечения свищей у больных с болезнью Крона?

дренирование, резекция поражённого сегмента кишки.

Показана ли аппендэктомия во время лапаротомии, предпринятой по поводу острого живота, если обнаружена болезнь Крона?

Если нет поражения слепой кишки допустима. Если имеется выраженный илеоколит на фоне болезни Крона, то показана правосторонняя гемиколэктомия.

Что такое поушит?
Нужна ли срочная биопсия краёв
поражённого сегмента тонкой кишки
при резекции по причине болезни
Крона?

Как называется состояние, когда все Воспаление илеоанального мешочка (для лечения назначают метронидазол).

Необходимости нет. Резекцию надо проводить в пределах 2 см от визуально определяемой границы здоровых участков кишки.

Панколит.

сегменты толстой кишки вовлечены В воспалительный процесс?

Необходима ли противорецидивная терапия после операций, выполняемых по поводу болезни Крона?
Этот вопрос остаётся дискуссионным. Большинство авторов рекомендуют проведение лечения в течение 3-12 месяцев с назначением антибиотиков. 


\section{Вопросы и ответы по псевдомембранозному колиту}

\begin{tabular}{|c|c|}
\hline Вопросы & Ответы \\
\hline $\begin{array}{l}\text { Что такое псевдомембранозный } \\
\text { колит? }\end{array}$ & $\begin{array}{l}\text { Колит, развивающийся после } \\
\text { длительной антибиотикотерапии. }\end{array}$ \\
\hline Этиология и факторы риска: & $\begin{array}{l}\text { - } \text { Антибиотикотерапия; } \\
\text { - Приём антидепрессантов, } \\
\text { ингибиторов протонной помпы; } \\
\text { - Приём противоопухолевых } \\
\text { препаратов (метотрексат); } \\
\text { - Гемолитический (уремический) } \\
\text { синдром; } \\
\text { - Ишемия кишечника; } \\
\text { - Хроническая почечная } \\
\text { недостаточность. }\end{array}$ \\
\hline $\begin{array}{l}\text { Патогенез псевдомембранозного } \\
\text { колита: }\end{array}$ & 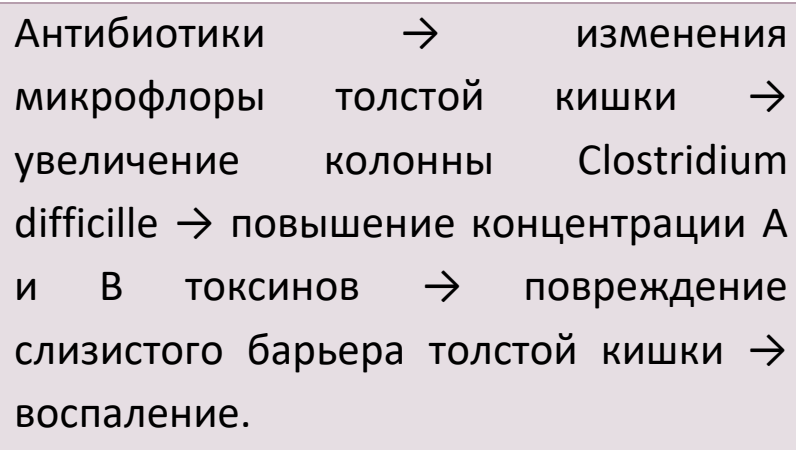 \\
\hline Осложнения: & $\begin{array}{l}\text { - Фульминантная (молниеносная) } \\
\text { форма клинического течения; } \\
\text { - Токсический мегаколон; } \\
\text { - Перфорация толстой кишки. }\end{array}$ \\
\hline Клинические признаки: & $\begin{array}{l}\text { - Диарея; } \\
\text { - Боли в животе; } \\
\text { - Общая слабость; } \\
\text { - Потеря аппетита; } \\
\text { - Субфебрильная температура; } \\
\text { - Тошнота. }\end{array}$ \\
\hline
\end{tabular}




\begin{tabular}{|c|c|}
\hline $\begin{array}{l}\text { У каких пациентов можно } \\
\text { заподозрить псевдомембранозный } \\
\text { колит? }\end{array}$ & $\begin{array}{l}\text { - Наличие в анамнезе приём } \\
\text { антибиотиков в течение последних } 3 \\
\text { месяцев; } \\
\text { - Наблюдение диареи при } \\
\text { поступлении в стационар или спустя } \\
48 \text { часов после госпитализации. }\end{array}$ \\
\hline Диагностика: & $\begin{array}{l}\text { - Анамнестические данные; } \\
\text { - Клинические обследования; } \\
\text { - Анализ кала (цитотоксический, } \\
\text { копрологический тест, } \\
\text { полимеразноцепная реакция); } \\
\text { - Ректороманоскопия или } \\
\text { фибросигмоидоскопия; } \\
\text { - Рентгенография; } \\
\text { - КТ. }\end{array}$ \\
\hline Лабораторные признаки: & $\begin{array}{l}\text { - Обнаружение в кале токсинов А и В; } \\
\text { - Лейкоцитоз, повышение } \\
\text { креатинина, гипоальбуминемия. }\end{array}$ \\
\hline $\begin{array}{l}\text { Признаки инструментальной } \\
\text { визуализации: }\end{array}$ & $\begin{array}{l}\text { - При ректороманоскопии и } \\
\text { сигмоидоскопии выявляются } \\
\text { наличие узлов жёлтого цвета } \\
\text { диаметром 2-10 мм. } \\
\text { - При контрастной рентгенографии - } \\
\text { утолщение слизистой оболочки, } \\
\text { отсутствие гаустрации, токсический } \\
\text { мегаколон, перфорация толстой } \\
\text { кишки. }\end{array}$ \\
\hline Методы лечения: & $\begin{array}{l}\text { При отсутствии } \\
\text { консервативное } \\
\text { метронидазол, } \\
\text { рифаксимин; }\end{array}$ \\
\hline
\end{tabular}




\begin{tabular}{|c|c|}
\hline & $\begin{array}{l}\text { - При возникновении осложнений и } \\
\text { неэффективности медикаментозной } \\
\text { терапии - хирургическое лечение. }\end{array}$ \\
\hline Показания к оперативному лечению: & $\begin{array}{l}\text { - Молниеносное (фульминантное) } \\
\text { течение; } \\
\text { - Токсическая дилатация толстой } \\
\text { кишки; } \\
\text { - Перфорация толстой кишки; } \\
\text { - Безуспешность консевативного } \\
\text { лечения. }\end{array}$ \\
\hline Методы оперативных вмешательств: & $\begin{array}{l}\text { Тотальная } \quad \text { колэктомия } \\
\text { формированием илеостомы. }\end{array}$ \\
\hline
\end{tabular}

\section{Вопросы и ответы по ишемическому колиту}

\begin{tabular}{|c|c|}
\hline Вопросы & Ответы \\
\hline Что такое ишемический колит? & $\begin{array}{l}\text { Колит, развивающийся в результате } \\
\text { нарушения кровоснабжения толстой } \\
\text { кишки. }\end{array}$ \\
\hline Частота встречаемости: & $\begin{array}{l}\text { Обычно поражается селезёночный } \\
\text { изгиб ободочной кишки, реже - прямая } \\
\text { кишка. }\end{array}$ \\
\hline Причины: & $\begin{array}{l}\text { - Окклюзия мелких сосудов; } \\
\text { - Перевязка нижней брыжеечной } \\
\text { артерии во время операции; } \\
\text { - Тромбоз и эмболия. }\end{array}$ \\
\hline Факторы риска: & $\begin{array}{l}\text { - Сосудистые заболевания; } \\
\text { - Сахарный диабет; } \\
\text { - Гипотензия; } \\
\text { - Курение. }\end{array}$ \\
\hline
\end{tabular}




\begin{tabular}{|c|c|}
\hline Осложнения: & Ишемический некроз, перитонит. \\
\hline Клинические признаки: & $\begin{array}{l}\text { - Диарея (часто кровавая); } \\
\text { - Упорный болевой синдром; } \\
\text { - Тошнота; } \\
\text { - Высокая температура. }\end{array}$ \\
\hline $\begin{array}{l}\text { Какие методы исследования } \\
\text { необходимы для уточнения диагноза? }\end{array}$ & $\begin{array}{l}\text { - Анамнестические данные; } \\
\text { - Клиническое обследование; } \\
\text { - Рентгенография; } \\
\text { - КТ; } \\
\text { - Ангиография; } \\
\text { - Сигмоидоскопия. }\end{array}$ \\
\hline Лабораторные признаки: & Высокий лейкоцитоз. \\
\hline \multirow[t]{3}{*}{$\begin{array}{l}\text { Признаки инструментальной } \\
\text { визуализации: }\end{array}$} & $\begin{array}{l}\text { Рентгенография - дилатация толстой } \\
\text { кишки, отёк гаустр. }\end{array}$ \\
\hline & $\begin{array}{l}\text { кт - утолщение стенок кишки, } \\
\text { сосудистые изменения. }\end{array}$ \\
\hline & $\begin{array}{l}\text { Сигмоидоскопия - геморрагическое } \\
\text { окрашивание слизистой толстой кишки. }\end{array}$ \\
\hline Методы лечения: & $\begin{array}{l}\text { - Дробный приём пищи; } \\
\text { - Антибиотики широкого спектра } \\
\text { действия; } \\
\text { - Коррекция кровоснабжения } \\
\text { кишечной стенки } \\
\text { - Хирургическое лечение. }\end{array}$ \\
\hline Показания к операции: & $\begin{array}{l}\text { - Отсутствие эффекта } \\
\text { консервативного лечения, } \\
\text { проведённого в течение 2-3 дней; } \\
\text { - Прогрессирование клинической } \\
\begin{array}{l}\text { картины. }\end{array}\end{array}$ \\
\hline
\end{tabular}




$\begin{array}{ll}\text { Методы оперативного лечения: } & \begin{array}{l}\text { Резекция некротически изменённого } \\ \text { сегмента кишки. }\end{array} \\ \text { Прогноз: } & \text { При развитии инфаркта кишки } \\ & \text { летальность возрастет. }\end{array}$

\section{Вопросы и ответы по инфекционному колиту}

\begin{tabular}{|ll|}
\hline \multicolumn{1}{|c|}{ Вопросы } & \multicolumn{1}{c|}{ Ответы } \\
\hline Что такое инфекционный колит? & Инфекционное воспаление толстой \\
& кишки, вызванное бактериями, \\
& вирусами и паразитами. \\
\hline Частота встречаемости: & Наиболее часто встречается у детей в \\
& возрасте до 1 года. \\
\hline Причины и факторы риска: & - Shigella; \\
& - Salmonella; \\
& - Campylobacter; \\
& - Yersinia; \\
& - Sitomeqalovirus; \\
& - Entamoebia hystolitica; \\
& - Balantidinm coli. \\
& - Дегидратация; \\
& - Судороги (часто у детей); \\
\hline Осложнения: & Кровотечение; \\
& - Токсическая дилатация толстой \\
& кишки. \\
\hline Клинические признаки: & - Диарея (водянистая или кровавая); \\
& Боль; \\
\hline
\end{tabular}




\begin{tabular}{|ll|}
\hline \multicolumn{1}{|c|}{ Вопросы } & \multicolumn{1}{c|}{ Ответы } \\
\hline $\begin{array}{l}\text { Какие методы исследования } \\
\text { необходимы для уточнения диагноза? }\end{array}$ & $\begin{array}{l}\text { • } \\
\text { Мысокая температура. }\end{array}$ \\
\hline Методы леченогическое исследование кала; & Консервативное \\
& (этиопатогенетическое). \\
\hline
\end{tabular}

\section{Вопросы и ответы по спастическому колиту}

\begin{tabular}{|c|c|}
\hline Вопросы & Ответы \\
\hline Что такое спастический колит? & $\begin{array}{l}\text { Функциональное } \\
\text { характеризующееся } \\
\text { сокращением толстого кишечника. }\end{array}$ \\
\hline Клинические варианты заболевания: & $\begin{array}{l}\text { - } \quad \text { IBS-D - с преобладанием диареи; } \\
\text { - IBS-C - с преобладанием запора; } \\
\text { - IBS-M - смешанная форма; } \\
\text { - IBS-U - неклассифицируемая форма. }\end{array}$ \\
\hline Клинические признаки: & $\begin{array}{l}\text { - Боли в животе и вздутие; } \\
\text { - Уменьшение болей } \\
\text { дефекации; } \\
\text { - Чередование запора с поносом; } \\
\text { - Диспепсические расстройства } \\
\text { (тошнота, отрыжка, рвота); } \\
\text { - Иногда субфебрильная температура. }\end{array}$ \\
\hline $\begin{array}{l}\text { У каких пациентов можно } \\
\text { заподозрить? }\end{array}$ & $\begin{array}{l}\text { - Беспричинная потеря веса; } \\
\text { - Железодефицитная анемия; } \\
\text { - Семейная предрасположенность. }\end{array}$ \\
\hline
\end{tabular}




\begin{tabular}{|c|c|}
\hline Вопросы & Ответы \\
\hline $\begin{array}{l}\text { Какие методы исследования } \\
\text { необходимы для уточнения диагноза? }\end{array}$ & $\begin{array}{l}\text { - Бактериоскопия кала (для } \\
\text { исключения инфекционного колита); } \\
\text { - КТ/МРТ - для исключения опухолей } \\
\text { толстой кишки. }\end{array}$ \\
\hline Методы лечения: & $\begin{array}{l}\text { Консервативное } \\
\text { антихолинергические, } \\
\text { противодиарейные препараты и др. }\end{array}$ \\
\hline
\end{tabular}




\section{ДИВЕРТИКУЛЫ И ДИВЕРТИКУЛИТ ТОЛСТОЙ КИШКИ}

- Дивертикул представляет собой мешковидное выпячивание одного или всех слоёв стенки толстой кишки.

○ Дивертикулёз - множественные дивертикулы.

○ Дивертикулёз в большинстве случаев не проявляется какими-либо клиническими признаками, локализуется в левой половине толстого кишечника, в редких случаях осложняется дивертикулитом и кровотечением.

○ Диагностика дивертикулёза основывается на результатах радиологического и эндоскопического (колоноскопия) исследований.

○ В случае отсутствия осложнений лечение не требуется.

- Дивертикулит - воспаление дивертикула толстого кишечника.

○ Дивертикулит может характеризоваться от слабой воспалительной инфильтрации вплоть до абсцесса и тяжёлого калового перитонита, осложнённого непроходимостью и образованием свищей.

○ Диагностика дивертикулита основана на клинических, лабораторных данных и результатах КТ.

О К диагностическим критериям относятся острый живот (боль в животе, напряжённость передней брюшной стенки, инфильтрат, абсцесс, перитонит), лейкоцитоз, повышение С-реактивного белка, утолщение стенки кишки, параколическая инфильтрация, наличие жидкости в брюшной полости, признаков перфорации на КТ (свободный газ в брюшной полости, экстравазация контрастного вещества).

○ Лечение неосложнённого дивертикулита - консервативное. При возникновении осложнений (абсцесс, перитонит, непроходимость) возникает необходимость в хирургическом лечении (чрескожное дренирование, резекция, операция по Гартману).

\section{Вопросы и ответы по дивертикулам и дивертикулиту толстой кишки}

\begin{tabular}{|c|c|}
\hline Вопросы & Oтветы \\
\hline Что такое дивертикул? & $\begin{array}{l}\text { Мешковидное выпячивание одного или } \\
\text { всех слоёв стенки толстой кишки. }\end{array}$ \\
\hline
\end{tabular}




\begin{tabular}{|c|c|}
\hline Вопросы & Ответы \\
\hline $\begin{array}{l}\text { Что представляют собой истинный и } \\
\text { ложный дивертикулы? }\end{array}$ & $\begin{array}{l}\text { Истинный дивертикул - выпячивание } \\
\text { всех слоёв стенки кишки. Ложный } \\
\text { дивертикул - выпячивание через } \\
\text { дефект в мышечной оболочке кишки } \\
\text { только слизистого и подслизистого } \\
\text { слоёв. }\end{array}$ \\
\hline $\begin{array}{l}\text { Какие виды дивертикулов наиболее } \\
\text { часто встречаются? }\end{array}$ & $\begin{array}{l}\text { Истинные дивертикулы встречаются } \\
\text { редко. Наиболее часто встречаются } \\
\text { ложные дивертикулы. }\end{array}$ \\
\hline Что такое дивертикулёз? & Множественные дивертикулы. \\
\hline Частота встречаемости: & $\begin{array}{l}\text { Составляют 10-65\% в общей популяции. } \\
\text { С возрастом имеет тенденцию к } \\
\text { увеличению. }\end{array}$ \\
\hline $\begin{array}{l}\text { Частая локализация дивертикулов } \\
\text { толстой кишки: }\end{array}$ & $\begin{array}{l}\text { У } 90 \% \text { пациентов локализуются в } \\
\text { сигмовидной кишке. }\end{array}$ \\
\hline Факторы риска: & $\begin{array}{l}\text { Употребление пищи, бедной } \\
\text { клетчаткой, хронический запор, } \\
\text { наличие дивертикулёза в семейном } \\
\text { анамнезе, возрастной фактор. }\end{array}$ \\
\hline Патогенез: & $\begin{array}{l}\text { Слабыми местами кишечной стенки } \\
\text { являются участки, где сосуды } \\
\text { проникают в стенку кишки. При } \\
\text { повышении внутрикишечного давления } \\
\text { происходит выпячивание кишечной } \\
\text { стенки в указанных зонах. }\end{array}$ \\
\hline Осложнения: & $\begin{array}{lr}\text { В 20\% наблюдений } & \text { осложняются } \\
\text { дивертикулитом, } & \text { кровотечением, } \\
\text { перфорацией } \\
\text { непроходимостью. }\end{array}$ \\
\hline
\end{tabular}




\begin{tabular}{|c|c|}
\hline Вопросы & Ответы \\
\hline $\begin{array}{l}\text { Является ли дивертикул предраковым } \\
\text { заболеванием? }\end{array}$ & Нет. \\
\hline Клинические признаки: & $\begin{array}{lrr}\text { У } 80 \% \text { пациентов } & \text { протекает } \\
\text { бессимптомно. } & \text { При } & \text { развитии } \\
\text { осложнений } & \text { наблюдаются } \\
\text { кровотечение, } & \text { дивертикулит, } \\
\text { непроходимость. } & \end{array}$ \\
\hline Диагностика: & $\begin{array}{l}\text { Контрастные исследования, } \\
\text { колоноскопия. }\end{array}$ \\
\hline Лечение: & $\begin{array}{l}\text { При бессимптомном течении лечение } \\
\text { не требуется. При устранении запоров } \\
\text { можно предотвратить развитие } \\
\text { осложнений, однако полностью } \\
\text { устранить дивертикулы невозможно. }\end{array}$ \\
\hline $\begin{array}{l}\text { Показания к операции при } \\
\text { дивертикулёзе: }\end{array}$ & $\begin{array}{l}\text { Развитие осложнений (дивертикулит, } \\
\text { кровотечение), рецидив осложнений, } \\
\text { невозможность дифференциации от } \\
\text { рака. }\end{array}$ \\
\hline Что такое дивертикулит? & $\begin{array}{lrr}\text { Воспаление дивертикулита } & \text { и его } \\
\text { перфорация } & \text { (микро- } & \text { и } \\
\text { макроперфорации). } & & \end{array}$ \\
\hline Патогенез: & $\begin{array}{l}\text { В результате закупорки дивертикула } \\
\text { каловыми камнями возникает застой } \\
\text { (внутрипросветная гипертензия, } \\
\text { ишемия стенки, воспаление, инфекция, } \\
\text { перфорация стенки кишки). }\end{array}$ \\
\hline Клиническое течение и осложнения: & 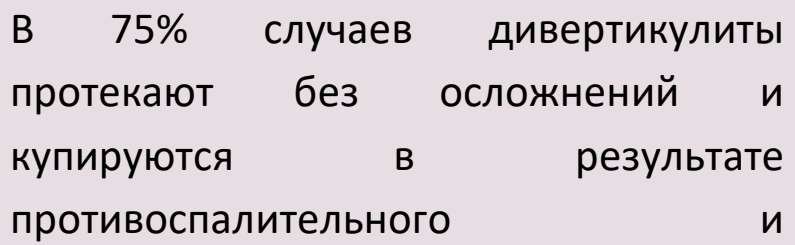 \\
\hline
\end{tabular}




\begin{tabular}{|c|c|}
\hline Вопросы & Ответы \\
\hline & $\begin{array}{lr}\text { антибактериального } & \text { лечения. У } 25 \% \\
\text { пациентов } & \text { дивертикулиты } \\
\text { сопровождаются } & \text { развитием } \\
\text { осложнений } & \text { (параколическая } \\
\text { флегмона, абсцесс, перитонит, свищи, } \\
\text { непроходимость). }\end{array}$ \\
\hline $\begin{array}{l}\text { Чем объясняется развитие } \\
\text { осложнений при дивертикулите? }\end{array}$ & $\begin{array}{l}\text { Возникновение осложнений зависит от } \\
\text { размеров дивертикула и реактивности } \\
\text { организма. Микроперфорации обычно } \\
\text { ограничиваются соседними органами и } \\
\text { закрываются без осложнений. Прорыв } \\
\text { гнойного дивертикулита в просвет } \\
\text { кишки заканчивается выздоровлением. } \\
\text { Перфорации дивертикула больших } \\
\text { размеров способствует развитию } \\
\text { перитонита и абсцесса брюшной } \\
\text { полости. }\end{array}$ \\
\hline $\begin{array}{l}\text { Хронические осложнения } \\
\text { дивертикулита: }\end{array}$ & $\begin{array}{l}\text { Внутренние и наружные свищи, } \\
\text { стриктуры просвета кишки. }\end{array}$ \\
\hline $\begin{array}{l}\text { Осложняется ли дивертикулит } \\
\text { массивным кровотечением? }\end{array}$ & $\begin{array}{l}\text { При одиночных дивертикулах } \\
\text { массивное кровотечение наблюдается } \\
\text { редко, оно характерно для } \\
\text { дивертикулёза. }\end{array}$ \\
\hline Клинические признаки: & $\begin{array}{l}\text { Боли в левой подвздошной области } \\
\text { (приступообразные), высокая } \\
\begin{array}{l}\text { температура, озноб, анорексия, } \\
\text { пальпация } \\
\text { образования, тошнота, рвота, дизурия. }\end{array}\end{array}$ \\
\hline Лабораторные признаки: & $\begin{array}{l}\text { Высокий лейкоцитоз, повышение } \\
\text { содержания С-реактивного белка. }\end{array}$ \\
\hline
\end{tabular}




\begin{tabular}{|c|c|}
\hline Вопросы & Ответы \\
\hline КТ признаки: & $\begin{array}{l}\text { Утолщение кишечной стенки, } \\
\text { параколическая инфильтрация, } \\
\text { абсцесс, экстравазация контрастного } \\
\text { вещества, наличие жидкости } \\
\text { брюшной полости, дивертикулёз. }\end{array}$ \\
\hline Показания к колоноскопии: & $\begin{array}{l}\text { При остром периоде дивертикулита } \\
\text { колоноскопия противопоказана в связи } \\
\text { с риском перфорации. Проводится } \\
\text { через 4-6 недель после купирования } \\
\text { острых явлений дивертикулита и для } \\
\text { исключения опухолей толстой кишки. }\end{array}$ \\
\hline $\begin{array}{l}\text { При каком варианте острого } \\
\text { дивертикулита показана } \\
\text { колоноскопия? }\end{array}$ & $\begin{array}{l}\text { При кровотечении, для уточнения } \\
\text { локализации и причины. }\end{array}$ \\
\hline $\begin{array}{l}\text { Показана ли ирригоскопия при } \\
\text { дивертикулите? }\end{array}$ & $\begin{array}{l}\text { В связи с риском перфорации при } \\
\text { дивертикулите } \\
\text { заполнение толстой кишки бариевой } \\
\text { смесью противопоказано. }\end{array}$ \\
\hline $\begin{array}{l}\text { Наиболее информативный метод } \\
\text { диагностики дивертикулита: }\end{array}$ & KT. \\
\hline $\begin{array}{l}\text { У каких больных можно заподозрить } \\
\text { наличие дивертикулита? }\end{array}$ & $\begin{array}{l}\text { При наличии болей в животе и высокой } \\
\text { температуры, пальпаторной } \\
\text { болезненности в левом нижнем } \\
\text { квадранте живота, признаков местного } \\
\text { воспаления, абсцесса, перитонита, } \\
\text { непроходимости, кишечно-пузырных, } \\
\text { ректовагинальных свищей. }\end{array}$ \\
\hline $\begin{array}{l}\text { Как верифицируют диагноз } \\
\text { дивертикулита? }\end{array}$ & $\begin{array}{l}\text { На основании клинико-лабораторных } \\
\text { (лейкоцитоз, повышение С-реактивного } \\
\text { белка) данных и КТ-признаков. }\end{array}$ \\
\hline
\end{tabular}




\begin{tabular}{|c|c|}
\hline Bonpocbl & Ответы \\
\hline $\begin{array}{l}\text { С какими заболеваниями необходимо } \\
\text { дифференцировать дивертикулит? }\end{array}$ & $\begin{array}{l}\text { Для дифференциации острого } \\
\text { дивертикулита с острым аппендицитом } \\
\text { необходима КТ. Для дифференциации с } \\
\text { раком толстой кишки, болезнью Крона } \\
\text { и ишемическим колитом после } \\
\text { купирования острых явлений } \\
\text { дивертикулита } \\
\text { колоноскопия с биопсией. }\end{array}$ \\
\hline Методы лечения: & $\begin{array}{l}\text { Консервативное } \\
\text { инфузионная терапия, функциональный } \\
\text { покой кишечника) и хирургическое } \\
\text { лечение. }\end{array}$ \\
\hline Показания к хирургическому лечению: & $\begin{array}{l}\text { Осложнения дивертикулита (абсцесс, } \\
\text { перитонит, свищи, непроходимость), } \\
\text { первичные случаи дивертикулита у } \\
\text { пациентов группы риска (молодой } \\
\text { возраст, диабет, } \\
\text { иммуносупрессия), } \\
\text { дифференциации с раком. }\end{array}$ \\
\hline $\begin{array}{l}\text { На что основывается выбор метода } \\
\text { лечения? }\end{array}$ & Степень тяжести дивертикулита. \\
\hline $\begin{array}{l}\text { Как проводят лечение при } \\
\text { дивертикулярном абсцессе? }\end{array}$ & $\begin{array}{l}\text { Вначале - консервативное лечение, } \\
\text { чрескожное дренирование. При } \\
\text { неэффективности консервативного } \\
\text { лечения, после стихания острых } \\
\text { явлений показана операция - резекция } \\
\text { сегмента кишки вместе с дивертикулом, } \\
\text { формирование анастомоза. }\end{array}$ \\
\hline $\begin{array}{l}\text { Почему нельзя проводить первичную } \\
\text { резекцию при дивертикулярном } \\
\text { абсцессе? }\end{array}$ & $\begin{array}{l}\text { В связи с опасностью возникновения } \\
\text { несостоятельности швов анастомоза. } \\
\text { Поэтому в таких случаях выполняют }\end{array}$ \\
\hline
\end{tabular}




\begin{tabular}{|c|c|}
\hline Вопросы & Ответы \\
\hline & $\begin{array}{l}\text { резекцию кишки с воспалительным } \\
\text { сегментом и формируют колостому. В } \\
\text { дальнейшем восстанавливают } \\
\text { непрерывность кишки. }\end{array}$ \\
\hline $\begin{array}{l}\text { Какую операцию выполняют при } \\
\text { дивертикулите, осложнённом } \\
\text { перитонитом? }\end{array}$ & $\begin{array}{l}\text { Наиболее оптимальным вариантом } \\
\text { операции является резекция кишки и } \\
\text { формирование колостомы по Гартману. } \\
\text { Через 2-3 месяца колостому } \\
\text { ликвидируют путём формирования } \\
\text { анастомоза. }\end{array}$ \\
\hline $\begin{array}{l}\text { Можно ли при дивертикулите, } \\
\text { осложнённом перитонитом, } \\
\text { формировать анастомоз после } \\
\text { резекции кишки? }\end{array}$ & 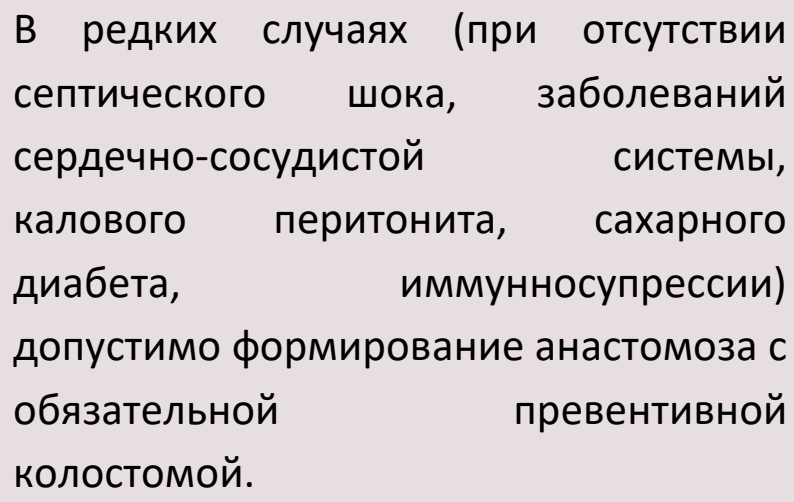 \\
\hline
\end{tabular}




\section{полипы толстой кишки}

- Полипы являются новообразованиями, исходящими из эпителия слизистой оболочки полых органов.

- Частая локализация гастроинтестинальных полипов - толстая и прямая кишки.

- Полипоз - множественные полипы

- Наследственный полипоз - наследственное заболевание, характеризующееся множественными полипами толстого кишечника.

- Полипы небольших размеров обычно протекают бессимптомно, однако при некрозе полипов наблюдается кровотечение, а при увеличении размеров могут возникнуть обструкция и малигнизация.

- Аденоматозные полипы и наследственный полипоз часто малигнизируются. Воспалительные и гиперпластические полипы же малигнизируются очень редко.

- Диагностика полипов осуществляется с помощью колоноскопии и биопсии.

- Лечение полипов заключается в эндоскопической полипэктомии: при обнаружении доброкачественных полипов показано наблюдение, а при злокачественных - возникает необходимость в дополнительной операции.

\section{Вопросы и ответы по полипам толстой кишки}

\begin{tabular}{|c|c|}
\hline Вопросы & Ответы \\
\hline Что такое полип? & $\begin{array}{l}\text { Новообразование, исходящая из } \\
\text { эпителия и свисающая в просвет кишки. }\end{array}$ \\
\hline Анатомические формы: & $\begin{array}{l}\text { Полипы на ножке, полипы без ножки (с } \\
\text { широким основанием, плоские). }\end{array}$ \\
\hline Гистологические формы: & $\begin{array}{l}\text { Неопластические, гиперпластические, } \\
\text { воспалительные, гамартоматозные. }\end{array}$ \\
\hline $\begin{array}{l}\text { При каких патологиях толстой кишки } \\
\text { встречаются воспалительные } \\
\text { полипы? }\end{array}$ & $\begin{array}{l}\text { При болезни } \text { Крона } \\
\text { неспецифическом язвенном колите. }\end{array}$ \\
\hline
\end{tabular}


Вопросы

Что такое гамартоматозные полипы?

\section{Ответы}

Состоят из нормальных тканей, но имеют бесформенную n нарушенную конфигурацию.

\section{Что такое гиперпластический полип? Имеют нормальное строение слизистой оболочки, малигнизируются очень редко.}

\begin{tabular}{|c|c|}
\hline Что такое неопластический полип? & $\begin{array}{l}\text { Пролиферация недифференцированных } \\
\text { клеток (предраковых или раковых). }\end{array}$ \\
\hline Виды неопластических полипов: & $\begin{array}{l}\text { - Тубулярная аденома; } \\
\text { - Виллёзная аденома; } \\
\text { • Тубуло-виллёзная аденома. }\end{array}$ \\
\hline $\begin{array}{l}\text { Чем определяется риск } \\
\text { малигнизации аденоматозных } \\
\text { полипов? }\end{array}$ & $\begin{array}{l}\text { Размерами, гистологической структурой, } \\
\text { атипией клеточных элементов, сроками } \\
\text { развития. }\end{array}$ \\
\hline $\begin{array}{l}\text { Наиболее распространенный вид } \\
\text { аденоматозных полипов: }\end{array}$ & Тубулярная аденома - 85\%. \\
\hline $\begin{array}{l}\text { Существует ли зависимость } \\
\text { малигнизации от размеров полипов? }\end{array}$ & $\begin{array}{l}\text { Полипы размером более } 2 \text { см более } \\
\text { склонны к малигнизации (45\%). }\end{array}$ \\
\hline $\begin{array}{l}\text { Каков злокачественный "потенциал" } \\
\text { аденоматозных полипов? }\end{array}$ & $\begin{array}{l}\text { Виллёзный > тубуло-виллёзный > } \\
\text { тубулярный. }\end{array}$ \\
\hline $\begin{array}{l}\text { Основные особенности виллёзных } \\
\text { аденом: }\end{array}$ & $\begin{array}{l}\text { Не имеют ножку, высокий риск } \\
\text { малигнизации, часто сопровождаются } \\
\text { диареей. }\end{array}$ \\
\hline $\begin{array}{l}\text { Чем объясняется частая диарея при } \\
\text { виллёзной аденоме? }\end{array}$ & $\begin{array}{l}\text { Они исходят из железистого эпителия, } \\
\text { секретирующего слизь. }\end{array}$ \\
\hline Частая локализация полипов: & Ректосигмоидный отдел (30\%). \\
\hline Клинические признаки: & $\begin{array}{l}\text { Небольшие полипы в большинстве } \\
\text { случаев бессимптомны. По мере }\end{array}$ \\
\hline
\end{tabular}




\begin{tabular}{|c|c|}
\hline Вопросы & Ответы \\
\hline & $\begin{array}{l}\text { увеличения размеров полипов } \\
\text { наблюдаются выделение крови и слизи } \\
\text { из прямой кишки, боли в животе, } \\
\text { запоры, понос, } \\
\text { дискомфорт». }\end{array}$ \\
\hline $\begin{array}{l}\text { Неинвазивный метод обнаружения } \\
\text { полипов: }\end{array}$ & Виртуальная колоноскопия. \\
\hline Как уточняют диагноз полипов? & Колоноскопия с биопсией. \\
\hline Лечение: & $\begin{array}{l}\text { Эндоскопическое или хирургическое } \\
\text { удаление. }\end{array}$ \\
\hline $\begin{array}{l}\text { Что такое диффузный семейный } \\
\text { полипоз? }\end{array}$ & $\begin{array}{l}\text { Является генетическим заболеванием. С } \\
\text { момента полового развития в толстой } \\
\text { кишке развиваются множество полипов, } \\
\text { злокачественная трансформация } \\
\text { которых возрастает в возрасте старше } \\
40-50 \text { лет. }\end{array}$ \\
\hline $\begin{array}{l}\text { В каком гене имеется генетический } \\
\text { дефект при диффузном семейном } \\
\text { полипозе? }\end{array}$ & $\begin{array}{l}\text { В гене аденоматозного полипоза толстой } \\
\text { кишки. }\end{array}$ \\
\hline $\begin{array}{l}\text { Какие патологии также встречаются у } \\
\text { пациентов с диффузным семейным } \\
\text { полипозом? }\end{array}$ & $\begin{array}{l}\text { Полипы тонкой кишки, десмоидные } \\
\text { опухоли, остеомы, медуллобластомы, } \\
\text { карциномы желудочно-кишечного } \\
\text { тракта. }\end{array}$ \\
\hline $\begin{array}{l}\text { Лечение диффузного семейного } \\
\text { полипоза: }\end{array}$ & $\begin{array}{l}\text { - Тотальная проктоколэктомия и } \\
\text { формирование илеостомы; } \\
\text { - Тотальная колэктомия, демукозация } \\
\text { культи прямой кишки и } \\
\text { формирование } \\
\text { анастомоза. }\end{array}$ \\
\hline
\end{tabular}


Вопросы

Чем характеризуется синдром

Пейтца-Егерса-Турена?

\section{Ответы}

Сочетание полипоза пищеварительного тракта с пигментными пятнами на слизистой оболочке щёк, вокруг рта и на коже ладони.

\section{Существует. \\ Существует ли риск малигнизации}

при синдроме Пейтца-Егерса-Турена?

\section{Существует ли риск возникновения} рака других органов у женщин с синдромом Пейтца-Егерса-Турена?

$\begin{array}{ll}\text { Генетическая особенность данного } & \text { Характерен аутосомный доминантный } \\ \text { синдрома: } & \text { тип наследования. }\end{array}$

\section{Чем объясняется механизм \\ Инвагинацией.}

\section{Имеется риск возникновения рака} яичников.

\begin{tabular}{|ll} 
Лечение: & Полипы размерами более 1,5 см и \\
& имеющие осложнения (кровотечение, \\
& инвагинация, обструкция) подлежат \\
& удалению. \\
\hline Что такое ювенильные полипы? & Гамартоматозные полипы тонкой и \\
& толстой кишки: железистый эпителий и \\
слизистая оболочка развиваются в & смешанном порядке, в результате чего \\
& формируются ретенционные полипы. \\
& Риск малигнизации очень низок, однако \\
& при полипозе возрастает риск развития \\
рака. & \\
\hline Что такое синдром Кронкайта- & Вариант ювенильного полипоза: наряду \\
Канады? & диффузным поражениемтолстой кишки, \\
наблюдаются & эктодермальные \\
\hline
\end{tabular}

\section{гамартоматозных полипах?}

\section{тонкокишечной непроходимости при}




\begin{tabular}{|c|c|}
\hline Boпросы & Ответы \\
\hline & $\begin{array}{l}\text { патологии (алопеция, } \\
\text { электролитные диарея, } \\
\text { белка, гиперпигментация кожи, атрофия } \\
\text { ногтей). }\end{array}$ \\
\hline Что такое синдром Туркота? & $\begin{array}{l}\text { Вариант диффузного семейного } \\
\text { полипоза, при котором множественный } \\
\text { полипоз толстой кишки сопровождается } \\
\text { медуллобластомой. }\end{array}$ \\
\hline
\end{tabular}




\section{ЗЛОКАЧЕСТВЕННЫЕ ОПУХОЛИ ТОЛСТОЙ КИШКИ}

- Большинство злокачественных новообразований толстого кишечника аденокарциномы, развивающиеся из слизистой оболочки. Карциноидные и мезенхимальные опухоли встречаются реже.

- Этиология аденокарцином до конца не изучена, однако некоторые наследственные заболевания (диффузный семейный полипоз), полипы, воспалительные заболевания и диета с высоким содержанием жира являются факторами риска. Считается, что большинство злокачественных новообразований толстого кишечника развивается из полипов.

- Заболевание на ранней стадии, как правило, бессимптомное. С ростом и распространением опухоли наблюдаются абдоминальные признаки (запор, диарея, вздутие, дискомфорт, боль) и осложнения (кровотечение, анемия, непроходимость, перфорация, абсцесс, перитонит).

- Диагностика рака толстого кишечника основана на результатах колоноскопии и биопсии. Для определения стадии возникает необходимость в проведении КТ, МРТ, эндоскопическое УЗИ, ПЭТ.

- Основным методом лечения колоректального рака является радикальная резекция. В целях профилактики рецидивов и метастазов применяют химио- и радиотерапию. При раке ободочной кишки после радикального хирургического удаления проводят адъювантную химиотерапию. При раке прямой кишки в предоперационном периоде проводят неадъювантную химиотерапию и радиотерапию, после радикального хирургического лечения проводят адъювантную химиотерапию.

\section{Вопросы и ответы по колоректальному раку}

\begin{tabular}{|llrr|}
\hline \multicolumn{1}{|c|}{ Вопросы } & \multicolumn{4}{c|}{ Ответы } \\
\hline Что такое колоректальный рак? & $\begin{array}{l}\text { Аденокарцинома толстой и } \\
\text { кишки. }\end{array}$ \\
\hline Частота встречаемости: & Самый & распространённый & рак \\
& желудочно-кишечного & тракта. & С \\
& возрастом & увеличивается & риск \\
\hline
\end{tabular}




\begin{tabular}{|c|c|}
\hline Вопросы & Ответы \\
\hline & $\begin{array}{l}\text { заболеваемости, достигая пикового } \\
\text { уровня в 70-80 лет. }\end{array}$ \\
\hline $\begin{array}{l}\text { Место колоректального рака в } \\
\text { структуре причин смертности: }\end{array}$ & $\begin{array}{l}\text { По уровню смертности занимает 3-4-е } \\
\text { место среди злокачественных опухолей } \\
\text { желудочно-кишечного тракта. }\end{array}$ \\
\hline $\begin{array}{l}\text { Частота заболеваемости в } \\
\text { зависимости от пола: }\end{array}$ & $1: 1$ \\
\hline Причины и факторы риска: & $\begin{array}{l}\text { - Диета с высоким содержанием } \\
\text { жиров, бедная клетчаткой; } \\
\text { • Генетически заболевания } \\
\text { (диффузный семейный полипоз, } \\
\text { наследственный неполипоз); } \\
\text { - Заболевания кишечника: полипы, } \\
\text { неспецифический язвенный колит, } \\
\text { болезнь Крона; } \\
\text { Возраст, наличие рака в семейном } \\
\text { анамнезе. }\end{array}$ \\
\hline $\begin{array}{l}\text { Роль генетических факторов в } \\
\text { онкогенезе колоректального рака: }\end{array}$ & $\begin{array}{l}\text { Наследственно-генетический } \\
\text { имеется у 10-15\% пациентов. }\end{array}$ \\
\hline Что такое синдром Линча? & $\begin{array}{l}\text { Наследственный неполипозный рак } \\
\text { толстой кишки, аутосомно доминантное } \\
\text { заболевание. }\end{array}$ \\
\hline $\begin{array}{l}\text { Современные рекомендации по } \\
\text { обследованию пациентов для } \\
\text { исключения (подтверждения) рака } \\
\text { толстой кишки при отсутствии } \\
\text { отягощённого семейного анамнеза: }\end{array}$ & $\begin{array}{l}\text { Ежегодный скрининг пациентов старше } \\
50 \text { лет с проведением пальцевого } \\
\text { исследования прямой кишки, } \\
\text { колоноскопии и теста на скрытую кровь } \\
\text { в кале. }\end{array}$ \\
\hline $\begin{array}{l}\text { Современные рекомендации по } \\
\text { обследованию пациентов с раком } \\
\text { толстого кишечника у родственников }\end{array}$ & $\begin{array}{l}\text { Пациентам в возрасте старше } 40 \text { лет при } \\
\text { наличии отягощённого семейного }\end{array}$ \\
\hline
\end{tabular}




\begin{tabular}{|c|c|}
\hline Вопросы & Ответы \\
\hline $\begin{array}{l}\text { первой степени для исключения } \\
\text { (подтверждения) рака: }\end{array}$ & $\begin{array}{l}\text { анамнеза проводится колоноскопия } 1 \\
\text { раз в год. }\end{array}$ \\
\hline $\begin{array}{l}\text { Клинические признаки рака правой } \\
\text { половины ободочной кишки: }\end{array}$ & $\begin{array}{l}\text { В связи с широким просветом правой } \\
\text { половины ободочной кишки кишечная } \\
\text { непроходимость развивается в поздней } \\
\text { стадии заболевания. Характеризуются } \\
\text { общими симптомами-анемия, мелена, } \\
\text { гематохезия, кишечный дискомфорт } \\
\text { после еды, недомогание, слабость. }\end{array}$ \\
\hline $\begin{array}{l}\text { Клинические признаки рака левой } \\
\text { половины ободочной кишки: }\end{array}$ & $\begin{array}{l}\text { Относительно узкий диаметр просвета, } \\
\text { оформленный и плотный кал, } \\
\text { эндофитный рост опухоли быстро } \\
\text { приводят к развитию обтурационной } \\
\text { кишечной непроходимости, болям, } \\
\text { тошноте, запорам, } \\
\text { кровотечению. }\end{array}$ \\
\hline $\begin{array}{l}\text { При какой локализации рака } \\
\text { наблюдается мелена? }\end{array}$ & $\begin{array}{l}\text { При поражении правой половины } \\
\text { ободочной кишки. }\end{array}$ \\
\hline $\begin{array}{l}\text { При какой локализации рака } \\
\text { наблюдается гематохезия? }\end{array}$ & $\begin{array}{l}\text { При поражении левой половины } \\
\text { ободочной кишки. }\end{array}$ \\
\hline Частота рака прямой кишки: & $\begin{array}{llr}\text { Составляет } & 20-30 \% & \text { всех } \\
\text { злокачественных } & \text { опухолей } & \text { толстой } \\
\text { кишки. } & & \end{array}$ \\
\hline $\begin{array}{l}\text { Пути метастазирования рака толстой } \\
\text { кишки: }\end{array}$ & $\begin{array}{l}\text { - Местное метастазирование: в } \\
\text { просвет, в стенку кишки, в органы } \\
\text { брюшной полости и промежности. } \\
\text { - Гематогенное метастазирование: } \\
\text { через воротную вены в печень, через } \\
\text { позвоночные вены в лёгкие. }\end{array}$ \\
\hline
\end{tabular}




\begin{tabular}{|c|c|}
\hline Вопросы & Ответы \\
\hline & $\begin{array}{l}\text { - Лимфогенное метастазирование: в } \\
\text { регионарные лимфатические узлы. }\end{array}$ \\
\hline $\begin{array}{l}\text { Клинические признаки рака прямой } \\
\text { кишки: }\end{array}$ & $\begin{array}{l}\text { Частые симптомы: гематохезия } \\
\text { (выделение с калом неизмененной } \\
\text { крови), выделение слизи из прямой } \\
\text { кишки, тенезмы, чувство неполного } \\
\text { опорожнения (инородного тела) } \\
\text { прямой кишки. }\end{array}$ \\
\hline Новообразования толстой кишки: & $\begin{array}{l}\text { Аденокарцинома, карциноидная } \\
\text { опухоль, липома, липосаркома, } \\
\text { лейомиома, лейомиосаркома, } \\
\text { лимфома, дивертикулёз, язвенный } \\
\text { колит, болезнь Крона, полипы. }\end{array}$ \\
\hline Диагностика колоректального рака: & Колоноскопия с биопсией. \\
\hline $\begin{array}{l}\text { О каком заболевании следует } \\
\text { задуматься при наличии анемии у } \\
\text { мужчин и женщин после менопаузы? }\end{array}$ & О раке толстой кишки. \\
\hline $\begin{array}{l}\text { Имеет ли диагностическую ценность } \\
\text { тест на карциноэмбриональный } \\
\text { антиген (CEA): }\end{array}$ & $\begin{array}{l}\text { Для скрининговой диагностики нет. Для } \\
\text { определения } \\
\text { информативен. }\end{array}$ \\
\hline $\begin{array}{l}\text { Какие методы исследования наиболее } \\
\text { информативны для определения } \\
\text { местной инвазии и } \\
\text { распространённости рака? }\end{array}$ & МРТ таза и эндоректальное УЗИ. \\
\hline $\begin{array}{l}\text { Какой метод исследования наиболее } \\
\text { информативен для оценки местного } \\
\text { распространения: МРТ или } \\
\text { эндоректальное УзИ? }\end{array}$ & $\begin{array}{l}\text { МРТ таза: точно определяется инвазия в } \\
\text { стенку, мезоректум и лимфатические } \\
\text { узлы. Эндоректальное узИ точно } \\
\text { показывает лишь инвазию в стенку } \\
\text { кишки. }\end{array}$ \\
\hline
\end{tabular}




\begin{tabular}{|c|c|}
\hline Вопросы & Ответы \\
\hline $\begin{array}{l}\text { Какие исследования проводят для } \\
\text { выявления метастазов рака толстой } \\
\text { кишки? }\end{array}$ & $\begin{array}{l}\text { - КТ грудной клетки - метастазы в } \\
\text { лёгкие; } \\
\text { - } \text { КТ брюшной полости и печёночные } \\
\text { пробы-метастазы в печень; } \\
\text { - Другие методы исследования } \\
\text { проводятся согласно анамнезу и } \\
\text { физикальным обследованиям (для } \\
\text { исключения метастазов в головной } \\
\text { мозг рекомендуется КТ черепа). }\end{array}$ \\
\hline $\begin{array}{l}\text { Какие классификационные системы } \\
\text { используют для стадирования рака } \\
\text { толстой кишки? }\end{array}$ & $\begin{array}{l}\text { Классификация Дюке (модификация } \\
\text { Astler and Cooler), стадирование по } \\
\text { системе TNM. }\end{array}$ \\
\hline $\begin{array}{l}\text { Охарактеризуйте классификацию } \\
\text { Дюке в модификации Astler and } \\
\text { Cooler: }\end{array}$ & $\begin{array}{l}\text { - } \text { А - инвазия в подслизистый слой; } \\
\text { - } \text { В1 - инвазия в мышечный слой; } \\
\text { - } \text { В2 - инвазия в субсерозный слой; } \\
\text { - } \text { С-метастазы в лимфоузлы; } \\
\text { - } \text { D - отдалённые метастазы. }\end{array}$ \\
\hline $\begin{array}{l}\text { Охарактеризуйте классификацию по } \\
\text { системе TNM: }\end{array}$ & $\begin{array}{l}\text { I стадия - инвазия в подслизистый и } \\
\text { мышечные слои (Т1-2N0М0); } \\
\text { II стадия - инвазия опухоли во все слои } \\
\text { кишечной стенки и за её пределы, но в } \\
\text { лимфоузлах метастазов нет (Т3-4NOM0); } \\
\text { III стадия - имеются метастазы в } \\
\text { лимфоузлах, но отдалённых метастазов } \\
\text { нет (любой TN1-3М0); } \\
\text { IV стадия - метастазы в отдалённые } \\
\text { органы (любой Т, любой N, М1). }\end{array}$ \\
\hline Методы лечения: & $\begin{array}{l}\text { Эндоскопическое, } \\
\text { химио- и радиотерапия. }\end{array}$ \\
\hline
\end{tabular}




\begin{tabular}{|c|c|}
\hline Вопросы & Ответы \\
\hline $\begin{array}{l}\text { Когда проводится эндоскопическая } \\
\text { резекция опухоли? }\end{array}$ & $\begin{array}{l}\text { В начальной стадии рака прямой кишки } \\
\text { при наличии опухоли небольшого } \\
\text { размера. }\end{array}$ \\
\hline Что такое радикальная резекция? & $\begin{array}{l}\text { Удаление опухоли } \\
\text { сегментарной резекции в пределах } \\
\text { здоровых участков кишки вместе с её } \\
\text { брыжейкой. }\end{array}$ \\
\hline $\begin{array}{l}\text { Как определяются границы резекции } \\
\text { при раке ободочной кишки? }\end{array}$ & $\begin{array}{l}\text { Проксимальная граница на } 5 \text { см выше, } \\
\text { дистальная на } 2 \text { см ниже опухоли. }\end{array}$ \\
\hline $\begin{array}{l}\text { Минимальная граница резекции при } \\
\text { раке прямой кишки: }\end{array}$ & На 2 см выше и ниже опухоли. \\
\hline $\begin{array}{l}\text { Существует ли принципиальная } \\
\text { разница в лечении рака толстой и } \\
\text { прямой кишки? }\end{array}$ & $\begin{array}{l}\text { При раке толстой кишки вначале } \\
\text { проводится хирургическое лечение } \\
\text { (радикальное удаление опухоли), а } \\
\text { потом по показаниям проводится } \\
\text { химиотерапия. При раке прямой кишки } \\
\text { проводятся химио-, радиотерапия, а } \\
\text { затем хирургическое лечение. В } \\
\text { дальнейшем проводится адъювантная } \\
\text { химиотерапия. }\end{array}$ \\
\hline $\begin{array}{l}\text { Показания к химиотерапии после } \\
\text { операции по поводу рака толстой } \\
\text { кишки: }\end{array}$ & $\begin{array}{l}\text { Метастазы в лимфоузлы и отдалённые } \\
\text { органы, наличие осложнений } \\
\text { (кишечная непроходимость, } \\
\text { перфорация толстой кишки). }\end{array}$ \\
\hline $\begin{array}{l}\text { В каких случаях рака толстой кишки } \\
\text { нет необходимости в проведении } \\
\text { адъювантной химиотерапии? }\end{array}$ & В начальной (I) стадии заболевания. \\
\hline $\begin{array}{l}\text { С какой целью проводится } \\
\text { химиотерапия до операции при раке } \\
\text { прямой кишки? }\end{array}$ & $\begin{array}{l}\text { С целью уменьшения размеров и } \\
\text { сокращения случаев рецидива. }\end{array}$ \\
\hline
\end{tabular}




\begin{tabular}{|c|c|}
\hline Вопросы & Ответы \\
\hline $\begin{array}{l}\text { С какой целью радиотерапия } \\
\text { дополняется химиотерапией? }\end{array}$ & $\begin{array}{l}\text { Цитостатические препараты повышают } \\
\text { чувствительность раковых клеток к } \\
\text { воздействию радиотерапии. }\end{array}$ \\
\hline $\begin{array}{l}\text { В какой стадии рака прямой кишки } \\
\text { нет необходимости в химиотерапии } \\
\text { до операции? }\end{array}$ & В I стадии рака. \\
\hline $\begin{array}{l}\text { При локализации опухоли на } 5 \text { см } \\
\text { выше анального сфинктера чем } \\
\text { дополняется формирование } \\
\text { анастомоза? }\end{array}$ & $\begin{array}{l}\text { Для профилактики несостоятельности } \\
\text { швов ректального анастомоза } \\
\text { формируют протективную илеостому. }\end{array}$ \\
\hline $\begin{array}{l}\text { Какая адъювантная терапия } \\
\text { целесообразна при раке толстой } \\
\text { кишки? }\end{array}$ & $\begin{array}{l}\text { Применение препарата FOLFOX или } \\
\text { FOLFIRI. }\end{array}$ \\
\hline $\begin{array}{l}\text { Когда проводятся дополнительные } \\
\text { методы лечения? }\end{array}$ & $\begin{array}{l}\text { При обнаружении в опухолевых клетках } \\
\text { мутации C-ras назначают блокаторы } \\
\text { рецепторов тирозинкиназы. }\end{array}$ \\
\hline $\begin{array}{l}\text { В чём заключается неоадъювантная } \\
\text { терапия при раке прямой кишки? }\end{array}$ & $\begin{array}{l}\text { В проведении радиотерапии в } \\
\text { сочетании с 5-фторурацилом. }\end{array}$ \\
\hline $\begin{array}{l}\text { Наиболее часто колоректальный рак } \\
\text { метастазирует: }\end{array}$ & В печень. \\
\hline $\begin{array}{l}\text { Как проводится лечение } \\
\text { колоректальных метастазов печени? }\end{array}$ & $\begin{array}{l}\text { При резектабельном раке - сначала } \\
\text { резекция потом химиотерапия. } \\
\text { При нерезектабельном раке - сначала } \\
\text { химиотерапия с целью перевести } \\
\text { опухоль в состоянии резектабельности. }\end{array}$ \\
\hline $\begin{array}{l}\text { Чем объясняется необходимость } \\
\text { обследования пациентов с }\end{array}$ & $\begin{array}{l}\text { Высокий риск рецидивов в течение } \\
\text { первых } 3 \text { месяцев после операции } \\
\text { (90\%). }\end{array}$ \\
\hline
\end{tabular}




\begin{tabular}{|c|c|}
\hline Вопросы & Ответы \\
\hline $\begin{array}{l}\text { колоректальным раком через } 3 \\
\text { месяца после операции? }\end{array}$ & \\
\hline $\begin{array}{l}\text { Какие исследования необходимы для } \\
\text { выявления рецидивов рака через } 3 \\
\text { месяца после операции? }\end{array}$ & $\begin{array}{l}\text { Клиническое обследование, тест на } \\
\text { скрытую кровь в кале, СЕА, } \\
\text { колоноскопия, КТ. }\end{array}$ \\
\hline $\begin{array}{l}\text { Частые причины обструкции } \\
\text { ободочной кишки у взрослых: }\end{array}$ & $\begin{array}{l}\text { Рак толстой кишки, дивертикулярная } \\
\text { болезнь, заворот толстой кишки. }\end{array}$ \\
\hline
\end{tabular}




\section{Вопросы и ответы по завороту толстой кишки}

\begin{tabular}{|c|c|}
\hline Вопросы & Ответы \\
\hline $\begin{array}{l}\text { Что представляет собой заворот } \\
\text { толстого кишечника? }\end{array}$ & $\begin{array}{l}\text { Перекрут сегмента толстого кишечника } \\
\text { вокруг брыжейки. }\end{array}$ \\
\hline Частота встречаемости: & $\begin{array}{l}\text { - Сигмовидная кишка - 60-75\%; } \\
\text { - Слепая кишка-20-35\%; } \\
\text { - Поперечная ободочная кишка - 3- } \\
\text { 5\%. }\end{array}$ \\
\hline Клинические формы: & $\begin{array}{l}\text { - Сигмовидная кишка; } \\
\text { - Слепая кишка; } \\
\text { - Поперечная ободочная кишка. }\end{array}$ \\
\hline Особенности клинического течения: & $\begin{array}{l}\text { Заворот может исправиться, однако } \\
\text { чаще наблюдаются осложнения. }\end{array}$ \\
\hline Осложнения: & $\begin{array}{l}\text { - Странгуляция; } \\
\text { - Гангрена; } \\
\text { - Перфорация. }\end{array}$ \\
\hline Характерная триада симптомов: & $\begin{array}{l}\text { - Острая боль в животе (в начале } \\
\text { приступообразная); } \\
\text { - Вздутие; } \\
\text { - Отсутствие перистальтических } \\
\text { шумов кишечника. }\end{array}$ \\
\hline Поздние клинические признаки: & $\begin{array}{l}\text { - Высокая температура; } \\
\text { - Озноб; } \\
\text { - Тошнота; } \\
\text { - Рвота; } \\
\text { - Гипотензия - шок; } \\
\text { - Признаки перитонита. }\end{array}$ \\
\hline Диагностика: & $\begin{array}{l}\text { - Анамнез; } \\
\text { - Клиническое обследование; }\end{array}$ \\
\hline
\end{tabular}




\begin{tabular}{|c|c|}
\hline Boпросы & Ответы \\
\hline & $\begin{array}{l}\text { - Общая и } \\
\text { рентгенография; } \\
\text { - } \text { КТ; } \\
\text { - } \text { Эндоскопия. }\end{array}$ \\
\hline Лабораторные признаки: & Нет специфических показателей. \\
\hline $\begin{array}{l}\text { Признаки инструментальной } \\
\text { визуализации: }\end{array}$ & $\begin{array}{l}\text { - Общая рентгенография - } \\
\text { расширение кишечника в виде } \\
\text { автомобильной шины или } \\
\text { кофейного зерна; } \\
\text { - Контрастная рентгенография - } \\
\text { признак «птичьего клюва»; } \\
\text { - КТ-признаки некроза (пневматоз); } \\
\text { - Эндоскопия - спиралевидное } \\
\text { сужение. }\end{array}$ \\
\hline Методы лечения: & $\begin{array}{l}\text { - Деторсия наблюдается после } \\
\text { ирригоскопии и колоноскопии; } \\
\text { - Хирургическое лечение. }\end{array}$ \\
\hline Показания к операции: & $\begin{array}{l}\text { - Деторсия при колоноскопии; } \\
\text { - Признаки перитонита; } \\
\text { - Невозможность деторсии. }\end{array}$ \\
\hline Виды операций: & $\begin{array}{l}\text { В соответствии с локализацией и } \\
\text { жизнеспособности кишечника: } \\
\text { - Деторсия; } \\
\text { - Резекция и формирования } \\
\text { анастомоза; } \\
\text { - Резекция и формирование стомы. }\end{array}$ \\
\hline Прогноз: & $\begin{array}{l}\text { Летальность после операции с } \\
\text { сохранным кишечником - 3-12\%, с } \\
\text { гангреной кишечника-10-20\%. }\end{array}$ \\
\hline
\end{tabular}




\section{Вопросы и ответы по мегаколону}

\begin{tabular}{|c|c|}
\hline Вопросы & Ответы \\
\hline Что представляет собой мегаколон? & $\begin{array}{l}\text { Дилатация, удлинение и гипертрофия } \\
\text { толстого кишечника. }\end{array}$ \\
\hline Частота встречаемости: & Встречается редко. \\
\hline Клинические формы: & $\begin{array}{l}\text { - Острая - псевдообструкция; } \\
\text { - Хроническая; } \\
\text { - Токсическая. }\end{array}$ \\
\hline $\begin{array}{l}\text { Клинические формы хронического } \\
\text { мегаколона: }\end{array}$ & $\begin{array}{l}\text { - Врождённая; } \\
\text { - Приобретённая. }\end{array}$ \\
\hline $\begin{array}{l}\text { Причины и факторы риска } \\
\text { приобретённого хронического } \\
\text { мегаколона: }\end{array}$ & $\begin{array}{l}\text { - Неврологические признаки: болезнь } \\
\text { Шагаса, Паркинсона, миотоническая } \\
\text { дистрофия, диабетическая } \\
\text { нейропатия, повреждения спинного } \\
\text { мозга; } \\
\text { - Системные заболевания: } \\
\text { склеродермия, дерматомиозит, } \\
\text { системная красная волчанка; } \\
\text { - Хроническая псевдообструкция. }\end{array}$ \\
\hline Патогенез: & $\begin{array}{l}\text { Длительное нарушение моторики } \\
\text { кишечника. }\end{array}$ \\
\hline Особенности клинического течения: & $\begin{array}{l}\text { - Врождённый мегаколон - } \\
\text { клинические признаки проявляются } \\
\text { до } 1 \text { года; } \\
\text { - Приобретённный - клинические } \\
\text { признаки проявляются после } 10 \text { лет. }\end{array}$ \\
\hline Осложнения: & Перфорация и перитонит. \\
\hline Клинические признаки: & Запоры. \\
\hline
\end{tabular}




\begin{tabular}{|c|c|}
\hline Вопросы & Ответы \\
\hline Диагностика: & $\begin{array}{l}\text { - } \text { Физикальное обследование; } \\
\text { - Контрастная рентгенография; } \\
\text { - Контрастная КТ; } \\
\text { - Колоноскопия и биопсия; } \\
\text { - Гистология - определение причины. }\end{array}$ \\
\hline Что выявляется при обследовании? & $\begin{array}{l}\text { - Пальпация - напряжённый живот; } \\
\text { - Пальцевое исследование - твёрдые } \\
\text { каловые массы. }\end{array}$ \\
\hline Методы лечения: & $\begin{array}{l}\text { - Консервативное (лаксативы, } \\
\text { инфузионная терапия и др.); } \\
\text { - Хирургическое. }\end{array}$ \\
\hline Показания к операции: & $\begin{array}{l}\text { - Неэффективность консервативного } \\
\text { лечения; } \\
\text { - Развитие осложнений. }\end{array}$ \\
\hline Виды операций: & $\begin{array}{l}\text { - Тотальная колэктомия с } \\
\text { формированием илеоректального } \\
\text { анастомоза; } \\
\text { - Тотальная проктоколэктомия с } \\
\text { формированием илеостомы; } \\
\text { - Тотальная проктоколэктомия с } \\
\text { формированием илеоанального } \\
\text { анастомоза. }\end{array}$ \\
\hline Прогноз: & Риск перфорации - 3\%. \\
\hline
\end{tabular}

\section{Вопросы и ответы по кишечной псевдообструкции}

\section{Вопросы}

Что представляет собой псевдообструкция?

\section{Ответы}

кишечная Функциональное характеризующееся заболевание, массивной 


\begin{tabular}{|c|c|c|}
\hline \multirow[t]{2}{*}{ Вопросы } & & Ответы \\
\hline & & $\begin{array}{l}\text { дилатацией толстого кишечника без } \\
\text { механической обструкции. }\end{array}$ \\
\hline Клинические формы: & & $\begin{array}{l}\text { - Острая - синдром Огилви; } \\
\text { - Хроническая. }\end{array}$ \\
\hline Частота встречаемости: & & Встречается редко. \\
\hline Причины и факторы риска: & & $\begin{array}{l}\text { - Перенесённые операции; } \\
\text { - Повреждения спинного мозга; } \\
\text { • Пожилой возраст; } \\
\text { - Сопутствующие заболевания - } \\
\text { неврологические, почечные, } \\
\text { респираторные, гипотиреоз; } \\
\text { - Нарушение электролитного баланса; } \\
\text { - Лекарственные п препараты } \\
\text { (наркотики, } \\
\text { фенотиазин, } \\
\text { противопаркинсонические средства } \\
\text { и др.) }\end{array}$ \\
\hline Патогенез: & & $\begin{array}{l}\text { Повышение } \\
\text { иннервации, симпатической } \\
\text { парасимпатической иннервации. }\end{array}$ \\
\hline Осложнения: & & Перфорация и перитонит. \\
\hline Клинические признаки: & & $\begin{array}{l}\text { - Боли в животе; } \\
\text { - Тошнота и рвота; } \\
\text { - Запоры; } \\
\text { - Высокая температура. }\end{array}$ \\
\hline $\begin{array}{l}\text { у каких пациентов } \\
\text { заподозрить? }\end{array}$ & Можно & $\begin{array}{l}\text { У пациентов с клиническими } \\
\text { признаками. }\end{array}$ \\
\hline Диагностика: & & $\begin{array}{l}\text { - Физикальное обследование; } \\
\text { - Контрастная рентгенография; }\end{array}$ \\
\hline
\end{tabular}




\begin{tabular}{|c|c|}
\hline Вопросы & Ответы \\
\hline & $\begin{array}{l}\text { - Контрастная КТ; } \\
\text { - Колоноскопия; } \\
\text { - Определение концентрации } \\
\text { электролитов в крови. }\end{array}$ \\
\hline Лабораторные признаки: & Гипонатриемия, гипокалиемия. \\
\hline $\begin{array}{l}\text { Признаки инструментальной } \\
\text { визуализации: }\end{array}$ & $\begin{array}{l}\text { Диффузная дилатация восходящей и } \\
\text { поперечной ободочной кишки (диаметр } \\
\text { слепой кишки - 12-14 см). }\end{array}$ \\
\hline Что выявляется при обследовании? & $\begin{array}{l}\text { - Пальпация - напряжённый живот; } \\
\text { - Аускультация - ослабление или } \\
\text { отсутствие перистальтических } \\
\text { шумов кишечника. }\end{array}$ \\
\hline Методы лечения: & $\begin{array}{l}\text { - Отмена лекарственных препаратов; } \\
\text { - Консервативное; } \\
\text { - } \quad \text { Эндоскопическая декомпрессия; } \\
\text { - Хирургическое. }\end{array}$ \\
\hline Консервативное лечение: & $\begin{array}{l}\text { • Усиление перистальтики кишечника } \\
\text { - метоклопрамид, цизаприд, } \\
\text { эритромицин, неостигмин; } \\
\text { • Инфузионная терапия. }\end{array}$ \\
\hline Показания к операции: & $\begin{array}{l}\text { - Ишемия; } \\
\text { - Перфорация; } \\
\text { - Перитонит. }\end{array}$ \\
\hline Виды операций: & $\begin{array}{l}\text { - Правосторонняя гемиколэктомия; } \\
\text { - Формирование стомы. }\end{array}$ \\
\hline Прогноз: & $\begin{array}{l}\text { - При перфорации риск летального } \\
\text { исхода возрастает до } 40 \% \text {. }\end{array}$ \\
\hline
\end{tabular}




\section{Вопросы и ответы по токсическому мегаколону}

\begin{tabular}{|c|c|}
\hline Вопросы & Ответы \\
\hline $\begin{array}{l}\text { Что представляет собой токсический } \\
\text { мегаколон? }\end{array}$ & $\begin{array}{l}\text { Дилатация толстой кишки на фоне } \\
\text { острого токсического колита. }\end{array}$ \\
\hline Клинические формы: & Тотальный и сегментарный. \\
\hline Причины и факторы риска: & $\begin{array}{l}\text { Колит - язвенный, ишемический, } \\
\text { радиационный, псевдомембранозный } \\
\text { и др. }\end{array}$ \\
\hline Осложнения: & Перфорация и перитонит. \\
\hline Клинические признаки: & $\begin{array}{l}\text { - Высокая температура; } \\
\text { - Болезненный и напряжённый живот; } \\
\text { - Тахикардия; } \\
\text { - Дегидратация. }\end{array}$ \\
\hline Диагностика: & $\begin{array}{l}\text { - Общий анализ крови; } \\
\text { - Колоноскопия и биопсия; } \\
\text { - Гистологическое исследование; } \\
\text { - Контрастная рентгенография; } \\
\text { - УзИ; } \\
\text { - Контрастная КТ. }\end{array}$ \\
\hline Лабораторные признаки: & $\begin{array}{l}\text { Признаки воспаления - повышение } \\
\text { РОЭ, лейкоцитоз, повышение уровня С- } \\
\text { реактивного белка. }\end{array}$ \\
\hline $\begin{array}{l}\text { Признаки } \\
\text { визуализации: }\end{array}$ & $\begin{array}{l}\text { - Диаметр поперечной ободочной } \\
\text { кишки >6 см; } \\
\text { - Потеря гаустрации, симптом } \\
\text { «отпечатка большого пальца»; } \\
\text { - Псевдополипы; } \\
\text { - Сегментарное истончение кишечной } \\
\text { стенки; } \\
\text { - Свободный газ в брюшной полости. }\end{array}$ \\
\hline
\end{tabular}




\begin{tabular}{|c|c|}
\hline Вопросы & Ответы \\
\hline Диагностические критерии: & $\begin{array}{l}\text { - Диаметр поперечной ободочной } \\
\text { кишки >6 см, определяемый при } \\
\text { радиологическом исследовании; } \\
\text { - Высокая температура }\left(>38,5^{\circ} \mathrm{C}\right) \text {, } \\
\text { тахикардия }(120 \text { уд/мин), } \\
\text { лейкоцитоз }\left(>10,5 \times 10^{3} / \mu л\right) ; \\
\text { - Дегидратация, нарушение сознания, } \\
\text { электролитные нарушения или } \\
\text { гипотензия. }\end{array}$ \\
\hline Методы лечения: & $\begin{array}{l}\text { - Консервативное - инфузионная, } \\
\text { антибактериальная, стероидная } \\
\text { терапия; } \\
\text { - Зондирование желудка; } \\
\text { - Хирургическое. }\end{array}$ \\
\hline Показания к операции: & $\begin{array}{l}\text { - Перфорация; } \\
\text { - Массивное кровотечение; } \\
\text { - Неэффективность консервативной } \\
\text { терапии в течение 24-72 часов, } \\
\text { увеличение дилатации. }\end{array}$ \\
\hline Виды операций: & Колэктомия. \\
\hline Прогноз: & $\begin{array}{l}\text { Перфорация повышает риск развития } \\
\text { летального исхода. }\end{array}$ \\
\hline
\end{tabular}

\section{Вопросы и ответы по эндометриозу кишечника}

\section{Вопросы}

Что представляет собой эндометриоз?

\section{Ответы}

Имплантация нормального эндометрия в другие органы. 


\begin{tabular}{|c|c|}
\hline Вопросы & Ответы \\
\hline Частота встречаемости: & $\begin{array}{l}\text { 5-12\% всех случаев эндометриоза } \\
\text { составляет кишечный. }\end{array}$ \\
\hline Клинические признаки: & $\begin{array}{l}\text { - Редко - бессимптомное течение; } \\
\text { - Тазовые и абдоминальные боли - во } \\
\text { время менструации; } \\
\text { - Запоры и диарея; } \\
\text { - Дисменорея; } \\
\text { - Ректальное кровотечение; } \\
\text { - Редко - высокая температура. }\end{array}$ \\
\hline Диагностика: & $\begin{array}{l}\text { - Лапароскопия; } \\
\text { - МРТ; } \\
\text { - УзИ; } \\
\text { - Колоноскопия; } \\
\text { - Трансректальное УзИ; } \\
\text { - Определение уровня СА-125 (>35 } \\
\text { U/mL). }\end{array}$ \\
\hline Методы лечения: & $\begin{array}{l}\text { - Наблюдение - при бессимптомном } \\
\text { течении; } \\
\text { - Консервативное лечение - } \\
\text { симптоматическое, гормональное; } \\
\text { - Хирургическое лечение. }\end{array}$ \\
\hline Показания к операции: & $\begin{array}{l}\text { - Инвазия в несколькие органы; } \\
\text { - Неэффективность консервативного } \\
\text { лечения. }\end{array}$ \\
\hline Виды операций: & $\begin{array}{l}\text { - Удаление эндометриальных узлов, } \\
\text { при необходимости - сегментарная } \\
\text { резекция кишки. }\end{array}$ \\
\hline
\end{tabular}




\section{СПИСОК ЛИТЕРАТУРЫ}

- Ağayev B.A. Cərrahi xəstəliklər. Bakı 2010.

- Blackbourne LH. Surgical Recall. 4 edition, 2006, LWW, Philadelphia

- Doherty GM. Current Diagnosis and Treatment: Surgery, $13^{\text {th }}$ edition, 2010, Lang International Edition.

- Omiraslanov Ә.T., Qazıyev A.Y. Onkologiya. Bakı, 2010.

- İsayev H.B. Cərrahi xəstəliklərin patofizologiyası. Bakı 2005

- Klingensmith ME, Aziz A, Bharat A, Fox AC, Porembka MR. The Washington Manual of Surgery, $6^{\text {th }}$ edition, 2012, LWW, Philadelphia.

- McNally PR. GI/Liver Secrets Plus. 4 edition. Mosby, Elsevier, 2010

- Medscape, http://www.medscape.com

- Oxford Handbook of Clinical Surgery, 3d edition, 2011, Oxford Press

- Sayek I. Sayek Temel Cerrahi 1-2. 4-cü baskı, 2016, Güneş Tıp Kitabevleri.

- Topçubaşov M.A. Xüsusi cərrahlıq. Bakı, 1979

- UpToDate, http://www.uptodate.com

- Гостищев B.К. Общая хирургия. GEOTAR-Media, 2019 


\title{
ХИРУРГИЧЕСКИЕ БОЛЕЗНИ
}

Н.Ю. Байрамов

\section{Хирургические заболевания аппендикса}

\author{
Н.Ю. Байрамов, С.С. Салахова, А.К. Сафиева
}

Перевод: Н.Ю. Байрамов, С.А. Алиев, М.Р. Гусейнова 


\section{ОСТРЫЙ АППЕНДИЦИТ}

- Острый аппендицит (ОА) - воспаление червеобразного отростка, развивающееся вследствие окклюзии просвета и проникновения в его стенку патогенной бактериальной флоры.

- Основу патогенеза острого аппендицита составляет внутрипросветный застой, гипертензия и ишемия стенки аппендикса.

- Типичными клиническими проявлениями ОА являются боль в эпигастральной области или вокруг пупка с последующим перемещением болей в правый нижний квадрант живота без иррадиации. Диспепсические расстройства проявляются в виде тошноты, рвоты, задержки стула и газов.

- При несвоевременном хирургическом лечении развиваются серьезные осложнения (перфорация, перитонит, абсцессы брюшной полости, кишечная непроходимость).

- Диагностика основывается на результатах клинических, лабораторных и инструментальных методов исследований (УЗИ, КТ, МРТ). При сомнительной клинической картине у детей и беременных применяют КТ/МРТ и лапароскопию. Наиболее информативными лабораторными маркерами являются лейкоцитоз, гранулоцитоз, повышение С-реактивного белка.

- Диагностические критерии острого аппендицита по значимости делятся на 3 группы: основные (продолжающаяся боль в правой подвздошной ямке, признаки воспаления, увеличение размеров аппендикса на КТ или МРТ), вторичные (мышечная напряжённость, симптом Щёткина-Блюмберга, тошнота, рвота, потеря аппетита, признаки на УзИ) и третичные (остро начавшаяся боль, иррадиирущая в нижний левый квадрант, гипогастральную, правую поясничную и подрёберную области, повторная рвота, дизурия).

- Стандартным методом лечения ОА является аппендэктомия, которую выполняют как традиционным (открытым), так и лапароскопическим способом. При осложненных формах ОА применяются консервативные и хирургические методы лечения. Показанием к консервативному лечению является инфильтративная форма заболевания. В последние годы при ОА, осложнённым периаппендикулярным абсцессом успешно применяют малоинвазивные методы (чрескожное дренирование под контролем УзИ или КТ). 


\section{Вопросы и ответы по острому аппендициту}

\begin{tabular}{|c|c|}
\hline Вопросы & Ответы \\
\hline Что такое острый аппендицит? & $\begin{array}{lcc}\text { Острое } & \text { воспаление } & \text { червеобразного } \\
\text { отростка, вызванное } & \text { окклюзией его } \\
\text { просвета } & \text { и } & \text { повышением } \\
\text { внутрипросветного давления. }\end{array}$ \\
\hline Этиология ОА: & $\begin{array}{l}\text { - Гиперплазия лимфоидных } \\
\text { фолликулов; } \\
\text { - Феколиты (копролиты); } \\
\text { - В редких случаях - паразиты, } \\
\text { инородные тела, опухоли. }\end{array}$ \\
\hline Частота встречаемости ОА: & Примерно 7-20\% общей популяции. \\
\hline $\begin{array}{l}\text { Часто встречаемая абдоминальная } \\
\text { хирургическая патология: }\end{array}$ & Острый аппендицит. \\
\hline $\begin{array}{l}\text { Классические клинические симптомы } \\
\text { ОА: }\end{array}$ & $\begin{array}{l}\text { Классическая хронология: } \\
\text { - Боль в животе (эпигастральная, } \\
\text { околопупочная); } \\
\text { - Тошнота и рвота; } \\
\text { - Анорексия; } \\
\text { - Боль, мигрирующая в правую } \\
\text { подвздошную ямку. }\end{array}$ \\
\hline $\begin{array}{l}\text { Чем объясняется механизм } \\
\text { околопупочных болей? }\end{array}$ & $\begin{array}{l}\text { Передача болевых импульсов в чревное } \\
\text { сплетение. }\end{array}$ \\
\hline $\begin{array}{l}\text { Причина локализации болей в правой } \\
\text { подвздошной ямке: }\end{array}$ & $\begin{array}{l}\text { При воспалении брюшины появляются } \\
\text { соматические боли. }\end{array}$ \\
\hline Клинико-объективные признаки ОА: & $\begin{array}{l}\text { Локальные симптомы раздражения } \\
\text { брюшины: }\end{array}$ \\
\hline
\end{tabular}




\begin{tabular}{|c|c|}
\hline Вопросы & Ответы \\
\hline & $\begin{array}{l}\text { - Пальпаторная болезненность в } \\
\text { правой подвздошной области; } \\
\text { - Напряжение брюшной стенки; } \\
\text { - Рефлекторная контрактура m. } \\
\text { ileopsoas (“псоас синдром”); } \\
\text { - Гиперестезия кожи в правой } \\
\text { подвздошной области; } \\
\text { - Субфебрильная температура } \\
\text { (высокая температура как } \\
\text { правило встречается при } \\
\text { перфорации). }\end{array}$ \\
\hline $\begin{array}{l}\text { Клиническое проявление } \\
\text { рефлекторного раздражения } \\
\text { обтураторной (запирательной) } \\
\text { мышцы: }\end{array}$ & $\begin{array}{lcr}\text { Усиление боли в лонной области при } \\
\text { ротации во } & \text { внутрь правой } & \text { нижней } \\
\text { конечности } & \text { в } \text { тазобедренном и } \\
\text { коленном } & \text { суставах. } \\
\text { наблюдается } & \text { оричн } \\
\text { расположении } & \text { червеобразного } \\
\text { отростка. } & & \end{array}$ \\
\hline Что такое "псоас синдром"? & $\begin{array}{l}\text { Боль, появляющаяся или } \\
\text { усиливающаяся при поднятии правой } \\
\text { нижней конечности вверх. Встречается } \\
\text { при ретроцекальном расположении } \\
\text { червеобразного отростка. }\end{array}$ \\
\hline Что такое симптом Ровзинга? & $\begin{array}{l}\text { Усиление боли в правой подвздошной } \\
\text { области при перкуссии левой } \\
\text { подвздошной области, что объясняется } \\
\text { ретроградным поступлением газов в } \\
\text { илеоцекальную область и её } \\
\text { раздражением. }\end{array}$ \\
\hline Где расположена точка Мак-Бурнея? & $\begin{array}{l}\text { На границе между средней и наружной } \\
\text { третями линии, соединяющей пупок и }\end{array}$ \\
\hline
\end{tabular}




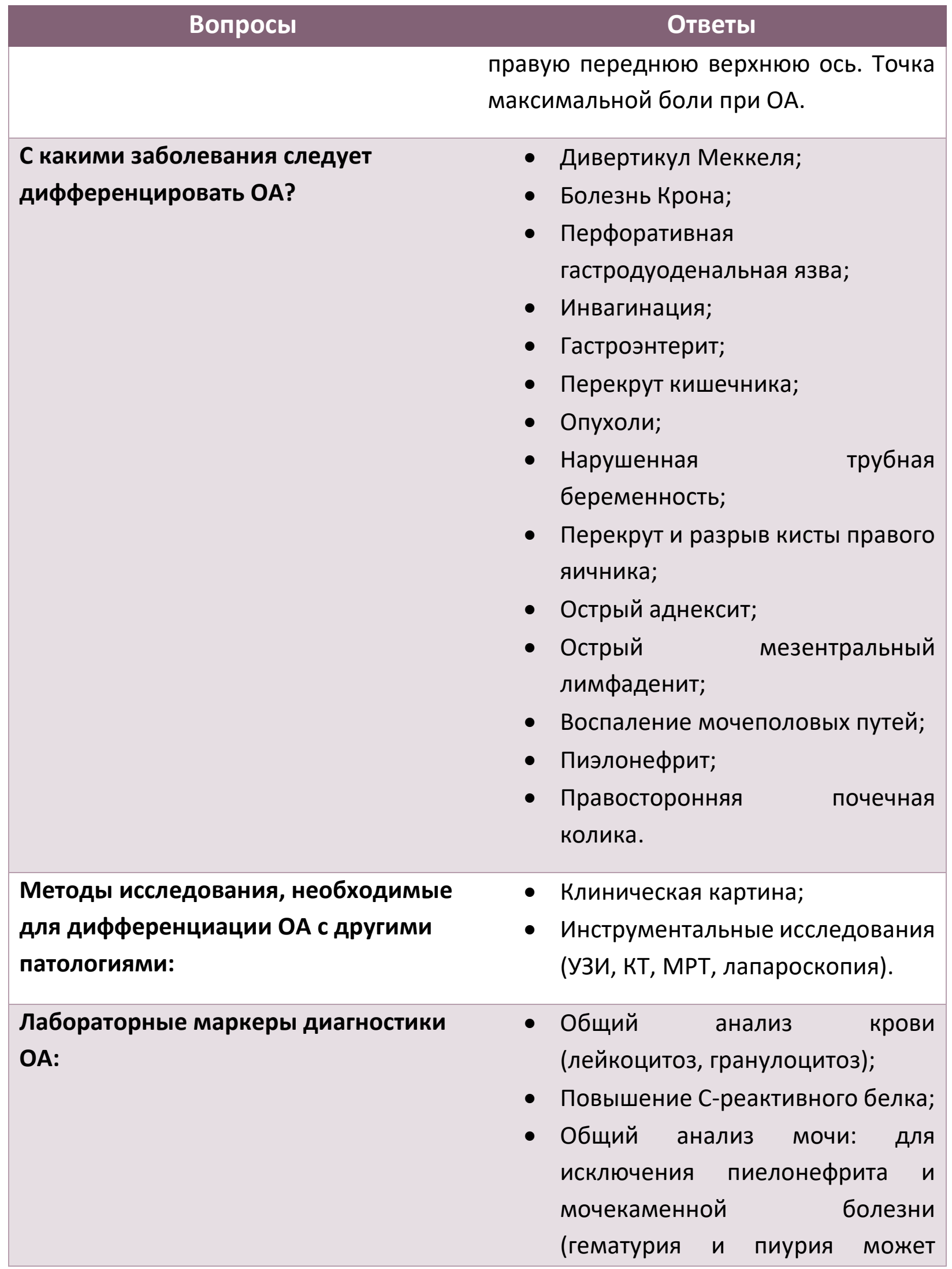




\begin{tabular}{|c|c|}
\hline Вопросы & Ответы \\
\hline & $\begin{array}{l}\text { наблюдаться при аппендицитах с } \\
\text { тазовым воспалением). } \\
\text { - Определение бета-ХГЧ у } \\
\text { молодых женщин. }\end{array}$ \\
\hline $\begin{array}{l}\text { Методы инструментальной } \\
\text { визуализации: }\end{array}$ & УЗИ, КТ, МРТ. \\
\hline Показание к МРТ: & $\begin{array}{l}\text { Неясная диагностика ОА у детей и } \\
\text { беременных. }\end{array}$ \\
\hline $\begin{array}{l}\text { Когда наблюдается классическая } \\
\text { рвота при ОА? }\end{array}$ & $\begin{array}{l}\text { При ОА рвота появляется после болей, а } \\
\text { при остром гастроэнтерите - наоборот, } \\
\text { рвота предшествует боли. }\end{array}$ \\
\hline $\begin{array}{l}\text { Может ли микроскопия мочи } \\
\text { исключить ОА? }\end{array}$ & $\begin{array}{l}\text { Не всегда. При ретроперитонеальном } \\
\text { расположении отростка возможно } \\
\text { вторичное воспаление мочеточника, } \\
\text { что может сопровождаться изменением } \\
\text { микроскопии мочи. }\end{array}$ \\
\hline КТ признаки острого аппендицита: & $\begin{array}{l}\text { Увеличение диаметра червеобразного } \\
\text { отростка более } 6 \text { мм, наличие } \\
\text { инфильтрата и жидкости. }\end{array}$ \\
\hline $\begin{array}{l}\text { В чем заключается предоперационная } \\
\text { подготовка? }\end{array}$ & $\begin{array}{l}\text { Умеренная инфузионная терапия и } \\
\text { антибиотикотерапия. }\end{array}$ \\
\hline $\begin{array}{l}\text { Принципы лечения неосложнённого } \\
\text { (простой, поверхностный, } \\
\text { катаральный) ОА: }\end{array}$ & $\begin{array}{l}\text { Инфузионная терапия, } \\
\text { антибиотикотерапия и аппендэктомия. }\end{array}$ \\
\hline $\begin{array}{l}\text { Принципы лечения острого } \\
\text { перфоративного аппендицита: }\end{array}$ & $\begin{array}{l}\text { Инфузионная терапия, аппендэктомия, } \\
\text { дренирование внутрибрюшной } \\
\text { жидкости и гноя, антибиотикотерапия. }\end{array}$ \\
\hline
\end{tabular}




\begin{tabular}{|c|c|}
\hline Вопросы & Ответы \\
\hline $\begin{array}{l}\text { Принципы лечения } \\
\text { периаппендикулярного абсцесса: }\end{array}$ & 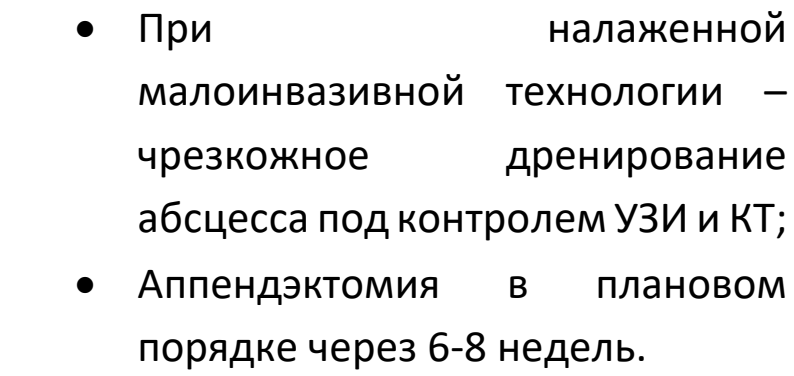 \\
\hline $\begin{array}{l}\text { Принципы лечения аппендикулярного } \\
\text { инфильтрата: }\end{array}$ & $\begin{array}{l}\text { - Консервативное (инфузионная и } \\
\text { антибактериальная терапия); } \\
\text { - Плановая аппендэктомия через } \\
\text { 6-8 нед. }\end{array}$ \\
\hline $\begin{array}{l}\text { Длительность антибиотикотерапии } \\
\text { при неосложненном ОА: }\end{array}$ & $\begin{array}{l}\text { Однократная доза в предоперационном } \\
\text { периоде. }\end{array}$ \\
\hline $\begin{array}{l}\text { Продолжительность } \\
\text { антибиотикотерапии при } \\
\text { перфоративном ОА: }\end{array}$ & $\begin{array}{l}\text { В среднем 3-5 дней (нормализация } \\
\text { уровня лейкоцитов в крови, отсутствие } \\
\text { температуры, } \\
\text { кишечной функции). }\end{array}$ \\
\hline Риск развития перфоративного ОА: & $\begin{array}{l}\text { Составляет: } \\
\begin{array}{l}\text { - } 25 \% \text { - в течение } 24 \text { ч. от начала } \\
\text { заболевания; } \\
\text { - } 50 \% \text { - в течение } 36 \text { ч; } \\
\text { - } 75 \% \text { - в течение } 48 \text { ч. }\end{array}\end{array}$ \\
\hline $\begin{array}{l}\text { Наиболее часто встречающаяся острая } \\
\text { хирургическая патология у } \\
\text { беременных: }\end{array}$ & $\begin{array}{l}\text { Острый аппендицит (в связи с } \\
\text { увеличением размеров матки боль } \\
\text { может наблюдаться в правом верхнем } \\
\text { кравданте). }\end{array}$ \\
\hline Осложнения ОА: & $\begin{array}{lr}\text { Перитонит, абсцессы брюшной полости, } \\
\text { аппендиккулярный } \\
\text { пилефлебит, } \\
\text { непроходимость. }\end{array}$ \\
\hline
\end{tabular}




\begin{tabular}{|c|c|}
\hline Вопросы & Ответы \\
\hline $\begin{array}{l}\text { Частота встречаемости ОА с } \\
\text { ретроцекальным и } \\
\text { ретроперитонеальным } \\
\text { расположением червеобразного } \\
\text { отростка: }\end{array}$ & Составляет примерно 15\%. \\
\hline $\begin{array}{l}\text { Стоит ли удалять неизменённый } \\
\text { аппендикс? }\end{array}$ & 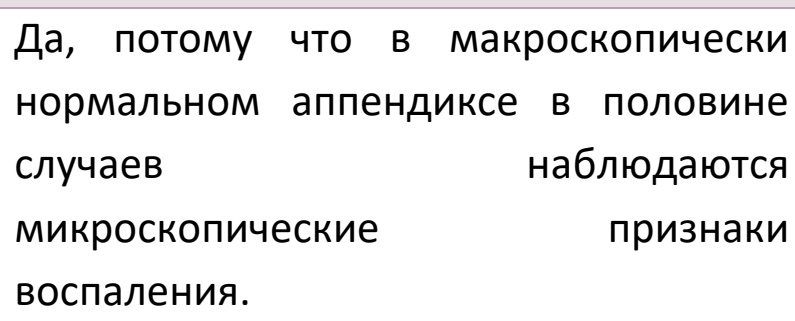 \\
\hline $\begin{array}{l}\text { Частота несоответствия между } \\
\text { клиническим и патогистологическим } \\
\text { диагнозами? }\end{array}$ & Составляет 20\%. \\
\hline Что такое “попутная" аппендэктомия? & $\begin{array}{l}\text { Удаление } \\
\begin{array}{l}\text { нервеобразного } \\
\text { четростка } \\
\text { операциях на ори } \\
\text { полости. }\end{array}\end{array}$ \\
\hline Осложнения аппендэктомии: & $\begin{array}{l}\text { Спаечная болезнь брюшной полости с } \\
\text { развитием кишечной непроходимости, } \\
\text { кишечные свищи, нагноение раны, } \\
\text { бесплодие у женщин, риск развития } \\
\text { правосторонней паховой грыжи, } \\
\text { абсцесс, кровотечение, перитонит. }\end{array}$ \\
\hline $\begin{array}{l}\text { Обязательно ли интраоперационное } \\
\text { культуральное исследование при ОА? }\end{array}$ & $\begin{array}{l}\text { Не обязательно. Оно проводится при } \\
\text { деструктивных и осложненных формах } \\
\text { ОА (гангренозный и перфоративный ОА, } \\
\text { перитонит). }\end{array}$ \\
\hline $\begin{array}{l}\text { Анатомические ориентиры } \\
\text { локализации червеобразного } \\
\text { отростка: }\end{array}$ & $\begin{array}{l}\text { Место слияния трех лент продольных } \\
\text { мышц слепой кишки. }\end{array}$ \\
\hline
\end{tabular}




\begin{tabular}{|c|c|}
\hline Вопросы & \\
\hline $\begin{array}{l}\text { Как осуществляют доступ при } \\
\text { ретроцекальном и } \\
\text { ретроперитонеальном ОА? }\end{array}$ & 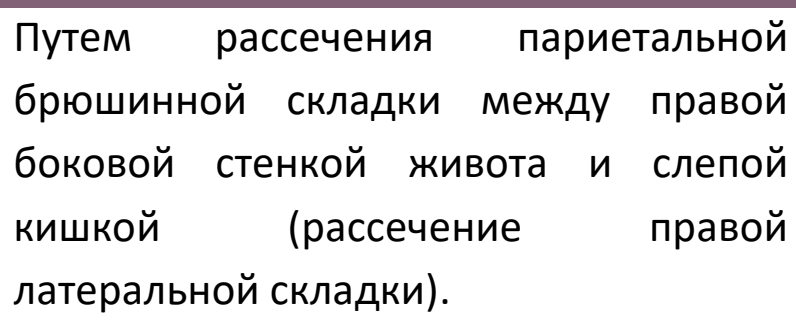 \\
\hline $\begin{array}{l}\text { С какой целью проводится } \\
\text { электрокоагуляция слизистой культи } \\
\text { червеобразного отростка при } \\
\text { аппендэктомии? }\end{array}$ & $\begin{array}{l}\text { Для предотвращения развития } \\
\text { мукоцеле. }\end{array}$ \\
\hline $\begin{array}{l}\text { Показана ли аппендэктомия при } \\
\text { обнаружении во время операции } \\
\text { болезни Крона? }\end{array}$ & $\begin{array}{l}\text { Да, показана, если в процесс не } \\
\text { вовлечено основание аппендикса. }\end{array}$ \\
\hline $\begin{array}{l}\text { Интраоперационная тактика при } \\
\text { несоответствии клинического диаг- } \\
\text { ноза операционной находке: }\end{array}$ & $\begin{array}{l}\text { Исключить или подтвердить: } \\
\text { Дивертикул Меккеля, болезнь Крона } \\
\text { (терминальный илеит), инвагинация, } \\
\text { гинекологическая патология } \\
\text { (сальпингит, кисты или перекрут } \\
\text { правого яичника), грыжи, гематома } \\
\text { влагалища прямой мышцы. }\end{array}$ \\
\hline $\begin{array}{l}\text { Наиболее часто встречающееся } \\
\text { послеоперационное осложнение: }\end{array}$ & $\begin{array}{l}\text { Раневая инфекция (инфильтраты, } \\
\text { абсцессы). }\end{array}$ \\
\hline
\end{tabular}




\section{ОПУХОЛИ АППЕНДИКСА}

- Опухоли червеобразного отростка встречаются редко. К доброкачественным опухолям относятся невромы, миомы, липомы, ангиомы, фибромы, полипы. К злокачественным - карциноиды (90\%), аденокарцинома и ретикулобластома.

- Почти все опухоли аппендикса, за исключением карциноидных, не проявляются какими-либо специфическими симптомами и, как правило, они обнаруживаются в процессе аппендэктомии. Диагноз верифицируется гистологически.

- При доброкачественных опухолях и карциноидных опухолях ранней стадии показана аппендэктомия. При аденокарциномах выполняется гемиколэктомия. Необходимо отличать мукоцеле от псевдомиксомы; при доброкачественной мукоцеле выполняется аппендэктомия, а при злокачественной - расширенная резекция.

\section{Вопросы и ответы по опухолям аппендикса}

\section{Вопросы}

Наиболее часто

опухоль аппендикса:

\section{Ответы}

встречающаяся Карциноидная опухоль.

\section{Хирургическая тактика при При отсутствии инвазии в стенку слепой карциноидной опухоли, размером кишки-аппендэктомия. менее 2 см:}

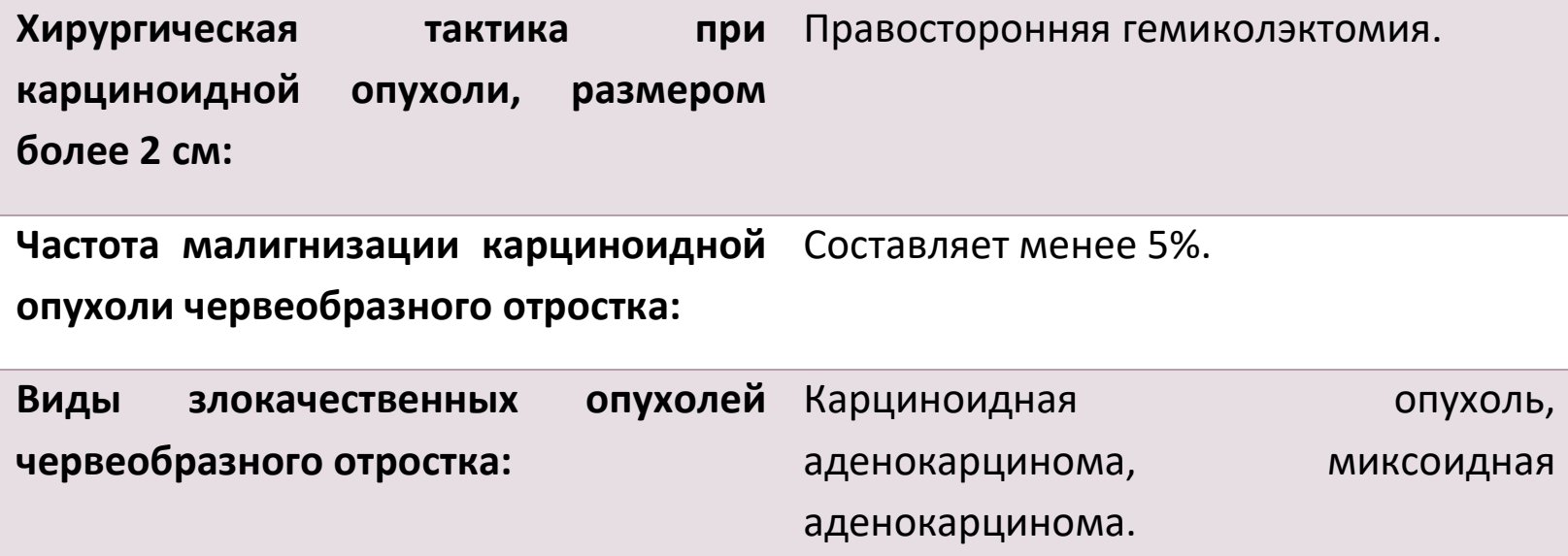




\section{Вопросы}

\section{Ответы}

Какой вид опухоли червеобразного Миксоидная аденокарцинома.

отростка осложняется диссеминацией

при перфорации отростка?

\section{СПИСОК ЛИТЕРАТУРЫ}

- Ağayev B.A. Cərrahi xəstəliklər. Bakı 2010.

- Blackbourne LH. Surgical Recall. 4 edition, 2006, LWW, Philadelphia

- Doherty GM. Current Diagnosis and Treatment: Surgery, $13^{\text {th }}$ edition, 2010, Lang International Edition.

- Omiraslanov Ә.T., Qazıyev A.Y. Onkologiya. Bakı, 2010.

- İsayev H.B. Cərrahi xəstəliklərin patofizologiyası. Bakı 2005

- Klingensmith ME, Aziz A, Bharat A, Fox AC, Porembka MR. The Washington Manual of Surgery, $6^{\text {th }}$ edition, 2012, LWW, Philadelphia.

- McNally PR. GI/Liver Secrets Plus. 4 edition. Mosby, Elsevier, 2010

- Medscape, http://www.medscape.com

- Oxford Handbook of Clinical Surgery, 3d edition, 2011, Oxford Press

- Sayek I. Sayek Temel Cerrahi 1-2. 4-cü baskı, 2016, Güneş Tıp Kitabevleri.

- Topçubaşov M.A. Xüsusi cərrahlıq. Bakı, 1979

- UpToDate, http://www.uptodate.com

- Гостищев В.К. Общая хирургия. GEOTAR-Media, 2019

- N.Y.Bayramov. Təcili Abdominal cərrahiyyədə müayinə və müalicə qaydaları. ISBN13 978-9952-8082-1-6, Qismət, Bakı 2009. $132 \mathrm{~s}$

- Mussack T, Schmidbauer S, Nerlich A, et al. [Chronic appendicitis as an independent clinical entity]. Chirurg 2002; 73:710.

- Leardi S, Delmonaco S, Ventura T, et al. [Recurrent abdominal pain and "chronic appendicitis"]. Minerva Chir 2000; 55:39. 


\title{
ХИРУРГИЧЕСКИЕ БОЛЕЗНИ
}

Н.Ю. Байрамов

\section{Хирургические заболевания прямой кишки и анального канала}

\author{
Н.Ю. Байрамов, С.С. Иманова
}

Перевод: Н.Ю. Байрамов, С.А. Алиев, М.Р. Гусейнова 


\section{АНАТОМО-ФИЗИОЛОГИЧЕСКИЕ ОСОБЕННОСТИ, ЗАБОЛЕВАНИЯ И ОБСЛЕДОВАНИЕ ПРЯМОЙ КИШКИ И АНАЛЬНОГО КАНАЛА}

- Прямая кишка, длиной 12-15 см, расположена в терминальном отделе кишечного тракта и состоит из надампулярной (1/5), ампулярной (3/5) и заднепроходной (анальной - 1/5) части.

- Прямая кишка выполняет 2 основные функции: удержание газов и кала (анальная континенция) и дефекация.

- Методы (алгоритмы) обследования прямой кишки:

○ Тщательный анамнез (кровотечение, боль, выделение слизи и гноя);

○ Осмотр (выпадение слизистой прямой кишки, патологические образования в перианальной области);

- Пальцевое исследование (состояние тонуса анального сфинктера, патологические изменения слизистой прямой кишки);

○ Инструментальные исследования (аноскопия, ректоскопия, ректосигмоидоскопия, колоноскопия, ирригоскопия, фистулография, ректальная ультрасонография, сфинктероманометрия, дефекография, KT, MPT, ПЭТ-КT).

\section{Вопросы и ответы по анатомии, физиологии и методам обследования прямой кишки}

\begin{tabular}{|c|c|}
\hline Вопросы & Ответы \\
\hline $\begin{array}{l}\text { Топографическая анатомия прямой } \\
\text { кишки: }\end{array}$ & $\begin{array}{l}\text { Прямая кишка расположена между } \\
\text { сигмовидной кишкой и анальным } \\
\text { отверстием. }\end{array}$ \\
\hline Отношение прямой кишки к брюшине: & $\begin{array}{l}\text { Верхнеампулярные } \text { отделы } \\
\text { брюшиной с с } \\
\text { нижнеампулярыты } \\
\text { канал не покрыты брюшиной. }\end{array}$ \\
\hline Где расположена зубчатая линия? & $\begin{array}{l}\text { В месте перехода слизистой оболочки } \\
\text { прямой кишки в анодерму. }\end{array}$ \\
\hline
\end{tabular}




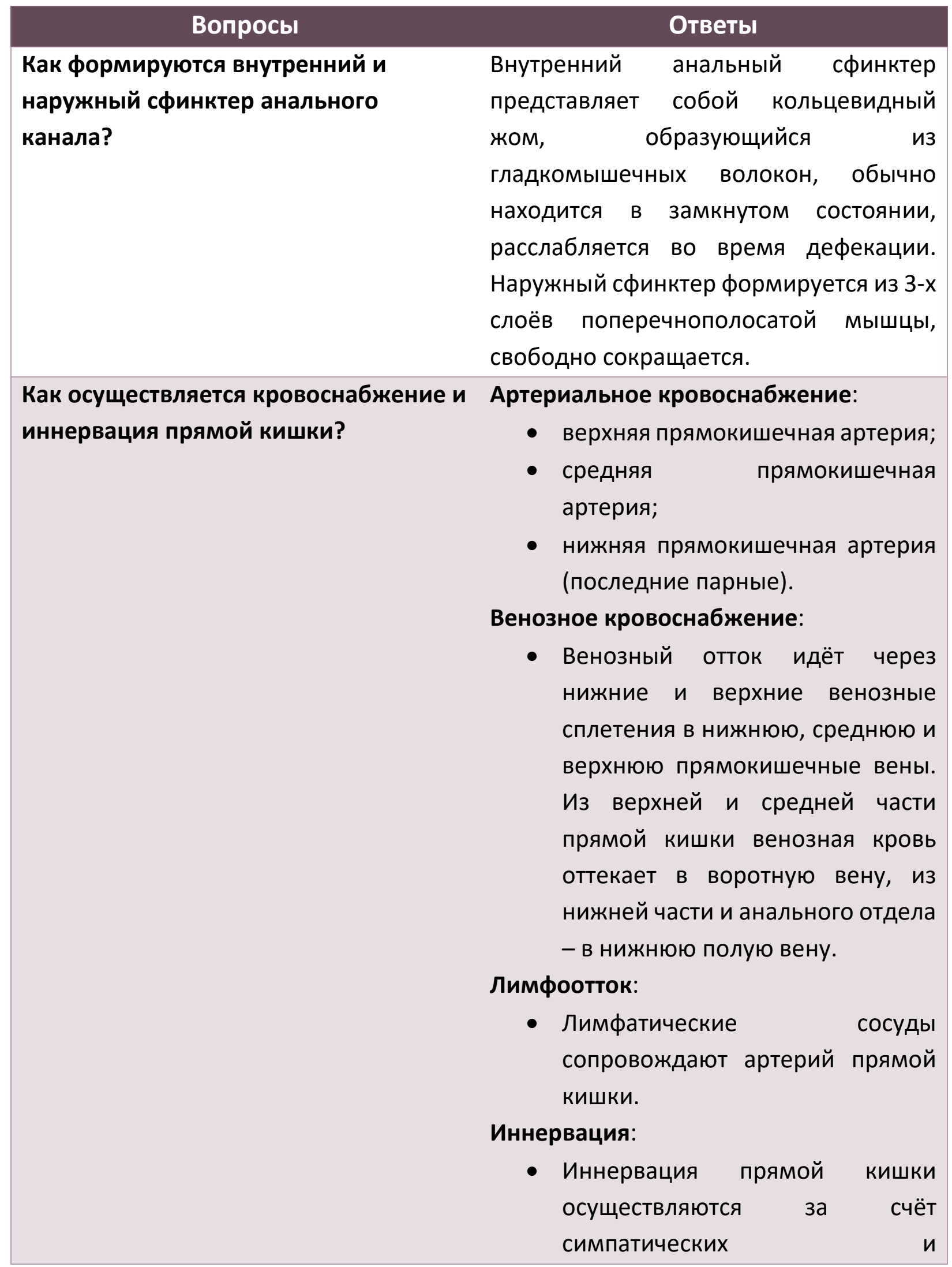




\begin{tabular}{|c|c|}
\hline Вопросы & Ответы \\
\hline & $\begin{array}{l}\text { парасимпатических нервных } \\
\text { волокон. }\end{array}$ \\
\hline Функции прямой кишки: & $\begin{array}{l}\text { Прямая кишка выполняет } 2 \text { основные } \\
\text { функции: } \\
\text { • анальная континенция - } \\
\text { удержание газов и кала; } \\
\text { • дефекация. }\end{array}$ \\
\hline $\begin{array}{l}\text { Инструментальные методы } \\
\text { исследования прямой кишки: }\end{array}$ & $\begin{array}{l}\text { Аноскопия, } \\
\text { фистулография, ректосигмоидоскопия, } \\
\text { колоноскопия, } \\
\text { дефекография, эндоректальное УзИ, } \\
\text { сфинктероманометрия, КТ, МРТ, ПЭТ- } \\
\text { КТ. }\end{array}$ \\
\hline
\end{tabular}




\section{ГЕМОРРОЙ}

- Геморрой представляет собой патологическое разрастание кавернозных телец, расположенных в подслизистом слое дистального отдела прямой кишки с обилием прямых артериовенозных шунтов.

- Геморрой встречается у $10 \%$ людей.

- К этиологическим факторам возникновения геморроя относятся хронические запоры, портальная гипертензия, беременность, употребление спиртных напитков, сидячий образ жизни.

- В развитии геморроя ведущую роль играют 2 теории: механическая и гемодинамическая.

- Заболевание проявляется дискомфортом (чувство инородного тела) в анальном канале, кровотечением из прямой кишки, выпадением венозных узлов и слизистой оболочки прямой кишки, анальным зудом, болью.

- Диагноз геморроя ставится на основании клинической картины и данных объективных методов исследования.

- Лечение зависит от стадии (степени) заболевания. Существуют консервативные и хирургические методы лечения. В последнее время применяются малоинвазивные методы хирургического лечения.

\section{Вопросы и ответы по диагностике и лечению геморроя}

\begin{tabular}{|ll|}
\hline \multicolumn{1}{|c|}{ Вопросы } & \multicolumn{1}{c|}{ Ответы } \\
\hline Что такое геморрой? & $\begin{array}{l}\text { Геморрой - патологическое } \\
\text { разрастание и выпадение кавернозных } \\
\text { телец, расположенных в подслизистом } \\
\text { слое дистального отдела прямой } \\
\text { кишки. }\end{array}$ \\
\hline Причины возникновения геморроя: & $\begin{array}{l}\text { Хронические запоры, портальная } \\
\text { гипертензия, беременность. }\end{array}$ \\
\hline Локализация внутреннего геморроя: & $\begin{array}{l}\text { Внутренние геморроидальные узлы } \\
\text { расположены выше зубчатой линии. }\end{array}$ \\
\hline
\end{tabular}




\begin{tabular}{|c|c|}
\hline Вопросы & Ответы \\
\hline $\begin{array}{l}\text { Локализация наружных } \\
\text { геморроидальных узлов: }\end{array}$ & $\begin{array}{l}\text { Наружные геморроидальные узлы } \\
\text { расположены ниже зубчатой линии. }\end{array}$ \\
\hline $\begin{array}{l}\text { В каких отделах анального канала } \\
\text { обычно локализуются } \\
\text { геморроидальные узлы? }\end{array}$ & $\begin{array}{l}\text { - Левый латеральный; } \\
\text { - Правый задний; } \\
\text { - Правый передний. }\end{array}$ \\
\hline Клинические проявления геморроя: & $\begin{array}{l}\text { Дискомфорт (чувство инородного тела) } \\
\text { в анальном канале, кровотечение из } \\
\text { прямой кишки, выпадение венозных } \\
\text { узлов и слизистой оболочки прямой } \\
\text { кишки, анальный зуд, боль. }\end{array}$ \\
\hline Наиболее тяжёлая форма геморроя: & $\begin{array}{l}\text { Наружный геморрой } \\
\text { расположены ниже зубчатой линии). }\end{array}$ \\
\hline $\begin{array}{l}\text { Какие методы исследования } \\
\text { необходимы для уточнения диагноза? }\end{array}$ & $\begin{array}{l}\text { - Клинические (анамнез, } \\
\text { объективное исследование); } \\
\text { - Ректоскопия; } \\
\text { - Колоноскопия. }\end{array}$ \\
\hline $\begin{array}{l}\text { Чем характеризуется I степень } \\
\text { геморроя? }\end{array}$ & $\begin{array}{l}\text { Геморроидальные узлы выступают в } \\
\text { просвет прямой кишки, но не выпадают. }\end{array}$ \\
\hline $\begin{array}{l}\text { Чем характеризуется II степень } \\
\text { геморроя? }\end{array}$ & $\begin{array}{l}\text { Геморроидальные узлы выпадают при } \\
\text { дефекации и самостоятельно } \\
\text { вправляются после неё. }\end{array}$ \\
\hline $\begin{array}{l}\text { Чем характеризуется III степень } \\
\text { геморроя? }\end{array}$ & $\begin{array}{l}\text { Узлы выпадают даже при } \\
\text { незначительной физической нагрузке, } \\
\text { самостоятельно не вправляются, } \\
\text { необходимо вправлять их рукой. }\end{array}$ \\
\hline $\begin{array}{l}\text { Чем характеризуется IV степень } \\
\text { геморроя? }\end{array}$ & $\begin{array}{l}\text { Геморроидальные узлы постоянно } \\
\text { находятся в выпавшем состоянии и не } \\
\text { вправляются в анальный канал. }\end{array}$ \\
\hline $\begin{array}{l}\text { Что включает в себя лечение } \\
\text { геморроя? }\end{array}$ & 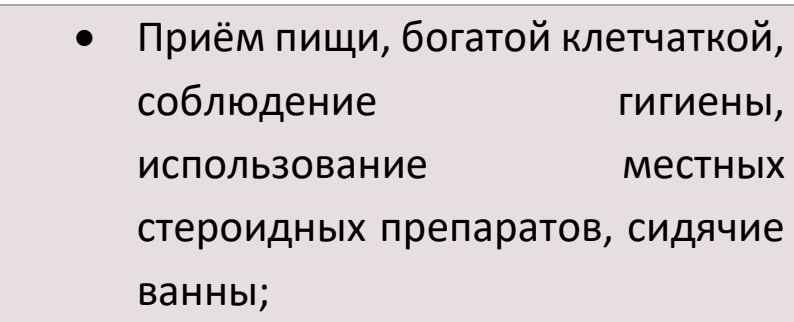 \\
\hline
\end{tabular}




\section{Boпросы}

\section{Ответы}

- Латексное лигирование внутренних узлов, ушивание сосуда и узла;

- Хирургическое лечение. 


\section{АНАЛЬНАЯ ТРЕЩИНА}

- Анальная трещина характеризуется образованием линейного дефекта (язвы) в дистальной части анального канала.

- Различают острую и хроническую формы трещины.

- Заболевание проявляется сильными болями в области анального отверстия, кровотечением во время дефекации. Характерной особенностью является повышение тонуса анального сфинктера.

- Диагностика анальной трещины основана на данных анамнеза, осмотра заднего прохода. При ректальном обследовании обнаруживается линейная поверхностная рана, в дистальном отделе которой определяется гипертрофическая папиллома (“сторожевой” бугорок).

- Острая анальная трещина требует консервативной терапии (слабительные, спазмолитики, ректальные свечи, содержащие анальгезирующие вещества, различные гели, мази на стероидной основе). В последние годы с успехом применяют ботулиновый токсин (ботокс). Основным условием лечения острой трещины является устранение гипертонуса анального сфинктера. Острая анальная трещина при своевременном лечении заживает в течение 36 недель.

- Хроническая анальная трещина приводит к рубцовому замещению и фиброзному перерождению мышечных элементов анального сфинктера, вследствие чего происходит сужение анального отверстия.

- При хронической анальной трещине показана операция - иссечение анальной трещины с боковой сфинктеротомией.

\section{Вопросы и ответы по анальной трещине}

\section{Вопросы}

Что такое анальная трещина?

Частая локализация трещины:

\section{Ответы}

Линейная рана слизисто-кожного перехода анального канала.

Задняя коммиссура анального канала (область со слабым кровообращением). 


\begin{tabular}{|c|c|}
\hline Вопросы & Ответы \\
\hline $\begin{array}{l}\text { Причины возникновения анальной } \\
\text { трещины: }\end{array}$ & $\begin{array}{l}\text { Хронический запор, повышенный тонус } \\
\text { анального сфинктера, заболевания } \\
\text { перианальной области (болезнь Крона). }\end{array}$ \\
\hline Клинические проявления: & $\begin{array}{l}\text { Боли в анальном отверстии, } \\
\text { усиливающиеся во время дефекации, } \\
\text { сопровождающиеся кровотечением, } \\
\text { гипертрофическая папиллома } \\
\text { анальном канале и кожный бугорок. }\end{array}$ \\
\hline Что такое кожный бугорок? & $\begin{array}{l}\text { Наличие бугорка в виде небольшого } \\
\text { геморроидального узла (гипертрофия } \\
\text { слизистой) в дистальном углу трещины. }\end{array}$ \\
\hline $\begin{array}{l}\text { Триада симптомов, характерных для } \\
\text { хронической анальной трещины: }\end{array}$ & $\begin{array}{l}\text { 1. Продольный дефект слизисто- } \\
\text { кожного перехода анального } \\
\text { канала с утолщенными краями; } \\
\text { 2. Кожный бугорок; } \\
\text { 3. Наличие гипертрофического } \\
\text { бугорка (папилломы) в } \\
\text { проксимальном углу. }\end{array}$ \\
\hline $\begin{array}{l}\text { В чем заключается консервативное } \\
\text { лечение? }\end{array}$ & $\begin{array}{l}\text { Урегулирование стула, диетотерапия, } \\
\text { теплые сидячие ванны, микроклизмы с } \\
\text { антисептическими растворами, } \\
\text { инъекция ботулинового токсина, } \\
\text { ректальные свечи, мази, гели, } \\
\text { спазмолитики. }\end{array}$ \\
\hline $\begin{array}{l}\text { Какие заболевания нужно исключить } \\
\text { при выявлении анальной трещины? }\end{array}$ & $\begin{array}{l}\text { Рак анального канала, болезнь Крона, } \\
\text { венерические заболевания, СпИД, } \\
\text { неспецифический язвенный колит. }\end{array}$ \\
\hline Показания к хирургическому лечению: & $\begin{array}{l}\text { Неэффективность консервативного } \\
\text { лечения. }\end{array}$ \\
\hline Метод хирургического лечения: & $\begin{array}{l}\text { Иссечение трещины, латеральная } \\
\text { сфинктеротомия. }\end{array}$ \\
\hline
\end{tabular}




\section{ПАРАПРОКТИТ}

- Парапроктит или параректальный абсцесс - гнойное воспаление околопрямокишечной клетчатки, которое может вызвать возникновение параректального свища и сепсиса.

- У мужчин встречается в 2-5 раз чаще чем у женщин.

- К этиологическим факторам относятся: хронический запор, сахарный диабет, наличие анальной трещины, венерические заболевания, воспалительные заболевания кишечника и др.

- Заболевание характеризуется формированием локального гнойника в параректальной клетчатки, которое сопровождается болью, высокой температурой, ознобом, явлениями гнойной интоксикации.

- Различают следующие клинические формы парапроктита: перианальный, подслизистый, интрасфинктерный, ишиоректальный, супралеваторный.

- Диагностика осуществляется на основании клинико-объективных и инструментальных методов исследований (УЗИ, КТ, МРТ). Диагностические критерии: боли вокруг анального отверстия, припухлость, гиперемия, гипертермия, выявление скопления жидкости (гноя) при ректальном УЗИ или KT/MPT.

- Основным методом лечения является хирургический - вскрытие и дренирование гнойника, а также антибиотикотерапия.

\section{Вопросы и ответы по парапроктиту}

\begin{tabular}{|l|c|}
\hline \multicolumn{1}{|c|}{ Вопросы } & \multicolumn{1}{c|}{ Ответы } \\
\hline Что такое парапроктит? & $\begin{array}{l}\text { Гнойное воспаление } \\
\text { параректальной клетчатки. }\end{array}$ \\
\hline Частота встречаемости: & Наиболее чаще встречается у \\
& пациентов в возрасте $30-50$ лет. \\
& У мужчин встречается в 2-5 раз \\
& чаще чем у женщин. \\
& Редко встречается у детей. \\
\hline
\end{tabular}




\begin{tabular}{|c|c|}
\hline Вопросы & Ответы \\
\hline $\begin{array}{l}\text { Какие клинические формы } \\
\text { парапроктитов различают? }\end{array}$ & $\begin{array}{l}\text { Нижние абсцессы: } \\
\text { 1. Перианальный }-40 \% ; \\
\text { 2. Интрасфинктерный }-40 \% \text {; } \\
\text { 3. Ишиоректальный }-20 \% \text {. } \\
\text { Верхние абсцессы: } \\
\text { 1. Супралеваторный }-6 \% \text {; } \\
\text { 2. Субмукозальный - } 3 \% \text {. }\end{array}$ \\
\hline Причины и факторы риска: & $\begin{array}{l}\text { - Хронический запор; } \\
\text { - Сахарный диабет; } \\
\text { - Анальная трещина; } \\
\text { - Венерические заболевания; } \\
\text { - Воспалительные заболевания } \\
\text { кишечника; } \\
\text { - Дивертикулит; } \\
\text { - Использование кортизоновых } \\
\text { свечей и мазей. }\end{array}$ \\
\hline Осложнения: & $\begin{array}{l}\text { - Сепсис; } \\
\text { - Параректальный свищ (40-50\%). }\end{array}$ \\
\hline Клинические проявления: & $\begin{array}{l}\text { - Боли вокруганального отверстия, } \\
\text { наличие гиперемии и } \\
\text { припухлости кожи перианальной } \\
\text { зоны; } \\
\text { - Высокая температура; } \\
\text { - Озноб, слабость; } \\
\text { - Наличие резко болезненного } \\
\text { инфильтрата в параректальной } \\
\text { зоне, деформация анального } \\
\text { отверстия; } \\
\text { - Болезненный инфильтрат } \\
\text { твёрдой консистенции. }\end{array}$ \\
\hline У каких больных можно заподозрить? & $\begin{array}{l}\text { Наличие болей в параректальной } \\
\text { области и признаков сепсиса. }\end{array}$ \\
\hline
\end{tabular}




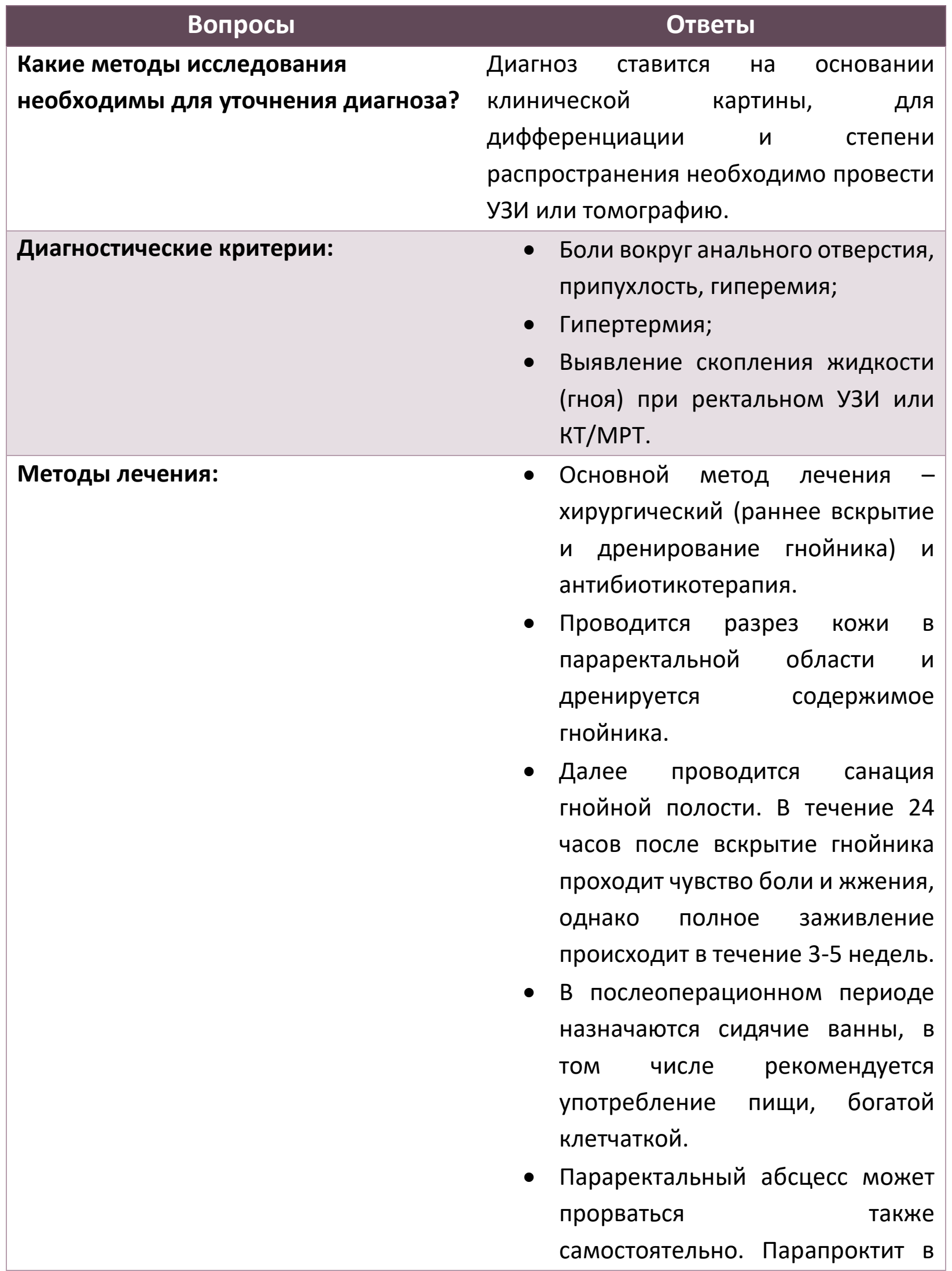




\begin{tabular}{|l|l|}
\hline Вопросы & \multicolumn{2}{c|}{ Ответы } \\
\hline & $40-50 \%$ случаев приводит к \\
& образованию параректального \\
& свища. \\
\hline
\end{tabular}




\section{ГАНГРЕНА ФУРНЬЕ}

- Гангрена Фурнье - это гнойно-некротическое заболевание, характеризующееся некротическим поражением генитальных органов.

- Чаще болеют мужчины.

- Основными нозологическими причинами являются патологии аноректальной зоны (25-30\%), урогенитального тракта (20-25\%) и кожные заболевания (20\%).

- Ведущими патогенетическими механизмами является тромбоз сосудов микроциркуляторного русла поверхностной фасции наружных половых органов.

- Клиническая картина характеризуется внезапным началом острого гнойнонекротического процесса, прогрессирующим некрозом кожи и подкожно жировой клетчатки, сопровождающееся высокой температурой, развитием сепсиса и полиорганной недостаточности.

- Диагноз ставится на основе клинической картины: перианальный некроз, отёк и признаки сепсиса.

- Лечение - должно проводиться в условиях отделении реанимации и интенсивной терапии. Раннее хирургическое вмешательство с широким иссечением некротизированных $и$ нежизнеспособных тканей, целенаправленная антибактериальная, гипербарическая оксигенация и интенсивная терапия являются залогом успешного лечения.

\section{Вопросы и ответы по гангрене Фурнье}

\begin{tabular}{|ll|}
\hline \multicolumn{1}{|c|}{ Вопросы } & \multicolumn{1}{c|}{ Ответы } \\
\hline Что такое гангрена Фурнье? & Прогрессирующий обширный некроз \\
& кожи, подкожной клетчатки \\
& генитальных органов. \\
\hline Этиология: & Нозологическими причинами являются \\
& патологии аноректальной зоны (25- \\
& $30 \%)$, урогенитального тракта (20-25\%) и \\
& кожные болезни (20\%). \\
\hline
\end{tabular}




\begin{tabular}{|c|c|}
\hline Вопросы & Ответы \\
\hline Диагностика: & $\begin{array}{l}\text { Наличие обширного некротического } \\
\text { поражения генитальных органов, } \\
\text { распространяющееся на промежность, } \\
\text { паховую область. }\end{array}$ \\
\hline Лечение: & $\begin{array}{l}\text { - Некрэктомия; } \\
\text { - Антибиотикотерапия; } \\
\text { - Гипербарическая оксигенация. }\end{array}$ \\
\hline
\end{tabular}




\section{ПАРАРЕКТАЛЬНЫЕ СВИЩИ}

- Параректальный свищ - это патологический канал, образовавшийся между анальным каналом и перианальной кожей.

- Частота встречаемости интрасфинктерных свищей - 45\%, транссфинктерных 30\%, супрасфинктерных - 20\%, экстрасфинктерных - 5\%.

- Этиологическим фактором возникновения параректальных свищей является инфицирование анальных крипт или желёз.

- Для диагностирования параректальных свищей проводят пальцевое исследование, зондирование прямой кишки, ректальное УзИ, МРТ, эндоскопическое исследование (аноскопия, сигмоидоскопия или колоноскопия).

- К диагностическим критериям относятся: гиперемия в перианальной области, наличие наружного отверстия свищевого канала, выделение гноя из данного отверстия. При введении смеси пероксида водорода и метиленовой сини через наружное отверстие наблюдается выделение данной смеси через внутреннее отверстие, находящееся в анальном канале на уровне зубчатой линии.

- Лечение параректальных свищей - консервативное (сидячие ванны, согревающие компрессы, урегулирование стула, мазевые перевязки, антибиотики, рентгенотерапия); нехирургическое лечение (фибриновый клей, техника Fistula Plug); хирургическое лечение - лазерная техника, применение сетона, техника VAAFT, LIFT, фистулотомия, фистулэктомия, ушивание свищевого канала.

\section{Вопросы и ответы по параректальным свищам}

\begin{tabular}{|ll}
\multicolumn{1}{c}{ Вопросы } & \multicolumn{1}{c|}{ Ответы } \\
\hline Что такое свищ? & $\begin{array}{l}\text { Это патологический канал между } \\
\text { прямой кишкой и перианальной кожей. }\end{array}$ \\
\hline $\begin{array}{l}\text { Причина возникновения } \\
\text { параректальных свищей: }\end{array}$ & $\begin{array}{l}\text { Инфицирование анальных крипт/желез } \\
\text { (перианальный абсцесс). }\end{array}$ \\
\hline
\end{tabular}




\begin{tabular}{|c|c|}
\hline Вопросы & Ответы \\
\hline $\begin{array}{l}\text { Признаки и симптомы } \\
\text { параректальных свищей: }\end{array}$ & $\begin{array}{l}\text { Выделения из прямой кишки, зуд, } \\
\text { параректальный абсцесс. }\end{array}$ \\
\hline $\begin{array}{l}\text { При каком заболевании можно } \\
\text { заподозрить о наличии } \\
\text { параректального свища? }\end{array}$ & Болезнь Крона. \\
\hline На основе чего ставится диагноз? & $\begin{array}{l}\text { - Клиническая картина; } \\
\text { - Проктоскопия. }\end{array}$ \\
\hline $\begin{array}{l}\text { Принципы лечения параректальных } \\
\text { свищей: }\end{array}$ & $\begin{array}{l}\text { - Определение анатомической } \\
\text { картины; } \\
\text { - Выявление свищевого хода; } \\
\text { - Уход за раной: сидячие ванны, } \\
\text { перевязки; } \\
\text { - Применение лигатуры при } \\
\text { транссфинктерных свищах. }\end{array}$ \\
\hline Что такое лигатура? & $\begin{array}{l}\text { Является толстой нитью, проходящей } \\
\text { через свищевой ход и способствующей } \\
\text { постепенному разрезу анального } \\
\text { сфинктера, формированию фиброзной } \\
\text { ткани. }\end{array}$ \\
\hline $\begin{array}{l}\text { Как интраоперационно обнаруживают } \\
\text { внутреннее отверстие свищевого } \\
\text { канала? }\end{array}$ & $\begin{array}{l}\text { Через наружное отверстие свищевого } \\
\text { канала вводят раствор перекиси } \\
\text { водорода или метиленовой сини, } \\
\text { который выделяется через внутреннее } \\
\text { отверстие. }\end{array}$ \\
\hline
\end{tabular}




\section{РЕКТОВАГИНАЛЬНЫЕ СВИЩИ}

- Ректовагинальные свищи представляют собой патологическое сообщение между прямой кишкой и влагалищем.

- Причинами возникновения ректовагинальных свищей являются родовые травмы (20-80\%), деструктивные воспалительные процессы прямой кишки, дивертикулы, злокачественные новообразования, болезнь Крона.

- Клиническая картина ректовагинальных свищей характеризуется выделением газов и кала из влагалища, патологическое выделение из влагалища с неприятным запахом.

- Различают верхний и нижний ректовагинальные свищи.

- У 45-50\% больных ректовагинальные свищи могут закрываться самостоятельно. Хирургическое лечение предусматривает ликвидацию патологического сообщения между прямой кишкой и влагалищем.

\section{Вопросы и ответы по ректовагинальным свищам}

\begin{tabular}{|c|c|}
\hline Вопросы & Ответы \\
\hline Что такое ректовагинальный свищ? & $\begin{array}{l}\text { Патологическое сообщение между } \\
\text { прямой кишкой и влагалищем. }\end{array}$ \\
\hline Диагностические критерии: & Выделение из влагалища газов и кала. \\
\hline Наиболее частая причина: & Родовые травмы (20-80\%). \\
\hline $\begin{array}{l}\text { Хирургические доступы при операции } \\
\text { по поводу ректовагинальных свищей: }\end{array}$ & $\begin{array}{l}\text { • Перинеальный } \\
\text { (промежностный); } \\
\text { • Абдоминальный. }\end{array}$ \\
\hline $\begin{array}{l}\text { Осложнения после оперативных } \\
\text { вмешательств: }\end{array}$ & $\begin{array}{l}\text { - Боли при половом акте; } \\
\text { - Недержание мочи; } \\
\text { - Недержание газов и кала. }\end{array}$ \\
\hline
\end{tabular}




\section{ВЫПАДЕНИЕ ПРЯМОЙ КИШКИ}

- Выпадение (пролапс) прямой кишки - выхождение кишки наружу за пределы анального отверстия.

- Основной причиной выпадения прямой кишки является слабость тазового дна и повышение внутрибрюшного давления. Немаловажную роль играет также слабость замыкательной функции анального сфинктера.

- Различают выпадение анального отверстия, выпадение прямой кишки, одновременное выпадение анального отверстия и прямой кишки.

- Различают 3 стадии выпадения:

○ I стадия - выпадение кишки лишь во время дефекации; после чего кишка самостоятельно вправляется;

○ II стадия - прямая кишка выпадает при физической нагрузке, самостоятельно не вправляется, больные вправляют кишку рукой;

О III стадия - выпадение кишки при незначительной физической нагрузке, ходьбе, вертикальном положении тела больного, после вправления кишка вновь выпадает.

- Диагноз ставится на основании клинических и объективных данных.

- Лечение проводится консервативным и хирургическим путем. Консервативное лечение (предотвращение запора, кашля, поноса) эффективно у больных детского возраста. Основным методом лечения взрослых является хирургический. Оперативное вмешательство выполняют промежностным и абдоминальным доступом.

\section{Вопросы и ответы по выпадению прямой кишки}

\section{Вопросы}

Что такое выпадение (пролапс) прямой кишки?

\section{Ответы}

Выхождение прямой кишки за пределы анального отверстия. 


\begin{tabular}{|c|c|}
\hline Вопросы & Ответы \\
\hline $\begin{array}{l}\text { Какие клинико-анатомические формы } \\
\text { различают? }\end{array}$ & $\begin{array}{l}\text { - Выпадение анального отверстия; } \\
\text { - Выпадение прямой кишки; } \\
\text { - Выпадение анального отверстия } \\
\text { и прямой кишки; } \\
\text { - Инвагинация проксимальных } \\
\text { отделов толстой кишки в прямую } \\
\text { кишку. }\end{array}$ \\
\hline Какие степени выпадения различают? & $\begin{array}{l}\text { Различают } 3 \text { стадии (степени): } \\
\text { - I стадия - } 5 \text { см; } \\
\text { - II стадия - } 10 \text { см; } \\
\text { - III стадия - более } 10 \text { см. }\end{array}$ \\
\hline Частота встречаемости: & $\begin{array}{l}\text { У женщин встречается в } 6 \text { раз чаще } \\
\text { (80\%). }\end{array}$ \\
\hline Осложнения: & $\begin{array}{l}\text { - Ущемление выпавшей кишки; } \\
\text { - Воспалительные процессы, } \\
\text { изъявление, перфорация прямой } \\
\text { кишки; } \\
\text { - Фекальная инконтиненция; } \\
\text { - Выпадение слизистой оболочки } \\
\text { прямой кишки; } \\
\text { - Формирование } \\
\text { абсцесса и свищей; } \\
\text { - Риск развития рака. }\end{array}$ \\
\hline Основные клинические проявления: & Недержание газов и кала (40-80\%). \\
\hline $\begin{array}{l}\text { С какими заболеваниями следует } \\
\text { дифференцировать? }\end{array}$ & $\begin{array}{l}\text { - Геморрой; } \\
\text { - Полипы анального канала; } \\
\text { - Рак анального канала. }\end{array}$ \\
\hline Лечение: & В основном хирургическое. \\
\hline
\end{tabular}




\section{РЕКТОЦЕЛЕ}

- Ректоцеле представляет собой выпячивание передней стенки прямой кишки во влагалище.

- Ректоцеле встречается у $30-90 \%$ женщин.

- Клиническая картина характеризуется затруднением акта дефекации, выпадением прямой кишки и дисфункциями генитальных органов, неудовлетворенностью после дефекации, запором. Больные с помощью руки осуществляют дефекацию.

- Различают 3 степени ректоцеле:

- Малая - менее 1 см;

○ Средняя-2-4 см;

○ Большая - более $4 \mathrm{~cm}$.

- Диагноз ставится на основании клинической симптоматики и данных инструментальных методов исследования (дефекография).

- Выбор метода лечения зависит от степени ректоцеле. В начальной стадии и при бессимптомном течении рекомендуется профилактика запоров, укрепление мышц тазового дна. При ректоцеле, достигшей размеров $3 \mathrm{~cm}$ и более, показано хирургическое лечение.

\section{Вопросы и ответы по ректоцеле}

\section{Вопросы}

Что такое ректоцеле?

Диагностические критерии ректоцеле: Хронический запор; чувство неполного опорожнения прямой кишки после дефекации; опорожнение прямой кишки с помощью руки, введенной во влагалище; выпячивание прямой кишки во влагалище, выявляемое при дефекации. 


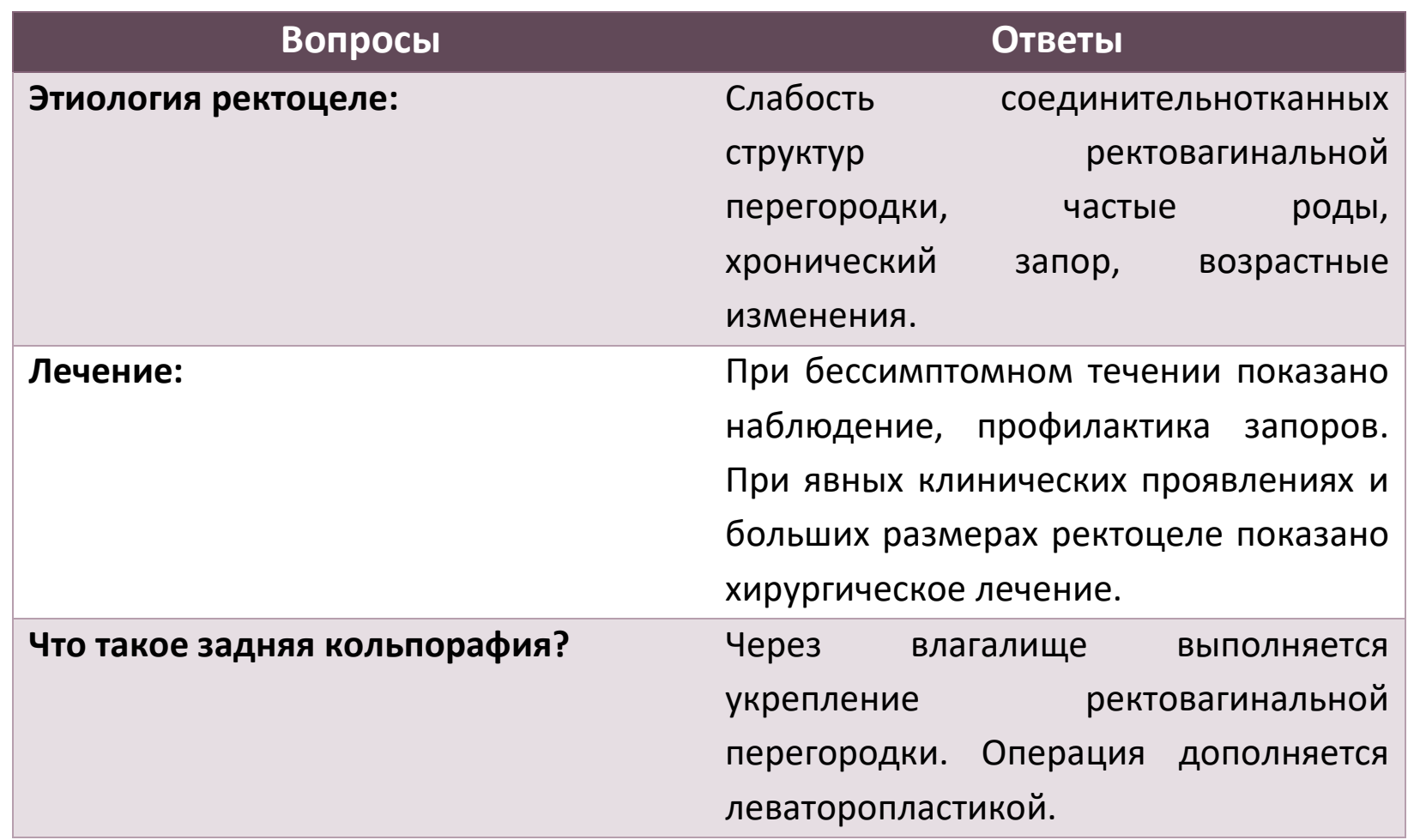




\section{ОСТРОКОНЕЧНАЯ ПЕРИАНАЛЬНАЯ КОНДИЛОМА}

- Остроконечные перианальные кондиломы - плотные бородавчатые образования, локализующиеся на перианальной коже, могут распространяться на часть заднего прохода, ниже гребешковой линии, имеющую эпидермис.

- Они могут быть представлены отдельными или множественными высыпаниями, локализованными по группам или сливающимися между собой, напоминая по виду разрастания типа цветной капусты.

- Основным этиологическим фактором развития остроконечных кондилом является вирус папилломы человека - Human papilloma Virus (HPV). Заболевание относится к патологии, передающейся половым путем. Болезнь передается HPV-6, HPV-11, HPV-16 или HPV-18.

- Диагноз ставится в основном на основании визуального выявления кондилом. Истинный диагноз устанавливается биопсией или вирусологическим исследованием (HIV, HPV, сифилис, гепатиты В и С).

- Кондиломы могут осложняться кровотечением и подвергаться изъязвлению и малигнизации.

- Выбор метода лечения зависит от размеров образований (кондилом). Консервативное лечение проводится при наличии небольших папиллом (подофиллин, мазь имиквимода, сидофовир, интерферон, 5-фторурацил). При больших кондиломах показано хирургическое лечение (эксцизия кондилом диатермокоагулятором). Применяются также криодеструкция, лазерная абляция, инфракрасное облучение.

\section{Вопросы и ответы по остроконечным перианальным кондиломам}




\begin{tabular}{|c|c|}
\hline Вопросы & Ответы \\
\hline $\begin{array}{l}\text { Что такое перианальная } \\
\text { остроконечная кондилома? }\end{array}$ & $\begin{array}{l}\text { Бородавчатые (папилломатозные) } \\
\text { образования, локализующиеся на } \\
\text { перианальной коже. }\end{array}$ \\
\hline Этиология кондилом: & $\begin{array}{l}\text { Возбудителем } \\
\text { папилломавирус человека (HPV). }\end{array}$ \\
\hline $\begin{array}{l}\text { Наиболее опасное осложнение } \\
\text { кондилом: }\end{array}$ & Трансформация в плоскоклеточный рак. \\
\hline $\begin{array}{l}\text { Методы лечения небольших } \\
\text { остроконечных кондилом: }\end{array}$ & $\begin{array}{l}\text { Консервативное - проводится при } \\
\text { наличии небольших кондилом (местное } \\
\text { применение подофиллина, альдары). }\end{array}$ \\
\hline $\begin{array}{l}\text { Методы лечения крупных } \\
\text { остроконечных кондилом: }\end{array}$ & $\begin{array}{l}\text { При больших кондиломах показано } \\
\text { хирургическое лечение (эксцизия, } \\
\text { криодеструкция, лазерная абляция). }\end{array}$ \\
\hline
\end{tabular}




\section{ПИлОНИДАЛЬНЫЙ СИнУс}

- Пилонидальный синус (эпителиальный ход крестцово-копчиковой области), представляет собой узкий канал, выстланный кожным эпителием, который слепо заканчивается в мягких тканях на 4-6 см выше анального отверстия.

- Характерным анатомическим субстратом эпителиального копчикового хода является парные воронкообразные втяжения кожи, расположенные в глубине межъягодичной складки (по средней линии). Имеющиеся в воронкообразных кожных втяжениях точечные отверстия служат входными воротами для инфекции.

- Неосложненные крестцово-копчиковые ходы длительное время протекают бессимптомно. При инфицировании отмечаются гиперемия, отёк и инфильтрат по ходу копчикового хода, выделение кровянисто-гнойного отделяемого из кожных отверстий. Закупорка воронкообразных кожных втяжений пучком волос и влажность (потливость) этой области способствуют инфицированию эпителиального крестцово-копчикового хода, что проявляется абсцедированием.

- Диагноз в большинстве случаев ставится на основе клинических признаков. Для дифференциации проводят фистулографию либо КТ.

- Лечение пилонидального синуса - хирургическое (радикальное иссечение эпителиального хода).

\section{Вопросы и ответы по пилонидальному синусу}

\begin{tabular}{|ll|}
\hline \multicolumn{1}{|c|}{ Вопросы } & \multicolumn{1}{c|}{ Ответы } \\
\hline $\begin{array}{l}\text { Что представляет собой } \\
\text { пилонидальный синус? }\end{array}$ & $\begin{array}{l}\text { Является врожденной патологией и } \\
\text { характеризуется } \\
\text { воронкообразных кожных втяжений в } \\
\text { глубине межъягодичной области. }\end{array}$ \\
\hline Диагностические признаки: & $\begin{array}{l}\text { Болезненная опухоль по средней } \\
\text { линии межъягодичной складки; }\end{array}$ \\
\hline
\end{tabular}




\begin{tabular}{|ll|}
\hline \multicolumn{1}{|c|}{ Вопросы } & \multicolumn{1}{c|}{ Ответы } \\
\hline & - Наличие точечных отверстий (от 1 \\
& до 4-5) в области опухоли; \\
& - Выделение из хода кровянисто- \\
& гнойного отделяемого. \\
\hline $\begin{array}{l}\text { Осложнения эпителиального } \\
\text { крестцово-копчикового хода: }\end{array}$ & - Абсцесс; \\
\hline
\end{tabular}




\section{СТРИКТУРЫ ПРЯМОЙ КИШКИ}

- Стриктуры прямой кишки характеризуются сужением просвета кишки и анального канала в результате врожденных аномалий развития, травм, воспалительных процессов и злокачественных новообразований.

- Врожденные стриктуры чаще локализуются в области гребешковой линии. К причинам приобретённых стриктур относятся травмы промежности и дистального отдела прямой кишки, в том числе оперативные вмешательства, выполняемые по причине геморроя, хронического парапроктита (свища прямой кишки), ожоги прямой кишки, болезнь Крона, неспецифический язвенной колит.

- Диагностика стриктур прямой кишки основывается на данных клинической картины заболевания и инструментальных методов исследований (пальцевое исследование прямой кишки, аноскопия, ректоскопия, эндоУЗИ).

- Лечение стриктур прямой кишки - хирургическое.

\section{Вопросы и ответы по структурам прямой кишки}

\begin{tabular}{|c|c|}
\hline Вопросы & Ответы \\
\hline $\begin{array}{l}\text { Что представляет собой стриктура } \\
\text { прямой кишки? }\end{array}$ & $\begin{array}{l}\text { Стриктура представляет собой сужение } \\
\text { просвета прямой кишки и анального } \\
\text { канала в результате потери их } \\
\text { эластичности и тонуса. }\end{array}$ \\
\hline $\begin{array}{l}\text { Клинические формы стриктуры } \\
\text { прямой кишки: }\end{array}$ & Имеются 3 типа стриктур. \\
\hline $\begin{array}{l}\text { Причины развития стриктуры прямой } \\
\text { кишки: }\end{array}$ & $\begin{array}{l}\text { - Геморроидэктомия (90\%); } \\
\text { - Рак прямой кишки и анального } \\
\text { канала; } \\
\text { - Воспалительные заболевания } \\
\text { прямой кишки; } \\
\text { - Операции по причине анальной } \\
\text { трещины; }\end{array}$ \\
\hline
\end{tabular}




\begin{tabular}{|c|c|}
\hline Вопросы & Ответы \\
\hline & $\begin{array}{l}\text { - Сфинктеропластика; } \\
\text { - Фистулэктомия; } \\
\text { - Удаление ректовагинального } \\
\text { - Увща; } \\
\text { - Аналение анальных кондилом; } \\
\text { - Хроническая анальная трещина; } \\
\text { - Эндометриоз; } \\
\text { - Хроническое } \\
\text { - улабительных препаратов; } \\
\text { - Хроническая диарея; } \\
\text { - Лравмы прямой кишки; } \\
\text { - пучевое } \\
\text { - Заболекекталие } \\
\text { половым путём. }\end{array}$ \\
\hline Клинические признаки: & $\begin{array}{l}\text { - Уменьшение калибра кала } \\
\text { (“карандашный стул”); } \\
\text { - Чувство неполного опорожнения } \\
\text { прямой кишки после дефекации; } \\
\text { - Боли во время дефекации; } \\
\text { - Кровотечение; } \\
\text { - Вздутие и абдоминальные боли; } \\
\text { - Запоры. }\end{array}$ \\
\hline $\begin{array}{l}\text { Методы исследования для уточнения } \\
\text { диагноза: }\end{array}$ & $\begin{array}{l}\text { - Аноскопия; } \\
\text { - } \text { Аноректальная манометрия; } \\
\text { - } \text { Дндекография; } \\
\text { - Аноректальная МРТ; } \\
\text { - КТ; } \\
\text { - Колоноскопия. }\end{array}$ \\
\hline
\end{tabular}




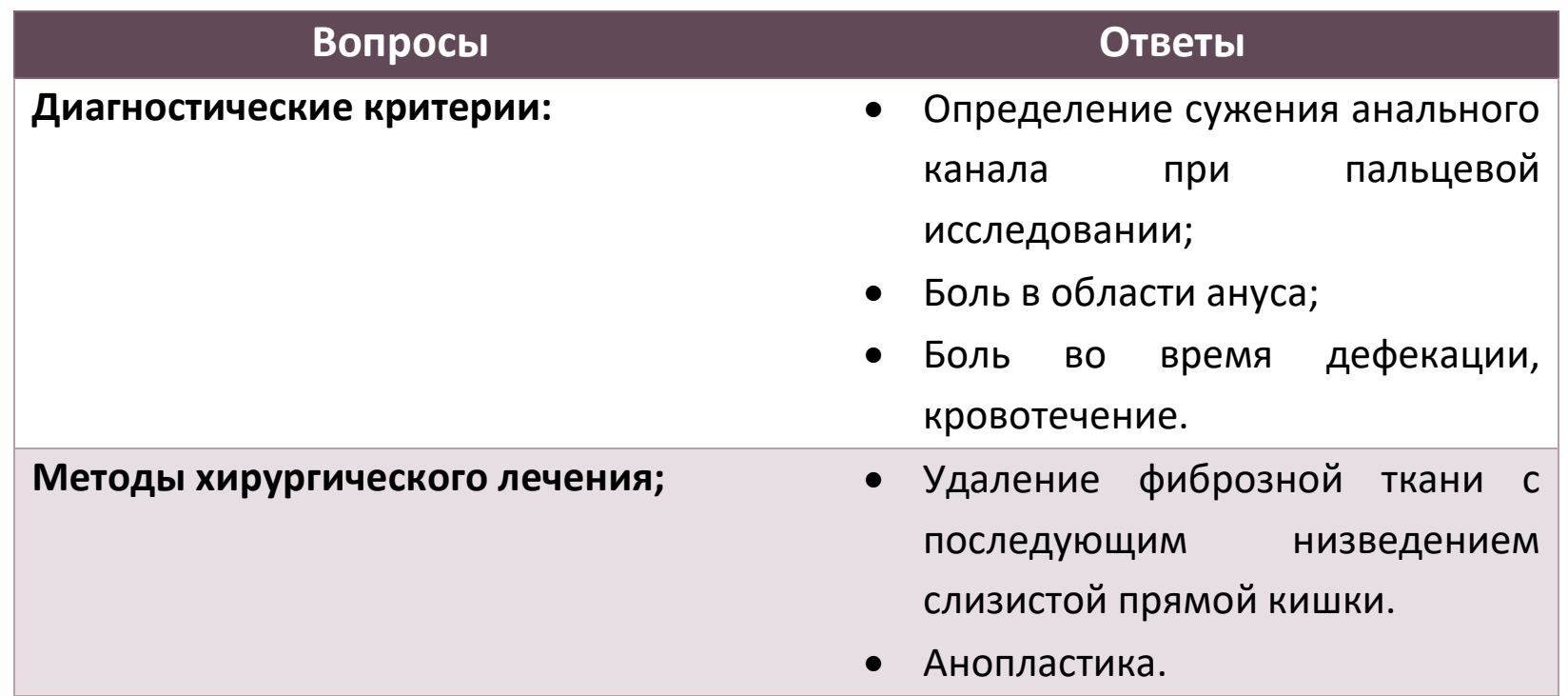




\section{АНАЛЬНАЯ ИНКОНТИНЕНЦИЯ}

- Анальная инконтиненция характеризуется нарушением функции удержания газов и кала в результате недостаточности замыкательной функции анального сфинктера.

- Заболевание часто встречается у пациентов старше 65 лет (4-24\% женщины, $5 \%$ мужчины).

- Основным диагностическим критерием является недержание газов и кала, а также снижение тонуса анального сфинктера (клинически или манометрически).

- У больных пожилого возраста анальная инконтиненция нередко сочетается с недержанием мочи.

\section{Вопросы и ответы по анальной инконтиненции}

\begin{tabular}{|c|c|}
\hline Вопросы & Ответы \\
\hline Что такое анальная инконтиненция? & $\begin{array}{l}\text { Недержание газов и кала в результате } \\
\text { нарушения замыкательной функции } \\
\text { анального сфинктера. }\end{array}$ \\
\hline Частота встречаемости: & $\begin{array}{l}\text { Составляет } 1-18 \% \text { в общей популяции (у } \\
\text { женщин - } 24 \% \text {, у мужчин }-5 \%) \text { в } \\
\text { возрасте старше } 65 \text { лет. Женщины } \\
\text { страдают в } 8 \text { раз чаще мужчин. }\end{array}$ \\
\hline Причины и факторы риска: & $\begin{array}{l}\text { - Повреждение тазовой кости и } \\
\text { мышц тазового дна; } \\
\text { - Хирургические операции в } \\
\text { аноректальной области; } \\
\text { - Родовые травмы; } \\
\text { - Сфинктеротомия-хирургическое } \\
\text { лечение хронической анальной } \\
\text { трещины; }\end{array}$ \\
\hline
\end{tabular}




\begin{tabular}{|c|c|}
\hline \multirow[t]{2}{*}{ Вопросы } & Ответы \\
\hline & $\begin{array}{l}\text { - Повреждение аноректальной } \\
\text { - Воны; } \\
\text { Возрастная инволюция } \\
\text { - Анального сфинктера; } \\
\text { - Анальная дилатация; } \\
\text { - Употребление слабительных } \\
\text { препаратов; } \\
\text { - Воспалительная диарея; } \\
\text { - Воспалительные заболевания } \\
\text { толстой кишечника; } \\
\text { - Рак анального канала; } \\
\text { - Спинная сухотка; } \\
\text { - Невропатия, связанная } \\
\text { сахарным диабетом; } \\
\text { - Выпадение прямой кишки; } \\
\text { - Ректоцеле; } \\
\text { - Радиотерапия. }\end{array}$ \\
\hline $\begin{array}{l}\text { Какие методы исследования, } \\
\text { необходимы для уточнения диагноза? }\end{array}$ & $\begin{array}{l}\text { Диагноз анальной инконтиненции как } \\
\text { правило ставится на основе } \\
\text { клинической картины: } \\
\text { • недержание газов и кала; } \\
\text { • снижение тонуса анального } \\
\text { сфинктера. } \\
\text { Для дифференциации, установления } \\
\text { причины и определения тонуса } \\
\text { анального сфинктера проводят: } \\
\text { • Эндоскопическое исследование; } \\
\text { • Аноректальная манометрия; } \\
\text { - Аноректальная } \\
\text { электромиография } \\
\text { определение мышечной силы } \\
\text { наружного анального сфинктера; } \\
\text { - Дефекография; }\end{array}$ \\
\hline
\end{tabular}




\begin{tabular}{|c|c|}
\hline Вопросы & Ответы \\
\hline & $\begin{array}{l}\text { • МРТ; } \\
\text { • } \quad \text { Эндоректальное УзИ. }\end{array}$ \\
\hline Диагностические критерии: & $\begin{array}{l}\text { Недержание газов и кала в результате } \\
\text { нарушения замыкательной функции } \\
\text { анального сфинктера. }\end{array}$ \\
\hline Методы лечения: & $\begin{array}{l}\text { - Диета; } \\
\text { - Упражнения Кегеля - для } \\
\text { укрепления и повышения тонуса } \\
\text { мышц тазового дна; } \\
\text { - Лекарственные препараты - } \\
\text { лоперамид, активированный } \\
\text { уголь, пектин, амитриптиллин, } \\
\text { морфин; } \\
\text { - Стимуляция тонуса } \\
\text { аноректальной } \\
\text { седалищного нерва; } \\
\text { - Гипербарическая оксигенация; } \\
\text { - Искусственный сфинктер; } \\
\text { - Формирование неосфинктера; } \\
\text { - Сфинктеропластика; } \\
\text { - Колостомия. }\end{array}$ \\
\hline
\end{tabular}




\section{АНАЛЬНЫЙ ЗУД}

- Анальный зуд - это постоянный зуд перианальной области.

- Характеризуется гиперемией, изъязвлением, болью, чувством жжения и уплотнением кожи перианальной области.

- Кожный зуд перианальной области возникает при различных инфекционных (грибковые, бактериальные, вирусные инфекции, паразитарные болезни), кожных, проктологических и гинекологических заболеваниях. У большинства больных (50-90\%) этиология остаётся невыясненной (идиопатический).

- Различают 3 клинические формы: лёгкая, средней тяжести, тяжёлая, хроническая.

- Длительный анальный зуд может быть причиной развития инфекционновоспалительных осложнений в перианальной зоне.

\section{Вопросы и ответы по анальному зуду}

\section{Вопросы}

Что такое анальный зуд?

Частота встречаемости анального зуда:

\section{Клинические варианты анального} зуда:

\section{Ответы}

Постоянный зуд перианальной области.

Составляет 1-4\% в общей популяции в возрасте 40-60 лет. Чаще встречается у мужчин.

- Лёгкая форма - в перианальной области нет видимых признаков, однако аноскопия болезненна.

- Средняя форма - в перианальной области определяется гиперемия, сухость, потрескивание кожи.

- Тяжелая форма - отмечается гиперемия, влажность, отёки, изъязвление кожи перианальной области. 


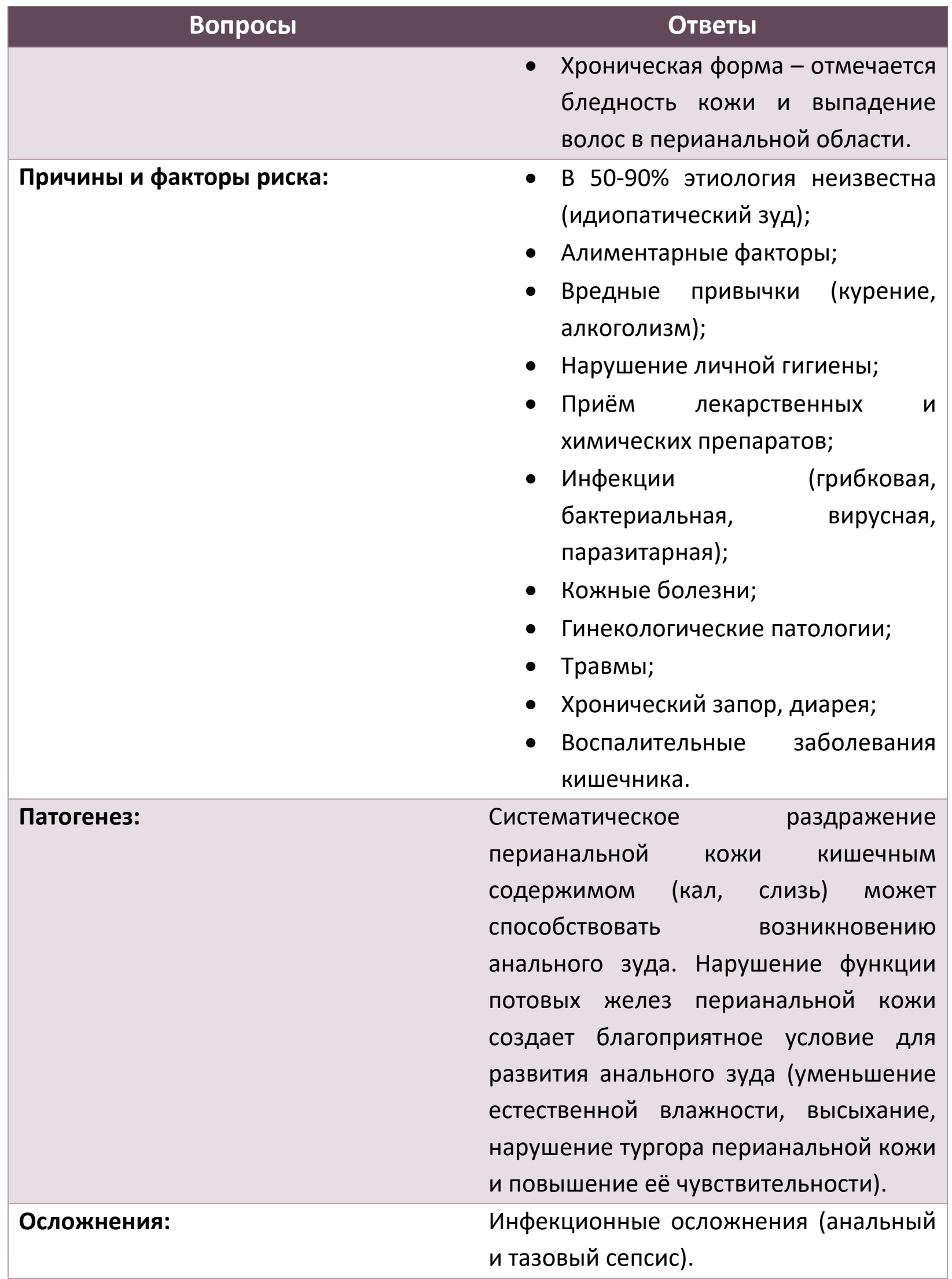




\begin{tabular}{|c|c|}
\hline Boпросы & Ответы \\
\hline Клинические проявления: & $\begin{array}{l}\text { - Гиперемия кожи перианальной } \\
\text { области; } \\
\text { - Повышенная влажность; } \\
\text { - Боль, чувство жжения; } \\
\text { - Уплотнение кожи перианальной } \\
\text { области. }\end{array}$ \\
\hline $\begin{array}{l}\text { Какие методы исследования } \\
\text { необходимы для уточнения диагноза? }\end{array}$ & $\begin{array}{l}\text { - Клинические признаки; } \\
\text { - Колоноскопия; } \\
\text { - Гинекологические обследования; } \\
\text { - Биопсия перианальной кожи; } \\
\text { - Аллергические тесты. }\end{array}$ \\
\hline Принципы лечения анального зуда: & $\begin{array}{l}\text { - Приём противогрибковых и } \\
\text { антигельминтных препаратов } \\
\text { (кремы, таблетки); } \\
\text { - Антибиотики; } \\
\text { - Антипаразитарные препараты: } \\
\text { альбендазол; } \\
\text { - Местное } \\
\text { противозудящих применение } \\
\text { кремы, пасты ит. д. } \\
\text { - Хирургическое лечение основной } \\
\text { патологии, вызвавшей анальный } \\
\text { зуд. }\end{array}$ \\
\hline
\end{tabular}




\section{АНАЛЬНЫЙ КРИПТИТ}

- Анальный криптит - воспаление анальных желез, расположенных в криптах анального канала на уровне зубчатой линии.

- Клинически проявляется запором, болью, припухлостью, зудом, жжением в перианальной области.

- Криптит - является основной причиной острого парапроктита (криптогландулярный абсцесс).

- Диагноз устанавливается на основании данных аноскопии и ректоскопии: наличие зоны воспаления на уровне зубчатой линии, выделение из крипт.

\section{Вопросы и ответы по анальным криптитам}

\begin{tabular}{|c|c|}
\hline Вопросы & Ответы \\
\hline Что такое анальный криптит? & $\begin{array}{l}\text { Воспаление } \text { анальных желез, } \\
\text { расположенных в криптах анального } \\
\text { канала. }\end{array}$ \\
\hline Клинические проявления: & $\begin{array}{l}\text { Запор, боль, чувство жжения, зуд, } \\
\text { припухлость } \text { и гиперемия } \\
\text { перианальной области. }\end{array}$ \\
\hline Дифференциальная диагностика: & $\begin{array}{l}\text { - Ректальный абсцесс; } \\
\text { - Параректальные свищи; } \\
\text { - Пилонидальный синус; } \\
\text { - } \text { Запор; } \\
\text { - Кровотечение из нижних отделов } \\
\text { кишечника; } \\
\text { - Воспалительные заболевания } \\
\text { кишечника; } \\
\text { - Дивертикулёз. }\end{array}$ \\
\hline
\end{tabular}




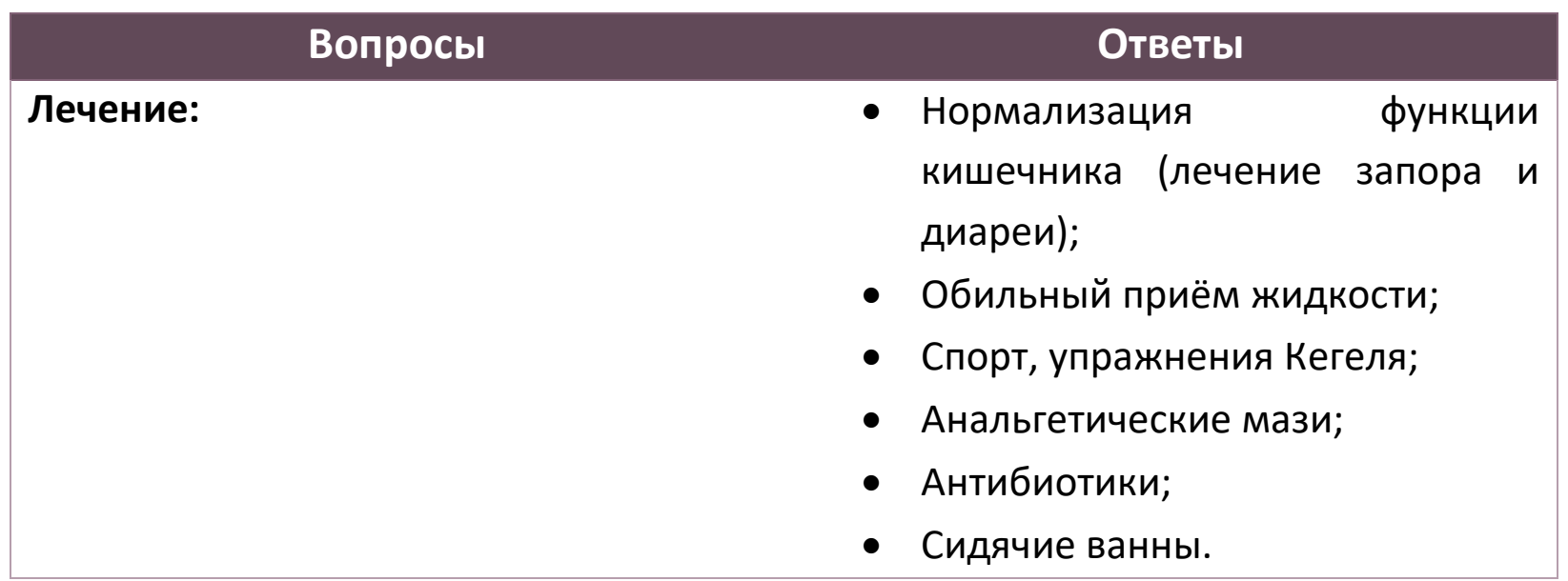




\section{кокцигодиния}

- Кокцигодиния характеризуется болевым синдромом в копчиковой области.

- Этиология до конца не изучена. В большинстве случаев развивается после травмы копчиковой области, но может быть признаком других заболеваний.

- Характеризуется пальпаторной болезненностью копчиковой области. При пальцевой исследовании прямой кишки боль усиливается.

- Лечение - консервативное и хирургическое. Консервативное лечение включает физиотерапевтические процедуры, ультразвуковое облучение, лазеротерапию, парафиновые аппликации, грязелечение. При неэффективности консервативной терапии, показано хирургическое лечение - удаление копчиковой кости.

\section{Вопросы и ответы по кокцигодинии}

\begin{tabular}{|ll|}
\hline \multicolumn{1}{|c|}{ Вопросы } & \multicolumn{1}{c|}{ Ответы } \\
\hline Что такое кокцигодиния? & $\begin{array}{l}\text { Болевой синдром в копчиковой } \\
\text { области. }\end{array}$ \\
\hline Частота встречаемости: & Уженщин встречается в 3 раза чаще. \\
\hline Клинические признаки: & Боль в копчиковой области. \\
\hline Диагностика: & $\begin{array}{l}\text { Пальпация копчиковой области, } \\
\text { пальцевое исследование прямой } \\
\text { кишки. }\end{array}$ \\
\hline
\end{tabular}




\section{ЗАПОРЫ}

- Запоры - нарушение суточной регулярности акта дефекации. Отсутствие суточного ритма дефекации и опорожнение прямой кишки менее 3 раз в неделю является запором. Таким образом, запор характеризуется нарушением как суточной регулярности дефекации, так и выделением скудного количества кала твёрдой консистенции.

- По нозологической причине различают кологенный и проктогенный запоры.

- При запорах нарушается один из следующих механизмов опорожнения кишечника:

○ В результате моторной активности кишечника с истечением 24 ч интервала происходит скопление каловой массы в дистальном отделе прямой кишки.

- Возникновение аноректального рефлекса с расслаблением тонуса внутренней порции анального сфинктера.

○ Повышение перистальтической активности прямой кишки.

○ Натуживание, повышение внутрибрюшного давления.

- Расслабление наружной порции анального сфинктера и пуборектальной мышцы и выпрямление аноректального угла.

\section{Вопросы и ответы по запорам}

\begin{tabular}{|ll|}
\hline \multicolumn{1}{|c|}{ Вопросы } & \multicolumn{1}{c|}{ Ответы } \\
\hline Что такое запор? & Отсутствие суточной регулярности \\
& дефекации и опорожнения кишечника \\
& менее 3 раз в неделю. \\
\hline Частота встречаемости: & Встречается у 15-30\% населения старше \\
& 65 лет. У женщин встречается в 3 раза \\
& чаще. \\
\hline
\end{tabular}




\section{СПИСОК ЛИТЕРАТУРЫ}

- Ağayev B.A. Cərrahi xəstəliklər. Bakı 2010.

- Blackbourne L.H. Surgical Recall. 4 edition, 2006, LWW, Philadelphia.

- Chang G.J., Shelton A.A, Welton M.L. Largeintestine. in: Current Diagnosis and Treatment.

- Surgery, 13th edition, 2010, Lang International Edition. P. 479-508.

- Hamilton N.A., Fleshman L.W. Colon, Rectum and Anus. in: The Washington Manual of Surgery, 6th edition, 2012, LWW, Philadelphia, p. 291-323.

- McNally P.R. G.I./Liver Serets Plus. 4 edition. Mosby, Elsevier, 2010. Miguel

- Rodriguez-Bigas, Axel Grothey Bigas, Axel Grothey, Kenneth K. Tanabe, Richard M. Goldberg, Diane M. F. Davarese. Over view of the management of primary colon cancer. Up-ToDate, Jan.

- Mowat C., Cole A., Windsor A., etal. Guidelines for the management of inflammatory bowel disease in adults. Gut 2011; 60:571.

- Wendell-Smith CP.Anorectal nomenclature.Dis Colon Rectum 2000. 43. 1349-58.

- Barleben A, MillsS.Anorectal anatomy and physiology.Surg clin n Am 2010. 90.115.

- Stoker J.Anorectal and pelvic floor anatomy. Best Pract Res Clin Qastroenterol 2009. 23.463-75. 


\title{
ХИРУРГИЧЕСКИЕ БОЛЕЗНИ
}

Н.Ю. Байрамов

\section{Хирургические заболевания печени}

\author{
Н.Ю. Байрамов, Р.А. Мамедов, А.К. Сафиева, Ш.А. Мамедова
}

Перевод: Н.Ю. Байрамов, С.А. Алиев, М.Р. Гусейнова 


\section{ПОРТАЛЬНАЯ ГИПЕРТЕНЗИЯ}

- В норме разность (градиент) между давлениями в воротной и нижней полой венах составляет 5 мм рт. ст. Повышение разности давлений более 5 мм рт. ст. расценивается как синдром портальной гипертензии.

- Повышение давления в воротной вене обусловлено двумя факторами: наличием препятствия (блокады) и повышение объёма крови, поступившей в портальную вену (портальная гиперволемия).

- В зависимости от анатомического уровня, на котором образуется препятствие (блок) для оттока крови по системе воротной вены, различают 3 формы портальной гипертензии: подпечёночная, внутрипечёночная и надпечёночная.

○ К причинам подпечёночной формы портальной гипертензии относятся тромбоз портальной вены и опухоли в области портальной вены (воротные, желудочные, опухоли поджелудочной железы, жёлчного пузыря, холедоха, лимфомы). К причинам портальной гиперволемии относятся спленомегалия, артериовенозные свищи, портосистемный шунт.

○ Внутрипечёночная форма, которая составляет $80 \%$ всех случаев портальной гипертензии, наиболее часто обусловлена циррозом печени.

- Надпечёночная форма портальной гипертензии обусловлена синдромом Бадд-Киари, тромбозом, констриктивным перикардитом, правожелудочковой недостаточностью.

- Повышение давления в системе портальной вены способствует развитию таких серьёзных осложнений, как асцит, варикозное расширение вен пищевода и кровотечение, энцефалопатия, спленомегалия, гепаторенальный синдром, портальная гипертензивная гастроэнтеропатия и т. д.

- Наличие асцита является недостаточным для уточнения (или исключения) синдрома портальной гипертензии. С этой целью выполняют эндоскопическое исследование, эластографию, по показаниям - определение градиента портокавального давления.

- Наличие варикозного расширения, повышения эхоплотности печени более 12 кРа (по данным эластографии), увеличение эхоплотности селезёнки более 33 кРа и повышение градиента портокавального давления более 5 мм рт.ст. являются диагностическими признаками портальной гипертензии. 
- Основной целью лечения синдрома портальной гипертензии является устранение причин его вызвавших. При невозможности реализации этой задачи, проводится профилактика и лечение осложнений синдрома портальной гипертензии.

○ Лечение осложнений проводится 2-мя методами: снижением давления в портальной системе и специфическое (непосредственное) лечение осложнений.

○ Для достижения снижения давления в портальной системе применяются портокавальные шунты (декомпрессия), спланхнические вазоконстрикторы (соматостатин, вазопрессин, $\beta$-адреноблокаторы), диуретики.

○ При отсутствии осложнений или риска их возникновения, нет необходимости в проведении профилактических мер по снижению давления в портальной системе.

\section{Вопросы и ответы по портальной гипертензии}

\section{Вопросы \\ Ответы}

Какие вены формируют портальную
венозную систему?

- Воротная вена;

- Селезёночная вена;

- Верхняя брыжеечная вена;

- Левая желудочная вена;

- Нижняя брыжеечная вена;

- Верхняя геморроидальная вена.

\section{Куда поступает кровь из нижней В селезёночную вену.}

брыжеечной вены?

Куда поступает кровь из верхней геморроидальной вены?

Как формируется портальная вена?
В нижнюю брыжеечную вену, далее в селезёночную и воротную вены.

Путём слияния верхней брыжеечной и селезёночной вен. 


\begin{tabular}{|c|c|}
\hline Вопросы & Ответы \\
\hline Механизм портальной гипертензии: & $\begin{array}{l}\text { Повышение портального давления в } \\
\text { результате повышения сопротивления в } \\
\text { портальной вене. }\end{array}$ \\
\hline $\begin{array}{l}\text { Нормальное давление в воротной } \\
\text { вене: }\end{array}$ & <10 мм рт. ст. \\
\hline Причины портальной гипертензии: & $\begin{array}{l}\text { - Надпечёночные: тромбоз воротной } \\
\text { вены, новообразования; } \\
\text { - Внутрипечёночные: цирроз, фиброз } \\
\text { печени, гепатоцеллюлярная } \\
\text { карцинома ит. д.; } \\
\text { - Надпечёночные: болезнь синдром } \\
\text { Бадд-Киари (тромбоз печёночных } \\
\text { вен). }\end{array}$ \\
\hline $\begin{array}{l}\text { Наиболее частая причина портальной } \\
\text { гипертензии: }\end{array}$ & Цирроз печени (90\%). \\
\hline $\begin{array}{l}\text { Частота встречаемости цирроза } \\
\text { печени при алкоголизме: }\end{array}$ & Примерно 20\%. \\
\hline $\begin{array}{l}\text { Частота формирования варикозных } \\
\text { вен пищевода при циррозе печени: }\end{array}$ & Примерно 60\%. \\
\hline $\begin{array}{l}\text { Риск развития синдрома портальной } \\
\text { гипертензии при циррозе печени: }\end{array}$ & Примерно 60\%. \\
\hline $\begin{array}{l}\text { Наиболее часто встречающийся } \\
\text { признак портальной гипертензии: }\end{array}$ & Спленомегалия. \\
\hline $\begin{array}{l}\text { Основные объективные признаки } \\
\text { портальной гипертензии: }\end{array}$ & $\begin{array}{l}\text { - “Голова медузы”; } \\
\text { - Расширение вен пищевода; } \\
\text { - Спленомегалия; } \\
\text { - Расширение геморроидальных вен. }\end{array}$ \\
\hline
\end{tabular}




\section{Вопросы}

Признаки, характерные для цирроза печени и синдрома портальной гипертензии:

\section{Ответы}

Асцит, энцефалопатия, симптомы хронического поражения печени (пальмарная эритема, “малиновый" язык, гинекомастия, телеангиоэктазии и др.)
Как измеряют портальное давление?

Существуют ли коллатерали

(портокавальные шунты) ранее или они являются результатом портальной гипертензии:
- Прямой метод- путём катетеризации воротной вены;

- Непрямой метод - измерение давления в печёночных венах.

Предполагается, что коллатерали заранее существуют, но не функционируют. При развитии гипертензии коллатерали расширяются.

\section{Портокавальные шунты:}

- Параумбиликальные вены;

- Гастроэзофагеальные вены;

- Забрюшинные вены;

- Диафрагмальные вены;

- Геморроидальные вены.

Из воротной вены - в коронарные, из коллатеральных вен - в непарную вену.

расширенных вен пищевода при портальной гипертензии?

Куда оттекает кровь из параумбиликальных коллатеральных вен при синдроме портальной гипертензии?
Из пупочной вены - в эпигастральные вены, далее в нижнюю и верхнюю полые вены.
Куда оттекает кровь из забрюшинных варикозных вен при синдроме портальной гипертензии?
Из мелких брыжеечных вен через коллатерали в люмбарные вены. 
Вопросы

Куда оттекает кровь из геморроидальных коллатеральных вен при портальной гипертензии?

Наиболее опасное осложнение портальной гипертензии:

\section{Ответы}

Из верхних геморроидальных вен - в средние и нижние геморроидальные вены, далее - в подвздошные вены.

\begin{tabular}{|c|c|c|}
\hline Кровотечение & из & варикозно \\
\hline расширенных & вен & пищевода \\
\hline
\end{tabular}

\section{Что представляет собой «правило} 60\%» при портальной гипертензии?

- При циррозе печени в $60 \%$ случаев развивается портальная гипертензия;

- При портальной гипертензии в 60\% случаев развиваются варикозно расширенные вены пищевода;
- в $60 \%$ случаев варикозно расширенные вены пищевода осложняются кровотечением.

\section{Какая часть кровотечений из верхних Примерно 50\%.}

отделов желудочно-кишечного тракта

у пациентов с циррозом и

варикозным расширением вен

пищевода имеет варикозное

происхождение?

\section{Признаки варикозного кровотечения: Кровавая рвота, мелена, гематохезия.}

\section{Летальность при острых Примерно 17\% (10-50\%).}

кровотечениях из варикозно расширенных вен пищевода:

Что включает в себя комплекс мероприятий, проводимых при варикозных кровотечениях:
Инфузионная терапия, установка назогастрального зонда, катетеризация мочевого пузыря, определение группы крови, эндоскопическое исследование, коррекция коагулопатии. 


\begin{tabular}{|c|c|}
\hline Вопросы & Ответы \\
\hline $\begin{array}{l}\text { Что является основным } \\
\text { диагностическим методом? }\end{array}$ & $\begin{array}{llr}\text { Гастроскопия } & \text { (примерно половина } \\
\text { верхних } & \text { гастроинтестинальных } \\
\text { кровотечений } & \text { имеет } \\
\text { происхождение). } & \end{array}$ \\
\hline $\begin{array}{l}\text { В чём заключаются основные } \\
\text { принципы лечения? }\end{array}$ & $\begin{array}{l}\text { Снижение давления в портальной } \\
\text { системе (медикаментозные, } \\
\text { эндоваскулярные методы или } \\
\text { установление портокавальных шунтов). }\end{array}$ \\
\hline $\begin{array}{l}\text { Препараты, снижающие давления в } \\
\text { портальной системе: }\end{array}$ & $\begin{array}{l}\text { - Вазопрессин и его аналоги; } \\
\text { - Сандостатин и его аналоги. }\end{array}$ \\
\hline $\begin{array}{l}\text { С каким препаратом надо сочетать } \\
\text { вазопрессин у пациентов с } \\
\text { коронарной недостаточностью? }\end{array}$ & $\begin{array}{l}\text { Применение вазопрессина сочетают с } \\
\text { нитроглицерином, что позволяет } \\
\text { избежать спазма коронарных артерий. }\end{array}$ \\
\hline Методы лечения: & $\begin{array}{l}\text { - Эндоскопическое - лигирование, } \\
\text { склерозирование; } \\
\text { • Трансъюгулярное внутрипеченочное } \\
\text { портосистемное шунтирование; } \\
\text { - Портокавальные шунты; } \\
\text { - Трансплантация печени. }\end{array}$ \\
\hline $\begin{array}{l}\text { Основной метод лечения } \\
\text { кровотечений из варикозных вен } \\
\text { пищевода: }\end{array}$ & $\begin{array}{l}\text { Экстренная эндоскопия, лигирование } \\
\text { или склерозирование варикозных вен. }\end{array}$ \\
\hline $\begin{array}{l}\text { Тактика при рецидиве кровотечения } \\
\text { после его временной остановки: }\end{array}$ & Повторное эндоскопическое лечение. \\
\hline $\begin{array}{l}\text { Тактика при продолжающемся } \\
\text { кровотечении и при отсутствии } \\
\text { возможности применения } \\
\text { эндоскопического гемостаза: }\end{array}$ & $\begin{array}{l}\text { Применение спланхнических } \\
\text { вазоконсрикторов (терлипрессин, } \\
\text { сандостатин) и баллонной тампонады } \\
\text { зондом Блекмора-Сенгстагена. }\end{array}$ \\
\hline
\end{tabular}


Вопросы

Что представляет собой зонд Блекмора-Сенгстагена?

\section{Ответы}

Зонд трубчатой конструкции, имеющий пищеводный и желудочный баллоны; используется для тампонады пищеводного кровотечения.

\section{Тактика при неэффективности} эндоскопического и консервативного методов гемостаза при варикозном кровотечении:

- Трансъюгулярное внутрипечёночное портосистемное шунтирование;

- Портошунтирующие хирургические операции (селективные, парциальные);

- Трансплантация печени.

\section{Что представляет собой}

трансъюгулярное внутрипечёночное портосистемное шунтирование?

Проникая через кожу и ярёмную вену, устанавливают внутрипечёночный стент между печёночной веной и ветвями портальной вены.

\section{Наиболее эффективные методы \\ - Портокавальные шунты; \\ остановки кровотечения из \\ - Трансплантация печени.}

\section{Варианты портокавальных шунтов: Тотальные, парциальные, селективные.}

Что представляют собой тотальные При таком шунтировании вся кровь из портокавальные шунты? воротной вены поступает в нижнюю полую вену.

Что представляют собой парциальные Шунт формируют между воротной и портокавальные шунты? нижней полой венами, диаметр которого составляет 0,8-1 см. При таком шунте часть крови из портальной вены поступает в нижнюю полую вену.

\section{Что представляют собой селективные} портокавальные шунты?
Выполняют разобщение портального бассейна на уровне селезёночной и брыжеечной вен. Формируют шунт 


\begin{tabular}{|c|c|}
\hline & Ответы \\
\hline & $\begin{array}{l}\text { между селезёночной и нижней полой } \\
\text { венами. }\end{array}$ \\
\hline $\begin{array}{l}\text { Что представляют собой } \\
\text { портокавальный шунт по Warren? }\end{array}$ & $\begin{array}{l}\text { Представляет собой дистальный } \\
\text { спленоренальный шунт. Наиболее часто } \\
\text { используют среди селективных } \\
\text { портокавальных шунтов. Выполняют } \\
\text { разобщение венозного бассейна на } \\
\text { уровне селезёночной и брыжеечной } \\
\text { вен, формируют шунт между } \\
\text { селезёночной и почечной венами. }\end{array}$ \\
\hline $\begin{array}{l}\text { Противопоказание к применению } \\
\text { шунта по Warren: }\end{array}$ & Асцит. \\
\hline $\begin{array}{l}\text { Что представляет собой } \\
\text { портокавальный шунт по типу “конец } \\
\text { в бок”? }\end{array}$ & $\begin{array}{l}\text { Является тотальным портокавальным } \\
\text { шунтом, при котором формируется } \\
\text { анастомоз между воротной и нижней } \\
\text { полой венами (конец воротной вены } \\
\text { вшивают в бок нижней полой вены). }\end{array}$ \\
\hline $\begin{array}{l}\text { Что представляет собой } \\
\text { портокавальный шунт по типу “ бок в } \\
\text { бок”? }\end{array}$ & $\begin{array}{l}\text { Формируется анастомоз между } \\
\text { портальной и нижней полой венами, } \\
\text { который функционирует вначале как } \\
\text { парциальный шунт, а в дальнейшем как } \\
\text { тотальный шунт. }\end{array}$ \\
\hline $\begin{array}{l}\text { Что представляет собой } \\
\text { портокавальный шунт «Н»-типа? }\end{array}$ & $\begin{array}{l}\text { Является парциальным шунтом, } \\
\text { формируется с помощью сосудистого } \\
\text { трансплантанта между воротной веной } \\
\text { (или её ветвями) и нижней полой веной } \\
\text { (или её ветвями). }\end{array}$ \\
\hline $\begin{array}{l}\text { В чём заключаются преимущества и } \\
\text { недостатки портокавальных шунтов? }\end{array}$ & $\begin{array}{l}\text { Преимущество заключается в остановке } \\
\text { варикозного кровотечения. Развитие }\end{array}$ \\
\hline
\end{tabular}




\begin{tabular}{|c|c|}
\hline Вопросы & Ответы \\
\hline & $\begin{array}{l}\text { дисфункции печени и энцефалопатии } \\
\text { относятся к недостаткам. }\end{array}$ \\
\hline $\begin{array}{l}\text { Чем объясняется причина развития } \\
\text { дисфункции печени после } \\
\text { формирования портокавальных } \\
\text { шунтов? }\end{array}$ & 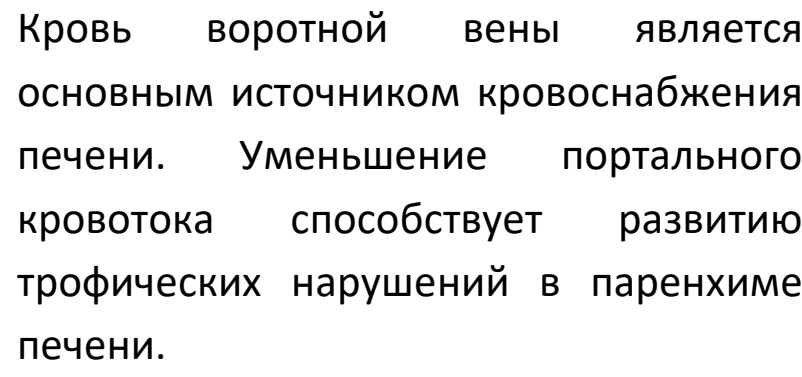 \\
\hline $\begin{array}{l}\text { Что является причиной смерти после } \\
\text { портокавального шунта? }\end{array}$ & $\begin{array}{l}\text { Печёночная недостаточность, } \\
\text { обусловленная снижением портального } \\
\text { кровотока и являющейся причиной } \\
\text { смерти 60\% пациентов. }\end{array}$ \\
\hline $\begin{array}{l}\text { Наиболее часто встречающееся } \\
\text { осложнение после формирования } \\
\text { портокавальных шунтов? }\end{array}$ & $\begin{array}{l}\text { Печёночная энцефалопатия, } \\
\text { развивающаяся вследствие уменьшения } \\
\text { портального кровотока и угнетения } \\
\text { детоксикационной функции печени. }\end{array}$ \\
\hline Метод диагностики энцефалопатии: & Клиническое обследование. \\
\hline $\begin{array}{l}\text { Как определяется степень тяжести } \\
\text { энцефалопатии? }\end{array}$ & На основании клинических данных. \\
\hline $\begin{array}{l}\text { Как корригируют степень тяжести } \\
\text { энцефалопатии с лабораторными } \\
\text { показателями? }\end{array}$ & $\begin{array}{l}\text { Определением концентрации аммиака в } \\
\text { крови. }\end{array}$ \\
\hline $\begin{array}{l}\text { Какие препараты используют для } \\
\text { лечения печёночной энцефалопатии? }\end{array}$ & $\begin{array}{l}\text { Лактулоза, рифаксимин, L-орнитин-L- } \\
\text { аспартат. }\end{array}$ \\
\hline
\end{tabular}




\section{ВАРИКОЗНОЕ РАСШИРЕНИЕ ВЕН ПИЩЕВОДА}

- Расширение вен пищевода представляет собой компенсаторное расширение портокавальных коллатералей вследствие повышения давления в воротной вене.

- При повышении градиента давления в воротной вене выше 8 мм рт. ст. происходит компенсаторное расширение вен и коллатералей. С повышением градиента до 10 мм рт. ст. происходит очевидное расширение, а при 12 мм рт. ст. возникает риск варикозного кровотечения.

- Варикозное расширение развивается начиная с вен пищевода и желудка, затем расширяются ректальные, параумбиликальные и забрюшинные вены.

- В зависимости от выраженности различают 4 степени варикозного расширения вен пищевода:

- I степень - расширение ограничивается в пределах вен подслизистого слоя, выпячивание в просвет пищевода не происходит;

○ II степень - расширенные вены пролабируют в просвет пищевода не сужая его;

○ III степень - пролабированные в полость пищевода вены занимают его просвет не полностью;

- IV степень - пролабированные в полость пищевода вены полностью занимают его просвет.

- Варикозно расширенные вены III-IV степени, тонкостенные варикозные вены, Child C, превышение градиента давления выше 12 мм рт. ст., а также повышение эхоплотности селезёнки более $60 \mathrm{kPa}$ по данным эластографии являются факторами высокого риска для кровотечений и требуют первичной профилактики.

- Цирроз печени у 60\% пациентов осложняется варикозным расширением вен пищевода и желудка, у 30\% которых в течение первых 2-х лет возникает кровотечение.

- Первые эпизоды варикозных кровотечений в 70-80\% случаев останавливаются спонтанно или под воздействием соответствующего лечения. Однако у 60-70\% пациентов эпизоды кровотечения повторяются в течение года. 
- Летальность при пищеводно-желудочных кровотечениях составляет 17\% (1050\%). Повторные эпизоды кровотечения на порядок увеличивает уровень летальности.

- При устранении причин синдрома портальной гипертензии, возможен регресс варикозных вен.

- Пищеводно-желудочное кровотечение клинически проявляется местными (кровавая рвота, мелена, поступление крови из назогастрального зонда) и общими (анемия, гиповолемия, шок) симптомами.

- Первичной диагностической процедурой является эндоскопическое исследование.

- Лечение пищеводно-желудочных кровотечений проводится в 2 этапа: первичные и окончательные мероприятия.

○ Первичные мероприятия заключаются в коррекции гемодинамики, в эндоскопической диагностике, остановке кровотечения медикаментозным или эндоскопическим способом.

○ При неэффективности первичных мероприятий и при рецидиве кровотечения выполняют внутрипечёночное портокавальное шунтирование (трансъюгулярное портокавальное шунтирование) или стентирование.

○ При невозможности проведения этих вмешательств применяют открытые хирургические операции (транссекция, прошивание, формирование анастомоза).

○ Решающим лечением у пациентов с остановкой кровотечения является лечение основного заболевания и вторичная профилактика кровотечений.

\section{Вопросы и ответы по варикозным расширениям вен пищевода}

\begin{tabular}{|c|c|}
\hline Вопросы & Ответы \\
\hline $\begin{array}{l}\text { Какая часть кровотечений из верхних } \\
\text { отделов желудочно-кишечного тракта } \\
\text { у пациентов с циррозом и варикозным } \\
\text { расширением вен пищевода имеет } \\
\text { варикозное происхождение? }\end{array}$ & Примерно 50\%. \\
\hline
\end{tabular}




\section{Вопросы - Ответы}

Клинические признаки варикозных Кровавая рвота, мелена, гематохезия. кровотечений:

Летальность при острых варикозных Примерно 17\% (10-50\%). кровотечениях пищевода:

Первичные мероприятия при варикозных кровотечениях:
Инфузионная терапия, назогастральный зонд, катетеризация мочевого пузыря, определение группы крови, коррекция коагулопатии (витамин К, переливание плазмы), эндоскопия.

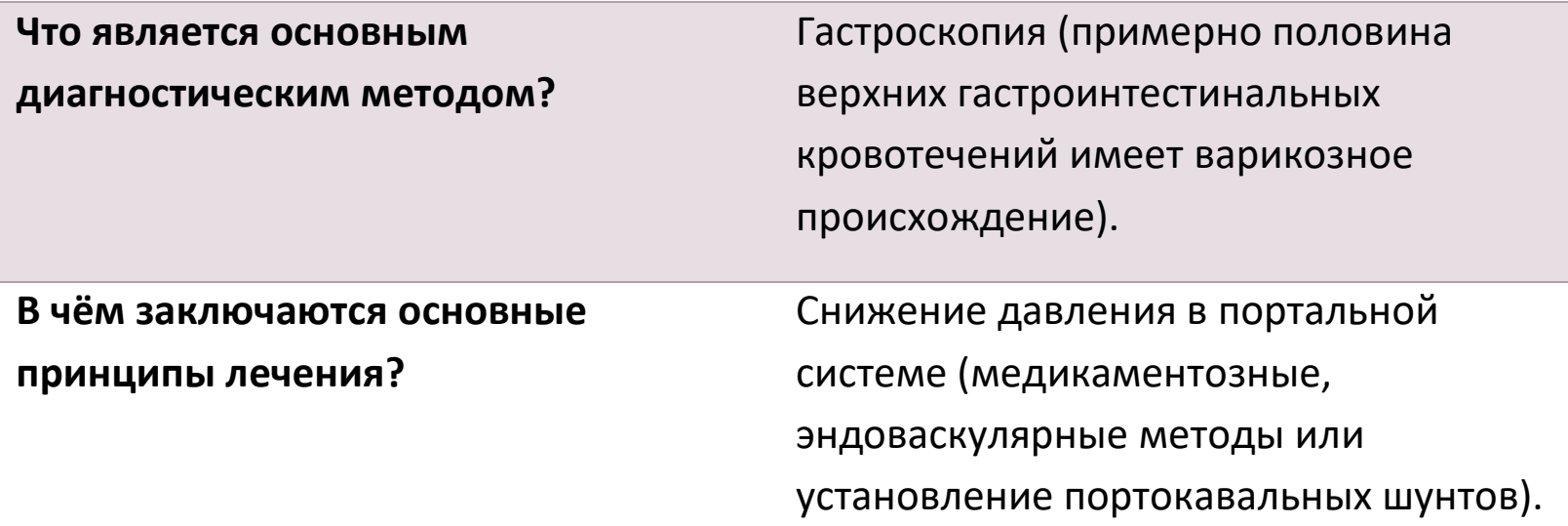

Препараты, снижающие давления в

- Вазопрессин и его аналоги;

портальной системе:

- Сандостатин и его аналоги.

\section{С каким препаратом надо сочетать вазопрессин у пациентов с коронарной недостаточностью?}

\section{Методы лечения:}

Применение вазопрессина сочетают с нитроглицерином, что позволяет избежать спазма коронарных артерий.

- Эндоскопическое - лигирование, склерозирование;

- Трансъюгулярное внутрипеченочное портосистемное шунтирование;

- Портокавальные шунты;

- Трансплантация печени. 
Вопросы

Основной метод лечения кровотечений из варикозных вен пищевода:

Тактика при рецидиве кровотечения после его временной остановки:

Тактика при продолжающемся кровотечении и при отсутствии возможности применения эндоскопического гемостаза:

Что представляет собой зонд Блекмора-Сенгстагена?

\section{Ответь}

Экстренная эндоскопия, лигирование или склерозирование варикозных вен.

Повторное эндоскопическое лечение.

Применение спланхнических вазоконсрикторов (терлипрессин, сандостатин) и пневмобаллонной тампонады зондом Блекмора-

\section{Сенгстагена.}

Зонд трубчатой конструкции, имеющий пищеводный и желудочный баллоны; используется для тампонады пищеводного кровотечения.

\section{Тактика при неэффективности}

эндоскопического и консервативного методов гемостаза при варикозном кровотечении:
- Трансъюгулярное внутрипечёночное портосистемное шунтирование;

- Портошунтирующие хирургические операции (селективные, парциальные);

- Трансплантация печени.
Проникая через кожу и ярёмную вену, устанавливают внутрипечёночный стент между печёночной веной и ветвями портальной вены.

Наиболее эффективные методы Портокавальные анастомозы n остановки варикозных кровотечении: трансплантация печени. 


\section{АСЦИТ}

- Асцит - скопление жидкости в брюшной полости.

- Происходит в результате нарушения баланса между секрецией и резорбцией перитонеального экссудата (портальная гипертензия, сердечная недостаточность, цирроз, нефротический синдром, микседема, мезотелиома, перитонеальный карциноматоз, экстравазация, лимфатический блок).

- Большинство асцитов имеет цирротическое происхождение.

- В зависимости от количества жидкости в брюшной полости различают асциты лёгкой (определяется на УзИ и КТ), средней (наличие клинических признаков) степени и большой асцит.

- $\mathrm{K}$ осложнениям асцита относятся рефрактерный асцит, спонтанный бактериальный перитонит (инфицирования жидкости), гепаторенальный синдром, гидроторакс и гипонатриемия.

- Диагноз подтверждается на УзИ и КТ. Для определения причины учитывают клинические, УзИ и КТ данные. При неинформативности этих методов определяют разницу альбумина в плазме и асцитической жидкости. Разница более 1,1 г/л является характерной для асцита обусловленной портальной гипертензией.

- Лечение асцита проводится с учётом патогенеза заболевания и предусматривает устранение причины, ограничение приёма натрия и назначение диуретиков. При резистентном асците, не поддающемся лечению диуретиками, производят пункцию и выполняют портокавальное шунтирование.

\section{Вопросы и ответы по асциту}

\begin{tabular}{|c|c|c|}
\hline Boпросы & \multicolumn{2}{|l|}{ Ответы } \\
\hline Что такое асцит? & $\begin{array}{l}\text { Скопление жидкости } \\
\text { полости. }\end{array}$ & брюшной \\
\hline Причины и факторы риска: & $\begin{array}{l}\text { • Гипертензия } \\
\text { гипертензия, } \\
\text { недостаточность); }\end{array}$ & $\begin{array}{r}\text { (портальная } \\
\text { сердечная }\end{array}$ \\
\hline
\end{tabular}




\begin{tabular}{|c|c|}
\hline Вопросы & Ответы \\
\hline & $\begin{array}{l}\text { • Осмотические причины (цирроз, } \\
\text { нефротический синдром, } \\
\text { микседема); } \\
\text { • Избыточная секреция жидкости } \\
\text { (мезотелиома, перитонеальный } \\
\text { карциноматоз); } \\
\text { • Избыточная экссудация жидкости } \\
\text { (воспаление); } \\
\text { • Экстравазация (перфорация); } \\
\text { • Лимфатический блок (опухоли). }\end{array}$ \\
\hline Наиболее частая причина: & Цирроз печени (80\%). \\
\hline Патогенез: & $\begin{array}{l}\text { Нарушение баланса между секрецией и } \\
\text { реабсорбцией жидкости брюшиной. } \\
\text { Портальная гипертензия, нарушение } \\
\text { водно-электролитного баланса и } \\
\text { снижение осмотического давления } \\
\text { способствуют развитию асцита. }\end{array}$ \\
\hline Особенность клинического течения: & $\begin{array}{l}\text { Зависит от причины (основного } \\
\text { заболевания). }\end{array}$ \\
\hline Осложнения: & $\begin{array}{l}\text { - } \text { Рефрактерный асцит; } \\
\text { - Спонтанный бактериальный } \\
\text { перитонит; } \\
\text { - Гепаторенальный синдром; } \\
\text { - Гипонатриемия; } \\
\text { - Абдоминальный компартмент- } \\
\text { синдром. }\end{array}$ \\
\hline Клинические формы: & $\begin{array}{l}\text { В зависимости от степени тяжести } \\
\text { различают лёгкой, средней тяжести и } \\
\text { большой асцит; в зависимости от } \\
\text { разницы альбумина в плазме и }\end{array}$ \\
\hline
\end{tabular}




\begin{tabular}{|c|c|}
\hline Вопросы & Ответы \\
\hline & $\begin{array}{l}\text { асцитической жидкости различают } \\
\text { асциты большой и малой разницы. }\end{array}$ \\
\hline Клинические признаки: & 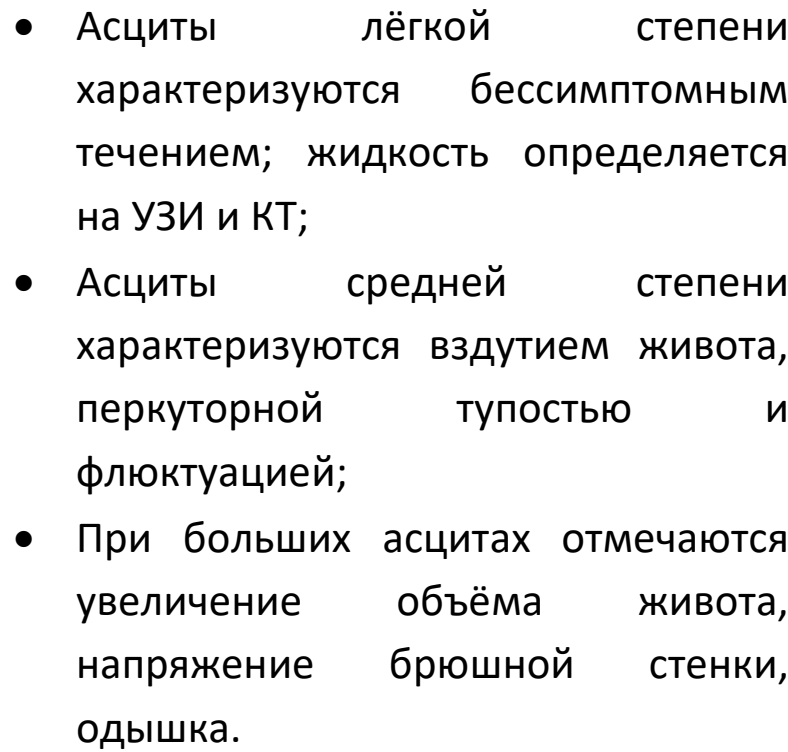 \\
\hline $\begin{array}{l}\text { У каких пациентов можно } \\
\text { заподозрить? }\end{array}$ & $\begin{array}{l}\text { - При заболеваниях печени; } \\
\text { - Заболевание желудочно-кишечного } \\
\text { тракта; } \\
\text { - Увеличение объёма живота; } \\
\text { - Перкуторная тупость; } \\
\text { - Компартмент-синдром. }\end{array}$ \\
\hline Диагностика: & УЗИ, КТ. \\
\hline Лабораторные признаки: & $\begin{array}{l}\text { Разница (градиент) в концентрации } \\
\text { альбумина в плазме и асцитической } \\
\text { жидкости более } 1,1 \text { г/л, характерный } \\
\text { признаки портальной гипертензии. }\end{array}$ \\
\hline $\begin{array}{l}\text { Признаки диагностической } \\
\text { визуализации: }\end{array}$ & Наличие жидкости в брюшной полости. \\
\hline Диагностические критерии: & $\begin{array}{l}\text { - Увеличение объёма живота, } \\
\text { напряжение, флюктуация; } \\
\text { - Наличие жидкости при УЗИ, КТ. }\end{array}$ \\
\hline
\end{tabular}




\begin{tabular}{|c|c|}
\hline Вопросы & Ответы \\
\hline Методы лечения: & $\begin{array}{l}\text { - Устранение причин; } \\
\text { - Ограничение приёма натрия, } \\
\text { назначение спиронолактона, } \\
\text { фуросемида; } \\
\text { - Инфузия альбумина; } \\
\text { - Парацентез; } \\
\text { - Портокавальное шунтирование. }\end{array}$ \\
\hline Показание к операции: & Рефрактерный асцит. \\
\hline Варианты оперативных вмешательств: & $\begin{array}{l}\text { Портокавальное } \quad \text { шунтирование или } \\
\text { трансъюгулярное } \\
\text { шунтирование. }\end{array}$ \\
\hline Прогноз: & $\begin{array}{l}\text { Малые и средние асциты поддаются } \\
\text { консервативному лечению. При } \\
\text { больших асцитах продолжительность } \\
\text { жизни укорачивается, летальность } \\
\text { увеличивается. }\end{array}$ \\
\hline
\end{tabular}




\section{ПЕЧЁНОЧНАЯ НЕДОСТАТОЧНОСТЬ}

- Под термином «печёночная дисфункция» подразумевается нарушение одной или нескольких функций печени.

- Различают 3 степени тяжести печёночной дисфункции: лёгкая, тяжёлая и печёночная недостаточность.

○ Лёгкая степень (соответствует острому гепатиту) - характеризуется повышением концентрации трансаминаз (АЛТ, АСТ), возможна и развитие желтухи;

○ Тяжёлая степень - наряду с повышением концентрации трансаминаз, наблюдаются признаки нарушения синтетической функций и коагулопатии с повышением INR.

○ Печёночная недостаточность является тяжёлой формой дисфункции печени, сопровождается желтухой и/или повышением INR и энцефалопатией.

- Выделяют следующие формы печёночной недостаточности: острую, хроническую, обострение хронической формы и пострезекционный или синдром малой доли печени.

- Острая печёночная недостаточность - коагулопатия и энцефалопатия, обусловленная повреждением (поражением) большей (более 80\%) части нормальной паренхимы печени у будучи здоровых людей.

○ Этиологическими факторами могут быть острые вирусные гепатиты (A, B, C и др.), гепатотоксические лекарственные препараты (парацетамол, галотан и др.), сепсис, ишемия печени.

○ Отличается тяжёлым и прогрессирующим течением, консервативная терапия при этой форме оказывается эффективной лишь в 20-40\% случаев.

○ Клинически проявляется желтухой, повышением концентрации энзимов и коагулопатией. В течение 1-36 недель могут наблюдаться энцефалопатия, сепсис и септический шок. Если острый гепатит проявляется энцефалопатией, то его можно расценивать как острая печёночная недостаточность.

○ Лечение носит этиотропный и заместительный характер. Основным методом лечения является трансплантация печени.

- Хроническая печёночная недостаточность - дисфункция и энцефалопатия, которые развиваются вследствие хронического гепатита и цирроза печени. 
О Обычно имеет стабильное хроническое течение, однако под влиянием провоцирующих факторов, может принимать острый характер.

○ Лечение направлено на коррекцию основного заболевания, послужившего причиной печёночной недостаточности.

- Обострение хронической печёночной недостаточности или осложнённая хроническая печёночная недостаточность (Acute on Chronic Liver Failure), характеризуется декомпенсацией хронической печёночной недостаточности (асцит, кровотечение, желтуха, энцефалопатия) и развитием органной дисфункции или полиорганной недостаточности (почечная недостаточность, развитие вторичной инфекции, септический шок и др.)

○ Наблюдается у пациентов со стабильным течением цирроза печени под влиянием провоцирующих факторов (инфекция, гепатотоксические препараты, алкоголь, тромбозы, варикозное кровотечение, сепсис и др.)

- Предполагается роль местной и системной воспалительной реакции в результате кишечного дисбиоза и бактериальной транслокации в развитии острой декомпенсации и органной недостаточности.

○ Проявляется в виде внезапного обострения состояния клинически стабильного пациента с циррозом печени симптомами декомпенсации и недостаточности органов.

○ Диагноз подтверждается на основании 3-х критериев: наличие хронической печеночной недостаточности, стадии декомпенсации (асцит, желудочнокишечное кровотечение, желтуха, энцефалопатия) и органная дисфункция (полиорганная недостаточность).

○ При отсутствии эффекта от заместительной терапии, проводимой в течение 1 недели, решается вопрос о трансплантации печени.

- Пострезекционный синдром или синдром малой доли печени характеризуется невозможностью восстановления синтетической, выделительной и детоксикационной функций печени после крупных резекций.

О Как правило, начинается в первые дни после резекции и проявляется желтухой, повышением INR, энцефалопатией и асцитом.

○ Течение тяжёлое, летальность составляет 80-90\%.

○ Эффективным способом лечения является трансплантация печени. 


\section{Вопросы и ответы по печёночной недостаточности}

\begin{tabular}{|c|c|}
\hline Вопросы & Ответы \\
\hline $\begin{array}{l}\text { Что такое дисфункция } \\
\text { печени? }\end{array}$ & $\begin{array}{l}\text { Нарушение одной или нескольких функций } \\
\text { печени, проявляющееся соответствующей } \\
\text { клинической симптоматикой и изменением пе- } \\
\text { чёночных тестов. }\end{array}$ \\
\hline $\begin{array}{l}\text { Степени острой дисфункции } \\
\text { печени: }\end{array}$ & $\begin{array}{l}\text { Лёгкая (гепатит), тяжёлая (повышение INR), } \\
\text { печёночная недостаточность. }\end{array}$ \\
\hline $\begin{array}{l}\text { Что такое печёночная } \\
\text { недостаточность? }\end{array}$ & $\begin{array}{l}\text { Тяжелая форма дисфункции печени, } \\
\text { характеризующаяся } \\
\text { коагулопатией. }\end{array}$ \\
\hline Диагностические критерии: & $\begin{array}{l}\text { - Дисфункция печени (повышение INR и } \\
\text { билирубина); } \\
\text { - Печёночная энцефалопатия. }\end{array}$ \\
\hline Клинические формы: & $\begin{array}{l}\text { - Острая; } \\
\text { - Хроническая; } \\
\text { - Обострение хронической печёночной } \\
\text { недостаточности; } \\
\text { - Пострезекционный или синдром малой доли } \\
\text { печени. }\end{array}$ \\
\hline $\begin{array}{l}\text { Что такое острая печёночная } \\
\text { недостаточность? }\end{array}$ & $\begin{array}{l}\text { Поражение значительного объёма (более } 80 \% \text { ) } \\
\text { печени у лиц, ранее не страдающих } \\
\text { заболеваниями печени. }\end{array}$ \\
\hline Клинические формы: & $\begin{array}{l}\text { В зависимости от продолжительности желтухи и } \\
\text { энцефалопатии: } \\
\text { - Сверхострая (менее } 7 \text { дней); } \\
\text { - Острая (1-4 нед.); } \\
\text { - Подострая (4-26 нед.) }\end{array}$ \\
\hline
\end{tabular}




\begin{tabular}{|c|c|}
\hline $\begin{array}{l}\text { Этиологические причины и } \\
\text { факторы риска: }\end{array}$ & $\begin{array}{l}\text { - Вирусные гепатиты (А, В, С и др.); } \\
\text { - Гепатотоксические препараты (парацетамол, } \\
\text { галотан и др.); } \\
\text { - Сепсис; } \\
\text { - Ишемия и др. }\end{array}$ \\
\hline Патогенез: & $\begin{array}{l}\text { Массивный гепатоцеллюлярный некроз, } \\
\text { дисфункция печени, сепсис, токсикоз, отёк } \\
\text { мозга. }\end{array}$ \\
\hline $\begin{array}{l}\text { Особенности клинического } \\
\text { течения: }\end{array}$ & $\begin{array}{l}\text { Тяжёлое, прогрессирующее заболевание. При } \\
\text { отсутствии трансплантации печени летальность } \\
\text { достигает } 40-80 \% \text {. }\end{array}$ \\
\hline Осложнения: & Сепсис, септический шок, отёк мозга. \\
\hline Клинические признаки: & $\begin{array}{l}\text { Боль в животе, желтуха, коагулопатия, энцефа- } \\
\text { лопатия и сепсис. }\end{array}$ \\
\hline $\begin{array}{l}\text { У каких пациентов можно } \\
\text { заподозрить? }\end{array}$ & $\begin{array}{l}\text { У пациентов с острым гепатитом, желтухой, } \\
\text { энцефалопатией. }\end{array}$ \\
\hline Диагностика: & Биохимическое исследования крови. \\
\hline Лабораторные признаки: & $\begin{array}{l}\text { - Гипербилирубинемия; } \\
\text { - Повышение INR. }\end{array}$ \\
\hline $\begin{array}{l}\text { Признаки диагностической } \\
\text { визуализации: }\end{array}$ & $\begin{array}{l}\text { Увеличение или уменьшение размеров печени, } \\
\text { уплотнение её паренхимы. }\end{array}$ \\
\hline $\begin{array}{l}\text { Что обнаруживается в других } \\
\text { методах исследования? }\end{array}$ & Признаки полиорганной дисфункции. \\
\hline Диагностические критерии: & $\begin{array}{l}\text { • } 2 \text { клинических признака - желтуха и } \\
\text { энцефалопатия; } \\
\text { • } 2 \text { лабораторный признака } \\
\text { гипербилирубинемия, повышение INR. }\end{array}$ \\
\hline Методы лечения: & - Хирургическое - трансплантация печени; \\
\hline
\end{tabular}




\begin{tabular}{|c|c|}
\hline & 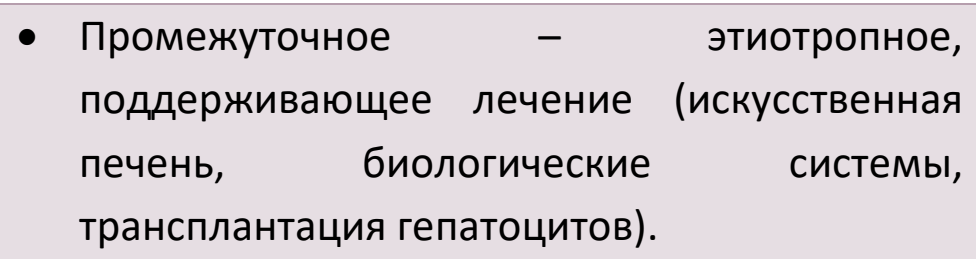 \\
\hline Прогноз: & $\begin{array}{l}\text { Летальность без лечения }- \text { 80-95\%, при } \\
\text { консервативном лечении }- \text { 20-40\%. } \\
\text { Выживаемость после трансплантации печени } \\
\text { составляет 70-80\%. }\end{array}$ \\
\hline $\begin{array}{l}\text { Что такое хроническая } \\
\text { печёночная недостаточность? }\end{array}$ & $\begin{array}{l}\text { Дисфункция печени, развивающаяся на фоне } \\
\text { существующих хронических заболеваний } \\
\text { печени, сопровождающаяся энцефалопатией. }\end{array}$ \\
\hline Клинические признаки: & $\begin{array}{l}\text { Различные проявления гепатоцеллюлярной } \\
\text { дисфункции, стабильная или медленно } \\
\text { прогрессирующая энцефалопатия. }\end{array}$ \\
\hline Лечение: & Устранение нозологической причины. \\
\hline $\begin{array}{l}\text { Что такое обострение } \\
\text { хронической печёночной } \\
\text { недостаточности? }\end{array}$ & $\begin{array}{l}\text { Декомпенсация функции печени на фоне её } \\
\text { хронических заболеваний и органная } \\
\text { дисфункция. }\end{array}$ \\
\hline $\begin{array}{l}\text { Критерии острой } \\
\text { декомпенсации: }\end{array}$ & $\begin{array}{l}\text { Возникновение острых осложнений на фоне } \\
\text { хронических заболеваний печени: асцит, } \\
\text { кровотечение, энцефалопатия и желтуха. }\end{array}$ \\
\hline $\begin{array}{l}\text { Факторы, провоцирующие } \\
\text { декомпенсацию: }\end{array}$ & $\begin{array}{l}\text { - Активная вирусная инфекция; } \\
\text { - Гепатотоксические препараты; } \\
\text { - Алкоголь; } \\
\text { - Тромбозы; } \\
\text { - Варикозно расширенные вены; } \\
\text { - Кровотечения; } \\
\text { - Сепсис. }\end{array}$ \\
\hline Диагностические критерии: & - Наличие хронической патологии печени; \\
\hline
\end{tabular}




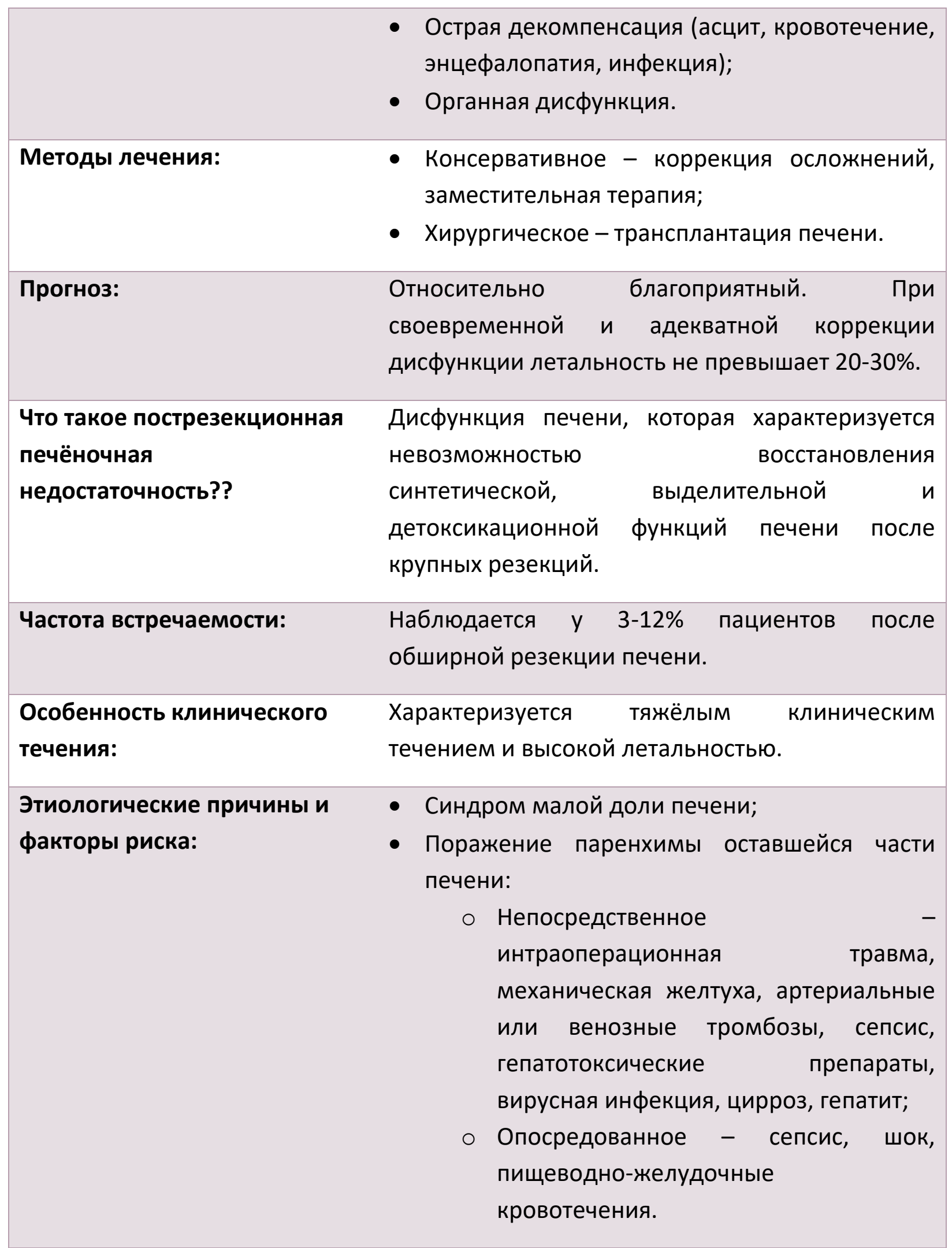




\begin{tabular}{|ll|}
\hline Патогенез: & $\begin{array}{l}\text { При резекции 80\% печени, оставшаяся часть не } \\
\text { регенерирует и, подвергаясь некрозу, } \\
\text { способствует пазвитию } \\
\text { недостаточности. }\end{array}$ \\
\hline $\begin{array}{l}\text { Что такое синдром малой } \\
\text { доли печени? }\end{array}$ & $\begin{array}{l}\text { Печёночная недостаточность, возникшая на } \\
\text { фоне недостаточного объёма печени после её } \\
\text { резекции или трансплантации. }\end{array}$ \\
\hline Методы лечения: & $\begin{array}{l}\text { Хирургическое - трансплантация печени; } \\
\text { Заместительная терапия. }\end{array}$ \\
\hline Показание к хирургическому & Прогрессирующая печёночная недостаточность. \\
лечению: & \\
\hline Виды пересадки печени: & Трансплантация от живого донора или трупной \\
& печени. \\
\hline Прогноз: & Летальность составляет 80-90\%. \\
\hline
\end{tabular}




\section{ГЕПАТОРЕНАЛЬНЫЙ СИНДРОМ}

- Гепаторенальный синдром - почечная дисфункция, развивающаяся вследствие острых и хронических заболеваний печени.

- Основными патогенетическими механизмами заболевания являются снижение фильтрационной функции и задержка ионов натрия и воды в организме, спазм почечных артерий. При этом не наблюдаются заболевания, морфологические изменения почек, нефротоксическое влияние и другие факторы, нарушающие функцию почек (гиповолемия, обструкция и др.)

- Различают субклиническую, острую и хроническую формы заболевания.

○ Острая форма (или I тип) гепаторенального синдрома характеризуется острым нарушением фильтрационной функции почек, которая развивается на фоне различных острых заболеваний (спонтанный бактериальный перитонит, сепсис, кровотечение и др.) или других отягощающих факторов.

○ При хронической форме или II типе гепаторенального синдрома нарушение функции почек развивается медленно и проявляется рефрактерным (резистентным к диуретикам) асцитом.

- Диагноз устанавливается на основании повышения концентрации креатинина в крови (более 1,5 мг/дл) и исключения других патологий почек.

- Основной целью лечения I типа гепаторенального синдрома является устранение нозологической причины и отягощающих факторов. Вторая цель направлена на расширение сосудов почек и снижение реабсорбции.

○ С этой целью используют волемически активные препараты (альбумин), вазоконстрикторы (мидодрин, норадреналин, терлипрессин) и ренальные вазодилататоры (ацетилцистеин, пентоксифиллин).

○ При неэффективности указанных методов лечения применяют диализ и внутрипечёночный портокавальный шунт. При резистентном асците показаны лапароцентез и трансъюгулярное портокавальное шунтирование.

- При лечении II типа гепаторенального синдрома используют спиронолактон (100-400 мг/день) и фуросемид (40-160 мг/день), способствующие задержке воды и ионов натрия в организме.

- Прогноз при I типе гепаторенального синдрома неблагоприятен, т.к. при отсутствии лечения больные умирают в течение 2-4 недель. При II типе гепаторенального синдрома, даже при условии эффективности лечения 
диуретиками, продолжительность жизни заметно сокращается (1-летняя выживаемость - на 20\%, 5-летняя - на 39\%). При отсутствии лечения наступает летальный исход в течение 4-6 месяцев.

\section{Вопросы и ответы по гепаторенальному синдрому}

\begin{tabular}{|c|c|}
\hline Вопросы & Ответы \\
\hline $\begin{array}{l}\text { Что такое гепаторенальный синд- } \\
\text { ром? }\end{array}$ & $\begin{array}{l}\text { Дисфункция почек, } \\
\text { заболеваниями печени. }\end{array}$ \\
\hline Клинические формы: & $\begin{array}{l}\text { - } \text { Субклинический; } \\
\text { - Острый или I тип; } \\
\text { - Хронический или II тип. }\end{array}$ \\
\hline Причины и факты риска: & 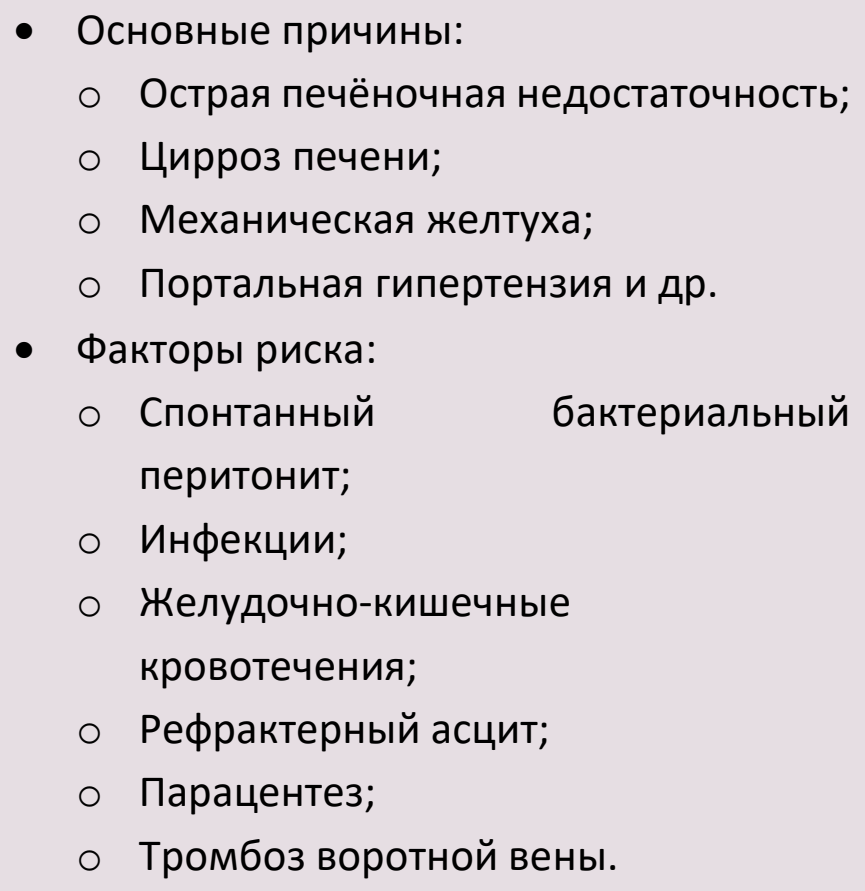 \\
\hline Патогенез: & 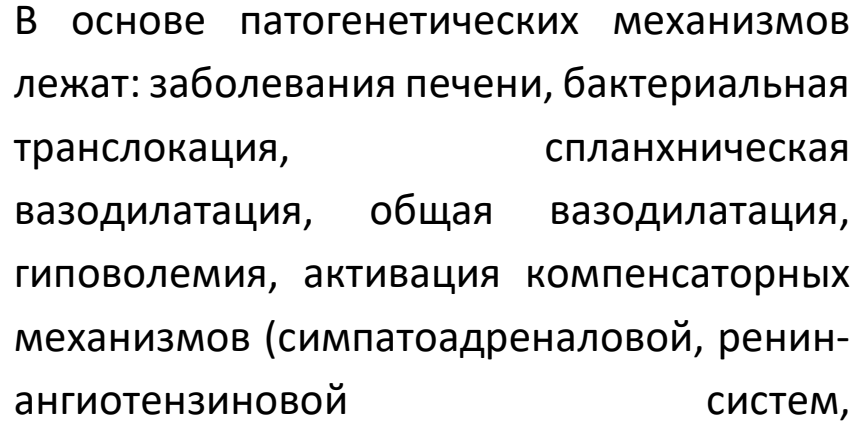 \\
\hline
\end{tabular}




\begin{tabular}{|c|c|}
\hline Вопросы & $\begin{array}{r}\text { Ответы } \\
\end{array}$ \\
\hline & $\begin{array}{l}\text { антидиуретический гормон) и спазм } \\
\text { почечных сосудов. }\end{array}$ \\
\hline $\begin{array}{l}\text { Особенности клинического } \\
\text { течения: }\end{array}$ & $\begin{array}{l}\text { - I тип гепаторенального синдрома } \\
\text { протекает как } \\
\text { недостаточность, } \\
\text { неблагоприятный, при отсутствии } \\
\text { лечения в течение 2-4 недель наступает } \\
\text { смерть; } \\
\text { - II тип протекает с признаками } \\
\text { рефрактерного асцита, при отсутствии } \\
\text { лечения наступает смерть в течение 4-6 } \\
\text { месяцев. }\end{array}$ \\
\hline Осложнения: & $\begin{array}{l}\text { Сердечная недостаточность, ацидоз, } \\
\text { гиперволемия, уремическая кома, сепсис. }\end{array}$ \\
\hline Клинические признаки: & $\begin{array}{l}\text { - Субклиническая форма протекает } \\
\text { бессимптомно; } \\
\text { - I тип - манифестирует явлениями } \\
\text { острой почечной недостаточности; } \\
\text { - ІІ тип - проявляется рефрактерным к } \\
\text { диуретикам асцитом. }\end{array}$ \\
\hline $\begin{array}{l}\text { У каких пациентов можно } \\
\text { заподозрить? }\end{array}$ & $\begin{array}{l}\text { - У пациентов с острыми и хроническими } \\
\text { заболеваниями печени; } \\
\text { - При печёночной, почечной и сердечной } \\
\text { недостаточности; } \\
\text { - При асците, рефрактерном к } \\
\text { диуретикам; } \\
\text { - При спонтанном бактериальном } \\
\text { перитоните. }\end{array}$ \\
\hline
\end{tabular}




\begin{tabular}{|c|c|}
\hline Вопросы & Ответы \\
\hline Диагностика: & $\begin{array}{l}\text { - УзИ; } \\
\text { - Допплерография; } \\
\text { - Общий анализ мочи; } \\
\text { - Биохимический анализ крови; } \\
\text { - Креатинин и клиренс креатинина; } \\
\text { - Остаточный азот; } \\
\text { - Тесты на экскрецию ионов натрия; } \\
\text { - Специфические тесты. }\end{array}$ \\
\hline Лабораторные признаки: & $\begin{array}{l}\text { - При острой форме (I типе) содержание } \\
\text { креатинина >2,5 мг/дл; } \\
\text { - При хронической форме (II типе) } \\
\text { концентрация креатинина - 1,5-2,5 } \\
\text { мг/дл. }\end{array}$ \\
\hline $\begin{array}{l}\text { Признаки диагностической } \\
\text { визуализации: }\end{array}$ & $\begin{array}{l}\text { При допплерографии выявляется спазм } \\
\text { почечных сосудов. }\end{array}$ \\
\hline Другие диагностические данные: & $\begin{array}{l}\text { Ацидоз, гиперкалиемия, повышение } \\
\text { остаточного азота. }\end{array}$ \\
\hline Диагностические критерии: & $\begin{array}{l}\text { - Цирроз, острая печёночная } \\
\text { недостаточность, портальная } \\
\text { гипертензия; } \\
\text { - Повышение концентрации креатинина } \\
>1,5 \text { мг/дл; } \\
\text { - Несмотря на отмену диуретиков и } \\
\text { повышение сосудистого объёма } \\
\text { волемически активными коллоидными } \\
\text { растворами, (альбумин 1-1,5 г/кг/день) } \\
\text { стойкое сохранение концентрации } \\
\text { креатинина на уровне 1,5 мг/дл; } \\
\text { - Отсутствие шока; } \\
\text { - Нефротоксические препараты не } \\
\text { применены; }\end{array}$ \\
\hline
\end{tabular}




\section{Вопросы}

\section{Ответы}

- Отсутствие патологии паренхимы почек (протеинурия <500мг/день, наличие $<50$ эритроцитов в поле зрения).

\section{Методы лечения:}

- Устранение причин и факторов риска (билиарный дренаж, трансплантация печени;

- Патогенетическое лечение: применение вазодилататоров, увеличение собъёма циркулирующей крови, использование общих или спланхнических вазоконстрикторов;

- Искусственные печёночные системы (диализ альбумином, внутрипечёночные портокавальные шунты);

- При рефрактерном асците периодический парацентез или трансъюгулярное портокавальное шунтирование;

- При II типе гепаторенального синдрома - использование антагонистов альдостерона, трансъюгулярное портокавальное шунтирование.

Прогноз:

- При I типе смерть наступает в течение 24 недель;

- При II типе больные умирают в течение 4-6 месяцев. 


\section{ПЕЧЁНОЧНАЯ ЭНЦЕФАЛОПАТИЯ}

- Печёночная энцефалопатия развивается вследствие острых и хронических заболеваний печени и характеризуется нейропсихологическими изменениями (сознания, восприятия и контроль движения). Эти нарушения могут усугубляться под воздействием провоцирующих факторов (инфекция, кровопотеря, электролитный дисбаланс и др.), но имеют обратимый характер.

- Диагноз и степень тяжести энцефалопатии определяются на основе клинических параметров.

○ В субклинической стадии отсутствуют явные признаки, при этом определённую информацию можно получить нейропсихологическими тестами.

○ При лёгкой форме энцефалопатии наблюдаются нарушение памяти и сна, тремор, но при этом пациент остаётся коммуникабельным.

- При тяжёлом течении контакт с пациентом становится невозможным, наблюдаются некоординированные движения, невнятная и бессвязная речь. Исходом такого состояния является печёночная кома.

- Основным методом лечения печёночной энцефалопатии, является этиотропная терапия, направленная на устранение причин её вызвавших.

- При отсутствии такой возможности проводятся медикаментозная коррекция, направленная на снижение концентрации аммиака (лактулоза, L-орнитин-Lаспартат, рифаксимин).

○ Проводятся также мероприятия с целью устранения отягощающих факторов (остановка желудочно-кишечных кровотечений, освобождение желудочнокишечного тракта от застойного содержимого, коррекция водноэлектролитных нарушений, профилактика отёка мозга и т.п.)

○ При неэффективности медикаментозной терапии, применяются методы экстракорпоральной детоксикации (искусственная печень, плазмаферез и т. д.) 


\section{Вопросы и ответы по печёночной энцефалопатии}

\begin{tabular}{|ll|}
\hline \multicolumn{1}{|c|}{ Вопросы } & \multicolumn{1}{c|}{ Ответы } \\
\hline $\begin{array}{l}\text { Основной метод диагностики } \\
\text { энцефалопатии: }\end{array}$ & Клиническая симптоматика. \\
\hline $\begin{array}{l}\text { Как определяется степень тяжести } \\
\text { энцефалопатии? }\end{array}$ & На основании клинических проявлений. \\
\hline $\begin{array}{l}\text { По каким лабораторным тестам } \\
\text { определяется энцефалопатия? }\end{array}$ & По концентрации аммиака в крови. \\
\hline $\begin{array}{l}\text { Какие медикаменты используют при } \\
\text { печёночной энцефалопатии? }\end{array}$ & $\begin{array}{l}\text { Лактулоза, рифаксимин, L-орнитин-L- } \\
\text { аспартат. }\end{array}$ \\
\hline
\end{tabular}




\section{ВРОЖДЁННЫЕ КИСТЫ ПЕЧЕНИ}

- Кисты печени, представляющие собой полость с жидкостью, бывают врождёнными, паразитарными, неопластическими, травматическими и воспалительными.

- Врождённые кисты печени являются клиническими и морфологическими формами фиброполикистозной болезни, которые включают простые кисты, поликистоз, болезнь Кароли и др.

- Солитарные кисты печени - обычно одиночные кисты размером 2-5 см, без перегородки или контакта с жёлчными протоками.

○ При диагностической визуализации определяется тонкостенное образование без перегородок, которое трудно отличить от эхинококковой кисты I типа.

○ Редко вызывает симптомы и осложнения.

○ При отсутствии осложнений или каких-либо симптомов нет необходимости в лечении.

- Поликистоз печени характеризуется множественными кистами размером 1-20 см без перегородки или сообщения с жёлчными протоками. Как правило, сочетается с поликистозом почек.

- Может проявляться симптомами компрессии печени (портальная гипертензия, желтуха).

○ При симптоматических формах поликистоза печени проводится хирургическое лечение - резекция, фенестрация.

- Болезнь Кароли характеризуется множественными кистами печени, имеющих сообщение с желчевыводящими путями.

○ Часто осложняются развитием холангита.

○ С лечебной целью проводится резекции печени, дренирование кист и даже трансплантация печени.

\section{Вопросы и ответы по врождённым кистам печени}

\begin{tabular}{|c|c|}
\hline Вопросы & Ответы \\
\hline $\begin{array}{l}\text { Что представляют собой врождённые } \\
\text { кисты печени? }\end{array}$ & $\begin{array}{ll}\text { Являются морфологической } & \text { формой } \\
\text { фиброполикистозной } & \text { болезни }\end{array}$ \\
\hline
\end{tabular}




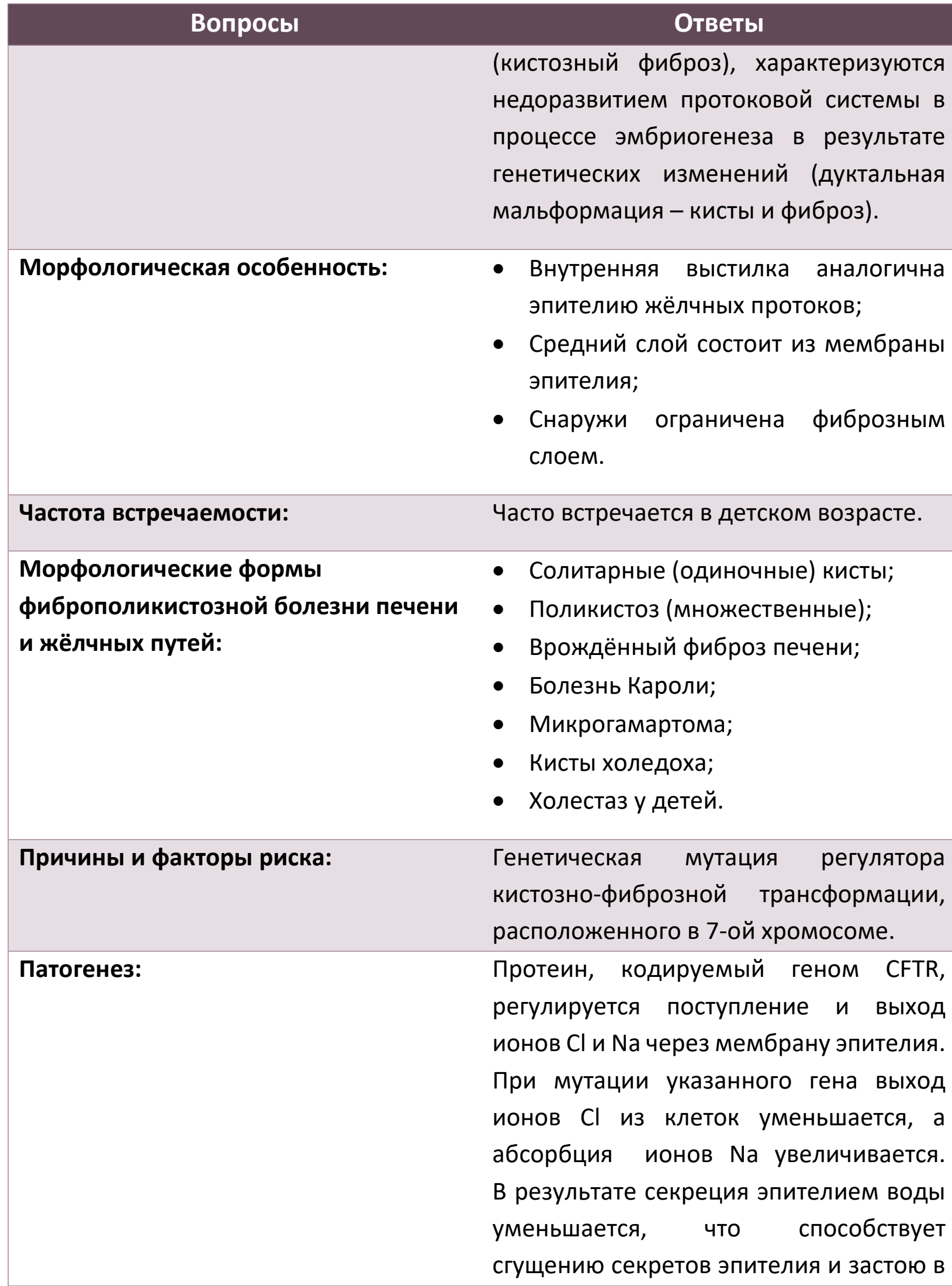




\begin{tabular}{|c|c|}
\hline Вопросы & Ответы \\
\hline & $\begin{array}{l}\text { протоковой системе, что в свою очередь } \\
\text { приводит к воспалительным и } \\
\text { инфекционным осложнениям. }\end{array}$ \\
\hline Особенность клинического течения: & $\begin{array}{l}\text { Имеется потенциальный риск } \\
\text { злокачественной трансформации. }\end{array}$ \\
\hline Клинические признаки: & $\begin{array}{l}\text { - В ряде случаев протекает } \\
\text { бессимптомно; } \\
\text { - Наличие пальпируемого } \\
\text { образования; } \\
\text { - Признаки холестаза; } \\
\text { - Признаки холангита; } \\
\text { - Портальная гипертензия. }\end{array}$ \\
\hline Особенности солитарных кист печени: & $\begin{array}{l}\text { - Одиночная киста, размером 2-5 см; } \\
\text { - Не сообщается с жёлчными } \\
\text { протоками и не имеет внутренних } \\
\text { перегородок. }\end{array}$ \\
\hline Клинические признаки: & $\begin{array}{l}\text { В большинстве случаев протекает } \\
\text { бессимптомно. В редких случаях } \\
\text { проявляется болью. }\end{array}$ \\
\hline Осложнения: & $\begin{array}{l}\text { - Кровотечение; } \\
\text { - Инфицирование кисты. }\end{array}$ \\
\hline Диагностика: & $\begin{array}{l}\text { - Узи, МРТ; } \\
\text { - Серологические исследования. }\end{array}$ \\
\hline $\begin{array}{l}\text { Методы диагностической } \\
\text { визуализации: }\end{array}$ & $\begin{array}{l}\text { УЗИ, МРТ - наличие тонкостенного } \\
\text { кистозного образования без внутренних } \\
\text { перемычек. }\end{array}$ \\
\hline Методы лечения: & $\begin{array}{l}\text { - При бессимптомном течении - } \\
\text { наблюдение; }\end{array}$ \\
\hline
\end{tabular}




\begin{tabular}{|c|c|}
\hline Вопросы & Ответы \\
\hline & $\begin{array}{l}\text { - При наличии соответствующей } \\
\text { клиники - хирургическое лечение, } \\
\text { пункция, склеротерапия. }\end{array}$ \\
\hline Противопоказания к склеротерапии: & $\begin{array}{l}\text { Наличие сообщения кисты с жёлчными } \\
\text { протоками. }\end{array}$ \\
\hline Показания к хирургическому лечению: & $\begin{array}{l}\text { Крупные кисты ближе к поверхности } \\
\text { печени. }\end{array}$ \\
\hline Методы хирургического лечения: & $\begin{array}{l}\text { Фенестрация открытым } \\
\text { лапароскопическим мли } \\
\text { создание сообщения между полостью } \\
\text { кисты и брюшиной. }\end{array}$ \\
\hline Особенности поликистоза печени: & $\begin{array}{l}\text { - Множественные кисты размером } \\
\text { варьируют 1-20 см; } \\
\text { - Кисты не имеют перегородок и } \\
\text { сообщения с жёлчными протоками; } \\
\text { - Сочетается с поликистозом почки. }\end{array}$ \\
\hline Клинические признаки: & $\begin{array}{l}\text { - Признаки сдавления печени: } \\
\text { о Портальная гипертензия; } \\
\text { о Желтуха; } \\
\text { О Боли; } \\
\text { - Почечные признаки: } \\
\text { О Почечная недостаточность; } \\
\text { О Пиелонефрит; } \\
\text { О Артериальная гипертония. }\end{array}$ \\
\hline Диагностика: & УЗИ, КТ. \\
\hline $\begin{array}{l}\text { Признаки диагностической } \\
\text { визуализации: }\end{array}$ & $\begin{array}{l}\text { Наличие тонкостенного полостного } \\
\text { образования, содержащего жидкость. } \\
\text { Выявление кисты без тканевого } \\
\text { компонента в почках и костях. }\end{array}$ \\
\hline
\end{tabular}




\begin{tabular}{|c|c|}
\hline Вопросы & Ответы \\
\hline Методы лечения: & $\begin{array}{l}\text { - При бессимптомном течении - } \\
\text { наблюдение; } \\
\text { - При симптоматических формах - } \\
\text { фенестрация, } \\
\text { трансплантация печени; } \\
\text { - При осложнённых кистах - } \\
\text { дренирование нагноившейся кисты, } \\
\text { эмболизация при кровотечени, } \\
\text { цистэктомия, цистоеюноанастомоз } \\
\text { при прорыве кисты в жёлчные } \\
\text { протоки. }\end{array}$ \\
\hline Что такое болезнь Кароли? & $\begin{array}{l}\text { Множественные кисты, занимающие } \\
\text { одну или обе доли печени, } \\
\text { сообщающиеся с жёлчными протоками. }\end{array}$ \\
\hline Клинические признаки: & Частые эпизоды холангита. \\
\hline Диагностика: & 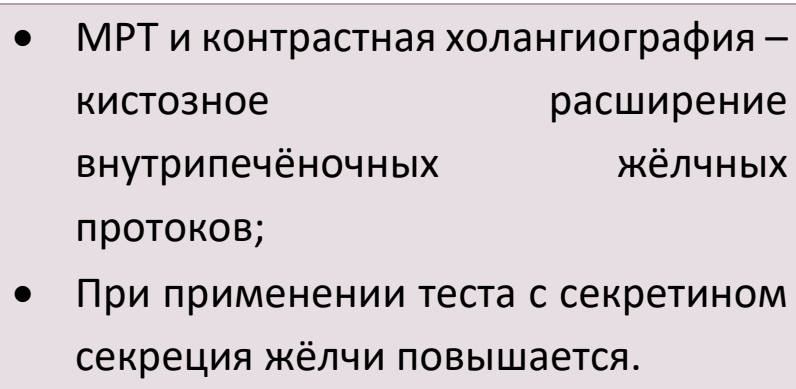 \\
\hline Методы лечения: & $\begin{array}{l}\text { - При бессимптомном течении - } \\
\text { динамическое наблюдение; } \\
\text { - При явных симптомах - операция: } \\
\text { при поражении одной доли - } \\
\text { резекция, при поражении обеих } \\
\text { долей - дренирование кист или } \\
\text { трансплантация печени. }\end{array}$ \\
\hline
\end{tabular}




\section{Вопросы Ответы}

Характерная особенность болезни

Болезнь Кароли может протекать

Кароли:

бессимптомно или может потребовать трансплантация печени. 


\section{ЭХИНОКОККОЗ ПЕЧЕНИ}

- K часто встречающимся паразитарным кистам относятся большие кисты гидатидозного типа (возбудитель Echinococcus granulosus) и микрокисты, похожие на опухоль (возбудитель Alveococcus multilocularis).

- Гидатидозный (кистозный) эхинококкоз имеет толстый слой хитина, обычно растёт и вызывает осложнения (давление, прорыв в жёлчные протоки, инфекция и др.)

○ Диагноз подтверждается на УЗИ, КТ/МРТ и серологическим исследованием (эхинококковый Ig).

○ К диагностическим критериям относятся наличие двойной стенки, дочерних пузырьков (симптом «пчелиных сот»), хитинового слоя (симптом «шерстяного клубка»), кальцификаций на стенке, положительный серологический анализ.

○ Основное лечение - хирургическое вмешательство (дренирование кисты, перицистэктомия, резекция), предоперационное и послеоперационное лечение альбендазолом. Некоторым пациентам проводится чрескожное дренирование кисты.

- Альвеолярный эхинококкоз, или альвеококкоз, состоит из соседних миллиметровых кист.

О По клинической картине $и$ данным диагностической визуализации альвеококкоз напоминает злокачественную опухоль, распространяющуюся перипортально и вдоль капсулы.

○ Диагноз подтверждается биопсией.

○ Наиболее эффективное лечение - хирургическое иссечение.

\section{Вопросы и ответы по эхинококкозам печени}

\begin{tabular}{|llr|}
\hline \multicolumn{2}{|c|}{ Вопросы } & \multicolumn{3}{c|}{ Ответы } \\
\hline Что собой представляет эхинококкоз & Паразитарная & киста, \\
печени? & вызывается ленточным глистом - \\
& Echinococcus granulosus.
\end{tabular}




\begin{tabular}{|c|c|}
\hline Вопросы & Ответы \\
\hline \multirow[t]{3}{*}{ Факторы риска: } & Встречается в эндемических очагах, где \\
\hline & основным занятием людей является \\
\hline & жИВОТнОВОДСтВо. \\
\hline \multirow[t]{3}{*}{ Клинические признаки: } & Бессимптомное течение, боль, \\
\hline & пальпируемое образование в правом \\
\hline & верхнем квадранте, желтуха. \\
\hline Диагностика: & УЗИ, КТ, МРТ. \\
\hline \multirow{4}{*}{$\begin{array}{l}\text { Характерные признаки } \\
\text { диагностической визуализации: }\end{array}$} & Наличие кистозного образования с \\
\hline & стенкой, наличие \\
\hline & пузырьков, \\
\hline & кальцинация в стенке кисты. \\
\hline Что можно обнаружить при & Кисту с кальцификацией. \\
\hline \multicolumn{2}{|l|}{ рентгенологическом исследовании? } \\
\hline \multirow[t]{3}{*}{ Наиболее опасные осложнения: } & Прорыв кисты во внутрипечёночные \\
\hline & жёлчные протоки, брюшную полость, \\
\hline & плевральную полость, перикард. \\
\hline \multirow{3}{*}{$\begin{array}{l}\text { Осложнения при хирургическом } \\
\text { лечении: }\end{array}$} & Прорыв кисты \\
\hline & пузырьков, \\
\hline & анафилактический шок. \\
\hline Показание к чрескожному & Нагноение кисты, не имеющей \\
\hline дренированию: & дочерних пузырьков и перегородок. \\
\hline \multirow[t]{3}{*}{ Лечение: } & Назначается консервативное лечение \\
\hline & альбендазолом, далее проводится \\
\hline & хирургическая операция. \\
\hline $\begin{array}{l}\text { Каким раствором проводится санация } \\
\text { полости кисты? }\end{array}$ & Гипертонический раствор (30\%), этанол. \\
\hline
\end{tabular}




\section{НЕОПЛАСТИЧЕСКИЕ КИСТЫ ПЕЧЕНИ}

- Неопластические кисты печени представляют собой кистозные образования, имеющие внутреннюю эпителиальную выстилку неопластического характера (многослойный, полипоидный, аденокарцинома).

○ Содержимое кисты - густая жидкость муцинозного характера, которая содержит высокую концентрацию СА 19-9.

○ Характеризуются толстой стенкой, полиповидными выпячиваниями, наличием перегородок или множественных камер.

○ Диагноз ставится на основании патогистологического исследования содержимого кисты.

○ Лечение - радикальное иссечение кисты.

- Травматические кисты формируются на месте гематомы и билиомы.

○ Стенка состоит из фиброзной ткани без внутреннего эпителиального слоя (псевдокисты).

○ При инфицировании травматических кист показано чрескожное дренирование.

\section{Вопросы и ответы по неопластическим кистам печени}

\begin{tabular}{|ll|}
\multicolumn{1}{c|}{ Вопросы } & \multicolumn{1}{c|}{ Ответы } \\
\hline Что представляют собой & Кисты печени, формирующиеся \\
неопластические кисты печени? & $\begin{array}{l}\text { вследствие первичных или вторичных } \\
\text { неопластических процессов. }\end{array}$ \\
\hline Частота встречаемости: & $\begin{array}{l}\text { Составляет } 1-2 \% \quad \text { всех кистозных } \\
\text { образований печени. }\end{array}$ \\
\hline Клинические формы: & Первичные: \\
& $\circ$ Цистаденома; \\
& $\circ$ Цистаденокарцинома. \\
& Вторичные: \\
& $\circ$ Метастатические. \\
\hline
\end{tabular}




\begin{tabular}{|c|c|}
\hline Вопросы & Ответы \\
\hline Что такое билиарная цистаденома? & $\begin{array}{l}\text { Представляет собой } \\
\text { доброкачественную первичную } \\
\text { неопластическую кисту печени. }\end{array}$ \\
\hline Морфологическая структура: & $\begin{array}{l}\text { Имеет трёхслойную стенку: } \\
\text { - Эпителий жёлчных протоков; } \\
\text { - Эпителиальная мембрана; } \\
\text { - Фиброзный слой. } \\
\text { В отличие от врождённых кист: } \\
\text { - Эпителиальный слой имеет } \\
\text { неопластический характер; } \\
\text { - Секретирует густую жидкость } \\
\text { муцинозного характера; } \\
\text { - В содержимом определяется } \\
\text { высокая концентрация СА 19-9; } \\
\text { - Имеет толстую стенку; } \\
\text { - Имеет перемычки и полиповидные } \\
\text { выпячивания. }\end{array}$ \\
\hline Причины и факторы риска: & Не известны. \\
\hline Патогенез: & Неизвестен. \\
\hline Особенность клинического течения: & В 25\% случаев малигнизируются. \\
\hline Осложнения: & $\begin{array}{l}\text { Малигнизация, инфицирование, } \\
\text { кровотечение, сдавление соседних } \\
\text { органов и окружающих тканей. }\end{array}$ \\
\hline Клинические признаки: & $\begin{array}{l}\text { - В большинстве случаев имеет } \\
\text { бессимптомное течение; } \\
\text { - При достижении больших размеров } \\
\text { возникают осложнения }\end{array}$ \\
\hline
\end{tabular}




\begin{tabular}{|c|c|}
\hline Вопросы & Ответы \\
\hline & $\begin{array}{l}\text { (инфицирование, кровотечение, } \\
\text { сдавление соседних органов). }\end{array}$ \\
\hline $\begin{array}{l}\text { У каких пациентов можно } \\
\text { заподозрить? }\end{array}$ & $\begin{array}{l}\text { У пациентов с наличием клинических и } \\
\text { диагностических признаков. }\end{array}$ \\
\hline Диагностика: & $\begin{array}{l}\text { - Биопсия; } \\
\text { - Узи, кТ; } \\
\text { - Определение онкомаркеров } \\
\text { содержимом кисты. }\end{array}$ \\
\hline Лабораторные признаки: & $\begin{array}{l}\text { Высокая концентрация С } 19-9 \text { в } \\
\text { содержимом кисты. }\end{array}$ \\
\hline $\begin{array}{l}\text { Признаки диагностической } \\
\text { визуализации: }\end{array}$ & $\begin{array}{l}\text { - Наличие множественных кист, } \\
\text { расположенных рядом друг с } \\
\text { другом; } \\
\text { - Многокамерная киста; } \\
\text { - Наличие толстой и шероховатой } \\
\text { стенки; } \\
\text { - Наличие в просвете полиповидных } \\
\text { выпячиваний; } \\
\text { - Наличие в просвете жидкости } \\
\text { различной плотности. }\end{array}$ \\
\hline Диагностические критерии: & $\begin{array}{l}\text { - Признаки диагностической } \\
\text { визуализации; } \\
\text { • Высокая концентрация СА 19-9 в } \\
\text { содержимом кисты; } \\
\text { - Выявление неопластического } \\
\text { эпителия при биопсии. }\end{array}$ \\
\hline Методы лечения: & Хирургическое. \\
\hline Показания к операции: & Наличие кисты. \\
\hline Методы оперативного вмешательства: & Устранение эпителия кисты: \\
\hline
\end{tabular}


Вопросы

\section{Ответы}

- Кистэктомия (энуклеация кисты);

- Резекция ;

- В тяжёлых случаях - мукозэктомия.

Рекомендуются ли парциальная

цистэктомия, абляция, фенестрация, котеризация и цистоеюностомия?

Прогноз:

Характерная особенность заболевания:

Что такое первичная

цистаденокарцинома?

Морфологическая структура:

Клинические признаки:

Диагностика:

Методы лечения:

Что такое метастатическая

цистаденокарцинома?

Источники метастазирования:

Клиническая картина и методы лечения:
Учитывая риск малигнизации кист, эти методы оперативного лечения не рекомендуются.

При радикальном удалении

благоприятный.

При подозрении на цистаденому показана тотальная резекция.

Неопластические образование, развивающееся первично или в результате малигнизации цистаденом.

Эпителиальный слой полностью или частично имеет атипичный характер.

В большинстве наблюдений протекают как билиарная цистаденома.

Патогистологическое исследование стенок кисты.

Радикальная резекция.

Представляют собой метастазы кистозной аденокарциномы.

Ободочная кишка, поджелудочная железа, желудок, почки, яичники и др.

Так же, как и при других метастатических опухолях. 


\begin{tabular}{|c|c|}
\hline Вопросы & Ответы \\
\hline $\begin{array}{l}\text { Характерные особенности } \\
\text { неопластических кист: }\end{array}$ & 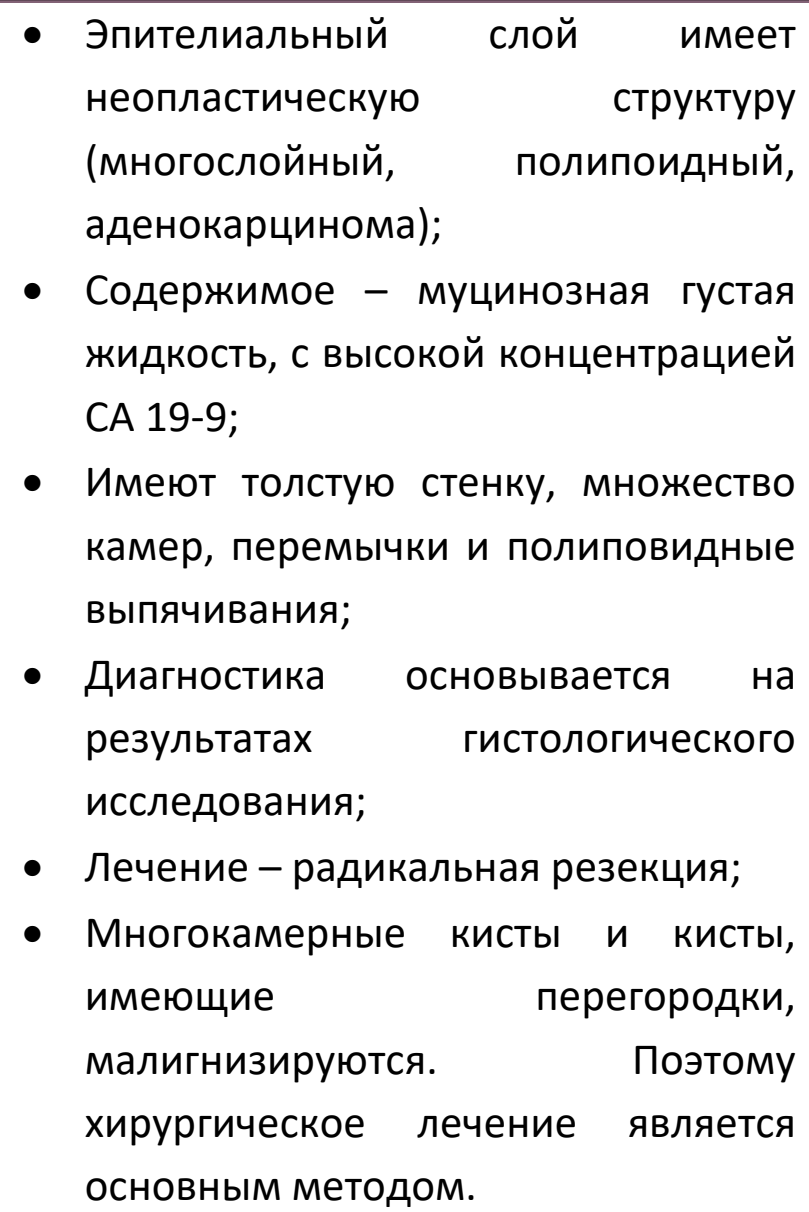 \\
\hline
\end{tabular}




\section{ГЕМАНГИОМЫ ПЕЧЕНИ}

- $\mathrm{K}$ доброкачественным новообразованиям печени относятся гемангиомы, фокальная нодулярная гиперплазия и аденомы. К редко встречаемым опухолям относятся липомы, ангиомиолипомы.

- Гемангиома - доброкачественная сосудистая опухоль мезенхимального происхождения, имеющая кавернозную структуру.

- Является наиболее распространённой опухолью печени.

- Гемангиомы растут медленно, в редких случаях (10\%) осложняются воспалением, некрозом, фиброзом, тромбозом, тромбоцитопенией. Гемангиомы очень редко подвергаются кровотечению, а риск малигнизации равен нулю.

- Диагноз в большинстве случаев (90\%) подтверждается при диагностической визуализации (гипоинтенсивный очаг в режиме Т1, яркая картина в режиме Т2, периферическое узловое контрастирование в артериальной фазе, отсутствие кровотока при допплерографии).

- При бессимптомных гемангиомах показано динамическое наблюдение, при симптоматических $и$ осложнённых гемангиомах проводится резекция $и$ энуклеация.

\section{Вопросы и ответы по гемангиомам печени}

\section{Вопросы Ответы}

$\begin{array}{ll}\text { Наиболее часто встречающийся рак } & \text { Метастатические опухоли встречаются } \\ \text { печени: } & \text { чаще рака печени (20:1). Источник в } \\ & \text { большинстве случаев - опухоль } \\ & \text { желудочно-кишечного тракта. } \\ \text { Наиболее часто встречающийся } & \text { Гепатоцеллюлярный рак (гепатома). } \\ \text { первичный рак печени: } & \end{array}$

Наиболее часто встречающаяся Гемангиома.

доброкачественная опухоль печени: 


\begin{tabular}{|c|c|}
\hline Вопросы & Ответы \\
\hline $\begin{array}{l}\text { Какие лабораторные анализы } \\
\text { определяют метастазы печени: }\end{array}$ & АЛТ, АСТ, щелочная фосфотаза, СЕА. \\
\hline $\begin{array}{l}\text { Радиологические методы } \\
\text { исследования: }\end{array}$ & УЗИ, КТ (трёхфазная). \\
\hline $\begin{array}{l}\text { Распространённые первичные } \\
\text { доброкачественные опухоли печени: }\end{array}$ & $\begin{array}{l}\text { - Гемангиомы; } \\
\text { - Гепатоцеллюлярная аденома; } \\
\text { - Фокальная нодулярная гиперплазия. }\end{array}$ \\
\hline $\begin{array}{l}\text { Распространённые первичные } \\
\text { злокачественные опухоли печени: }\end{array}$ & $\begin{array}{l}\text { - Гепатоцеллюлярная карцинома; } \\
\text { - Холангиокарцинома } \\
\text { (внутрипечёночная); } \\
\text { - Ангиосаркома; } \\
\text { - Гепатобластома (чаще встречается у } \\
\text { детей и новорожденных). }\end{array}$ \\
\hline $\begin{array}{l}\text { Другие доброкачественные опухоли } \\
\text { печени: }\end{array}$ & $\begin{array}{l}\text { - Доброкачественные кисты печени; } \\
\text { - Гамартома жёлчных протоков; } \\
\text { - Аденома жёлчных протоков. }\end{array}$ \\
\hline $\begin{array}{l}\text { Что представляет собой гамартома } \\
\text { печени? }\end{array}$ & $\begin{array}{l}\text { Твёрдый узел белого цвета, } \\
\text { развивающийся из нормальной } \\
\text { печёночной клетки. }\end{array}$ \\
\hline Что такое гемангиома печени? & $\begin{array}{l}\text { Доброкачественная опухоль сосудистой } \\
\text { этиологии. }\end{array}$ \\
\hline Характерная особенность: & $\begin{array}{l}\text { Самая распространённая первичная } \\
\text { доброкачественная опухоль печени. }\end{array}$ \\
\hline Клинические признаки: & $\begin{array}{l}\text { В большинстве случаев протекают } \\
\text { бессимптомно. При больших размерах } \\
\text { отмечаются тупые боли в правом } \\
\text { верхнем квадранте живота, иногда } \\
\text { пальпируется } \\
\text { опухолевидное }\end{array}$ \\
\hline
\end{tabular}




\begin{tabular}{|c|c|}
\hline Вопросы & Ответы \\
\hline & $\begin{array}{l}\text { образование. Может осложняться } \\
\text { кровотечением. }\end{array}$ \\
\hline Осложнения: & $\begin{array}{lr}\text { Кровотечение } & (10 \%), \\
\text { воспалительный } & \text { процесс, сердечоз, } \\
\text { недостаточность, } & \text { коагулопатия } \\
\text { (синдром } & \text { Kassabach-Merritt), } \\
\text { механическая желтуха. }\end{array}$ \\
\hline Что такое синдром Kassabach-Merritt? & $\begin{array}{l}\text { Тромбоцитопения, фибриногенопения } \\
\text { и кровоизлияния, вызванные } \\
\text { тромбозом при гемангиоме. }\end{array}$ \\
\hline Диагностика: & МРТ, контрастная КТ, контрастное УзИ. \\
\hline $\begin{array}{l}\text { Характерные признаки } \\
\text { диагностической визуализации: }\end{array}$ & $\begin{array}{l}\text { При МРТ - гипоинтенсивный очаг в } \\
\text { режиме Т1, яркая картина в режиме Т2, } \\
\text { периферическое } \\
\text { контрастирование в артериальной фазе. }\end{array}$ \\
\hline Информативность биопсии: & $\begin{array}{l}\text { Из-за высокого риска кровотечения не } \\
\text { применяется. В } 90 \% \text { наблюдений } \\
\text { диагноз уточняется МРТ. }\end{array}$ \\
\hline Методы лечения: & $\begin{array}{l}\text { При бессимптомном течении (90\%) } \\
\text { показано динамическое наблюдение. } \\
\text { При симптоматических гемангиомах и } \\
\text { развитии осложнений - хирургическое } \\
\text { лечение (резекция печени). }\end{array}$ \\
\hline Показания к резекции печени: & $\begin{array}{l}\text { Симптоматические формы, развитие } \\
\text { осложнения, } \\
\text { дифференциальной диагностики. }\end{array}$ \\
\hline $\begin{array}{l}\text { Эффективна ли эмболизация } \\
\text { гемангиомы? }\end{array}$ & $\begin{array}{l}\text { Имеет временный эффект, используют } \\
\text { при резекции с целью уменьшения } \\
\text { интраоперационной кровопотери. }\end{array}$ \\
\hline
\end{tabular}




\section{ФОКАЛЬНАЯ НОДУЛЯРНАЯ ГИПЕРПЛАЗИЯ ПЕЧЕНИ}

- Фокальная нодулярная гиперплазия представляет собой регенеративный узел в печени, формирующийся в результате увеличения количества нормальных гепатоцитов вокруг сосудистой мальформации. Не является неопластическим образованием.

- Обычно протекает бессимптомно, выявляется случайно при других обследованиях. В редких случаях, достигая больших размеров, вызывает сдавление внутрипечёночных жёлчных протоков.

- Основное клиническое значение - необходимость дифференциации от злокачественных опухолей, что очень часто встречается при атипичном варианте.

- В диагностике помимо стандартной томографии возникает необходимость в MPT: наличие разветвлённых артерий и рубца в центре узла, гомогенная структура вокруг рубца, гиперваскулярная в артериальной фазе, изоваскулярная в венозной фазе, задержка гепатоцитарного контраста.

- Пациенты нуждаются в динамическом наблюдении. Появление серьёзных симптомов, рост узла, трудность дифференциальной диагностики со злокачественными новообразованиями являются показаниями к операции резекции печени.

\section{Вопросы и ответы по фокальной нодулярной гиперплазии печени}

\begin{tabular}{|ll|}
\hline \multicolumn{2}{|c|}{ Вопросы } \\
\hline $\begin{array}{l}\text { Что представляет собой фокальная } \\
\text { нодулярная гиперплазия печени? }\end{array}$ & $\begin{array}{l}\text { Доброкачественное новообразование } \\
\text { печени. }\end{array}$ \\
\hline Гистологическая структура узла: & $\begin{array}{l}\text { Гепатоцитарная гиперплазия вокруг } \\
\text { сосудистых и протоковых структур. }\end{array}$ \\
\hline $\begin{array}{l}\text { В каком возрасте встречается } \\
\text { наиболее часто? }\end{array}$ & В возрасте 40 лет. \\
\hline
\end{tabular}




\begin{tabular}{|c|c|}
\hline Вопросы & Ответы \\
\hline Факторы риска: & Женский пол. \\
\hline $\begin{array}{l}\text { Имеет ли связь образование опухоли с } \\
\text { приёмом контрацептивных } \\
\text { препаратов? }\end{array}$ & Нет. \\
\hline Диагностика: & КТ или МРТ. \\
\hline $\begin{array}{l}\text { Признаки диагностической } \\
\text { визуализации: }\end{array}$ & $\begin{array}{l}\text { Наличие рубца и разветвлённой } \\
\text { артерии в центре узла. }\end{array}$ \\
\hline Осложнения: & $\begin{array}{l}\text { В редких случаях увеличиваются и } \\
\text { вызывают сдавление окружающих } \\
\text { анатомических структур } \\
\text { кровотечение. Нет риска малигнизации. }\end{array}$ \\
\hline Лечение: & $\begin{array}{l}\text { При бессимптомном течении - } \\
\text { динамическое наблюдение. При } \\
\text { развитии симптомов и невозможности } \\
\text { дифференциальной диагностики с } \\
\text { раком печени показана резекция или } \\
\text { эмболизация. }\end{array}$ \\
\hline $\begin{array}{l}\text { Чем обосновано применение } \\
\text { эмболизации при фокальной } \\
\text { нодулярной гиперплазии? }\end{array}$ & $\begin{array}{l}\text { Особенностью кровоснабжения, т. к. } \\
\text { узел обычно кровоснабжается одной } \\
\text { магистральной артерией. }\end{array}$ \\
\hline
\end{tabular}




\section{ГЕПАТОЦЕЛЛЮЛЯРНАЯ АДЕНОМА ПЕЧЕНИ}

- Аденома печени - доброкачественная опухоль, развивающаяся из гепатоцитов, склонная к кровотечению и малигнизации.

- К факторам риска развития заболевания относятся применение стероидных (в том числе контрацептивных) препаратов, женский пол, частые беременности и болезни накопления гликогена.

- Опухоли малых размеров характеризуются бессимптомным течением, при кровотечении из опухолей больших размеров наблюдаются боль, анемия, геморрагический шок.

- Диагноз основан на данных контрастных методов визуализации: гиперваскуляризация, гетерогенная структура, гиперинтенсивный узел в режиме T1, наличие капсулы. Эти показатели позволяют дифференцировать аденому от гемангиомы и фокальной нодулярной гиперплазии. Однако эти данные недостаточны для дифференциации с гепатоцеллюлярной карциномой.

- Радикальное лечение аденомы печени заключается в отмене контрацептивов и резекции опухоли.

\section{Вопросы и ответы по аденоме печени}

\begin{tabular}{|ll|}
\hline \multicolumn{1}{|c|}{ Вопросы } & \multicolumn{1}{c|}{ Ответы } \\
\hline $\begin{array}{l}\text { Что такое гепатоцеллюлярная } \\
\text { аденома? }\end{array}$ & Доброкачественная опухоль печени. \\
\hline Гистологическая структура: & $\begin{array}{l}\text { Нормальные клетки печени без } \\
\text { жёлчных протоков. }\end{array}$ \\
\hline Факторы риска: & $\begin{array}{l}\text { Женский пол, приём контрацептивов, } \\
\text { стероидных преператов, болезни } \\
\text { накопления гликогена. }\end{array}$ \\
\hline Соотношение женщин и мужчин: & \begin{tabular}{l}
$9: 1$. \\
\hline
\end{tabular} \\
\hline
\end{tabular}




\begin{tabular}{|c|c|}
\hline Вопросы & Ответы \\
\hline Морфологические формы: & $\begin{array}{l}\text { Сидеротическая, геморрагическая и } \\
\text { смешанная. }\end{array}$ \\
\hline $\begin{array}{l}\text { В каком возрасте встречается } \\
\text { наиболее часто? }\end{array}$ & В возрасте от 30 до 35 лет. \\
\hline Клинические признаки: & $\begin{array}{l}\text { Боли в правом верхнем квадранте } \\
\text { живота, пальпируемое опухолевидное } \\
\text { образование. В редких случаях } \\
\text { наблюдается кровотечение. }\end{array}$ \\
\hline Осложнения: & $\begin{array}{l}\text { Разрыв, кровотечение, некроз, } \\
\text { малигнизация. }\end{array}$ \\
\hline Диагностика: & УзИ, КТ, биопсия. \\
\hline $\begin{array}{l}\text { С какими заболеваниями следует } \\
\text { дифференцировать? }\end{array}$ & С гепатоцеллюлярным раком. \\
\hline Методы лечения: & $\begin{array}{l}\text { Хирургическая резекция, отмена } \\
\text { анаболических и контрацептивных } \\
\text { препаратов. }\end{array}$ \\
\hline $\begin{array}{l}\text { Оптимальный срок хирургического } \\
\text { лечения при беременности? }\end{array}$ & 2-й триместр. \\
\hline
\end{tabular}




\section{ДРУГИЕ ДОБРОКАЧЕСТВЕННЫЕ НОВООБРАЗОВАНИЯ ПЕЧЕНИ}

- Ангиомиолипома - доброкачественная опухоль, состоящая из трёх компонентов (крупных кровеносных сосудов, гладкомышечных клеток и жировой ткани).

○ Обычно бессимптомная, может возникать как в почках, так и в печени.

- На МРТ гиперинтенсивные изображения в режимах Т1 и Т2 исчезают в режиме супрессии жировой ткани, а также хорошо удерживают контрастное вещество.

○ Нет необходимости в лечении.

- Липомы состоят из жировой ткани, обычно одиночный, исчезают в режиме супрессии жировой ткани и не удерживают контрастное вещество.

○ Нет необходимости в лечении.

- Узловая трансформация печени - это диффузное поражение печени многочисленными узлами диаметром 1-1,5 cм.

○ Узелки состоят из нормальных гепатоцитов, нарушают архитектуру печени, не имеют жёлчных протоков, центральной артерии или фиброза.

○ Заболевание характеризуется признаками портальной гипертензии на фоне сдавления воротной и центральной вен.

○ Есть риск малигнизации.

○ Диагноз обычно подтверждается биопсией.

○ При отсутствии признаков портальной гипертензии и малигнизации лечение не требуется.

- Воспалительная псевдоопухоль печени состоит из хронических воспалительных клеток (лимфоциты, плазматические и дендритные клетки), миофибробластов и соединительной ткани.

- Нет риска малигнизации.

○ Диагноз обычно подтверждается биопсией и патогистологическим исследованием после её удаления.

○ При симптоматических формах и трудности дифференциации показана резекция опухоли.

- Билиарная аденома - опухоль небольших размеров (<1 см), развивающаяся из жёлчного эпителия и богатая фиброзной тканью.

- Располагается под капсулой, в большинстве случаев протекает бессимптомной и не вызывает осложнений. 
○ Дифференциальная диагностика проводится с метастатическими опухолями печени. Диагноз подтверждается биопсией.

○ Нет необходимости в лечении.

- Билиарные гамартомы - это небольшие субкапсулярные опухоли, состоящие из фиброзной ткани и воспалительных клеток.

О Обычно протекают бессимптомно, не вызывают осложнений. Есть необходимость в дифференциации с метастатическими опухолями печени.

О Лечения не требуют.

- Пелиоз печени представляет собой наполненные кровью кисты диаметром 4-6 см, окружённые фиброзной тканью.

○ При диагностической визуализации определяются множественные кисты различной формы гиперинтенсивные в режиме Т1 и Т2.

○ Лечения не требуют.

- Локальные участки ожирения в печени могут выглядеть иначе, чем остальные участки, и порой воспринимаются как опухоли.

О Обычно обнаруживаются в IV сегменте или вокруг него, по форме напоминают карту.

○ В режиме супрессии жировой ткани эти участки исчезают.

\section{Вопросы и ответы по доброкачественным новообразованиям печени}

\begin{tabular}{|c|c|}
\hline Bonpocbl & Ответы \\
\hline Что такое ангиомиолипома? & $\begin{array}{l}\text { Доброкачественная опухоль, состоящая } \\
\text { их трёх компонентов: крупных } \\
\text { кровеносных } \\
\text { (микроаневризмы), гладкомышечных } \\
\text { клеток и жировой ткани. }\end{array}$ \\
\hline Особенности клинического течения: & $\begin{array}{l}\text { Как правило, не растут и не вызывают } \\
\text { симптомов сдавления. Нет риска } \\
\text { малигнизации. }\end{array}$ \\
\hline Клинические признаки: & Обычно протекают бессимптомно. \\
\hline Диагностика: & $\begin{array}{ll}\text { - } & \mathrm{MPT} ; \\
\text { - } \mathrm{KT} ;\end{array}$ \\
\hline
\end{tabular}




\begin{tabular}{|c|c|}
\hline Вопросы & Ответы \\
\hline & $\begin{array}{l}\text { - УзИ; } \\
\text { - Биопсия. }\end{array}$ \\
\hline $\begin{array}{l}\text { Признаки диагностической } \\
\text { визуализации: }\end{array}$ & $\begin{array}{l}\text { - МРТ - гиперинтенсивные } \\
\text { изображения в режимах Т1 и Т2, } \\
\text { которые исчезают в режиме } \\
\text { супрессии жировой ткани; } \\
\text { - УзИ и КТ - опухоль с ровными } \\
\text { краями. }\end{array}$ \\
\hline Дифференциальная диагностика: & 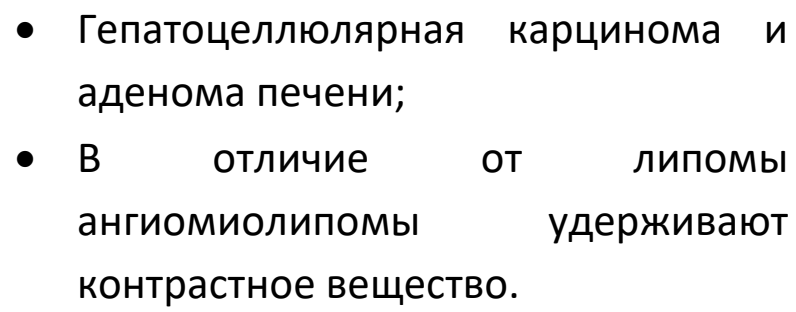 \\
\hline Лечение: & Динамическое наблюдение. \\
\hline Показания к хирургическому лечению: & $\begin{array}{l}\text { При невозможности дифференциации } \\
\text { со злокачественными опухолями. }\end{array}$ \\
\hline Методы хирургического лечения: & Резекция. \\
\hline Что такое липома? & $\begin{array}{l}\text { Опухоль, состоящая из жировой ткани, } \\
\text { со слабой васкуляризацией. }\end{array}$ \\
\hline Особенности клинического течения: & Не склонна к росту и малигнизации. \\
\hline Клинические признаки: & Характерно бессимптомное течение. \\
\hline Диагностика: & - УзИ, КТ, МРТ. \\
\hline $\begin{array}{l}\text { Признаки диагностической } \\
\text { визуализации: }\end{array}$ & $\begin{array}{l}\text { - УзИ-гомогенная опухоль с ровными } \\
\text { краями; } \\
\text { - КТ - гипоинтенсивный очаг, не } \\
\text { задерживающий контрастное } \\
\text { вещество; }\end{array}$ \\
\hline
\end{tabular}




\begin{tabular}{|c|c|}
\hline Вопросы & Ответы \\
\hline & $\begin{array}{l}\text { - } \mathrm{MPT}-\text { гиперинтенсивный очаг в } \\
\text { режимах Т1 и Т2, исчезают в режиме } \\
\text { супрессии жировой ткани. }\end{array}$ \\
\hline Лечение: & Нет необходимости. \\
\hline $\begin{array}{l}\text { Что такое узловая трансформация } \\
\text { печени? }\end{array}$ & $\begin{array}{l}\text { Диффузное поражение печени } \\
\text { многочисленными узлами диаметром } \\
\text { 1-1,5 см. }\end{array}$ \\
\hline Частота встречаемости: & Встречается примерно у 3\% населения. \\
\hline Гистологическая структура: & $\begin{array}{l}\text { Узелки состоят из нормальных } \\
\text { гепатоцитов, однако структура печени } \\
\text { нарушается: нет жёлчных протоков, } \\
\text { центральной артерии и фиброза. }\end{array}$ \\
\hline Дифференциальная диагностика: & $\begin{array}{l}\text { - В отличие от фокальной нодулярной } \\
\text { гиперплазии нет центрального } \\
\text { рубца, жёлчных протоков и } \\
\text { центральной артерии; } \\
\text { • В отличие от цирротического узла } \\
\text { нет фиброза вокруг и внутри узла; } \\
\text { • В отличие от аденомы печени, это } \\
\text { диффузное заболевание, не имеют } \\
\text { обширных синусоидов и не склонны } \\
\text { к кровотечению. }\end{array}$ \\
\hline Осложнения: & $\begin{array}{l}\text { • Портальная гипертензия - при } \\
\text { сдавлении центральной } \\
\text { портальной вен; } \\
\text { • Малигнизация. }\end{array}$ \\
\hline Методы лечения: & $\begin{array}{l}\text { Нет специфического лечения. При } \\
\text { осложнении портальной гипертензией }\end{array}$ \\
\hline
\end{tabular}




\begin{tabular}{|c|c|}
\hline Вопросы & Ответы \\
\hline & $\begin{array}{l}\text { и гепатоцеллюлярной карциномой } \\
\text { проводится соответствующее лечение. }\end{array}$ \\
\hline $\begin{array}{l}\text { Что такое воспалительная } \\
\text { псевдоопухоль? }\end{array}$ & $\begin{array}{l}\text { Гиповаскулярная бескапсульная } \\
\text { опухоль, состоящая из хронических } \\
\text { воспалительных клеток (лимфоциты, } \\
\text { плазматические и дендритные клетки), } \\
\text { миофибробластов и соединительной } \\
\text { ткани. }\end{array}$ \\
\hline $\begin{array}{l}\text { Этиологические причины и факторы } \\
\text { риска: }\end{array}$ & $\begin{array}{l}\text { Неизвестны. Предполагается роль } \\
\text { пролиферации миофибробластов и } \\
\text { хронического воспаления. }\end{array}$ \\
\hline Клинические признаки: & $\begin{array}{l}\text { - Признаки инфекционного процесса; } \\
\text { - Повышение концентрации } \\
\text { печёночных ферментов, признаки } \\
\text { жёлчной и портальной обструкции. }\end{array}$ \\
\hline Диагностика: & $\begin{array}{l}\text { Нет специфических диагностических } \\
\text { признаков. Основную роль в } \\
\text { диагностике играет биопсия, а иногда и } \\
\text { резекция. }\end{array}$ \\
\hline Показания к хирургическому лечению: & Невозможность дифференциации. \\
\hline Что такое билиарная аденома? & $\begin{array}{l}\text { Доброкачественная субкапсулярная } \\
\text { опухоль небольших размеров (<1 см), } \\
\text { развивающаяся из жёлчного эпителия и } \\
\text { богатая фиброзной тканью. }\end{array}$ \\
\hline Клинические признаки: & $\begin{array}{l}\text { Протекают бессимптомно и без } \\
\text { осложнений. }\end{array}$ \\
\hline Дифференциальная диагностика: & Метастатические опухоли печени. \\
\hline Лечение: & Нет необходимости. \\
\hline
\end{tabular}




\begin{tabular}{|c|c|}
\hline Вопросы & Ответы \\
\hline Что такое билиарная гамартома? & $\begin{array}{l}\text { Небольшие доброкачественные } \\
\text { субкапсулярные опухоли, состоящие из } \\
\text { фиброзной ткани, воспалительных } \\
\text { клеток и жёлчного протока. }\end{array}$ \\
\hline Клинические признаки: & $\begin{array}{l}\text { Протекают бессимптомно и без } \\
\text { осложнений. }\end{array}$ \\
\hline Дифференциальная диагностика: & Метастатические опухоли печени. \\
\hline Лечение: & Нет необходимости. \\
\hline Что такое пелиоз печени? & $\begin{array}{l}\text { Наполненные кровью кисты диаметром } \\
\text { 4-6 см, окружённые фиброзной тканью. }\end{array}$ \\
\hline Факторы риска: & $\begin{array}{l}\text { - Беременность; } \\
\text { - Частые роды; } \\
\text { - Приём андрогенов и антибиотиков в } \\
\text { большом количестве. }\end{array}$ \\
\hline Осложнения: & $\begin{array}{l}\text { Осложнения маловероятны, но может } \\
\text { вызвать сыпь и кровотечение у } \\
\text { беременных. }\end{array}$ \\
\hline Клинические признаки: & $\begin{array}{l}\text { Нет специфических клинических и } \\
\text { лабораторных признаков. }\end{array}$ \\
\hline Диагностика: & $\begin{array}{l}\text { - Контрастная КТ; } \\
\text { - МРТ. }\end{array}$ \\
\hline $\begin{array}{l}\text { Признаки диагностической } \\
\text { визуализации: }\end{array}$ & $\begin{array}{l}\text { - Контрастная КТ - множественные } \\
\text { кисты различной формы; } \\
\text { - } \text { МРТ - гиперинтенсивные участки в } \\
\text { режимах Т1 и Т2. }\end{array}$ \\
\hline Лечение: & Нет необходимости. \\
\hline
\end{tabular}




\begin{tabular}{|ll|}
\hline \multicolumn{1}{|c|}{ Вопросы } & \multicolumn{1}{c|}{ Ответы } \\
\hline $\begin{array}{l}\text { Что представляют собой локальные } \\
\text { участки ожирения в печени? }\end{array}$ & $\begin{array}{l}\text { Участки печени в IV сегменте или вокруг } \\
\text { него с точными краями, по форме } \\
\text { напоминающие карту. }\end{array}$ \\
\hline Диагностика: & КT; \\
& $\bullet$ МРТ. \\
\hline $\begin{array}{l}\text { Признаки диагностической } \\
\text { визуализации: }\end{array}$ & В режиме супрессии жировой ткани эти \\
Лечение: & участки исчезают. \\
\hline
\end{tabular}




\section{ГЕПАТОЦЕЛЛЮЛЯРНАЯ КАРЦИНОМА}

- Гепатоцеллюлярная карцинома развивается из гепатоцитов и является наиболее часто встречающимся первичным злокачественным новообразованием печени.

- К факторам риска относятся цирроз печени, хронические вирусные гепатиты, приём препаратов, обладающих канцерогенным эффектом (афлатоксин, сидероз, оральные контрацептивы, торотраст), метаболические нарушения (дефицит $\alpha$-антитрипсина, болезнь Вильсона, галактоземия), аденома печени, диспластические узлы печени.

- Заболевание характеризуется прогрессирующим течением и местным распространением. В редких случаях метастазирует.

- В начальных стадиях болезнь протекает бессимптомно и проявляется неспецифическими признаками: боль в животе, гепатомегалия, желтуха, резкое ухудшение состояние пациентов с циррозом печени, внутрибрюшное кровотечение, высокая температура.

- Диагноз устанавливается с помощью КТ (с трёхфазным контрастированием контрастирование в артериальной фазе, вымывание контрастного вещества в венозной фазе) и МРТ. Биопсия проводится по показаниям.

- В начальных резектабельных стадиях проводится радикальная операция (резекция, трансплантация, деструкция). При больших неоперабельных опухолях проводится циторедуктивное лечение (внутриартериальная химиоэмболизация, радиотерапия, химиотерапия). В терминальной стадии же показано симптоматическое лечение.

- В начальной стадии 5-летняя выживаемость составляет 50-70\%, в поздних стадиях заболевания средняя продолжительность жизни не превышает 1 года.

\section{Вопросы и ответы по гепатоцеллюлярной карциноме}

\begin{tabular}{|lll}
\multicolumn{2}{|c}{ Вопросы } & \multicolumn{1}{c}{ Ответы } \\
\hline Что представляет собой & Первичная & злокачественная опухоль \\
гепатоцеллюлярная карцинома? & печени. & \\
\hline
\end{tabular}




\begin{tabular}{|c|c|}
\hline Вопросы & Ответы \\
\hline Другое название болезни: & Гепатома. \\
\hline Частота встречаемости: & $\begin{array}{l}\text { В структуре первичных злокачественных } \\
\text { опухолей печени составляет } 80 \% .\end{array}$ \\
\hline Факторы риска: & $\begin{array}{l}\text { Цирроз, гепатиты B, C, дефицит } \alpha- \\
\text { антитрипсина, гемохроматоз, приём } \\
\text { анаболических стероидов, болезнь } \\
\text { накопления гликогена, афлотоксин. }\end{array}$ \\
\hline $\begin{array}{l}\text { Частота встречаемости } \\
\text { гепатоцеллюлярной карциномы при } \\
\text { циррозе печени: }\end{array}$ & Примерно 5\%. \\
\hline $\begin{array}{l}\text { Частота цирроза при } \\
\text { гепатоцеллюлярной карциноме: }\end{array}$ & Примерно 80\%. \\
\hline Типы гепатоцеллюлярной карциномы: & $\begin{array}{l}\text { - Классический; } \\
\text { - Фиброламеллярный. }\end{array}$ \\
\hline $\begin{array}{l}\text { Чем отличаются эти типы друг от } \\
\text { друга? }\end{array}$ & $\begin{array}{l}\text { Классический тип развивается на фоне } \\
\text { цирроза печени, встречается у пожилых } \\
\text { пациентов, прогноз не благоприятен. } \\
\text { Фиброламеллярный тип развивается у } \\
\text { молодых пациентов, на фоне здоровой } \\
\text { печени, прогноз более благоприятен. }\end{array}$ \\
\hline Наиболее часто метастазирует: & В лёгкие. \\
\hline Клинические признаки: & 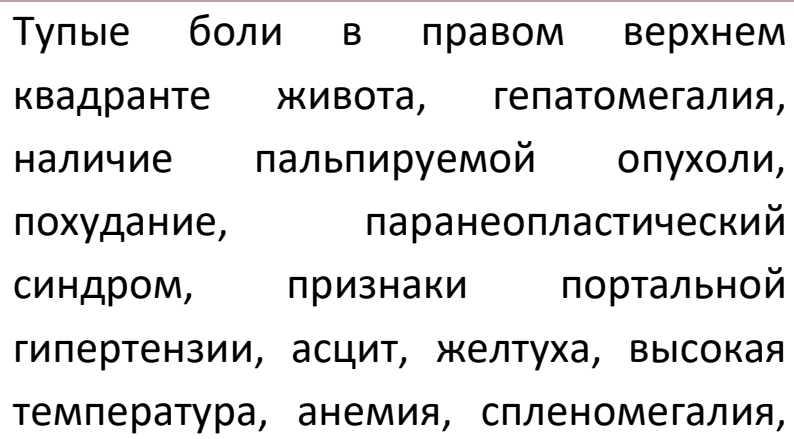 \\
\hline
\end{tabular}




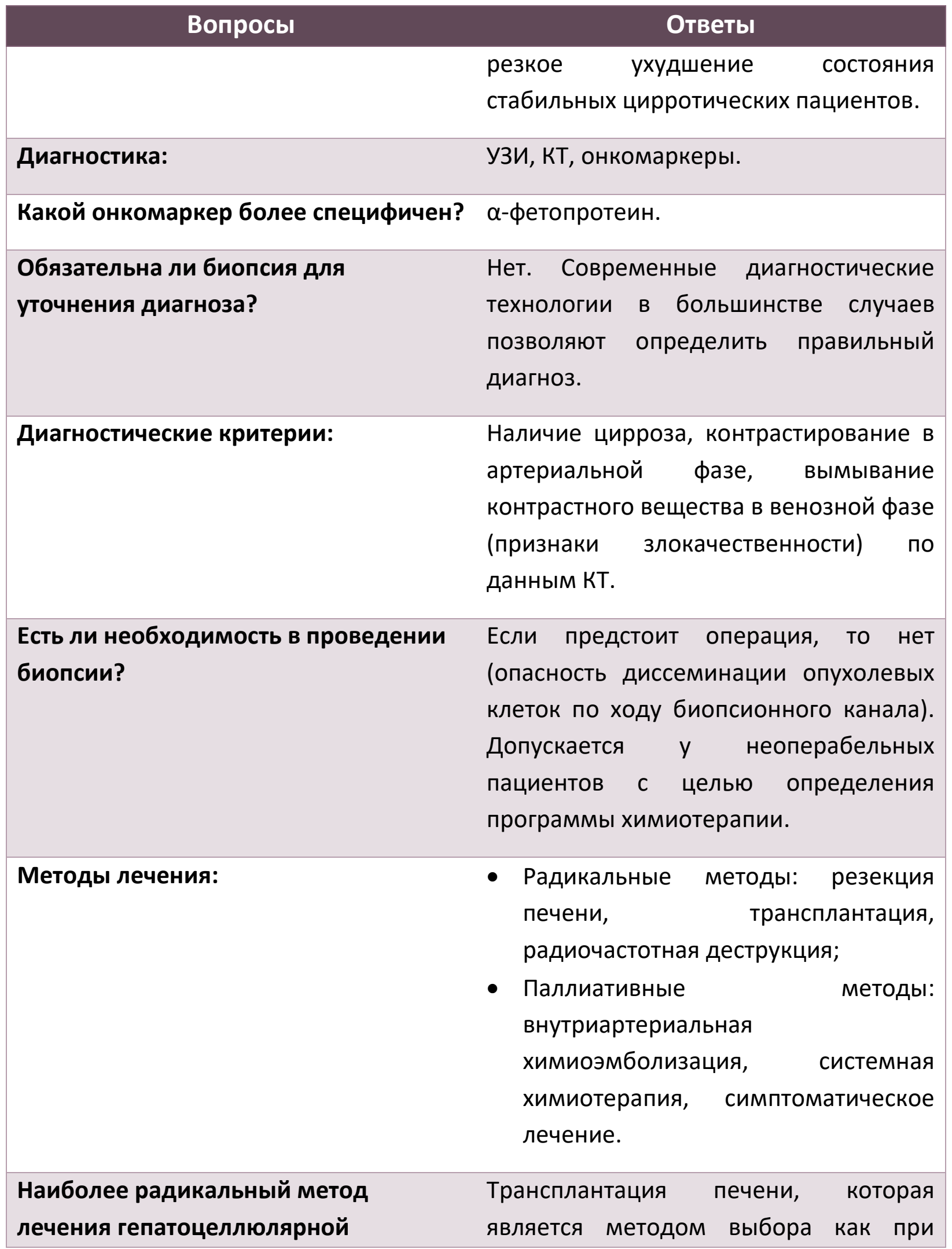




\begin{tabular}{|c|c|}
\hline Bопросы & Ответы \\
\hline $\begin{array}{l}\text { карциномы, развившейся на фоне } \\
\text { цирроза печени: }\end{array}$ & $\begin{array}{l}\text { циррозе, так и при гепатоцеллюлярной } \\
\text { карциноме. }\end{array}$ \\
\hline $\begin{array}{l}\text { Характерные особенности } \\
\text { гепатоцеллюлярной карциномы: }\end{array}$ & $\begin{array}{l}\text { - Является наиболее часто } \\
\text { встречающейся первичной } \\
\text { злокачественной опухолью печени; } \\
\text { - Развивается на фоне цирроза } \\
\text { печени; } \\
\text { - Склонна к местному } \\
\text { распространению и сосудистым } \\
\text { инвазиям; } \\
\text { - Повышение концентрации } \\
\text { фетопротеина; } \\
\text { - Особенность контрастирования: } \\
\text { контрастирование в артериальной } \\
\text { фазе, вымывание контрастного } \\
\text { вещества в венозной фазе; } \\
\text { - Резектабельность } \\
\text { составляет менее 15\%. }\end{array}$ \\
\hline $\begin{array}{l}\text { Можно ли без биопсии поставить } \\
\text { правильный диагноз } \\
\text { гепатоцеллюлярной карциномы? }\end{array}$ & $\begin{array}{l}\text { При выявлении характерного } \\
\text { контрастирования диагноз не вызывает } \\
\text { сомнения. }\end{array}$ \\
\hline Радик & \\
\hline
\end{tabular}




\section{ДРУГИЕ ЗЛОКАЧЕСТВЕННЫЕ ОПУХОЛИ ПЕЧЕНИ}

- Внутрипечёночная холангиокарцинома развивается из эпителия внутрипечёночных жёлчных протоков.

- Наиболее часто встречающееся первичное злокачественное новообразование печени после гепатоцеллюлярной карциномы.

О Первичный билиарный цирроз и склерозирующий холангит являются факторами риска.

○ Локализуется в центре печени вокруг жёлчных протоков. Отличается быстрой инвазией во внутрипечёночные жёлчные протоки и ветви воротной вены. Редко метастазирует.

○ В отличие от гепатоцеллюлярной карциномы реже встречаются при циррозе.

○ Диагностика и лечение аналогичны гепатоцеллюлярной карциноме, однако при диффузном распространении трансплантация печени не даёт хороших результатов.

- Гепатобластома - первичная злокачественная опухоль печени, наиболее часто встречающаяся у детей. Образование часто подвергается кальцификации и отличается высокой вероятностью резектабельности.

- Ангиосаркома - развивается из Купферовских клеток, отличается более злокачественным течением. Резектабельность опухоли минимальна.

- Гемангиоэндотелиома - развивается из эндотелия сосудов печени.

○ Занимает промежуточную позицию между добро- и злокачественными опухолями. В большинстве случаев бывают множественными, образуя конгломераты как при лимфоме.

○ При диффузной форме - эффективна трансплантация печени.

\section{Вопросы и ответы по злокачественным опухолям печени}

\begin{tabular}{|ll}
\hline \multicolumn{1}{|c|}{ Вопросы } & \multicolumn{1}{c}{ Ответы } \\
\hline Что такое холангиокарцинома? & Злокачественная \\
& развивающаяся из эпителия жёлчных \\
& протоков.
\end{tabular}




\begin{tabular}{|c|c|}
\hline Вопросы & Ответы \\
\hline Клинические формы: & $\begin{array}{l}\text { - Внутрипечёночная; } \\
\text { - Внепечёночная (рак холедоха). }\end{array}$ \\
\hline Частота встречаемости: & 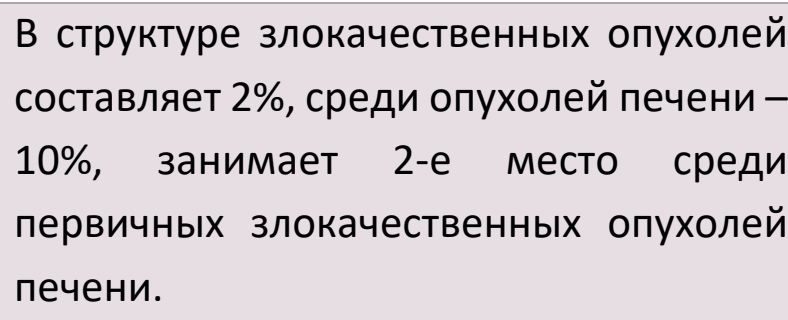 \\
\hline Факторы риска: & $\begin{array}{l}\text { - Первичный билиарный цирроз; } \\
\text { - Склерозирующий холангит. }\end{array}$ \\
\hline Особенности клинического течения: & $\begin{array}{l}\text { Отличается быстрой инвазией во } \\
\text { внутрипечёночные жёлчные протоки и } \\
\text { ветви воротной вены. Редко } \\
\text { метастазирует. }\end{array}$ \\
\hline Осложнения: & $\begin{array}{lll}\text { Механическая желтуха, тромбоз } \\
\begin{array}{ll}\text { воротной } \\
\text { распространение. }\end{array}\end{array}$ \\
\hline Клинические признаки: & $\begin{array}{l}\text { - В ранней стадии характеризуется } \\
\text { незначительными симптомами; } \\
\text { - Боли в животе; } \\
\text { - Чувство } \\
\text { дискомфорта"; } \\
\text { - Похудание; } \\
\text { - Механическая желтуха. }\end{array}$ \\
\hline $\begin{array}{l}\text { У каких пациентов можно } \\
\text { заподозрить? }\end{array}$ & $\begin{array}{l}\text { - У пациентов с наличием } \\
\text { образования в брюшной полости; } \\
\text { - Перипортально расположенное } \\
\text { гиповаскулярное образование с } \\
\text { ретракцией капсулы; }\end{array}$ \\
\hline
\end{tabular}




\begin{tabular}{|c|c|}
\hline Вопросы & Ответы \\
\hline & $\begin{array}{l}\text { - У пациентов с первичном } \\
\text { билиарном циррозом } \\
\text { склерозирующим холангитом; } \\
\text { - При наличии холестаза и желтухи. }\end{array}$ \\
\hline Диагностика: & $\begin{array}{l}\text { - КТ, МРТ; } \\
\text { - Биопсия и патогистологическое } \\
\text { исследование; } \\
\text { - Иммуногистохимия. }\end{array}$ \\
\hline Лабораторные признаки: & Повышение концентрации СА 19-9. \\
\hline $\begin{array}{l}\text { Признаки диагностической } \\
\text { визуализации: }\end{array}$ & $\begin{array}{l}\text { Контрастная КТ: } \\
\text { - Контрастирование в артериальной } \\
\text { фазе, вымывание контрастного } \\
\text { вещества в венозной фазе (признак } \\
\text { малигнизации); } \\
\text { - Перипортально расположенная } \\
\text { гиповаскулярная опухоль с } \\
\text { ретракцией опухоли. }\end{array}$ \\
\hline $\begin{array}{l}\text { Информативность других } \\
\text { диагностических методов: }\end{array}$ & $\begin{array}{l}\text { - Данные биопсии сходны с таковыми } \\
\text { при аденокарциноме; } \\
\text { - Трудно дифференцировать с } \\
\text { метастатическими формами } \\
\text { аденокарцином без } \\
\text { иммуногистохимического анализа. }\end{array}$ \\
\hline Диагностические критерии: & $\begin{array}{l}\text { - Данные клинических и } \\
\text { инструментальных } \\
\text { исследований; } \\
\text { - Исключение } \\
\text { злокачественных опухолей. }\end{array}$ \\
\hline
\end{tabular}




\begin{tabular}{|c|c|}
\hline Вопросы & Ответы \\
\hline $\begin{array}{l}\text { Дифференциально-диагностические } \\
\text { критерии с гепатоцеллюлярным } \\
\text { раком: }\end{array}$ & 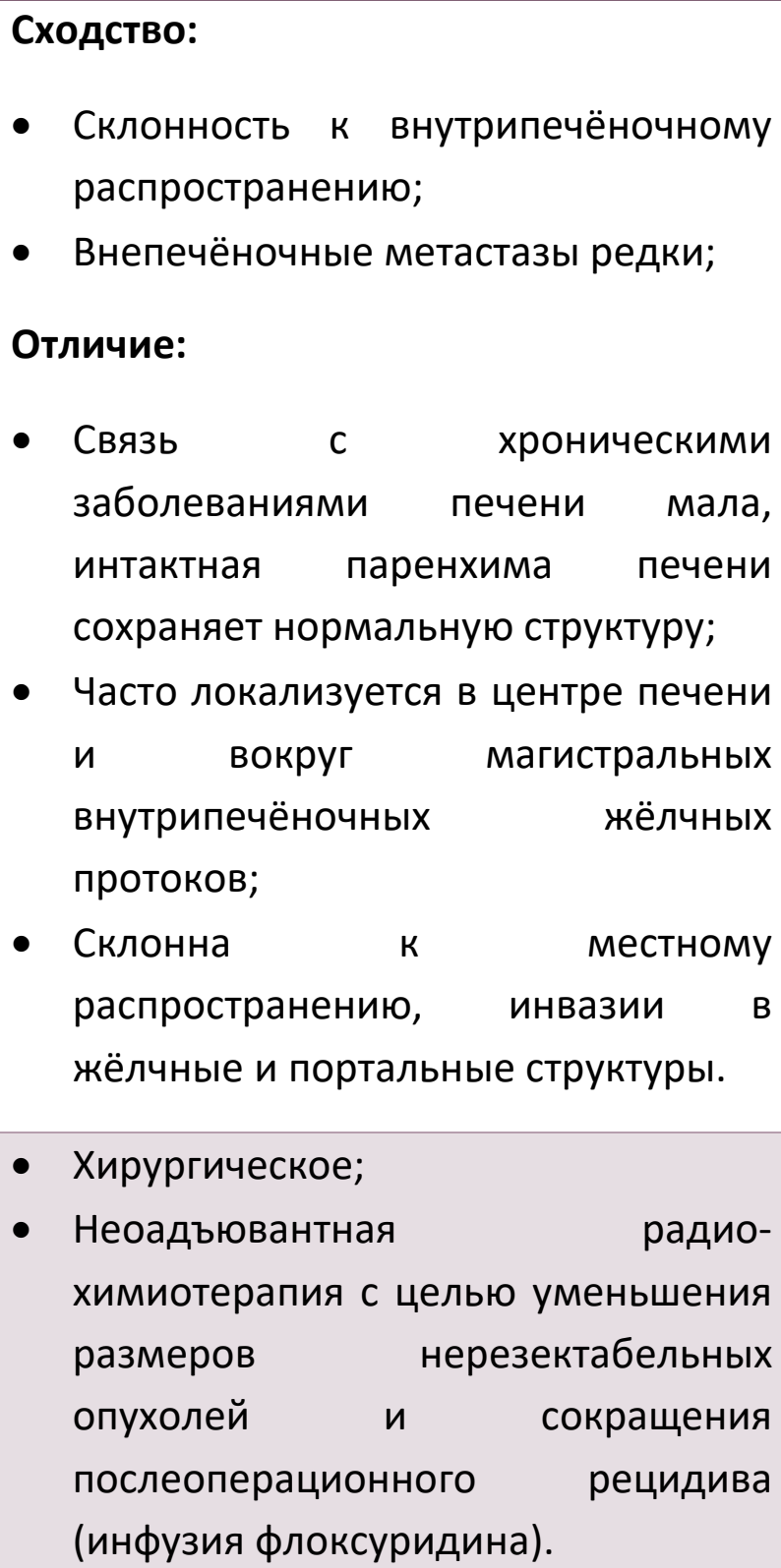 \\
\hline Показания к операции: & $\begin{array}{l}\text { Отсутствие } \\
\text { распространения, внепечёночного } \\
\text { магистральные сосудистые, поражения } \\
\text { обеих долей печени (без метастазов). }\end{array}$ \\
\hline Виды операций: & Резекция печени. \\
\hline Прогноз: & $\begin{array}{l}\text { Рецидив опухоли в первый год после } \\
\text { радикальной резекции составляет 80- }\end{array}$ \\
\hline
\end{tabular}




\begin{tabular}{|ll|}
\hline \multicolumn{1}{|c|}{ Вопросы } & \multicolumn{1}{c|}{ Ответы } \\
\hline Х0\%. 5-летняя выживаемость составляет \\
8-50 месяцев. \\
Характерная особенность & Имеет множество сходств с \\
заболевания: & гепатоцеллюлярным раком, однако \\
& результаты трансплантации печени \\
& неудовлетворительны. \\
\hline
\end{tabular}




\section{МЕТАСТАЗЫ КОЛОРЕКТАЛЬНОГО РАКА В ПЕЧЕНЬ}

- Метастатические опухоли встречаются в 20 раз чаще, чем первичные злокачественные опухоли печени.

- Все опухоли желудочно-кишечного тракта и более половины других опухолей метастазируют в печень.

- Наиболее часто метастатический рак печени развивается на фоне первичного рака толстой кишки, желудка, поджелудочной железы, молочных желез, лёгких.

- Колоректальный рак является наиболее частым источником метастазирования в печень.

- При этом у 1/3 пациентов выявляется синхронное поражение (наличие первичного колоректального рака и метастазов в печени). У 2/3 больных метастазы в печень обнаруживают в отдалённом периоде после радикального хирургического лечения колоректального рака (метахронный рак).

- Колоректальные метастазы не имеют специфических диагностических признаков. К диагностическим критериям относятся характерное контрастирование (слабое контрастирование в артериальной фазе, вымывание контрастного вещества - в венозной фазе), нормальная структура печени при УЗИ, высокое содержание СЕА.

- Наиболее рекомендуемые методы лечения - это резекция, радиочастотная деструкция, внутриартериальная и системная химиотерапия.

- Средняя продолжительность жизни после резекции составляет 30-40 месяцев, 5летняя выживаемость - 25-40\%, 10-летняя - 25\%, 20-летняя - 20\%.

\section{Вопросы и ответы по метастазам колоректального рака в печень}

\begin{tabular}{|ll}
\multicolumn{1}{c}{ Вопросы } & \multicolumn{1}{c}{ Ответы } \\
\hline Характерные особенности метастазов & - Большинство колоректальных \\
колоректального рака в печень: & \multicolumn{1}{c}{ опухолей метастазируют в печень; } \\
& - Множественные опухоли; \\
& - Метастазы имеют, в основном, \\
& $\begin{array}{l}\text { артериальное кровоснабжение и } \\
\text { слабую васкуляризацию; }\end{array}$
\end{tabular}




\section{Boпросы}

\section{Ответы}

- Развивается на фоне нормальной печени;

- Метастазы могут быть синхронными и метахронными;

- Отличаются высокой чувствительностью к химиотерапии;

- Современные методы лечения могут способствовать удлинению продолжительности жизни в 2-3 раза;

- Основным методом лечения является резекция печени. 


\section{НЕЙРОЭНДОКРИННЫЕ ОПУХОЛИ ПЕЧЕНИ}

- Нейроэндокринные опухоли - это опухоли, которые развиваются из локальных эндокринных клеток в органах и тканях и островковых клеток поджелудочной железы.

- Карциноидные (развивающиеся из тканей желудочно-кишечного тракта) и некарциноидные опухоли (развивающиеся из островковых клеток поджелудочной железы) могут метастазировать в печень.

- Нейроэндокринные опухоли могут быть гормонально активными или неактивными.

○ Активная форма карциноидов, выделяя серотонин и другие активные вещества (простагландины, хинин и др.), вызывают карциноидные кризы.

○ Активные формы некарциноидных опухолей вызывают эндокринопатию в зависимости от выделяемых ими гормонов.

- Злокачественные и доброкачественные формы нейроэндокринных опухолей цитологически и гистологически не различаются, единственным признаком злокачественности является наличие метастазов.

- Помимо клинических признаков, в диагностике используется эндокринное обследование, томография и сцинтиграфия.

- При всех нейроэндокринных опухолях обнаруживаются хромогранин А и нейрон-специфическая энолаза, что необходимо для дифференциации от других опухолей.

- Основное лечение метастазов- резекция. В отличие от других злокачественных опухолей печени, при метастазах нейроэндокринных опухолей может выполняться циторедуктивная резекция (удаляется более 90\% опухоли).

\section{Вопросы и ответы по нейроэндокринным опухолям печень}

\begin{tabular}{|ll|}
\multicolumn{1}{|c}{ Вопросы } & \multicolumn{1}{c|}{ Ответы } \\
\hline $\begin{array}{l}\text { Что представляют собой } \\
\text { нейроэндокринные опухоли? }\end{array}$ & $\begin{array}{l}\text { Опухоли, } \\
\text { эндокринных клеток в органах и тканях. }\end{array}$ \\
\hline Виды нейроэндокринных опухолей: & Карциноидные и некарциноидные. \\
\hline
\end{tabular}




\section{Вопросы}

\section{Ответы}

Возможно ли определить характер

Нет.

Единственным

признаком нейроэндокринных опухолей? злокачественности является наличие метастазов.

\section{Характерные особенности метастазов} нейроэндокринных опухолей в печень:
- Развиваются эндокринных из островковых клеток поджелудочной железы;

- Единственный признак злокачественности - наличие метастазов;

- Растут медленно;

- Могут быть гормонально активными и неактивными;

- Существует параллель между количеством опухоли и степенью эндокринопатии;

- При всех нейроэндокринных опухолях обнаруживаются хромогранин А и нейронспецифическая энолаза;

- Менее чувствительны к химио- и радиотерапии;

- Возможно проведение циторедуктивной резекции (следует удалить более $90 \%$ опухоли). 


\section{АБСЦЕСС ПЕЧЕНИ}

- Абсцесс печени - ограниченный гнойный очаг в печени, характеризующееся некрозом печёночной ткани, инфекционным и воспалительным процессом и септическими признаками.

- Различают гнойный (пиогенный), амёбный и грибковый абсцессы.

- Гнойный абсцесс обычно является осложнением заболеваний печени и желчевыводящих протоков.

- Развивается в результате некроза, ишемии, холестаза и инфицирования паренхимы печени.

○ Заболевание характеризуется сильной болью, лихорадкой, желтухой, признаками сепсиса, состояние пациента тяжёлое, при отсутствии лечения летальность очень высока.

○ Диагноз ставится на основании клинической картины и данных диагностической визуализации.

- С лечебной целью проводится чрескожное дренирование полости абсцесса, антибактериальная и поддерживающая терапия.

- Амёбный абсцесс вызывается Entamoeba histolytica, часто встречается после перенесённой амёбной дизентерии.

○ Летальность меньше, чем при гнойном абсцессе.

- Характерны частые плевролёгочные осложнения.

○ Диагноз устанавливается на основе иммунологического анализа и ПЦР.

○ Лечение в большинстве случаев даёт положительный эффект, в редких случаях требуется дренирование абсцесса.

- Грибковые абсцессы встречаются преимущественно у пациентов, получающих иммуносупрессивную терапию.

○ Возбудителем являются грибки рода Candida.

○ Характеризуются высокой летальностью.

○ Лечение проводится методом чрескожного дренирования в сочетании с антифунгальной терапией. 


\section{Вопросы и ответы по абсцессам печени}

\begin{tabular}{|c|c|}
\hline Вопросы & Ответы \\
\hline Что такое абсцесс печени? & Ограниченный гнойный очаг в печени. \\
\hline Виды абсцессов печени: & $\begin{array}{l}\text { В зависимости от этиологии различают } 3 \\
\text { вида: амёбный, гнойный, грибковый. }\end{array}$ \\
\hline $\begin{array}{l}\text { Характерные особенности амёбных } \\
\text { абсцессов печени: }\end{array}$ & $\begin{array}{l}\text { - Возбудителем является Entamoeba } \\
\text { histolytica; } \\
\text { - Часто встречается у пациентов, } \\
\text { перенёсшихамёбную дизентерию; } \\
\text { - Летальность меньше, чем при } \\
\text { гнойном абсцессе; } \\
\text { - Часто сопровождается } \\
\text { плевролёгочными осложнениями; } \\
\text { - Диагноз устанавливается на основе } \\
\text { иммунологического анализа и ПцР; } \\
\text { - В большинстве случаев } \\
\text { антипаразитарное лечение даёт } \\
\text { положительный эффект. }\end{array}$ \\
\hline $\begin{array}{l}\text { Характерные особенности гнойного } \\
\text { абсцесса: }\end{array}$ & 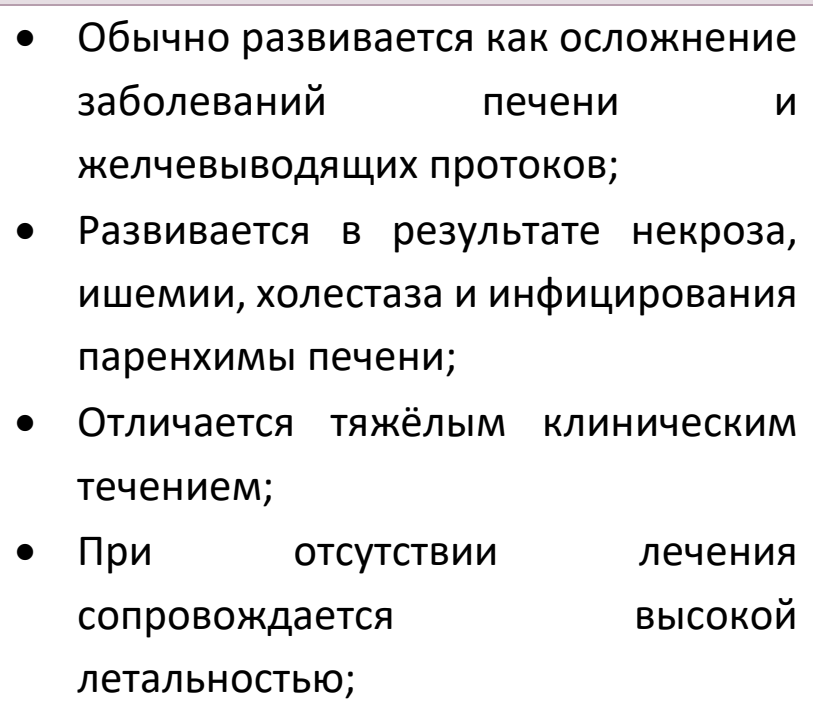 \\
\hline
\end{tabular}




\begin{tabular}{|c|c|}
\hline Вопросы & Ответы \\
\hline & $\begin{array}{l}\text { - Необходимы дренирование } \\
\text { антибактериальная терапия. }\end{array}$ \\
\hline $\begin{array}{l}\text { Характерные особенности грибкового } \\
\text { абсцесса: }\end{array}$ & $\begin{array}{l}\text { - Обычно встречается у пациентов на } \\
\text { фоне иммуносупрессивной терапии; } \\
\text { - Возбудителем являются грибки рода } \\
\text { Сandida; } \\
\text { - Отличается высокой летальностью; } \\
\text { - Необходимы дренирование } \\
\text { антифунгальная терапия. }\end{array}$ \\
\hline $\begin{array}{l}\text { Частая локализуются абсцессов } \\
\text { печени: }\end{array}$ & Правая доля > левая доля. \\
\hline $\begin{array}{l}\text { Какие виды абсцессов печени } \\
\text { встречаются наиболее часто? }\end{array}$ & Бактериальный и амёбный. \\
\hline $\begin{array}{l}\text { Бактериальный абсцесс развивается } \\
\text { как первичный процесс или возникает } \\
\text { вторично? }\end{array}$ & $\begin{array}{l}\text { Развивается вторично, как осложнение } \\
\text { других заболеваний. }\end{array}$ \\
\hline $\begin{array}{l}\text { Причины бактериального абсцесса и } \\
\text { пути распространения инфекции: }\end{array}$ & $\begin{array}{l}\text { - Заболевания печени (травма, } \\
\text { ишемический некроз, кисты, } \\
\text { опухоли); } \\
\text { - Билиарный путь - воспалительные } \\
\text { заболевания жёлчных путей; } \\
\text { - Портальный путь - желудочно- } \\
\text { кишечные инфекции (аппендицит, } \\
\text { дивертикулит, панкреатит); } \\
\text { - Системные заболевания (сепсис, } \\
\text { бактериемия); } \\
\text { - Криптогенный путь. }\end{array}$ \\
\hline $\begin{array}{l}\text { Какой абсцесс может быть излечен } \\
\text { консервативным методом? }\end{array}$ & Амёбный абсцесс. \\
\hline
\end{tabular}




\begin{tabular}{|c|c|}
\hline Вопросы & Ответы \\
\hline $\begin{array}{l}\text { У каких пациентов часто встречается } \\
\text { грибковый абсцесс? }\end{array}$ & $\begin{array}{l}\text { У } \quad \text { пациентов, получавших } \\
\text { иммуносупрессивную терапию. }\end{array}$ \\
\hline $\begin{array}{l}\text { При каком абсцессе прогноз } \\
\text { неблагоприятен? }\end{array}$ & При грибковом абсцессе. \\
\hline $\begin{array}{l}\text { Возбудители бактериальных } \\
\text { абсцессов: }\end{array}$ & $\begin{array}{l}\text { - Грамотрицательные } \\
\text { микроорганизмы: E. coli, Klebsiella, } \\
\text { Proteus vulgaris; } \\
\text { - Анаэробы. }\end{array}$ \\
\hline $\begin{array}{l}\text { Наиболее частый источник } \\
\text { бактериальных абсцессов печени: }\end{array}$ & $\begin{array}{l}\text { Холангит, дивертикулит, рак печени, } \\
\text { метастазы печени. }\end{array}$ \\
\hline Клинические признаки: & $\begin{array}{l}\text { Высокая температура, озноб, боли, } \\
\text { желтуха, сепсис, повышение } \\
\text { концентрации печёночных энзимов, } \\
\text { лейкоцитоз. }\end{array}$ \\
\hline Диагностика: & $\begin{array}{l}\text { Клиническая картина заболевания, КТ } \\
\text { (наличие ограниченной гнойной } \\
\text { полости с уровнем жидкости). }\end{array}$ \\
\hline Лечение: & $\begin{array}{l}\text { Дренирование гнойника в сочетании с } \\
\text { антибиотикотерапией. }\end{array}$ \\
\hline Варианты дренирования абсцесса: & $\begin{array}{l}\text { Чрескожное (под контролем УзИ и КТ) и } \\
\text { хирургическое (открытым } \\
\text { лапароскопическим доступом). }\end{array}$ \\
\hline $\begin{array}{l}\text { Показания к хирургическому } \\
\text { дренированию: }\end{array}$ & $\begin{array}{l}\text { Неудача } \text { при } \\
\text { дренировании. } \\
\text { дренирование } \text { чрескожном } \\
\text { множественных абсцессах. }\end{array}$ \\
\hline Возбудитель амёбного абсцесса: & Entamoeba histolytica \\
\hline
\end{tabular}




\begin{tabular}{|c|c|}
\hline Вопросы & Ответы \\
\hline Пути заражения инфекцией: & Фекально-оральный путь. \\
\hline Факторы риска: & $\begin{array}{l}\text { Эндемические зоны, гомосексуализм, } \\
\text { алкоголизм. }\end{array}$ \\
\hline Клинические признаки: & $\begin{array}{l}\text { Боли, высокая температура, } \\
\text { гепатомегалия, диарея. Озноб при } \\
\text { амёбных абсцессах встречается реже, } \\
\text { чем при гнойных абсцессах. }\end{array}$ \\
\hline $\begin{array}{l}\text { Какая доля печени поражается } \\
\text { наиболее часто? }\end{array}$ & Правая доля. \\
\hline $\begin{array}{l}\text { Характерный внешний вид } \\
\text { содержимого амёбного абсцесса: }\end{array}$ & Шоколадный (кофейный) цвет. \\
\hline Диагностика: & Лабораторные тесты, УзИ, КТ. \\
\hline Лабораторные тесты: & $\begin{array}{l}\text { Иммуноферментный } \\
\text { (определение амёбных антител) или } \\
\text { ПцР. }\end{array}$ \\
\hline Медикаментозное лечение: & Метронидазол. \\
\hline $\begin{array}{l}\text { Показание к хирургическому } \\
\text { дренированию: }\end{array}$ & $\begin{array}{l}\text { При неэффективности лечения } \\
\text { метронидазолом или прорыве абсцесса. }\end{array}$ \\
\hline $\begin{array}{l}\text { Возможные осложнения при } \\
\text { локализации амёбного абсцесса } \\
\text { больших размеров в левой доле: }\end{array}$ & $\begin{array}{l}\text { Эрозия перикарда } \text { (характеризуется } \\
\text { летальным исходом). }\end{array}$ \\
\hline
\end{tabular}




\section{ЦИРРОЗ ПЕЧЕНИ}

- Цирроз - заболевание печени, возникающее в результате хронических заболеваний.

- Характеризуется формированием фиброза и узловым перерождением печёночной паренхимы.

- Циррозу характерно «правило двух»: возникает по 2-м группам причин (хронические заболевания печени и заболевания неясной этиологии), характерны 2 типа изменений (фиброз и узловое повреждение), вызывает 2 группы синдромов (печёночная дисфункция и портальная гипертензия).

- Заболевание длительное время протекает бессимптомно без каких-либо лабораторных изменений (компенсаторная фаза). По мере прогрессирования заболевания развиваются серьёзные осложнения, что свидетельствует о фазе декомпенсации: асцит, варикозное кровотечение, энцефалопатия, инфекционные осложнения, гепатоцеллюлярная карцинома и др.

- Диагностика цирроза проводится на основании клинической картины, результатов диагностической визуализации и эластографии.

- К К характерным признакам относятся развитие осложнений, неровность контуров печени при визуализации, неровные стенки печёночных вен, увеличение плотности паренхимы более 12 кРа.

- Рано начатое этиотропное лечение (антивиральное, лечение гемохроматоза) может предотвратить дальнейшее прогрессирование заболевания и даже вызвать его регресс. При развитии фазы декомпенсации эффективным методом лечения является трансплантация печени. При невозможности пересадки печени лечебные мероприятия должны быть направлены на профилактику осложнений.

\section{Вопросы и ответы по циррозу печени}

\begin{tabular}{|ll}
\hline Вопросы & \multicolumn{1}{c}{ Ответы } \\
Что такое цирроз печени? & Фиброз и узловое перерождение \\
& печёночной паренхимы.
\end{tabular}




\begin{tabular}{|c|c|}
\hline Вопросы & Ответы \\
\hline Чем отличается цирроз от фиброза? & $\begin{array}{l}\text { При фиброзе рубцовое перерождение } \\
\text { печени составляет 10-20\%, функция } \\
\text { печени не нарушается. При циррозе } \\
\text { фибротический процесс занимает } \\
\text { более 30\% паренхимы, ткань печени } \\
\text { приобретает нодулярную структуру и } \\
\text { развивается } \\
\text { нарушение. }\end{array}$ \\
\hline Клинические формы: & $\begin{array}{l}\text { - Стадия компенсации (нет } \\
\text { осложнений); } \\
\text { - Стадия декомпенсации (имеются } \\
\text { осложнения); } \\
\text { - обострение хронической } \\
\text { печёночной недостаточности } \\
\text { (острая декомпенсация и органная } \\
\text { недостаточность). }\end{array}$ \\
\hline $\begin{array}{l}\text { Что представляет собой «правило } \\
\text { двух» при циррозе: }\end{array}$ & $\begin{array}{l}\text { - Возникает по 2-м группам причин } \\
\text { (хронические заболевания печени и } \\
\text { заболевания неясной этиологии); } \\
\text { - Характерны } 2 \text { типа изменений } \\
\text { (фиброз и уловое повреждение); } \\
\text { - Вызывает } 2 \text { группы синдромов } \\
\text { (печёночная дисфункция и } \\
\text { портальная гипертензия); } \\
\text { Цирроз необратим по двум } \\
\text { причинам: онобратим } \\
\text { самостоятельно и вызывает рак - } \\
\text { второе по необратимости } \\
\text { заболевание. }\end{array}$ \\
\hline Патогенез: & $\begin{array}{l}\text { Точный патогенетический механизм } \\
\text { неизвестен. } \\
\text { распространенное мнение: постоянное }\end{array}$ \\
\hline
\end{tabular}




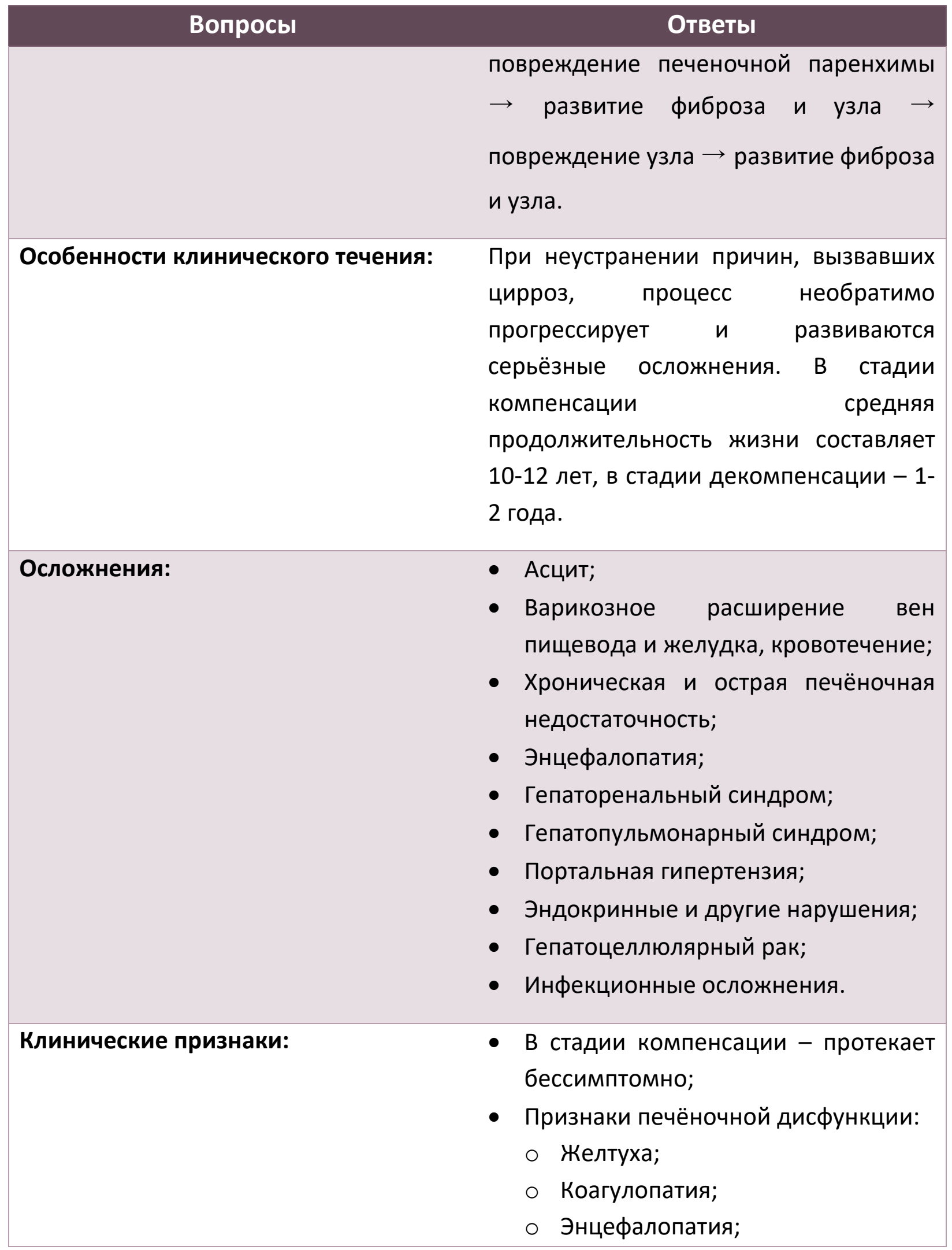




\begin{tabular}{|c|c|}
\hline Вопросы & Ответы \\
\hline & 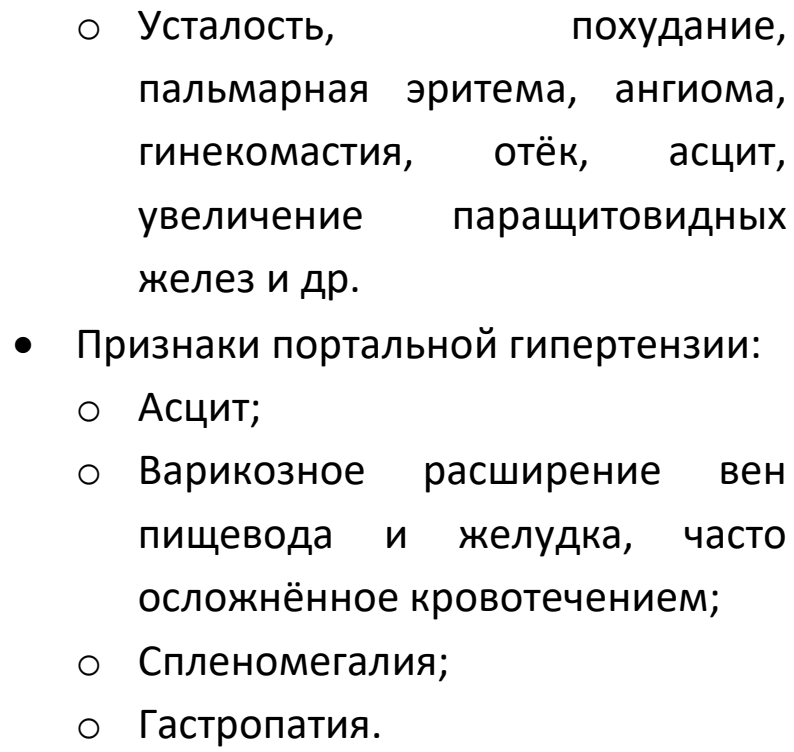 \\
\hline $\begin{array}{l}\text { У каких пациентов можно } \\
\text { заподозрить? }\end{array}$ & $\begin{array}{l}\text { - При хроническом заболевании } \\
\text { печени; } \\
\text { - При портальной гипертензии; } \\
\text { - При наличие характерной картины } \\
\text { при визуализации. }\end{array}$ \\
\hline Диагностика: & $\begin{array}{l}\text { - } \quad \text { Эластография; } \\
\text { - УзИ, КТ, МРТ, эндоскопия; } \\
\text { • } \quad \text { Функциональные тесты печени; } \\
\text { - } \quad \text { В редких случаях - биопсия печени. }\end{array}$ \\
\hline Лабораторные признаки: & $\begin{array}{l}\text { Признаки повреждения и дисфункции } \\
\text { печени (повышение концентрации } \\
\text { энзимов, билирубина и INR, } \\
\text { гипопротеинемия ит.д.) }\end{array}$ \\
\hline $\begin{array}{l}\text { Признаки диагностической } \\
\text { визуализации: }\end{array}$ & $\begin{array}{lr}\text { Повышение плотности } & \text { структуры } \\
\text { печёночной паренхимы (более } 12 \text { кPa), } \\
\text { неровность контуров } \\
\text { нечёткость визуализации печёночных } \\
\text { вен, утолщение стенки жёлчного }\end{array}$ \\
\hline
\end{tabular}




\begin{tabular}{|c|c|}
\hline Вопросы & Ответы \\
\hline & $\begin{array}{l}\text { пузыря, определение коллатералей, } \\
\text { варикозных вен, спленомегалия. }\end{array}$ \\
\hline Лабораторные признаки: & $\begin{array}{l}\text { Снижение концентрации гемоглобина, } \\
\text { количества лейкоцитов, тромбоцитов. }\end{array}$ \\
\hline Диагностические критерии: & $\begin{array}{l}\text { - Повышение плотности эхоструктуры } \\
\text { печени (более } 12 \text { кРа); } \\
\text { - Неровные края печени и нечёткость } \\
\text { визуализации печёночных вен; } \\
\text { - Признаки портальной гипертензии } \\
\text { (выявление варикозных вен, } \\
\text { коллатералей, спленомегалии, } \\
\text { асцит). }\end{array}$ \\
\hline Методы лечения: & $\begin{array}{l}\text { - Хирургическое; } \\
\text { - Профилактика и лечение } \\
\text { осложнений; } \\
\text { - Этиотропное лечение цирроза; } \\
\text { - Симптоматическое. }\end{array}$ \\
\hline Показания к операции: & $\begin{array}{l}\text { Стадия декомпенсации, развитие } \\
\text { осложнений. }\end{array}$ \\
\hline Метод операции: & Трансплантация печени. \\
\hline Прогноз: & $\begin{array}{l}\text { В стадии компенсации средняя } \\
\text { продолжительность жизни составляет } \\
\text { 10-12 лет, в стадии декомпенсации - 1- } \\
2 \text { года. }\end{array}$ \\
\hline $\begin{array}{l}\text { Характерная особенность } \\
\text { заболевания: }\end{array}$ & $\begin{array}{l}\text { Пациенты с циррозом печени являются } \\
\text { кандидатами на трансплантацию } \\
\text { печени. }\end{array}$ \\
\hline
\end{tabular}




\section{СОСУДИСТЫЕ ЗАБОЛЕВАНИЯ ПЕЧЕНИ}

- По степени обструкции заболевания, замедляющие венозный кровооток из печени, делятся на три группы:

○ K первой группе относятся веноокклюзионные заболевания, характеризующиеся тромбозом и склерозом венозных синусов и мелких вен.

○ Венозный застой, вызванный обструкцией крупных печёночных вен, называется синдромом Бадд-Киари. При синдроме Бадд-Киари, помимо печёночных вен, может быть и обструкция нижней полой вены.

○ В третьей группе, называемой внепечёночным веностазом, кровоток блокируется В нижней полой вене. $\mathrm{K}$ этой группе относятся правожелудочковая недостаточность, констриктивный перикардит. В отличие от синдрома Бадд-Киари, при внепечёночном веностазе печёночные вены не только открыты, но и расширены.

- Синдром Бадд-Киари - это венозный застой, обусловленный обструкцией крупных печёночных вен. Обструкция может возникать и в нижней полой вене.

○ Наиболее частыми причинами являются тромбоз, фиброз, мембрана и инфильтрация (опухоли, воспалительный процесс).

- На ранних стадиях могут возникать острый гепатит и острая печёночная недостаточность, в хронической стадии - цирроз и портальная гипертензия.

○ Диагностика требует томографии и контрастной ангиографии для подтверждения тромботической обструкции печёночных вен. Другой характерной особенностью является гипертрофия первого сегмента печени.

○ На ранней стадии проводится декомпрессия (хирургическая операция или стентирование), при развитии цирроза печени приоритет отдается трансплантации.

- Тромбоз портальной вены развивается при тромботической окклюзии основного ствола или крупных ветвей воротной вены.

○ К причинам окклюзии воротной вены относятся венозный застой, тромбофилия или лечебно-диагностические процедуры.

○ В зависимости от локализации, различают четыре формы тромбоза воротной вены: внепечёночная форма (тромбоз главного венозного ствола), тромбоз внутрипечёночных ветвей, селезёночной вен и брыжеечных вен. 
- Острая фаза (тромбоз) внепечёночной формы характеризуется симптомами острого гепатита. В хронической стадии (кавернозная трансформация) развивается симптомы портальной гипертензии. При внутрипечёночной форме тромбоза развивается некроз печени. При тромбозе селезёночной вены наблюдаются спленомегалия, гиперспленизм и варикозное расширение фундальных вен желудка. Тромбоз брыжеечных вен характеризуется венозной гангреной кишечника.

○ Для установления диагноза показано контрастное КТ исследование. Наличие тромба в просвете вены или кавернозной трансформации подтверждает диагноз.

○ Методы лечения зависят от клинических форм заболевания. При внепечёночной форме проводятся антикоагулянтная терапия и лечение портальной гипертензии. При тромбозе селезёночной вены может быть показана спленэктомия. При тромбозе брыжеечных вен проводятся антикоагулянтная терапия иногда резекция кишечника и эмболэктомия. При внутрипечёночной форме может быть показаны резекция или трансплантация печени.

\section{Вопросы и ответы по сосудистым заболеваниям печени}

\section{Синдром Бадд- Киари}

\begin{tabular}{|ll|}
\hline \multicolumn{1}{|c|}{ Вопросы } & \multicolumn{1}{c|}{ Ответы } \\
Что такое синдром Бадд-Киари? & Венозный застой, обусловленный \\
& обструкцией крупных печёночных вен. \\
& Обструкция может возникать и в \\
& нижней полой вене. \\
& Фульминантный, острый, хронический, \\
Клинические формы: & субклинический. \\
& П Тромбоз; \\
\hline Причины и факторы риска: & Фиброз; \\
& - Мембрана; \\
\hline
\end{tabular}




\begin{tabular}{|c|c|}
\hline Вопросы & Ответы \\
\hline & $\begin{array}{l}\text { - Инфильтрация (опухоли, } \\
\text { воспалительный процесс). }\end{array}$ \\
\hline Патогенез: & $\begin{array}{l}\text { Острый гепатит } \rightarrow \text { некроз } \rightarrow \\
\text { гепатоцеллюлярная дисфункция } \rightarrow \\
\text { фиброз } \rightarrow \text { цирроз, гипертрофия I и IV } \\
\text { сегментов. }\end{array}$ \\
\hline Особенности клинического течения: & $\begin{array}{l}\text { - Фульминантная форма - начинается } \\
\text { остро признаками печёночной } \\
\text { недостаточности, развивается } \\
\text { массивный некроз печени; } \\
\text { - При острой форме - постепенно } \\
\text { развивается } \\
\text { недостаточность; печёночная } \\
\text { Хроническая } \\
\text { характеризуется развитием цирроза } \\
\text { и портальной гипертензии. }\end{array}$ \\
\hline Осложнения: & $\begin{array}{l}\text { - Острая печёночная недостаточность; } \\
\text { - Острый ишемический гепатит; } \\
\text { - } \quad \text { Цирроз печени; } \\
\text { - Портальная гипертензия; } \\
\text { - Синдром нижней полой вены. }\end{array}$ \\
\hline Клинические признаки: & $\begin{array}{l}\text { - Фульминантное течение - острая } \\
\text { печёночная недостаточность: } \\
\text { О Энцефалопатия; } \\
\text { о Коагулопатия; } \\
\text { о Желтуха; } \\
\text { О Общее тяжелое состояние. } \\
\text { - Острое течение - острый гепатит и } \\
\text { рефрактерный асцит: } \\
\text { О Болевой синдром; } \\
\text { о Гепатомегалия; }\end{array}$ \\
\hline
\end{tabular}




\begin{tabular}{|c|c|}
\hline Вопросы & Ответы \\
\hline & $\begin{array}{l}\text { О Асцит в сочетании с умеренной } \\
\text { желтухой; } \\
\text { О Тошнота. } \\
\text { - Хроническое течение - признаки } \\
\text { цирроза печени: } \\
\text { О Асцит; } \\
\text { О Признаки } \\
\text { гипертензии. } \\
\text { Субклиническая } \\
\text { бессимптомное течение. } \\
\text { При сонмой } \\
\text { печёночных вен с тромбозом } \\
\text { нижней полой вены развивается } \\
\text { синдром нижней полой вены: } \\
\text { О Отёки нижних конечностей; } \\
\text { О “Кавальные” коллатерали. }\end{array}$ \\
\hline $\begin{array}{l}\text { У каких пациентов можно } \\
\text { заподозрить? }\end{array}$ & $\begin{array}{l}\text { При наличии: } \\
\text { • Острой печёночной недоста- } \\
\text { точности; } \\
\text { - Острого гепатита; } \\
\text { - Гипертрофии I сегмента печени при } \\
\text { диагностической визуализации; } \\
\text { • Цирроза; } \\
\text { - Рефрактерного асцита; } \\
\text { - Высокого содержания протеина в } \\
\text { асцитической жидкости. }\end{array}$ \\
\hline Диагностика: & $\begin{array}{l}\text { Для визуализации печёночных вен } \\
\text { показаны: } \\
\text { • Ультразвуковая допплерография; } \\
\text { • КТ-ангиография; } \\
\text { - МРТ-ангиография; }\end{array}$ \\
\hline
\end{tabular}




\begin{tabular}{|c|c|}
\hline Bonpocbl & Ответы \\
\hline & - Контрастная венография. \\
\hline $\begin{array}{l}\text { Признаки диагностической } \\
\text { визуализации: }\end{array}$ & Печёночные вены не визуализируются. \\
\hline Лабораторные признаки: & Признаки дисфункции печени. \\
\hline $\begin{array}{l}\text { Что выявляют при других методах } \\
\text { исследования? }\end{array}$ & $\begin{array}{l}\text { Асцит, увеличение плотности печени } \\
\text { при эластографии, выявление } \\
\text { гепатомегалии при остром течении } \\
\text { заболевания. }\end{array}$ \\
\hline Диагностические критерии: & $\begin{array}{l}\text { - Клиническая картина; } \\
\text { - Выявление окклюзии печёночных } \\
\text { вен и гипертрофии I сегмента (при } \\
\text { хронической форме) при } \\
\text { диагностической визуализации. }\end{array}$ \\
\hline $\begin{array}{l}\text { В чём заключаются принципы } \\
\text { лечения? }\end{array}$ & $\begin{array}{l}\text { В основе лечения лежат } 4 \text { принципа: } \\
\text { - Профилактика прогрессирования } \\
\text { тромбоза; } \\
\text { - Лечение основного заболевания; } \\
\text { - Профилактика венозного застоя с } \\
\text { целью предупреждения развития } \\
\text { необратимых изменений в печени; } \\
\text { - Лечение осложнений. }\end{array}$ \\
\hline Методы лечения: & $\begin{array}{l}\text { - Хирургическое - если есть } \\
\text { возможность оперативного лечения } \\
\text { основного заболевания; } \\
\text { - Наблюдение - при субклинической } \\
\text { форме; }\end{array}$ \\
\hline & $\begin{array}{l}\text { - При невозможности лечения } \\
\text { основного заболевания или }\end{array}$ \\
\hline
\end{tabular}




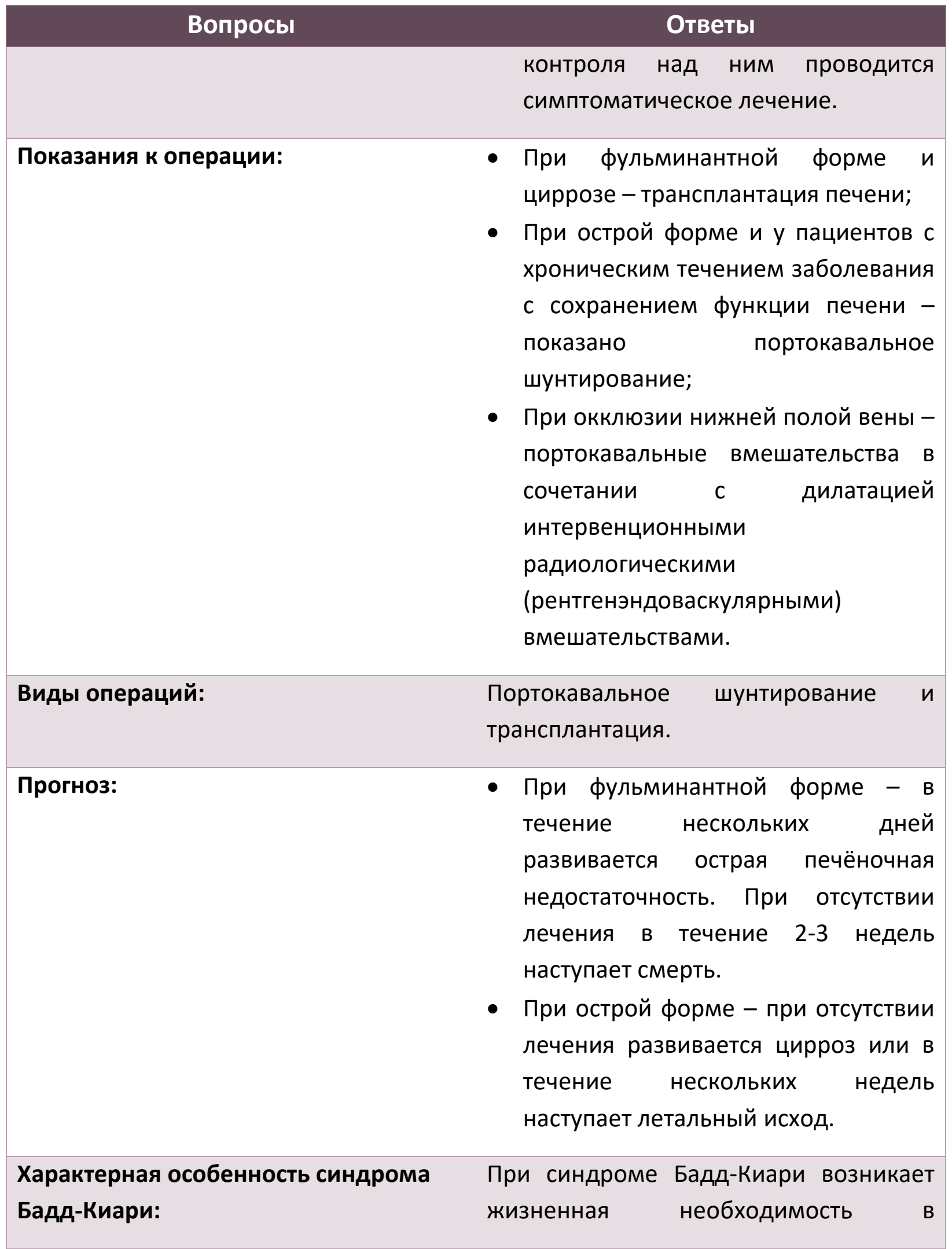




\section{Boпросы}

\section{Ответы}

портокавальном

шунтировании

и трансплантации печени.

Тромбоз портальной вены

\begin{tabular}{|c|c|}
\hline Вопросы & Ответы \\
\hline Что такое тромбоз портальной вены? & $\begin{array}{l}\text { Полная или частичная тромботическая } \\
\text { окклюзия основного ствола или крупных } \\
\text { ветвей воротной вены (брыжеечные и } \\
\text { селезёночные вены, правая и левая } \\
\text { печёночные } \\
\text { проявляется остро или хронически. }\end{array}$ \\
\hline Частота встречаемости: & $\begin{array}{l}\text { Тромбоз воротной вены является } \\
\text { причиной портальной гипертензии у } \\
\text { 50\% детей, а у взрослых частота этой } \\
\text { патологии составляет 10-15\%. }\end{array}$ \\
\hline Клинические формы: & $\begin{array}{l}\text { - Тромбоз основного ствола воротной } \\
\text { вены (внепечёночная окклюзия); } \\
\text { - Тромбоз внутрипечёночных ветвей } \\
\text { воротной вены; } \\
\text { - Тромбоз селезёночной вены - } \\
\text { левосторонняя, } \\
\text { портальная гипертензия. }\end{array}$ \\
\hline Причины и факторы риска: & $\begin{array}{l}\text { - Венозный застой, обусловленный } \\
\text { циррозом или опухолями; } \\
\text { - Тромбофилия } \\
\text { (миелопролиферативная, } \\
\text { тромбофилическая, воспалительная, }\end{array}$ \\
\hline
\end{tabular}




\begin{tabular}{|c|c|}
\hline Вопросы & Ответы \\
\hline & $\begin{array}{l}\text { инфекционная, неопластическая и } \\
\text { др.); } \\
\text { - Повреждение сосудов (лечебно- } \\
\text { диагностические процедуры, } \\
\text { спленэктомия 5-10\%, склеротерапия } \\
\text { варикозных вен 40-60\%); } \\
\text { - Инфекции пупочной вены у детей. }\end{array}$ \\
\hline Патогенез: & $\begin{array}{l}\text { Застой, сосудистые заболевания, } \\
\text { тромбофилия могут способствовать } \\
\text { тромбозу воротной вены. }\end{array}$ \\
\hline Особенности клинического течения: & $\begin{array}{l}\text { Имеются острая (тромбоз), хроническая } \\
\text { (кавернозная трансформация) фазы и } \\
\text { фаза ретромбоза. Исход зависит от } \\
\text { локализации тромбоза. }\end{array}$ \\
\hline Осложнения: & $\begin{array}{l}\text { - Асцит; } \\
\text { - Портальная гипертензия; } \\
\text { - Спленомегалия; } \\
\text { - Некроз и атрофия печени. }\end{array}$ \\
\hline Клинические признаки: & $\begin{array}{l}\text { - В острой фазе - признаки острого } \\
\text { гепатита (боль, желтуха, асцит; } \\
\text { порой протекает бессимптомно); } \\
\text { - В хронической фазе - } \\
\text { бессимптомное течение или } \\
\text { признаки портальной гипертензии; } \\
\text { - Ретромбоз - признаки острой фазы } \\
\text { заболевания; } \\
\text { - Тромбоз внутрипечёночных ветвей- } \\
\text { признаки некроза печени, тяжёлой } \\
\text { печёночная недостаточность; } \\
\text { - Тромбоз селезёночной вены - } \\
\text { спленомегалия, варикозное }\end{array}$ \\
\hline
\end{tabular}




\begin{tabular}{|c|c|}
\hline Вопросы & Ответы \\
\hline & $\begin{array}{lr}\text { расширение } & \text { фундальных } \\
\text { желудка, } & \text { ген } \\
\text { гастропатия, } & \text { признаки } \\
\text { кровотечения. } & \end{array}$ \\
\hline $\begin{array}{l}\text { У каких пациентов можно } \\
\text { заподозрить? }\end{array}$ & $\begin{array}{l}\text { - Острое развитие желтухи, асцита и } \\
\text { спленомегалии; } \\
\text { - Резкое повышение концентрации } \\
\text { печёночных энзимов; } \\
\text { - Стабильное течение цирроза, } \\
\text { перенесённая операция по поводу } \\
\text { гепатоцеллюлярной карциномы, } \\
\text { наличие в анамнезе спленэктомии, } \\
\text { склеротерапии, сепсис, интенсивная } \\
\text { желтуха, асцит, спленомегалия, } \\
\text { желудочно-кишечное кровотечение; } \\
\text { Развитие портальной гипертензии на } \\
\text { фоне нормальной печени. }\end{array}$ \\
\hline Диагностика: & $\begin{array}{l}\text { Портография - УЗ-допплерография, КТ- } \\
\text { или МРТ-ангиография. }\end{array}$ \\
\hline $\begin{array}{l}\text { Признаки диагностической } \\
\text { визуализации: }\end{array}$ & $\begin{array}{l}\text { - Наличие тромба в просвете } \\
\text { воротной вены при портографии; } \\
\text { - Расширение вены дистальнее } \\
\text { тромба, наличие кавернозной } \\
\text { трансформации тромба. }\end{array}$ \\
\hline $\begin{array}{l}\text { Что ещё выявляется при других } \\
\text { методах исследования? }\end{array}$ & $\begin{array}{l}\text { Дисфункция печени и признаки } \\
\text { портальной гипертензии. }\end{array}$ \\
\hline Диагностические критерии: & $\begin{array}{l}\text { - Портальная гипертензия, } \\
\text { дисфункция печени; } \\
\text { - Наличие тромба или его } \\
\text { кавернозной трансформации при }\end{array}$ \\
\hline
\end{tabular}




\begin{tabular}{|c|c|}
\hline Вопросы & Ответы \\
\hline & $\begin{array}{ll}\text { контрастных } & \text { методах } \\
\text { исследованиях. } & \end{array}$ \\
\hline Методы лечения: & $\begin{array}{l}\text { - Устранение причин; } \\
\text { - Лечение портальной гипертензии; } \\
\text { - Антикоагулянтная терапия - при } \\
\text { отсутствии противопоказаний в } \\
\text { остром периоде, при тромбофилии; } \\
\text { - Динамическое наблюдение - при } \\
\text { хроническом (бессимптомном) } \\
\text { течении заболевания; } \\
\text { Хирургическое: при тромбозе левой } \\
\text { ветви портальной вены (при } \\
\text { тромбозе селезёночной вены) - } \\
\text { спленэктомия, при кровотечении - } \\
\text { трансъюгулярное портокавальное } \\
\text { шунтирование, при некрозе } \\
\text { кишечника - резекция. }\end{array}$ \\
\hline Показания к операции: & $\begin{array}{l}\text { Тромбоз левой ветви портальной вены, } \\
\text { желудочно-кишечное кровотечение, } \\
\text { гангрена (некроз) кишечника. }\end{array}$ \\
\hline Прогноз: & $\begin{array}{l}\text { При нормальной функции печени } \\
\text { течение относительно благоприятное. } \\
\text { При развитии цирроза и опухолей - } \\
\text { течение тяжёлое. }\end{array}$ \\
\hline $\begin{array}{l}\text { Характерная особенность тромбоза } \\
\text { портальной вены: }\end{array}$ & $\begin{array}{lrr}\text { Тромбоз воротной вены } & \text { обычно } \\
\text { развивается как осложнение } & \text { других } \\
\text { заболеваний. В большинстве } & \text { случаев } \\
\text { консервативное } & \text { лечение } \\
\text { положительный } & \text { дает } \\
\text { Необходимость } & \text { в } & \text { эирургиче } \\
\end{array}$ \\
\hline
\end{tabular}




\begin{tabular}{c} 
Вопросы \\
Ответы \\
$\begin{array}{l}\text { лечении возникают редко - при } \\
\text { развитии осложнений. }\end{array}$ \\
\hline
\end{tabular}




\section{СПИСОК ЛИТЕРАТУРЫ}

\section{обшая литература}

- Ağayev B.A. Cərrahi xəstəliklər. Bakı 2010.

- Blackbourne LH. Surgical Recall. 4 edition, 2006, LWW, Philadelphia

- Doherty GM. Current Diagnosis and Treatment: Surgery, $13^{\text {th }}$ edition, 2010, Lang International Edition.

- Omiraslanov D.T., Qazıyev A.Y. Onkologiya. Bakı, 2010.

- İsayev H.B. Cərrahi xəstəliklərin patofizologiyası. Bakı 2005

- Klingensmith ME, Aziz A, Bharat A, Fox AC, Porembka MR. The Washington Manual of Surgery, $6^{\text {th }}$ edition, 2012, LWW, Philadelphia.

- McNally PR. GI/Liver Secrets Plus. 4 edition. Mosby, Elsevier, 2010

- Medscape, http://www.medscape.com

- Oxford Handbook of Clinical Surgery, 3d edition, 2011, Oxford Press

- Sayek I. Sayek Temel Cerrahi 1-2. 4-cü baskı, 2016, Güneş Tıp Kitabevleri.

- Topçubaşov M.A. Xüsusi cərrahlıq. Bakı, 1979

- UpToDate, http://www.uptodate.com

- Гостищев B.К. Общая хирургия. GEOTAR-Media, 2019

\section{Специальная литература}

- Bayramov N.Y. Cərrahiyyə Seminarları: Portal Hipertenziya. ISBN:13 978-9952-80-823-0, Bakı, Qismət, 2007, 160 s.

- Bayramov N.Y. Qaraciyərin Cərrahi Xəstəlikləri. ISBN 978-9952-460-27-8. Bakı 2012, $324 \mathrm{~s}$.

- Jarnagin WR. Liver and Portal Venouse System. in: Current Diagnosis and Treatment: Surgery, $13^{\text {th }}$ edition, 2010, Lang International Edition. p: 509-543.

- Marrero JA, Ahn J, Rajender Reddy K, Americal College of Gastroenterology. ACG clinical guideline: the diagnosis and management of focal liver lesions.Am J Gastroenterol. 2014 Sep. 109 (9):1328-47; quiz 1348.

- McNally PR. GI/Liver Secrets Plus. 4 edition. Mosby, Elsevier, 2010

- NCCN Clinical Practice Guidelines in Oncology: Hepatobiliary Cancers. Version 2.2015. Accessed: April 13, 2015. 


\section{ХИРУРГИЧЕСКИЕ БОЛЕЗНИ}

Н.Ю. Байрамов

\section{Хирургические заболевания жёлчных путей}

Н.Ю. Байрамов, Р.А. Мамедов, А.К. Сафиева, Ш.А. Мамедова

Перевод: Н.Ю. Байрамов, С.А. Алиев, М.Р. Гусейнова 


\section{ЖЁЛЧНЫЕ КОЛИКИ}

- Жёлчные колики - это боли, остро возникшие в правой подрёберной и эпигастральной области, которые усиливаются в течение 15-30 минут и могут продолжаться несколько часов (3-6 часов). Жёлчные колики могут периодически повторяться.

- В литературе жёлчные колики представлены как симптом, синдром, болезнь.

- В основе жёлчных колик лежит ишемия жёлчного пузыря. Предполагается, что начинающиеся боли связаны со спазмом, продолжающиеся - с напряжением стенки пузыря, а стихающие боли - д декомпрессией органа.

- Острый и хронический калькулёзный холецистит, акалькулёзный холецистит, холедохолитиаз, холангит, панкреатит, как правило, проявляются жёлчными коликами. К другим причинам жёлчных колик относятся дискинезия жёлчного пузыря, дискинезия сфинктера Одди, полипы, аденоматоз жёлчного пузыря, холестероз, идиопатическое расширение и стриктуры, кисты холедоха и т. д.

- Диагностика основана на клинической картине (динамика боли), определении причины (УзИ, при необходимости МРТ, лабораторные анализа - билирубин, ЩФ, ГГТ, АЛТ, АСТ, амилаза, общий анализ крови, С-реактивный белок). При обнаружении органических и функциональных патологий проводятся дополнительные обследования.

\section{Вопросы и ответы по жёлчным коликам}

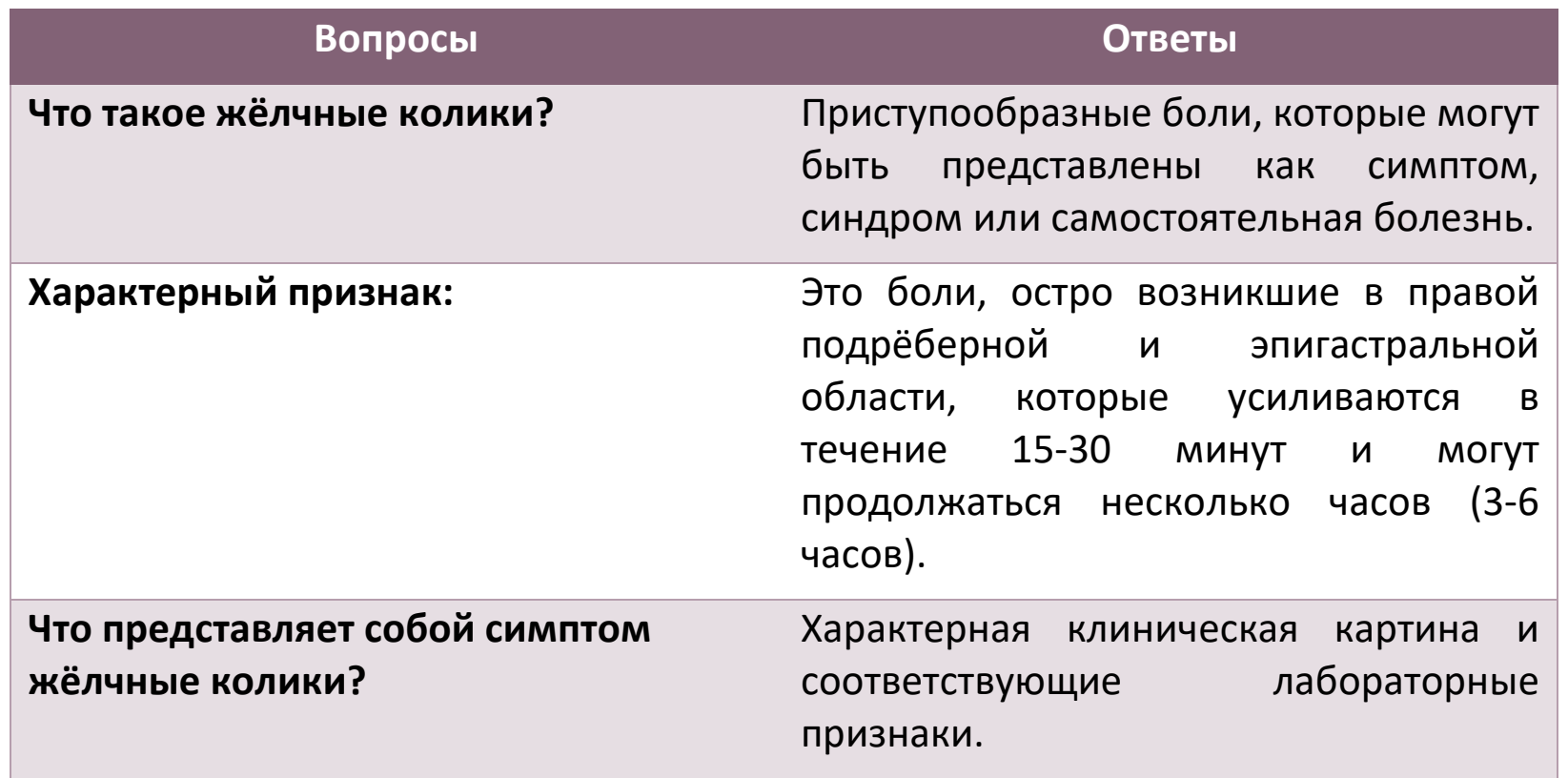




\begin{tabular}{|c|c|}
\hline Вопросы & Ответы \\
\hline \multirow[t]{2}{*}{$\begin{array}{l}\text { Что представляет собой синдром } \\
\text { жёлчные колики? }\end{array}$} & $\begin{array}{l}\text { Принимается как рабочий диагноз. У } \\
\text { пациентов с характерными болями при }\end{array}$ \\
\hline & $\begin{array}{l}\text { клиническом и лабораторном } \\
\text { исследованиях не выявляются какие- } \\
\text { либо патологии. }\end{array}$ \\
\hline $\begin{array}{l}\text { Что представляет собой болезнь } \\
\text { жёлчные колики? }\end{array}$ & $\begin{array}{lll}\text { Приступы } & \text { боли, } & \text { вызванные } \\
\text { желчекаменной болезнью. } & \end{array}$ \\
\hline
\end{tabular}




\section{ЖЕЛТУХА}

- Симптом желтухи - признак окрашивания тканей в жёлтый цвет, синдром желтухи - состояние, связанное с повышением билирубина, которое проявляется окрашиванием тканей в жёлтый цвет. Окрашивание тканей в жёлтый цвет характеризуется повышением как прямого, так и непрямого билирубина.

- Согласно этиопатогенезу различают гемолитическую, гепатоцеллюлярную (паренхиматозная) и обструктивную желтухи.

- С целью диагностики необходимо определить наличие желтухи и причину её возникновения. Повышение общего билирубина >1 мг/дл подтверждает наличие желтухи. Для определения причины возникновения желтухи проводятся клинические, лабораторные (общий анализ крови, прямой и непрямой билирубин, ЩФ, ГГТ, АЛТ, АСТ) и инструментальные (УЗИ, при необходимости МРТ) методы исследования.

- Гемолитическая желтуха характеризуется повышением прямого билирубина в крови и уробилиногена в моче.

○ Для подтверждения диагноза определяется гаптоглобин в крови.

- Гепатоцеллюлярная (паренхиматозная) желтуха характеризуется повышением либо непрямого билирубина, либо прямого и непрямого билирубина.

○ При этом уровень печёночных ферментов повышается больше холестатических ферментов.

О С целью определения причины проводятся клинические и лабораторные исследования.

- Внутрипечёночная холестатическая желтуха характеризуется повышением либо непрямого билирубина, либо прямого и непрямого билирубина.

○ При этом уровень холестатических ферментов повышается больше печёночных ферментов.

○ Характерным признаком является нерасширение жёлчных путей.

○ С целью определения причины проводятся клинические исследования, определение аутоиммунных маркеров, а также биопсия.

- Обструктивная (механическая, внепечёночная) желтуха характеризуется повышением либо непрямого билирубина, либо прямого $и$ непрямого билирубина, холестатических ферментов и печёночных ферментов.

○ На УЗИ и МРТ определяется расширение жёлчных путей. По показаниям проводится ЭРХПГ. Для определения причин обструкции (камни, стриктуры, опухоли, воспалительные заболевания, травмы, хирургические операции, сосудистые заболевания, паразитарные заболевания, инородные тела) проводится МРТ. При затруднении диагностики возникает необходимость в 
проведении контрастной холангиографии (ЭРХПГ, ПТХ, Т-холангиография, интраоперационная холангиография) и холедохоскопии.

○ Лечение механической желтухи направлено на устранение причины и декомпрессию жёлчных путей с помощью хирургических и малоинвазивных методов.

\section{Вопросы и ответы по жёлчным коликам}

\begin{tabular}{|ll|}
\hline \multicolumn{1}{|c|}{ Вопросы } & \multicolumn{1}{c|}{ Ответы } \\
\hline Что такое желтуха? & $\begin{array}{l}\text { Как симптом - окрашивание тканей в } \\
\text { жёлтый цвет, как синдром - повышение } \\
\text { общего билирубина. }\end{array}$ \\
\hline Причины желтухи: & $\begin{array}{l}\text { Гемолиз, печёночная дисфункция, } \\
\text { обструкция. }\end{array}$ \\
\hline $\begin{array}{l}\text { Чем подтверждается диагноз } \\
\text { желтухи? }\end{array}$ & $\begin{array}{l}\text { Повышение общего билирубина в крови } \\
\text { Какие методы исследования } \\
\text { необходимы для определения } \\
\text { причины желтухи? }\end{array}$ \\
\hline
\end{tabular}




\section{ХОЛЕСТАЗ}

- Холестаз характеризуется застоем жёлчи во внутри- и внепечёночных жёлчных путях и нарушением её поступления в желудочно-кишечный тракт, что сопровождается ахолией и повышением концентрации жёлчных пигментов в крови (холемия).

- Клиническим проявлением холестаза является желтуха, которая называется холестатической.

- В зависимости от этиологических причин различают внутрипечёночный и внепечёночный холестаз.

- При внутрипечёночном холестазе отмечается повышение концентрации связанного (прямого) и свободного (непрямого) билирубина и холестатических ферментов, иногда и печёночных ферментов, что сопровождается отсутствием расширения желчевыводящих протоков.

○ Диагноз уточняется на основании клинических признаков, аутоиммунных маркеров. В сложных случаях показана биопсия печени.

- Внепечёночный холестаз (обструктивная желтуха, механическая желтуха) характеризуется повышением либо связанного билирубина, либо прямого и непрямого билирубина, холестатических ферментов, иногда и печёночных ферментов.

○ На УзИ и МРТ определяется расширение жёлчных путей. По показаниям проводится ЭРХПГ. Для определения причин обструкции (камни, стриктуры, опухоли, воспалительные заболевания, травмы, хирургические операции, сосудистые заболевания, паразитарные заболевания, инородные тела) проводится МРТ. При затруднении диагностики возникает необходимость в проведении контрастной холангиографии (ЭРХПГ, ПТХ, Т-холангиография, интраоперационная холангиография) и холедохоскопии.

○ Лечение механической желтухи направлено на устранение причины и декомпрессию жёлчных путей с помощью хирургических и малоинвазивных методов.

\section{Вопросы и ответы по холестазу}

\begin{tabular}{|lll}
\multicolumn{4}{c}{ Вопросы } & \multicolumn{3}{c}{ Ответы } \\
\hline Что такое холестаз? & $\begin{array}{l}\text { Застой жёлчи во внутри- } \\
\text { внепечёночных жёлчных путях }\end{array}$ \\
нарушение её поступления & в \\
желудочно-кишечный тракт. & \\
\hline Чем отличается холестаз от желтухи? & $\begin{array}{l}\text { Желтуха - повышение билирубина в } \\
\text { крови. Холестаз - застой жёлчи, при }\end{array}$ \\
\hline
\end{tabular}




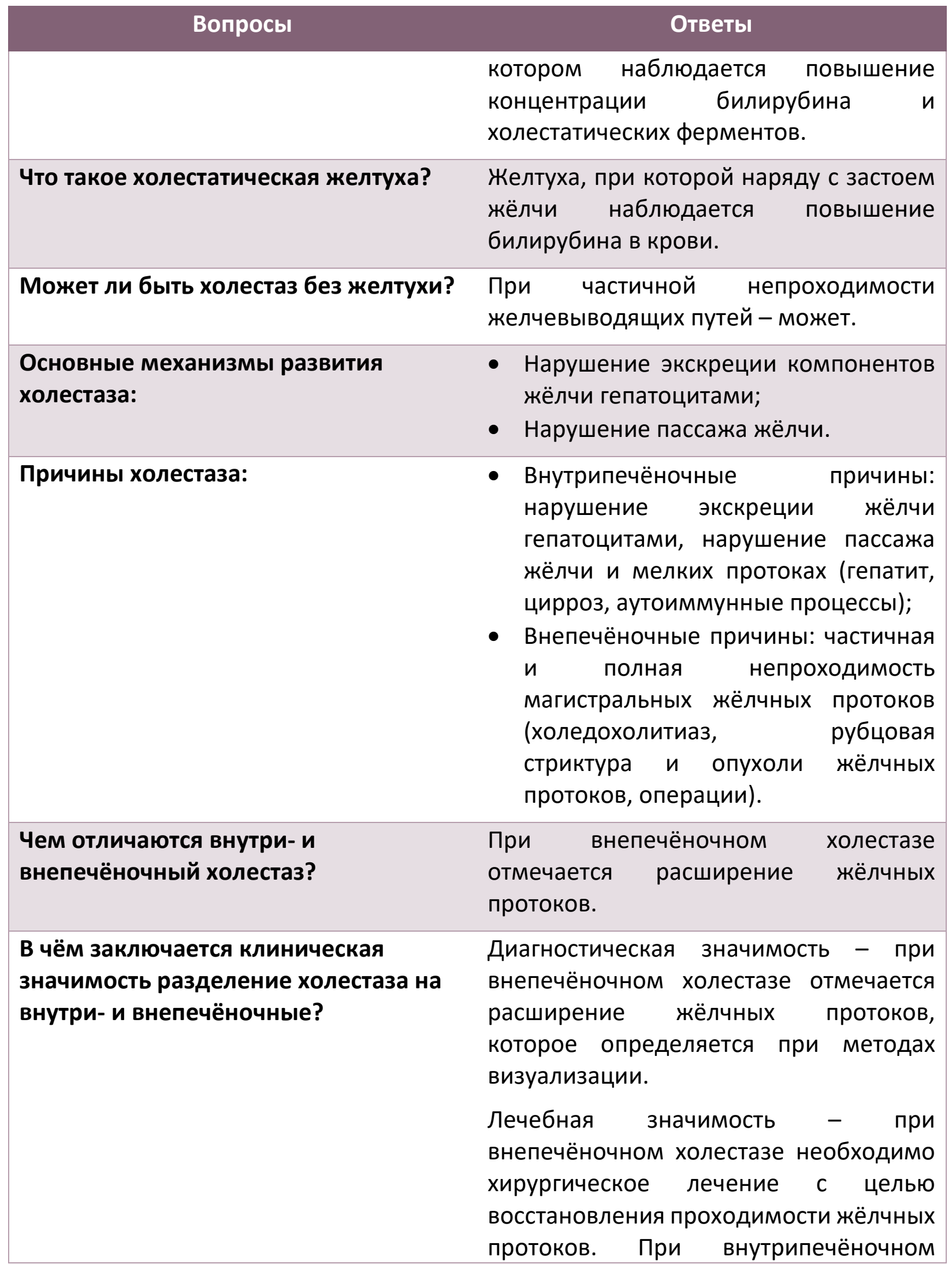




\section{Вопросы}

\section{Ответы}

холестазе проводится консервативное лечение.

Другое название внепечёночного холестаза:

Клинические признаки:

Какой симптом является более характерным при холестазе: зуд или желтуха?
Механическая желтуха, обтурационная желтуха, обструктивная желтуха.

- Кожный зуд - 40-50\%;

- Желтуха -40-80\%.

\section{Диагностика:}

Как можно исключить холестаз?
Возможно ли развитие холестаза при
нормальном значении ЩФ?

Возможно ли развитие холестаза при нормальном значении ГГТ?

\section{Подтверждается ли холестаз} повышением билирубина?
Кожный зуд.
- Повышение концентрации ЩФ иГГТ в крови;

- Повышение концентрации жёлчных кислот в крови.

При нормальных концентрациях ЩФ и ГГТ.

Редко - при гипофосфатемии, гипотиреоидизме.

Редко - при рецидивирующем доброкачественном холестазе.

Повышение связанного билирубина с повышением концентрации ГГТ и ЩФ подтверждают диагноз, хотя нормальные значения этих показателей также не исключают диагноз.

Первичная диагностическая процедура - УЗИ. Для уточнения диагноза - МРТ.
Какой метод эффективен для

дифференциальной диагностики внутрипечёночного и внепечёночного холестаза? 


\begin{tabular}{|c|c|}
\hline Вопросы & Ответы \\
\hline $\begin{array}{l}\text { Диагностика внутрипечёночного } \\
\text { холестаза: }\end{array}$ & $\begin{array}{l}\text { - Наличие признаков холестаза; } \\
\text { - Отсутствие расширения жёлчных } \\
\text { протоков по данным МРТ. }\end{array}$ \\
\hline $\begin{array}{l}\text { Диагностика внепечёночного } \\
\text { холестаза: }\end{array}$ & $\begin{array}{l}\text { - Признаки холестаза; } \\
\text { - Расширение жёлчных протоков по } \\
\text { данным МРТ. }\end{array}$ \\
\hline $\begin{array}{l}\text { Как определяют причины } \\
\text { внутрипечёночного холестаза? }\end{array}$ & $\begin{array}{l}\text { - Клинические данные; } \\
\text { - Лабораторные показатели; } \\
\text { - Биопсия. }\end{array}$ \\
\hline
\end{tabular}




\section{МЕХАНИЧЕСКАЯ ЖЕЛТУХА}

- Механическая желтуха (обструктивная желтуха, внепечёночный холестаз) характеризуется повышением либо связанного билирубина, либо прямого и непрямого билирубина, холестатических ферментов и расширением жёлчных путей.

- Расширение жёлчных путей определяется при УзИ и МРТ. По показаниям проводится ЭРХПГ. Для определения причин обструкции (камни, стриктуры, опухоли, воспалительные заболевания, травмы, хирургические операции, сосудистые заболевания, паразитарные заболевания, инородные тела) проводится МРТ. При затруднении диагностики возникает необходимость в проведении контрастной холангиографии (ЭРХПГ, ПТХ, Т-холангиография, интраоперационная холангиография) и холедохоскопии.

- Лечение механической желтухи направлено на устранение причины и декомпрессию жёлчных путей с помощью хирургических и малоинвазивных методов.

\section{Вопросы и ответы по механической желтухе}

\begin{tabular}{|c|c|}
\hline Вопросы & Ответы \\
\hline Что такое механическая желтуха? & $\begin{array}{l}\text { Холестаз, связанный с обструкцией } \\
\text { магистральных желчных протоков. }\end{array}$ \\
\hline $\begin{array}{l}\text { Как еще называется механическая } \\
\text { желтуха? }\end{array}$ & $\begin{array}{l}\text { Внепечёночная, } \\
\text { обтурационная. }\end{array}$ \\
\hline Причины: & $\begin{array}{l}\text { Жёлчные камни, рубцовые стриктуры } \\
\text { жёлчных протоков, операции на } \\
\text { жёлчных путях, воспалительные и } \\
\text { паразитарные заболевания. }\end{array}$ \\
\hline $\begin{array}{l}\text { Основные патогенетические } \\
\text { механизмы: }\end{array}$ & $\begin{array}{l}\text { Внутрипротоковая обтурация, } \\
\text { патология жёлчных путей, сдавление } \\
\text { извне. }\end{array}$ \\
\hline Осложнения: & $\begin{array}{l}\text { Повреждения печени, жёлчных путей, } \\
\text { дисфункция кишечника и других } \\
\text { органов. }\end{array}$ \\
\hline $\begin{array}{l}\text { Какие изменения развиваются в } \\
\text { жёлчных протоках? }\end{array}$ & $\begin{array}{ll}\text { Расширение жёлчных протоков, } \\
\text { развитие } \\
\text { бактериального холангита, фиброз. }\end{array}$ \\
\hline
\end{tabular}




\begin{tabular}{|c|c|}
\hline Вопросы & Ответы \\
\hline $\begin{array}{l}\text { Какие изменения происходят в } \\
\text { печени? }\end{array}$ & $\begin{array}{l}\text { Холестатический гепатит, печёночная } \\
\text { недостаточность, билиарный цирроз. }\end{array}$ \\
\hline $\begin{array}{l}\text { Какие изменения развиваются в } \\
\text { кишечнике? }\end{array}$ & 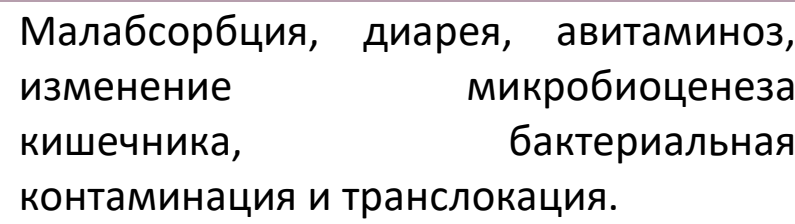 \\
\hline $\begin{array}{l}\text { Общие патофизиологические } \\
\text { расстройства: }\end{array}$ & $\begin{array}{l}\text { Внеклеточная дегидратация, } \\
\text { гиповолемия, сепсис, почечная } \\
\text { недостаточность, } \\
\text { миокарда, иммуносупрессия. }\end{array}$ \\
\hline $\begin{array}{l}\text { Чем объясняется развитие } \\
\text { внеклеточной дегидратации? }\end{array}$ & $\begin{array}{lr}\text { Вследствие } & \text { повышения } \\
\text { предсердного } & \text { синтеза } \\
\text { пептида. } & \text { натрийуретического }\end{array}$ \\
\hline Механизм развития сепсиса: & $\begin{array}{l}\text { Бактериальная транслокация в } \\
\text { кишечнике, дисфункция купферовских } \\
\text { клеток и лейкоцитов, эндотоксемия. }\end{array}$ \\
\hline $\begin{array}{l}\text { Механизм развития гепаторенального } \\
\text { синдрома: }\end{array}$ & $\begin{array}{l}\text { Внеклеточная дегидратация, } \\
\text { гиповолемия и сепсис. }\end{array}$ \\
\hline Клинические признаки: & $\begin{array}{l}\text { Желтуха, зуд, боль, окрашивание мочи, } \\
\text { обесцвечивание кала. }\end{array}$ \\
\hline $\begin{array}{l}\text { Первичная диагностическая } \\
\text { процедура: }\end{array}$ & УЗИ. \\
\hline $\begin{array}{l}\text { Характерные лабораторные признаки } \\
\text { механической желтухи: }\end{array}$ & $\begin{array}{l}\text { - Повышение холестатических } \\
\text { Ферментов (ЩФ, ГГТ); } \\
\text { - Повышение билирубина; } \\
\text { - Функциональные нарушения } \\
\text { печени. }\end{array}$ \\
\hline \multirow[t]{2}{*}{$\begin{array}{l}\text { Может ли отсутствовать повышение } \\
\text { билирубина при механической } \\
\text { желтухе? }\end{array}$} & $\begin{array}{l}\text { В раннем периоде, при частичной } \\
\text { обструкции жёлчных протоков и } \\
\text { формировании билиодигестивных }\end{array}$ \\
\hline & $\begin{array}{l}\text { свищей билирубин может не } \\
\text { повышаться. }\end{array}$ \\
\hline $\begin{array}{l}\text { Как диагностируют механическую } \\
\text { желтуху? }\end{array}$ & $\begin{array}{l}\text { На основании расширения жёлчных } \\
\text { протоков. }\end{array}$ \\
\hline
\end{tabular}




\begin{tabular}{|c|c|}
\hline Вопросы & Ответы \\
\hline $\begin{array}{l}\text { Отличительная особенность } \\
\text { механической желтухи от других } \\
\text { видов желтух: }\end{array}$ & Расширение жёлчных протоков. \\
\hline $\begin{array}{l}\text { Как можно выявить расширение } \\
\text { жёлчных путей? }\end{array}$ & $\begin{array}{l}\text { Выявляется изначально на УзИ, } \\
\text { подтверждается на МРТ. }\end{array}$ \\
\hline $\begin{array}{l}\text { Чем объясняется отсутствие } \\
\text { расширения жёлчных протоков при } \\
\text { наличии в них обструкции? }\end{array}$ & $\begin{array}{l}\text { - } \text { Фиброз, цирроз печени; } \\
\text { - } \text { Склероз жёлчных протоков; } \\
\text { - Билиодигестивные свищи. }\end{array}$ \\
\hline $\begin{array}{l}\text { Как подтверждается механическая } \\
\text { желтуха при отсутствии расширения } \\
\text { жёлчных протоков? }\end{array}$ & $\begin{array}{l}\text { При наличии лабораторных признаков } \\
\text { холестаза и определении обструкции } \\
\text { при холангиографии. }\end{array}$ \\
\hline $\begin{array}{l}\text { Может ли быть диагностирована } \\
\text { механическая желтуха при } \\
\text { расширении жёлчных протоков и } \\
\text { отсутствии клинических признаков } \\
\text { желтухи и холестаза? }\end{array}$ & $\begin{array}{l}\text { Практически невозможно. Это может } \\
\text { быть при врождённых кистах холедоха } \\
\text { или при идиопатическом расширении } \\
\text { общего жёлчного протока. }\end{array}$ \\
\hline $\begin{array}{l}\text { Каким диагностическим методом } \\
\text { определяется причина механической } \\
\text { желтухи? }\end{array}$ & МР-холангиография. \\
\hline $\begin{array}{l}\text { Возможно ли наличие жёлчных } \\
\text { камней при отсутствии их } \\
\text { визуализации на МРТ? }\end{array}$ & Практически нет. \\
\hline $\begin{array}{l}\text { Какие методы исследования } \\
\text { необходимы при неинформативности } \\
\text { МРТ? }\end{array}$ & $\begin{array}{l}\text { Эндоскопическое УЗИ, контрастная МР- } \\
\text { холангиография, методы прямого } \\
\text { контрастирования жёлчных протоков } \\
\text { (ЭРХПГ, ПХГ), холедохоскопия. }\end{array}$ \\
\hline $\begin{array}{l}\text { Как можно верифицировать } \\
\text { варикозное расширение вен жёлчных } \\
\text { протоков? }\end{array}$ & $\begin{array}{l}\text { Контрастные КТ/МРТ, эндоскопическое } \\
\text { Уз-допплерография, холедохоскопия с } \\
\text { оптическим холедоскопом. }\end{array}$ \\
\hline
\end{tabular}




\section{ЖЕЛЧЕКАМЕННАЯ БОЛЕЗНЬ}

- Желчнокаменная болезнь связана с загустением жёлчи и образованием жёлчных камней (холестериновые, билирубиновые).

- Данное заболевание является наиболее распространённым среди популяций населения и частой причиной абдоминальной хирургии.

- К этиологическим факторам относятся пожилой возраст, женский пол, ожирение, беременность, гормональная терапия (эстроген, прогестерон), генетические факторы, дислипопротеинемия, воспалительные процессы и дискинезия жёлчного пузыря.

- В большинстве случаев заболевание протекает бессимптомно, однако при развитии обтурации, эрозии, некроза жёлчного пузыря проявляются характерные клинические признаки: жёлчные колики, острый холецистит, холедохолитиаз, панкреатит и т. д.

- Камни жёлчного пузыря определяются на УзИ, а камни холедоха - на МРТ.

- Стандартное лечение симптоматической желчекаменной болезни лапароскопическая холецистэктомия. Камни холедоха удаляются путём лапароскопии или ЭРХПГ. При бессимптомном течении заболевания лечение не требуется.

\section{Вопросы и ответы по желчекаменной болезни}

\begin{tabular}{|c|c|}
\hline Вопросы & Ответы \\
\hline Что такое желчекаменная болезнь? & $\begin{array}{l}\text { Образование жёлчных камней в } \\
\text { жёлчном пузыре. }\end{array}$ \\
\hline Частота встречаемости: & $10-20 \%$. \\
\hline Основные факторы риска: & $\begin{array}{l}\text { Женский пол, употребление жирной } \\
\text { пищи, возраст старше } 40 \text { лет, частая } \\
\text { беременность. }\end{array}$ \\
\hline Другие факторы риска: & $\begin{array}{l}\text { - Оральные контрацептивы; } \\
\text { - Застой жёлчи; } \\
\text { - Хронический гемолиз; } \\
\text { - Цирроз печени; } \\
\text { - Инфекции; } \\
\text { - Резкая потеря веса; } \\
\text { - Воспалительные } \\
\quad \text { кишечника; }\end{array}$ \\
\hline
\end{tabular}




\begin{tabular}{|c|c|}
\hline Вопросы & Ответы \\
\hline & $\begin{array}{l}\text { - Резекция терминальной части } \\
\text { - } \text { Подвздошной кишки; } \\
\text { - Вагольное парентеральное питание; } \\
\text { - Возраст; } \\
\text { - Гиперлипидемия; } \\
\text { - Соматостатинома. }\end{array}$ \\
\hline Виды жёлчных камней: & $\begin{array}{l}\text { - Холестериновые (75-90\%); } \\
\text { - } \text { Пигментные камни (10-25\%). }\end{array}$ \\
\hline Виды пигментных камней: & $\begin{array}{l}\text { - Чёрные камни (в составе имеется } \\
\text { билирубинат кальция); } \\
\text { - Коричневые камни (связаны с } \\
\text { инфекцией). }\end{array}$ \\
\hline $\begin{array}{l}\text { Причины образования чёрных } \\
\text { пигментных камней: }\end{array}$ & Цирроз печени, гемолиз. \\
\hline $\begin{array}{l}\text { Причины образования коричневых } \\
\text { пигментных камней: }\end{array}$ & Стриктуры и инфекция в жёлчных путях. \\
\hline $\begin{array}{l}\text { Причины образования } \\
\text { холестериновых камней: }\end{array}$ & $\begin{array}{l}\text { Насыщение жёлчи холестерином и } \\
\text { образование частичек, которые } \\
\text { скапливаются и оседают в жёлчном } \\
\text { пузыре, образуя камни. }\end{array}$ \\
\hline $\begin{array}{l}\text { Считается ли гиперхолестеринемия } \\
\text { фактором риска развития } \\
\text { желчекаменной болезни? }\end{array}$ & Нет! (В отличие от гиперлипидемии). \\
\hline Клинические признаки: & $\begin{array}{l}\text { Жёлчная колика, холангит, } \\
\text { холедохолитиаз, жёлчные камни, } \\
\text { панкреатит. }\end{array}$ \\
\hline $\begin{array}{l}\text { Является ли жёлчная колика } \\
\text { приступообразной болью? }\end{array}$ & $\begin{array}{l}\text { Нет! Боль появляется и длится } \\
\text { несколько часов. }\end{array}$ \\
\hline $\begin{array}{l}\text { Частота встречаемости } \\
\text { бессимптомной желчекаменной } \\
\text { болезни: }\end{array}$ & $80 \%$. \\
\hline Механизм жёлчной колики: & $\begin{array}{lrr}\text { Вследствие } & \text { закупорки } & \text { пузырного } \\
\text { протока } & \text { жёлчными } & \text { камнями }\end{array}$ \\
\hline
\end{tabular}




\begin{tabular}{|c|c|}
\hline Bonросы & Ответы \\
\hline & $\begin{array}{l}\text { происходит сокращение, а затем } \\
\text { расширение пузыря, которое приводит } \\
\text { к ишемии стенки и появлению болей. }\end{array}$ \\
\hline $\begin{array}{l}\text { Основные осложнения } \\
\text { желчекаменной болезни: }\end{array}$ & $\begin{array}{l}\text { - Острый холецистит; } \\
\text { - Холедохолитиаз; } \\
\text { - Холангит; } \\
\text { - Панкреатит; } \\
\text { - Кишечная непроходимость. }\end{array}$ \\
\hline Диагностика: & $\begin{array}{l}\text { - Анамнез; } \\
\text { - Объективное обследование; } \\
\text { - УзИ. }\end{array}$ \\
\hline $\begin{array}{l}\text { Чувствительность УЗИ при } \\
\text { желчекаменной болезни: }\end{array}$ & $98 \%$. \\
\hline Что такое ультранегативные камни? & Камни, не выявленные на УЗИ (2\%). \\
\hline $\begin{array}{l}\text { Чувствительность УЗИ при } \\
\text { холедохолитиазе: }\end{array}$ & Менее $50 \%$. \\
\hline $\begin{array}{l}\text { Стандартное лечение } \\
\text { симптоматической желчекаменной } \\
\text { болезни: }\end{array}$ & Лапароскопическая холецистэктомия. \\
\hline $\begin{array}{l}\text { Осложнения лапароскопической } \\
\text { холецистэктомии: }\end{array}$ & $\begin{array}{l}\text { Повреждение общего жёлчного } \\
\text { протока, правого печёночного протока } \\
\text { или артерии, несостоятельность культи } \\
\text { пузырного протока, билиома. }\end{array}$ \\
\hline $\begin{array}{l}\text { Показания к холецистэктомии при } \\
\text { бессимптомном течении } \\
\text { желчекаменной болезни: }\end{array}$ & $\begin{array}{l}\text { - Серповидноклеточная анемия; } \\
\text { - Фарфоровый жёлчный пузырь; } \\
\text { - Камни размером более } 2 \text { см; } \\
\text { - Детский возраст. }\end{array}$ \\
\hline $\begin{array}{l}\text { По какой причине при фарфоровом } \\
\text { жёлчном пузыре и камнях размером } \\
\text { более } 2 \text { см показана хирургическая } \\
\text { операция? }\end{array}$ & Высокий риск малигнизации. \\
\hline $\begin{array}{l}\text { Какие лекарственные препараты } \\
\text { способны растворить жёлчные камни? }\end{array}$ & $\begin{array}{lr}\text { Хенодезоксихолевая } & \text { кислота, } \\
\text { урсодезоксихолевая кислота. Однако } \\
\text { при отмене препаратов возможно }\end{array}$ \\
\hline
\end{tabular}




\begin{tabular}{|lll}
\hline Вопросы & \multicolumn{1}{c}{ Ответы } \\
\hline & $\begin{array}{l}\text { повторное } \\
\text { камней. }\end{array}$ & образование жёлчных \\
\hline
\end{tabular}

Вопросы и ответы по билиарному илеусу

\begin{tabular}{|c|c|}
\hline Вопросы & Ответы \\
\hline Что такое билиарный илеус? & $\begin{array}{l}\text { Обтурация } \quad \text { тонкого } \\
\text { крупными }(>2,5 \text { см) жёлчными камнями. }\end{array}$ \\
\hline $\begin{array}{l}\text { Как происходит попадание жёлчных } \\
\text { камней в кишечник? }\end{array}$ & Через билиодигестивные свищи. \\
\hline локализация & Илеоцекальный угол. \\
\hline У кого может наблюдаться? & $\begin{array}{l}\text { Женщины старше } 70 \text { лет с крупными } \\
\text { жёлчными камнями. }\end{array}$ \\
\hline Клинические признаки: & $\begin{array}{l}\text { Признаки } \\
\text { непроходимости: вздутие, рвота, } \\
\text { гиповолемия, боль в правом верхнем } \\
\text { квадранте. }\end{array}$ \\
\hline Дифференциальная диагностика: & $\begin{array}{l}\text { Другие причины тонкокишечной } \\
\text { непроходимости (спайки, грыжа, рак). }\end{array}$ \\
\hline $\begin{array}{l}\text { Частота билиарного илеуса среди } \\
\text { причин } \\
\text { непроходимости: }\end{array}$ & Менее $1 \%$. \\
\hline \multirow[t]{3}{*}{ Диагностика: } & КТ - признаки непроходимости, \\
\hline & выявление \\
\hline & $\begin{array}{l}\text { кишечника, газ в жёлчных путях, } \\
\text { контрастирование жёлчного пузыря. }\end{array}$ \\
\hline \multirow[t]{2}{*}{ Лечение: } & Хирургическая операция: энтеротомия и \\
\hline & $\begin{array}{l}\text { удаление камня, холецистэктомия, } \\
\text { устранение билиодигестивного свища. }\end{array}$ \\
\hline
\end{tabular}




\section{ХРОНИЧЕСКИЙ КАЛЬКУЛЁЗНЫЙ ХОЛЕЦИСТИТ (ЖЁЛЧНАЯ КОЛИКА)}

- Хронический калькулёзный холецистит или жёлчная колика характеризуется морфофункциональными изменениями (застой, гипоактивный пузырь, фиброз, воспаление) в стенке жёлчного пузыря вследствие повторяющейся или временной обтурации пузырного протока жёлчными камнями.

- Заболевание, как правило, начинается жёлчной коликой, которая проходит спонтанно или под действием лекарственных препаратов (спазмолитики, анальгетики) в течение 6-24 часов.

- Характерной особенностью являются периодически повторяющиеся жёлчные колики. Подобное течение приводит к развитию фиброза жёлчного пузыря, застоя, фиброза сфинктера Одди, хронического панкреатита.

- В некоторых случаях возможно развитие осложнений (острый холецистит и панкреатит, холедохолитиаз и холангит и т. д.)

- Диагностика основана на клинической картине, лабораторных данных и УзИ.

- диагностическим критериям относятся жёлчные колики, определение жёлчных камней на УЗИ, отсутствие признаков воспаления, холестаза и повреждения в лабораторных анализах и методах визуализации в течение 12-24 часов.

- Стандартное лечение - лапароскопическая холецистэктомия.

\section{Вопросы и ответы по хроническому калькулёзному холециститу}

\begin{tabular}{|ll}
\hline \multicolumn{1}{|c}{ Вопросы } & \multicolumn{1}{c}{ Ответы } \\
\hline $\begin{array}{l}\text { Что такое хронический калькулёзный } \\
\text { холецистит или жёлчная колика? }\end{array}$ & $\begin{array}{l}\text { Заболевание, которое характеризуется } \\
\text { морфофункциональными изменениями } \\
\text { (застой, гипоактивный пузырь, фиброз, } \\
\text { воспаление) в стенке жёлчного пузыря } \\
\text { вследствие повторяющейся и } \\
\text { временной обтурации пузырного } \\
\text { протока жёлчными камнями. }\end{array}$ \\
\hline Частота встречаемости: & В 20-30\% случаев с желчекаменной \\
болезнью. \\
\hline Причины и факторы риска:
\end{tabular}




\begin{tabular}{|c|c|}
\hline Вопросы & Ответы \\
\hline & $\begin{array}{ll}\text { внутрипузырной } & \text { гипертензии } \\
\text { развитию болей. } & \end{array}$ \\
\hline Особенности клинического течения: & $\begin{array}{l}\text { - Обтурация в большинстве случаев } \\
\text { (90\%) проходит спонтанно или под } \\
\text { действием спазмолитиков или } \\
\text { анальгетиков в течение 6-24 часов. }\end{array}$ \\
\hline Осложнения: & $\begin{array}{l}\text { - Острый холецистит; } \\
\text { - Острый панкреатит; } \\
\text { - Хронический панкреатит; } \\
\text { - Холедохолитиаз; } \\
\text { - Холангит; } \\
\text { - Фиброз сфинктера Одди. }\end{array}$ \\
\hline Клинические признаки: & $\begin{array}{l}\text { - Боли в правой подрёберной или } \\
\text { эпигастральной } \\
\text { иррадиирующие в правое плечо, } \\
\text { шею; } \\
\text { - Тошнота, рвота. }\end{array}$ \\
\hline $\begin{array}{l}\text { У каких пациентов можно } \\
\text { заподозрить? }\end{array}$ & $\begin{array}{l}\text { У пациентов с приступообразными } \\
\text { болями в эпигастральной или правой } \\
\text { подрёберной областях. }\end{array}$ \\
\hline Диагностика: & $\begin{array}{l}\text { Клиническая картина, лабораторные } \\
\text { данные, УзИ. }\end{array}$ \\
\hline Лабораторные признаки: & Нет специфических признаков. \\
\hline $\begin{array}{l}\text { Признаки диагностической } \\
\text { визуализации: }\end{array}$ & УзИ - определение жёлчных камней. \\
\hline Диагностические критерии: & $\begin{array}{l}\text { - Боли в правой подрёберной или } \\
\text { эпигастральной областях в течение } 6 \\
\text { часов; } \\
\text { - Наличие жёлчных камней; } \\
\text { - Отсутствие признаков воспаления, } \\
\text { холестаза и повреждения в } \\
\text { лабораторных анализах и методах } \\
\text { визуализации в течение 12-24 часов. }\end{array}$ \\
\hline Лечение: & Хирургическое. \\
\hline
\end{tabular}




\begin{tabular}{|ll|}
\multicolumn{1}{|c|}{ Вопросы } & \multicolumn{1}{c|}{ Ответы } \\
\hline $\begin{array}{l}\text { Показания к хирургическому } \\
\text { лечению: }\end{array}$ & Наличие приступов боли. \\
\hline Методы хирургического лечения: & $\begin{array}{l}\text { Лапароскопическая холецистэктомия - } \\
\text { «золотой стандарт». }\end{array}$ \\
\hline Прогноз: & Благоприятный. \\
\hline $\begin{array}{l}\text { Характерная особенность данного } \\
\text { заболевания: }\end{array}$ & $\begin{array}{l}\text { Хронический калькулёзный холецистит } \\
\text { (жёлчная с сомая } \\
\text { распространённая } \\
\text { патология. }\end{array}$ \\
\end{tabular}




\section{ОСТРЫЙ КАЛЬКУЛЁЗНЫЙ ХОЛЕЦИСТИТ}

- Острый холецистит - это острое воспаление жёлчного пузыря, которое в большинстве случаев (90\%) развивается в результате полной или частичной обтурации пузырного протока камнем.

- Редко развивается на фоне тяжёлых заболеваний или перенесённой операции.

- Острый калькулёзный холецистит в большинстве случаев начинается жёлчной коликой, которая длится более 6 часов и сопровождается характерными клиническими признаками воспалительного процесса.

- У более половины пациентов обтурация пузырного протока проходит спонтанно, в результате чего происходит стихание воспалительных процессов в течение 710 дней. У другой половины пациентов вследствие присоединения вторичной инфекции развиваются деструктивные формы (флегмонозный, гангренозный холецистит) или осложнения (перфорация, инфильтрат, абсцесс, свищ, перитонит, эмфизематозный холецистит, эмпиема, сепсис).

- К факторам риска развития деструктивных форм холецистита относятся диабет, пожилой возраст, сердечно-сосудистые заболевания.

- Диагностика основана на клинической картине, лабораторных данных и методах диагностической визуализации.

- К диагностическим критериям относятся жёлчные колики в течение более 6 часов, признаки местные и общие воспалительных процессов (тяжесть в правом подреберье, положительный симптомы Ортнера, Мерфи, лейкоцитоз, повышение концентрации С-реактивного белка, гранулоцитоз), увеличение размеров, утолщение стенки (>2 мм), наличие жидкости вокруг жёлчного пузыря при диагностической визуализации.

- Основным методом лечения острого калькулёзного холецистита является ранняя лапароскопическая холецистэктомия. Другие методы лечения (консервативное, декомпрессия) проводятся в качестве поддерживающей терапии или при наличии противопоказаний к хирургическому лечению.

- При отсутствии соответствующего лечения летальность составляет 1-3\%, послеоперационная летальность при остром калькулёзном холецистите составляет $<0,5 \%$. 
Вопросы и ответы по острому калькулёзному холециститу

\begin{tabular}{|c|c|}
\hline Вопросы & Ответы \\
\hline $\begin{array}{l}\text { Что такое острый калькулёзный } \\
\text { холецистит? }\end{array}$ & $\begin{array}{l}\text { Воспаление жёлчного пузыря, } \\
\text { обусловленное обтурацией пузырного } \\
\text { протока камнем. }\end{array}$ \\
\hline Причины острого холецистита: & $\begin{array}{l}\text { В 90-95\% случаев развивается как } \\
\text { осложнение желчнокаменной болезни. }\end{array}$ \\
\hline Патогенез калькулёзного холецистита: & $\begin{array}{l}\text { Вследствие обтурации пузырного } \\
\text { протока развивается внутрипузырная } \\
\text { гипертензия с } \\
\text { микроциркуляции стенки жёлчного } \\
\text { пузыря и развитием воспалительного } \\
\text { процесса. }\end{array}$ \\
\hline $\begin{array}{l}\text { Какова роль инфекции в } \\
\text { возникновении острого холецистита? }\end{array}$ & Как правило играет вторичную роль. \\
\hline Клинические признаки: & $\begin{array}{l}\text { Боли в верхнем правом квадранте } \\
\text { живота, напряжение мышц брюшной } \\
\text { стенки, высокая температура, тошнота, } \\
\text { рвота, положительные симптомы } \\
\text { раздражения брюшины (симптомы } \\
\text { Ортнера, Мерфи). }\end{array}$ \\
\hline $\begin{array}{l}\text { В чём заключается суть симптома } \\
\text { Мерфи? }\end{array}$ & $\begin{array}{l}\text { Глубокий вдох в момент пальпации } \\
\text { правого подреберья резко ограничен } \\
\text { ввиду резкой болезненности. }\end{array}$ \\
\hline Осложнения: & $\begin{array}{l}\text { Абсцесс, перфорация, холедохолитиаз, } \\
\text { холецистодуоденальный } \\
\text { билиарный илеус. }\end{array}$ \\
\hline Лабораторные признаки: & $\begin{array}{l}\text { Лейкоцитоз, повышение концентрации } \\
\text { С-реактивного белка, незначительное } \\
\text { повышение ЩФ, АЛТ, АСТ, билирубина, } \\
\text { амилазы. }\end{array}$ \\
\hline Основной метод визуализации: & УЗИ. \\
\hline $\begin{array}{l}\text { УЗ признаки острого калькулёзного } \\
\text { холецистита: }\end{array}$ & $\begin{array}{l}\text { - Утолщение стенки жёлчного пузыря } \\
\text { (более } 2 \text { см); } \\
\text { - Увеличение размеров жёлчного } \\
\text { пузыря; }\end{array}$ \\
\hline
\end{tabular}




\begin{tabular}{|c|c|}
\hline Вопросы & Ответы \\
\hline & $\begin{array}{l}\text { - Наличие жидкости вокруг жёлчного } \\
\text { пузыря; } \\
\text { - Положительный симптом Мерфи } \\
\text { при проведении УзИ. }\end{array}$ \\
\hline $\begin{array}{l}\text { Являются ли УЗ признаки } \\
\text { патогномоничными для острого } \\
\text { холецистита? }\end{array}$ & $\begin{array}{l}\text { Нет, т. к. указанные признаки могут } \\
\text { наблюдаться при циррозе печени, } \\
\text { остром панкреатите, перфоративной } \\
\text { гастродуоденальной язве. }\end{array}$ \\
\hline $\begin{array}{l}\text { Отличие жёлчной колики от острого } \\
\text { холецистита: }\end{array}$ & $\begin{array}{l}\text { Для острого холецистита характерны } \\
\text { боли, продолжающиеся более } 6 \text { часов, } \\
\text { лейкоцитоз, высокая температура и } \\
\text { другие признаки воспалительного } \\
\text { процесса. }\end{array}$ \\
\hline $\begin{array}{l}\text { Диагностические критерии острого } \\
\text { калькулёзного холецистита: }\end{array}$ & $\begin{array}{l}\text { - Боли, продолжающиеся более } 6 \\
\text { часов; } \\
\text { - Местные и общие признаки } \\
\text { воспалительного процесса; } \\
\text { - Уз признаки. }\end{array}$ \\
\hline $\begin{array}{l}\text { Исключает ли острый холецистит } \\
\text { отсутствие камней? }\end{array}$ & Нет. \\
\hline $\begin{array}{l}\text { Метод исследования, } \\
\text { подтверждающий острый холецистит: }\end{array}$ & Лапароскопия. \\
\hline $\begin{array}{l}\text { Метод исследования, исключающий } \\
\text { острый холецистит: }\end{array}$ & $\begin{array}{l}\text { Сцинтиграфия - выявление жёлчного } \\
\text { пузыря при сцинтиграфии исключает } \\
\text { острый холецистит. }\end{array}$ \\
\hline Лечение: & $\begin{array}{l}\text { Инфузионная терапия, } \\
\text { антибиотикотерапия, холецистэктомия. }\end{array}$ \\
\hline $\begin{array}{l}\text { Что такое фарфоровый жёлчный } \\
\text { пузырь? }\end{array}$ & 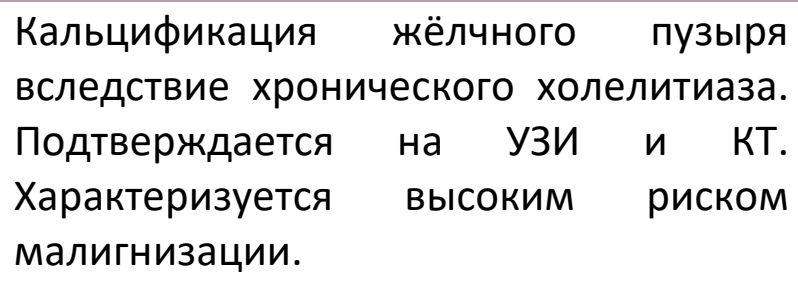 \\
\hline Что такое водянка жёлчного пузыря? & $\begin{array}{l}\text { Заполнение жёлчного пузыря секретом } \\
\text { слизистой оболочки вследствие полной }\end{array}$ \\
\hline
\end{tabular}




\begin{tabular}{|c|c|}
\hline Вопросы & Ответы \\
\hline & $\begin{array}{l}\text { обтурации пузырного протока } \\
\text { конкрементом. }\end{array}$ \\
\hline Что такое синдром Жильбера? & 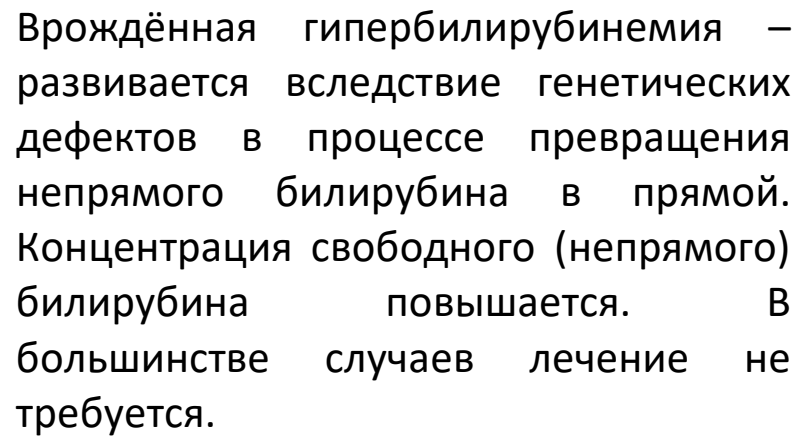 \\
\hline Что такое симптом Курвуазье? & $\begin{array}{l}\text { Увеличенный, напряженный, } \\
\text { безболезненный жёлчный пузырь и } \\
\text { обтурационная желтуха; характерен для } \\
\text { рака головки поджелудочной железы. }\end{array}$ \\
\hline Что такое синдром Мириззи? & $\begin{array}{ll}\text { Сдавление общего жёлчного протока } \\
\text { конкрементом, } \\
\text { пузырный проток. }\end{array}$ \\
\hline
\end{tabular}




\section{ОСТРЫЙ АКАЛЬКУЛЁЗНЫЙ ХОЛЕЦИСТИТ}

- Острый акалькулёзный (бескаменный) холецистит - это острое воспаление жёлчного пузыря, которое встречается реже острого калькулёзного холецистита (10\%/90\%).

- Основным механизмом развития считается ишемия стенки жёлчного пузыря, вследствие нарушения микроциркуляции.

- Как правило, наблюдается у пациентов с тяжёлым общим состоянием (при ожогах, политравмах, тяжёлых операциях, сепсисе, острой сердечно-сосудистой недостаточности и т. д.).

- В отличие от острого калькулёзного холецистита акалькулёзный холецистит чаще встречается у мужчин и пациентов с тяжёлым общим состоянием.

- Характеризуется тяжёлым течением и высокой летальностью (40\%), в 75\% случаев осложняется гангреной, в $25 \%$ случаев проявляется классическими признаками.

- K характерным признакам относятся высокая температура, лейкоцитоз, гиперамилаземия.

- С помощью методов диагностической визуализации (УзИ, КТ, сцинтиграфия) определяется увеличение размеров, утолщение стенки и жидкость вокруг жёлчного пузыря.

- Радикальное лечение данного заболевания - холецистэктомия. При наличии серьёзных противопоказаний на первом этапе проводится холецистостома.

\section{Вопросы и ответы по острому акалькулёзному холециститу}

\begin{tabular}{|c|c|}
\hline Вопросы & Ответы \\
\hline $\begin{array}{l}\text { Что такое акалькулёзный } \\
\text { (бескаменный) холецистит? }\end{array}$ & $\begin{array}{l}\text { Воспалительный процесс жёлчного } \\
\text { пузыря при отсутствии в нём } \\
\text { конкремента или обструкции в } \\
\text { пузырном протоке. }\end{array}$ \\
\hline Частота встречаемости: & $\begin{array}{l}\text { Составляет } 5-10 \% \quad \text { всех } \quad \text { острых } \\
\text { холециститов. }\end{array}$ \\
\hline Клинические формы: & $\begin{array}{l}\text { - Форма, которая наблюдается у } \\
\text { пациентов с тяжёлым общим } \\
\text { состоянием; } \\
\text { - Форма, которая наблюдается у } \\
\text { некритичных пациентов. }\end{array}$ \\
\hline
\end{tabular}




\begin{tabular}{|c|c|}
\hline Вопросы & Ответы \\
\hline Причины и факторы риска: & $\begin{array}{l}\text { - Механическая вентиляция лёгких; } \\
\text { - Парентеральное питание; } \\
\text { - ептические состояния; } \\
\text { - обши } \\
\text { - Спид; } \\
\text { - Кардиохирургические операции; } \\
\text { - Длительное голодание; } \\
\text { - Многократные трансфузии; } \\
\text { - Дегидратация; } \\
\text { - Длительный постельный режим в } \\
\text { условия отделения реанимации. }\end{array}$ \\
\hline \multirow[t]{5}{*}{ Патогенез: } & \multirow{5}{*}{$\begin{array}{l}\text { Основным } \\
\text { механизмом является нарушение } \\
\text { микроциркуляции (у пациентов с } \\
\text { тяжёлым общим состоянием, без } \\
\text { орального питания, при отсутствии } \\
\text { стимуляции холецистокинина), но } \\
\text { считается, что в развитии патологии } \\
\text { играют роль также отложения в } \\
\text { жёлчном пузыре. }\end{array}$} \\
\hline & \\
\hline & \\
\hline & \\
\hline & \\
\hline $\begin{array}{l}\text { Отличается ли клиническое течение } \\
\text { острого акалькулёзного холецистита } \\
\text { от такового при калькулёзном? }\end{array}$ & $\begin{array}{lr}\text { Акалькулёзный } & \text { холецистит } \\
\text { характеризуется } & \text { более } \\
\text { течением и высокой летальностью. }\end{array}$ \\
\hline Осложнения: & $\begin{array}{l}\text { Перфорация или гангрена жёлчного } \\
\text { пузыря, сепсис. }\end{array}$ \\
\hline Причина высокой летальности: & $\begin{array}{l}\text { Общее критическое состояние, } \\
\text { тромбозы в сосудах печени и других } \\
\text { органов, быстрое развитие гангрены и } \\
\text { сепсиса, выраженные } \\
\text { клинические признаки. }\end{array}$ \\
\hline \multirow[t]{2}{*}{ Клинические признаки: } & Боли в правом подреберье, напряжение \\
\hline & $\begin{array}{l}\text { мышц брюшной стенки, высокая } \\
\text { температура. }\end{array}$ \\
\hline $\begin{array}{l}\text { У каких пациентов можно } \\
\text { заподозрить? }\end{array}$ & $\begin{array}{l}\text { При наличии болей в правом } \\
\text { подреберье, высокой температуры и }\end{array}$ \\
\hline
\end{tabular}




\begin{tabular}{|c|c|}
\hline Вопросы & Ответы \\
\hline & $\begin{array}{l}\text { повышении амилазы у критических } \\
\text { пациентов. }\end{array}$ \\
\hline Диагностика: & $\begin{array}{l}\text { Клиническая картина, лабораторные } \\
\text { исследования, УзИ. }\end{array}$ \\
\hline Лабораторные признаки: & $\begin{array}{l}\text { - Лейкоцитоз; } \\
\text { - Гипербилирубинемия; } \\
\text { - Повышение щФ и ГГТ (при } \\
\text { отсутствии признаков холангита); } \\
\text { - Повышение АЛТ, АСТ, амилазы }\end{array}$ \\
\hline $\begin{array}{l}\text { Признаки диагностической } \\
\text { визуализации: }\end{array}$ & $\begin{array}{l}\text { - Увеличение размеров жёлчного } \\
\text { пузыря; } \\
\text { - Утолщение стенок жёлчного пузыря } \\
\text { (>5 мм), перихолецистическая } \\
\text { жидкость; } \\
\text { - Перихолецистический абсцесс. }\end{array}$ \\
\hline Диагностические критерии: & $\begin{array}{l}\text { - Боли в правом подреберье; } \\
\text { - Признаки сепсиса; } \\
\text { - Увеличение размеров жёлчного } \\
\text { пузыря, утолщение его стенок. }\end{array}$ \\
\hline Методы лечения: & Хирургическое. \\
\hline Показания к хирургической операции: & Наличие акалькулезного холецистита. \\
\hline Виды операций: & 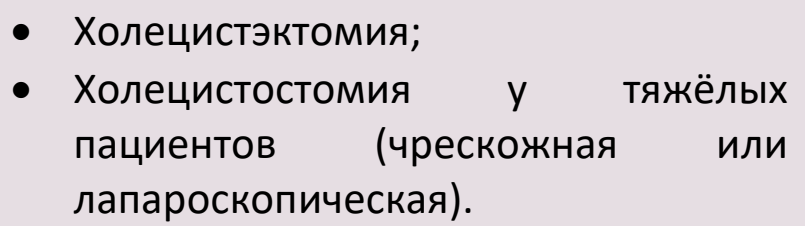 \\
\hline Прогноз: & $\begin{array}{l}\text { Отличается высокой летальностью - } \\
40 \% \text {. }\end{array}$ \\
\hline
\end{tabular}




\section{ХОЛЕДОХОЛИТИАЗ}

- Наличие конкрементов в общем жёлчном протоке называется холедохолитиазом.

- Первичные камни холедоха образуются в нём самом, а вторичные попадают в холедох из жёлчного пузыря.

- Холедохолитиаз редко протекает бессимптомно, в большинстве же случаев, вызывая обструкцию в жёлчных путях, приводит к развитию механической желтухи, холангита, панкреатита, билиарного цирроза.

- При наличии соответствующей клинической картины (боль, жёлчные камни, желтуха, холангит, панкреатит), лабораторных изменений (повышение холестатических ферментов) и признаков диагностической визуализации (расширение холедоха) проводят холангиографию или МРТ с целью определения конкрементов в холедохе.

- В отличие от желчекаменной болезни бессимптомный холедохолитиаз требует соответствующего лечения.

- Лечение первичного холедохолитиаза направлено на устранение причины (ликвидация стриктуры, удаление кисты, лечение инфекции и т. д.) При вторичных камнях холедоха выполняется лапароскопическая холецистэктомия, удаление камней холедоха лапароскопическим или эндоскопическим способом.

Вопросы и ответы по холедохолитиазу

\begin{tabular}{|ll}
\hline \multicolumn{1}{|c}{ Вопросы } & \multicolumn{1}{c}{ Ответы } \\
\hline Что такое холедохолитиаз? & $\begin{array}{l}\text { Наличие камней в общем жёлчном } \\
\text { протоке. }\end{array}$ \\
\hline $\begin{array}{l}\text { Что является источником } \\
\text { холедохолитиаза? }\end{array}$ & $\begin{array}{l}\text { Первичные камни образуются в самом } \\
\text { холедохе, вторичные же попадают из } \\
\text { жёлчного пузыря. }\end{array}$ \\
\hline $\begin{array}{l}\text { Отличаются ли первичные и } \\
\text { вторичные камни холедоха? }\end{array}$ & $\begin{array}{l}\text { Первичные камни обычно пигментные, } \\
\text { вторичные } \\
\text { холестериновые. }\end{array}$ \\
\hline $\begin{array}{l}\text { Как формируются первичные камни } \\
\text { холедоха? }\end{array}$ & $\begin{array}{l}\text { При условии воспаления или стриктуры } \\
\text { и застоя в протоке. }\end{array}$ \\
\hline $\begin{array}{l}\text { Какие камни встречаются чаще: } \\
\text { первичные или вторичные? }\end{array}$ & Вторичные камни из жёлчного пузыря. \\
\hline
\end{tabular}




\begin{tabular}{|c|c|}
\hline Вопросы & Ответы \\
\hline $\begin{array}{l}\text { Частота холедохолитиаза при } \\
\text { желчекаменной болезни: }\end{array}$ & Составляет 8-15\%. \\
\hline $\begin{array}{l}\text { Судьба камней, попадающих в } \\
\text { холедох: }\end{array}$ & $\begin{array}{l}\text { - } \text { Попадают в кишечник; } \\
\text { - Остаются в холедохе и } \\
\text { характеризуются бессимптомным } \\
\text { течением (20\%); } \\
\text { - } \text { Вызывают осложнения (80\%). }\end{array}$ \\
\hline Осложнения холедохолитиаза: & $\begin{array}{l}\text { - Частичная обтурация } \\
\text { (субклинический холедохолитиаз); } \\
\text { - Временная обтурация } \\
\text { (повторяющаяся желтуха); } \\
\text { - Полная обтурация (механическая } \\
\text { желтуха); } \\
\text { - Холангит; } \\
\text { - Панкреатит; } \\
\text { - Фиброз сфинктера Одди; } \\
\text { - Билиарный цирроз. }\end{array}$ \\
\hline $\begin{array}{l}\text { У каких пациентов можно } \\
\text { заподозрить? }\end{array}$ & $\begin{array}{l}\text { - При желчекаменной болезни; } \\
\text { - При механической желтухе; } \\
\text { - При признаках холестаза; } \\
\text { - При холангите; } \\
\text { - При панкреатите; } \\
\text { - У пациентов, перенёсших операцию } \\
\quad \text { на жёлчных путях. }\end{array}$ \\
\hline Диагностика: & $\begin{array}{l}\text { - УзИ; } \\
\text { - Лабораторные маркеры (ЩФ, ГГТ, } \\
\text { билирубин); } \\
\text { - МР-холангиография, } \\
\text { эндоскопическое УзИ. }\end{array}$ \\
\hline Основной метод диагностики: & MPT. \\
\hline $\begin{array}{l}\text { Почему даже бессимптомные камни } \\
\text { холедоха подлежат удалению? }\end{array}$ & $\begin{array}{l}\text { Из-за высокой вероятности развития } \\
\text { серьёзных осложнений со всеми } \\
\text { неблагоприятными последствиями } \\
\text { (механическая желтуха, холангит, } \\
\text { цирроз печени, панкреатит). }\end{array}$ \\
\hline
\end{tabular}




\begin{tabular}{|c|c|}
\hline Вопросы & Ответы \\
\hline Методы оперативного лечения: & $\begin{array}{l}\text { • } \text { ЭРХПГ, папиллосфинктеротомия с } \\
\text { - } \text { Литоэкстракцией; } \\
\text { холедохоскопическая } \\
\text { - Лапаротомия, эксплорация общего } \\
\text { жёлчного протока. }\end{array}$ \\
\hline
\end{tabular}




\section{ОСТРЫЙ БАКТЕРИАЛЬНЫЙ ХОЛАНГИТ}

- Воспаление жёлчных протоков называется холангит или холангиолит:

○ Холангиолит - воспаление мелких жёлчных протоков; возникает на фоне различных аутоиммунных патологий, туберкулёза, саркоидоза, хронического гепатита, трансплантации печени, приёма лекарственных препаратов.

○ Холангит-воспаление крупных внутри-и внепечёночных жёлчных протоков, которое характеризуется изменениями и повреждениями в жёлчных протоках.

- Острый бактериальный холангит - бактериальная инфекция, которая развивается на фоне обтурации или повреждения крупных жёлчных протоков.

- Острый холангит в литературе также называется острым бактериальным холангитом, гнойным холангитом, обструктивным холангитом.

- Заболевания, при которых наблюдается обтурация жёлчных протоков, являются причиной развития холангита. К частым причинам относятся жёлчные камни, стриктуры и опухоли жёлчных протоков.

- Характерным клиническим проявлением заболевания является триада Шарко (боль в правом подреберье, желтуха, высокая температура с ознобом). Заболевание быстро прогрессирует, сопровождается признаками сепсиса (органная недостаточность) и при несвоевременном лечении приводит к летальному исходу. Если не устранить этиологический фактор, возможен рецидив заболевания.

- Диагноз острого бактериального холангита клинически основан на триаде Шарко; признаки холестаза и воспалительного процесса в лабораторных исследованиях и данных холангиографии также подтверждают диагноз.

- Лечение начинают немедленно: сначала купируется воспалительный процесс (антибактериальная терапия, инфузия, поддерживающая терапия, при необходимости декомпрессия), а затем устраняется причина обтурации. Для декомпрессии используются эндоскопический, чрескожный, лапароскопический или лапаротомический методы.

Вопросы и ответы по острому бактериальному холангиту

Вопросы

Ответы

Что такое гнойный холангит?

Бактериальное воспаление жёлчных протоков, обусловленное обтурацией 


\begin{tabular}{|c|c|}
\hline Вопросы & Ответы \\
\hline & $\begin{array}{l}\text { жёлчных протоков; является причиной } \\
\text { развития сепсиса. }\end{array}$ \\
\hline Причины: & $\begin{array}{l}\text { - Холедохолитиаз; } \\
\text { - } \text { Стриктура жёлчных протоков; } \\
\text { - } \text { Новообразования } \\
\text { карцинома); } \\
\text { - Компрессия извне (псевдокиста } \\
\text { поджелудочной } \\
\text { панкреатит); } \\
\text { - Лечебно-диагностические } \\
\text { процедуры на жёлчных протоках } \\
\text { (ЭРхПГ, стентирование). }\end{array}$ \\
\hline Наиболее частая причина холангита: & Холедохолитиаз. \\
\hline $\begin{array}{l}\text { Основные возбудители гнойного } \\
\text { холангита: }\end{array}$ & $\begin{array}{l}\text { - Грамотрицательные бактерии (Е. } \\
\text { coli, Klebsiella, Pseudomonas, } \\
\text { Enterobacter, Proteus, Serratia); } \\
\text { - Грамположительные бактерии } \\
\text { (Enterococcus); } \\
\text { - Анаеробы (B. fragilis); } \\
\text { - Кандида. }\end{array}$ \\
\hline Осложнения: & $\begin{array}{l}\text { Сепсис, печёночная недостаточность, } \\
\text { гепаторенальный синдром, абсцесс. }\end{array}$ \\
\hline Клинические признаки: & $\begin{array}{l}\text { - Триада Шарко: боль, желтуха, } \\
\text { высокая температура с ознобом. } \\
\text { - Пентада Рейнольдса: триада Шарко, } \\
\text { энцефалопатия, шок. }\end{array}$ \\
\hline Лабораторная признаки: & $\begin{array}{l}\text { Лейкоцитоз, гипербилирубинемия, } \\
\text { повышение концентрации щФ, } \\
\text { бактериохолия при посеве жёлчи. }\end{array}$ \\
\hline $\begin{array}{l}\text { Какие методы исследования } \\
\text { необходимы для диагностики острого } \\
\text { холангита? }\end{array}$ & $\begin{array}{l}\text { УЗИ, МРТ. Контрастнуюхолангиографию } \\
\text { (ЭРХПГ, ЧКХГ) желательно проводить } \\
\text { после стихания воспалительного } \\
\text { процесса. }\end{array}$ \\
\hline $\begin{array}{l}\text { Чем обоснован диагноз острого } \\
\text { холангита? }\end{array}$ & $\begin{array}{l}\text { Холангит диагностируют при наличии } \\
\text { клинических признаков наряду с }\end{array}$ \\
\hline
\end{tabular}




\begin{tabular}{|c|c|}
\hline Вопросы & Ответы \\
\hline & $\begin{array}{l}\text { лабораторными и клиническими } \\
\text { признаками холестаза. }\end{array}$ \\
\hline Степени тяжести холангита: & $\begin{array}{l}\text { - Легкая степень - консервативная } \\
\text { терапия эффективна; } \\
\text { - Степень средней тяжести - } \\
\text { консервативное } \\
\text { неэффективно; } \\
\text { - Тяжёлая степень - характеризуется } \\
\text { септическим шоком. }\end{array}$ \\
\hline Принципы лечения холангита: & $\begin{array}{l}\text { В остром периоде проводится } \\
\text { противовоспалительное } \\
\text { антибактериальное лечение. После } \\
\text { купирования острых явлений } \\
\text { проводится лечение, направленное на } \\
\text { устранение причины холангита. }\end{array}$ \\
\hline Лечение холангита: & 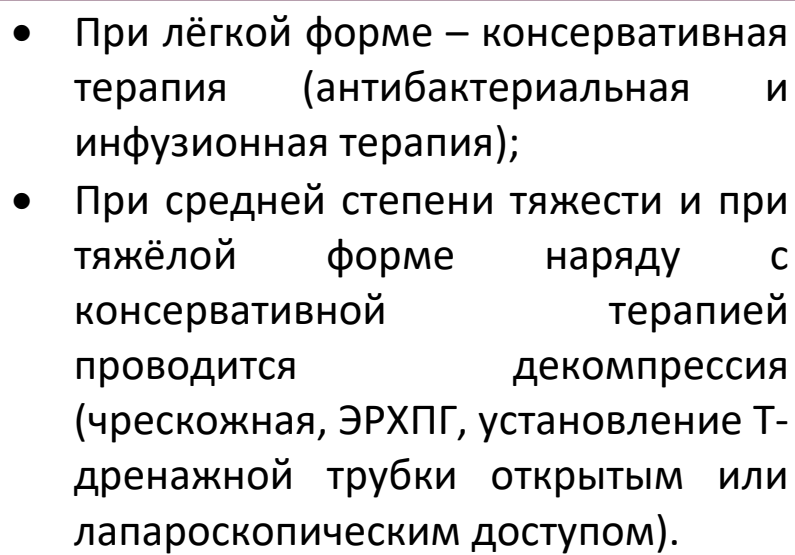 \\
\hline $\begin{array}{l}\text { В каких случаях обнаруживают воздух } \\
\text { В жёлчных протоках? }\end{array}$ & $\begin{array}{l}\text { - } \text { Эмфизематозный холангит; } \\
\text { - Билиоэнтерический свищ; } \\
\text { - Билиоэнтерический анастомоз; } \\
\text { - Вмешательства на жёлчных } \\
\text { протоках. }\end{array}$ \\
\hline
\end{tabular}




\section{РЕЦИДИВИРУЮЩИЙ ГНОЙНЫЙ ХОЛАНГИТ}

- Рецидивирующий гнойный (пиогенный) холангит - это заболевание, характеризующееся диффузным расширением крупных жёлчных протоков (сегментарный, долевой, общий), локальными сужениями внутрипечёночных жёлчных протоков, многочисленными конкрементами и периодическими рецидивами острого холангита.

- В литературе также называется ориентальным холангиогепатитом, гепатолитиазом.

- Заболевание чаще встречается в странах Дальнего Востока (Тайвань, Китай, Япония и др.) К этиологическим факторам относятся паразитарные инфекции (Clonorchis, Opisthorchis, Ascarides), недоедание и генетические факторы.

- Заболевание, как правило, начинается с признаков острого холангита. Является причиной развития сепсиса, перфорации холедоха, перитонита, холангиокарциномы, нередко приводит к летальному исходу.

- Диагностика основана на клинико-лабораторных данных. Также проводится холангиография и томография.

- $\mathrm{K}$ диагностическим критериям относятся наличие признаки холангита, расширение жёлчных протоков, обнаружение в них камней и стриктур.

- Лечение, как и при остром бактериальном холангите, направлено на устранение острого воспалительного процесса и предотвращение рецидивов. 


\section{СКЛЕРОЗИРУЮЩИЙ ХОЛАНГИТ}

- Первичный склерозирующий холангит (ПСХ) является аутоиммунным заболеванием, характеризуется множественными фибротическими и рубцовыми стриктурами и сегментарными расширениями жёлчных протоков.

○ Нередко первичный склерозирующий холангит сочетается с воспалительными заболеваниями кишечника и другими аутоиммунными заболеваниям.

- Прогрессирующее течение заболевания на фоне хронического холестаза приводит к развитию цирроза печени, повышает риск заболеваемости холангиокарциномой (30\%) и колоректальным раком. После постановки диагноза выживаемость составляет 10 лет.

○ Заболевание может протекать бессимптомно, но в большинстве случаев проявляется признаками холестаза, холангита и цирроза печени.

○ В уточнении диагноза ценную информацию дают контрастное исследование жёлчных протоков, лабораторные тесты.

○ К диагностическим критериям относятся признаки холестаза, характерная картина на холангиографии (чёткообразные жёлчные протоки), исключение других видов холангита и наличие воспалительных заболеваний кишечника.

○ С лечебной целью пациентам назначают урсодезоксихолевую кислоту, проводится трансплантация печени, эндоскопическая дилатация. В редких случаях формируют обходные анастомозы.

- Вторичные склерозирующие холангиты или рубцовые стриктуры развиваются вследствие травмы, хронических воспалительных процессов или врождённых аномалий жёлчных протоков.

○ Большинство из них развиваются после хирургических операций, в редких случаях связаны с хроническими воспалительными процессами (холангит, панкреатит, язвенная болезнь, болезнь Крона, жёлчные камни и др.)

○ Клинически характеризуется либо бессимптомным течением, либо признаками холестаза и холангита. Хроническое течение, прогрессирование заболевания приводит к развитию цирроза печени.

○ Для уточнения диагноза используют холангиографию и томографию.

○ При лечении вторичного склерозирующего холангита применяют билиоэнтероанастомозы на выключенной по Ру петле и стентирование жёлчных протоков. 


\section{Вопросы и ответы по первичному склерозирующему холангиту}

\begin{tabular}{|c|c|}
\hline Вопросы & Ответы \\
\hline $\begin{array}{l}\text { Что такое первичный билиарный } \\
\text { холангит (первичный билиарный } \\
\text { цирроз)? }\end{array}$ & $\begin{array}{l}\text { Хронический и прогрессирующий } \\
\text { холестаз внутрипечёночных жёлчных } \\
\text { протоков и их гранулематозное } \\
\text { воспаление. }\end{array}$ \\
\hline Частота встречаемости: & $\begin{array}{l}\text { 1:3000-4000. } \\
\text { Соотношение женщин и мужчин - 9:1. }\end{array}$ \\
\hline Клинические формы: & $\begin{array}{l}\text { - } \text { АМА-позитивная форма; } \\
\text { - АМА-негативная } \\
\text { (аутоиммунный холангит). }\end{array}$ \\
\hline Причины и факторы риска: & $\begin{array}{l}\text { Этиология неизвестна. Предполагается } \\
\text { аутоиммунная природа. }\end{array}$ \\
\hline Патогенез: & $\begin{array}{l}\text { Гранулематозное воспаление мелких } \\
\text { жёлчных протоков. }\end{array}$ \\
\hline Особенности клинического течения: & $\begin{array}{l}\text { Хроническое прогрессирующее } \\
\text { течение. При отсутствии лечения в } \\
\text { течение 10-и лет приводит к циррозу } \\
\text { печени. }\end{array}$ \\
\hline Осложнения: & $\begin{array}{l}\text { - Остеопороз; } \\
\text { - Цирроз печени; } \\
\text { - Гиперхолестеринемия, } \\
\text { - Гиперлипидемия (85\%); } \\
\text { - } \text { Стеаторея; } \\
\text { - Гичечный тубулярный ацидоз; } \\
\text { - Гепатоцеллюлярный рак (6\%); } \\
\text { - Бессимптомная бактериурия (35\%). }\end{array}$ \\
\hline Клинические признаки: & $\begin{array}{l}\text { - Бессимптомное течение; } \\
\text { • Признаки холестаза (слабость, } \\
\text { кожный зуд, желтуха и др.); } \\
\text { - Признаки цирроза. }\end{array}$ \\
\hline $\begin{array}{l}\text { У каких пациентов можно } \\
\text { заподозрить? }\end{array}$ & У пациентов с циррозом и холестазом. \\
\hline
\end{tabular}




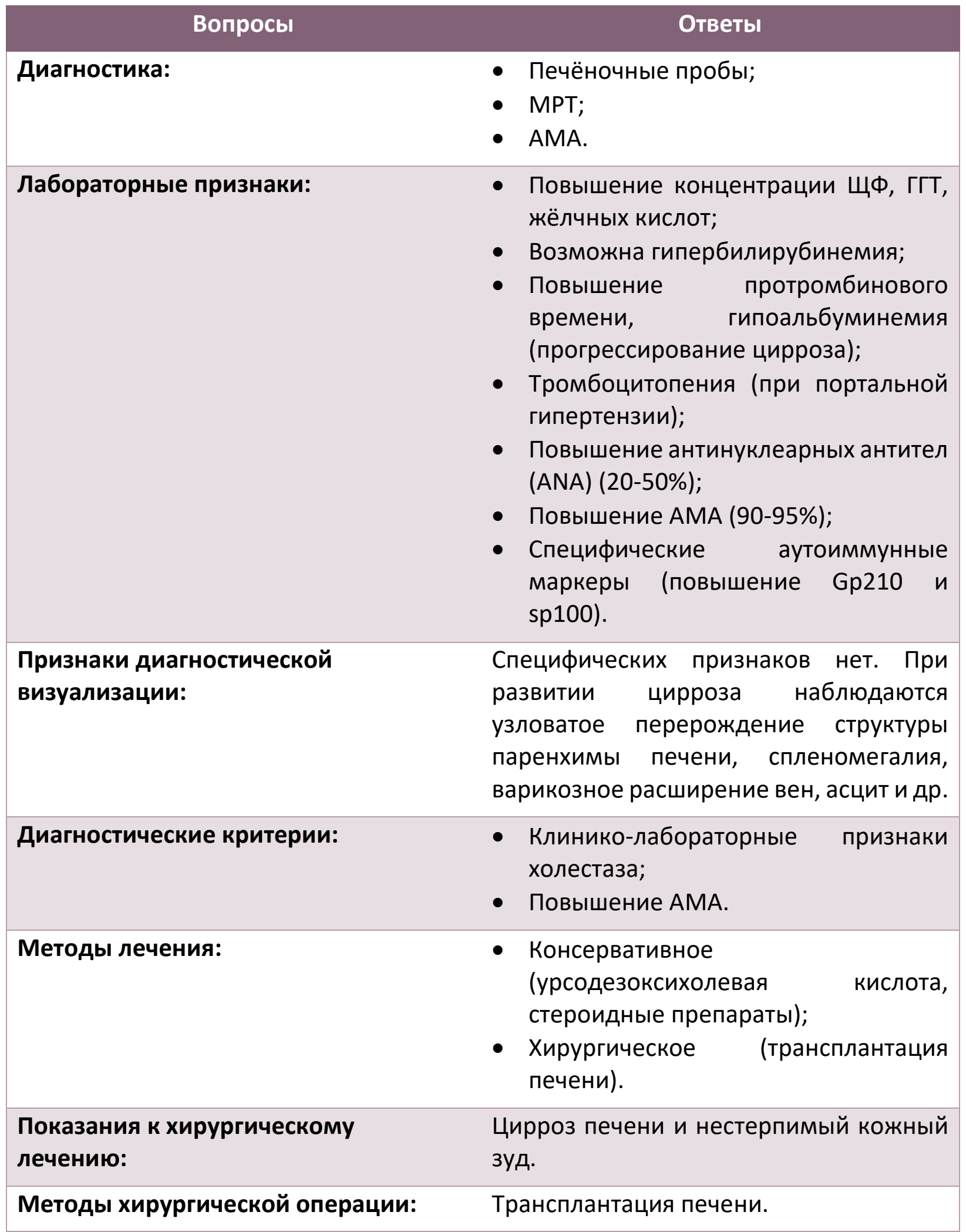




\begin{tabular}{ll} 
& \multicolumn{1}{c}{ Ответы } \\
Пропросы & \multicolumn{1}{c}{ У симптоматических пациентов после } \\
& установления диагноза длительность \\
& жизни составляет 7,5 лет. \\
& При бессимптомном течении - 15-16 \\
& лет.
\end{tabular}

\section{Вопросы и ответы по рубцовым стриктурам}

\begin{tabular}{|c|c|}
\hline Вопросы & Ответы \\
\hline Что такое стриктура? & $\begin{array}{l}\text { Различные внутрипротоковые (камни, } \\
\text { паразитарные инфекции), протоковые } \\
\text { (воспалительные процессы, опухоли) } \\
\text { заболевания способствуют сужению } \\
\text { просвета жёлчных протоков. Стриктура } \\
\text { - это фиброзное (рубцовое) сужение. }\end{array}$ \\
\hline Причины: & $\begin{array}{l}\text { Ятрогенные (интраоперационные) и } \\
\text { травматические } \\
\text { воспалительные повреждения, } \\
\text { (склерозирующий холангит, панкреатит } \\
\text { и др.) }\end{array}$ \\
\hline Частая причина рубцовых стриктур: & $\begin{array}{l}\text { Интраоперационные повреждения } \\
\text { (80\%). }\end{array}$ \\
\hline $\begin{array}{l}\text { Частая причина воспалительных } \\
\text { стриктур: }\end{array}$ & $\begin{array}{lr}\text { Хронический } & \text { панкреатит, } \\
\text { склерозирующий } \\
\text { сфинктера Одди. }\end{array}$ \\
\hline $\begin{array}{l}\text { Для каких анастомозов характерны } \\
\text { рубцовые стриктуры? }\end{array}$ & Билиарные анастомозы конец в конец. \\
\hline $\begin{array}{l}\text { Факторы риска рубцовых стриктур } \\
\text { анастомозов: }\end{array}$ & $\begin{array}{l}\text { Ишемия, травма, воспаление области } \\
\text { анастомоза. }\end{array}$ \\
\hline Классификация: & $\begin{array}{l}\text { Классификации Bismuth в зависимости } \\
\text { от локализации стриктуры: }\end{array}$ \\
\hline
\end{tabular}




\begin{tabular}{|c|c|}
\hline Вопросы & Ответы \\
\hline & $\begin{array}{l}\text { - I тип - стриктура на } 2 \text { см дистальнее } \\
\text { бифуркации; } \\
\text { - II тип - стриктура на менее чем } 2 \text { см } \\
\text { дистальнее бифуркации; } \\
\text { - III тип - стриктура на уровне } \\
\text { бифуркации; } \\
\text { - IV тип - стриктура на уровне } \\
\text { бифуркации и долевых протоков; } \\
\text { - V тип - стриктура добавочных } \\
\text { жёлчных протоков. }\end{array}$ \\
\hline Осложнения: & $\begin{array}{l}\text { - Механическая желтуха; } \\
\text { - Холедохолитиаз; } \\
\text { - Холангит; } \\
\text { - Билиарный цирроз. }\end{array}$ \\
\hline Когда возникает билиарный цирроз? & При длительной стриктуре. \\
\hline Клинические признаки: & $\begin{array}{l}\text { Механическая желтуха, холангит, } \\
\text { признаки билиарного цирроза. }\end{array}$ \\
\hline Диагностика: & $\begin{array}{l}\text { Контрастная холангиография, МРТ, } \\
\text { эндоскопическое УЗИ. }\end{array}$ \\
\hline $\begin{array}{l}\text { Какие исследования необходимы для } \\
\text { дифференциации рубцовых стриктур } \\
\text { от злокачественных } \\
\text { новообразований? }\end{array}$ & МРТ, эндоскопическое УЗИ. \\
\hline Методы лечения: & $\begin{array}{l}\text { Хирургическая операция, баллонная } \\
\text { дилатация, стентирование (чрескожное } \\
\text { или эндоскопическое). }\end{array}$ \\
\hline $\begin{array}{l}\text { Наиболее эффективный метод } \\
\text { хирургического лечения: }\end{array}$ & $\begin{array}{l}\text { Билиоэнтероанастомоз на } \\
\text { выключенной по Ру петле тощей кишки. }\end{array}$ \\
\hline
\end{tabular}




\section{ПОЛИПЫ ЖЁЛЧНОГО ПУЗЫРЯ}

- Полипы - это доброкачественные опухоли, исходящие из слизистого эпителия жёлчного пузыря и свисающие в его полость.

- Различают холестериновые, аденоматозные, воспалительные и неопластические полипы. Большинство полипов жёлчного пузыря неопухолевого происхождения (холестериновые, воспалительные).

- Полипы могут сочетаться с желчекаменной болезнью; холестериновые полипы могут быть причиной образования жёлчных камней.

- Полипы, размерами более 10 мм, склонны к малигнизации.

- В большинстве наблюдений полипы жёлчного пузыря протекают бессимптомно, редко проявляются желчной коликой, панкреатитом или гемобилией.

- Для диагностики используют УзИ. С целью дифференциальной диагностики применяют допплерографию для определения кровотока в опухолевидном образовании. Изучение гистологической структуры полипов до операции не представляется возможным. Диагноз верифицируют при патогистологическом исследовании жёлчного пузыря.

- При симптоматических полипах или полипах размером более 10 мм рекомендуется лапароскопическая холецистэктомия, при бессимптомном течении и полипах размером менее 10 мм показано динамическое наблюдение.

\section{Вопросы и ответы по полипам жёлчного пузыря}

\begin{tabular}{|c|c|}
\hline Вопросы & Ответы \\
\hline Что такое полип жёлчного пузыря? & $\begin{array}{l}\text { Доброкачественное образование, } \\
\text { исходящее из слизистого эпителия } \\
\text { жёлчного пузыря. }\end{array}$ \\
\hline Частота встречаемости: & $\begin{array}{l}\text { - Встречается редко (1-4\%); } \\
\text { - В 10-50\% случаев сочетается с } \\
\text { желчекаменной болезнью. }\end{array}$ \\
\hline Клинические формы: & $\begin{array}{l}\text { - Неопластические (аденоматозные); } \\
\text { - Неопухолевые } \\
\text { холестериновые, воспалительные. }\end{array}$ \\
\hline Причины и факторы риска: & Точно не известен. \\
\hline Патогенез: & Точно не известен. \\
\hline
\end{tabular}




\begin{tabular}{|c|c|}
\hline Вопросы & Ответы \\
\hline Особенности клинического течения: & $\begin{array}{l}\text { - В большинстве случаев протекает } \\
\text { бессимптомно (90\%); } \\
\text { - Возможен переход 1\% случаев в год } \\
\text { в симптоматическую форму; } \\
\text { - Аденоматозные полипы размером } \\
\text { более } 10 \text { мм склонны к } \\
\text { малигнизации. }\end{array}$ \\
\hline Осложнения: & $\begin{array}{l}\text { - Панкреатит; } \\
\text { - Жёлчной колика; } \\
\text { - Гемобилия; } \\
\text { - Острый холецистит; } \\
\text { - Малигнизация (аденоматозные } \\
\quad \text { полипы). }\end{array}$ \\
\hline Клинические признаки: & $\begin{array}{l}\text { Жёлчная колика, кровотечение, } \\
\text { панкреатит и др. }\end{array}$ \\
\hline $\begin{array}{l}\text { У каких пациентов можно } \\
\text { заподозрить? }\end{array}$ & $\begin{array}{l}\text { При наличии жёлчной колики, } \\
\text { панкреатита, гемобилии, утолщении } \\
\text { стенки жёлчного пузыря по данным } \\
\text { Узи. }\end{array}$ \\
\hline Диагностика: & $\begin{array}{l}\text { - УзИ; } \\
\text { - Допплерография; } \\
\text { - Контрастная КТ. }\end{array}$ \\
\hline Лабораторные признаки: & Нет специфических признаков. \\
\hline $\begin{array}{l}\text { Признаки диагностической } \\
\text { визуализации: }\end{array}$ & $\begin{array}{l}\text { - Выявление } \\
\text { образования в стенке жёлчного } \\
\text { пузыря без акустической тени; } \\
\text { - Контрастирование и наличие } \\
\text { сосудистого рисунка } \\
\text { допплерографии. }\end{array}$ \\
\hline Диагностические критерии: & $\begin{array}{l}\text { Наличие включения в стенке жёлчного } \\
\text { пузыря. }\end{array}$ \\
\hline Методы лечения: & $\begin{array}{l}\text { Динамическое наблюдение } \\
\text { хирургическое лечение. }\end{array}$ \\
\hline
\end{tabular}




\begin{tabular}{|c|c|}
\hline Вопросы & Ответы \\
\hline $\begin{array}{l}\text { Показания к хирургическому } \\
\text { лечению: }\end{array}$ & $\begin{array}{l}\text { - Симптоматические полипы; } \\
\text { - Асимптоматические } \\
\text { крупных размеров (>10 мм). }\end{array}$ \\
\hline Методы хирургического лечения: & Лапароскопическая холецистэктомия. \\
\hline Прогноз: & Благоприятный. \\
\hline
\end{tabular}




\section{ОПУХОЛИ ЖЁЛЧнЫХ ПРОТОКОВ}

- $\mathrm{K}$ злокачественным опухолям, исходящим из эпителия жёлчных протоков, относятся рак жёлчного пузыря, внепечёночные и внутрипечёночные холангиокарциномы.

- Большинство злокачественных новообразований жёлчного пузыря являются аденокарциномой.

○ К факторам риска относятся аденомы, кальцификация жёлчного пузыря, наличие крупных камней (>2 см) у пожилых пациентов, аномалии холедоха (кисты).

○ Начальная стадия заболевания протекает бессимптомно. По мере прогрессирования злокачественного процесса проявляются жёлчная колика, признаки острого холецистита и механической желтухи. В симптоматической стадии большинство опухолей нерезектабельны.

- В ранней стадии диагностика базируется на результатах патогистологического исследования. В поздних стадиях на УзИ и КТ выявляется опухоль жёлчного пузыря и перифокальные изменения.

○ Основным методом лечения рака жёлчного пузыря является операция - на ранней стадии проводят холецистэктомию. При прорастании опухоли в паренхиму печени и резектабельной стадии выполняют радикальную холецистэктомию или резекцию печени. При неоперабельных опухолях выполняют паллиативные операции - формирование обходных анастомозов или стентирование жёлчных протоков.

- Холангиокарциномы чаще развиваются в области ворот печени, редко - на внутрипечёночных жёлчных протоках (6\%).

○ Первичный склерозирующий холангит, внутрипечёночный холелитиаз, стриктуры, холедохолитиаз, кисты холедоха, аномалии развития являются факторами риска для возникновения холангиокарциномы.

○ Внутрипечёночные холангиокарциномы проявляютя как гепатоцеллюлярный рак, но в отличие от него развиваются на фоне нормальной печени.

○ Холангиокарциномы внепечёночных жёлчных протоков в начальной стадии протекают бессимптомно. По мере роста опухоли развиваются симптомы механической желтухи.

○ Для диагностики применяют холангиографию, томографию и ангиографию.

○ Лечение холангиокарциномы - радикальная резекция: при внутрипечёночной локализации злокачественного процесса показана резекция печени; при локализации опухоли в паренхиме и воротах печени резекция печени вместе с бифуркацией; при дистальной локализации 
опухоли выполняют панкреатодуоденальную резекцию. При нерезектабельных опухолях выполняют паллиативные операции: билиодигестивные анастомозы, стентирование.

\section{Вопросы и ответы по опухолям жёлчного пузыря}

\begin{tabular}{|c|c|}
\hline Вопросы & Ответы \\
\hline $\begin{array}{l}\text { Что такое карцинома жёлчного } \\
\text { пузыря? }\end{array}$ & $\begin{array}{l}\text { Злокачественная опухоль жёлчного } \\
\text { пузыря; большинство из них - } \\
\text { аденокарциномы (90\%). }\end{array}$ \\
\hline Частота встречаемости: & 0,3-1\% пациентов с холелитиазом. \\
\hline Факторы риска: & $\begin{array}{l}\text { - Желчекаменная болезнь (крупные } \\
\text { жёлчные камни); } \\
\text { - Наличие холецистоэнтерических } \\
\text { свищей; } \\
\text { - Кальциноз жёлчного пузыря; } \\
\text { - Аденома. }\end{array}$ \\
\hline Пути метастазирования: & $\begin{array}{l}\text { Как правило, локо-региональное (в } \\
\text { печень, окружающие ткани) } \\
\text { лимфатическое метастазирование. }\end{array}$ \\
\hline Клинические признаки: & $\begin{array}{l}\text { - } \text { Жёлчные колики (40\%); } \\
\text { - Острый холецистит (20\%); } \\
\text { - } \text { Механическая желтуха (35\%); } \\
\text { - Общие симптомы злокачественного } \\
\text { процесса (похудание, боли, потеря } \\
\text { аппетита), желудочно-кишечные } \\
\text { расстройства (30\%). }\end{array}$ \\
\hline Диагностика: & УЗИ, КТ, МРТ. \\
\hline $\begin{array}{l}\text { Дооперационная диагностика рака } \\
\text { жёлчного пузыря: }\end{array}$ & $\begin{array}{l}\text { Трудна. Инвазия в ткань печени, } \\
\text { кальциноз жёлчного пузыря, локальное } \\
\text { утолщение стенки могут вызвать } \\
\text { сомнение на рак жёлчного пузыря. }\end{array}$ \\
\hline $\begin{array}{l}\text { Интраоперационная диагностика рака } \\
\text { жёлчного пузыря: }\end{array}$ & $\begin{array}{l}\text { Трудно дифференцировать при наличии } \\
\text { деструктивного процесса. } \quad \text { При }\end{array}$ \\
\hline
\end{tabular}




\begin{tabular}{|c|c|}
\hline Вопросы & Ответы \\
\hline & $\begin{array}{l}\text { подозрении на рак проводится } \\
\text { интраоперационная срочная биопсия. }\end{array}$ \\
\hline Метод лечения: & Радикальная резекция. \\
\hline $\begin{array}{l}\text { Тактика лечения при локализации } \\
\text { процесса лишь в слизистом слое: }\end{array}$ & $\begin{array}{l}\text { Достаточно проведение } \\
\text { холецистэктомии. }\end{array}$ \\
\hline $\begin{array}{l}\text { Тактика лечения при распространении } \\
\text { процесса до мышечного слоя: }\end{array}$ & $\begin{array}{l}\text { Радикальная холецистэктомия: } \\
\text { холецистэктомия, краевая резекция } \\
\text { печени, лимфодиссекция. }\end{array}$ \\
\hline $\begin{array}{l}\text { Тактика лечения при распространении } \\
\text { процесса на долю печени: }\end{array}$ & Гемигепатэктомия. \\
\hline $\begin{array}{l}\text { Тактика лечения при } \\
\text { нерезектабельном раке осложнённом } \\
\text { механической желтухой: }\end{array}$ & $\begin{array}{l}\text { Паллиативные операции: } \\
\text { стентирование, сегментэктомия, } \\
\text { обходные анастомозы. }\end{array}$ \\
\hline $\begin{array}{l}\text { Тактика при обнаружении рака в } \\
\text { макропрепарате после } \\
\text { лапароскопической холецистэктомии: }\end{array}$ & $\begin{array}{l}\text { При локализации опухоли в слизистом } \\
\text { слое показано динамическое } \\
\text { наблюдение; при распространении } \\
\text { процесса на мышечный слой и глубже } \\
\text { показана повторная операция - } \\
\text { радикальная холецистэктомия или } \\
\text { резекция печени. }\end{array}$ \\
\hline
\end{tabular}

\section{Вопросы и ответы по холангиокарциноме}

\begin{tabular}{|c|c|}
\hline Вопросы & Ответы \\
\hline Что такое холангиокарцинома? & $\begin{array}{l}\text { Первичная злокачественная опухоль } \\
\text { внутри- и внепечёночных жёлчных } \\
\text { протоков. }\end{array}$ \\
\hline Гистологическая стриктура опухоли: & $\begin{array}{l}\text { В большинстве } \\
\text { аденокарцинома. }\end{array}$ \\
\hline Факторы риска: & $\begin{array}{l}\text { - Кисты холедоха; } \\
\text { - Неспецифический язвенный колит; } \\
\text { - Склерозирующий холангит; } \\
\text { - Паразиты в печени (chlonochiasis); } \\
\text { - Токсины. }\end{array}$ \\
\hline
\end{tabular}




\begin{tabular}{|c|c|}
\hline Вопросы & Ответы \\
\hline Клинические признаки: & $\begin{array}{l}\text { Признаки механической желтухи: } \\
\text { желтуха, кожный зуд, интенсивное } \\
\text { окрашивание мочи, ахоличный кал. }\end{array}$ \\
\hline Формы: & $\begin{array}{l}\text { По локализации различают } \\
\text { внутрипечёночную, воротную (опухоль } \\
\text { Клацкина) и внепечёночную формы. }\end{array}$ \\
\hline Что такое опухоль Клацкина? & $\begin{array}{l}\text { Холангиокарцинома места слияния } \\
\text { правого и левого долевого протока } \\
\text { печени. }\end{array}$ \\
\hline $\begin{array}{l}\text { Характерные особенности опухоли } \\
\text { Клацкина: }\end{array}$ & $\begin{array}{l}\text { - Наиболее часто встречающаяся } \\
\text { форма рака жёлчных протоков; } \\
\text { Расширение внутрипечёночных } \\
\text { жёлчных протоков, при нормальных } \\
\text { диаметрах внепечёночных } \\
\text { протоков; } \\
\text { - Склонна к распространению вдоль } \\
\text { жёлчных протоков и на окружающие } \\
\text { сосуды. }\end{array}$ \\
\hline Диагностика: & $\begin{array}{l}\text { УзИ, КТ, МРТ, эндоскопическое УЗИ, } \\
\text { ангиография, биопсия. }\end{array}$ \\
\hline Диагностические критерии: & $\begin{array}{l}\text { Наличие утолщения в стенке жёлчных } \\
\text { протоков при эндоскопическом УЗИ и } \\
\text { МРТ, данные эндоскопической } \\
\text { щёточной биопсии. }\end{array}$ \\
\hline $\begin{array}{l}\text { Лечение внутрипечёночной } \\
\text { холангиокарциномы: }\end{array}$ & Резекция печени. \\
\hline Лечение опухоли Клацкина: & $\begin{array}{l}\text { Резекция печени и формирование } \\
\text { гепатикоеюноанастомоза на } \\
\text { выключенной по Ру петле тощей кишки. }\end{array}$ \\
\hline $\begin{array}{l}\text { Лечение дистальной } \\
\text { холангиокарциномы: }\end{array}$ & Панкреатодуоденальная резекция. \\
\hline $\begin{array}{l}\text { Тактика при неоперабельной форме } \\
\text { опухоли: }\end{array}$ & $\begin{array}{l}\text { С целью устранения механической } \\
\text { желтухи проводят стентирование или } \\
\text { формирование обходных анастомозов. } \\
\text { При внутрипечёночной }\end{array}$ \\
\hline
\end{tabular}




\section{Вопросы}

Ответы

холангиокарциноме

проводится химиоэмболизация. 


\section{ПОВРЕЖДЕНИЕ ЖЁЛЧНЫХ ПРОТОКОВ}

- Повреждения жёлчных путей могут происходить в процессе хирургической операции или в результате полученной травмы (перерезка, перевязка протока), а также при повреждении артерии и развитии ишемии.

- Большинство повреждений жёлчных протоков происходит в процессе хирургической операции, меньшая часть - во время травмы.

- Холецистэктомия - частая причина повреждений жёлчных протоков; в 0,3-0,6\% случаев возможно развитие повреждений. Недостаточный обзор во время операции, ожирение, кровотечение, воспаление, грубая техника, недостаточный опыт хирургической бригады создают условия для повреждения жёлчных протоков.

- К клиническим признакам относятся утечка жёлчи при повреждении во время операции или в раннем послеоперационном периоде (из дренажной трубка, раны, скопление жёлчи в брюшной полости), а также механическая желтуха и холангит в позднем послеоперационном периоде.

- Для подтверждения диагноза проводят МР-холангиография. В большинстве случаев возникает необходимость в проведении контрастной холангиографии (ЭРХПГ или ЧЧХГ).

- С лечебной целью проводят формирование анастомозов (билио-билиарный, билиодигестивный), дренирование, стентирование. Выбор метода лечения зависит от времени обнаружения, локализации и степени повреждения. Выявленные во время операции повреждения при отсутствии противопоказаний могут быть восстановлены опытным хирургом. Если такой возможности нет, зону повреждения дренируют и больного переводят в специализированный центр. При повреждениях, выявленных в послеоперационном периоде, хирургическая коррекция должна быть отсрочена до полного стихания воспалительных процессов в зоне повреждения. При этом сроки восстановительных операций колеблются от 2-3 недель до 3-4 месяцев. В таких случаях для профилактики осложнений могут быть проведены стентирование или установление специальных билиарных катетеров. Срочная операция провидится при наличии абсцесса и перитонита. 


\section{Вопросы и ответы по повреждениям жёлчных протоков}

\section{Вопросы}

Что представляют собой повреждения жёлчных протоков?

Частота встречаемости:

Клинические формы:

Причины и факторы риска:

Механизмы повреждений:

Особенности клинического течения:

\section{Ответы}

Механическое нарушение целостности жёлчных протоков во время операции или в результате закрытой или открытой травмы живота.

При лапароскопической холецистэктомии составляет 0,2-0,3\%.

- Перерезка и формирование свищей (с утечкой жёлчи);

- Перевязка или окклюзия жёлчных протоков (признаки механической желтухи);

- Смешанные повреждения.

- Хирургические операции (95\%), травмы живота;

- Воспалительные процессы, фибротические и склеротические изменения, аномалии жёлчных протоков.

Перерезка, перевязка, котеризация, удаление части протока, недостаточное клипирование и др.

В раннем периоде - образование наружных жёлчных свищей или развитие механической желтухи.

В позднем - формирование рубцовой стриктуры жёлчных протоков.

\section{Осложнения:}

- Жёлчный асцит;

- Жёлчный перитонит;

- Билиома;

- Наружный жёлчный свищ;

- Рубцовая стриктура жёлчных протоков;

- Холангит;

- Холестатический гепатит; 


\begin{tabular}{|c|c|}
\hline Вопросы & Ответы \\
\hline & - Почечная недостаточность. \\
\hline Клинические признаки: & $\begin{array}{l}\text { - Интраоперационно - утечка жёлчи; } \\
\text { - В послеоперационном периоде - } \\
\text { утечка жёлчи и механическая } \\
\text { желтуха, стриктуры. }\end{array}$ \\
\hline $\begin{array}{l}\text { У каких пациентов можно } \\
\text { заподозрить? }\end{array}$ & $\begin{array}{l}\text { При неясной анатомии, утечке жёлчи во } \\
\text { время и после операции, выделении } \\
\text { жёлчи из дренажной трубки, желтухе, } \\
\text { перитоните, наличии жидкости в } \\
\text { брюшной полости, признаках } \\
\text { холангита, зуде, } \\
\text { внутрибрюшном абсцессе. }\end{array}$ \\
\hline Диагностика: & $\begin{array}{l}\text { МРТ, } \quad \text { интраоперационная } \\
\text { холангиография, ЭРХПГ, чЧХГ. }\end{array}$ \\
\hline Лабораторные признаки: & Признаки холестаза. \\
\hline $\begin{array}{l}\text { Признаки диагностической } \\
\text { визуализации: }\end{array}$ & $\begin{array}{l}\text { Экстравазация контрастного вещества } \\
\text { за пределы жёлчных протоков, наличие } \\
\text { «блока», стриктуры. }\end{array}$ \\
\hline Диагностические критерии: & 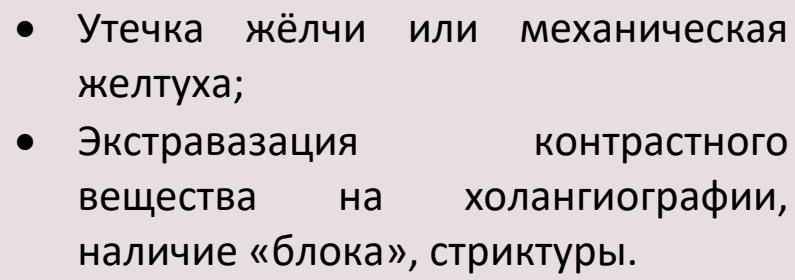 \\
\hline Методы лечения: & $\begin{array}{l}\text { - Хирургическое; } \\
\text { - Эндоскопическое; } \\
\text { - Чрескожное. }\end{array}$ \\
\hline Показания к хирургическому лечению: & $\begin{array}{l}\text { Жёлчный перитонит, рубцовая } \\
\text { стриктура жёлчных протоков. }\end{array}$ \\
\hline Методы хирургического лечения: & $\begin{array}{l}\text { - Первичное восстановление жёлчных } \\
\text { протоков путем формирования } \\
\text { анастомоза конец в конец; } \\
\text { - Реконструкция (формирование } \\
\text { билиодигестивных анастомозов). }\end{array}$ \\
\hline
\end{tabular}




\section{Вопросы}

\section{Ответы}

Прогноз:

Своевременное

выявление

и адекватное восстановление дефекта дают благоприятные результаты. 


\section{ФУНКЦИОНАЛЬНЫЕ ЗАБОЛЕВАНИЯ ЖЁЛЧНЫХ ПУТЕЙ}

- Обнаружение у пациентов с признаками нарушения функции жёлчный путей морфологических (конкременты, опухоли, воспаление и др.) или гормональных изменений (беременность, диабет и др.) в процессе клинических, лабораторных исследований, а также в методах визуализации определяется как вторичные функциональные заболевания жёлчных путей, при отсутствии таковых - это первичные функциональные заболевания.

- Самые часто встречаемые функциональные заболевания жёлчных путей - это дискинезия жёлчного пузыря и дисфункция сфинктера Одди.

- Дискинезия жёлчного пузыря - функциональное заболевание, характеризующееся нарушением функции (сокращения) жёлчного пузыря.

○ При этом макроскопически не обнаруживается какая-либо патология, однако имеются изменения на микроскопическом уровне.

○ Заболевание чаще встречается у женщин 25-30 лет.

○ Различают 2 клинические формы: гиперкинетическая и гипокинетическая.

○ Гиперкинетическая форма характеризуется классическим приступом жёлчной колики, а гипокинетическая форма проявляется тупыми болями в правом подреберье после приёма пищи.

○ Диагностика основана на исключении заболеваний жёлчных путей, желудочно-кишечного тракта, сердца. Определяют также объём порций жёлчи.

○ К диагностическим критериям относятся наличие жёлчной колики, отсутствие органической патологии в жёлчном пузыре и жёлчных путях при клинических, лабораторных и инструментальных методах диагностики, снижение объёма порций жёлчи (<30\%), определение кристаллов в составе жёлчи.

○ Лечение - лапароскопическая холецистэктомия.

- Дисфункция сфинктера Одди - это частичное или полное сужение сфинктера Одди в результате фиброза, воспалительного процесса или спазма.

○ Основным клиническим признаком является боль.

- Имеются 3 клинические формы: билиарная, панкреатическая и смешанная.

- Билиарная форма проявляется жёлчной коликой у пациентов с акалькулёзным холециститом и постхолецистэктомическим синдромом. Панкреатическая форма проявляется признаками острого и хронического панкреатита.

○ Диагноз подтверждается при исключении других заболеваний, являющихся причиной жёлчной колики, и при определении проходимости сфинктера Одди. Для определения состояния сфинктера Одди проводятся нагрузочные пробы (приём жирной пищи, проба с секретином, холецистокинином), 
манометрия, учитываются клинические показатели (диаметр холедоха, наличие болей, приём ферментных препаратов), время пассажа контрастного вещества, а также лечебные пробы (стентирование, дилатация, введение ботулотоксина).

○ Наличие приступов жёлчной колики и панкреатита, отсутствие конкрементов в холедохе и дискинезии жёлчного пузыря, расширение холедоха или нарушение проходимости сфинктера Одди относятся к диагностическим критериям.

О Основное лечение дисфункции сфинктера Одди - папиллосфинктеротомия. Расширение диаметра холедоха, высокое давление в области сфинктера и повторные случаи панкреатита являются показаниями к данной процедуре.

Вопросы и ответы по функциональным заболеваниям жёлчных путей

\begin{tabular}{|c|c|}
\hline Вопросы & Ответы \\
\hline $\begin{array}{l}\text { Что представляют собой } \\
\text { функциональные заболевания } \\
\text { жёлчных путей? }\end{array}$ & $\begin{array}{lrr}\text { Состояния, при которых наблюдаются } \\
\text { клинические } \quad \text { признаки } \\
\text { функциональные } \quad \text { нарушения } \\
\text { макроскопических изменений. }\end{array}$ \\
\hline $\begin{array}{l}\text { Функциональные заболевания } \\
\text { жёлчных путей: }\end{array}$ & $\begin{array}{l}\text { - Дискинезия жёлчного пузыря; } \\
\text { - Дисфункция сфинктера Одди. }\end{array}$ \\
\hline $\begin{array}{l}\text { Другие названия дискинезии } \\
\text { жёлчного пузыря: }\end{array}$ & $\begin{array}{l}\text { Хронический акалькулёзный } \\
\text { холецистит, бескаменная жёлчная } \\
\text { колика. }\end{array}$ \\
\hline $\begin{array}{l}\text { Механизм дискинезии жёлчного } \\
\text { пузыря: }\end{array}$ & 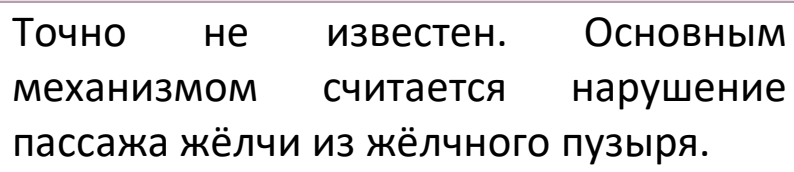 \\
\hline Формы дискинезии жёлчного пузыря: & Гиперкинетическая и гипокинетическая. \\
\hline Клинические признаки: & $\begin{array}{l}\text { Гиперкинетическая форма проявляется } \\
\text { классической жёлчной коликой, при } \\
\text { гипокинетической форме наблюдаются } \\
\text { тупые боли после приёма пищи. }\end{array}$ \\
\hline Диагностика: & $\begin{array}{l}\text { Диагноз основан на трёх основных } \\
\text { критериях: } \\
\text { • Наличие жёлчной колики и болей; }\end{array}$ \\
\hline
\end{tabular}




\begin{tabular}{|c|c|}
\hline Вопросы & Ответы \\
\hline & $\begin{array}{l}\text { - Отсутствие камней в жёлчном } \\
\text { пузыре и органических патологий } \\
\text { жёлчных протоков; } \\
\text { - Снижение фракции жёлчи (<35-50\%), } \\
\text { наличие в составе кристаллов. }\end{array}$ \\
\hline Лечение: & Лапароскопическая холецистэктомия. \\
\hline $\begin{array}{l}\text { Что такое дисфункция сфинктера } \\
\text { Одди? }\end{array}$ & $\begin{array}{l}\text { Частичное или полное сужение } \\
\text { сфинктера Одди в результате фиброза, } \\
\text { воспалительного процесса или спазма. }\end{array}$ \\
\hline $\begin{array}{l}\text { Относятся ли сужения, вызванные } \\
\text { опухолью сфинктера или окружающих } \\
\text { тканей, к дисфункции сфинктера } \\
\text { Одди? }\end{array}$ & Нет. \\
\hline $\begin{array}{l}\text { У каких пациентов встречается } \\
\text { наиболее часто? }\end{array}$ & 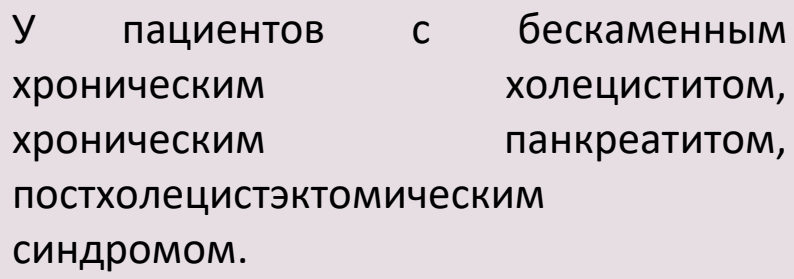 \\
\hline Клинические признаки: & $\begin{array}{l}\text { - Билиарный тип - с признаками } \\
\text { жёлчной колики; } \\
\text { - Панкреатический тип-спризнаками } \\
\text { острого панкреатита и болями в } \\
\text { левом подреберье; } \\
\text { - Смешанный тип - с признаками } \\
\text { обоихтипов. }\end{array}$ \\
\hline Диагностика: & $\begin{array}{l}\text { УЗИ, лабораторные исследования, МРТ, } \\
\text { эндоскопия, эндоскопическое УЗИ, } \\
\text { ЭРХПГ, манометрия. }\end{array}$ \\
\hline Диагностические критерии: & $\begin{array}{l}\text { - Наличие признаков жёлчной колики } \\
\text { и острого панкреатита; } \\
\text { - Отсутствие дискинезии и } \\
\text { конкрементов в желчном пузыре, } \\
\text { холедохе; }\end{array}$ \\
\hline
\end{tabular}




\begin{tabular}{|c|c|}
\hline Вопросы & Ответы \\
\hline & 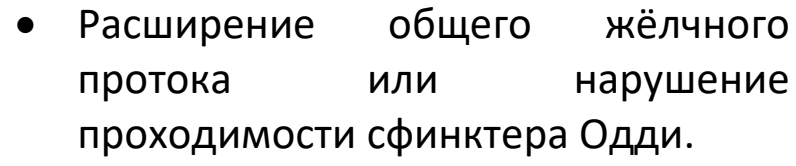 \\
\hline $\begin{array}{l}\text { Как определяют проходимость } \\
\text { сфинктера Одди? }\end{array}$ & $\begin{array}{l}\text { - Нагрузочные пробы (приём жирной } \\
\text { пищи, проба с секретином, } \\
\text { холецистокинином); } \\
\text { - Манометрия; } \\
\text { - Клинические показатели (диаметр } \\
\text { холедоха, наличие болей, приём } \\
\text { ферментныхпрепаратов); } \\
\text { - Время пассажа контрастного } \\
\text { вещества; } \\
\text { - Лечебные пробы (стентирование, } \\
\text { дилатация, } \\
\text { ботулотоксина). }\end{array}$ \\
\hline Лечение: & Папиллосфинктеротомия. \\
\hline
\end{tabular}




\section{КИСТЫ ЖЁЛЧНЫХ ПРОТОКОВ}

- Кисты жёлчных протоков представляют собой локальное мешковидное или шаровидное расширение.

- В развитии кист жёлчных протоков лежат врождённые аномалии. Часто они сочетаются с аномалиями протока поджелудочной железы и общего печёночного жёлчного протока.

- В зависимости от локализации различают следующие виды кист:

○ І тип-диффузное расширение холедоха;

○ II тип - дивертикул холедоха;

О III тип - холедохоцеле;

○ IV тип - множественные внутренние и наружные кисты жёлчных протоков;

○ V тип - множественные кисты внутренних жёлчных протоков (болезнь Кароли).

- Большинство кист обнаруживаются в возрасте до 10-и лет. Могут протекать бессимптомно или проявляться желтухой, холестазом, тупыми болями в эпигастральной области и правом подреберье, пальпируемым образованием в этой области, признаками холангита.

- Имеется риск малигнизации эпителия кисты.

- Кисты обнаруживаются на УЗИ, КТ и во время операции. Для подтверждения проводят холангиографию для определения сообщения кисты с жёлчными протоками.

- С лечебной целью проводится удаление кисты и формирование билиодигестивного анастомоза. Если нет возможности удаление кисты, необходимо удалить эпителий кисты из-за риска малигнизации. При болезни Кароли проводится резекция, а при необходимости - трансплантация печени.

\section{Вопросы и ответы по кистам жёлчных протоков}

\begin{tabular}{|c|c|}
\hline Вопросы & Ответы \\
\hline $\begin{array}{l}\text { Что собой представляют кисты } \\
\text { жёлчных протоков? }\end{array}$ & $\begin{array}{l}\text { Локальное мешковидное расширение } \\
\text { жёлчных протоков. }\end{array}$ \\
\hline Частота встречаемости: & $\begin{array}{l}\text { - } 1: 100000 ; \\
\text { - Чаще встречается у женского пола } \\
\text { (1:3); } \\
\text { - Основным контингентом (60\%) } \\
\text { являются дети в возрасте до } 10 \text { лет. }\end{array}$ \\
\hline
\end{tabular}




\begin{tabular}{|c|c|}
\hline Вопросы & Ответы \\
\hline Клинические формы: & $\begin{array}{l}\text { В зависимости от локализации } \\
\text { различают } 5 \text { типов кист (классификация } \\
\text { Алонсо-Лей): } \\
\text { - I тип - диффузное расширение } \\
\text { холедоха; } \\
\text { - II тип-дивертикул холедоха; } \\
\text { - III тип-холедохоцеле; } \\
\text { - IV тип-множественные внутренние } \\
\text { и наружные кисты жёлчных } \\
\text { протоков; } \\
\text { - V тип - множественные кисты } \\
\text { внутренних жёлчных протоков } \\
\text { (болезнь Кароли). }\end{array}$ \\
\hline Причины: & $\begin{array}{l}\text { В основном обусловлены } \\
\text { врождёнными аномалиями жёлчных } \\
\text { протоков. }\end{array}$ \\
\hline Патогенез: & $\begin{array}{l}\text { Считают, что развиваются вследствие } \\
\text { мутации гена кистозного фиброза. }\end{array}$ \\
\hline Особенности клинического течения: & $\begin{array}{l}\text { - В большинстве случаев протекает } \\
\text { бессимптомно; } \\
\text { - У зо\% больных проявляются застоем } \\
\text { жёлчи, холангитом и механической } \\
\text { желтухой, образованием жёлчных } \\
\text { камней. }\end{array}$ \\
\hline Осложнения: & $\begin{array}{l}\text { - В редких случаях развивается } \\
\text { панкреатит, хроническая } \\
\text { дуоденальная непроходимость, } \\
\text { портальная гипертензия; } \\
\text { - В 15-20\% случаев являются причиной } \\
\text { холангиокарциномы. }\end{array}$ \\
\hline Клинические признаки: & $\begin{array}{l}\text { - Боли в эпигастральной области и } \\
\text { правом подреберье; } \\
\text { - Пальпируемое образование в этой } \\
\text { области; } \\
\text { - Механическая желтуха. }\end{array}$ \\
\hline
\end{tabular}




\begin{tabular}{|c|c|}
\hline Вопросы & Ответы \\
\hline $\begin{array}{l}\text { У каких пациентов можно } \\
\text { заподозрить? }\end{array}$ & $\begin{array}{l}\text { - У пациентов с холангитом; } \\
\text { - При наличии расширенных жёлчных } \\
\text { протоков на УзИ без признаков } \\
\text { холестаза; } \\
\text { - Наличие кист в паренхиме или в } \\
\text { воротах печение на УзИ и КТ. }\end{array}$ \\
\hline Диагностика: & $\begin{array}{l}\text { - МР-холангиография; } \\
\text { - ЭРХПГ, ЧЧХГ. }\end{array}$ \\
\hline Лабораторные признаки: & $\begin{array}{l}\text { Нет специфических признаков. Могут } \\
\text { быть изменения в печёночных пробах. }\end{array}$ \\
\hline $\begin{array}{l}\text { Признаки диагностической } \\
\text { визуализации: }\end{array}$ & $\begin{array}{l}\text { Наличие кистозных расширений, } \\
\text { сообщающихся с жёлчными протоками, } \\
\text { при холангиографии. }\end{array}$ \\
\hline Диагностические критерии: & $\begin{array}{l}\text { Наличие кистозных расширений, } \\
\text { сообщающихся с жёлчными протоками, } \\
\text { при холангиографии. }\end{array}$ \\
\hline Методы лечения: & Хирургическое. \\
\hline Показание к хирургическому лечению: & Наличие кисты. \\
\hline Методы хирургического лечения: & 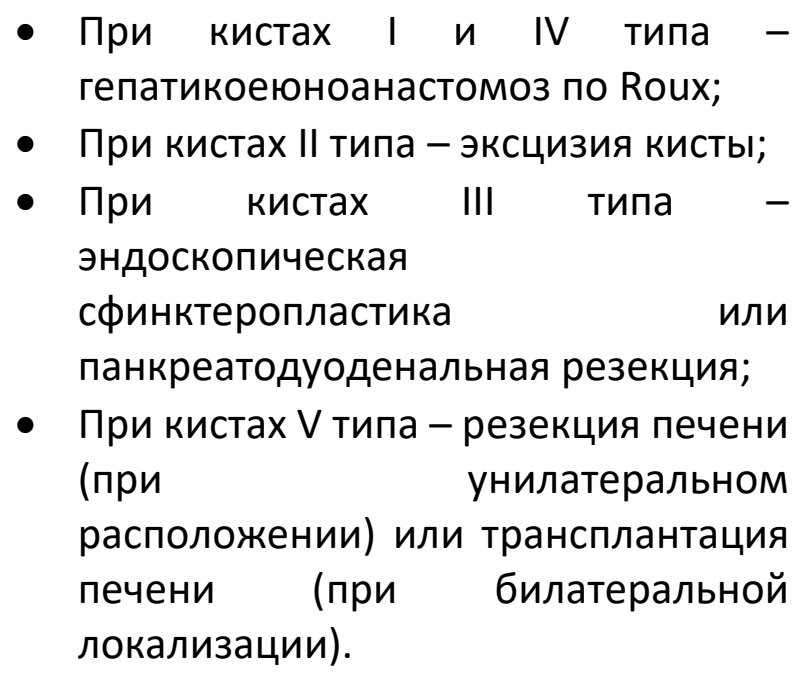 \\
\hline Какая операция не рекомендуется: & $\begin{array}{l}\text { Формирование } \\
\text { анастомозов, т. к. естодигестивных } \\
\text { малигнизации кисты. }\end{array}$ \\
\hline
\end{tabular}




\begin{tabular}{|ll|}
\hline \multicolumn{1}{|c|}{ Вопросы } & \multicolumn{1}{c|}{ Ответы } \\
\hline Прогноз: & $\begin{array}{l}\text { После хирургического лечения - } \\
\text { благоприятный. }\end{array}$ \\
\hline $\begin{array}{l}\text { Характерная особенность данного } \\
\text { заболевания: }\end{array}$ & $\begin{array}{l}\text { При наличии кисты жёлчных протоков } \\
\text { показана радикальная операция. }\end{array}$ \\
\hline
\end{tabular}




\section{ПОСТХОЛЕЦИСТЭКТОМИЧЕСКИЙ СИНДРОМ}

- Постхолецистэктомический синдром представляет собой боли и признаки диспепсии, которые возникают или сохраняются (рецидивируют) после холецистэктомии. Боль может быть такой же или отличаться от предоперационной и обычно повторяется.

- Диагноз постхолецистэктомического синдрома ставится в 2-х случаях: в качестве первоначального (рабочего) диагноза или основного заболевания.

- Постхолецистэктомический синдром может использоваться в качестве первоначального (рабочего) диагноза у пациентов с жёлчной коликой после холецистэктомии и отсутствием объективных причин.

- Если последующие лабораторные, функциональные исследования и методы диагностической визуализации не выявляют причин жёлчной колики, патологий в поджелудочной железе, желудочно-кишечном тракте и других органах, и при исключении патологий, которые могут быть вызваны хирургическим вмешательством (длинная культя пузырного протока, стеноз, спайки и невринома раны), то постхолецистэктомический синдром может быть представлен как основной диагноз.

- В большинстве случаев удаётся определить причину постхолецистэктомического синдрома, но примерно у $1 / 5$ пациентов причина боли не может быть определена, что называется истинным постхолецистэктомическим синдромом.

- Холедохолитиаз, язвенная болезнь, панкреатит, дисфункция сфинктера Одди и спастический колит являются наиболее частыми причинами постхолецистэктомического синдрома.

- Лечение постхолецистэктомического синдрома включает устранение причины, тогда как при истинном постхолецистэктомическом синдроме на первый план выходят седативные препараты и психотерапия.

\section{Вопросы и ответы по постхолецистэктомическому синдрому}

\begin{tabular}{|ll|}
\multicolumn{1}{|c|}{ Вопросы } & \multicolumn{2}{c|}{ Ответы } \\
\hline $\begin{array}{l}\text { Что такое постхолецистэктомический } \\
\text { синдром? }\end{array}$ & $\begin{array}{l}\text { Боли и диспепсические явления после } \\
\text { холецистэктомии. }\end{array}$ \\
\hline Частота встречаемости: & $20 \%$. \\
\hline Причины: & Патологии, несвязанные с \\
& $\begin{array}{l}\text { хирургической операцией; } \\
\text { Осложнения }\end{array}$ \\
& операций;
\end{tabular}




\begin{tabular}{|c|c|}
\hline Вопросы & Ответы \\
\hline & $\begin{array}{l}\text { - Функциональные нарушения, } \\
\text { связанные с удалением жёлчного } \\
\text { пузыря. }\end{array}$ \\
\hline $\begin{array}{l}\text { Частые причины } \\
\text { постхолецистэктомического } \\
\text { синдрома: }\end{array}$ & $\begin{array}{l}\text { - Холедохолитиаз (30\%); } \\
\text { - Язвенная болезнь, панкреатит и } \\
\text { гепатит (30\%); } \\
\text { - Дисфункция сфинктера Одди (10\%); } \\
\text { - Спастический колит и другие } \\
\text { патологии кишечника. }\end{array}$ \\
\hline $\begin{array}{l}\text { Функциональные нарушения, } \\
\text { связанные с удалением жёлчного } \\
\text { пузыря: }\end{array}$ & Диарея и рефлюкс-гастрит. \\
\hline $\begin{array}{l}\text { Какие осложнения после } \\
\text { холецистэктомии могут быть } \\
\text { причиной постхолецистэктомического } \\
\text { синдрома? }\end{array}$ & $\begin{array}{l}\text { Длинная культя пузырного протока, } \\
\text { спайки, невринома раны. }\end{array}$ \\
\hline $\begin{array}{l}\text { В каких случаях ставится диагноз } \\
\text { постхолецистэктомического } \\
\text { синдрома? }\end{array}$ & $\begin{array}{l}\text { Как первоначальный (рабочий) диагноз } \\
\text { и как основной диагноз. }\end{array}$ \\
\hline $\begin{array}{l}\text { Что представляет собой } \\
\text { постхолецистэктомический синдром в } \\
\text { качестве первоначального диагноза? }\end{array}$ & $\begin{array}{l}\text { Наличие жёлчных колик после } \\
\text { холецистэктомии и } \\
\text { объективных причин при клиническом } \\
\text { обследовании. }\end{array}$ \\
\hline $\begin{array}{l}\text { Что представляет собой } \\
\text { постхолецистэктомический синдром в } \\
\text { качестве основного диагноза? }\end{array}$ & 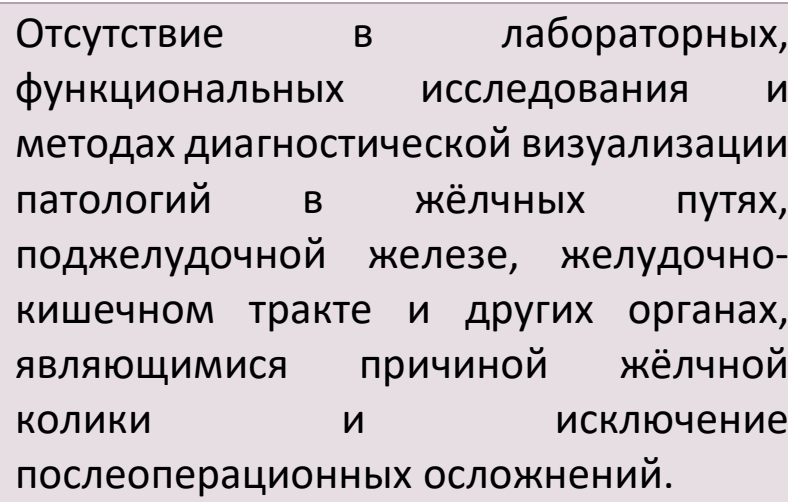 \\
\hline $\begin{array}{l}\text { Цель и последовательность } \\
\text { диагностических методов при } \\
\text { постхолецистэктомическом синдроме: }\end{array}$ & $\begin{array}{l}\text { Основная цель-определение причины: } \\
\text { обследуются жёлчные протоки, } \\
\text { поджелудочная железа, желудочно- }\end{array}$ \\
\hline
\end{tabular}




\begin{tabular}{|c|c|}
\hline Вопросы & Ответы \\
\hline & $\begin{array}{l}\text { кишечный тракт, печень, сфинктер } \\
\text { Одди и другие органы. }\end{array}$ \\
\hline \multirow[t]{2}{*}{ Диагностика: } & обследование, \\
\hline & $\begin{array}{l}\text { лабораторные данные, МРТ, } \\
\text { эндоскопия, функциональные методы } \\
\text { исследования. }\end{array}$ \\
\hline $\begin{array}{l}\text { У скольких пациентов невозможно } \\
\text { определить причину } \\
\text { постхолецистэктомического } \\
\text { синдрома? }\end{array}$ & y $20 \%$ \\
\hline $\begin{array}{l}\text { Лечение постхолецистэктомического } \\
\text { синдрома: }\end{array}$ & Устранение причины. \\
\hline $\begin{array}{l}\text { Лечение постхолецистэктомического } \\
\text { синдрома при невозможности } \\
\text { определения причины: }\end{array}$ & $\begin{array}{l}\text { Транквилизаторы, спазмолитики, } \\
\text { динамическое наблюдение. }\end{array}$ \\
\hline
\end{tabular}




\section{СПИСОК ЛИТЕРАТУРЫ}

\section{Общая литература}

- Ağayev B.A. Cərrahi xəstəliklər. Bakı 2010.

- Blackbourne LH. Surgical Recall. 4 edition, 2006, LWW, Philadelphia

- Doherty GM. Current Diagnosis and Treatment: Surgery, $13^{\text {th }}$ edition, 2010, Lang International Edition.

- Omiraslanov Ә.T., Qazıyev A.Y. Onkologiya. Bakı, 2010.

- İsayev H.B. Cərrahi xəstəliklərin patofizologiyası. Bakı 2005

- Klingensmith ME, Aziz A, Bharat A, Fox AC, Porembka MR. The Washington Manual of Surgery, $6^{\text {th }}$ edition, 2012, LWW, Philadelphia.

- McNally PR. GI/Liver Secrets Plus. 4 edition. Mosby, Elsevier, 2010

- Medscape, http://www.medscape.com

- Oxford Handbook of Clinical Surgery, 3d edition, 2011, Oxford Press

- Sayek I. Sayek Temel Cerrahi 1-2. 4-cü baskı, 2016, Güneş Tıp Kitabevleri.

- Topçubaşov M.A. Xüsusi cərrahlıq. Bakı, 1979

- UpToDate, http://www.uptodate.com

- Гостищев B.К. Общая хирургия. GEOTAR-Media, 2019

\section{Специальная литература}

- Alan A Bloom, Julian Katz. Cholecystitis. Medscape, Apr 01, 2014.

- Bayramov N.Y. Təcili Abdominal cərrahiyyədə müayinə və müalicə qaydaları. ISBN13 978-9952-8082-1-6, Qismət, Bakı 2009. $132 \mathrm{~s}$.

- Bayramov N.Y. Cərrahiyyə Seminarları: Öd yollarının cərrahi xəstəlikləri. ISBN: 97592103-0-4, Ankara 2004, 320s.

- Evaluation and management of gallstone-related diseases in non-pregnant adults.2014 May. NGC:010429. University of Michigan Health System - Academic Institution. http://www.guideline.gov

- McNally PR. GI/Liver Serets Plus. 4 edition. Mosby, Elsevier, 2010 


\section{ХИРУРГИЧЕСКИЕ БОЛЕЗНИ}

Н.Ю. Байрамов

\section{Хирургические заболевания поджелудочной железы}

Н.Ю. Байрамов, Т.И. Омаров, А.К. Сафиева, Ф.Ф. Ахмадов

Перевод: Н.Ю. Байрамов, С.А. Алиев, М.Р.Гусейнова 


\section{ОСТРЫЙ ПАНКРЕАТИТ}

- Острый панкреатит - аутокаталитический деструктивный процесс, вызванный липолитическими и активированными протеолитическими ферментами поджелудочной железы, который может осложняться SiRS/сепсисом.

- $\mathrm{K}$ самым распространённым причинам острого панкреатита относятся заболевания жёлчных путей, алкоголь и гипертриглицеридемия.

- Заболевание начинается острой эпигастральной болью, неукротимой рвотой, состояние пациента ухудшается в течение нескольких часов.

- В большинстве случаев заболевание протекает в лёгкой форме, состояние пациента стабилизируется в течение 5-6 дней на фоне анальгетиков и инфузионной терапии. Однако у $1 / 5$ пациентов наблюдается тяжёлое течение с деструкцией самой железы и окружающих тканей, инфекционными и геморрагическими осложнениями, сепсисом и летальным исходом.

- Диагностика острого панкреатита основывается на лабораторных обследованиях (повышение амилазы), данных УзИ, КТ, МРТ (наличие отёка, некроза, жидкости вокруг поджелудочной железы), наличии острой продолжающей боли.

- Лечение острого панкреатита в большинстве случаев консервативное, хирургическое и малоинвазивное лечение проводится по показаниям (дифференциация с другими острыми хирургическими патологиями, ухудшение состояния несмотря на интенсивную терапию, билиарный панкреатит, инфекционный некроз).

\section{Вопросы и ответы по острому панкреатиту}

\begin{tabular}{|ll|}
\hline \multicolumn{1}{|c|}{ Вопросы } & \multicolumn{1}{c|}{ Ответы } \\
\hline Что такое острый панкреатит? & $\begin{array}{l}\text { Воспалительный } \\
\text { поджелудочной железы. }\end{array}$ \\
\hline $\begin{array}{ll}\text { Основные причины острого } \\
\text { панкреатита: }\end{array}$ & Заболевание желчевыводящих \\
& протоков (40\%); \\
& - Алкоголизм (35-40\%); \\
& $\bullet$ Гиперлипидемия $(5-10 \%) ;$ \\
\hline
\end{tabular}




\begin{tabular}{|c|c|}
\hline Вопросы & Ответы \\
\hline & • Идиопатические панкреатит (3-10\%). \\
\hline Патогенез острого панкреатита: & $\begin{array}{l}\text { Аутолиз ткани поджелудочной железы } \\
\text { собственными ферментами. }\end{array}$ \\
\hline $\begin{array}{l}\text { Где и каким путём активируются } \\
\text { ферменты поджелудочной железы? }\end{array}$ & 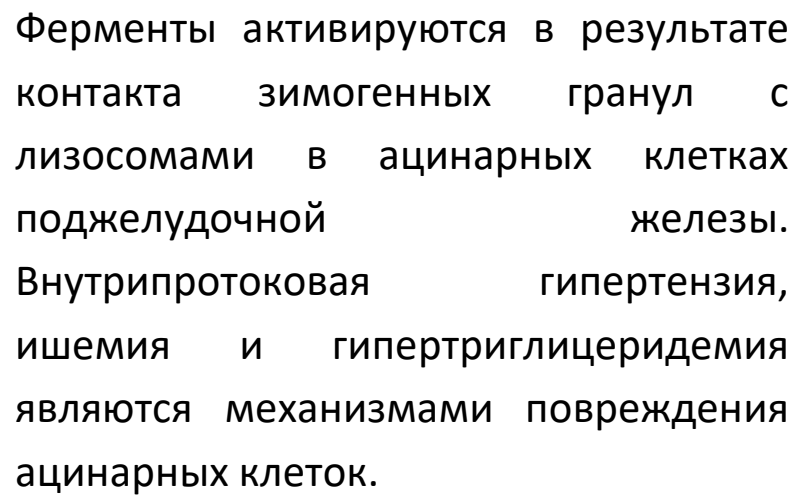 \\
\hline $\begin{array}{l}\text { Клинические формы острого } \\
\text { панкреатита: }\end{array}$ & $\begin{array}{l}\text { - ёгкая (отёчная, абортивная); } \\
\text { • Тяжёлая; } \\
\text { • Молниеносная (фульминантная). }\end{array}$ \\
\hline $\begin{array}{l}\text { Являются ли клинические формы } \\
\text { отдельными формами или } \\
\text { представляют собой разные фазы } \\
\text { единого патологического процесса? }\end{array}$ & $\begin{array}{l}\text { Являются самостоятельными } \\
\text { клиническими формами. }\end{array}$ \\
\hline $\begin{array}{l}\text { Что представляет собой лёгкая форма } \\
\text { острого панкреатита? }\end{array}$ & $\begin{array}{l}\text { Называется также отёчной формой } \\
\text { острого панкреатита, составляет 80-85\% } \\
\text { всех форм, имеет абортивное течение } \\
\text { (в 90-95\%) или подлежит } \\
\text { консервативному лечению. }\end{array}$ \\
\hline Чем характеризуется тяжёлая форма? & $\begin{array}{l}\text { Называется также деструктивным } \\
\text { панкреатитом, встречается в 10-15\% } \\
\text { случаев, характеризуется наличием }\end{array}$ \\
\hline & $\begin{array}{lcc}\text { макроскопических } & \text { липидных } & \text { и } \\
\text { геморрагических } & \text { некрозов }(10 \%) & \text { в }\end{array}$ \\
\hline
\end{tabular}




\begin{tabular}{|c|c|}
\hline Boпросы & Ответы \\
\hline & $\begin{array}{l}\text { самой железе и вокруг неё, развитием } \\
\text { органной (полиорганной) дисфункции и } \\
\text { осложнений. }\end{array}$ \\
\hline $\begin{array}{l}\text { Чем характеризуется фульминантная } \\
\text { форма? }\end{array}$ & 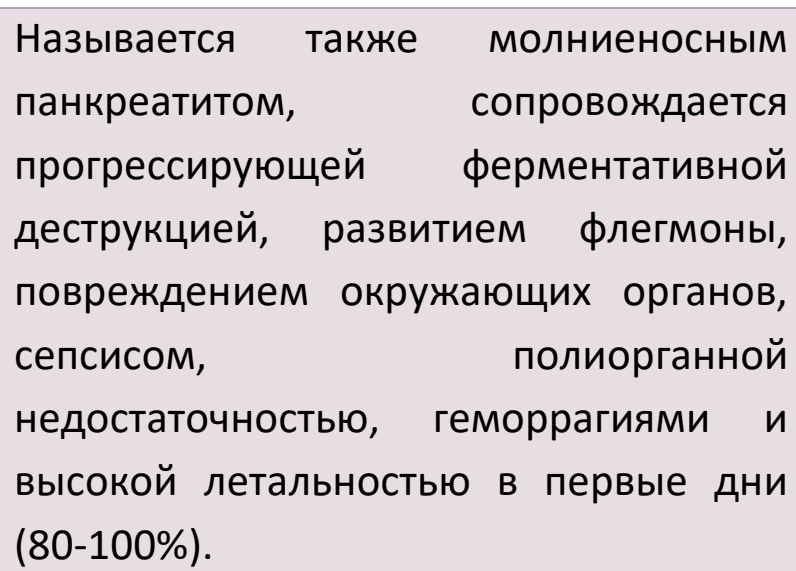 \\
\hline Осложнения острого панкреатита: & $\begin{array}{l}\text { - Перитонит; } \\
\text { - Асептический некроз; } \\
\text { - Инфекционный панкреатит; } \\
\text { - Псевдокисты; } \\
\text { - Перфорация полых органов; } \\
\text { - Псевдоаневризмы (селезёночной и } \\
\text { левой желудочной артерий); } \\
\text { - Кровотечения; } \\
\text { - Плеврит; } \\
\text { - Панкреатический асцит; } \\
\text { - Диабет; } \\
\text { - Шок, сепсис, полиорганная } \\
\text { недостаточность. }\end{array}$ \\
\hline $\begin{array}{l}\text { Клинические признаки острого } \\
\text { панкреатита: }\end{array}$ & $\begin{array}{l}\text { Сильные и продолжающие боли в } \\
\text { эпигастральной } \\
\text { иррадирующие в лопаточную область, } \\
\text { тошнота, обильная рвота. }\end{array}$ \\
\hline $\begin{array}{l}\text { Объективные признаки острого } \\
\text { панкреатита: }\end{array}$ & $\begin{array}{ll}\text { Пальпаторная } & \text { болезненность в } \\
\text { эпигастральной } & \text { области, наличие }\end{array}$ \\
\hline
\end{tabular}




\begin{tabular}{|c|c|}
\hline Вопросы & Ответы \\
\hline & $\begin{array}{l}\text { инфильтрата в эпигастральной области, } \\
\text { отсутствие перистальтических шумов } \\
\text { кишечника, высокая температура, } \\
\text { дегидратация, шок. }\end{array}$ \\
\hline $\begin{array}{l}\text { С какими заболеваниями необходимо } \\
\text { дифференцировать? }\end{array}$ & $\begin{array}{l}\text { - Тромбоз мезентериальных сосудов; } \\
\text { - } \text { Разрыв аневризмы аорты; } \\
\text { - Перфоративная } \\
\text { - астродуоденальная язва; } \\
\text { - Острый холецистит; } \\
\text { - Острый холангит; } \\
\text { - } \text { Острый аппендицит; } \\
\text { Разрыв кисты яичника и др. }\end{array}$ \\
\hline Лабораторная диагностика: & 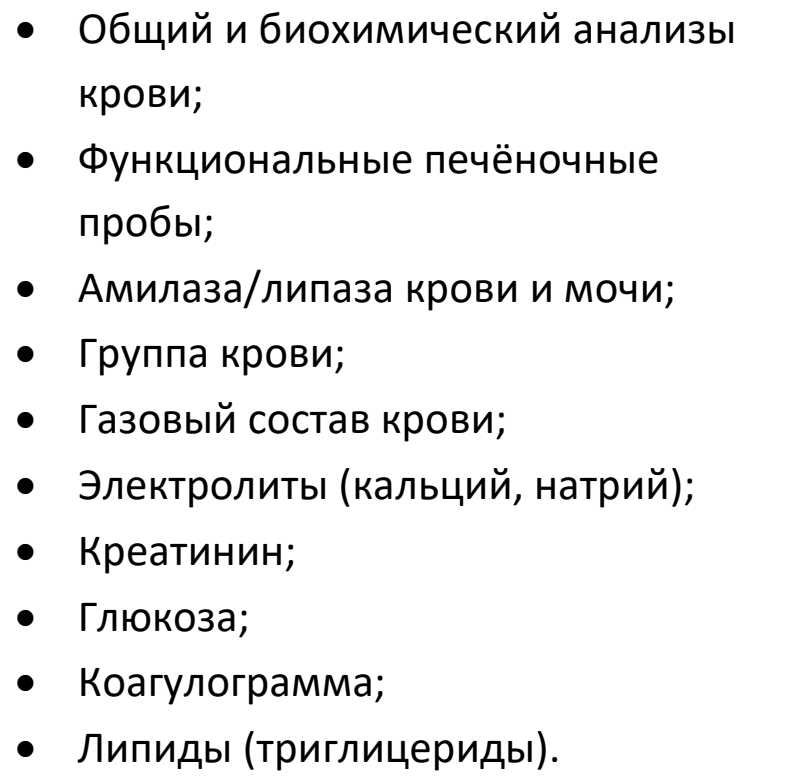 \\
\hline $\begin{array}{l}\text { Какие лабораторные изменения } \\
\text { характерны для острого панкреатита? }\end{array}$ & $\begin{array}{l}\text { Повышение концентрации амилазы в } 3 \\
\text { раза и более, повышение липазы, } \\
\text { гипокальциемия, гипергликемия, } \\
\text { лейкоцитоз, показатели дисфункции } \\
\text { органов. }\end{array}$ \\
\hline
\end{tabular}




\begin{tabular}{|c|c|}
\hline Вопросы & Ответы \\
\hline Чем объясняется гипокальциемия? & $\begin{array}{ll}\text { Вследствие } & \text { жирового } \\
\text { происходит } & \text { скопленоза } \\
\text { кальция в очаги некроза. } & \text { катионов }\end{array}$ \\
\hline $\begin{array}{l}\text { Методы инструментальной } \\
\text { диагностики: }\end{array}$ & УЗИ, КТ, МРТ, эндоскопическое УЗИ. \\
\hline $\begin{array}{l}\text { Наиболее информативный метод } \\
\text { диагностики: }\end{array}$ & КТ ("золотой стандарт"). \\
\hline Что определяется на УЗИ? & $\begin{array}{l}\text { Увеличение размеров, изменение } \\
\text { контуров и структуры поджелудочной } \\
\text { железы, наличие жидкости в } \\
\text { парапанкреатической } \\
\text { наличие кист. }\end{array}$ \\
\hline Что определяется на КТ/МРТ? & $\begin{array}{l}\text { Увеличение размеров, изменение } \\
\text { контуров, структуры железистой } \\
\text { паренхимы, скопление жидкости в } \\
\text { парапанкреатическое пространство и } \\
\text { брюшную полость. }\end{array}$ \\
\hline $\begin{array}{l}\text { В какие сроки заболевания КТ более } \\
\text { информативна? }\end{array}$ & $\begin{array}{l}\text { В течение 24-48 часов от момента } \\
\text { начала заболевания. }\end{array}$ \\
\hline Когда информативна МРТ: & $\begin{array}{l}\text { При сомнении на патологию } \\
\text { желчевыводящих протоков. }\end{array}$ \\
\hline $\begin{array}{l}\text { Диагностические критерии острого } \\
\text { панкреатита: }\end{array}$ & $\begin{array}{l}\text { Клинические: сильные постоянные } \\
\text { боли в эпигастральной области } \\
\text { опоясывающего характера, наличие } \\
\text { образования в брюшной полости. } \\
\text { Лабораторные: повышение амилазы в } 3 \\
\text { раза и более. } \\
\text { Инструментальные: } \\
\text { размеров, изменение контуров и } \\
\text { структуры поджелудочной железы, }\end{array}$ \\
\hline
\end{tabular}




\begin{tabular}{|c|c|}
\hline Вопросы & Ответы \\
\hline & $\begin{array}{ll}\text { наличие } \quad \text { жидкости } & \text { в } \\
\text { парапанкреатическом пространстве и } \\
\text { брюшной полости, абсцесс. }\end{array}$ \\
\hline $\begin{array}{l}\text { Системы оценки тяжести острого } \\
\text { панкреатита: }\end{array}$ & $\begin{array}{l}\text { - Критерии Рансона; } \\
\text { - КТ индекс тяжести; } \\
\text { - Шкала Глазго; } \\
\text { - Шкала АРАСНЕ II; } \\
\text { - Клинические критерии оценки. }\end{array}$ \\
\hline $\begin{array}{l}\text { Какова роль амилаземии } \\
\text { (амилазурии) в оценке тяжести } \\
\text { острого панкреатита? }\end{array}$ & Не имеет прогностической значимости. \\
\hline $\begin{array}{l}\text { Степени тяжести по классификации } \\
\text { Атланты: }\end{array}$ & 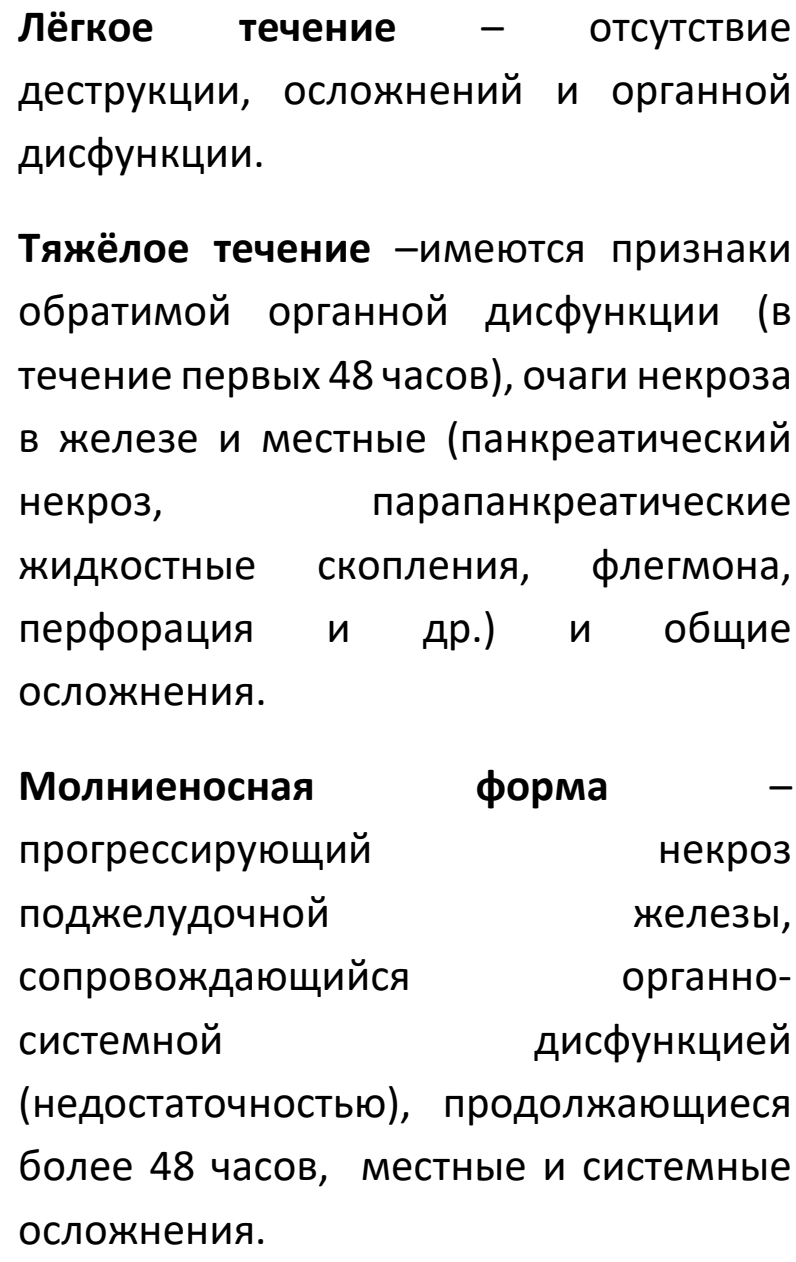 \\
\hline
\end{tabular}




\section{Вопросы}

Что включает в себя критерии

\section{Рансона?}

\section{Как проводится расчёт критериев}

Рансона?

\section{Ответы}

При поступлении:

- Возраст более 55 лет;

- Лейкоцитоз свыше 16 000;

- Глюкоза крови свыше 200 мг/\%;

- ЛДГ свыше 350 п.е./л;

- АСТ свыше 250 п.е./л.

Через 48 часов:

- Гематокрит ниже 10\%;

- Мочевина более 5 мг/дл;

- Снижение кальция ниже 8 мг/л;

- $\mathrm{PO}_{2}$ ниже 60 мм рт. ст.;

- Дефицит буферных оснований свыше 4 мэкв/л;

- Секвестрация жидкости более 6 л. Каждый критерий оценивают по 1 баллу, по сумме которых определяют вероятность летального исхода:

- 0-2 балла - летальность 5\%;

- 3-4 балла - летальность 15\%;

- 5-6 баллов - летальность 40\%;

- 7-8 баллов - летальность 80-100\%.

Принципы лечения острого Основным методом лечения является панкреатита: консервативный. По показаниям хирургическое лечение.

\section{Варикозным расширением вен} желудка.

Можно при отсутствии

гиперлипидемии (триглицериды <300). 


\begin{tabular}{|c|c|}
\hline Вопросы & Ответы \\
\hline \multirow{7}{*}{$\begin{array}{l}\text { Показания к срочной операци при } \\
\text { остром панкреатите: }\end{array}$} & - Невозможность топической \\
\hline & диагностики; \\
\hline & - Неэффективность \\
\hline & консервативной терапии, развитие \\
\hline & осложнений \\
\hline & $\begin{array}{l}\text { синдром, перитонит, некроз } \\
\text { толстого кишечника); }\end{array}$ \\
\hline & • обструкция холедоха, холангит. \\
\hline $\begin{array}{l}\text { Показания к плановым операциям } \\
\text { при остром панкреатите: }\end{array}$ & $\begin{array}{l}\text { - Инфицированный некроз; } \\
\text { - Калькулезный холецистит; } \\
\text { - Холедохолитиаз; } \\
\text { - Крупные и симптоматические } \\
\text { псевдокисты. }\end{array}$ \\
\hline
\end{tabular}

\section{Вопросы и ответы по билиарному панкреатиту}

\begin{tabular}{|c|c|}
\hline Вопросы & Ответы \\
\hline Что такое билиарный панкреатит? & $\begin{array}{l}\text { Панкреатит, развившийся на фоне } \\
\text { заболеваний желчевыводящих путей } \\
\text { (калькулезный } \\
\text { холедохолитиаз). }\end{array}$ \\
\hline $\begin{array}{l}\text { Как можно объяснить развитие } \\
\text { острого панкреатита при } \\
\text { желчекаменной болезни? }\end{array}$ & $\begin{array}{l}\text { Обтурация большого } \\
\text { двенадцатиперстной кишки камнем } \\
\text { вызывает рефлюкс желчи в главный } \\
\text { панкреатический проток и способствует } \\
\text { активации ферментов поджелудочной } \\
\text { железы. }\end{array}$ \\
\hline Как ставится диагноз? & $\begin{array}{l}\text { На основании наличия желчекаменной } \\
\text { болезни, } \\
\text { холедожнённой } \\
\text { других патологий. }\end{array}$ \\
\hline
\end{tabular}




\begin{tabular}{|c|c|}
\hline Вопросы & Ответы \\
\hline $\begin{array}{l}\text { Какие инструментальные методы } \\
\text { диагностики необходимы? }\end{array}$ & $\begin{array}{l}\text { • УзИ-верификация желчекаменной } \\
\text { болезни. } \\
\text { • КТ - оценка состояния } \\
\text { поджелудочной железы. } \\
\text { - } \\
\text { МРТ - оценка состояния протоковой } \\
\text { системы (холедоха). }\end{array}$ \\
\hline $\begin{array}{l}\text { В чём заключаются принципы } \\
\text { лечения? }\end{array}$ & 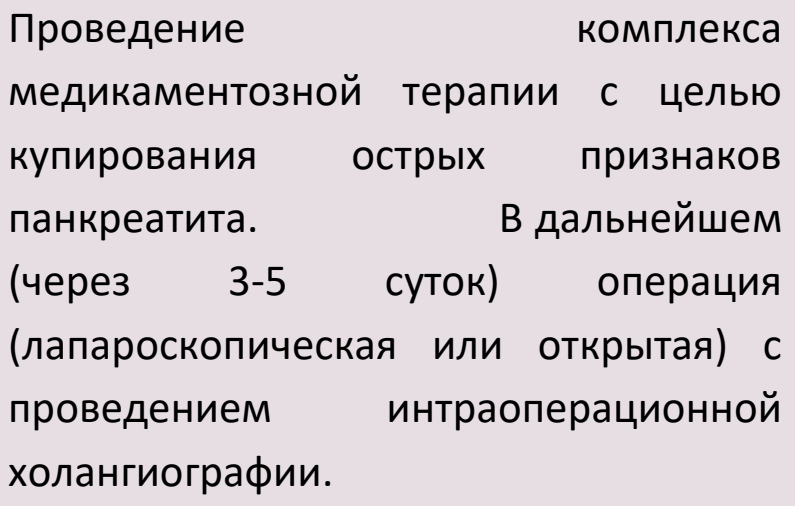 \\
\hline $\begin{array}{l}\text { Чем объясняется необходимость } \\
\text { проведения ранней холецистэктомии } \\
\text { при билиарном панкреатите? }\end{array}$ & $\begin{array}{l}\text { Примерно у } 1 / 3 \text { пациентов наблюдается } \\
\text { рецидив панкреатита в течение } 8 \\
\text { недель. }\end{array}$ \\
\hline Показания к ЭРХПГ: & Холангит. \\
\hline
\end{tabular}

\section{Вопросы и ответы по геморрагическому панкреатиту}

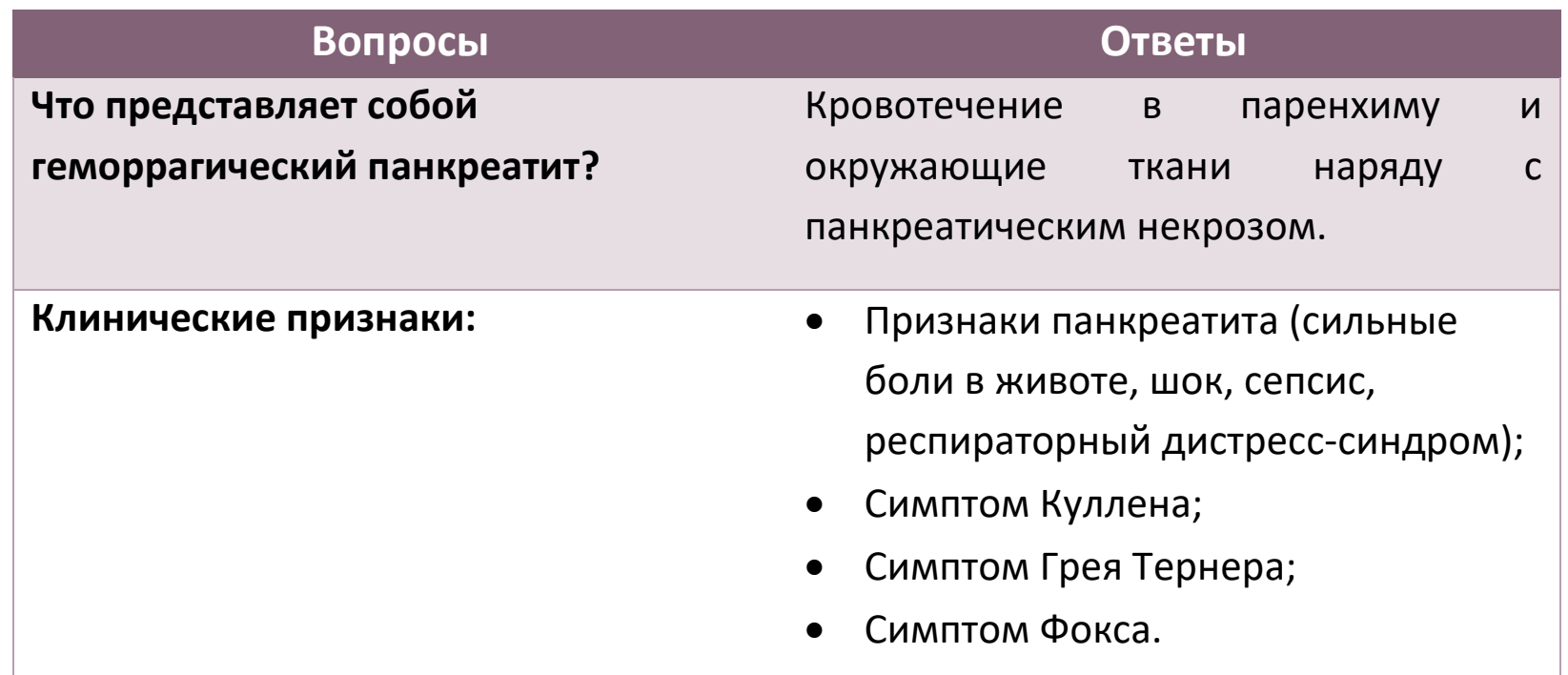




\begin{tabular}{|c|c|}
\hline Вопросы & Ответы \\
\hline Что такое симптом Куллена? & $\begin{array}{l}\text { Наличие синюшных пятен и подкожных } \\
\text { кровоизлияний } \\
\text { пупка. }\end{array}$ \\
\hline Что такое симптом Грея Тернера? & $\begin{array}{l}\text { Наличие синюшных пятен с желтоватым } \\
\text { оттенком на левой боковой стенке } \\
\text { живота. }\end{array}$ \\
\hline Что такое симптом Фокса? & Наличие экхимозов в паховой области. \\
\hline Как подтверждается кровотечение? & $\begin{array}{l}\text { Наличие гематомы на КТ, снижение } \\
\text { гемоглобина. }\end{array}$ \\
\hline
\end{tabular}

\section{Вопросы и ответы по панкреатическому некрозу}

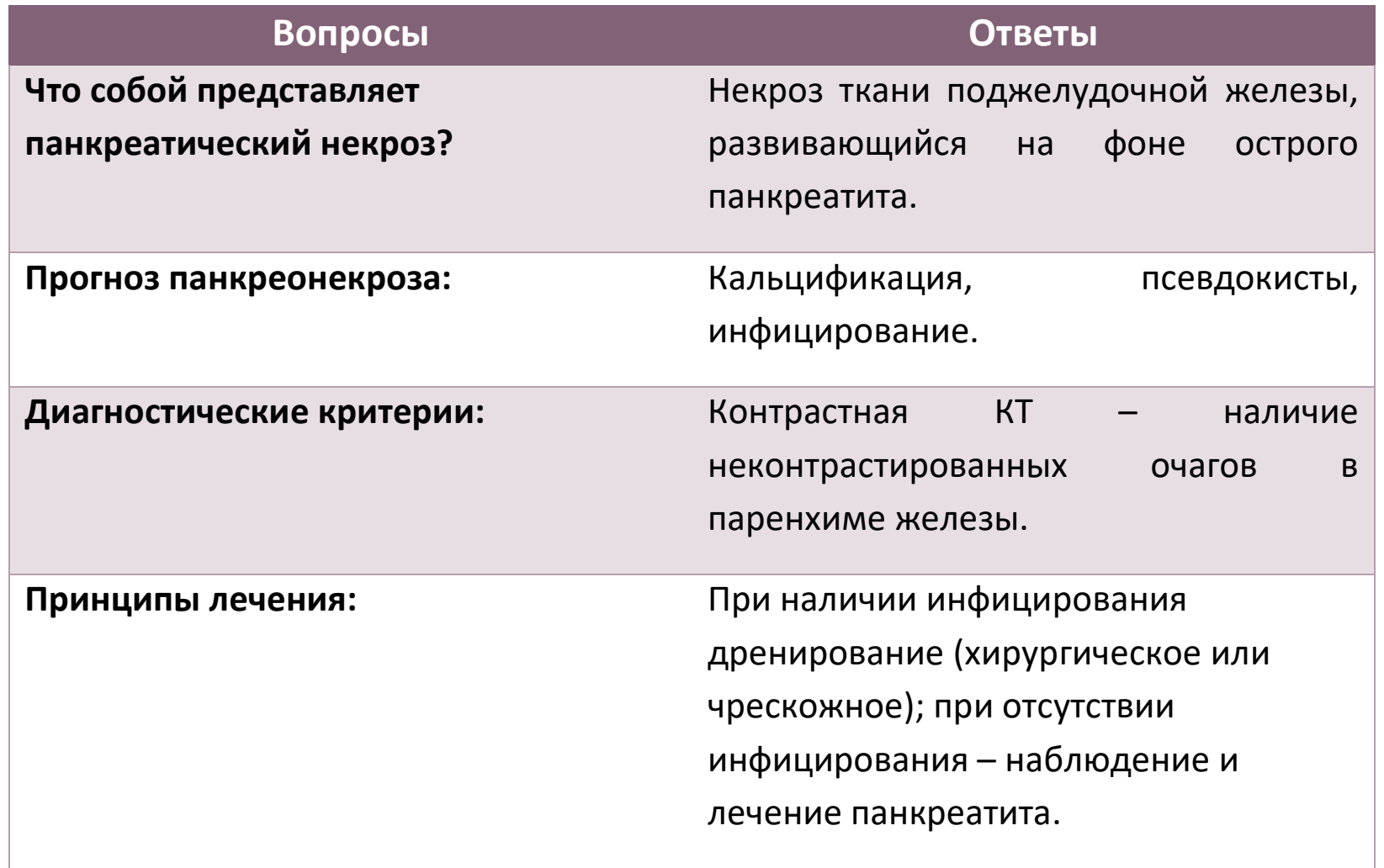




\section{Вопросы и ответы по панкреатическому абсцессу}

\begin{tabular}{|c|c|}
\hline Вопросы & Ответы \\
\hline $\begin{array}{l}\text { Что собой представляет панкреатический } \\
\text { абсцесс? }\end{array}$ & $\begin{array}{l}\text { Гнойник, образующийся в результате } \\
\text { инфицирования парапанкреатического } \\
\text { скопления или панкреатического некроза. }\end{array}$ \\
\hline Клинические признаки: & $\begin{array}{l}\text { Высокая температура, признаки } \\
\text { панкреатита, эпигастральное образование. }\end{array}$ \\
\hline Методы инструментальной диагностики: & Абдоминальная КТ. \\
\hline Лабораторные признаки: & $\begin{array}{l}\text { Лейкоцитоз, } \\
\text { положительный культуральный анализ. }\end{array}$ \\
\hline $\begin{array}{l}\text { Какие микроорганизмы обнаруживаются } \\
\text { в панкреатических абсцессах? }\end{array}$ & $\begin{array}{l}\text { Грамотрицательные - Escherichia coli, } \\
\text { Pseudomonas, Klebsiella. } \\
\text { Грамположительные - Staphylococcus } \\
\text { aureus, Candida. }\end{array}$ \\
\hline Диагностические критерии: & $\begin{array}{l}\text { - Признаки сепсиса и панкреатита; } \\
\text { - Наличие скопления и абсцесса на КТ; } \\
\text { - Положительный культуральный анализ. }\end{array}$ \\
\hline В чём заключается лечение? & $\begin{array}{l}\text { Инфузионная } \\
\text { антибиотикотерапия, черапия, } \\
\text { хирургическое дренирование. }\end{array}$ \\
\hline Показания к хирургическому лечению: & $\begin{array}{l}\text { Неэффективность или невозможность } \\
\text { чрескожного дренирования, наличие } \\
\text { крупных некротических масс. }\end{array}$ \\
\hline $\begin{array}{l}\text { Когда эффективно проведение } \\
\text { хирургической операции? }\end{array}$ & $\begin{array}{l}\text { После формирования стенки абсцесса } \\
\text { (обычно через } 4 \text { недели). }\end{array}$ \\
\hline
\end{tabular}




\section{ХРОНИЧЕСКИЙ ПАНКРЕАТИТ}

- Хронический панкреатит характеризуется пролиферативным фиброзом паренхимы поджелудочной железы, стриктурой протоковой системы и образованием камней, которые приводят к экзо- и эндокринной дисфункциям, возникновению болей и осложнениям.

- Ведущую роль в этиологии хронического панкреатита играет чрезмерное употребление алкоголя, а также идиопатические факторы. Значительно реже причинами данного заболевания является желчекаменная болезнь и её осложнения (холедохолитиаз, рубцовая стриктура большого дуоденального сосочка).

- Заболевание проявляется приступами острого панкреатита (боль, тошнота, рвота, интоксикация) или постоянными тупыми болями в эпигастральной области, правом или левом подреберье опоясывающего характера, экзо- и эндокринной недостаточностью (стеаторея, диабет).

- Хронический фибротический процесс ведёт к сморщиванию или увеличению, склерозу железы, нарушению архитектоники протока, вовлечению в процесс окружающих тканей. В результате развиваются экзо- и эндокринная недостаточность, осложнения (стеноз холедоха, 12-перстной кишки, формирование свищей, тромбоз селезёночной вены и др.)

- Различают следующие клинико-морфологические формы: дуктальная, диффузно-фибротическая, фиброзно-индуративная и осложнённая.

- Диагноз хронического панкреатита ставится на основании анамнеза, клинической картины заболевания, данных физикального, лабораторного и инструментальных методов исследования.

- $\mathrm{K}$ диагностическим критериям относятся боль, экзо-, эндокринная недостаточность, наличие фиброза, воспаления, кальцификаций при инструментальных методах диагностики и гистологическом исследовании.

- Лечение направлено на устранение боли, экзо-, эндокринной недостаточности, осложнений. С этой целью проводят консервативное (диетотерапия, энзимы, анальгетики), эндоскопическое (стентирование, дилатация, литотрипсия) и хирургическое (резекция, дренирование, денервация) лечение. При неэффективности консервативного лечения, наличии воспалительных 
образований, расширении протока, для дифференциации от злокачественных образований и стенотических осложнениях показано хирургическое лечение.

\section{Вопросы и ответы по хроническому панкреатиту}

\begin{tabular}{|c|c|}
\hline Вопросы & Ответы \\
\hline $\begin{array}{l}\text { Что представляет собой хронический } \\
\text { панкреатит? }\end{array}$ & 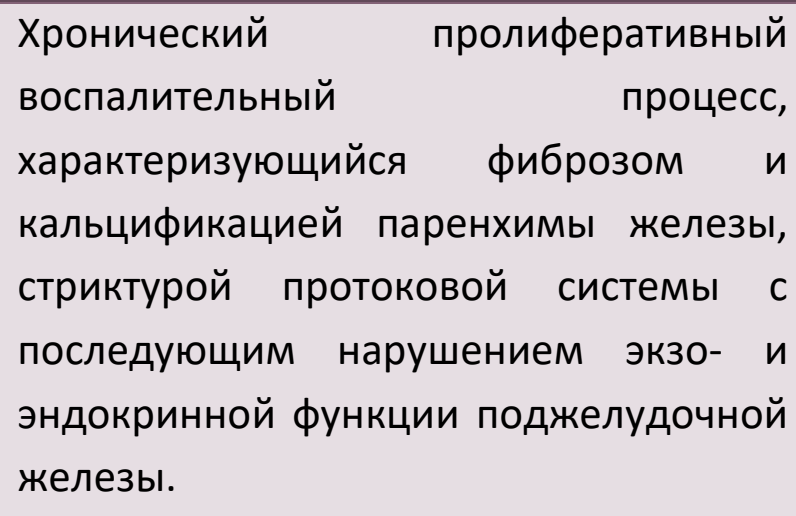 \\
\hline $\begin{array}{l}\text { Морфологические формы } \\
\text { хронического панкреатита: }\end{array}$ & $\begin{array}{l}\text { - Дуктальная; } \\
\text { - Инфильтративная; } \\
\text { • Фибротическая. }\end{array}$ \\
\hline Этиология: & $\begin{array}{l}\text { - Алкоголизм; } \\
\text { - Идиопатические } \\
\text { (криптогенный); } \\
\text { - Аутоиммунные формы; } \\
\text { - Генетические факторы; } \\
\text { - Другие факторы } \\
\text { ятрогенные } \\
\text { желчекаменная факторы, } \\
\text { гиперлипидемия, гиперкальциемия } \\
\text { идр.) }\end{array}$ \\
\hline Возможные осложнения: & $\begin{array}{l}\text { - Стеноз холедоха; } \\
\text { - Стеноз 12-перстной кишки; } \\
\text { - Панкреатокишечные свищи; } \\
\text { - Панкреатоплевральные свищи; } \\
\text { - Псевдокисты; } \\
\text { - Тромбоз селезёночной вены; } \\
\text { - Рак поджелудочной железы; }\end{array}$ \\
\hline
\end{tabular}




\begin{tabular}{|c|c|}
\hline Вопросы & Ответы \\
\hline & - Сахарный диабет (15-65\%). \\
\hline Субъективные признаки: & $\begin{array}{l}\text { Боли в эпигастральной и лопаточной } \\
\text { областях, снижение веса, стеаторея. }\end{array}$ \\
\hline Характер болей: & $\begin{array}{l}\text { Боли, возникающие после приёма } \\
\text { пищи, локализованные } \\
\text { эпигастральной области } \\
\text { иррадирующие в лопаточную область. }\end{array}$ \\
\hline $\begin{array}{l}\text { Чем характеризуется нарушение } \\
\text { экзокринной функции поджелудочной } \\
\text { железы? }\end{array}$ & $\begin{array}{l}\text { - Стеаторея, креаторея } \\
\text { (мальабсорбция жиров, связанная с } \\
\text { недостаточностью липазы). } \\
\text { - Мальнутриция. }\end{array}$ \\
\hline $\begin{array}{l}\text { Чем проявляется нарушение } \\
\text { эндокринной функции } \\
\text { поджелудочной железы? }\end{array}$ & Развитием сахарного диабета. \\
\hline $\begin{array}{l}\text { С какими заболеваниями необходимо } \\
\text { дифференцировать? }\end{array}$ & $\begin{array}{l}\text { Язвенная болезнь желудка и } 12- \\
\text { перстной кишки, желчнокаменная } \\
\text { болезнь, рак поджелудочной железы, } \\
\text { окклюзия мезентериальных сосудов, } \\
\text { другие } \\
\text { заболевания, инфаркт и др. }\end{array}$ \\
\hline $\begin{array}{l}\text { Частота возникновения рака } \\
\text { поджелудочной железы у больных с } \\
\text { хроническим панкреатитом: }\end{array}$ & Составляет 2\%. \\
\hline Лабораторная диагностика: & $\begin{array}{l}\text { - Определение амилазы (липазы) в } \\
\text { крови, амилазы в моче; } \\
\text { - Тест толерантности к глюкозе; } \\
\text { - Копрологический анализ. }\end{array}$ \\
\hline $\begin{array}{l}\text { По какой причине уровень } \\
\text { амилазы/липазы остаётся в норме у }\end{array}$ & Потеря ткани поджелудочной железы. \\
\hline
\end{tabular}




\section{Вопросы}

\section{Ответы}

пациентов с хроническим

панкреатитом?

Методы инструментальной

диагностики:
- КТ - увеличение или уменьшение размеров поджелудочной железы, обнаружение кальцинатов, образований в паренхиме железы, псевдокисты;

- MPT - определение состояния протоковой системы;

- Эндоскопическое УЗИвизуализация протоковой системы, оценка состояния железистой структуры.

- ЭРХПГ - состояние проходимости холедоха и главного панкреатического протока.

\section{Обязательно ли исследование протоковой системы при хроническом панкреатите?} Обязательно - для определения

клинической формы хронического панкреатита и выбора адекватной лечебной тактики.

\section{Какие инструментальные методы} МРТ, эндо-УЗИ, ЭРХПГ. состояние протоковой системы?

Диагностические критерии хронического панкреатита:
Болевой

синдром,

при инструментальных исследованиях обнаружение фиброза, склероза, кальцификации железистой стриктуры, признаки нарушения эндо- и экзокринной функции. 


\begin{tabular}{|c|c|}
\hline Вопросы & Ответы \\
\hline Методы консервативного лечения: & 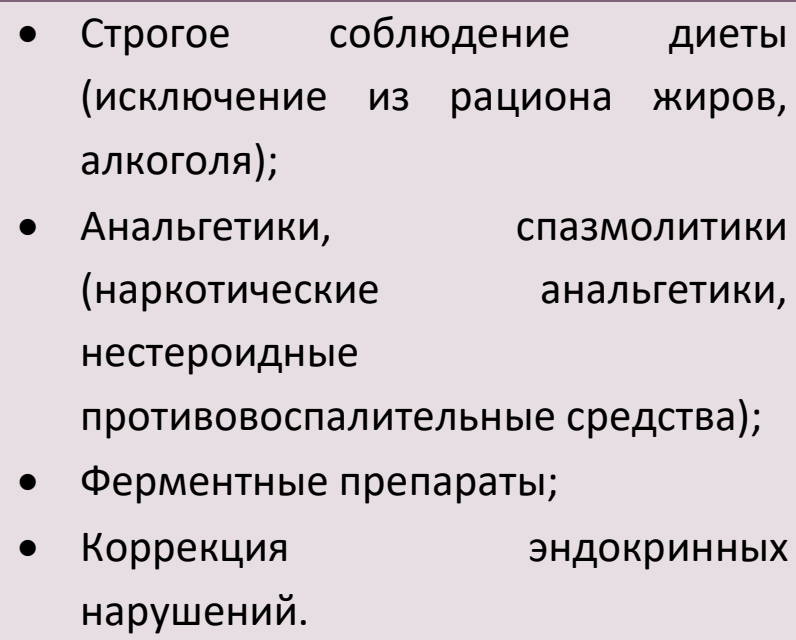 \\
\hline Показания к хирургическому лечению: & $\begin{array}{l}\text { - Хронический болевой синдром, } \\
\text { неподдающийся консервативному } \\
\text { устранению; } \\
\text { - Образование в поджелудочной } \\
\text { железе; } \\
\text { - Дилатация протока. }\end{array}$ \\
\hline Методы хирургического лечения: & $\begin{array}{l}\text { - Денервация (хирургическая и } \\
\text { химическая); } \\
\text { - Дренирование } \\
\text { (панкреатоеюностомия по Дювалю, } \\
\text { Пестову, Партингтону-Ришелье); } \\
\text { - Резекция (ПДР, дистальная, } \\
\text { центральная, тотальная); } \\
\text { - Резекция + дренирования (по } \\
\text { Бегеру, Фрею, Берне). }\end{array}$ \\
\hline $\begin{array}{l}\text { Что представляет собой операция } \\
\text { Фрея? }\end{array}$ & $\begin{array}{l}\text { Центральная резекция головки } \\
\text { поджелудочной железы и продольная } \\
\text { панкреатоеюностомия. }\end{array}$ \\
\hline
\end{tabular}




\section{Вопросы и ответы по аутоиммунному панкреатиту}

\begin{tabular}{|c|c|}
\hline Вопросы & Ответы \\
\hline Что такое аутоиммунный панкреатит? & $\begin{array}{l}\text { Характеризуется частыми рецидивами } \\
\text { острого панкреатита. }\end{array}$ \\
\hline Клинические варианты: & Тип 1, Тип 2. \\
\hline Патогенез заболевания: & $\begin{array}{l}\text { Аутоиммунное заболевание связанное } \\
\text { c IgG4. }\end{array}$ \\
\hline Осложнения: & $\begin{array}{l}\text { - Недостаточность поджелудочной } \\
\text { железы; } \\
\text { • Сахарный диабет; } \\
\text { • Кальцификация и некроз } \\
\text { поджелудочной железы. }\end{array}$ \\
\hline Клинические признаки: & $\begin{array}{l}\text { Картина острого панкреатита (болевой } \\
\text { синдром, диспепсические } \\
\text { расстройства). }\end{array}$ \\
\hline $\begin{array}{l}\text { Методы диагностики, необходимые } \\
\text { для уточнения диагноза: }\end{array}$ & $\begin{array}{l}\text { - Лабораторные исследования - } \\
\text { повышение амилазы в крови и } \\
\text { моче; } \\
\text { - KT/MPT; } \\
\text { - IgG4. }\end{array}$ \\
\hline Лабораторные показатели: & $\begin{array}{l}\text { - Повышение концентрации } \\
\text { амилазы; } \\
\text { - При типе 1 - повышение IgG4; } \\
\text { - При типе 2 - IgG4 не повышается. }\end{array}$ \\
\hline $\begin{array}{l}\text { Признаки инструментальных методов } \\
\text { диагностики: }\end{array}$ & $\begin{array}{l}\text { - Сегментарное или диффузное } \\
\text { увеличение поджелудочной железы } \\
\text { («сосискообразная» поджелудочная } \\
\text { железа); } \\
\text { - Стеноз протока поджелудочной } \\
\text { железы и холедоха на ЭРХПг; }\end{array}$ \\
\hline
\end{tabular}




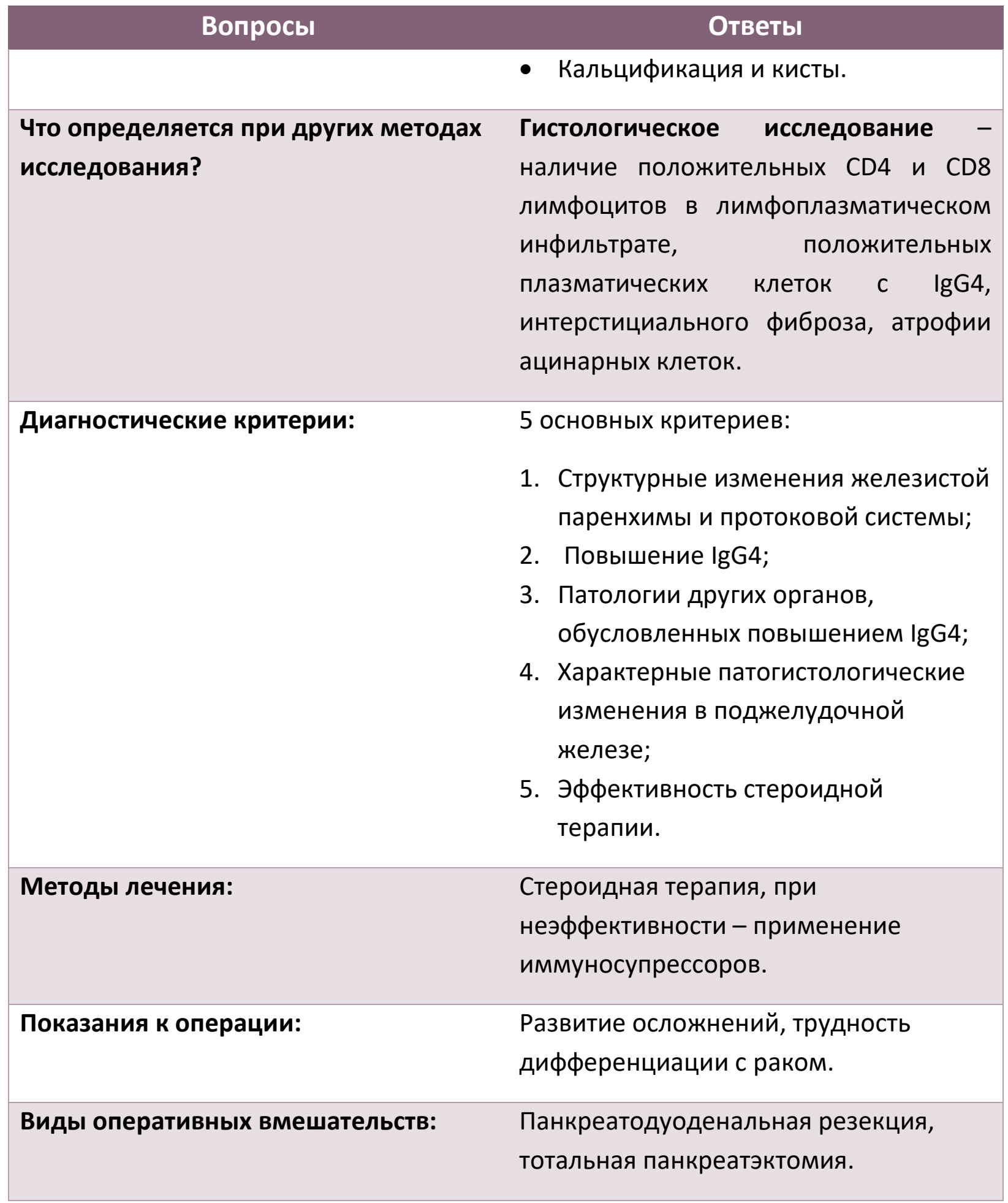




\section{Вопросы и ответы по наследственному панкреатиту}

\begin{tabular}{|c|c|}
\hline Вопросы & Ответы \\
\hline $\begin{array}{l}\text { Что такое наследственный } \\
\text { панкреатит? }\end{array}$ & $\begin{array}{l}\text { Генетически } \\
\text { заболевание, } \\
\text { частыми эпизодами панккреатита. }\end{array}$ \\
\hline Причины и факторы риска: & Мутация гена PRSS1. \\
\hline Патогенез заболевания: & Связан с мутацией гена PRSS1. \\
\hline Особенность клинического течения: & $\begin{array}{l}\text { Хроническое течение со склонностью к } \\
\text { малигнизации. }\end{array}$ \\
\hline Осложнения: & $\begin{array}{l}\text { - Фиброз поджелудочной железы; } \\
\text { - Экокринная недостаточность; } \\
\text { - Сахарный диабет; } \\
\text { - Хронический болевой синдром; } \\
\text { - Дуктальная аденокарцинома. }\end{array}$ \\
\hline Клинические признаки: & $\begin{array}{l}\text { - Картина острого панкреатита; } \\
\text { - Внезапно начавшаяся боль в животе; } \\
\text { - Высокая температура, тошнота, } \\
\text { рвота. }\end{array}$ \\
\hline $\begin{array}{l}\text { Какие методы исследования } \\
\text { необходимы для верификации } \\
\text { диагноза? }\end{array}$ & Генетический анализ. \\
\hline
\end{tabular}

\section{Вопросы и ответы по панкреатогенному асциту}

\begin{tabular}{cl} 
Вопросы & \multicolumn{3}{c}{ Ответы } \\
Что такое панкреатогенный асцит? & Экстравазия панкреатического сока в \\
& брюшную полость в результате \\
& деструкци (панкреонекроз) или \\
& травмы протоковой системы.
\end{tabular}




\begin{tabular}{|c|c|}
\hline Bonpocbl & Ответы \\
\hline Причины и факторы риска: & $\begin{array}{l}\text { - Алкоголизм; } \\
\text { - Травма живота; } \\
\text { - Формирование кист; } \\
\text { - Дистальный спленоренальный } \\
\text { шунт; } \\
\text { - Стриктура Фатерова сосочка; } \\
\text { - Камни протоков поджелудочной } \\
\text { железы; } \\
\text { - Карциноидная опухоль; } \\
\text { - Лимфома Ходжкина. }\end{array}$ \\
\hline Клинические признаки: & $\begin{array}{l}\text { - Боли в эпигастральной области; } \\
\text { - Жидкость в брюшной полости; } \\
\text { - Похудание. }\end{array}$ \\
\hline $\begin{array}{l}\text { Какие исследования необходимы для } \\
\text { верификации диагноза? }\end{array}$ & 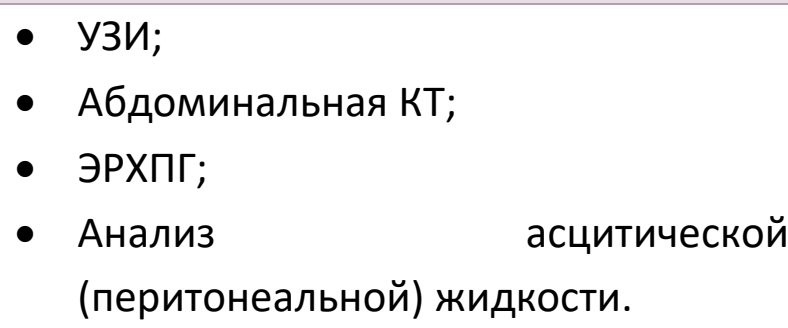 \\
\hline Лабораторные признаки: & $\begin{array}{l}\text { Высокое содержание амилазы и белка в } \\
\text { асцитической жидкости. }\end{array}$ \\
\hline Методы лечения: & $\begin{array}{l}\text { - Консервативное (октреотид); } \\
\text { - } \text { Эндоскопическое; } \\
\text { - Хирургическое. }\end{array}$ \\
\hline Методы оперативного лечения: & $\begin{array}{l}\text { - Эндоскопическая } \\
\text { папиллосфинктеротомия и стен- } \\
\text { тирование; } \\
\text { • Цистогастростомия; } \\
\text { - Цистоеюностомия; } \\
\text { - Цистодуоденостомия. }\end{array}$ \\
\hline
\end{tabular}




\section{ОПУХОЛИ ПОДЖЕЛУДОЧНОЙ ЖЕЛЕЗЫ}

- По происхождению различают первичные и вторичные опухоли поджелудочной железы.

- Первичные опухоли развиваются из клеток эпителия протоков, ацинарных клеток и мезенхимальной ткани. Большинство первичных опухолей являются тканевыми опухолями, развивающимися из эпителиальной ткани, меньшая часть является кистозными неоплазиями (7\%) и опухолями островкового аппарата (3\%). Эпителиальные опухоли в 90-95\% случаев имеют злокачественную природу (аденокарциномы), доброкачественные аденомы встречаются относительно редко (1-2\%). Метастатические опухоли встречаются в 3 раза чаще первичных.

- Рак поджелудочной железы - злокачественная опухоль, исходящая из железистого эпителия.

○ Клинические проявления рака поджелудочной железы зависят от размеров опухоли и его локализации. Рак головки поджелудочной железы в ранней стадии протекает бессимптомно. Симптомы проявляются по мере роста опухоли: боль, похудание, желтуха, дуоденальная обструкция, паранеопластические синдромы.

○ Диагностика рака поджелудочной железы основывается на данных анамнеза, клинической картины заболевания и результатах инструментальных методов исследований (КТ, МРТ). Характерным признаком является быстрое выведение контрастного вещества из опухоли в венозную фазу. В большинстве случаев нет необходимости в проведении биопсии. Для определения стадии опухолевого процесса применяют КТ-ангиографию. По показаниям проводят эндоскопическое УзИ и ПЭТ.

○ На резектабельных стадиях заболевания (при отсутствии инвазии опухолевого процесса на соседние органы и ткани и отсутствии отдалённых метастазов), применяют радикальные операции, на нерезектабельных паллиативные операции (при желтухе и дуоденальной обструкции билиодигестивные анастомозы, стентирование) и химиотерапия.

- Опухоли островкового аппарата развиваются из островковых клеток поджелудочной железы. 
О Могут быть функционально активными и неактивными, добро- и злокачественными, что определяется наличием метастазов. Большинство этих опухолей (50-60\%), кроме инсулиномы, являются злокачественными.

○ К функционально активным опухолям относятся инсулинома, гастринома, VIP-ома, глюкагонома, соматостинома, РР-ома.

○ Клинически функциональные активные опухоли проявляются гиперпродукцией того или иного гормона. Функционально неактивные опухоли протекают без гиперпродукции гормонов и поэтому не имеют характерных клинических признаков.

○ Характерными клиническими проявлениями гормонально-активных опухолей являются:

- При инсулиноме - гипогликемия;

- При гастриноме - множественные эрозии желудка, гиперсекреция желудочного сока, диарея;

- При глюкагономе - диабет, анемия;

- При соматостатиноме - диабет, жёлчные камни, стеаторея;

- При VIP-оме - секреторная диарея.

○ Для уточнения диагноза нейроэндокринных опухолей, кроме клинической картины, учитывается также гормональный профиль. При отсутствии повышения уровня гормонов применяют стимуляционные пробы (с секретином, или с раствором глюконата кальция). Спектр инструментальных методов исследований для всех видов нейроэндокринных опухолей поджелудочной железы одинаков: УЗИ, контрастная КТ, МРТ, эндоскопическое УЗИ, ПЭТ-КТ, изотопное исследование рецепторов соматостатина.

○ Лечение нейроэндокринных опухолей поджелудочной железы в основном хирургическое - по возможности, радикальное удаление. Консервативное лечение носит симптоматический характер и проводится с учётом патогенеза отдельных видов нейроэндокринных опухолей (при инсулиноме - глюкоза, при гастриноме - ингибиторы протонной помпы, блокаторы протонной помпы, при VIP-оме - коррекция водно-электролитных нарушений и др.) 


\section{Вопросы и ответы по раку поджелудочной железы}

\begin{tabular}{|c|c|}
\hline Вопросы & Ответы \\
\hline $\begin{array}{l}\text { Определите понятие «рак } \\
\text { поджелудочной железы»: }\end{array}$ & $\begin{array}{l}\text { Злокачественная опухоль, } \\
\text { развивающаяся из эпителия выводных } \\
\text { протоков поджелудочной железы. }\end{array}$ \\
\hline $\begin{array}{l}\text { Что означает понятие «80\% при раке } \\
\text { поджелудочной железы»? }\end{array}$ & $\begin{array}{l}\text { - } 80 \% \text { - дуктальные аденокарциномы; } \\
\text { - } 80 \% \text { локализуются в головке железы; } \\
\text { - У } 80 \% \text { пациентов наблюдается боль; } \\
\text { - Более } 80 \% \text { опухолей } \\
\text { нерезектабельны; } \\
\text { - У } 80 \% \text { пациентов с локализацией } \\
\text { опухоли в головке железы } \\
\text { наблюдается желтуха. }\end{array}$ \\
\hline Факторы риска: & $\begin{array}{l}\text { - Курение; } \\
\text { - Алкоголизм; } \\
\text { - Жирная пища; } \\
\text { - Хронический панкреатит; } \\
\text { - Сахарный диабет; } \\
\text { - Генетические факторы. }\end{array}$ \\
\hline $\begin{array}{l}\text { Соотношение между мужчинами и } \\
\text { женщинами: }\end{array}$ & Составляет 3:2. \\
\hline $\begin{array}{l}\text { В каком возрасте встречается } \\
\text { наиболее часто? }\end{array}$ & В возрасте старше 60 лет. \\
\hline Клинико-анатомические формы: & $\begin{array}{l}\text { - Дуктальная (80-90\%); } \\
\text { - Ацинарная (10-20\%). }\end{array}$ \\
\hline $\begin{array}{l}\text { Частота поражения головки } \\
\text { поджелудочной железы: }\end{array}$ & $\begin{array}{l}\text { В } 2 / 3 \text { случаев (80\%) опухоль } \\
\text { локализируется в головке, } 1 / 3 \text { - в теле и } \\
\text { хвостовой части (15-20\%). }\end{array}$ \\
\hline $\begin{array}{l}\text { Почему рак хвостовой части } \\
\text { поджелудочной железы в }\end{array}$ & $\begin{array}{l}\text { В связи с бессимптомным течением и } \\
\text { поздней диагностикой. }\end{array}$ \\
\hline
\end{tabular}




\begin{tabular}{|c|c|}
\hline Вопросы & Ответы \\
\hline $\begin{array}{l}\text { большинстве случаев бывает } \\
\text { нерезектабельным? }\end{array}$ & \\
\hline $\begin{array}{l}\text { Особенности клинических } \\
\text { проявлений: }\end{array}$ & $\begin{array}{l}\text { Зависят от локализации поражения и } \\
\text { стадии развития. }\end{array}$ \\
\hline $\begin{array}{l}\text { Клинические признаки рака головки } \\
\text { поджелудочной железы: }\end{array}$ & $\begin{array}{l}\text { - Желтуха без предшествующего } \\
\text { болевого синдрома; } \\
\text { - Похудание; } \\
\text { - Абдоминальные боли, } \\
\text { иррадирующие в лопаточную } \\
\text { область; } \\
\text { - Слабость; } \\
\text { - Кожный зуд; } \\
\text { - Анорексия; } \\
\text { - Симптом Курвуазье; } \\
\text { - Ахолический стул, моча тёмного } \\
\text { цвета. }\end{array}$ \\
\hline $\begin{array}{l}\text { Клинические признаки рака тела и } \\
\text { хвостовой части поджелудочной } \\
\text { железы: }\end{array}$ & $\begin{array}{l}\text { - Боль и похудание; } \\
\text { - Тромбофлетит; } \\
\text { - Желтуха; } \\
\text { - Диспепсические явления; } \\
\text { - Слабость. }\end{array}$ \\
\hline Что такое симптом Курвуазье? & $\begin{array}{l}\text { Наличие увеличенного, напряжённого и } \\
\text { безболезненного жёлчного пузыря. }\end{array}$ \\
\hline $\begin{array}{l}\text { Частота выявления симптома } \\
\text { Курвуазье? }\end{array}$ & Составляет 33\%. \\
\hline $\begin{array}{l}\text { Классический признак рака головки } \\
\text { поджелудочной железы: }\end{array}$ & Желтуха без болевого синдрома. \\
\hline Лабораторная признаки: & $\begin{array}{l}\text { Гипербилирубинемия, повышение } \\
\text { содержания печёночных энзимов } \\
\text { (щелочной фосфатазы, ГГТ, АСТ, АЛТ), }\end{array}$ \\
\hline
\end{tabular}




\begin{tabular}{|c|c|}
\hline Вопросы & Ответы \\
\hline & $\begin{array}{l}\text { повышение уровня опухолевых } \\
\text { маркеров. }\end{array}$ \\
\hline $\begin{array}{l}\text { Какой онкомаркер информативен для } \\
\text { рака поджелудочной железы? }\end{array}$ & CA 19-9. \\
\hline $\begin{array}{l}\text { Методы инструментальной } \\
\text { диагностики: }\end{array}$ & КТ, МРТ, эндоскопическое УЗИ, ПЭТ. \\
\hline $\begin{array}{l}\text { Клинические стадии рака } \\
\text { поджелудочной железы: }\end{array}$ & $\begin{array}{l}\text { - I стадия - опухоль не выходит за } \\
\text { пределы железы; } \\
\text { - II стадия-опухоль распространяется } \\
\text { на соседние органы и окружающие } \\
\text { ткани (холедох, двенадцатиперстная } \\
\text { кишка, парапанкреатическая } \\
\text { клетчатка); } \\
\text { - III стадия - имеются метастазы в } \\
\text { региональные лимфатические узлы; } \\
\text { - ІV стадия - имеются метастазы на } \\
\text { отдалённые органы и инвазия в } \\
\text { окружающие ткани (селезёночная и } \\
\text { мезентериальная вены, воротная } \\
\text { вена, желудок, толстый кишечник, } \\
\text { чревный ствол). }\end{array}$ \\
\hline $\begin{array}{l}\text { Основной метод лечения рака } \\
\text { поджелудочной железы: }\end{array}$ & $\begin{array}{l}\text { Радикальное удаление опухоли вместе } \\
\text { с лимфодиссекцией. }\end{array}$ \\
\hline $\begin{array}{l}\text { Варианты оперативных вмешательств } \\
\text { при раке поджелудочной железы: }\end{array}$ & $\begin{array}{l}\text { При локализации рака в головке - } \\
\text { панкреатодуоденальная } \\
\text { (операция Уиппла); в теле и хвостовой } \\
\text { части - дистальная } \\
\text { поджелудочной железы. }\end{array}$ \\
\hline $\begin{array}{l}\text { Критерии нерезектабельности рака } \\
\text { поджелудочной железы: }\end{array}$ & • Наличие отдалённых метастазов; \\
\hline
\end{tabular}




\begin{tabular}{|c|c|}
\hline Вопросы & Ответы \\
\hline & $\begin{array}{l}\text { - Инвазия опухоли в чревное } \\
\text { сплетение и ствол верхней } \\
\text { брыжеечной артерии. }\end{array}$ \\
\hline $\begin{array}{l}\text { Обязательно ли стентирование зоны } \\
\text { опухолевой обструкции } \\
\text { поджелудочной железы до операции? }\end{array}$ & $\begin{array}{l}\text { Нет. Если больной операбелен } \\
\text { стентирование противопоказано, } \\
\text { поскольку это усложняет ход операции } \\
\text { и повышает риск } \\
\text { инфекционных осложнений. }\end{array}$ \\
\hline $\begin{array}{l}\text { Технические элементы операции } \\
\text { Уиппла: }\end{array}$ & $\begin{array}{l}\text { - Холецистэктомия; } \\
\text { - Антрумэктомия и трункальная } \\
\text { ваготомия; } \\
\text { - Панкреатодуодунэктомия } \\
\text { удаление головки поджелудочной } \\
\text { железы и 12-перстной кишки; } \\
\text { - Панкреатоеюностомия - анастомоз } \\
\text { между дистальной } \\
\text { поджелудочной железы и тонкой } \\
\text { кишкой; } \\
\text { Холедохоеюностомия - анастомоз } \\
\text { между общим жёлчным протоком и } \\
\text { тонкой кишкой; } \\
\text { Гастроеюностомия - анастомоз } \\
\text { между желудком и тонкой кишкой. }\end{array}$ \\
\hline $\begin{array}{l}\text { Уровень летальности после } \\
\text { панкреатодуоденальной резекции: }\end{array}$ & Пятилетняя выживаемость - 3\%. \\
\hline $\begin{array}{l}\text { В чём заключается } \\
\text { пилоросохраняющий вариант } \\
\text { операции Уиппла? }\end{array}$ & $\begin{array}{l}\text { Сохранение антральной, пилорической } \\
\text { части желудка и луковицы } \\
\text { двенадцатиперстной } \\
\text { формирование диоденоеюнального } \\
\text { анастомоза. }\end{array}$ \\
\hline
\end{tabular}




\begin{tabular}{|c|c|}
\hline Вопросы & Ответы \\
\hline $\begin{array}{l}\text { Осложнения панкреатодуоденальной } \\
\text { резекции: }\end{array}$ & $\begin{array}{l}\text { - Гастростаз; } \\
\text { - Несостоятельность швов } \\
\text { анастомозов; } \\
\text { - Формирование } \\
\text { панкреатобилиарных свищей; } \\
\text { - Панкреатит; } \\
\text { - Постгастрэктомические синдромы; } \\
\text { - Инфекционные осложнения } \\
\text { (нагноение раны, сепсис). }\end{array}$ \\
\hline $\begin{array}{l}\text { Послеоперационная адъювантная } \\
\text { терапия: }\end{array}$ & Химиотерапия. \\
\hline $\begin{array}{l}\text { Варианты паллиативных операций при } \\
\text { неоперабельном раке поджелудочной } \\
\text { железы, осложнённом механической } \\
\text { желтухой: }\end{array}$ & $\begin{array}{l}\text { - Формирование обходных путей } \\
\text { (гепатикоеюностомия или сегмент- } \\
\text { 3-обходной путь); } \\
\text { - Чрескожное дренирование жёлчных } \\
\text { путей или стентирование зоны } \\
\text { опухолевого стеноза. }\end{array}$ \\
\hline
\end{tabular}

\section{Вопросы и ответы по опухолям островкового аппарата}

\section{Вопросы}

Наиболее часто встречающаяся форма Инсулинома.

опухолей островкового аппарата:

Характерные клинические признаки инсулиномы:
Триада Уиппла:

- Гипогликемия (уровень глюкозы менее 50 мг/дл);

- Симптомы гипогликемии:

- Симптомы мозгового голодания: головные боли, слабость, потемнение в глазах, нарушение 


\begin{tabular}{|c|c|}
\hline Вопросы & Ответы \\
\hline & $\begin{array}{l}\text { памяти и ориентации, голод, } \\
\text { кома и др.; } \\
\text { о Симпатический гипертонус: } \\
\text { тахикардия, холодный пот, } \\
\text { нервозность, ментальные } \\
\text { изменения, } \\
\text { нестабильность. } \\
\text { • Улучшемоторная } \\
\text { глюкозы. }\end{array}$ \\
\hline $\begin{array}{l}\text { Какие инструментальные методы } \\
\text { более информативны для топической } \\
\text { диагностики инсулиномы? }\end{array}$ & Эндоскопическое УЗИ, ПЭТ-КТ. \\
\hline Что такое VIP-ома? & 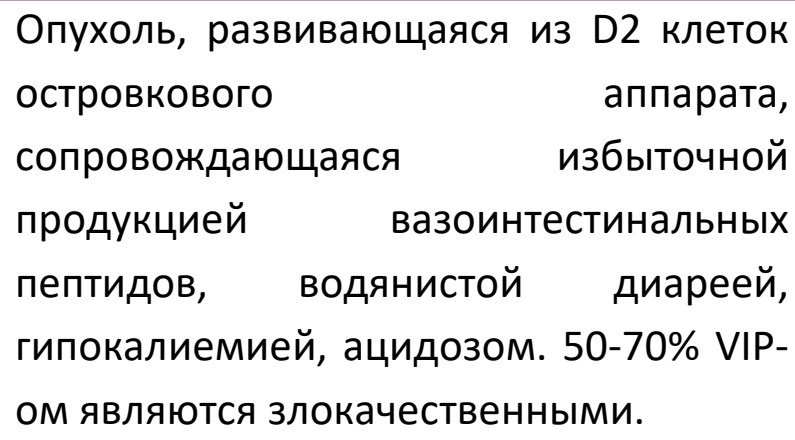 \\
\hline $\begin{array}{l}\text { При какой форме нейроэндокринных } \\
\text { опухолей образуются жёлчные камни? }\end{array}$ & При соматостатиноме. \\
\hline $\begin{array}{l}\text { Триада, характерная для } \\
\text { соматостатиномы: }\end{array}$ & $\begin{array}{l}\text { - Желчнокаменная болезнь; } \\
\text { - Сахарный диабет; } \\
\text { - Стеаторея. }\end{array}$ \\
\hline $\begin{array}{l}\text { Основные клинические признаки } \\
\text { гастриномы: }\end{array}$ & $\begin{array}{l}\text { Гиперсекреция желудочного сока, } \\
\text { множественные язвы желудка и } \\
\text { двенадцатиперстной кишки. }\end{array}$ \\
\hline Причина диареи при гастриноме: & $\begin{array}{l}\text { Большое количество кислого } \\
\text { желудочного сока, поступающего в } \\
\text { толстую кишку, приводит к усилению }\end{array}$ \\
\hline
\end{tabular}




\begin{tabular}{|c|c|}
\hline Вопросы & Ответы \\
\hline & $\begin{array}{l}\text { перистальтики кишечника и ингибиции } \\
\text { липазной } \quad \text { активности } \\
\text { поджелудочной железы. }\end{array}$ \\
\hline Классические признаки глюкагономы: & $\begin{array}{l}\text { • Диабет; } \\
\text { • Некролитический дерматит. }\end{array}$ \\
\hline $\begin{array}{l}\text { Чем определяется характер течения } \\
\text { нейроэндокринных опухолей? }\end{array}$ & $\begin{array}{lr}\text { Наличием } & \text { (злокачественная) } \\
\text { отсутствием } \\
\text { метастазов. }\end{array}$ \\
\hline
\end{tabular}




\section{КИСТЫ ПОДЖЕЛУДОЧНОЙ ЖЕЛЕЗЫ}

- Кисты поджелудочной железы представляют собой ограниченные эпителиальной или фиброзной капсулой скопления жидкости.

- В зависимости от строения стенки и происхождения различают 4 основных вида кист поджелудочной железы: истинные, ложные, неопластические и паразитарные.

- Характерной особенностью истинной кисты является наличие внутренней эпителиальной выстилки. По происхождению могут быть врождёнными и приобретёнными. Врождённые кисты формируются в результате нарушения развития, приобретённые же-в результате закупорки и расширения дистальной части протока (ретенционные кисты). При отсутствии выраженных клинических проявлений показано наблюдение, симптоматические кисты же удаляются хирургическим путём.

- Стенки ложной кисты представляют собой утолщённую брюшину, фиброзную ткань и, в отличие от истинной кисты, изнутри покрыты грануляционной тканью.

- Псевдокисты образуются в результате повреждения протока поджелудочной железы по причине травмы или панкреатита и скопления жидкости в ложной полости.

- Псевдокисты в большинстве случаев протекают бессимптомно. Клинические признаки проявляются при сдавлении окружающих тканей и возникновении осложнений (инфицирование, кровотечение, формирование свищей и др.)

- Характерными признаками являются наличие травмы и перенесённого панкреатита в анамнезе, повышение концентрации амилазы в содержимом псевдокисты, отсутствие эпителиальной выстилки в стенке псевдокисты.

- При небольших псевдокистах с тонкими стенками при отсутствии выраженных клинических проявлений показано наблюдение. При симптоматических и крупных (более 6 см) показаны различные варианты цистодигестивных анастомозов (цистоеюностомия, цистогастростомия или цистодуоденостомия).

- Неопластические кисты - это кисты, выстланные изнутри опухолевым эпителием. По характеру могут быть доброкачественными и злокачественными.

- $\mathrm{K}$ неопластическим кистам относятся цистаденомы и цистаденокарциномы. Помимо этого, встречаются также эндокринные и метастатические кисты. 
- К Карактерным признакам неопластических кист относятся отсутствие в анамнезе перенесённого панкреатита, наличие толстой стенки, перегородок, повышение концентрации СА 19-9 в содержимом кисты.

- Для подтверждения диагноза проводят биопсию.

- Лечение неопластических кист заключается в радикальном удалении.

- К К паразитарным кистам поджелудочной железы относится эхинококковая киста.

- Изолированный эхинококк поджелудочной железы встречается относительно редко, обычно он сочетается с эхинококкозом других органов (печени и лёгких).

- Лечение - кистэктомия.

\section{Вопросы и ответы по кистам поджелудочной железы}

\begin{tabular}{|c|c|}
\hline Вопросы & Ответы \\
\hline $\begin{array}{l}\text { Что собой представляет псевдокиста } \\
\text { поджелудочной железы? }\end{array}$ & $\begin{array}{l}\text { Ложная киста - жидкостное скопление, } \\
\text { ограниченное фиброзной тканью или } \\
\text { уплотненной брюшиной. }\end{array}$ \\
\hline Когда формируются ложные кисты? & $\begin{array}{l}\text { Через } 4 \text { нед. после перенесённого } \\
\text { панкреонекроза. }\end{array}$ \\
\hline Почему она называется ложной? & $\begin{array}{l}\text { Потому, что стенки ложной кисты } \\
\text { представляют собой фиброзную ткань } \\
\text { или уплотнённую брюшину. Внутренней } \\
\text { эпителиальной выстилки нет. }\end{array}$ \\
\hline Содержимое ложной кисты: & $\begin{array}{l}\text { Панкреатический сок из повреждённых } \\
\text { протоков поджелудочной железы. }\end{array}$ \\
\hline Частота встречаемости: & $\begin{array}{l}\text { Встречается у 20-30\% больных с } \\
\text { деструктивным панкреатитом. }\end{array}$ \\
\hline $\begin{array}{l}\text { Основные нозологические причины } \\
\text { ложных кист: }\end{array}$ & Острые и хронические панкреатиты. \\
\hline Как формируются ложные кисты: & 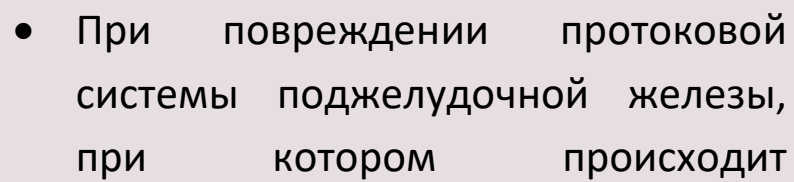 \\
\hline
\end{tabular}




\begin{tabular}{|c|c|}
\hline Bonpocbl & Ответы \\
\hline & $\begin{array}{l}\text { экстравазация ферментов с } \\
\text { последующей инкапсуляцией; } \\
\text { - При обструкции выводных протоков, } \\
\text { в результате чего формируется } \\
\text { ретенционная киста. }\end{array}$ \\
\hline Осложнения псевдокисты: & $\begin{array}{l}\text { Инфицирование, кровотечение, } \\
\text { разрывом, обструкция, формирование } \\
\text { свищей, панкреатогенный асцит. }\end{array}$ \\
\hline Клинические признаки: & $\begin{array}{l}\text { - Боли в эпигастральной области; } \\
\text { - Похудание; } \\
\text { • Пальпируемое образование в } \\
\text { эпигастральной области; } \\
\text { - Периодическая субфебрильная } \\
\text { температура. }\end{array}$ \\
\hline Лабораторные анализы: & $\begin{array}{l}\text { - Амилаза (липаза) в крови; } \\
\text { - Билирубина; } \\
\text { - СА 19-9; } \\
\text { - Общий анализ крови. }\end{array}$ \\
\hline $\begin{array}{l}\text { Что обнаруживают при } \\
\text { инструментальных методах } \\
\text { исследований? }\end{array}$ & $\begin{array}{l}\text { Кистозное образование, содержащее } \\
\text { жидкостное скопление. }\end{array}$ \\
\hline Диагностические критерии: & $\begin{array}{l}\text { - Наличие в анамнезе перенесённого } \\
\text { деструктивного панкреатита или } \\
\text { травмы поджелудочной железы; } \\
\text { - Наличие жидкостного скопления, } \\
\text { ограниченного капсулой, при } \\
\text { инструментальных } \\
\text { исследования; } \\
\text { Высокая концентрация амилазы } \\
\text { (липазы) водержимом } \\
\text { псевдокисты; }\end{array}$ \\
\hline
\end{tabular}




\begin{tabular}{|c|c|}
\hline Вопросы & Ответы \\
\hline & - Нормальная концентрация СА 19-9. \\
\hline $\begin{array}{l}\text { С какими заболеваниями необходимо } \\
\text { дифференцировать? }\end{array}$ & $\begin{array}{l}\text { В первую очередь с неопластическими } \\
\text { (цистаденома, цистаденокарцинома) и } \\
\text { паразитарными кистами. }\end{array}$ \\
\hline Лечение: & $\begin{array}{l}\text { Дренирование кисты (наружное или } \\
\text { внутреннее). }\end{array}$ \\
\hline $\begin{array}{l}\text { Сколько времени необходимо для } \\
\text { полного формирования стенок } \\
\text { ложных кист? }\end{array}$ & 6 недель. \\
\hline Возможность регрессии ложных кист: & $\begin{array}{l}\text { Около 50\% рассасывается и полость } \\
\text { облитерируется. }\end{array}$ \\
\hline $\begin{array}{l}\text { Какие псевдокисты требуют } \\
\text { дренирования? }\end{array}$ & $\begin{array}{l}\text { Кисты, размером более } 6 \text { см, } \\
\text { сформированные в течение } 6 \text { недель и } \\
\text { более. }\end{array}$ \\
\hline Варианты дренирования ложных кист: & $\begin{array}{l}\text { - Чрескожное дренирование; } \\
\text { - } \quad \text { Эндоскопическое дренирование; } \\
\text { - Хирургическое дренирование. }\end{array}$ \\
\hline $\begin{array}{l}\text { Тактика лечения ложных кист, } \\
\text { спаянных с желудком: }\end{array}$ & Формирование цистогастроанастомоза. \\
\hline $\begin{array}{l}\text { Тактика лечения ложных кист, } \\
\text { спаянных с 12-перстной кишкой: }\end{array}$ & $\begin{array}{l}\text { Формирование } \\
\text { цистодуоденоанастомоза. }\end{array}$ \\
\hline $\begin{array}{l}\text { Тактика лечения ложных кист, } \\
\text { неспаянных с желудком и 12-перстной } \\
\text { кишкой: }\end{array}$ & $\begin{array}{l}\text { Цистоеюноанастомоз на выключенной } \\
\text { по Ру петле тощей кишки. }\end{array}$ \\
\hline $\begin{array}{l}\text { Тактика лечения ложных кист, } \\
\text { расположенных в хвостовой части } \\
\text { поджелудочной железы: }\end{array}$ & $\begin{array}{l}\text { Дистальная резекция поджелудочной } \\
\text { железы. }\end{array}$ \\
\hline
\end{tabular}




\begin{tabular}{|c|c|}
\hline Вопросы & Ответы \\
\hline $\begin{array}{l}\text { Эндоскопические методы лечения } \\
\text { ложных кист: }\end{array}$ & $\begin{array}{l}\text { Эндоскопическая цистогастростомия, } \\
\text { эндоскопическая цистодуоденостомия, } \\
\text { внутрипротоковое стентирование. }\end{array}$ \\
\hline $\begin{array}{l}\text { Необходимый этап при хирургическом } \\
\text { лечении псевдокисты поджелудочной } \\
\text { железы: }\end{array}$ & $\begin{array}{l}\text { Необходима биопсия стенки кисты для } \\
\text { исключения карциномы. }\end{array}$ \\
\hline $\begin{array}{l}\text { Что является основной причиной } \\
\text { летального исхода при ложных кистах } \\
\text { поджелудочной железы? }\end{array}$ & Массивное кровотечение из кисты. \\
\hline Что такое неопластические кисты? & $\begin{array}{l}\text { Кистозные образования, внутренние } \\
\text { стенки которых выстланы клетками } \\
\text { опухлевой или эндокринной природы. }\end{array}$ \\
\hline Какие формы различают? & $\begin{array}{l}\text { Серозная, } \\
\text { цистаденокарциномы. }\end{array}$ \\
\hline Что такое серозная цистаденома? & $\begin{array}{l}\text { Кистозное образование } \\
\text { доброкачественной природы. }\end{array}$ \\
\hline Частота встречаемости: & В структуре кист составляет 30\%. \\
\hline Особенность клинического течения: & Имеет доброкачественное течение. \\
\hline Клинические признаки: & $\begin{array}{l}\text { Боли, симптомы компрессии соседних } \\
\text { органов. }\end{array}$ \\
\hline $\begin{array}{l}\text { Методы исследования, необходимые } \\
\text { для уточнения диагноза: }\end{array}$ & $\begin{array}{l}\text { УЗИ, КТ, МРТ, определение } \\
\text { концентрации СА 19-9 в содержимом } \\
\text { кисты, биопсия. }\end{array}$ \\
\hline Что такое цистаденокарцинома? & $\begin{array}{l}\text { Злокачественная } \\
\text { развивающаяся из ппухль, } \\
\text { эпителия поджелудочной железы. }\end{array}$ \\
\hline Клинические признаки: & $\begin{array}{l}\text { Боли, симптомы сдавления соседних } \\
\text { органов. }\end{array}$ \\
\hline
\end{tabular}




\begin{tabular}{|c|c|}
\hline Вопросы & Ответы \\
\hline $\begin{array}{l}\text { Методы исследования, необходимые } \\
\text { для уточнения диагноза: }\end{array}$ & $\begin{array}{l}\text { УЗИ, КТ, МРТ, определение } \\
\text { концентрации СА 19-9 в содержимом } \\
\text { кисты, биопсия. }\end{array}$ \\
\hline Лабораторные признаки: & $\begin{array}{l}\text { Высокая концентрация СА } 19-9 \text { в } \\
\text { содержимом кисты. }\end{array}$ \\
\hline Лечение: & Радикальная резекция. \\
\hline $\begin{array}{l}\text { Наиболее часто встречающиеся } \\
\text { паразитарные кисты поджелудочной } \\
\text { железы: }\end{array}$ & Эхинококковая киста. \\
\hline Частота встречаемости: & $\begin{array}{lcc}\text { Составляет } & 75 \% & \text { всех }\end{array}$ \\
\hline $\begin{array}{l}\text { Методы исследования, необходимые } \\
\text { для уточнения диагноза: }\end{array}$ & $\begin{array}{l}\text { УЗИ, КТ, серологические исследования. } \\
\text { Однако диагноз подтверждается } \\
\text { интраоперационно. }\end{array}$ \\
\hline Методы лечения: & Хирургическое и антигельминтное. \\
\hline
\end{tabular}

\section{СПИСОК ЛИТЕРАТУРЫ}

\section{Ümumi adabiyyat}

- Ağayev B.A. Cərrahi xəstəliklər. Bakı 2010.

- Blackbourne LH. Surgical Recall. 4 edition, 2006, LWW, Philadelphia

- Doherty GM. Current Diagnosis and Treatment: Surgery, $13^{\text {th }}$ edition, 2010, Lang International Edition.

- Omiraslanov D.T., Qazıyev A.Y. Onkologiya. Bakı, 2010.

- İsayev H.B. Cərrahi xəstəliklərin patofizologiyası. Bakı 2005

- Klingensmith ME, Aziz A, Bharat A, Fox AC, Porembka MR. The Washington Manual of Surgery, $6^{\text {th }}$ edition, 2012, LWW, Philadelphia. 
- McNally PR. GI/Liver Secrets Plus. 4 edition. Mosby, Elsevier, 2010

- Medscape, http://www.medscape.com

- Oxford Handbook of Clinical Surgery, 3d edition, 2011, Oxford Press

- Sayek I. Sayek Temel Cerrahi 1-2. 4-cü baskı, 2016, Güneş Tıp Kitabevleri.

- Topçubaşov M.A. Xüsusi cərrahlıq. Bakı, 1979

- UpToDate, http://www.uptodate.com

- Гостищев В.К. Общая хирургия. GEOTAR-Media, 2019

\section{Xüsusi adabiyyat}

- Bayramov N.Y. Təcili Abdominal cərrahiyyədə müayinə və müalicə qaydaları. ISBN13 978-9952-8082-1-6, Qismat, Bakı 2009. $132 \mathrm{~s}$.

- Bayramov N.Y. Təcili Abdominal cərrahiyyədə müayinə və müalicə qaydaları. ISBN13 978-9952-8082-1-6, Qismət, Bakı 2009. $132 \mathrm{~s}$.

- Bayramov N.Y. Cərrahiyyə Seminarları: Mədəaltı vəzin cərrahi xəstəlikləri. ISBN: 97594665-1-0, Ankara 2002, 217s.

- Lewis J Rose. Pancreatic Cancer Guidelines. Medscape, Dec 15, 2014. http://emedicine.medscape.com/article/2246978

- NCCN Clinical Practice Guidelines in Oncology: Pancreatic Adenocarcinoma. V2.2014. Available athttp://www.nccn.org/professionals/physician gls/pdf/pancreatic.pdf. Accessed: November 2, 2014.

- Tenner S, Baillie J, Dewitt J, Vege SS. American College of Gastroenterology guideline: management of acute pancreatitis. Am J Gastroenterol. 2013 Sep;108(9):1400-15/

- Sven M van Dijk; Nora D L Hallensleben; Hjalmar C van Santvoort; Paul Fockens; Harry van Goor; Marco J Bruno; Marc G Besselink. Acute Pancreatitis: Recent Advances Through Randomised Trials. Gut. 2017;66(11):2024-2032. 


\section{ХИРУРГИЧЕСКИЕ БОЛЕЗНИ}

Н.Ю. Байрамов

\section{Хирургические заболевания селезёнки}

Н.Ю. Байрамов, Т.М. Рзаев, А.К. Сафиева, Ш.А. Мамедова

Перевод: Н.Ю. Байрамов, С.А. Алиев, М.Р.Гусейинова 


\section{СПЛЕНОМЕГАЛИЯ}

- Под спленомегалией подразумевается увеличение селезёнки в размерах.

- Гиперспленизм - увеличение размеров селезёнки и повышение её функции. Таким образом, для гиперспленизма характерно наличие следующих критериев: спленомегалия, цитопения (моно-, ди-, трицитопения) и реактивная гиперплазия костного мозга.

- Обычно спленомегалия бывает вторичной и среди её причин лидирующее положение занимают болезни кроветворной системы, печени, инфекционные заболевания и аутоиммунные процессы.

- Клинические проявления спленомегалии зависят от нозологических причин, у большинства больных заболевание впервые манифестирует симптомами основной болезни. Встречаются и бессимптомные варианты клинического течения. Болезнь проявляется симптомами осложнений (портальная гипертензия, цитопения, сдавление соседних органов).

- Главной задачей диагностики является выявление причин, вызвавших спленомегалию. В комплексе диагностики применяют гематологические исследования, исключают или подтверждают заболевания печени, инфекционные болезни и аутоиммунные процессы.

- Лечение предусматривает устранение нозологических причин, вызвавших спленомегалии. При отсутствии такой возможности выполняют спленэктомию (тотальную или парциальную), эмболизацию селезёночной артерии.

\section{Вопросы и ответы по спленомегалии}

\begin{tabular}{|c|c|}
\hline Bonpocbl & Ответы \\
\hline Что такое спленомегалия? & Увеличение размеров селезенки. \\
\hline Что такое гиперспленизм? & $\begin{array}{l}\text { - Спленомегалия; } \\
\text { - Гиперфункция селезенки } \\
\text { (цитопения); } \\
\text { - Реактивная гиперплазия костного } \\
\text { мозга. }\end{array}$ \\
\hline
\end{tabular}




\begin{tabular}{|c|c|}
\hline Вопросы & Ответы \\
\hline Клинические формы спленомегалии: & $\begin{array}{l}\text { - Застойная; } \\
\text { - Гипертрофированная, } \\
\text { гиперплазированная; } \\
\text { - Реактивная; } \\
\text { - Неопластическая; } \\
\text { - Метаболическая и др. }\end{array}$ \\
\hline Этиология и факторы риска: & $\begin{array}{l}\text { - Портальная гипертензия; } \\
\text { - Инфекционные заболевания; } \\
\text { - Воспалительные и аутоиммунные } \\
\text { процессы; } \\
\text { - Метаболические синдромы. }\end{array}$ \\
\hline $\begin{array}{l}\text { В чём заключается патогенез } \\
\text { спленомегалии? }\end{array}$ & $\begin{array}{l}\text { - Застой; } \\
\text { - Гиперфункция селезёнки, связанная } \\
\text { с чрезмерным разрушением } \\
\text { клеточных элементов крови; } \\
\text { - Воспаление и пролиферация } \\
\text { мезенхимальных клеток. }\end{array}$ \\
\hline $\begin{array}{l}\text { Что является наиболее частым } \\
\text { признаком портальной гипертензии? }\end{array}$ & Спленомегалия. \\
\hline $\begin{array}{l}\text { Чем характеризуется особенность } \\
\text { клинического течения? }\end{array}$ & Зависит от нозологических причин. \\
\hline $\begin{array}{l}\text { Какие осложнения характерны для } \\
\text { спленомегалии? }\end{array}$ & $\begin{array}{l}\text { - Тромбоцитопения и кровотечение; } \\
\text { - Анемия; } \\
\text { - Лейкопения, инфекции; } \\
\text { - Портальная гипертензия и } \\
\text { варикозное кровотечение; } \\
\text { - Сдавление внутренних органов; } \\
\text { - При чрезмерном увеличении } \\
\text { селезенки могут наблюдаться } \\
\text { поражение печени (синдром Банти) } \\
\text { и сердечная недостаточность. }\end{array}$ \\
\hline Клинические признаки: & - Симптомы основного заболевания; \\
\hline
\end{tabular}




\begin{tabular}{|c|c|}
\hline Вопросы & Ответы \\
\hline & $\begin{array}{l}\text { - Наличие объёмного образования в } \\
\text { брюшной полости; } \\
\text { - Кровотечение и анемия, связанные с } \\
\text { цитопенией; } \\
\text { - Повторяющиеся инфекции; } \\
\text { - Желудочно-кишечные } \\
\text { кровотечения. }\end{array}$ \\
\hline $\begin{array}{l}\text { У каких пациентов можно } \\
\text { заподозрить спленомегалию? }\end{array}$ & $\begin{array}{l}\text { - Увеличение объёма живота; } \\
\text { - Определение объёмного } \\
\text { образования в брюшной полости (в } \\
\text { левом поддиафрагмальном } \\
\text { пространстве); } \\
\text { - Наличие признаков цитопении; } \\
\text { - Признаки портальной гипертензии; } \\
\text { - } \text { Признаки сдавления } \\
\text { внутрибрюшных органов - } \\
\text { дискомфортв животе, одышка после } \\
\text { приёма пищи. }\end{array}$ \\
\hline $\begin{array}{l}\text { Какие исследования необходимы для } \\
\text { уточнения диагноза? }\end{array}$ & $\begin{array}{l}\text { - Общий анализ крови; } \\
\text { - УзИ; } \\
\text { - КТ. }\end{array}$ \\
\hline Лабораторные показатели: & Цитопения (моно-, ди-, панцитопения). \\
\hline $\begin{array}{l}\text { Признаки, выявляемые при } \\
\text { инструментальной диагностике: }\end{array}$ & $\begin{array}{l}\text { Увеличение размеров селезёнки по } \\
\text { продольной оси более } 14 \text { см и по } \\
\text { ширине более } 5 \text { см, или увеличением } \\
\text { объёма органа более } 250 \text { cм }^{3} \text {. }\end{array}$ \\
\hline Современные методы лечения: & $\begin{array}{l}\text { - Устранение причины; } \\
\text { - Хирургическое. }\end{array}$ \\
\hline Показания к хирургическому лечению: & $\begin{array}{l}\text { - Невозможность выявления причин; } \\
\text { - Новообразование. }\end{array}$ \\
\hline Методы хирургического лечения: & $\begin{array}{l}\text { - Спленэктомия; } \\
\text { • } \quad \text { Эмболизация } \\
\text { артерии; }\end{array}$ \\
\hline
\end{tabular}




\begin{tabular}{|ll|}
\hline \multicolumn{1}{|c|}{ Вопросы } & \multicolumn{1}{c|}{ Ответы } \\
\hline & - Перевязка селезёночной артерии; \\
& - Применение факторов роста. \\
\hline Охарактеризуйте сущность & Увеличение размеров селезёнки \\
заболевания: & (спленомегалия, гиперспленизм), как \\
& правило, является вторичным и \\
& развивается на фоне различных \\
& заболеваний. \\
\end{tabular}




\section{НОВООБРАЗОВАНИЯ СЕЛЕЗЁНКИ}

- Под новообразованиями селезёнки подразумеваются расположенные в нём различные неопластические или другие образования, имеющие кистозные, тканевые или смешанные структуры.

- Новообразования селезёнки в большинстве случаев имеют злокачественную природу, среди которых наиболее часто встречаются лимфома и метастатические аденокарциномы. Более половины доброкачественных образований селезёнки составляют кисты, в том числе и паразитарные.

- Клиническая картина новообразований селезёнки вариабельна. Так, кисты, размерами менее 5 см и имеющие тканевые структуры протекают бессимптомно. Кисты больших размеров, вызывая сдавление соседних органов и окружающих тканей, нередко сопровождаются гиперспленизмом. Метастатические же опухоли проявляются симптомами основного заболевания.

- Для диагностики новообразований селезёнки используют УзИ, КТ с учётом клинической картины заболевания. При невозможности уточнить истинный диагноз или исключить злокачественный процесс, проводят биопсию или выполняют спленэктомию.

- Лечение новообразований селезёнки проводится с учётом их этиологии.

\section{Вопросы и ответы по новообразованиям селезёнки}

\begin{tabular}{|c|c|}
\hline Вопросы & Ответы \\
\hline $\begin{array}{l}\text { Классификация новообразований } \\
\text { селезёнки по клинико- } \\
\text { морфологическим признакам: }\end{array}$ & $\begin{array}{l}\text { - Кисты; } \\
\text { - Образования, имеющие тканевые и } \\
\text { смешанные структуры: } \\
\text { о Неопластические } \\
\text { образования; } \\
\text { О Гематома; } \\
\text { О Инфаркт; } \\
\text { О Кальцификация; } \\
\text { - Абсцесс. }\end{array}$ \\
\hline
\end{tabular}




\begin{tabular}{|c|c|}
\hline Bопросы & Ответы \\
\hline $\begin{array}{l}\text { Наиболее часто встречающиеся } \\
\text { злокачественные } \\
\text { новообразования селезёнки: }\end{array}$ & $\begin{array}{l}\text { Лимфомы и метастатические } \\
\text { аденокарциномы. }\end{array}$ \\
\hline $\begin{array}{l}\text { Наиболее часто встречающиеся } \\
\text { доброкачественные } \\
\text { новообразования селезёнки: }\end{array}$ & Кисты (паразитарные). \\
\hline $\begin{array}{l}\text { Клинические проявления } \\
\text { новообразований селезёнки: }\end{array}$ & $\begin{array}{l}\text { - Доброкачественные образования, } \\
\text { размерами менее } 5 \text { см протекают } \\
\text { бессимптомно; } \\
\text { - Новообразования, размером более } \\
5 \text { см, вызывают сдавление } \\
\text { окружающих органов и тканей, } \\
\text { сопровождаются гиперспленизмом; } \\
\text { - Метастатические новообразования } \\
\text { проявляются симптомами } \\
\text { основного заболевания. }\end{array}$ \\
\hline $\begin{array}{l}\text { У каких пациентов можно } \\
\text { заподозрить новообразования } \\
\text { селезёнки? }\end{array}$ & $\begin{array}{l}\text { При наличии следующих симптомов: } \\
\text { - Чувство быстрого насыщения; } \\
\text { - Пальпаторная болезненность в } \\
\text { эпигастральной области и левом } \\
\text { подреберье; } \\
\text { - Боли в левом подреберье; } \\
\text { - Наличие эхинококкоза печени; } \\
\text { - Лимфома; } \\
\text { - Высокая температура. }\end{array}$ \\
\hline $\begin{array}{l}\text { Какие методы исследования } \\
\text { необходимы для уточнения диагноза? }\end{array}$ & УзИ или венозная фаза контрастной КТ. \\
\hline $\begin{array}{l}\text { Почему неинформативна } \\
\text { артериальная фаза КТ для уточнения } \\
\text { диагноза объёмных образований } \\
\text { селезёнки? }\end{array}$ & $\begin{array}{l}\text { В связи с мозаичным (полосатым) } \\
\text { окрашиванием селезёнки (вид зебры). }\end{array}$ \\
\hline
\end{tabular}




\begin{tabular}{|c|c|}
\hline Вопросы & Ответы \\
\hline $\begin{array}{l}\text { Какой метод исследования показан } \\
\text { при подозрении на кистозное } \\
\text { образование селезёнки? }\end{array}$ & УЗИ. \\
\hline $\begin{array}{l}\text { Какие методы исследования } \\
\text { необходимы для диагностики } \\
\text { тканевых образований селезёнки? }\end{array}$ & $\begin{array}{l}\text { - УЗИ, контрастная КТ или МРТ; } \\
\text { - Диагностическая спленэктомия. }\end{array}$ \\
\hline $\begin{array}{l}\text { Признаки диагностической } \\
\text { визуализации: }\end{array}$ & $\begin{array}{l}\text { При УзИ - обнаружение изо-, гипер- } \\
\text { или гетерогенного включения } \\
\text { (образования). При КТ - } \\
\text { контрастирование образования. }\end{array}$ \\
\hline Характерны признаки гематомы: & $\begin{array}{l}\text { - Наличие травмы в анамнезе; } \\
\text { - Выявление при КТ } \\
\text { неконтрастированного } \\
\text { образования. }\end{array}$ \\
\hline $\begin{array}{l}\text { Характерны признаки дермоидных } \\
\text { кист: }\end{array}$ & $\begin{array}{l}\text { При КТ: } \\
\text { • образование с толстой стенкой; } \\
\text { • Наличие в содержимом элементов } \\
\text { эктодермальной природы (кость, } \\
\text { зубы, волосы). }\end{array}$ \\
\hline Характерны признаки гемангиомы: & $\begin{array}{l}\text { В артериальной фазе контрастной КТ } \\
\text { или МРТ узловое контрастирование по } \\
\text { периферии, задержка контраста в } \\
\text { венозной фазе. }\end{array}$ \\
\hline $\begin{array}{l}\text { Методы лечения образований } \\
\text { селезёнки: }\end{array}$ & $\begin{array}{l}\text { Зависит от характера и вида } \\
\text { новообразований. }\end{array}$ \\
\hline Показания к хирургическому лечению: & $\begin{array}{l}\text { Наличие паразитарных кист, больших } \\
\text { эпителиальных и ложных кист, кисты } \\
\text { неизвестной природы. }\end{array}$ \\
\hline
\end{tabular}




\begin{tabular}{|c|c|}
\hline Вопросы & Ответы \\
\hline Что такое абсцесс селезёнки? & $\begin{array}{l}\text { Ограниченный гнойник паренхимы } \\
\text { селезёнки. }\end{array}$ \\
\hline Частота встречаемости: & Встречается у 0,05-0,7\% населения. \\
\hline $\begin{array}{l}\text { Клинические формы абсцесса } \\
\text { селезёнки: }\end{array}$ & $\begin{array}{l}\text { - Первичный абсцесс селезенки; } \\
\text { - Абсцесс, вскрывшийся в селезёнку; } \\
\text { - Абсцесс, окружающий селезёнку. }\end{array}$ \\
\hline Этиология и факторы риска: & $\begin{array}{l}\text { - Гнойно-воспалительные } \\
\text { заболевания других органов; } \\
\text { - Повреждение паренхимы } \\
\text { селезёнки; } \\
\text { - Перфорация желудка или толстой } \\
\text { кишки; } \\
\text { - Бактериемия и др. }\end{array}$ \\
\hline Патогенез абсцесса селезёнки: & $\begin{array}{l}\text { - Гематогенный занос инфекции из } \\
\text { отдаленных гнойных очагов; } \\
\text { - Инфицирование селезёночной } \\
\text { паренхимы из окружающих тканей } \\
\text { и соседних органов; } \\
\text { - Инфицирование кисты, инфаркта и } \\
\text { гематомы селезёнки. }\end{array}$ \\
\hline Осложнения абсцесса селезёнки: & $\begin{array}{l}\text { - Спонтанный прорыв гнойника в } \\
\text { брюшную полость и развитие } \\
\text { перитонита; } \\
\text { - Сепсис и его осложнения. }\end{array}$ \\
\hline $\begin{array}{l}\text { Клинические признаки абсцесса } \\
\text { селезёнки: }\end{array}$ & $\begin{array}{l}\text { - Боли в области левого подреберья; } \\
\text { - Высокая температура; } \\
\text { - Пальпация увеличенной селезёнки; } \\
\text { - Напряжённость брюшной стенки, } \\
\text { связанная с перитонитом. }\end{array}$ \\
\hline $\begin{array}{l}\text { У каких пациентов можно заподозрить } \\
\text { абсцесс селезёнки? }\end{array}$ & $\begin{array}{l}\text { Пациенты с характерной клинической } \\
\text { картиной и признаками абсцесса на } \\
\text { Узи. }\end{array}$ \\
\hline
\end{tabular}




\begin{tabular}{|c|c|}
\hline Вопросы & Ответы \\
\hline $\begin{array}{l}\text { Какие методы исследования } \\
\text { необходимы для диагностики } \\
\text { абсцесса селезёнки? }\end{array}$ & $\begin{array}{l}\text { - Лабораторные анализы; } \\
\text { - УзИ; } \\
\text { - КТ. }\end{array}$ \\
\hline $\begin{array}{l}\text { Лабораторные признаки абсцесса } \\
\text { селезёнки? }\end{array}$ & $\begin{array}{l}\text { - Лейкоцитоз; } \\
\text { • Повышение С-реактивного } \\
\text { протеина. }\end{array}$ \\
\hline $\begin{array}{l}\text { Признаки диагностической } \\
\text { визуализации абсцесса: }\end{array}$ & $\begin{array}{l}\text { При КТ обнаруживают очаг затемнения } \\
\text { с уровенем жидкости с наличием газа } \\
\text { над ним. }\end{array}$ \\
\hline $\begin{array}{l}\text { Перечислите диагностические } \\
\text { критерии абсцесса селезёнки: }\end{array}$ & $\begin{array}{l}\text { Образование кистозной или } \\
\text { смешанной структуры, признаки } \\
\text { сепсиса и SiRS. }\end{array}$ \\
\hline Методы лечения абсцесса селезёнки: & $\begin{array}{l}\text { Консервативное (антибиотикотерапия) } \\
\text { и хирургическое. }\end{array}$ \\
\hline Показания к хирургическому лечению: & $\begin{array}{l}\text { - При одиночных и периферических } \\
\text { абсцессах показано чрескожное } \\
\text { дренирование под контролем УзИ } \\
\text { (КТ); } \\
\text { - При множественных абсцессах и } \\
\text { невозможности дренирования - } \\
\text { спленэктомия или частичная } \\
\text { резекция. }\end{array}$ \\
\hline Методы хирургического лечения: & $\begin{array}{l}\text { - Спленэктомия; } \\
\text { - Чрескожное дренирование абсцесса } \\
\text { под контролем УзИ; } \\
\text { - Лапароскопическое дренирование; } \\
\text { - Резекция селезёнки. }\end{array}$ \\
\hline Прогноз: & Летальность составляет 10-47\%. \\
\hline
\end{tabular}




\section{Вопросы и ответы по кистам селезёнки}

\begin{tabular}{|c|c|}
\hline Bопросы & Ответы \\
\hline Что такое ложная киста? & $\begin{array}{l}\text { Кисты, формирующиеся после травмы } \\
\text { и инфаркта селезёнки, не имеющие } \\
\text { внутренней эпителиальной выстилки. }\end{array}$ \\
\hline Какие кисты являются истинными? & $\begin{array}{l}\text { Кисты, имеющие внутреннюю } \\
\text { эпительную выстилку. Обычно } \\
\text { врождённые. }\end{array}$ \\
\hline Частота встречаемости: & $\begin{array}{l}\text { Дермоидные и эпидермальные кисты } \\
\text { встречаются редко. }\end{array}$ \\
\hline Клинические формы: & $\begin{array}{l}\text { - Паразитарные- эхинококк; } \\
\text { - Непаразитарные: } \\
\text { ○ Эпителиальные; } \\
\text { ○ Ложные; } \\
\text { ○ Дермоидные; } \\
\text { ○ Неопластические. }\end{array}$ \\
\hline Этиология и фактора риска: & $\begin{array}{l}\text { - Паразитарные кисты (эхинококк); } \\
\text { - Врожденные истинные кисты } \\
\text { (дермоидные и эпителиальные); } \\
\text { - Псевдокисты - кисты, формирую- } \\
\text { щиеся вследствие травмы и } \\
\text { инфаркта. }\end{array}$ \\
\hline Особенности клинического течения: & $\begin{array}{l}\text { Эхинококковые кисты склонны к } \\
\text { увеличению, разрыву и диссеминации. }\end{array}$ \\
\hline Осложнения кист селезёнки: & $\begin{array}{l}\text { - Инфицирование; } \\
\text { - Разрыв; } \\
\text { - Кровотечение. }\end{array}$ \\
\hline Клинические проявления: & $\begin{array}{l}\text { Обычно протекают бессимптомно, при } \\
\text { увеличении размеров более } 5 \text { см или } \\
\text { при разрыве развиваются } \\
\text { соответствующие симптомы. }\end{array}$ \\
\hline $\begin{array}{l}\text { У каких пациентов можно заподозрить } \\
\text { наличие кисты селезёнки? }\end{array}$ & $\begin{array}{l}\text { У пациентов, имеющих в анамнезе } \\
\text { травмы или эхинококкоз селезёнки. }\end{array}$ \\
\hline
\end{tabular}




\begin{tabular}{|c|c|}
\hline $\begin{array}{l}\text { Какие методы исследования } \\
\text { необходимы для диагностики кист } \\
\text { селезёнки? }\end{array}$ & $\begin{array}{l}\text { - УзИ и КТ; } \\
\text { - Гистологическое исследование - } \\
\text { для дифференциальной } \\
\text { диагностики истинной и ложной } \\
\text { кисты. }\end{array}$ \\
\hline $\begin{array}{l}\text { Признаки диагностической } \\
\text { визуализации: }\end{array}$ & $\begin{array}{l}\text { На УзИ - наличие анэхогенного участка. } \\
\text { При контрастном КТ - отсутствие } \\
\text { контрастирования. }\end{array}$ \\
\hline $\begin{array}{l}\text { Характерные визуальные признаки } \\
\text { эхинококковых кист: }\end{array}$ & $\begin{array}{l}\text { - Утолщение (удвоение) стенки кисты; } \\
\text { - Наличие дочерних пузырьков, } \\
\text { перегородок, признаков разрыва } \\
\text { кисты; } \\
\text { - Кальцификация стенок; } \\
\text { - Наличие эхинококкоза другой } \\
\text { локализации (печени). }\end{array}$ \\
\hline Методы лечения: & $\begin{array}{l}\text { П При кистах, диаметром менее } 5 \text { см - } \\
\text { наблюдение; } \\
\text { - Консервативное - антигельминтное } \\
\text { лечение; } \\
\text { - Хирургическое - кисты, размером } \\
\text { более } 5 \text { см и имеющие } \\
\text { соответствующую симптоматику. }\end{array}$ \\
\hline Показания к хирургическому лечению: & $\begin{array}{l}\text { Большие кисты с соответствующей } \\
\text { клинической симптоматикой. }\end{array}$ \\
\hline Виды хирургических вмешательств: & $\begin{array}{l}\text { - Спленэктомия; } \\
\text { - Резекция кисты, фенестрация кисты; } \\
\text { - Резекция селезёнки. }\end{array}$ \\
\hline
\end{tabular}




\section{СОСУДИСТЫЕ ЗАБОЛЕВАНИЯ СЕЛЕЗЁНКИ}

- K наиболее часто встречающимся сосудистым заболеваниям селезёнки относятся: инфаркт селезёнки, аневризма селезёночной артерии и тромбоз селезёночной вены.

- Инфаркт селезёнки - представляет собой ишемический некроз селезёночной ткани, обусловленный тромбозом (эмболией) или сдавлением селезёночной артерии или её ветвей.

- Причинами развития инфаркта селезёнки могут быть тромбофилические состояния (злокачественные процессы, антифосфолипидный синдром), портальная гипертензия, атеросклероз, бактериальный септический эндокардит, лечебная эмболизация селезёночной артерии, миелопролиферативные заболевания (полицитемия, миелофиброз, тромбоцитемия), гемоглобинопатия, травмы, заворот селезёнки.

- Мелкие инфаркты селезёнки у половины больных протекают бессимптомно или слабовыраженными клиническими признаками. У более чем половины больных заболевание начинается внезапно с интенсивных резких болей в левом подреберье, сопровождающихся лихорадкой, высокой температурой, тахикардией, лейкоцитозом, рвотой и парезом кишечника.

- В большинстве случаев наступает самоизлечение с организацией, фиброзом и рубцеванием зоны инфаркта. Реже наблюдаются инфицирование и гнойное расплавление поражённой зоны, кровотечение или образование абсцесса селезёнки. Иногда в зоне инфаркта развивается ложная киста.

- Среди инструментальных методов диагностики наиболее информативны УзИ и КТ. Характерным признаком инструментальной визуализации является выявление зоны без контраста.

- Выбор метода лечения зависит от обширности поражения и выраженности клинических проявлений. Наиболее часто выполняют спленэктомию. При бессимптомном течении показано наблюдение, при развитии осложнений хирургическое вмешательство.

- Аневризма селезёночной артерии - занимает 3-е место среди аневризм сосудов органов брюшной полости после аневризм аорты и подвздошных артерий. 
- Клинически проявляются болью и признаками инфаркта селезёнки. У беременных высокий риск спонтанного разрыва аневризмы селезёночной артерии.

- Диагноз уточняется КТ ангиографией.

- Выбор метода лечения определяется размером, выраженностью клинических симптомов. При планировании беременности, При аневризме, размером более 2 см, а также имеющей соответствующую симптоматику - хирургическое лечение (перевязку артерии выше и ниже аневризмы, спленэктомия). Аневризмы бессимптомные аневризмы размером менее 2 см требуют наблюдения.

- Тромбоз селезёночной вены проявляется синдромом левосторонней портальной гипертензии и является наиболее частым видом тромбоза вен органов брюшной полости.

- Наиболее частыми причинами являются хронический панкреатит, рак поджелудочной железы, язва задней стенки желудка, ретроперитонеальный фиброз и спленэктомия.

- Тромбоз селезёночной вены проявляется симптомами варикоза фундальных вен желудка и варикозным кровотечением (15-20\%), может сопровождаться спленомегалией и гиперспленизмом.

- Диагноз ставят на основании данных КТ/МРТ-ангиографии.

- Если причиной тромбоза является неопухолевое заболевание, то выполняют спленэктомию. При тромбозах, вызванных злокачественными процессами, спленэктомия неэффективна.

\section{Вопросы и ответы по сосудистым заболеваниям селезёнки}

\begin{tabular}{|ll}
\hline \multicolumn{1}{|c|}{ Вопросы } & \multicolumn{1}{c}{ Ответы } \\
\hline Что такое инфаркт селезёнки? & Ишемический некроз, вызванный \\
& тромбозом или эмболией, или \\
& сдавлением селезёночной артерии иеё \\
& ветвей. \\
\hline Этиология и факторы риска развития & Инфаркт селезёнки развивается на фоне \\
инфаркта селезёнки: & следующих заболеваний: \\
& - Тромбофилические состояния; \\
\hline
\end{tabular}




\begin{tabular}{|c|c|}
\hline Вопросы & Ответы \\
\hline & $\begin{array}{l}\text { - Эмбологенные факторы - стеноз } \\
\text { левого атриовентрикулярного } \\
\text { отверстия, фибриляция левого } \\
\text { предсердия, атеросклероз, лечебная } \\
\text { эмболизация; } \\
\text { - Миелопролиферативные болезни; } \\
\text { - Гемоглобинопатии; } \\
\text { - Спленомегалия; } \\
\text { - Заворот селезёнки; } \\
\text { - Травмы селезёнки. }\end{array}$ \\
\hline Осложнения инфаркта селезёнки: & $\begin{array}{l}\text { - Кровотечение; } \\
\text { - Абсцедирование зоны инфаркта. }\end{array}$ \\
\hline $\begin{array}{l}\text { Клинические проявления инфаркта } \\
\text { селезёнки: }\end{array}$ & $\begin{array}{l}\text { - Слабовыраженные симптомы или } \\
\text { бессимптомное течение (в 50\% } \\
\text { случаев); } \\
\text { - Интенсивные боли в левой половине } \\
\text { живота; } \\
\text { - Тошнота и рвота; } \\
\text { - Болезненность в левом подреберье } \\
\text { при пальпации; } \\
\text { - Высокая температура; } \\
\text { - Повышение концентрации ЛДг; } \\
\text { - Лейкоцитоз. }\end{array}$ \\
\hline $\begin{array}{l}\text { Какие методы исследования } \\
\text { необходимы для диагностики } \\
\text { инфаркта селезёнки? }\end{array}$ & Контрастная КТ. \\
\hline $\begin{array}{l}\text { Признаки визуализации при } \\
\text { инструментальном исследовании: }\end{array}$ & $\begin{array}{lr}\text { При контрастной КТ } & \text { выявляется } \\
\text { неконтрастированный } & \text { участок } \\
\text { пирамидной формы. } & \end{array}$ \\
\hline Методы лечения: & $\begin{array}{l}\text { - При бессимптомном } \\
\text { неосложнённом течении } \\
\text { наблюдение; }\end{array}$ \\
\hline
\end{tabular}




\begin{tabular}{|c|c|}
\hline Вопросы & Ответы \\
\hline & $\begin{array}{l}\text { - При развитии осложнений } \\
\text { хирургическое вмешательство. }\end{array}$ \\
\hline Показания к хирургическому лечению: & $\begin{array}{l}\text { Потенциальная опасность развития } \\
\text { тяжёлых осложнений. }\end{array}$ \\
\hline Методы хирургического лечения: & Спленэктомия. \\
\hline Прогноз: & $\begin{array}{l}\text { В большинстве наблюдений наступает } \\
\text { организация и рубцевание зоны } \\
\text { инфаркта. } \\
\text { псевдокиста. }\end{array}$ \\
\hline $\begin{array}{l}\text { Что такое аневризма селезёночной } \\
\text { артерии? }\end{array}$ & $\begin{array}{l}\text { Мешковидное расширение стенок } \\
\text { селезёночной артерии. }\end{array}$ \\
\hline $\begin{array}{l}\text { Частота встречаемости аневризмы } \\
\text { селезёночной артерии: }\end{array}$ & Редко встречающаяся патология. \\
\hline Осложнения: & $\begin{array}{l}\text { Разрыв с массивным кровотечением, } \\
\text { инфаркт селезёнки. }\end{array}$ \\
\hline $\begin{array}{l}\text { Клинические проявления аневризмы } \\
\text { селезёночной артерии: }\end{array}$ & $\begin{array}{l}\text { Болевой синдром и симптомы инфаркта } \\
\text { селезёнки. }\end{array}$ \\
\hline $\begin{array}{l}\text { У каких пациентов можно } \\
\text { заподозрить наличие аневризмы } \\
\text { селезёночной артерии? }\end{array}$ & $\begin{array}{l}\text { При выявлении объёмного образования } \\
\text { в проекции селезёночной артерии во } \\
\text { время УзИ и КТ. }\end{array}$ \\
\hline $\begin{array}{l}\text { Какое исследование необходимо для } \\
\text { уточнения диагноза? }\end{array}$ & КТ-ангиография. \\
\hline $\begin{array}{l}\text { Признаки инструментальной } \\
\text { визуализации: }\end{array}$ & Сегментарное расширение артерии. \\
\hline Современные методы лечения: & $\begin{array}{l}\text { - При планировании беременности } \\
\text { показано хирургическое лечение в } \\
\text { связи с высоким риском разрыва; } \\
\text { - При бессимптомно протекающей } \\
\text { аневризме, размером менее } 2 \text { см - } \\
\text { наблюдение; } \\
\text { - При аневризме, размером более } 2 \\
\text { см, имеющей соответствующую } \\
\text { симптоматику, а также при наличии }\end{array}$ \\
\hline
\end{tabular}




\begin{tabular}{|c|c|}
\hline Вопросы & Ответы \\
\hline & $\begin{array}{l}\begin{array}{l}\text { признаков } \\
\text { воспаления } \\
\text { лечение. }\end{array} \quad \text { хируфокального } \\
\end{array}$ \\
\hline Виды хирургических операций: & $\begin{array}{l}\text { - Перевязка артерии выше и ниже } \\
\text { - Сневризмы (как первичный выбор); } \\
\text { Спленэктомия + эневризматического мешка или } \\
\text { эндоваскулярная эмболизация. }\end{array}$ \\
\hline $\begin{array}{l}\text { Вероятные осложнения при } \\
\text { эмболизации аневризмы: }\end{array}$ & $\begin{array}{l}\text { Возможно развитие инфаркта } \\
\text { селезёнки. }\end{array}$ \\
\hline Прогноз: & $\begin{array}{l}\text { Худший исход может наблюдаться У } \\
\text { беременных в связи с разрывом } \\
\text { аневризмы. }\end{array}$ \\
\hline $\begin{array}{l}\text { Показание к спленэктомии при } \\
\text { тромбозе селезёночной вены: }\end{array}$ & $\begin{array}{l}\text { Гиперспленизм и } \quad \text { фундальные } \\
\text { варикозные вены желудка. }\end{array}$ \\
\hline $\begin{array}{l}\text { Частота встречаемости } \\
\text { изолированного тромбоза } \\
\text { селезёночной вены и левосторонней } \\
\text { портальной гипертензии: }\end{array}$ & $\begin{array}{l}\text { Среди тромбоза вен органов брюшной } \\
\text { полости занимают лидирующее } \\
\text { положение. }\end{array}$ \\
\hline Этиология и факторы риска: & $\begin{array}{l}\text { - Хронический панкреатит; } \\
\text { - Рак поджелудочной железы; } \\
\text { - Язва задней стенки желудка; } \\
\text { - Ретроперитонеальный фиброз; } \\
\text { - Спленэктомия. }\end{array}$ \\
\hline $\begin{array}{l}\text { Наиболее частая причина тромбоза } \\
\text { селезёночной вены: }\end{array}$ & Панкреатиты. \\
\hline Что относится к осложнениям? & Варикозное кровотечение. \\
\hline Клинические признаки: & $\begin{array}{l}\text { - Субклиническое или бессимптомное } \\
\text { течение; } \\
\text { - Спленомегалия; } \\
\text { - Гиперспленизм; } \\
\text { - Фундальные варикозные вены } \\
\text { желудка. }\end{array}$ \\
\hline
\end{tabular}




\begin{tabular}{|c|c|}
\hline Вопросы & Ответы \\
\hline $\begin{array}{l}\text { У каких пациентов можно } \\
\text { заподозрить? }\end{array}$ & $\begin{array}{l}\text { Выявление изолированных фундальных } \\
\text { варикозных вен при гастроскопии. }\end{array}$ \\
\hline $\begin{array}{l}\text { Наиболее частая причина развития } \\
\text { изолированных фундальных } \\
\text { варикозных вен желудка? }\end{array}$ & Тромбоз селезёночной вены. \\
\hline $\begin{array}{l}\text { Причина развития изолированных } \\
\text { варикозных фундальных вен желудка } \\
\text { при тромбозе селезёночной вены? }\end{array}$ & $\begin{array}{l}\text { Венозное дренирование посредством } \\
\text { вен с малыми диаметрами в } \\
\text { желудочные вены. }\end{array}$ \\
\hline $\begin{array}{l}\text { Какие методы исследования } \\
\text { необходимы для уточнения диагноза? }\end{array}$ & КТ/МРТ-ангиография. \\
\hline Современные методы лечения: & Спленэктомия. \\
\hline Показания к хирургическому лечению: & $\begin{array}{l}\text { Тромбоз селезёночной вены, } \\
\text { обусловленный неопухолевым } \\
\text { заболеванием. }\end{array}$ \\
\hline $\begin{array}{l}\text { Эффективна ли спленэктомия при } \\
\text { тромбозе селезёночной вены, } \\
\text { обусловленном злокачественным } \\
\text { процессом? }\end{array}$ & Неэффективна. \\
\hline $\begin{array}{l}\text { В чём заключается лечение } \\
\text { фундальных варикозных вен желудка, } \\
\text { развившихся при тромбозе } \\
\text { селезёночной вены? }\end{array}$ & Спленэктомия. \\
\hline
\end{tabular}




\section{СПЛЕНЭКТОМИЯ И ОСЛОЖНЕНИЯ ПОСЛЕ НЕЁ}

- Спленэктомия - это удаление селезёнки оперативным путём с лечебной или диагностической целью. Данная операция проводится открытым, либо лапароскопическим доступом.

- При наличии некоторых заболеваний спленэктомия является первичным (тяжёлая травма, злокачественные образования селезёнки, некроз селезёнки, тромбоз селезёночной вены, варикозное кровотечение, большая эхинококковая киста селезёнки и др.), либо вторичным методом лечения (сфероцитоз, аутоиммунная гемолитическая анемия, серповидноклеточная анемия, иммунная тромбоцитопения, иммунная нейтропения, абсцесс селезёнки, гиперспленизм, десенсибилизация и др.)

- Острый лейкоз, агранулоцитоз и симптоматический гиперспленизм являются противопоказанием к спленэктомии.

- После спленэктомии могут наблюдаться такие осложнения как плевральный выпот, кровотечение, гематома, повреждение какого-либо органа, абсцесс, тромбоз селезёночной вены, тромбоцитоз, спленоз, постспленэктомический сепсис.

- С целью профилактики осложнений в пре- и постоперационном периоде необходимо сделать прививку против капсульных бактерий, назначить антиагреганты при тромбоцитозах, а также необходимо проведение операции с минимальной травматизацией.

\section{Вопросы и ответы по спленэктомии и осложнениям после неё}

\begin{tabular}{|lll|}
\hline \multicolumn{1}{|c|}{ Вопросы } & \multicolumn{3}{c|}{ Ответы } \\
\hline $\begin{array}{l}\text { Чем известна селезёнка в } \\
\text { хирургической практике? }\end{array}$ & $\begin{array}{l}\text { Является } \\
\text { повреждаемым органом при тупых } \\
\text { интраабдоминальных травмах. }\end{array}$ \\
\hline Что такое спленэктомия? & Операция по удалению селезёнки. \\
\hline Что является обязательным & - Тяжёлая травма $\quad$ селезёнки \\
показанием к спленэктомии? & (продолжающееся кровотечение и \\
& шок); \\
\hline
\end{tabular}




\begin{tabular}{|c|c|}
\hline Вопросы & Ответы \\
\hline & $\begin{array}{l}\text { - Инвазивные злокачественные } \\
\text { образования селезёнки; } \\
\text { - Большая эхинококковая киста } \\
\text { селезёнки; } \\
\text { - Спленомегалия, связанная с } \\
\text { тромбозом селезёночной вены, } \\
\text { наличие желудочных варикозных } \\
\text { вен; } \\
\text { - Первичные образования селезёнки; } \\
\text { - Повреждение селезёнки с } \\
\text { патологией. }\end{array}$ \\
\hline $\begin{array}{l}\text { Что является относительным } \\
\text { показанием к спленэктомии? }\end{array}$ & $\begin{array}{l}\text { - Сфероцитоз; } \\
\text { - Аутоиммунная гемолитическая } \\
\text { анемия; } \\
\text { - Серповидноклеточная анемия; } \\
\text { - Идиопатическая } \\
\text { тромбоцитопеническая пурпура; } \\
\text { - Синдром (иммунная } \\
\text { нейтропения); } \\
\text { - Абсцесс селезёнки; } \\
\text { - Первичный гиперспленизм. }\end{array}$ \\
\hline $\begin{array}{l}\text { Что является спорным показанием к } \\
\text { спленэктомии? }\end{array}$ & $\begin{array}{l}\text { - Непаразитарные кисты; } \\
\text { - Талассемия; } \\
\text { • Лимфомы; } \\
\text { - Тромботическая } \\
\text { - тромбоцитопеническая пурпура; } \\
\text { - Миелофибротические заболевания. }\end{array}$ \\
\hline $\begin{array}{l}\text { Какие злокачественные заболевания } \\
\text { являются показанием к } \\
\text { спленэктомии? }\end{array}$ & $\begin{array}{l}\text { - Ходжкинские лимфомы, стадии } \\
\text { которых не уточняются на КТ; } \\
\text { - Образования селезёнки (первичные, } \\
\text { метастатические, инвазивные); } \\
\text { - Гиперспленизм. }\end{array}$ \\
\hline
\end{tabular}




\begin{tabular}{|c|c|}
\hline Вопросы & Ответы \\
\hline $\begin{array}{l}\text { Что является противопоказанием к } \\
\text { спленэктомии? }\end{array}$ & $\begin{array}{l}\text { - Острый лейкоз; } \\
\text { - Агранулоцитоз; } \\
\text { - Асимптоматический гиперспленизм. }\end{array}$ \\
\hline $\begin{array}{l}\text { Что не является нормой в } \\
\text { лабораторных тестах после } \\
\text { спленэктомии? }\end{array}$ & $\begin{array}{l}\text { - Повышение лейкоцитов на 50\%; } \\
\text { - Заметный тромбоцитоз; } \\
\text { - Изменения в микроскопии капли } \\
\text { крови. }\end{array}$ \\
\hline $\begin{array}{l}\text { Что обнаруживается в микроскопии } \\
\text { капли крови у пациентов со } \\
\text { спленэктомией? }\end{array}$ & $\begin{array}{l}\text { - Тельца Паппенгейма; } \\
\text { - Тельца Хауэлла-Жолли; } \\
\text { - Тельца Гейнца. }\end{array}$ \\
\hline $\begin{array}{l}\text { Что относится к осложнениям } \\
\text { спленэктомии? }\end{array}$ & $\begin{array}{l}\text { - Левосторонний плевральный выпот } \\
\text { - ателектаз лёгкого; } \\
\text { - Ковреждение соседнего органа; } \\
\text { - Субдтечение; } \\
\text { - Тромбоцитоз; } \\
\text { - Тромбоз селезёночной вены; } \\
\text { - Спленоз; } \\
\text { - Постспленэктомический сепсис. }\end{array}$ \\
\hline $\begin{array}{l}\text { Часто встречаемое осложнение } \\
\text { спленэктомии? }\end{array}$ & $\begin{array}{l}\text { Левосторонний плевральный выпот и } \\
\text { ателектаз лёгкого. }\end{array}$ \\
\hline $\begin{array}{l}\text { Что является основной причиной } \\
\text { возникновения левостороннего } \\
\text { плеврального выпота и ателектаза } \\
\text { лёгкого после спленэктомии? }\end{array}$ & Боль и поддиафрагмальный абсцесс. \\
\hline $\begin{array}{l}\text { Какие профилактические меры } \\
\text { необходимы для предотвращения } \\
\text { возникновения левостороннего } \\
\text { плеврального выпота и ателектаза } \\
\text { лёгкого после спленэктомии? }\end{array}$ & $\begin{array}{l}\text { - Необходимое обезболивание; } \\
\text { - Проведение операции } \\
\text { лапароскопическим доступом; } \\
\text { - Ранняя активация пациента; } \\
\text { - Физиотерапия. }\end{array}$ \\
\hline $\begin{array}{l}\text { Какой орган наиболее часто } \\
\text { повреждается при спленэктомии? }\end{array}$ & $\begin{array}{l}\text { Хвостовой отдел поджелудочной } \\
\text { железы. }\end{array}$ \\
\hline
\end{tabular}




\begin{tabular}{|c|c|}
\hline Вопросы & Ответы \\
\hline $\begin{array}{l}\text { В чём заключается лечебная тактика } \\
\text { при повреждении соседнего органа? }\end{array}$ & $\begin{array}{l}\text { Ушивание повреждённого органа и } \\
\text { дренирование. }\end{array}$ \\
\hline $\begin{array}{l}\text { В чём заключается лечебная тактика } \\
\text { при кровотечении? }\end{array}$ & $\begin{array}{l}\text { - При массивных кровотечениях - } \\
\text { срочная повторная операция; } \\
\text { - При асимптоматических гематомах - } \\
\text { наблюдение; } \\
\text { - При инфицированных гематомах - } \\
\text { дренирование. }\end{array}$ \\
\hline $\begin{array}{l}\text { Что является причиной возникновения } \\
\text { постспленэктомического } \\
\text { (поддиафрагмального) абсцесса? }\end{array}$ & $\begin{array}{l}\text { Инфицирование гематомы и скопления } \\
\text { жидкости, повреждение органов. }\end{array}$ \\
\hline $\begin{array}{l}\text { Какова частота встречаемости } \\
\text { постспленэктомического } \\
\text { (поддиафрагмального) абсцесса? }\end{array}$ & В 2-3\% случаев. \\
\hline $\begin{array}{l}\text { Что относится к клиническим } \\
\text { признакам постспленэктомического } \\
\text { (поддиафрагмального) абсцесса? }\end{array}$ & $\begin{array}{l}\text { - Боль; } \\
\text { - Признаки SiRS, сепсиса. }\end{array}$ \\
\hline $\begin{array}{l}\text { Какие методы исследования } \\
\text { необходимы для уточнения диагноза? }\end{array}$ & КТ - наличие скопления. \\
\hline Что относится к методам лечения? & $\begin{array}{l}\text { Чрескожный дренаж } \\
\text { антибиотикотерапия. }\end{array}$ \\
\hline $\begin{array}{l}\text { Что является причиной тромбоцитоза } \\
\text { после спленэктомии? }\end{array}$ & Уменьшение элиминации тромбоцитов. \\
\hline Что относится к факторам риска? & $\begin{array}{l}\text { Спленэктомии, проводимые по причине } \\
\text { спленомегалии и миелофиброза. }\end{array}$ \\
\hline $\begin{array}{l}\text { При каких случаях необходимо } \\
\text { проводить профилактику тромбоза? }\end{array}$ & $\begin{array}{l}\text { При увеличении } \\
\text { тромбоцитов свыше } 1 \text { количества } \\
\text { назначают аспирин. }\end{array}$ \\
\hline $\begin{array}{l}\text { Какова частота встречаемости } \\
\text { тромбоза селезёночной вены? }\end{array}$ & В 8-10\% случаев после спленэктомии. \\
\hline Что относится к факторам риска? & $\begin{array}{l}\text { - Широкая селезёночная } \\
\text { (спленомегалия); } \\
\text { - Миелофиброз; }\end{array}$ \\
\hline
\end{tabular}




\begin{tabular}{|c|c|}
\hline Вопросы & Ответы \\
\hline & - Перевязка, а не ушивание вены. \\
\hline Что относится к патогенезу? & $\begin{array}{l}\text { - Снижение кровотока в вене; } \\
\text { - Тромбоцитоз; } \\
\text { - Тромбофилия. }\end{array}$ \\
\hline Клинические признаки: & $\begin{array}{l}\text { - Боль; } \\
\text { - Субфебрильная температура. }\end{array}$ \\
\hline $\begin{array}{l}\text { Какие методы исследования } \\
\text { необходимы для уточнения диагноза? }\end{array}$ & Контрастная КТ. \\
\hline Что относится к методам лечения? & Срочная антикоагулянтная терапия. \\
\hline $\begin{array}{l}\text { Что относится к методам } \\
\text { профилактики? }\end{array}$ & $\begin{array}{l}\text { - При увеличении количества } \\
\text { тромбоцитов свыше } 1 \text { млн/мл - } \\
\text { назначение аспирина; } \\
\text { - Притромбофилических состояниях и } \\
\text { больших спленомегалиях } \\
\text { назначение антикоагулянтов. }\end{array}$ \\
\hline Каков прогноз? & $\begin{array}{l}\text { При отсутствии лечения возможно } \\
\text { распространение тромбоза на } \\
\text { воротную и брыжеечную вены. }\end{array}$ \\
\hline Что такое спленоз? & $\begin{array}{l}\text { Диффузная имплантация и развитие } \\
\text { ткани селезёнки в брюшной полости. }\end{array}$ \\
\hline $\begin{array}{l}\text { Что является причиной и фактором } \\
\text { риска? }\end{array}$ & $\begin{array}{l}\text { Травматический, спонтанный или } \\
\text { ятрогенный разрыв селезёнки. }\end{array}$ \\
\hline $\begin{array}{l}\text { Что относится к осложнениям } \\
\text { спленоза? }\end{array}$ & $\begin{array}{l}\text { - Спайки; } \\
\text { - Кишечная непроходимость; } \\
\text { - Рецидив заболевания. }\end{array}$ \\
\hline Клинические признаки: & $\begin{array}{l}\text { - Асимптоматическое течение; } \\
\text { - Признаки осложнения. }\end{array}$ \\
\hline $\begin{array}{l}\text { У каких пациентов можно } \\
\text { заподозрить? }\end{array}$ & $\begin{array}{l}\text { У пациентов со спленэктомией и } \\
\text { травмой селезёнки: } \\
\text { - кишечная непроходимость; } \\
\text { - наличие тромбоцитоза; } \\
\text { - нормальная форма кровяных } \\
\text { клеток; }\end{array}$ \\
\hline
\end{tabular}




\begin{tabular}{|c|c|}
\hline Вопросы & Ответы \\
\hline & $\begin{array}{l}\text { - наличие многочисленных } \\
\text { образований в брюшной полости. }\end{array}$ \\
\hline $\begin{array}{l}\text { Какие методы исследования } \\
\text { необходимы для уточнения диагноза? }\end{array}$ & $\begin{array}{l}\text { - Микроскопия капли крови; } \\
\text { - } \text { КТ; } \\
\text { - Биопсия. }\end{array}$ \\
\hline $\begin{array}{l}\text { Что относится к лабораторным } \\
\text { признакам? }\end{array}$ & 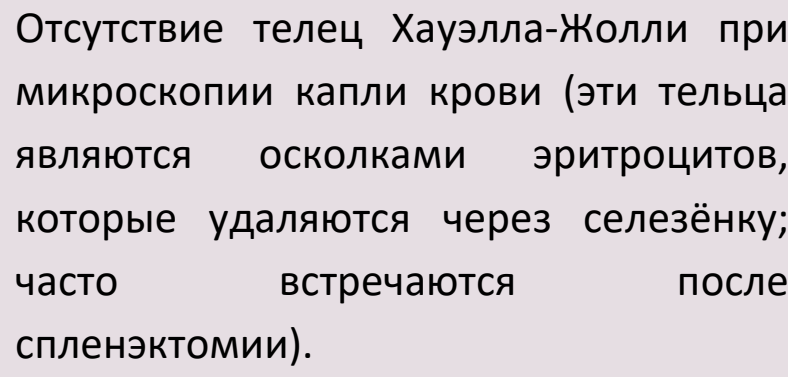 \\
\hline $\begin{array}{l}\text { Что относится к признакам, } \\
\text { выявляемым при методах } \\
\text { визуализации? }\end{array}$ & $\begin{array}{l}\text { Наличие многочисленных образований } \\
\text { в брюшной полости в виде селезёнки. }\end{array}$ \\
\hline Что относится к методам лечения? & $\begin{array}{l}\text { - При отсутствии осложнений лечение } \\
\text { - } е \text { проводится; } \\
\text { удаление образований и устранений } \\
\text { спаек. }\end{array}$ \\
\hline $\begin{array}{l}\text { Что относится к методам } \\
\text { профилактики? }\end{array}$ & $\begin{array}{l}\text { Обращение внимания на целостность } \\
\text { селезёнки при её удалении. }\end{array}$ \\
\hline $\begin{array}{l}\text { Что такое постспленэктомический } \\
\text { сепсис? }\end{array}$ & $\begin{array}{l}\text { Снижение сопротивляемости } \\
\text { организма к бактериям в результате } \\
\text { утраты функции селезёнки и развитие } \\
\text { сепсиса и септического шока. }\end{array}$ \\
\hline $\begin{array}{l}\text { Какова частота встречаемости } \\
\text { постспленэктомического сепсиса у } \\
\text { взрослых? }\end{array}$ & $<1 \%$. \\
\hline $\begin{array}{l}\text { Какова частота встречаемости и } \\
\text { летальность постспленэктомического } \\
\text { сепсиса у детей? }\end{array}$ & $\begin{array}{l}\text { Частота встречаемости } \\
\text { летальность 50\%. }\end{array}$ \\
\hline
\end{tabular}




\begin{tabular}{|c|c|}
\hline Вопросы & Ответы \\
\hline $\begin{array}{l}\text { По какой причине } \\
\text { постспленэктомический сепсис чаще } \\
\text { встречается у детей 5-6 лет? }\end{array}$ & $\begin{array}{l}\text { Иммунная система у такие детей } \\
\text { полностью не сформирована. }\end{array}$ \\
\hline $\begin{array}{l}\text { Какие бактерии чаще всего являются } \\
\text { причиной постспленэктомического } \\
\text { сепсиса? }\end{array}$ & $\begin{array}{l}\text { Капсульные бактерии: Streptococcus } \\
\text { pneumaniae, Neiserria meningitis, H. } \\
\text { influenza }\end{array}$ \\
\hline Каков патогенез? & $\begin{array}{l}\text { Устранение иммунной функции } \\
\text { селезёнки - снижение опсонинов, } \\
\text { снижение синтеза IgM, замедление } \\
\text { фагоцитоза и уничтожения бактерий. }\end{array}$ \\
\hline $\begin{array}{l}\text { Типичная клиника } \\
\text { постспленэктомического сепсиса: }\end{array}$ & $\begin{array}{l}\text { - В начале проявляются } \\
\text { неспецифические признаки: } \\
\text { о недомогание; } \\
\text { о усталость; } \\
\text { о ринорея. } \\
\text { - Затем происходит } \\
\text { прогрессирование: } \\
\text { О высокая температура; } \\
\text { О септический шок; } \\
\text { о синдром } \\
\text { диссеминированного } \\
\text { внутрисосудистого } \\
\text { свёртывания. }\end{array}$ \\
\hline $\begin{array}{l}\text { В чём заключается профилактика } \\
\text { постспленэктомического сепсиса? }\end{array}$ & $\begin{array}{l}\text { - Проведение вакцинации против } \\
\text { капсульных бактерий за 2-3 недели } \\
\text { до либо после спленэктомии; } \\
\text { - Назначение длительной } \\
\text { антибиотикотерапии в группах } \\
\text { высокого риска (детям до 2-х лет } \\
\text { назначают пенициллин или } \\
\text { ампициллин до } 6 \text { лет); } \\
\text { - Аутотрансплантация селезёнки при } \\
\text { её травмах; }\end{array}$ \\
\hline
\end{tabular}




\begin{tabular}{|c|c|}
\hline Вопросы & Ответы \\
\hline & $\begin{array}{l}\text { - Назначение антибиотикотерапии } \\
\text { после спленэктомии пациентам с } \\
\text { первичными признаками. }\end{array}$ \\
\hline $\begin{array}{l}\text { Наиболее благоприятное время } \\
\text { иммунизации пациентов со } \\
\text { спленэктомией: }\end{array}$ & $\begin{array}{l}\text { - До операции; } \\
\text { - Через } 2 \text { недели после срочной } \\
\text { операции. }\end{array}$ \\
\hline $\begin{array}{l}\text { Какие вакцины назначают пациентам } \\
\text { со спленэктомией? }\end{array}$ & $\begin{array}{l}\text { Pneumococcus, Meningococcus, } \\
\text { Haemophilius influenza } B .\end{array}$ \\
\hline Методы лечения: & $\begin{array}{l}\text { - Антибиотики в высокой дозе; } \\
\text { - Поддерживающая терапия. }\end{array}$ \\
\hline Каков прогноз? & $\begin{array}{l}\text { Без лечения завершается летально в } \\
\text { течение } 12-48 \text { ч. }\end{array}$ \\
\hline Что такое гипоспленизм? & Снижение функции селезёнки. \\
\hline $\begin{array}{l}\text { Что относится к причинам и факторам } \\
\text { риска? }\end{array}$ & $\begin{array}{l}\text { - Врождённая аспления; } \\
\text { - Старческий возраст; } \\
\text { повторяющиеся секвестрационные } \\
\text { о серповидноклеточная } \\
\text { анемия; } \\
\text { О эссенциальный тромбоцитоз; } \\
\text { О малярия; } \\
\text { О тромбоз } \\
\text { артерии. } \\
\text { - Аутоиммунные заболевания: } \\
\text { О язвенный колит; } \\
\text { о гломерулонефрит; } \\
\text { О системный люпус эритематоз; } \\
\text { О ревматоидный артрит; } \\
\text { О саркоидоз. } \\
\text { - Опухоли или кисты; } \\
\text { - Амилоидоз; } \\
\text { - Спленэктомия и др. }\end{array}$ \\
\hline
\end{tabular}




\begin{tabular}{|c|c|}
\hline Вопросы & Ответы \\
\hline $\begin{array}{l}\text { Какие методы исследования } \\
\text { проводятся для уточнения диагноза? }\end{array}$ & Микроскопия капли крови. \\
\hline $\begin{array}{l}\text { Что относится к лабораторным } \\
\text { признакам? }\end{array}$ & Наличие телец Хауэлла-Жолли в крови. \\
\hline Методы лечения: & Нет специфического лечения. \\
\hline $\begin{array}{l}\text { У каких пациентов наблюдается } \\
\text { гипоспленизм? }\end{array}$ & У пациентов с язвенным колитом. \\
\hline $\begin{array}{l}\text { Эффективная профилактика } \\
\text { постспленэктомического } \\
\text { гипоспленизма: }\end{array}$ & Аутотрансплантация селезёнки. \\
\hline $\begin{array}{l}\text { В каких случаях советуют проводить } \\
\text { аутотрансплантацию селезёнки? }\end{array}$ & $\begin{array}{l}\text { При спленэктомии, проводимой по } \\
\text { причине застоя и травмы. }\end{array}$ \\
\hline
\end{tabular}

\section{Вопросы по гематологическим заболеваниям}

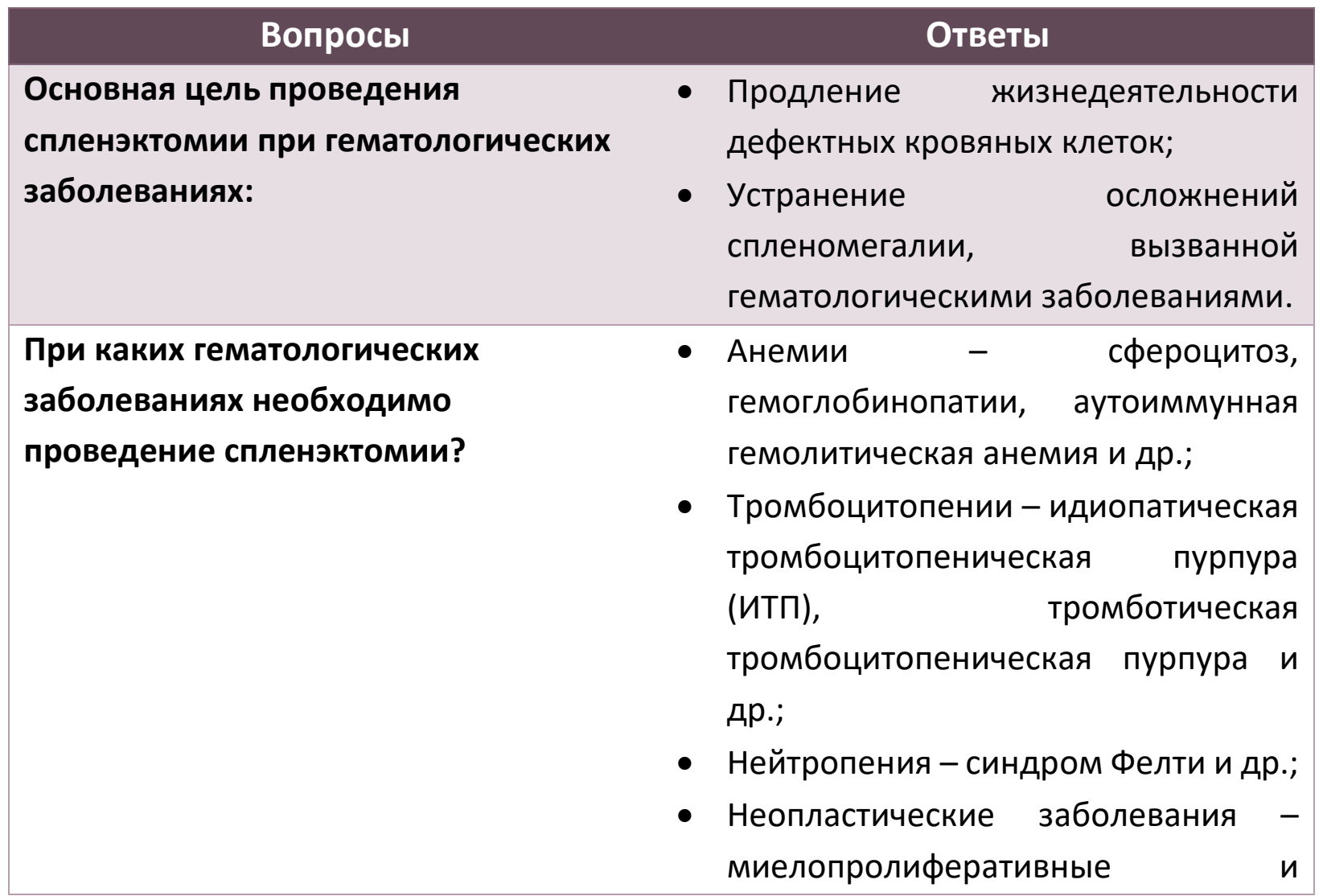




\begin{tabular}{|c|c|}
\hline & $\begin{array}{l}\text { лимфопролиферативные } \\
\text { заболевания. }\end{array}$ \\
\hline $\begin{array}{l}\text { Цель спленэктомии при } \\
\text { гемолитических анемиях: }\end{array}$ & $\begin{array}{l}\text { Продление жизнедеятельности } \\
\text { дефектных эритроцитов. }\end{array}$ \\
\hline $\begin{array}{l}\text { При какой гемолитической анемии } \\
\text { спленэктомия является самым } \\
\text { эффективным лечением? }\end{array}$ & Сфероцитоз. \\
\hline $\begin{array}{l}\text { При какой гемолитической анемии } \\
\text { спленэктомия не устраняет анемию? }\end{array}$ & Талассемия. \\
\hline Что такое сфероцитоз? & $\begin{array}{l}\text { Врождённый дефект мембран } \\
\text { эритроцитов. }\end{array}$ \\
\hline Патогенез: & $\begin{array}{l}\text { В результате дефицита белка спектина в } \\
\text { мембране эритроциты приобретают } \\
\text { сферическую форму и теряют } \\
\text { эластичность, что в свою очередь } \\
\text { приводит к их застою и разрушению в } \\
\text { микроциркуляции селезёнки. }\end{array}$ \\
\hline Клинические признаки: & $\begin{array}{l}\text { Проявляется бессимптомно или } \\
\text { гемолитическими кризами. }\end{array}$ \\
\hline Диагностические критерии: & $\begin{array}{l}\text { - Повышение осмотической } \\
\text { устойчивости; } \\
\text { - Отрицательный тест Кумбса; } \\
\text { - Тест криогемолиза (гемолиз } \\
\text { инкубированных эритроцитов). }\end{array}$ \\
\hline Методы лечения: & 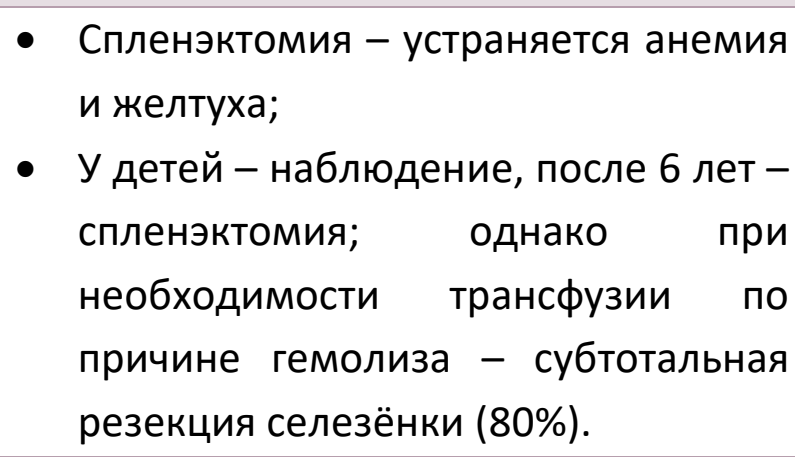 \\
\hline $\begin{array}{l}\text { Механизм аутоиммунной } \\
\text { гемолитической анемии: }\end{array}$ & $\begin{array}{l}\text { K мембране } \\
\text { присоединяются эритроцитов } \\
\text { результате чего они разрушаются в } \\
\text { селезёнке. }\end{array}$ \\
\hline
\end{tabular}




\begin{tabular}{|c|c|}
\hline $\begin{array}{l}\text { Диагностические критерии } \\
\text { аутоиммунной гемолитической } \\
\text { анемии: }\end{array}$ & $\begin{array}{l}\text { - Анемия - снижение гемоглобина, } \\
\text { ретикулоцитоз; } \\
\text { - Гемолиз - повышение билирубина, } \\
\text { снижение гаптоглобина, повышение } \\
\text { лдг; } \\
\text { - Аутоиммунный механизм - } \\
\text { положительный прямой тест Кумбса. }\end{array}$ \\
\hline $\begin{array}{l}\text { Возможно ли снижение количества } \\
\text { тромбоцитов и лейкоцитов при } \\
\text { аутоиммунных гемолитических } \\
\text { анемиях? }\end{array}$ & $\begin{array}{l}\text { Возможно. Аутоиммунный процесс } \\
\text { наряду с анемией и тромбоцитопенией } \\
\text { носит название синдрома Эванса. }\end{array}$ \\
\hline $\begin{array}{l}\text { В чём причина неэффективности } \\
\text { плазмафереза при аутоиммунных } \\
\text { гемолитических анемиях? }\end{array}$ & $\begin{array}{l}\text { По причине связывания большинства } \\
\text { антител, в особенности «горячих», с } \\
\text { эритроцитами. }\end{array}$ \\
\hline Что показывает тест Кумбса? & $\begin{array}{l}\text { Наличие антител против эритроцитов: } \\
\text { прямой тест Кумбса определяет } \\
\text { антитела, связанные с эритроцитами, а } \\
\text { непрямой - свободные антитела в } \\
\text { плазме. }\end{array}$ \\
\hline $\begin{array}{l}\text { При какой тромбоцитопении показана } \\
\text { спленэктомия в качестве лечения? }\end{array}$ & ИТП. \\
\hline $\begin{array}{l}\text { Что такое иммунная } \\
\text { тромбоцитопеническая пурпура } \\
\text { (ИТП)? }\end{array}$ & $\begin{array}{l}\text { Кровотечения } \\
\text { аутоиммунной } \\
\text { тромбоцитов. }\end{array}$ \\
\hline $\begin{array}{l}\text { По какой причине после спленэктомии } \\
\text { по причине ИТП наблюдается рецидив } \\
\text { заболевания? }\end{array}$ & Добавочная селезёнка. \\
\hline $\begin{array}{l}\text { Что такое тромботическая } \\
\text { тромбоцитопеническая пурпура? }\end{array}$ & $\begin{array}{l}\text { Острый иммунный воспалительный } \\
\text { процесс, вызванный антителами против } \\
\text { эндотелиальных клеток и тромбоцитов. }\end{array}$ \\
\hline Характерная клиническая пентада: & $\begin{array}{l}\text { - Высокая температура; } \\
\text { - Тромбоцитопеническая пурпура; } \\
\text { - Гемолитическая анемия; } \\
\text { - Неврологические расстройства; }\end{array}$ \\
\hline
\end{tabular}




\begin{tabular}{|c|c|}
\hline & - Почечная недостаточность. \\
\hline $\begin{array}{l}\text { Какие методы исследования } \\
\text { необходимы для уточнения диагноза? }\end{array}$ & $\begin{array}{lrr}\text { Микроскопия } & \text { капли } & \text { крови } \\
\text { (микроангиопатия), } & \text { биопсия } \\
\text { пурпурического повреждения. } & \end{array}$ \\
\hline Методы лечения: & $\begin{array}{l}\text { - Плазмаферез - на первом месте; } \\
\text { - Стероиды или ритуксимаб + } \\
\text { плазмаферез; } \\
\text { - Спленэктомия + плазмаферез - при } \\
\text { неэффективности других методов } \\
\text { лечения. }\end{array}$ \\
\hline $\begin{array}{l}\text { Для устранения какой нейтропении } \\
\text { проводят спленэктомию? }\end{array}$ & $\begin{array}{l}\text { Синдром Фелти } \quad \text { (иммунная } \\
\text { нейтропения). }\end{array}$ \\
\hline Что такое синдром Фелти? & Иммунная нейтропения. \\
\hline Характерная клиническая триада: & $\begin{array}{l}\text { - Ревматоидный артрит; } \\
\text { - Спленомегалия; } \\
\text { - Нейтропения. }\end{array}$ \\
\hline Патогенез: & $\begin{array}{l}\text { Считается, что при ревматоидном } \\
\text { артрите на поверхности нейтрофилов } \\
\text { скапливается большое количество IgG, } \\
\text { такие нейтрофилы задерживаются в } \\
\text { селезёнке, что приводит к нейтропении. }\end{array}$ \\
\hline Клинические признаки: & Повторяющиеся инфекции. \\
\hline Диагностические критерии: & $\begin{array}{l}\text { - Клиническая триада; } \\
\text { - Повышенный уровень } \lg \text { в } \\
\text { нейтрофилах; } \\
\text { - Повышение гранулопоэза в костном } \\
\text { мозге. }\end{array}$ \\
\hline Методы лечения: & $\begin{array}{l}\text { Спленэктомия - при симптоматических } \\
\text { случаях. }\end{array}$ \\
\hline $\begin{array}{l}\text { При какой нейтропении } \\
\text { противопоказана спленэктомия? }\end{array}$ & Агранулоцитоз. \\
\hline $\begin{array}{l}\text { Является ли показанием к } \\
\text { спленэктомии недостаточность } \\
\text { глюкоза-6-фосфатдегидрогеназы? }\end{array}$ & Нет!!! \\
\hline
\end{tabular}




$\begin{array}{ll}\text { Основная цель проведения } & \text { Устранение спленомегалии и } \\ \text { спленэктомии при } & \text { гиперспленизма. } \\ \begin{array}{l}\text { миелопролиферативных и } \\ \text { миелодиспластических заболеваниях? }\end{array}\end{array}$

\section{СПИСОК ЛИТЕРАТУРЫ}

\section{Общая литература}

- Ağayev B.A. Cərrahi xəstəliklər. Bakı 2010.

- Blackbourne LH. Surgical Recall. 4. edition, 2006, LWW, Philadelphia

- Doherty GM. Current Diagnosis and Treatment: Surgery, $13^{\text {th }}$ edition, 2010, Lang International Edition.

- Omiraslanov D.T., Qazıyev A.Y. Onkologiya. Bakı, 2010.

- İsayev H.B. Cərrahi xəstəliklərin patofizologiyası. Bakı 2005

- Klingensmith ME, Aziz A, Bharat A, Fox AC, Porembka MR. The Washington Manual of Surgery, $6^{\text {th }}$ edition, 2012, LWW, Philadelphia.

- McNally PR. GI/Liver Secrets Plus. 4 edition. Mosby, Elsevier, 2010

- Medscape, http://www.medscape.com

- Oxford Handbook of Clinical Surgery, 3d edition, 2011, Oxford Press

- Sayek I. Sayek Temel Cerrahi 1-2. 4-cü baskı, 2016, Güneş Tıp Kitabevleri.

- Topçubaşov M.A. Xüsusi cərrahlıq. Bakı, 1979

- UpToDate, http://www.uptodate.com

- Гостищев B.К. Общая хирургия. GEOTAR-Media, 2019

\section{Специальная литература}

- N.Y.Bayramov, H.A.Sultanov, A.H.Abbasov, P.F.Məhərrəmov. Splenomeqaliya və Hipersplenizm. Metodik tövsiyə. Bakı, 2007

- Schrier SL, Mentzer WC, Tirnauer JS, Approach to the adult patient with splenomegaly and other splenic disorders. UpToDate, http://www.uptodate.com 


\section{ХИРУРГИЧЕСКИЕ БОЛЕЗНИ}

Н.Ю. Байрамов

\section{Хирургические заболевания брюшины \\ Н.Ю. Байрамов, С.М. Зейналов, Т.Г. Алиев, А.К. Сафиева, Ф.Ф. Ахмедов}

Перевод: Н.Ю. Байрамов, С.А. Алиев, М.Р.Гусейнова 


\section{ПЕРИТОНИТ}

- Перитонит - острое диффузное воспаление висцеральной и париетальной брюшины по причине септических и асептических состояний.

- По клиническому течению различают острый и хронический перитонит.

- Острый перитонит характеризуется острым повреждением и экссудативным воспалением и имеет 3 клинические формы: первичный, вторичный и третичный.

- Первичный перитонит - первичное внутрибрюшное воспаление без экстравазации содержимого какого-либо органа (первичный бактериальный, туберкулёзный, бруцеллёзный перитонит).

- Вторичный или хирургический перитонит - развивается вследствие распространения содержимого полостных и секрета железистых органов или воспалительного экссудата по всей брюшной полости (воспаление, перфорация, некроз, травмы).

○ Заболевание в большинстве случаев начинается острыми абдоминальными болями, в течение нескольких часов присоединяются признаки SIRS и сепсиса, затем развивается компартмент-синдром и полиорганная недостаточность.

○ Диагностика основывается на данных клинической картины заболевания (болезненный и напряжённый живот, признаки SIRS и сепсиса). С целью определения степени тяжести, причины и дифференциальной диагностики проводят лабораторные и инструментальные методы исследования.

○ Лечение - срочная операция (устранение причины и гнойно-некротических тканей), антибиотикотерапия, поддерживающая терапия, устранение компартмент-синдрома.

- Третичный перитонит - продолжающийся вторичный перитонит несмотря на устранение причины. Предполагается связь развития третичного перитонита с иммуносупрессией.

- Хронический перитонит характеризуется хроническим повреждением или развитием гранулём (туберкулёзный, гранулематозный, фиброзносклерозирующий и др.)

- Туберкулёзный перитонит - может быть первичным поражением брюшины или следствием распространения инфекции из других органов. 
○ В большинстве случаев проявляется признаками хронического асцита, очень редко - признаками острого перитонита. Наряду с асцитом наблюдаются высокая температура и ночное потоотделение.

○ Диагноз основан на исследовании асцитической жидкости, данных КТ и биопсии брюшины. Обнаружение туберкулёзных палочек в асцитической жидкости и казеозных гранулём при биопсии подтверждает диагноз.

○ Основное лечение - противотуберкулёзные препараты; хирургическая операция проводится по показаниям (непроходимость, перфорация, сложность в диагностике).

\section{Вопросы и ответы по вторичному перитониту}

\begin{tabular}{|c|c|}
\hline Вопросы & Ответы \\
\hline Что такое вторичный перитонит? & $\begin{array}{l}\text { Воспаление брюшины вследствие } \\
\text { распространения содержимого } \\
\text { полостных и секрета железистых } \\
\text { органов или воспалительного экссудата } \\
\text { по всей брюшной полости. }\end{array}$ \\
\hline Клинические формы: & $\begin{array}{l}\text { - Диффузный; } \\
\text { - Местный; } \\
\text { - Ограниченный (абсцессы). }\end{array}$ \\
\hline Причины и факторы риска: & 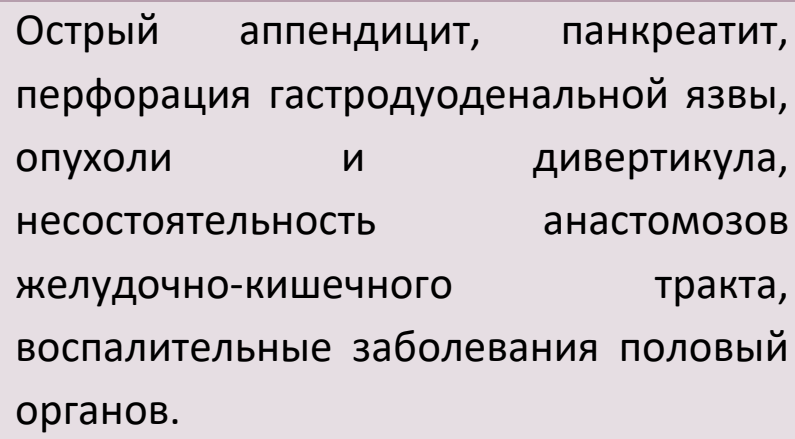 \\
\hline Патогенез: & $\begin{array}{l}\text { Хирургический } \quad \text { перитонит } \\
\text { абдоминальное воспаление + SIRS- } \\
\text { сепсис + компартмент-синдром. }\end{array}$ \\
\hline
\end{tabular}




\begin{tabular}{|c|c|}
\hline Вопросы & Ответы \\
\hline Особенности клинического течения: & $\begin{array}{l}\text { Прогрессирующее течение, летальность } \\
\text { составляет } 10-80 \% .\end{array}$ \\
\hline Осложнения: & $\begin{array}{l}\text { - Абсцесс, сепсис, септический } \\
\text { шок; } \\
\text { - Полиорганная недостаточность; } \\
\text { - Летальность- } 40 \%(10-80 \%) \text {. }\end{array}$ \\
\hline Клинические признаки: & $\begin{array}{l}\text { - Боли в животе; } \\
\text { - Наличие симптомов раздражения } \\
\text { брюшины; } \\
\text { - Признаки сепсиса; } \\
\text { - Компартмент-синдром. }\end{array}$ \\
\hline $\begin{array}{l}\text { У каких пациентов можно } \\
\text { заподозрить? }\end{array}$ & $\begin{array}{l}\text { У пациентов с острой абдоминальной } \\
\text { болью. }\end{array}$ \\
\hline Диагностика: & $\begin{array}{l}\text { Острый перитонит не имеет } \\
\text { патогномоничных признаков, диагноз } \\
\text { основывается на клинических } \\
\text { критериях, } \\
\text { лапароскопией и лапаротомией. }\end{array}$ \\
\hline Лабораторная признаки: & $\begin{array}{l}\text { Лейкоцитоз, повышение С-реактивного } \\
\text { протеина, маркеры органной } \\
\text { дисфункции. }\end{array}$ \\
\hline $\begin{array}{l}\text { Признаки инструментальной } \\
\text { визуализации: }\end{array}$ & $\begin{array}{l}\text { - Узи - наличие жидкости в брюшной } \\
\text { полости, малоподвижные петли } \\
\text { кишечника, патология органов; } \\
\text { - кт - наличие жидкости и газа в } \\
\text { брюшной полости, экстравазация } \\
\text { контрастного вещества за пределы } \\
\text { полого органа, признаки } \\
\text { деструктивного воспаления органа. }\end{array}$ \\
\hline
\end{tabular}




\begin{tabular}{|c|c|}
\hline Вопросы & Ответы \\
\hline Диагностические критерии: & $\begin{array}{l}\text { - Острые боли в животе; } \\
\text { - Симптомы раздражения брюшины; } \\
\text { - Признаки сепсиса; } \\
\text { - УзИ/Кт - наличие жидкости и газа в } \\
\text { брюшной полости, экстравазация } \\
\text { контрастного вещества за пределы } \\
\text { полого органа, признаки } \\
\text { деструктивного воспаления органа; } \\
\text { - Обнаружение экссудата и } \\
\text { воспаления брюшины во время } \\
\text { лапароскопии и лапаротомии. }\end{array}$ \\
\hline Методы лечения: & $\begin{array}{l}\text { Классический «принцип 4+»: } \\
\text { - Поддерживающая терапия при SIRS } \\
\text { и сепсисе; } \\
\text { - Предотвращение контаминации; } \\
\text { - Устранение гнойно-некротических } \\
\text { масс (санация и дренирование); } \\
\text { - Антибактериальная терапия; } \\
\text { - При компартмент-синдроме - } \\
\text { декомпрессия брюшной полости. } \\
\text { - Основное лечение - хирургическое. }\end{array}$ \\
\hline Показания к операции: & Наличие вторичного перитонита. \\
\hline Методы операции: & $\begin{array}{l}\text { Устранение причины путём } \\
\text { лапаротомии и лапароскопии, санация } \\
\text { и дренирование брюшной полости. }\end{array}$ \\
\hline Прогноз: & $\begin{array}{l}\text { Запоздалые операции способствуют } \\
\text { увеличению летальности. }\end{array}$ \\
\hline $\begin{array}{l}\text { Определите характерную особенность } \\
\text { заболевания: }\end{array}$ & $\begin{array}{l}\text { Перитонит является самым тяжёлым } \\
\text { осложнением травм, заболеваний } \\
\text { брюшной полости, после хирургических }\end{array}$ \\
\hline
\end{tabular}




\section{Вопросы}

\section{Ответы}

операций, требующий неотложное хирургическое лечение.

\section{Вопросы и ответы по туберкулёзному перитониту}

\begin{tabular}{rlr}
\multicolumn{2}{c|}{ Вопросы } & \multicolumn{2}{c}{ Ответы } \\
Что такое туберкулёзный перитонит? & Специфическое \\
& брюшины, \\
& туберкулёзными палочками.
\end{tabular}

\section{Частота встречаемости туберкулёзного перитонита:}

Причины и факторы риска:
Клинические формы:

Среди пациентов, страдающих туберкулёзом, составляет 0,5-1,5\%.

- Первичный;

- Вторичный;

- Диссеминированный.

Этиология - Mycobacterium tuberculosis.

Факторы риска:

- СпИД;

- Сахарный диабет;

- Алкоголизм;

- Цирроз;

- Эндемическая зона проживания.

Патогенез: Считается, что туберкулёзная инфекция способствует развитию лимфаденита и казеозного некроза.

\section{Особенности клинического течения:}

В большинстве случаев туберкулёзный перитонит поддаётся консервативному лечению. Нелеченные и осложнённые формы туберкулёзного перитонита могут привести к летальному исходу. 


\begin{tabular}{|c|c|}
\hline Вопросы & Ответы \\
\hline Осложнения: & $\begin{array}{l}\text { - Кишечная непроходимость; } \\
\text { - Присоединение вторичных } \\
\text { инфекций; } \\
\text { - Туберкулёз внутренних органов; } \\
\text { - Диссеминация. }\end{array}$ \\
\hline Клинические признаки: & $\begin{array}{l}\text { - Боли; } \\
\text { - Вздутие (60\%); } \\
\text { - Высокая температура и обильное } \\
\text { потоотделение (60\%); } \\
\text { - Явления раздражения брюшины. }\end{array}$ \\
\hline $\begin{array}{l}\text { У каких пациентов можно } \\
\text { заподозрить? }\end{array}$ & 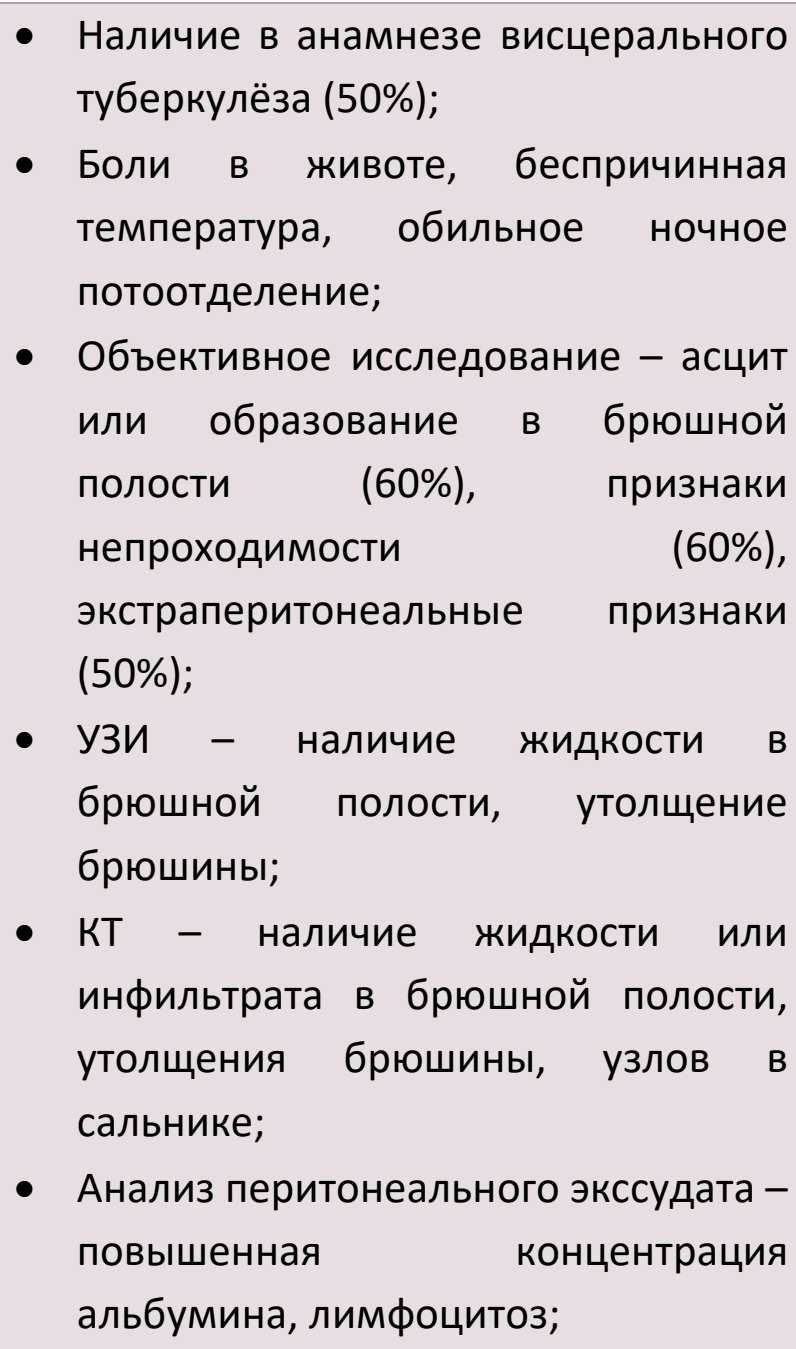 \\
\hline
\end{tabular}




\begin{tabular}{|c|c|}
\hline Вопросы & Ответы \\
\hline & $\begin{array}{l}\text { - Положительный туберкулиновый } \\
\text { тест (реакция Манту)-50\%; } \\
\text { - Ускорение СОЭ; } \\
\text { - Наличие милиарных узлов на } \\
\text { брюшине при лапаротомии и } \\
\text { лапароскопии. }\end{array}$ \\
\hline Диагностика: & $\begin{array}{l}\text { Клинические, лабораторные (СОЭ, } \\
\text { туберкулиновый } \\
\text { инструментальные (УЗИ, КТ) методы } \\
\text { исследования, биопсия. }\end{array}$ \\
\hline Лабораторные признаки: & $\begin{array}{l}\text { Выявление туберкулёзных палочек в } \\
\text { асцитической жидкости или при } \\
\text { культуральном исследовании. }\end{array}$ \\
\hline $\begin{array}{l}\text { Признаки инструментальной } \\
\text { визуализации: }\end{array}$ & $\begin{array}{l}\text { - Узи - наличие жидкости и } \\
\text { инфильтрата в брюшной полости, } \\
\text { утолщения брюшины; } \\
\text { ЕТ - наличие жидкости или } \\
\text { инфильтрата в брюшной полости, } \\
\text { утолщения брюшины, узлов в } \\
\text { сальнике. }\end{array}$ \\
\hline Диагностические критерии: & $\begin{array}{l}\text { - Асцит, спайки; } \\
\text { - Выявление туберкулёзных палочек в } \\
\text { асцитической жидкости или при } \\
\text { культуральном исследовании; } \\
\text { - обнаружение гранулематозного } \\
\text { воспаления прюшины при } \\
\text { лапароскопии; } \\
\text { Выявление казеозной гранулёмы } \\
\text { при патогистологическом } \\
\text { исследовании. }\end{array}$ \\
\hline
\end{tabular}




\begin{tabular}{|c|c|}
\hline Вопросы & Ответы \\
\hline Методы лечения: & $\begin{array}{l}\text { - Противотуберкулёзная терапия; } \\
\text { • Хирургическое лечение. }\end{array}$ \\
\hline Показания к операции: & $\begin{array}{l}\text { - Наличие кишечной непроходимости } \\
\text { и перфорации кишечника; } \\
\text { • Трудность диагностики. }\end{array}$ \\
\hline
\end{tabular}




\section{АБСЦЕССЫ БРЮШНОЙ ПОЛОСТИ}

- Абсцессы брюшной полости возникают вследствие ограничения и инфицирования жидкости, скоплённой в брюшной полости при заболеваниях органов брюшной полости, травмах и после хирургических вмешательств (перфорация, некроз, несостоятельность анастомоза, ранения, мочеполовые инфекции, кровотечение, инородные тела и др.)

- Ретроперитонеальные абсцессы формируются в результате инфицирования скопления жидкости или гематомы, возникших при травмах, операциях и заболеваниях органов забрюшинного пространства (почки, кишечник, поджелудочная железа, позвоночник).

- Клиническая картина характеризуется болями в животе, высокой температурой, признаками SIRS-сепсиса.

- Для подтверждения диагноза необходимо проведение КТ (наличие ограниченного жидкостного скопления).

- К диагностическим критериям относятся абдоминальные боли, признаки SIRSсепсиса, визуализация полости с жидкостью на КТ.

- Лечение - комплексное, предусматривает антибиотикотерапию, дренирование (чрескожное или хирургическое) и санацию гнойной полости, поддерживающую терапию и устранение причины возникновения абсцесс.

- При отсутствии надлежащего лечения абсцессов возможно развитие сепсиса, органной недостаточности, летального исхода, межорганных свищей.

\section{Вопросы и ответы по абсцессам брюшной полости}

\begin{tabular}{|ll|}
\multicolumn{1}{|c}{ Вопросы } & \multicolumn{1}{c|}{ Ответы } \\
\hline $\begin{array}{l}\text { Что представляет собой абсцесс } \\
\text { брюшной полости? }\end{array}$ & Ограниченный гнойно-некротический \\
очаг в брюшной полости. & \\
\hline Клинические формы: & Внутрибрюшные: \\
& О Поддиафрагмальные; \\
& О Подпечёночные; \\
& О Межпетельные; \\
\hline
\end{tabular}




\begin{tabular}{|c|c|}
\hline Вопросы & Ответы \\
\hline & $\begin{array}{l}\text { О Тазовые. } \\
\text { • Ретроперитонеальные. }\end{array}$ \\
\hline Причины и факторы риска: & 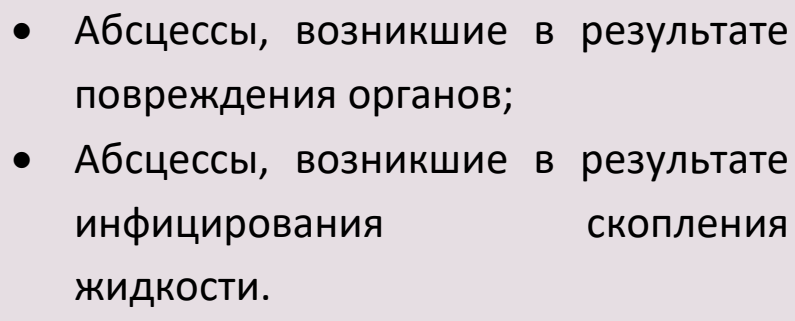 \\
\hline Патогенез: & $\begin{array}{l}\text { Внутрибрюшные абсцессы } \\
\text { формируются в результате ограничения } \\
\text { гнойно-некротического очага. }\end{array}$ \\
\hline Особенности клинического течения: & $\begin{array}{l}\text { - Длительное течение и хронизация } \\
\text { процесса; } \\
\text { - Перфорация; } \\
\text { - Сепсис (органная недостаточность) и } \\
\text { летальный исход (30\%). }\end{array}$ \\
\hline Осложнения: & $\begin{array}{l}\text { - Сепсис; } \\
\text { - Перфорация; } \\
\text { - Кровотечение. }\end{array}$ \\
\hline Клинические признаки: & $\begin{array}{l}\text { - Боли; } \\
\text { - Высокая температура; } \\
\text { - Парез кишечника; } \\
\text { - Наличие ограниченного гнойника в } \\
\text { брюшной полости. }\end{array}$ \\
\hline $\begin{array}{l}\text { У каких пациентов можно } \\
\text { заподозрить? }\end{array}$ & $\begin{array}{l}\text { - Боли в животе, наличие инфильтрата } \\
\text { в брюшной полости, признаки } \\
\text { сепсиса; } \\
\text { • Возникновение болей, высокая } \\
\begin{array}{l}\text { температура, } \\
\text { лейкоцитоз, }\end{array}\end{array}$ \\
\hline & $\begin{array}{l}\text { повышение концентрации С- } \\
\text { реактивного протеина после }\end{array}$ \\
\hline
\end{tabular}




\begin{tabular}{|c|c|}
\hline Boпросы & Ответы \\
\hline & $\begin{array}{l}\text { перенесённой абдоминальной } \\
\text { операции, травмы; } \\
\text { • Гектическая температура, высокий } \\
\text { лейкоцитоз и повышение С- } \\
\text { реактивного протеина на фоне } \\
\text { перитонита. }\end{array}$ \\
\hline Диагностика: & $\begin{array}{l}\text { Клинические, } \\
\text { инструментальные лабораторные, } \\
\text { исследования. }\end{array}$ \\
\hline Лабораторные показатели: & $\begin{array}{l}\text { Лейкоцитоз, повышение С-реактивного } \\
\text { белка. }\end{array}$ \\
\hline $\begin{array}{l}\text { Признаки инструментальной } \\
\text { визуализации: }\end{array}$ & $\begin{array}{l}\text { Наличие ограниченного жидкостного } \\
\text { скопления с горизонтальным уровнем } \\
\text { на КТ. }\end{array}$ \\
\hline Диагностические критерии: & $\begin{array}{l}\text { - Острые хирургические заболевания, } \\
\text { операции, травмы в анамнезе; } \\
\text { • Боли в животе, наличие } \\
\text { ограниченного гнойника в животе; } \\
\text { - Признаки воспаления: высокая } \\
\text { температура, лейкоцитоз, } \\
\text { повышение уровня С-реактивного } \\
\text { протеина); } \\
\text { Характерные } \\
\text { визуализации. }\end{array}$ \\
\hline Принципы лечения: & $\begin{array}{l}4 \text { классических принципа: } \\
\text { - Устранение причины; } \\
\text { - Удаление гнойно-некротических } \\
\text { тканей (санация и дренирование); } \\
\text { - Антибиотикотерапия; }\end{array}$ \\
\hline
\end{tabular}




\begin{tabular}{|c|c|}
\hline Вопросы & Ответы \\
\hline & $\begin{array}{l}\text { - Поддерживающая терапия } \\
\text { развитии SIRS и сепсиса. }\end{array}$ \\
\hline Виды операций: & $\begin{array}{l}\text { - Чрескожное дренирование и } \\
\text { санация; } \\
\text { - Лапароскопическое дренирование; } \\
\text { - Открытые операции. }\end{array}$ \\
\hline
\end{tabular}

Вопросы и ответы по ретроперитонеальным гематомам и абсцессам

\begin{tabular}{|c|c|}
\hline Вопросы & Ответы \\
\hline $\begin{array}{l}\text { Что такое ретроперитонеальная } \\
\text { гематома? }\end{array}$ & $\begin{array}{l}\text { Скопление крови в забрюшинное } \\
\text { пространство. }\end{array}$ \\
\hline Причины и факторы риска: & $\begin{array}{l}\text { - Травмы таза (переломы тазовых } \\
\text { костей-60\%); } \\
\text { - Антикоагулянты; } \\
\text { - Сосудистые патологии; } \\
\text { - Опухоли; } \\
\text { - Острый панкреатит; } \\
\text { - Ятрогенное повреждение. }\end{array}$ \\
\hline Осложнения: & $\begin{array}{l}\text { Геморрагический } \\
\text { ретроперитонеальный абсцесс. }\end{array}$ \\
\hline Клинические признаки: & $\begin{array}{l}\text { - Головокружение; } \\
\text { - Обморок; } \\
\text { - Общая слабость; } \\
\text { - Боли в пояснице и в животе; } \\
\text { - Локальная чувствительность; } \\
\text { - Шок; } \\
\text { - Гематурия (80\%). }\end{array}$ \\
\hline
\end{tabular}




\begin{tabular}{|c|c|}
\hline Вопросы & Ответы \\
\hline $\begin{array}{l}\text { У каких пациентов можно } \\
\text { заподозрить? }\end{array}$ & $\begin{array}{l}\text { у пациентов с } \text { признаками } \\
\text { геморрагического шока. }\end{array}$ \\
\hline Диагностика: & УЗИ, КТ, МРТ. \\
\hline Лабораторные показатели: & $\begin{array}{l}\text { Снижение уровня гемоглобина и } \\
\text { гематокрита. }\end{array}$ \\
\hline Методы лечения: & $\begin{array}{l}\text { - Консервативное; } \\
\text { - Хирургическое. }\end{array}$ \\
\hline Методы хирургического лечения: & $\begin{array}{l}\text { - Лапаротомия; } \\
\text { - Чрескожное дренирование. }\end{array}$ \\
\hline $\begin{array}{l}\text { Показание к дренированию } \\
\text { ретроперитонеальных гематом: }\end{array}$ & $\begin{array}{l}\text { Увеличение размеров } \\
\text { инфицирование гематомы. }\end{array}$ \\
\hline
\end{tabular}




\section{ДРУГИЕ ЗАБОЛЕВАНИЯ БРЮШИНЫ}

- По происхождению опухоли брюшины делятся на 2 группы: первичные и вторичные (метастатические).

- Первичные опухоли брюшины встречаются редко, могут быть доброкачественными (липома, фиброма и др.) и злокачественными (мезотелиома, псевдомиксома). Вторичные опухоли (перитонеальный карциноматоз) развиваются в результате метастазирования из первичных очагов опухолей (желудочно-кишечный тракт, яичники и др.)

- Перитонеальные опухоли проявляются развитием асцита и наличием пальпируемого образования в брюшной полости.

- Ретроперитонеальный фиброз - редкая патология, характеризующаяся развитием воспаления и фиброза и сдавлением органов в забрюшинном пространстве.

- В большинстве случаев заболевание является первичным - идиопатическим (болезнь Ормонда, периаортит, фиброзный периуретрит), редко развивается на фоне приёма лекарственных препаратов, химио- и радиотерапии, травмы, проведённой операции и др.

- Клиническая картина ретроперитонеального фиброза характеризуется болями в поясничной области, высокой температурой, обструкцией мочеточников и сосудов.

- Постановке диагноза помогают КТ и МРТ - наличие инфильтрата. Для дифференциальной диагностики проводят гистологическое исследование биоптата из забрюшинной клетчатки.

- Для лечения первичного фиброза применяют иммуносупрессивную терапию преднизолоном. При вторичном фиброзе лечение должно быть направлено на устранение нозологической причины. При сдавлениях мочеточников применяют стентирование участков обструкции. 


\section{ЗАБОЛЕВАНИЯ САЛЬНИКА}

- Инфаркт сальника - ишемический некроз, развившийся вследствие перекрута сальника или ущемления грыжевого мешка.

○ Начинается, как правило, острыми болями, характеризуется высокой температурой, умеренным лейкоцитозом, в некоторых случаях пальпируемым болезненным образованием в брюшной полости.

○ При обнаружении во время операции проводится резекция.

- Кисты брыжейки - врождённая аномалия развития, которая является кистозной трансформацией эктопической лимфоидной ткани или ткани яичников.

○ В большинстве случаев не отличаются от других кистозных образований клинической картиной и во время инструментальной диагностики.

○ Лечение - радикальная удаление кисты.

\section{Вопросы и ответы по инфаркту сальника}

\section{Вопросы Ответы}

Что такое инфаркт сальника?

Ишемический некроз, развившийся вследствие перекрута сальника или ущемления грыжевого мешка.

Причины и факторы риска:

Патогенез:

Особенность клинического течения: Острое начало.

Осложнения:

Некроз сальника.

Клинические признаки:

У каких пациентов можно заподозрить?

Диагностика:
- Идиопатический инфаркт;

- Травма.
Ишемический некроз сальника.
Остро начавшиеся боли.

У пациентов с острыми
абдоминальными болями.




\begin{tabular}{|c|c|}
\hline Вопросы & Ответы \\
\hline Лабораторные признаки: & Умеренный лейкоцитоз. \\
\hline $\begin{array}{l}\text { Признаки диагностической } \\
\text { визуализации: }\end{array}$ & $\begin{array}{l}\text { - УзИ - жидкость или образование в } \\
\text { брюшной полости; } \\
\text { • } \\
\text { КТ - инфильтрация сальника и } \\
\text { жидкость в брюшной полости. }\end{array}$ \\
\hline Методы лечения: & $\begin{array}{l}\text { При обнаружении патологии до } \\
\text { операции показано наблюдение. } \\
\text { Некроз сальника, обнаруженный во } \\
\text { время операции, является показанием к } \\
\text { резекции. }\end{array}$ \\
\hline Показания к операции: & Перекрут сальника. \\
\hline Виды операций: & Резекция сальника. \\
\hline
\end{tabular}

\section{Вопросы и ответы по оментиту}

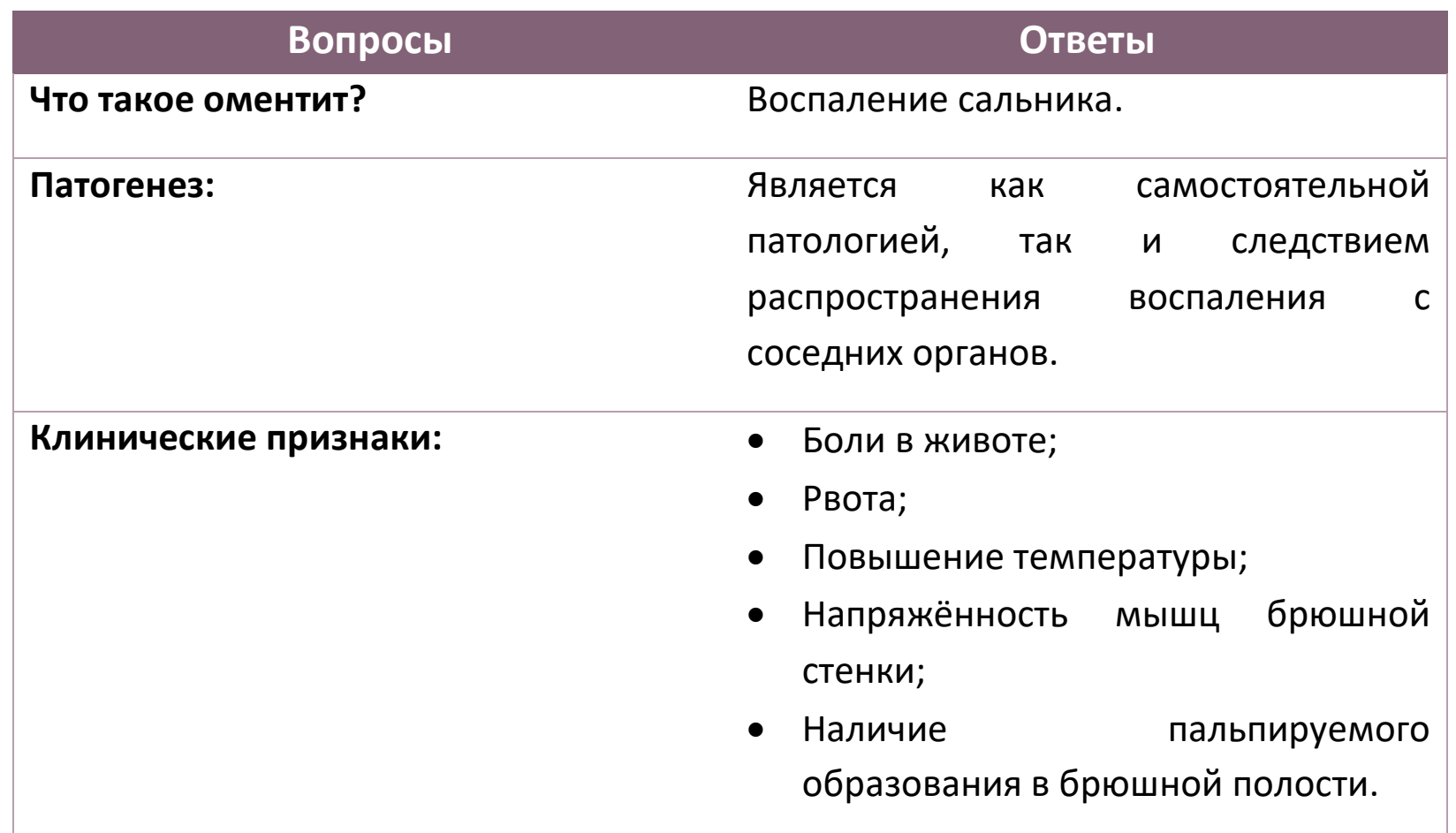




\section{Вопросы}

У каких пациентов можно заподозрить?

\section{Ответы}

У пациентов с острой болью в животе.

\section{Вопросы и ответы по десмоидным опухолям}

\begin{tabular}{|c|c|}
\hline Bопросы & Ответы \\
\hline $\begin{array}{l}\text { Что представляют собой десмоидные } \\
\text { опухоли? }\end{array}$ & $\begin{array}{l}\text { Медленно растущие и не дающих } \\
\text { метастазов опухоли мягких тканей. }\end{array}$ \\
\hline Частота встречаемости: & $\begin{array}{l}\text { Встречаются редко, составляют } 0,03 \% \\
\text { всех опухолей. }\end{array}$ \\
\hline Причины и факторы риска: & $\begin{array}{l}\text { - Синдром Гарднера (FAP); } \\
\text { - Травмы; } \\
\text { - Мутация гена CTNNB1. }\end{array}$ \\
\hline Клинические признаки: & $\begin{array}{l}\text { - Боли; } \\
\text { - Чувство тяжести; } \\
\text { - Дискомфорт. }\end{array}$ \\
\hline Диагностика: & КТ, МРТ, УЗИ, биопсия. \\
\hline Методы лечения: & $\begin{array}{l}\text { - Наблюдение; } \\
\text { - Радиотерапия; } \\
\text { - Хирургическая операция. }\end{array}$ \\
\hline Показания к операции: & $\begin{array}{l}\text { Размер опухоли и сдавление соседних } \\
\text { органов. }\end{array}$ \\
\hline Прогноз: & Склонны к росту без лечения. \\
\hline
\end{tabular}




\section{СПИСОК ЛИТЕРАТУРЫ}

\section{Ümumi adabiyyat}

- Ağayev B.A. Cərrahi xəstəliklər. Bakı 2010.

- Blackbourne LH. Surgical Recall. 4 edition, 2006, LWW, Philadelphia

- Doherty GM. Current Diagnosis and Treatment: Surgery, $13^{\text {th }}$ edition, 2010, Lang International Edition.

- Omiraslanov D.T., Qazıyev A.Y. Onkologiya. Bakı, 2010.

- İsayev H.B. Cərrahi xəstəliklərin patofizologiyası. Bakı 2005

- Klingensmith ME, Aziz A, Bharat A, Fox AC, Porembka MR. The Washington Manual of Surgery, $6^{\text {th }}$ edition, 2012, LWW, Philadelphia.

- McNally PR. GI/Liver Secrets Plus. 4 edition. Mosby, Elsevier, 2010

- Medscape, http://www.medscape.com

- Oxford Handbook of Clinical Surgery, 3d edition, 2011, Oxford Press

- Sayek I. Sayek Temel Cerrahi 1-2. 4-cü baskı, 2016, Güneş Tıp Kitabevleri.

- Topçubaşov M.A. Xüsusi cərrahlıq. Bakı, 1979

- UpToDate, http://www.uptodate.com

- Гостищев B.К. Общая хирургия. GEOTAR-Media, 2019

\section{Xüsusi adabiyyat}

- Brian J Daley, Julian Katz. Peritonitis and Abdominal Sepsis/ Medscape 2015. http://emedicine.medscape.com/article/180234-overview\#a6

- Alexander HR, Tanabe KK, Savarese $\mathrm{D}$, Malignant peritoneal mesothelioma: Epidemiology, risk factors, clinical presentation, diagnosis, and staging. UpToDate, http://www.uptodate.com

- N.Y.Bayramov. Təcili Abdominal cərrahiyyədə müayinə və müalicə qaydaları. ISBN13 978-9952-8082-1-6, Qismət, Bakı 2009. 132 s. 


\section{ХИРУРГИЧЕСКИЕ БОЛЕЗНИ}

Н.Ю. Байрамов

\section{Грыжи живота}

Н.Ю. Байрамов, А.Э. Намазов, А.К. Сафиева, Ф.Ф. Ахмадов

Перевод: Н.Ю. Байрамов, С.А. Алиев, М.Р.Гусейнова 


\section{ГРЫЖИ ЖИВОТА}

- Выхождение органов за пределы полости организма осуществляется 3 путями: грыжа, эвентрация, пролапс.

- Грыжа - это выхождение покрытых париетальной брюшиной органов за пределы полости организма через естественные или приобретённые дефекты.

- Эвентрация - выхождение внутренних органов из брюшной полости без брюшины.

- Пролапс (выпадение) - выхождение органов через естественное отверстие организма.

- В формировании грыжи играют роль основные и вспомогательные факторы. Основные факторы способствуют ослаблению брюшной стенки, увеличению размеров естественных анатомических дефектов. К вспомогательным факторам относятся повышение внутрибрюшного давления.

- По локализации различают внутренние и наружные грыжи живота. К наружным грыжам относятся паховая, пупочная, бедренная, поясничная, послеоперационная грыжи, грыжа белой линии живота.

- По клиническому течению различают неосложнённую (вправимую), невправимую, осложнённую (ущемлённую) грыжи.

- Наиболее частым осложнением грыжи является ущемление.

- Грыжи могут протекать бессимптомно, с классическими признаками и с признаками осложнений.

- Основным методом диагностики грыжи является клиническое обследование. Методы диагностической визуализации (УЗИ, КТ, МРТ) применяются с целью подтверждения диагноза и дифференциальной диагностики.

- Диагностическими критериями являются выпячивание и болевые ощущения в области грыжи при натуживании, кашле, физическом напряжении, ходьбе, при вертикальном положении больного, самостоятельное или ручное вправление грыжевого содержимого, определение дефекта и грыжевого содержимого при диагностических методах визуализации.

- Основным методом лечения грыжи является хирургический. Операция состоит из следующих этапов: обнаружение и мобилизация грыжевого мешка, вправление органов в брюшную полость и пластика грыжевых ворот. С этой целью применяют 3 основных метода: герниотомия (устранение грыжевого 
мешка), герниорафия (проводится герниотомия и пластика грыжевых ворот собственными тканями), герниопластика (проводится герниотомия и аллопластика грыжевых ворот - ненатяжной метод).

- Паховые грыжи выходят через паховый канал.

- Различают косые, прямые, смешанные паховые грыжи и грыжи у спортсменов.

○ Хирургическое лечение проводится ненатяжным (аллопластика с применением синтетических сетчатых материалов) лапароскопическим или открытым способами. Натяжные методы применяются при наличии противопоказаний к использованию синтетических сетчатых материалов (методы Бассини, Шоулдайса, Мак- Вея и др.)

- Бедренные грыжи выходят через бедренный канал.

○ Формируются в связи с дефектом поперечной фасции на уровне внутреннего отверстия бедренного канала.

○ В отличие от паховой грыжи, грыжевые ворота расположены ниже пупартовой связки.

○ Часто встречаются у женщин и склонны к ущемлению.

○ При оперативном лечении применяют открытые и лапароскопические ненатяжные методы пластики.

- Пупочная грыжа выходит через расширенное пупочное кольцо.

○ У детей до 2-х лет, при малых размерах и бессимптомных грыжах показано наблюдение.

○ В других случаях проводится ненатяжная герниопластика с синтетическими сетчатыми материалами.

- Послеоперационные грыжи образуются в области послеоперационного рубца в результате расхождения краев сшитого апоневроза или нагноения раны.

○ Высока вероятность образование многокамерных грыж со спайками.

○ Стандартное лечение заключается в аллопластике грыжевых ворот, которую выполняют открытым и лапароскопическим способами.

- Грыжи у спортсменов - встречаются у мужчин, занимающихся тяжёлой атлетикой.

○ Характерным признаком этих грыж является боль, которая возникает и усиливается при повышении внутрибрюшного давления. Боли не проходят после отдыха или применения противовоспалительных препаратов. 
О Обычно при клиническом обследовании грыжу не обнаруживают, несмотря на наличие болевого синдрома в паховой области.

○ На МРТ не выявляются грыжевой дефект, повреждения мышц, паховой кости, надкостницы и других органов.

○ Лечение - оперативное, которое выполняют открытым и лапароскопическим способами.

\section{Вопросы и ответы по грыжам живота}

\begin{tabular}{|c|c|}
\hline Вопросы & Ответы \\
\hline Что такое грыжа? & $\begin{array}{l}\text { Выхождение покрытых париетальной } \\
\text { брюшиной органов за пределы полости } \\
\text { организма через естественные или } \\
\text { приобретённые дефекты. }\end{array}$ \\
\hline Частота встречаемости: & $\begin{array}{l}\text { Встречается у 5-10\% населения. } 75 \% \\
\text { составляют паховые грыжи, (50\% - } \\
\text { косая, } 25 \% \text { - прямая), 5\% - бедренные, } \\
20 \% \text { - грыжи другой локализации. }\end{array}$ \\
\hline Причины и факторы риска: & $\begin{array}{l}\text { - Повышение внутрибрюшного } \\
\text { давления; } \\
\text { - Постоянное натуживание при } \\
\text { дефекации и мочеиспускании; } \\
\text { - Хронические кашель. }\end{array}$ \\
\hline $\begin{array}{l}\text { Чем объясняется необходимость } \\
\text { хирургического лечения грыж? }\end{array}$ & $\begin{array}{l}\text { С целью } \\
\text { возникновения } \\
\text { (ущемление, } \\
\text { тонкокишечная непрохроз, осложнений } \\
\text { недимость). }\end{array}$ \\
\hline Какие грыжи наиболее опасны? & $\begin{array}{l}\text { Грыжи небольших размеров более } \\
\text { опасны в связи с высоким риском } \\
\text { ущемления. }\end{array}$ \\
\hline
\end{tabular}




\begin{tabular}{|c|c|}
\hline Вопросы & Ответы \\
\hline Что такое вправимая грыжа? & $\begin{array}{l}\text { Грыжа, содержимое которой } \\
\text { вправляется в брюшную полость. }\end{array}$ \\
\hline Что такое ущемлённая грыжа? & $\begin{array}{l}\text { Содержимое грыжи подвергается } \\
\text { сдавлению на уровне шейки грыжевого } \\
\text { мешка. В случае ущемления кишки } \\
\text { развивается кишечная непроходимость } \\
\text { и ишемический некроз органа. }\end{array}$ \\
\hline Что такое скользящая грыжа? & $\begin{array}{l}\text { Часть стенки грыжевого мешка } \\
\text { составляет мезоперитонеальный орган } \\
\text { (мочевой пузырь, слепая, сигмовидная } \\
\text { кишка). }\end{array}$ \\
\hline Что такое грыжа Литтре? & $\begin{array}{l}\text { Содержимое грыжи с составляет } \\
\text { дивертикул Меккеля. }\end{array}$ \\
\hline Что такое грыжа спигелиевой линии? & \begin{tabular}{llr} 
Выхождение органа из дефекта & \multicolumn{1}{c}{ из } \\
спигелиевой (полулунной) & линии \\
(латеральная грыжа). &
\end{tabular} \\
\hline Что такое внутренняя грыжа? & $\begin{array}{l}\text { Формирование грыжи во внутренних } \\
\text { карманах брюшины или диафрагмы. }\end{array}$ \\
\hline Что такое запирательная грыжа? & $\begin{array}{l}\text { Содержимое грыжи выходит через } \\
\text { запирательное отверстие. }\end{array}$ \\
\hline Что такое поясничная грыжа? & $\begin{array}{l}\text { Содержимое грыжи выходит через } \\
\text { отверстия Пти и Грюнвальда в } \\
\text { поясничной области. }\end{array}$ \\
\hline Что такое грыжа Пти? & $\begin{array}{l}\text { Содержимое грыжи выходит через } \\
\text { треугольник Пти. Также называется } \\
\text { грыжей, выходящей через нижний } \\
\text { поясничный треугольник. }\end{array}$ \\
\hline
\end{tabular}




\begin{tabular}{|c|c|}
\hline Вопросы & Ответы \\
\hline Что такое грыжа Грюнвальда? & $\begin{array}{l}\text { Содержимое грыжи выходит через } \\
\text { треугольник } \quad \text { Грюнвальда-Лесгафга } \\
\text { (верхний поясничный треугольник). }\end{array}$ \\
\hline Что такое панталонная грыжа? & $\begin{array}{l}\text { Грыжа состоит из комбинации косой и } \\
\text { прямой паховой грыжи. При этом } \\
\text { нижние эпигастральные сосуды делят } \\
\text { грыжу на } 2 \text { части. }\end{array}$ \\
\hline Что такое послеоперационная грыжа? & $\begin{array}{l}\text { Грыжа формируется в области } \\
\text { послеоперационного рубца вследствие } \\
\text { инфицирования и нагноения раны и } \\
\text { расхождение швов. }\end{array}$ \\
\hline Что такое вентральная грыжа? & Грыжа передней брюшной стенки. \\
\hline Что такое парастомальная грыжа? & $\begin{array}{l}\text { Грыжа, формирующаяся вокруг } \\
\text { кишечных стом. }\end{array}$ \\
\hline Что такое грыжа Рихтера? & $\begin{array}{l}\text { Пристеночное ущемление петли } \\
\text { кишечника. При отсутствии признаков } \\
\text { обструкции происходит некроз и } \\
\text { перфорация кишки. }\end{array}$ \\
\hline Что такое эпигастральная грыжа? & $\begin{array}{l}\text { Содержимое грыжи выходит через } \\
\text { белую линию живота выше пупка. }\end{array}$ \\
\hline Что такое пупочная грыжа? & $\begin{array}{l}\text { Содержимое грыжи выходит через } \\
\text { пупочное кольцо. Часто встречается у } \\
\text { беременны и у больных, страдающих } \\
\text { ожирением и асцитом. }\end{array}$ \\
\hline Что такое интрапариетальная грыжа? & $\begin{array}{l}\text { Грыжевой мешок располагается между } \\
\text { слоями брюшной стенки. }\end{array}$ \\
\hline Что такое бедренная грыжа? & $\begin{array}{l}\text { Содержимое грыжи выходит через } \\
\text { бедренное кольцо и располагается } \\
\text { кнутри от сосудов. }\end{array}$ \\
\hline
\end{tabular}




\begin{tabular}{|c|c|}
\hline Вопросы & Ответы \\
\hline Что такое грыжа Гессельбаха? & $\begin{array}{l}\text { Грыжа, расположенная кнаружи от } \\
\text { бедренных сосудов под пупартовой } \\
\text { связкой. }\end{array}$ \\
\hline Что такое грыжа Бохдалека? & $\begin{array}{l}\text { Диафрагмальная } \\
\text { формирующаяся в } \text { в трежа, } \\
\text { Бохдалека и и выходящая через } \\
\text { пояснично-рёберное пространство. }\end{array}$ \\
\hline Что такое грыжа Морганьи? & $\begin{array}{l}\text { Диафрагмальная грыжа, которая } \\
\text { формируются в результате выхождения } \\
\text { органов через грудинно-рёберное } \\
\text { пространство (парастернальная грыжа). }\end{array}$ \\
\hline Что такое преперитонеальная грыжа? & $\begin{array}{l}\text { Грыжа формируется между } \\
\text { париетальной брюшиной и поперечной } \\
\text { фасцией. }\end{array}$ \\
\hline Что такое грыжа Купера? & $\begin{array}{l}\text { Содержимое грыжи выходит через } \\
\text { бедренный канал и опускается в } \\
\text { мошонку или большие половые губы. }\end{array}$ \\
\hline Что такое косая паховая грыжа? & $\begin{array}{l}\text { Грыжа выходит латеральнее нижних } \\
\text { надчревных сосудов. }\end{array}$ \\
\hline Что такое прямая паховая грыжа? & $\begin{array}{l}\text { Грыжа формируется медиальнее } \\
\text { нижних эпигастральных сосудов. }\end{array}$ \\
\hline Что такое хиатальная грыжа? & $\begin{array}{l}\text { Грыжа формируется через пищеводное } \\
\text { отверстие диафрагмы. }\end{array}$ \\
\hline Что такое грыжа Амианда? & $\begin{array}{l}\text { Содержимое паховой грыжи составляет } \\
\text { деструктивно } \\
\text { червеобразный отросток. }\end{array}$ \\
\hline $\begin{array}{l}\text { Какие структуры формируют } \\
\text { треугольник Гессельбаха? }\end{array}$ & $\begin{array}{l}\text { - Нижние эпигастральные сосуды; } \\
\text { - Пупартовая связка; }\end{array}$ \\
\hline
\end{tabular}




\begin{tabular}{|c|c|}
\hline Вопросы & Ответы \\
\hline & $\begin{array}{l}\text { - Наружный краё прямой мышцы } \\
\text { живота. }\end{array}$ \\
\hline $\begin{array}{l}\text { Сколько слоёв имеется в брюшной } \\
\text { стенке? }\end{array}$ & $\begin{array}{l}\text { Брюшная стенка состоит из кожи, } \\
\text { подкожной жировой клетчатки, } \\
\text { поверхностной фасции, наружной, } \\
\text { внутренней косой и поперечной мышц, } \\
\text { поперечной фасции, предбрюшинной } \\
\text { жировой клетчатки, париетальной } \\
\text { брюшины. }\end{array}$ \\
\hline $\begin{array}{l}\text { Что является причиной выпячивания в } \\
\text { паховой области? }\end{array}$ & $\begin{array}{l}\text { Паховая грыжа, паховой лимфаденит, } \\
\text { гематома, серома, абсцесс, гидроцеле, } \\
\text { аневризма бедренной артерии, паховая } \\
\text { эктопия яичка, саркома яичка, перекрут } \\
\text { яичка. }\end{array}$ \\
\hline Методы лечения грыж: & $\begin{array}{l}\text { - Герниотомия; } \\
\text { - Герниорафия; } \\
\text { - Герниопластика. }\end{array}$ \\
\hline Что такое герниотомия? & $\begin{array}{l}\text { Устранение грыжевого мешка. Как } \\
\text { правило, проводится у детей. }\end{array}$ \\
\hline Что такое герниорафия? & $\begin{array}{lrr}\text { При этом проводится герниотомия и } \\
\text { пластика } & \text { грыжевых } \\
\text { собственными } & \text { торанями } \\
\text { Бассини). } & & \text { (метод } \\
& \end{array}$ \\
\hline Что такое герниопластика? & $\begin{array}{l}\text { Пластика грыжевых ворот } \\
\text { синтетическими сетчатыми } \\
\text { материалами (метод Лихтенштейна). }\end{array}$ \\
\hline $\begin{array}{l}\text { Какая операция должна быть } \\
\text { выполнена в первую очередь у } \\
\text { пациента с паховой грыжей и } \\
\text { аденомой предстательной железы? }\end{array}$ & $\begin{array}{l}\text { Трансуретральная резекция } \\
\text { предстательной железы (ТУР). }\end{array}$ \\
\hline
\end{tabular}




\begin{tabular}{|c|c|}
\hline Вопросы & Ответы \\
\hline $\begin{array}{l}\text { Какой вид хиатальной грыжи } \\
\text { сопровождается гастроэзофагеальным } \\
\text { рефлюксом? }\end{array}$ & Скользящая хиатальная грыжа. \\
\hline $\begin{array}{l}\text { Как проводится вправление } \\
\text { ущемлённой грыжи в отделении } \\
\text { скорой помощи? }\end{array}$ & $\begin{array}{l}\text { - На грыжевое выпячивание кладут } \\
\text { пузырь со льдом; } \\
\text { - Проводят седацию пациента; } \\
\text { - При паховой грыже пациенту } \\
\text { придают пложение } \\
\text { Тренделенбурга; } \\
\text { - Продолжительными умеренными } \\
\text { давлениями приступают к } \\
\text { вправлению грыжи. } \\
\text { - После вправления ущемлённой } \\
\text { грыжи пациент должен находиться } \\
\text { на стационарном наблюдении. } \\
\text { В дальнейшем } \\
\text { герниопластику. }\end{array}$ \\
\hline $\begin{array}{l}\text { Существует ли разница в } \\
\text { герниопластике у детей и взрослых? }\end{array}$ & $\begin{array}{l}\text { У новорожденных и детей раннего } \\
\text { возраста выполняют герниотомию и } \\
\text { перевязку грыжевого мешка у шейки. } \\
\text { У взрослых герниотомию обязательно } \\
\text { завершают пластикой грыжевых ворот. }\end{array}$ \\
\hline $\begin{array}{l}\text { Что такое признак "шёлковых } \\
\text { перчаток"? }\end{array}$ & $\begin{array}{l}\text { При пальпации грыжи у } \\
\text { новорождённых грыжевой мешок } \\
\text { напоминает палец "шёлковых } \\
\text { перчаток". }\end{array}$ \\
\hline
\end{tabular}




\begin{tabular}{|c|c|}
\hline Вопросы & Ответы \\
\hline Что такое прямая паховая грыжа? & $\begin{array}{l}\text { Грыжа выходит через } \\
\text { Гессельбаха (медильник } \\
\text { надчревных } \\
\text { внутреннее паховое кольцо. }\end{array}$ \\
\hline Частота встречаемости: & $\begin{array}{l}\text { Встречается у } 1 \% \text { мужчин. С возрастом } \\
\text { частота увеличивается. }\end{array}$ \\
\hline $\begin{array}{l}\text { Причины и факторы риска } \\
\text { формирования прямой паховой } \\
\text { грыжи: }\end{array}$ & $\begin{array}{l}\text { В результате продолжительного } \\
\text { действия механических факторов. }\end{array}$ \\
\hline Что такое косая паховая грыжа: & $\begin{array}{l}\text { Грыжа выходит через внутреннее } \\
\text { паховое кольцо (латеральнее нижних } \\
\text { эпигастральных сосудов), через } \\
\text { паховый канал и наружное паховое } \\
\text { кольцо. Нередко опускается в мошонку } \\
\text { (паховомошоночная грыжа). }\end{array}$ \\
\hline $\begin{array}{l}\text { Причины и факторы риска } \\
\text { образования косой паховой грыжи? }\end{array}$ & $\begin{array}{l}\text { В большинстве случаев формируется в } \\
\text { результате незаращения влагалищного } \\
\text { отростка брюшины в процессе } \\
\text { опускания яичка. }\end{array}$ \\
\hline Частота встречаемости: & $\begin{array}{l}\text { - Встречается у } 5 \% \text { мужчин; } \\
\text { - Распространено как у мужчин, так и } \\
\text { у женщин. }\end{array}$ \\
\hline Осложнения: & $\begin{array}{l}\text { - Ущемление; } \\
\text { - Воспаление (абсцесс и флегмона, } \\
\text { связанные с некрозом кишечника); } \\
\text { - Кишечная непроходимость; } \\
\text { - Хронический запор и др. }\end{array}$ \\
\hline Степень риска ущемления: & $\begin{array}{l}\text { Косая паховая грыжа по сравнению с } \\
\text { прямой более склонна к ущемлению. }\end{array}$ \\
\hline
\end{tabular}




\begin{tabular}{|c|c|}
\hline & $\begin{array}{l}\text { Риск ущемления бедренной грыжи } \\
\text { тоже высок. }\end{array}$ \\
\hline Клинические признаки: & $\begin{array}{l}\text { - Появление выпячивания и боли в } \\
\text { паховой области при физической } \\
\text { нагрузке; } \\
\text { - Расширение наружного пахового } \\
\text { кольца; } \\
\text { - Положительный } \\
\text { «кашлевого толчка»; } \\
\text { Вправление содержимого } \\
\text { брюшную полость. }\end{array}$ \\
\hline Диагностика: & $\begin{array}{lcr}\text { Диагноз ставится } & \text { на } & \text { основании } \\
\text { анамнеза } & \text { и } & \text { физикального } \\
\text { обследования. } & \text { При } \\
\text { обследовании } & \text { наружного } \\
\text { кольца выявляется грыжевой мешоко }\end{array}$ \\
\hline $\begin{array}{l}\text { Какие методы исследования } \\
\text { необходимы для подтверждения } \\
\text { диагноза паховой грыжи? }\end{array}$ & УЗИ и КТ. \\
\hline Лабораторные признаки: & Не имеет диагностического значения. \\
\hline $\begin{array}{l}\text { Признаки диагностической } \\
\text { визуализации: }\end{array}$ & $\begin{array}{l}\text { - При УзИ-наличие грыжевого мешка } \\
\text { и изменение положения грыжевого } \\
\text { содержимого пробе } \\
\text { Вальсальвы; } \\
\text { - При КТ и МРТ - наличие дефекта на } \\
\text { брюшной стенке, определение } \\
\text { грыжевого мешка и содержимого } \\
\text { (кишечник, большой сальник). }\end{array}$ \\
\hline Диагностические критерии: & $\begin{array}{l}\text { - Клинически - положительный } \\
\text { симптом "кашлевого толчка", } \\
\text { вправление содержимого } \\
\text { брюшную полость; }\end{array}$ \\
\hline
\end{tabular}




\begin{tabular}{|c|c|}
\hline & $\begin{array}{l}\text { - } \quad \text { При УзИ - наличие грыжевого мешка } \\
\text { и изменение положения грыжевого }\end{array}$ \\
\hline & содержимого при пробе \\
\hline & $\begin{array}{l}\text { Вальсальвы; } \\
\text { - При Кт или МРТ - наличие дефекта } \\
\text { на брюшной стенке, определение } \\
\text { грыжевого мешка и содержимого } \\
\text { (кишечник, большой сальник); } \\
\text { - При лапароскопии или лапаротомии } \\
\text { - определение грыжевого мешка, }\end{array}$ \\
\hline & имеющего связь с брюшной \\
\hline & полостью. \\
\hline $\begin{array}{l}\text { С какими заболеваниями следует } \\
\text { дифференцировать паховую грыжу? }\end{array}$ & $\begin{array}{l}\text { - } \text { Паховый лимфаденит; } \\
\text { - } \text { Бедренный лимфаденит; } \\
\text { - } \text { Эктопесс; } \\
\text { - Гидроцеле; } \\
\text { - Варикоцеле; } \\
\text { - Липома. }\end{array}$ \\
\hline Методы лечения: & Основным методом является \\
\hline & хирургический. При ущемлённой грыже \\
\hline & $\begin{array}{l}\text { показана срочная, при свободной } \\
\text { грыже - плановая операция. }\end{array}$ \\
\hline Методы хирургического лечения: & $\begin{array}{l}\text { - Герниотомия; } \\
\text { - Герниорафия; } \\
\text { - Герниопластика. }\end{array}$ \\
\hline $\begin{array}{l}\text { В чём заключается суть способа } \\
\text { пластики по Бассини? }\end{array}$ & $\begin{array}{l}\text { Способ предусматривает укрепление } \\
\text { задней стенки пахового канала. После } \\
\text { удаления грыжевого мешка нижний } \\
\text { край внутренней косой и поперечной } \\
\text { мышцы вместе с поперечной фасцией }\end{array}$ \\
\hline
\end{tabular}




\begin{tabular}{|c|c|}
\hline & $\begin{array}{l}\text { подшивают к пупартовой связке под } \\
\text { семенным канатиком. }\end{array}$ \\
\hline $\begin{array}{l}\text { В чём заключается суть методики } \\
\text { Мак-Вея? }\end{array}$ & $\begin{array}{l}\text { Поперечная фасция подшивается к } \\
\text { куперовой связке. }\end{array}$ \\
\hline $\begin{array}{l}\text { В чём заключается суть методики } \\
\text { Шоулдайса? }\end{array}$ & $\begin{array}{l}\text { Выполняется 4-хслойная пластика } \\
\text { задней стенки пахового канала: } \\
\text { формируют дубликатуру из поперечной } \\
\text { фасции, которую вместе с нижним } \\
\text { краем внутренней косой мышцы } \\
\text { подшивают к паховой связке. }\end{array}$ \\
\hline $\begin{array}{l}\text { В чём заключается суть методики } \\
\text { Лихтенштейна? }\end{array}$ & $\begin{array}{l}\text { Поперечная фасция подшивается к } \\
\text { надкостнице лобковой кости под } \\
\text { семенным канатиком, после чего на } \\
\text { укреплённую заднюю стенку } \\
\text { укладывают полипропиленовую сетку, } \\
\text { которую фиксируют к латеральному } \\
\text { краю прямой мышцы, куперовой и } \\
\text { пупартовой связкам. }\end{array}$ \\
\hline Что такое операция ТАРP? & 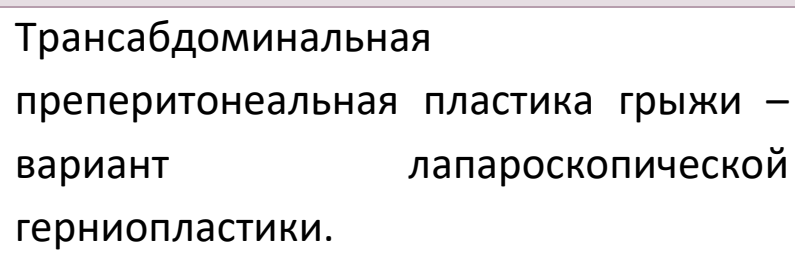 \\
\hline Что такое операция ТЕРP? & $\begin{array}{l}\text { Трансабдоминальная } \\
\text { экстраперитониальная пластика грыжи } \\
\text { - вариант лапароскопической гернио- } \\
\text { пластики. }\end{array}$ \\
\hline $\begin{array}{l}\text { Как называется слой передней } \\
\text { брюшной стенки после подкожной } \\
\text { жировой клетчатки? }\end{array}$ & Скарповая фасция. \\
\hline Какая подкожная вена лигирируется? & Поверхностная эпигастральная вена. \\
\hline
\end{tabular}




\begin{tabular}{|c|c|}
\hline $\begin{array}{l}\text { Что является последствием } \\
\text { пересечения подвздошно-пахового } \\
\text { нерва? }\end{array}$ & $\begin{array}{l}\text { Наступает онемение на медиальной } \\
\text { поверхности бедра и латеральной } \\
\text { поверхности мошонки, которое длится } \\
6 \text { месяцев. }\end{array}$ \\
\hline $\begin{array}{l}\text { Из какого мышечного слоя } \\
\text { формируется m. cremaster? }\end{array}$ & Из внутренней косой мышцы живота. \\
\hline $\begin{array}{l}\text { Из чего формируется паховая } \\
\text { (пупартовая) связка? }\end{array}$ & $\begin{array}{l}\text { Из аноневроза наружной косой мышцы } \\
\text { живота. }\end{array}$ \\
\hline Куда прикреплена пупартовая связка? & $\begin{array}{l}\text { К передней верхней ости подвздошной } \\
\text { кости и к паховому бугорку. }\end{array}$ \\
\hline $\begin{array}{l}\text { Какой нерв расположен в паховом } \\
\text { канале? }\end{array}$ & Подвздошно-паховый нерв. \\
\hline $\begin{array}{l}\text { Что представляет собой семенной } \\
\text { канатик? }\end{array}$ & $\begin{array}{l}\text { Волокна кремастерной мышцы, } \\
\text { семявыносящий проток, яичковая } \\
\text { артерия, яичковая венозная сеть, } \\
\text { генитальная ветвьгенитофеморального } \\
\text { нерва. }\end{array}$ \\
\hline $\begin{array}{l}\text { Из чего формируется грыжевой } \\
\text { мешок? }\end{array}$ & $\begin{array}{l}\text { Из париетальной брюшины (прямая } \\
\text { грыжа) или из влагалищного отростка } \\
\text { брюшины (косая грыжа). }\end{array}$ \\
\hline $\begin{array}{l}\text { Что наиболее часто является } \\
\text { содержимым паховой грыжи у } \\
\text { мужчин? }\end{array}$ & Тонкая кишка. \\
\hline $\begin{array}{l}\text { Что наиболее часто является } \\
\text { содержимым паховой грыжи у } \\
\text { женщин? }\end{array}$ & Яичники и маточные трубы. \\
\hline $\begin{array}{l}\text { Что расположено в паховом канале у } \\
\text { женщин? }\end{array}$ & Круглая связка матки. \\
\hline
\end{tabular}




$\begin{array}{ll}\text { Что такое липома семенного } & \begin{array}{l}\text { Предбрюшинная жировая ткань, } \\ \text { канатика? }\end{array} \\ \text { расположенная на семенном канатике, } \\ \text { иногда, достигая больших размеров, } \\ \text { симулирует симптомы грыжи. } \\ \text { Удаляется во время операции. }\end{array}$

\section{Вопросы и ответы по бедренным грыжам}

\begin{tabular}{|c|c|}
\hline Вопросы & Ответы \\
\hline \multirow[t]{3}{*}{ Что такое бедренная грыжа? } & $\begin{array}{l}\text { Грыжа, которая выходит через } \\
\text { бедренный канал. Формируется из-за } \\
\text { дефекта поперечной фасции на уровне }\end{array}$ \\
\hline & внутреннего отверстия бедренного \\
\hline & $\begin{array}{l}\text { канала. Локализуется медиальнее } \\
\text { бедренных сосудов. }\end{array}$ \\
\hline $\begin{array}{l}\text { Какие структуры формируют границы } \\
\text { бедренного канала? }\end{array}$ & $\begin{array}{l}\text { Сзади - куперовая связка, спереди - } \\
\text { паховая связка, с латеральной стороны } \\
\text { - бедренная вена, с медиальной - } \\
\text { лакунарная связка. }\end{array}$ \\
\hline $\begin{array}{l}\text { Частота бедренной грыжи в общей } \\
\text { структуре грыж: }\end{array}$ & $5 \%$ \\
\hline
\end{tabular}




\begin{tabular}{|c|c|}
\hline $\begin{array}{l}\text { Частота бедренной грыжи в общей } \\
\text { структуре паховых грыж среди } \\
\text { женщин: }\end{array}$ & $30 \%$. \\
\hline Причины и факторы риска: & $\begin{array}{l}\text { Женский пол, беременность и } \\
\text { физическая нагрузка. }\end{array}$ \\
\hline Особенности клинического течения: & $\begin{array}{l}\text { - В редких случаях протекает } \\
\text { бессимптомно; } \\
\text { - Склонна к ущемлению и рецидиву; } \\
\text { - Ущемление наблюдается у 30\% } \\
\text { пациентов с бедренной грыжей, у } \\
50 \% \text { из которых возникает } \\
\text { необходимость резекции } \\
\text { кишечника. }\end{array}$ \\
\hline Осложнения: & Ущемление. \\
\hline Клинические признаки: & $\begin{array}{l}\text { Наличие выпячивания и боли в паховой } \\
\text { области. }\end{array}$ \\
\hline $\begin{array}{l}\text { У каких пациентов можно } \\
\text { заподозрить? }\end{array}$ & $\begin{array}{l}\text { У пациентов с припухлостью в паховой } \\
\text { области. }\end{array}$ \\
\hline Диагностика: & УЗИ и КТ. \\
\hline Лабораторные признаки: & Неинформативны. \\
\hline $\begin{array}{l}\text { Признаки диагностической } \\
\text { визуализации: }\end{array}$ & Наличие грыжевого мешка. \\
\hline Методы лечения: & Хирургическое. \\
\hline Методы хирургического лечения: & 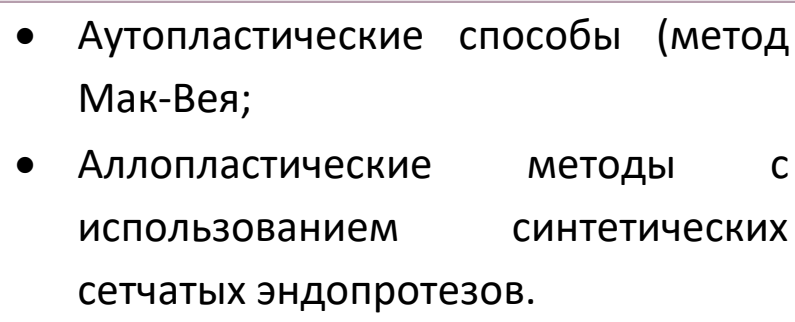 \\
\hline
\end{tabular}




$\begin{array}{ll}\text { Характерная особенность бедренной } & \text { Грыжа характеризуется частым } \\ \text { грыжи: } & \text { ущемлением. }\end{array}$

\section{Вопросы и ответы по пупочным грыжам}

\begin{tabular}{|c|c|}
\hline Вопросы & Ответы \\
\hline Что такое пупочная грыжа? & $\begin{array}{l}\text { Грыжа, которая выходит из пупочного } \\
\text { кольца. }\end{array}$ \\
\hline Причины и факторы риска: & $\begin{array}{l}\text { В основном бывают врождёнными. } \\
\text { Предрасполагающими факторами } \\
\text { являются беременность, чрезмерная } \\
\text { физическая нагрузка, другие факторы, } \\
\text { способствующие повышению } \\
\text { внутрибрюшного давления. }\end{array}$ \\
\hline Особенности клинического течения: & $\begin{array}{l}\text { - У детей до 2-3 лет происходит } \\
\text { самоизлечение; } \\
\text { - Грыжи небольших размеров могут } \\
\text { длительное время протекать } \\
\text { бессимптомно; } \\
\text { - Грыжа, возникшая во время } \\
\text { беременности, может исчезнуть } \\
\text { после родов; } \\
\text { - Обычно бывают небольших } \\
\text { размеров (менее } 1,5 \text { см), } \\
\text { содержимыми являются большой } \\
\text { сальник или предбрюшинная } \\
\text { жировая ткань (липома); } \\
\text { Большие грыжи склонны к } \\
\text { ущемлению. }\end{array}$ \\
\hline Клинические признаки: & $\begin{array}{l}\text { - Грыжи небольших размеров могут } \\
\text { протекать бессимптомно; }\end{array}$ \\
\hline
\end{tabular}




\begin{tabular}{|c|c|}
\hline & $\begin{array}{l}\text { - При больших грыжах определяются } \\
\text { выпячивание и боли в области пупка. }\end{array}$ \\
\hline $\begin{array}{l}\text { У каких пациентов можно } \\
\text { заподозрить? }\end{array}$ & $\begin{array}{l}\text { При наличии боли и выпячивания в } \\
\text { области пупка. }\end{array}$ \\
\hline $\begin{array}{l}\text { Какие методы исследования } \\
\text { необходимы для уточнения диагноза? }\end{array}$ & 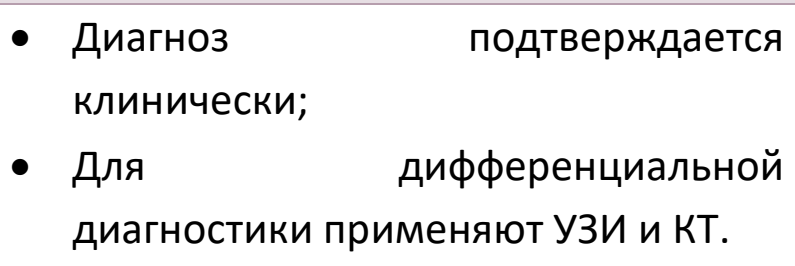 \\
\hline Методы лечения: & $\begin{array}{l}\text { - Наблюдение (у детей в возрасте до } \\
\text { 2-х лет, при грыжах небольших } \\
\text { размеров (менее } 1,5 \text { см), при } \\
\text { бессимптомных и не имеющих } \\
\text { тенденции к увеличению грыжах); } \\
\text { - Хирургическое лечение. }\end{array}$ \\
\hline Показания к хирургическому лечению: & $\begin{array}{l}\text { Симптоматические и осложнённые } \\
\text { грыжи. }\end{array}$ \\
\hline Методы хирургического лечения: & $\begin{array}{l}\text { - Герниорафия - применяется при } \\
\text { грыжах малого размера: проводится } \\
\text { однослойное или двуслойное } \\
\text { (метод Мейо) ушивание дефекта; } \\
\text { - Герниопластика - при грыжах } \\
\text { размером более 3-хсм. }\end{array}$ \\
\hline
\end{tabular}

\section{Вопросы и ответы по послеоперационным грыжам}

\section{Вопросы \\ Ответы}

Что такое послеоперационная грыжа? Грыжа, формирующаяся в области послеоперационного рубца.

Частота встречаемости:

Наблюдается у 10-20\% пациентов, перенёсших лапаротомию. 


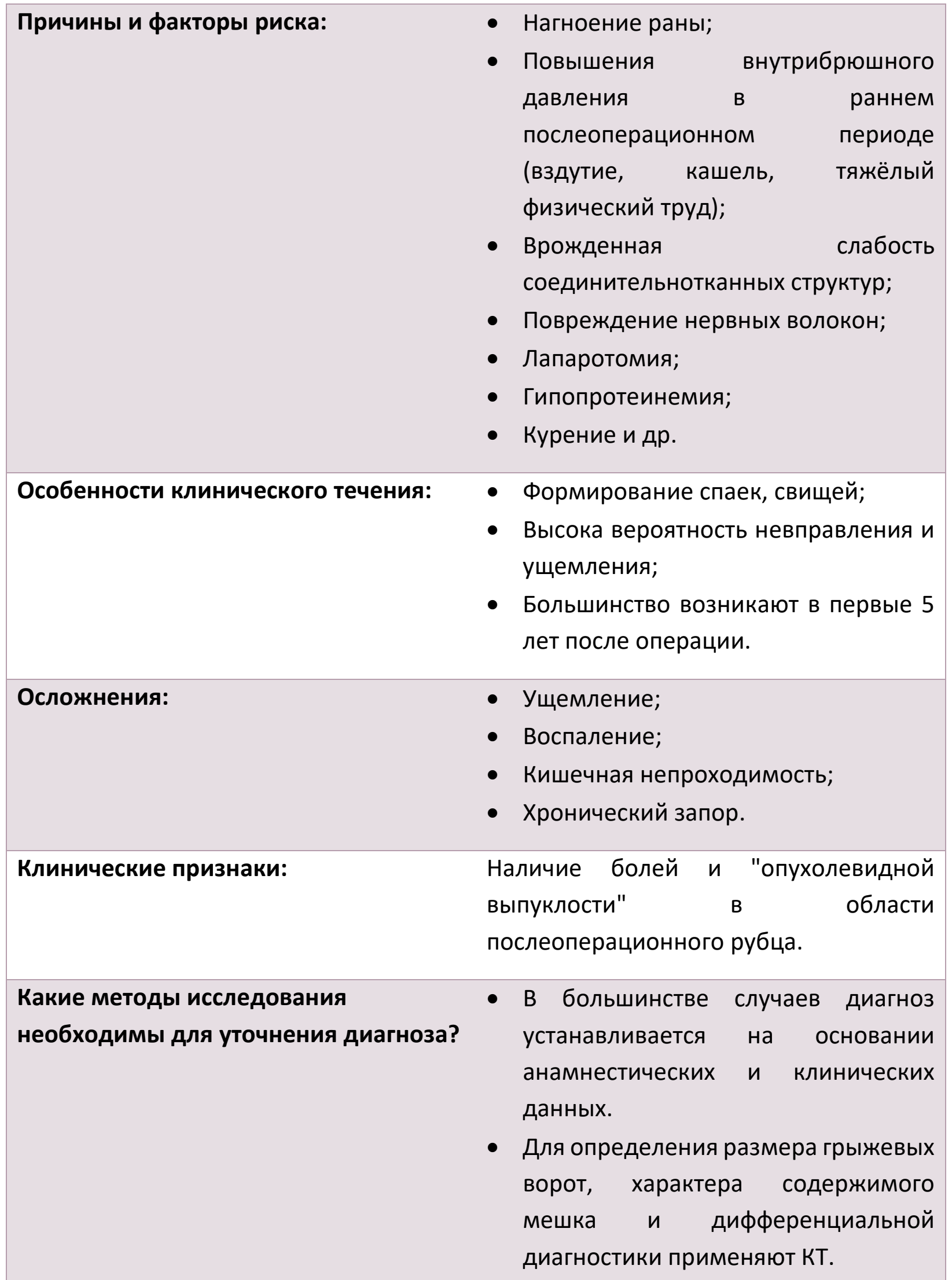




\section{Методы лечения: \\ Стандартное лечение - герниопластика.

$\begin{array}{ll}\text { Методы хирургического лечения: } & \text { Открытая или лапароскопическая } \\ \text { герниопластика. }\end{array}$ \\ Вопросы и ответы по хиатальным грыжам}

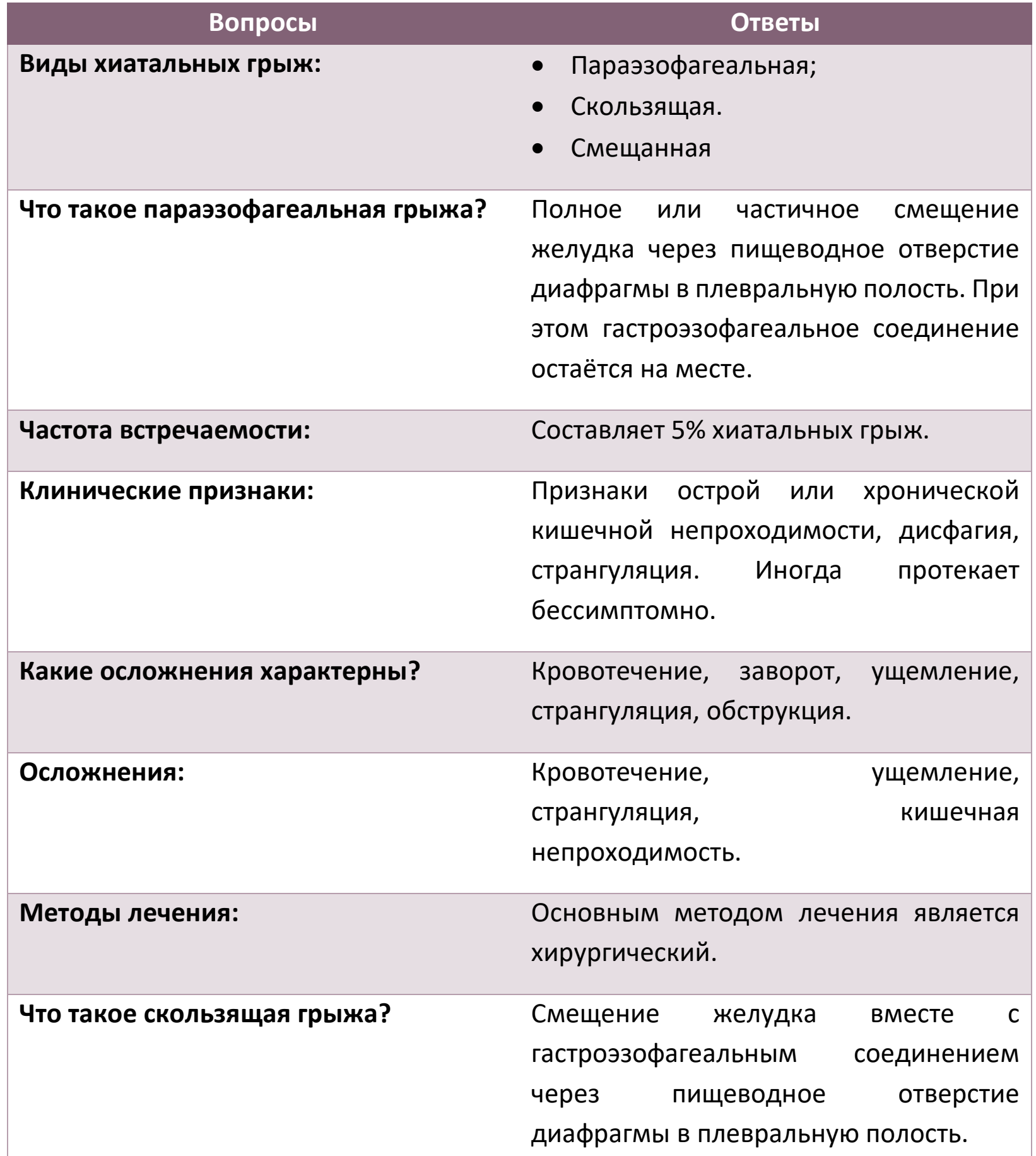




\begin{tabular}{|c|c|}
\hline Частота встречаемости? & 90\% среди всех видов хиатальных грыж. \\
\hline Симптомы: & $\begin{array}{lcc}\text { В большинстве } & \text { случаев } \\
\text { бессимптомно. } & \text { по } & \text { времекает } \\
\text { развиваются } & \text { рефлюкс-эзофагит, } \\
\text { дисфагия, лёгочная патология. }\end{array}$ \\
\hline Диагностика: & $\begin{array}{l}\text { Рентгеноскопия, КТ манометрия, } \\
\text { эндоскопическое исследование. }\end{array}$ \\
\hline Осложнения: & $\begin{array}{l}\text { - Рефлюкс-эзофагит; } \\
\text { - Пищевод Баррета; } \\
\text { - Рак; } \\
\text { - Стриктура пищевода; } \\
\text { - Пептическая язва; } \\
\text { - Кровотечение; } \\
\text { - Аспирационная пневмония. }\end{array}$ \\
\hline Методы лечения: & $\begin{array}{l}\text { - В 85\% случаев - консервативное: } \\
\text { О Антациды; } \\
\text { о Блокаторы протонной помпы и } \\
\text { ингибиторы гистаминовых } \\
\text { рецепторов; } \\
\text { О Сидячее положение после } \\
\text { приёма пищи; } \\
\text { О Малые порции пищи; } \\
\text { О Не есть перед сном; } \\
\text { При неэффективности } \\
\text { консервативного лечения показано } \\
\text { хирургическое } \\
\text { (лапароскопическая } \\
\text { фундопликация). }\end{array}$ \\
\hline
\end{tabular}




\section{СПИСОК ЛИТЕРАТУРЫ}

- Ağayev B.A. Cərrahi xəstəliklər. Bakı 2010.

- Blackbourne LH. Surgical Recall. 4 edition, 2006, LWW, Philadelphia

- Doherty GM. Current Diagnosis and Treatment: Surgery, $13^{\text {th }}$ edition, 2010, Lang International Edition.

- İsayev H.B. Cərrahi xəstəliklərin patofizologiyası. Bakı 2005

- Klingensmith ME, Aziz A, Bharat A, Fox AC, Porembka MR. The Washington Manual of Surgery, $6^{\text {th }}$ edition, 2012, LWW, Philadelphia.

- Medscape, http://www.medscape.com

- Oxford Handbook of Clinical Surgery, 3d edition, 2011, Oxford Press

- Sayek I. Sayek Temel Cerrahi 1-2. 4-cü baskı, 2016, Güneş Tıp Kitabevleri.

- Topçubaşov M.A. Xüsusi cərrahlıq. Bakı, 1979

- UpToDate, http://www.uptodate.com

- Гостищев B.К. Общая хирургия. GEOTAR-Media, 2019 


\section{ХИРУРГИЧЕСКИЕ БОЛЕЗНИ}

Н.Ю. Байрамов

\section{Острый живот}

Н.Ю. Байрамов, А.Б. Гасанов, Р.Я. Алиев, А.К. Сафиева, Ш.А. Мамедова

Перевод: Н.Ю. Байрамов, С.А. Алиев, М.Р.Гусейнова 


\section{ОСТРЫЙ жИвОт}

- Под термином «острый живот» подразумевается состояние, которое сопровождается острой и спонтанной нетравматической болью и другими абдоминальными признаками (рвота, диарея, запор и др.), требующее срочной диагностики и операции.

- Обычно используется в качестве первичного диагноза на первых этапах диагностики.

- Признаки острого живота могут быть вызваны заболеваниями как абдоминальных, так и экстраабдоминальных органов, требующих срочного оперативного вмешательства, либо консервативного лечения:

\begin{tabular}{|c|c|c|}
\hline Органы & $\begin{array}{c}\text { Острые хирургические } \\
\text { патологии }\end{array}$ & $\begin{array}{l}\text { Заболевания, требующие } \\
\text { консервативного лечения }\end{array}$ \\
\hline $\begin{array}{l}\text { Заболевания } \\
\text { желудочно- } \\
\text { кишечного тракта }\end{array}$ & $\begin{array}{l}\text { - Острый аппендицит; } \\
\text { - Перфоративная } \\
\text { гастродуоденальная } \\
\text { язва; } \\
\text { - Перфорация язвы и } \\
\text { дивертикула толстой } \\
\text { кишки; } \\
\text { - Перфорация пищевода } \\
\text { (синдром Бурхаве). }\end{array}$ & $\begin{array}{l}\text { - } \text { Воспалительные } \\
\text { - } \text { Оаболевания кишечника; } \\
\text { - Геморрогический гастрит; } \\
\text { - } \text { Паразитарные } \\
\text { заболевания; } \\
\text { - Дивертикулиты; } \\
\text { - Иерсиниозы; } \\
\text { - Мезентериальный } \\
\text { аденит. }\end{array}$ \\
\hline $\begin{array}{l}\text { Заболевание печени } \\
\text { и жёлчных путей }\end{array}$ & $\begin{array}{l}\text { - Жёлчная колика; } \\
\text { - Острый холецистит; } \\
\text { - Острый холангит; } \\
\text { - Абсцесс печени; } \\
\text { - Разрыв опухоли печени; } \\
\text { - Синдром Бадд-Киари. }\end{array}$ & $\begin{array}{l}\text { - Острый гепатит; } \\
\text { - Спонтанный } \\
\text { бактериальный } \\
\text { перитонит; } \\
\text { - Тромбоз воротной вены; } \\
\text { - Синдром Бадд-Киари. }\end{array}$ \\
\hline
\end{tabular}




\begin{tabular}{|c|c|c|}
\hline $\begin{array}{l}\text { Заболевания } \\
\text { поджелудочной } \\
\text { железы }\end{array}$ & $\begin{array}{l}\text { Острый геморрагический } \\
\text { панкреонекроз }\end{array}$ & Хронический панкреатит \\
\hline $\begin{array}{l}\text { Заболевания } \\
\text { селезёнки }\end{array}$ & $\begin{array}{l}\text { Спонтанный разрыв } \\
\text { селезёнки }\end{array}$ & Инфаркт селезёнки \\
\hline $\begin{array}{l}\text { Заболевание } \\
\text { мочевыделительной } \\
\text { системы }\end{array}$ & $\begin{array}{l}\text { Мочекаменная болезнь } \\
\text { (почечная колика) }\end{array}$ & $\begin{array}{l}\text { - Острый пиелонефрит; } \\
\text { - Острый цистит; } \\
\text { - Инфаркт почки; } \\
\text { - Паранефрит. }\end{array}$ \\
\hline $\begin{array}{l}\text { Гинекологические } \\
\text { заболевания }\end{array}$ & $\begin{array}{l}\text { - Нарушенная } \\
\text { внематочная } \\
\text { беременность; } \\
\text { - Разрыв и перекрут } \\
\text { кисты яичника; } \\
\text { - Пельвиоперитонит. }\end{array}$ & $\begin{array}{l}\text { - Острый сальпингит; } \\
\text { - Дисменорея; } \\
\text { - } \text { Эндометриоз. }\end{array}$ \\
\hline $\begin{array}{l}\text { Сосудистые } \\
\text { заболевания }\end{array}$ & $\begin{array}{l}\text { - Разрыв аневризмы } \\
\text { аорты; } \\
\text { - Эмболия и тромбоз } \\
\text { мезентериальных } \\
\text { сосудов; } \\
\text { - Ишемический колит. }\end{array}$ & \\
\hline $\begin{array}{l}\text { Заболевание } \\
\text { брюшины }\end{array}$ & $\begin{array}{l}\text { - Перитонит; } \\
\text { - Абсцесс брюшной } \\
\text { полости. }\end{array}$ & $\begin{array}{l}\text { - } \text { Первичный перитонит; } \\
\text { - Туберкулёзный } \\
\text { перитонит; } \\
\text { - Инфаркт большого } \\
\text { сальника. }\end{array}$ \\
\hline $\begin{array}{l}\text { Заболевания } \\
\text { забрюшиного } \\
\text { пространства }\end{array}$ & $\begin{array}{l}\text { Ретроперитонеальная } \\
\text { флегмона и абсцесс }\end{array}$ & $\begin{array}{l}\text { Ретроперитонеальная } \\
\text { гематома }\end{array}$ \\
\hline
\end{tabular}


- Эти заболевания могут вызвать 6 классических патологий (внутреннее кровотечение, перфорация, ишемия-некроз, деструктивное воспаление, непроходимость и компартмент-синдром), являющихся причиной острого живота.

- Пациенты с клиникой острого живота срочно госпитализируются, обследуются и проходят лечение.

- Основная цель обследований - подтверждение или опровержение критических состояний (гемодинамика, дыхание, мозговые симптомы) и острых хирургических заболеваний (требующих хирургического вмешательства в течение 24 часов).

- Клиническое обследование является решающим в постановке диагноза, лабораторные и инструментальные исследования же необходимы для подтверждения диагноза и дифференциальной диагностики.

- Основной целью всех этапов диагностики является определение показаний к срочному оперативному вмешательству (внутреннее кровотечение, перфорация, ишемия-некроз, деструктивное воспаление, непроходимость и компартментсиндром). Определение нозологической причины стоит на втором плане.

- Выявленный на начальных этапах диагностики (клиническая картина, лабораторные исследования, УЗИ) симптомокомплекс, включающий боль, шок, доскообразный живот, компартмент-синдром, образование в животе, сепсис, местный перитонит, непроходимость, является признаком острого живота.

- Для подтверждения диагноза у стабильных пациентов проводится КТ, в некоторых же случаях возникает необходимость в инвазивных методах диагностики (диагностическая лапароскопия, лапаротомия, эндоскопия и др.)

- Подтверждение кровотечения, перфорации, инфаркта, деструктивного воспаления, непроходимости или компартмент-синдрома на каком-либо этапе обследования является показанием к хирургической операции.

\section{Вопросы и ответы по острому животу}

\section{Вопросы}

Что такое синдром острого живота?

\section{Ответы}

Состояние, которое сопровождается острой и спонтанной нетравматической болью и другими абдоминальными 


\begin{tabular}{|c|c|}
\hline Вопросы & Ответы \\
\hline & $\begin{array}{l}\text { признаками (рвота, диарея, запор и } \\
\text { др.), требующее срочной диагностики и } \\
\text { операции. }\end{array}$ \\
\hline $\begin{array}{l}\text { Что в себя включают перитонизм и } \\
\text { симптомы раздражения брюшины? }\end{array}$ & $\begin{array}{l}\text { Пальпаторная и перкуторная } \\
\text { болезненность, напряжение брюшной } \\
\text { стенки. }\end{array}$ \\
\hline $\begin{array}{l}\text { Какие препараты и состояния могут } \\
\text { способствовать уменьшению болевого } \\
\text { синдрома при остром животе? }\end{array}$ & $\begin{array}{l}\text { Стероиды, сахарный диабет, } \\
\text { параплегия, наркотические препараты. }\end{array}$ \\
\hline $\begin{array}{l}\text { Основная хирургическая патология, } \\
\text { являющаяся причиной острого } \\
\text { живота: }\end{array}$ & Острый аппендицит. \\
\hline $\begin{array}{l}\text { Первичная диагностика при остром } \\
\text { животе: }\end{array}$ & $\begin{array}{l}\text { Выявление заболеваний, являющихся } \\
\text { причиной критических состояний. }\end{array}$ \\
\hline $\begin{array}{l}\text { Основной симптом при остром } \\
\text { животе: }\end{array}$ & Болевой синдром. \\
\hline $\begin{array}{l}\text { Какие симптомы с большей } \\
\text { вероятностью могут вызвать сомнения } \\
\text { об острой хирургической патологии? }\end{array}$ & $\begin{array}{l}\text { Боль, высокая температура, шок, } \\
\text { сепсис, перитонизм или признаки } \\
\text { кишечной непроходимости. }\end{array}$ \\
\hline $\begin{array}{l}\text { Как надо проводить опрос пациента с } \\
\text { острым животом? }\end{array}$ & $\begin{array}{l}\text { - Имели ли место в прошлом } \\
\text { подобные боли? } \\
\text { - Определите интенсивность болей по } \\
\text { 10-бальной шкале? } \\
\text { - Имеются ли высокая температура } \\
\text { или лихорадка? } \\
\text { - Каков характер болей? } \\
\text { - Имеются ли } \\
\text { провоцирующие болевой синдром? } \\
\text { - Есть ли иррадиация (или миграция) } \\
\text { болей? }\end{array}$ \\
\hline
\end{tabular}




\begin{tabular}{|c|c|}
\hline Вопросы & Ответы \\
\hline & $\begin{array}{l}\text { - Имеются ли дизурических } \\
\text { - } \text { Есть литомы? } \\
\text { расстройства, диарея? } \\
\text { - Анорексия. } \\
\text { - Регулярность и характер дефекации } \\
\text { (запор, диарея). } \\
\text { - Есть ли связь болей с приёмом } \\
\text { пищи? } \\
\text { - Последняя менструация. Выделения } \\
\text { из влагалища и их характер. } \\
\text { - Мелена, кровавая } \\
\text { гемотохезия. } \\
\text { - Приём лекарственных препаратов. } \\
\text { - Аллергия. } \\
\text { - Сопутствующие } \\
\text { ваболевания. } \\
\text { - Пперенесённые) } \\
\text { Веменесённые операции. } \\
\text { Вредные пнамнез. } \\
\text { наркотиков, курение). }\end{array}$ \\
\hline $\begin{array}{l}\text { Какие объективные методы } \\
\text { исследования проводятся при остром } \\
\text { животе? }\end{array}$ & $\begin{array}{l}\text { - Осмотр - оценивается состояние, } \\
\text { внешний вид живота (наличие } \\
\text { рубца, деформации, вздутия) и } \\
\text { участие его в акте дыхания. } \\
\text { - Аускультация - отсутствие или } \\
\text { сохранение перистальтических } \\
\text { шумов кишечника. } \\
\text { Пальпация - наличие (или } \\
\text { отсутствие) болезненности, } \\
\text { напряжения мышц брюшной стенки, } \\
\text { ректальное, } \\
\text { исследование. }\end{array}$ \\
\hline
\end{tabular}




\begin{tabular}{|c|c|}
\hline Вопросы & Ответы \\
\hline & $\begin{array}{l}\text { - Перкуссия - сохранение (или } \\
\text { отсутствие) печёночной тупости } \\
\text { (тимпанит, размеры печени, } \\
\text { селезёнки). }\end{array}$ \\
\hline $\begin{array}{l}\text { Самый лучший способ для указания } \\
\text { локализации боли: }\end{array}$ & $\begin{array}{l}\text { Указание точки с наиболее интенсивной } \\
\text { болью. }\end{array}$ \\
\hline $\begin{array}{l}\text { Типичная позиция пациентов с } \\
\text { перитонитом: }\end{array}$ & $\begin{array}{l}\text { Вынужденное положение } \\
\text { приведением колен к животу. }\end{array}$ \\
\hline $\begin{array}{l}\text { Типичная позиция пациентов с } \\
\text { почечной коликой: }\end{array}$ & $\begin{array}{l}\text { Беспокойное поведение, больной } \\
\text { мечется. }\end{array}$ \\
\hline $\begin{array}{l}\text { Наилучший метод выявления } \\
\text { болевого синдрома: }\end{array}$ & $\begin{array}{l}\text { Возникновение болей при любых } \\
\text { движениях пациента (глубокий вдох, } \\
\text { кашель, поворот на бок). }\end{array}$ \\
\hline $\begin{array}{l}\text { Какие лабораторные анализы } \\
\text { наиболее часто проводятся при } \\
\text { остром животе? }\end{array}$ & $\begin{array}{l}\text { Общий анализ крови, биохимический } \\
\text { анализ крови (глюкоза, креатинин, } \\
\text { билирубин, АЛТ, АСТ, ГГТ), общий } \\
\text { анализ мочи, определение у женщин ß- } \\
\text { HCG. }\end{array}$ \\
\hline $\begin{array}{l}\text { Определите понятия "сдвиг } \\
\text { лейкоформулы влево": }\end{array}$ & Признаки воспалительной реакции. \\
\hline $\begin{array}{l}\text { Какие лабораторные тесты должны } \\
\text { проводиться у женщин } \\
\text { репродуктивного возраста? }\end{array}$ & $\begin{array}{l}\text { Хорионический гонадотропин человека } \\
\text { (ß-HCG) - для уточнения беременности } \\
\text { (или трубной беременности). }\end{array}$ \\
\hline $\begin{array}{l}\text { Какое рентгенологическое } \\
\text { исследование проводится для оценки } \\
\text { острого живота? }\end{array}$ & 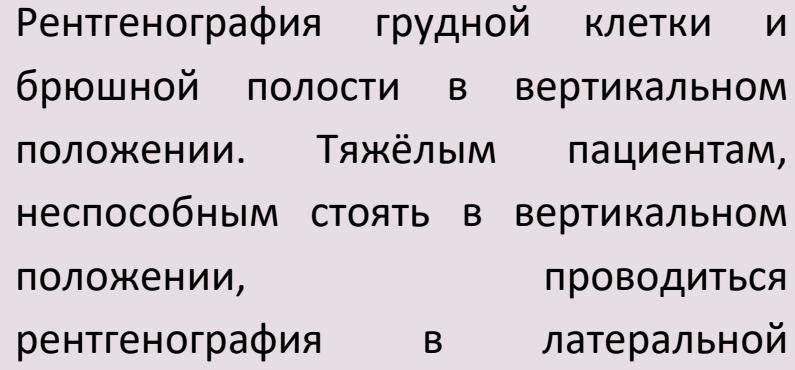 \\
\hline
\end{tabular}




\begin{tabular}{|c|c|}
\hline Bonpocbl & Ответы \\
\hline & $\begin{array}{l}\text { проекции в } \quad \text { горизонтальном } \\
\text { положении. }\end{array}$ \\
\hline $\begin{array}{l}\text { Если состояние больного не позволяет } \\
\text { проводить рентгенологическое } \\
\text { исследование в вертикальном } \\
\text { положении, то как можно исключить } \\
\text { (или подтвердить) наличие } \\
\text { свободного } \\
\text { газа в брюшной полости? }\end{array}$ & $\begin{array}{l}\text { При латеропозиции (положение } \\
\text { больного на левом боку) можно } \\
\text { обнаружить наличие свободного газа } \\
\text { под правым куполом диафрагмы. }\end{array}$ \\
\hline Показания к УЗИ при остром животе? & $\begin{array}{l}\text { УзИ показано всем больным с острым } \\
\text { животом. }\end{array}$ \\
\hline Диагностические признаки при УЗИ: & $\begin{array}{l}\text { Наличие жидкости в брюшной полости, } \\
\text { инфильтрата, утолщение стенки полого } \\
\text { органа, увеличение размеров органа и } \\
\text { т.п. }\end{array}$ \\
\hline $\begin{array}{l}\text { Что является основным } \\
\text { диагностическим методом при остром } \\
\text { животе? }\end{array}$ & $\begin{array}{l}\text { Клиническое } \\
\text { обследование. }\end{array}$ \\
\hline $\begin{array}{l}\text { Какие клинические критерии } \\
\text { характерны для постановки диагноза } \\
\text { острого живота? }\end{array}$ & $\begin{array}{lr}\text { Внутрибрюшное } & \text { кровотечение, } \\
\text { перфорация } & \text { полых } \\
\text { деструктивный } & \text { воспаланов, }\end{array}$ \\
\hline & $\begin{array}{l}\text { процесс, ишемический некроз, } \\
\text { обтурация просвета полых органов. }\end{array}$ \\
\hline $\begin{array}{l}\text { Показания к КТ у пациентов с острым } \\
\text { животом: }\end{array}$ & Для дифференциальной диагностики. \\
\hline $\begin{array}{l}\text { Для каких патологий характерны боли } \\
\text { в правом верхнем квадранте? }\end{array}$ & 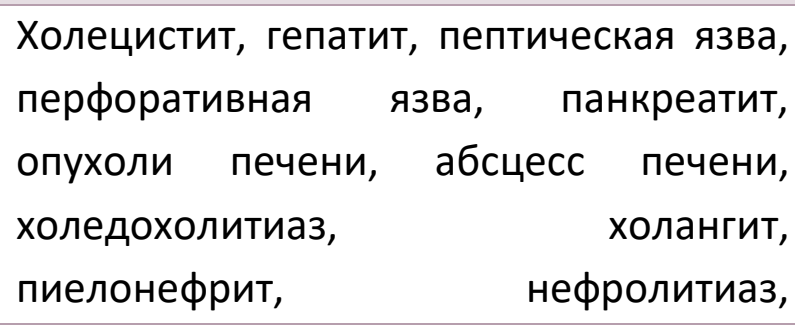 \\
\hline
\end{tabular}




\begin{tabular}{|c|c|}
\hline Вопросы & Ответы \\
\hline & $\begin{array}{l}\text { аппендицит (особенно во время } \\
\text { беременности), } \\
\text { перикардит, инфаркт миокарда. }\end{array}$ \\
\hline $\begin{array}{l}\text { Для каких патологий характерны боли } \\
\text { в левом верхнем квадранте? }\end{array}$ & $\begin{array}{l}\text { Пептическая язва, перфоративная язва, } \\
\text { гастрит, заболевания или разрыв } \\
\text { селезёнки, абсцесс, рефлюксная } \\
\text { болезнь, аневризма, диссекция аорты, } \\
\text { заболевания грудной стенки, } \\
\text { пиелонефрит, нефролитиаз, хиатальная } \\
\text { грыжа, синдром Бурхаве, Меллори- } \\
\text { Вейса, аневризма селезёночной } \\
\text { артерии. }\end{array}$ \\
\hline
\end{tabular}

Для каких патологий характерны боли в левом нижнем квадранте?

Дивертикулит, перекрут сигмовидной кишки, перфорация толстого кишечника, рак толстого кишечника, инфекции мочевыводящих путей, тонкокишечная непроходимость, воспалительные заболевания кишечника, нефролитиаз, пиелонефрит, воспалительные заболевания половых органов, кисты яичника, эндометриоз, опухоли женских половых органов.

\footnotetext{
Для каких патологий характерны боли Острый аппендицит, мезентериальный в правом нижнем квадранте? лимфаденит, дивертикулы слепой кишки, дивертикул Меккеля, инвагинация.

Для каких заболеваний характерны боли в эпигастральной области?

Пептическая язва, острый гастрит, дуоденит, холецистит, панкреатит, заворот и острое расширение желудка, синдром Меллори-Вейса, инфаркт миокарда.
} 


\begin{tabular}{|c|c|}
\hline Вопросы & Ответы \\
\hline $\begin{array}{l}\text { Какие гинекологические заболевания } \\
\text { протекают под маской острого } \\
\text { живота? }\end{array}$ & 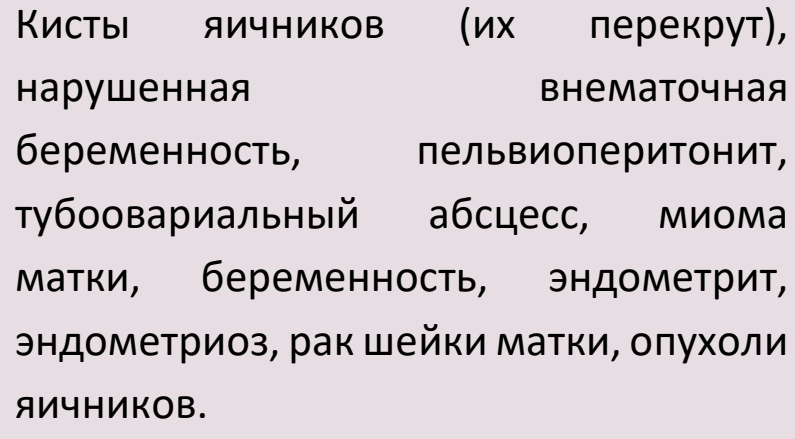 \\
\hline $\begin{array}{l}\text { Какие заболевания органов грудной } \\
\text { клетки симулируют картину острого } \\
\text { живота? }\end{array}$ & $\begin{array}{l}\text { Инфаркт миокарда, пневмония, } \\
\text { аневризма, диссекция аорты, эмпиема, } \\
\text { перфорация пищевода, пневмоторакс, } \\
\text { плеврит, инородное тело пищевода. }\end{array}$ \\
\hline $\begin{array}{l}\text { Заболевания органов мошонки, } \\
\text { протекающие под маской острого } \\
\text { живота? }\end{array}$ & Перекрут яичка, орхит, эпидидимит. \\
\hline $\begin{array}{l}\text { Нехирургические заболевания, } \\
\text { симулирующие острый живот: }\end{array}$ & 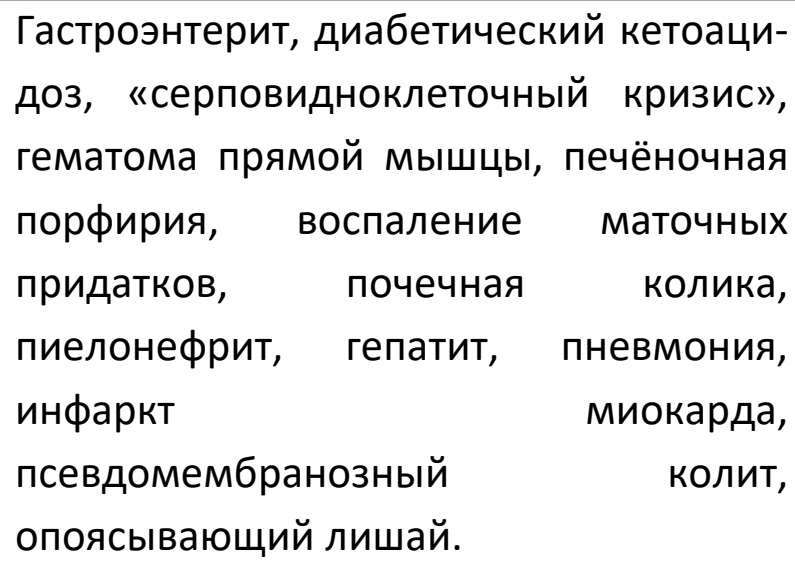 \\
\hline $\begin{array}{l}\text { Нехирургические патологии, } \\
\text { протекающие под маской острого } \\
\text { живота у ВИЧ-инфицированных } \\
\text { пациентов: }\end{array}$ & $\begin{array}{l}\text { Цитомегаловирус, туберкулёз, } \\
\text { пневмококки, саркома Капоши, } \\
\text { лимфома. }\end{array}$ \\
\hline $\begin{array}{l}\text { Какие эндокринные патологии } \\
\text { протекают под маской острого }\end{array}$ & $\begin{array}{l}\text { Аддисонический криз, диабетический } \\
\text { кетоацидоз. }\end{array}$ \\
\hline
\end{tabular}
живота? 


\begin{tabular}{|c|c|}
\hline Вопросы & Ответы \\
\hline $\begin{array}{l}\text { Причины надлобковых болей при } \\
\text { остром животе: }\end{array}$ & $\begin{array}{l}\text { Острый цистит, острый аппендицит, } \\
\text { гинекологические патологии, } \\
\text { заболевания толстой кишки. }\end{array}$ \\
\hline Что такое гастроэнтерит? & $\begin{array}{l}\text { Инфекционное воспаление желудочно- } \\
\text { кишечного тракта вирусной или } \\
\text { бактериальной этиологии. Обычно } \\
\text { проявляется рвотой, диареей, а потом } \\
\text { присоединяется и боль. }\end{array}$ \\
\hline $\begin{array}{l}\text { Типичная локализация болей при } \\
\text { остром холецистите: }\end{array}$ & $\begin{array}{l}\text { Правое подреберье и эпигастральная } \\
\text { область. }\end{array}$ \\
\hline $\begin{array}{l}\text { Характерная локализация болей при } \\
\text { остром аппендиците: }\end{array}$ & $\begin{array}{l}\text { Вначале вокруг пупка, в дальнейшем в } \\
\text { правом нижнем квадранте живота. }\end{array}$ \\
\hline $\begin{array}{l}\text { Локализация болей при } \\
\text { воспалительном процессе } \\
\text { поддиафрагмального пространства: }\end{array}$ & Лопаточная область. \\
\hline $\begin{array}{l}\text { Типичная локализация болей при } \\
\text { остром панкреатите: }\end{array}$ & Эпигастральная и поясничная области. \\
\hline $\begin{array}{l}\text { Типичная локализация болей при } \\
\text { аноректальной патологии: }\end{array}$ & Пояснично-крестцовая область. \\
\hline $\begin{array}{l}\text { Типичная локализация болей при } \\
\text { нефролитиазе: }\end{array}$ & Поясничная область, мошонка. \\
\hline $\begin{array}{l}\text { Типичная локализация болей при } \\
\text { заболеваниях тонкой кишки: }\end{array}$ & Околопупочные боли. \\
\hline $\begin{array}{l}\text { Типичная локализация болей при } \\
\text { острой гинекологической патологии: }\end{array}$ & $\begin{array}{l}\text { Нижний средний квадрант и } \\
\text { поясничная область. }\end{array}$ \\
\hline $\begin{array}{l}\text { О какой патологии следует задуматься } \\
\text { при сложности определения причины } \\
\text { сильных болей в животе? }\end{array}$ & Мезентериальная ишемия. \\
\hline
\end{tabular}




\section{Вопросы Ответы}

О какой патологии следует задуматься Разрыв аневризмы брюшной аорты. при наличии гипотонии и пульсирующего образования в животе?

О какой патологии следует задуматься Разрыв аневризмы, аорты, тромбоз в первую очередь у пациентов с мезентериальных сосудов, панкреатит, сильными абдоминальными болями? перфорация полых органов.

О каком заболевании следует задуматься в первую очередь при абдоминальном болевом синдроме, сопровождающимся шоком?

Что такое симптом доскообразного живота»?

Для какой хирургической патологии характерен симптом доскообразного живота?

\section{Внутрибрюшное} перфорация полых органов, острый панкреатит, мезентериальный тромбоз, перитонит, инфаркт миокарда.

Втянутый, ладьевидный живот, резкое ограничение дыхательной экскурсии, доскообразное напряжение передней брюшной стенки.

Перфорация полых органов.

\section{Для какой нехирургической патологии \\ Семейная средиземноморская характерен симптом доскообразного лихорадка (периодическая болезнь). живота? \\ Что такое абдоминальный Патологическое повышение компартмент-синдром? внутрибрюшного сопровождающееся гипоперфузионным давления, компрессией органов.}

Какие признаки характерны для Резкое вздутие и напряжение живота, абдоминального компартментодышка, олигурия. 


\begin{tabular}{|c|c|}
\hline Вопросы & Ответы \\
\hline $\begin{array}{l}\text { Основные нозологические причины } \\
\text { абдоминального компартмент- } \\
\text { синдрома: }\end{array}$ & $\begin{array}{lrr}\text { Острые } & \text { деструктивные } & \text { заболевания } \\
\text { органов } & \text { брюшной } & \text { полости, } \\
\text { сопровождающиеся } & \text { перитонитом } \\
\text { и кишечной непроходимостью. }\end{array}$ \\
\hline $\begin{array}{l}\text { О чём свидетельствует наличие } \\
\text { локальной боли и перитонизма? }\end{array}$ & $\begin{array}{l}\text { Воспалительные } \\
\text { отдельных органов. }\end{array}$ \\
\hline $\begin{array}{l}\text { О чём свидетельствует наличие боли, } \\
\text { пальпаторно определяемого } \\
\text { образования и сепсиса? }\end{array}$ & Абсцесс. \\
\hline $\begin{array}{l}\text { O чём свидетельствует наличие боли } \\
\text { в левом нижнем квадранте живота, } \\
\text { высокой температуры, нарушения } \\
\text { функции кишечника? }\end{array}$ & Дивертикулит. \\
\hline $\begin{array}{l}\text { Признак внутрибрюшного } \\
\text { кровотечения: }\end{array}$ & Кровь в брюшной полости. \\
\hline $\begin{array}{l}\text { Симптомы, подтверждающие } \\
\text { перфорацию полого органа: }\end{array}$ & $\begin{array}{l}\text { Свободный газ в брюшной полости, } \\
\text { экстравазация контрастного вещества } \\
\text { за по подего } \\
\text { органа, наличие жидкости } \\
\text { брюшной полости. }\end{array}$ \\
\hline $\begin{array}{l}\text { Какой метод диагностики } \\
\text { подтверждает ишемический некроз? }\end{array}$ & $\begin{array}{l}\text { Наличие сосудистого блока при } \\
\text { ангиографии. }\end{array}$ \\
\hline $\begin{array}{l}\text { Какой метод является более } \\
\text { информативным для диагностики } \\
\text { деструктивных процессов в брюшной } \\
\text { полости? }\end{array}$ & $\mathrm{KT}$. \\
\hline $\begin{array}{l}\text { Какой признак указывает на } \\
\text { непроходимость? }\end{array}$ & $\begin{array}{l}\text { Проксимальная дилатация и задержка } \\
\text { контрастного вещества. }\end{array}$ \\
\hline
\end{tabular}




\begin{tabular}{ll}
\multicolumn{1}{|c}{ Вопросы } & \multicolumn{1}{c}{ Ответы } \\
\hline $\begin{array}{l}\text { Основным методом диагностики } \\
\text { калькулёзного холецистита: }\end{array}$ & УЗИ. \\
\hline $\begin{array}{l}\text { Наиболее точный метод диагностики } \\
\text { разрыва абдоминального отдела } \\
\text { аорты: }\end{array}$ & Лапаротомия. \\
\hline $\begin{array}{l}\text { Какое исследование проводится для } \\
\text { подтверждения диагноза аневризмы } \\
\text { брюшной аорты? }\end{array}$ & УЗИ или КТ. \\
\hline $\begin{array}{l}\text { Первичный инструментальный метод } \\
\text { диагностики абсцесса брюшной } \\
\text { полости: }\end{array}$ & Абдоминальная КТ. \\
\hline $\begin{array}{l}\text { Первичный инструментальный метод } \\
\text { диагностики дивертикулита: }\end{array}$ & Абдоминальная КТ. \\
\hline
\end{tabular}

\section{СПИСОК ЛИТЕРАТУРЫ}

- Ağayev B.A. Cərrahi xəstəliklər. Bakı 2010.

- Blackbourne LH. Surgical Recall. 4 edition, 2006, LWW, Philadelphia

- Doherty GM. Current Diagnosis and Treatment: Surgery, $13^{\text {th }}$ edition, 2010, Lang International Edition.

- Omiraslanov Ә.T., Qazıyev A.Y. Onkologiya. Bakı, 2010.

- İsayev H.B. Cərrahi xəstəliklərin patofizologiyası. Bakı 2005

- Klingensmith ME, Aziz A, Bharat A, Fox AC, Porembka MR. The Washington Manual of Surgery, $6^{\text {th }}$ edition, 2012, LWW, Philadelphia.

- McNally PR. GI/Liver Secrets Plus. 4 edition. Mosby, Elsevier, 2010

- Medscape, http://www.medscape.com

- Oxford Handbook of Clinical Surgery, 3d edition, 2011, Oxford Press

- Sayek I. Sayek Temel Cerrahi 1-2. 4-cü baskı, 2016, Güneş Tıp Kitabevleri.

- Topçubaşov M.A. Xüsusi cərrahlıq. Bakı, 1979

- UpToDate, http://www.uptodate.com

- Гостищев В.К. Общая хирургия. GEOTAR-Media, 2019 


\title{
ХИРУРГИЧЕСКИЕ БОЛЕЗНИ
}

Н.Ю. Байрамов

\section{Желудочно-кишечное кровотечение}

Н.Ю. Байрамов, Н. М. Хыдырова, А.К. Сафиева, Ф.А. Гахраманова

\author{
Перевод: Н.Ю. Байрамов, С.А. Алиев, М.Р.Гусейнова
}




\section{ЖЕЛУДОЧНО-КИШЕЧНОЕ КРОВОТЕЧЕНИЕ}

- Желудочно-кишечное кровотечение является одним из грозных осложнений различных заболеваний органов пищеварительной системы.

- В структуре нозологических причин кровотечений из верхних отделов желудочно-кишечного тракта лидирующее положение занимают язвенная болезнь, варикозное расширение, эрозивный гастрит, синдром Мэллори-Вейса.

- Причинами профузных кровотечений из нижних отделов гастроинтестинального тракта являются дивертикулёз толстой кишки, телеангиоэктазии, геморрой.

- Кровотечение из верхних отделов желудочно-кишечного тракта:

○ Заболевания пищевода:

- Варикозное расширение вен;

- Опухоли;

- Язвенный эзофагит;

- Ожоги, травмы.

○ Заболевания желудка и 12-перстной кишки:

- Язвенная болезнь;

- Стрессовые язвы;

- Синдром Мэллори-Вейса;

- Синдром портальной гипертензии;

- Опухоли;

- Дивертикулы;

- Геморрагический гастрит;

- Травмы;

- Аорта-дуоденальные свищи.

- Заболевания гепатобилиарной системы:

- Опухоли;

- Травмы.

- Кровотечение из нижних отделов желудочно-кишечного тракта:

○ Заболевания тонкой, толстой и прямой кишки:

- Дивертикул Меккеля;

- Дивертикулёз;

- Полипы;

- Рак; 
- Язвенный колит;

- Геморрой, анальная трещина;

- Дизентерия.

- Другие причины желудочно-кишечных кровотечений:

○ Системные заболевания;

○ Заболевания кроветворной системы;

○ Сосудистые заболевания.

- Клинические проявления желудочно-кишечных кровотечений характеризуются кровавой рвотой, меленой, кровавой диареей и общими симптомами кровопотери (гиповолемия, шок, постгеморрагическая анемия). Незначительное кровотечение сопровождается хронической анемией. При этом тест на скрытое кровотечение - положительный (анализ кала выявляет наличие следов крови).

- Диагностика желудочно-кишечных кровотечений основана на клинических, лабораторных, эндоскопических исследованиях, при которых определяются характер кровотечений, степень тяжести, локализация и причина.

- При желудочно-кишечных кровотечениях первым делом проводится госпитализация пациента, стабилизация его состояния, эндоскопическое обследование, медикаментозно-эндоскопический гемостаз. В последующем проводятся мероприятия, направленные на устранение причины. Хирургическое лечение проводится при неэффективности медикаментозного и эндоскопического гемостаза, а также с целью устранения хирургических причин кровотечений.

\section{Вопросы и ответы по кровотечениям из верхних отделов желудочно- кишечного тракта}

\begin{tabular}{|llrr}
\multicolumn{1}{c}{ Вопросы } & \multicolumn{3}{c}{ Ответы } \\
\hline Что представляет собой желудочно- & Это кровотечение & из & участков \\
кишечное кровотечение из верхних & желудочно-кишечного & тракта, \\
отделов желудочно-кишечного & расположенных проксимальнее связки \\
тракта? & Трейца (из пищевода, желудка, 12- \\
& перстной кишки).
\end{tabular}




\begin{tabular}{|c|c|}
\hline Вопросы & Ответы \\
\hline $\begin{array}{l}\text { Какие заболевания являются } \\
\text { нозологическими причинами } \\
\text { желудочно-кишечных кровотечений? }\end{array}$ & 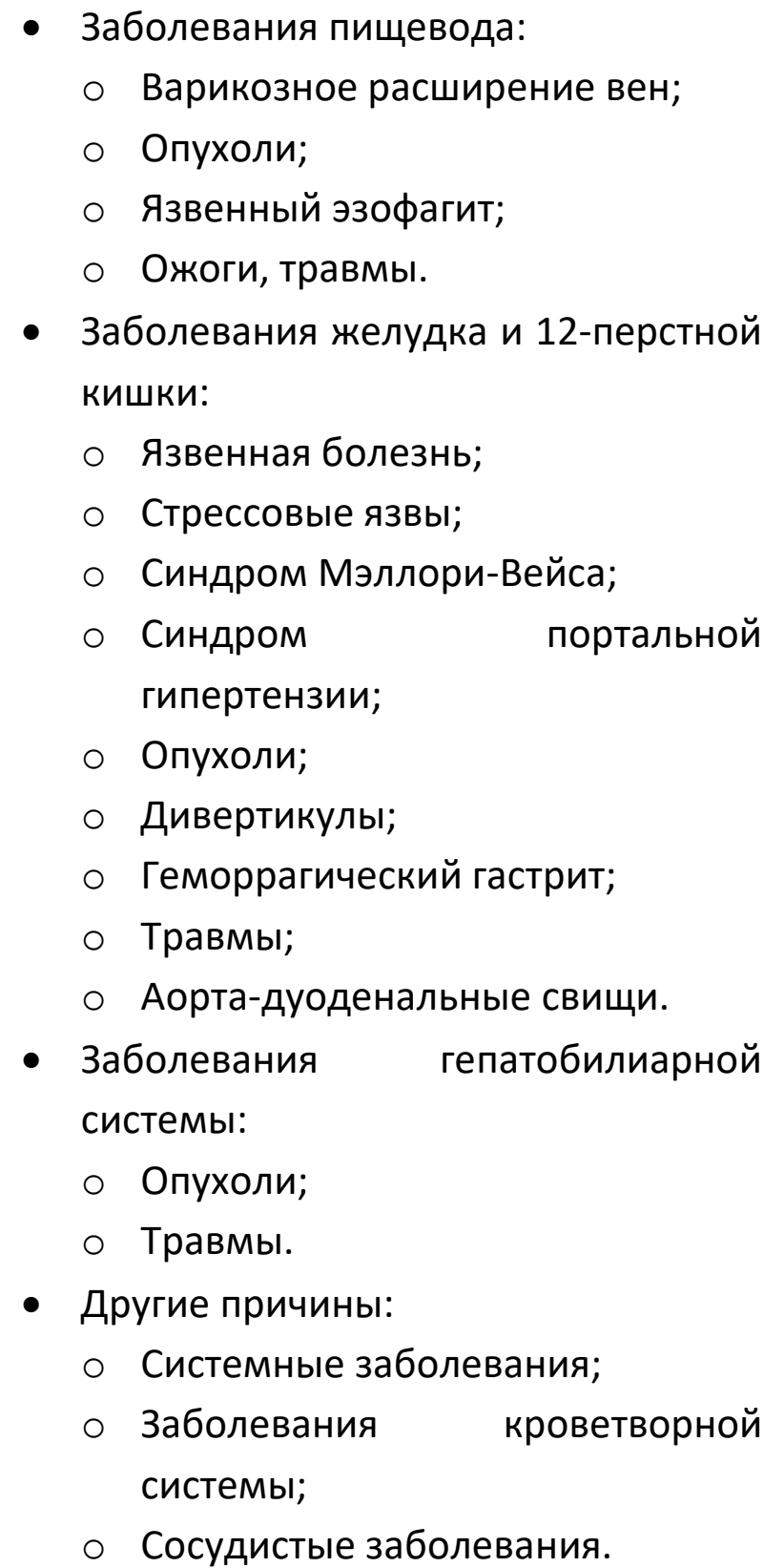 \\
\hline $\begin{array}{l}\text { Наиболее частые нозологические } \\
\text { причины желудочно-кишечных } \\
\text { кровотечений: }\end{array}$ & $\begin{array}{l}\text { - Язвенная болезнь желудка и 12- } \\
\text { - перстной кишки (45\%); } \\
\text { Варикозное расширение вен } \\
\text { пищевода }(20 \%) ; \\
\text { - Геморрагический гастрит }(20 \%) ; \\
\text { - Синдром Мэллори-Вейса (10\%). }\end{array}$ \\
\hline
\end{tabular}




\begin{tabular}{|c|c|}
\hline Вопросы & Ответы \\
\hline Клинические признаки: & $\begin{array}{l}\text { Местные симптомы: } \\
\text { - Кровавая рвота; } \\
\text { • Мелена; } \\
\text { - Гематохезия. } \\
\text { общие симптомы: } \\
\text { - Анемия; } \\
\text { - Геморрагический } \\
\text { (гипоперфузия) } \\
\text { гипотония, ортостатический коллапс, } \\
\text { бледность кахикардия, } \\
\text { олигурия. }\end{array}$ \\
\hline $\begin{array}{l}\text { Может ли наблюдаться гематохезия } \\
\text { (кровянистые выделения)? }\end{array}$ & 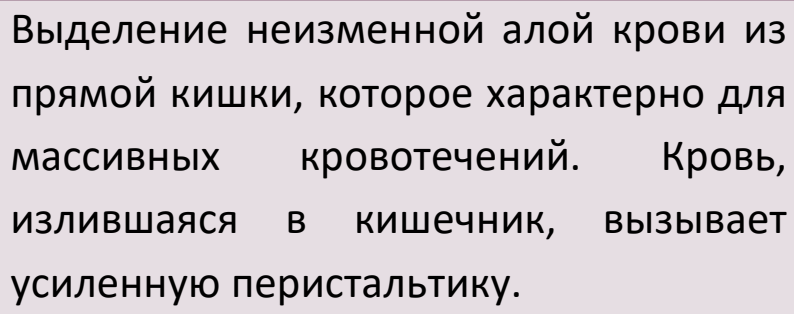 \\
\hline $\begin{array}{l}\text { Какое количество крови должно } \\
\text { изливаться в кишечник для } \\
\text { наблюдения мелены? }\end{array}$ & Более 50 мл. \\
\hline $\begin{array}{l}\text { Какие лабораторные анализы } \\
\text { необходимы? }\end{array}$ & $\begin{array}{l}\text { Общий анализ крови (гемограмма), } \\
\text { группа крови, резус фактор, } \\
\text { коагулограмма, амилаза. }\end{array}$ \\
\hline $\begin{array}{l}\text { Чем объясняется повышение } \\
\text { концентрации остаточного азота? }\end{array}$ & $\begin{array}{l}\text { В связи с всасыванием крови из } \\
\text { желудочно-кишечного тракта. }\end{array}$ \\
\hline $\begin{array}{l}\text { Какой метод следует проводить при } \\
\text { невозможности эндоскопического } \\
\text { исследования? }\end{array}$ & Ангиография. \\
\hline \multirow[t]{2}{*}{ Принципы лечебной тактики: } & Лечебные мероприятия \\
\hline & быть направлены на \\
\hline
\end{tabular}




\begin{tabular}{|c|c|}
\hline Вопросы & Ответы \\
\hline & $\begin{array}{l}\text { проведение гемостатической и } \\
\text { заместительной терапии. В дальнейшем } \\
\text { проводится этиотропная терапия. }\end{array}$ \\
\hline Первичные меры при кровотечении: & $\begin{array}{l}\text { - Госпитализация для стационарного } \\
\text { лечения; } \\
\text { - Стабилизация (инфузия и др.); } \\
\text { - Катетеризация мочевого пузыря, } \\
\text { зондирование и промывание } \\
\text { желудка; } \\
\text { - Эндоскопическое исследование; } \\
\text { - Проведение } \\
\text { эндоскопического гемостаза. }\end{array}$ \\
\hline $\begin{array}{l}\text { Возможности и методы } \\
\text { эндоскопического гемостаза: }\end{array}$ & $\begin{array}{l}\text { Коагуляция, лигирование, } \\
\text { клипирование сосудов, склеротерапия, } \\
\text { обкалывание периульцерозной зоны } \\
\text { раствором норадреналина. }\end{array}$ \\
\hline $\begin{array}{l}\text { Показания к хирургическому } \\
\text { лечению: }\end{array}$ & 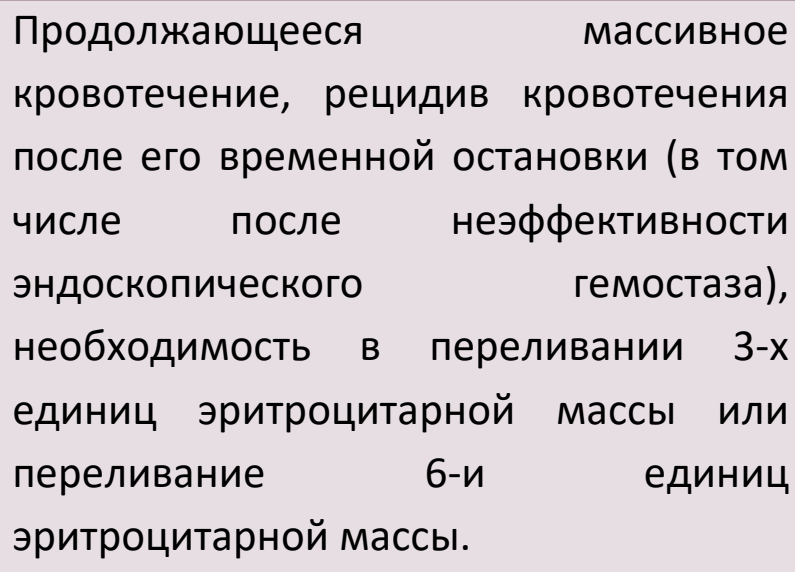 \\
\hline $\begin{array}{l}\text { У какого количества пациентов } \\
\text { возникает необходимость в } \\
\text { хирургическом лечении? }\end{array}$ & У 10-15\% пациентов. \\
\hline $\begin{array}{l}\text { У какого количества пациентов } \\
\text { происходит спонтанная остановка } \\
\text { кровотечения? }\end{array}$ & У 80-85\% пациентов. \\
\hline
\end{tabular}




\begin{tabular}{|c|c|}
\hline Вопросы & Ответы \\
\hline Частота летальности: & $\begin{array}{l}\text { Летальность составляет примерно } 10 \% \text {. } \\
\text { У пациентов пожилого и старческого } \\
\text { возраста (60-80 лет) достигает 15\%. У } \\
\text { пациентов старше } 80 \text { лет составляет } \\
25 \% \text {. Наиболее высокая летальность } \\
\text { наблюдается при продолжающемся } \\
\text { кровотечении (30\%). }\end{array}$ \\
\hline $\begin{array}{l}\text { Что является предиктором (фактором } \\
\text { риска) летальности? }\end{array}$ & $\begin{array}{l}\text { - Возраст старше } 60 \text { лет; } \\
\text { - Шок; } \\
\text { - Трансфузия более } 5 \text { единиц } \\
\text { эритроцитарной массы. }\end{array}$ \\
\hline
\end{tabular}

\section{Вопросы и ответы по синдрому Мэллори-Вейса}

\begin{tabular}{|c|c|}
\hline Вопросы & Ответы \\
\hline Что такое синдром Мэллори-Вейса? & $\begin{array}{l}\text { разрыв слизистой } \\
\text { кардиоэзофагеального }\end{array}$ \\
\hline $\begin{array}{l}\text { Частота встречаемости синдрома } \\
\text { Мэллори-Вейса в общей структуре } \\
\text { причин кровотечений из верхних } \\
\text { отделов желудочно-кишечного } \\
\text { тракта: }\end{array}$ & $10 \%$. \\
\hline Причина синдрома Мэллори-Вейса: & $\begin{array}{lr}\text { Внезапное } & \text { повышение } \\
\text { внутрижелудочного } & \text { давления } \\
\text { вследствие упорной рвоты. } & \end{array}$ \\
\hline Клинические признаки: & $\begin{array}{l}\text { Боли в эпигастральной области, } \\
\text { загрудинной зоне, кровавая рвота. }\end{array}$ \\
\hline $\begin{array}{l}\text { Частота гематомезиса при синдроме } \\
\text { Мэллори-Вейса: }\end{array}$ & $85 \%$. \\
\hline
\end{tabular}




\begin{tabular}{|c|c|}
\hline Вопросы & Ответы \\
\hline Диагностика: & Эндоскопическое исследование. \\
\hline $\begin{array}{l}\text { Классические анамнестические } \\
\text { сведения: }\end{array}$ & $\begin{array}{l}\text { Синдром часто встречается у лиц, } \\
\text { злоупотребляющих алкоголем. Приём } \\
\text { обильной пищи сопровождается } \\
\text { многократной тошнотой, вслед за } \\
\text { которой возникает кровавая рвота. }\end{array}$ \\
\hline Лечение: & 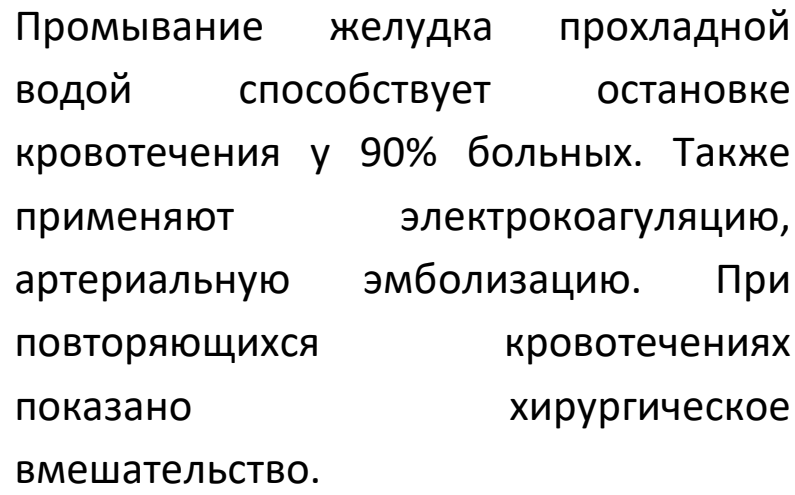 \\
\hline Показание к операции: & $\begin{array}{l}\text { Неэффективность консервативной } \\
\text { терапии и эндоскопических методов } \\
\text { гемостаза. }\end{array}$ \\
\hline $\begin{array}{l}\text { Можно ли применять баллонную } \\
\text { тампонаду с использованием зонда- } \\
\text { обтуратора Блекмора-Сенгестакена } \\
\text { при синдроме Мэллори-Вейса? }\end{array}$ & $\begin{array}{l}\text { Нельзя. Потому что баллонная } \\
\text { тампонада, ещё больше растягивая } \\
\text { стенки желудка, может способствовать } \\
\text { усилению кровотечения. Данный зонд } \\
\text { используется лишь при кровотечениях } \\
\text { из варикозных вен пищевода. }\end{array}$ \\
\hline
\end{tabular}

\section{Кровотечение из нижних отделов желудочно-кишечного тракта}

Вопросы

Что представляют собой кровотечения из нижних отделов желудочно-кишечного тракта?

\section{Ответы}

Это кровотечения, которые возникают из участков желудочно-кишечного тракта, расположенных дистальнее связки Трейца (тонкая, толстая и прямая кишка). Наиболее 


\begin{tabular}{|c|c|}
\hline & $\begin{array}{l}\text { часто наблюдается кровотечение из } \\
\text { толстого кишечника. }\end{array}$ \\
\hline $\begin{array}{l}\text { Участвуют ли лекарственные препараты в } \\
\text { возникновении кровотечений из нижних } \\
\text { отделов желудочно-кишечного тракта? }\end{array}$ & $\begin{array}{l}\text { Некоторые лекарственные препараты } \\
\text { (кумадин, аспирин, плавикс) могут вызвать } \\
\text { кровотечение. }\end{array}$ \\
\hline Нозологические причины кровотечений: & $\begin{array}{l}\text { - Дивертикул Меккеля (с эктопией } \\
\text { - } \text { Длизистой желудка); } \\
\text { Дивертикулёз (как правило, } \\
\text { серьёзных кровотечений); } \\
\text { - Васкулярные эктазии; } \\
\text { - Инвагинация, перекрут; } \\
\text { - Полипы; } \\
\text { - Рак; } \\
\text { - Воспалительные } \\
\text { кишечника (язвенный колит, болезнь } \\
\text { Крона); } \\
\text { - Инфекционный колит; } \\
\text { - Ректальная язва; } \\
\text { - Аорто-энтерические свищи; } \\
\text { - Ущемлённая грыжа; } \\
\text { - Химиотерапия; } \\
\text { - Геморрой, анальная трещина. }\end{array}$ \\
\hline $\begin{array}{l}\text { Наиболее частые причины кровотечений } \\
\text { из нижних отделов желудочно- } \\
\text { кишечного тракта: }\end{array}$ & $\begin{array}{l}\text { - Дивертикулёз; } \\
\text { - Васкулярная эктазия. }\end{array}$ \\
\hline Клинические признаки: & $\begin{array}{l}\text { Местные симптомы: } \\
\text { - Гематохезия; } \\
\text { - Мелена. } \\
\text { общие симптомы: } \\
\text { - Шок; } \\
\text { - Анемия. }\end{array}$ \\
\hline
\end{tabular}




\begin{tabular}{|c|c|}
\hline $\begin{array}{l}\text { Необходимые лабораторные } \\
\text { исследования: }\end{array}$ & $\begin{array}{l}\text { Общий и биохимический анализ крови, } \\
\text { коагулограмма, группа крови. }\end{array}$ \\
\hline $\begin{array}{l}\text { Какие методы исследования } \\
\text { необходимы для уточнения диагноза? }\end{array}$ & $\begin{array}{l}\text { Данные анамнеза, лабораторные, } \\
\text { объективные (физикальные) и инструмен- } \\
\text { тальные } \\
\text { исследования. }\end{array}$ \\
\hline $\begin{array}{l}\text { Что должно быть исключено при } \\
\text { кровотечениях из нижних отделов } \\
\text { желудочно-кишечного тракта? }\end{array}$ & $\begin{array}{l}\text { Кровотечения из верхних отделов } \\
\text { желудочно-кишечного тракта. }\end{array}$ \\
\hline $\begin{array}{l}\text { При какой локализации источника } \\
\text { кровотечения содержимое, поступающее } \\
\text { из назогастрального зонда, бывает } \\
\text { чистым? }\end{array}$ & $\begin{array}{l}\text { При умеренном кровотечении из язвы 12- } \\
\text { перстной кишки, кровь в основном } \\
\text { поступает в дистальные отделы, в связи с } \\
\text { чем желудочное содержимое может быть } \\
\text { чистым. }\end{array}$ \\
\hline $\begin{array}{l}\text { Диагностический алгоритм при } \\
\text { кровотечениях из дистальных отделов } \\
\text { желудочно-кишечного тракта: }\end{array}$ & $\begin{array}{l}\text { - Есть ли кровотечение? - Клиническое } \\
\text { обследование и анализ кала на скрытую } \\
\text { кровь. } \\
\text { - Степень тяжести - гемодинамика и Нb. } \\
\text { - Локализация и причина } \\
\text { колоноскопия. } \\
\text { - Продолжительность - клинические, } \\
\text { лабораторные, гемодинамические и } \\
\text { эндоскопические данные. }\end{array}$ \\
\hline $\begin{array}{l}\text { Какие диагностические методы } \\
\text { необходимы для оценки степени тяжести } \\
\text { кровотечений? }\end{array}$ & $\begin{array}{l}\text { Клинические признаки (гемодинамические } \\
\text { и перфузионные показатели), } \\
\text { лабораторные данные и колоноскопия. }\end{array}$ \\
\hline $\begin{array}{l}\text { При наличии клинической картины } \\
\text { активного кровотечения и } \\
\text { невозможности топической диагностики, } \\
\text { какой метод является альтернативным? }\end{array}$ & Ангиография. \\
\hline $\begin{array}{l}\text { При умеренном и рецидивирующим } \\
\text { кровотечении какой метод является }\end{array}$ & $\begin{array}{l}\text { - При незначительном (со скоростью 0,1 } \\
\text { мл/мин) кровотечении радионуклидная } \\
\text { диагностика } \\
\text { (исследование }\end{array}$ \\
\hline
\end{tabular}




\begin{tabular}{|c|c|}
\hline $\begin{array}{l}\text { более информативным - ангиография } \\
\text { или радионуклидное исследование? }\end{array}$ & $\begin{array}{l}\text { эритроцитами, меченными } \\
\text { радиоизотопом) является более точной. } \\
\text { - Ангиография информативна при более } \\
\text { выраженном (со скоростью } 0,5-1 \\
\text { мл/мин) кровотечении. }\end{array}$ \\
\hline Первичные мероприятия: & $\begin{array}{l}\text { - } \quad \text { Срочная госпитализация; } \\
\text { - } \quad \text { Стабилизация (кислород, инфузия); } \\
\text { - } \quad \text { Трансфузия эритроцитарной массы (по } \\
\text { - } \text { Кеобходимости); } \\
\text { - Отетеризация мочевого пузыря; } \\
\text { - Установление назогастрального зонда. }\end{array}$ \\
\hline $\begin{array}{l}\text { Какой метод эндоскопического гемостаза } \\
\text { является более эффективным при } \\
\text { полипах и ангиодисплазиях, } \\
\text { осложнённых кровотечением? }\end{array}$ & $\begin{array}{l}\text { Лазерная или электрокоагуляция, } \\
\text { локальная инъекция адреналина. }\end{array}$ \\
\hline $\begin{array}{l}\text { Лечебная тактика при массивном и } \\
\text { рецидивном толстокишечном } \\
\text { кровотечении: }\end{array}$ & Сегментарная резекция толстой кишки. \\
\hline $\begin{array}{l}\text { Тактика при неясном источнике кровоте- } \\
\text { чения: }\end{array}$ & $\begin{array}{l}\text { Энтероскопия, ангиография, } \\
\text { радиоизотопное исследование. }\end{array}$ \\
\hline $\begin{array}{l}\text { Тактика при невозможности уточнения } \\
\text { источника кровотечения энтероскопией, } \\
\text { ангиографией, радиоизотопным } \\
\text { исследованием: }\end{array}$ & $\begin{array}{l}\text { Лапаротомия и интраоперационная } \\
\text { эндоскопия. }\end{array}$ \\
\hline $\begin{array}{l}\text { Тактика при невозможности уточнения } \\
\text { источника кровотечения } \\
\text { интраоперационной эндоскопией: }\end{array}$ & $\begin{array}{l}\text { Формирование илеостомы с целью } \\
\text { уточнения характера кровотечения (тонко- } \\
\text { или толстокишечное). }\end{array}$ \\
\hline $\begin{array}{l}\text { Тактика при толстокишечном кровотече- } \\
\text { нии и невозможности верификации } \\
\text { источника колоноскопией или } \\
\text { ангиографией: }\end{array}$ & Тотальная колэктомия. \\
\hline
\end{tabular}




\section{Частота спонтанной остановки 80-90\%. \\ кровотечения: \\ Частота хирургических вмешательств при $10-15 \%$. \\ кровотечениях из нижних отделов \\ желудочно-кишечного тракта:}

\section{СПИСОК ЛИТЕРАТУРЫ}

- Acute upper gastrointestinal bleeding: management.2012 Jun (reaffirmed 2014). NGC:009131/ National Clinical Guideline Centre - National Government Agency [NonU.S.].

- Ağayev B.A. Cərrahi xəstəliklər. Bakı 2010.

- Blackbourne LH. Surgical Recall. 4 edition, 2006, LWW, Philadelphia

- Doherty GM. Current Diagnosis and Treatment: Surgery, $13^{\text {th }}$ edition, 2010, Lang International Edition.

- Omiraslanov D.T., Qazıyev A.Y. Onkologiya. Bakı, 2010.

- İsayev H.B. Cərrahi xəstəliklərin patofizologiyası. Bakı 2005

- Klingensmith ME, Aziz A, Bharat A, Fox AC, Porembka MR. The Washington Manual of Surgery, $6^{\text {th }}$ edition, 2012, LWW, Philadelphia.

- McNally PR. GI/Liver Secrets Plus. 4 edition. Mosby, Elsevier, 2010

- Medscape, http://www.medscape.com

- Y.Bayramov. Təcili Abdominal cərrahiyyədə müayinə və müalicə qaydaları. ISBN13 978-9952-8082-1-6, Qismət, Bakı 2009. $132 \mathrm{~s}$.

- Oxford Handbook of Clinical Surgery, 3d edition, 2011, Oxford Press

- Saltzman JR, Feldman M,Travis AC.Approach to acute upper gastrointestinal bleeding in adults. UpToDate, http://www.uptodate.com

- Sayek I. Sayek Temel Cerrahi 1-2. 4-cü baskı, 2016, Güneş Tıp Kitabevleri.

- Strate L, Saltzman JR, Travis AC. Approach to acute lower gastrointestinal bleeding in adults. UpToDate, http://www.uptodate.com

- Topçubaşov M.A. Xüsusi cərrahlıq. Bakı, 1979

- UpToDate, http://www.uptodate.com

- Гостищев B.К. Общая хирургия. GEOTAR-Media, 2019 


\section{ХИРУРГИЧЕСКИЕ БОЛЕЗНИ}

Н.Ю. Байрамов

\section{Хирургические заболевания лёгкого \\ Н.Ю. Байрамов, С.А. Алиев, Б.М. Зейналов, Ш.А. Мамедова}

Перевод: Н.Ю. Байрамов, С.А. Алиев, М.Р.Гусейнова 


\section{АБСЦЕСС ЛЕГКОГО}

- В структуре гнойно-деструктивных заболеваний легкого наиболее часто встречаются абсцесс, гангрена, бронхоэктатическая болезнь, синдром средней доли и кистозный фиброз.

- Абсцесс - гнойно-некротическая полость, ограниченная со всех сторон пиогенной капсулой, которая развивается как осложнение ряда заболеваний легкого.

- Аспирационные (бронхолегочный), постпневмонические и постишемические факторы способствуют развитию абсцесса лёгкого согласно классической схеме: некроз $\rightarrow$ воспаление $\rightarrow$ инфекция $\rightarrow$ ограничение.

- Заболевание обычно начинается на фоне одной из перечисленных нозологических причин (чаще пневмонии) и характеризуется кашлем, болью в грудной клетке, одышкой, высокой температурой (до 38-40), общей слабостью и явлениями синдрома системной воспалительной реакции (CCBP - SIRS). Возможен прорыв гнойника в бронхиальное дерево или плевральную полость, аспирация гноя в контралатеральное лёгкое, септический шок и летальный исход. При отсутствии летального исхода возможна хронизация процесса.

- K диагностическим критериям помимо признаков SIRS-сепсиса относятся соответствующие изменения, выявленные при КТ (наличие участка некроза с полостью деструкции, заполненной воздухом и гноем, выявление секвестров).

- Основными методами лечения считаются рациональная антибактериальная и заместительная терапия, по показаниям производят чрескожное дренирование и хирургическое лечение.

\section{Вопросы и ответы по абсцессу лёгкого}

\begin{tabular}{|ll}
\multicolumn{1}{c|}{ Вопросы } & \multicolumn{1}{c|}{ Ответы } \\
\hline Что такое абсцесс лёгкого? & $\begin{array}{l}\text { Ограниченный, очаговый гнойно- } \\
\text { некротический процесс. }\end{array}$ \\
\hline
\end{tabular}


Вопросы

Ответы

Клинические формы абсцесса лёгкого: Острый (длительностью до 6 недель) и хронический (длительностью более 6 недель).

\section{Что относится к причинам и факторам}

риска развития абсцесса лёгкого?

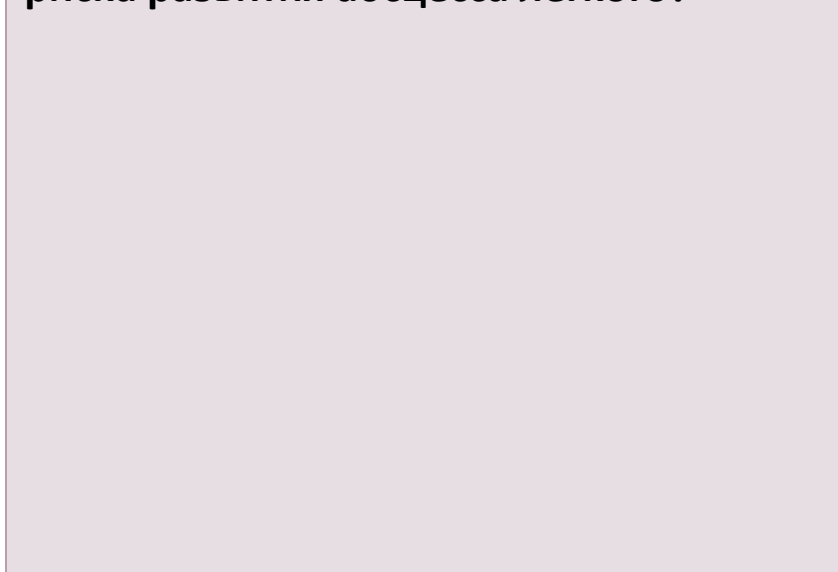

\section{Патогенез развития абсцесса лёгкого:}

\section{Особенности клинического течения} абсцесса лёгкого:

лёгкого:
- Аспирационные (бронхолегочные) причины: аспирация, опухоли бронхов, инородные тела, кровотечение;

- Постпневмонические причины: некротические пневмонии, хронические пневмонии;

- Постишемические некротические причины: инфаркт, ушиб легкого, рак легкого, септические эмболы.

Некроз $\rightarrow$ воспаление $\rightarrow$ инфекция $\rightarrow$ ограничение.

Характеризуется острым течением, при котором наблюдаются пневмония, прорыв полости абсцесса в бронхи и плевральную полость, хронизация процесса.

- SIRS, септический шок

- Органная дисфункция (недостаточность)

- Аспирационная пневмония, кровотечение

- Гнойный плеврит, пиопневмоторакс

- При хроническом абсцессе мальнутриция, кахексия, рецидивирующее течение, амилоидоз. 


\begin{tabular}{|c|c|}
\hline Вопросы & Ответы \\
\hline $\begin{array}{l}\text { Какие клинические признаки } \\
\text { характерны для стадии пневмонии } \\
\text { абсцесса лёгкого? }\end{array}$ & $\begin{array}{l}\text { - Остро начавшийся кашель } \\
\text { - } \text { Боль в грудной клетке } \\
\text { - Одышка } \\
\text { - бщая слабость } \\
\text { - } \text { Признаки SIRS - сепсиса. }\end{array}$ \\
\hline $\begin{array}{l}\text { Признаки прорыва абсцесса лёгкого в } \\
\text { бронх: }\end{array}$ & $\begin{array}{l}\text { • В начале наблюдается кашель с } \\
\text { мокротой с примесью крови, в } \\
\text { дальнейшем - отхождение } \\
\text { обильной гнойной зловонной } \\
\text { мокроты; } \\
\text { - } \quad \text { Снижение температуры; } \\
\text { • При аспирации гноя в бронхи } \\
\text { контралатерального легкого } \\
\text { развивается аспирационная } \\
\text { пневмония и ухудшение общего } \\
\text { состояния. }\end{array}$ \\
\hline $\begin{array}{l}\text { Чем характерен прорыв абсцесса в } \\
\text { плевральную полость? }\end{array}$ & $\begin{array}{l}\text { - Усиление болевого синдрома и } \\
\text { одышка; } \\
\text { - Развитие SIRS - сепсиса; } \\
\text { - Отсутствие дыхательных шумов; } \\
\text { - } \text { Укорочение перкуторного звука над } \\
\text { пораженным участком легкого. }\end{array}$ \\
\hline $\begin{array}{l}\text { Признаки хронического абсцесса } \\
\text { лёгкого: }\end{array}$ & $\begin{array}{l}\text { - Выделение большого количества } \\
\text { гнойной зловонной мокроты; } \\
\text { • Истощение; } \\
\text { • Пальцы в виде барабанных } \\
\text { палочек; } \\
\text { - Интермиттирующая гипертермия, } \\
\text { снижение температуры после } \\
\text { отхождения гнойной мокроты. }\end{array}$ \\
\hline $\begin{array}{l}\text { При наличии каких заболеваний } \\
\text { можно заподозрить развитие абсцесса } \\
\text { лёгкого? }\end{array}$ & $\begin{array}{l}\text { - Пневмония; } \\
\text { - Гнойный плеврит; }\end{array}$ \\
\hline
\end{tabular}




\begin{tabular}{|c|c|}
\hline Вопросы & Ответы \\
\hline & $\begin{array}{l}\text { - Легочные заболевания, } \\
\text { сопровождающиеся гнойно- } \\
\text { резорбтивной лихорадкой. }\end{array}$ \\
\hline $\begin{array}{l}\text { Какие методы исследования } \\
\text { необходимы для уточнения диагноза? }\end{array}$ & $\begin{array}{l}\text { - КТ; } \\
\text { - Бронхоскопия; } \\
\text { - Бактериологическое исследование } \\
\text { мокроты. }\end{array}$ \\
\hline $\begin{array}{l}\text { Лабораторные признаки абсцесса } \\
\text { лёгкого: }\end{array}$ & $\begin{array}{l}\text { Лейкоцитоз со сдвигом лейкоформулы } \\
\text { влево за счет палочкоядерных } \\
\text { нейтрофилов. }\end{array}$ \\
\hline $\begin{array}{l}\text { Признаки инструментальной } \\
\text { визуализации? }\end{array}$ & $\begin{array}{l}\text { - Интенсивное затемнение в зоне } \\
\text { поражения (до опорожнения } \\
\text { абсцесса в бронх); } \\
\text { - Наличие полости с уровнем } \\
\text { жидкости (после опорожнения в } \\
\text { бронх). }\end{array}$ \\
\hline $\begin{array}{l}\text { Диагностические критерии абсцесса } \\
\text { легкого: }\end{array}$ & $\begin{array}{l}\text { - Наличие в легком воспалительного } \\
\text { процесса, сопровождающегося } \\
\text { клиническими признаками SIRS -- } \\
\text { сепсиса; } \\
\text { - Наличие на КТ участка затемнения } \\
\text { (воспалительного инфильтрата) или } \\
\text { гнойной полости с уровнем } \\
\text { жидкости. }\end{array}$ \\
\hline Методы лечения: & $\begin{array}{l}\text { - Антибиотикотерапия; } \\
\text { - } \text { Физиотерапия; } \\
\text { - Заместительная и } \\
\text { поддерживающая терапия при } \\
\text { наличии сепсиса; } \\
\text { - Устранение причины; } \\
\text { - Эвакуация гнойно-некротических } \\
\text { тканей (санация и дренирование). }\end{array}$ \\
\hline
\end{tabular}




\begin{tabular}{|c|c|}
\hline Вопросы & Ответы \\
\hline $\begin{array}{l}\text { Показания к дренированию абсцесса } \\
\text { легкого: }\end{array}$ & $\begin{array}{l}\text { Неэффективность антибиотикотерапии, } \\
\text { проводимой в течение 48-72 ч. }\end{array}$ \\
\hline Показания к хирургическому лечению: & $\begin{array}{l}\text { - Массивное кровотечение; } \\
\text { - Абсцедирование } \\
\text { резектабельной опухоли } \\
\text { лёгкого; } \\
\text { - Гнойный плеврит, } \\
\text { пиопневмоторакс; } \\
\text { - Абсцессы лёгкого, не } \\
\text { поддающиеся консервативному } \\
\text { и другим методам } \\
\text { (дренирование) лечения. }\end{array}$ \\
\hline $\begin{array}{l}\text { Методы хирургического лечения } \\
\text { абсцесса лёгкого: }\end{array}$ & Лобэктомия. \\
\hline Прогноз заболевания: & $\begin{array}{l}\text { Эффективность консервативного } \\
\text { лечения наблюдается в 70\% случаев. } \\
\text { Летальность наблюдается в 5-20\% } \\
\text { случаев, а у иммуносупрессивных } \\
\text { пациентов - в 28\% случаев. }\end{array}$ \\
\hline
\end{tabular}




\section{ГАНГРЕНА ЛЕГКОГО}

- Гангрена легкого наиболее тяжелая форма гнойно-некротического поражения и характеризуется обширной гнилостной деструкцией легочной паренхимы без четкой демаркационной линии.

- В настоящее время встречается редко.

- Гангрена обычно развивается на фоне тромбоза ветвей легочной артерии легкого.

- Проявляется тяжелым клиническим течением, манифестацией сепсиса, септического шока и полиорганной недостаточностью.

- $\mathrm{K}$ диагностическим критериям гангрены лёгкого относятся выделение большого количества зловонной мокроты, одышка, дыхательная недостаточность, SIRS, признаки сепсиса и деструкция легочной паренхимы, выявленная при КТ.

- В комплексе лечения применяются антибиотикотерапия, коррекция систем и хирургическое лечение (лобэктомия, дренирование плевральной полости).

\section{Вопросы и ответы по гангрене легкого}

\begin{tabular}{|c|c|}
\hline Вопросы & Ответы \\
\hline Что такое гангрена легкого? & $\begin{array}{l}\text { Гнойно-некротическое поражение, } \\
\text { характеризующееся обширной } \\
\text { гнилостной деструкцией легочной } \\
\text { паренхимы. }\end{array}$ \\
\hline $\begin{array}{l}\text { Частота встречаемости гангрены } \\
\text { лёгкого: }\end{array}$ & $\begin{array}{l}\text { Встречалась достаточно часто до } \\
\text { использования антибиотиков, а в } \\
\text { настоящее время - редко. }\end{array}$ \\
\hline $\begin{array}{l}\text { Причины и факты риска развития } \\
\text { гангрены легкого: }\end{array}$ & $\begin{array}{l}\text { - Тромбоз (эмболия) ветвей легочной } \\
\text { артерии, сопровождающийся } \\
\text { инфаркт-пневмонией; } \\
\text { • Другие гнойно-воспалительные } \\
\text { заболевания легких. }\end{array}$ \\
\hline
\end{tabular}




\begin{tabular}{|c|c|}
\hline Вопросы & Ответы \\
\hline Патогенез гангрены легкого: & $\begin{array}{l}\text { Обширный некроз легочной ткани без } \\
\text { четкой демаркационной линии } \rightarrow \\
\text { расширение зоны деструкции } \rightarrow \\
\text { гнилостный распад легочной ткани } \rightarrow \\
\text { секвестрация и формирование полости, } \\
\text { содержащей газ и жидкость. }\end{array}$ \\
\hline Особенности клинического течения: & $\begin{array}{l}\text { Отличается острым тяжелым } \\
\text { клиническим течением. }\end{array}$ \\
\hline Осложнения гангрены легкого: & $\begin{array}{l}\text { - } \text { Сепсис, септический шок; } \\
\text { - Органная дисфункция } \\
\text { (полиорганная недостаточность); } \\
\text { - Геморрагический плеврит; } \\
\text { - Легочное кровотечение; } \\
\text { - Дистрофия паренхиматозных } \\
\text { органов; } \\
\text { - Амилоидоз; } \\
\text { - Пиопневмоторакс. }\end{array}$ \\
\hline $\begin{array}{l}\text { Клинические проявления гангрены } \\
\text { легкого: }\end{array}$ & $\begin{array}{l}\text { - Кашель с обильным отхождением } \\
\text { гнойной (иногда кровянистой) } \\
\text { зловонной мокроты; } \\
\text { - } \text { Одышка, дыхательная } \\
\text { недостаточность; } \\
\text { - } \text { Анемия; } \\
\text { - } \quad \text { SIRS, сепсис. }\end{array}$ \\
\hline $\begin{array}{l}\text { Какие исследования необходимы для } \\
\text { уточнения диагноза? }\end{array}$ & $\begin{array}{l}\text { - Клинические признаки; } \\
\text { - Физикальные методы } \\
\text { исследования; } \\
\text { - Лабораторные маркеры; } \\
\text { - Рентгенография и КТ; } \\
\text { - Бронхоскопия с } \\
\text { бактериологическим } \\
\text { исследованием бронхиального } \\
\text { секрета. }\end{array}$ \\
\hline
\end{tabular}




\section{Вопросы}

Лабораторные признаки гангрены легкого:

Диагностические критерии гангрены легкого:
- Выделение большого количества зловонной, пенистой, трехслойной гнойной (иногда кровянистой) мокроты;

- Одышка, дыхательная недостаточность;

- SIRS, признаки сепсиса;

- Деструкция легочной паренхимы, выявленная при КТ.

Методы лечения гангрены легкого:

- Консервативный;

- Хирургический.

Что включает в себя консервативное лечение гангрены легкого?
- Антибиотикотерапия с использованием цефалоспоринов III поколения и карбапенем, антибактериальные препараты из антипротозойной группы, аминогликозиды;

- Бронхолитики, муколитики, поэтапная бронхоскопическая санация бронхиального дерева;

- Адекватная коррекция гиповолемии, анемии и гипопротеинемии;

- Бронхоскопическая санация, применение постурального дренажа;

- Нутриционная поддержка;

- Коррекция функций сердечнососудистой, дыхательной систем и печени. 
Вопросы

Что является показанием к

хирургическому лечению?

Варианты оперативных вмешательств:
Неэффективность комплексной консервативной терапии.

- Лобэктомия;

- Пульмонэктомия;

- При внутриплевральных осложнениях - торакоскопическая санация плевральной полости. 


\section{БРОНХОЭКТАЗИЯ}

- Необратимые цилиндрические или мешковидные расширения просвета сегментарных и субсегментарных бронхов называется бронхоэктазией. Возникновение инфекции В расширенных бронхах называется бронхоэктатической болезнью. Различают врожденные и приобретенные бронхоэктазы.

- Необратимое расширение просвета бронхов способствует застою и инфицированию бронхиального секрета. Возникновение инфекции приводит к развитию гнойного воспаления и деструкции стенки бронхов и перибронхиальной ткани с последующим развитием фиброза, обструкции или дилатации бронхов. Вследствие этого развивается порочный круг и процесс принимает хроническое течение, развиваются необратимые анатомические изменения (бронхоэктатическая болезнь), нарастающие при каждом обострении заболевания.

- Клинические проявления характеризуются симптомами рецидивирующегося бронхита или пневмонии. Больных беспокоят кашель с выделением обильной трехслойной гнойной или слизисто-гнойной мокроты, высокая температура.

- Для диагностики бронхоэктатической болезни необходима КТ легких, а для уточнения нозологической причины, важное значение имеет бронхоскопия.

- Хроническое течение с периодическими обострениями, утолщение стенок бронхов с очагами разрастания фиброзной ткани, локальные или диффузные расширения просвета бронхов и сохранение их дилатации после устранения причин, являются характерными диагностическими признаками бронхоэктатической болезни.

- Основным методом лечения бронхоэктатической болезни является подавление хронической инфекции, которое проводится по общим принципам лечения острых гнойных заболеваний легких. Консервативное лечение сочетают с бронхоскопической санацией. Хирургическое лечение проводят редко и лишь по показаниям. 


\section{Вопросы и ответы по бронхоэктатической болезни}

\begin{tabular}{|c|c|}
\hline Вопросы & Ответы \\
\hline Что такое бронхоэктазия? & $\begin{array}{l}\text { Патологическое расширение просвета } \\
\text { бронхов. }\end{array}$ \\
\hline $\begin{array}{l}\text { Что такое бронхоэктатическая } \\
\text { болезнь? }\end{array}$ & $\begin{array}{l}\text { Необратимые расширения просвета } \\
\text { бронхов, сопровождающиеся } \\
\text { инфицированием его содержимого. }\end{array}$ \\
\hline Клинические варианты бронхоэктазий: & $\begin{array}{l}\text { - Истинные бронхоэктазии - } \\
\text { просвет бронха не } \\
\text { восстанавливается после } \\
\text { устранения причин дилатации; } \\
\text { - Ложные бронхоэктазии - } \\
\text { восстановление просвета бронха } \\
\text { после устранения причин } \\
\text { дилатации. }\end{array}$ \\
\hline $\begin{array}{l}\text { Причины и факторы риска } \\
\text { возникновения бронхоэктазии: }\end{array}$ & 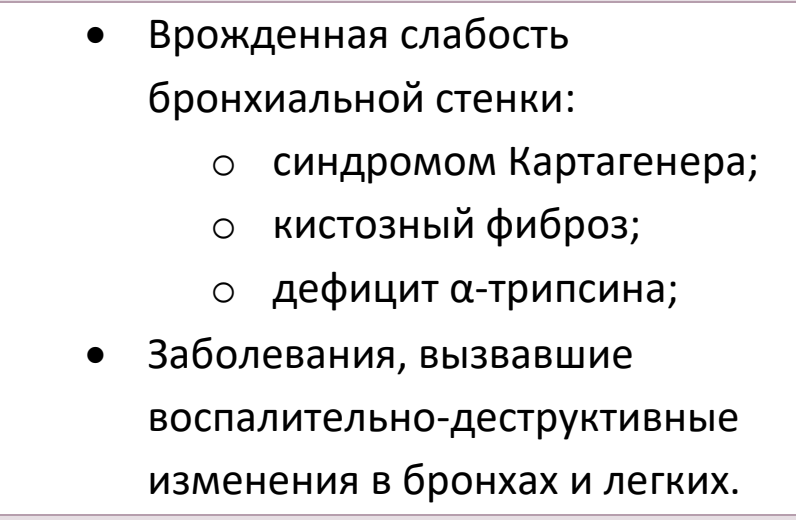 \\
\hline Патогенез развития бронхоэктазии: & $\begin{array}{ll}\text { - } & \text { Обструкция } \rightarrow \text { инфекция } \rightarrow \\
& \text { фиброз } \rightarrow \text { дилатация; } \\
\text { - } & \text { Инфекция } \rightarrow \text { фиброз } \rightarrow \\
& \text { дилатация. }\end{array}$ \\
\hline $\begin{array}{l}\text { Особенности клинического течения } \\
\text { бронхоэктазии: }\end{array}$ & $\begin{array}{l}\text { Характерно хроническое течение с } \\
\text { периодическими обострениями } \\
\text { инфекции. }\end{array}$ \\
\hline $\begin{array}{l}\text { Чем объясняется хроническое течение } \\
\text { заболевания? }\end{array}$ & Порочный круг дилатация-инфекция. \\
\hline
\end{tabular}




\begin{tabular}{|c|c|}
\hline Вопросы & Ответы \\
\hline $\begin{array}{l}\text { Какие осложнения характерны для } \\
\text { бронхоэктазии? }\end{array}$ & $\begin{array}{l}\text { - Фиброз легочной ткани; } \\
\text { - Легочная гипертензия; } \\
\text { - Амилоидоз. }\end{array}$ \\
\hline Клинические признаки бронхоэктазии: & $\begin{array}{l}\text { - Кашель с мокротой (до } 500 \text { мл в } \\
\text { с сутки), особенно по утрам; } \\
\text { Сухой кашель при } \\
\text { гранулематозных заболеваниях; } \\
\text { - Высокая температура; } \\
\text { - Кровохарканье (40-60\%); } \\
\text { - Одышка, цианоз. }\end{array}$ \\
\hline $\begin{array}{l}\text { При каких заболеваниях возможно } \\
\text { развитие бронхоэктазии? }\end{array}$ & $\begin{array}{l}\text { - Заболевания легких, } \\
\text { сопровождающехся постоянным } \\
\text { кашлем с обильным } \\
\text { отхождением мокроты; } \\
\text { - При наличии эпизодов } \\
\text { обострения бронхитов и } \\
\text { пневмонии. }\end{array}$ \\
\hline $\begin{array}{l}\text { Какие исследования необходимы для } \\
\text { уточнения диагноза? }\end{array}$ & $\begin{array}{l}\text { - Компьютерная томография; } \\
\text { - Бронхоскопия - для уточнения } \\
\text { причины; } \\
\text { - Бронхография по особым } \\
\text { показаниям. }\end{array}$ \\
\hline Лабораторные признаки: & Признаки воспалительного процесса. \\
\hline $\begin{array}{l}\text { Признаки инструментальной } \\
\text { визуализации? }\end{array}$ & $\begin{array}{l}\text { Наличие множественных расширений } \\
\text { бронхов при КТ. }\end{array}$ \\
\hline $\begin{array}{l}\text { Что выявляется при других методах } \\
\text { исследования? }\end{array}$ & $\begin{array}{l}\text { При объективном обследовании } \\
\text { выявляются хрипы, наличие } \\
\text { хронической инфекции и признаки } \\
\text { гипоксии. }\end{array}$ \\
\hline Диагностические критерии: & $\begin{array}{l}\text { - Признаки обострения инфекции; } \\
\text { - Локальные или диффузные } \\
\text { расширения бронхов на КТ; }\end{array}$ \\
\hline
\end{tabular}




\begin{tabular}{|c|c|}
\hline Вопросы & Ответы \\
\hline & $\begin{array}{l}\text { - Сохранение расширения } \\
\text { бронхов после устранения } \\
\text { причины. }\end{array}$ \\
\hline Методы лечения: & 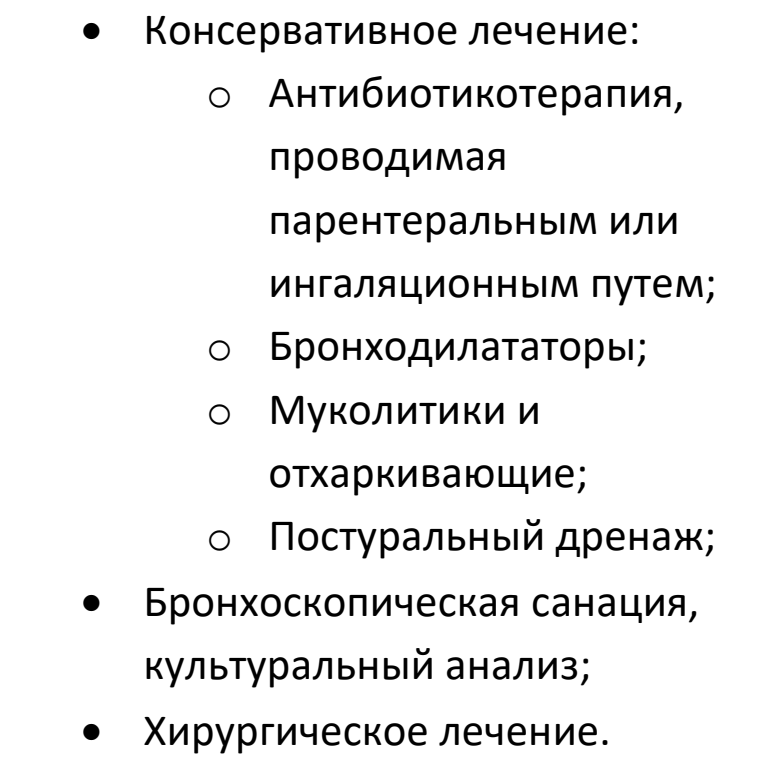 \\
\hline Показания к хирургическому лечению: & $\begin{array}{l}\text { Отсутствие эффекта от консервативной } \\
\text { терапии и бронхоскопической } \\
\text { санации. }\end{array}$ \\
\hline Методы хирургического лечения: & $\begin{array}{l}\text { - Резекция легкого (при } \\
\text { локальной форме поражения у } \\
\text { больных с хорошим } \\
\text { функциональным резервом } \\
\text { легкого); } \\
\text { - Трансплантация легкого - при } \\
\text { диффузной форме заболевания, } \\
\text { сопровождающейся легочной } \\
\text { гипертензией или другими } \\
\text { серьезными осложнениями. }\end{array}$ \\
\hline Прогноз заболевания: & $\begin{array}{l}\text { Консервативное лечение дает } \\
\text { положительный эффект в 80\% случаев. } \\
\text { Осложнения составляют 3-5\%, } \\
\text { летальность - 2\%. }\end{array}$ \\
\hline $\begin{array}{l}\text { Характерная особенность } \\
\text { заболевания: }\end{array}$ & $\begin{array}{l}\text { Не забудьте о бронхоэктазии при } \\
\text { наличии кашля с обильной мокротой. }\end{array}$ \\
\hline
\end{tabular}




\section{СИНДРОМ СРЕДНЕЙ ДОЛИ}

- Синдром средней доли развивается в результате обструкции среднедолевого бронха правого легкого $и$ характеризуется возникновением долевой пневмонии.

- Причины, вызвавшие обструкцию среднедолевого бронха (увеличенные перибронхиальные лимфатические узлы, бронхиальный фиброз, бронхиальные камни, бронхоэктазии, инородные тела и опухоли бронха и др.), способствуют застою в средней доле, ателектазу и развитию пневмонии.

- Заболевание обычно начинается с признаками пневмонии (высокая температура, кашель, потливость, общая слабость, лейкоцитоз и др.) и характеризуется периодическими обострениями.

- Неоценимую помощь в уточнении диагноза оказывают КТ и бронхоскопия.

- Консервативное лечение является основным методом и у большинства больных оказывается эффективным.

- Хирургическое лечение обычно проводится с целью устранения причин, вызвавших синдром средней доли.

\section{Вопросы и ответы по синдрому средней доли}

\begin{tabular}{|ll|}
\hline \multicolumn{1}{|c|}{ Вопросы } & \multicolumn{1}{c|}{ Ответы } \\
\hline Что такое синдром средней доли? & $\begin{array}{l}\text { Обструкция среднедолевого бронха } \\
\text { правого легкого, характеризущаяся } \\
\text { развитием долевой пневмонии с } \\
\text { частыми обострениями. }\end{array}$ \\
\hline $\begin{array}{ll}\text { Причины и факторы риска развития } \\
\text { синдрома средней доли: }\end{array}$ & Увеличенные перибронхиальные \\
& лимфатические узлы; \\
& - Бронхиальный фиброз; \\
& - Бронхиальные камни; \\
& - Инонхоэктазия; \\
\hline
\end{tabular}




\begin{tabular}{|c|c|}
\hline Bonpocbl & Ответы \\
\hline & - Опухоли бронха и др. \\
\hline Патогенез синдрома средней доли: & $\begin{array}{l}\text { Обструкция бронха } \rightarrow \text { застой } \rightarrow \\
\text { ателектаз } \rightarrow \text { пневмония. }\end{array}$ \\
\hline $\begin{array}{l}\text { Особенности клинического течения } \\
\text { синдрома средней доли: }\end{array}$ & $\begin{array}{l}\text { Характерной особенностью является } \\
\text { пневмония с частыми эпизодами } \\
\text { обострения. }\end{array}$ \\
\hline Какие осложнения характерны? & $\begin{array}{l}\text { Фиброзные разрастания средней доли и } \\
\text { бронха, абсцесс и бронхоэктазия. }\end{array}$ \\
\hline Характерные клинические признаки: & $\begin{array}{l}\text { Признаками часто повторяющейся } \\
\text { пневмонии - высокая температура, } \\
\text { кашель, потливость, общая слабость, } \\
\text { лейкоцитоз и др. }\end{array}$ \\
\hline $\begin{array}{l}\text { При каких заболеваниях можно } \\
\text { заподозрить развитие синдрома } \\
\text { средней доли? }\end{array}$ & $\begin{array}{l}\text { С часто повторяющейся пневмонией, } \\
\text { локализующейся в правой доле. }\end{array}$ \\
\hline $\begin{array}{l}\text { Какие инструментальные методы } \\
\text { исследования необходимы для } \\
\text { уточнения диагноза? }\end{array}$ & $\begin{array}{l}\text { - Рентгенография; } \\
\text { - КТ; } \\
\text { - Бронхоскопия. }\end{array}$ \\
\hline $\begin{array}{l}\text { Признаки инструментальной } \\
\text { визуализации: }\end{array}$ & $\begin{array}{l}\text { - При КТ - воспалительная } \\
\text { инфильтрация (пневмония) в } \\
\text { средней доле правого легкого. } \\
\text { - Бронхоскопия - обструкция } \\
\text { средне-долевого бронха. }\end{array}$ \\
\hline \multirow[t]{3}{*}{$\begin{array}{l}\text { Диагностические критерии синдрома } \\
\text { средней доли: }\end{array}$} & $\begin{array}{l}\text { - Часто повторяющаяся } \\
\text { пневмония; }\end{array}$ \\
\hline & - При КТ - \\
\hline & $\begin{array}{l}\text { пневмонического очага } \\
\text { средней доле; } \\
\text { - При бронхоскопии - обструкция } \\
\text { просвета средне-долевого } \\
\text { бронха. }\end{array}$ \\
\hline Методы лечения: & $\begin{array}{l}\text { - Консервативное лечение: } \\
\text { о Антибиотики; }\end{array}$ \\
\hline
\end{tabular}




\begin{tabular}{|c|c|}
\hline Вопросы & Ответы \\
\hline & $\begin{array}{c}\text { O Муколитики; } \\
\text { о Бронходилататоры; } \\
\text { ○ Ингаляция; } \\
\text { • Хирургическое лечение. }\end{array}$ \\
\hline Показания к хирургическому лечению: & $\begin{array}{l}\text { Бронхоэктазия, бронхиальный фиброз, } \\
\text { абсцесс, повторяющаяся пневмония, } \\
\text { опухоли бронха. }\end{array}$ \\
\hline Вид операции: & Лобэктомия. \\
\hline
\end{tabular}




\section{БРОНХОЛИТИАЗ}

- Бронхолитиазом называется наличие в просвете бронха свободных или фиксированных камней.

- Основными причинами образования камней в бронхах являются гистоплазмоз и туберкулёз.

- Заболевание обычно проявляется признаками повторяющейся пневмонии (высокая температура, кашель) и иногда сопровождается кровотечением и даже формированием бронхопищеводных свищей.

- В диагностике ведущую роль играет бронхоскопия, которая позволяет выявить наличие камней в просвете бронха.

- Для лечения бронхолитиаза применяют бронхоскопию (бронхоскопическое удаление камней) и хирургическое вмешательство.

\section{Вопросы и ответы по бронхолитиазу}

\begin{tabular}{|c|c|}
\hline Вопросы & Ответы \\
\hline Что такое бронхолитиаз? & $\begin{array}{l}\text { Наличие в просвете бронха свободных } \\
\text { или фиксированных камней. }\end{array}$ \\
\hline $\begin{array}{l}\text { Что относится к причинам и факторам } \\
\text { риска? }\end{array}$ & Гистоплазмоз, туберкулёз. \\
\hline Патогенез развития бронхолитиаза: & $\begin{array}{l}\text { - Увеличение и кальцификация } \\
\text { перибронхиальных } \\
\text { лимфатических узлов и } \\
\text { протрузия их в стенку бронха } \\
\text { (фиксированные камни); } \\
\text { - Концентрация (сгущение) } \\
\text { мокроты. }\end{array}$ \\
\hline Осложнения: & $\begin{array}{l}\text { - Пневмония; } \\
\text { - Кровотечение; } \\
\text { - Обструкция бронха; }\end{array}$ \\
\hline
\end{tabular}




\begin{tabular}{|c|c|}
\hline Вопросы & Ответы \\
\hline & $\begin{array}{l}\text { • Тракционный дивертикул } \\
\text { пищевода; } \\
\text { • Бронхопищеводный свищ. }\end{array}$ \\
\hline Клинические признаки: & $\begin{array}{l}\text { - Кашель; } \\
\text { - Мокрота с камнями; } \\
\text { - Кровохарканье; } \\
\text { - Признаки пневмонии - высокая } \\
\text { температура, озноб, боль. }\end{array}$ \\
\hline $\begin{array}{l}\text { У каких пациентов можно заподозрить } \\
\text { наличие бронхолитиаза? }\end{array}$ & $\begin{array}{l}\text { - Пациенты с клиническими } \\
\text { признаками; } \\
\text { • Пациенты с повторяющейся } \\
\text { пневмонией; } \\
\text { • Выявление кальцификаций и } \\
\text { ателектаза при } \\
\text { рентгенологическом и КТ- } \\
\text { исследованиях. }\end{array}$ \\
\hline $\begin{array}{l}\text { Какие инструментальные методы } \\
\text { необходимы для уточнения диагноза? }\end{array}$ & $\begin{array}{l}\text { - Бронхоскопия; } \\
\text { - КТ. }\end{array}$ \\
\hline Диагностические критерии: & $\begin{array}{l}\text { - Клиническая картина; } \\
\text { - Выявление долевого ателектаза } \\
\text { и пневмонии при КТ; } \\
\text { - Наличие камней в просвете } \\
\text { бронха при бронхоскопии. }\end{array}$ \\
\hline Методы лечения: & $\begin{array}{l}\text { - Бронхоскопическое удаление } \\
\text { камней (20\%); } \\
\text { - Хирургическое лечение. }\end{array}$ \\
\hline Показания к хирургическому лечению: & $\begin{array}{l}\text { - Наличие в просвете бронха } \\
\text { фиксированных камней; } \\
\text { - Наличие бронхообструктивных } \\
\text { осложнений; } \\
\text { - Формирование свища. }\end{array}$ \\
\hline Методы хирургического лечения: & $\begin{array}{l}\text { гментэктомия или лобэктомия, } \\
\text { дких случаях - бронхотомия. }\end{array}$ \\
\hline
\end{tabular}




\section{КИСТОЗНЫЙ ФИБРОЗ}

- Кистозный фиброз является генетическим заболеванием, развивающимся вследствие мутации CFTR гена, расположенного в 7-ой хромосоме.

- В результате данной мутации происходит уменьшение секреции эпителием воды, хлоридов и ионов натрия, что способствует сгущению секрета (мокрота, жёлчь, панкреатический секрет, желудочно-кишечный секрет), что в свою очередь ведет к закупорке просвета органа, застою с последующим инфицированием и развитием воспаления.

- Кистозный фиброз развивается с раннего детского возраста и проявляется признаками пневмонии и её осложнений. У ряда больных выявляются и другие заболевания (панкреатит, холецистит).

- Для уточнения диагноза требуется генетическое обследование.

- Основным методом лечения является консервативный. Хирургическое лечение применяется по показаниям (резекция, трансплантация).

\section{Вопросы и ответы по кистозному фиброзу}

\begin{tabular}{|c|c|}
\hline Вопросы & Ответы \\
\hline Что такое кистозный фиброз легкого? & $\begin{array}{l}\text { Генетическое заболевание, } \\
\text { характеризующееся формированием } \\
\text { кистозного образования, содержащего } \\
\text { густой секрет. }\end{array}$ \\
\hline Причины и факторы риска: & $\begin{array}{l}\text { Мутация гена CFTR (cystic fibrosis } \\
\text { transmembrane conductance regulator), } \\
\text { расположенного в 7-ой хромосоме. }\end{array}$ \\
\hline Патогенез: & $\begin{array}{l}\text { Снижение секреции альвеолярным } \\
\text { эпителием хлоридов, натрия и воды } \rightarrow \\
\text { сгущение секрета } \rightarrow \text { закупорка просвета } \\
\rightarrow \text { инфекция и воспаления. }\end{array}$ \\
\hline Осложнения: & - Бронхоэктазии; \\
\hline
\end{tabular}




\begin{tabular}{|c|c|}
\hline Вопросы & Ответы \\
\hline & $\begin{array}{l}\text { • Фиброз лёгкого; } \\
\text { • Лёгочная гипертензия; } \\
\text { • ёгочная недостаточность. }\end{array}$ \\
\hline Клинические признаки: & Часто рецидивирующая пневмония. \\
\hline $\begin{array}{l}\text { Какие признаки могут вызвать } \\
\text { подозрение на кистозный фиброз? }\end{array}$ & $\begin{array}{l}\text { Частые эпизоды пневмонии, } \\
\text { развивающиеся в раннем детском } \\
\text { возрасте, устойчивость к антибиотикам. }\end{array}$ \\
\hline $\begin{array}{l}\text { Какие обследования необходимы для } \\
\text { уточнения диагноза? }\end{array}$ & $\begin{array}{l}\text { - Рентгенологическое } \\
\text { исследование, КТ и бронхоскопия } \\
\text { обычно не специфичны; } \\
\text { - Генетическое исследование } \\
\text { более информативно. }\end{array}$ \\
\hline Диагностические критерии: & $\begin{array}{l}\text { - Часто рецидивирующие } \\
\text { бронхиты и пневмонии; } \\
\text { - Мутации гена CFTR. }\end{array}$ \\
\hline Методы лечения: & $\begin{array}{l}\text { - Консервативное; } \\
\text { - Хирургическое. }\end{array}$ \\
\hline $\begin{array}{l}\text { В чем заключается спектр } \\
\text { консервативной терапии? }\end{array}$ & $\begin{array}{l}\text { - Модулятор белка CFTR } \\
\text { (ивакафтор); } \\
\text { - Муколитики (ацетилцистеин), } \\
\text { эндонуклеаза (ДНК-аза), } \\
\text { гипертоническая ингаляция (7\% } \\
\text { раствор NaCl) и др.; } \\
\text { - Бронходилататоры - } \\
\text { агонисты, } \\
\text { теофиллин и др.; } \\
\text { - Противовоспалительные } \\
\text { ибупрофен, глюкокортикоиды; } \\
\text { - Антибиотики; } \\
\text { Физиотерапевтические } \\
\text { процедуры. }\end{array}$ \\
\hline Показания к хирургическому лечению: & $\begin{array}{l}\text { Отсутствии эффекта от консервативной } \\
\text { терапии и возникновение осложнений. }\end{array}$ \\
\hline
\end{tabular}




\begin{tabular}{|c|c|}
\hline Вопросы & Ответы \\
\hline Методы хирургического лечения: & $\begin{array}{l}\text { - Лобэктомия, пульмонэктомия } \\
\text { (при локальных вариантах } \\
\text { заболевания); } \\
\text { - Трасплантация. }\end{array}$ \\
\hline Показания к трансплантации легкого: & $\begin{array}{l}\text { - Тяжелая степень бронхиальной } \\
\text { обструкции (FEV } 1 \text { <30\%); } \\
\text { - Невозможность преодоления } \\
\text { расстояния до } 400 \text { м в течение } 6 \\
\text { мин.; } \\
\text { - Лёгочная гипертензия (при ЭхоКг } \\
\text { давление >35мм рт. ст., при } \\
\text { катетеризации->25мм рт. ст.); } \\
\text { - Повторяющаяся инфекция; } \\
\text { - Наличие других осложнений - } \\
\text { пневмоторакс, кровохарканье, } \\
\text { мальнутриция. }\end{array}$ \\
\hline
\end{tabular}




\section{ТУБЕРКУЛЁЗ ЛЁГКИХ}

- Туберкулёз - гранулематозная инфекция лёгких и органов внелёгочной локализации, вызванная Mycobacterium Tuberculosis.

- Клиническими вариантами туберкулеза лёгких являются: первичное поражение лёгкого, реактивация, эндобронхиальный туберкулёз и туберкулома.

- Для уточнения диагноза кроме клинической картины, важное значение имеют методы визуализации и полимеразная цепная реакция.

- Основным методом лечения туберкулёза является консервативный (изониазид, стрептомицин, рифампицин, этамбутол). Хирургическое лечение показано при развитии осложнений.

\section{Вопросы и ответы по туберкулёзу лёгких}

\begin{tabular}{|c|c|}
\hline Bonpocbl & Ответы \\
\hline Что такое туберкулёз? & $\begin{array}{l}\text { Специфическое воспаление лёгких и } \\
\text { органов внелёгочной локализации, } \\
\text { вызванное Mycobacterium Tuberculosis. }\end{array}$ \\
\hline Клинические варианты туберкулёза: & $\begin{array}{l}\text { • Лёгочный туберкулёз; } \\
\text { • Внелёгочный туберкулёз с } \\
\text { поражением кости, перикарда, } \\
\text { брюшины, плевры, мозга } \\
\text { лимфатических узлов, } \\
\text { мочеполовой системы. }\end{array}$ \\
\hline $\begin{array}{l}\text { Клинические формы туберкулёза } \\
\text { лёгких: }\end{array}$ & $\begin{array}{l}\text { - Первичный туберкулёз - общие } \\
\text { и местные симптомы, } \\
\text { инфильтрация лёгких, } \\
\text { лимфаденопатия, плеврит; } \\
\text { - Реактивация - пневмония, чаще } \\
\text { поражающая верхушечные и } \\
\text { задние сегменты лёгких; }\end{array}$ \\
\hline
\end{tabular}




\begin{tabular}{|c|c|}
\hline Вопросы & Ответы \\
\hline & $\begin{array}{l}\text { - } \text { Эндобронхиальный туберкулёз - } \\
\text { признаки хронического бронхита } \\
\text { (лающий кашель); } \\
\text { - Туберкулома. }\end{array}$ \\
\hline Причины и факторы риска: & $\begin{array}{l}\text { - Mycobacterium tuberculosis } \\
\text { - Myco); } \\
\text { - Mycobacterium bovis; } \\
\text { - Mycobacterium avium. }\end{array}$ \\
\hline Особенности клинического течения: & $\begin{array}{l}\text { Первичный туберкулёз } \rightarrow \text { латентная } \\
\text { форма } \rightarrow \text { реактивация. }\end{array}$ \\
\hline $\begin{array}{l}\text { Какие осложнения характерны для } \\
\text { туберкулёза? }\end{array}$ & $\begin{array}{l}\text { - Кровохарканье; } \\
\text { - Пневмоторакс; } \\
\text { - Бронхоэктазия; } \\
\text { - Обширное поражение лёгкого; } \\
\text { - Малигнизация; } \\
\text { - Венозный тромбоз; } \\
\text { - Хронический лёгочный } \\
\text { аспергиллёз. }\end{array}$ \\
\hline Клинические признаки: & $\begin{array}{l}\text { - } \text { Общие симптомы: } \\
\text { о слабость; } \\
\text { о высокая температура; } \\
\text { о анорексия; } \\
\text { о похудание; } \\
\text { О потливость в ночное } \\
\text { время; } \\
\text { - Местные симптомы: } \\
\text { О одышка; } \\
\text { О кашель; } \\
\text { о боль в груди. }\end{array}$ \\
\hline $\begin{array}{l}\text { У каких пациентов можно } \\
\text { заподозрить туберкулёз? }\end{array}$ & $\begin{array}{l}\text { - Периодический субфебрилитет, } \\
\text { ночная потливость, общая } \\
\text { слабость, упорный кашель, } \\
\text { кровохарканье; }\end{array}$ \\
\hline
\end{tabular}




\begin{tabular}{|c|c|}
\hline Вопросы & Ответы \\
\hline & $\begin{array}{l}\text { - Пневмония, плеврит, } \\
\text { пневмоторакс; } \\
\text { - Наличие туберкулёза в анамнезе } \\
\text { или в семье. }\end{array}$ \\
\hline $\begin{array}{l}\text { Какие исследования необходимы для } \\
\text { уточнения диагноза? }\end{array}$ & $\begin{array}{l}\text { - Рентгенография и КТ } \\
\text { н } \text { Беспецифичны; } \\
\text { эндохобронхиальном туберкулёзе; } \\
\text { - Бактериологическое } \\
\text { исследование мокроты, ПцР; } \\
\text { - Биопсия. }\end{array}$ \\
\hline Критерии визуализации: & $\begin{array}{l}\text { При рентгенографии и КТ - признаки } \\
\text { специфической пневмонии, каверна, } \\
\text { туберкулома. }\end{array}$ \\
\hline Информативность других методов: & 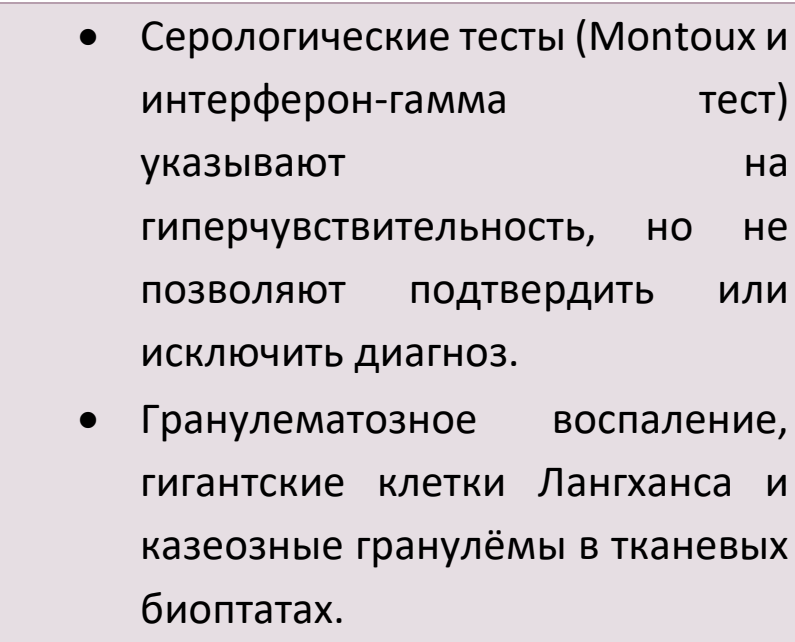 \\
\hline Диагностические критерии: & $\begin{array}{l}\text { - Диагноз туберкулёза, } \\
\text { п Клдтверждённый лабораторно; } \\
\text { туберкулёза - ПЦР негативна, } \\
\text { бактерии не выявляются. }\end{array}$ \\
\hline Методы лечения: & $\begin{array}{l}\text { - Консервативное лечение - } \\
\text { изониазид, стрептомицин, } \\
\text { рифампицин, этамбутол; } \\
\text { - Хирургическое лечение. }\end{array}$ \\
\hline
\end{tabular}




\section{Вопросы \\ Ответы}

Показание к хирургическому лечению:

- Обширная деструкция лёгкого;

- Профузное кровотечение;

- Бронхопищеводный свищ;

- Инфицированная каверна;

- Невозможность дифференциации от рака лёгкого.

Прогноз:

Вследствие повышения эффективности химиотерапии, летальность составляет $10 \%$. 


\section{РАК ЛЁГКОГО}

- Опухоли лёгкого могут быть зло- и доброкачественными. По происхождению злокачественные новообразования лёгких делятся на 2 группы: первичные и метастатические. Первичная злокачественная опухоль (рак) лёгкого имеет 2 клинико-патологические разновидности: мелкоклеточный и немелкоклеточный рак.

- Мелкоклеточный рак составляет $20 \%$ от общего количества рака лёгкого, отличается агрессивным течением и диффузным поражением.

○ Наиболее часто встречается у курильщиков.

- Основным методом лечения данной формы рака лёгкого является химиотерапия. Возможности хирургического лечения ограничены. 5летняя выживаемость составляет $10 \%$.

○ Предполагается, что мелкоклеточный рак имеет бронхогенно нейроэндокринную природу.

- Немелкоклеточный рак составляет $80 \%$ всех раков лёгкого. Основным методом лечения является хирургический. По гистологической структуре различают аденокарциному (бронхоальвеолярная карцинома), плоскоклеточный и крупноклеточный рак.

- Аденокарциномы развиваются из более мелких (периферических) бронхов, склонны к прогрессивному росту и быстрому гематогенному метастазированию.

○ Плоскоклеточный рак развивается, как правило, из центральных (главных, долевых и сегментарных) бронхов, отличается относительно медленным течением и поздним метастазированием.

○ Крупноклеточный рак имеет периферическую локализацию и высокую злокачественность.

- В начальной (ранней) стадии обычно протекает бессимптомно или проявляется неспецифическими симптомами. По мере роста опухоли, особенно в случаях преимущественно эндобронхиального роста, пораженный бронх суживается - возникает бронхостеноз.

- Больных беспокоят упорный кашель, кровохарканье, выделение обильной мокроты, одышка, явления пневмонии. Нередко наблюдаются внелегочные проявления (боль в груди, изменение фонации голоса, синдром верхней 
полой вены, синдром Бернара-Горнера (птоз, миоз, энофтальм). У ряда больных развиваются паранеопластические синдромы.

- Для уточнения диагноза ценную информацию дают КТ, бронхоскопия, биопсия.

- В большинстве случаев методы визуализации и результаты биопсии позволяют подтвердить диагноз. Для определения стадии опухолевого процесса используют клинико-анатомическую классификацию по системе TNM.

- Лечение зависит от клинико-патологической формы и стадии заболевания. Основным методом лечения мелкоклеточного рака является химиотерапия. При немелкоклеточном раке применяют хирургическое лечение (лобэктомия, пульмонэктомия). Химиотерапия проводится по показаниям.

- Критериями резектабильности при раке легкого являются:

○ Опухоль должна быть резектабельной (одностороннее поражение, нет распространения на средостение, отсутствие отдаленных метастазов);

○ Сохранение адекватной резервной функциональной возможности лёгкого (FEV1 при лобэктомии - более 0,8-1 л, при пульмонэктомии - более 2 л), отсутствие гиперкапнии;

○ Отсутствие общих противопоказаний к операции.

\section{Вопросы и ответы по раку лёгких}

\begin{tabular}{|ll|}
\hline \multicolumn{1}{|c|}{ Вопросы } & \multicolumn{1}{c|}{ Ответы } \\
\hline Что такое рак лёгкого? & Злокачественная опухоль лёгкого. \\
\hline Частота встречаемости заболевания: & $\bullet \quad$ Мелкоклеточный рак $-20 \% ;$ \\
\hline Причины, факторы риска: & $\bullet \quad$ Немелкоклеточный рак - 80\%. \\
\hline & Табакокурение, интенсивное \\
& загрязнение атмосферного воздуха \\
& являются основными причинами. \\
& Туберкулёз лёгких, асбестоз, \\
& хроническая пневмония повышают \\
& риск развития рака. \\
\hline
\end{tabular}




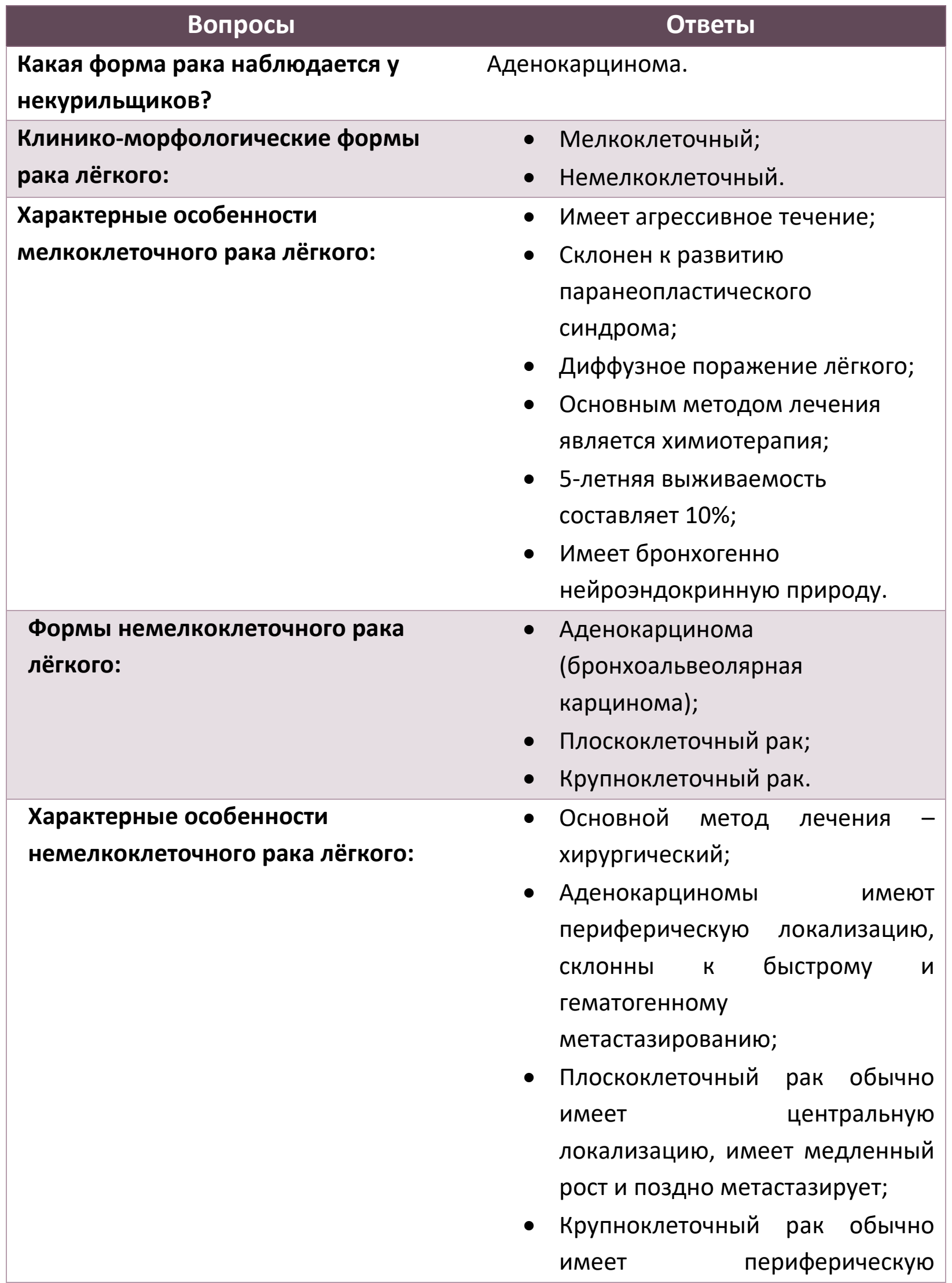




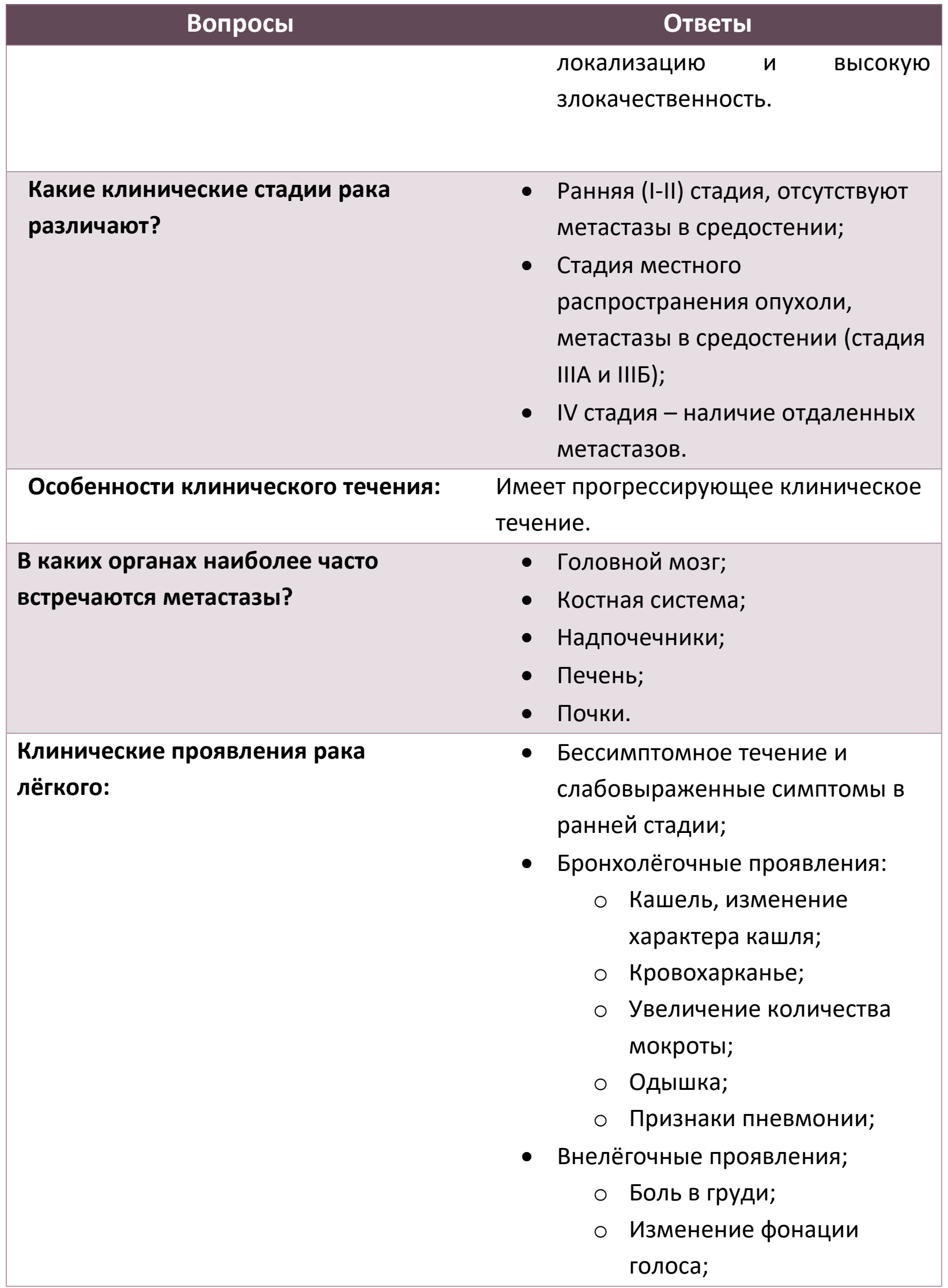




\begin{tabular}{|c|c|}
\hline Bonpocbl & Ответы \\
\hline & $\begin{array}{c}\text { ○ Симптом верхней полой } \\
\text { вены; } \\
\text { О Синдром Бернара- } \\
\text { Горнера; } \\
\text { - Паранеопластические синдромы: } \\
\text { О Синдром Кушинга; } \\
\text { О Несахарный диабет; } \\
\text { ○ Гиперкальциемия; } \\
\text { О Гиперпластическая } \\
\text { остеоартропатия. }\end{array}$ \\
\hline $\begin{array}{l}\text { Что такое гипертрофическая лёгочная } \\
\text { остеоартропатия? }\end{array}$ & $\begin{array}{l}\text { Периостальная пролиферация эпифиза } \\
\text { трубчатых костей и костей кисти (10\%). }\end{array}$ \\
\hline Что такое сидром Бернара-Горнера? & $\begin{array}{l}\text { Поражение шейного симпатического } \\
\text { нервного сплетения: } \\
\text { • Миоз; } \\
\text { • Птоз; } \\
\text { • Энофтальм; } \\
\text { - Ангидроз - одностороннее } \\
\quad \text { нарушение потоотделения лица. }\end{array}$ \\
\hline Как можно заподозрить рак лёгкого? & $\begin{array}{l}\text { На основании выявления клинико- } \\
\text { инструментальных признаков рака. }\end{array}$ \\
\hline $\begin{array}{l}\text { Какие методы исследования } \\
\text { необходимы для верификации } \\
\text { диагноза? }\end{array}$ & $\begin{array}{l}\text { • Биопсия - бронхоскопическая, } \\
\text { чрескожная, торакоскопия или } \\
\text { торакотомия; } \\
\text { • КТ, пЭТ-КТ и эндобронхиальное } \\
\text { УзИ- выявление степени } \\
\text { распространения и } \\
\text { метастазирования в органы } \\
\text { средостения. }\end{array}$ \\
\hline Диагностические критерии: & $\begin{array}{l}\text { - Наличие бронхолёгочных, } \\
\text { внелёгочных признаков и } \\
\text { паранеопластических } \\
\text { синдромов; }\end{array}$ \\
\hline
\end{tabular}




\begin{tabular}{|c|c|}
\hline Вопросы & $\begin{array}{l}\text { Ответы } \\
\text { - } \text { Обнаружение раковых клеток } \\
\text { при биопсии. }\end{array}$ \\
\hline $\begin{array}{l}\text { Критерии резектабельности рака } \\
\text { лёгкого: }\end{array}$ & $\begin{array}{l}\text { • Опухоль должна быть } \\
\text { резектабельной } \\
\text { (одностороннее поражение, } \\
\text { нет распространения на } \\
\text { средостение, отсутствие } \\
\text { отдаленных метастазов); } \\
\text { Сохранение адекватной } \\
\text { резервной функциональной } \\
\text { возможности лёгкого (FEV1 } \\
\text { при лобэктомии - более 0,8-1 } \\
\text { л, при пульмонэктомии - } \\
\text { более 2 л), отсутствие } \\
\text { гиперкапнии; } \\
\text { Отсутствие общих противопоказаний к } \\
\text { операции. }\end{array}$ \\
\hline $\begin{array}{l}\text { Противопоказания к резекции } \\
\text { лёгкого: }\end{array}$ & $\begin{array}{l}\text { - Наличие отдалённых метастазов } \\
\text { (за исключением одиночного } \\
\text { метастаза в головной мозг); } \\
\text { - Синдром верхней полой вены; } \\
\text { - Билатеральная обструкция } \\
\text { бронхов; } \\
\text { - Наличие метастазов в } \\
\text { лимфоузлах противоположной } \\
\text { стороны; } \\
\text { - Карциноматоз плевры; } \\
\text { - FEV1 <1 л; } \\
\text { - Гиперкапния (рСО2 >45 мм рт. } \\
\text { ст.); } \\
\text { Инфаркт миокарда. }\end{array}$ \\
\hline
\end{tabular}




\begin{tabular}{|c|c|}
\hline Вопросы & Ответы \\
\hline $\begin{array}{l}\text { Методы лечения рака в ранней стадии } \\
\text { заболевания (I-II ст.): }\end{array}$ & Резекция \pm химиотерапия. \\
\hline $\begin{array}{l}\text { Методы лечения при локальных } \\
\text { ограниченных и резектабельных } \\
\text { опухолях (III ст.): }\end{array}$ & $\begin{array}{l}\text { Предоперационная химиотерапия } \pm \\
\text { резекция поражённой доли } \pm \\
\text { послеоперационная радиотерапия. }\end{array}$ \\
\hline $\begin{array}{l}\text { Методы лечения при } \\
\text { местнораспространённом } \\
\text { нерезектабельном раке лёгкого? }\end{array}$ & Химиорадиотерапия. \\
\hline $\begin{array}{l}\text { Лечение при наличии отдаленных } \\
\text { метастазов: }\end{array}$ & $\begin{array}{l}\text { Химиотерапия + симптоматическое } \\
\text { лечение. }\end{array}$ \\
\hline
\end{tabular}




\section{ДРУГИЕ НОВООБРАЗОВАНИЯ ЛЁГКИХ}

- В структуре злокачественных опухолей лёгких после рака наиболее часто встречается бронхиальная аденома.

○ Различают 3 гистологические формы бронхиальной аденомы: карциноид, аденоидная кистозная карцинома и мукоэпидермоидная карцинома.

О Основными клиническими проявлениями бронхиальной аденомы являются кашель и удушье.

○ В уточнении диагноза ведущее место занимают КТ, бронхоскопия с биопсией.

○ Основным методом лечения является хирургический. В зависимости от локализации поражения и степени распространённости, выполняют лобэктомию, пульмонэктомию или резекцию.

- Первичные доброкачественные опухоли лёгких встречаются редко. К ним относятся гамартомы, фибромы, лейомиомы, нейрофибромы, миобластомы.

О Обычно первичные доброкачественные опухоли выявляются при случайном обследовании, в виде одиночного узла с участками кальцинатов.

○ Диагноз подтверждается биопсией.

○ Лечение обычно хирургическое.

\section{Вопросы и ответы по доброкачественным новообразованиям лёгких}

\begin{tabular}{|c|c|}
\hline Вопросы & Ответы \\
\hline $\begin{array}{l}\text { Гистологическая классификация } \\
\text { доброкачественных } \\
\text { опухолей лёгких: }\end{array}$ & $\begin{array}{l}\text { - Карциноидные опухоли (85-90\%); } \\
\text { - Аденоидная кистозная карцинома } \\
\text { (10\%); } \\
\text { - Мукоэпидермоидная карцинома (5\%). }\end{array}$ \\
\hline Что такое карциноидная опухоль? & $\begin{array}{l}\text { Нейроэндокринная опухоль, развивающаяся } \\
\text { из APUD-системы бронхов. }\end{array}$ \\
\hline Особенности клинического течения: & $\begin{array}{l}\text { Характеризуется замедленным ростом. (Может } \\
\text { иметь злокачественное течение). }\end{array}$ \\
\hline
\end{tabular}




\begin{tabular}{|c|c|}
\hline Вопросы & Ответы \\
\hline Первичные локальные признаки: & $\begin{array}{l}\text { Хриплое дыхание, ателектаз лёгкого } \\
\text { вследствие бронхиальной обструкции и } \\
\text { стеноза. }\end{array}$ \\
\hline $\begin{array}{l}\text { С каким заболеванием необходимо } \\
\text { дифференцировать? }\end{array}$ & Бронхиальная астма. \\
\hline Как ставится диагноз? & $\begin{array}{l}\text { Выявление опухолевидной массы, покрытой } \\
\text { эпителием, пролабирующей в просвет бронха } \\
\text { при бронхоскопии. }\end{array}$ \\
\hline В чём заключается принцип лечения? & $\begin{array}{l}\text { - Резекция лёгкого или лобэктомия в } \\
\text { сочетании слимфодиссекцией; } \\
\text { - При поражении проксимальных } \\
\text { бронхов-трубчатая резекция. }\end{array}$ \\
\hline $\begin{array}{l}\text { Что такое трубчатая трахеобронхиальная } \\
\text { резекция? }\end{array}$ & $\begin{array}{l}\text { Сегментарная резекция бронха с } \\
\text { формированием анастомоза “конец в конец", } \\
\text { сохранение нижней доли лёгкого. }\end{array}$ \\
\hline $\begin{array}{l}\text { 5-летняя выживаемость после радикального } \\
\text { хирургического лечения карциноидных } \\
\text { опухолей: }\end{array}$ & $\begin{array}{l}\text { - При негативных узлах - более 90\%; } \\
\text { - При позитивных узлах - 66\%. }\end{array}$ \\
\hline $\begin{array}{l}\text { Характерные особенности аденоидной } \\
\text { кистозной карциномы: }\end{array}$ & $\begin{array}{l}\text { - } \text { Склонность к локальной инвазии; } \\
\text { - } \text { Метастазирует на поздних стадиях; } \\
\text { - } \text { Локализуется в нижних отделах трахеи. }\end{array}$ \\
\hline $\begin{array}{l}\text { Характерные особенности } \\
\text { мукоэпидермоидной карциномы: }\end{array}$ & $\begin{array}{l}\text { - Состоит из ткани, похожей на ткань } \\
\text { слюнной железы; } \\
\text { - Имеются плоские и промежуточные } \\
\text { клетки, выделяющие слизь. }\end{array}$ \\
\hline Особенности клинического течения: & Имеет замедленный рост. \\
\hline Клинические признаки: & Кашель, симптомы удушья. \\
\hline Методы обследования, уточняющие диагноз: & $\begin{array}{ll}\text { - } & \text { КT; } \\
\text { - } & \text { Бронхоскопия; } \\
\text { - } & \text { Биопсия. }\end{array}$ \\
\hline Методы лечения: & Хирургический. \\
\hline Варианты оперативного вмешательства: & $\begin{array}{l}\text { Лобэктомия, пульмонэктомия или резекция } \\
\text { бронха. }\end{array}$ \\
\hline Прогноз: & $\begin{array}{l}\text { В редких случаях развивается карциноидный } \\
\text { синдром. }\end{array}$ \\
\hline $\begin{array}{l}\text { Частота встречаемости первичных } \\
\text { доброкачественных новообразований } \\
\text { лёгкого: }\end{array}$ & $\begin{array}{lcc}\text { Частота встречаемости } & \text { среди } & \text { всех } \\
\text { новообразований составляет менее } 1 \% . & \end{array}$ \\
\hline Наиболее часто встречающаяся форма: & мартома. \\
\hline
\end{tabular}




\begin{tabular}{|c|c|}
\hline Вопросы & Ответы \\
\hline $\begin{array}{l}\text { Клинические признаки доброкачественных } \\
\text { новообразований лёгких: }\end{array}$ & $\begin{array}{l}\text { - Малые опухоли периферической } \\
\text { локализации, чаще протекают } \\
\text { бессимптомно. } \\
\text { - Большие новообразования, имеющие } \\
\text { центральную локализацию, имеют } \\
\text { соответствующую симптоматику. }\end{array}$ \\
\hline $\begin{array}{l}\text { Какие методы исследования необходимы } \\
\text { для уточнения диагноза? }\end{array}$ & $\begin{array}{l}\text { - Выявляются случайно } \\
\text { одиночного узла с } \quad \text { участками } \\
\text { кальцинатов (10-30). } \\
\text { - Биопсия. }\end{array}$ \\
\hline Методы лечения: & $\begin{array}{l}\text { - Экономная резекция (краевая, } \\
\text { сегментарная) лёгкого; } \\
\text { - Резекция бронха, лобэктомия (в } \\
\text { случаях центральной локализации и } \\
\text { обструкции бронхов). }\end{array}$ \\
\hline
\end{tabular}

\section{СПИСОК ЛИТЕРАТУРЫ}

- Ağayev B.A. Cərrahi xəstəliklər. Bakı 2010.

- Blackbourne LH. Surgical Recall. 7 edition, 2014, LWW, Philadelphia

- Doherty GM. Current Diagnosis and Treatment: Surgery, $13^{\text {th }}$ edition, 2010, Lang International Edition.

- $\quad$ Omiraslanov Ә.T., Qazıyev A.Y. Onkologiya. Bakı, 2010.

- Ettinger DS et al. Non-Small Cell Lung Cancer, Version 5.2017. NCCN

- İsayev H.B.Cərrahi xəstəliklərin patofizologiyası. Bakı 2005

- Klingensmith ME, Aziz A, Bharat A, FoxAC, Porembka MR. The Washington Manual of Surgery, $6^{\text {th }}$ edition, 2012, LWW, Philadelphia.

- MacMahon $\mathrm{H}$ et al. Guidelines for Management of Incidental Pulmonary Nodules Detected on CT Images: From the Fleischner Society 2017., https://doi.org/10.1148/radiol.2017161659

- Sayek i. Sayek Temel Cerrahi 1-2. 4-cü baskı, 2016, Güneş Tıp Kitabevleri

- Medscape, http://www.medscape.com

- Oxford Handbook of Clinical Surgery, 3d edition, 2011, Oxford Press

- UpToDate, http://www.uptodate.com

- Гостищев В.К. Общая хирургия. GEOTAR-Media, 2019 


\section{ХИРУРГИЧЕСКИЕ БОЛЕЗНИ}

Н.Ю. Байрамов

\section{Хирургические заболевания плевры \\ Н.Ю. Байрамов, С.А. Алиев, Б.М. Зейналов, Ф.А. Гахраманова}

Перевод: Н.Ю. Байрамов, С.А. Алиев, М.Р.Гусейнова 


\section{ПЛЕВРАЛЬНАЯ ЖИДКОСТЬ}

- Основной механизм скопления жидкости в плевральной полости заключается в нарушении равновесия между процессами выделения и всасывания плевральной жидкости.

- К Косновным этиологическим факторам нарушения данного равновесия относятся воспалительные, неопластические заболевания, травмы, органная недостаточность.

- В зависимости от характера жидкости различают серозный (экссудат, транссудат), гнойный (пиоторакс) плеврит, гемоторакс, хилоторакс и билиоторакс.

- Небольшое скопление жидкости в плевральной полости не проявляется клинически. При увеличении количества плевральной жидкости и присоединении вторичной инфекции проявляются боль в грудной клетке, признаки дыхательной недостаточности и SIRS.

- Информативными диагностическими методами являются УзИ и КТ. Важной задачей диагностики является определение характера плевральной жидкости. При этом ценную информацию дают клинические и инструментальные исследования (КТ, пункция плевральной полости).

- Лечение плевральных скоплений проводится с учётом причин их возникновения.

- Гидроторакс - скопление в плевральной полости асептической серозной жидкости.

- В зависимости от белкового состава различают транссудат и экссудат.

- Транссудат (содержание белка <3 г/л), как правило, наблюдается при сердечной недостаточности, циррозе печени и почечной недостаточности. Устранение причин, вызвавших скопление жидкости, приводит к регрессу.

- Экссудат (содержание белка >3 г/л) встречается при воспалительных (пневмония, травматические повреждения) и неопластических заболеваниях. 


\section{Вопросы и ответы по плевральной жидкости}

\begin{tabular}{|c|c|}
\hline Вопросы & Ответы \\
\hline Что такое плевральная жидкость? & $\begin{array}{l}\text { Скопление жидкости в плевральной } \\
\text { полости. }\end{array}$ \\
\hline Формы плевральной жидкости: & $\begin{array}{l}\text { - По причине: воспалительная, } \\
\text { неопластическая, травматическая, } \\
\text { при полиорганной (печёночная, } \\
\text { сердечно-сосудистая и почечная) } \\
\text { недостаточности; } \\
\text { - По характеру жидкости: гидроторакс } \\
\text { (серозная) - экссудат, транссудат; } \\
\text { пиоторакс, гемоторакс, хилоторакс, } \\
\text { билиоторакс. }\end{array}$ \\
\hline Причины и факторы риска: & $\begin{array}{l}\text { Воспалительные и неопластические } \\
\text { процессы, травмы груди, полиорганная } \\
\text { (печёночная, сердечно-сосудистая и } \\
\text { почечная) недостаточность. }\end{array}$ \\
\hline Патогенез: & $\begin{array}{l}\text { Нарушении равновесия между } \\
\text { процессами выделения и всасывания } \\
\text { плевральной жидкости. }\end{array}$ \\
\hline Осложнения: & $\begin{array}{l}\text { Дыхательная недостаточность, } \\
\text { вторичная инфекция, фиброторакс. }\end{array}$ \\
\hline Клинические признаки: & $\begin{array}{l}\text { Боль в груди, дыхательная } \\
\text { недостаточность, признаки сепсиса (при } \\
\text { вторичной инфекции). }\end{array}$ \\
\hline
\end{tabular}




\begin{tabular}{|c|c|}
\hline Вопросы & Ответы \\
\hline $\begin{array}{l}\text { У каких пациентов можно } \\
\text { заподозрить наличие плевральной } \\
\text { жидкости? }\end{array}$ & 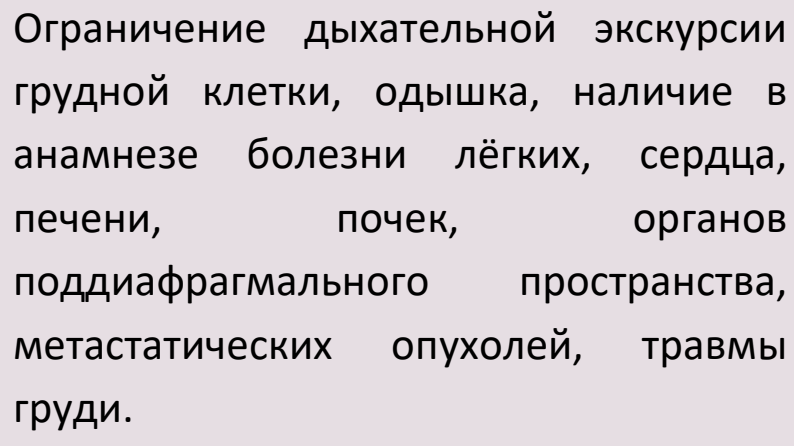 \\
\hline Диагностика: & $\begin{array}{l}\text { УзИ или КТ, иногда рентгенологическое } \\
\text { исследование. }\end{array}$ \\
\hline Лабораторные признаки: & Нет специфических признаков. \\
\hline $\begin{array}{l}\text { Признаки диагностической } \\
\text { визуализации: }\end{array}$ & $\begin{array}{l}\text { Наличие жидкости в плевральной } \\
\text { полости. }\end{array}$ \\
\hline $\begin{array}{l}\text { Как можно определить } \\
\text { нозологическую причину? }\end{array}$ & $\begin{array}{l}\text { На основании анамнеза, данных КТ, } \\
\text { результатов плевральной пункции. }\end{array}$ \\
\hline Диагностические критерии: & $\begin{array}{l}\text { Наличие жидкости в плевральной } \\
\text { полости при инструментальных методах } \\
\text { исследования. }\end{array}$ \\
\hline Методы лечения: & $\begin{array}{l}\text { Проводится с учётом этиологических } \\
\text { причин. }\end{array}$ \\
\hline
\end{tabular}




\section{ГНОЙНЫЙ ПЛЕВРИТ}

- Пиоторакс или гнойный плеврит - скопление гнойного экссудата в плевральной полости с $\mathrm{pH}<7$.

- Развивается как осложнение пневмонии, хирургических вмешательств и других факторов с присоединением вторичной инфекции.

- Гнойный плеврит сопровождается местными (боль, притупление перкуторного звука, одышки и др.) и общими проявлениями гнойно-воспалительного процесса.

- При отсутствии соответствующего лечения возможно развитие сепсиса и даже летального исхода.

- Экссудат в начале (в первые 24-48 4) имеет серозный характер, в дальнейшем (на 3-7 сутки) принимает фибринозно-гнойный характер. Формирование фибрина в дальнейшем способствует образованию осумкованных эмпием.

- В диагностике ведущее значение имеют клиническая картина заболевания, анамнез, инструментальные методы исследования (УЗИ, КТ, рентгенологическое). Ценную информацию даёт также лабораторное и бактериологическое исследование плеврального пунктата (гнойный характер экссудата с содержанием белка >3 г/л, $\mathrm{pH}<7$, глюкозы <40 мг/дл, выявление аэробной и анаэробной микрофлоры).

- Принципы лечения гнойного плеврита основаны на общих принципах лечения гнойных заболеваний и сводятся к следующим мероприятиям:

○ Антибиотикотерапия;

○ Заместительная терапия;

○ Дренирование и санация плевральной полости;

○ Лечение основного заболевания (ранее дренирование, декортикация или торакопластика). 


\section{Вопросы и ответы по гнойному плевриту}

\begin{tabular}{|c|c|}
\hline Вопросы & Ответы \\
\hline Что такое гнойный плеврит? & $\begin{array}{l}\text { Гнойное воспаление плевры (пиоторакс } \\
\text { или эмпиема). }\end{array}$ \\
\hline Формы гнойного плеврита: & 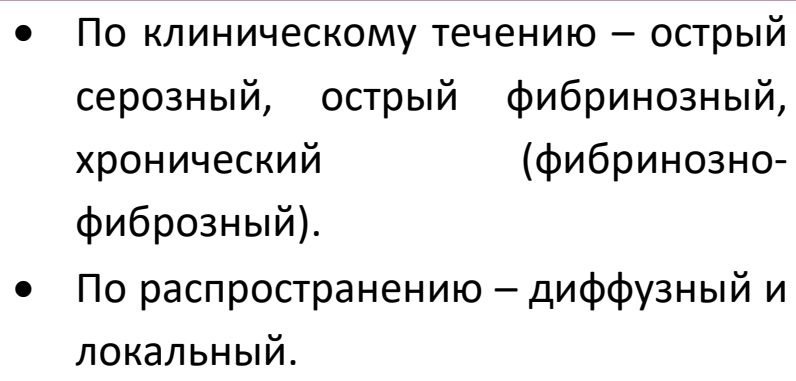 \\
\hline Причины и факторы риска: & $\begin{array}{l}\text { - Пневмония (60\%) - частая причина; } \\
\text { - Внутриплевральные операции (20\%); } \\
\text { - Травмы (10\%); } \\
\text { - Другие причины (перфорация } \\
\text { пищевода, медиастинит, гнойно- } \\
\text { воспалительные процессы } \\
\text { поддиафрагмального пространства). }\end{array}$ \\
\hline Патогенез: & $\begin{array}{l}\text { I механизм - инфицирование } \\
\text { первичного очага воспаления; } \\
\text { II механизм - распространение гнойной } \\
\text { инфекции в плевральную полость из } \\
\text { соседних органов. }\end{array}$ \\
\hline Особенности клинического течения: & 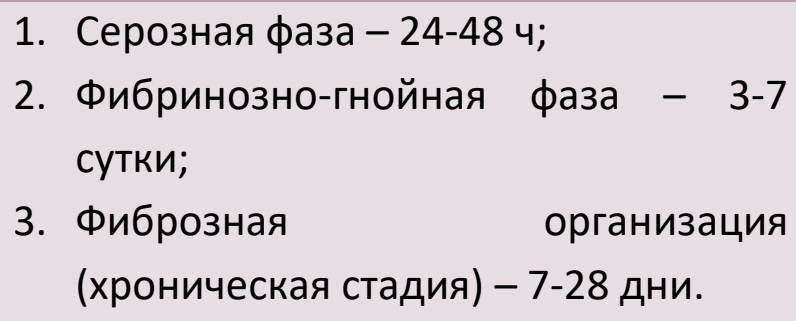 \\
\hline Осложнения: & $\begin{array}{l}\text { Сепсис, лёгочная недостаточность, } \\
\text { бронхоплевральные свищи, амилоидоз. }\end{array}$ \\
\hline
\end{tabular}




\begin{tabular}{|c|c|}
\hline \multirow{3}{*}{$\begin{array}{r}\text { Вопросы } \\
\text { Клинические признаки: }\end{array}$} & Ответы \\
\hline & $\begin{array}{l}\text { Местные проявления: боль в груди, } \\
\text { притупление перкуторного } \\
\text { ослабление дыхательных шумов. }\end{array}$ \\
\hline & $\begin{array}{l}\text { Общие симптомы: признаки SiRS, } \\
\text { сепсиса - гипертермия, тахикардия, } \\
\text { тахипноэ, лейкоцитоз; признаки } \\
\text { дыхательной недостаточности - цианоз, } \\
\text { одышка и др. }\end{array}$ \\
\hline $\begin{array}{l}\text { У каких пациентов можно } \\
\text { заподозрить наличие гнойного } \\
\text { плеврита? }\end{array}$ & $\begin{array}{l}\text { Наличие боли в груди, одышки, } \\
\text { признаков сепсиса. В анамнезе } \\
\text { пневмония, } \\
\text { операции, травмы груди. Получение } \\
\text { гноя при плевральной пункции. }\end{array}$ \\
\hline Диагностика: & $\begin{array}{l}\text { УзИ, КТ грудной клетки, пункция } \\
\text { плевральной полости. }\end{array}$ \\
\hline Лабораторные признаки: & $\begin{array}{l}\text { Признаки SiRS-сепсиса } \\
\text { лейкоцитоз, посокий } \\
\text { реактивного белка и др.) }\end{array}$ \\
\hline $\begin{array}{l}\text { Признаки инструментальной } \\
\text { диагностики: }\end{array}$ & $\begin{array}{l}\text { Наличие жидкости в плевральной } \\
\text { полости. }\end{array}$ \\
\hline $\begin{array}{l}\text { Информативность других методов } \\
\text { исследования: }\end{array}$ & $\begin{array}{l}\text { Наличие гноя в пунктате, содержащем } \\
\text { белок >3 г/л, рН <7, глюкозы <40 мг/дл, } \\
\text { аэробных и анаэробных микробов. }\end{array}$ \\
\hline Диагностические критерии: & $\begin{array}{l}\text { - Боль в груди, признаки SIRS-сепсиса, } \\
\text { дыхательная недостаточность. } \\
\text { - Выявление гнойной жидкости в } \\
\text { плевральной полости при } \\
\text { инструментальныхисследованиях. } \\
\text { - При анализе пунктата выявления } \\
\text { гноя, бактерии, (рН<7) }\end{array}$ \\
\hline
\end{tabular}




\begin{tabular}{|c|c|}
\hline Вопросы & Ответы \\
\hline Лечение: & $\begin{array}{l}\text { Базируется на 4+ классических } \\
\text { принципах: } \\
\text { • Дренирование плевральной } \\
\text { полости; } \\
\text { - Антибиотикотерапия; } \\
\text { - Поддерживающая терапия; } \\
\text { • Ликвидация первичного очага; } \\
\text { - Ликвидация эмпиематозной полости } \\
\text { (раннее дренирование, } \\
\text { декортикация, торакопластика). }\end{array}$ \\
\hline Показание к хирургическому лечению: & $\begin{array}{l}\text { Хроническое течение (фиброзная фаза), } \\
\text { наличие деструкции в паренхиме } \\
\text { лёгкого и бронхоплевральных свищей. }\end{array}$ \\
\hline Методы хирургического лечения: & $\begin{array}{l}\text { Декортикация, } \\
\text { резекция легкого, пульмонэктомия. }\end{array}$ \\
\hline
\end{tabular}




\section{ЗЛОКАЧЕСТВЕННЫЙ ГИДРОТОРАКС}

- Злокачественные гидротораксы развиваются при злокачественных новообразованиях лёгкого, молочной железы, лимфоме, мезотелиоме плевры и других неопластических процессах.

- Характерной особенностью злокачественного гидроторакса является высокое содержание белка в экссудате, обнаружение опухолевых клеток при биопсии и гистологическом исследовании экссудата.

- Лечение паллиативное, направлено на уменьшение скопления жидкости, создание условий для расправления лёгкого (дренирование плевральной полости, плевродез, плеврэктомия).

\section{Вопросы и ответы по злокачественному гидротораксу}

\begin{tabular}{|c|c|}
\hline Вопросы & Ответы \\
\hline Частота встречаемости: & $\begin{array}{l}\text { Составляет } 25 \% \text { от всех плевральных } \\
\text { жидкостных скоплений. }\end{array}$ \\
\hline Причины и факторы риска: & $\begin{array}{l}\text { Злокачественные опухоли лёгкого } \\
\text { (35\%), молочной железы }(25 \%), \\
\text { лимфомы (10\%), мезотелиома плевры } \\
\text { (10\%) и др. }\end{array}$ \\
\hline $\begin{array}{l}\text { Наиболее информативный метод } \\
\text { диагностики: }\end{array}$ & $\begin{array}{l}\text { Плевральная пункция, биопсия } \\
\text { пунктата. }\end{array}$ \\
\hline $\begin{array}{l}\text { Диагностические признаки } \\
\text { инструментальных исследований: }\end{array}$ & $\begin{array}{l}\text { Обнаружение жидкости в плевральной } \\
\text { полости. }\end{array}$ \\
\hline $\begin{array}{l}\text { Информативность других методов } \\
\text { исследования: }\end{array}$ & $\begin{array}{l}\text { Высокое содержание белка в } \\
\text { плевральной жидкости, обнаружение } \\
\text { опухолевых клеток при цитологическом } \\
\text { исследовании (50\%). }\end{array}$ \\
\hline
\end{tabular}




\section{Вопросы}

\section{Ответы}

Методы лечения:

Паллиативное - дренирование плевральной полости, плевродез.

Методы хирургического лечения: Плеврэктомия - самый эффективный метод. 


\section{ХИЛОТОРАКС}

- Хилоторакс - скопление лимфы в плевральной полости, возникающее вследствие повреждений и заболеваний грудного лимфатического протока.

- Скопление представляет собой молочно-белую жидкость, содержащую много жира, холестерина, триглицеридов и лимфоцитов.

- Для лечения назначают парентеральное питание, сандостатина, применяют дренирование плевральной полости, плевродез или хирургическую перевязку (открытым или видеоторакоскопическим методом).

\section{Вопросы и ответы по хилотораксу}

\begin{tabular}{|c|c|}
\hline Boпросы & Ответы \\
\hline Что такое хилоторакс? & $\begin{array}{l}\text { Скопление лимфатической жидкости в } \\
\text { плевральной полости. }\end{array}$ \\
\hline Причины или факторы риска: & $\begin{array}{l}\text { Повреждение грудного лимфатического } \\
\text { протока при механической травме или } \\
\text { оперативных вмешательствах. }\end{array}$ \\
\hline Диагностика: & $\begin{array}{l}\text { Обнаружение высокой концентрации } \\
\text { холестерина и лимфоцитов в } \\
\text { плевральной жидкости. }\end{array}$ \\
\hline Методы лечения: & $\begin{array}{l}\text { Дренирование плевральной полости, } \\
\text { прекращение орального питания, } \\
\text { назначение сандостатина. При } \\
\text { отсутствии эффекта - плевродез. }\end{array}$ \\
\hline Показания к хирургическому лечению: & $\begin{array}{l}\text { Неэффективность } \\
\text { лечения. }\end{array}$ \\
\hline Методы хирургического лечения: & $\begin{array}{l}\text { Перевязка } \\
\text { прудного лима } \\
\text { видеоторакоскопическим методом). }\end{array}$ \\
\hline
\end{tabular}




\section{ПНЕВMOTOPAKC}

- Пневмоторакс - скопление воздуха в плевральной полости вследствие повреждения грудной стенки и органов плевральной полости.

- По происхождению различают травматический и спонтанный; по характеру закрытый, открытый и клапанный (напряженный); по распространённости малый, средний, тотальный.

- В диагностике важное значение имеют клиническая картина и данные инструментальных методов исследований (рентгеноскопия и КТ).

- Клапанный пневмоторакс отличается тяжелым клиническим течением, характеризуется гиповентиляцией и шоком. Наряду с признаками пневмоторакса (одышка, отсутствие дыхательных шумов, асимметрия, тимпанит) наблюдаются набухание шейных вен и снижение артериального давления.

- К Карактерным признакам открытого пневмоторакса относятся одышка, наличие "сосущей" раны на грудной стенке и подкожная эмфизема.

- При закрытом пневмотораксе скопление воздуха в плевральной полости может быть незначительным или достичь большого количества и заполнить всю плевральную полость.

- Bce виды пневмотораксов могут вызвать жизнеугрожающее состояние вследствие серьёзного нарушения внешнего дыхания и газообмена и требуют немедленного вмешательства - плевральное дренирование.

\section{Вопросы и ответы по пневмотораксу}

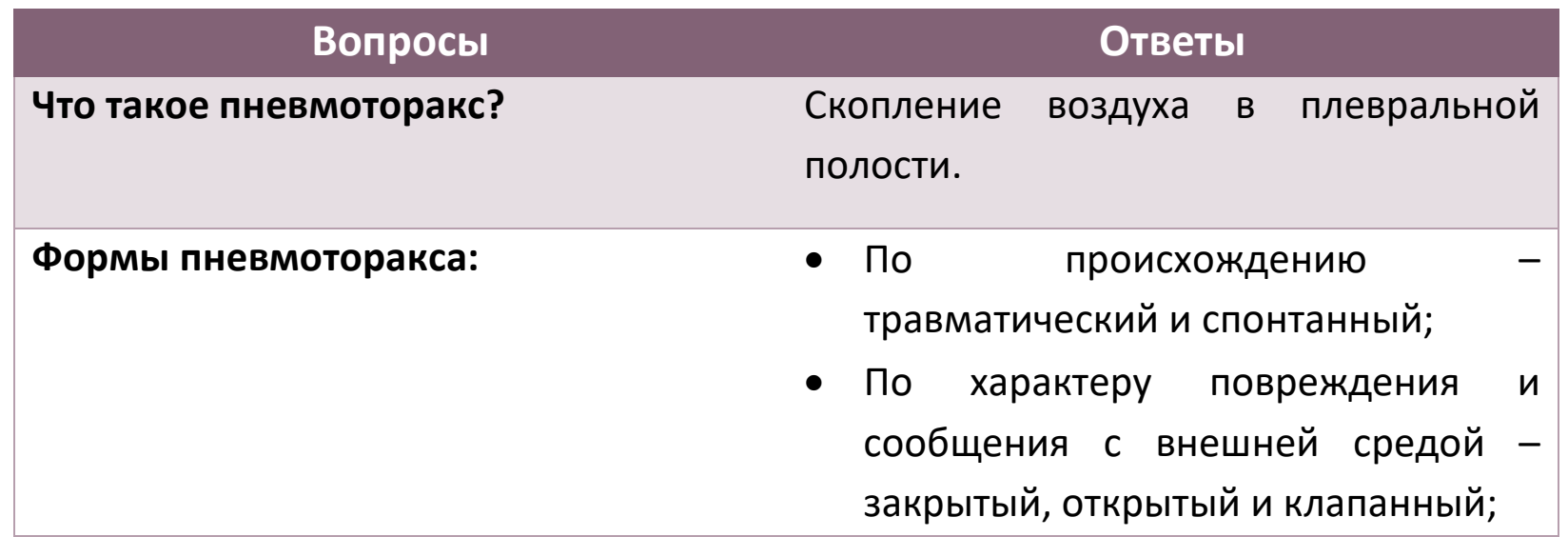




\begin{tabular}{|c|c|}
\hline Вопросы & Ответы \\
\hline & $\begin{array}{l}\text { - По распространению - малый, } \\
\text { средний, тотальный. }\end{array}$ \\
\hline Причины и факторы риска: & $\begin{array}{l}\text { Повреждение грудной стенки и органов } \\
\text { плевральной полости, патологические } \\
\text { процессы лёгких (буллёзная эмфизема, } \\
\text { деструктивные заболевания лёгких). }\end{array}$ \\
\hline Патогенез: & $\begin{array}{l}\text { Повреждение плевры } \rightarrow \text { скопление } \\
\text { воздуха в плевральной полости } \rightarrow \\
\text { устранение отрицательного давления } \\
\rightarrow \text { ателектаз лёгкого } \rightarrow \text { нарушение } \\
\text { вентиляции. }\end{array}$ \\
\hline Особенности клинического течения: & $\begin{array}{l}\text { Малые пневмотораксы протекают } \\
\text { бессимптомно. Средние и тотальные } \\
\text { пневмотораксы сопровождаются } \\
\text { развитием осложнений. Напряженный } \\
\text { пневмоторакс характеризуется шоком и } \\
\text { дыхательной недостаточностью. }\end{array}$ \\
\hline Осложнения: & Шок, дыхательная недостаточность. \\
\hline Клинические признаки: & $\begin{array}{l}\text { Боль, одышка, ослабление или полное } \\
\text { отсутствие дыхательных шумов, } \\
\text { перкуторный тимпанит, “флотация” } \\
\text { средостения пткрытом } \\
\text { пневмотораксе, выхождение пузырьков } \\
\text { воздуха с кровью из раны грудной } \\
\text { стенки. }\end{array}$ \\
\hline $\begin{array}{l}\text { У каких пациентов можно } \\
\text { заподозрить? }\end{array}$ & $\begin{array}{l}\text { - У всех больных с травмой груди; } \\
\text { - При наличии шока и явлений } \\
\text { дыхательной недостаточности; } \\
\text { - Появление болей в груди и одышки } \\
\text { внезапно или после упорного кашля } \\
\text { или физического напряжения; }\end{array}$ \\
\hline
\end{tabular}




\begin{tabular}{|c|c|}
\hline Вопросы & Ответы \\
\hline & $\begin{array}{l}\text { - Ухудшение состояния пациентов, } \\
\text { страдающих лёгочной патологией; } \\
\text { - Отсутствие дыхательных шумов при } \\
\text { аускультации }\end{array}$ \\
\hline Диагностика: & Рентгенологическое ислледование и КТ. \\
\hline Лабораторные признаки: & Не имеют диагностической ценности. \\
\hline $\begin{array}{l}\text { Признаки диагностической } \\
\text { визуализации: }\end{array}$ & $\begin{array}{l}\text { Скопление воздуха в плевральной } \\
\text { полости. }\end{array}$ \\
\hline \multirow[t]{2}{*}{ Диагностические критерии: } & $\begin{array}{l}\text { Клиническая картина, данные } \\
\text { инструментальных }\end{array}$ \\
\hline & $\begin{array}{lll}\text { исследования } & \text { (скопление } & \text { газа в } \\
\text { плевральной } & \text { полости, } & \text { ателектаз } \\
\text { лёгкого). } & \end{array}$ \\
\hline Методы лечения: & $\begin{array}{l}\text { Декомпрессия плевральной полости } \\
\text { (пункция, дренирование плевральной } \\
\text { полости), плевродез. }\end{array}$ \\
\hline Показания к хирургическому лечению: & $\begin{array}{l}\text { Неэффективность дренирования } \\
\text { плевральной полости, рецидивы. }\end{array}$ \\
\hline Методы хирургического лечения: & Торакотомия, торакоскопия. \\
\hline
\end{tabular}




\section{ГЕМОТОРАКС}

- Гемоторакс - скопление крови в плевральной полости при травме груди, ятрогенных повреждениях плевры, лёгкого и подключичной вены.

- Малый гемоторакс не вызывает серьёзных нарушений дыхания, хотя может осложняться присоединением вторичной инфекции и развитием гнойного плеврита.

- Большой и тотальный гемотораксы сопровождаются геморрагическим шоком и дыхательной недостаточностью.

- Диагностика осуществляется на основании клинической картины и данных инструментальных методов исследований, пункции плевральной пункции.

- Основным методом лечения гемоторакса является возможно раннее дренирование плевральной полости. Хирургическое лечение показано при продолжающемся массивном и жизнеугрожающем внутриплевральном кровотечении (обширное повреждение лёгкого, магистральных кровеносных сосудов, ранение и тампонада сердца и т.п.)

\section{Вопросы и ответы по гемотораксу}

\begin{tabular}{|ll}
\hline \multicolumn{1}{c}{ Вопросы } & \multicolumn{1}{c}{ Ответы } \\
Что такое гемоторакс? & $\begin{array}{l}\text { Скопление крови в плевральной } \\
\text { полости. }\end{array}$ \\
\hline Формы гемоторакса: & По причине - травматический, \\
& послеоперационный, деструктивные \\
& и неопластические процессы \\
& лёгкого; \\
& По степени распространённости: \\
& малый (в пределахсинуса), средний, \\
& большой и тотальный - является \\
& причиной развития шока;
\end{tabular}




\begin{tabular}{|c|c|}
\hline Вопросы & Ответы \\
\hline & $\begin{array}{l}\text { - По наличию осложнений - } \\
\text { свернувшийся, } \\
\text { осумкованный. }\end{array}$ \\
\hline Причины и факторы риска: & $\begin{array}{l}\text { Травмы груди, внутриплевральные } \\
\text { диагностические } \\
\begin{array}{l}\text { манипуляции, } \\
\text { деструктивные и } \\
\text { процессы лёгкого. }\end{array} \\
\text { опеоебные }\end{array}$ \\
\hline Патогенез: & $\begin{array}{l}\text { Повреждение грудной } \\
\text { внутригрудных сосудов и органов } \\
\text { плевральной полости. }\end{array}$ \\
\hline Особенности клинического течения: & $\begin{array}{l}\text { В большинстве случаев имеет острое } \\
\text { течение, при несвоевременном } \\
\text { лечении приводит к развитию } \\
\text { осложнений. }\end{array}$ \\
\hline Осложнения: & $\begin{array}{l}\text { Геморрагический } \quad \text { шок, } \\
\text { недоегочная } \\
\text { свернувшийся гемоторакс. }\end{array}$ \\
\hline Клинические признаки: & $\begin{array}{l}\text { Боль в груди, одышка, гиповентиляция, } \\
\text { шок, г гипотензия, } \\
\text { перкутного звука. }\end{array}$ \\
\hline $\begin{array}{l}\text { У каких пациентов можно заподозрить } \\
\text { гемоторакс? }\end{array}$ & У всех пострадавших с травмой груди. \\
\hline Диагностика: & $\begin{array}{l}\text { Рентгенологическое исследование, УЗИ, } \\
\text { КТ, пункция плевральной полости. }\end{array}$ \\
\hline Лабораторные признаки: & Нет специфических признаков. \\
\hline $\begin{array}{l}\text { Признаки диагностической } \\
\text { визуализации: }\end{array}$ & $\begin{array}{l}\text { Наличие жидкости в плевральной } \\
\text { полости. }\end{array}$ \\
\hline
\end{tabular}




\begin{tabular}{|c|c|}
\hline Вопросы & Ответы \\
\hline Данные других методов исследования: & $\begin{array}{l}\text { Получение крови при пункции или } \\
\text { дренировании плевральной полости. }\end{array}$ \\
\hline Диагностические критерии: & $\begin{array}{l}\text { - Наличие жидкости в плевральной } \\
\text { полости, подтверждённое клинико- } \\
\text { инструментальным обследованием: } \\
\text { одышка, отсутствие дыхательных } \\
\text { шумов, притупление перкуторного } \\
\text { звука, визуализация жидкости в } \\
\text { плевральной полости при } \\
\text { рентгенологическом исследовании, } \\
\text { УзИи кт. } \\
\text { Получение крови при пункции и } \\
\text { дренировании плевральной } \\
\text { полости. }\end{array}$ \\
\hline Методы лечения: & $\begin{array}{l}\text { Первичной лечебной процедурой } \\
\text { является дренирование плевральной } \\
\text { полости. }\end{array}$ \\
\hline Показания к хирургическому лечению: & $\begin{array}{l}\text { Массивное, } \\
\text { внутриплевральное } \\
\text { (выделение более } 1500 \text { мл крови при } \\
\text { первичном дренировании плевральной } \\
\text { полости и более } 200 \text { мл крови в течение } \\
1 \text { часа). }\end{array}$ \\
\hline $\begin{array}{l}\text { Виды хирургических операции при } \\
\text { гемотораксе: }\end{array}$ & $\begin{array}{l}\text { Перевязка повреждённых сосудов, } \\
\text { ушивание раны лёгкого, лобэктомия, } \\
\text { пульмонэктомия. }\end{array}$ \\
\hline
\end{tabular}




\section{ОПУХОЛИ ПЛЕВРЫ}

- Опухоли плевры делятся на 2 группы: первичные (локальная мезотелиома, диффузная злокачественная мезотелиома) и вторичные (метастатические).

- Локальная мезотелиома развивается из субплевральной фиброзной ткани, в большинстве случаев доброкачественная. Диагноз уточняется биопсией. Лечение - хирургическое (радикальная резекция).

- Диффузная злокачественная мезотелиома развивается из мезотелия плевры.

- Проявляется признаками поражения лёгких (боль в груди, кашель, одышка). Характеризуется фиброзным разрастанием, утолщением плевры и скоплением жидкости в плевральной полости.

- Диагноз подтверждается на основе данных биопсии.

- Лечение требует мультидисциплинарного подхода (химиорадиотерапия, хирургическое лечение, радиотерапия).

\section{Вопросы и ответы по опухолям плевры}

\begin{tabular}{|c|c|}
\hline Вопросы & Ответы \\
\hline Что такое мезотелиома? & $\begin{array}{l}\text { Первичная неоплазия, исходящая из } \\
\text { плевры. }\end{array}$ \\
\hline Формы мезотелиомы: & $\begin{array}{l}\text { Локальная (доброкачественная - 70\%), } \\
\begin{array}{l}\text { диффузная } \\
\text { злокачественная). }\end{array}\end{array}$ \\
\hline Факторы риска: & $\begin{array}{l}\text { Табакокурение, интенсивное } \\
\text { загрязнение атмосферного воздуха } \\
\text { асбестом и силикатом. }\end{array}$ \\
\hline Клинические признаки: & $\begin{array}{l}\text { При локальной форме - боль в груди, } \\
\text { одышка, боли и отёки в суставах. } \\
\text { При диффузной форме - боль в груди, } \\
\text { слабость, кашель, похудание. }\end{array}$ \\
\hline
\end{tabular}




\begin{tabular}{|c|c|}
\hline & $\begin{array}{l}\text { Скопление жидкости в плевральной } \\
\text { полости: при локальной форме у 10- } \\
\text { 15\%, при диффузной - у 75\%. }\end{array}$ \\
\hline Диагностика: & $\begin{array}{l}\text { KT, цитологическое исследование } \\
\text { пунктата плевры и экссудата, биопсия. }\end{array}$ \\
\hline $\begin{array}{l}\text { Признаки диагностической } \\
\text { визуализации: }\end{array}$ & $\begin{array}{l}\text { Утолщение плевры, наличие опухоли и } \\
\text { жидкости в плевральной полости. }\end{array}$ \\
\hline Показания к хирургическому лечению: & $\begin{array}{l}\text { Опухоль имеет одностороннюю } \\
\text { локализацию и состояние больного } \\
\text { операбельное. }\end{array}$ \\
\hline Виды оперативных вмешательств: & $\begin{array}{l}\text { Радикальная } \\
\text { пневмонэктомия, } \\
\text { декортикация. }\end{array}$ \\
\hline $\begin{array}{l}\text { Методы лечения локальной } \\
\text { мезотелиомы: }\end{array}$ & Радикальная резекция. \\
\hline $\begin{array}{l}\text { Методы лечения диффузной } \\
\text { мезотелиомы: }\end{array}$ & $\begin{array}{l}\text { При операбельных } \rightarrow \text { случаях: } \\
\text { химиотерапия } \rightarrow \text { операция } \rightarrow \\
\text { радиотерапия. }\end{array}$ \\
\hline & $\begin{array}{l}\text { При неоперабельных случаях: } \\
\text { паллиативное дренирование } \\
\text { плевральной полости, химиотерапия. }\end{array}$ \\
\hline Прогноз: & $\begin{array}{l}\text { При локальной мезотелиоме - } \\
\text { неблагоприятен. } \\
\text { При диффузной форме - после } \\
\text { установления диагноза, выживаемость } \\
\text { составляет около } 1 \text { года. }\end{array}$ \\
\hline
\end{tabular}




\section{СПИСОК ЛИТЕРАТУРЫ}

- Ağayev B.A. Cərrahi xəstəliklər. Bakı 2010.

- Blackbourne LH. Surgical Recall. 6th edition, 2012, LWW, Philadelphia

- Doherty GM. Current Diagnosis and Treatment: Surgery, $13^{\text {th }}$ edition, 2010, Lang International Edition.

- Omiraslanov D.T., Qazıyev A.Y. Onkologiya. Bakı, 2010.

- Issayev H.B.Cərrahi xəstəliklərin patofizologiyası. Bakı 2005

- Klingensmith ME, Aziz A, Bharat A, FoxAC, Porembka MR. The Washington Manual of Surgery, $6^{\text {th }}$ edition, 2012, LWW, Philadelphia.

- Medscape, http://www.medscape.com

- Oxford Handbook of Clinical Surgery, 3rd edition, 2011, Oxford Press

- Sayek i. Sayek Temel Cerrahi 1-2. 4-cü baskı, 2016, Güneş Tıp Kitabevleri.

- UpToDate, http://www.uptodate.com

- Гостищев B.K. Общая хирургия. GEOTAR-Media, 2019 


\section{ХИРУРГИЧЕСКИЕ БОЛЕЗНИ}

Н.Ю. Байрамов

\section{Хирургические заболевания грудной стенки}

Н.Ю. Байрамов, М. Г. Махмудов, Ф.А. Гахраманова

Перевод: Н.Ю. Байрамов, С.А. Алиев, М.Р.Гусейнова 


\section{ЛЁГОЧНАЯ ГРЫЖА}

- Лёгочная грыжа - это выпячивание лёгочной ткани в подкожную клетчатку через врождённые или приобретённые дефекты грудной стенки.

- Клинически проявляется наличием подкожного образования мягкой консистенции, которое изменяется в размере во время дыхания.

- Диагноз ставится на основании рентгенологического исследования и КТ.

- В лёгких случаях рекомендуется наблюдение, в более тяжёлых же хирургическое лечение.

\section{Вопросы и ответы по лёгочной грыже}

\begin{tabular}{|c|c|}
\hline Вопросы & Ответы \\
\hline Что такое лёгочная грыжа? & $\begin{array}{llr}\text { Выпячивание } & \text { лёгочной } & \text { ткани в } \\
\text { подкожную } & \text { клетчатку } & \text { через } \\
\text { врождённые } & \text { или приобретённые } \\
\text { дефекты грудной стенки. }\end{array}$ \\
\hline Этиология и факторы риска: & $\begin{array}{l}\text { - Травмы; } \\
\text { - Заболевания и хирургические } \\
\text { операции; } \\
\text { - Острый кашель; } \\
\text { - Тяжёлый физический труд; } \\
\text { - Врождённая деформация грудной } \\
\text { стенки; } \\
\text { - Хроническое применение } \\
\text { стероидов. }\end{array}$ \\
\hline Клинические признаки: & $\begin{array}{l}\text { - Острая боль при кашле и чихании; } \\
\text { - Одышка и затруднение дыхания; } \\
\text { - Чувствительность, припухлость в } \\
\text { определённой части грудной стенки; } \\
\text { - Высокая температура. }\end{array}$ \\
\hline
\end{tabular}




\begin{tabular}{|ll|}
\hline \multicolumn{1}{|c|}{ Вопросы } & \multicolumn{1}{c|}{ Ответы } \\
\hline Диагностика: & Рентгенологическое исследование, КТ. \\
\hline Лабораторные признаки: & Нет специфических показателей. \\
\hline Методы лечения: & $\begin{array}{l}\text { Консервативное лечение (постельный } \\
\text { режим, } \\
\text { анальгетики, } \\
\text { препараты). }\end{array}$ \\
\hline Показания к операции: & противокашлевые \\
\hline Методы хирургического лечения: & Ауто-или аллопластика. \\
\hline
\end{tabular}




\section{ОСТЕОМИЕЛИТ ГРУДИНЫ И РЁБЕР}

- Остеомиелит грудины и рёбер развивается в результате травм груди и оперативных вмешательств на грудной стенке и органах плевральной полости.

- Диагноз ставится на основании клинической картины и инструментальных методов исследований.

- Лечение в острой фазе заключается во вскрытии гнойника, некрэктомии в сочетании с антибиотикотерапией. При хроническом остеомиелите со свищом и наличием секвестра, выполняют резекцию ребра.

\section{Вопросы и ответы по остеомиелиту рёбер и грудины}

\begin{tabular}{|c|c|}
\hline Вопросы & Ответы \\
\hline $\begin{array}{l}\text { Что собой представляет остеомиелит } \\
\text { костей грудной клетки? }\end{array}$ & $\begin{array}{l}\text { Гнойно-воспалительный } \\
\text { грудины и рёбер. }\end{array}$ \\
\hline Этиология и факторы риска: & $\begin{array}{l}\text { Операции на грудной клетке, травмы } \\
\text { груди. }\end{array}$ \\
\hline Клинические признаки: & $\begin{array}{l}\text { Тупые боли, наличие гиперемии и } \\
\text { опухоли на грудной клетке, выделения } \\
\text { различного характера, высокая } \\
\text { температура. }\end{array}$ \\
\hline Диагностика: & $\begin{array}{l}\text { Рентгенологическое исследование, КТ, } \\
\text { МРТ, фистулография. }\end{array}$ \\
\hline $\begin{array}{l}\text { Признаки инструментальной } \\
\text { визуализации: }\end{array}$ & $\begin{array}{l}\text { Деструкция рёбер, грудины, } \\
\text { секвестрация. }\end{array}$ \\
\hline Методы лечения: & Некрэктомия, антибиотикотерапия. \\
\hline
\end{tabular}




\section{НОВООБРАЗОВАНИЯ ГРУДНОЙ КЛЕТКИ}

- Новообразования грудной клетки могут развиваться из различных структур (мышечной, костно-хрящевой ткани) груди и делятся на доброкачественные и злокачественные.

- Из доброкачественных опухолей наиболее часто встречается липома, из злокачественных саркома.

- Для уточнения диагноза проводят рентгенологическое исследование, КТ, биопсию.

- Лечение - хирургическое, проводится радикальная резекция.

\section{Вопросы и ответы по новообразованиям грудной клетки}

\section{Вопросы}

Какие клинико-анатомические формы Доброкачественные и злокачественные. опухоли грудной клетки различают?

Какие виды доброкачественных опухолей различают?
Липома, гемангиома, кавернозная лимфангиома, хондрома, остеома, эозинофильная гранулёма,

остеобластокластома.

\section{Наиболее часто встречающаяся форма Липома.} доброкачественной опухоли:

\section{Клинические признаки} доброкачественных новообразований:

Методы лечения:
Наличие безболезненного образования, мягкой эластической консистенции. По мере увеличения размеров липомы, могут развиваться симптомы сдавления нервно-сосудистого пучка.

Хирургическое - удаление липомы в пределах здоровых тканей. 


\begin{tabular}{|c|c|}
\hline Вопросы & Ответы \\
\hline $\begin{array}{l}\text { Какие опухоли относятся к } \\
\text { злокачественным новообразованиям } \\
\text { грудной клетки? }\end{array}$ & $\begin{array}{l}\text { Фибросаркома, остеосаркома, } \\
\text { хондросаркома, ретикулосаркома, } \\
\text { ангиолейомиосаркома, } \\
\text { гемангиоперицитарная } \\
\text { метастатические опухоли. }\end{array}$ \\
\hline $\begin{array}{l}\text { Клинические признаки } \\
\text { злокачественных новообразований: }\end{array}$ & $\begin{array}{l}\text { На ранних этапах - бессимптомное } \\
\text { течение. С ростом опухоли проявляются } \\
\text { дискомфорт в грудной клетке, боли, } \\
\text { высокая температура, потеря аппетита, } \\
\text { похудение, деформация грудной } \\
\text { клетки. }\end{array}$ \\
\hline Диагностика: & $\begin{array}{l}\text { Рентгенологическое исследование, КТ, } \\
\text { МРТ, биопсия. }\end{array}$ \\
\hline Методы лечения: & $\begin{array}{l}\text { Хирургическое лечение, лучевая } \\
\text { терапия, химиотерапия. }\end{array}$ \\
\hline
\end{tabular}




\section{БОЛЕЗНЬ МОНДОРА}

- Болезнь Мондора - тромбофлебит поверхностных вен молочной железы и грудной стенки.

- Встречается у пациентов в возрасте 30-60 лет. Заболевание в большинстве случаев развивается односторонне.

- В 50-60\% случаев этиология неизвестна. В структуре этиологических причин наиболее часто встречаются травмы, операции на грудной клетке, рак молочной железы, радиация.

- Заболевание начинается с появления припухлости, гиперемии и боли в молочной железе и грудной стенки. Симптомы заболевания длятся 2-8 нед.

- Тромбоэмболия и осложнения не характерны.

- Для уточнения диагноза показаны маммография, УзИ, Уз-допплерография. При Уз-допплерографии отмечается отсутствие кровотока в поверхностных венах молочной железы, грудной стенки.

- Лечение - консервативное (тепловые процедуры, антибиотики, анальгетики).

\section{Вопросы и ответы по болезни Мондора}

\begin{tabular}{|c|c|}
\hline Вопросы & Ответы \\
\hline $\begin{array}{l}\text { Что представляет собой болезнь } \\
\text { Мондора? }\end{array}$ & $\begin{array}{l}\text { Острый тромбофлебит поверхностных } \\
\text { вен молочной железы и грудной клетки. }\end{array}$ \\
\hline Этиология и факторы риска: & 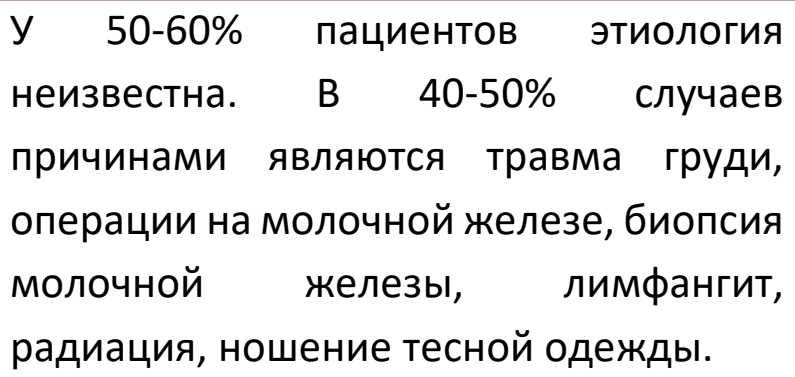 \\
\hline Клинические признаки: & $\begin{array}{l}\text { На наружной поверхности молочной } \\
\text { железы отмечаются гиперемия, } \\
\text { припухлость, боль. }\end{array}$ \\
\hline
\end{tabular}




\begin{tabular}{|ll|}
\hline \multicolumn{1}{|c|}{ Вопросы } & \multicolumn{1}{c|}{ Ответы } \\
\hline Диагностика: & Маммография, Уз-допплерография. \\
\hline $\begin{array}{l}\text { Признаки инструментальной } \\
\text { визуализации: }\end{array}$ & Отсутствие кровотока в поверхность \\
\hline Методы лечения: & венахпри Уз-допплерографии. \\
\hline & $\begin{array}{l}\text { Консервативное (тепловые процедуры, } \\
\text { антибиотики, анальгетики). }\end{array}$ \\
\hline
\end{tabular}




\section{СИНДРОМ ТИТЦЕ}

- Синдром Титце - остеохондропатия и асептическое воспаление грудиннорёберного и грудинно-подключичного сочленения.

- Заболевания встречается среди пациентов 20-40-летнего возраста. Нередко наблюдается у спортсменов.

- Диагностика осуществляется на основании рентгенологического исследования и KT.

- Лечение в основном консервативное, при неэффективности которого выполняют удаление поражённого хряща и части ребра.

\section{Вопросы и ответы по синдрому Титце}

\begin{tabular}{|c|c|}
\hline Вопросы & Ответы \\
\hline Что такое синдром Титце? & $\begin{array}{l}\text { Остеохондропатия и асептическое } \\
\text { воспаление грудинно-рёберного и } \\
\text { грудинно-подключичного сочленений. }\end{array}$ \\
\hline Этиология и факторы риска: & Травмы, тяжёлый физический труд. \\
\hline Особенность клинического течения: & $\begin{array}{l}\text { Протекает с ремиссиями и частыми } \\
\text { обострениями. }\end{array}$ \\
\hline Клинические признаки: & Боль, припухлость, гиперемия. \\
\hline Диагностика: & $\begin{array}{l}\text { Рентгенологическое исследование, КТ, } \\
\text { МРТ, Узи. }\end{array}$ \\
\hline Лабораторные признаки: & Нет специфических показателей. \\
\hline $\begin{array}{l}\text { Признаки инструментальной } \\
\text { визуализации: }\end{array}$ & $\begin{array}{l}\text { Структурные изменения хрящевой } \\
\text { части - утолщение периостальной } \\
\text { ткани, сужение межрёберного } \\
\text { пространства. }\end{array}$ \\
\hline Методы лечения: & Консервативное и хирургическое. \\
\hline
\end{tabular}




\section{Вопросы}

Показания к операции:

Методы хирургического лечения:

\section{Ответы}

Неэффективность консервативного лечения.

Хондрэктомия.

\section{СПИСОК ЛИТЕРАТУРЫ}

- Ağayev B.A. Cərrahi xəstəliklər. Bakı 2010.

- Blackbourne LH. Surgical Recall. 6th edition, 2012, LWW, Philadelphia

- Doherty GM. Current Diagnosis and Treatment: Surgery, $13^{\text {th }}$ edition, 2010, Lang International Edition.

- Omiraslanov Ә.T., Qazıyev A.Y. Onkologiya. Bakı, 2010.

- İsayev H.B. Cərrahi xəstəliklərin patofizologiyası. Bakı 2005

- Klingensmith ME, Aziz A, Bharat A, Fox AC, Porembka MR. The Washington Manual of Surgery, $6^{\text {th }}$ edition, 2012, LWW, Philadelphia.

- McNally PR. GI/Liver Secrets Plus. 4th edition. Mosby, Elsevier, 2010

- Medscape, http://www.medscape.com

- Oxford Handbook of Clinical Surgery, 3rd edition, 2011, Oxford Press

- Sayek I. Sayek Temel Cerrahi 1-2. 4-cü baskı, 2016, Güneş Tıp Kitabevleri.

- Topçubaşov M.A. Xüsusi cərrahlıq. Bakı, 1979

- UpToDate, http://www.uptodate.com

- Гостищев В.К. Общая хирургия. GEOTAR-Media, 2019 


\section{ХИРУРГИЧЕСКИЕ БОЛЕЗНИ}

Н.Ю. Байрамов

\section{Хирургические заболевания средостения}

Н.Ю. Байрамов, Н.М. Хыдырова, Ф.А. Гахраманова

Перевод: Н.Ю. Байрамов, С.А. Алиев, М.Р.Гусейнова 


\section{ОСТРЫЙ МЕДИАСТИНИТ}

- Острый медиастинит - гнойное воспаление средостения.

- Нозологическими причинами острого медиастинита являются гнойновоспалительные процессы шеи, органов грудной клетки и брюшной полости, последствия травмы груди и живота. Более чем в $50 \%$ случаев причиной является смешанная аэробно-анаэробная инфекция, реже инфекция исходит из ретрофарингеальных абсцессов, ятрогенных повреждений пищевода, лимфаденита шейных лимфатических узлов и острого тиреоидита.

- Клиническая картина острого медиастинита характеризуются болью в грудной клетке, гектической температурой, ознобом, одышкой, симптомами SIRS и сепсиса.

- Несвоевременное хирургическое лечение приводит к летальному исходу.

- Для уточнения диагноза необходимо КТ. К диагностическим критериям относятся отёк тканей, скопление жидкости в средостение и плевральную полость, эмфизема средостения и шеи, признаки экстравазации контрастного вещества.

- Лечение - хирургическое и базируется на проведении неотложных мероприятий, состоящих из 4-х принципов: антибиотикотерапия, дренирование средостения, санация (ликвидация) первичного очага и заместительная терапия.

\section{Вопросы и ответы по острому медиастиниту}

\begin{tabular}{|c|c|}
\hline Вопросы & Ответы \\
\hline Что такое острый медиастинит? & $\begin{array}{l}\text { Острое гнойное } \\
\text { средостения. }\end{array}$ \\
\hline $\begin{array}{l}\text { Какие формы медиастинита } \\
\text { различают? }\end{array}$ & $\begin{array}{l}\text { По степени распространения - } \\
\text { ограниченный (абсцесс) и диффузный. }\end{array}$ \\
\hline & $\begin{array}{l}\text { По механизму развития - первичное } \\
\text { инфицирование, } \\
\text { распространение из отдалённых очагов. }\end{array}$ \\
\hline
\end{tabular}




\begin{tabular}{|c|c|}
\hline Вопросы & Ответы \\
\hline Причины и факторы риска: & $\begin{array}{l}\text { Перфорация пищевода, травмы груди и } \\
\text { внутригрудные оперативные } \\
\text { вмешательства, } \\
\text { воспалительные процессы шеи, органов } \\
\text { плевральной полости. }\end{array}$ \\
\hline Патогенез медиастинита: & $\begin{array}{l}\text { Порочный круг, } \\
\text { «повреждение } \quad \text { включающий } \\
\text { гнойной инфекции - повреждение». }\end{array}$ \\
\hline Особенность клинического течения: & $\begin{array}{ll}\text { Характеризуется } & \text { тяжелым } \\
\text { (фульминантным) течением. } & \end{array}$ \\
\hline Осложнения медиастинита: & $\begin{array}{l}\text { Эмпиема плевры, пневмоторакс, } \\
\text { сепсис. }\end{array}$ \\
\hline Клинические признаки: & $\begin{array}{l}\text { Боль в груди, озноб, высокая } \\
\text { (гектическая) температура, эмфизема и } \\
\text { крепитация в области шеи, затруднение } \\
\text { дыхания, вынужденное положение } \\
\text { тела. }\end{array}$ \\
\hline $\begin{array}{l}\text { У каких пациентов можно } \\
\text { заподозрить острый медиастинит? }\end{array}$ & $\begin{array}{l}\text { При наличии в } \\
\text { эндоскопического анамнезе } \\
\text { пищевода (ятрогенный фактор), } \\
\text { операций на органах плевральной } \\
\text { полости, воспалительные процессы } \\
\text { шеи, органов грудной клетки и } \\
\text { брюшной полости. }\end{array}$ \\
\hline Методы диагностики: & KT. \\
\hline $\begin{array}{l}\text { Лабораторные признаки } \\
\text { медиастинита: }\end{array}$ & Признаки SIRS и сепсиса. \\
\hline
\end{tabular}




\begin{tabular}{|c|c|}
\hline Вопросы & Ответы \\
\hline $\begin{array}{l}\text { Признаки диагностической } \\
\text { визуализации: }\end{array}$ & $\begin{array}{l}\text { Обнаружение на КТ отёка, жидкости, } \\
\text { эмфиземы средостения, экстравазация } \\
\text { контрастного вещества. }\end{array}$ \\
\hline $\begin{array}{l}\text { Диагностические критерии } \\
\text { медиастинита: }\end{array}$ & 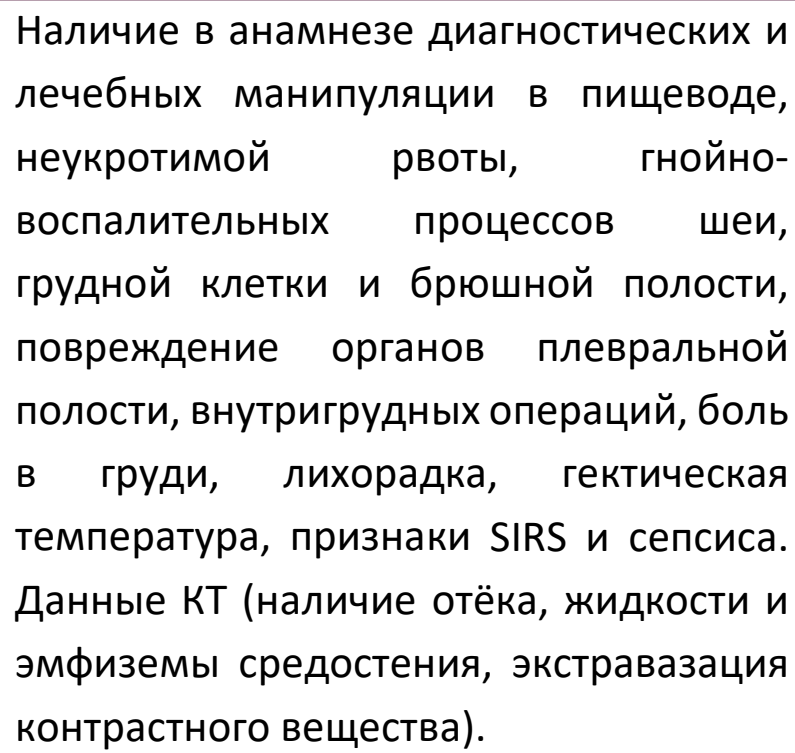 \\
\hline Принципы лечения: & $\begin{array}{l}\text { - Поддерживающая терапия при } \\
\text { сепсисе; } \\
\text { - Антибиотикотерапия; } \\
\text { - Дренирование и санация гнойного } \\
\text { очага; } \\
\text { - Ликвидация первичного гнойного } \\
\text { очага. }\end{array}$ \\
\hline Показание к операци: & Острый гнойный медиастинит. \\
\hline Виды операций: & $\begin{array}{l}\text { При перфорации пищевода, трахеи и } \\
\text { бронхов в зависимости от конкретных } \\
\text { ситуаций - ушивание участков } \\
\text { перфорации, стентирование, резекция } \\
\text { повреждённых участков, дренирование } \\
\text { средостения и плевральной полости. }\end{array}$ \\
\hline Прогноз: & Летальность при интенсивном \\
\hline
\end{tabular}




\begin{tabular}{|ll}
\multicolumn{1}{c}{ Вопросы } & \multicolumn{1}{c}{ Ответы } \\
\hline Как можно охарактеризовать & Не стоит забывать о медиастините у \\
клиническую особенность острого & пациентов с сепсисом, у которых резко \\
медиастинита? & ухудшается состояние и наблюдаются \\
& болипри движении головой назад. \\
\hline
\end{tabular}




\section{ХРОНИЧЕСКИЙ МЕДИАСТИНИТ}

- Хронический медиастинит является гранулематозным и склерозирующим воспалительным процессом, характеризуется прогрессирующим разрастанием фиброзной ткани в средостении и развивается на фоне хронических инфекций.

- Встречается относительно редко и характеризуется прогрессивным течением.

- Этиологическими причинами чаще являются гистоплазмоз и туберкулёз. Встречаются и идиопатические (саркоидоз, аутоиммунные) формы заболевания.

- Болезнь чаще протекает бессимптомно. Клинические признаки обусловлены сдавлением и уменьшением просвета органов средостения (верхней полой вены, бронхов, лёгочных сосудов и пищевода). Наиболее частыми проявлениями болезни являются кашель, одышка, затруднение дыхания, синдром компрессии верхней полой вены. Значительно реже наблюдаются дисфагия, боль в груди, выделение кровянистой мокроты.

- Для уточнения диагноза наиболее информативным методом является КТ (МРТ), позволяющая выявить распространённый фиброз, гранулёму и отложения кальция в ней (кальцификация), сдавления анатомических структур средостения.

- В арсенале лечения применяют консервативную терапию, стентирование и хирургическое лечение. Медикаментозное лечение, включая стероидные гормоны, практически неэффективно. Оперативные вмешательства при склерозирующем (хроническом) медиастините рискованны и опасны, поэтому их следует рекомендовать с осторожностью для пациентов с прогрессирующим фиброзом средостения.

\section{Вопросы и ответы по хроническому медиастиниту}

\begin{tabular}{|ll}
\multicolumn{1}{c}{ Вопросы } & \multicolumn{1}{c}{ Ответы } \\
Что такое хронический медиастинит? & $\begin{array}{l}\text { Склерозирующее и гранулематозное } \\
\text { воспаление } \\
\text { характеризующееся прогрессирующим } \\
\text { разрастанием фиброзной ткани. }\end{array}$ \\
\end{tabular}




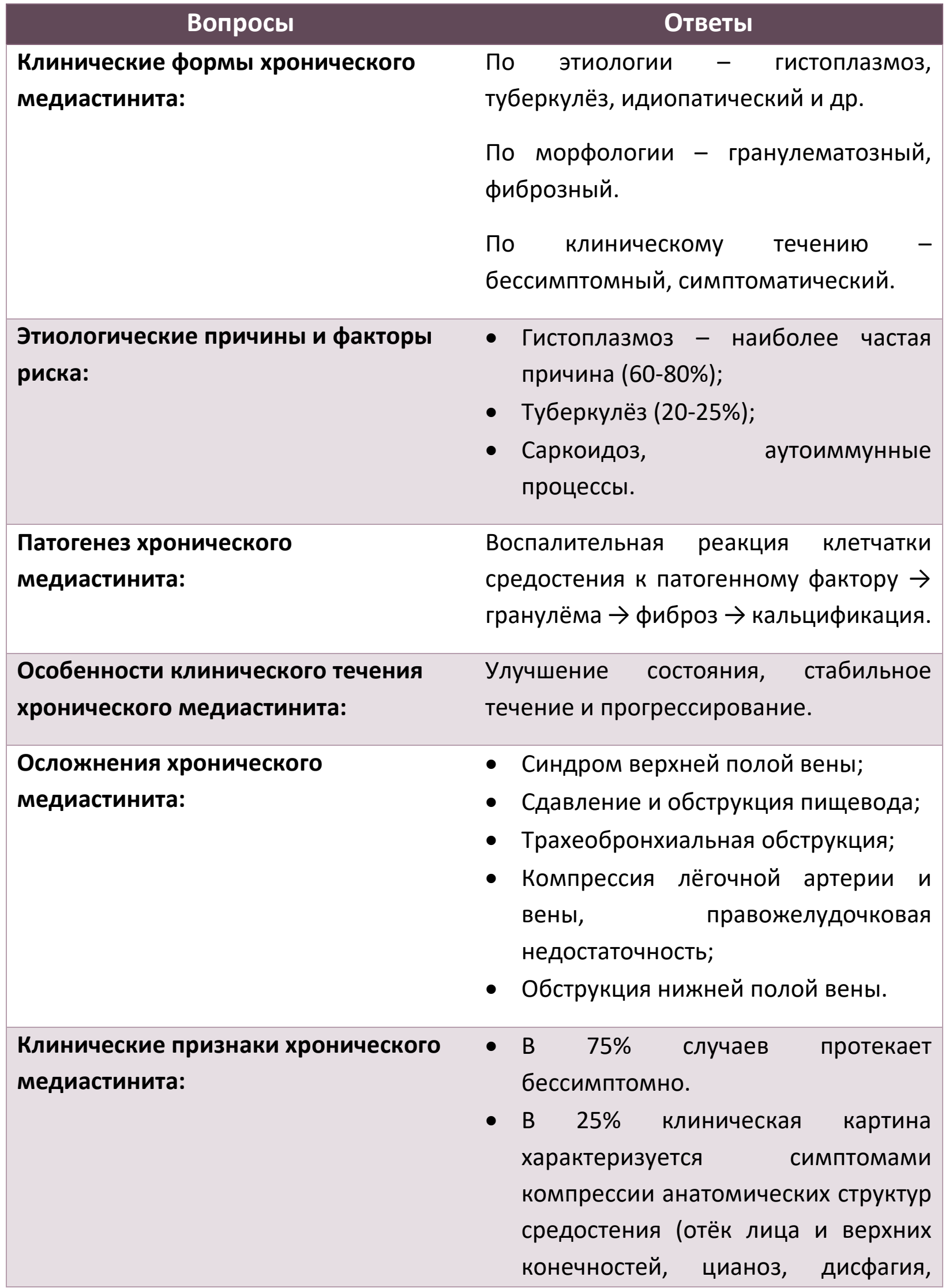




\begin{tabular}{|c|c|}
\hline Вопросы & Ответы \\
\hline & $\begin{array}{l}\text { одышка, кашель, } \\
\text { правожелудочковая } \\
\text { недостаточность). }\end{array}$ \\
\hline $\begin{array}{l}\text { На основании каких данных можно } \\
\text { заподозрить хронический } \\
\text { медиастинит? }\end{array}$ & $\begin{array}{l}\text { Наличие признаков сдавления } \\
\text { жизненноважных анатомических } \\
\text { структур средостения, признаки } \\
\text { компрессии органов средостения на КТ, } \\
\text { отсутствие другой патологии. }\end{array}$ \\
\hline $\begin{array}{l}\text { Диагностика хронического } \\
\text { медиастинита: }\end{array}$ & KT. \\
\hline $\begin{array}{l}\text { Лабораторные признаки хронического } \\
\text { медиастинита: }\end{array}$ & Диагностической значимости не имеют. \\
\hline $\begin{array}{l}\text { Признаки диагностической } \\
\text { визуализации: }\end{array}$ & $\begin{array}{l}\text { Наличие распространённого фиброза, } \\
\text { гранулёмы и отложений кальция в ней } \\
\text { (точечных кальцинатов), сдавление } \\
\text { анатомических структур средостения. }\end{array}$ \\
\hline $\begin{array}{l}\text { Диагностические критерии } \\
\text { хронического медиастинита: }\end{array}$ & $\begin{array}{l}\text { - Симптомы компрессии и обструкции } \\
\text { анатомических } \\
\text { средостения; } \\
\text { - } \text { обнаруктур } \\
\text { и гранулёмы с с участками } \\
\text { кальцификации при КТ. }\end{array}$ \\
\hline $\begin{array}{l}\text { Методы лечения хронического } \\
\text { медиастинита: }\end{array}$ & $\begin{array}{l}\text { - Консервативное (антибиотики, } \\
\text { антифунгальные препараты, } \\
\text { кортикостероиды); } \\
\text { - Стентирование - при обструкции } \\
\text { органов средостения; } \\
\text { - Хирургическое. }\end{array}$ \\
\hline
\end{tabular}




\begin{tabular}{|ll|}
\hline \multicolumn{1}{|c|}{ Вопросы } & \multicolumn{2}{c|}{ Ответы } \\
\hline Показания к операции: & $\begin{array}{l}\text { Наличие клинических признаков } \\
\text { компрессии и обструкции органов } \\
\text { средостения. }\end{array}$ \\
\hline Виды оперативных вмешательств: & $\begin{array}{l}\text { Резекция у участка обструкции, } \\
\text { формирование анастомоза, вено- } \\
\text { венозные шунтирующие операции. }\end{array}$ \\
\hline
\end{tabular}




\section{СИНДРОМ ВЕРХНЕЙ ПОЛОЙ ВЕНЫ}

- Под синдромом верхней полой вены подразумевается симптомокомплекс, развивающийся вследствие застоя в верхней полой вене.

- Наиболее частыми нозологическими причинами являются опухоли и тромбозы. К редким этиологическим факторам относятся травмы и хронический медиастинит.

- Синдром верхней полой вены имеет 3 клинические формы: бессимптомное течение, острый и хронический застой.

- Клинические проявления характеризуются отёком головного мозга и глоточногортанной зоны, дисфагией, отёком лица и шеи, цианозом, расширением вен.

- Для подтверждения диагноза необходима КТ-ангиография.

- При жизнеугрожающей острой форме первоначально с целью уменьшения венозного застоя выполняется стентирование вены. В дальнейшем уточняется причина заболевания и проводится этиотропное лечение.

\section{Вопросы и ответы по синдрому верхней полой вены}

\begin{tabular}{|c|c|}
\hline Вопросы & Ответы \\
\hline $\begin{array}{l}\text { Что такое «синдром верхней полой } \\
\text { вены»? }\end{array}$ & $\begin{array}{l}\text { Симптомокомплекс, развивающийся } \\
\text { вследствие застоя в верхней полой вене. }\end{array}$ \\
\hline Клинические формы: & $\begin{array}{l}\text { - Бессимптомный; } \\
\text { - Симптоматический: } \\
\text { хронический. }\end{array}$ \\
\hline Причины и факторы риска: & $\begin{array}{l}\text { Основными этиологическими причинами } \\
\text { являются злокачественные (60-80\%) и } \\
\text { доброкачественные опухоли, тромбоз, } \\
\text { травмы, хронический медиастинит. }\end{array}$ \\
\hline $\begin{array}{l}\text { В чём заключается патогенез } \\
\text { заболевания? }\end{array}$ & $\begin{array}{l}\text { Венозный застой и гипертензия } \rightarrow \text { отёк, } \\
\text { венозная ишемия. }\end{array}$ \\
\hline Особенности клинического течения: & Имеет острую и хроническую формь \\
\hline
\end{tabular}




\begin{tabular}{|c|c|}
\hline Вопросы & Ответы \\
\hline $\begin{array}{l}\text { Осложнения синдрома верхней полой } \\
\text { вены: }\end{array}$ & $\begin{array}{l}\text { - Отёк головного мозга, кома; } \\
\text { - Отёк глоточно-гортанной зоны, } \\
\text { кровотечение, асфиксия, дыхательная } \\
\text { недостаточность. } \\
\text { - Отёк верхних конечностей. }\end{array}$ \\
\hline Клинические признаки заболевания: & $\begin{array}{l}\text { - Признаки отёка мозга - головные боли, } \\
\text { сонливость, тошнота, рвота, нарушение } \\
\text { зрения, кома. } \\
\text { - Симптомы отёка глотки и гортани - } \\
\text { охриплость, дисфагия, асфиксия, } \\
\text { одышка. } \\
\text { - Пищеводные проявления - дисфагия, } \\
\text { кровотечение. } \\
\text { Отёчный синдром шеи, верхних } \\
\text { конечностей, расширение вен, цианоз, } \\
\text { отсутствие пульсации. } \\
\text { Плевральные симптомы. - гидроторакс. }\end{array}$ \\
\hline $\begin{array}{l}\text { У каких пациентов можно заподозрить } \\
\text { наличие синдрома верхней полой вены? }\end{array}$ & $\begin{array}{l}\text { При наличии симптомов венозного застоя } \\
\text { (расширение вен, венозная гипертензия) и } \\
\text { отёчного синдрома. }\end{array}$ \\
\hline Методы диагностики: & КТ-ангиография. \\
\hline Лабораторные признаки: & Специфических признаков нет. \\
\hline Признаки диагностической визуализации: & $\begin{array}{l}\text { Наличие обструкции в верхней полой вене } \\
\text { (тромбоз, опухолевая инвазия, сдавление). }\end{array}$ \\
\hline Диагностические критерии: & $\begin{array}{l}\text { - Клинические проявления венозного } \\
\text { застоя и отёчного синдрома; } \\
\text { - При КТ-ангиографии - сужение } \\
\text { просвета верхней полой вены. }\end{array}$ \\
\hline Методы лечения: & $\begin{array}{l}\text { Этиотропное лечение, восстановление } \\
\text { венозного кровотока, устранение отёчного } \\
\text { синдрома. }\end{array}$ \\
\hline
\end{tabular}




\section{Вопросы}

Показания к операци:

Варианты оперативных вмешательств:

Прогноз:

\section{Ответы}

Наличие резектабельных опухолей.

Резекция.

Зависит от исхода основного заболевания.

\section{СПИСОК ЛИТЕРАТУРЫ}

- Ağayev B.A. Cərrahi xəstəliklər. Bakı 2010.

- Blackbourne LH. Surgical Recall. 6th edition, 2012, LWW, Philadelphia

- Doherty GM. Current Diagnosis and Treatment: Surgery, $13^{\text {th }}$ edition, 2010, Lang International Edition.

- Omiraslanov Ә.T., Qazıyev A.Y. Onkologiya. Bakı, 2010.

- İsayev H.B. Cərrahi xəstəliklərin patofizologiyası. Bakı 2005

- Klingensmith ME, Aziz A, Bharat A, Fox AC, Porembka MR. The Washington Manual of Surgery, $6^{\text {th }}$ edition, 2012, LWW, Philadelphia.

- McNally PR. GI/Liver Secrets Plus. 4th edition. Mosby, Elsevier, 2010

- Medscape, http://www.medscape.com

- Oxford Handbook of Clinical Surgery, 3rd edition, 2011, Oxford Press

- Sayek I. Sayek Temel Cerrahi 1-2. 4-cü baskı, 2016, Güneş Tıp Kitabevleri.

- Topçubaşov M.A. Xüsusi cərrahlıq. Bakı, 1979

- UpToDate, http://www.uptodate.com

- Гостищев B.К. Общая хирургия. GEOTAR-Media, 2019 


\section{ХИРУРГИЧЕСКИЕ БОЛЕЗНИ}

Н.Ю. Байрамов

\section{Хирургические заболевания диафрагмы}

Н.Ю. Байрамов, С.А. Алиев, С.Ф. Рафиев, Ш.А. Мамедова

Перевод: Н.Ю. Байрамов, С.А. Алиев, М.Р.Гусейнова 


\section{ЗАБОЛЕВАНИЯ ДИАФРАГМЫ}

- Диафрагма - плоская перегородка, состоящая из сухожильно-мышечной структуры, разделяющая грудную и брюшную полости.

- Диафрагма выполняет 3 основные функции: участие в дыхании, повышение внутрибрюшного давления и ограничение плевральной полости от брюшной.

- $\mathrm{K}$ заболеваниям диафрагмы относятся грыжи, релаксация и редкие опухоли.

- Диафрагмальные грыжи - дислокация органов брюшной полости в плевральную через врождённые и приобретённые дефекты.

○ Различают врождённые, приобрётенные (скользящие, параэзофагеальные, смешанные) и посттравматические грыжи.

○ За исключением скользящей, все виды диафрагмальных грыж осложняются ущемлением, сдавлением органов плевральной полости.

О Основными симптомами скользящих грыж являются отрыжка, срыгивание, изжога, других - боль за грудиной с иррадиацией в область сердца, лопатку, левое плечо, одышка.

○ Диагностика скользящих грыж осуществляется эндоскопическим методом, других же форм - рентгенологически или с помощью КТ.

○ При неосложнённых формах скользящих грыж проводят консервативное лечение, направленное на снижение желудочно-пищеводного рефлюкса.

○ Основным методом лечения всех диафрагмальных грыж является хирургический, при скользящих грыжах проводят фундопликацию, при других формах - пластику с использованием синтетических (биологических) протезов.

- Релаксация диафрагмы - истончение и смещение её вместе с прилежащими к ней органами брюшной полости в плевральную.

○ Причиной является врождённая мышечная аплазия и повреждение диафрагмального нерва.

○ Релаксация может быть полной, когда весь купол перемещается в грудную полость, и частичной, когда перемещается её какой-либо отдел.

○ Ограниченная правосторонняя релаксация протекает бессимптомно. Левосторонняя релаксация проявляется симптомами, характерными для диафрагмальной грыжи.

○ Для диагностики применяют рентгенологическое исследование и КТ. 
○ При наличии выраженных клинических симптомов проводят хирургическое лечение, заключающееся в низведении перемещённых брюшных органов в нормальное положение и создании дупликатуры источённой диафрагмы или пластическим её укреплении синтетическим протезом.

- Опухоли диафрагмы - обычно вторичные. Первичные опухоли встречаются крайне редко и имеют в основном доброкачественную природу (фиброма, липома, нейрофиброма, лимфангиома, кисты и др.)

- Среди злокачественных новообразований чаще встречаются лейомиосаркома, фибросаркома и метастатические опухоли (аденокарциномы).

○ Опухоли размером менее 10 см, как правило, бессимптомны; при злокачественных же опухолях на первый план выходят признаки основного заболевания.

○ Диагностика базируется на данных клинических признаков и инструментальных методов исследований (рентгенологическое исследование, КT).

○ Лечение - хирургическая эксцизия.

\section{Вопросы и ответы по заболеваниям диафрагмы}

\begin{tabular}{|c|c|}
\hline Вопросы & Ответы \\
\hline Что такое диафрагма? & $\begin{array}{l}\text { Сухожильно-мышечная перегородка, } \\
\text { разделяющая плевральную и брюшную } \\
\text { полость. }\end{array}$ \\
\hline Функция диафрагмы: & $\begin{array}{l}\text { - Ограничивающая функция; } \\
\text { - Участие в дыхании; } \\
\text { - Повышение } \\
\text { давления. }\end{array}$ \\
\hline $\begin{array}{l}\text { Какие отверстия имеются в } \\
\text { диафрагме? }\end{array}$ & $\begin{array}{l}\text { Большие отверстия - через которые } \\
\text { проходят пищевод, аорта, нижняя } \\
\text { полая вена. }\end{array}$ \\
\hline & $\begin{array}{l}\text { Малые отверстия - парастернальное } \\
\text { (треугольник Морганьи, Ларрея), }\end{array}$ \\
\hline
\end{tabular}




\begin{tabular}{|c|c|}
\hline Вопросы & Ответы \\
\hline & $\begin{array}{l}\text { пояснично-рёберное } \quad \text { (пространство } \\
\text { Бохдалека). }\end{array}$ \\
\hline Виды диафрагмальных грыж: & $\begin{array}{l}\text { - Хиатальная (скользящая, } \\
\text { - Параэзофагеальная, смешанная); } \\
\text { • Парастернальная (грыжа Морганьи); } \\
\text { - Пояснично-рёберная } \\
\text { Бохдалека); } \\
\text { - Посттравматическая. }\end{array}$ \\
\hline Что такое хиатальная грыжа? & $\begin{array}{l}\text { Грыжа, формирующася из пищеводного } \\
\text { отверстия диафрагмы. }\end{array}$ \\
\hline Виды хиатальных грыж: & $\begin{array}{l}\text { - Скользящая; } \\
\text { - Парастериальная; } \\
\text { - Смешанная. }\end{array}$ \\
\hline Что такое скользящая грыжа? & $\begin{array}{l}\text { Формируется } \\
\text { веремещения кардиального отдела } \\
\text { желудка и гастроэзофагеального } \\
\text { соединения выше диафрагмы (через } \\
\text { пищеводное отверстие). }\end{array}$ \\
\hline $\begin{array}{l}\text { Частота встречаемости скользящих } \\
\text { грыж: }\end{array}$ & $\begin{array}{l}\text { Составляет } 90 \% \text { всех видов хиатальных } \\
\text { грыж. }\end{array}$ \\
\hline Симптомы скользящей грыжи: & $\begin{array}{l}\text { В большинстве случаев протекают } \\
\text { бессимптомно. Однако у пациентов } \\
\text { могут наблюдаться такие симптомы, как } \\
\text { загрудинные боли, } \\
\text { срыгивание, изжога. }\end{array}$ \\
\hline Диагностика: & $\begin{array}{l}\text { Рентгеноскопия, } \\
\text { манометрия. }\end{array}$ \\
\hline Осложнения: & $\begin{array}{l}\text { - Рефлюкс-эзофагит; } \\
\text { - Пищевод Баррета; }\end{array}$ \\
\hline
\end{tabular}




\begin{tabular}{|c|c|}
\hline Вопросы & Ответы \\
\hline & $\begin{array}{l}\text { - Рак; } \\
\text { - Стриктуры; } \\
\text { - Язва; } \\
\text { - Кровотечение; } \\
\text { - Аспирационная пневмония. }\end{array}$ \\
\hline Лечение: & $\begin{array}{l}\text { - В 85\% случаев- консервативное: } \\
\text { О Антациды; } \\
\text { ○ Ингибиторы протонных насосов, } \\
\text { блокаторы гистаминовых } \\
\text { рецепторов; } \\
\text { О Вертикальное положение тела } \\
\text { после приёма пищи; } \\
\text { О Питание малыми порциями; } \\
\text { О Не есть перед сном. } \\
\text { - При неэффективности консерва- } \\
\text { тивного лечения - хирургическое. }\end{array}$ \\
\hline Методы хирургического лечения: & $\begin{array}{l}\text { Лапароскопическая фундопликация - } \\
\text { Toupet или Nissen. }\end{array}$ \\
\hline Что такое параэзофагеальная грыжа? & $\begin{array}{l}\text { Перемещение части желудка (дна или } \\
\text { антрального отдела) и других органов в } \\
\text { плевральную полость } \\
\text { пищеводное отверстие. При этом } \\
\text { гастроэзофагеальное } \\
\text { остаётся на месте. }\end{array}$ \\
\hline Частота встречаемости: & Составляет 5\% всех хиатальных грыж. \\
\hline Клинические признаки: & $\begin{array}{l}\text { Явления острой и хронической } \\
\text { кишечной непроходимости, дисфагия, } \\
\text { странгуляция. }\end{array}$ \\
\hline Осложнения: & $\begin{array}{l}\text { Кровотечение, ущемление, } \\
\text { странгуляция, обструкция. }\end{array}$ \\
\hline
\end{tabular}




\begin{tabular}{|ll|}
\hline \multicolumn{1}{|c|}{ Вопросы } & \multicolumn{2}{c|}{ Ответы } \\
\hline Лечение: & Хирургическое. \\
\hline Что такое постравматическая грыжа? & $\begin{array}{l}\text { Формируется } \\
\text { диафрагмы. }\end{array}$ \\
\hline Что такое релаксация диафрагмы? & $\begin{array}{l}\text { Истончение и смещение её вместе с } \\
\text { прилежащими к ней органами } \\
\text { брюшной полости в плевральную. }\end{array}$ \\
\hline $\begin{array}{l}\text { Часто встречаемые опухоли } \\
\text { диафрагмы: }\end{array}$ & Вторичные. \\
\hline
\end{tabular}

\section{СПИСОК ЛИТЕРАТУРЫ}

- Ağayev B.A. Cərrahi xəstəliklər. Bakı 2010.

- Blackbourne LH. Surgical Recall. 4 edition, 2006, LWW, Philadelphia

- Doherty GM. Current Diagnosis and Treatment: Surgery, $13^{\text {th }}$ edition, 2010, Lang International Edition.

- Omiraslanov D.T., Qazıyev A.Y. Onkologiya. Bakı, 2010.

- İsayev H.B. Cərrahi xəstəliklərin patofizologiyası. Bakı 2005

- Klingensmith ME, Aziz A, Bharat A, Fox AC, Porembka MR. The Washington Manual of Surgery, $6^{\text {th }}$ edition, 2012, LWW, Philadelphia.

- Medscape, http://www.medscape.com

- Oxford Handbook of Clinical Surgery, 3d edition, 2011, Oxford Press

- Sayek I. Sayek Temel Cerrahi 1-2. 4-cü baskı, 2016, Güneş Tıp Kitabevleri.

- Topçubaşov M.A. Xüsusi cərrahlıq. Bakı, 1979

- UpToDate, http://www.uptodate.com

- Гостищев В.К. Общая хирургия. GEOTAR-Media, 2019 


\title{
ХИРУРГИЧЕСКИЕ БОЛЕЗНИ
}

Н.Ю. Байрамов

\section{Хирургические заболевания сердца \\ Н.Ю. Байрамов, А. Амрах, Ч. Ибрагимов, Э. Валиев}

\author{
Перевод: Н.Ю. Байрамов, С.А. Алиев, М.Р.Гусейнова
}




\section{ОПЕРАЦИИ НА СЕРДЦЕ}

- Особенностью операций на сердце является детальное обследование пациентов и оснащенность операционной современной высокотехнологической аппаратурой. Детальное обследование пациентов необходимо для того, чтобы предупредить возникновение каких-либо проблем, которые могут привести к серьёзным последствиям.

- В большинстве случаев применяется лёгочно-сердечный насос, который обеспечивает оксигенацию и кровообращение, заменяя функцию сердца и лёгких во время операции.

- Экстракорпоральная мембранная оксигенация - применяется для замены функции сердца и лёгких на несколько дней.

- Искусственое сердце - длительное время (недели, месяцы) заменяет функцию сердца.

- Для остановки сердца с целью выполнения кардиохирургических операций на небьющемся сердце применяют фибрилляцию, гипотермию и кардиоплегию.

- При хирургическом лечении клапанных пороков проводится пластика или протезирование клапанов. С целью пластики проводят аннулопластику, вальвулопластику, комиссуротомию, баллонную дилатацию. Протезирование проводится синтетическими или биологическими клапанами, которая выполняется открытым хирургическим доступом или эндоваскулярным способом.

- Аортокоронарное шунтирование - создание сосудистого анастомоза между аортой и поражённой коронарной артерией. Применяется при заболевании коронарных артерий.

\section{Вопросы и ответы по операциям на сердце}

\section{Вопросы}

Какие методы и технические приборы используют для замены лёгких и сердца?

\section{Ответы}

- Лёгочно-сердечный насос;

- Эстракорпоральная мембранная оксигенация; 


\begin{tabular}{|c|c|}
\hline & - Искусственое сердце \\
\hline $\begin{array}{l}\text { Что такое экстракорпоральная } \\
\text { мембранная оксигенация? }\end{array}$ & $\begin{array}{l}\text { Аппарат для замены лёгких и сердца на } \\
\text { относительно длительный срок. Режим } \\
\text { работы аппарата рассчитан как на } \\
\text { оксигенацию, так и на замену } \\
\text { кровообращения. }\end{array}$ \\
\hline Что такое лёгочно-сердечный насос? & 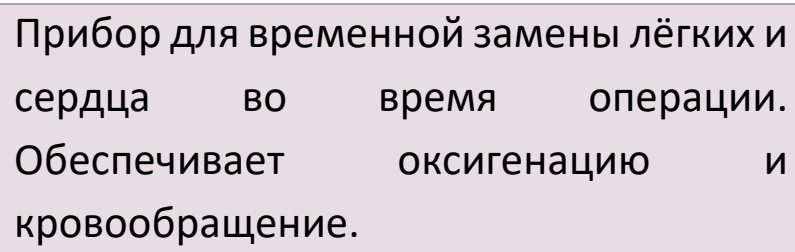 \\
\hline $\begin{array}{l}\text { Как функционирует лёгочно- } \\
\text { сердечный насос? }\end{array}$ & $\begin{array}{l}\text { Берёт кровь из верхней и нижней полой } \\
\text { вен, подаёт в оксигенатор, заменяющий } \\
\text { функцию лёгких, и возвращает в аорту. }\end{array}$ \\
\hline $\begin{array}{l}\text { При каких операциях используют } \\
\text { лёгочно-сердечный насос? }\end{array}$ & $\begin{array}{l}\text { При операциях на открытом сердце, при } \\
\text { трансплантации сердца, лёгких, } \\
\text { комплекса лёгкие-сердце, при } \\
\text { операциях на магистральных артериях. }\end{array}$ \\
\hline $\begin{array}{l}\text { Необходима ли антикоагулянтная } \\
\text { терапия? }\end{array}$ & $\begin{array}{l}\text { Необходима, проводится до и после } \\
\text { операции гепарином. }\end{array}$ \\
\hline $\begin{array}{l}\text { Как восстанавливается } \\
\text { антикоагуляционное состояние? }\end{array}$ & Протамином. \\
\hline $\begin{array}{l}\text { Как регулируется сердечный выброс } \\
\text { после применения лёгочно- } \\
\text { сердечного насоса? }\end{array}$ & 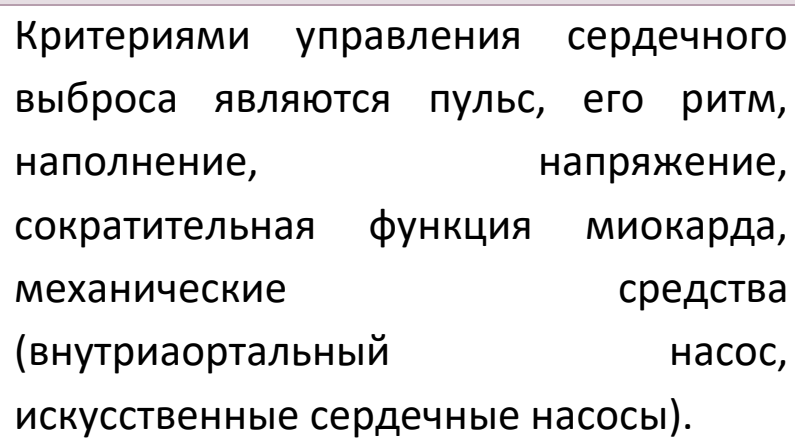 \\
\hline $\begin{array}{l}\text { Какие механические причины могут } \\
\text { способствовать уменьшению } \\
\text { сердечного выброса после }\end{array}$ & Тампонада сердца, пневмоторакс. \\
\hline
\end{tabular}




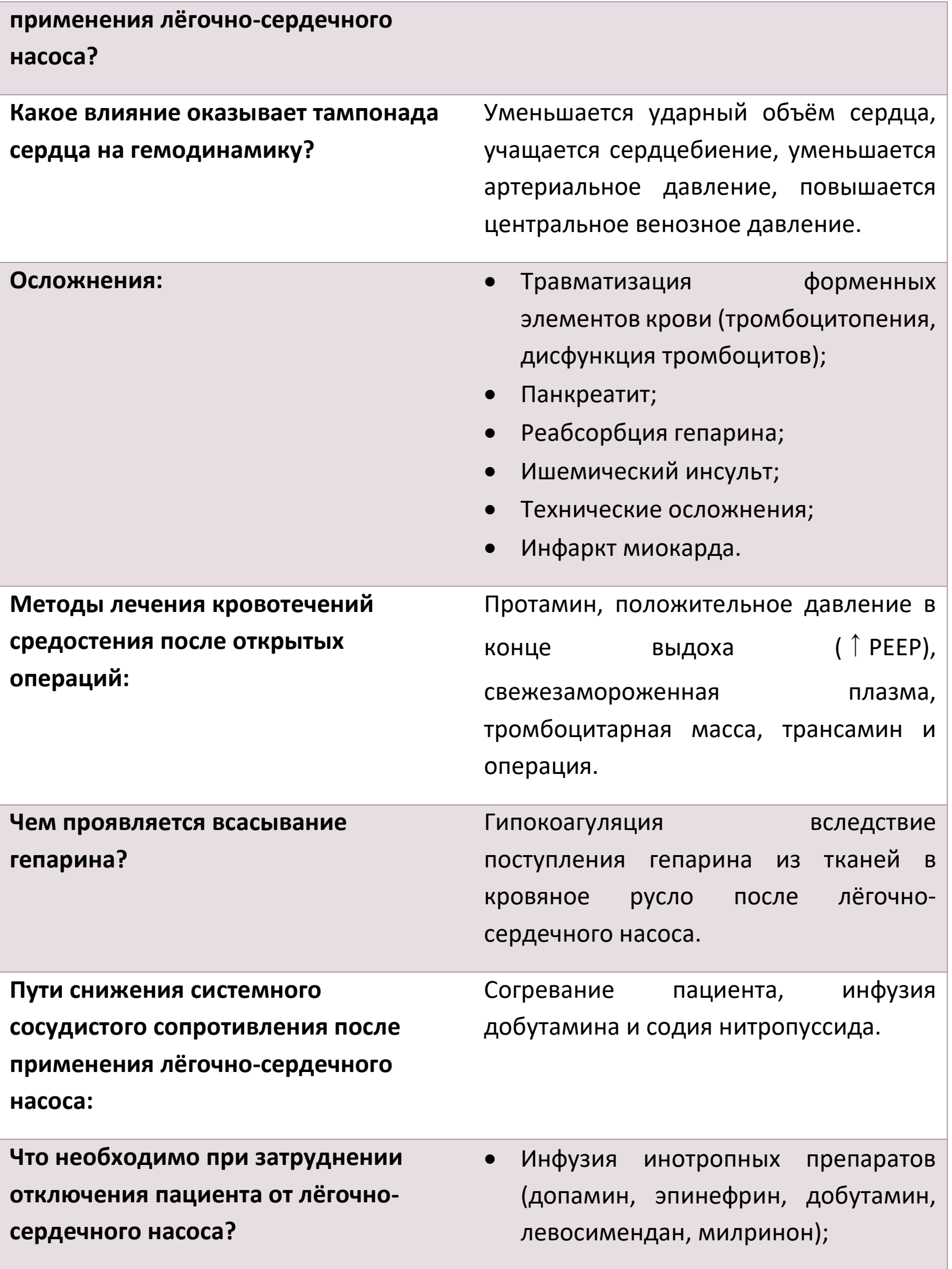




\begin{tabular}{|c|c|}
\hline & $\begin{array}{l}\text { - Аппарат для поддержания функции } \\
\text { желудочка; } \\
\text { • Применение внутриаортального } \\
\text { насоса. }\end{array}$ \\
\hline $\begin{array}{l}\text { Частота фибрилляции предсердий } \\
\text { после лёгочно-сердечного насоса: }\end{array}$ & $33 \%$. \\
\hline $\begin{array}{l}\text { Принцип работы внутриаортального } \\
\text { насоса: }\end{array}$ & $\begin{array}{l}\text { Насос (баллон) размещают в аорту } \\
\text { между левой подключичной и почечной } \\
\text { артерией. Во время диастолы баллон } \\
\text { раздуваясь повышает диастолическое } \\
\text { давление, усиливает коронарный и } \\
\text { мозговой кровоток. В фазе систолы } \\
\text { баллонспадаясьсоздаетотрицательное } \\
\text { давление, снижает периферическое } \\
\text { сопротивление и увеличивает } \\
\text { систолическое давление. }\end{array}$ \\
\hline Что такое наружная контрпульсация? & $\begin{array}{l}\text { Это вариант наружного применения } \\
\text { внутриаортального насоса. В фазе } \\
\text { диастолы улучшая перфузию в } \\
\text { коронарных, церебральных и } \\
\text { брыжеечных артериях и способствует } \\
\text { формированию новых коллатералей в } \\
\text { указанных органах. }\end{array}$ \\
\hline
\end{tabular}

\section{Вопросы и ответы по операциям на клапанах}

\section{Вопросы \\ Ответы}

Операции на клапанах сердца:

Пластика и протезирование.

Что такое протезирование клапанов?

Замещение поражённых клапанов

биологическими или механическими клапанами. 


\begin{tabular}{|c|c|}
\hline Вопросы & Ответы \\
\hline Что такое биологический клапан? & $\begin{array}{l}\text { Клапаны, сконструированные из тканей } \\
\text { человека или животного. }\end{array}$ \\
\hline $\begin{array}{l}\text { Преимущества и недостатки } \\
\text { биологических клапанов: }\end{array}$ & $\begin{array}{lrr}\text { Не } & \text { требуют } & \text { применения } \\
\text { антикоагулянтов на всю жизнь, однако } \\
\text { по стечению времени подвергаются } \\
\text { деградации, } \\
\text { необходимости повторной операции. }\end{array}$ \\
\hline $\begin{array}{l}\text { Что собой представляют механические } \\
\text { клапаны? }\end{array}$ & $\begin{array}{l}\text { Синтетические клапаны, } \\
\text { сконструированные обычно из } \\
\text { керамики. }\end{array}$ \\
\hline $\begin{array}{l}\text { Преимущества и недостатки } \\
\text { механических клапанов: }\end{array}$ & 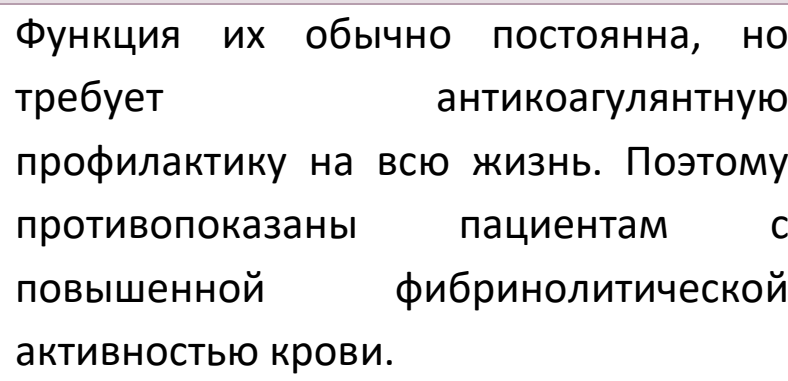 \\
\hline Летальность после операции: & $1-5 \%$. \\
\hline $\begin{array}{l}\text { Какие препараты назначают } \\
\text { пациентам с искусственным клапаном } \\
\text { перед удалением зуба? }\end{array}$ & $\begin{array}{l}\text { Антибиотики с целью профилактики } \\
\text { эндокардита. }\end{array}$ \\
\hline Что такое операция Росса? & $\begin{array}{l}\text { Клапан лёгочной артерии больного } \\
\text { пересаживают в аорту, а клапан } \\
\text { лёгочной артерии заменяется } \\
\text { биологическим клапаном. }\end{array}$ \\
\hline
\end{tabular}


Вопросы и ответы по аортокоронарному шунтированию

\begin{tabular}{|c|c|}
\hline Вопросы & Ответы \\
\hline $\begin{array}{l}\text { Что такое аортокоронарное } \\
\text { шунтирование? }\end{array}$ & $\begin{array}{l}\text { Формирование анастомоза между } \\
\text { аортой и коронарными артериями. }\end{array}$ \\
\hline $\begin{array}{l}\text { Показания к аортокоронарному } \\
\text { шунтированию: }\end{array}$ & $\begin{array}{l}\text { - Стеноз левой главной коронарной } \\
\text { артерии; } \\
\text { - Стеноз передне-левой нисходящей } \\
\text { артерии; } \\
\text { - Болезнь трёх сосудов; } \\
\text { - Тромбоз и диссекция коронарных } \\
\text { артерий после их стентирования. }\end{array}$ \\
\hline $\begin{array}{l}\text { В чём заключается методика } \\
\text { операции? }\end{array}$ & $\begin{array}{l}\text { Отрезок сосудистого трансплантата } \\
\text { вшивают в восходящую аорту и } \\
\text { соединяют с коронарной артерией } \\
\text { ниже места сужения. }\end{array}$ \\
\hline $\begin{array}{l}\text { Какие сосуды используют в качестве } \\
\text { трансплантата? }\end{array}$ & $\begin{array}{l}\text { - Внутренняя грудная артерия; } \\
\text { - Большая подкожная вена; } \\
\text { - Лучевая артерия; } \\
\text { - Правая гастроэпиплоическая } \\
\text { артерия; } \\
\text { - Малая подкожная вена; } \\
\text { - Селезёночная артерия. }\end{array}$ \\
\hline Осложнения: & $\begin{array}{l}\text { - К Кровотечение, тампонада сердца; } \\
\text { - Инфаркт миокарда, аритмии; } \\
\text { - Нагноение раны; } \\
\text { - Плевральный, перикардиальный } \\
\text { выпот; } \\
\text { - Тромбоз сосудистого трансплантата; } \\
\text { - Диастаз краёв стернотомии; } \\
\text { - Постперикардиотомический } \\
\text { синдром, инсульт. }\end{array}$ \\
\hline
\end{tabular}




\begin{tabular}{|c|c|}
\hline Вопросы & Ответы \\
\hline $\begin{array}{l}\text { Летальность после аортокоронарного } \\
\text { шунтирования: }\end{array}$ & $\begin{array}{l}\text { Составляет 0,6-1,3\%, у пациентов, } \\
\text { перенёсших инфаркт миокарда - 5-10\%. }\end{array}$ \\
\hline $\begin{array}{l}\text { Какие препараты назначают } \\
\text { пациентам в послеоперационном } \\
\text { периоде? }\end{array}$ & Аспирин, бета-блокаторы, статины. \\
\hline $\begin{array}{l}\text { Выполнимо ли аортокоронарное } \\
\text { шунтирование без аппаратов } \\
\text { искусственного кровообращения и } \\
\text { вентиляции лёгких? }\end{array}$ & Выполнимо. \\
\hline $\begin{array}{l}\text { Что такое постперикардиотомический } \\
\text { синдром? }\end{array}$ & $\begin{array}{l}\text { Перикардит неизвестной этиологии, } \\
\text { возникший после перикардиотомии } \\
\text { (развивается в течение } 3 \text { мес.) }\end{array}$ \\
\hline Клинические признаки: & $\begin{array}{l}\text { - Гипертермия; } \\
\text { - Боль в груди; } \\
\text { - Фибрилляция предсердий; } \\
\text { - Недомогание; } \\
\text { - Шум трения перикарда; } \\
\text { - Гидроперикардиум, гидроторакс. }\end{array}$ \\
\hline Лечение: & $\begin{array}{l}\text { - Нестероидные } \\
\text { - противовоспалительные препараты; } \\
\text { - Диероидные препараты; } \\
\text { Диуретики. }\end{array}$ \\
\hline $\begin{array}{l}\text { Как называется перикардит, } \\
\text { развившийся после инфаркта } \\
\text { миокарда? }\end{array}$ & Синдром Дресслера. \\
\hline $\begin{array}{l}\text { Что такое минимально инвазивное } \\
\text { аортокоронарное шунтирование? }\end{array}$ & $\begin{array}{l}\text { Мини торакотомией без лёгочно- } \\
\text { сердечного насоса формируют } \\
\text { анастомоз между внутренней грудной }\end{array}$ \\
\hline
\end{tabular}




\begin{tabular}{|ll|}
\hline \multicolumn{1}{|c|}{ Вопросы } & \multicolumn{1}{c}{ Ответы } \\
\hline $\begin{array}{l}\text { Чтортерй и передней межжелудочной } \\
\text { лазерная реваскуляризация? }\end{array}$ & $\begin{array}{l}\text { Для улучшения перфузии крови в } \\
\text { миокарде на ней лазерными лучами } \\
\text { наносят мелкие отверстия. }\end{array}$ \\
\hline $\begin{array}{l}\text { Кому характерно трансмуральное коронарной артерии. } \\
\text { кровообращение сердце? }\end{array}$ & у пресмыкающихся и человеческого \\
\hline
\end{tabular}




\section{ВРОЖДЁННЫЕ ПОРОКИ СЕРДЦА}

- Врождённые пороки сердца включают аномалии клапанов, стенки сердца или сосудов.

- С функциональной точки зрения кровь либо протекает в патологическом направлении, например, справа налево или слева направо, либо нарушается нормальный кровоток.

- Пороки делятся на две группы: цианотические (синие) и белые пороки сердца.

- При цианотических пороках происходит сброс венозной крови в артериальное русло (“справа на лево”) и наблюдается цианоз.

○ К этой группе относятся триада, тетрада и пентада Фалло, атрезия трёхстворчатого клапана в сторону правого желудочка с дефектом межпредсердной перегородки, транспозиция сосудов.

- При белых пороках происходит сброс артериальной крови в венозное русло. В начальных этапах цианоз не наблюдается, при стадии декомпенсации происходит сброс венозной крови справа на лево и проявляется цианоз.

- В эту группу входят: дефект межпредсердной перегородки, дефект межжелудочковой перегородки, открытый артериальный проток, аортолёгочный свищ, митральный стеноз с дефектом межпредсердной перегородки.

- Клинически пороки проявляются цианозом, сердечными шумами, сердечной недостаточностью, обмороками и т. д.

- Диагноз подтверждается на эхокардиографии.

- Для лечения врождённых пороков применяют эндоваскулярную катетеризацию и хирургическую коррекцию, а также трансплантацию сердца.

\section{Вопросы и ответы по цианотическим порокам сердца}

\begin{tabular}{|ll}
\hline \multicolumn{1}{|c|}{ Вопросы } & \multicolumn{1}{c}{ Ответы } \\
\hline Когда развивается цианоз? & Когда уровень дезоксигемоглобина \\
& больше 5 г/дл, уровень гемоглобина \\
ниже 5 мг.
\end{tabular}




\begin{tabular}{|ll}
\multicolumn{1}{c|}{ Вопросы } & \multicolumn{1}{c|}{ Ответы } \\
\hline Причины цианоза: & Ненасыщение гемоглобина \\
& кислородом или избыточный расход \\
& кислорода. \\
\hline Цианотичные пороки сердца: & Тетрада Фалло; \\
& - Атрезия трёхстворчатого клапана; \\
& - Аномалия лёгочного венозного \\
& кровотока; \\
& - Открытый артериальный кровоток; \\
& - Транспозиция \\
& сосудов. \\
&
\end{tabular}

\section{Вопросы и ответы по тетраде Фалло}

\section{Вопросы}

Что такое тетрада Фалло?

Клинические признаки:

Объективные признаки:

\section{Ответы}

Сочетание следующих пороков:

- Стеноз устья лёгочного ствола;

- Декстрапозиция аорты;

- Гипертрофия стенки правого желудочка;

- Дефект межжелудочковой перегородки.

Цианоз, обмороки.

Цианоз кожных покровов, пальцы в виде "барабанных" палочек, систолический шум.

Эхокардиография.

Хирургическое - коррекция или

трансплантация.

В 95\% случаев - выздоровление.

Прогноз: 


\section{Вопросы и ответы по транспозиции крупных сосудов}

\begin{tabular}{|ll|}
\hline \multicolumn{1}{|c|}{ Вопросы } & \multicolumn{1}{c|}{ Ответы } \\
\hline $\begin{array}{l}\text { Что представляет собой транспозиция } \\
\text { сосудов? }\end{array}$ & $\begin{array}{l}\text { Аорта начинается с правого желудочка, } \\
\text { лёгочная артерия - слевого желудочка. }\end{array}$ \\
\hline Частота встречаемости: & $\begin{array}{l}\text { Составляет } 5-8 \% \quad \text { всех врождённых } \\
\text { пороков сердца. }\end{array}$ \\
\hline Клинические признаки: & $\begin{array}{l}\text { Цианоз; } \\
\text { В 90\% случаев признаки сердечной } \\
\text { недостаточности через день после } \\
\text { рождения. }\end{array}$ \\
\hline Диагностика: & $\begin{array}{l}\text { Эхокардиография, } \\
\text { полостей сердца. }\end{array}$ \\
\hline Методы летеризация \\
\hline
\end{tabular}

\section{Вопросы и ответы по дефекту межжелудочковой перегородки}

\begin{tabular}{|c|c|}
\hline Вопросы & Ответы \\
\hline $\begin{array}{l}\text { Что такое дефект межжелудочковой } \\
\text { перегородки? }\end{array}$ & $\begin{array}{l}\text { Частичное или полное незаращение } \\
\text { межжелудочковой перегородки. }\end{array}$ \\
\hline Частота встречаемости: & $\begin{array}{l}\text { Часто встречаемый врождённый порок } \\
\text { сердца. }\end{array}$ \\
\hline $\begin{array}{l}\text { Что такое синдром обструктивной } \\
\text { лёгочной артерии? }\end{array}$ & $\begin{array}{l}\text { В связи с забросом крови слева направо } \\
\text { развивается гипертензия лёгочной } \\
\text { артерии. }\end{array}$ \\
\hline Что такое синдром Эйзенменгера? & $\begin{array}{l}\text { В связи со стойкой гипертензией в } \\
\text { лёгочной артерии, сброс крови справа } \\
\text { налево. }\end{array}$ \\
\hline Лечение синдрома Эйзенменгера: & $\begin{array}{l}\text { Трансплантация комплекса "сердце- } \\
\text { лёгкие". }\end{array}$ \\
\hline
\end{tabular}




\section{Вопросы и ответы по открытому артериальному протоку}

\begin{tabular}{|c|c|}
\hline Вопросы & Ответы \\
\hline $\begin{array}{l}\text { Что собой представляет открытый } \\
\text { артериальный проток? }\end{array}$ & $\begin{array}{l}\text { Во внутриутробном периоде } \\
\text { обеспечивает поступление крови из } \\
\text { правого желудочка и ствола лёгочной } \\
\text { артерии, минуя нефункционирующие } \\
\text { лёгкие, в аорту и большой круг } \\
\text { кровообращения. Закрывается в } \\
\text { течение 12-24 часов после рождения. }\end{array}$ \\
\hline $\begin{array}{l}\text { Причины открытого артериального } \\
\text { протока: }\end{array}$ & $\begin{array}{l}\text { Ранние роды, гипоксия, увеличение } \\
\text { концентрации простагландинов в } \\
\text { крови. }\end{array}$ \\
\hline Клинические признаки: & $\begin{array}{l}\text { - В большинстве случаев протекает } \\
\text { бессимптомно; } \\
\text { - Недостаточное питание; } \\
\text { - Одышка; } \\
\text { - Респираторные инфекции; } \\
\text { - Сердечная недостаточность. }\end{array}$ \\
\hline Объективные признаки: & $\begin{array}{l}\text { Отсутствие цианоза, непрерывный } \\
\text { систоло-диастолический (“машинный”) } \\
\text { шум. }\end{array}$ \\
\hline Диагностика: & $\begin{array}{l}\text { - } \text { Эхокардиография (также } \\
\text { определяются другие пороки); } \\
\text { - Катетеризация полостей сердца. }\end{array}$ \\
\hline Лечение: & $\begin{array}{l}\text { - Консервативное; } \\
\text { - Эндоваскулярное; } \\
\text { - Хирургическое. }\end{array}$ \\
\hline $\begin{array}{l}\text { Что составляет медикаментозное } \\
\text { лечение? }\end{array}$ & $\begin{array}{l}\text { Индометацин } \\
\text { простагландинов. }\end{array}$ \\
\hline
\end{tabular}




\section{Вопросы и ответы по аномалии Эбштейна}

\begin{tabular}{|c|c|}
\hline Вопросы & Ответы \\
\hline \multirow[t]{3}{*}{ Что такое аномалия Эбштейна? } & $\begin{array}{l}\text { В связи с низким расположением } \\
\text { трёхстворчатого клапана развивается }\end{array}$ \\
\hline & $\begin{array}{lcl}\text { клапанная недостаточность. При этом } \\
\text { объём } & \text { правого } & \text { желудочка }\end{array}$ \\
\hline & $\begin{array}{l}\text { уменьшается, а предсердия - } \\
\text { увеличивается. }\end{array}$ \\
\hline Факторы риска: & $\begin{array}{l}\text { Если во время беременности больная } \\
\text { принимает препараты лития, то риск } \\
\text { заболеваемости возрастает в } 400 \text { раз. }\end{array}$ \\
\hline
\end{tabular}

\section{Вопросы и ответы по коарктации аорты}

\begin{tabular}{|c|c|}
\hline Вопрось & Ответы \\
\hline Что такое коарктация аорты? & $\begin{array}{l}\text { Сужение проксимального } \\
\text { нисходящей аорты. }\end{array}$ \\
\hline Виды коарктации аорты: & $\begin{array}{l}\text { - Надклапанный; } \\
\text { - Клапанный; } \\
\text { • Подклапанный. }\end{array}$ \\
\hline $\begin{array}{l}\text { Частота встречаемости в сочетании с } \\
\text { другими пороками: }\end{array}$ & $\begin{array}{l}\text { Составляет 60\% (чаще с аортальным } \\
\text { пороком). }\end{array}$ \\
\hline $\begin{array}{l}\text { Основные коллатеральные пути } \\
\text { кровообращения: }\end{array}$ & $\begin{array}{l}\text { Подключичная артерия } \rightarrow \text { внутренняя } \\
\text { грудная артерия } \rightarrow \text { межрёберные } \\
\text { артерии } \rightarrow \text { нисходящая аорта. }\end{array}$ \\
\hline Факторы риска: & $\begin{array}{l}\text { Синдром Тернера. } \\
\text { встречается чаще. }\end{array}$ \\
\hline Клинические признаки: & - Головные боли; \\
\hline
\end{tabular}




\begin{tabular}{|c|c|}
\hline & $\begin{array}{l}\text { - Носовое кровотечение; } \\
\text { - Слабость в нижних конечностях - } \\
\text { перемежающаяся хромота. }\end{array}$ \\
\hline Объективные признаки: & $\begin{array}{l}\text { Ослабление пульса на артериях нижних } \\
\text { конечностей, систолический шум. }\end{array}$ \\
\hline Диагностика: & $\begin{array}{l}\text { Эхокардиография, } \\
\text { полостей сердца при соризация } \\
\text { пороке. }\end{array}$ \\
\hline Методы лечения: & $\begin{array}{l}\text { Эндоваскулярная баллонная } \\
\text { ангиопластика } \\
\text { стентирование): } \\
\text { - Резекция участка стеноза, } \\
\text { формирование анастомоза } \\
\text { “конецв конец”; зоны стеноза } \\
\text { - Замещение или } \\
\text { подключичной артерией или } \\
\text { синтетическим протезом. }\end{array}$ \\
\hline $\begin{array}{l}\text { Показания к хирургическому } \\
\text { лечению: }\end{array}$ & $\begin{array}{l}\text { - Выраженная клиническая } \\
\text { симптоматика; } \\
\text { - Градиент давления на } \\
\text { нисходящей аорте выше } 20 \text { мм рт. } \\
\text { ст.; } \\
\text { - Возраст старше 3-4 лет. }\end{array}$ \\
\hline Послеоперационные осложнения: & $\begin{array}{l}\text { - Параплегия; } \\
\text { - Парадоксальная гипертензия; } \\
\text { - Мезентериальный некротический } \\
\text { панартериит; } \\
\text { - Синдром Горнера; }\end{array}$ \\
\hline
\end{tabular}




\begin{tabular}{ll} 
& $\begin{array}{l}\text { Повреждение возвратного } \\
\text { гортанного нерва. }\end{array}$ \\
Осложнения в отдалённом & $\begin{array}{l}\text { Диссекция аорты, гипертензия, } \\
\text { послеоперационном периоде: }\end{array}$ \\
\hline
\end{tabular}




\section{ЗАБОЛЕВАНИЯ КЛАПАНОВ СЕРДЦА}

- Клапаны сердца расположены у входа и выхода желудочков и обеспечивают одностороннее направление кровотока.

- Патологии клапанов делятся на 2 группы: стеноз или недостаточность клапанов, либо комбинированный порок.

- Основными причинами поражения клапанов сердца и развития порока является ревматизм, септический эндокардит, коллагенозы, дисфункция и деструкция папиллярной мышцы.

- Недостаточность клапанов способствует обратному забросу (регургитация) крови, стеноз затрудняет поступление крови в желудочек и магистральные сосуды. В результате развивается гипертензия и застой до клапанов и уменьшение объёма крови после клапанов.

- В начальной стадии заболевание протекает бессимптомно в связи с компенсацией кровообращения. При прогрессировании заболевания наступает декомпенсация, которая проявляется признаками сердечной недостаточности. Течение болезни и прогноз зависят от степени и локализации пороков. Митральный и аортальный стенозы отличаются более тяжелым клиническим течением.

- Клинические проявления пороков сердца характеризуются одышкой при физической нагрузке, быстрой утомляемостью. При объективном обследовании обнаруживаются сердечные шумы.

- Для диагностики пороков сердца, патологии клапанов применяются эхокардиография, катетеризация (зондирование) и измерение давления в полостях сердца.

- При лечении пороков сердца используют вальвулопластику, аннулопластику, комиссиротомию, замену поражённых клапанов механическими или биологическими клапанами. Выбор метода хирургической коррекции определяется особенностью течения заболевания (острое или хроническое), характером пороков (недостаточность или стеноз) и их локализацией (трёхстворчатый, митральный, аортальный). 


\section{Вопросы и ответы по митральному стенозу}

\begin{tabular}{|c|c|}
\hline Вопросы & Ответы \\
\hline $\begin{array}{l}\text { Что такое стеноз митрального } \\
\text { клапана? }\end{array}$ & $\begin{array}{l}\text { Кальцификация (недостаточность) или } \\
\text { стеноз певого предсердно- } \\
\text { желудочкового отверстия. }\end{array}$ \\
\hline $\begin{array}{l}\text { Наиболее частая причина } \\
\text { митрального порока: }\end{array}$ & Ревматизм. \\
\hline Клинические признаки: & $\begin{array}{l}\text { - Одышка - повышение давления в } \\
\text { левом предсердии способствует } \\
\text { лёгочной гипертензии и застою в } \\
\text { малом кругу кровообращения; } \\
\text { - Кровохарканье - связано с застоем в } \\
\text { лёгких; } \\
\text { - Изменение фонации голоса, } \\
\text { обусловленное сдавлением } \\
\text { гортанного нерва расширенным } \\
\text { левым предсердием; } \\
\text { - Сердцебиение - фибрилляция } \\
\text { предсердий. }\end{array}$ \\
\hline Объективные признаки: & $\begin{array}{l}\text { - Сердечный шум (как правило, } \\
\text { диастолический); } \\
\text { - Аритмии; } \\
\text { - Инсульт (эмболия из левого } \\
\text { предсердия). }\end{array}$ \\
\hline Диагностика: & $\begin{array}{l}\text { - Эхокардиография; } \\
\text { - Катетеризация полостей сердца. }\end{array}$ \\
\hline Методы лечения: & $\begin{array}{l}\text { - Коммиссуротомия на открытом } \\
\text { сердце; } \\
\text { - Баллонная вальвулопластика; } \\
\text { - Замена клапанов (протезирование). }\end{array}$ \\
\hline
\end{tabular}




\begin{tabular}{|c|c|}
\hline Вопросы & Ответы \\
\hline $\begin{array}{l}\text { Какие препараты используются в } \\
\text { качестве консервативного лечения } \\
\text { симптоматических пациентов в лёгкой } \\
\text { форме? }\end{array}$ & Диуретики, ингибиторы АПФ. \\
\hline Прогноз: & $\begin{array}{l}\text { 10-летняя выживаемость составляет } \\
80 \% .\end{array}$ \\
\hline $\begin{array}{l}\text { Показания к хирургическому } \\
\text { лечению: }\end{array}$ & 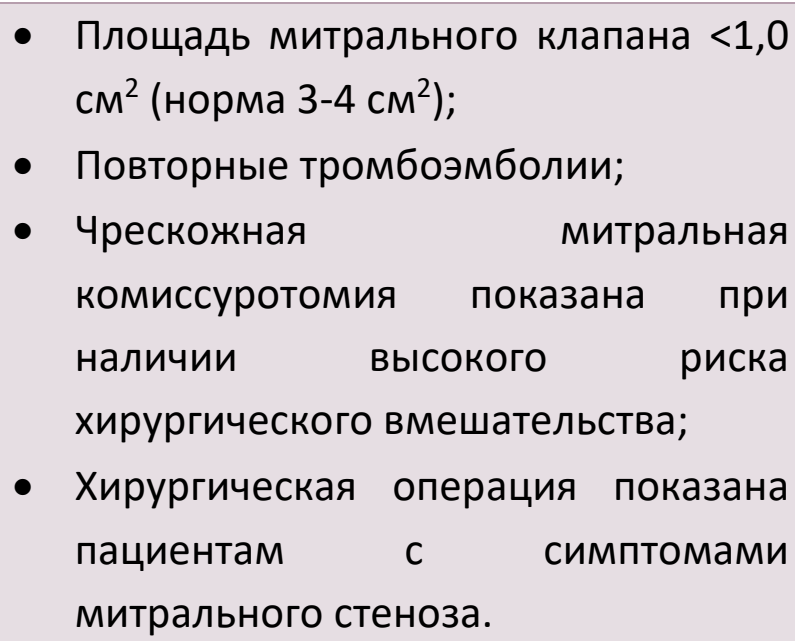 \\
\hline
\end{tabular}

\section{Вопросы и ответы по недостаточности митрального клапана}

\begin{tabular}{|ll}
\multicolumn{1}{c|}{ Вопросы } & \multicolumn{2}{c|}{ Ответы } \\
\hline $\begin{array}{l}\text { Что такое недостаточность } \\
\text { митрального клапана? }\end{array}$ & $\begin{array}{l}\text { Неполное смыкание створок левого } \\
\text { предсердно-желудочкового клапана. }\end{array}$ \\
\hline Причины: & Пролапс митрального клапана - \\
& встречается у $5 \%$ населения, чаще у \\
& женщин;
\end{tabular}




\begin{tabular}{|c|c|}
\hline Вопросы & Ответы \\
\hline Клинические признаки: & $\begin{array}{l}\text { Как правило, протекает бессимптомно и } \\
\text { проявляется одышкой, сердцебиением, } \\
\text { усталостью на поздних стадиях } \\
\text { заболевания. }\end{array}$ \\
\hline Объективные признаки: & $\begin{array}{l}\text { Систолический шум, смешение } \\
\text { верхушечного толчка влево. }\end{array}$ \\
\hline Диагностика: & $\begin{array}{l}\text { - } \text { Эхокардиография; } \\
\text { - Катетеризация полостей сердца. }\end{array}$ \\
\hline Метод лечения: & $\begin{array}{l}\text { - Замена поражённого клапана; } \\
\text { - Пластика поражённого клапана } \\
\text { (аннулопластика). }\end{array}$ \\
\hline Показания к хирургическому лечению: & $\begin{array}{l}\text { - Острая митральная недостаточность; } \\
\text { - Симптоматическое течение с } \\
\text { сердечным выбросом<30\%; } \\
\text { - Асимптоматическое течение с } \\
\text { дисфункцией левого желудочка } \\
<60 \% \text { и диаметром левого } \\
\text { желудочка в конце систолы >45 мм; } \\
\text { - Пациентам с высоким риском и с } \\
\text { соответствующими } \\
\text { эхокардиографическими } \\
\text { показателями показано чрескожное } \\
\text { вмешательство. }\end{array}$ \\
\hline
\end{tabular}

\section{Вопросы и ответы по аортальному стенозу}

\begin{tabular}{|ll}
\hline Вопросы & \multicolumn{2}{c}{ Ответы } \\
\hline Что такое аортальный стеноз? & Сужение устья аорты в результате \\
& деструкции и кальцификации створок \\
клапана, которое приводит к
\end{tabular}




\begin{tabular}{|c|c|}
\hline Вопросы & Ответы \\
\hline & $\begin{array}{l}\text { уменьшению выброса крови из левого } \\
\text { желудочка. }\end{array}$ \\
\hline Причины: & $\begin{array}{l}\text { - Кальцификация двухстворчатого } \\
\text { клапана - частый врождённый } \\
\text { порок; } \\
\text { - Ревматизм; } \\
\text { - Возрастная кальцификация-возраст } \\
\text { старше 70-80 лет. }\end{array}$ \\
\hline Клинические признаки: & $\begin{array}{l}\text { - Боли в области сердца; } \\
\text { - Синкопа - потеря сознания (средняя } \\
\text { продолжительность жизни без } \\
\text { операции -3 года); } \\
\text { - Сердечная недостаточность } \\
\text { (средняя продолжительность жизни } \\
\text { без операции - } 2 \text { года); } \\
\text { - В некоторых случаев протекает } \\
\text { бессимптомно. }\end{array}$ \\
\hline Объективные признаки: & Систолический шум над устьем аорты. \\
\hline $\begin{array}{l}\text { О чём свидетельствует сильный } \\
\text { систолический шум? }\end{array}$ & $\begin{array}{l}\text { О компенсации (сохранности) функции } \\
\text { левого желудочка. }\end{array}$ \\
\hline $\begin{array}{l}\text { Чем объясняется ослабление шума с } \\
\text { истечением времени? }\end{array}$ & $\begin{array}{l}\text { Декомпенсацией функции левого } \\
\text { желудочка. }\end{array}$ \\
\hline Диагностика: & $\begin{array}{l}\text { - Эхокардиография; } \\
\text { - Катетеризация полостей сердца. }\end{array}$ \\
\hline Методы лечения: & $\begin{array}{l}\text { Вальвулопластика и протезирование } \\
\text { клапана. }\end{array}$ \\
\hline Показания к операции: & $\begin{array}{l}\text { - Симптоматический стеноз с высоким } \\
\text { градиентом давления (средний } \\
\text { градиент давления } \geqq 40 \text { мм рт. ст.); }\end{array}$ \\
\hline
\end{tabular}




\begin{tabular}{|c|c|}
\hline Вопросы & Ответы \\
\hline & $\begin{array}{l}\text { - Низкий сердечный выброс (<50\%), } \\
\text { стеноз с низким градиентом } \\
\text { давления (средний градиент } \\
\text { давления } 50 \text { мм рт. ст.); } \\
\text { - Бессимптомное течение, при } \\
\text { котором признаки проявляются при } \\
\text { физической нагрузке; } \\
\text { - Площадь клапана менее } 0,75 \text { см². }^{2}\end{array}$ \\
\hline $\begin{array}{l}\text { Методы лечения при высоком риске } \\
\text { операции: }\end{array}$ & 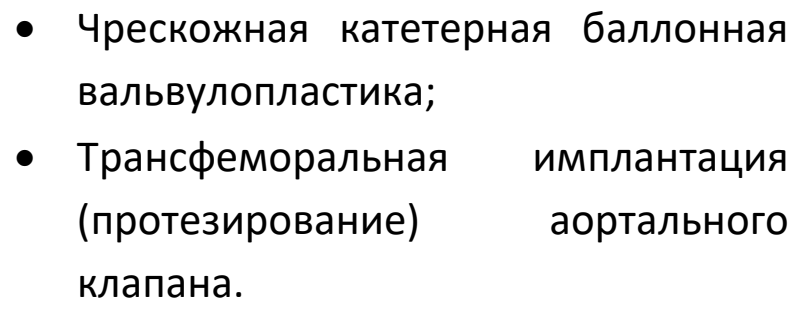 \\
\hline $\begin{array}{l}\text { Что такое трансфеморальная } \\
\text { имплантация аортального клапана? }\end{array}$ & $\begin{array}{l}\text { Пациентам с высоким риском операции } \\
\text { проводят протезирование аортального } \\
\text { клапана без торакотомии и анестезии. }\end{array}$ \\
\hline
\end{tabular}

\section{Вопросы и ответы по аортальной недостаточности}

\begin{tabular}{|ll|}
\multicolumn{1}{c}{ Вопросы } & \multicolumn{1}{c|}{ Ответы } \\
\hline $\begin{array}{l}\text { Что такое аортальная } \\
\text { недостаточность? }\end{array}$ & $\begin{array}{l}\text { Нарушение замыкательной функции } \\
\text { аортального клапана. }\end{array}$ \\
\hline Причины: & $\bullet$ Бактериальный эндокардит; \\
& - Ревматизм; \\
& $\bullet$ Коллагеноз (синдром Марфана). \\
\hline Клинические признаки: & $\bullet$ Сердцебиение; \\
& $\bullet$ Одышка; \\
\hline Объективные признаки: & Боли в груди. \\
\hline
\end{tabular}




\begin{tabular}{|c|c|}
\hline Вопросы & Ответы \\
\hline & $\begin{array}{l}\text { - Повышение пульсового давления: } \\
\text { пальпируемый пульс Коригена над } \\
\text { периферическими артериями. }\end{array}$ \\
\hline На что указывает пульс Коригена? & $\begin{array}{l}\text { - Понижение диастолического } \\
\text { давления; } \\
\text { - Повышенное пульсовое давление. }\end{array}$ \\
\hline Диагностика: & $\begin{array}{l}\text { Эхокардиография } \quad \text { и катетеризация } \\
\text { полостей сердца. }\end{array}$ \\
\hline Метод лечения: & $\begin{array}{l}\text { Вальвулопластика или протезирование } \\
\text { клапана. }\end{array}$ \\
\hline Показания к хирургическому лечению: & $\begin{array}{l}\text { - Острая недостаточность аортального } \\
\text { клапана (инфекционный эндокардит } \\
\text { и диссекция аорты; } \\
\text { - Симптоматическая аортальная } \\
\text { недостаточность; } \\
\text { - Сердечный выброс <50\%, } \\
\text { гипертрофия левого желудочка } \\
\text { (диаметр левого желудочка в конце } \\
\text { диастолы >70 мм или диаметр } \\
\text { левого желудочка в конце систолы } \\
\text { >50 мм). }\end{array}$ \\
\hline
\end{tabular}

\section{Вопросы и ответы по инфекционному эндокардиту}

\begin{tabular}{|c|c|}
\hline Bonpocbl & Ответы \\
\hline Что такое инфекционный эндокардит? & $\begin{array}{l}\text { Бактериальное инфекционное } \\
\text { воспаление клапанов сердца. }\end{array}$ \\
\hline Предрасполагающие факторы: & $\begin{array}{l}\text { - Заболевания клапанов; } \\
\text { - Процедуры, которые приводят к } \\
\text { бактеремии - внутривенное }\end{array}$ \\
\hline
\end{tabular}




\begin{tabular}{|c|c|}
\hline Вопросы & Ответы \\
\hline & $\begin{array}{ll}\text { введение } & \text { лекарственных } \\
\text { препаратов. } & \end{array}$ \\
\hline $\begin{array}{l}\text { Частые возбудители инфекционного } \\
\text { эндокардита: }\end{array}$ & $\begin{array}{l}\text { - S. viridans: при повреждённых } \\
\text { клапанах; } \\
\text { - S. aureus: при внутривенном } \\
\text { введении } \\
\text { препаратов; } \\
\text { - S. epidermitidis: при мехарственных } \\
\text { клапанах. }\end{array}$ \\
\hline Клинические признаки: & $\begin{array}{l}\text { - Шумы в сердце; } \\
\text { - Петехии; } \\
\text { - Кровоизлияния под ногтми; } \\
\text { - Пятна Рота на сетчатке; } \\
\text { - Узелки Ослера на ладонной или } \\
\text { плантарной поверхности; } \\
\text { - Симптом Джейнуэя. }\end{array}$ \\
\hline Диагностика: & $\begin{array}{l}\text { - Эхокардиография, } \\
\text { трансэзофагеальная } \\
\text { эхокардиография; } \\
\text { - Бактериологическое исследование. }\end{array}$ \\
\hline Методы лечения: & Антибиотикотерапия. \\
\hline Прогноз: & $\begin{array}{l}\text { При развитии недостаточности } \\
\text { клапанов выполняют пластику или } \\
\text { протезирование. }\end{array}$ \\
\hline
\end{tabular}




\section{ИШЕМИЧЕСКАЯ БОЛЕЗНЬ СЕРДЦА}

- Ишемическая болезнь сердца включает ишемические патологии, обусловленные сужением коронарных артерий.

- Проявляется тремя основными клиническими формами: стенокардия, инфаркт миокарда и кардиомиопатия.

- Стенокардия обусловлена временной ишемией сердечной мышцы.

○ Клинически проявляется повторяющейся болью в груди и одышкой.

- Инфаркт миокарда - острая ишемия и некроз сердечной мышцы.

О Клинически проявляется сильными болями, аритмией, острой сердечной недостаточностью, разрывом сердечной мышцы и папиллярных мышц, аневризмой сердца.

- Хроническая ишемическая кардиомиопатия характеризуется повторными инфарктами и диффузным поражением сердца.

О Клинически проявляется сердечной недостаточностью.

- В диагностике ишемической болезни сердца применяют контрастную ангиографию (КТ, МР). Специфическим показателем является сужение сосудов.

- Лечение направлено на реваскуляризацию миокарда. С этой целью применяется медикаментозное лечение, ангиопластика, стентирование, аортокоронарное шунтирование.

\section{Вопросы и ответы по ишемической болезни сердца}

\begin{tabular}{|ll|}
\multicolumn{1}{c|}{ Вопросы } & \multicolumn{2}{c|}{ Ответы } \\
\hline $\begin{array}{l}\text { Что представляют собой коронарные } \\
\text { болезни? }\end{array}$ & $\begin{array}{l}\text { Хронические ишемические болезни, } \\
\text { обусловленные стенозом или } \\
\text { окклюзией коронарных артерий. }\end{array}$ \\
\hline Клинические формы: & $\bullet$ Стенокардия; \\
& Инфаркт миокарда; \\
& Кардиомиопатия. \\
\hline
\end{tabular}




\begin{tabular}{|c|c|}
\hline Вопросы & Ответы \\
\hline Что такое стенокардия? & $\begin{array}{l}\text { Временный спазм коронарных артерий } \\
\text { без некроза сердечной мышцы. }\end{array}$ \\
\hline Что такое инфаркт миокарда? & $\begin{array}{l}\text { Ишемический некроз сердечной } \\
\text { мышцы. }\end{array}$ \\
\hline $\begin{array}{l}\text { Что такое ишемическая } \\
\text { кардиомиопатия? }\end{array}$ & $\begin{array}{l}\text { Ишемическая болезнь, обусловленная } \\
\text { повторными инфарктами, диффузным } \\
\text { поражением сердца и сердечной } \\
\text { недостаточностью. }\end{array}$ \\
\hline Частота встречаемости: & $\begin{array}{l}\text { Хроническая ишемическая болезнь } \\
\text { сердца занимает 1-ое место в структуре } \\
\text { причин смертности во всём мире. У } \\
\text { более чем 50\% пациентов поражаются } \\
\text { не менее } 3 \text { сосудов. }\end{array}$ \\
\hline Клинические признаки: & $\begin{array}{l}\text { Тяжесть в груди, загрудинные боли с } \\
\text { иррадиацией в левую лопаточную } \\
\text { область, одышка, тошнота. В редких } \\
\text { случаях наблюдаются безболевые } \\
\text { формы. }\end{array}$ \\
\hline $\begin{array}{l}\text { У каких пациентов наблюдается } \\
\text { бессимптомное течение? }\end{array}$ & $\begin{array}{l}\text { У пациентов с сахарным диабетом (в } \\
\text { связи с автономной дисфункцией боль } \\
\text { не наблюдается). }\end{array}$ \\
\hline $\begin{array}{l}\text { Какие артерии наиболее часто } \\
\text { поражаются? }\end{array}$ & $\begin{array}{l}\text { Левая нисходящая, правая коронарная } \\
\text { и огибающая артерия. }\end{array}$ \\
\hline Что такое болезнь трёх сосудов? & $\begin{array}{l}\text { Сужение левой передней, огибающей и } \\
\text { правой коронарной артерий. }\end{array}$ \\
\hline Факторы риска: & $\begin{array}{l}\text { - Артериальная гипертензия; } \\
\text { - Курение; } \\
\text { - Гиперлипидемия, } \\
\text { гиперхолестеринемия; } \\
\text { - Морбидное ожирение; }\end{array}$ \\
\hline
\end{tabular}




\begin{tabular}{|c|c|}
\hline Вопросы & Ответы \\
\hline & $\begin{array}{l}\text { - Сахарный диабет; } \\
\text { - Наследственность; } \\
\text { - Неправильное питание; } \\
\text { - Адинамия. }\end{array}$ \\
\hline Диагностика: & $\begin{array}{l}\text { - ЭКГ; } \\
\text { - Стресс-тест; } \\
\text { - Эхокардиография: дискинезия } \\
\text { стенки, дисфункция клапанов, } \\
\text { снижение сердечного выброса; } \\
\text { - Ангиография (КТ, инвазивная): } \\
\text { сужение сосудов. }\end{array}$ \\
\hline Методы лечения: & $\begin{array}{l}\text { - Консервативное (ß-блокаторы, } \\
\text { аспирин, антикоагулянты, нитраты, } \\
\text { антигипертензивные препараты); } \\
\text { - Ангиопластика, стентирование; } \\
\text { - Хирургическое (аортокоронарное } \\
\text { шунтирование). }\end{array}$ \\
\hline
\end{tabular}




\section{СПИСОК ЛИТЕРАТУРЫ}

\section{общая литература}

- Ağayev B.A. Cərrahi xəstəliklər. Bakı 2010.

- Blackbourne LH. Surgical Recall. 4 edition, 2006, LWW, Philadelphia

- Doherty GM. Current Diagnosis and Treatment: Surgery, $13^{\text {th }}$ edition, 2010, Lang International Edition.

- İsayev H.B. Cərrahi xəstəliklərin patofizologiyası. Bakı 2005

- Klingensmith ME, Aziz A, Bharat A, Fox AC, Porembka MR. The Washington Manual of Surgery, $6^{\text {th }}$ edition, 2012, LWW, Philadelphia.

- Medscape, http://www.medscape.com

- Oxford Handbook of Clinical Surgery, 3d edition, 2011, Oxford Press

- Sayek I. Sayek Temel Cerrahi 1-2. 4-cü baskı, 2016, Güneş Tıp Kitabevleri.

- Topçubaşov M.A. Xüsusi cərrahlıq. Bakı, 1979

- UpToDate, http://www.uptodate.com

- Гостищев B.К. Общая хирургия. GEOTAR-Media, 2019

\section{Специальная литература}

- 2017 AHA/ACC Focused Update of the 2014 AHA/ACC Guideline for theManagement of Patients With Valvular Heart Disease

- 2011 ACCF/AHA Guideline for Coronary Artery Bypass Graft Surgery

- 2010 ACCF/AHA/AATS/ACR/ASA/SCA/SCAI/SIR/STS/SVM Guidelines for the Diagnosis and Management of Patients With Thoracic Aortic Disease

- CC/AHA/HRS 2008 Guidelines for Device-Based Therapy of Cardiac Rhythm Abnormalities

- Effect of bosentan on intimal hyperplasia of carotid artery anastomoses in rabbits. Jahollari A, et al. Turk KardiyolDernArs. 2014. Authors Jahollari $A^{1}$, Emrahov $\underline{A}^{2}$, Tavlaşoğlu $\mathrm{M}^{3}$, Şahin $\mathrm{MA}^{2}$

- Evaluation of skill-acquisition process in mitral valve repair techniques: a simulationbased study.

- An instrument facilitates mitral valve repair training at home. Tavlasoglu M, et al. Eur J Cardiothorac Surg. 2012. Authors Tavlasoglu M, Amrahov A, Sahin MA.

- Eksperimental siçovullarda işemik reperfuziya zədələnməsi zamanı silostazolun təsirinin tətqiqi. Anar כmrahov. 


\title{
ХИРУРГИЧЕСКИЕ БОЛЕЗНИ
}

Н.Ю. Байрамов

\section{Хирургические заболевания сосудов \\ Н.Ю. Байрамов, М.М. Каримов, Ш.А. Мамедова}

\author{
Перевод: Н.Ю. Байрамов, С.А. Алиев, М.Р.Гусейнова
}




\section{ЗАБОЛЕВАНИЯ ПЕРИФЕРИЧЕСКИХ АРТЕРИЙ}

- Заболевания периферических артерий характеризуются частичной или полной облитерацией (стенозом) их просвета, клиническим проявлением которой являются нарушение кровотока, ишемия, гипоперфузия, частичная или полная утрата функции конечности.

- Основной этиологической причиной нарушения проходимости периферических артерий является атеросклероз.

- Клиническая картина окклюзирующих заболеваний периферических артерий характеризуется болью, бледностью, нарушением кожной чувствительности и функции конечности, ослаблением пульса на пораженной артерии. Прогрессирующая окклюзия приводит к стойкому нарушению кровообращению в пораженной конечности с последующим развитием дистрофических изменений (язвы, некроз и т. п).

- По клиническому течению различают острые и хронические нарушения периферического кровообращения.

- Причинами острой артериальной непроходимости являются тромбозы и эмболии. Острый артериальный тромбоз развивается постепенно, чем и отличается от эмболии, которая возникает внезапно и быстро приводит к критической ишемии конечности, ввиду отсутствия коллатеральной сети.

- Основной причиной хронической ишемии является атеросклероз. Хроническая ишемия проявляется 4-мы стадиями: асимптоматическая, перемежающаяся хромота, боли в покое, язва/гангрена.

- Диагностика осуществляется на основании анамнестических данных, клинической симптоматики (характер пульса, кожи, определение лодыжечноплечевого индекса), результатов лабораторных (общий анализ крови, липидный профиль, показатели свёртывания) и инструментальных (артериография, УзИдопплерография, КТ-ангиография, МР-ангиография).

- Лечение окклюзирующих заболеваний периферических артерий нижней конечностей проводится консервативным и хирургическим методами.

- Основными компонентами консервативной терапии, которая является методом выбора, являются спазмолитики, ангиопротекторы, сосудорасширяющие, антикоагулянты, препараты, улучшающие реологические свойства крови (дезагреганты). Важными условиями эффективности лечения являются 
устранение провоцирующих факторов риска (охлаждение, травма) и вредных привычек (курение, приём алкоголя).

- Хирургические методы включают эндартерэктомию, шунтирование, протезирование поражённой артерии, операции на симпатической нервной системе. При развитии гангрены применяют экзартикуляцию и ампутацию.

- В последнее десятилетие широко применяются минимально инвазивные методы (рентгеноэндоваскулярные) хирургической коррекции непроходимости периферических артерий (баллонная дилатация, стентирование, эндопротезирование).

\section{Вопросы и ответы по заболеваниям периферических артерий}

\begin{tabular}{|c|c|}
\hline Вопросы & Ответы \\
\hline $\begin{array}{l}\text { Что подразумевается под заболеванием } \\
\text { периферических артерий? }\end{array}$ & $\begin{array}{l}\text { Заболевания, способствующие частичной } \\
\text { и полной окклюзии просвета артерии, } \\
\text { сопровождающиеся ишемическими и } \\
\text { перфузионными нарушениями и } \\
\text { частичной или полной утратой функции } \\
\text { конечности. }\end{array}$ \\
\hline $\begin{array}{l}\text { Нозологические причины заболеваний } \\
\text { периферических артерий: }\end{array}$ & $\begin{array}{l}\text { - Атеросклероз; } \\
\text { - Флебит; } \\
\text { - Аутоиммунные процессы - васкулиты } \\
\text { и др.; } \\
\text { - Травмы и операции; } \\
\text { - Коагулопатии. }\end{array}$ \\
\hline Факторы риска: & $\begin{array}{l}\text { - Сахарный диабет; } \\
\text { - } \text { Гиперлипидемия; } \\
\text { - Курение; } \\
\text { - Коагулопатия. }\end{array}$ \\
\hline Клинические признаки: & $\begin{array}{l}\text { - Боль (pain); } \\
\text { - Бледность (pallor); } \\
\text { - Отсутствие пульса (pulselessness); } \\
\text { - } \text { Парестезия (paresthesia); }\end{array}$ \\
\hline
\end{tabular}




\begin{tabular}{|c|c|}
\hline Вопросы & Ответы \\
\hline & - Паралич (paralysis). \\
\hline Методы диагностики: & $\begin{array}{l}\text { - Объективные - определение } \\
\text { характера кожи и пульса; } \\
\text { - Лабораторные - общий и } \\
\text { биохимический анализы крови } \\
\text { (электролиты, креатинин, липиды, Д- } \\
\text { димер); } \\
\text { Инструментальные - } \\
\text { артериография, КТ, МРТ. }\end{array}$ \\
\hline $\begin{array}{l}\text { Оценка каких артерий проводится тестом } \\
\text { Аллена? }\end{array}$ & Лучевая и локтевая артерии. \\
\hline Как проводится тест Аллена? & $\begin{array}{l}\text { При давлении на лучевую и локтевую } \\
\text { артерии в области лучезапястного сустава } \\
\text { пациент сгибает и разгибает пальцы кисти. } \\
\text { При этом отмечается бледность кожи. По } \\
\text { мере расслабления сдавления, кровоток в } \\
\text { кисти восстанавливается. }\end{array}$ \\
\hline $\begin{array}{l}\text { Как определяется лодыжечно-плечевой } \\
\text { индекс? }\end{array}$ & $\begin{array}{l}\text { Отношение систолического давления на } \\
\text { лодыжке к артериальному давлению в } \\
\text { плечевой области. }\end{array}$ \\
\hline $\begin{array}{l}\text { Показатели лодыжечно-плечевого } \\
\text { индекса: }\end{array}$ & $\begin{array}{l}\text { - } \quad \text { В норме } \geq 1,0 ; \\
\text { - } \text { При перемежающейся хромоте <0,6; } \\
\text { - } \text { Боль В покое <0,4. }\end{array}$ \\
\hline $\begin{array}{l}\text { Когда происходит отклонение этих } \\
\text { показателей? }\end{array}$ & $\begin{array}{l}\text { При кальцинозе артерий (у больных с } \\
\text { сахарным диабетом). }\end{array}$ \\
\hline Методы лечения: & $\begin{array}{l}\text { - Консервативное (устранение факторов } \\
\text { риска, антикоагулянты); } \\
\text { - Хирургическое. }\end{array}$ \\
\hline $\begin{array}{l}\text { Обязательные противопоказания к } \\
\text { хирургическому лечению: }\end{array}$ & $\begin{array}{l}\text { Агональное или очень тяжёлое состояние } \\
\text { пациента. }\end{array}$ \\
\hline
\end{tabular}




\begin{tabular}{|c|c|}
\hline Вопросы & Ответы \\
\hline $\begin{array}{l}\text { Относительные противопоказания к } \\
\text { хирургическому лечению: }\end{array}$ & $\begin{array}{l}\text { Тяжёлые сопутствующие заболевания - } \\
\text { острый инфаркт миокарда, лёгкие ишемии } \\
\text { у пациентов с неоперабельной } \\
\text { злокачественной опухолью. }\end{array}$ \\
\hline Виды хирургического лечения: & $\begin{array}{l}\text { - } \text { Эмболэктомия; } \\
\text { - Шунтирование; } \\
\text { - Ампутация. }\end{array}$ \\
\hline Виды эмболэктомии: & $\begin{array}{l}\text { - Прямая (открытая) - артериотомия с } \\
\text { удалением тромба; } \\
\text { - Непрямая (закрытая) - дистальная или } \\
\text { проксимальная артериотомия с } \\
\text { последующим удалением тромба с } \\
\text { помощью баллонного катетера } \\
\text { Фогарти. }\end{array}$ \\
\hline $\begin{array}{l}\text { Техника удаления тромба с помощью } \\
\text { катетера Фогарти: }\end{array}$ & $\begin{array}{l}\text { После небольшого разреза в артерию } \\
\text { вводится баллонный катетер Фогарти, } \\
\text { который проводится выше тромба. После } \\
\text { раздувания баллона катетер выводится } \\
\text { обратно вместе стромбом. }\end{array}$ \\
\hline $\begin{array}{l}\text { Какие осложнения наблюдаются в } \\
\text { постоперационном периоде при } \\
\text { реперфузии конечности после длительной } \\
\text { острой ишемии? }\end{array}$ & $\begin{array}{l}\text { - Компартмент-синдром; } \\
\text { - } \quad \text { Гиперкалиемия; } \\
\text { - } \text { Почечная недостаточность, связанная с } \\
\text { миоглобинурией; } \\
\text { - Инфаркт миокарда. }\end{array}$ \\
\hline Что такое компартмент-синдром? & $\begin{array}{l}\text { Повышение давления в фасциально- } \\
\text { мышечном футляре голени после } \\
\text { реперфузии, что способствует снижению } \\
\text { скорости капиллярного кровотока, } \\
\text { ишемии и некрозу мышц. Некроз мышц } \\
\text { происходит при повышении давления в } \\
\text { фасциально-мышечном пространстве до } \\
30 \text { мм рт.ст. }\end{array}$ \\
\hline
\end{tabular}




\begin{tabular}{|c|c|}
\hline Вопросы & Ответы \\
\hline $\begin{array}{l}\text { Основные признаки компартмент- } \\
\text { синдрома? }\end{array}$ & $\begin{array}{l}\text { - Боль (особенно при пассивном } \\
\text { движении конечности); } \\
\text { - Парестезия; } \\
\text { - Паралич; } \\
\text { - Бледность кожи; } \\
\text { - У большинства больных пульс на } \\
\text { артерии определяется. }\end{array}$ \\
\hline $\begin{array}{l}\text { Какие методы исследования необходимы } \\
\text { для уточнения диагноза? }\end{array}$ & $\begin{array}{l}\text { - Анамнез; } \\
\text { - Измерение давления в фасциально- } \\
\text { мышечном футляре. }\end{array}$ \\
\hline Методы лечения: & Билатеральная фасциотомия. \\
\hline $\begin{array}{l}\text { Основные причины острой артериальной } \\
\text { непроходимости: }\end{array}$ & Тромбоз и эмболия. \\
\hline $\begin{array}{l}\text { Частота встречаемости острого } \\
\text { артериального тромбоза: }\end{array}$ & $\begin{array}{l}\text { Составляет } 60 \% \text { всех острых ишемий } \\
\text { конечности. }\end{array}$ \\
\hline Факторы риска тромбоза: & $\begin{array}{l}\text { - Дегидратация; } \\
\text { - Гипотензия; } \\
\text { • Малигнизация; } \\
\text { - Полицитемия; } \\
\text { • Врождённые } \\
\text { состояния. }\end{array}$ \\
\hline Клинические признаки: & $\begin{array}{l}\text { - } \text { Перемежающаяся хромота; } \\
\text { - } \text { Стеноз или неполная окклюзия сосуда; } \\
\text { - Неизвестность источника эмболии; } \\
\text { - Ослабление или отсутствие пульса на } \\
\text { контралатеральной конечности. }\end{array}$ \\
\hline Что такое эмболия? & $\begin{array}{l}\text { Закупорка просвета артерии каким-либо } \\
\text { субстратом и развивающаяся в результате } \\
\text { этого острая ишемия. }\end{array}$ \\
\hline Классификация эмболии: & $\begin{array}{l}\text { - Комбинированная форма - } \\
\text { одномоментное поражение артерий 2- } \\
\text { х и более конечностей; }\end{array}$ \\
\hline
\end{tabular}




\begin{tabular}{|c|c|}
\hline Вопросы & Ответы \\
\hline & $\begin{array}{l}\text { - Прерывистая форма - закупорка } \\
\text { просвета одной артерии на различных } \\
\text { уровнях; } \\
\text { - Сочетанная форма - синхронное } \\
\text { поражение артерий конечностей, } \\
\text { висцеральных и церебральных } \\
\text { артерий. }\end{array}$ \\
\hline Особенности эмболии: & $\begin{array}{l}\text { - Отсутствие ранее перемежающей } \\
\text { хромоты; } \\
\text { - Прогрессирующее течение и полная } \\
\text { закупорка просвета сосуда; } \\
\text { - Развитие аритмий, в особенности } \\
\text { фибрилляции предсердий. }\end{array}$ \\
\hline Наиболее частая локализация эмболов: & $\begin{array}{l}\text { В местах наибольшего сужения просвета } \\
\text { сосудов (бифуркации). }\end{array}$ \\
\hline Степени острой ишемии конечности: & $\begin{array}{l}\text { - I степень-боль в покое или при лёгкой } \\
\text { физической работе, парестезия, } \\
\text { усталость; } \\
\text { - II степень - появление двигательных } \\
\text { расстройств: } \\
\text { О ІІа - парез конечности; } \\
\text { О ІІІ - паралич конечности; } \\
\text { О ІІс-субфасциальный отёк; } \\
\text { - III степень - глубокие ишемические } \\
\text { повреждения: } \\
\text { - ІІІа - ограниченные, дистальные } \\
\text { контрактуры конечности; } \\
\text { - ІІІь - тотальная контрактура } \\
\text { конечности. }\end{array}$ \\
\hline Осложнения острой ишемии: & $\begin{array}{l}\text { - Хроническая ишемия конечности; } \\
\text { - Постишемический синдром; } \\
\text { - } \text { Гангрена конечности; } \\
\text { - Венозный тромбоз, тромбоэмболия } \\
\text { лёгочной артерии; }\end{array}$ \\
\hline
\end{tabular}




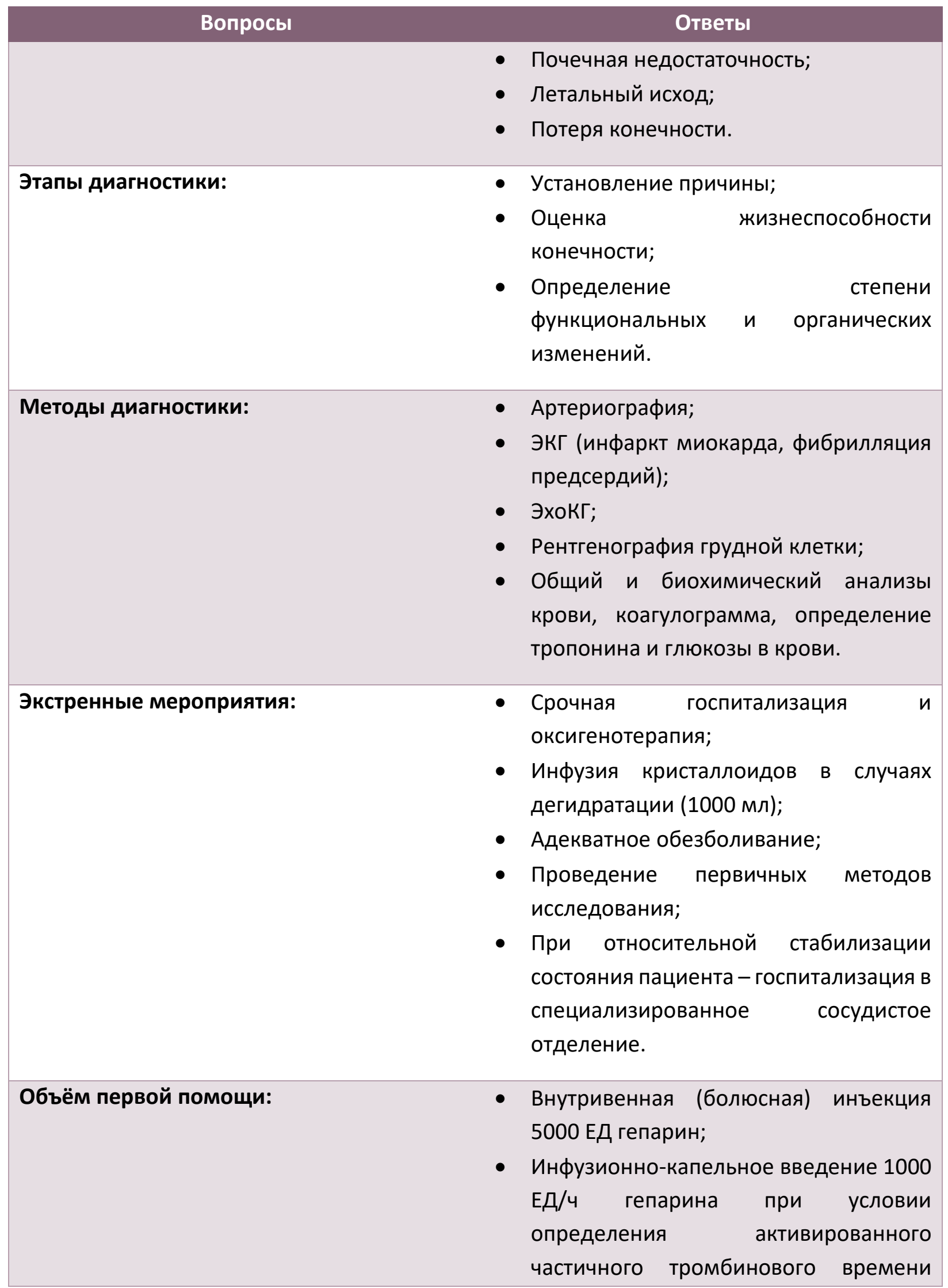




\begin{tabular}{|c|c|}
\hline Вопросы & Ответы \\
\hline & $\begin{array}{l}\text { через каждые 4-6 часов и } \\
\text { поддержания последнего на уровне 2- } \\
2,5 \text {. }\end{array}$ \\
\hline $\begin{array}{l}\text { Преимущества низкомолекулярных } \\
\text { гепаринов: }\end{array}$ & $\begin{array}{l}\text { - Более эффективное лечебное } \\
\text { воздействие при минимальном риске } \\
\text { кровотечения; } \\
\text { - Применяется } 1 \text { раз в сутки; } \\
\text { - Отсутствие необходимости строгого } \\
\text { контроля за показателями } \\
\text { коагулограммы. }\end{array}$ \\
\hline $\begin{array}{l}\text { Основные противопоказания к } \\
\text { гепаринотерапии: }\end{array}$ & $\begin{array}{l}\text { - Травмы различного происхождения (в } \\
\text { особенности черепно-мозговые); } \\
\text { - } \text { Расслоившаяся аневризма аорты. }\end{array}$ \\
\hline Окончательные мероприятия: & 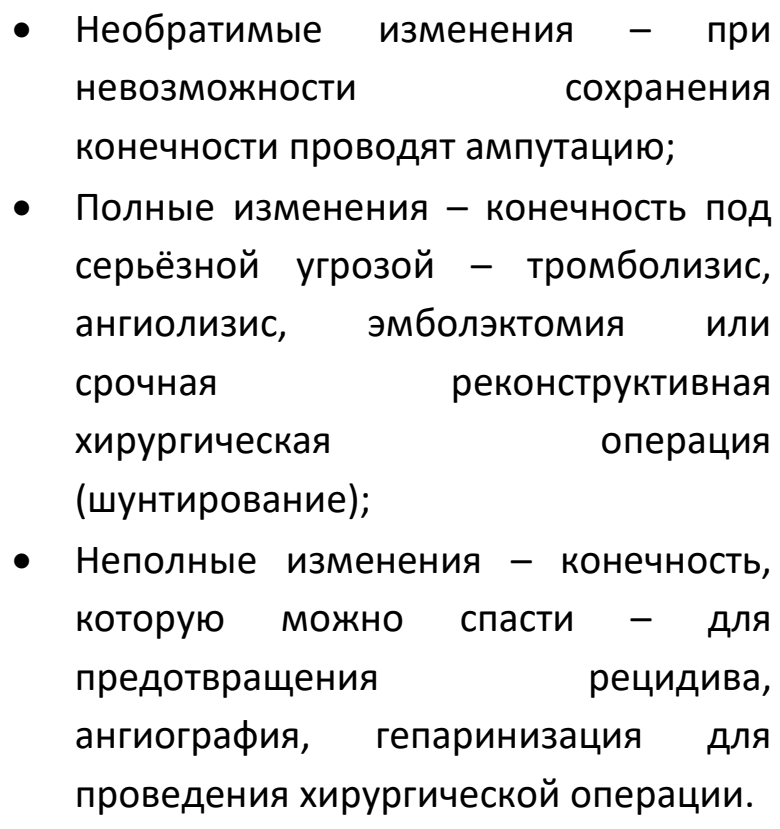 \\
\hline Стадии хронической ишемии: & $\begin{array}{l}\text { - I стадия - бессимптомная; } \\
\text { - II стадия - перемежающаяся хромота; } \\
\text { - III стадия - болевой синдром в покое; } \\
\text { - IV стадия - трофические изменения } \\
\text { (трофические язвы, некроз, гангрена). }\end{array}$ \\
\hline Что такое перемежающаяся хромота? & $\begin{array}{l}\text { При прохождении определённого } \\
\text { расстояния в нижних конечностях, в }\end{array}$ \\
\hline
\end{tabular}




\begin{tabular}{|c|c|}
\hline Вопросы & Ответы \\
\hline & $\begin{array}{l}\text { особенности икроножных } \\
\text { наблюдаются боли, спазмы, которые } \\
\text { проходят через определённое время. }\end{array}$ \\
\hline $\begin{array}{l}\text { Частота встречаемости перемежающейся } \\
\text { хромоты: }\end{array}$ & $\begin{array}{l}\text { Составляет } 50 \% \text { среди мужчин старше } 50 \\
\text { лет. }\end{array}$ \\
\hline Прогноз: & $\begin{array}{l}\text { У } 1 / 3 \text { пациентов наступает } \\
\text { выздоровление; у } 1 / 3 \text { - течение остаётся } \\
\text { без изменений; у } 1 / 3 \text { - отмечается } \\
\text { ухудшение. } 4 \% \text { больных нуждаются в } \\
\text { хирургическом лечении. Необходимость в } \\
\text { ампутации конечности возникает у } 1 \% \\
\text { пациентов. }\end{array}$ \\
\hline Факторы риска: & $\begin{array}{l}\text { - Гипертоническая болезнь; } \\
\text { - } \quad \text { Гиперлипидемия; } \\
\text { - Сахарный диабет; } \\
\text { - Курение; } \\
\text { - Наследственно-генетические факторы. }\end{array}$ \\
\hline $\begin{array}{l}\text { Какие методы диагностики необходимы } \\
\text { для уточнения диагноза? }\end{array}$ & $\begin{array}{l}\text { - Клиническое обследование; } \\
\text { - Лабораторные исследования (глюкоза, } \\
\text { холестерин, триглицериды); } \\
\text { - Инструментальные исследования } \\
\text { (ангиография, КТ/МР- ангиография); } \\
\text { - УзИ брюшной полости (при аневризме } \\
\text { аорты). }\end{array}$ \\
\hline Методы лечения: & $\begin{array}{l}\text { - Устранение факторов риска; } \\
\text { - Консервативное лечение (аспирин, } \\
\text { трентал); } \\
\text { - Эндоваскулярное лечение } \\
\text { (ангиопластика, стентирование); } \\
\text { - Хирургическое лечение. }\end{array}$ \\
\hline $\begin{array}{l}\text { Схема лечения перемежающейся } \\
\text { хромоты: }\end{array}$ & $\begin{array}{l}\text { - } \text { Pentoksifillin; } \\
\text { - Aspirin; } \\
\text { - } \text { прекращение курения; }\end{array}$ \\
\hline
\end{tabular}




\begin{tabular}{|c|c|}
\hline Вопросы & Ответы \\
\hline $\begin{array}{l}\text { Что такое критическая ишемия } \\
\text { конечности? }\end{array}$ & $\begin{array}{l}\text { III-IV степени хронической ишемии } \\
\text { конечности. }\end{array}$ \\
\hline Диагностические критерии: & $\begin{array}{l}\text { - Продолжение болевого синдрома в } \\
\text { покое более 2-х недель и отсутствие } \\
\text { лечебного эффекта анальгетиков; } \\
\text { - Уровень артериального давления на } \\
\text { лодыжке, определяемое допплерог- } \\
\text { рафией-составляет ниже } 50 \text { мм рт. ст. } \\
\text { (у пациентов с сахарным диабетом - } \\
\text { ниже } 30 \text { мм рт. ст.); } \\
\text { - Наличие трофических нарушений } \\
\text { (язва, некроз, гангрена). }\end{array}$ \\
\hline Что такое боль в покое? & $\begin{array}{l}\text { Возникает ночью, усиливается при } \\
\text { поднятии конечности, уменьшается при её } \\
\text { опускании. }\end{array}$ \\
\hline $\begin{array}{l}\text { Какие методы исследования необходимы } \\
\text { для уточнения диагноза? }\end{array}$ & $\begin{array}{l}\text { - Допплерография; } \\
\text { - Ангиография; } \\
\text { - МРТ. }\end{array}$ \\
\hline Методы лечения: & $\begin{array}{l}\text { - Реваскуляризация; } \\
\text { - } \quad \text { Эндоваскулярное лечение; } \\
\text { - Хирургическое лечение: } \\
\text { О Бедренно-дистальное } \\
\text { шунтирование; } \\
\text { О Ампутация. }\end{array}$ \\
\hline Показания к хирургическому лечению: & $\begin{array}{l}\text { - Снижение качества жизни из-за } \\
\text { постоянного болевого синдрома; } \\
\text { • Некроз ткани; } \\
\text { • Присоединения инфекции. }\end{array}$ \\
\hline Что такое синдром Лериша? & $\begin{array}{l}\text { Атеросклеротическая } \\
\text { дистальной части аорты. }\end{array}$ \\
\hline
\end{tabular}




\begin{tabular}{|c|c|}
\hline Вопросы & Ответы \\
\hline Клинические признаки: & $\begin{array}{ll}\text { - } & \text { Перемежающаяся хромота; } \\
\text { - } & \text { Импотенция (эректильная } \\
& \text { дисфункция); } \\
\text { - } & \text { Атрофия мышц нижних конечностей. }\end{array}$ \\
\hline Что такое сухая гангрена? & $\begin{array}{l}\text { Некроз тканей без инфекции с наличием } \\
\text { демаркационной линии. }\end{array}$ \\
\hline Что такое влажная гангрена? & $\begin{array}{l}\text { Некроз тканей с наличием инфекции и } \\
\text { отсутствием демаркационной линии. }\end{array}$ \\
\hline Что такое синдром синюшного пальца? & $\begin{array}{l}\text { Цианоз пальца кисти или стопы, } \\
\text { возникшей при острой окклюзии } \\
\text { проксимальных сегментов артерии. }\end{array}$ \\
\hline
\end{tabular}




\section{ОСТРЫЙ ТРОМБОЗ ГЛУБОКИХ ВЕН НИЖНИХ КОНЕЧНОСТЕЙ}

- Основными этиологическими факторами тромбоза глубоких вен являются изменение эндотелия сосудов, нарушение кровотока и изменение состава крови: сдавление вены, врождённые и приобретённые гиперкоагуляционные состояния.

- Клиническая картина в начальной стадии заболевания может быть бессимптомной. В дальнейшем могут проявляться симптомы локального венозного застоя (отёк, боль, покраснения, припухлость), признаки воспаления (субфебрильная температура, тахикардия), симптом Хоманса.

- Наиболее серьёзными осложнениями являются тромбоэмболия лёгочной артерии и венозная гангрена нижней конечности.

- Диагностика острого тромбоза глубоких вен базируется на данных клинической симптоматики и инструментальных методов исследований. Комплекс инструментальных исследований предусматривает флебографию, УзИ, ультразвуковое дуплексное сканирование, МРТ, КТ-ангиографию лёгочной артерии.

- Лечение в основном консервативное (строгий постельный режим, антикоагулянты, компрессионная терапия). Хирургическое лечение заключается в тромбэктомии, имплантации кава-фильтров, перевязке магистральных вен, локальной тромболитической терапии.

\section{Вопросы и ответы по острому тромбозу глубоких вен}

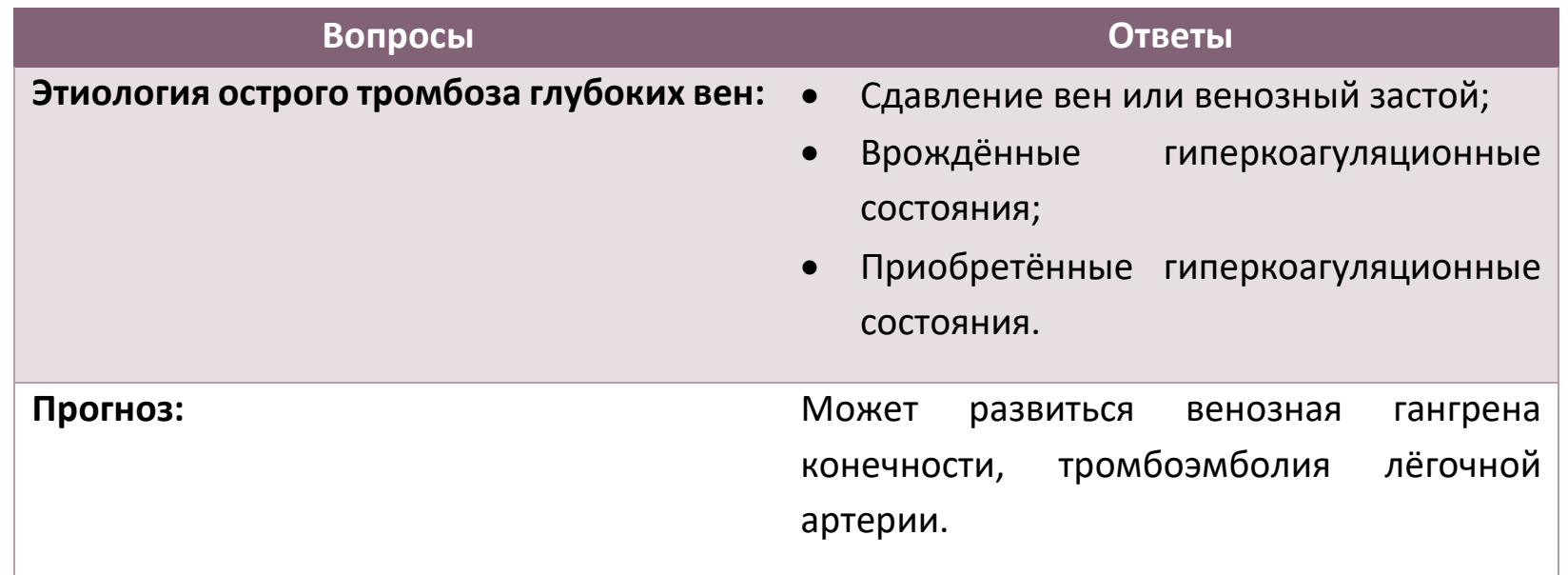




\begin{tabular}{|c|c|}
\hline Вопросы & Ответы \\
\hline Клинические признаки: & $\begin{array}{l}\text { - Бессимптомное течение; } \\
\text { - Признаки локального венозного застоя: } \\
\text { о Отёк конечности; } \\
\text { О Боль; } \\
\text { О Покраснение; } \\
\text { - Субфебрильная температура и } \\
\text { тахикардия; } \\
\text { - Симптом Хоманса. }\end{array}$ \\
\hline Что такое симптом Хоманса? & $\begin{array}{l}\text { Появление боли при тыльном сгибании } \\
\text { стопы или при компрессии средней трети } \\
\text { голени. }\end{array}$ \\
\hline $\begin{array}{l}\text { Какие методы исследования необходимы } \\
\text { для уточнения диагноза? }\end{array}$ & $\begin{array}{l}\text { - Уз-дуплексное сканирование (для } \\
\text { определения тромбоза глубоких вен } \\
\text { голени); } \\
\text { - Вентиляционно-перфузионное } \\
\text { сканирование лёгких (для определения } \\
\text { тромбоэмболии лёгочной артерии); } \\
\text { - КТ-ангиография лёгочной артерии; } \\
\text { - Восходящая флебография. }\end{array}$ \\
\hline Методы лечения: & $\begin{array}{l}\text { - Консервативное; } \\
\text { - Хирургическое. }\end{array}$ \\
\hline $\begin{array}{l}\text { В чём заключается консервативное } \\
\text { лечение? }\end{array}$ & $\begin{array}{l}\text { - Строгий постельный режим - до } \\
\text { исключения флотирующего тромба; } \\
\text { - Антикоагулянтная терапия; } \\
\text { - Компрессионная терапия; } \\
\text { - Регидратация. }\end{array}$ \\
\hline
\end{tabular}




\begin{tabular}{|c|c|}
\hline Вопросы & Ответы \\
\hline Методы хирургического лечения: & $\begin{array}{l}\text { • } \quad \text { Хирургическая тромбоэктомия; } \\
\text { • Имплантация кава-фильтра в инфраре- } \\
\text { - Пальный сегмент нижней полой вены; } \\
\text { - } \quad \text { Радикальная тромбэктомия и локальная } \\
\quad \text { тромболитическая терапия. }\end{array}$ \\
\hline Показания к имплантации кава-фильтра: & $\begin{array}{l}\text { - Наличие илеофеморального или } \\
\text { илеокавального флотирующего тромба } \\
\text { (при противопоказании кхирургической } \\
\text { операции); } \\
\text { - Повторная тромбоэмболия лёгочной } \\
\text { артерии несмотря на лечение; } \\
\text { - Эмболия ствола лёгочной артерии; } \\
\text { - Высокий риск диссеминированного } \\
\text { внутрисосудистого свёртывания. }\end{array}$ \\
\hline Осложнения кава-фильтра: & $\begin{array}{l}\text { - Окклюзия нижней полой вены; } \\
\text { - Окклюзия почечных вен; } \\
\text { • Тромбоз фильтра. }\end{array}$ \\
\hline $\begin{array}{l}\text { Какие методы исследования необходимы } \\
\text { для уточнения диагноза? }\end{array}$ & $\begin{array}{l}\text { - Допплерография; } \\
\text { - Ангиография; } \\
\text { - МРТ. }\end{array}$ \\
\hline Методы лечения: & $\begin{array}{l}\text { - Реваскуляризация; } \\
\text { - } \text { Эндоваскулярное лечение; } \\
\text { - Хирургическое лечение: } \\
\text { о Бедренно-дистальное } \\
\text { шунтирование; } \\
\text { о Ампутация. }\end{array}$ \\
\hline
\end{tabular}




\section{ХРОНИЧЕСКАЯ ВЕНОЗНАЯ НЕДОСТАТОЧНОСТЬ}

- Термин “хроническая венозная недостаточность" объединяет различные патологии венозной системы нижних конечностей, сопровождающихся недостаточностью клапанов вен, окклюзией или сужением венозных магистралей, нарушением венозного кровообращения, трофическими изменениями конечности.

- Основными причинами являются варикозная болезнь вен и посттромботический синдром.

- Основными признаками хронической венозной недостаточности нижних конечностей являются тяжесть и боль, усиливающиеся при длительном пребывании на ногах, периодически отмечаются судороги. При сочетанном поражении бедренных и подвздошных вен отёк распространяется на всю конечность.

- Длительный венозный застой способствует нарастанию отёка, что в конечном счёте ведёт к нарушению лимфооттока и венозной гемодинамики, повышению проницаемости капилляров, склерозу кожи и подкожной клетчатки (дерматолипосклероз).

- Финалом хронического нарушения венозного кровообращения является развитие некроза кожи и формирование трофических венозных язв.

- Для диагностики хронической венозной недостаточности применяют УзИ, дуплексное флебоангиосканирование, флебографию.

- Лечение хронической венозной недостаточности включает применение консервативного и хирургического методов. Консервативное лечение предусматривает применение эластической компрессии, медикаментозных средств, улучшающих венозную гемодинамику. Хирургическое лечение направлено на ликвидацию венозного застоя и осложнений (эндоваскулярное лечение, артериальная реваскуляризация, пересадка кожи, очищение язвы от инфекции). Различные шунтирующие операции с формированием веновенозных анастомозов малоэффективны из-за повторных тромбозов. В настоящее время при лечения варикозной болезнь предпочтение отдают малоинвазивным методам лечения (термальная абляция, химическая или механохимическая абляция). 


\section{Вопросы и ответы по хронической венозной недостаточности}

\begin{tabular}{|c|c|}
\hline Вопросы & Ответы \\
\hline $\begin{array}{l}\text { Клинические признаки хронической } \\
\text { венозной недостаточности: }\end{array}$ & $\begin{array}{l}\text { - Отёк лодыжки либо всей } \\
\text { конечности; } \\
\text { - Варикозы, экзема, пигментация, } \\
\text { липодерматосклероз; } \\
\text { - Образование венозных трофических } \\
\text { язв; } \\
\text { - Боль, усиливающаяся или } \\
\text { уменьшающаяся в зависимости от } \\
\text { положения конечности; } \\
\text { - Венозная хромота (в редких } \\
\text { случаях). }\end{array}$ \\
\hline $\begin{array}{l}\text { Методы диагностики хронической } \\
\text { венозной недостаточности: }\end{array}$ & Дуплексное и триплексное УзИ. \\
\hline Методы лечения: & $\begin{array}{l}\text { - Консервативное лечение: } \\
\text { - Эндоваскулярное - лазерная, } \\
\text { радиочастотная } \\
\text { эхосклеротерапия; } \\
\text { - Хирургическое лечение. }\end{array}$ \\
\hline $\begin{array}{l}\text { В чём заключается } \text { методы } \\
\text { консервативного лечения? }\end{array}$ & $\begin{array}{l}\text { - Придание пораженной конечности } \\
\text { возвышенного положения; } \\
\text { - Применение эластической } \\
\text { компрессионных чулков. }\end{array}$ \\
\hline $\begin{array}{l}\text { Показания к применению } \\
\text { компрессионных чулков: }\end{array}$ & $\begin{array}{l}\text { - Класс I- давление на лодыжке <25 } \\
\text { мм рт. ст. - профилактическое } \\
\text { применение; } \\
\text { - Класс ІІ- давление на лодыжке 25-35 } \\
\text { мм рт. ст. - наличие варикозных вен } \\
\text { и хронической венозной } \\
\text { недостаточности; }\end{array}$ \\
\hline
\end{tabular}




\begin{tabular}{|c|c|}
\hline Вопросы & Ответы \\
\hline & $\begin{array}{l}\text { - Класс III - давление на лодыжке 35- } \\
45 \text { мм рт. ст. - наличие хронической } \\
\text { венозной недостаточности; } \\
\text { - } \text { Класс IV - давление на лодыжке 45- } \\
60 \text { мм рт. ст. - лимфедема. }\end{array}$ \\
\hline Методы хирургического лечения: & $\begin{array}{l}\text { - Кожная пластика; } \\
\text { - Очищение язвы от инфекции; } \\
\text { - Артериальная реваскуляризация; } \\
\text { - Перевязка перфорантных вен; } \\
\text { - Вальвулопластика; } \\
\text { - Стентирование вены; } \\
\text { - Шунтирование. }\end{array}$ \\
\hline
\end{tabular}




\section{АНЕВРИЗМЫ СОСУДОВ}

- Аневризмы сосудов представляют собой локальное или диффузное расширение просвета сосуда, превышающее нормальный диаметр в 1,5-2 раза и более.

- Причиной аневризмы является дисбаланс между коллагеновым и эластическим компонентами сосудистой стенки. Факторами риска могут быть артериальная гипертензия, курение, наследственно-генетические причины.

- По патологоанатомическим особенностям различают истинные (включающие все слои артерии) и ложные (состоящие из адвентиции и паравазальных тканей), по локализации - грудные, брюшные и периферические (подвздошные, бедренные, подколенные, каротидные, висцеральные), по форме - мешотчатые и веретенообразные (фузиформные) аневризмы.

- В начальной стадии аневризмы протекают без каких-либо клинических проявлений. Клиническая картина развивается по мере увеличения размеров аневризмы и при возникновении осложнений (разрыв). Симптомы могут быть общими и местными, определяются локализацией и диаметром патологического сосуда: боль, осиплость голоса, одышка, дисфагия, признаки дистальной эмболии, гематурия, тошнота и др.

- Диагностика основана на клинических, лабораторных (общий анализ крови, электролиты, коагулограмма, группа крови) и инструментальных (рентгенография, УЗИ, ЭхоКГ, КТ/МРТ-ангиография) методах исследования.

- Лечение аневризм осуществляется хирургическим и эндоваскулярным (стентирование) путём. Вид вмешательства определяется размером и опасностью развития серьёзных осложнений.

\section{Вопросы и ответы по аневризмам}

\section{Вопросы}

Что такое аневризма?

\section{Ответы}

Локальное или диффузное расширение просвета сосуда, превышающее нормальный диаметр в 1.5-2 раза и более. 


\begin{tabular}{|c|c|}
\hline Вопросы & Ответы \\
\hline Факторы риска развития аневризмы: & $\begin{array}{l}\text { - Артериальная гипертензия; } \\
\text { - Атеросклероз; } \\
\text { - Курение; } \\
\text { - Травмы; } \\
\text { - Врождённые заболевания (болезнь } \\
\text { Марфана, синдром Элерса-Данло); } \\
\text { - Аортоартериит; } \\
\text { - Хроническое обструктивное } \\
\text { - заболевание лёгких; } \\
\text { - Мжирение; } \\
\text { - Вужской пол; } \\
\text { - Назраст >50 лет; } \\
\text { Наследственность. }\end{array}$ \\
\hline $\begin{array}{l}\text { Частота встречаемости среди мужчин } \\
\text { и женщин: }\end{array}$ & $9: 1$. \\
\hline $\begin{array}{l}\text { По патолоанатомическим } \\
\text { особенностям различают: }\end{array}$ & $\begin{array}{l}\text { - Истинные; } \\
\text { - Ложные. }\end{array}$ \\
\hline Что такое истинная аневризма? & $\begin{array}{l}\text { Стенки аневризмы состоят из всех слоёв } \\
\text { нормальной стенки артерии. }\end{array}$ \\
\hline $\begin{array}{l}\text { Что такое ложная аневризма } \\
\text { (псевдоаневризма)? }\end{array}$ & $\begin{array}{l}\text { В формировании аневризмы } \\
\text { принимают участие только адвентиция } \\
\text { и паравазальная ткань. }\end{array}$ \\
\hline $\begin{array}{l}\text { По локализации аневризмы } \\
\text { различают: }\end{array}$ & $\begin{array}{l}\text { - Грудные; } \\
\text { - Брюшные; } \\
\text { - Периферические. }\end{array}$ \\
\hline Виды периферических аневризм: & $\begin{array}{l}\text { - Аневризма подвздошной артерии; } \\
\text { - Аневризма бедренной артерии; } \\
\text { - Аневризма подколенной артерии; } \\
\text { - Аневризма каротидной артерии; }\end{array}$ \\
\hline
\end{tabular}




\begin{tabular}{|c|c|}
\hline Вопросы & Ответы \\
\hline & - Аневризма висцеральных артерий. \\
\hline $\begin{array}{l}\text { По форме различают следующие } \\
\text { аневризмы: }\end{array}$ & $\begin{array}{l}\text { - Мешотчатая; } \\
\text { - Веретенообразная (фузиформная). }\end{array}$ \\
\hline $\begin{array}{l}\text { Классификация аневризм грудной } \\
\text { аорты в зависимости от их } \\
\text { локализации: }\end{array}$ & $\begin{array}{l}\text { - Аневризма восходящей аорты; } \\
\text { - Аневризма дуги аорты; } \\
\text { - Аневризма нисходящей аорты или } \\
\text { аневризма торакоабдоминального } \\
\text { отдела аорты. }\end{array}$ \\
\hline $\begin{array}{l}\text { Классификация } \\
\text { торакоабдоминальной аневризмы по } \\
\text { Crawford: }\end{array}$ & $\begin{array}{l}\text { - I тип - аневризма от левой } \\
\text { подключичной артерии до } \\
\text { почечной; } \\
\text { - II тип - аневризма от левой } \\
\text { подключичной артерии до } \\
\text { бифуркации аорты; } \\
\text { - III тип - аневризма от средней трети } \\
\text { нисходящей аорты до бифуркации; } \\
\text { І IV тип - аневризма от уровня } \\
\text { диафрагмы до почечной артерии } \\
\text { или бифуркации аорты. }\end{array}$ \\
\hline $\begin{array}{l}\text { Клинические проявления аневризмы } \\
\text { грудной аорты: }\end{array}$ & $\begin{array}{l}\text { • Обычно протекает бессимптомно. } \\
\text { Симптомы проявляются по мере } \\
\text { увеличения аневризмы и развитии } \\
\text { осложнений (разрыв): } \\
\text { • Загрудинные боли, иррадиирующие } \\
\text { в шею, лопатку, эпигастральную } \\
\text { область; } \\
\text { • Припухлость и расширение шейных } \\
\text { вен; } \\
\text { • Одышка; } \\
\text { - Осиплость голоса; }\end{array}$ \\
\hline
\end{tabular}




\begin{tabular}{|c|c|}
\hline Вопросы & Ответы \\
\hline & $\begin{array}{l}\text { • Дисфагия; } \\
\text { • Признаки дистальной эмболии; } \\
\text { • Гемоптиз, гематомезис или } \\
\text { признаки желудочно-кишечного } \\
\text { кровотечения. }\end{array}$ \\
\hline Методы диагностики: & $\begin{array}{l}\text { - Лабораторные; } \\
\text { - Инструментальные. }\end{array}$ \\
\hline $\begin{array}{l}\text { Какие лабораторные анализы } \\
\text { проводятся при аневризме грудной } \\
\text { аорты? }\end{array}$ & $\begin{array}{l}\text { - Общий анализ крови; } \\
\text { - Электролитный профиль, уровень } \\
\text { креатинина; } \\
\text { - Коагулограмма; } \\
\text { - Группа крови. }\end{array}$ \\
\hline $\begin{array}{l}\text { Инструментальная диагностика } \\
\text { аневризмы грудной аорты: }\end{array}$ & $\begin{array}{l}\text { - } \text { Рентгенография грудной клетки; } \\
\text { - } \text { ЭКГ, ЭхоКГ; } \\
\text { - } \text { Аортография; } \\
\text { - } \text { КТ-ангиография; } \\
\text { - МР-ангиография; } \\
\text { - Интраоперационное УЗИ. }\end{array}$ \\
\hline Методы лечения: & $\begin{array}{l}\text { - Консервативное лечение, устране- } \\
\text { ние факторов риска; } \\
\text { Эндоваскулярное лечение } \\
\text { (стентирование); } \\
\text { - Хирургическое - протезирование } \\
\text { аорты с использованием } \\
\text { синтетических протезов. }\end{array}$ \\
\hline $\begin{array}{l}\text { Показания к хирургическому } \\
\text { лечению: }\end{array}$ & $\begin{array}{l}\text { - Симптоматические аневризмы; } \\
\text { - При диаметре восходящей аорты } \\
\text { более } 5 \text { см, нисходящей - более 6,5 } \\
\text { см; }\end{array}$ \\
\hline
\end{tabular}




\begin{tabular}{|c|c|}
\hline Вопросы & Ответы \\
\hline & $\begin{array}{l}\text { - Увеличение диаметра аневризмы } \\
\text { - более чем на } 1 \text { см в течение года; } \\
\text { - Псевдоаневризмы; } \\
\text { - Большие мешотчатые аневризмы; } \\
\text { - Микотическая аневризма; } \\
\text { - Сдавление бронха аневризмой; } \\
\text { - Коарктация аорты; } \\
\text { - Формирование аортобронхиальных } \\
\text { и аортоэзофагеальных свищей; } \\
\text { - Острая диссекция и разрыв аорты } \\
\text { типа В, дистальная ишемия. }\end{array}$ \\
\hline $\begin{array}{l}\text { Клинические признаки аневризмы } \\
\text { брюшной аорты: }\end{array}$ & $\begin{array}{l}\text { - Обычно протекает бессимптомно; } \\
\text { При увеличении размеров и развитии } \\
\text { осложнений (разрыв): } \\
\text { - Боль - в пояснице, животе, иногда в } \\
\text { лобковой области; } \\
\text { - Высокая температура; } \\
\text { - Ц Цианоз пальцев стоп; } \\
\text { - Быстрое насыщение, тошнота, рвота; } \\
\text { - Острая хромота; } \\
\text { - Обструкция мочевыводящих путей; } \\
\text { - Симптомы желудочно-кишечного } \\
\text { кровотечения; } \\
\text { - Гематурия; } \\
\text { - Шок. }\end{array}$ \\
\hline $\begin{array}{l}\text { Методы диагностики аневризмы } \\
\text { брюшной аорты: }\end{array}$ & $\begin{array}{l}\text { - Клинические признаки - } \\
\text { пульсирующего образования вокруг } \\
\text { пупка; } \\
\text { - Лабораторные анализы - общий } \\
\text { анализ крови, группа крови; }\end{array}$ \\
\hline
\end{tabular}




\begin{tabular}{|c|c|}
\hline Вопросы & Ответы \\
\hline & - Методы визуализации. \\
\hline $\begin{array}{l}\text { Инструментальные методы } \\
\text { исследования, необходимые для } \\
\text { диагностики аневризмы брюшной } \\
\text { аорты: }\end{array}$ & $\begin{array}{l}\text { - УзИ; } \\
\text { - Рентгенография брюшной полости; } \\
\text { - КТ-ангиография; } \\
\text { - МР-ангиография; } \\
\text { - Аортография. }\end{array}$ \\
\hline Методы лечения: & $\begin{array}{l}\text { - Консервативное лечение } \\
\text { устранения факторов риска; } \\
\text { - Эндоваскулярное } \\
\text { (стентирование); } \\
\text { - Хирургическое } \\
\text { протезирование. }\end{array}$ \\
\hline $\begin{array}{l}\text { Показания к хирургическому } \\
\text { лечению: }\end{array}$ & $\begin{array}{l}\text { - Симптоматическая аневризма; } \\
\text { - Увеличение диаметра восходящей } \\
\text { аорты более } 5 \text { см (у женщин более } \\
4,5 \text { см); } \\
\text { - Увеличение диаметра аневризмы } \\
\text { более чем на } 1 \text { см в течение года; } \\
\text { - Мешотчатая аневризма. }\end{array}$ \\
\hline Что такое диссекция аорты? & $\begin{array}{l}\text { Образование ложного просвета внутри } \\
\text { аорты в результате расслоения её } \\
\text { стенки. }\end{array}$ \\
\hline Клинические признаки: & $\begin{array}{l}\text { - Острые боли в груди, животе, } \\
\text { иррадиирующие в лопатку (90\%); } \\
\text { - Обморок; } \\
\text { - Нарушение мозгового кровообра- } \\
\text { щения (гемианестезия, гемипарез, } \\
\text { гемиплегия); } \\
\text { - Синдром Горнера (птоз, миоз, } \\
\text { ангидроз); } \\
\text { - Одышка, дисфагия; }\end{array}$ \\
\hline
\end{tabular}




\begin{tabular}{|c|c|}
\hline Вопросы & Ответы \\
\hline & $\begin{array}{l}\text { - Гемоптиз; } \\
\text { - Высокая температура. }\end{array}$ \\
\hline Методы диагностики: & $\begin{array}{l}\text { - Анамнез и физикальное } \\
\text { обследование; } \\
\text { - Лабораторное исследование - } \\
\text { общий анализ крови, соотношение } \\
\text { ВUN/креатинин, лдг, продукты } \\
\text { деградации фибрина; } \\
\text { - Методы визуализации. }\end{array}$ \\
\hline Классификация по Де Бейки: & $\begin{array}{l}\text { - І тип-аневризма нисходящей аорты, } \\
\text { дуги аорты и восходящей аорты; } \\
\text { - II тип - аневризма восходящей } \\
\text { аорты; } \\
\text { - III тип - аневризма нисходящей } \\
\text { аорты. }\end{array}$ \\
\hline Классификация по Станфорду: & $\begin{array}{l}\text { - Тип А - аневризма восходящей } \\
\text { аорты; } \\
\text { - Тип Б - аневризма нисходящей } \\
\text { аорты. }\end{array}$ \\
\hline
\end{tabular}




\section{СОСУДИСТЫЕ МАЛЬФОРМАЦИИ}

- Сосудистые мальформации делятся на 2 группы: первичные гемангиомы и истинные мальформации (врождённые, травматические и ятрогенные).

- Врождённые мальформации обычно обнаруживают во время родов.

- Выраженность клинической симптоматики зависит от размеров мальформаций, вида поражённого сосуда и скорости кровотока. При большом диаметре сосуда с замедленным кровотоком может развиваться косметический дефект. При венозном тромбозе первым клиническим проявлением заболевания может быть боль. Симптомы бывают выраженными при движении. При мальформациях с большим диаметром сосуда заболевание может протекать бессимптомно.

- Над пораженным сосудом выслушивается шум, отмечаются гиперемия и изъязвление кожи. Иногда возникает кровотечение.

- При отсутствии соответствующего лечения мальформации с большим диаметром сосудов может развиваться кардиальные осложнения.

- В диагностике сосудистых мальформаций используют допплерографию, цветное картирование кровотока (цветное допплеровское картирование кровотока). Ценную информацию дают также МРТ-ангиография.

- Врождённые сосудистые мальформации обычно с возрастом подвергаются регрессу. У взрослых лечение проводится в соответствии с характером осложнений и с учётом косметических показаний. Применяются интервенционные радиологические и хирургические методы.

\section{Вопросы и ответы по сосудистым мальформациям}

\section{Bompocbl}

Виды сосудистых мальформаций:

\section{Ответы}

- Первичная гемангиома;

- Истинная артериовенозная мальформация.

\section{Этиология:}

- Врождённые;

- Травматические;

- Ятрогенные. 


\begin{tabular}{|c|c|}
\hline Вопросы & Ответы \\
\hline & $\begin{array}{l}\text { - С увеличением размеров } \\
\text { косметические дефекты; } \\
\text { - Боль (при тромбозе). }\end{array}$ \\
\hline $\begin{array}{l}\text { Какие осложнения могут возникнуть } \\
\text { при мальформациях с повышенной } \\
\text { скоростью кровотока? }\end{array}$ & $\begin{array}{l}\text { - Локальная гипергидратация; } \\
\text { - Гиперемия; } \\
\text { - Изъязвление кожи, кровотечение; } \\
\text { - Кардиальные осложнения. }\end{array}$ \\
\hline Методы диагностики: & $\begin{array}{l}\text { - Ц Цветное дуплексное УзИ; } \\
\text { - МРТ-ангиография. }\end{array}$ \\
\hline Методы лечения: & $\begin{array}{l}\text { - При врождённых мальформациях } \\
\text { лечение не требуется; } \\
\text { - Консервативное; } \\
\text { - Хирургическое. }\end{array}$ \\
\hline $\begin{array}{l}\text { Что такое } \text { интервенционая } \\
\text { радиологическая терапия? }\end{array}$ & $\begin{array}{llr}\text { Чрескожная } & \text { эмболизация } & \text { или } \\
\text { склеротерапия } & \text { приводящего } \\
\text { сосуда. } & & \end{array}$ \\
\hline $\begin{array}{l}\text { Признаки } \quad \text { постэмболизационного } \\
\text { синдрома: }\end{array}$ & $\begin{array}{l}\text { - Слабость; } \\
\text { - Гипертермия; } \\
\text { - Лейкоцитоз; } \\
\text { - Гиперкалиемия; } \\
\text { - Развиваются в течение 24-48 ч и по } \\
\text { мере уменьшения уровня цитокинов } \\
\text { исчезают. }\end{array}$ \\
\hline Методы хирургического лечения: & $\begin{array}{l}\text { - При небольших мальформациях - } \\
\text { склеротерапия; } \\
\text { - Открытая хирургическая операция - } \\
\text { при неэффективности неинвазивных } \\
\text { методов лечения. }\end{array}$ \\
\hline
\end{tabular}




\section{ВАРИКОЗНАЯ БОЛЕЗНЬ ВЕН НИЖНИХ КОНЕЧНОСТЕЙ}

- Под варикозом подразумевают мешковидное или цилиндрическое расширение стенок вен, змеевидную извитость, увеличением их длины и недостаточность клапанов.

- Частота встречаемости среди взрослого населения составляет 25-30\%.

- Различают нитевидные, цилиндрические, комбинированные, прерывистые, сочетанные варикозные вены.

- Является полиэтиологическим заболеванием, возникает в результате множества факторов риска. Главной же причиной заболевания является недостаточность клапанов и связанное с этим повышение внутрипросветного давления в поверхностных венах.

- Основными клиническими признаками являются боль, кожный зуд, чувство тяжести, припухлость, отёк, судороги.

- К частым осложнениям варикоза относятся экзема, экскориация, флебит, липодерматосклероз, трофические нарушения и язвы, кровотечение, тромбоз, тромбофлебит.

- В комплексе диагностики применяют функциональные пробы для определения состояния клапанов, флебография, Уз-допплерография, ангиосканирование.

- Лечение проводится консервативным (микросклеротерапия, чрескожная лазеротерапия, фотодинамическая терапия, склеротерапия, компрессионная терапия) эндоваскулярным и хирургическим методами.

- Хирургическим путём проводится локальная флебэктомия, отделение сафенофеморального или сафено-подколенного соустья, удаление большой/малой подкожной вены, перевязка перфорантных вен в области голени, субфасциальная эндоскопическая диссекция перфорантных вен.

- В последние годы в основном применяется эндоваскулярные методы лечения (эндовенозная лазерная абляция, абляция радиочастотными волнами, абляция паром, механохимическая облитерация, химическая облитерация). 


\section{Вопросы и ответы по варикозной болезни вен нижних конечностей}

\begin{tabular}{|c|c|}
\hline Вопросы & Ответы \\
\hline $\begin{array}{l}\text { Факторы риска развития варикозных вен } \\
\text { нижних конечностей: }\end{array}$ & $\begin{array}{l}\text { Возраст, наследственность, пол, частые } \\
\text { беременности, тяжелый физический труд, } \\
\text { гиподинамия. }\end{array}$ \\
\hline $\begin{array}{l}\text { Вторичные причины развития варикозных } \\
\text { вен нижних конечностей: }\end{array}$ & $\begin{array}{l}\text { - Повышение внутритазового давления; } \\
\text { - Аномалии тазовых вен; } \\
\text { - Хирургические операции на тазовых } \\
\text { органах, лучевая терапия; } \\
\text { - Перенесённый илеофеморальный } \\
\quad \text { тромбоз. }\end{array}$ \\
\hline Клинические признаки: & $\begin{array}{l}\text { - } \text { Боль; } \\
\text { - Кожный зуд; } \\
\text { - Чувство тяжести; } \\
\text { - } \text { Припухлость; } \\
\text { - Отёк; } \\
\text { - } \text { Судороги; } \\
\text { - Ухудшение состояния в конце дня. }\end{array}$ \\
\hline Осложнения варикозной болезни: & $\begin{array}{l}\text { - Экзема; } \\
\text { - Экскориация; } \\
\text { - Флебит; } \\
\text { - Липодерматосклероз; } \\
\text { - Трофические нарушения и язвы; } \\
\text { - Кровотечение; } \\
\text { - Тромбоз и тромбофлебит. }\end{array}$ \\
\hline Методы диагностики: & $\begin{array}{l}\text { - Клинический осмотр, анамнез; } \\
\text { - } \text { Функциональные пробы - симптом } \\
\text { кашлевого толчка; } \\
\text { - Уз-допплерография; } \\
\text { - Ангиосканирование. }\end{array}$ \\
\hline Как определяют симптом кашлевого толчка? & $\begin{array}{l}\text { В вертикальном положении пациента в } \\
\text { процессе кашля в результате ретроградного } \\
\text { движения крови определяется толчок в области } \\
\text { сафено-феморального или сафено- } \\
\text { подколенного соустья. }\end{array}$ \\
\hline
\end{tabular}




\begin{tabular}{|c|c|}
\hline Bonросы & Ответы \\
\hline Основная цель диагностики: & $\begin{array}{l}\text { - Подтверждение клинического диагноза; } \\
\text { Определение показаний к } \\
\text { скловаскулярной абляции или } \\
\text { - Опрерапии; } \\
\text { повреждённых перфорантных вен до } \\
\text { операции; } \\
\text { - Динамическое наблюдение в процессе и } \\
\text { после эндоваскулярных и других мини- } \\
\text { инвазивных процедур. }\end{array}$ \\
\hline Методы лечения: & $\begin{array}{l}\text { - Консервативное лечение; } \\
\text { - Эндоваскулярное лечения; } \\
\text { - Хирургическое лечение. }\end{array}$ \\
\hline Консервативные методы лечения: & $\begin{array}{l}\text { - Микросклеротерапия, чрескожная } \\
\text { лазеротерапия, фотодинамическая } \\
\text { терапия; } \\
\text { - Склеротерапия (простая, } \\
\text { эхосклеротерапия); } \\
\text { - Компрессионная терапия. }\end{array}$ \\
\hline Методы хирургического лечения: & $\begin{array}{l}\text { - } \text { Локальная флебэктомия; } \\
\text { - Отделение сафено-феморального или } \\
\text { сафено-подколенного соустья } \\
\text { (кроссэктомия); } \\
\text { - Удаление большой/малой подкожной } \\
\text { вены (стриппинг); } \\
\text { - Перевязка перфорантных вен в области } \\
\text { голени; } \\
\text { - Субфасциальная эндоскопическая } \\
\text { диссекция перфорантных вен. }\end{array}$ \\
\hline Эндоваскулярные методы лечения: & $\begin{array}{l}\text { - } \quad \text { Эндовенозная лазерная абляция; } \\
\text { - Абляция радиочастотными волнами; } \\
\text { - } \text { Абляция паром; } \\
\text { - } \text { Механохимическая абляция; } \\
\text { - Химическая абляция. }\end{array}$ \\
\hline
\end{tabular}




\section{КАРОТИДНАЯ БОЛЕЗНЬ}

- Каротидная болезнь развивается вследствие окклюзии или стеноза сонной артерии, которая сопровождается нарушением мозгового кровообращения.

- Основными причинами являются окклюзирующие заболевания артерий, патологическая извитость артерий (кинкинг), сдавление артерий, расслаивающая аневризма сонной артерии.

- Клинически проявляется неврологическими признаками: потеря зрения в одном или двух глазах, капсулярный паралич, гемианопсия.

- В постановке диагноза ценную информацию дают доплер, КТ/МРТ ангиография.

- Лечебный комплекс включает применение дезагрегантов, препаратов, улучшающих реологические свойства крови, нормализацию артериального давления. Хирургическое лечение заключается в каротидной эндартерэктомии, протезировании артерии, формировании экстра- и интракраниальных сосудистых анастомозов, стентировании сосуда.

\section{Вопросы и ответы по каротидной болезни}

\begin{tabular}{|c|c|}
\hline Вопросы & Ответы \\
\hline Что такое каротидная болезнь? & $\begin{array}{l}\text { Облитерация или стеноз каротидной } \\
\text { артерии, сопровождающиеся } \\
\text { нарушением мозгового } \\
\text { кровообращения. }\end{array}$ \\
\hline $\begin{array}{l}\text { Причины возникновения ишемии } \\
\text { головного мозга: }\end{array}$ & $\begin{array}{l}\text { - Окклюзирующие заболевания } \\
\text { сосудов головного мозга; } \\
\text { - Патологическая извитость и } \\
\text { деформация артерий (кинкинг); } \\
\text { - } \text { Сдавление каротидных артерий; } \\
\text { - Расслоившаяся аневризма сонной } \\
\text { артерии. }\end{array}$ \\
\hline
\end{tabular}




\begin{tabular}{|c|c|}
\hline Вопросы & Ответы \\
\hline $\begin{array}{l}\text { Клинические признаки каротидной } \\
\text { болезни: }\end{array}$ & $\begin{array}{l}\text { - Преходящее нарушение зрения, } \\
\text { двоение в глазах (диплопия); } \\
\text { - Кратковременная потеря сознания, } \\
\text { обмороки; } \\
\text { - Нарушение координации при } \\
\text { ходьбе (пошатывание); } \\
\text { - Инсульт; } \\
\text { - Инфаркт мозга. }\end{array}$ \\
\hline Диагностика: & $\begin{array}{l}\text { - Допплер } \\
\text { - Артериография; } \\
\text { - КТ-ангиография; } \\
\text { - МРТ-ангиография. }\end{array}$ \\
\hline $\begin{array}{l}\text { Золотой стандарт в диагностике } \\
\text { каротидной болезни: }\end{array}$ & Артериография. \\
\hline Методы лечения: & $\begin{array}{l}\text { - Устранение факторов риска; } \\
\text { - Консервативное лечение; } \\
\text { - Хирургическое лечение. }\end{array}$ \\
\hline Методы хирургического лечения: & $\begin{array}{l}\text { - Каротидная эндартерэктомия; } \\
\text { - Протезирование каротидной } \\
\text { артерии; } \\
\text { - } \text { Стентирование; } \\
\text { - Формирование интра-и } \\
\text { экстракраниальных сосудистых } \\
\text { анастомозов. }\end{array}$ \\
\hline $\begin{array}{l}\text { Что является показанием к } \\
\text { каротидной эндартерэктомии при } \\
\text { бессимптомном течении болезни? }\end{array}$ & При стенозе каротидной артерии >60\%. \\
\hline $\begin{array}{l}\text { Что является показанием к } \\
\text { каротидной эндартерэктомии при } \\
\text { симптоматическом течении болезни? }\end{array}$ & Стеноз каротидной артерии >70\% \\
\hline
\end{tabular}




\begin{tabular}{|c|c|}
\hline Вопросы & Ответы \\
\hline $\begin{array}{l}\text { Осложнения каротидной } \\
\text { эндартерэктомии: }\end{array}$ & $\begin{array}{l}\text { - Инсульт мозга; } \\
\text { - Инфаркт миокарда; } \\
\text { - Инфицирование раны; } \\
\text { - Кровотечение; } \\
\text { - Гипотензия, гипертензия; } \\
\text { - Тромбоз; } \\
\text { - Повреждение черепно-мозговых } \\
\text { нервов. }\end{array}$ \\
\hline
\end{tabular}




\section{СИНДРОМ ДИАБЕТИЧЕСКОЙ СТОПЫ}

- Повреждение сосудов является важным патогенетическим фактором сахарного диабета, который определяет течение заболевания, характер осложнений, прогноз и результаты.

- В зависимости от диаметра повреждённых сосудов различают микро- и макроангиопатии.

- Основной особенностью синдрома диабетической стопы является образование трофических язв, их инфицирование и позднее заживление даже мелких ран. Патогенетическими механизмами формирования синдрома диабетической стопы являются нейропатия (45\%), ишемия (10\%) и сочетание нейропатии с ишемией (45\%).

- При нейропатических язвах наблюдается слабая пульсация, высокая температура конечности, слабо выраженные поверхностные вены, потеря чувствительности, нормальный или повышенный кровоток в сосудах.

- При ишемических и нейро-ишемических язвах конечности бывают холодными, теряется пульс, язвы чаще локализуются на терминальных фалангах пальцев стопы, пятке или в метатарзальной области, наблюдается гнойно-некротическая инфекция, либо целлюлит.

- С целью профилактики необходимо находиться под наблюдением специалистов, обращать внимание на возможность возникновения язв на ногах, всегда носить широкую обувь, регулярно ухаживать за ногами и ногтями, посещать ортопеда, избегать горячих и холодных процедур, а также не ходить босиком.

- Лечение проводится хирургическим и консервативным (спазмолитики, коррекция микроциркуляции и метаболизма в тканях, гиполипидемические препараты, ангиопротекторы, иммуностимуляторы, препараты, улучшающие венозный и лимфатический дренаж) методами. При гнойно-некротических инфекциях назначают антибиотики широкого спектра действия, проводят удаление некротических участков, дренирование и санацию гнойника, экстракорпольную детоксикацию, при подозрении на остеомиелит проводят рентгенографию, при наличии показаний и соответствующих условий проводят реваскуляризацию (ангиопластика, стентирование, шунтирование, реконструкция). При отсутствии эффекта от консервативных и хирургических методов проводят ампутацию. 


\section{Вопросы и ответы по синдрому диабетической стопы}

\begin{tabular}{|c|c|}
\hline Вопросы & Ответы \\
\hline $\begin{array}{l}\text { Основные клинические особенности } \\
\text { диабетической стопы: }\end{array}$ & $\begin{array}{l}\text { - Появление трофических язв; } \\
\text { - Инфицирование стопы после } \\
\text { незначительной травмы; } \\
\text { - Раннее появление симптомов } \\
\text { нейропатии; } \\
\text { - Позднее заживление мелких раню }\end{array}$ \\
\hline $\begin{array}{l}\text { Факторы риска } \\
\text { трофических язв: }\end{array}$ & $\begin{array}{l}\text { - Наличие язв в прошлом; } \\
\text { - Нейропатия; } \\
\text { • Поражение периферических } \\
\text { артерий; } \\
\text { - Деформация стопы; } \\
\text { - Образование мозолей на стопе; } \\
\text { - Нефропатия; } \\
\text { - Вторичное повреждение крупных и } \\
\text { мелких сосудов вследствие } \\
\text { нейропатии и окклюзии. }\end{array}$ \\
\hline $\begin{array}{l}\text { Особенности нейропатических язв при } \\
\text { сахарном диабете: }\end{array}$ & $\begin{array}{l}\text { - Нормальная температура } \\
\text { конечности при ослабленной } \\
\text { пульсации артерий; } \\
\text { - Слабо выраженные поверхностные } \\
\text { вены; } \\
\text { - Нарушение поверхностной и } \\
\text { глубокой чувствительности вплоть } \\
\text { до полной потери; } \\
\text { Нормальный или повышенный } \\
\text { кровоток в сосудах. }\end{array}$ \\
\hline $\begin{array}{l}\text { Особенности ишемических и } \\
\text { нейроишемических язв при сахарном } \\
\text { диабете: }\end{array}$ & 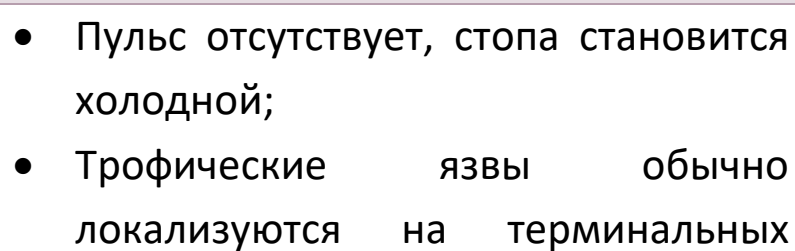 \\
\hline
\end{tabular}




\begin{tabular}{|c|c|}
\hline Вопросы & Ответы \\
\hline & $\begin{array}{l}\text { фалангах пальцев стопы, пятке или } \\
\text { метатарзальной области; } \\
\text { • Развивается целлюлит или гнойно- } \\
\text { некротический процесс. }\end{array}$ \\
\hline Методы профилактики: & $\begin{array}{l}\text { - } \text { Наблюдение; } \\
\text { - } \text { Избегать } \\
\text { возникновения язв на ногах; } \\
\text { - Носить широкую обувь; } \\
\text { - Регулярный уход за ногами и } \\
\text { ногтяи; } \\
\text { - Консультация подиатра по поводу } \\
\text { мозолей; } \\
\text { - Неходить босиком, избегать горячих } \\
\text { ихолодных процедур. }\end{array}$ \\
\hline Методы лечения: & 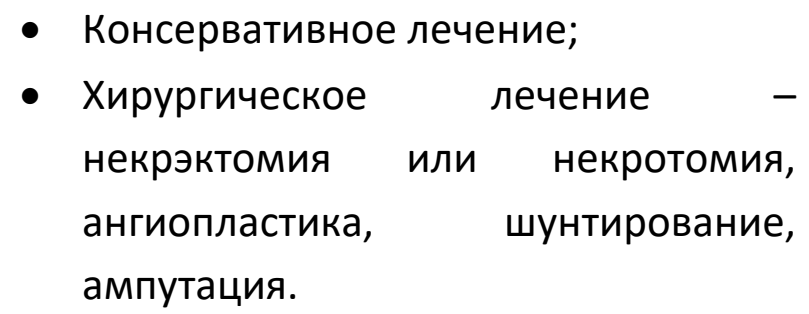 \\
\hline Спектр консервативного лечения: & 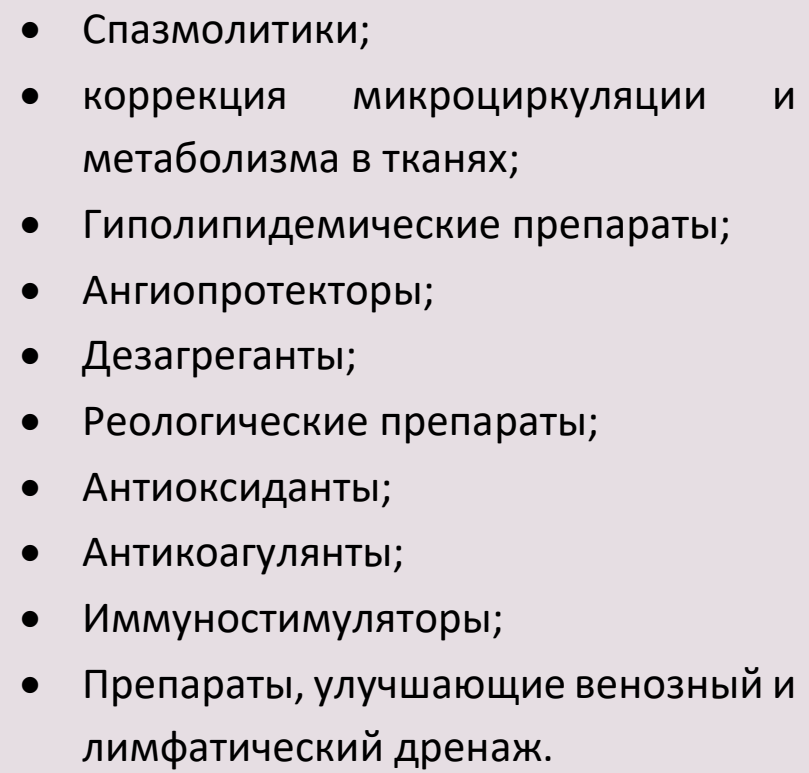 \\
\hline
\end{tabular}




\section{ВАЗОСПАСТИЧЕСКИЕ ЗАБОЛЕВАНИЯ}

- Этиологическими причинами вазоспастических заболеваний являются такие патологии, как ревматологические заболевания (системный склероз, системная красная волчанка, ревматоидный артрит, дерматомиозит, полимиозит), неврологические заболевания (рефлекторная симпатическая дистрофия, посттравматический вазоспазм, вибрационный белый палей) и идиопатические заболевания (феномен Рейно).

- Феномен Рейно включает в себя такие понятия, как болезнь Рейно (первичный феномен Рейно) и синдром Рейно (вторичный феномен Рейно).

- Феномен Рейно представляет собой ангиотрофоневроз с преимущественным поражением мелких артерий и артериол.

- Заболевание является наследственным и в большей степени поражает сосуды верхних конечностей. Как правило, проявляется симметрично на обеих конечностях. Чаще встречается у молодых женщин в возрасте 20-40 лет со склонностью к мигрени.

- Факторами риска являются длительное охлаждение, нарушение функции эндокринной системы, психоэмоциональный стресс, профессиональные патологии, ревматические и аутоиммунные заболевания.

- В клиническом течении болезни Рейно различают 3 стадии: ангиоспастическую (кратковременный спазм сосудов, бледность кожи; затем происходит расширение сосудов, покраснение кожи $и$ согревание пальцев), ангиопаралитическую (происходит цианоз рук и пальцев, наблюдается отёк) и трофропаралитическую (на пальцах развивается воспалительный процесс, образуются участки некроза по типу сухой гангрены, после формирования демаркационной линии участки некроза отторгаются, образуются длительно незаживающие язвы).

- Для диагностики необходимо приостановить применение всех вазоактивных препаратов на 24 часа. Проводиться допплерография артерий верхних конечностей, измерение систолического давления на различных участках, в том числе и на пальцах, по показаниям рентгенография грудной клетки. Из лабораторных исследований диагностическое значение имеют общий анализ крови, общий анализ мочи, тиреоидные гормоны, плотность плазмы, ревматоидные тесты, иммунологические анализы. 
- С целью лечения первым делом необходимо прекращение курения, использование тёплый перчаток, защита конечностей от холода. При прогрессировании симптомов и ухудшении качества жизни назначают медикаментозное лечение (блокаторы кальциевых каналов, инфузия простациклинов). При отсутствии эффекта от медикаментозного лечения и возникновении вторичных осложнений (язвы на пальцах) применяют хирургические методы лечения (поясничная или грудная симпатэктомия).

- При избежании холода и стресса болезнь Рейно в 99\% случаев неопасна. Однако, помимо этого, болезнь Рейно может привести к гангрене и ампутации конечности.

\section{Вопросы и ответы по вазоспастическим заболеваниям}

\begin{tabular}{|c|c|}
\hline Вопросы & Ответы \\
\hline $\begin{array}{l}\text { Причины вазоспастических } \\
\text { заболеваний: }\end{array}$ & $\begin{array}{l}\text { Ревматологические заболевания: } \\
\text { - системный склероз; } \\
\text { - системная красная волчанка; } \\
\text { - ревматоидный артрит; } \\
\text { - дерматомиозит; } \\
\text { - полимиозит. } \\
\text { Неврологические заболевания: } \\
\text { - рефлекторная симпатическая дистрофия; } \\
\text { - посттравматический вазоспазм; } \\
\text { - вибрационный белый палей. } \\
\text { Идиопатические заболевания: } \\
\text { - феномен Рейно. }\end{array}$ \\
\hline Что такое феномет Рейно? & $\begin{array}{l}\text { Ангиотрофоневроз с поражением мелких } \\
\text { артерий и артериол. }\end{array}$ \\
\hline
\end{tabular}




\begin{tabular}{|c|c|}
\hline Вопросы & Ответы \\
\hline $\begin{array}{l}\text { Чем отличаются синдром и } \\
\text { болезнь Рейно? }\end{array}$ & $\begin{array}{l}\text { Болезнь Рейно - это первичный феномен } \\
\text { Рейно. } \\
\text { Синдром Рейно - это вторичный феномен } \\
\text { Рейно. }\end{array}$ \\
\hline Основные факторы риска: & $\begin{array}{l}\text { - Длительное охлаждение верхних } \\
\text { конечностей; } \\
\text { • Эндокринные нарушения (патологии } \\
\text { щитовидной, половых желез); } \\
\text { - Тяжёлый эмоциональные стрессы; } \\
\text { - Профессиональные патологии, вредные } \\
\text { производственные факторы (вибрация); } \\
\text { - Ревматизм и другие аутоиммунные } \\
\text { заболевания. }\end{array}$ \\
\hline Клинические стадии: & $\begin{array}{l}\text { - Ангиоспастическая - кратковременный } \\
\text { спазм сосудов пальцев; } \\
\text { - Ангиопаралитическая - пальцы и кисти } \\
\text { становятся синюшными, отёчными и } \\
\text { пастозными; } \\
\text { - Трофопаралитическая - развиваются } \\
\text { панариций, участки некроза, длительно } \\
\text { незаживающие язвы. }\end{array}$ \\
\hline Диагностика: & $\begin{array}{l}\text { - Допплерография артерий верхних } \\
\text { конечностей; } \\
\text { - Определение систолического давления на } \\
\text { различных участках конечности, в том } \\
\text { числе, и на пальцах; } \\
\text { - Рентгенологическое исследование грудной } \\
\text { клетки (для исключения экстравазальной } \\
\text { компрессии). }\end{array}$ \\
\hline Лабораторные исследования: & $\begin{array}{l}\text { - Общий анализ крови; } \\
\text { - Общий анализ мочи; }\end{array}$ \\
\hline
\end{tabular}




\begin{tabular}{|c|c|}
\hline Вопросы & Ответы \\
\hline & $\begin{array}{l}\text { - Тиреоидные тесты; } \\
\text { - Ревматические пробы; } \\
\text { - Иммунологические анализы. }\end{array}$ \\
\hline Методы лечения: & $\begin{array}{l}\text { - Консервативное лечение; } \\
\text { - Хирургическое лечение (грудная или пояс- } \\
\text { ничная симпатэктомия, ампутация - при } \\
\text { осложнениях). }\end{array}$ \\
\hline $\begin{array}{l}\text { Принципы консервативной } \\
\text { терапии: }\end{array}$ & $\begin{array}{l}\text { • Избегать охлождений, курения; } \\
\text { - При прогрессировании симптомов - } \\
\text { блокаторы кальциевых каналов, инфузия } \\
\text { простациклинов. }\end{array}$ \\
\hline Прогноз синдрома Рейно: & $\begin{array}{l}\text { При избежании холода и стресса болезнь } \\
\text { Рейно в 99\% случаев неопасна. Однако, } \\
\text { помимо этого, болезнь Рейно может привести } \\
\text { к гангрене и ампутации конечности. }\end{array}$ \\
\hline
\end{tabular}

\section{СПИСОК ЛИТЕРАТУРЫ}

- Ağayev B.A. Cərrahi xəstəliklər. Bakı 2010.

- Blackbourne LH. Surgical Recall. 7 edition, 2006, LWW, Philadelphia

- Doherty GM. Current Diagnosis and Treatment: Surgery, $13^{\text {th }}$ edition, 2010, Lang International Edition.

- İsayev H.B.Cərrahi xəstəliklərin patofizologiyası. Bakı 2005

- Medscape, http://www.medscape.com

- Klingensmith ME, Aziz A, Bharat A, FoxAC, Porembka MR. The Washington Manual of Surgery, $6^{\text {th }}$ edition, 2012, LWW, Philadelphia.

- Oxford Handbook of Clinical Surgery, 3d edition, 2011, Oxford Press

- UpToDate, http://www.uptodate.com 


\section{ХИРУРГИЧЕСКИЕ БОЛЕЗНИ}

Н.Ю. Байрамов

\section{Хирургические заболевания щитовидной железы}

А.Г. Аббасов, А. Ф. Гумматов, Х.Н. Ширинова

Перевод: С.А. Алиев, М.Р. Гусейнова 


\section{ЗАБОЛЕВАНИЯ ЩИТОВИДНОЙ ЖЕЛЕЗЫ. ЗОБ.}

- Зоб характеризуется увеличением размеров щитовидной железы вследствие каких-либо причин.

- Вес нормальной щитовидной железы составляет 18-25 г. При зобе вес железы может увеличиться в 2 раза.

- Дефицит йода в эндемических регионах способствует увеличению размеров железы у 10\% популяции. Данное состояние оценивается как эндемический зоб.

- З Зоб может быть узловым, многоузловым и диффузным.

- При зобе тиреоидные гормоны характеризуют функциональное состояние щитовидной железы, а концентрация йода в моче указывает на эндемический характер распространённости.

- Объём железы определяется на УзИ.

- При ретростернальном зобе 50\% железы располагается за грудиной.

- К клиническим признакам относятся одышка, хрипы, "комок" в горле, дисфагия, сдавление верхней полой вены, приступы стенокардии.

- Диагноз подтверждается КТ.

- При наличии симптомов сдавления в горле показано хирургическое лечение.

\section{Вопросы и ответы по зобу}

\begin{tabular}{|c|c|}
\hline Вопросы & Ответы \\
\hline $\begin{array}{l}\text { Классификация зоба по клиническому } \\
\text { течению: }\end{array}$ & Токсический и нетоксический. \\
\hline Что такое эндемический зоб? & $\begin{array}{l}\text { Состояние дефицита йода в } \\
\text { эндемических регионах, при котором } \\
\text { происходит увеличение размеров } \\
\text { железы у } 10 \% \text { популяции. }\end{array}$ \\
\hline Профилактика кретинизма: & $\begin{array}{l}\text { Единственный метод профилактики } \\
\text { данного заболевания }- \text { приём }\end{array}$ \\
\hline
\end{tabular}




\begin{tabular}{|c|c|}
\hline Вопросы & Ответы \\
\hline & $\begin{array}{l}\text { препаратов йода во время } \\
\text { беременности. }\end{array}$ \\
\hline Лечение эндемического зоба: & $\begin{array}{l}\text { - Консервативное; } \\
\text { - Хирургическое; } \\
\text { - Радиоактивный йод. }\end{array}$ \\
\hline $\begin{array}{l}\text { Основной показатель поступления } \\
\text { йода в организм: }\end{array}$ & Количество выделяемого йода мочой. \\
\hline $\begin{array}{l}\text { Какая часть железы расположена за } \\
\text { грудиной при ретростернальном } \\
\text { зобе? }\end{array}$ & Более $50 \%$. \\
\hline $\begin{array}{l}\text { По каким показателям } \\
\text { классифицируется зоб? }\end{array}$ & Форма, локализация, развитие, рост. \\
\hline $\begin{array}{l}\text { С какими заболевания следует } \\
\text { дифференцировать зоб? }\end{array}$ & 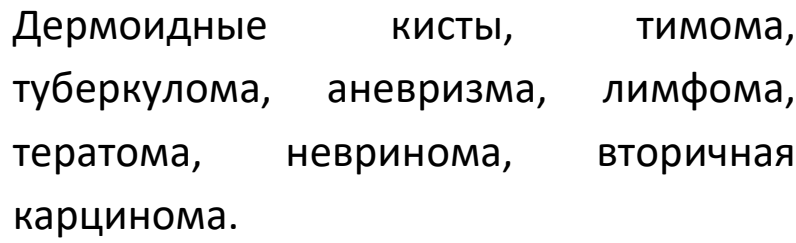 \\
\hline
\end{tabular}




\section{БОЛЕЗНЬ ГРЕЙВСА (ДИФФУЗНЫЙ ТОКСИЧЕСКИЙ ЗОБ)}

- Тиреотоксикоз - заболевание, обусловленное стойким патологическим повышением синтеза и секреции тиреоидных гормонов.

- Гипертиреоз - гиперфункция щитовидной железы.

- Тиреотоксикоз в большинстве случаев встречается наряду с гипертиреозом.

- $\mathrm{K}$ клиническим признакам относятся синусная тахикардия, фибрилляция, повышенное потоотделение, тремор, мышечная слабость, проксимальная миопатия, бессонница, раздражительность, похудание, диарея, нарушение менструального цикла, выпадение волос и др.

- Диагноз устанавливается на основании концентрации тиреоидных гормонов (снижение TSH, повышение сT3, сT4).

- При опухолях гипофиза, синтезирующих TSH, и при состояниях отсутствия реакция на тиреоидные гормоны концентрация TSH может быть нормальной.

- В $80 \%$ случаев причиной тиреотоксикоза является болезнь Грейвса.

- У большинства пациентов наблюдается эндокринная офтальмопатия.

- Патогенез заболевания основан на том, что аутоантитела к рецепторам TSH стимулируют железистые клетки к повышению синтеза гормонов.

- В лечении тиреотоксикоза применяют консервативный, хирургический и радиоактивный методы.

\section{Вопросы и ответы по болезни Грейвса}

\begin{tabular}{|c|c|c|c|c|}
\hline Bonpocbl & \multicolumn{4}{|c|}{ Ответы } \\
\hline $\begin{array}{l}\text { Наиболее частая нозологическая } \\
\text { причина гипертиреоза: }\end{array}$ & Болезнь Грейвс & & & \\
\hline Что такое болезнь Грейвса? & $\begin{array}{l}\text { Диффузный } \\
\text { гипертиреоз, } \\
\text { претибиальная }\end{array}$ & $\begin{array}{r}\text { то } \\
\text { микс }\end{array}$ & $\begin{array}{l}\text { ический } \\
\text { экз } \\
\text { дема. }\end{array}$ & $\begin{array}{l}\text { зоб: } \\
\text { альм, }\end{array}$ \\
\hline Этиология и патогенез: & $\begin{array}{l}\text { Аутоиммунное } \\
\text { обусловленное } \\
\text { рецепторов }\end{array}$ & TSH & $\begin{array}{r}\text { забо } \\
\text { стил } \\
\text { аутоант }\end{array}$ & $\begin{array}{l}\text { ание, } \\
\text { лцией } \\
\text { лами, }\end{array}$ \\
\hline
\end{tabular}




\begin{tabular}{|c|c|}
\hline Вопросы & Ответы \\
\hline & $\begin{array}{l}\text { которое приводит к дисрегуляции } \\
\text { тиреоидных гормонов. }\end{array}$ \\
\hline $\begin{array}{l}\text { Распространённость среди женщин и } \\
\text { мужчин: }\end{array}$ & Соотношение составляет 6:1. \\
\hline $\begin{array}{l}\text { Основное клиническое проявление } \\
\text { болезни Грейвса: }\end{array}$ & Экзофтальм. \\
\hline Диагностика: & $\begin{array}{l}\text { Повышение уровня гормонов сT3, сT4 и } \\
\text { антител к рецепторам TSH, снижения } \\
\text { уровня TSH. }\end{array}$ \\
\hline Лечение болезни Грейвса: & $\begin{array}{l}\text { - Медикаментозное - йод, } \\
\text { пропилтиоурацил (ПтУ), метимазол, } \\
\text { раствор Люголя; } \\
\text { - Радиоабляция; } \\
\text { - Хирургическое - билатеральная } \\
\text { субтотальная тиреоидэктомия. }\end{array}$ \\
\hline Показания к хирургической резекции: & $\begin{array}{l}\text { Выявление сомнительного узла при } \\
\text { отсутствии клинической симптоматики, } \\
\text { при беременности, при толерантности к } \\
\text { медикаментозной терапии, у детей и } \\
\text { при отказе от радиоабляции. }\end{array}$ \\
\hline $\begin{array}{l}\text { Основное осложнение хирургического } \\
\text { лечения и радиотерапии? }\end{array}$ & Гипотиреоз. \\
\hline Что такое ПтУ? & Пропилтиоурацил. \\
\hline Механизм действия ПТУ: & $\begin{array}{l}\text { - Ингибирует соединение йода с } \\
\text { ТЗ/Т4; } \\
\text { - Ингибирует периферическую } \\
\text { конверсию Т4 в Т3. }\end{array}$ \\
\hline Механизм действия метимазола: & Ингибирует соединение йода с Т4/Т3. \\
\hline
\end{tabular}




\section{ТОКСИЧЕСКАЯ АДЕНОМА (БОЛЕЗНЬ ПЛАММЕРА)}

- Токсическая аденома или болезнь (Пламмера) - клинический вариант тиреотоксикоза, характеризующийся избыточной продукцией тиреоидных гормонов автономной аденомой.

- Данное заболевание встречается в основном у женщин старше 50 лет. На его долю приходится 5-15\% тиреотоксикозов.

- Одиночная токсическая аденома оценивается как фолликулярная неоплазия. Риск малигнизации составляет $1 \%$.

- Диагностика основана на показателях тиреоидных гормонов, данных УзИ и сцинтиграфии. Для гиперфункционирующих узлов характерно повышение сТ3 (иногда и сT4) и снижение TSH.

- Дифференциальную диагностику проводят с болезнью Грейвса, Хашимото, многоузловым токсическим зобом.

- Лечение - консервативное или хирургическое.

\section{Вопросы и ответы по токсической аденоме}

\begin{tabular}{|c|c|}
\hline Вопросы & Ответы \\
\hline $\begin{array}{l}\text { Как определяют } \\
\text { гиперфункционирующий узел? }\end{array}$ & При радионуклидном сканировании. \\
\hline Лечение: & $\begin{array}{lr}\text { Хирургическое } & \text { удаление } \\
\text { гиперфункционирующего } & \text { узла, } \\
\text { лобэктомия } \quad \text { или } & \text { тотальная } \\
\text { тиреоидэктомия. } & \end{array}$ \\
\hline Что такое признак Пембертона? & $\begin{array}{l}\text { Гигантская щитовидная желез, } \\
\text { простирающаяся до обоих плеч. }\end{array}$ \\
\hline Диагностика: & $\begin{array}{l}\text { Повышение концентрации сT3, сT4, } \\
\text { антител к рецепторам TSH, снижение } \\
\text { концентрации TSH. }\end{array}$ \\
\hline
\end{tabular}




\section{ХРОНИЧЕСКИЙ ЛИМФОЦИТАРНЫЙ ТИРЕОИДИТ (ТИРЕОИДИТ ХАШИМОТО, АУТОИММУННЫЙ ТИРЕОИДИТ)}

- Одно из самых распространённых заболеваний щитовидной железы хронический аутоиммунный тиреоидит, который открыт Х. Хашимото в 1912-ом году.

- Различают 2 формы аутоиммунного тиреоидита: гипертрофическая и атрофическая.

- При гистологическом исследовании обнаруживают локальную или диффузную лимфоцитарную инфильтрацию. Характерным признаком атрофической формы заболевания является инфильтрация железистой ткани крупными оксифильными клетками (клетки Ашкенази-Гюртле) и фибробластами. В зонах повреждения определяется скопление лимфоцитов, плазматических клеток и макрофагов.

- Клиника заболевания полиморфна. Характерным признаком является увеличение размеров железы, уплотнение её структуры, гетерогенность, в некоторых случаях наблюдается пальпируемый узел. Пациенты жалуются на давление в области шеи, дисфагию. Всё это происходит в результате быстрого роста железа. В некоторых случаях железа увеличивается постепенно, в результате чего заболевание протекает бессимптомно.

- Общая клиническая картина определяется функциональным статусом щитовидной железы (гипотиреоз, эутиреоидное состояние, тиреотоксикоз).

- На основании клинических, лабораторных и инструментальных методов исследования определяются:

○ Характерные клинические и лабораторные признаки;

о Функциональное состояния щитовидной железы;

○ УЗИ;

О Концентрация антител к тканевым компонентам (анти-ТПО);

○ Пункционная биопсия.

- В большинстве случаев аутоиммунный тиреоидит приводит к спонтанному гипотиреозу. При этом назначают консервативное поддерживающее лечение (Левотироксин 2-3 мкг утром натощак). Целью консервативного лечения является устранение гипотиреоза, неприятных ощущений в области шеи, уменьшение размеров железы. 


\section{ХРОНИЧЕСКИЙ ФИБРОЗНЫЙ ТИРЕОИДИТ (ТИРЕОИДИТ РИДЕЛЯ)}

- Первое описание болезни принадлежит шведскому хирургу Риделю (1896).

- Это очень редкое заболевание, которое характеризуется разрастанием в щитовидной железе соединительной ткани, замещающей паренхиму органа и вовлечением в фибротический процесс окружающих тканей и анатомических структур.

- Этиология до сих пор неизвестна.

- Обычно фибротический процесс развивается в одной доле и постепенно переходит в другую долю.

- В 25\% случаев функциональное состояние щитовидной железы характеризуется гипотиреозом. В дальнейшем с прогрессивным ростом ткани наблюдается компрессионный синдром.

- Клиническая картина проявляется малоподвижным зобом плотной (каменистой) консистенции. В связи со сдавлением возвратного гортанного нерва пациенты жалуются на охриплость голоса, давление в области шеи, затруднение дыхания и глотания в связи со сдавлением трахеи и пищевода.

- Клиническая диагностика заболевания очень сложна из-за его редкости, большого сходства с недифференцированным раком и меньшей информативности цитологического исследования.

- Диагностика заболевания основана на интраоперационном гистологическом экспресс-исследовании.

- K показаниям к хирургическому лечению тиреоидита Риделя относятся сдавление, дислокация, функциональные нарушения окружающих тканей и анатомических структур в связи с увеличением размеров щитовидной железы, обструкция дыхательных путей, тяжёлая дисфагия, невозможность дифференциации со злокачественным процессом. 


\section{ПОДОСТРЫЙ ЛИМФОЦИТАРНЫЙ ТИРЕОИДИТ (ПОСЛЕРОДОВОЙ ТИРЕОИДИТ)}

- Данное заболевание характеризуется внезапно начавшимися симптомами тиреотоксикоза, повышением концентрации сТ3 и сT4 в крови, снижением абсорбции $\mathrm{J}^{131}$ тканями щитовидной железы, развитием безболезненного диффузного зоба.

- Часто возникает у женщин после родов.

- Патогенетически схож с хроническим лимфоцитарным тиреоидитом.

- Начальная тиреотоксическая фаза длится от 1 до 4 месяцев.

- Для облегчения симптомов тиреотоксикоза предпочтительны ßадреноблокаторы. Антитиреоидные препараты не применяют.

- У 25-40\% пациентов в дальнейшем развивается гипотиреоидная, которая длится не более 2-3 месяцев. На этом этапе проводится адъювантная терапия Lтироксином. 


\section{ПОДОСТРЫЙ ГРАНУЛЕМАТОЗНЫЙ ТИРЕОИДИТ (ТИРЕОИДИТ ДЕ КЕРВЕНА)}

- В этиопатогенезе данного заболевания ведущее место отводится вирусным инфекциям (вирус Коксаки, аденовирусы, вирус ECHO, вирус гриппа и эндемического паротита). Длительное скрытый период, эндемический характер, сезонность заболевания (осенне-зимний период) подтверждают вирусную этиологию данной патологии.

- Скрытый период длится несколько недель.

- Пациентов беспокоят боли в мышцах, субфебрилитет, общая слабость и ларингит. Основной клинический симптом - боль в одной части щитовидной железы, иррадиирующая в нижнюю челюсть и ухо. По мере прогрессирования заболевания боли носят диффузный характер и усиливаются при движении головы и глотании.

- На этом фоне у половины пациентов развиваются симптомы тиреотоксикоза тахикардия, повышенное потоотделение, повышенная чувствительность к раздражителям.

- Пальпаторно определяется резко болезненный твёрдый узел. В лабораторных исследованиях определяются умеренный лейкоцитоз, повышение СОЭ (50 Mм/с), повышение концентрации ст3 и сT4, повышение титра антитиреоидных антител в течение нескольких недель, которые вовсе не обнаруживаются через несколько месяцев.

- Диагноз уточняется на основании УзИ и сцинтиграфии.

- Начальная стадия заболевания длится 4-8 недель. На этом этапе предпочтительны терапия преднизолоном (10-20 мг перорально 2 раза в день) и ультрафиолетовое облучение крови (4-5 сеансов).

\section{Вопросы и ответы по тиреоидитам}

\section{Вопросы}

Особенности острого тиреоидита:

\section{Ответы}

Болезненность, увеличение размеров железы, высокая температура, эритема, дисфагия. 


\begin{tabular}{|c|c|}
\hline Вопросы & Ответы \\
\hline Этиология острого тиреоидита: & $\begin{array}{l}\text { Бактериальная инфекция } \\
\text { (стрептококки, стафилококки). }\end{array}$ \\
\hline Лечение острого тиреоидита: & $\begin{array}{l}\text { Антибактериальная терапия, } \\
\text { дренирования абсцесса, тонкоигольная } \\
\text { аспирация для культурального анализа, } \\
\text { хирургическое удаление свищевого } \\
\text { хода. }\end{array}$ \\
\hline Особенности подострого тиреоидита: & $\begin{array}{l}\text { Отёчная, напряжённая железа, } \\
\text { повышение СОэ. }\end{array}$ \\
\hline Этиология подострого тиреоидита: & Вирусная инфекция. \\
\hline Лечение подострого тиреоидита: & $\begin{array}{l}\text { Поддерживающая терапия: НПВС +/- } \\
\text { стероиды. }\end{array}$ \\
\hline $\begin{array}{l}\text { Что представляет собой тиреоидит де } \\
\text { Кервена? }\end{array}$ & $\begin{array}{l}\text { Другое название подострого } \\
\text { тиреоидита. }\end{array}$ \\
\hline $\begin{array}{l}\text { Как дифференцировать этиологию } \\
\text { острого и подострого тиреоидита? }\end{array}$ & $\begin{array}{l}\text { В алфавитном порядке: A перед В, В } \\
\text { перед V - острый (acute) предшествует } \\
\text { подострому (subacute), бактериальный } \\
\text { (bacterial) предшествует вирусному } \\
\text { (viral). }\end{array}$ \\
\hline $\begin{array}{l}\text { Этиология острого гнойного } \\
\text { тиреоидита: }\end{array}$ & Стрептококки или стафилококки. \\
\hline Типы хронического тиреоидита: & $\begin{array}{l}\text { - Тиреоидит Хашимото; } \\
\text { - Тиреоидит Риделя. }\end{array}$ \\
\hline Особенности тиреоидита Хашимото: & $\begin{array}{l}\text { Высокая температура, эритема, } \\
\text { лимфатическая инвазия в 95\% случаев. }\end{array}$ \\
\hline $\begin{array}{l}\text { Распространённая особенность } \\
\text { тиреоидита Хашимото: }\end{array}$ & Частая причина гипотиреоза в США. \\
\hline Этиология тиреоидита Хашимото: & Аутоиммунное заболевание. \\
\hline
\end{tabular}




\begin{tabular}{|c|c|}
\hline Вопросы & Ответы \\
\hline $\begin{array}{l}\text { Лабораторная диагностика } \\
\text { тиреоидита Хашимото: }\end{array}$ & $\begin{array}{l}\text { Антитиреоглобулин, микросомальные } \\
\text { антитела. }\end{array}$ \\
\hline Что такое тиреоидит Риделя? & $\begin{array}{l}\text { Доброкачественное воспалительное } \\
\text { заболевание щитовидной железы, для } \\
\text { которого характерно увеличение } \\
\text { размеров и фиброзное разрастание } \\
\text { доброкачественное воспалительное } \\
\text { заболевание щитовидной железы. } \\
\text { Пациент жалуется на безболезненное } \\
\text { увеличение железы. Фиброз также } \\
\text { может распространиться и на } \\
\text { окружающие ткани. }\end{array}$ \\
\hline
\end{tabular}




\section{ОСТРЫЙ ГНОЙНЫЙ ТИРЕОИДИТ (СТРУМИТ)}

- Острый гнойный тиреоидит - острое инфекционное заболевание щитовидной железы, вызванное различными микроорганизмами (стафилококки, стрептококки, кишечные палочки, грибки).

- Инфицирование железистой паренхимы происходит гематогенным, лимфогенным путем. Риск развития гнойного воспаления возникает при травме, повреждениях и диагностических процедурах (пункция).

- Заболевание начинается остро, появляются боли и припухлость в области шеи. Боли носят режущий характер, иррадиируют в нижнюю челюсть и уши. При вовлечении в гнойно-воспалительный процесс трахеи и гортани наблюдается кашель и дисфагия. При формировании абсцесса появляется синдром системной реакции организма на воспаление (высокая температура, озноб, общая слабость и др.)

- Основным методом диагностики является УзИ (выявление полости с секвестрами).

- Адекватную антибактериальную и общеукрепляющую терапию следует проводить в ранние сроки заболевания. При отсутствии улучшения состояния пациента в течение 1-2 дней и при подозрении на формирование абсцесса проводится пункция под контролем УЗИ с последующим культуральным анализом содержимого. При больших размерах абсцесса выполняют вскрытие, санацию и дренирование гнойной полости.

\section{Вопросы и ответы по острому гнойному тиреоидиту}

\begin{tabular}{|ll}
\multicolumn{1}{|c}{ Вопросы } & \multicolumn{2}{c}{ Ответы } \\
\hline $\begin{array}{l}\text { Клинические формы острого } \\
\text { гнойного тиреоидита: }\end{array}$ & $\bullet$ Инфильтративная форма; \\
\hline $\begin{array}{ll}\text { Пути распространения инфекции при } \\
\text { остром гнойном тиреоидите: }\end{array}$ & $\begin{array}{l}\text { Инфицирование железистой паренхимы } \\
\text { происходит } \\
\end{array}$ \\
& лимфогенным путем. Риск развития \\
& гнойного воспаления возникает при
\end{tabular}




\begin{tabular}{|c|c|}
\hline Вопросы & Ответы \\
\hline & $\begin{array}{l}\text { травме, повреждениях и } \\
\text { диагностических процедурах (пункция). }\end{array}$ \\
\hline $\begin{array}{l}\text { Характер болей при остром гнойном } \\
\text { тиреоидите: }\end{array}$ & $\begin{array}{l}\text { Боли носят режущий характер, } \\
\text { иррадиируют в нижнюю челюсть и уши, } \\
\text { усиливаются при глотании и движении } \\
\text { головой. }\end{array}$ \\
\hline $\begin{array}{l}\text { Характерная картина на УЗИ при } \\
\text { остром гнойном тиреоидите: }\end{array}$ & Выявление полости с секвестрами. \\
\hline $\begin{array}{l}\text { Тактика при отсутствии эффекта от } \\
\text { адекватной антибактериальной и } \\
\text { общеукрепляющей терапии: }\end{array}$ & $\begin{array}{l}\text { Проводится пункция под контролем УзИ } \\
\text { с последующим культуральным } \\
\text { анализом содержимого. При больших } \\
\text { размерах абсцесса выполняют вскрытие, } \\
\text { санацию и дренирование гнойной } \\
\text { полости. }\end{array}$ \\
\hline
\end{tabular}




\section{ГИПОТИРЕОЗ}

- Первичный гипотиреоз - функциональная недостаточность щитовидной железы, обусловленная снижением секреции гормонов сT3 и сТ4 и повышением уровня $\mathrm{TSH}$.

- Вторичный гипотиреоз возникает на фоне заболеваний гипофиза и гипоталамуса вследствие снижения синтеза тиреоидных гормонов.

- Основными симптомами являются брадикардия, адинамия, снижение памяти, чувствительность к холоду, гиперкератоз, отёчность лица и конечностей, запоры, изменение тембра голоса и т. д.

- Лечение проводится препаратами Т4.

\section{Вопросы и ответы по гипотиреозу}

\begin{tabular}{|c|c|}
\hline Вопросы & Ответы \\
\hline Что такое первичный гипотиреоз? & $\begin{array}{l}\text { Функциональная недостаточность } \\
\text { щитовидной железы, сопровождающаяся } \\
\text { снижением уровня гормонов сT3 и сT4, } \\
\text { повышением продукции TSH. }\end{array}$ \\
\hline Что такое вторичный гипотиреоз? & $\begin{array}{l}\text { Снижение секреции тиреоидных гормонов } \\
\text { на фоне заболеваний гипофиза и } \\
\text { гипоталамуса. }\end{array}$ \\
\hline $\begin{array}{l}\text { Какие жалобы пациента вызывают } \\
\text { подозрение на гипотиреоз? }\end{array}$ & $\begin{array}{l}\text { Слабость, усталость, снижение памяти, } \\
\text { отёчность лица и конечностей, запоры, } \\
\text { сухость кожи, выпадение волос, нарушение } \\
\text { менструального цикла и т. д. }\end{array}$ \\
\hline Диагностика: & $\begin{array}{l}\text { - УзИ щитовидной железы; } \\
\text { - Лабораторные показатели по } \\
\text { гормональному профилю (TSH, сT3 и } \\
\text { сT4, антитиреоглобулин). }\end{array}$ \\
\hline Лечение: & Препараты Т4. \\
\hline
\end{tabular}




\section{ДОБРОКАЧЕСТВЕННЫЕ ОПУХОЛИ ЩИТОВИДНОЙ ЖЕЛЕЗЫ}

- Доброкачественные опухоли щитовидной железы развиваются в виде разных типов аденом; чаще всего имеют эпителиальное происхождение.

- Аденомы чаще встречаются у женщин в возрасте от 30 до 40 лет.

- Этиология точно неизвестна.

- Доброкачественные опухоли развиваются бессимптомно, растут медленно, функциональное состояние железы, как правило, не изменяется, а в некоторых случаях развиваются симптомы тиреотоксикоза.

- Узел обнаруживается при случайном или запланированном УзИ.

- Метод лечения зависит от размера узла, наличия или отсутствия признаков компрессии окружающих органов и эстетического дефекта.

\section{Вопросы и ответы по доброкачественным опухолям щитовидной железы}

\begin{tabular}{|ll|}
\hline \multicolumn{1}{|c|}{ Вопросы } & \multicolumn{1}{c|}{ Ответы } \\
\hline $\begin{array}{l}\text { Виды доброкачественных опухолей } \\
\text { щитовидной железы: }\end{array}$ & $\bullet \quad$ Эпителиальные; \\
$\begin{array}{l}\text { Критерии УзИ при доброкачественных } \\
\text { опухолей щитовидной железы: }\end{array}$ & $\begin{array}{l}\text { Солидный, изо- или гиперэхогенный узел с } \\
\text { ровными краями и периферической } \\
\text { васкуляризацией. }\end{array}$ \\
\hline $\begin{array}{l}\text { Способы дифференциации добро- и } \\
\text { злокачественных узлов щитовидной } \\
\text { железы: }\end{array}$ & $\begin{array}{l}\text { Тонкоигольная аспирационная биопсия и } \\
\text { цитологическое исследование. }\end{array}$ \\
\hline
\end{tabular}

\section{Вопросы и ответы по узлам щитовидной железы}

\begin{tabular}{|c|c|}
\hline Вопросы & Ответы \\
\hline $\begin{array}{l}\text { Какой процент холодных узлов является } \\
\text { злокачественным? }\end{array}$ & Примерно 25\%. \\
\hline $\begin{array}{l}\text { Какой процент мультинодулярных } \\
\text { образований является злокачественным? }\end{array}$ & Примерно 1\%. \\
\hline
\end{tabular}


Вопросы

Лечение пациентов с радиационным облучением, узлами щитовидной железы узла.

и отрицательным результатом ТИАБ:

Следующий этап после аспирации кисты Цитологическое исследование. щитовидной железы:

\section{Ответы}

Предпочтительно хирургическое удаление 


\section{ПАПИЛЛЯРНЫЙ РАК}

- Папиллярный рак составляет $75 \%$ всех новообразований щитовидной железы.

- Папиллярный рак чаще встречается у женщин в возрасте 20-50 лет в условиях избытка йода в биосфере. У пациентов, подвергшихся радиационному облучению, папиллярный рак встречается чаще, чем в нормальной популяции.

- Папиллярный рак имеет несколько вариантов: фолликулярный, макрофолликулярный, диффузный склерозирующий, Гюртле-клеточный, высококлеточный) и солидный. Самыми агрессивными формами являются диффузный склерозирующий и высококлеточный варианты.

- Метастазирование папиллярного рака в лимфатические узлы составляет 15-30\%.

- Послеоперационная 10-летняя выживаемость пациентов моложе 45 лет составляет 100\%, старше 45 лет - 90\%.

\section{Вопросы и ответы по папиллярный раку щитовидной железы}

\begin{tabular}{|c|c|}
\hline Вопросы & Ответы \\
\hline $\begin{array}{l}5 \text { основных типов карциномы } \\
\text { щитовидной железы: }\end{array}$ & $\begin{array}{l}\text { - } \text { Папиллярная карцинома: 80\%; } \\
\text { - } \text { Фолликулярная карцинома: 10\%; } \\
\text { - Гедуллярная карциномы: 5\%; } \\
\text { - Анапластическая } \\
\text { (недифференцированная) } \\
\text { карцинома: 1-2\%. }\end{array}$ \\
\hline Клинические признаки и симптомы: & $\begin{array}{l}\text { Наличие } \\
\text { лимфаденопатия, } \\
\text { состояние. }\end{array}$ \\
\hline Диагностика: & $\begin{array}{l}\text { ТИАБ, УЗИ, ТSH, концентрация кальция в } \\
\text { крови, рентгенография грудной клетки, } \\
\text { сцинтиграфия. }\end{array}$ \\
\hline
\end{tabular}


Вопросы

Какие онкомаркеры ассоциируются с раком щитовидной железы?

С каким синдромом связан

Синдром Гарднера, иррадиация в шею. папиллярный рак щитовидной железы?

Гистологическая картина:

Псаммомные

тельца

(П=Псаммом=Папиллярный, составляет 80\% всех раков щитовидной железы).

Пути распространения папиллярного

Лимфогенное метастазирование рака: (цервикальная лимфаденопатия).

Назначается ли приём йода? Желательно да.

10-летняя выживаемость составляет: Примерно 95\%.

Тактика лечения пациентов с опухолью $<1,5$ см не получивших радиотерапию:

\section{Тактика лечения пациентов с}

билатеральной опухолью $<1,5 \mathrm{~cm}$, шейными метастатическими лимфоузлами и получивши радиотерапию:

\section{Тактика лечения пациентов с} пальпируемыми латеральными лимфоузлами:

\section{Влияют ли позитивные лимфоузлы на Нет! прогноз заболевания?}

Послеоперационное консервативное лечение:

Заместительная гормональная терапия с целью супрессии TSH. 


\begin{tabular}{|c|c|}
\hline Вопросы & Ответы \\
\hline $\begin{array}{l}\text { Послеоперационное лечение } \\
\text { папиллярной карциномы: }\end{array}$ & $\begin{array}{lr}\text { Послеоперационное сканирование } \\
\text { абляционной дозой } \\
\text { устранить локальную резидуальную } \\
\text { опухоль и отдалённые метастазы. }\end{array}$ \\
\hline $\begin{array}{l}\text { Значение «П» для папиллярного рака } \\
\text { щитовидной железа: }\end{array}$ & $\begin{array}{l}\text { - Папиллярный рак; } \\
\text { - Популярный } \\
\text { распространённый); } \\
\text { • Псамый } \\
\text { - Пальпируемые лимфоузлы } \\
\text { (лимфогенное метастазирование); } \\
\text { • Позитивный эффект от приёма йода; } \\
\text { - Позитивный прогноз; } \\
\text { - Постоперационное сканирование } \\
\text { йодом помогает в диагностике и } \\
\text { лечении метастазов. }\end{array}$ \\
\hline
\end{tabular}




\section{ФОЛЛИКУЛЯРНЫЙ РАК}

- Фолликулярный рак щитовидной железы составляет 10-30\% дифференцированного рака щитовидной железы.

- Чаще встречается в районах с дефицитом йода.

- Фолликулярный рак гематогенным путём метастазирует в кости, печень, лёгкие И Мозг.

- Поскольку фолликулярный рак не распространяется лимфогенно, метастатические лимфоузлы очень редки. По этой причине не проводится шейная лимфодиссекция.

- Послеоперационная выживаемость у 80-85\% пациентов при фолликулярном раке составляет более 10 лет.

\section{Вопросы и ответы по фолликулярному раку}

\begin{tabular}{|c|c|}
\hline Вопросы & Ответы \\
\hline $\begin{array}{l}\text { Каков процентный показатель } \\
\text { фолликулярного рака среди всех } \\
\text { случаев рака щитовидной железы? }\end{array}$ & Примерно 10\%. \\
\hline $\begin{array}{l}\text { Опишите консистенцию узла при } \\
\text { фолликулярном раке: }\end{array}$ & Эластичный с капсулой. \\
\hline Пути метастазирования: & $\begin{array}{l}\text { Гематогенный путь. Агрессивен } \\
\text { папиллярной аденокарциномы. }\end{array}$ \\
\hline $\begin{array}{l}\text { Соотношение мужчины/женщины } \\
\text { составляет: }\end{array}$ & $1: 3$. \\
\hline Эффект от приёма йода: & Положительный. \\
\hline 10-летняя выживаемость: & Примерно 85\%. \\
\hline
\end{tabular}




\section{Вопросы}

\section{Ответы}

Возможна ли диагностика

Нет.

тонкоигольной аспирационной

биопсией?

Особенность роста опухоли:

Инвазия в капсулу и в сосуды.

Частая локализация отдалённых Кости. метастазов:

Лечение:

- Лобэктомия/истмусэктомия;

- Субтотальная или тотальная тиреоидэктомия.

Консервативное лечение в Заместительная гормональная терапия послеоперационном периоде: с целью супрессии TSH. 


\section{ГЮРТЛЕ-КЛЕТОЧНЫЙ РАК}

- В 1928 году Юинг впервые ввёл в практику термин «Гюртле-клеточная опухоль», которая развивается из В-клеток (оксифильных и онкоцитарных клеток).

- Встречается у людей в возрасте 60-75 лет.

- Этот тип опухоли характеризуется прорастанием изменённых фолликулярных клеток.

- Некоторые исследования показали, что прогноз при Гюртле-клеточном раке хуже, чем при фолликулярном раке, но эта информация не получила всеобщего признания.

\section{Вопросы и ответы по Гюртле-клеточному раку}

\section{Вопросы \\ Ответы}

Каков процентный показатель Гюртле- Примерно 5\%.

клеточного рака среди всех случаев

рака щитовидной железы?

Из каких клеток развивается? олликулярные клетки.

Эффект от приёма йода: Нет.

Диагностика: Можно идентифицировать при ТИАБ.

Для определения малигнизации необходимо провести гистологический анализ ткани железы.

Пути метастазирования: Лимфогенный путь > гематогенный путь.

Лечение:

Как и при фолликулярном раке. 


\section{МЕДУЛЛЯРНЫЙ РАК}

- Медуллярный рак - высокодифференцированная опухоль щитовидной железы, которая развивается из парафолликулярных С-клеток.

- Медуллярный рак секретирует кальцитонин, который является биологическим маркером. Высокий уровень кальцитонина - ценный индикатор в диагностике медуллярного рака. Несмотря на повышенный уровень кальцитонина, гипокальциемия не наблюдается.

- На его долю приходится 5-10\% всех злокачественных опухолей щитовидной железы.

- Медуллярный рак может быть спорадическим (75\% случаев), так же может возникать как компонент MEN 2A или MEN 2B (25\% случаев).

- Прогноз при MEN 2A лучше, чем при MEN 2B и спорадическом медуллярном раке.

- Наличие в семейном анамнезе медуллярного рака, пальпируемая опухоль на шее, фронтальная головная боль, гипертонические кризы, сердцебиение, панические атаки (признаки феохромоцитомы), камни в почках, панкреатит, язвенная болезнь, остеопороз (признаки гиперпаратиреоза) вызывают подозрение на наличие медуллярного рака.

\section{Вопросы и ответы по медуллярному раку}

\begin{tabular}{|ll|}
\multicolumn{1}{|c|}{ Вопросы } & \multicolumn{1}{c|}{ Ответы } \\
\hline $\begin{array}{l}\text { Каков процентный показатель } \\
\text { медуллярного рака среди всех случаев } \\
\text { рака щитовидной железы? }\end{array}$ & Примерно 5\%. \\
\hline С какой патологией ассоциируется? & $\begin{array}{l}\text { Является } \\
\text { множественных составной нейроэндокринных } \\
\text { неоплазий 2-го типа. }\end{array}$ \\
\hline Гистологическая картина: & Амилоид. \\
\hline Что продуцирует? & Кальцитонин. \\
\hline
\end{tabular}




\begin{tabular}{|c|c|}
\hline Вопросы & Ответы \\
\hline Что такое стимуляционный тест? & $\begin{array}{l}\text { Тест Пентагастрином (является } \\
\text { причиной повышения кальцитонина). }\end{array}$ \\
\hline Пути метастазирования: & Лимфогенный и гематогенный пути. \\
\hline Диагностика: & ТИАБ. \\
\hline Эффект от приёма йода: & Слабый. \\
\hline Прогноз: & $\begin{array}{l}\text { 10--летняя выживаемость составляет } \\
\text { 50\%. При случайном обнаружении рака } \\
\text { у пациентов с повышенным } \\
\text { кальцитонином и при наличии } \\
\text { множественных нейроэндокринных } \\
\text { неоплазий 2-го типа выживаемость } \\
\text { составляет 95\%, при проявляении } \\
\text { клинических признаков-<20\%. }\end{array}$ \\
\hline Лечение: & $\begin{array}{l}\text { Тиреоидэктомия с лимфодиссекцией } \\
\text { через 2-3 месяца после операции и } \\
\text { каждый год определение уровня } \\
\text { кальцитонина и карциноэмбриональ- } \\
\text { ного антигена и проведение УзИ шеи. }\end{array}$ \\
\hline $\begin{array}{l}\text { Что означает буква «М» в названии } \\
\text { медуллярного рака? }\end{array}$ & $\begin{array}{l}\text { - Медуллярный рак; } \\
\text { - МЕN II; } \\
\text { - аМилоид; } \\
\text { - Медиальная лимфодиссекция; } \\
\text { - Модифицировання } \\
\text { лимфодиссекция при позитивных } \\
\text { латеральных лимфоузлах. }\end{array}$ \\
\hline
\end{tabular}




\section{АНАПЛАСТИЧЕСКИЙ РАК ЩИТОВИДНОЙ ЖЕЛЕЗЫ}

- Длительная трансформация ткани щитовидной железы приводит к развитию анапластического рака.

- Эта форма опухоли отличается от других форм тем, что имеет тенденцию к агрессивному инфильтративному росту, вызывающему дыхательную недостаточность в результате сдавления органов шеи и жизненно важных структур за короткий период времени (2,5 месяца).

- Анапластический рак щитовидной железы составляет 1\% всех случаев рака щитовидной железы.

- Прогноз - неблагоприятный. Выживаемость исчисляется месяцами (4-12 месяцев).

\section{Вопросы и ответы по анапластическому раку щитовидной железы}

\begin{tabular}{|c|c|}
\hline Вопросы & Ответы \\
\hline $\begin{array}{l}\text { Другое название анапластического } \\
\text { рака: }\end{array}$ & Недифференцированный рак. \\
\hline Что такое анапластический рак? & $\begin{array}{l}\text { Недифференцированный } \\
\text { щитовидной железы, который в } 75 \% \\
\text { случаев развивается из ранее } \\
\text { дифференцированного рака (чаще из } \\
\text { фолликулярного рака). }\end{array}$ \\
\hline $\begin{array}{l}\text { Каков процентный показатель } \\
\text { анапластического рака среди всех } \\
\text { случаев рака щитовидной железы? }\end{array}$ & Примерно 2\%. \\
\hline Соотношение мужчины/женщины: & Женщины > мужчины. \\
\hline $\begin{array}{l}\text { Чем характеризуется гистологическая } \\
\text { структура анапластического рака? }\end{array}$ & Гигантские и стреловидные клетки. \\
\hline Эффект от приёма йода: & Очень слабый. \\
\hline
\end{tabular}




\begin{tabular}{|c|c|}
\hline Вопросы & Ответы \\
\hline Диагностика: & ТИАБ (при больших опухолях). \\
\hline $\begin{array}{l}\text { С какими новообразованиями следует } \\
\text { дифференцировать? }\end{array}$ & $\begin{array}{l}\text { С лимфомой щитовидной железы } \\
\text { (прогноз при нём - благоприятный). }\end{array}$ \\
\hline Лечение: & $\begin{array}{l}\text { - При малых опухолях - } \\
\text { тиреоидэктомия в сочетании с } \\
\text { радиотерапией; } \\
\text { - При сообщении с дыхательными } \\
\text { путями - } \\
\text { циторедуктивная хирургия. }\end{array}$ \\
\hline Прогноз: & $\begin{array}{l}\text { Неблагоприятный, т. к. пациенты } \\
\text { обращаются к врачу в поздний период } \\
\text { заболевания (IV стадия). } 5 \text {-летняя } \\
\text { выживаемость-3\%. }\end{array}$ \\
\hline
\end{tabular}




\section{ЛИМФОМА ЩИТОВИДНОЙ ЖЕЛЕЗЫ}

- Лимфома щитовидной железы является наиболее распространённой Bклеточной неходжкинской лимфомой.

- Первичная лимфома щитовидной железы встречается крайне редко, однако случаи её выявления продолжают расти.

- Клиническое течение схоже с клиникой анапластического рака.

- Для подтверждения диагноза проводятся пальпация, УЗИ, ТИАБ, ларингоскопия, KT и MPT.

\section{Вопросы и ответы по лимфоме щитовидной железы}

\begin{tabular}{|c|c|}
\hline Вопросы & Ответы \\
\hline $\begin{array}{l}\text { Что такое лимфома щитовидной } \\
\text { железы? }\end{array}$ & В-клеточная неходжкинская лимфома. \\
\hline Диагностика: & $\begin{array}{l}\text { Пальпация, УЗИ, ТИАБ, ларингоскопия, } \\
\text { КТ и МРТ. }\end{array}$ \\
\hline
\end{tabular}

\section{СПИСОК ЛИТЕРАТУРЫ}

- H.Abbasov.,A.F.Hümmətov., N.Y.Bayramov. Qalxanabənzər vəzin xəstəlikləri dərs vəsaiti. Bakı 2012 səh.147

- McGraw-Hill Manual Endokrin Cerrahisi. Çeviri editörü doç.dr. Öner Menteş səh 2120

- Yeşim Erbil, Selçuk Özarmağan Cerrahi endokrinolji rehberi 2011 seh 3-123

- А.П.Калинина, Н.А.Майстренко, П.С.Ветшева Хирургическая эндокринология 87268 c. 


\section{ХИРУРГИЧЕСКИЕ БОЛЕЗНИ}

Н.Ю. Байрамов

\section{Хирургические заболевания паращитовидной железы}

Н.Ю. Байрамов, А.Ф. Гумматов, А.Г. Аббасов, Ш.А. Мамедова

Перевод: Н.Ю. Байрамов, С.А. Алиев, М.Р.Гусейнова 


\section{ХИРУРГИЧЕСКИЕ ЗАБОЛЕВАНИЯ ПАРАЩИТОВИДНОЙ ЖЕЛЕЗЫ}

- Болезни щитовидной железы делятся на 4 группы: первичный, вторичный, третичный гиперпаратиреоз и гипопаратиреоз.

- Первичный гиперпаратиреоз характеризуется повышенной продукцией паратгормона и гиперкальциемией по причине гиперплазии или неоплазии паращитовидной железе.

○ Заболевание обусловлено солитарной аденомой, гиперплазией или раком.

○ У более чем половины пациентов заболевание протекает бессимптомно. Гиперкальциемия обнаруживается при случайном обследовании. При симптоматическом течении у пациентов наблюдается остеопороз, мочекаменная болезнь, депрессия, слабость и др.

○ Диагноз подтверждается на основании лабораторных (повышение кальция, паратгормона в крови, нормальный или повышенный уровень кальция в моче) и инструментальных исследований (УзИ, биопсия, сцинтиграфия, КТ, MPT).

- При симптоматических формах заболевания основным методом лечения является хирургический (удаление аденомы). При бессимптомном течении проводят либо хирургическое, либо консервативное лечение.

- Вторичный гиперпаратиреоз развивается вследствие компенсаторного повышения секреции паратгормона в ответ на длительную гипокальциемию, вызванную различными причинами.

О Основными причинами возникновения вторичного гиперпаратиреоза является хроническая почечная недостаточность, синдром мальабсорбции, хроническая недостаточность кальция в пище.

○ Заболевание в большинстве случаев начинается бессимптомно, симптоматическая форма характеризуется болями в костях, дискомфортом в пищеварительной системе, артритом, миопатиями, разрывом связок, кожным зудом, образованием кальцификатов за пределами опорнодвигательной системы.

О К диагностическим критериям относятся пониженный уровень кальция, повышенный уровень паратгормона, наличие остеопороза, кальцификатов.

○ Лечение направлено на устранение этиологического фактора. В случае невозможности этиотропного лечения, проводится коррекции уровня 
кальция или хирургическое лечение (тотальная паратиреоидэктомия и аутотрансплантация).

- Третичный гиперпаратиреоз обусловлен автономной функционирующей аденомой паращитовидной железы на фоне длительно существующего вторичного гиперпаратиреоза.

○ Повышенный уровень паратгормона после трансплантации почки подтверждает диагноз.

О Лечение проводится консервативным и хирургическим методами. Консервативное лечение заключается в коррекции уровня кальция. При неэффективности медикаментозной терапии показана операция.

- Гипопаратиреоз обычно связан с перенесённой операцией, может быть постоянной и преходящей.

○ Клиническая картина характеризуется приступами тонических судорог.

○ Диагноз устанавливают на основании клинической картины, лабораторных исследований (гипокальциемия и снижение паратгормона).

○ Лечение заключается в назначении препаратов кальция и паратгормона.

\section{Вопросы и ответы по заболеваниям паращитовидной железы}

\begin{tabular}{|c|c|}
\hline Вопросы & Ответы \\
\hline Что такое первичный гиперпаратиреоз? & $\begin{array}{l}\text { Повышение концентрации паратгормона } \\
\text { и кальция вследствие различных } \\
\text { заболеваний } \quad \text { и } \\
\text { паращитовидной железы. }\end{array}$ \\
\hline Что такое вторичный гиперпаратиреоз? & $\begin{array}{l}\text { Развивается вследствие } \\
\text { компенсаторного повышения продукции } \\
\text { паратгормона в ответ на длительную } \\
\text { гипокальциемию. }\end{array}$ \\
\hline Что такое третичный гиперпаратиреоз? & $\begin{array}{l}\text { Обусловлен } \\
\text { функционирующей аденомой, паращито- } \\
\text { видной железы на фоне длительно } \\
\text { существующего вторичного гиперпа- } \\
\text { ратиреоза. }\end{array}$ \\
\hline
\end{tabular}




\begin{tabular}{|c|c|}
\hline Вопросы & Ответы \\
\hline $\begin{array}{l}\text { Методы визуализации паращитовидных } \\
\text { желез: }\end{array}$ & $\begin{array}{l}\text { - Хирургическая операция; } \\
\text { - УзИ; } \\
\text { - Сцинтиграфия с технецием }\left(\mathrm{Ti}^{201}\right) \text {; } \\
\text { - КТ/МРТ; }\end{array}$ \\
\hline $\begin{array}{l}\text { Наиболее частая причина первичного } \\
\text { гиперпаратиреоза: }\end{array}$ & Аденома (>85\%). \\
\hline Этиология первичного гиперпаратиреоза: & 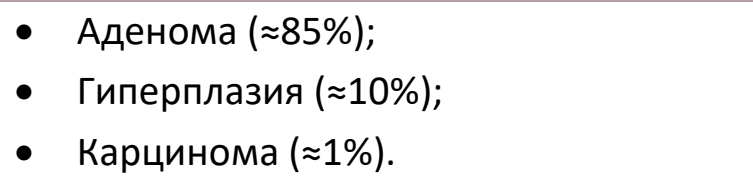 \\
\hline $\begin{array}{l}\text { Факторы риска первичного } \\
\text { гиперпаратиреоза: }\end{array}$ & $\begin{array}{l}\text { - } \text { Семейный анамнез; } \\
\text { - } \mathrm{MEN} \mathrm{I;} \\
\text { - } \text { MEN II; } \\
\text { - Радиация. }\end{array}$ \\
\hline $\begin{array}{l}\text { Клинические признаки первичного } \\
\text { гиперпаратиреоза: }\end{array}$ & $\begin{array}{l}\text { - Типичные признаки - боли в костях, } \\
\text { патологические переломы, слабость, } \\
\text { нефролитиаз, усталость, полидипсия, } \\
\text { полиурия; } \\
\text { - Атипичные признаки - запоры, } \\
\text { быстрая утомляемость, сонливость, } \\
\text { депрессия, нарушение памяти. }\end{array}$ \\
\hline $\begin{array}{l}\text { Классические рентгенологические } \\
\text { признаки при первичном } \\
\text { гиперпаратиреозе: }\end{array}$ & $\begin{array}{l}\text { - Субпериостальная резорбция (в } \\
\text { особенности в пальцевых фалангах). }\end{array}$ \\
\hline $\begin{array}{l}\text { Основные методы диагностики первичного } \\
\text { гиперпаратиреоза: }\end{array}$ & $\begin{array}{l}\text { - Определение концентрации } \\
\text { паратгормона в крови; } \\
\text { - Определение концентрации кальция } \\
\text { в крови; } \\
\text { - Определение концентрации кальция } \\
\text { в моче - при семейной } \\
\text { гипокальциурической } \\
\text { гиперкальциемии. }\end{array}$ \\
\hline $\begin{array}{l}\text { Что такое семейная гипокальциурическая } \\
\text { гиперкальциемия? }\end{array}$ & $\begin{array}{l}\text { Семейная (аутосомно-доминантная) } \\
\text { асимптоматическая гиперкальциемия, } \\
\text { снижение концентрации кальция в моче. }\end{array}$ \\
\hline
\end{tabular}




\begin{tabular}{|c|c|}
\hline Вопросы & Ответы \\
\hline $\begin{array}{l}\text { Показано ли проведение } \\
\text { паратиреоидэктомии при семейной } \\
\text { гипокальциурической гиперкальциемии? }\end{array}$ & Нет. \\
\hline $\begin{array}{l}\text { Частота встречаемости множественной } \\
\text { аденомы паращитовидной железы: }\end{array}$ & $\approx 5 \%$. \\
\hline $\begin{array}{l}\text { Дифференциальная диагностика при } \\
\text { гиперкальциемии: }\end{array}$ & $\begin{array}{l}\text { повышение кальция; } \\
\text { гиперпаратиреоз; } \\
\text { иммобильность; } \\
\text { метастазы, молочно-щелочной синдром; } \\
\text { болезнь Педжета; } \\
\text { болезнь Аддисона, акромегалия; } \\
\text { неоплазия; } \\
\text { синдром Золлингера-Эллисона; } \\
\text { избыток витамина A, D; } \\
\text { саркоид. }\end{array}$ \\
\hline $\begin{array}{l}\text { Первичное лечение первичного } \\
\text { гиперпаратиреоза: }\end{array}$ & $\begin{array}{l}\text { Инфузионная терапия и фуросемид } \\
\text { (противопоказаны тиазидные } \\
\text { диуретики). }\end{array}$ \\
\hline $\begin{array}{l}\text { При каких случаях бессимптомного } \\
\text { первичного гиперпаратиреоза показано } \\
\text { хирургическое лечение: }\end{array}$ & $\begin{array}{l}\text { - } \text { Почечная недостаточность; } \\
\text { - Остеопороз; } \\
\text { - } \text { Возраст старше } 50 \text { лет; } \\
\text { - } \quad \text { Концентрация Са >1 мг/дл; } \\
\text { - } \quad \text { Гиперкальциурия (>400 мг/день). }\end{array}$ \\
\hline $\begin{array}{l}\text { Тактика при гиперплазии паращитовидных } \\
\text { желез: }\end{array}$ & $\begin{array}{l}\text { Необходимо удалить все } \\
\text { паращитовидные железы и произвести } \\
\text { аутотрансплантацию одной из них в руку. }\end{array}$ \\
\hline $\begin{array}{l}\text { Тактика при аденоме паращитовидных } \\
\text { желез: }\end{array}$ & $\begin{array}{l}\text { Необходимо удалить аденому и сделать } \\
\text { биопсию из изменённых желез. }\end{array}$ \\
\hline $\begin{array}{l}\text { Тактика при карциноме паращитовидных } \\
\text { желез: }\end{array}$ & $\begin{array}{l}\text { Необходимо удалить карциному, } \\
\text { прилежащую долю щитовидной железы } \\
\text { и увеличенные лимфатические узлы. }\end{array}$ \\
\hline $\begin{array}{l}\text { Тактика лечения вторичного } \\
\text { гиперпаратиреоза: }\end{array}$ & $\begin{array}{l}\text { - Коррекция кальциевого и фосфорного } \\
\text { обмена; } \\
\text { - При необходимости - трансплантация } \\
\text { почки. }\end{array}$ \\
\hline
\end{tabular}




\begin{tabular}{|c|c|}
\hline Вопросы & Ответы \\
\hline $\begin{array}{l}\text { Тактика лечения третичного } \\
\text { гиперпаратиреоза: }\end{array}$ & $\begin{array}{l}\text { - Коррекция кальциевого и фосфорного } \\
\text { обмена; } \\
\text { - Удаление всех паращитовидных } \\
\text { желез саутотрансплантацией 30-40 мг } \\
\text { железистой ткани в руку. }\end{array}$ \\
\hline $\begin{array}{l}\text { С какой целью проводится } \\
\text { аутотрансплантация 30-40 мг железистой } \\
\text { ткани в руку? }\end{array}$ & $\begin{array}{l}\text { Для поддержания } \quad \text { функции } \\
\text { паращитовидной железы. }\end{array}$ \\
\hline $\begin{array}{l}\text { Какие карциномы характеризуются } \\
\text { гиперкальциемией? }\end{array}$ & $\begin{array}{l}\text { - } \text { Метастазы в грудной клетке; } \\
\text { - } \text { Рак простаты; } \\
\text { - } \text { Рак почки; } \\
\text { - Рак лёгких; } \\
\text { - Рак поджелудочной железы; } \\
\text { - } \text { Множественная миелома. }\end{array}$ \\
\hline $\begin{array}{l}\text { О чёс свидетельствует наличие } \\
\text { пальпируемого образования на шее, } \\
\text { гиперкальциемия и повышение уровня } \\
\text { паратгормона? }\end{array}$ & Карцинома паращитовидной железы. \\
\hline $\begin{array}{l}\text { Что такое карцинома паращитовидной } \\
\text { железы? }\end{array}$ & Первичный рак паращитовидной железы. \\
\hline Клинические признаки: & $\begin{array}{l}\text { - Гиперкальциемия; } \\
\text { - Повышение уровня паратгормона; } \\
\text { - Пальпируемая паращитовидная } \\
\text { железа; } \\
\text { - Боль в шее; } \\
\text { - Парез возвратного гортанного нерва } \\
\text { (изменение тембра голоса); } \\
\text { - Гиперкальциемический криз (Са >14 } \\
\text { мг/дл). }\end{array}$ \\
\hline $\begin{array}{l}\text { Маркер карциномы паращитовидной } \\
\text { железы: }\end{array}$ & Хорионический гонадотропин (ХГЧ). \\
\hline
\end{tabular}




\begin{tabular}{|c|c|}
\hline Вопросы & Ответы \\
\hline $\begin{array}{l}\text { Каков процент случаев первичного } \\
\text { гиперпаратиреоза, вызванного } \\
\text { карциномой паращитовидных желез? }\end{array}$ & $1 \%$. \\
\hline Осложнения после паратиреоидэктомии: & $\begin{array}{l}\text { - Повреждение возвратного гортанного } \\
\text { нерва (одностороннее - изменение } \\
\text { тембра голоса, двустороннее - } \\
\text { удушье); } \\
\text { - Гематома на шее; } \\
\text { - Гипокальциемия; } \\
\text { - Повреждение верхнего гортанного } \\
\text { нерва. }\end{array}$ \\
\hline Что такое синдром «голодных костей»? & $\begin{array}{lc}\text { Гипокальциемия, } & \text { возникающая после } \\
\text { хирургического } & \text { вмешательства, } \\
\text { обусловленная } & \text { захватом костями } \\
\text { кальция из крови. } & \end{array}$ \\
\hline $\begin{array}{l}\text { Признаки постоперационной } \\
\text { гипокальциемии: }\end{array}$ & $\begin{array}{l}\text { - Парестезии (периоральные); } \\
\text { - } \text { Симптом Хвостека; } \\
\text { - Симптом Труссо; } \\
\text { - Тетания. }\end{array}$ \\
\hline Что такое симптом Хвостека? & $\begin{array}{lcr}\text { Сокращение лицевых мышц, в } \\
\text { особенности верхней губы, } \\
\text { постукивании по скуловой кости. }\end{array}$ \\
\hline Что такое симптом Труссо? & $\begin{array}{l}\text { Тонические судороги кисти, } \\
\text { возникающие в ответ на давление в } \\
\text { области нервно-сосудистого пучка на } \\
\text { плече. }\end{array}$ \\
\hline Лечение гипопаратироидизма: & $\begin{array}{l}\text { - При остром - препараты кальция } \\
\text { внутривенно; } \\
\text { - При хроническом - препараты } \\
\text { кальция и витамин D перорально. }\end{array}$ \\
\hline Что такое паратироматоз? & $\begin{array}{l}\text { Обнаружение множественных, мелких, } \\
\text { гиперфункциональных тканей } \\
\text { паращитовидной железы на шее и в } \\
\text { средостении. }\end{array}$ \\
\hline
\end{tabular}




\section{Вопросы}

Проводится ли хирургическое лечение паратироматоза?

\section{Ответы}

В редких случаях.

\section{СПИСОК ЛИТЕРАТУРЫ}

\section{Ümumi adabiyyat}

- Ağayev B.A. Cərrahi xəstəliklər. Bakı 2010.

- Blackbourne LH. Surgical Recall. 7 edition, 2014, LWW, Philadelphia

- Doherty GM. Current Diagnosis and Treatment: Surgery, 13th edition, 2010, Lang International Edition.

- Omiraslanov D.T., Qazıyev A.Y. Onkologiya. Bakı, 2010.

- İsayev H.B. Cərrahi xəstəliklərin patofizologiyası. Bakı 2005

- Klingensmith ME, Aziz A, Bharat A, Fox AC, Porembka MR. The Washington Manual of Surgery, 6th edition, 2012, LWW, Philadelphia.

- McNally PR. GI/Liver Secrets Plus. 4 edition. Mosby, Elsevier, 2010

- Medscape, http://www.medscape.com

- Oxford Handbook of Clinical Surgery, 3d edition, 2011, Oxford Press

- Sayek I. Sayek Temel Cerrahi 1-2. 4-cü baskı, 2016, Güneş Tıp Kitabevleri.

- Topçubaşov M.A. Xüsusi cərrahlıq. Bakı, 1979

- UpToDate, http://www.uptodate.com

\section{Xüsusi adabiyyat}

American Association of Endocrine Surgeons (AAES): Guidelines for definitive management of primary hyperparathyroidism (2016) 


\title{
ХИРУРГИЧЕСКИЕ БОЛЕЗНИ
}

Н.Ю. Байрамов

\section{Хирургические заболевания надпочечников}

\author{
Н.Ю. Байрамов, С.А. Алиев, Н.Г. Новрузов, А.К. Сафиева, Ш.А. Мамедова
}

Перевод: Н.Ю. Байрамов, С.А. Алиев, М.Р.Гусейнова 


\section{АДРЕНАЛОВАЯ НЕДОСТАТОЧНОСТЬ}

- Адреналовая недостаточность - симптомокомплекс, развивающийся в результате уменьшения секреции гормонов корковым слоем надпочечников.

- По причине развития различают первичную и вторичную, а по клиническому течению - острую и хроническую формы.

- Первичная адреналовая недостаточность развивается в связи с первичным поражением надпочечников. Вторичная адреналовая недостаточность (адреналовая гиперфункция) обусловлена недостаточной продукцией АКТГ.

- Острая адреналовая недостаточность (адреналовый криз) обычно проявляется признаками шока и развивается при отмене стероидной терапии (синдром отмены), возникновении инфекции, стрессовых состояний, травме (в том числе, операционной травмы), сепсисе, септическом шоке, острой деструкции надпочечника, острой печёночной недостаточности.

- Хроническая адреналовая недостаточность проявляется общим недомоганием, утомляемостью, анорексией, тошнотой, рвотой, потерей веса, гипотензией, гиперпигментацией, электролитными нарушениями (гипонатриемия, гиперкалиемия). Хроническая адреналовая недостаточность в литературе носит название Аддисоновой болезни.

- Для установления диагноза определяют содержание кортизола в крови или слюне, а также проводится тест стимуляции АКТГ.

- Лечение острой адреналовой недостаточности проводится в неотложном порядке. Больным назначают инфузионную терапию с переливанием более 2 литров изотонического раствора хлорида натрия и глюкокартикоиды. 


\section{НОВООБРАЗОВАНИЯ НАДПОЧЕЧНИКОВ}

- Адреналовые опухоли бывают первичными и вторичными, доброкачественными и злокачественными, гормонально активными и неактивными. Опухоли развиваются как из коркового слоя, так и из мозгового вещества надпочечников.

- Гиперкортицизм или Синдром Кушинга - состояние, при котором повышается уровень кортизола в организме. Данное состояние наблюдается при steroidnoy terapii (ятрогенnı), при аденоме гипофиза, выделяющей АКТГ (Болезнь Кушинга), при опухоли надпочечников, выделяющей кортикостероиды (кортикостерома), и при паранеопластическом синдроме. Клинически проявляется стойкой артериальной гипертензией, лунообразным лицом, абдоминальным ожирением, повышенной мышечной слабостью, сахарным диабетом, депрессией и другими признаками. Для уточнения диагноза важное значение имеет биохимический тест на определение концентрации кортизола (экспрессия свободного кортизола в суточной моче, тест на свободный кортизол в слюне или тест подавления дексаметазона). В дальнейшем выясняют нозологическую причину и локализацию поражения (тест на АКТГ, МРТ головного мозга, абдоминальная КТ).

- Лечение тяжёлых форм синдрома Кушинга обычно проводится хирургическим методом, за исключением ятрогенного гиперкортицизма.

- Гиперальдостеронизм - характеризуется повышением уровня альдостерона, проявляется артериальной гипертензией и гипокалиемией, может быть первичным и вторичным. Первичный гиперальдостеронизм характеризуется автономной продукцией альдостерона надпочечниками (альдостерома, двусторонняя адреналовая гиперплазия, адренокортикальная карцинома) и носит название синдрома Конна. Развитие вторичного гиперальдостеронизма связано с повышением продукции ренина. Для уточнения диагноза необходимо определение уровня альдостерона и ренина в крови. Лечение аденомы и односторонней гиперплазии - хирургическое. При двусторонней адреналовой гиперплазии лечение проводится антагонистом альдостерона спиронолактоном.

- Андростерома - опухоль, продуцирующая андрогены (дегидроэпиандростерон, тестостерон, андростендион). Клинически у женщин проявляется маскулинизацией, у мужчин - ранним половым и физическим развитием. 
Диагноз подтверждается результатами лабораторных исследований отмечается повышенное содержание в крови дегидроэпиандростерона, андростендиона и тестостерона. В топической диагностике заболевания наибольшее значение имеют УЗИ, КТ, МРТ. Лечение - хирургическое (удаление опухоли вместе с пораженным надпочечником).

- Кортикостерома - опухоль коры надпочечников, в избытке продуцирующая эстрогены. Обычно злокачественная. Гиперпродукция эстрогенов ведет к развитию симптомов феминизации у мужчин (гинекомастия, распределение жировой клетчатки по женскому типу, повышение тембра голоса, атрофия яичек и полового члена, нарушение половой функции, олигоспермия). У девочек болезнь проявляется ранним физическим и половым развитием. Для уточнения диагноза важное значение имеет определение повышенного уровня эстрогенов (эстрадиола) в крови. Результаты УЗИ, КТ или МРТ позволяют уточнить топический диагноз. Лечение хирургическое - удаление опухоли с пораженным надпочечником.

- Адренокортикальная карцинома - опухоль, развивающаяся из коркового слоя надпочечников. Обычно злокачественная, в большинстве случаев гормонально активная. От доброкачественных опухолей отличается не столько по гистологической структуре, а сколько - особенностью местного распространения и метастазирования. Клинически проявляется синдромом Кушинга и симптомами вирилизма. Лечение - хирургическое (радикальная адреналэктомия в сочетании с лимфодиссекцией и химиотерапией). С паллиативной целью возможны циторедуктивные операции.

- Феохромоцитома - опухоль, исходящая из хромаффинных клеток диффузной нейроэндокринной системы (АПUД-системы). В $90 \%$ наблюдений опухоль исходит из мозгового вещества надпочечника. В $10 \%$ случаев отмечается вненадпочечниковая локализация опухоли (параганглиома). В патогенезе важное значение придают повышенной продукции опухолью катехоламинов. Клинически проявляется головной болью, сердцебиением, дрожью во всём теле, одышкой, потливостью, повышением температуры. Лабораторные методы диагностики направлены на выявление высокого уровня катехоламинов и их метаболитов в моче. В топической диагностике наибольшее значение имеют КТ и МРТ. Лечение - хирургическое (радикальное удаление опухоли).

- Инциденталома - опухоль надпочечников более 1 см, выявляемая, как правило, случайно при выполнении УЗИ, КТ и МРТ органов брюшной полости и 
забрюшинного пространства. Причинами могут быть первичные и вторичные адреналовые опухоли. Основной целью диагностики инциденталом является определение их гормональной активности и клеточной структуры. При этом обращают внимание на размеры опухоли, её структуру, контуры, особенности контрастирования. Гормонально активные и имеющие злокачественное течение инциденталомы (опухоли, превышающие 4 см в диаметре, имеющие неровные контуры, микрокальцинаты, задерживающие контраст) подлежат хирургическому лечению. Функционально неактивные и имеющие малую вероятность злокачественности инциденталомы (опухоли, не превышающие 4 см в диаметре, контуры ровные) подлежат динамическому наблюдению с проведением КТ в течение 2 лет с интервалом 6 мес.

\section{Вопросы и ответы по заболеваниям надпочечников}

\section{Вопросы}

Куда впадает левая надпочечниковая вена?

\section{Ответы}

В левую почечную вену.

\section{Куда впадает правая надпочечниковая В нижнюю полую вену. вена?}

Что такое кортикотропин-рилизинггормон (КРГ)?

Что такое адренокортикотропный гормон (АКТГ)?
Гормон, выделяемый передней долей гипоталамуса, который способствует выделению АКТГ.

Гормон, выделяемый передней долей гипофиза, который стимулирует выделение кортизола в надпочечниках.

Что такое синдром Кушинга?

Состояние, при котором повышается уровень кортизола в организме.

Наиболее часто встречающаяся причина: 


\begin{tabular}{|c|c|}
\hline Вопросы & Ответы \\
\hline Что такое болезнь Кушинга? & обусловленное \\
\hline & выделением \\
\hline & опухолью гипоф \\
\hline $\begin{array}{l}\text { Что относится к источникам } \\
\text { эктопического АКтГ? }\end{array}$ & $\begin{array}{l}\text { Все опухоли, расположенные вне } \\
\text { гипофиза. }\end{array}$ \\
\hline $\begin{array}{l}\text { Клинические признаки синдрома } \\
\text { Кушинга: }\end{array}$ & $\begin{array}{l}\text { - Абдоминальный тип ожирения; } \\
\text { - Гирсутизм; } \\
\text { - Лунообразное (округлое) лицо; } \\
\text { - Акне; } \\
\text { - Избыточное скопление жировой } \\
\text { ткани на шее; } \\
\text { - Синюшно- багровые полосы } \\
\text { растяжения (стрии); } \\
\text { - Артериальная гипертензия; } \\
\text { - Депрессия; } \\
\text { - Повышенная мышечная слабость. }\end{array}$ \\
\hline $\begin{array}{l}\text { Уровень кортизола в крови у } \\
\text { здоровых людей: }\end{array}$ & $\begin{array}{l}\text { Концентрация кортизола по утрам } \\
\text { повышается, по вечерам - снижается. }\end{array}$ \\
\hline $\begin{array}{l}\text { Какие первичные анализы } \\
\text { необходимо провести при синдроме } \\
\text { Кушинга? }\end{array}$ & $\begin{array}{l}\text { - Электролиты; } \\
\text { - Кортизол в сыворотке; } \\
\text { - Свободный кортизол в моче; } \\
\text { - Малая дексаметазоновая проба. }\end{array}$ \\
\hline $\begin{array}{l}\text { Что такое низкий дексаметозоновый } \\
\text { тест? }\end{array}$ & $\begin{array}{l}\text { После приёма дексаметазона } \\
\text { определяют уровень кортизола в крови. } \\
\text { у здоровых людей после приёма } \\
\text { дексаметазона концентрация } \\
\text { кортизола уменьшается. При опухолях, } \\
\text { синтезирующих кортизол, уровень } \\
\text { кортизола не снижается. }\end{array}$ \\
\hline
\end{tabular}




\begin{tabular}{|c|c|}
\hline Вопросы & Ответы \\
\hline $\begin{array}{l}\text { Какую пробу проводят после } \\
\text { дексаметазонового теста? }\end{array}$ & Определяют уровень АКТГ. \\
\hline $\begin{array}{l}\text { Как необходимо дифференцировать } \\
\text { болезнь Кушинга, обусловленную } \\
\text { аденомой гипофиза, с } \\
\text { эктопированным АКТГ-синдромом? }\end{array}$ & $\begin{array}{l}\text { С этой целью проводят большую } \\
\text { дексаметазоновую пробу: } \\
\text { - При аденомах гипофиза уровень } \\
\text { кортизола снижается; } \\
\text { - При эктопированном АКТГ- } \\
\text { синдроме уровень кортизола не } \\
\text { снижается. }\end{array}$ \\
\hline $\begin{array}{l}\text { Чем характеризуются лабораторные } \\
\text { показатели при синдроме Кушинга? }\end{array}$ & $\begin{array}{l}\text { - У здоровых: } \\
\text { О Уровень кортизола и АКТГ в } \\
\text { норме; } \\
\text { Супрессия уровня кортизола и } \\
\text { АКТГ после малой и большой } \\
\text { дексаметазоновой пробы; } \\
\text { - При болезни Кушинга (АКТГ } \\
\text { зависимая форма опухоли } \\
\text { гипофиза): } \\
\text { О Высокий уровень кортизола и } \\
\text { АКТГ; } \\
\text { Отсутствие супрессии при малой } \\
\text { дексаметазоновой пробе; } \\
\text { Супрессия кортизола и АКТГ } \\
\text { после большой } \\
\text { дексаметазоновой пробы. } \\
\text { Адреналовая опухоль: } \\
\text { Высокий уровень кортизола и } \\
\text { низкий уровень АКТГ; } \\
\text { О Отсутствие супрессии кортизола } \\
\text { после малой и большой } \\
\text { дексаметазоновой пробы. }\end{array}$ \\
\hline
\end{tabular}




\begin{tabular}{|c|c|}
\hline Вопросы & Ответы \\
\hline & $\begin{array}{l}\text { - Эктопированный АКТГ-синдром, } \\
\text { обусловленный опухолями другой } \\
\text { локализации: } \\
\text { о Высокий уровень кортизола и } \\
\text { АКТГ; } \\
\text { О Отсутствие супрессии кортизола } \\
\text { после малой и большой } \\
\text { дексаметазоновой пробы. }\end{array}$ \\
\hline $\begin{array}{l}\text { Наиболее частая причина } \\
\text { эктопированного АКТГ-синдрома: }\end{array}$ & $\begin{array}{l}\text { 2/3 опухолей составляет } \\
\text { мелкоклеточный рак лёгкого. }\end{array}$ \\
\hline $\begin{array}{l}\text { В чём заключается лечение } \\
\text { адреналовой аденомы? }\end{array}$ & $\begin{array}{ll}\text { Адреналэктомия } & \text { (исключительно } \\
\text { унилатеральная). } & \end{array}$ \\
\hline $\begin{array}{l}\text { В чём заключается лечение } \\
\text { адреналовой карциномы? }\end{array}$ & $\begin{array}{l}\text { Хирургическая эксцизия (возможна у } \\
\text { 1/3 больных). }\end{array}$ \\
\hline $\begin{array}{l}\text { В чём заключается лечение } \\
\text { эктопированного АКТГ-синдрома? }\end{array}$ & $\begin{array}{l}\text { Хирургическая } \quad \text { эксцизия } \\
\text { возможности). }\end{array}$ \\
\hline $\begin{array}{l}\text { Какой препарат назначают перед } \\
\text { операцией при синдроме Кушинга? }\end{array}$ & Кортизол (обычно гидрокортизон). \\
\hline $\begin{array}{l}\text { Какие препараты назначают больным } \\
\text { с повышенным уровнем кортизола? }\end{array}$ & $\begin{array}{l}\text { - Кетоконазол; } \\
\text { - Метирапон (ингибитор кортизола); } \\
\text { - Аминоглютетимид; } \\
\text { - Митотан. }\end{array}$ \\
\hline $\begin{array}{l}\text { Осложнение после билатеральной } \\
\text { (двусторонней) адреналэктомии: }\end{array}$ & Синдром Нельсона. \\
\hline Что такое Синдром Нельсона? & 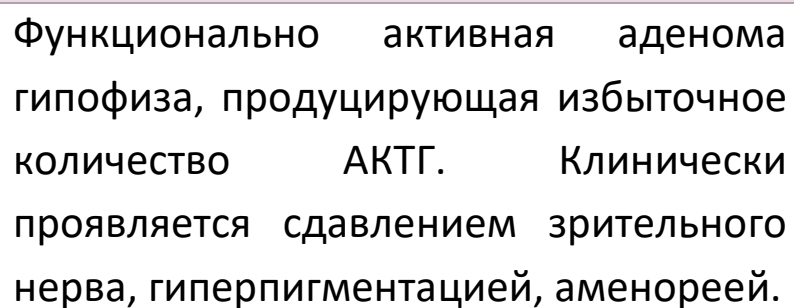 \\
\hline
\end{tabular}




\begin{tabular}{|c|c|c|}
\hline Вопросы & \multicolumn{2}{|c|}{ Ответы } \\
\hline Частота встречаемости синдрома & Наблюдается & 10\% пациентов, \\
\hline Нельсона: & $\begin{array}{l}\text { перенёсших } \\
\text { адреналэктомию. }\end{array}$ & двустороннюю \\
\hline
\end{tabular}

\section{Вопросы и ответы по гиперальдостеронизму}

\begin{tabular}{|c|c|}
\hline \multirow{4}{*}{$\begin{array}{c}\text { Вопросы } \\
\text { Что такое синдром Конна? }\end{array}$} & Ответы \\
\hline & Первичный гиперальдостеронизм, \\
\hline & (альдостеромой) \\
\hline & надпочечников. \\
\hline $\begin{array}{l}\text { Наиболее часто встречающаяся } \\
\text { причина синдрома Конна: }\end{array}$ & $\begin{array}{l}\text { Адреналовая аденома или гиперплазия } \\
\text { коры надпочечников. }\end{array}$ \\
\hline $\begin{array}{l}\text { В чём заключается физиологическая } \\
\text { действие альдостерона? }\end{array}$ & $\begin{array}{l}\text { Альдостерон способствует избыточной } \\
\text { экскреции почками ионов калия, } \\
\text { повышенной реабсорбции ионов } \\
\text { натрия, гиперволемии и артериальной } \\
\text { гипертензии. }\end{array}$ \\
\hline $\begin{array}{l}\text { Клинические признаки синдрома } \\
\text { Конна: }\end{array}$ & $\begin{array}{l}\text { - Артериальная гипертензия за счёт } \\
\text { повышения диастолического } \\
\text { давления; } \\
\text { - Головные боли; } \\
\text { - Полиурия; } \\
\text { - Слабость. }\end{array}$ \\
\hline $\begin{array}{l}\text { «Ключевые» признаки синдрома } \\
\text { Конна: }\end{array}$ & $\begin{array}{l}\text { - Артериальная гипертензия за счёт } \\
\text { повышения диястолического } \\
\text { давления; } \\
\text { - Гипокалиемия. }\end{array}$ \\
\hline
\end{tabular}




\begin{tabular}{|c|c|}
\hline Вопросы & Ответы \\
\hline Уровень ренина при синдроме Конна: & В норме или ниже нормы. \\
\hline $\begin{array}{l}\text { Частота выявления синдрома Конна у } \\
\text { больных с артериальной гипертензией: }\end{array}$ & $\begin{array}{l}\text { Встречается у 1\% больных, страдающих } \\
\text { гипертонической болезнью. }\end{array}$ \\
\hline $\begin{array}{l}\text { Какие лабораторные тесты проводят } \\
\text { для уточнения диагноза? }\end{array}$ & $\begin{array}{l}\text { - Альдостерон в плазме; } \\
\text { - Активность ренина в плазме. }\end{array}$ \\
\hline $\begin{array}{l}\text { Что такое } \\
\text { гиперальдостеронизм? }\end{array}$ & $\begin{array}{l}\text { Альдостеронизм, обусловленный } \\
\text { повышенным уровнем ренина. }\end{array}$ \\
\hline $\begin{array}{l}\text { Какие методы исследования } \\
\text { необходимы для диагностики? }\end{array}$ & $\begin{array}{l}\text { КТ, определение уровня альдостерона, } \\
\text { солевая нагрузка. }\end{array}$ \\
\hline Что такое солевая нагрузка? & $\begin{array}{l}\text { Солевая нагрузка снижает уровень } \\
\text { альдостерона у здоровых людей, что не } \\
\text { наблюдается при синдроме Конна. }\end{array}$ \\
\hline $\begin{array}{l}\text { В чём заключается предоперационная } \\
\text { подготовка? }\end{array}$ & Больным назначает спиронолактон. \\
\hline Что такое спиронолактон? & $\begin{array}{l}\text { Антогонист альдостерона (действует на } \\
\text { клубочки почек). }\end{array}$ \\
\hline Лечение адреналовой аденомы: & $\begin{array}{l}\text { Унилатеральная } \quad \text { лапароскопическая } \\
\text { адреналэктомия. }\end{array}$ \\
\hline $\begin{array}{l}\text { Лечение односторонней гиперплазии } \\
\text { надпочечника: }\end{array}$ & Унилатеральная адреналэктомия. \\
\hline $\begin{array}{l}\text { Лечение двусторонней гиперплазии } \\
\text { надпочечников: }\end{array}$ & Лечение спиронолактаном. \\
\hline
\end{tabular}




\section{Вопросы и ответы по феохромоцитоме}

\begin{tabular}{|c|c|}
\hline Вопросы & Ответы \\
\hline Что такое феохромоцитома? & $\begin{array}{l}\text { Опухоль, исходящая из хромаффинных } \\
\text { клеток нейроэндокринной системы (APUD- } \\
\text { системы). Хромаффинную ткань можно } \\
\text { обнаружить в области симпатических } \\
\text { ганглиев и сплетений. }\end{array}$ \\
\hline Частота встречаемости: & $\begin{array}{l}\text { Наблюдается у 1/500 пациентов, } \\
\text { страдающих артериальной гипертензией. }\end{array}$ \\
\hline $\begin{array}{l}\text { В какой возрастной группе наиболее } \\
\text { часто встречается? }\end{array}$ & $\begin{array}{l}\text { Во всех возрастных группах, но обычно } \\
\text { наблюдается в возрасте } 40-60 \text { лет и старше. }\end{array}$ \\
\hline $\begin{array}{l}\text { В каком органе наиболее часто } \\
\text { Выявляется? }\end{array}$ & $\begin{array}{l}\text { В 90\% наблюдений опухоль исходит из } \\
\text { мозгового слоя надпочечников. }\end{array}$ \\
\hline $\begin{array}{l}\text { Как часто поражаются феохромациомой } \\
\text { другие органы? }\end{array}$ & $\begin{array}{l}\text { Орган Цуккеркандля (по ходу брюшной } \\
\text { аорты), грудная клетка, средостение, } \\
\text { мочевой пузырь, мошонка. }\end{array}$ \\
\hline Что относится к органу Цукеркандля? & $\begin{array}{l}\text { Хромаффинные клетки, расположенные по } \\
\text { ходу абдоминальной аорты. }\end{array}$ \\
\hline Причины и факторы риска: & $\begin{array}{l}\text { - Множественные эндокринные } \\
\text { неоплазии; } \\
\text { - Семейный анамнез; } \\
\text { - Болезнь Реклингхаузена; } \\
\text { - Болезнь фон Гиппеля-Линдау. }\end{array}$ \\
\hline Клинические признаки: & $\begin{array}{l}\text { - Характеризуется классической триадой: } \\
\text { О Тахикардия; } \\
\text { О Головные боли; } \\
\text { О Потливость; } \\
\text { - Артериальная гипертензия; } \\
\text { - Синюшно-багровые полосы (стрии); }\end{array}$ \\
\hline
\end{tabular}




\begin{tabular}{|c|c|}
\hline Вопросы & Ответы \\
\hline & $\begin{array}{l}\text { - } \quad \text { Чувство тревоги; } \\
\text { - } \quad \text { Потеря веса; } \\
\text { - } \quad \text { Гипергликемия. }\end{array}$ \\
\hline симптом феохромоцитомы: & Артериальная гипертензия. \\
\hline Дифференциальная диагностика: & $\begin{array}{l}\text { - Реноваскулярная гипертония; } \\
\text { - Менопауза; } \\
\text { - Головные боли (по типу мигрени); } \\
\text { - Карциноидный синдром; } \\
\text { - Преэклампсия; } \\
\text { - Нейробластома; } \\
\text { - Панические атаки; } \\
\text { - Гипертироидизм; } \\
\text { - Инсулинома. }\end{array}$ \\
\hline $\begin{array}{l}\text { Какие методы исследования необходимы } \\
\text { для уточнения диагноза? }\end{array}$ & $\begin{array}{l}\text { Определение метаболитов катехоламинов } \\
\text { в моче: } \\
\text { - Ванилилминдальная кислота (VMA); } \\
\text { - Метанефрин и норметанефрин. }\end{array}$ \\
\hline $\begin{array}{l}\text { Наиболее часто встречающиеся другие } \\
\text { лабораторные признаки заболевания: }\end{array}$ & $\begin{array}{l}\text { - Гипергликемия (эпинефрин повышает } \\
\text { глюкозу, норэпинефрин снижает } \\
\text { инсулин); } \\
\text { - Полицитемия (за счёт уменьшения } \\
\text { интраваскулярного объёма). }\end{array}$ \\
\hline $\begin{array}{l}\text { Какие методы исследования необходимы } \\
\text { для топической диагностики? }\end{array}$ & КТ, МРТ, ПЭТ. \\
\hline $\begin{array}{l}\text { Частота озлокачествления } \\
\text { феохромоцитомы: }\end{array}$ & Наблюдается в 10\% случаев. \\
\hline $\begin{array}{l}\text { Достаточно ли гистологическое } \\
\text { исследование для уточнения } \\
\text { злокачественной природы опухоли? }\end{array}$ & 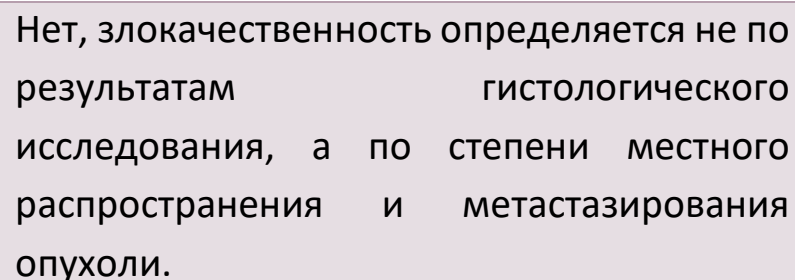 \\
\hline
\end{tabular}




\begin{tabular}{|c|c|}
\hline Вопросы & Ответы \\
\hline $\begin{array}{l}\text { Что такое правило } 10 \% \text { при классической } \\
\text { феохромацитоме? }\end{array}$ & $\begin{array}{l}\text { - В } 10 \% \text { - малигнизурует. } \\
\text { - В } 10 \% \text { - имеет одностороннюю } \\
\text { локализацию. } \\
\text { - В } 10 \% \text { - наблюдается у детей. } \\
\text { - } 10 \% \text { - носит характер множественной } \\
\text { эндокринной неоплазии. } \\
\text { - В } 10 \% \text { - имеет вненадпочечниковую } \\
\text { локализацию. }\end{array}$ \\
\hline $\begin{array}{l}\text { В чём заключается предоперационная } \\
\text { подготовка? }\end{array}$ & $\begin{array}{l}\text { Назначение } \alpha \text {-адреноблокаторов } \\
\text { (феноксибензамин или празозин). }\end{array}$ \\
\hline $\begin{array}{l}\text { В чём заключается хирургическое } \\
\text { лечение? }\end{array}$ & $\begin{array}{l}\text { Раннее васкулярное лигирование в } \\
\text { сочетании с резекцией опухоли. }\end{array}$ \\
\hline $\begin{array}{l}\text { Чем проявляется пред- и } \\
\text { послеоперационные осложнения? }\end{array}$ & $\begin{array}{l}\text { Гипертонический криз (до операции), } \\
\text { гипотония и аритмия (после радикального } \\
\text { удаления опухоли). }\end{array}$ \\
\hline $\begin{array}{l}\text { Какую патологию необходимо исключить } \\
\text { у больных с феохромоцитомой? }\end{array}$ & $\begin{array}{l}\text { Множественную эндокринную неоплазию } \\
\text { (МЭН). }\end{array}$ \\
\hline Что такое инциденталома? & $\begin{array}{l}\text { Опухоль надпочечников, случайно } \\
\text { выявленная при визуализации органов } \\
\text { брюшной полости. }\end{array}$ \\
\hline Частота встречаемости: & При КТ выявляется у 1-4\% пациентов. \\
\hline Наиболее частая причина: & $\begin{array}{l}\text { Функционально неактивная аденома (75\% } \\
\text { и более). }\end{array}$ \\
\hline $\begin{array}{l}\text { Другие нозологические причины } \\
\text { инциденталомы: }\end{array}$ & $\begin{array}{l}\text { - Феохромоцитома; } \\
\text { - Адренокортикальная карцинома; } \\
\text { - Альдостерома; } \\
\text { - Нодулярная гиперплазия; } \\
\text { - Метастатический очаг. }\end{array}$ \\
\hline $\begin{array}{l}\text { Какие опухоли имеют наиболее высокую } \\
\text { вероятность озлокачествления? }\end{array}$ & $\begin{array}{l}\text { Солидные опухоли, размером более } 4 \text { см в } \\
\text { диаметре. }\end{array}$ \\
\hline
\end{tabular}




\begin{tabular}{|c|c|}
\hline Вопросы & Ответы \\
\hline В чём заключается лечение? & $\begin{array}{l}\text { - При гормонально активных и } \\
\text { злокачественных } \\
\text { хирургическое лечение. } \\
\text { - При гормонально неактивных опухолях } \\
\text { и отсутствии } \\
\text { озлокачествления - динамнаков } \\
\text { наблюдение. }\end{array}$ \\
\hline $\begin{array}{l}\text { Что является показателем к операции при } \\
\text { инциденталомах менее } 4 \text { см в диаметре? }\end{array}$ & $\begin{array}{l}\text { - Выявление более } 2 \text { сигнальных узлов } \\
\text { при МРТ; } \\
\text { - Склонность к увеличению опухоли; } \\
\text { - Отсутствие сходства опухоли на } \\
\text { аденомупри КТ. }\end{array}$ \\
\hline $\begin{array}{l}\text { Какая опухоль должна быть исключена } \\
\text { при адреналовых образованиях перед } \\
\text { биопсией и операцией? }\end{array}$ & Феохромоцитома. \\
\hline
\end{tabular}

\section{СПИСОК ЛИТЕРАТУРЫ}

- Ağayev B.A. Cərrahi xəstəliklər. Bakı 2010.

- Blackbourne LH. Surgical Recall. 4 edition, 2006, LWW, Philadelphia

- Doherty GM. Current Diagnosis and Treatment: Surgery, $13^{\text {th }}$ edition, 2010, Lang International Edition.

- $\quad$ Omiraslanov כ.T., Qazıyev A.Y. Onkologiya. Bakı, 2010.

- İsayev H.B. Corrahi xəstəliklərin patofizologiyası. Bakı 2005

- Klingensmith ME, Aziz A, Bharat A, Fox AC, Porembka MR. The Washington Manual of Surgery, $6^{\text {th }}$ edition, 2012, LWW, Philadelphia.

- McNally PR. GI/Liver Secrets Plus. 4 edition. Mosby, Elsevier, 2010

- Medscape, http://www.medscape.com

- Oxford Handbook of Clinical Surgery, 3d edition, 2011, Oxford Press

- Sayek i. Sayek Temel Cerrahi 1-2. 4-cü baskı, 2016, Güneş Tıp Kitabevleri.

- Topçubaşov M.A. Xüsusi cərrahlıq. Bakı, 1979

- UpToDate, http://www.uptodate.com

- Гостищев В.К. Общая хирургия. GEOTAR-Media, 2019 


\section{ХИРУРГИЧЕСКИЕ БОЛЕЗНИ}

Н.Ю. Байрамов

\section{Ожирение. Бариатрическая и метаболическая хирургия.}

Н.Ю. Байрамов, Т.И. Омаров

Перевод: Н.Ю. Байрамов, С.А. Алиев, М.Р.Гусейнова 
- Ожирение - хроническое заболевание, характеризующееся избыточным накоплением жировой ткани в организме и сопровождающееся развитием серьёзных осложнений со стороны различных органов и систем (сердечнососудистая, эндокринная, опорно-двигательная, пищеварительная и др.)

○ Осложнения наиболее часто наблюдаются при центральной (висцеральной) форме и III степени (избыточное ожирение) ожирения. Снижение веса на 5$10 \%$ приводит к регрессии случаев осложнения.

○ Диагноз ожирения ставится на основании повышения индекса массы тела более $30 \mathrm{kг} / \mathrm{M}^{2}$ и исключении других заболеваний, являющихся причиной повышения веса.

- Лечение предусматривает изменение образа жизни, диетотерапию, фармакотерапию и выполнение бариатрических операций. Бариатрическая хирургия является самым эффективным методом лечения, при котором возможно снижение веса более чем на $60 \%$ на длительное время и избавление от осложнений, вызванных ожирением.

- Бариатрическая хирургия предусматривает снижение массы тела путём выполнения различных операций на желудочно-кишечном тракте. В основе бариатрической хирургии лежат 2 концепции: классическая механическая и современная эндокринная.

○ Механическая концепция преследует реализацию одной из 2-х целей: снижение процессов всасывания пищевых ингредиентов из просвета тонкой кишки (мальабсорбтивные операции) или уменьшение объёма желудка (рестриктивные операции).

- Согласно эндокринной концепции бариатрические операции способствуют снижению массы тела путём коррекции гормонального дисбаланса: уровень гормонов голода (грелин и лептин) снижается, а концентрация гормонов, обеспечивающих чувство насыщения (GLP, PYY) увеличивается.

○ Показаниями к бариатрической коррекции морбидного ожирения является индекс массы тела более $40 \mathrm{kr} / \mathrm{m}^{3}$ или ожирение II степени наряду с осложнениями, а также неэффективность комплексной консервативной терапии. 
О В настоящее время с целью снижения веса проводятся рестриктивные (продольная резекция желудка, бандажирование желудка, гастропликация и др.), мальабсорбтивные (еюно-илеальный обходной путь, билиопанкреатическая диверсия и др.) и смешанные операции (шунтирование и мини-шунтирование желудка, дуоденальный переключатель и др.)

○ К самым часто применяемым операциям относятся продольная резекция желудка, шунтирование желудка по Ру, билио-панкреатическая диверсия (классическая или дуоденальный переключатель) и бандажирование желудка.

○ Несмотря на то, что мальабсорбтивные операции приводят к быстрому снижению веса и оказывают антидиабетическое действие, для них характерны также мальабсорбтивные осложнения. При рестриктивных же операциях эффективность снижения массы тела относительно низка.

- Метаболическая хирургия - предусматривает коррекцию метаболических дисфункций путём выполнения оперативных вмешательств на желудочнокишечном тракте.

О В последние годы метаболическая хирургия стала одной из приоритетных направлений лечения морбидного ожирения, ассоциирующегося с сахарным диабетом типа 2.

○ Показаниями к метаболической хирургии относятся ожирение II и III степени наряду с сахарным диабетом типа 2, ожирение I степени с неконтролируемым сахарным диабетом.

○ Из-за отсутствия специфических методов лечения сахарного диабета применяются бариатрические/метаболические операции. $\mathrm{K}$ самым эффективным относятся дуоденальный переключатель, обходные пути, продольная резекция желудка и бандажирование желудка.

\section{Вопросы и ответы по ожирению, бариатрической и метаболической хирургии}

\section{Вопросы Ответы}

Что такое ожирение?

Накопление избыточной жировой ткани в организме. 


\begin{tabular}{|c|c|}
\hline Основные факторы риска: & $\begin{array}{l}\text { Наследственно-генетические факторы, } \\
\text { образ жизни и питания, стресс, } \\
\text { гипокинезия. }\end{array}$ \\
\hline Клинические формы: & $\begin{array}{l}\text { Висцеральная (центральную) и } \\
\text { подкожную (периферическую). }\end{array}$ \\
\hline $\begin{array}{l}\text { Критерий оценки степени тяжести } \\
\text { ожирения: }\end{array}$ & Индекс массы тела. \\
\hline Что такое индекс массы тела? & $\begin{array}{l}\text { Соотношение между весом (массой) } \\
\text { тела и ростом. }\end{array}$ \\
\hline $\begin{array}{l}\text { Чем осложняется избыточное } \\
\text { ожирение? }\end{array}$ & 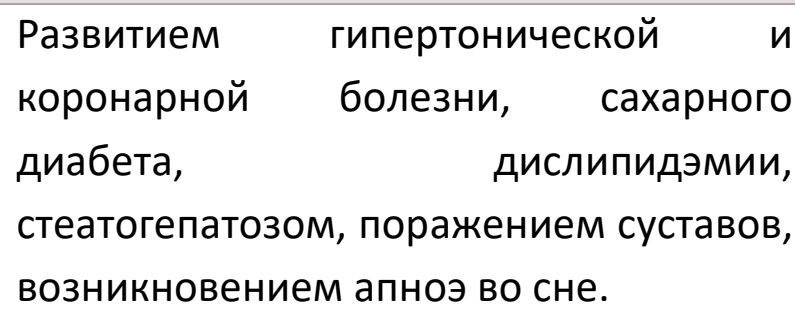 \\
\hline $\begin{array}{l}\text { Диагностические морбидного } \\
\text { ожирения: }\end{array}$ & $\begin{array}{l}\text { Индекс массы тела, превышающий } 30 \\
\text { кг/м² и отсутствие других заболеваний. }\end{array}$ \\
\hline Методы лечения ожирения: & $\begin{array}{l}\text { Нормализация образа жизни и питания, } \\
\text { медикоментозная терапия, } \\
\text { бариатрические операции. }\end{array}$ \\
\hline $\begin{array}{l}\text { Почему снижение массы тела } \\
\text { является главной задачей? }\end{array}$ & $\begin{array}{l}\text { Потому что снижение избыточной } \\
\text { массы тела способствует устранению } \\
\text { осложнений. }\end{array}$ \\
\hline $\begin{array}{l}\text { Какой порог снижения массы тела } \\
\text { является условием для регрессии } \\
\text { осложнений? }\end{array}$ & Снижение массы на 5-10\%. \\
\hline $\begin{array}{l}\text { Наиболее эффективный метод } \\
\text { лечения ожирения: }\end{array}$ & Бариатрические операции. \\
\hline
\end{tabular}




\begin{tabular}{|c|c|}
\hline Что такое бариатрическая хирургия? & $\begin{array}{l}\text { Хирургические операции, выполняемые } \\
\text { с целью снижения избыточной массы } \\
\text { тела. }\end{array}$ \\
\hline Типы бариатрических операций: & $\begin{array}{l}\text { Мальабсорбтивные, рестриктивные, } \\
\text { смешанные. }\end{array}$ \\
\hline $\begin{array}{l}\text { Что представляют собой } \\
\text { мальабсорбтивные операции? }\end{array}$ & $\begin{array}{l}\text { Устранение сегмента кишечника из } \\
\text { пищеварения с целью снижения } \\
\text { всасывания. }\end{array}$ \\
\hline $\begin{array}{l}\text { Преимущества и недостатки } \\
\text { мальабсорбтивных операций: }\end{array}$ & $\begin{array}{l}\text { Быстрое снижение } \\
\text { антидиабетическое действие, однако } \\
\text { для них характерны } \\
\text { мальабсорбтивные осложнения. }\end{array}$ \\
\hline $\begin{array}{l}\text { Наиболее часто применяемая } \\
\text { мальабсорбтивная операция: }\end{array}$ & $\begin{array}{l}\text { Билиопанкреатическая диверсия: } \\
\text { дистальная резекция желудка, } \\
\text { формирование гастроилеального } \\
\text { анастомоза по Ру. }\end{array}$ \\
\hline $\begin{array}{l}\text { Что представляют собой } \\
\text { рестриктивные операции? }\end{array}$ & $\begin{array}{l}\text { Уменьшение объёма желудка и } \\
\text { количества потребляемой пищи. }\end{array}$ \\
\hline $\begin{array}{l}\text { Наиболее часто выполняемый } \\
\text { вариант рестриктивных операций: }\end{array}$ & $\begin{array}{l}\text { Продольная (рукавная) резекция } \\
\text { желудка и бандажирование желудка. }\end{array}$ \\
\hline $\begin{array}{l}\text { Преимущества и недостатки } \\
\text { рестриктивных операций: }\end{array}$ & $\begin{array}{l}\text { Простота техники выполнения, } \\
\text { отсутствие мальабсорбции, однако } \\
\text { эффективность снижения массы тела } \\
\text { относительно низка. }\end{array}$ \\
\hline $\begin{array}{l}\text { Что включает в себя смешанные } \\
\text { операции? }\end{array}$ & $\begin{array}{l}\text { Происходит уменьшение объёма } \\
\text { желудка и снижение всасывающей } \\
\text { поверхности. }\end{array}$ \\
\hline $\begin{array}{l}\text { Наиболее часто применяемый } \\
\text { вариант смешанных операций: }\end{array}$ & Шунтирование желудка по типу Ru-Y. \\
\hline
\end{tabular}




\begin{tabular}{|c|c|}
\hline $\begin{array}{l}\text { Что является основной задачей и } \\
\text { требованием к бариатрической } \\
\text { хирургии? }\end{array}$ & $\begin{array}{l}\text { Снижение массы тела на 50\% и более на } \\
\text { долгосрочный период, минимальный } \\
\text { побочный эффект, малая инвазивность. }\end{array}$ \\
\hline Что такое метаболическая хирургия? & $\begin{array}{l}\text { Хирургические вмешательства, } \\
\text { выполняемые на желудочно-кишечном } \\
\text { тракте, с целью коррекции ожирения и } \\
\text { сахарного диабета типа } 2 .\end{array}$ \\
\hline $\begin{array}{l}\text { Чем отличается бариатрическая } \\
\text { хирургия от метаболической? }\end{array}$ & $\begin{array}{l}\text { Бариатрическая хирургия } \\
\text { предусматривает снижение массы тела. } \\
\text { Задачей метаболической хирургии } \\
\text { является коррекция сахарного диабета } \\
\text { и других метаболических дисфункций. } \\
\text { Следовательно, бариатрическая } \\
\text { хирургия является составной частью } \\
\text { метаболической хирургии. }\end{array}$ \\
\hline $\begin{array}{l}\text { Показания к метаболической } \\
\text { хирургии: }\end{array}$ & $\begin{array}{l}\text { Ожирение II и III степени наряду с } \\
\text { сахарным диабетом типа 2, ожирение I } \\
\text { степени с неконтролируемым сахарным } \\
\text { диабетом }\end{array}$ \\
\hline $\begin{array}{l}\text { Наиболее часто выполняемый } \\
\text { варианты метаболической операции: }\end{array}$ & $\begin{array}{l}\text { • Билио-панкреатическая диверсия } \\
\text { (классическая или дуоденальный } \\
\text { выключатель); } \\
\text { • Шунтирование или мини- } \\
\text { шунтирование желудка по типу Ru-Y; } \\
\text { • Продольная резекция желудка; } \\
\text { • Бандажирование желудка; } \\
\text { • Простые анастомозы. }\end{array}$ \\
\hline $\begin{array}{l}\text { Наиболее эффективный метод } \\
\text { хирургической коррекции сахарного } \\
\text { диабета: }\end{array}$ & $\begin{array}{l}\text { Билио-панкреатическая диверсия } \\
\text { (классическая или дуоденальный } \\
\text { выключатель). }\end{array}$ \\
\hline
\end{tabular}




\section{СПИСОК ЛИТЕРАТУРЫ}

- Blackbourne LH. Surgical Recall. 6th edition, 2012, LWW, Philadelphia

- Doherty GM. Current Diagnosis and Treatment: Surgery, $13^{\text {th }}$ edition, 2010, Lang International Edition.

- Medscape, http://www.medscape.com

- Klingensmith ME, Aziz A, Bharat A, FoxAC, Porembka MR. The Washington Manual of Surgery, $6^{\text {th }}$ edition, 2012, LWW, Philadelphia.

- Oxford Handbook of Clinical Surgery, 3rd edition, 2011, Oxford Press

- UpToDate, http://www.uptodate.com

- Bariatric Surgery Worldwide: Baseline DemographicDescription and One-Year Outcomes from the Second IFSO Global Registry Report 2013-2015/ R.

- Bariatric Today. (n.d.) Retrieved 15 November 2012 from http://www.bariatrictoday.com/bariatric-surgery-information/the-mostimportant-questions-to-ask-your-doctor.html

- National Institutes of Health Consensus Development Conference Statement 1991. Gastrointestinal surgery for severe obesity. Am J Clin Nutr 1992;52(Suppl 2):615-619.

- Schirmer B, Schauer PR. The surgical management of obesity. Schwart's Principles of Surgery 2010; 949-978.

- World Health Organization. Obesity and overweight factsheet [WHO website]. Jan 2015. http://www.who.int/mediacentre/factshetts/fs311/en/.Accessed 22 Feb 2015. 


\section{ХИРУРГИЧЕСКИЕ БОЛЕЗНИ}

Н.Ю. Байрамов

\section{Хирургические заболевания молочной железы}

Н.Ю. Байрамов, А. Ибрагимова

Перевод: Н.Ю. Байрамов, С.А. Алиев, М.Р. Гусейнова 


\section{МОЛОЧНЫЕ ЖЕЛЕЗЫ. АНАТОМИЯ ПОДМЫШЕЧНОЙ ЯМКИ.}

- Молочные железы, имеющие железисто-жировую структуру, расположены на передней стенке грудной клетки, в передне-верхнем правом и левом отделах.

- Железа богата нервными окончаниями, кровеносными и лимфатическими сосудами.

- Основная функция молочных желез, являющихся железами апокринного типа, лактация.

- Соединительная ткань и связки поддерживают молочные железы и придают им формы.

- Границы подмышечной ямки: верхняя - подмышечная вена, задняя широчайшая мышца спины, передняя - передняя зубчатая мышца, нижняя длинный грудной нерв.

- По расположению лимфатических узлов по отношению к малой грудной мышце подмышечную ямку разделяют на 3 уровня. Наличие позитивных узлов даёт неблагоприятный прогноз.

\section{Вопросы и ответы по молочным железам и анатомии подмышечной впадины}

\begin{tabular}{|c|c|}
\hline Вопросы & Ответы \\
\hline $\begin{array}{l}\text { Границы подмышечной } \\
\text { лимфодиссекции: }\end{array}$ & $\begin{array}{l}\text { - Верхняя граница - подмышечная } \\
\text { вена; } \\
\text { • Нижняя граница - длинный грудной } \\
\text { нерв; } \\
\text { - Боковая (латеральная) граница - } \\
\text { широчайшая мышца спины; } \\
\text { - Медиальная граница - от } \\
\text { латеральной границы до малой } \\
\text { грудной мышцы. }\end{array}$ \\
\hline $\begin{array}{l}\text { Какие нервы могут быть повреждены } \\
\text { при подмышечной лимфодиссекции? }\end{array}$ & $\begin{array}{l}\text { - Длинный грудной нерв; } \\
\text { • Торакодорсальный нерв; } \\
\text { • Медиальный грудной нерв; }\end{array}$ \\
\hline
\end{tabular}


Boпросы

\section{Ответы}

- Латеральный грудной нерв.

Локализация и иннервируемые мышцы следующих нервов:

Длинный грудной нерв: $\quad$ От средней подмышечной линии по ходу боковой стенки грудной клетки до передней зубчатой мышцы.

Торакодорсальный нерв:

Простираясь по наружной поверхности длинного грудного нерва, иннервирует широчайшую мышцу спины.

Медиальный грудной нерв:

Располагаясь в малой грудной мышце или латеральнее неё иннервирует малую и большую грудную мышцы.

Боковой (латеральный) грудной Расположен медиальнее внутреннего нерв: грудного нерва, иннервирует большую грудную мышцу.

Как называется нерв, пересекающий N. intercostobrachialis. подмышечную впадину поперечно?

Какой большой веной разграничена Подмышечной веной. верхняя граница подмышечной впадины?

\section{Как осуществляется лимфоотток от} молочных желез?
- От латеральных квадрантов - в подмышечные лимфоузлы;

- От медиальных квадрантов - в парастернальные лимфоузлы по ходу внутренней грудной артерии.

- І уровень (нижний) - лимфоузлы, расположенные кнаружи от малой грудной мышцы; 


\begin{tabular}{|c|c|}
\hline Вопросы & Ответы \\
\hline & $\begin{array}{l}\text { - ІІ уровень (средний) - лимфоузлы, } \\
\text { расположенные под малой грудной } \\
\text { мышцей; } \\
\text { - } \text { ІІІ уровень (верхний) - } \\
\text { подключичные лимфоузлы, } \\
\text { расположенные медиальнее малой } \\
\text { грудной мышцы. }\end{array}$ \\
\hline Что такое узел Роттера? & $\begin{array}{l}\text { Лимфатический узел, расположенный } \\
\text { между большой и малой грудной } \\
\text { мышцами (обычно не удаляют). }\end{array}$ \\
\hline $\begin{array}{l}\text { Как называется поддерживающая } \\
\text { связка молочной железы? }\end{array}$ & Связка Купера. \\
\hline Что такое линия "mammary milk"? & $\begin{array}{l}\text { Линия, проходящая от плечевого пояса } \\
\text { до бёдер, по ходу которой обычно } \\
\text { расположены ареола или сосок. }\end{array}$ \\
\hline Что такое хвост Спенса? & $\begin{array}{l}\text { Клетчатка, расположенная от молочной } \\
\text { железы до подмышечной впадины. }\end{array}$ \\
\hline $\begin{array}{l}\text { Какой гормон является } \\
\text { ответственным за синтез молока? }\end{array}$ & Пролактин. \\
\hline
\end{tabular}




\section{ЗАБОЛЕВАНИЯ И МЕТОДЫ ИССЛЕДОВАНИЯ МОЛОЧНОЙ ЖЕЛЕЗЫ}

- $\mathrm{K}$ доброкачественным заболеваниям молочной железы относятся фибрознокистозные мастопатии, кисты, фиброаденома, гинекомастия; к злокачественным же - рак молочной железы, лимфома и метастатические опухоли.

- Диагностика заболеваний молочной железы основывается на клинической картине, результатах лабораторного исследования, данных диагностической визуализации и биопсии.

- Биопсия является одним из трёх компонентов (другие - клиническая картина и методы диагностической визуализации) стандартной диагностики опухолей молочной железы.

Вопросы и ответы по заболеваниям и методам исследования молочной железы

\section{Вопросы}

Какое заболевание молочной железы не относится к доброкачественным?

Показания к маммографии:

Возраст старше 30 лет, пациенткам моложе 30 лет проводится по показаниям.

Показание к первичной

маммографии:

\section{Когда проводится маммография} пациенткам в возрасте старше 40 лет?

Что такое BIRADS 2?

\section{Ответы}

Лимфома молочной железы.
Первичная (профилактическая) маммография должна быть проведена в возрасте 35-40 лет.

В интервале 40-50 лет - каждый год или через год. Женщинам старше 50 лет - в течение года.

При маммографии выявляется
доброкачественное образование без
риска малигнизации. Необходимо
ежегодное обследование.




\begin{tabular}{|c|c|}
\hline Вопросы & Ответы \\
\hline Что такое BIRADS 5 ? & $\begin{array}{l}\text { Выявление образования с высоким } \\
\text { риском малигнизации. Обязательна } \\
\text { биопсия. }\end{array}$ \\
\hline $\begin{array}{l}\text { У пациентки обнаружена } \\
\text { злокачественная опухоль, } \\
\text { подтверждённая биопсией. Как это } \\
\text { оценивается по шкале BIRADS } \\
\text { Американской Ассоциации } \\
\text { Радиологов? }\end{array}$ & BIRADS 6. \\
\hline $\begin{array}{l}\text { Показания к тонкоигольной } \\
\text { биопсии молочной железы: }\end{array}$ & $\begin{array}{l}\text { - Сохранение образования после } \\
\text { аспирационной биопсии; } \\
\text { - Наличие солидного образования; } \\
\text { - Наличие крови при аспирации } \\
\text { кистозного образования; } \\
\text { - Наличие подозрительного } \\
\text { образования при маммографии, Узи } \\
\text { или МРТ; } \\
\text { - Выделение кровянистого отделяемого } \\
\text { из соска; } \\
\text { - Изъязвление соска и наличие } \\
\text { дерматита; } \\
\text { - Выявление какого-либо отклонения в } \\
\text { молочной железе. }\end{array}$ \\
\hline
\end{tabular}




\section{ДИАГНОСТИЧЕСКИЕ ПОДХОДЫ ПРИ НОВООБРАЗОВАНИЯХ МОЛОЧНОЙ ЖЕЛЕЗЫ}

- Новообразования молочной железы выявляются либо при наличии соответствующей симптоматики, либо у пациентов с бессимптомным течением заболевания во время случайного обследования.

- У 90\% пациентов доброкачественные новообразования пальпируются в виде безболезненных узлов, имеющих чёткие контуры, или в виде конгломерата, включающего окружающие ткани.

- При обнаружении любого образования, необходимо проведение исследований, направленных на исключение (или подтверждение) злокачественного процесса.

\section{Вопросы и ответы по диагностике новообразований молочной железы}

\begin{tabular}{|c|c|}
\hline Вопросы & Ответы \\
\hline $\begin{array}{l}\text { При наличии каких признаков } \\
\text { следует думать о новообразовании } \\
\text { молочной железы? }\end{array}$ & 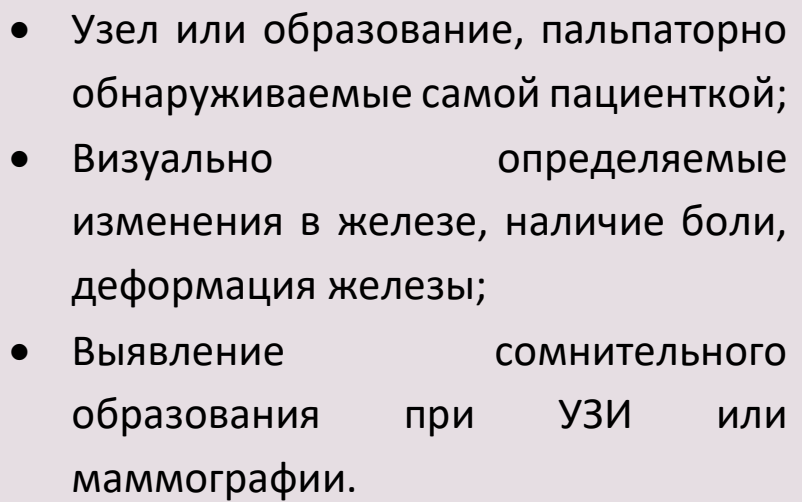 \\
\hline $\begin{array}{l}\text { Какое исследование проводится при } \\
\text { наличии сомнительного образования } \\
\text { в молочной железе? }\end{array}$ & $\begin{array}{l}\text { При подозрении на наличие } \\
\text { опухолевидного образования в } \\
\text { молочной железе необходимы: } \\
\text { - Клинико-объективное обследование } \\
\text { с учётом анамнеза; } \\
\text { - Диагностическая визуализация - } \\
\text { маммография, УзИ; } \\
\text { - Биопсия. }\end{array}$ \\
\hline
\end{tabular}




\begin{tabular}{|c|c|}
\hline Вопросы & Ответы \\
\hline $\begin{array}{l}\text { Какое исследование необходимо } \\
\text { при невозможности исключения } \\
\text { рака молочной железы? }\end{array}$ & $\begin{array}{l}\text { - МРТ; } \\
\text { - ТИАБ; } \\
\text { - При неинформативности ТИАБ - } \\
\text { хирургическое удаление узла с } \\
\text { морфологическим исследованием. }\end{array}$ \\
\hline
\end{tabular}

- В зависимости от морфологической структуры доброкачественные заболевания молочной железы делятся на эпителиальные и неэпителиальные.

- Эпителиальные опухоли в зависимости от патоморфологической формы и риска малигнизации делятся на 3 группы: непролиферативные эпителиальные опухоли без риска малигнизации; пролиферативные эпителиальные опухоли без клеточной атипии и с низким риском малигнизации; эпителиальные пролиферативные опухоли с выраженной клеточной атипией и высоким риском малигнизации.

- При атипичной гиперплазии в 10-30\% случаев обнаруживается рак молочной железы. С учётом высокого риска развития рака в этих случаях показано хирургическое лечение (удаление опухоли).

\section{Вопросы и ответы по доброкачественным заболеваниям молочной железы}

\begin{tabular}{|c|c|}
\hline Вопросы & Ответы \\
\hline $\begin{array}{l}\text { Классификация доброкачественных } \\
\text { эпителиальных новообразований в } \\
\text { зависимости от патоморфологической } \\
\text { структуры и риска малигнизации: }\end{array}$ & $\begin{array}{l}\text { Эпителиальные опухоли делятся на } 3 \\
\text { группы: } \\
\text { 1. Эпителиальные опухоли без } \\
\text { пролиферации; } \\
\text { 2. Пролиферативные эпителиальные } \\
\text { опухоли без клеточной атипии; } \\
\text { 3. Атипичная гиперплазия. }\end{array}$ \\
\hline $\begin{array}{l}\text { Эпителиальные опухоли без } \\
\text { пролиферации: }\end{array}$ & $\begin{array}{l}\text { Эпителиальные опухоли без риска } \\
\text { малигнизации: }\end{array}$ \\
\hline
\end{tabular}




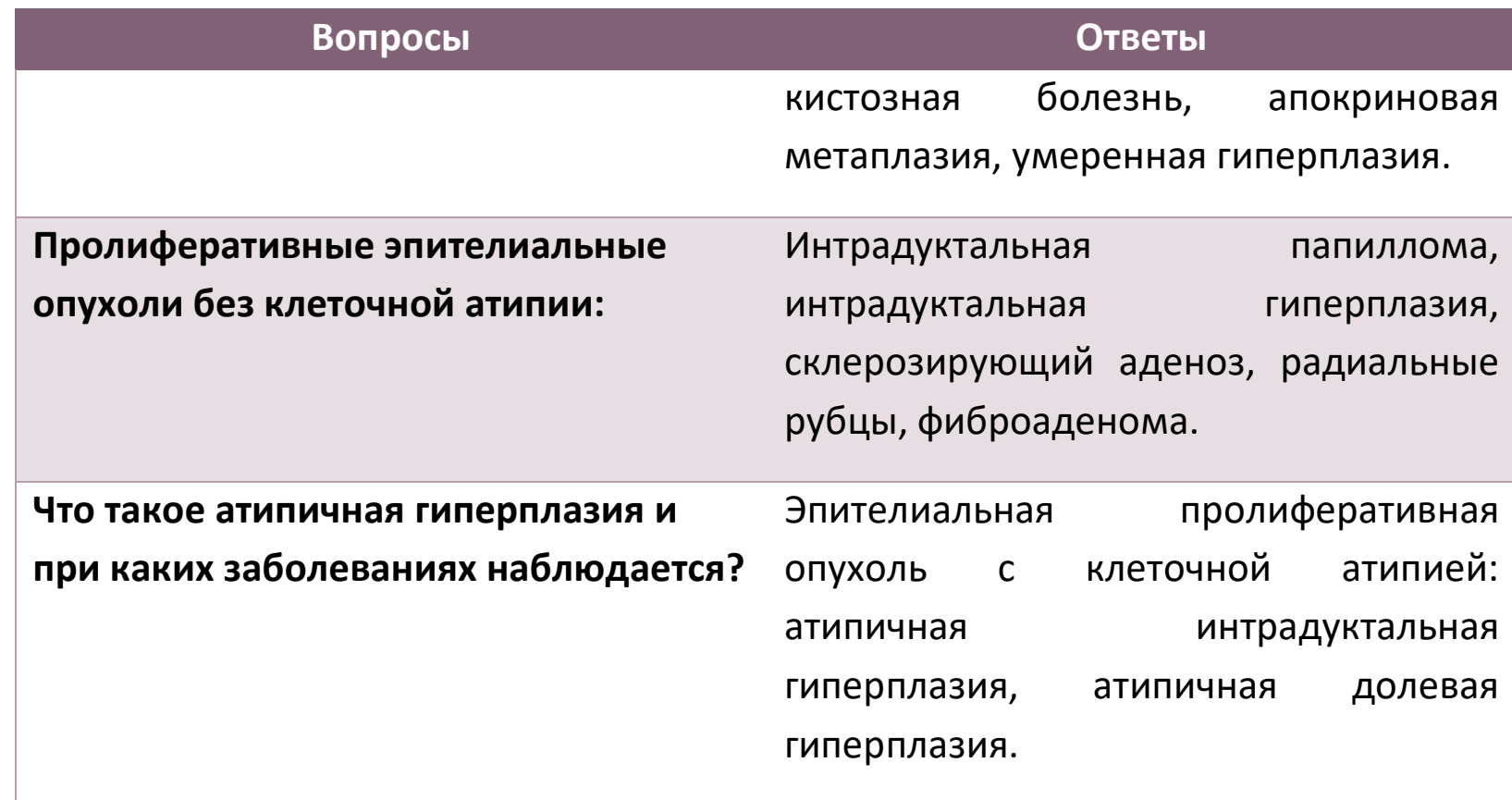

\section{ИНФЕКЦИОННЫЕ ЗАБОЛЕВАНИЯ МОЛОЧНОЙ ЖЕЛЕЗЫ}

- Инфекции молочной железы могут иметь лактационную и нелактационную природу.

- Мастит, как правило, встречается у женщин в лактационный период.

- Острый мастит - инфекционное воспаление молочной железы, которое характеризуется покраснением, болью, отёком и высокой температурой.

- При инфильтративной форме показано консервативное лечение, при абсцедировании - дренирование. Лечение нелактационного мастита хирургическое.

- При неизлечимых и рецидивирующих маститах следуют исключить злокачественный процесс.

\section{Вопросы и ответы по маститу и абсцессу молочной железы}

\begin{tabular}{|ll|}
\hline \multicolumn{1}{|c|}{ Вопросы } & \multicolumn{1}{c|}{ Ответы } \\
\hline Что такое мастит? & $\begin{array}{l}\text { Инфекционное заболевание молочной } \\
\text { железы (целлюлит). }\end{array}$ \\
\hline Частая причина мастита: & Период лактации. \\
\hline
\end{tabular}




\begin{tabular}{|c|c|}
\hline $\begin{array}{l}\text { Что является основным возбудителем } \\
\text { острого лактационного мастита? }\end{array}$ & Staphylococcus aureus. \\
\hline Лечение лактационного мастита: & $\begin{array}{l}\text { Прекращение кормления грудью, } \\
\text { устранение лактостаза, подавление } \\
\text { лактации, антибактериальная терапия. }\end{array}$ \\
\hline $\begin{array}{l}\text { Почему пациенты с маститом должны } \\
\text { находиться под наблюдением? }\end{array}$ & $\begin{array}{l}\text { Для исключения маститоподобных } \\
\text { форм рака молочной железы. }\end{array}$ \\
\hline $\begin{array}{l}\text { Причины абсцедирования молочной } \\
\text { железы: }\end{array}$ & $\begin{array}{l}\text { Лактационный мастит, эктазия протоков } \\
\text { молочной железы. }\end{array}$ \\
\hline Частая причина абсцесса: & Staphylococcus aureus. \\
\hline Лечение: & $\begin{array}{l}\text { Антибактериальная } \\
\text { тонкоигольное иерапия, } \\
\text { дренирование (для культурального } \\
\text { анализа), резекция повреждённых } \\
\text { протоков и сцеживание молока. }\end{array}$ \\
\hline
\end{tabular}




\section{ГИНЕКОМАСТИЯ}

- Гинекомастия - гиперплазия тканей молочной железы у мужчин вследствие гормонального дисбаланса.

- Может наблюдаться у новорожденных, подростков и зрелых мужчин.

- Лечение консервативное (коррекция гормонального дисбаланса) и хирургическое (удаление железы).

\section{Вопросы и ответы по гинекомастии}

\begin{tabular}{|c|c|}
\hline Вопросы & Ответы \\
\hline Что такое гинекомастия? & $\begin{array}{l}\text { Гиперплазия молочной железы } \\
\text { мужчин. }\end{array}$ \\
\hline Этиология: & $\begin{array}{l}\text { - Приём гормональных, } \\
\text { - Наркотических препаратов; } \\
\text { - Печёночная недостаточность; } \\
\text { - Избыток эстрогенов; } \\
\text { - Снижение уровня тестостерона. }\end{array}$ \\
\hline $\begin{array}{l}\text { С какими заболеваниями следует } \\
\text { дифференцировать? }\end{array}$ & У взрослых - с раком молочной железы. \\
\hline Лечение: & $\begin{array}{l}\text { Прекращение приёма лекарственных } \\
\text { препаратов или их замена другими, } \\
\text { коррекция гормонального дисбаланса. } \\
\text { По показаниям - биопсия, подкожная } \\
\text { мастэктомия. }\end{array}$ \\
\hline
\end{tabular}




\section{ПРЕДРАКОВЫЕ ЗАБОЛЕВАНИЯ МОЛОЧНОЙ ЖЕЛЕЗЫ}

- $\mathrm{K}$ предраковым заболеваниям молочной железы относятся атипичная интрадуктальная гиперплазия, атипичная долевая гиперплазия, дуктальная карцинома.

- Эти опухоли не имеют никаких клинических признаков и обнаруживаются при случайной биопсии, однако повышают риск развития инвазивного рака молочной железы.

- Лечение - динамическое наблюдение и хирургическая операция.

\section{Вопросы и ответы по предраковым заболеваниям молочной железы}

\section{Дуктальная кариинома (in situ)}

\begin{tabular}{|c|c|}
\hline Вопросы & Ответы \\
\hline $\begin{array}{l}\text { Что такое дуктальная карцинома in } \\
\text { situ? }\end{array}$ & $\begin{array}{l}\text { Наличие раковых клеток в протоках } \\
\text { молочной железы; инвазия не } \\
\text { наблюдается - раковые клетки не } \\
\text { инвазируют в базальную мембрану. }\end{array}$ \\
\hline Клинические признаки: & Как правило, не наблюдаются. \\
\hline $\begin{array}{l}\text { Что обнаруживается } \\
\text { маммографии? }\end{array}$ & Микрокальцинаты. \\
\hline Диагностика: & Биопсия. \\
\hline Риск лимфогенного метастазирования: & $\begin{array}{l}\text { Ниже 25\% (наблюдается при наличии } \\
\text { микроинвазии). }\end{array}$ \\
\hline Осложнение: & $\begin{array}{l}\text { Развитие инфильтративной дуктальной } \\
\text { карциномы в той же молочной железе. }\end{array}$ \\
\hline $\begin{array}{l}\text { Лечение опухоли размером менее } 1 \\
\text { см: }\end{array}$ & $\begin{array}{l}\text { Удаление опухоли вместе с } \\
\text { окружающей тканью размером в } 1 \text { см }\end{array}$ \\
\hline
\end{tabular}




\begin{tabular}{|c|c|}
\hline & (возможно проведение \\
\hline & химиотерапии). \\
\hline $\begin{array}{l}\text { Лечение опухоли размером более } 1 \\
\text { см: }\end{array}$ & $\begin{array}{l}\text { Лампэктомия вместе с окружающей } \\
\text { тканью размером в } 1 \text { см + радиотерапия }\end{array}$ \\
\hline & или тотальная мастэктомия \\
\hline & аксиллярной лимфодиссекции). \\
\hline $\begin{array}{l}\text { Что такое тотальная мастэктомия } \\
\text { (простая)? }\end{array}$ & $\begin{array}{l}\text { Полное удаление молочной железы } \\
\text { вместе с соском (без аксиллярной } \\
\text { лимфодиссекции). }\end{array}$ \\
\hline $\begin{array}{l}\text { В каких случаях при карциноме in situ } \\
\text { проводится простая мастэктомия? }\end{array}$ & $\begin{array}{l}\text { При диффузном распространении } \\
\text { процесса по всей молочной железе } \\
\text { (диффузный микрокальциноз), при } \\
\text { наличии опухоли размером более } 1 \text { см, } \\
\text { при противопоказании к радиотерапии. }\end{array}$ \\
\hline $\begin{array}{l}\text { Роль аксиллярной лимфодиссекции } \\
\text { при дуктальной карциноме in situ? }\end{array}$ & $\begin{array}{l}\text { При истинной дуктальной карциноме in } \\
\text { situ не имеет никакого значения. }\end{array}$ \\
\hline $\begin{array}{l}\text { Адъювантная терапия при дуктальной } \\
\text { карциноме in situ? }\end{array}$ & $\begin{array}{l}\text { - Тамоксифен; } \\
\text { - Радиотерапия. }\end{array}$ \\
\hline
\end{tabular}

Долевая карцинома (in situ)

\begin{tabular}{|c|c|}
\hline Вопросы & Ответы \\
\hline Что такое долевая карцинома in situ? & $\begin{array}{l}\text { В дольке молочной железы } \\
\text { обнаруживаются клетки карциномы, } \\
\text { однако инвазия отсутствует. }\end{array}$ \\
\hline Клинические признаки: & Отсутствуют. \\
\hline Признаки при маммографии: & Отсутствуют. \\
\hline Диагностика: & $\begin{array}{l}\text { Обнаруживается случайно во время } \\
\text { биопсии. }\end{array}$ \\
\hline
\end{tabular}




\begin{tabular}{|c|c|}
\hline Осложнение: & $\begin{array}{l}\text { 30\%-ный риск развития инвазивной } \\
\text { карциномы в молочных железах в } \\
\text { течение } 20 \text { лет. }\end{array}$ \\
\hline $\begin{array}{l}\text { В какой из молочных желез } \\
\text { встречается наиболее часто? }\end{array}$ & В обеих одинаково. \\
\hline $\begin{array}{l}\text { Какой тип рака может развиться у } \\
\text { пациентов с долевой карциномой in } \\
\text { situ? }\end{array}$ & $\begin{array}{l}\text { Инфильтративная дуктальная } \\
\text { карцинома, односторонняя или } \\
\text { двусторонняя. }\end{array}$ \\
\hline Лечение: & $\begin{array}{l}\text { Динамическое наблюдение; пациентам } \\
\text { с высоким риском показана } \\
\text { билатеральная простая мастэктомия. }\end{array}$ \\
\hline $\begin{array}{l}\text { Отличие инвазивной карциномы при } \\
\text { долевой карциноме in situ от } \\
\text { дуктальной карциномы in situ: }\end{array}$ & $\begin{array}{l}\text { При долевой карциноме in situ рак } \\
\text { развивается в одной из 2-х молочных } \\
\text { желез, а при дуктальной карциноме in } \\
\text { situ-в ипсилатеральной железе. }\end{array}$ \\
\hline $\begin{array}{l}\text { Причина кровянистого выделения из } \\
\text { соска у молодых женщин: }\end{array}$ & Интрадуктальная папиллома. \\
\hline $\begin{array}{l}\text { Какая опухоль молочной железы } \\
\text { встречается наиболее часто у } \\
\text { пациентов моложе } 30 \text { лет? }\end{array}$ & Фиброаденома. \\
\hline $\begin{array}{l}\text { Что такое болезнь Педжета молочной } \\
\text { железы? }\end{array}$ & $\begin{array}{l}\text { Опухоль, развивающаяся из дуктальной } \\
\text { карциномы, охватывающая кожу, } \\
\text { вызвающая кожный зуд и дерматит. }\end{array}$ \\
\hline
\end{tabular}




\section{РАК МОЛОЧНОЙ ЖЕЛЕЗЫ}

- Рак молочной железы - злокачественная опухоль, встречающаяся у каждой 8-ой женщины.

- Наиболее часто локализуется верхненаружном квадранте.

- В субклинической стадии заболевание протекает бессимптомно. Клинические проявления характеризуются обнаружением в железе образования, болью, выделениями из соска, отёком, гиперемией, втяжением соска, увеличением подмышечных лимфоузлов.

- Диагноз основан на данных визуализации и биопсии.

- Основным методом лечения является хирургическое. Химио- и радиотерапия являются вспомогательными методами лечения и направлены на предотвращение рецидивов заболевания.

\section{Вопросы и ответы по раку молочной железы}

\section{Вопросы}

\section{Ответы}

Частота встречаемости рака молочной $12 \%$.
железы:
Какова вероятность развития рака
молочной железы при отсутствии
факторов риска?

Какова вероятность развития рака Около $2 \%$.

молочной железы у женщин моложе

30 лет?

Какова вероятность развития рака $\quad 33 \%$.

молочной железы у женщин старше

70 лет?

Какие гены являются наиболее

BRCA 1 и BRCA 2.

чувствительными при раке молочной

железы? 


\begin{tabular}{|c|c|}
\hline Вопросы & Ответы \\
\hline Факторы риска: & $\begin{array}{l}\text { - Отсутствие родов; } \\
\text { - } \text { Раннее менархе (до } 13 \text { лет); } \\
\text { - } \text { Поздняя менопауза (старше } 55 \text { лет); } \\
\text { - Наличие рака молочной железы у } \\
\quad \text { прямых родственников; } \\
\text { - } \text { Поздние первые роды (после } 30 \text { лет). }\end{array}$ \\
\hline $\begin{array}{l}\text { Анатомические факторы риска } \\
\text { развития рака молочной железы: }\end{array}$ & $\begin{array}{l}\text { - Одновременное поражение обеих } \\
\text { желез (3\%); } \\
\text { - Гиперпластические процессы; } \\
\text { - Атипичные гиперплазии; } \\
\text { - Женский пол (в } 10 \text { раз чаще чем у } \\
\text { мужчин); } \\
\text { - Дуктальная карцинома in situ; } \\
\text { - Долевая карцинома in situ; } \\
\text { - Наследственные гены (BRCA } 1 \text { и 2); } \\
\text { - Внутрипротоковая папиллома; } \\
\text { - Склеротическая аденома. }\end{array}$ \\
\hline Риск гормональной терапии: & $\begin{array}{l}\text { Повышает риск заболеваемости в 1-1,5 } \\
\text { раза. }\end{array}$ \\
\hline $\begin{array}{l}\text { Является ли фиброзно-кистозная } \\
\text { болезнь фактором риска? }\end{array}$ & Нет. \\
\hline Субъективные признаки: & $\begin{array}{l}\text { - В субклинической стадии симптомы } \\
\text { отсутствуют; } \\
\text { - Образование в молочной железе; } \\
\text { - Боль (встречается редко); } \\
\text { - Выделения из соска; } \\
\text { - Локальный отёк; } \\
\text { - Втяжение соска; } \\
\text { - Ретракция кожи; } \\
\text { - . }\end{array}$ \\
\hline
\end{tabular}




\begin{tabular}{|c|c|}
\hline Вопросы & Ответы \\
\hline $\begin{array}{l}\text { Чем объясняется появление } \\
\text { ретракции кожи? }\end{array}$ & $\begin{array}{l}\text { В связи с инвазией опухоли в связку } \\
\text { Купера и тракцией последней. }\end{array}$ \\
\hline $\begin{array}{l}\text { Объективные признаки рака } \\
\text { молочной железы: }\end{array}$ & $\begin{array}{l}\text { - Пальпаторно определяемое узловое } \\
\text { - Вбразование, размером более } 1 \text { см; } \\
\text { - Выяжение соска; } \\
\text { - Отёк; } \\
\text { - Увеличение подмышен на соске; } \\
\text { лимфоузлов. }\end{array}$ \\
\hline Частая локализация рака: & $\begin{array}{l}\text { Более половины опухолей расположены } \\
\text { в верхненаружном квадранте. }\end{array}$ \\
\hline $\begin{array}{l}\text { Наиболее распространенный тип } \\
\text { инвазивной карциномы: }\end{array}$ & $\begin{array}{l}\text { - Инвазивная дуктальная карцинома } \\
\text { (90\%); } \\
\text { • Инвазивная долевая карцинома } \\
(10 \%) ; \\
\text { - Воспалительная карцинома. }\end{array}$ \\
\hline $\begin{array}{l}\text { Наиболее часто встречаемый тип рака } \\
\text { молочной железы; }\end{array}$ & $\begin{array}{l}\text { Инфильтративная дуктальная } \\
\text { карцинома. }\end{array}$ \\
\hline $\begin{array}{l}\text { С какими заболеваниями необходимо } \\
\text { дифференцировать? }\end{array}$ & $\begin{array}{l}\text { - Фиброзно-кистозные мастопатии; } \\
\text { - Фиброаденома; } \\
\text { - Интрадуктальная папиллома; } \\
\text { - Эктазия протока молочной железы; } \\
\text { - Жировой некроз железы; } \\
\text { - Абсцесс; } \\
\text { - Радиальные рубцы; } \\
\text { - Кисты молочной железы. }\end{array}$ \\
\hline Характерные изменения кожи: & Наличие симптома «лимонной корки». \\
\hline $\begin{array}{l}\text { Скрининговые обследования при раке } \\
\text { молочной железы: }\end{array}$ & $\begin{array}{l}\text { Объективный осмотр железы: } \\
\text { - Ежемесячное самообследование; }\end{array}$ \\
\hline
\end{tabular}




\begin{tabular}{|c|c|}
\hline Вопросы & Ответы \\
\hline & $\begin{array}{l}\text { - } \text { Обследование у врача в возрасте 20- } \\
40 \text { лет через каждые 2-3 года; } \\
\text { • } \quad \text { Ежегодное обследование у врача в } \\
\text { возрасте старше } 40 \text { лет. } \\
\text { Маммография: } \\
\text { - } \quad \text { Профилактическая - в возрасте 35-40 } \\
\text { лет; } \\
\text { - Ежегодно или через год женщинам в } \\
\text { возрасте 40-50 лет; } \\
\text { - Ежегодно в возрасте старше } 50 \text { лет. }\end{array}$ \\
\hline Время для самообследования: & Через неделю после менструации. \\
\hline $\begin{array}{l}\text { Почему у женщин старших } \\
\text { возрастных групп маммография } \\
\text { более информативна, чем у } \\
\text { молодых? }\end{array}$ & $\begin{array}{l}\text { С возрастом ткань молочной железы } \\
\text { трансформируется в жировую, потому и } \\
\text { хорошо визуализируется. У молодых в } \\
\text { молочной железе преобладает } \\
\text { соединительно-фиброзная } \\
\text { затрудняющая } \\
\text { маммографии. }\end{array}$ \\
\hline $\begin{array}{l}\text { Какие методы диагностической } \\
\text { визуализации применяются для } \\
\text { обследования молочной железы? }\end{array}$ & Маммография, УзИ, МРТ. \\
\hline $\begin{array}{l}\text { Классический признаки рака } \\
\text { молочной железе при маммографии: }\end{array}$ & Наличие массы «звёздчатой» формы. \\
\hline $\begin{array}{l}\text { Наиболее информативный } \\
\text { диагностический метод обследования } \\
\text { женщин моложе } 30 \text { лет: }\end{array}$ & узи. \\
\hline Методы биопсии: & $\begin{array}{l}\text { - Тонкоигольная аспирация; } \\
\text { - Биопсия с применением режущей } \\
\text { иглы; } \\
\text { - Стереотаксическая биопсия; }\end{array}$ \\
\hline
\end{tabular}




\begin{tabular}{|c|c|}
\hline Вопросы & $\begin{array}{l}\text { - Ответы } \\
\text { • Биопсия открытым способом } \\
\text { биопсия удалённого материала. }\end{array}$ \\
\hline Показания к биопсии: & $\begin{array}{l}\text { - Сохранение патологического } \\
\text { образования после аспирации; } \\
\text { - Наличие солидного образования; } \\
\text { - Наличие крови в аспирационном } \\
\text { материале; } \\
\text { - Выявление } \\
\text { образования при маммографии, Узи } \\
\text { и МРТ; } \\
\text { - Кровянистое выделение из соска; } \\
\text { - Изъязвление соска и дерматит кожи } \\
\text { молочной железы; } \\
\text { - Любое сомнение по отношению к } \\
\text { нормальной структуре молочной } \\
\text { железы. }\end{array}$ \\
\hline $\begin{array}{l}\text { Какой вид биопсии проводится при } \\
\text { выявлении непальпируемого узла на } \\
\text { маммографии? }\end{array}$ & $\begin{array}{l}\text { - Стереотактическая биопсия; } \\
\text { - Биопсия локализационной иглой. }\end{array}$ \\
\hline $\begin{array}{l}\text { Что такое биопсия локализационной } \\
\text { иглой? }\end{array}$ & $\begin{array}{l}\text { Предварительно иглой определяется } \\
\text { место биопсии радиологом, а потом } \\
\text { производится биопсия. Удалённая ткань } \\
\text { проверяется при маммографии. }\end{array}$ \\
\hline Что такое мамматонная биопсия? & $\begin{array}{l}\text { Компьютерно-стереотаксическая } \\
\text { биопсия } \quad \text { маммографической } \\
\text { направленности. }\end{array}$ \\
\hline $\begin{array}{l}\text { Что делается первым: маммография } \\
\text { или биопсия? }\end{array}$ & $\begin{array}{l}\text { Сначала выполняется маммография, т. к. } \\
\text { биопсия может изменить результат } \\
\text { маммографии (лишь тонкоигольная } \\
\text { биопсия может предшествовать } \\
\text { маммографии). }\end{array}$ \\
\hline
\end{tabular}




\begin{tabular}{|c|c|}
\hline Вопросы & Ответы \\
\hline $\begin{array}{l}\text { Сомнительные признаки, } \\
\text { указывающие на рак при } \\
\text { маммографии: }\end{array}$ & $\begin{array}{l}\text { - Наличие микрокальцинатов; } \\
\text { - Образование «звёздчатой» } \\
\text { формы. }\end{array}$ \\
\hline $\begin{array}{l}\text { Последовательность методов } \\
\text { обследования при обнаружении } \\
\text { образования в молочной железе: }\end{array}$ & $\begin{array}{l}\text { - Клиническое обследование } \\
\text { молочной железы; } \\
\text { - Маммография или УзИ; } \\
\text { - Биопсия. }\end{array}$ \\
\hline $\begin{array}{l}\text { Тактика при обнаружении кистозного } \\
\text { образования в молочной железе: }\end{array}$ & Пункционная аспирация. \\
\hline $\begin{array}{l}\text { Обязательно ли цитологическое } \\
\text { исследование аспирационного } \\
\text { материала кисты? }\end{array}$ & $\begin{array}{l}\text { Необязательно, но при получении } \\
\text { кровянистой жидкости - обязательно. }\end{array}$ \\
\hline $\begin{array}{l}\text { Когда проводится открытая биопсия } \\
\text { кисты молочной железы? }\end{array}$ & $\begin{array}{l}\text { - При рецидиве кисты; } \\
\text { - При наличии кровянистого } \\
\text { содержимого; } \\
\text { - Сохранение кисты после её } \\
\text { аспирации. }\end{array}$ \\
\hline $\begin{array}{l}\text { Какие предоперационные } \\
\text { исследования проводятся для } \\
\text { определения стадии рака молочной } \\
\text { железы? }\end{array}$ & $\begin{array}{l}\text { - Двусторонняя маммография } \\
\text { (поражение контралатеральной } \\
\text { железы обычно } \\
\text { метастатический характер); } \\
\text { - КТ (для исключения метастазов в } \\
\text { лёгкие); } \\
\text { - Печёночные пробы (для исключения } \\
\text { метастазов в печень); } \\
\text { - Определение концентрации кальция } \\
\text { и щелочной фосфатазы в крови (для } \\
\text { исключения метастазов в костную } \\
\text { ткань); } \\
\text { Другие исследования (КТ головы); }\end{array}$ \\
\hline
\end{tabular}




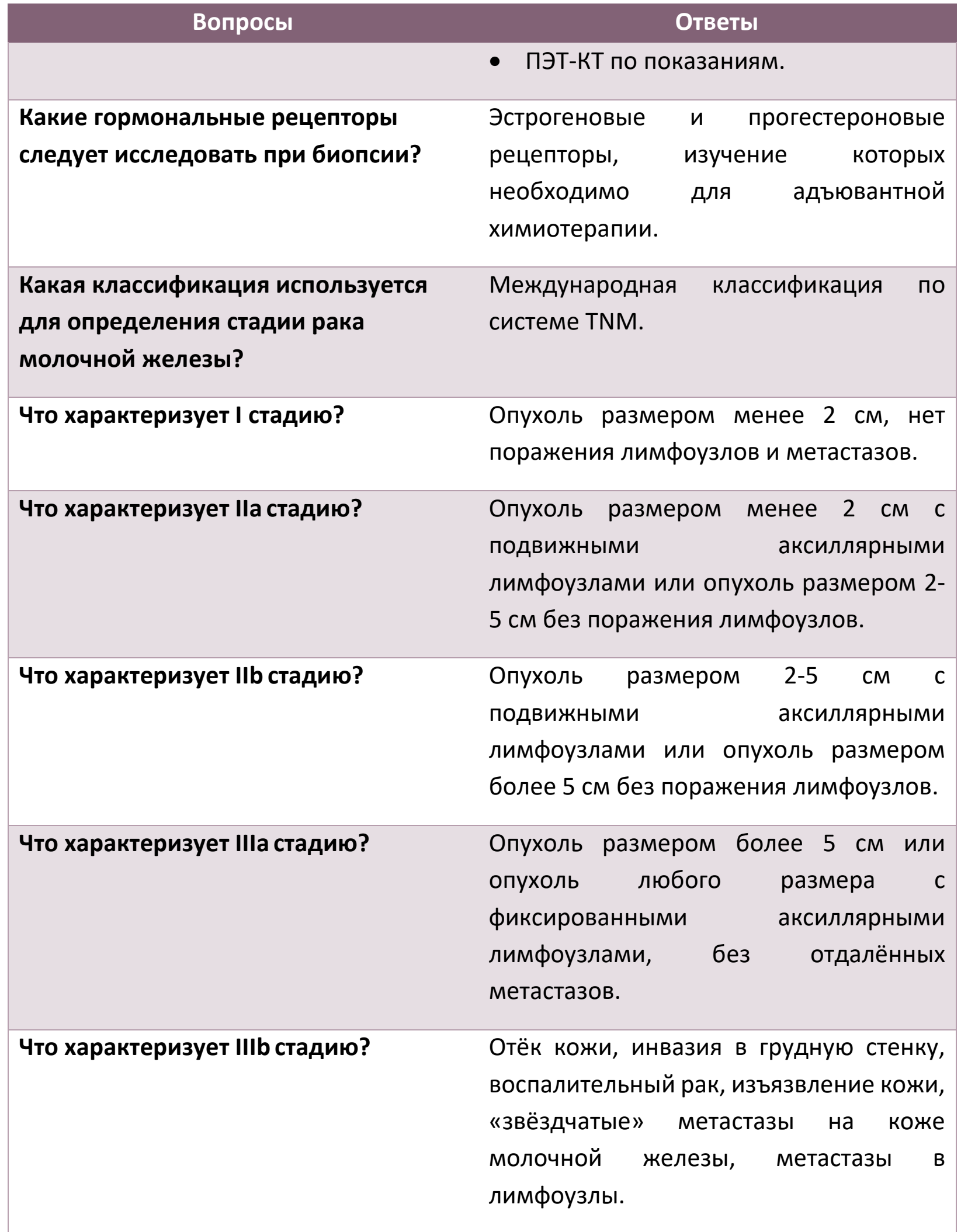




\begin{tabular}{|c|c|}
\hline Вопросы & Ответы \\
\hline Что характеризует IV стадию? & $\begin{array}{l}\text { Характеризуется наличием отдалённых } \\
\text { метастазов. }\end{array}$ \\
\hline $\begin{array}{l}\text { Наиболее частая локализация } \\
\text { метастазов: }\end{array}$ & $\begin{array}{l}\text { - Лимфатические узлы; } \\
\text { - Лёгкие/плевра; } \\
\text { - Печень; } \\
\text { - Кости; } \\
\text { - Головной мозг. }\end{array}$ \\
\hline $\begin{array}{l}\text { Основные методы лечения рака } \\
\text { молочной железы: }\end{array}$ & $\begin{array}{l}\text { - Модифицированная радикальная } \\
\text { мастэктомия; } \\
\text { - Лампэктомия + радиотерапия; } \\
\text { - Химиотерапия } \\
\text { хирургического лечения). }\end{array}$ \\
\hline $\begin{array}{l}\text { Показание к радиотерапии после } \\
\text { модифицированной радикальной } \\
\text { мастэктомии: }\end{array}$ & $\begin{array}{l}\text { Вовлечение в опухолевый процесс } \\
\text { более } 4 \text { лимфоузлов и инвазия опухоли } \\
\text { в грудную стенку. }\end{array}$ \\
\hline $\begin{array}{l}\text { Показания к лампэктомии и } \\
\text { радиотерапии: }\end{array}$ & $\begin{array}{l}\text { Рак молочной железы I и II стадии (при } \\
\text { опухоли размером менее } 5 \text { см). }\end{array}$ \\
\hline $\begin{array}{l}\text { Лечение воспалительной карциномы } \\
\text { рака молочной железы: }\end{array}$ & $\begin{array}{l}\text { В первую очередь - химиотерапия, } \\
\text { далее - радиотерапия, мастэктомия } \\
\text { (или одномоментно последние } 2 \\
\text { метода). }\end{array}$ \\
\hline $\begin{array}{l}\text { Что такое лампэктомия и } \\
\text { радиотерапия: }\end{array}$ & $\begin{array}{l}\text { Лампэктомия или сегментарная } \\
\text { мастэктомия: резекция части молочной } \\
\text { железы, аксиллярная лимфодиссекция, } \\
\text { радиотерапия после операции. }\end{array}$ \\
\hline $\begin{array}{l}\text { Противопоказание к лампэктомии и } \\
\text { радиотерапии: }\end{array}$ & Беременность. \\
\hline $\begin{array}{l}\text { Другие противопоказания к } \\
\text { лампэктомии и радиотерапии: }\end{array}$ & $\begin{array}{l}\text { - Радиация молочной железы; } \\
\text { - Позитивные края; }\end{array}$ \\
\hline
\end{tabular}




\begin{tabular}{|c|c|}
\hline Вопросы & Ответы \\
\hline & $\begin{array}{l}\text { - Коллагеноз (системный); } \\
\text { - Распространённая дуктальная } \\
\text { карцинома in situ (диффузный } \\
\text { микрокальциноз); } \\
\text { Относительные противопоказания: } \\
\text { - Не дифференцированная ткань при } \\
\text { маммографии; } \\
\text { - Малая молочная железа. }\end{array}$ \\
\hline $\begin{array}{l}\text { Что такое модифицированная } \\
\text { радикальная мастэктомия: }\end{array}$ & $\begin{array}{l}\text { Удаление молочной железы вместе с } \\
\text { соском, аксиллярная лимфодиссекция І- } \\
\text { II уровня с оставлением малой и } \\
\text { большой грудной мышц (модификация } \\
\text { по Auchincloss), дренированием раны } \\
\text { (для оттока лимфы). }\end{array}$ \\
\hline $\begin{array}{l}\text { Где устанавливают дренажную трубку } \\
\text { при выполнении модифицированной } \\
\text { радикальной мастэктомии? }\end{array}$ & $\begin{array}{l}\text { - В подмышечной впадине; } \\
\text { - В ложе молочной железы. }\end{array}$ \\
\hline Когда удаляют дренажную трубку? & $\begin{array}{l}\text { При суточном количестве отделяемого } \\
\text { не более } 30 \text { мл. }\end{array}$ \\
\hline $\begin{array}{l}\text { Осложнения после } \\
\text { модифицированной радикальной } \\
\text { мастэктомии: }\end{array}$ & $\begin{array}{l}\text { - Отёк подмышечной области; } \\
\text { - Инфекционно-воспалительные } \\
\text { осложнения; } \\
\text { - Повреждение нервов; } \\
\text { - Некроз кожи операционной раны; } \\
\text { - Гематома (серома); } \\
\text { - Фантомно-болевой синдром. }\end{array}$ \\
\hline $\begin{array}{l}\text { Есть ли опасность развития паралича } \\
\text { при аксиллярной лимфодиссекции? }\end{array}$ & $\begin{array}{l}\text { Нет. Раздражение длинного грудного } \\
\text { нерва позволяет идентифицировать его. }\end{array}$ \\
\hline
\end{tabular}




\begin{tabular}{|c|c|}
\hline Вопросы & Ответы \\
\hline Что такое «sentinel» биопсия? & $\begin{array}{l}\text { Удаляются не все подмышечные узлы, а } \\
\text { те узлы, которые непосредственно } \\
\text { дренируют молочную железу. }\end{array}$ \\
\hline Как обнаруживают узел «sentinel»? & $\begin{array}{l}\text { Путем инъекции в ткань молочной } \\
\text { железы метиленового синего или } \\
\text { технеция. }\end{array}$ \\
\hline $\begin{array}{l}\text { Тактика при позитивном узле } \\
\text { «Sentinel»: }\end{array}$ & Удаление всех остальных узлов. \\
\hline $\begin{array}{l}\text { Тактика при обнаружении атипичной } \\
\text { гиперплазии после мамматонной } \\
\text { биопсии: }\end{array}$ & Выполняют открытую биопсию. \\
\hline $\begin{array}{l}\text { Какое действие оказывает } \\
\text { тамоксифен? }\end{array}$ & Блокирует эстрогеновые рецепторы. \\
\hline $\begin{array}{l}\text { Предупреждает ли тамоксифен } \\
\text { развитие рака молочной железы? }\end{array}$ & $\begin{array}{l}\text { Снижает риск заболеваемости раком на } \\
50 \% .\end{array}$ \\
\hline Побочные эффекты тамоксифена: & $\begin{array}{l}\text { - Риск развития рака эндометрия; } \\
\text { - Тромбоз глубоких вен; } \\
\text { - Эмболия лёгочной артерии; } \\
\text { - Катаракта; } \\
\text { - Депрессия. }\end{array}$ \\
\hline $\begin{array}{l}\text { Тактика при рецидиве рака после } \\
\text { лампэктомии и радиотерапии: }\end{array}$ & Удаление всей оставщейся железы. \\
\hline $\begin{array}{l}\text { Методы реконструкции молочной } \\
\text { железы: }\end{array}$ & $\begin{array}{l}\text { TRAMP лоскут, искусственный } \\
\text { имплантат, имплантат из широкой } \\
\text { мышцы спины. }\end{array}$ \\
\hline Расшифровка аббревиатуры TRAMP: & $\begin{array}{l}\text { Tranvrsus rectus abdominis mucocutaneus } \\
\text { flap. }\end{array}$ \\
\hline
\end{tabular}




\section{Вопросы}

Какой вид химиотерапии проводится при раке молочной железы?

\section{Ответы}

CMF (циклофосфамид, метотрексат, 5фторурацил) или САМ (циклофосфамид, адриамицин, 5 -фторурацил).

\section{ДРУГИЕ ЗАБОЛЕВАНИЯ МОЛОЧНОЙ ЖЕЛЕЗЫ}

- Патологические процессы, развивающиеся в молочной железе при беременности (особенно во II и III триместре), характеризуются кровянистым выделением из соска, формированием образований в железе и развитием рака.

- Кровянистое выделение из соска, наблюдаемое во II и III триместре, связано с расширением протоков под гормональным воздействием и прекращается в течение 2 месяцев после родов.

- Образования идентифицируются с помощью УзИ или пункционной биопсии.

- Частота развития рака молочной железы составляет по 1 случаю на 5000 беременных, что составляет 3\% от общего числа заболеваемости раком молочной железы.

- Выбор метода лечения определяется с учётом стадии злокачественного процесса и срока беременности. Химиотерапия показана во II триместре, лучевая терапия - в послеродовом периоде.

\section{Вопросы и ответы по заболеваниям молочной железы во время беременности}

\begin{tabular}{|ll}
\hline \multicolumn{2}{c}{ Вопросы } \\
$\begin{array}{ll}\text { набие патологии молочной железы } \\
\text { беременности в период }\end{array}$ & $\begin{array}{l}\text { Кровянистые выделения из соска, } \\
\text { новообразования в железе, рак } \\
\text { молочной железы. }\end{array}$ \\
\hline $\begin{array}{l}\text { Причины кровянистых выделений из } \\
\text { соска у беременных: }\end{array}$ & $\begin{array}{l}\text { Расширение эпителия молочных } \\
\text { протоков на фоне гормональной } \\
\text { перестройки у женщин; прекращается в } \\
\text { течение } 2 \text { месяцев после родов. }\end{array}$ \\
\hline
\end{tabular}




\begin{tabular}{|c|c|}
\hline Вопросы & Ответы \\
\hline $\begin{array}{l}\text { Как проводится идентификация } \\
\text { образований в молочной железы у } \\
\text { беременных? }\end{array}$ & $\begin{array}{l}\text { Образования идентифицируются с } \\
\text { помощью узи или пункционной } \\
\text { биопсии. При подтверждении } \\
\text { злокачественной опухоли, проводится } \\
\text { хирургическое лечение аналогично } \\
\text { тому, что и у небеременных. }\end{array}$ \\
\hline $\begin{array}{l}\text { Частота развития рака молочной } \\
\text { железы у беременных: }\end{array}$ & 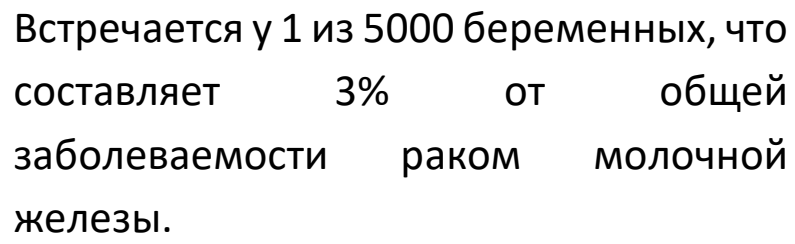 \\
\hline спис & ІТЕРАТУРЫ \\
\hline
\end{tabular}

\section{Общая литература}

- $\quad$ Ağayev B.A. Cərrahi xəstəliklər. Bakı 2010.

- Blackbourne LH. Surgical Recall. 4 edition, 2006, LWW, Philadelphia

- Doherty GM. Current Diagnosis and Treatment: Surgery, $13^{\text {th }}$ edition, 2010, Lang International Edition.

- $\quad$ Omiraslanov Ә.T., Qazıyev A.Y. Onkologiya. Bakı, 2010.

- $\quad$ İsayev H.B. Cərrahi xəstəliklərin patofizologiyası. Bakı 2005

- Klingensmith ME, Aziz A, Bharat A, Fox AC, Porembka MR. The Washington Manual of Surgery, 6 $6^{\text {th }}$ edition, 2012, LWW, Philadelphia.

- McNally PR. GI/Liver Secrets Plus. 4 edition. Mosby, Elsevier, 2010

- $\quad$ Medscape, http://www.medscape.com

- $\quad$ Oxford Handbook of Clinical Surgery, 3d edition, 2011, Oxford Press

- $\quad$ Sayek I. Sayek Temel Cerrahi 1-2. 4-cü baskı, 2016, Güneş Tıp Kitabevleri.

- Topçubaşov M.A. Xüsusi cərrahlıq. Bakı, 1979

- UpToDate, http://www.uptodate.com

- Гостищев B.К. Общая хирургия. GEOTAR-Media, 2019

\section{Специальная литература}

- $\quad$ Narula HS, Carlson HE. Gynaecomastia: pathophysiology, diagnosis and treatment. Nat Rev Endocrinol 2014; 10:684.

- Barros AC, Sampaio Mde C. Gynecomastia: Physiopathology, evaluation and treatment. Sao Paulo Med J. 2012;130:187-97

- Deepinder F, Braunstein GD. Drug-induced gynecomastia: An evidence-based review. Expert Opin Drug Saf. 2012

- Sir E, Ucer O, Aksoy A, Gungor M, Ceylan Y. Hormone profile in young adult men with idiopathic gynecomastia: Comparison with healthy controls. Breast Dis. 2016 Jan 22. 36 (1):1-4.

- Laituri CA, Garey CL, Ostlie DJ, et al. Treatment of adolescent gynecomastia. J Pediatr Surg. 2010 Mar. 45(3):650-4

- $\quad$ Ordaz DL, Thompson JK. Gynecomastia and psychological functioning: A review of the literature. Body Image. 2015 Sep. $15: 141-8$ 


\section{ХИРУРГИЧЕСКИЕ БОЛЕЗНИ}

Н.Ю. Байрамов

\section{Травмы}

Н.Ю. Байрамов, С.А. Алиев, Ф.М. Гапагов, Ш.А. Мамедова

Перевод: Н.Ю. Байрамов, С.А. Алиев, М.Р. Гусейнова 


\section{ОБЩИЕ ПРИНЦИПЫ ОКАЗАНИЯ ПЕРВОЙ ПОМОЩИ ПРИ ТРАВМЕ}

- Под травмой подразумевается повреждение органов и тканей под острым воздействием физических, механических, химических, термических и биологических факторов, которое сопровождается морфофункциональными нарушениями организма.

- Травма составляет основную нозологическую причину инвалидности и смертности среди взрослого населения в возрасте от 20 до 50 лет.

- Смертность наиболее часто встречается в ранние сроки после травмы:

О В первые минуты травмы смертность обусловлена тяжелой черепномозговой травмой, обширными повреждениями крупных сосудов (аорта) и сердца, множественными и сочетанными повреждениями других анатомических областей, несовместимыми с жизнью (летальность составляет $50 \%)$;

○ $30 \%$ случаев летальных исходов, наблюдающихся в течение первых часов после травмы, связаны с тяжёлыми повреждениями мозга, массивной кровопотерей, гипоксией и дыхательной недостаточностью;

○ 20\% случаев смертности наступают через 24 и более часов после травмы в результате инфекционных осложнений и сепсиса.

- Оказание помощи пострадавшим с травмой базируется на следующих принципах с учётом особенности течения травматической болезни:

○ Ранняя помощь - должна быть оказана в первые 60 мин после травмы (“золотой час");

○ Последовательная помощь, основанная на алгоритме ABCDE;

○ Поэтапная помощь - поочерёдное обследование жизненно важных органов и устранение выявленной патологии;

○ Стадийная помощь - сначала проводятся мероприятия для спасения жизни, затем восстановителные мероприятия: оказание помощи до госпитализации (эвакуация), первичная стационарная (врачебная) помощь (спасение жизни стабилизация и эвакуация), оказание специализированной помощи - раннее восстановление и профилактика сепсиса.

- Основная цель оказания помощи до госпитализации заключается в освобождении пострадавшего от постоянного воздействия травмирующего 
агента, оказании необходимой элементарной помощи и организации ранней транспортировки (эвакуации) в стационар.

- Оказание первой помощи включает быстрое и оперативное восстановление жизненноважных функций организма и проведение реанимационных мероприятий:

○ Восстановление спонтанного дыхания (восстановление проходимости воздухоносных путей), проведение искусственного дыхания;

○ Восстановление деятельности сердечно-сосудистой системы (пульс, артериальное давление), проведение непрямого массажа сердца;

○ Остановка наружного кровотечения;

○ Исключить наличие повреждения шеи и позвоночника. При подозрении на вертеброспинальное повреждение создание условий для полной иммобилизации позвоночника при транспортировке;

○ При наличии переломов костей - иммобилизация.

- Первичная стационарная (врачебная) помощь - направлена на быстрое и оперативное восстановление и стабилизацию функций жизненноважных органов в течение первых 60 минут после травмы и организацию незамедлительной транспортировки пострадавшего в специализированное лечебное учреждение.

- При этом проводятся следующие первичные и вторичные диагностические и лечебные мероприятия:

- Первичные лечебно-диагностические мероприятия направлены на восстановление и стабилизацию жизненноважных функций организма восстановление проходимости воздухоносных путей, вентиляции, перфузии и функции мозга.

○ С этой целью последовательно проводится целенаправленное обследование, позволяющее выявить повреждение, представляющее опасность для жизни пострадавшего, определить его характер и степень тяжести. Выявленные повреждения быстро и оперативно устраняются.

- После проведения первичного лечебно-диагностического алгоритма приступают ко второму этапу.

○ Второй этап лечебно-диагностических мероприятий преследует цель тщательного обследования больного $и$ выявления всех возможных повреждений и в зависимости от характера и профиля выявленных 
повреждений, направления пострадавшего в соответствующее специализированное (квалифицированное) лечебное учреждение.

○ На этом этапе обследованию подвергаются все анатомические области (голова, шея, грудь, живот, таз, опорно-двигательная система). При обнаружении патологий назначаются специфические инструментальные и лабораторные исследования.

○ По достижении надёжной стабилизации витальных функций и других показателей системы гомеостаза вследствие интенсивной терапии, проводятся тщательное инструментальное обследование и адекватная коррекция других повреждений, представляющих относительно меньшую опасность для жизни больного.

- По завершении первичных и вторичных лечебно-диагностических мероприятий и стабилизации жизненноважных функций организма начинается следующий более ответственный этап - оказание квалифицированной помощи, которая осуществляется в специализированных стационарах.

○ Задачей квалифицированной помощи является полное устранение выявленных повреждений и их последствий на основе реконструктивновосстановительных вмешательств.

Вопросы и ответы по общим принципам оказания первой помощи при травме

\section{Вопросы}

В каком периоде травмы наблюдается наиболее высокая летальность?

\section{Причина смерти у пациентов с} травмой:

Причины развития полиорганной недостаточности:

Механизмы гипоксии при травме:

\section{Ответы}

- Первые минуты (50\%);

- Первые часы (30\%);

- Через 24 часа (20\%).

Полиорганная

дисфункция (недостаточность).

- В первые 24 часа - гипоксия;

- В дальнейшем - SIRS и сепсис.

- Гипоксемия;

- Гипоперфузия (шок). 


\begin{tabular}{|c|c|}
\hline Вопросы & Ответы \\
\hline $\begin{array}{l}\text { В чём заключается порочный круг, } \\
\text { развивающийся при травме? }\end{array}$ & $\begin{array}{l}\text { Обструкция воздухоносных путей } \rightarrow \\
\text { нарушение вентиляции } \rightarrow \text { нарушение } \\
\text { перфузии } \rightarrow \text { повреждение мозга } \rightarrow \\
\text { нарушение вентиляции и перфузии. }\end{array}$ \\
\hline $\begin{array}{l}\text { Этапы оказания помощи пациентам } \\
\text { при травме: }\end{array}$ & $\begin{array}{l}\text { - Доврачебная помощь; } \\
\text { - Первая врачебная (стационарная) } \\
\text { помощь; } \\
\text { - Специализированная помощь. }\end{array}$ \\
\hline $\begin{array}{l}\text { Принципы оказания помощи при } \\
\text { травме: }\end{array}$ & $\begin{array}{l}\text { - } \text { Ранняя помощь; } \\
\text { - оследовательная } \\
\text { (алгоритм ABCDE); } \\
\text { - Поэтапная помощь; } \\
\text { - Стадийная помощь. }\end{array}$ \\
\hline В чём заключается алгоритм ABCDE? & 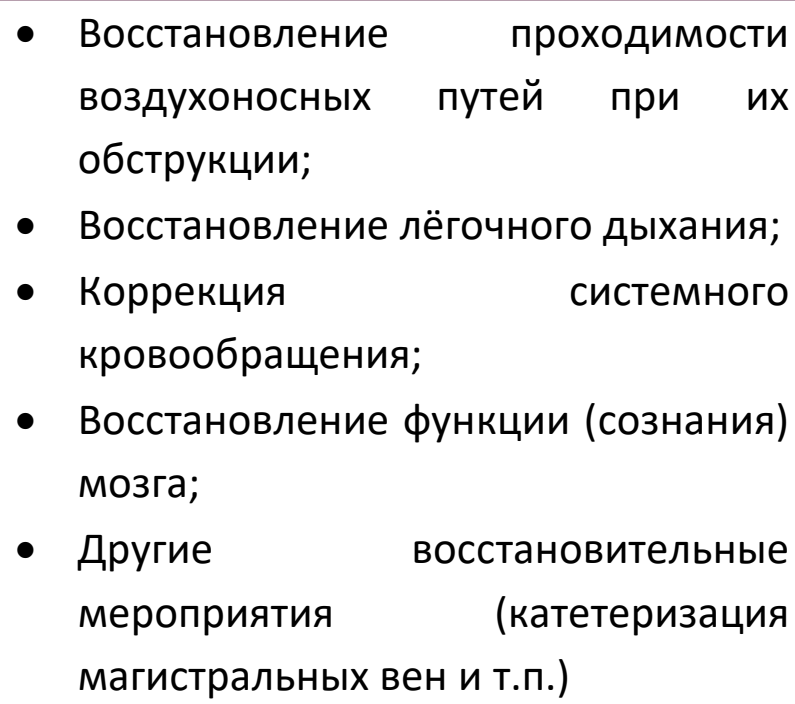 \\
\hline $\begin{array}{l}\text { Цель обследования воздухоносных } \\
\text { путей: }\end{array}$ & $\begin{array}{l}\text { Определение проходимости } \\
\text { воздухоносных путей, } \\
\text { иммобилизации шеи. }\end{array}$ \\
\hline $\begin{array}{l}\text { Признаки обструкции воздухоносных } \\
\text { путей: }\end{array}$ & $\begin{array}{l}\text { - Трудность и нарушение речи; } \\
\text { - Апноэ; } \\
\text { - Звучное дыхание; } \\
\text { - Вялость, цианоз; }\end{array}$ \\
\hline
\end{tabular}




\begin{tabular}{|c|c|}
\hline Вопросы & Ответы \\
\hline & $\begin{array}{l}\text { - Потребность } \\
\begin{array}{l}\text { вспомогательных } \\
\text { мышц. }\end{array}\end{array}$ \\
\hline $\begin{array}{l}\text { Простой метод определения } \\
\text { проходимость (обструкцию) } \\
\text { воздухоносных путей? }\end{array}$ & Опрос пострадавшего. \\
\hline $\begin{array}{l}\text { Признаки повреждения } \\
\text { воздухоносных путей: }\end{array}$ & $\begin{array}{l}\text { - Появление в ране пузырьков } \\
\text { воздуха; } \\
\text { - Подкожная эмфизема; } \\
\text { - Хриплость (осиплость) голоса, } \\
\text { нарушение тембра голоса; } \\
\text { - Кровохарканье; } \\
\text { - Признаки удушья; } \\
\text { - Видимая рана при повреждении } \\
\text { - } \text { Мрахеи; } \\
\text { - Гассивное кровотечение из раны; } \\
\text { Гематома и шум (пульсация) на шее. }\end{array}$ \\
\hline $\begin{array}{l}\text { Комплекс мероприятий, проводимых } \\
\text { при обструкции воздухоносных путей: }\end{array}$ & $\begin{array}{l}\text { - Оксигенация; } \\
\text { - Фиксация шеи; } \\
\text { - Санация ротоглотки; } \\
\text { - Искусственная } \\
\text { вентиляция; } \\
\text { - Вытяжение челюсти; } \\
\text { - Применение орофарингеальной или } \\
\text { назофарингеальной трубок; } \\
\text { - Надёжная оротрахеальная или } \\
\text { назотрахеальная интубация; } \\
\text { - Хирургическая коррекция } \\
\text { крикотиреоидотомия. }\end{array}$ \\
\hline $\begin{array}{l}\text { Цель обследования лёгочного } \\
\text { дыхания: }\end{array}$ & $\begin{array}{l}\text { Выявление повреждений, нарушающих } \\
\text { вентиляцию и представляющих } \\
\text { опасность для жизни. }\end{array}$ \\
\hline
\end{tabular}




\begin{tabular}{|c|c|}
\hline Вопросы & Ответы \\
\hline $\begin{array}{l}\text { Что включает в себя обследование } \\
\text { лёгочного дыхания: }\end{array}$ & $\begin{array}{l}\text { - Осмотр, аускультация; } \\
\text { - Дыхательная экскурсия грудной } \\
\text { клетки, её симметричность; } \\
\text { - Частота и глубина дыхания; } \\
\text { - Наличие раны и повреждения; } \\
\text { - Участие при дыхании } \\
\text { вспомогательных мышц; } \\
\text { - Определение состояния шейных вен } \\
\text { (наличие или отсутствие набухания). }\end{array}$ \\
\hline Признаки нарушения вентиляции: & $\begin{array}{l}\text { - Апноэ; } \\
\text { - Одышка; } \\
\text { - Затруднение дыхания; } \\
\text { - Цианоз; } \\
\text { - Асимметричность дыхательной } \\
\text { экскурсии грудной клетки; } \\
\text { - Ослабление или полное отсутствие } \\
\text { дыхательных шумов; } \\
\text { - Наличие раны со свистом воздуха } \\
\text { или пузырьков газа. }\end{array}$ \\
\hline $\begin{array}{l}\text { Что входит в комплекс мероприятий } \\
\text { при нарушении вентиляции? }\end{array}$ & $\begin{array}{l}\text { - Подача кислорода; } \\
\text { - Проведение } \\
\text { вентиляции; } \\
\text { - Дренирование } \\
\text { полости. }\end{array}$ \\
\hline $\begin{array}{l}\text { Цель обследования системы } \\
\text { кровообразования? }\end{array}$ & $\begin{array}{l}\text { Выявление наличия продолжающегося } \\
\text { кровотечения или шока, } \\
\text { представляющих опасность для жизни. }\end{array}$ \\
\hline $\begin{array}{l}\text { Критерии оценки показателей } \\
\text { кровообращения: }\end{array}$ & $\begin{array}{l}\text { Гемодинамические показатели: } \\
\text { • Пульс; } \\
\text { - Пульсовое давление; } \\
\text { - Центральное венозное давление; }\end{array}$ \\
\hline
\end{tabular}




\begin{tabular}{|c|c|}
\hline Вопросы & Ответы \\
\hline & $\begin{array}{l}\text { - Ортостатическая гипотензия. } \\
\text { Показатели перфузии: } \\
\text { - Температура и цвет кожи; } \\
\text { - Капиллярный тест на ногтевой } \\
\text { фаланге; } \\
\text { - Диурез; } \\
\text { - Сознание; } \\
\text { - рН артериальной крови, лактат } \\
\text { крови. }\end{array}$ \\
\hline $\begin{array}{l}\text { Признаки нарушения } \\
\text { кровообращения: }\end{array}$ & $\begin{array}{l}\text { - Кровотечение; } \\
\text { - Тахикардия; } \\
\text { - Гипотония; } \\
\text { - Бледность кожи и снижение кожной } \\
\text { температуры; } \\
\text { - Помрачнение сознания; } \\
\text { - Невозможность коррекции } \\
\text { гиповолемии; } \\
\text { - Местные проявления кровотечения. }\end{array}$ \\
\hline $\begin{array}{l}\text { У каких пациентов при гиповолемии } \\
\text { может наблюдаться нормальное } \\
\text { артериальное давление? }\end{array}$ & У молодых пациентов. \\
\hline $\begin{array}{l}\text { У каких пациентов при } \\
\text { гиповолемическом шоке может } \\
\text { отсутствовать тахикардия? }\end{array}$ & $\begin{array}{l}\text { У пациентов с вертеброспинальными } \\
\text { повреждениями, при использовании } \beta- \\
\text { блокаторов, у спортсменов. }\end{array}$ \\
\hline $\begin{array}{l}\text { Комплекс противошоковых } \\
\text { мероприятий: }\end{array}$ & $\begin{array}{l}\text { - Остановка кровотечения; } \\
\text { - Восстановление } \\
\text { циркулирующей крови; } \\
\text { - Улучшение доставки кислорода и } \\
\text { уменьшение потребности в ней } \\
\text { тканей организма; }\end{array}$ \\
\hline
\end{tabular}




\begin{tabular}{|c|c|}
\hline Вопросы & Ответы \\
\hline & $\begin{array}{l}\text { - Защита адекватной тканевой } \\
\text { перфузии. }\end{array}$ \\
\hline Цель обследования головного мозга: & $\begin{array}{l}\text { Выявление (исключение) повреждения } \\
\text { мозга, защита мозга от вторичных } \\
\text { повреждений. }\end{array}$ \\
\hline $\begin{array}{l}\text { Основные факторы вторичного } \\
\text { повреждения мозга: }\end{array}$ & $\begin{array}{l}\text { Гипоксемия, } \\
\begin{array}{l}\text { внутричерепная } \\
\text { гипертермия, судороги. }\end{array}\end{array}$ \\
\hline $\begin{array}{l}\text { Критерии оценки функциональной } \\
\text { активности мозга: }\end{array}$ & $\begin{array}{l}\text { - Ментальный статус (оценка комы по } \\
\text { шкале Глазго); } \\
\text { - Размеры зрачков и их реакция; } \\
\text { - Моторные } \\
\text { повреждения. }\end{array}$ \\
\hline $\begin{array}{l}\text { Показатели системы оценки по шкале } \\
\text { Глазго: }\end{array}$ & $\begin{array}{l}\text { - Движения глаз, реакция глаз на } \\
\text { внешние раздражители; } \\
\text { - Моторная реакция - адекватная, } \\
\text { пациент указывает на локализацию } \\
\text { боли, декортикационная поза, } \\
\text { децеребрализационная } \\
\text { отсутствие движений; } \\
\text { - Вербальный ответ - адекватный, } \\
\text { смешанный, редкое произношение } \\
\text { отдельных фраз, неразборчивая } \\
\text { речь, отсутствие речи. }\end{array}$ \\
\hline $\begin{array}{l}\text { Ментальный статус по шкале Глазго у } \\
\text { здоровых людей: }\end{array}$ & 15 баллов. \\
\hline $\begin{array}{l}\text { Ментальный статус по шкале Глазго у } \\
\text { мертвых людей: }\end{array}$ & 3 балла. \\
\hline
\end{tabular}




\section{Вопросы}

Балльная оценка комы по шкале

Глазго:

Балльная оценка сознания по шкале

$\leq 8$

Глазго для проведения интубации:

$\leq 8$

Ответы

- Амнезия;

- Ментальный статус $\leq 15$ по шкале Глазго;

- Анизокория;

- Снижение реакции зрачков;

- Латерализация.

Меры защиты мозга при его повреждении:

Цель открытого исследования:
- Оксигенация;

- Адекватная коррекция шока;

- Уменьшение внутричерепной гипертензии;

- Декомпрессия черепа;

- Возвышенное положение головы;

- Гипервентиляция;

- Диуретики;

- Седативное лечение.

Предупреждение обширных повреждений, кровотечений, облегчение повторных обследований, подготовка ко 2-му этапу диагностических мероприятий.

\begin{tabular}{|c|c|}
\hline Кто является объектом вторичных & Пациенты со \\
\hline обследований? & показателями гомеостаза. \\
\hline Что такое специализированная & Лечебно-диагностические \\
\hline (квалифицированная) помощь? & $\begin{array}{l}\text { мероприятия, } \quad \text { оказываемые } \\
\text { специалистами после первичного и } \\
\text { вторичного этапов обследований. }\end{array}$ \\
\hline
\end{tabular}


- Черепно-мозговые и максиллофасциальные травмы наиболее часто встречаются при дорожно-транспортных происшествиях, падении с высоты и борьбе.

- Повреждения головы делятся на экстракраниальные (повреждение покровных тканей и костей черепа) и интракраниальные (с повреждением головного мозга).

- По степени тяжести различают лёгкую, среднюю и тяжёлую степени черепномозговой травмы.

- Диагностика краниоцеребральных и максиллофасциальных повреждений базируется на данных клинического обследования и КТ и направлено на подтверждение или исключение повреждений мозга.

- Лечение пациентов данной категории проводится соответствующими специалистами.

- При интракраниальных травмах с повреждением головного мозга главной задачей является защита мозга от вторичных повреждений и решение вопроса о показаниях к декомпрессивному вмешательству.

○ Гипоксия, гипоперфузия, внутричерепная гипертензия, гипертермия и судороги являются потенциальными факторами, вызывающими вторичное повреждение мозга. Поэтому ранняя профилактика этих осложнений имеет важное практическое значение.

○ Лечение краниоцеребральных и максиллофасциальных повреждений носит в основном восстановительный характер.

\section{Вопросы и ответы по травмам головы и лица}

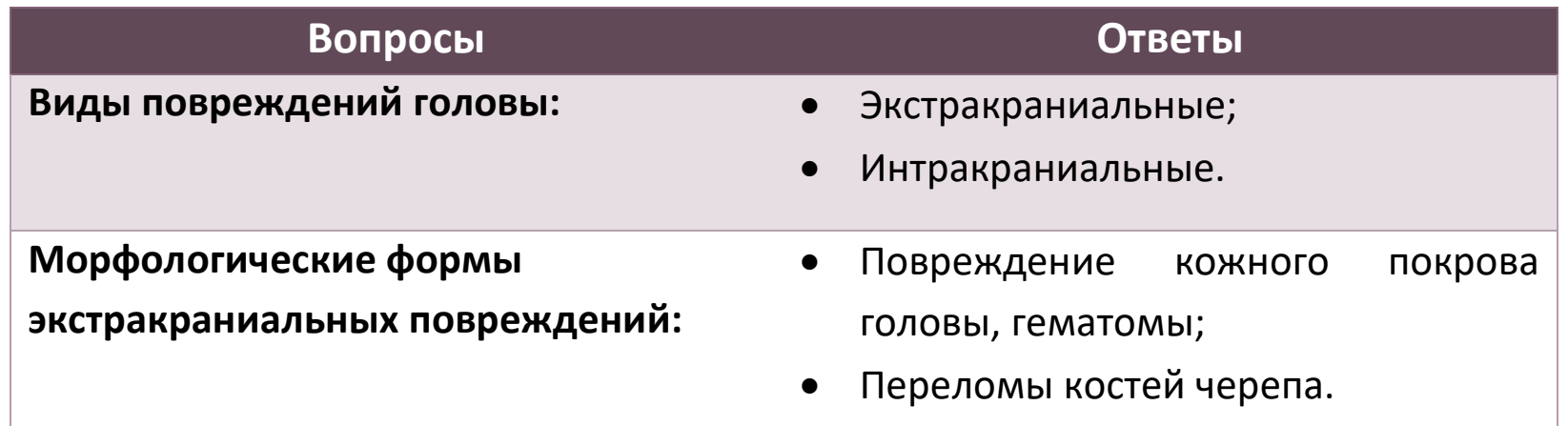




\begin{tabular}{|c|c|}
\hline Вопросы & Ответы \\
\hline $\begin{array}{l}\text { Морфологические формы } \\
\text { повреждений головного мозга: }\end{array}$ & $\begin{array}{l}\text { - } \text { Эпидуральная гематома; } \\
\text { - Субдуральная гематома; } \\
\text { - } \text { Субарохноидальное кровоизлияние; } \\
\text { кровотечение (гематома); } \\
\text { - Интравентрикулярные } \\
\text { кровотечения; } \\
\text { - Ушиб мозга; } \\
\text { - Сотрясение головного мозга. }\end{array}$ \\
\hline $\begin{array}{l}\text { Методы диагностики повреждений } \\
\text { мозга: }\end{array}$ & $\begin{array}{l}\text { - Клиническое обследование; } \\
\text { • КТ. }\end{array}$ \\
\hline $\begin{array}{l}\text { Принципы диагностической и } \\
\text { лечебной тактики при травме головы: }\end{array}$ & $\begin{array}{l}\text { Остановка кровотечения } \rightarrow \text { исключение } \\
\text { (подтверждение) переломов костей } \\
\text { черепа и внутримозговых повреждений } \\
\rightarrow \text { наложение швов на рану. }\end{array}$ \\
\hline $\begin{array}{l}\text { Основные принципы лечения } \\
\text { интракраниальных повреждений: }\end{array}$ & $\begin{array}{l}\text { Уточнить показания } \\
\text { декомпрессионному вмешательству. }\end{array}$ \\
\hline В чём заключается первая помощь? & $\begin{array}{l}\text { Обеспечение } \\
\text { перфузионного дсигенации давления головного } \\
\text { мозга. }\end{array}$ \\
\hline $\begin{array}{l}\text { Что такое перфузионное давление } \\
\text { головного мозга? }\end{array}$ & $\begin{array}{l}\text { Разница между средним показателем } \\
\text { артериального давления (>70-80 мм рт. } \\
\text { ст.) и интракраниальным давлением } \\
\text { (<10-15 мм рт.ст.) }\end{array}$ \\
\hline $\begin{array}{l}\text { Метод контроля перфузионного } \\
\text { давления головного мозга: }\end{array}$ & $\begin{array}{l}\text { Обеспечение адекватного } \\
\text { артериального давления, снижение } \\
\text { интракраниального давления. }\end{array}$ \\
\hline $\begin{array}{l}\text { Метод контроля интракранильного } \\
\text { давления: }\end{array}$ & субарахноидального \\
\hline
\end{tabular}




\begin{tabular}{|c|c|}
\hline Вопросы & Ответы \\
\hline $\begin{array}{l}\text { Меры, необходимые для уменьшения } \\
\text { внутричерепного давления: }\end{array}$ & $\begin{array}{l}\text { - } \text { Подъём головы на 30-45 градусов; } \\
\text { - } \text { Умеренная гипервентиляция; } \\
\text { - Созденение диуретиков; } \\
34^{\circ} \mathrm{C} \text { (при отсутствии коагулопатии); } \\
\text { - Лечение судорог в течение } 1 \text { недели; } \\
\text { - Антипиретики; } \\
\text { - По показаниям - хирургическая } \\
\text { декомпрессия. }\end{array}$ \\
\hline $\begin{array}{l}\text { Тактика лечения переломов лобной } \\
\text { кости: }\end{array}$ & $\begin{array}{l}\text { - При отсутствии смещения } \\
\text { фрагментов - динамическое } \\
\text { наблюдение; } \\
\text { - При наличии смещения фрагментов } \\
\text { - хирургическая операция. }\end{array}$ \\
\hline $\begin{array}{l}\text { Тактика лечения перелома костей } \\
\text { носа: }\end{array}$ & $\begin{array}{l}\text { - При смещении костных фрагментов } \\
\text { - хирургическая операция; } \\
\text { - При септальных гематомах - срочная } \\
\text { декомпрессия. }\end{array}$ \\
\hline $\begin{array}{l}\text { Можно ли установить } \\
\text { назогастральный зонд при } \\
\text { максиллофасциальных переломах? }\end{array}$ & $\begin{array}{l}\text { Нет. Однако орогастральный зонд } \\
\text { можно установить. }\end{array}$ \\
\hline $\begin{array}{l}\text { Основные симптомы перелома костей } \\
\text { основания черепа: }\end{array}$ & 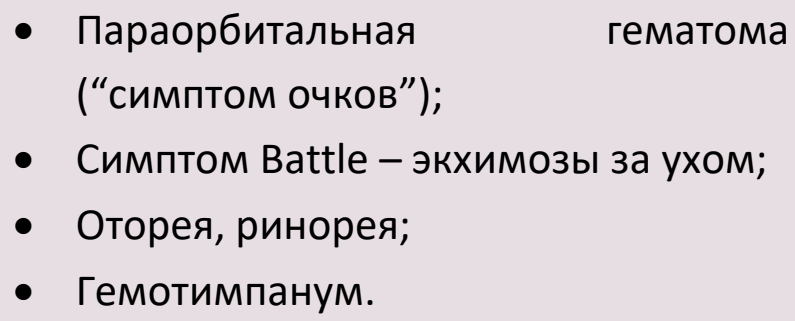 \\
\hline
\end{tabular}




\section{ТРАВМЫ ШЕИ}

- Травмы шеи относятся к категории тяжёлых травм.

- В общей структуре травм, частота травм шеи составляет 5-10\%, при этом в $10 \%$ случаев отмечается летальный исход.

- Классификация:

- Различают открытые (ранения) и закрытые (тупые) травмы шеи.

○ Открытые повреждения классифицируют в зависимости от глубины (поверхностные и глубокие), от локализации (I, II, III зоны), от клинических признаков (большие и малые симптомы), от повреждённого органа (аэродигестивные, сосудистые, вертебральные и др.)

- Тактика при травмах шеи:

○ В эволюции концепции лечения больных с травмами шеи различают следующий лечебно-тактический алгоритм: консервативная тактика, активная хирургическая тактика, подход в зависимости от зоны повреждения и от клинических данных и данных КТ.

○ В настоящее время широко применяется индивидуализированнодифференцированная тактика с учётом клинических данных и результатов КТ.

- У всех пациентов с травмами шеи диагностический, лечебно-тактический алгоритм базируется на общих принципах травм и травматической болезни.

- При повреждениях шеи с выраженной клинической манифестацией (наличие нарастающей подкожной эмфиземы и гематомы, осиплости голоса, кровохарканья, кровавой рвоты, симптомов удушья, массивного кровотечения из раны, выслушивание шумов на шее, выделение из раны пузырьков воздуха и т.п.) проводятся интенсивные реанимационные мероприятия в условиях операционной.

- При этом основное внимание уделяется на возможные повреждения верхних воздухоносных путей. При наличии признаков обструкции или повреждений воздухоносных путей, необходима эндотрахеальная интубация.

- У пострадавших со стабильными показателями гомеостаза в первую очередь определяется необходимость в интубации трахеи.

- При отсутствии показаний к интубации трахеи, проводится оценка "малых" клинических симптомов повреждения шеи (умеренно кровоточащая рана, некорригируемая гипотензия, подкожная или медиастинальная эмфизема, 
нарастающая гематома, изменение фонации голоса, дисфагия); при их наличии выполняется КТ с целью уточнения топического диагноза.

- При обнаружении на КТ повреждений показано соответствующее хирургическое вмешательство, которое может выполнено открытым доступом или с использованием малоинвазивной технологии.

- При отсутствии на КТ признаков аэродигестивных повреждений, но при сохранении клинических признаков (малая эмфизема, изменение фонации голоса, дисфагия, кровавая рвота), показаны бронхоскопия и эзофагоскопия.

- За пациентами с отсутствием клинических признаков повреждений шеи проводится динамическое наблюдение в течение 24 часов.

\section{Вопросы и ответы по травмам шеи}

\begin{tabular}{|c|c|}
\hline Вопросы & Ответы \\
\hline $\begin{array}{l}\text { Частота травм шеи в общей структуре } \\
\text { механической травмы: }\end{array}$ & Составляет 5-10\% всех травм. \\
\hline Виды травм шеи: & Закрытые и открытые. \\
\hline $\begin{array}{l}\text { Виды открытых травм в зависимости } \\
\text { от глубины раны: }\end{array}$ & $\begin{array}{l}\text { - Поверхностные - непроникающие в } \\
\text { платизму; } \\
\text { - Глубокие - проникающие в } \\
\text { платизму. }\end{array}$ \\
\hline $\begin{array}{l}\text { Виды открытых травм в зависимости } \\
\text { от их локализации: }\end{array}$ & $\begin{array}{l}\text { - Травмы I зоны; } \\
\text { - Травмы II зоны; } \\
\text { - Травмы III зоны. }\end{array}$ \\
\hline Клинические признаки: & $\begin{array}{l}\text { - “Манифестные” признаки, } \\
\text { указывающие на повреждение } \\
\text { важных анатомических структур } \\
\text { шеи; } \\
\text { • “Малые” симптомы, исключающие } \\
\text { обширные повреждения; } \\
\text { • Бессимптомное течение. }\end{array}$ \\
\hline
\end{tabular}




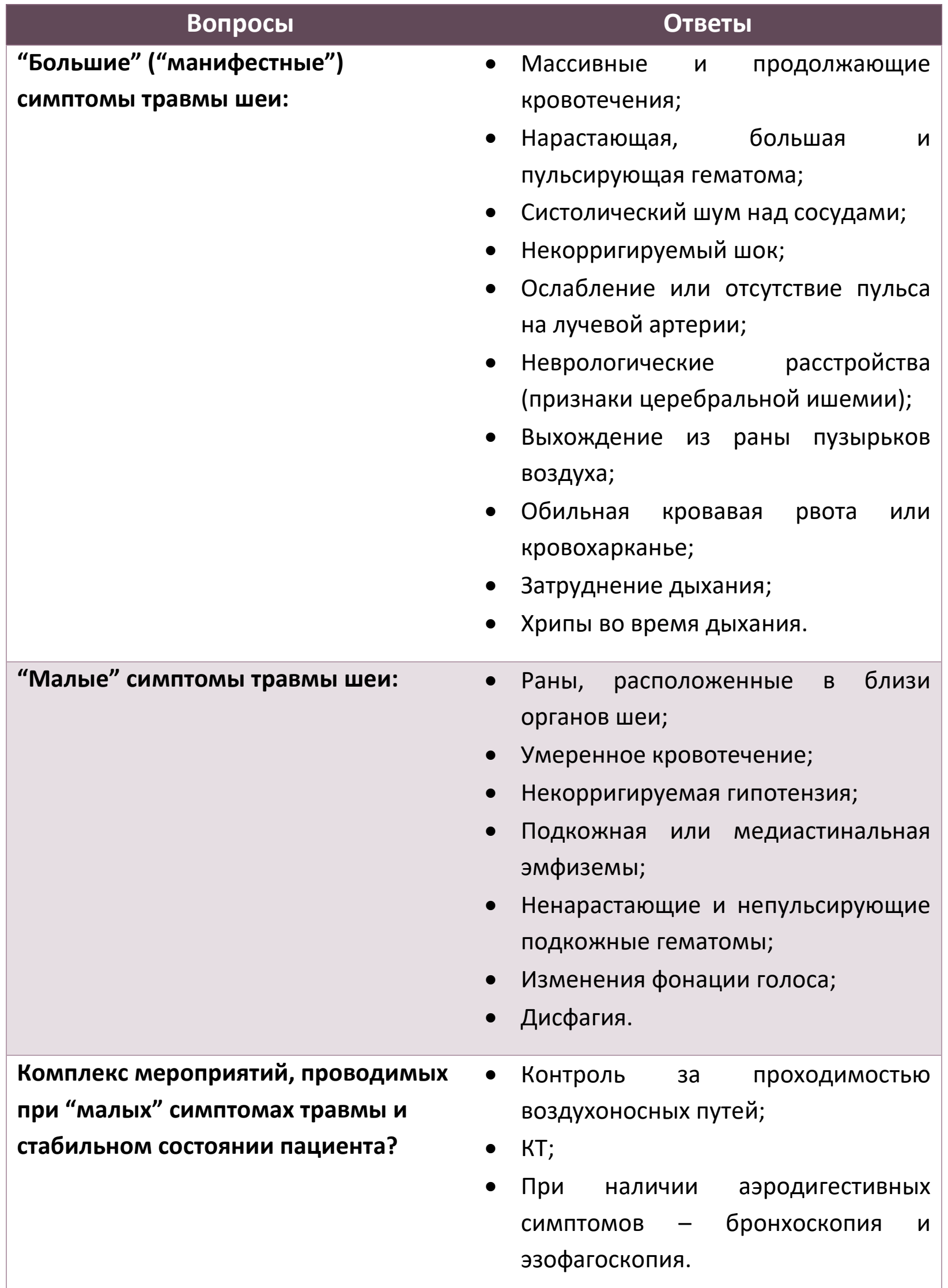




\begin{tabular}{|c|c|}
\hline Вопросы & Ответы \\
\hline Тактика при бессимптомном течении: & 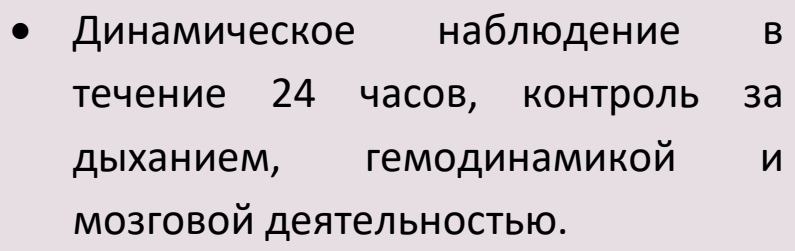 \\
\hline Показания к срочной торакотомии: & $\begin{array}{l}\text { - Нарастающий (напряжённый) } \\
\text { пневмоторакс, обусловленный } \\
\text { повреждением } \\
\text { бронхоальвеолярного комплекса; } \\
\text { • Подозрение на повреждение } \\
\text { крупных сосудистых магистралей. }\end{array}$ \\
\hline Прогноз: & $\begin{array}{l}\text { При обширных повреждениях } \\
\text { летальность составляет } 10 \% .\end{array}$ \\
\hline
\end{tabular}




\section{ТРАВМЫ ГРУДНОЙ КЛЕТКИ}

- При травмах грудной клетки независимо от состояния пострадавшего оценивается стабильность его состояния по алгоритму ABCDE и при необходимости проводятся мероприятия по его стабилизации.

- Основной задачей при травмах грудной стенки является выявление повреждений жизненноважных органов и проведение адекватных диагностических и лечебных мероприятий:

○ При наличии обструкции дыхательных путей - интубация трахеи;

○ При наличии напряжённого пневмоторакса - дренирование плевральной полости;

○ При открытом пневмотораксе - дренирование плевральной полости;

○ При флотирующей грудной клетке - искусственная вентиляция лёгких;

О При массивном внутриплевральном кровотечении - торакотомия;

○ При тампонаде сердца - перикардиоцентез и торакотомия;

○ При повреждении крупных кровеносных сосудов - торакотомия, эндоваскулярные вмешательства;

О Обширная контузия лёгких - искусственная вентиляция.

- При стабилизации состояния пострадавшего производятся вторичные лечебнопрофилактические мероприятия. В дальнейшем определяются характер, локализация и тяжесть повреждений. Для уточнения топической диагностики проводится комплекс клинико-инструментальных обследований и КТ. По показаниям в алгоритм обследования можно включить ЭКГ, ЭхоКГ, эзофагоскопию, бронхоскопию и лабораторные исследования.

- В зависимости от локализации, характера и тяжести повреждений, определяется тактика лечения.

\section{Вопросы и ответы по травмам грудной клетки}

\section{Вопросы \\ Ответы}

Тактика при ранениях грудной клетки: Ревизия раны; 


\begin{tabular}{|c|c|}
\hline Вопросы & Ответы \\
\hline & $\begin{array}{l}\text { - При непроникающей ране - } \\
\text { первичная хирургическая обработка } \\
\text { раны и наложение швов; } \\
\text { - При проникающих ранениях - } \\
\text { дренирование олевральной } \\
\text { полости, обработка раны, } \\
\text { определение } \\
\text { внутренних органов. }\end{array}$ \\
\hline $\begin{array}{l}\text { Тактика при гематомах грудной } \\
\text { стенки: }\end{array}$ & $\begin{array}{l}\text { - Наблюдение; } \\
\text { - При нарастающей гематоме - } \\
\text { хирургическая операция; } \\
\text { • При нагноившейся гематоме - } \\
\text { дренирование. }\end{array}$ \\
\hline $\begin{array}{l}\text { Клинические признаки переломов } \\
\text { рёбер: }\end{array}$ & $\begin{array}{l}\text { - Боли при вдохе; } \\
\text { - Наличие крепитации при пальпации; } \\
\text { - Признаки повреждения плевры, } \\
\text { лёгких и сосудов. }\end{array}$ \\
\hline $\begin{array}{l}\text { Клинические признаки перелома } \\
\text { грудины: }\end{array}$ & $\begin{array}{l}\text { Боли при вдохе и болезненность при } \\
\text { пальпации. }\end{array}$ \\
\hline $\begin{array}{l}\text { Первая помощь при переломе } \\
\text { грудины: }\end{array}$ & $\begin{array}{l}\text { - При отсутствии смещения костных } \\
\text { фрагментов - консервативное } \\
\text { лечение (анальгетики); } \\
\text { - При наличии смещения отломков - } \\
\text { хирургическая коррекция. }\end{array}$ \\
\hline $\begin{array}{l}\text { Лечение переломов лопаточной } \\
\text { кости: }\end{array}$ & Консервативное. \\
\hline $\begin{array}{l}\text { Клинические признаки переломов } \\
\text { ключицы: }\end{array}$ & Боли, деформация плечевого пояса. \\
\hline
\end{tabular}




\begin{tabular}{|c|c|}
\hline Вопросы & Ответы \\
\hline $\begin{array}{l}\text { Методы лечения переломов } \\
\text { ключицы: }\end{array}$ & Хирургическая коррекция. \\
\hline $\begin{array}{l}\text { Диагностика переломов костного } \\
\text { каркаса грудной клетки: }\end{array}$ & Рентгенологическое исследование и КТ. \\
\hline $\begin{array}{l}\text { Клинические признаки при ушибе } \\
\text { лёгкого: }\end{array}$ & $\begin{array}{l}\text { - При небольших ушибах и гематомах } \\
\text { - бессимптомное течение; } \\
\text { - При обширных контузиях - признаки } \\
\text { гипоксии. }\end{array}$ \\
\hline Диагностика ушиба лёгкого: & Рентгенологическое исследование и КТ. \\
\hline Лечение ушиба лёгкого: & $\begin{array}{l}\text { Искусственная вентиляция лёгких, } \\
\text { санация трахеобронхиального дерева } \\
\text { (при наличии гипоксии). }\end{array}$ \\
\hline $\begin{array}{l}\text { Клинические признаки ранения } \\
\text { лёгкого: }\end{array}$ & $\begin{array}{l}\text { - Признаки малого пневмоторакса и } \\
\text { гемоторакса - при повреждении } \\
\text { периферических отделов; } \\
\text { - Большой (массивный) гемоторакс, } \\
\text { пневмоторакс, эндобронхиальное } \\
\text { кровотечение - при повреждениях } \\
\text { крупных бронхов и кровеносных } \\
\text { сосудов. }\end{array}$ \\
\hline Диагностика ранения лёгкого: & КТ и бронхоскопия. \\
\hline Лечение ранения лёгкого: & 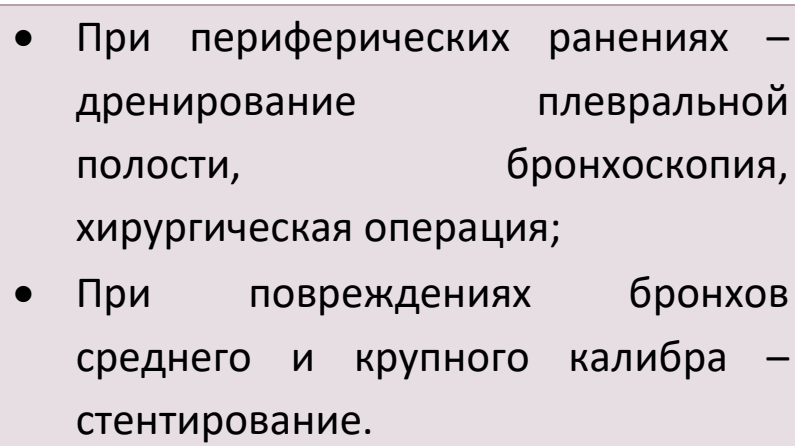 \\
\hline
\end{tabular}




\begin{tabular}{|c|c|}
\hline Вопросы & Ответы \\
\hline $\begin{array}{l}\text { Показания к хирургической операции } \\
\text { при ранениях лёгкого: }\end{array}$ & $\begin{array}{l}\text { - Постоянное выделение пузырьков } \\
\text { воздуха через плевральную } \\
\text { дренажную трубку; } \\
\text { - Повреждения долевых бронхов. }\end{array}$ \\
\hline Лечение гемоторакса: & $\begin{array}{l}\text { - Дренирование плевральной } \\
\text { полости; } \\
\text { - Хирургическая операция. }\end{array}$ \\
\hline $\begin{array}{l}\text { Показание к хирургической операции } \\
\text { при гемотораксе: }\end{array}$ & $\begin{array}{l}\text { Массивный, свернувшийся гемоторакса } \\
\text { (в течение } 5 \text { дней). }\end{array}$ \\
\hline $\begin{array}{l}\text { Показания к торакотомии при } \\
\text { гемотораксе: }\end{array}$ & $\begin{array}{l}\text { Первоначальное выделение более } 1,5 \text { л } \\
\text { крови при дренировании грудной } \\
\text { клетки или выделение более } 200 \text { мл } \\
\text { крови в час при 6-часовом наблюдении. }\end{array}$ \\
\hline $\begin{array}{l}\text { Диагностика эндобронхиального } \\
\text { кровотечения: }\end{array}$ & Бронхоскопия. \\
\hline $\begin{array}{l}\text { Лечение эндобронхиального } \\
\text { кровотечения: }\end{array}$ & $\begin{array}{l}\text { - Срочная бронхоскопическая } \\
\text { санация; } \\
\text { - Интубация контралатерального } \\
\text { бронха у пострадавшего с } \\
\text { признаками гипоксии; } \\
\text { - Срочная операция, стентирование } \\
\text { бронха, эмболизация сосуда. }\end{array}$ \\
\hline $\begin{array}{l}\text { Клинические признаки } \\
\text { трахеобронхиальных повреждений: }\end{array}$ & Массивная подкожная эмфизема. \\
\hline $\begin{array}{l}\text { Диагностика трахеобронхиальных } \\
\text { повреждений: }\end{array}$ & КT, бронхоскопия. \\
\hline $\begin{array}{l}\text { Лечение трахеобронхиальных } \\
\text { повреждений: }\end{array}$ & $\begin{array}{l}\text { - Интубация трахеи - для } \\
\text { стабилизации состояния; } \\
\text { - Срочная операция. }\end{array}$ \\
\hline
\end{tabular}




\begin{tabular}{|c|c|}
\hline Вопросы & Ответы \\
\hline $\begin{array}{l}\text { Методы хирургической операции при } \\
\text { трахеобронхиальных повреждениях: }\end{array}$ & $\begin{array}{l}\text { - При колото-резанных ранениях - } \\
\text { первичная хирургическая обработка } \\
\text { раны и наложение швов; } \\
\text { - При закрытой травме резекция 2-3 } \\
\text { колец трахеи и бронха, } \\
\text { формирование анастомоза. }\end{array}$ \\
\hline $\begin{array}{l}\text { Клинические признаки травмы } \\
\text { пищевода: }\end{array}$ & $\begin{array}{l}\text { - Ранние симптомы - подкожная } \\
\text { эмфизема на шее, медиастинальная } \\
\text { эмфизема, кровавая рвота; } \\
\text { - Поздние симптомы - флегмона шеи, } \\
\text { медиастинит, перитонит, сепсис. }\end{array}$ \\
\hline Диагностика травм пищевода: & $\begin{array}{l}\text { - Кт; } \\
\text { - Эндоскопическое исследование } \\
\text { - исследование с использованием } \\
\text { водорастворимого контрастного } \\
\text { вещества. }\end{array}$ \\
\hline Лечение травм пищевода: & $\begin{array}{l}\text { - При повреждениях І-ІІІ степени - } \\
\text { ушивание раны; } \\
\text { - При сегментарных дефектах и } \\
\text { деваскуляризации: } \\
\text { О Резекция и эзофагостомия У } \\
\text { стабильных пациентов; } \\
\text { Оренирование или изоляция } \\
\text { зоны повреждения } \\
\text { нестабильных пациентов; } \\
\text { При поздних сроках повреждений } \\
\text { (через 24-48 часов) - широкое } \\
\text { дренирование средостения, } \\
\text { стентирование или изоляция; } \\
\text { - При обширных повреждениях - } \\
\text { тотальная резекция. }\end{array}$ \\
\hline
\end{tabular}




\begin{tabular}{|c|c|}
\hline Вопросы & Ответы \\
\hline Диагностика травм сердца: & ЭхоКГ. \\
\hline Лечение травм сердца: & $\begin{array}{l}\text { - При тампонаде - перикардиоцентез } \\
\text { или субксифоидальная } \\
\text { перикардиотомия; } \\
\text { - } \quad \text { Срочная торакотомия. }\end{array}$ \\
\hline $\begin{array}{l}\text { Клинические признаки закрытой } \\
\text { травмы сердца: }\end{array}$ & $\begin{array}{l}\text { - Бессимптомное течение; } \\
\text { - Кардиогенный шок; } \\
\text { - Тампонада сердца. }\end{array}$ \\
\hline Диагностика закрытых травм сердца: & 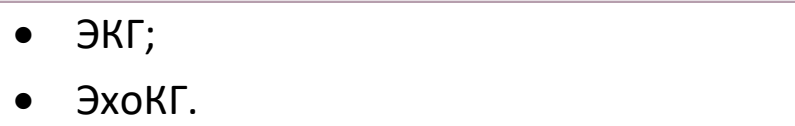 \\
\hline Лечение закрытых травм сердца: & $\begin{array}{l}\text { - Консервативное лечение - } \\
\text { аналогичное при инфаркте } \\
\text { миокарда; } \\
\text { - Хирургическое - при повреждении } \\
\text { миокарда или клапанов. }\end{array}$ \\
\hline $\begin{array}{l}\text { Клинические признаки травм крупных } \\
\text { внутригрудных сосудов: }\end{array}$ & $\begin{array}{l}\text { - Массивный гемоторакс; } \\
\text { - Тампонада сердца; } \\
\text { - Шок, признаки расширения контуров } \\
\text { средостения д (по данным } \\
\text { рентгенологического исследования). }\end{array}$ \\
\hline $\begin{array}{l}\text { Диагностика травм внутригрудных } \\
\text { крупных кровеносных сосудов: }\end{array}$ & $\begin{array}{l}\text { - У стабильных пациентов - КТ, } \\
\text { ангиография, ЭхоКГ; } \\
\text { - у нестабильных пациентов - } \\
\text { диагностическая операция. }\end{array}$ \\
\hline $\begin{array}{l}\text { Лечение травм внутригрудных } \\
\text { крупных кровеносных сосудов: }\end{array}$ & $\begin{array}{l}\text { Хирургическое лечение - первичное } \\
\text { восстановление повреждений или } \\
\text { шунтирование (ангиопластика). }\end{array}$ \\
\hline $\begin{array}{l}\text { Клинические признаки травмы } \\
\text { грудного лимфатического протока: }\end{array}$ & $\begin{array}{l}\text { Постоянное поступление лимфы по } \\
\text { дренажной трубке. }\end{array}$ \\
\hline
\end{tabular}




\begin{tabular}{|c|c|}
\hline Вопросы & Ответы \\
\hline $\begin{array}{l}\text { Диагностика травмы грудного } \\
\text { лимфатического протока: }\end{array}$ & $\begin{array}{l}\text { Обнаружение высокой концентрации } \\
\text { триглицеридов в лимфе. }\end{array}$ \\
\hline $\begin{array}{l}\text { Лечение травмы грудного } \\
\text { лимфатического протока: }\end{array}$ & $\begin{array}{l}\text { - Консервативное лечение: } \\
\text { О Безжировая диета; } \\
\text { О Парентеральное питание и } \\
\text { октреотид (в течение } 4 \text { недель); } \\
\text { - Хирургическое лечение - перевязка } \\
\text { протока. }\end{array}$ \\
\hline $\begin{array}{l}\text { Показания к хирургическому лечению } \\
\text { при травме грудного лимфатического } \\
\text { протока: }\end{array}$ & $\begin{array}{l}\text { Поступление по дренажной трубке } \\
\text { более } 1500 \text { мл лимфы несмотря на 4- } \\
\text { недельное консервативное лечение. }\end{array}$ \\
\hline $\begin{array}{l}\text { Клинические признаки травм } \\
\text { диафрагмы: }\end{array}$ & $\begin{array}{l}\text { - В раннем периоде “малые”, } \\
\text { клинически незначимые симптомы; } \\
\text { При поздних сроках - признаки } \\
\text { травматической диафрагмальной } \\
\text { грыжи. }\end{array}$ \\
\hline Диагностика травм диафрагмы: & $\begin{array}{l}\text { - Рентгенологическое исследование (в } \\
\text { - } \quad \text { КТ; } \\
\text { - Интраоперационная диагностика. }\end{array}$ \\
\hline Лечение травм диафрагмы: & $\begin{array}{l}\text { - Дренирование плевральной полости } \\
\text { при гемо-и пневмотораксе; } \\
\text { - Ушивание дефекта - первичное } \\
\text { ушивание, пластика дефекта. }\end{array}$ \\
\hline
\end{tabular}


- Травмы живота одна из наиболее распространённых областей травм; на травмы живота приходится около $1 / 3$ всех летальных исходов по причине травмы (внутрибрюшное кровотечение, повреждение полостных органов).

- Диагностический алгоритм при травмах живота:

- При повреждениях живота вне зависимости от тяжести состояния пострадавших, последовательно проводятся стандартные обследования пострадавшего в соответствии с общими принципами лечебнодиагностического подхода (алгоритм $\mathrm{ABCDE}$ ), оценивается $и$, при необходимости, обеспечивается стабильность пострадавшего.

○ С этой целью проводятся клинические обследования, УзИ, КТ у стабильных пациентов, осмотр открытых ранений, эндоскопия, лапароскопия, лабораторные и другие методы исследования.

○ Первоочередной задачей при травмах живота является решение вопроса о показаниях к лапаротомии:

- открытые или закрытые травмы живота у нестабильных пациентов;

- повреждение полостных органов или крупных сосудов у стабильных пациентов;

- проникающие ранения брюшной полости;

- огнестрельное ранение брюшной полости;

- признаки перитонита и перфорации.

○ Диагноз повреждений паренхиматозных органов у пациентов с закрытой травмой живота уточняется с помощью УЗИ и КТ.

\section{- Принципы хирургической операции:}

○ При абдоминальной травме методом выбора является лапаротомия, у стабильных пациентов возможно проведение лапароскопии.

О Основным этапом интраоперационной тактики является остановка кровотечения и устранение контаминации (восстановление). При невозможности окончательной остановки кровотечения из-за тяжести состояния пострадавшего применяется контроль повреждения (тампонада источника кровотечения в течение 24-48 часов, затем удаление или восстановление в зависимости от локализации органа и степени его повреждения). 
- При повреждениях полых органов обрабатывают и ушивают раневые дефекты, гематомы должны быть ревизированы с целью окончательной остановки кровотечения (исключение составляют гематомы пищевода, 12перстной кишки), при деструкции органа проводится его резекция.

- При повреждениях паренхиматозных органов выполняется хирургический гемостаз, при авульсиях - резекция, удаление всего органа (селезёнка) и даже трансплантация (печень). Гематомы паренхиматозных не следует вскрывать.

○ При повреждениях крупных сосудов показана срочная операция и восстановление дефекта (открытые травмы, центральные гематомы).

\section{Вопросы и ответы по травмам живота}

\begin{tabular}{|c|c|}
\hline Вопросы & Ответы \\
\hline $\begin{array}{l}\text { Классификация открытых травм } \\
\text { живота: }\end{array}$ & $\begin{array}{l}\text { - Непроникающие }(1 / 3) \text {; } \\
\text { - Проникающие без повреждения } \\
\text { органов брюшной полости (1/3); } \\
\text { - Проникающие с повреждением } \\
\text { органов брюшной полости }(1 / 3) .\end{array}$ \\
\hline $\begin{array}{l}\text { Критерии проникающей } \\
\text { абдоминальной раны: }\end{array}$ & $\begin{array}{l}\text { - Изолированное ранение живота у } \\
\text { больного с нестабильными } \\
\text { показателями гемодинамики; } \\
\text { - Эвентрация в рану внутрибрюшных } \\
\text { органов; } \\
\text { - Диффузный перитонит и признаки } \\
\text { сепсиса; } \\
\text { - Исчезновение печёночной тупости; } \\
\text { - Увеличение объёма живота в } \\
\text { динамике; } \\
\text { - Огнестрельное ранение живота; } \\
\text { - Наличие жидкости в брюшной } \\
\text { полости при УЗИили КТ. }\end{array}$ \\
\hline
\end{tabular}




\begin{tabular}{|c|c|}
\hline Вопросы & Ответы \\
\hline $\begin{array}{l}\text { Тактика при открытых повреждениях } \\
\text { живота: }\end{array}$ & $\begin{array}{l}\text { - Срочная лапаротомия или } \\
\text { лапароскопия - при проникающих } \\
\text { ранах; } \\
\text { - Ревизия раны; } \\
\text { - КТ по показаниям - при } \\
\text { непроникающих ранах. }\end{array}$ \\
\hline $\begin{array}{l}\text { Тактика при огнестрельном ранении } \\
\text { живота: }\end{array}$ & $\begin{array}{l}\text { При отсутствии перитонита и } \\
\text { стабильном состоянии пострадавшего - } \\
\text { КТ с тройным контрастным усилением, } \\
\text { динамическое наблюдение. }\end{array}$ \\
\hline Тактика при закрытой травме живота: & $\begin{array}{l}\text { - При нестабильном состоянии } \\
\text { пациента и явных клинических } \\
\text { признаках-срочная лапаротомия; } \\
\text { - При стабильном состоянии } \\
\text { пациентов с множественной } \\
\text { травмой-КТ. }\end{array}$ \\
\hline $\begin{array}{l}\text { Показания к срочной лапаротомии } \\
\text { при травмах живота: }\end{array}$ & $\begin{array}{l}\text { - Открытые и закрытые травмы } \\
\text { живота у пострадавшего с } \\
\text { нестабильной гемодинамикой; } \\
\text { - Проникающие ранения живота; } \\
\text { - Повреждение органов брюшной } \\
\text { полости или магистральных сосудов } \\
\text { при закрытой травме; } \\
\text { - Перфорация (разрывы) полых } \\
\text { органов и перитонит. }\end{array}$ \\
\hline $\begin{array}{l}\text { Тактика при закрытой травме живота с } \\
\text { повреждением паренхиматозных } \\
\text { органов у пострадавшего со } \\
\text { стабильной гемодинамикой: }\end{array}$ & $\begin{array}{l}\text { - Динамическое наблюдение; } \\
\text { - При продолжающемся } \\
\text { кровотечении - лапаротомия или } \\
\text { эндоваскулярные вмешательства. }\end{array}$ \\
\hline
\end{tabular}




\begin{tabular}{|c|c|}
\hline Вопросы & Ответы \\
\hline $\begin{array}{l}\text { Методы операции при повреждении } \\
\text { полых органов: }\end{array}$ & $\begin{array}{l}\text { - При повреждениях I, II, III степени - } \\
\text { первичная обработка, ушивание } \\
\text { раны (поперечное); } \\
\text { - При множественных повреждениях } \\
\text { - резекция (с формированием } \\
\text { анастомоза). }\end{array}$ \\
\hline $\begin{array}{l}\text { Тактика при гематомах стенки полых } \\
\text { органов: }\end{array}$ & $\begin{array}{l}\text { Ревизия гематомы, гемостаз, } \\
\text { определение } \\
\text { (герметичности) стенки полых органов. }\end{array}$ \\
\hline $\begin{array}{l}\text { Показания к операции при гематомах } \\
\text { печени и селезёнки: }\end{array}$ & $\begin{array}{l}\text { - Повреждение магистральных } \\
\text { сосудов (нарастающая и } \\
\text { пульсирующая гематома); } \\
\text { - Разрыв гематомы. }\end{array}$ \\
\hline $\begin{array}{l}\text { Тактика при ретроперитонеальной } \\
\text { гематоме: }\end{array}$ & $\begin{array}{l}\text { - При центральных гематомах - } \\
\text { ревизия; } \\
\text { - Ревизия при подозрении или } \\
\text { явных признаках латеральных и } \\
\text { тазовых гематом (повреждения } \\
\text { подвздошных и почечных } \\
\text { артерий). }\end{array}$ \\
\hline Диагностика травмы желудка: & $\begin{array}{l}\text { - Поступление кровянистого } \\
\text { содержимого по назогастральному } \\
\text { зонду; } \\
\text { - Наличие жидкости в брюшной } \\
\text { полости при УзИ; } \\
\text { - Обнаружение свободного газа в } \\
\text { брюшной полости и экстравазация } \\
\text { контрастного вещества при КТ. }\end{array}$ \\
\hline $\begin{array}{l}\text { Что такое “симптом пояса" и когда он } \\
\text { наблюдается? }\end{array}$ & $\begin{array}{l}\text { Является ценным симптомом при } \\
\text { перфорации тонкой }\end{array}$ \\
\hline
\end{tabular}




\begin{tabular}{|c|c|}
\hline Вопросы & Ответы \\
\hline & $\begin{array}{l}\text { Характеризуется опоясывающим } \\
\text { экхимозом. }\end{array}$ \\
\hline $\begin{array}{l}\text { Клинические признаки травмы 12- } \\
\text { перстной кишки: }\end{array}$ & $\begin{array}{l}\text { • Признаки кишечной } \\
\text { • непроходимости - при гематомах; } \\
\text { Кровотечение, перитонит и } \\
\text { признаки забрюшинной флегмоны. }\end{array}$ \\
\hline $\begin{array}{l}\text { Диагностика травм 12-перстной } \\
\text { кишки: }\end{array}$ & $\begin{array}{l}\text { - Контрастная КТ; } \\
\text { - Интраоперационная диагностика. }\end{array}$ \\
\hline Лечение травм 12-перстной кишки: & $\begin{array}{l}\text { - При гематомах - назогастральный } \\
\text { зонд и наблюдение (2 недели); } \\
\text { - При явлениях кишечной } \\
\text { непроходимости - операция; } \\
\text { - При непроникающих ранах - } \\
\text { ушивание раневого дефекта, } \\
\text { назогастральный } \\
\text { дренирование; } \\
\text { - При проникающих ранениях - } \\
\text { изоляция 12-перстной кишки; } \\
\text { При повреждениях ампулы - } \\
\text { стентирование или } \\
\text { панкреатодуоденальная резекция. }\end{array}$ \\
\hline $\begin{array}{l}\text { В чём заключается изоляция } \\
\text { повреждённого участка 12-перстной } \\
\text { кишки? }\end{array}$ & 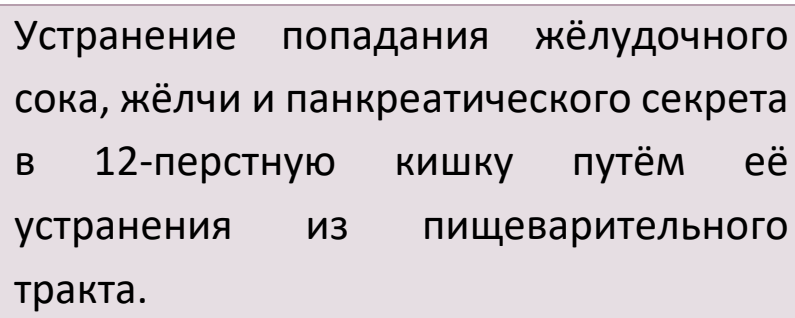 \\
\hline $\begin{array}{l}\text { Методы изоляции 12-перстной кишки } \\
\text { при её повреждениях: }\end{array}$ & $\begin{array}{l}\text { - Декомпрессия; } \\
\text { - Перевязка пилорического отдела; } \\
\text { - Дивертикулизация. }\end{array}$ \\
\hline
\end{tabular}


Вопросы

Показания к проведению изоляции

12-перстной кишки:

Степени тяжести повреждений 12перстной кишки по данных ЭРХПГ:

Лечение повреждений 12-перстной кишки по критериям ЭРХПГ:

Диагностика травм печени:

Лечение травм печени:

\section{Ответы}

Высокий риск несостоятельности швов раны или анастомоза.

- Лёгкая степень - микроперфорация;

- Средняя степень - небольшие повреждения;

- Тяжёлая степень - большие дефекты дуоденальной стенки, наличие жидкости в брюшной полости и забрюшинном пространстве.

- При лёгкой степени консервативное лечение в течение 3-4 дней;

- При средней степени консервативное лечение в течение 10 дней;

- При тяжёлой степени консервативное лечение более 10 дней или операция.

- Интраоперационная диагностика во время лапаротомии;

- УзИ, КТ.

- Гемостаз;

- При тупых травмах - консервативное лечение;

- Эмболизация кровоточащих сосудов при продолжающемся кровотечении (по данным КТ);

- При разрыве гематомы - операция;

- При нарастающих и расположенных в зоне ворот печени гематома операция; 


\begin{tabular}{|c|c|}
\hline Boпросы & Ответы \\
\hline & $\begin{array}{l}\text { - При авульсиях печени } \\
\text { трансплантация печени. }\end{array}$ \\
\hline $\begin{array}{l}\text { Показания к консервативному } \\
\text { лечению травм печени: }\end{array}$ & $\begin{array}{l}\text { - Стабильная гемодинамика; } \\
\text { - Отсутствие повреждений других } \\
\text { внутрибрюшных органов; } \\
\text { - Тщательный мониторинг. }\end{array}$ \\
\hline $\begin{array}{l}\text { Диагностика травм жёлчных } \\
\text { протоков: }\end{array}$ & $\begin{array}{l}\text { - Интраоперационная } \\
\text { холангиография; } \\
\text { - МРТ и ЭРХПГ у стабильных } \\
\text { пациентов. }\end{array}$ \\
\hline Лечение травм жёлчных протоков: & $\begin{array}{l}\text { - Холецистэктомия - при гематоме, } \\
\text { авульсиях жёлчного пузыря; } \\
\text { - Билиодигестивные анастомозы по } \\
\text { типу Roux-еn-Y - при сегментарных } \\
\text { повреждениях; } \\
\text { - Т-образный дренаж - при IV, V } \\
\text { степенях повреждений. }\end{array}$ \\
\hline $\begin{array}{l}\text { Диагностика травм поджелудочной } \\
\text { железы: }\end{array}$ & $\begin{array}{l}\text { - Интраоперационно во время } \\
\text { лапаротомии; } \\
\text { - Определение уровня амилазы и КТ в } \\
\text { динамике; } \\
\text { - МРТ, ЭРХПГ, интраоперационная } \\
\text { панкреатикография. }\end{array}$ \\
\hline $\begin{array}{l}\text { Лечение травм поджелудочной } \\
\text { железы: }\end{array}$ & $\begin{array}{l}\text { - Консервативное лечение - при } \\
\text { закрытой травме; } \\
\text { - Операция - при открытой травме. }\end{array}$ \\
\hline $\begin{array}{l}\text { Тактика при гематомах } \\
\text { поджелудочной железы: }\end{array}$ & $\begin{array}{l}\text { Ревизия гематомы, гемостаз, уточнение } \\
\text { наличия или отсутствия повреждений } \\
\text { протоковой системы. }\end{array}$ \\
\hline
\end{tabular}


Вопросы

Тактика при ранениях поджелудочной железы:

\section{Ответы}

- При повреждениях I, II степени дренирование;

- При повреждениях III степени дистальная панкреатотомия;

- При повреждениях IV степени некрэктомия, панкреатоеюностомия по типу Roux-en-Y;

- При повреждениях V степени панкреатодуоденальная резекция.

\section{Показания к операции при закрытой} травме поджелудочной железы:

Диагностика травм селезёнки:

Лечение при травмах селезёнки:

Диагностика при травмах мочеточников:
- Нестабильная гемодинамика;

- Большая и нарастающая гематома, перипанкреатическая жидкость по данным КT;

- Перитонит, абсцесс, псевдокиста;

- Невозможность исключения повреждений других органов.

- Интраоперационно;

- $\mathrm{KT}$.

- При стабильной гемодинамике динамическое наблюдение;

- При нестабильном состоянии пациента - срочная операция.

- КТ с контрастным усилением до операции;

- Во время операции - внутривенное введение индигокармина или внутриуретральное введение метиленового синего.

Варианты операций при травмах мочеточников:
- При повреждении нижней 1/3 реимплантация; 


\begin{tabular}{|c|c|}
\hline Bonpocbl & Ответы \\
\hline & 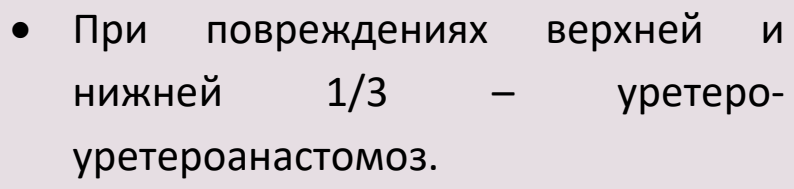 \\
\hline Диагностика травм мочевого пузыря: & $\begin{array}{l}\text { - Макрогематурия; } \\
\text { - Наличие жидкости в брюшной } \\
\text { полости при УзИ; } \\
\text { - КТ-цистография. }\end{array}$ \\
\hline $\begin{array}{l}\text { Лечение при травмах мочевого } \\
\text { пузыря: }\end{array}$ & $\begin{array}{l}\text { - При интраперитонеальных } \\
\text { экстравазациях - ушивание дефекта; } \\
\text { • При экстраперитонеальных } \\
\text { экстравазациях - консервативное } \\
\text { лечение. }\end{array}$ \\
\hline $\begin{array}{l}\text { Показания к фиксирующей операции } \\
\text { при травмах мочевого пузыря: }\end{array}$ & $\begin{array}{l}\text { - Неэффективность консервативного } \\
\text { лечения (катетеризации) в течение } 3 \\
\text { недель; } \\
\text { - Повреждение шейки мочевого } \\
\text { пузыря; } \\
\text { - Сопутствующие } \\
\text { прямой кишки и влагалища. }\end{array}$ \\
\hline $\begin{array}{l}\text { Диагностика повреждений } \\
\text { мочеиспускательного канала: }\end{array}$ & $\begin{array}{l}\text { - Выделение алой крови из уретры; } \\
\text { - Отёк и кровоизлияния мошонки; } \\
\text { - Определение гематомы при } \\
\text { ректальном исследовании; } \\
\text { - } \text { Ретроградная уретрография. }\end{array}$ \\
\hline $\begin{array}{l}\text { Лечение травм мочеиспускательного } \\
\text { канала: }\end{array}$ & $\begin{array}{l}\text { - Постоянная катетеризация в течение } \\
\text { 3-6 месяцев; } \\
\text { - Эпицистостома; } \\
\text { - Хирургическое восстановление. }\end{array}$ \\
\hline Лечение при травмах почек: & $\begin{array}{l}\text { - Органосохраняющее } \\
\text { консервативное лечение; }\end{array}$ \\
\hline
\end{tabular}




\begin{tabular}{|c|c|}
\hline Bonpocbl & Ответы \\
\hline & - Хирургическое лечение. \\
\hline $\begin{array}{l}\text { Показания к капсулотомии при } \\
\text { травмах почек: }\end{array}$ & $\begin{array}{l}\text { - Нарастающая и пульсирующая } \\
\text { периренальная гематома; } \\
\text { - Повреждение артерии; } \\
\text { - Авульсия почки. }\end{array}$ \\
\hline Лечение травм матки: & $\begin{array}{l}\text { - Гистерэктомия - при тяжёлых } \\
\text { травмах и деструкциях, при } \\
\text { кровотечениях и мёртвых плодах у } \\
\text { беременных; } \\
\text { - Строгое динамическое наблюдение } \\
\text { при беременности. }\end{array}$ \\
\hline
\end{tabular}

\section{СПИСОК ЛИТЕРАТУРЫ}

\section{Общая литература}

- $\quad$ Ağayev B.A. Cərrahi xəstəliklər. Bakı 2010.

- Blackbourne LH. Surgical Recall. 7 edition, 2014, LWW, Philadelphia

- Doherty GM. Current Diagnosis and Treatment: Surgery, $13^{\text {th }}$ edition, 2010, Lang International Edition.

- İsayev H.B. Cərrahi xəstəliklərin patofizologiyası. Bakı 2005

- Klingensmith ME, Aziz A, Bharat A, Fox AC, Porembka MR. The Washington Manual of Surgery, $6^{\text {th }}$ edition, 2012, LWW, Philadelphia.

- McNally PR. GI/Liver Secrets Plus. 4 edition. Mosby, Elsevier, 2010

- Medscape, http://www.medscape.com

- Oxford Handbook of Clinical Surgery, 3d edition, 2011, Oxford Press

- Sayek I. Sayek Temel Cerrahi 1-2. 4-cü baskı, 2016, Güneş Tıp Kitabevleri.

- Topçubaşov M.A. Xüsusi cərrahlıq. Bakı, 1979

- UpToDate, http://www.uptodate.com

- Гостищев B.К. Общая хирургия. GEOTAR-Media, 2019

\section{Специальная литература}

- American College of Surgeons. Advanced Trauma Life Support (Student Manual). American College of Surgeons 1997.

- Injury Scoring Scales - The American Association for the Surgery of Trauma. www.aast.org/library/traumatools/injuryscoringscales.aspx

- Kenneth Mattox, Ernest Moore, David Feliciano. Trauma. McGraw-Hill Education. 2017 


\section{ХИРУРГИЧЕСКИЕ БОЛЕЗНИ}

Н.Ю. Байрамов

\section{Реанимация}

Н.Ю. Байрамов, А.М. Ахмадов, Ф.Ф. Ахмадов

Перевод: Н.Ю. Байрамов, С.А. Алиев, М.Р. Гусейнова 
- Под термином «критическое состояние» подразумевают дисфункцию органов и систем которые обеспечивают жизненно важные процесы, таких как, газообмена, водно-электролитного, энергетического и теплового баланса.

- Органная дисфункция - неспособность какого-либо органа адекватно выполнять свою функцию.

- Тяжёлое состояние, при котором возникает необходимость в заместительной и корригирующей терапии, называется органной недостаточностью.

- Основными нозологическими причинами критических состояний в хирургии являются шок, сепсис, кома, тяжелые травмы, дыхательная, почечная и печёночная недостаточности, системная коагулопатия.

- Диагностические и лечебно-тактические мероприятия при критических состояниях основаны на неотложности, стабилизации (обеспечение оксигенации), пошаговом лечении, мониторинге, принципах синдромного подхода (сначала определяется синдром, затем - причина).

\section{Вопросы и ответы по критическим состояниям}

\begin{tabular}{|c|c|}
\hline Вопросы & Ответы \\
\hline Что такое критическое состояние? & $\begin{array}{l}\text { Опасная для жизни дисфункция органов } \\
\text { и риск дисфункции. }\end{array}$ \\
\hline Что такое органная дисфункция? & $\begin{array}{l}\text { Неспособность какого-либо органа } \\
\text { адекватно выполнять свою функцию. }\end{array}$ \\
\hline Что такое органная недостаточность? & $\begin{array}{l}\text { Тяжёлая дисфункция, при котором } \\
\text { возникает веобходимость } \\
\text { заместительной и корригирующей } \\
\text { терапии. }\end{array}$ \\
\hline
\end{tabular}




\begin{tabular}{|c|c|}
\hline Что такое реанимация? & $\begin{array}{l}\text { Комплекс мероприятий по оживлению } \\
\text { организма и восстановлению функций } \\
\text { органов и систем. }\end{array}$ \\
\hline Что такое интенсивная терапия? & $\begin{array}{l}\text { Заместительная терапия } \text { для } \\
\text { временного поддержания функций } \\
\text { органов и систем. }\end{array}$ \\
\hline Что такое мониторинг? & $\begin{array}{l}\text { Динамическое заблюдение за } \\
\text { состоянием органов посредством } \\
\text { клинических и лабораторных данных и } \\
\text { параметров специальных аппаратур. }\end{array}$ \\
\hline $\begin{array}{l}\text { Что относится к нозологическим } \\
\text { причинам критических состояний? }\end{array}$ & $\begin{array}{lr}\text { Тяжёлые } & \text { состояния, } \\
\text { сопровождающиеся } & \text { нарушением } \\
\text { газообмена, водно-электролитного и } \\
\text { энергетического } \\
\text { термодинамики: шок, сепсис, кома, } \\
\begin{array}{l}\text { тяжелые травмы, } \\
\text { почечная } \\
\text { недостаточности, } \\
\text { коагулопатия. }\end{array} \\
\text { печёночная } \\
\text { системная }\end{array}$ \\
\hline Что такое «большой порочный круг»? & $\begin{array}{l}\text { Дыхательная, гемодинамическая или } \\
\text { мозговая недостаточность приводит к } \\
\text { развитию гипоксии, что в свою очередь } \\
\text { также является причиной этих } \\
\text { состояний. }\end{array}$ \\
\hline $\begin{array}{l}\text { Клинические проявления критических } \\
\text { состояний? }\end{array}$ & $\begin{array}{l}\text { - Отсутствие сознания и неадекватная } \\
\text { коммуникабельность, сонливость; } \\
\text { - Нарушение дыхания } \\
\text { (поверхностное, хриплое, тяжёлое), } \\
\text { одышка, цианоз; } \\
\text { - Тахикардия, аритмия, холодный пот, } \\
\text { гипотензия, ортостатический } \\
\text { коллапс, кровотечение; }\end{array}$ \\
\hline
\end{tabular}




\begin{tabular}{|c|c|}
\hline & $\begin{array}{l}\text { - Высокая температура, отёки, } \\
\text { олигурия, напряжённый живот. }\end{array}$ \\
\hline $\begin{array}{l}\text { Что такое стабилизация показателей } \\
\text { жизнеобеспечения? }\end{array}$ & $\begin{array}{l}\text { Заместительная } \\
\begin{array}{l}\text { восстановлению } \\
\text { нарушений и поддержанию функций } \\
\text { жизнеобеспечения } \\
\text { гемодинамики, мозга). }\end{array}\end{array}$ \\
\hline $\begin{array}{l}\text { Показатели стабилизации функции } \\
\text { жизнеобеспечения: }\end{array}$ & $\begin{array}{l}\text { Стабильность гемодинамики, } \\
\text { нормализация лабораторных } \\
\text { показателей (рh крови }-7,4 \text {, лактат), } \\
\text { восстановление функции почек (диурез } \\
\text { у взрослых - 0,5-1 мл/кг/4, у детей - 1-2 } \\
\text { мл/кг/ч). }\end{array}$ \\
\hline $\begin{array}{l}\text { Что представляет собой этапное и } \\
\text { пошаговое лечение? }\end{array}$ & $\begin{array}{l}\text { Алгоритм АВCDE: } \\
\text { • А - проходимость дыхательных } \\
\text { путей; } \\
\text { • В-дыхание; } \\
\text { - } \text { С-кровообращение; } \\
\text { - D-неврологический статус; } \\
\text { - Е-внешний вид. }\end{array}$ \\
\hline $\begin{array}{l}\text { Что представляет собой коррекция } \\
\text { синдромных нарушений? }\end{array}$ & 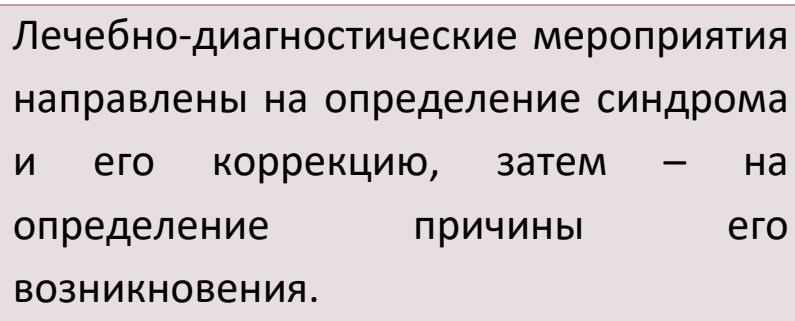 \\
\hline $\begin{array}{l}\text { Какие показатели должны быть } \\
\text { мониторизированы при критических } \\
\text { состояниях? }\end{array}$ & $\begin{array}{l}\text { - Температура тела; } \\
\text { - } \text { ЭКг; } \\
\text { - Артериальное давление; } \\
\text { - Центральное венозное давление; } \\
\text { - Пульсоксиметрия; } \\
\text { - Капнография; }\end{array}$ \\
\hline
\end{tabular}


- Ш Шала комы Глазго;

- Общий анализ крови;

- Диурез;

- Анализ газового состава крови;

- Креатинин;

- Глюкоза в крови;

- Печёночные пробы. 


\section{ДЫХАТЕЛЬНАЯ НЕДОСТАТОЧНОСТЬ}

- Нарушение жизненно важной функции лёгких, которая заключается в газообмене кислорода и углекислого газа, называется синдромом дыхательной недостаточности.

- Основными нозологическими причинами дыхательной недостаточности являются факторы, приводящие к нарушению лёгочной вентиляции (обструкция воздухоносных путей, патологии нервной системы и грудной клетки, снижение эластичности лёгочной ткани и т. д.) и альвеолярно-капиллярного обмена (сердечная недостаточность, эмболии, отёк лёгких, острый респираторный дистресс-синдром, пневмония и т. д.)

- Клиническая картина характеризуется гипоксией (тревожность, сонливость, цианоз, снижение сатурации), гиперкапнией (тахикардия, гипертензия, диафорез, одышка) и повышением активности вспомогательных дыхательных мышц (ретракция, парадоксальное дыхание).

- Диагноз определяется на основании клинической картины, уточняется по результатам анализа газового состава крови: парциальное давления кислорода (<60 мм рт. ст.), парциальное давления углекислого газа (>50 мм рт. ст.), гипоксемия, гиперкапния и повышение активности вспомогательных дыхательных мышц.

- Различают 2 клинико-патогенетические формы дыхательной недостаточности: гипоксемический тип и гиперкапнический тип.

О Гипоксемический тип дыхательной недостаточности характеризуется снижением оксигенации крови, основной причиной которой является повреждение лёгочной ткани и нарушение процессов диффузии и перфузии в альвеолярно-капиллярной системе (истинная лёгочная недостаточность).

- Характерным признаком является высокий градиент кислорода в альвеолярном воздухе и крови (разница составляет более 15 мм рт. ст.): парциальное давление кислорода в крови снижается, а углекислого газа остаётся в норме или понижено, рН - в пределах нормы $(7,3-7,4)$.

- Если гипоксемия корректируется после кислородной терапии, то определяется нарушение вентиляционного градиента, а если коррекция не наблюдается - возникает подозрение на наличие шунта. 
○ Гиперкапнический тип дыхательной недостаточности характеризуется повышением содержания углекислого газа в крови и гипоксиемией.

- Основными механизмами являются гиповентиляция и повышение синтеза углекислого газа.

- В отличие от гипоксемической формы, при этой разница кислорода в альвеолярном воздухе и артериальной крови не повышается и остаётся в пределах нормы (менее 15 мм рт. ст.)

- Лечение острой дыхательной недостаточности проводится в 2 этапа: на первом этапе обеспечивается оксигенация по алгоритму ABCDE (восстановление проходимости дыхательных путей, достаточная оксигенация, вентиляция, кровообращение, адекватные мозговые функции). На втором этапе уточняются клиническая форма и причины.

- Коррекция вентиляции является основных моментом как при гипоксемической, так и при гиперкапнической дыхательной недостаточности. Самым эффективным методом коррекции является механическая вентиляция.

- $\mathrm{K}$ показаниям для проведения механической вентиляции лёгких относятся тяжёлая гипоксемия $\left(\mathrm{PaO}_{2}<55\right.$ мм рт. ст.), тяжёлая гиперкапния $\left(\mathrm{PaCO}_{2}>50 \mathrm{Mm}\right.$ рт.ст.), тяжёлый дыхательный ацидоз (рH $\leqq 7,3)$, тахипноэ $\geqq 35$, бессознательное состояние, повышенная активность дыхательных мышц.

\section{Вопросы и ответы по дыхательной недостаточности}

\begin{tabular}{|ll|}
\hline \multicolumn{1}{|c|}{ Вопросы } & \multicolumn{1}{c|}{ Ответы } \\
\hline $\begin{array}{l}\text { Что такое дыхательная } \\
\text { недтаточность? }\end{array}$ & $\begin{array}{l}\text { Уменьшение оксигенации и выделения } \\
\text { углекислого газа. }\end{array}$ \\
\hline $\begin{array}{l}\text { Какие механизмы обеспечивают } \\
\text { оксигенацию крови? }\end{array}$ & $\begin{array}{l}\text { Альвеолярная } \\
\text { альвеолярно-капиллярная диффузия. }\end{array}$ \\
\hline $\begin{array}{l}\text { Какие механизмы обеспечивают } \\
\text { выведения углекислого газа? }\end{array}$ & $\begin{array}{l}\text { Альвеолярная вентиляция и почечная } \\
\text { фильтрация. }\end{array}$ \\
\hline $\begin{array}{l}\text { Основные механизмы дыхательной } \\
\text { недостаточности: }\end{array}$ & $\begin{array}{l}\text { Гиповентиляция, снижение } \\
\text { вентиляционно- перфузионного }\end{array}$ \\
\hline
\end{tabular}




\begin{tabular}{|c|c|}
\hline Вопросы & Ответы \\
\hline & $\begin{array}{l}\text { соотнощения (V/Q), наличие обходного } \\
\text { шунта. }\end{array}$ \\
\hline $\begin{array}{l}\text { Клинические формы дыхательной } \\
\text { недостаточности: }\end{array}$ & $\begin{array}{l}\text { - Гипоксиемическая; } \\
\text { • Гиперкапническая. }\end{array}$ \\
\hline $\begin{array}{l}\text { Механизм гипоксиемической } \\
\text { дыхательной недостаточности: }\end{array}$ & $\begin{array}{l}\text { Наличие шунта, нарушения } \\
\text { вентиляционно-перфузионного } \\
\text { соотнощения. }\end{array}$ \\
\hline $\begin{array}{l}\text { Механизмы гиперкапнической } \\
\text { дыхательной недостаточности: }\end{array}$ & $\begin{array}{l}\text { Альвеолярная гиповентиляция, } \\
\text { повышение синтеза углекислого газа. }\end{array}$ \\
\hline $\begin{array}{l}\text { Что означает нарушение } \\
\text { вентиляционно-перфузионного } \\
\text { соотношения? }\end{array}$ & $\begin{array}{l}\text { Вентиляционно- перфузионное } \\
\text { соотнощение показывает (V/Q) } \\
\text { площадь лёгочной поверхности, } \\
\text { которая участвует в газообмене. } \\
\text { Низкий V/Q означает, что кровь } \\
\text { протекает через участок лёгочной } \\
\text { поверхности со слабой вентиляцией. }\end{array}$ \\
\hline Что такое шунт? & $\begin{array}{l}\text { Циркуляция крови в невентилируемом } \\
\text { участке лёгкого. }\end{array}$ \\
\hline $\begin{array}{l}\text { Возможно ли нормальное } \mathrm{PaO}_{2} \text { при } \\
\text { гиперкапнии? }\end{array}$ & $\begin{array}{lr}\text { Возможно: при } & \text { оксигенотерапии } \\
\text { пациентов } & \text { с } \\
\text { гипертермическим } & \text { сепсисом, } \\
\text { хроническими } & \text { синдромом, } \\
\text { заболеваниями лёгких, перееданием. }\end{array}$ \\
\hline $\begin{array}{l}\text { Причины дыхательной } \\
\text { недостаточности в } \\
\text { послеоперационном периоде: }\end{array}$ & $\begin{array}{l}\text { Гиповентиляция, связанная с болевым } \\
\text { синдромом и применением наркотиков } \\
\text { и миорелаксантов. } \\
\text { Альвеолярно-капилярная дисфункция, } \\
\text { связанная с отёком лёгких при } \\
\text { инфузионной терапии и SIRS. }\end{array}$ \\
\hline
\end{tabular}




\begin{tabular}{|c|c|}
\hline Вопросы & \\
\hline $\begin{array}{l}\text { Чем объясняется возможность } \\
\text { развития дыхательной } \\
\text { недостаточности при подаче } \\
\text { кислорода пациентам с хроническим } \\
\text { обструктивным заболеванием лёгких? }\end{array}$ & $\begin{array}{lr}\text { Оксигенация } & \text { способствует } \\
\text { нормализации } & \text { концентрации } \\
\text { кислорода в крови, что может } \\
\text { сопровождаться } \\
\text { стимуляции дыхательного центра, что } \\
\text { приводит к гиповентиляции. }\end{array}$ \\
\hline $\begin{array}{l}\text { Клинические признаки дыхательной } \\
\text { недостаточности: }\end{array}$ & $\begin{array}{l}\text { - Гипоксиемия; } \\
\text { - Гиперкапния; } \\
\text { - Повышение } \\
\text { вспомогательных } \\
\text { мышц. }\end{array}$ \\
\hline Уточнение диагноза: & Анализ газового состава крови. \\
\hline $\begin{array}{l}\text { Что представляет собой анализ } \\
\text { газового состава крови? }\end{array}$ & $\begin{array}{l}\text { Определение газового состава } \\
\text { артериальной крови. }\end{array}$ \\
\hline $\begin{array}{l}\text { Какими показателями определяется } \\
\text { газовый состав артериальной крови? }\end{array}$ & $\begin{array}{l}\mathrm{pH}, \mathrm{PaO}_{2}, \mathrm{PaCO}_{2}, \text { буферный дефицит, } \\
\mathrm{HCO}_{2} \text {. }\end{array}$ \\
\hline $\begin{array}{l}\text { Клиническое значение определения } \\
\text { газового состава венозной крови: }\end{array}$ & Определение рН крови. \\
\hline $\begin{array}{l}\text { Цель механической вентиляции } \\
\text { лёгких? }\end{array}$ & $\begin{array}{l}\text { Обеспечение альвеолярной } \\
\text { вентиляции, повышение количества } \\
\text { функциональных альвеол, снижение } \\
\text { работы дыхательных мышц. }\end{array}$ \\
\hline $\begin{array}{l}\text { Показания к проведению } \\
\text { механической вентиляции лёгких: }\end{array}$ & $\begin{array}{l}\text { - Бессознательное состояние; } \\
\text { - Повышенная активность } \\
\text { дыхательных мышц; } \\
\text { - Тяжёлая гипоксемия }\left(\mathrm{PaO}_{2}<55 \text { мм }\right. \\
\text { рт. ст.); } \\
\text { - Тяжёлая гиперкапния }\left(\mathrm{PaCO}_{2}>50 \text { мм }\right. \\
\text { рт.ст.); }\end{array}$ \\
\hline
\end{tabular}




\begin{tabular}{|c|c|}
\hline Вопросы & Ответы \\
\hline & $\begin{array}{l}\text { - Тяжёлый дыхательный ацидоз (рН } \\
\leqq 7,3) ; \\
\text { - Тахипноэ } \geqq 35 \text {. }\end{array}$ \\
\hline $\begin{array}{l}\text { Какие параметры должны } \\
\text { учитываться при механической } \\
\text { вентиляции лёгких? }\end{array}$ & $\begin{array}{l}\text { - Фракция кислорода во вдыхаемом } \\
\text { воздухе; } \\
\text { - Объём вентиляции; } \\
\text { - Вентиляционное давление; } \\
\text { - Частота вентиляции; } \\
\text { - Соотношение между вдохом и } \\
\text { выдохом; } \\
\text { - Режим вентиляции; } \\
\text { - Седация. }\end{array}$ \\
\hline Цель оксигенации: & $\mathrm{PaO}_{2} \geq 60$ мм рт.ст., $\mathrm{SpO}_{2} \geq 92 \%$. \\
\hline $\begin{array}{l}\text { Какие параметры являются наиболее } \\
\text { значимыми при коррекции } \\
\text { оксигенации? }\end{array}$ & $\begin{array}{l}\text { - Фракция кислорода во вдыхаемом } \\
\text { воздухе; } \\
\text { • Вентиляционное давление; } \\
\text { - Время вдоха (продолжительность). }\end{array}$ \\
\hline $\begin{array}{l}\text { Чем объясняется повышение } \\
\text { оксигенации при повышении } \\
\text { вентиляционного давления? }\end{array}$ & $\begin{array}{ll}\text { В связи с } & \text { расправлением } \\
\text { коллабированного } & \text { лёгкого } \\
\text { увеличением } & \text { диффузионной } \\
\text { поверхности. } & \end{array}$ \\
\hline $\begin{array}{l}\text { Критерий коррекции углекислого газа } \\
\text { в выдыхаемом воздухе? }\end{array}$ & $\mathrm{PaCO}_{2} \leq 50$ мм рт.ст. \\
\hline $\begin{array}{l}\text { Какие параметры являются наиболее } \\
\text { значимыми при коррекции } \\
\text { углекислого газа в выдыхаемом } \\
\text { воздухе? }\end{array}$ & $\begin{array}{l}\text { - Объём вентиляции; } \\
\text { - Частота вентиляции. }\end{array}$ \\
\hline $\begin{array}{l}\text { Чем объясняется повышение } \\
\text { сатурации при оксигенации? }\end{array}$ & $\begin{array}{l}\text { Наличием гиповентиляции и нарушения } \\
\text { V/Q. }\end{array}$ \\
\hline
\end{tabular}




\begin{tabular}{|ll|}
\multicolumn{1}{|c|}{ Вопросы } & \multicolumn{1}{c|}{ Ответы } \\
Чем объясняется отсутстви & Обструкция воздухоносных путей, \\
$\begin{array}{l}\text { востановления сатурации несмотря на } \\
\text { проведение оксигенации? }\end{array}$ & $\begin{array}{l}\text { тяёлые повреждения лёгких, тяжёлая } \\
\text { гиповентиляция, наличие шунта. }\end{array}$ \\
\hline $\begin{array}{l}\text { Чем объясняется повышение } \\
\text { концентрации углекислого газа при } \\
\text { оксигенации? }\end{array}$ & $\begin{array}{l}\text { Гиповентиляция, } \\
\text { оксигенотерапией. }\end{array}$ \\
\hline Что такое РЕЕР? & \\
& $\begin{array}{l}\text { Положительное } \\
\text { давление в конце вдоха. }\end{array}$ \\
\hline Что такое СРАР? & Режим искусственной вентиляции \\
& лёгких постоянным положительным \\
& давлением. \\
\hline
\end{tabular}




\section{ШOK}

- Шок - это гипоперфузия, т. е. острая недостаточность кровообращения, последствием которой является снижение доставки кислорода тканям.

- Частичная или полная гипоксия, которая возникает вследствие гипоперфузии, приводит к нарушению клеточного метаболизма и дисфункции органов (ацидоз, отёк, эндотелиальное повреждение, SIRS - сепсис).

- Ведущими механизмами шока являются уменьшение объёма циркулирующей крови, резкое снижение сердечной деятельности и системная вазодилатация.

- Различают 4 клинические формы шока: гиповолемический, кардиогенный, вазомоторный и септический.

- Шок, как правило, возникает остро на фоне заболеваний или травмы, проявляется тахикардией, одышкой, гипотензией. За короткий промежуток времени может развиться органная дисфункция, которая при отсутствии соответствующего лечения приводит к полиорганной недостаточности и летальному исходу.

- Диагностика шока основывается на 3-х клинических критериях: причина шока (травма, заболевание), гемодинамические признаки (тахикардия, гипотензия, ортостатический коллапс) и признаки гипоперфузии (холодный пот, олигурия, задержка капиллярного наполнения, нарушение сознание, метаболический ацидоз, повышение лактата).

- Лечение шока начинается немедленно; основными принципами являются оксигенация, инфузионная терапия, устранение причины и трансфузия в соответствии с показаниями.

О При лечении гиповолемического шока основные меры направлены на остановку кровообращения и восстановления объёма циркулирующей крови.

○ При кардиогенном шоке важно восстановить функцию сердцу.

○ Инфузионная терапия и вазопрессоры (фенилефрин, норадреналин) являются основными методами лечения нейрогенного шока.

О При септическом шоке важными мерами являются инфузионная терапия, вазопрессоры, антибиотики и устранение причины. 


\section{Вопросы и ответы по шоку}

\begin{tabular}{|ll|}
\hline \multicolumn{1}{c|}{ Вопросы } & \multicolumn{1}{c}{ Ответы } \\
\hline Что такое шок? & $\begin{array}{l}\text { Гипоперфузия (микроциркуляторная } \\
\text { недостаточность). }\end{array}$ \\
\hline Патогенез: & Нозологическая причина \\
& гипоперфузия $\rightarrow$ гипоксия $\rightarrow$ нарушение \\
& клеточного метаболизма $\rightarrow$ системные \\
& повреждения (сепсис, ацидоз и др.)
\end{tabular}




\begin{tabular}{|c|c|}
\hline Вопросы & Ответы \\
\hline & 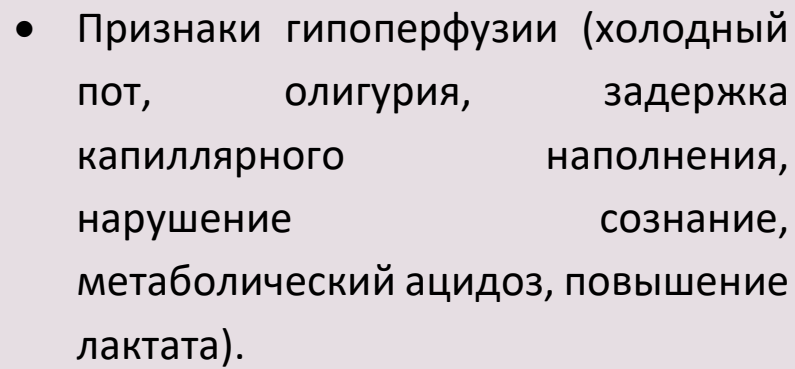 \\
\hline $\begin{array}{l}\text { Клинически значимые показатели } \\
\text { перфузии: }\end{array}$ & Диурез, сознание. \\
\hline Лабораторные показатели перфузии: & pH, лактат. \\
\hline Кардинальный признак шока: & Тахикардия. \\
\hline $\begin{array}{l}\text { Возможно ли отсутствие тахикардии } \\
\text { при шоке? }\end{array}$ & $\begin{array}{l}\text { Возможно при спинальном блоке, } \\
\text { приёме бета-адреноблокаторов, } \\
\text { повреждении вегетативной нервной } \\
\text { системы (диабет), успортсменов. }\end{array}$ \\
\hline Возможна ли нормотония при шоке? & Возможно в компенсаторной фазе. \\
\hline $\begin{array}{l}\text { Основные лечебные мероприятия, } \\
\text { проводимые при шоке: }\end{array}$ & $\begin{array}{l}\text { Оксигенация, инфузионная терапия, } \\
\text { устранение причины. }\end{array}$ \\
\hline Что такое гиповолемический шок? & $\begin{array}{l}\text { Шок, обусловленный дефицитом } \\
\text { объёма циркулирующей крови. }\end{array}$ \\
\hline Причины гиповолемического шока: & $\begin{array}{l}\text { - Острая кровопотеря; } \\
\text { - Плазмопотеря (термические ожоги, } \\
\text { кишечная непроходимость, } \\
\text { панкреатит, дегидратация). }\end{array}$ \\
\hline \multirow[t]{2}{*}{ Ранние клинические признаки: } & $\begin{array}{l}\text { Тахикардия, тахипноэ, ортостатическая } \\
\text { гипотония, } \\
\text { тревожность, }\end{array}$ \\
\hline & $\begin{array}{l}\text { вазоконстрикция } \quad \text { (холодный пот, } \\
\text { пониженное пульсовое давление). }\end{array}$ \\
\hline
\end{tabular}




\begin{tabular}{|c|c|}
\hline Вопросы & Ответы \\
\hline Поздние клинические признаки: & $\begin{array}{l}\text { Гипотензия, спутанность сознания, } \\
\text { тахикардия, органная дисфункция. }\end{array}$ \\
\hline Что такое ортостатическая гипотония? & $\begin{array}{l}\text { Снижение артериального давления } \\
\text { более чем на } 15 \text { мм рт. ст. при переходе } \\
\text { из положения лёжа в сидячее } \\
\text { (вертикальное). }\end{array}$ \\
\hline $\begin{array}{l}\text { Что такое ортостатическая тахикар- } \\
\text { дия? }\end{array}$ & $\begin{array}{l}\text { Повышение частоты пульса более чем } \\
\text { на } 20 \text { при переходе из положения лёжа } \\
\text { в сидячее (вертикальное). }\end{array}$ \\
\hline $\begin{array}{l}\text { Чем объясняется снижение } \\
\text { пульсового давления при шоке? }\end{array}$ & В связи с вазоспазмом. \\
\hline Что такое кровопотеря I степени? & $\begin{array}{l}\text { Дефицит объёма циркулирующей крови } \\
\text { (Оцк) составляет менее } 15 \% \text { от } \\
\text { исходного, нет клинических симптомов } \\
\text { или есть ортостатическая тахикардия. }\end{array}$ \\
\hline Что такое кровопотеря II степени? & $\begin{array}{l}\text { Дефицит ОЦК - 20-25\%, ортостатическая } \\
\text { тахикардия, диурез в норме. }\end{array}$ \\
\hline Что такое кровопотеря III степени? & $\begin{array}{l}\text { Дефицит ОцК - 30-40\%, гипотензия, } \\
\text { олигурия. }\end{array}$ \\
\hline Что такое кровопотеря IV степени? & $\begin{array}{l}\text { Дефицит Оцк более } 40 \% \text {, нарушение } \\
\text { мозгового } \\
\text { расстройство сознания, кома. }\end{array}$ \\
\hline Лечение: & $\begin{array}{l}\text { Остановка кровотечения, адекватная и } \\
\text { полноценная коррекция гиповолемии и } \\
\text { ОцК - инфузия, трансфузия. }\end{array}$ \\
\hline $\begin{array}{l}\text { Что является клинически более } \\
\text { значимым: ОЦК или гемоглобин? }\end{array}$ & ОЦК. \\
\hline
\end{tabular}




\begin{tabular}{|c|c|}
\hline Bonросы & Ответы \\
\hline \multirow[t]{2}{*}{ Начальный объём инфузии: } & 1-2 литра (20-30 мл/кг) тёплого раствора \\
\hline & $\begin{array}{l}\text { Рингер Лактата или } 4 \text { мл/кг } \\
\text { гипертонического раствора. }\end{array}$ \\
\hline Показания к гемотрансфузии: & $\begin{array}{l}\text { - Отсутствие коррекции } \\
\text { артериального давления после } \\
\text { инфузии } 2 \text { л кристаллоидов; } \\
\text { - Кровопотеря III-IV степени; } \\
\text { - Снижение уровня гемоглобина } \\
\text { более чем на 50\%. }\end{array}$ \\
\hline $\begin{array}{l}\text { При гемотрансфузии переливают } \\
\text { цельную кровь или эритроцитарную } \\
\text { массу? }\end{array}$ & Эритроцитарную массу. \\
\hline $\begin{array}{l}\text { Кровь какой группы переливают если } \\
\text { неизвестна группа крови пациента? }\end{array}$ & $\mathrm{O}(\mathrm{I}) \mathrm{Rh}(-)$. \\
\hline Что такое необратимый шок? & $\begin{array}{l}\text { Несмотря на реанимационные меры } \\
\text { невозможность коррекции ОцК и } \\
\text { кровообращения и летальный исход. }\end{array}$ \\
\hline Причины необратимого шока: & $\begin{array}{l}\text { Продолжающаяся } \\
\text { кровопотеря. }\end{array}$ \\
\hline $\begin{array}{l}\text { Что является критериями } \\
\text { эффективности противошоковой } \\
\text { терапии? }\end{array}$ & $\begin{array}{l}\text { - Клинически - пульс, давление, } \\
\text { диурез, сознание, температура, } \\
\text { капиллярное наполнение; } \\
\text { - Лабораторно-рН, лактат, буферный } \\
\text { дефицит. }\end{array}$ \\
\hline $\begin{array}{l}\text { Показатели стабилизации } \\
\text { гемодинамики: }\end{array}$ & $\begin{array}{l}\text { - } \text { рН крови-7,4; } \\
\text { - Восстановление уровня лактата, } \\
\text { буферной системы; } \\
\text { - Восстановление диуреза: у взрослых } \\
-0,5-1 \text { мл/кг/ч; у детей-1-2 мл/кг/ч. }\end{array}$ \\
\hline
\end{tabular}




\begin{tabular}{|c|c|}
\hline Вопросы & Ответы \\
\hline $\begin{array}{l}\text { Причины неэффективности } \\
\text { противошоковой терапии: }\end{array}$ & 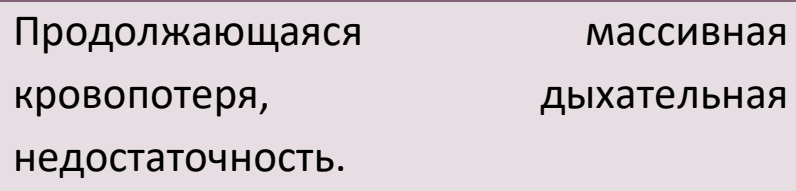 \\
\hline $\begin{array}{l}\text { Применяются ли вазопрессоры при } \\
\text { гиповолемическом шоке? }\end{array}$ & Нет. \\
\hline $\begin{array}{l}\text { Положение пациента при } \\
\text { гиповолемическом шоке: }\end{array}$ & Положение Тренделенбурга. \\
\hline Что такое септический шок? & $\begin{array}{l}\text { Гипотония и гиперлактатемия у } \\
\text { пациентов с сепсисом (инфекция + } \\
\text { органная дисфункция), которая не } \\
\text { корректируется несмотря на } \\
\text { адекватную инфузионную терапию и } \\
\text { требующая применения вазопрессоров. }\end{array}$ \\
\hline Частые причины: & $\begin{array}{l}\text { Заболевания, при которых развивается } \\
\text { сепсис, в том числе инфекции брюшной, } \\
\text { грудной полостей и мягких тканей. }\end{array}$ \\
\hline Лечение: & $\begin{array}{l}\text { Инфузионная терапия, вазопрессоры, } \\
\text { антибиотики, устранение причины. }\end{array}$ \\
\hline Что такое кардиогенный шок? & $\begin{array}{l}\text { Гипоперфузия, связанная с острой } \\
\text { сердечной недостаточностью. }\end{array}$ \\
\hline Причины: & $\begin{array}{l}\text { - Повреждение и дисфункция } \\
\text { миокарда (инфаркт миокарда, } \\
\text { мышечная дисфункция, ушиб } \\
\text { сердца, клапанная недостаточность); } \\
\text { - Сдавление сердца (тампонада, } \\
\text { напряжённый пневмоторакс). }\end{array}$ \\
\hline $\begin{array}{l}\text { Ведущий патогенетический механизм } \\
\text { при кардиогенном шоке: }\end{array}$ & $\begin{array}{l}\text { Критическое уменьшение ударного } \\
\text { объёма сердца (сердечного выброса). }\end{array}$ \\
\hline
\end{tabular}




\begin{tabular}{|c|c|}
\hline Вопросы & Ответы \\
\hline Клинические признаки: & $\begin{array}{l}\text { Тахикардия, одышка, гипотензия, } \\
\text { расширение вен шеи, хрипы в лёгких, } \\
\text { олигурия. }\end{array}$ \\
\hline Диагностика: & ЭхоКГ. \\
\hline Лечение: & $\begin{array}{l}\text { Этиотропное: } \\
\text { • При сдавлении - пункционная } \\
\text { декомпрессия; } \\
\text { - При инфаркте миокарда - } \\
\text { применение инотропов } \\
\text { вазодилататоров; } \\
\text { - При хронической недостаточности - } \\
\text { применение диуретиков, } \\
\text { вазодилататоров, инотропов. }\end{array}$ \\
\hline $\begin{array}{l}\text { Какие меры проводятся при } \\
\text { отсутствии эффекта от вышеуказанных } \\
\text { мероприятий? }\end{array}$ & $\begin{array}{l}\text { - Интрааортальная установка } \\
\text { баллона; } \\
\text { - Имплантация } \\
\text { сердца. }\end{array}$ \\
\hline Что такое вазомоторный шок? & $\begin{array}{lr}\text { Гипоперфузия, обусловленная } \\
\begin{array}{l}\text { вазодилатацией и } \\
\text { венозного снижением } \\
\text { недостаточность). }\end{array} & \text { (сосудистая } \\
& \end{array}$ \\
\hline Основные причины: & $\begin{array}{l}\text { Сепсис, SIRS, } \\
\begin{array}{l}\text { повреждение анафилаксия, } \\
\text { надпочечниковая } \\
\text { недостаточность. }\end{array}\end{array}$ \\
\hline $\begin{array}{l}\text { Основной патогенетический } \\
\text { механизм: }\end{array}$ & Снижение венозного возврата. \\
\hline
\end{tabular}




\begin{tabular}{|ll|}
\hline \multicolumn{1}{|c|}{ Вопросы } & \multicolumn{1}{c}{ Ответы } \\
Что такое нейрогенный шок? & $\begin{array}{l}\text { Наряду с гипотензией отмечаются } \\
\text { брадикардия, снижение тонуса прямой } \\
\text { кишки. }\end{array}$ \\
\hline Лечение: & $\begin{array}{l}\text { Инфузионная терапия с применением } \\
\text { вазопрессоров. }\end{array}$ \\
\hline
\end{tabular}




\section{ДИСФУНКЦИИ МОЗГА}

- Под дисфункцией мозга подразумевают нарушение управленческой и координирующей функции центральной нервной системы.

- Клинически проявляется в виде нескольких форм. В диагностике большую роль играет клиническое обследование.

- Агитация проявляется признаками тревоги и беспокойства при сохранности сознания.

○ Для профилактики и лечения этого состояния применяют бензодиазепины (мидазолам, лоразепам), пропофол и дексмедетомидин.

- Делириозное состояние характеризуется бредом, галлюцинациями.

○ Для лечения данного состояния используют галоперидол.

- Кома - полное отсутствие реакции на любой вид раздражения, в том числе болевое (недостаточность мозга).

○ В отличие от состояния мозговой смерти при коме некоторые функции стволовых структур (в особенности, функция дыхания) сохраняются.

○ Диагноз основан на клинической симптоматике - пациент без сознания, не реагирует на словесные и болевые раздражения, степень тяжести по шкале Глазго соответствует 8-3 баллу.

○ Состояние требует применения искусственной вентиляции лёгких, адекватной коррекции кровообращения и устранения причины.

- Мозговая смерть - необратимое поражение мозга и его стволовых структур.

- Характеризуется отсутствием всех условных и безусловных рефлексов, параличом дыхательного центра.

\section{Вопросы и ответы по дисфункциям мозга}

\begin{tabular}{ll}
\multicolumn{2}{c}{ Вопросы } \\
Как оценивается активность мозговой & По адекватности словесного и \\
деятельности? & тактильного контакта, качеству \\
& ориентации по месту и времени, \\
& уровню интеллектуального анализа.
\end{tabular}




\begin{tabular}{|c|c|}
\hline Bonpocbl & Ответы \\
\hline $\begin{array}{l}\text { Какими критериями оценивают } \\
\text { активность мозга у реанимационных } \\
\text { больных? }\end{array}$ & $\begin{array}{l}\text { - Состояние сознания; } \\
\text { - Моторная реакция на словесное и } \\
\text { болевое раздражения; } \\
\text { - Рефлексы стволовых структур. }\end{array}$ \\
\hline Что такое агитация? & $\begin{array}{l}\text { Беспокойство и тревога при } \\
\text { сохранности сознания. }\end{array}$ \\
\hline Причины: & Боль и психологическое воздействие. \\
\hline Лечение: & $\begin{array}{l}\text { Препараты из группы безодиазепинов, } \\
\text { пропофол, дексмедетомидин. }\end{array}$ \\
\hline Что такое делириозное состояние? & Проявляется бредом и галлюцинацией. \\
\hline Причины: & $\begin{array}{l}\text { Алкоголизм, отмена наркотиков, } \\
\text { гипоксия, токсикоз. }\end{array}$ \\
\hline Лечение: & Галоперидол. \\
\hline Что такое кома? & $\begin{array}{lr}\text { Недостаточность } & \text { функции мозга, } \\
\text { характеризующаяся } & \text { отсутствием } \\
\text { реакции на все виды раздражения. }\end{array}$ \\
\hline Диагностика: & $\begin{array}{l}\text { Диагноз основан на клинической } \\
\text { симптоматике - отсутствие реакций на } \\
\text { словесное и болевой раздражения, } \\
\text { степень тяжести соответствует 8-3 баллу } \\
\text { по шкале Глазго. }\end{array}$ \\
\hline Лечение: & $\begin{array}{l}\text { Защита мозга от вторичных } \\
\text { повреждений (интубация, вентиляция, } \\
\text { адекватная } \\
\text { кровообращения), } \\
\text { нозологических причин и их коррекция. }\end{array}$ \\
\hline Что такое смерть мозга? & $\begin{array}{l}\text { Необратимое поражение корковых и } \\
\text { стволовых } \\
\begin{array}{l}\text { Характеризтур } \\
\text { мозга. }\end{array}\end{array}$ \\
\hline
\end{tabular}




\begin{tabular}{|c|c|}
\hline Вопросы & Ответы \\
\hline & $\begin{array}{l}\text { условных и безусловных рефлексов, } \\
\text { параличом дыхательного центра. }\end{array}$ \\
\hline Диагностика: & $\begin{array}{l}\text { На основании клинической картины, } \\
\text { отсутствия всех видов рефлексов. } \\
\text { Наличии пзолинии } \\
\text { электроэнцефалографии. }\end{array}$ \\
\hline
\end{tabular}




\section{ПОЧЕЧНАЯ ДИСФУНКЦИЯ}

- Почечная дисфункция развивается вследствие уменьшения фильтрационной и/или концентрационной функции органа, которая проявляется нарушением водно-электролитного баланса и уремией.

- Тяжёлая форма почечной дисфункции квалифицируется как почечная недостаточность.

- В зависимости от этиологических причин различают 3 формы почечной дисфункции: преренальная, ренальная, постренальная.

- Преренальная форма почечной дисфункции развивается вследствие резкого уменьшения перфузии почки (гиповолемия, шок, компартмент-синдром).

○ В ранней стадии при адекватной коррекции функция почки может восстанавливаться. При отсутствии соответствующей коррекции развиваются ишемия и тубулярный некроз.

○ Показателями эффективной коррекции являются нормализация микроскопии мочи и экскреции ионов натрия.

- Ренальная форма развивается в результате повреждения клубочков и канальцев почек (ишемия, сепсис, интоксикация) и расценивается как острый тубулярный некроз.

○ Данная форма дисфункции почек требует длительного времени коррекции.

О Характерными проявлениями являются появление эпителия при микроскопии мочи и повышение экскресции ионов натрия более чем на $2 \%$.

- Постренальная или обструктивная форма почечной дисфункции развивается при нарушении уродинамики в результате повреждения мочевыводящих путей (травмы, манипуляции, гипертрофия простаты, обтурация мочевого катетера, сгустки крови, сдавление извне).

- При своевременном и адекватном устранении причин, функция почки восстанавливается. При отсутствии адекватной коррекции уродинамики развиваются гидронефроз и острый тубулярный некроз.

○ Характерным признаком является расширение мочевыводящих путей.

- Преренальная дисфункция и острый тубулярный некроз являются ведущими причинами острой почечной недостаточности, встречающейся в отделении хирургической реанимации. 
- Клиническими проявлениями почечной дисфункции являются олигурия или анурия.

- При отсутствии адекватного лечения развиваются почечная недостаточность и осложнения: диффузный отёк, гиперкалиемия, уремия, ацидоз и др.

- В своевременной диагностике важное значение имеют определение клиренса креатинина, концентрации креатинина и количество мочи.

- Если в течение первых 6 часов количество мочи не превышает 0,5 мл/кг или уровень креатинина выше 0,3 мг/дл в течение первых 48 часов, то развивается почечная дисфункция. Состояние, при котором уровень креатинина выше 4 мг/дл, а гломерулярная фильтрация ниже 35 мл/мин, расценивается как почечная недостаточность (тяжёлая почечная дисфункция).

- Для определения причины учитывается анамнез пациента и клиническая картина, исключаются причины обструкции, затем проводится дифференциация между преренальными причинами и острым тубулярным некрозом (микроскопия мочи, экскреция ионов натрия, положительная реакция на инфузионную терапию).

- Лечение основано на 2-х принципах:

○ профилактика и устранение причины (гипоперфузии и нефротоксикоза)

○ профилактика и лечение осложнений (заместительная терапия - диализ).

\section{Вопросы и ответы по почечной дисфункции}

\begin{tabular}{|c|c|}
\hline Вопросы & Ответы \\
\hline Что такое почечная дисфункция? & $\begin{array}{l}\text { Уменьшение фильтрационной и/или } \\
\text { концентрационной функции почек. }\end{array}$ \\
\hline Что такое почечная недостаточность? & 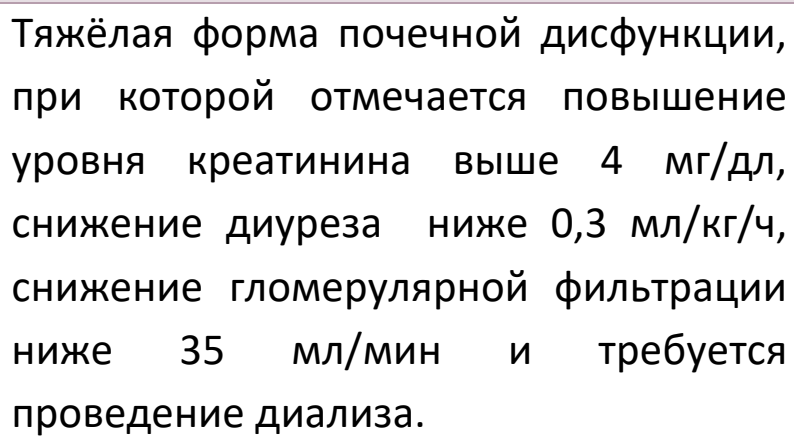 \\
\hline
\end{tabular}




\begin{tabular}{|c|c|}
\hline Вопросы & Ответы \\
\hline Клинические формы: & 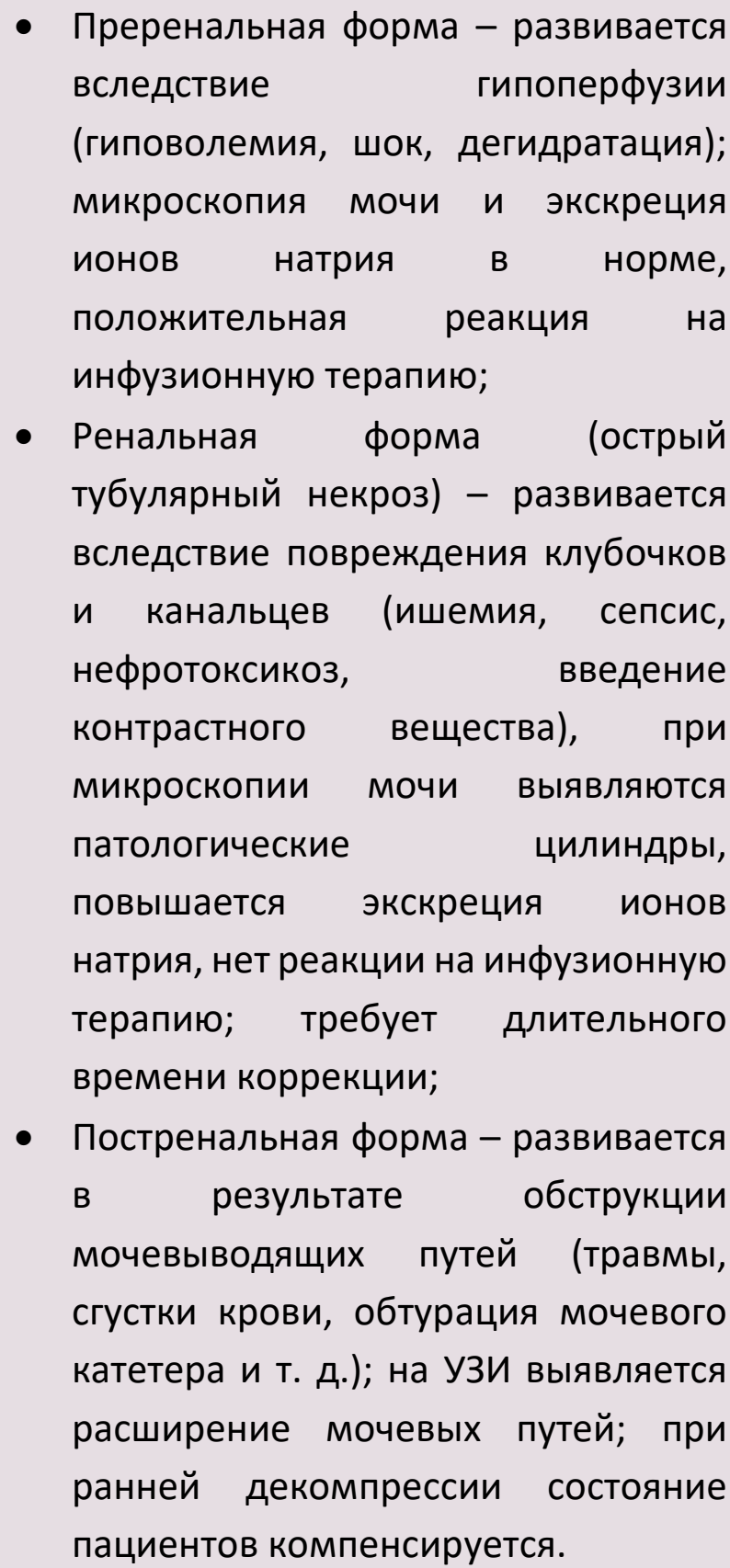 \\
\hline $\begin{array}{l}\text { Какие формы наиболее часто } \\
\text { встречаются у хирургических } \\
\text { пациентов? }\end{array}$ & Преренальная и ренальная. \\
\hline Осложнения: & $\begin{array}{l}\text { Гиперволемия (диффузный отёк), } \\
\text { гиперкалиемия, уремия, ацидоз. }\end{array}$ \\
\hline
\end{tabular}




\begin{tabular}{|c|c|}
\hline Вопросы & Ответы \\
\hline Клинические признаки: & Олигурия, отёки, анурия. \\
\hline $\begin{array}{l}\text { У каких пациентов можно } \\
\text { заподозрить? }\end{array}$ & $\begin{array}{l}\text { При наличии полиурии, олигурии, } \\
\text { отёков. }\end{array}$ \\
\hline $\begin{array}{l}\text { Какие исследования необходимы для } \\
\text { уточнения диагноза? }\end{array}$ & $\begin{array}{l}\text { Определение уровня креатинина, } \\
\text { количества мочи. }\end{array}$ \\
\hline $\begin{array}{l}\text { Как можно диагностировать } \\
\text { обструктивную форму? }\end{array}$ & $\begin{array}{l}\text { При Узи отмечается расширение } \\
\text { мочевыводящих путей. }\end{array}$ \\
\hline $\begin{array}{l}\text { Какие исследования необходимы для } \\
\text { дифференциации преренальной } \\
\text { формы и острого тубулярного } \\
\text { некроза? }\end{array}$ & 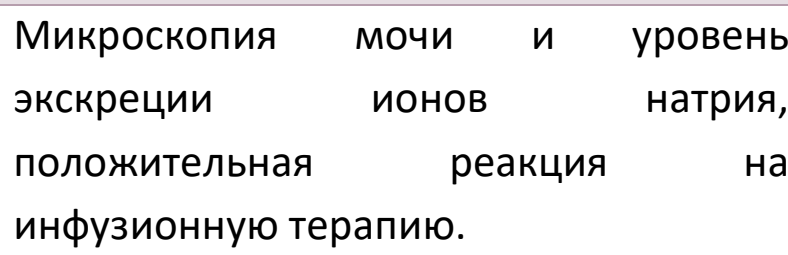 \\
\hline Диагностические критерии: & $\begin{array}{l}\text { - Повышение концентрации креати- } \\
\text { нина более 0,3 мг/дл в течение } \\
\text { первых } 48 \text { часов; } \\
\text { - Уменьшение выделения мочи ниже } \\
\text { 0,5 мл/кг/ч в течение первых } 6 \text { ч. }\end{array}$ \\
\hline Методы лечения: & $\begin{array}{l}\text { - Консервативный; } \\
\text { - Диализ. }\end{array}$ \\
\hline Показания к диализу: & $\begin{array}{l}\text { - Гиперволемия; } \\
\text { - Ацидоз; } \\
\text { - Некоррегирующаяся } \\
\text { гиперкалиемия; } \\
\text { - Уремические осложнения } \\
\text { (энцефалопатия, перикардиальная } \\
\text { жидкость). }\end{array}$ \\
\hline Методы диализа: & $\begin{array}{l}\text { • Постоянный гемодиализ; } \\
\text { • Этапный (прерывистый) диализ; } \\
\text { • Перитонеальный диализ. }\end{array}$ \\
\hline
\end{tabular}




\begin{tabular}{|c|c|c|}
\hline Вопросы & Ответы & \\
\hline \multirow[t]{3}{*}{ Прогноз: } & При своевременной и & адекватной \\
\hline & коррекции & почки \\
\hline & восстанавливается. & \\
\hline
\end{tabular}




\section{СЕПСИС}

- По современным научным представлениям, сепсис - это дисфункция жизненно важных органов и систем вследствие нарушения иммунной реакции организма на инфекцию: сепсис = инфекция + органная дисфункция. Другими словами, сепсис - это опасное для жизни состояние, при котором иммунная реакция на инфекцию повреждет собственных тканей и развивается органная дисфункция.

- Сепсис проявляется в виде осложнения большинства заболеваний. Основными этиологическими причинами сепсиса являются травма, шок, воспаление, инфекционные заболевания, ишемия, некроз, токсикозы.

- Клинически проявляется признаками SIRS и органной дисфункции.

- Диагноз, как правило, основан на клинической картине.

- $\mathrm{K}$ диагностическим критериям относятся наличие очага инфекции и органной дисфункции.

- Лечение заключается в поддерживающей, антибактериальной терапии и устранении очага инфекции.

\section{Вопросы и ответы по сепсису}

Вопросы
Что такое инфекция? $\begin{aligned} & \text { Воспалительная реакция организма в } \\ & \text { ответ на бактериальную, вирусную и } \\ & \text { грибковую инвазию. } \\ & \text { Что такое SIRS? }\end{aligned}$




\begin{tabular}{|c|c|}
\hline Bonрocы & Ответы \\
\hline & $\begin{array}{l}\text { - Лейкоцитоз свыше } 12 \times 10^{9} / л \text { или } \\
\text { лейкопения ниже } 4 \times 10^{9} / л .\end{array}$ \\
\hline Что такое сепсис? & Инфекция + органная дисфункция. \\
\hline Что такое септический шок? & $\begin{array}{l}\text { Сепсис наряду с гипотензией и } \\
\text { гиперлактатемией, для коррекции } \\
\text { которых необходимы вазопрессоры. }\end{array}$ \\
\hline Причины сепсиса: & $\begin{array}{l}\text { Шок, воспалительные и инфекционные } \\
\text { заболевания, ишемия, некроз, } \\
\text { токсикозы. }\end{array}$ \\
\hline Патогенез сепсиса: & $\begin{array}{l}\text { Дисрегуляция иммунной реакции и } \\
\text { повреждение органа (аутодеструкция) в } \\
\text { ответ на инфекцию. }\end{array}$ \\
\hline Особенность клинического течения: & $\begin{array}{l}\text { При отсутствии этиопатогенетической } \\
\text { терапии заканчивается летальным } \\
\text { исходом. }\end{array}$ \\
\hline Осложнения: & $\begin{array}{l}\text { Септический шок, респираторный } \\
\text { дистресс синдром, полиорганная } \\
\text { недостаточность, летальный исход. }\end{array}$ \\
\hline Клинические признаки: & $\begin{array}{l}\text { Симптомы SIRS, признаки инфекции и } \\
\text { органной дисфункции. }\end{array}$ \\
\hline $\begin{array}{l}\text { У каких пациентов можно } \\
\text { заподозрить? }\end{array}$ & $\begin{array}{l}\text { Пациенты с наличием установленного } \\
\text { очага инфекции и полиорганной } \\
\text { дисфункцией. }\end{array}$ \\
\hline Диагностика: & $\begin{array}{l}\text { Определение очага инфекции } \\
\text { (культуральный анализ, методы } \\
\text { визуализации, клиническая Картина) и } \\
\text { органной дисфункции. }\end{array}$ \\
\hline
\end{tabular}




\begin{tabular}{|c|c|}
\hline Вопросы & Ответы \\
\hline Методы идентификации инфекции: & $\begin{array}{l}\text { Клинические признаки, культуральные } \\
\text { исследования, методы визуализации } \\
\text { (УзИ, КТ, МРТ, ПЭТ-КТ). }\end{array}$ \\
\hline $\begin{array}{l}\text { Как определяется органная } \\
\text { дисфункция? }\end{array}$ & $\begin{array}{l}\text { Клиническая картина, сокращённая } \\
\text { SOFA, SOFA, CLIF-C-OF, APACHE и другие } \\
\text { шкалы. }\end{array}$ \\
\hline Что такое сокращённая шкала SOFA? & $\begin{array}{l}\text { Наличие одного из 3-х признаков } \\
\text { органной дисфункции: систолическое } \\
\text { давление ниже } 100 \text { мм рт. ст., } \\
\text { изменение сознания, менее } 13 \text { баллов } \\
\text { по шкале Глазго, частота дыхательных } \\
\text { движений свыше } 22 \text { в минуту. }\end{array}$ \\
\hline Что характеризует шкала CLIF-C-OF? & $\begin{array}{l}\text { Данная шкала определяет дисфункцию } \\
\text { 6-и органов (кровообращение, лёгкие, } \\
\text { мозг, печень, почки, коагуляция) по } \\
\text { степени тяжести; 3-я степень } \\
\text { оценивается как } \\
\text { недостаточность. }\end{array}$ \\
\hline Лабораторные признаки: & $\begin{array}{l}\text { Признаки воспаления и дисфункции } \\
\text { органов. }\end{array}$ \\
\hline $\begin{array}{l}\text { Признаки диагностической } \\
\text { визуализации: }\end{array}$ & 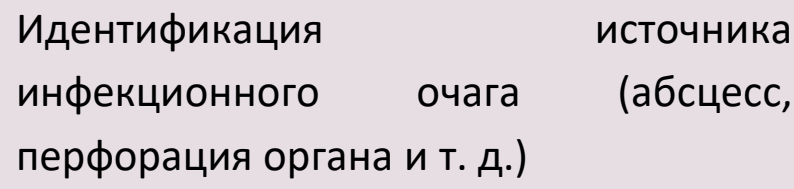 \\
\hline Диагностические критерии: & $\begin{array}{l}\text { Инфекционный очаг и органная } \\
\text { дисфункция. }\end{array}$ \\
\hline Лечение: & $\begin{array}{l}\text { Поддерживающая, антибактериальная } \\
\text { терапия, устранение очага инфекции. }\end{array}$ \\
\hline Когда начинается лечение? & Безотлагательно. \\
\hline
\end{tabular}




\begin{tabular}{|c|c|}
\hline Вопросы & Ответы \\
\hline Объём инфузионной терапии: & $\begin{array}{l}\text { Начальный объём - } 30 \text { мл/кг в течение } \\
\text { первых 3-х часов. }\end{array}$ \\
\hline Компоненты инфузионной терапии: & $\begin{array}{l}\text { Кристаллоидные и коллоидные } \\
\text { растворы. }\end{array}$ \\
\hline $\begin{array}{l}\text { Каким кристаллоидным препаратам } \\
\text { отдаётся предпочтение? }\end{array}$ & Рингер, Рингер лактат. \\
\hline $\begin{array}{l}\text { Каким коллоидным препаратам } \\
\text { отдаётся предпочтение? }\end{array}$ & Альбумин, желатин. \\
\hline $\begin{array}{l}\text { Как определяется адекватность } \\
\text { инфузионной терапии? }\end{array}$ & $\begin{array}{l}\text { По стабилизации уровня среднего } \\
\text { артериального давления, ударному } \\
\text { объёму, уровню лактата и количеству } \\
\text { мочи. }\end{array}$ \\
\hline Когда назначают вазопрессоры? & $\begin{array}{l}\text { Если в течение } 3 \text { часов несмотря на } \\
\text { введение } 30 \text { мл/кг кристаллоидов } \\
\text { среднее артериальное давление } \\
\text { держится на уровне } 65 \text { мм рт. ст. и не } \\
\text { снижается уровень лактата. }\end{array}$ \\
\hline Когда назначают антибиотики? & $\begin{array}{l}\text { В течение первого часа после } \\
\text { проведения } \\
\text { исследования. }\end{array}$ \\
\hline $\begin{array}{l}\text { Показание к хирургическому } \\
\text { лечению: }\end{array}$ & Хирургическая инфекция. \\
\hline Время выполнения операции: & В течение первых 6 часов. \\
\hline Методы операции: & $\begin{array}{l}\text { Дренирование, удаление очага } \\
\text { деструкции. }\end{array}$ \\
\hline Прогноз: & $\begin{array}{l}\text { В зависимости от тяжести и степени } \\
\text { органной дисфункции летальность } \\
\text { варьирует от } 30 \% \text { до } 100 \% \text {. }\end{array}$ \\
\hline
\end{tabular}




\section{НАРУШЕНИЯ ВОДНО-ЭЛЕКТРОЛИТНОГО ОБМЕНА}

- Суточная потребность организма в жидкости составляет 2000-2500 мл (30-35 мл/кг).

- Вода в организме распределяется в двух пространствах: внутриклеточным и внеклеточным (внутрисосудистый и межклеточный).

- Общий водный баланс регулируется объёмом поступающей и выделяющейся жидкости, баланс же между пространствами - осмолярностью и гидростатическим давлением.

- Изменения в объёме поступающей и выделяющейся жидкости и осмолярности являются основными механизмами нарушения водно-электролитного обмена.

- Нарушение водного баланса происходит в следующих формах:

○ повышение общего количества воды в организме - гипергидратация;

○ уменьшение общего количества воды в организме - дегидратация;

○ повышение количества внеклеточной жидкости - гиперволемия;

○ уменьшение количества внеклеточной жидкости - гиповолемия.

- Для диагностики используются две группы показателей (статические и динамические).

- Основным методом восстановления нарушенного баланса является адекватная коррекция перфузии и предотвращение гиперволемии.

- Гиповолемия - характеризуется снижением объёма жидкости во внеклеточном пространстве.

○ Как правило, происходит на фоне массивной потери жидкости, приводит к развитию гипоперфузии.

- Несвоевременная и неадекватная коррекция способствуют развитию шока и органной дисфункции.

○ Диагностика основывается на клинической картине, лабораторные показатели и данные визуализации определяют причину, тип и степень тяжести нарушения.

○ К характерным признакам относятся патологическая потеря жидкости, недостаточное потребление воды, жажда, отрицательный жидкостный баланс, снижение тургора кожи, спадение ярёмных вен, признаки гипоперфузии. 
О Лечение проводится инфузионной терапией, адекватной коррекцией перфузии с использованием изотонических растворов.

- Гиперволемия - характеризуется повышением объёма жидкости во внеклеточном пространстве. При этом внутриклеточный объём, концентрация ионов натрия могут быть нормальными, повышенными или сниженными.

○ Ведущим патогенетическим механизмом гиперволемии является гипернатриемия вследствие задержки ионов натрия или их избыточного поступления в организм.

○ Гиперволемия сопровождается отёком тканей, что приводит к органной дисфункции, нарушению заживления анастомозов и ран.

○ Проявляется двумя клиническими формами - гипоперфузионная и негипоперфузионная.

○ Диагноз основан на клинической картине.

О Характерными клиническими признаками являются отёчный синдром, увеличение веса, расширение ярёмных вен, в тяжёлых случаях наблюдаются хрипы в лёгких, гидроторакс, асцит, компартмент-синдром. При гипоперфузионной форме наблюдается и гипотензия.

О Основными компонентами лечения являются коррекция перфузии, выведение избыточной жидкости из организма и проведение этиотропной терапии.

- Целью и задачей инфузионной терапии у хирургических пациентов является адекватная коррекция водно-электролитного обмена в до- и послеоперационном периодах.

- С этой целью инфузионная терапия проводится в трёх режимах: в свободном (классическом), рестриктивном и направленном режимах.

○ Классическая (свободная) инфузионная терапия проводится с учётом потери и степени дефицита жидкости. Полное восполнение водного баланса в таком режиме нередко способствует гиперволемии и экстравазации жидкости в «третье» пространство. Данный режим применяется при проведении «малых» по объёму оперативных вмешательств у пациентов с наименьшим операционным риском.

○ Рестриктивный режим проводится с учётом предотвращения гиперволемии, степени дефицита водного баланса и суточной потребности организма в жидкости. Данный режим применяется при выполнении «больших» по объёму оперативных вмешательств. 
○ Целенаправленная инфузионная терапия проводится под контролем динамических показателей (вариации систолического давления, пульсового давления, ударного объёма сердца) и применяется у пациентов с высоким операционным риском при выполнении расширенных и травматичных оперативных вмешательств.

- Электролитные нарушения у хирургических пациентов проявляются повышением или снижением уровня отдельных ионов.

\section{Вопросы и ответы по нарушениям водно-электролитного обмена}

\begin{tabular}{|c|c|}
\hline Bonросы & Ответы \\
\hline $\begin{array}{l}\text { Механизмы интраоперационной } \\
\text { потери жидкости: }\end{array}$ & $\begin{array}{l}\text { Основные потери, вазодилатация в } \\
\text { связи с анестезией, накопление } \\
\text { жидкости в третье пространство, } \\
\text { кровотечение, испарение жидкости из } \\
\text { раны. }\end{array}$ \\
\hline Принципы инфузионной терапии: & $\begin{array}{l}\text { Полноценная коррекция перфузии, } \\
\text { профилактика } \\
\text { коррекция электролитных нарушений. }\end{array}$ \\
\hline Режимы инфузионной терапии: & $\begin{array}{l}\text { - Свободный; } \\
\text { - Рестриктивный; } \\
\text { - Целенаправленный. }\end{array}$ \\
\hline $\begin{array}{l}\text { В чём заключается стандартный } \\
\text { режим? }\end{array}$ & $\begin{array}{l}\text { Полная коррекция } \\
\text { электролитных потерь, обеспечение } \\
\text { положительного жидкостного баланса. }\end{array}$ \\
\hline $\begin{array}{l}\text { Что является недостатком } \\
\text { стандартного режима? }\end{array}$ & Развитие гиперволемии. \\
\hline $\begin{array}{l}\text { Причина гиперволемии, возникающей } \\
\text { после операции: }\end{array}$ & $\begin{array}{l}\text { Массивная инфузия, проведённая во } \\
\text { время операции. }\end{array}$ \\
\hline Осложнения гиперволемии: & $\begin{array}{l}\text { Периферические отёки, отёк лёгкого, } \\
\text { асцит, гидроторакс, компартмент- }\end{array}$ \\
\hline
\end{tabular}




\begin{tabular}{|c|c|}
\hline Вопросы & Ответы \\
\hline & $\begin{array}{l}\text { синдром, несостоятельность } \\
\text { анастомозов и раневые осложнения. }\end{array}$ \\
\hline $\begin{array}{l}\text { Причина повышения проницаемости } \\
\text { капилляров при гиперволемии: }\end{array}$ & $\begin{array}{l}\text { Повреждение гликокаликса эндотелия } \\
\text { капилляров. }\end{array}$ \\
\hline $\begin{array}{l}\text { В чём заключается рестриктивный } \\
\text { режим? }\end{array}$ & $\begin{array}{l}\text { Жидкостный баланс поддерживается на } \\
\text { нулевом уровне во избежание развития } \\
\text { гиперволемии. }\end{array}$ \\
\hline $\begin{array}{l}\text { Объём инфузионной терапии при } \\
\text { ретроспективном режиме: }\end{array}$ & В среднем 1-2 мл/кг/ч. \\
\hline $\begin{array}{l}\text { В чём заключается целенаправленный } \\
\text { режим? }\end{array}$ & $\begin{array}{l}\text { Инфузия, проводимая под контролем } \\
\text { динамических } \\
\text { кровообращения } \\
\text { периферического } \\
\text { сопротивления. }\end{array}$ \\
\hline $\begin{array}{l}\text { Что относится к динамическим } \\
\text { показателям? }\end{array}$ & $\begin{array}{l}\text { Вариации гемодинамических } \\
\text { показателей под } \\
\text { различных факторов. }\end{array}$ \\
\hline $\begin{array}{l}\text { Недостаток целенаправленного } \\
\text { режима: }\end{array}$ & Требуется инвазивное вмешательство. \\
\hline $\begin{array}{l}\text { Наиболее часто переливаемый } \\
\text { раствор в предоперационном } \\
\text { периоде? }\end{array}$ & Раствор Рингер Лактата. \\
\hline
\end{tabular}


- Синдром диссеминированного внутрисосудистого свёртывания (ДВС-синдром) развивается вследствие интенсивного поступления в кровь прокоагулянтов, последствием которого являются тромбозы, микроангиопатии, органная дисфункция.

- При угнетении адаптационно-компенсаторных механизмов организма, направленных на нейтрализацию негативного эффекта внутрисосудистого свёртывания, развиваются фибринолиз и кровотечение.

- В хирургической практике ДВС-синдром встречается как осложнение заболеваний. Факторами риска могут быть сепсис, травмы, злокачественные опухоли, патологии беременности, печёночная недостаточность, токсикозы.

- Выделяют 2 клинические формы: острую и хроническую.

- Острая или декомпенсаторная форма развивается на фоне острых заболеваний.

- Обусловлена массивным поступлением в кровь факторов свёртывания, в результате чего происходит избыточное свёртывание, истощение факторов свёртывания и нарушение фибринолиза.

○ Клиническими проявлениями острой формы являются тромбоз, органная дисфункция, кровотечение.

○ Диагноз основывается на следующих критериях: характер основной патологии, нарушения в показателях коагуляционной системы (повышение INR, AЧTB, снижение фибриногена, тромбоцитопения, повышение D-димера), микроангиопатии (шистоциты в мазке периферической крови, гемолитическая анемия) и исключения других разновидностей коагулопатических синдромов.

○ Специфического лечения нет. Радикальное лечение основного заболевания в сочетании с коррекцией коагуляции являются основными условиями лечения.

- Хроническая или компенсаторная форма развивается на фоне различных хронических заболеваний вследствие постоянного поступления в кровь прокоагулянтов.

○ Осложняется тромбозами и микроангиопатиями.

○ Диагноз, как правило, основан на лабораторных данных (наличие микроангиопатий). 
О Лечение направлено на терапию основного заболевания.

\section{Вопросы и ответы по ДВС-синдрому}

\begin{tabular}{|c|c|}
\hline Вопросы & Ответы \\
\hline Что такое ДВС-синдром? & $\begin{array}{l}\text { Патологический } \\
\text { характеризующийся мроцесс, } \\
\text { внутрисосудистым тромбозом. }\end{array}$ \\
\hline Осложнения: & $\begin{array}{l}\text { Тромбозы, микроангиопатии, } \\
\text { кровотечения, органная дисфункция. }\end{array}$ \\
\hline $\begin{array}{l}\text { Является ли ДВС-синдром первичным } \\
\text { заболеванием или осложнением } \\
\text { какого-либо заболевания? }\end{array}$ & $\begin{array}{l}\text { ДВС-синдром встречается как } \\
\text { осложнение заболеваний. }\end{array}$ \\
\hline Причины: & $\begin{array}{l}\text { Сепсис, травмы, злокачественные } \\
\text { опухоли, патологии беременности, } \\
\text { печёночная } \\
\text { токсикозы, шок, массивные трансфузии } \\
\text { ит.д. }\end{array}$ \\
\hline Патогенетические механизмы: & $\begin{array}{llr}\text { Неконтролируемое } & \text { и } & \text { массивное } \\
\text { поступление в кровь } & \text { факторов } \\
\text { свёртывания, угнетение } & \text { процесса } \\
\text { фибринолиза. } & & \end{array}$ \\
\hline Клинические формы: & Острая и хроническая. \\
\hline $\begin{array}{l}\text { Что представляет собой острый ДВС- } \\
\text { синдром? }\end{array}$ & $\begin{array}{l}\text { Острая или декомпенсаторная форма } \\
\text { развивается вследствие интенсивного } \\
\text { поступления в кровь прокоагулянтов, } \\
\text { характеризуется тромбозом, органной } \\
\text { дисфункцией и кровотечениями. }\end{array}$ \\
\hline $\begin{array}{l}\text { Что представляет собой хронический } \\
\text { ДВС-синдром? }\end{array}$ & $\begin{array}{l}\text { Компенсаторная форма-постепенное и } \\
\text { постоянное поступление в кровь } \\
\text { прокоагулянтов, которое приводит к }\end{array}$ \\
\hline
\end{tabular}




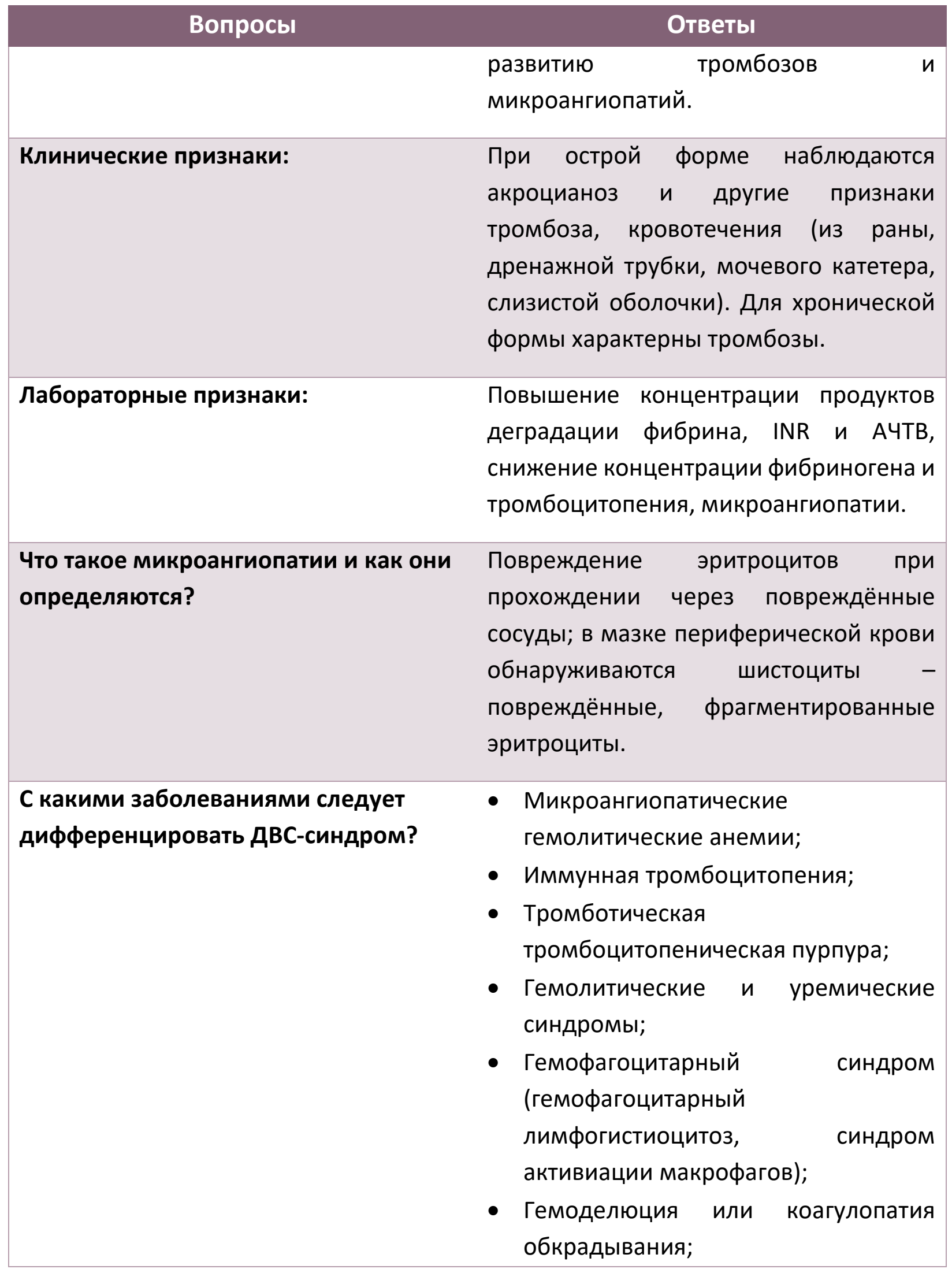




\begin{tabular}{|c|c|}
\hline Вопросы & Ответы \\
\hline & $\begin{array}{l}\text { - Тромбоцитопения, связанная с } \\
\text { гепаринотерапией; } \\
\text { • Заболевания печени, } \\
\text { сопровождающиеся коагулопатией. }\end{array}$ \\
\hline Диагностические критерии: & $\begin{array}{l}\text { - Установление нозологической } \\
\text { причины; } \\
\text { - Повышение маркеров коагуляции } \\
\text { (INR, AчTB, D-димера), снижение } \\
\text { фибриногена и тромбоцитопения; } \\
\text { - Признаки микроангиопатии } \\
\text { (шистоциты в мазке периферической } \\
\text { крови, гемолитическая анемия); } \\
\text { - Исключение других коагулопатий. }\end{array}$ \\
\hline $\begin{array}{l}\text { Чем отличается от других видов } \\
\text { микроангиопатических } \\
\text { гемолитических ангиопатий? }\end{array}$ & $\begin{array}{l}\text { При других видах } \\
\text { микроангиопатических гемолитических } \\
\text { ангиопатий не наблюдаются изменения } \\
\text { в показателях свёртывания (АЧТВ). }\end{array}$ \\
\hline $\begin{array}{l}\text { Чем отличается от иммунной } \\
\text { тромбоцитопении? }\end{array}$ & $\begin{array}{l}\text { В отличие от ДВС-синдрома при } \\
\text { иммунной тромбоцитопении не } \\
\text { наблюдаются изменения в показателях } \\
\text { свёртывания. }\end{array}$ \\
\hline $\begin{array}{l}\text { Чем отличается от тромботических } \\
\text { микроангиопатий (гемолитический } \\
\text { уремический синдром, } \\
\text { тромботическая } \\
\text { тромбоцитопеническая пурпура)? }\end{array}$ & 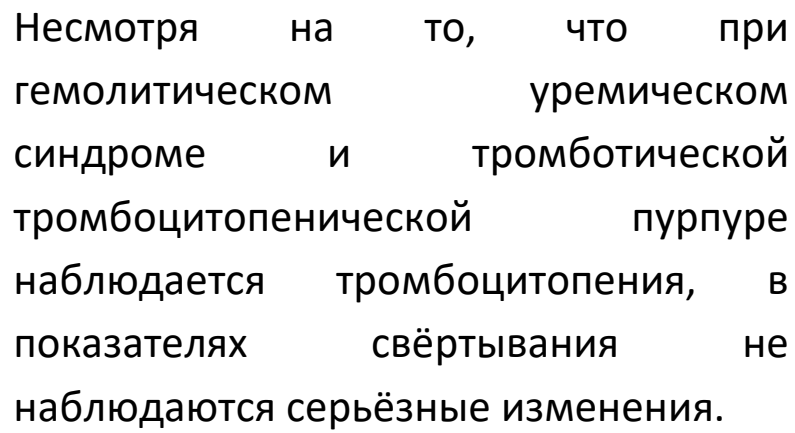 \\
\hline $\begin{array}{l}\text { Чем объясняются незначительные } \\
\text { изменения в системе свёртывания } \\
\text { несмотря на тромбозы при }\end{array}$ & $\begin{array}{l}\text { При гемолитическом уремическом } \\
\text { синдроме и тромботической } \\
\text { тромбоцитопенической пурпуре в }\end{array}$ \\
\hline
\end{tabular}




\begin{tabular}{|c|c|}
\hline Вопросы & Ответы \\
\hline $\begin{array}{l}\text { гемолитическом уремическом } \\
\text { синдроме и тромботической } \\
\text { тромбоцитопенической пурпуре в } \\
\text { отличие от ДВС-синдрома? }\end{array}$ & $\begin{array}{l}\text { процессе тромбообразования } \\
\text { участвуют тромбоцитарные факторы. А } \\
\text { при ДВС-синдроме участвуют как } \\
\text { тромбоцитарные факторы, так и } \\
\text { плазматические факторы свёртывания. }\end{array}$ \\
\hline $\begin{array}{l}\text { Как можно дифференцировать ДВС- } \\
\text { синдром с коагулопатией, } \\
\text { обусловленной дисфункцией печени? }\end{array}$ & $\begin{array}{l}\text { В связи с угнетением синтеза VIII } \\
\text { фактора из эндотелия сосудов, что } \\
\text { отсутствует при дисфункции печени. }\end{array}$ \\
\hline Лечение: & $\begin{array}{l}\text { - Лечение основного заболевания; } \\
\text { - Поддерживающая терапия } \\
\text { (устранение дефицита факторов } \\
\text { свёртывания). }\end{array}$ \\
\hline
\end{tabular}




\section{АБДОМИНАЛЬНЫЙ КОМПАРТМЕНТ-СИНДРОМ}

- Абдоминальный компартмент-синдром - повышение внутрибрюшного давления свыше 20 мм рт. ст., сопровождающееся органной дисфункцией.

- Причины, способствующие развитию абдоминального компартмент-синдрома, делятся на 2 группы: интраабдоминальные (травмы, панкреатит, перитонит, кишечная непроходимость, кровотечения и т. д.) и экстраабдоминальные (массивная инфузионная терапия, сепсис, тампонада и т. д.)

- Клинические проявления характеризуются резким вздутием и напряжением живота, нарушением дыхания, гемодинамики и диуреза.

- При несвоевременной и неадекватной коррекции внутрибрюшного давления приводит к летальному исходу.

- Диагноз устанавливается на основании клинической картины, подтверждается измерением внутрибрюшного давления и признаками органной дисфункции.

- С лечебной целью применяются хирургические и консервативные методы. При интраабдоминальной форме проводится хирургическая декомпрессия, а при экстраабдоминальной применяют консервативное лечение.

\section{Вопросы и ответы по абдоминальному компартмент-синдрому}

\begin{tabular}{|c|c|}
\hline Вопросы & Ответы \\
\hline $\begin{array}{l}\text { Что такое абдоминальная } \\
\text { гипертензия? }\end{array}$ & $\begin{array}{l}\text { Повышение внутрибрюшного давления } \\
\text { свыше } 12 \text { мм рт.ст. }\end{array}$ \\
\hline Что такое компартмент-синдром? & $\begin{array}{l}\text { Повышение внутрибрюшного давления } \\
\text { более } 20 \text { мм рт.ст., сопровождающееся } \\
\text { органной дисфункцией. }\end{array}$ \\
\hline Клинические формы: & Острая и хроническая. \\
\hline $\begin{array}{l}\text { Нозологические причины и факторы } \\
\text { риска: }\end{array}$ & $\begin{array}{l}\text { - Первичные причины: травмы, } \\
\text { перитонит, панкреатит, перфорация, } \\
\text { кровотечение, опухоли ит. д.; }\end{array}$ \\
\hline
\end{tabular}




\begin{tabular}{|c|c|}
\hline Вопросы & Ответы \\
\hline & $\begin{array}{l}\text { - Вторичные причины: массивная } \\
\text { инфузионная терапия, сепсис и т. д. }\end{array}$ \\
\hline Патогенез: & $\begin{array}{l}\text { Порочный застойный круг: гипертензия } \\
\rightarrow \text { венозный застой } \rightarrow \text { ишемия } \rightarrow \\
\text { воспаление } \rightarrow \text { отёк, асцит } \rightarrow \\
\text { дисфункция, гипертензия. }\end{array}$ \\
\hline $\begin{array}{l}\text { Особенности клинического течения и } \\
\text { прогноз: }\end{array}$ & $\begin{array}{l}\text { - При острой форме - высокая } \\
\text { летальность; } \\
\text { - При хронической форме - прогноз } \\
\text { благоприятен. }\end{array}$ \\
\hline Осложнения: & $\begin{array}{l}\text { Почечная, лёгочная, циркуляторная } \\
\text { недостаточность, ишемия кишечника, } \\
\text { реперфузионные нарушения ит.д. }\end{array}$ \\
\hline Клинические признаки: & $\begin{array}{l}\text { Вздутие и напряжение живота, } \\
\text { олигурия, одышка, гипотензия и т. д. }\end{array}$ \\
\hline $\begin{array}{l}\text { У каких пациентов можно } \\
\text { заподозрить? }\end{array}$ & $\begin{array}{l}\text { У пациентов с острым животом и } \\
\text { реанимационных пациентов. }\end{array}$ \\
\hline Диагностика: & Измерение внутрибрюшного давления. \\
\hline Лабораторная признаки: & Нет специфических признаков. \\
\hline $\begin{array}{l}\text { Признаки диагностической } \\
\text { визуализации: }\end{array}$ & $\begin{array}{l}\text { На КТ: «округление» живота - } \\
\text { отношение переднезадних размеров к } \\
\text { поперечным более 0,8, сдавление } \\
\text { нижней полой вены, утолщение } \\
\text { кишечной } \\
\text { двусторонней паховой грыжи. }\end{array}$ \\
\hline $\begin{array}{l}\text { Что обнаруживается при других } \\
\text { методах исследования? }\end{array}$ & Признаки органной дисфункции. \\
\hline Диагностические критерии: & $\begin{array}{l}\text { Вздутие и напряжение живота, } \\
\text { абдоминальные боли, признаки }\end{array}$ \\
\hline
\end{tabular}




\begin{tabular}{|c|c|}
\hline Вопросы & Ответы \\
\hline & $\begin{array}{l}\text { органной дисфункции, повышение } \\
\text { внутрибрюшного давления более } 20 \text { мм } \\
\text { рт.ст. }\end{array}$ \\
\hline Методы лечения: & $\begin{array}{l}\text { - Консервативный; } \\
\text { - Хирургический. }\end{array}$ \\
\hline Показания к хирургическому лечению: & $\begin{array}{l}\text { Первичная } \\
\text { (интраабдоминальные причины) или } \\
\text { экстраабдоминальные причины, не } \\
\text { поддающиеся консервативному } \\
\text { лечению. }\end{array}$ \\
\hline Методы хирургического лечения: & Лапаротомия и лапаростомия. \\
\hline Прогноз: & $\begin{array}{l}\text { При первичной форме летальность } \\
\text { составляет 25-75\%, при хронической } \\
\text { форме прогноз благоприятен. }\end{array}$ \\
\hline
\end{tabular}

\section{СПИСОК ЛИТЕРАТУРЫ}

\section{Общая литература}

- Ağayev B.A. Cərrahi xəstəliklər. Bakı 2010.

- Axunbəyli A.ə., İsmayılov i.S., Məhərrəmbəyli i.ş., Kərimova T.B. Reanimatologiya. Bakı 2014.

- Blackbourne LH. Surgical Recall. 4 edition, 2006, LWW, Philadelphia

- Doherty GM. Current Diagnosis and Treatment: Surgery, $13^{\text {th }}$ edition, 2010, Lang International Edition.

- Oliyev S.C., Jliyev M.X. Patoloji fiziologiya. I və II hissə. Bakı 2016.

- Omiraslanov O.T., Qazıyev A.Y. Onkologiya. Bakı, 2010. 
- İsayev H.B. Cərrahi xəstəliklərin patofizologiyası. Bakı 2005

- Klingensmith ME, Aziz A, Bharat A, Fox AC, Porembka MR. The Washington Manual of Surgery, $6^{\text {th }}$ edition, 2012, LWW, Philadelphia.

- McNally PR. GI/Liver Secrets Plus. 4 edition. Mosby, Elsevier, 2010

- Medscape, http://www.medscape.com

- Oxford Handbook of Clinical Surgery, 3d edition, 2011, Oxford Press

- Sayek i. Sayek Temel Cerrahi 1-2. 4-cü baskı, 2016, Güneş Tıp Kitabevleri.

- Topçubaşov M.A. Xüsusi cərrahlıq. Bakı, 1979

- UpToDate, http://www.uptodate.com

- Гостищев B.К. Общая хирургия. GEOTAR-Media, 2019

\section{Специальная литература}

- Qianyun Pang, MM, Hongliang Liu, MD, PhD, Bo Chen, MM, and Yan Jiang, MM. Restrictive and liberal fluid administration in major abdominal surgery. Saudi Med J. 2017 Feb; 38(2): 123-131

- Lais Helena Camacho Navarro et all. Perioperative fluid therapy: a statement from the international Fluid Optimization Group. Perioperative

Medicine 2015, 4:3. https://doi.org/10.1186/s13741-015-0014-z.

- Giorgio Della Rocca, Luigi Vetrugno, Gabriella Tripi, Cristian Deana, Federico Barbario I, Livia Pompei. Liberal or Restricted Fluid Administration.

BMC Anesthesiol. 2014;14(62)

- Laurence Weinberg, Derrick Wong, Dharshi Karalapillai, Brett Pearce, Chong O Tan, Stanley Tay, Chris Christophi, Larry McNicol, Mehrdad Nikfarjam. The Impact of Fluid Intervention on Complications and Length of Hospital Stay After Pancreaticoduodenectomy (Whipple's Procedure). BMC Anesthesiol. 2014;14(35) 


\section{ХИРУРГИЧЕСКИЕ БОЛЕЗНИ}

Н.Ю. Байрамов

\section{Трансплантация}

Н.Ю. Байрамов, С.А. Алиев, С. Йылмаз. Р.А. Мамедов, Э.М. Исазаде, Ф.А.

Гахраманова

Перевод: Н.Ю. Байрамов, С.А. Алиев, М.Р. Гусейнова 


\section{ОБЩИЕ ПОНЯТИЯ ПО ТРАНСПЛАНТАЦИИ}

\section{Вопросы и ответы}

\begin{tabular}{|c|c|}
\hline Вопросы & Ответы \\
\hline Что такое трансплантация? & Пересадка здоровых органов и тканей. \\
\hline Объекты при трансплантации: & $\begin{array}{l}\text { - Донор; } \\
\text { - Трансплантат; } \\
\text { - Реципиент. }\end{array}$ \\
\hline $\begin{array}{l}\text { Виды трансплантации в зависимости } \\
\text { от степени родства донора и } \\
\text { реципиента: }\end{array}$ & $\begin{array}{l}\text { - Аутотрансплантация; } \\
\text { - Изотрансплантация; } \\
\text { - Аллотрансплантация; } \\
\text { - Ксенотрансплантация. }\end{array}$ \\
\hline Что такое аутотрансплантация? & $\begin{array}{l}\text { Пересадка собственных тканей из } \\
\text { одной области организма в другую. }\end{array}$ \\
\hline Что такое изотрансплантация? & $\begin{array}{l}\text { Трансплантация между генетически } \\
\text { идентичными близнецами. }\end{array}$ \\
\hline Что такое аллотрансплантация? & $\begin{array}{l}\text { Трансплантация между особями одного } \\
\text { вида. }\end{array}$ \\
\hline Что такое ксенотрансплантация? & $\begin{array}{l}\text { Трансплантация между особями } \\
\text { разного вида. }\end{array}$ \\
\hline $\begin{array}{l}\text { Виды трансплантации в зависимости } \\
\text { от цели: }\end{array}$ & $\begin{array}{l}\text { - } \text { Постоянная или полная замена; } \\
\text { - } \text { Постоянная частичная замена; } \\
\text { - Временная замена. }\end{array}$ \\
\hline $\begin{array}{l}\text { Виды трансплантации в зависимости } \\
\text { от удаления больного органа у } \\
\text { реципиента: }\end{array}$ & $\begin{array}{l}\text { - Замена - орган реципиента } \\
\text { удаляется; } \\
\text { - Адъювантная - орган реципиента не } \\
\text { удаляется. }\end{array}$ \\
\hline
\end{tabular}




\begin{tabular}{|c|c|}
\hline Bonpocbl & Ответы \\
\hline $\begin{array}{l}\text { Виды трансплантации в зависимости } \\
\text { от места пересадки донорского } \\
\text { органа: }\end{array}$ & $\begin{array}{l}\text { - Ортотопическая; } \\
\text { - Гетеротопическая; } \\
\text { - Паратопическая. }\end{array}$ \\
\hline $\begin{array}{l}\text { Что такое ортотопическая } \\
\text { трансплантация? }\end{array}$ & $\begin{array}{l}\text { Трансплантат пересаживается в } \\
\text { типичную анатомическую позицию - } \\
\text { печень, сердце. }\end{array}$ \\
\hline $\begin{array}{l}\text { Что такое гетеротопическая } \\
\text { трансплантация? }\end{array}$ & $\begin{array}{l}\text { Трансплантат пересаживается в } \\
\text { атипичную анатомическую позицию - } \\
\text { почки, поджелудочная железа. }\end{array}$ \\
\hline $\begin{array}{l}\text { Что такое паратопическая } \\
\text { трансплантация? }\end{array}$ & $\begin{array}{l}\text { Трансплантат пересаживается ближе к } \\
\text { его естественной позиции. }\end{array}$ \\
\hline $\begin{array}{l}\text { Виды трансплантации в зависимости } \\
\text { от состояния донора: }\end{array}$ & $\begin{array}{l}\text { - Живой донор; } \\
\text { - Донор с мозговой смертью; } \\
\text { - Донор с остановкой сердца. }\end{array}$ \\
\hline $\begin{array}{l}\text { Виды трансплантации в зависимости } \\
\text { от консервации трансплантата: }\end{array}$ & $\begin{array}{l}\text { - Статическое охлаждение - в } \\
\text { холодном защитном растворе; } \\
\text { - Перфузионные методы - перфузия в } \\
\text { процессе консервации защитным } \\
\text { раствором. }\end{array}$ \\
\hline Противопоказания к трансплантации: & 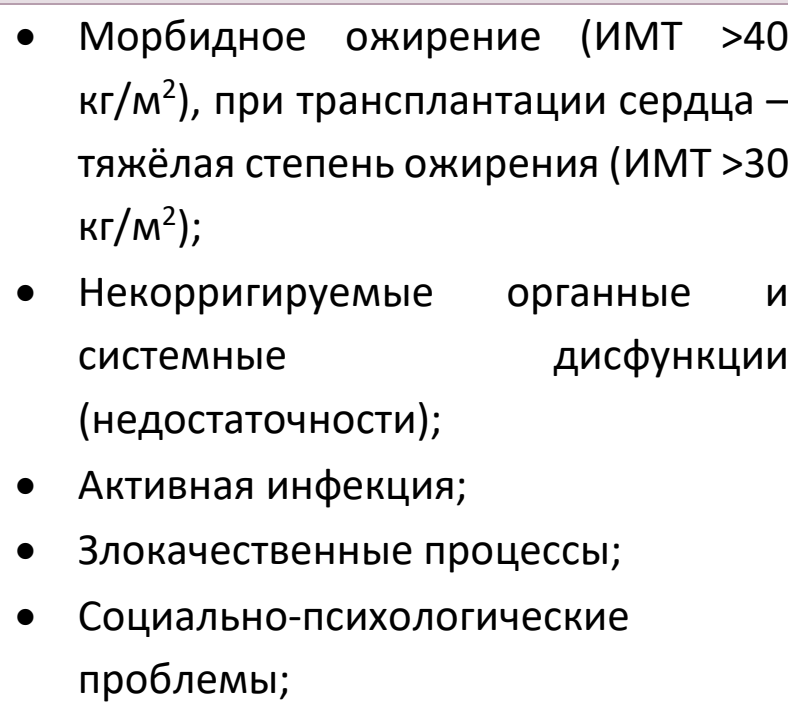 \\
\hline
\end{tabular}




\begin{tabular}{|c|c|}
\hline Вопросы & Ответы \\
\hline & $\begin{array}{l}\text { - Трудно контролируемый и } \\
\text { осложнённый сахарный диабет } \\
(\mathrm{HbA} 1 \mathrm{C}>7,5) .\end{array}$ \\
\hline Противопоказания к донорству: & $\begin{array}{l}\text { - Возраст <18 лет (для живых } \\
\text { доноров); } \\
\text { - Заболевания, повышающие риск } \\
\text { трансплантации; } \\
\text { - Высокий органоспецифический риск } \\
\text { - ограниченные функциональные } \\
\text { резервы, наличие патологии, } \\
\text { представляющей опасность для } \\
\text { трансплантанта; } \\
\text { - Наличие } \\
\text { представляющей опасность для } \\
\text { здоровья реципиента; } \\
\text { - Беременность; } \\
\text { - Морбидное ожирение; } \\
\text { - Психологические проблемы; } \\
\text { - Отсутствие добровольного согласия } \\
\text { (под давлением или ради } \\
\text { финансовой выгоды). }\end{array}$ \\
\hline $\begin{array}{l}\text { Показатели несовместимости } \\
\text { трансплантата: }\end{array}$ & $\begin{array}{l}\text { - Малый размер трансплантата; } \\
\text { - Недостаточные функциональные } \\
\text { резервы органа; } \\
\text { - Серьёзные повреждения органа; } \\
\text { - Несоответствие сосудистой и } \\
\text { протоковой систем; } \\
\text { - Высокий иммунологический риск. }\end{array}$ \\
\hline $\begin{array}{l}\text { Что такое маргинальный } \\
\text { трансплантат? }\end{array}$ & $\begin{array}{l}\text { - Трансплантат, не отвечающий } \\
\text { стандартным критериям, хотя в }\end{array}$ \\
\hline
\end{tabular}




\begin{tabular}{|c|c|}
\hline Вопросы & Ответы \\
\hline & $\begin{array}{l}\text { вынужденных ситуациях может быть } \\
\text { использован. }\end{array}$ \\
\hline $\begin{array}{l}\text { Какие трансплантаты считаются } \\
\text { маргинальными? }\end{array}$ & $\begin{array}{l}\text { - Возраст донора >60-65 лет; } \\
\text { - Трансплантат от донора с сахарным } \\
\text { диабетом и артериальной } \\
\text { гипертензией; } \\
\text { - Трансплантат от донора с } \\
\text { остановившимся сердцем; } \\
\text { - Трансплантаты с длительным } \\
\text { периодом холодовой ишемии; } \\
\text { - Трансплантаты, имеющие } \\
\text { органические патологии } \\
\text { повреждения; и } \\
\text { - Трансплантаты, несовместимые по } \\
\text { группе крови и други } \\
\text { иммунологическим тестам. }\end{array}$ \\
\hline
\end{tabular}




\section{РОЛЬ ИИМУНОЛИГИИ ПРИ ТРАНСПЛАНТАЦИИ}

- Иммунная система - это защитная система организма, которая поддерживает гомеостаз антигенов.

- Её основные функции заключаются в предотвращении развития инфекции, отторжении чужеродных тканей и восстановлении повреждённых тканей. Иммунная система выполняет эти функции, формируя антитела против антигенов.

- Антигены в трансплантате, способные вызывать иммунный ответ, можно разделить на четыре группы:

о Антигены группы крови;

○ Большие тканевые антигены;

- Малые тканевые антигены;

○ Молекулярные паттерны распада (DAMP).

- К антителам относятся иммуноглобулины и специфические Т-клетки, которые могут существовать заранее (готовые антитела) или образовываться после воздействия антигена.

- Есть два типа иммунных систем: врождённая и приобретённая (адаптивная). Существенные различия между этими двумя типами заключаются в характере иммунного ответа и наличии или отсутствии иммунной памяти.

- При врождённом иммунном ответе антигены обычно экспрессируются свободно и процесс их удаления длится недолго, потому что антитела заранее присутствуют в организме.

О При адаптивном иммунном ответе процесс идёт поэтапно: экспрессия антигена, активация лимфоцитов и элиминация антигена.

- Отторжение пересаженного органа или ткани, по сути, является иммунным ответом на трансплантат, при котором могут быть задействованы как врождённые, так и адаптивные иммунные механизмы.

- По механизмам и срокам отторжения выделяют 4 клинические формы:

○ Молниеносное;

○ Ишемия-реперфузия;

○ Острое.

О Хроническое. 
- Одним из наиболее частых осложнений трансплантации является отторжение, и основной причиной этого являются донор-специфические антитела, готовые или сформированные у реципиента против донора.

- Цель иммуноанализа - выявление наличия антител против донора и возможности их возникновения. С этой целью проводятся тесты на совместимость, которые отличаются в зависимости от источника антигена (лимфоцитарные антигены и антигены твёрдой фазы) и метода определения комбинации антиген-антитело (комплементарный лизис, флуориметрический и ферментативный ELISA).

- Для определения вероятности образования антител используются тесты на типирование PRA и HLA. Эти тесты более информативны при совместной оценке.

- Проводятся следующие тесты:

○ Совместимость по группе крови - проводится по правилам переливания крови;

- Совместимость комплемент-связывающих лимфоцитов - выявляет специфические для донора антитела, которые доступны у реципиента и связываются с донорскими лимфоцитами, вызывая комплементарный лизис;

○ Соответствие лимфоцитов при проточной цитометрии - выявляет специфические для донора антитела, которые доступны у реципиента и связываются с донорскими лимфоцитами, может определить к какому классу HLA относятся антитела, но не указывает их тип;

- Виртуальные тесты - панельные реактивные антитела и специфические для донора антитела по показанию - выполняются для определения типа и титра донор-специфических антител (ДСА), доступных у реципиента или возникающих после трансплантации против HLA человека, прикреплённых к синтетическим гранулам;

- HLA-типирование - определяет и сравнивает подтипы больших тканевых антигенов у донора и реципиента.

- По результатам 5 классических иммунных тестов определяется 3 степени риска отторжения:

○ высокий риск - имеется несоответствие групп крови, тесты на соответствие лимфоцитов положительны (KBSLQ и/или ASLQ) или есть ДСА, или ПРА >80\%. В этих случаях трансплантация противопоказана или требуется десенсибилизация; 
О умеренный риск - тесты на соответствие групп крови и лимфоцитов отрицательны, ДСА отсутствует, ПРА - в пределах 20-80\%. Таким пациентам возможна трансплантация органов, но может потребоваться высокая иммуносупрессия;

О низкий риск - тесты на соответствие групп крови и лимфоцитов отрицательны, ДСА отсутствует, ПРА <20\%. В таких случаях возможна трансплантация органов и требуется стандартная иммуносупрессия.

- Иммуносупрессия проводится для профилактики и лечения реакции отторжения и делится на 3 фазы: индукция (инициирование), постоянного и лечение острого отторжения.

- Используемые в настоящее время иммунодепрессанты классифицируются по их эффекту и механизму действия.

- По своему действию иммунодепрессанты можно разделить на две группы: деактиваторы и деплеторы. Деактиваторы предотвращают активацию иммунной системы, в особенности Т-лимфоцитов, в то время как деплеторы устраняют активированные лимфоциты или иммуноглобулины.

- Наиболее часто используются следующие иммунодепрессанты:

○ Стероиды используются в трансплантации более 50 лет и считаются неспецифическими иммунодепрессантами. Они являются очень мощными иммунодепрессантами, но имеют множество побочных эффектов;

○ Ингибиторы кальциневрина являются очень сильнодействующими иммунодепрессантами и считаются основным лекарственным средством для предотвращения острого отторжения при трансплантации, но играют незначительную роль при хроническом отторжении; к отрицательным чертам относятся чрезмерная иммуносупрессия (инфекции, злокачественные новообразования) и токсикоз (нефротоксический, нейротоксический, диабет и сердечно-сосудистые заболевания);

○ Микофенолата мофетил является мощным и относительно специфическим иммунодепрессантом, снижает риск острого отторжения в сочетании с ингибиторами кальциневрина, эффективен при хроническом отторжении, не является нефротоксичным, однако увеличивает реактивность полиомы и ЦМВ; вызывает миелосупрессию и желудочно-кишечные проблемы;

○ Азатиоприн рекомендуется при непереносимости ММФ и у пациентов с вирусом гепатита C; 
○ Ингибиторы mTOR - это иммунодепрессанты, рекомендуемые для снижения дозы и замены (> 3 месяцев) ингибиторов кальциневрина в отдалённом периоде (непереносимость ингибиторов кальциневрина, токсикоз) и при злокачественных новообразованиях (гепатоцеллюлярный рак, саркома Капоши и т. д.);

○ Кроме того, для иммуносупрессии используются блокаторы ко-стимуляторов (белатосепт), блокаторы рецепторов IL-2, разрушители T-клеток (ATG, OKT-3, анти-CD52), иммуноглобулины, плазмаферез и трансплантация стволовых клеток.

\section{Вопросы и ответы по роли иммунологии при трансплантации}

\begin{tabular}{|c|c|}
\hline Вопросы & Ответы \\
\hline Функции иммунной системы: & $\begin{array}{l}\text { Предотвращение развития инфекции, } \\
\text { отторжение чужеродных тканей, } \\
\text { восстановление повреждённых тканей. }\end{array}$ \\
\hline $\begin{array}{l}\text { Принцип действия иммунной } \\
\text { системы: }\end{array}$ & $\begin{array}{l}\text { Образование антител в ответ на } \\
\text { проникновение антигенов в организм. }\end{array}$ \\
\hline Составляющие иммунной системы: & Лейкоциты и иммуноглобулины. \\
\hline $\begin{array}{l}\text { Группы антигенов, способные вызвать } \\
\text { иммунный ответ: }\end{array}$ & $\begin{array}{l}\text { - Антигены группы крови; } \\
\text { - Большие тканевые антигены; } \\
\text { - Малые тканевые антигены; } \\
\text { - Молекулярные паттерны распада } \\
\text { (DАMP). }\end{array}$ \\
\hline Что такое антитела? & $\begin{array}{l}\text { Иммуноглобулины и специфические Т- } \\
\text { клетки. }\end{array}$ \\
\hline $\begin{array}{l}\text { Характерные особенности антигенов } \\
\text { группы крови: }\end{array}$ & $\begin{array}{l}\text { - Расположены на эритроцитах и } \\
\text { большинстве ядерных клетках; } \\
\text { - Против них есть готовые антитела; }\end{array}$ \\
\hline
\end{tabular}




\begin{tabular}{|c|c|}
\hline Вопросы & Ответы \\
\hline & 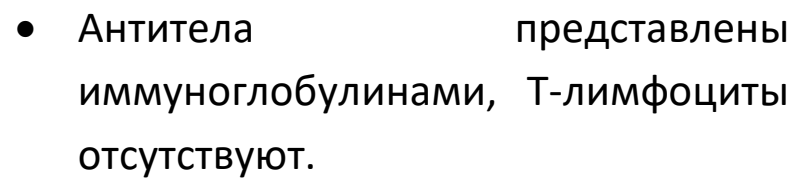 \\
\hline Функции HLA: & $\begin{array}{l}\text { - Представляют чужеродные } \\
\text { - } \text { Онтигены лимфоцитам; } \\
\text { Определяют антигенную } \\
\text { специфичность человека. }\end{array}$ \\
\hline $\begin{array}{l}\text { В чём разница между антигенами } \\
\text { группы крови и HLA? }\end{array}$ & $\begin{array}{l}\text { - Врождённые антитела против HLA } \\
\text { отсутствуют, а против групп крови - } \\
\text { имеются; } \\
\text { - Иммуногенность антигенов HLA } \\
\text { различна, а группы крови - } \\
\text { стабильна; } \\
\text { - Может быть как гуморальный } \\
\text { (иммуноглобулины), так и } \\
\text { клеточный ответ на HLA, и только } \\
\text { гуморальный ответ к антигенам } \\
\text { групп крови. }\end{array}$ \\
\hline $\begin{array}{l}\text { В каких случаях образуются антитела } \\
\text { против HLA? }\end{array}$ & $\begin{array}{l}\text { При переливании крови, беременности } \\
\text { и после трансплантации. }\end{array}$ \\
\hline $\begin{array}{l}\text { Почему для трансплантации сначала } \\
\text { проверяются антигены HLA групп A, B } \\
\text { и DR? }\end{array}$ & $\begin{array}{l}\text { Потому что HLA групп А, В и DR } \\
\text { обладают высокой иммуногенностью. }\end{array}$ \\
\hline $\begin{array}{l}\text { Что представляют собой малые } \\
\text { клеточные антигены? }\end{array}$ & Изомерные формы белков. \\
\hline $\begin{array}{l}\text { Каковы характеристики } \\
\text { молекулярных паттернов распада } \\
\text { (DAMP)? }\end{array}$ & $\begin{array}{l}\text { - Они запускают воспалительный } \\
\text { процесс, выходя за пределы } \\
\text { повреждённых клеток; } \\
\text { - Неизвестны индивидуальная и } \\
\text { тканевая специфичность; }\end{array}$ \\
\hline
\end{tabular}




\begin{tabular}{|c|c|}
\hline Вопросы & Ответы \\
\hline & - Против них нет иммунной памяти. \\
\hline $\begin{array}{l}\text { В чём разница между врождённым и } \\
\text { приобретённым (адаптивным) } \\
\text { иммунным ответом? }\end{array}$ & $\begin{array}{l}\text { Характер иммунного ответа и наличие } \\
\text { или отсутствие иммунной памяти. }\end{array}$ \\
\hline $\begin{array}{l}\text { В чём разница между иммунным } \\
\text { ответом при трансплантации и } \\
\text { инфекции? }\end{array}$ & $\begin{array}{l}\text { Иммунный ответ на внеклеточные } \\
\text { микробы никогда не прекращается, но } \\
\text { реакция на трансплантат может }\end{array}$ \\
\hline & $\begin{array}{lll}\text { ослабляться } & \text { или } & \text { полностью } \\
\text { отсутствовать. } & & \end{array}$ \\
\hline Что такое отторжение? & $\begin{array}{l}\text { Иммунная реакция в ответ на } \\
\text { трансплантат. }\end{array}$ \\
\hline $\begin{array}{l}\text { Клинические формы отторжения в } \\
\text { зависимости от механизма и срока? }\end{array}$ & $\begin{array}{l}\text { - Молниеносное - в первые минуты; } \\
\text { - Ишемия-реперфузия - в первые } \\
\text { минуты; } \\
\text { - Острое - в течение первых } 3 \\
\text { месяцев; } \\
\text { - Хроническое - развивается с годами. }\end{array}$ \\
\hline $\begin{array}{l}\text { Что вызывает молниеносное } \\
\text { отторжение? }\end{array}$ & $\begin{array}{l}\text { Цитотоксические гуморальные } \\
\text { антитела, имеющиеся у реципиента, } \\
\text { против донора. }\end{array}$ \\
\hline Что вызывает ишемию-реперфузию? & $\begin{array}{l}\text { DAMP из клеток, повреждённых } \\
\text { ишемией. }\end{array}$ \\
\hline Что вызывает острое отторжение? & $\begin{array}{l}\text { Готовые или недавно образованные } \\
\text { гуморальные и клеточные антитела к } \\
\text { донору. }\end{array}$ \\
\hline $\begin{array}{l}\text { Что вызывает хроническое } \\
\text { отторжение? }\end{array}$ & Гуморальные и клеточные антитела. \\
\hline
\end{tabular}




\begin{tabular}{|c|c|}
\hline Вопросы & Ответы \\
\hline Цель иммунологического анализа: & $\begin{array}{l}\text { Определение у реципиента антител } \\
\text { против донора и вероятность их } \\
\text { появления. }\end{array}$ \\
\hline $\begin{array}{l}\text { Как выявляются антитела против } \\
\text { донора у реципиента? }\end{array}$ & Тесты на совместимость. \\
\hline $\begin{array}{l}\text { Как проводятся тесты на } \\
\text { совместимость? }\end{array}$ & $\begin{array}{l}\text { Донорские антиген-несущие клетки } \\
\text { смешиваются с сывороткой крови } \\
\text { реципиента } \\
\text { соединение антиген-антитело. }\end{array}$ \\
\hline $\begin{array}{l}\text { Как определяется вероятность } \\
\text { образования антител? }\end{array}$ & ПРА, HLA, группы крови. \\
\hline $\begin{array}{l}\text { Какие тесты чаще всего используются } \\
\text { для проверки совместимости донора и } \\
\text { реципиента (риск отторжения)? }\end{array}$ & $\begin{array}{l}\text { - } \text { Совместимость по группе крови; } \\
\text { - Совместимость комплемент- } \\
\text { связывающих лимфоцитов; } \\
\text { - Соответствие лимфоцитов при } \\
\text { проточной цитометрии; } \\
\text { - Виртуальные тесты; } \\
\text { - НLA-типирование. }\end{array}$ \\
\hline $\begin{array}{l}\text { Что используется для профилактики } \\
\text { отторжения? }\end{array}$ & Иммуносупрессивная терапия. \\
\hline $\begin{array}{l}\text { Какой иммунодепрессивный препарат } \\
\text { используется чаще всего? }\end{array}$ & $\begin{array}{l}\text { Ингибиторы кальциневрина } \\
\text { такролимус и циклоспорин. }\end{array}$ \\
\hline $\begin{array}{l}\text { Отрицательные черты } \\
\text { иммуносупрессивной терапии: }\end{array}$ & $\begin{array}{l}\text { - Чрезмерная иммуносупрессия; } \\
\text { - Токсикоз. }\end{array}$ \\
\hline $\begin{array}{l}\text { Как проявляется чрезмерная } \\
\text { иммуносупрессия? }\end{array}$ & $\begin{array}{l}\text { Развитием оппортунистических } \\
\text { инфекций и новообразований. }\end{array}$ \\
\hline $\begin{array}{l}\text { Что относится к лекарственным } \\
\text { токсикозам? }\end{array}$ & $\begin{array}{l}\text { - Метаболический эффект (диабет); } \\
\text { - Побочные эффекты со стороны } \\
\text { сердечно-сосудистой } \\
\text { системы }\end{array}$ \\
\hline
\end{tabular}




\begin{tabular}{|ll|}
\hline \multicolumn{1}{|c|}{ Вопросы } & \multicolumn{1}{c|}{ Ответы } \\
\hline & (гипертония, ишемическая болезнь \\
& сердца и др.); \\
& - Токсикоз почек и печени; \\
& - Миелосупрессия; \\
& Побочные эффекты со стороны \\
& желудочно-кишечной системы \\
& (диарея и др.); \\
& Побочные эффекты со стороны \\
& костной системы. \\
\hline Лечение молниеносного отторжения: & Удаление трансплантата. \\
\hline Лечение острого отторжения: & Высокие дозы стероидов - при Т- \\
& клеточном отторжении, плазмаферез - \\
& при гуморальном отторжении, Іg и анти- \\
& В-лимфоцитарная терапия. \\
\hline Лечение хронического отторжения: & Нет эффективного лечения. \\
\hline
\end{tabular}




\section{ПРЕДОПЕРАЦИОННЫЕ ОБСЛЕДОВАНИЯ}

- Целью предоперационного обследования пациента, нуждающегося в трансплантации, является решение следующих задач:

○ Нужна ли трансплантация?

○ Возможна ли трансплантация?

○ Определение срока (времени) вмешательства.

- Для того, чтобы ответить на эти вопросы, необходимо уточнить диагноз заболевания, степень тяжести и прогнозировать возможные послеоперационные осложнения.

- В отличие от классической хирургической операции, в трансплантологии имеются 3 объекта, задействованных в операции: реципиент, донор, трансплантат. Поэтому в процессе предоперационного обследования необходимо обследовать все 3 объекта для принятия решения о проведении операции.

- У реципиента проводятся 2 группы обследований: общие и органоспецифические.

○ Целью органоспецифических обследований является установление диагноза заболевания и степени его тяжести, обоснование показаний и противопоказаний к трансплантации, определение оптимального срока операции. Обычно показаниями к трансплантации считаются стадия декомпенсации заболевания с необратимыми повреждениями органа и неэффективность других методов лечения.

○ Основной целью общих обследований, проводимых у реципиента, является правильное определение показаний и противопоказаний к операции, выявление всевозможных (вероятных) причин, осложняющих выполнение трансплантации и проведение иммуносупрессивной терапии. Противопоказаниями к пересадке органов являются: наличие некорригируемых сопутствующих заболеваний и системной дисфункции (недостаточности), активной инфекции, злокачественных новообразований, серьёзных психологических и социальных причин.

- Целью обследования донора является определение состояния его здоровья, наличия или отсутствия заболеваний, представляющих опасность для здоровья реципиента, выявление общего и органоспецифического риска операции и 
согласие донора к планируемой трансплантации. Для этого проводятся общие, органоспецифические, социальные и правовые исследования.

- Исследование трансплантата заключается в определении его морфологической, функциональной и иммунологической совместимости.

\section{Вопросы и ответы по предоперационным обследованиям}

\begin{tabular}{|c|c|}
\hline Вопросы & Ответы \\
\hline $\begin{array}{l}\text { Чем отличается трансплантация от } \\
\text { других хирургической операции? }\end{array}$ & $\begin{array}{l}\text { - Имеются } 3 \text { объекта: реципиент, } \\
\text { донор и трансплантат; } \\
\text { - Возникает необходимость в } \\
\text { иммуносупрессии. }\end{array}$ \\
\hline Показания к трансплантации: & $\begin{array}{l}\text { Стадия декомпенсации заболевания с } \\
\text { необратимыми повреждениями органа } \\
\text { и неэффективность других методов } \\
\text { лечения. }\end{array}$ \\
\hline $\begin{array}{l}\text { Какие процессы развиваются у } \\
\text { реципиента после трансплантации? }\end{array}$ & $\begin{array}{l}\text { - Восстановление после } \\
\text { хирургического стресса; } \\
\text { - Реакция отторжения } \\
\text { трансплантата/иммуносупрессия; } \\
\text { - Регенерация } \\
\text { трансплантата. }\end{array}$ \\
\hline $\begin{array}{l}\text { В чём заключается цель } \\
\text { предоперационных обследований в } \\
\text { трансплантологии? }\end{array}$ & $\begin{array}{l}\text { - Установление диагноза заболевания } \\
\text { и степени его тяжести (показаний); } \\
\text { • Выявление вероятных причин } \\
\text { осложнений (противопоказаний): } \\
\text { сопутствующие заболевания и } \\
\text { резервная функция организма, } \\
\text { противопоказания } \\
\text { иммуносупрессии и и } \\
\text { отторжения. }\end{array}$ \\
\hline
\end{tabular}




\begin{tabular}{|c|c|}
\hline Вопросы & Ответы \\
\hline $\begin{array}{l}\text { Тактика при выявлении } \\
\text { сопутствующей патологии у } \\
\text { реципиента: }\end{array}$ & $\begin{array}{l}\text { При возможности коррекции патологии } \\
\text { - трансплантация после полного } \\
\text { устранения сопутствующей патологии; } \\
\text { при невозможности коррекции и } \\
\text { устранения сопутствующей патологии - } \\
\text { симультанная трансплантация; } \\
\text { противном случае - полный отказ от } \\
\text { трансплантации. }\end{array}$ \\
\hline Противопоказания к трансплантации: & 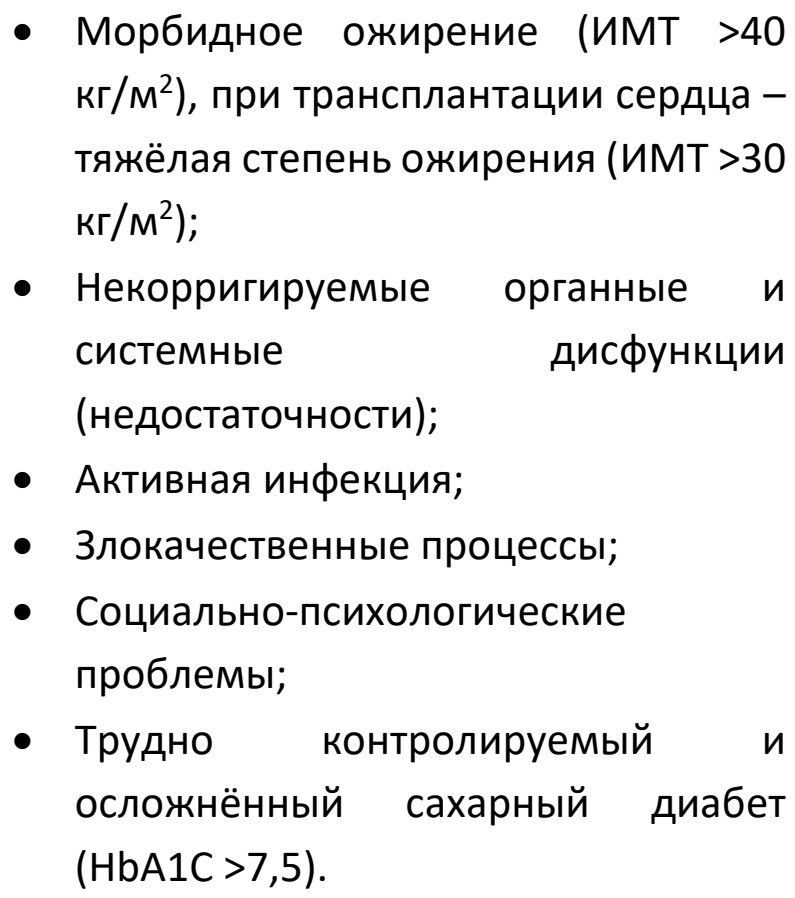 \\
\hline Противопоказания к донорству: & $\begin{array}{l}\text { - Отсутствие добровольного согласия } \\
\text { (под давление или ради финансовой } \\
\text { выгоды). } \\
\text { - Возраст <18 лет (для живых } \\
\text { доноров); } \\
\text { - Заболевания, повышающие риск } \\
\text { трансплантации; } \\
\text { - Высокий органоспецифический риск } \\
\text { - ограниченные функциональные } \\
\text { резервы, наличие патологии, }\end{array}$ \\
\hline
\end{tabular}




\begin{tabular}{|c|c|}
\hline Вопросы & Ответы \\
\hline & $\begin{array}{l}\text { представляющей опасность для } \\
\text { трансплантанта; } \\
\text { • Наличие заболевания, } \\
\text { представляющей опасность для } \\
\text { здоровья реципиента; } \\
\text { - Беременность; } \\
\text { - Морбидное ожирение; } \\
\text { - Психологические проблемы; }\end{array}$ \\
\hline $\begin{array}{l}\text { Показатели несоответствия } \\
\text { трансплантанта: }\end{array}$ & $\begin{array}{l}\text { - Малый размер трансплантата; } \\
\text { - Недостаточные функциональные } \\
\text { резервы органа; } \\
\text { - Серьёзные повреждения органа; } \\
\text { - Несоответствие сосудистой и } \\
\text { протоковой систем; } \\
\text { - Высокий иммунологический риск. }\end{array}$ \\
\hline $\begin{array}{l}\text { Что такое маргинальный } \\
\text { трансплантат? }\end{array}$ & $\begin{array}{l}\text { Трансплантат, не отвечающий } \\
\text { стандартным критериям, хотя в } \\
\text { вынужденных ситуациях может быть } \\
\text { использован. }\end{array}$ \\
\hline $\begin{array}{l}\text { Какие трансплантаты считаются } \\
\text { маргинальными? }\end{array}$ & $\begin{array}{l}\text { - Возраст донора >60-65 лет; } \\
\text { - Трансплантат от донора с сахарным } \\
\text { диабетом и артериальной } \\
\text { гипертензией; } \\
\text { - Трансплантат от донора с } \\
\text { остановившимся сердцем; } \\
\text { - Трансплантаты с длительным } \\
\text { периодом холодовой ишемии; } \\
\text { - Трансплантаты, имеющие } \\
\text { органические } \\
\text { повреждения; патологии }\end{array}$ \\
\hline
\end{tabular}




\section{Вопросы Ответы}

- Трансплантаты, несовместимые по группе крови и другим иммунологическим тестам. 


\section{ЗАБОР И КОНСЕРВАЦИЯ ОРГАНОВ}

- Органы для трансплантации получают из трёх источников: у пациента со смертью мозга, у пациента с остановкой сердца и живых доноров.

- Смертью мозга называется состояние арефлексии коры и ствола головного мозга, которое проявляется полным отсутствием рефлексов ствола головного мозга и необратимой комой: отсутствие реакции на какое-либо раздражение, дыхательный центр не функционирует (апноэ), отсутствие зрачкового, корнеального, вестибулоокулярного, глотательного рефлексов.

- Диагноз ставится бригадой врачей в основном на основании клинических признаков. Забор донорских органов осуществляется в рамках медицинских и правовых норм: у донора не должно быть заболеваний, передаваемых реципиенту, донорский орган должен быть подходящим и необходимо получить согласие для забора органа.

- В целом трансплантат подвержен 5 типам повреждений: тёплая и холодовая ишемии, ишемии-реперфузия, острое и хроническое отторжение. Ишемическое повреждение при консервации является основным повреждающим механизмом.

- По этой причине основная цель мероприятий направлена на защиту трансплантата от ишемии: снижение потребности в кислороде (холод), обеспечение запаса энергии (глюкоза и АТФ), уменьшение повреждения (отёк, ацидоз, ионный обмен, антиоксиданты). В настоящее время состав растворов для консервации органов основан на этих принципах.

- Существуют 2 метода для сохранения жизнеспособности органов, подлежащих трансплантации: статическое охлаждение и перфузионные методы. В последние годы наиболее широко применяется последний метод.

\section{Вопросы и ответы по забору и консервации органов}

\section{Вопросы}

Источники донорских органов и

тканей:

\section{Ответы}

- Пациенты со смертью мозга;

- Пациенты с остановкой сердца; 


\section{Boпросы}

\section{Ответы}

- Живые доноры.

Что представляет собой смерть мозга? Состояние арефлексии коры и ствола головного мозга, которое проявляется полным отсутствием стволовых рефлексов и необратимой комой.

\section{Основной рефлекс ствола мозга: Дыхательный рефлекс.}

\section{Критерии смерти мозга:}

\section{Клинические критерии:}

- Температура $>35^{\circ} \mathrm{C}$;

- Отсутствие медикаментозного токсикоза и нейромускулярной блокады;

- Отсутствие метаболических расстройств;

- Отсутствие рефлексов коры и ствола мозга (арефлексия):

○ Рвотный, кашлевой, корнеальный рефлексы;

○ Вестибулоокулярный рефлекс (фиксированный взгляд);

○ Зрачковый рефлекс (расширенный зрачок);

○ Апноэ (отсутствие спонтанного дыхания);

О Отсутствие реакции на внешние раздражители.

Критерии

инструментальных исследований:

- Изоэлектрическая электроэнцефалограмма;

- КТ - дислокация мозга; 


\begin{tabular}{|c|c|}
\hline Вопросы & Ответы \\
\hline & $\begin{array}{l}\text { - Нарушения } \\
\text { кровообращения. }\end{array}$ \\
\hline $\begin{array}{l}\text { Какие рефлексы должны } \\
\text { отсутствовать для установления факта } \\
\text { смерти мозга? }\end{array}$ & Отсутствие всех рефлексов. \\
\hline Кто констатирует факт смерти мозга? & Бригада врачей. \\
\hline $\begin{array}{l}\text { Может ли трансплантолог участвовать } \\
\text { в процедуре констатации смерти } \\
\text { мозга? }\end{array}$ & Нет. \\
\hline $\begin{array}{l}\text { Каким повреждениям подвергается } \\
\text { трансплантат? }\end{array}$ & $\begin{array}{l}\text { Тепловая и холодовая ишемия, } \\
\text { ишемия-реперфузия, острое и } \\
\text { хроническое отторжение. }\end{array}$ \\
\hline $\begin{array}{l}\text { Какому повреждению подвергается } \\
\text { трансплантат при хранении? }\end{array}$ & Ишемия. \\
\hline $\begin{array}{l}\text { В чём заключаются принципы защиты } \\
\text { трансплантата при хранении? }\end{array}$ & $\begin{array}{l}\text { Снижение потребности к кислороду } \\
\text { (холодовая ишемия), обеспечение } \\
\text { запаса энергии (глюкоза, АТФ), } \\
\text { уменьшение повреждения (борьба с } \\
\text { отёком, ацидозом, электролитными } \\
\text { нарушениями, антиоксидантами). }\end{array}$ \\
\hline Методы хранения трансплантата: & $\begin{array}{l}\text { - Статическое охлаждение - } \\
\text { сохранение в холодном растворе; } \\
\text { - Перфузионные методы - перфузия } \\
\text { специальным раствором. }\end{array}$ \\
\hline $\begin{array}{l}\text { На какие сроки можно сохранить } \\
\text { органы методом статического } \\
\text { охлаждения? }\end{array}$ & $\begin{array}{l}\text { - Сердце - } 6 \text { часов; } \\
\text { - Лёгкие - } 6 \text { часов; } \\
\text { - Поджелудочная железа - } 24 \text { часов; } \\
\text { - Печень - } 24 \text { часов; } \\
\text { - Почки - } 48 \text { часов. }\end{array}$ \\
\hline
\end{tabular}


Вопросы

Преимущества хранения трансплантата перфузионным методом:

\section{Ответы}

- Позволяет увеличить продолжительность холодовой ишемии;

- Позволяет оценить функциональную пригодность органа;

- Обеспечивает восстановление повреждения органа. 


\section{ВЕДЕНИЕ ПОСТТРАНСПЛАНТАЦИОННОГО ПЕРИОДА}

- Задачей послеоперационного ведения пациентов после трансплантации является изучение особенностей восстановительных процессов, обеспечение адаптации трансплантата, неосложнённого течения реакции отторжения трансплантата и иммуносупрессии.

- С этой целью проводятся профилактика, ранняя диагностика - мониторинг и лечение осложнений.

- В зависимости от причин возникновения, посттрансплантационные осложнения подразделяются на следующие виды: общие осложнения (связанные с операцией), осложнения, обусловленные трансплантатом и иммуносупрессией. По времени развития различают ранние и поздние осложнения.

○ В раннем послеоперационном периоде наиболее часто встречаются общие осложнения, связанные с перенесённой операцией (органная или системная дисфункции, раневая или системная инфекции, кровотечение и др.), и осложнения, обусловленные трансплантатом (дисфункция пересаженного органа, отторжение, проблемы, связанные с сосудистыми и протоковыми структурами).

○ В позднем послеоперационном периоде наблюдаются осложнения, связанные с дисфункцией трансплантата (острое и хроническое отторжение, рецидив основного заболевания, протоковые проблемы и др.), и иммуносупрессией (возникновение оппортунистической инфекции, токсикоза, развитие неопластических процессов).

- Посттрансплантационные инфекции имеют бактериальное, вирусное, грибковое и паразитарное происхождения.

○ В течение первых месяцев обычно у реципиента и донора наблюдается обострение имеющихся инфекций или развиваются новые инфекции, связанные с трансплантацией.

○ В сроки от 2 до 6 месяцев после трансплантации развиваются оппортунистические инфекции, связанные с иммуносупрессией.

○ По истечению 6 месяцев после пересадки приобретённые инфекции имеют общую закономерность, принципиально не отличающуюся от здоровых.

- С целью профилактики развития инфекционных осложнений проводится комплексная система мероприятий до-, во время и после операции: 
○ Бережное отношение к тканям, минимизация их травматизации;

○ Обеспечение полного и надёжного гемо- и желчестаза;

- Формирование анастомозов без травматизации протоков и сосудов;

○ Антибиотикопрофилактика;

- Раннее удаление катетеров;

○ Ранняя активизация пациентов с проведением дыхательной гимнастики;

○ Профилактическое лечение оппортунистических инфекций (ЦМВ, ЭБВ, герпетическая инфекция, криптококковая инфекция, грибковая инфекция и др.)

- Повышение температуры тела после трансплантации обоснованно может наводить на мысль о вероятности инфекционных осложнений. Послеоперационные исследования должны быть направлены на выявление наличия или отсутствия инфекционных, тромбоэмболических осложнений и вероятности развития реакции отторжения трансплантата.

○ В первую очередь исследуются наиболее распространённые инфекции (инфекции горла, лёгких, мочевых пути, вирусные инфекции - ЦМВ, ВГЧ, ЭБВ, раневые инфекции, инфекции дренажной трубки и катетеров) и вероятность тромбоза.

○ При исключении этих причин, поиски должны быть направлены на выявление других инфекций (грибковая, туберкулёзная, криптококковая инфекции, легионеллёз).

О Нередко причинами инфекционных осложнений являются абсцессы, холангит, гепатит, вагинальные инфекции.

- В посттрансплантационном периоде на фоне иммуносупрессивной терапии риск развития злокачественных опухолей возрастает в 5-30 раз. Часто наблюдаются саркома Капоши, рак кожи и лимфопролиферативные процессы. Все это диктует необходимость тщательного предоперационного обследования реципиента и донора, а также периодического динамического контроля.

- Отмена иммуносупрессивной терапии и назначение адекватного противоопухолевого лечения, проведение хирургического лечения, химиотерапии и радиотерапии составляют основу комплексной системы лечения этих пациентов. 


\section{Вопросы и ответы по ведению посттрансплантационного периода}

\begin{tabular}{|c|c|}
\hline Вопросы & Ответы \\
\hline $\begin{array}{l}\text { Какие процессы развиваются в } \\
\text { организме после трансплантации? }\end{array}$ & $\begin{array}{l}\text { - Восстановление после } \\
\text { хирургического стресса; } \\
\text { - Адаптация трансплантата; } \\
\text { - Реакция отторжения } \\
\text { трансплантата/иммуносупрессия. }\end{array}$ \\
\hline $\begin{array}{l}\text { Цель ведения послеоперационного } \\
\text { периода: }\end{array}$ & $\begin{array}{l}\text { Обеспечение неосложнённого течения } \\
\text { посттрансплантационного периода, } \\
\text { ранняя диагностика, лечение и } \\
\text { профилактика осложнений. }\end{array}$ \\
\hline $\begin{array}{l}\text { Какие осложнения могут возникнуть } \\
\text { после трансплантации? }\end{array}$ & $\begin{array}{l}\text { Общие осложнения, связанные с } \\
\text { операцией, и специфические } \\
\text { осложнения, } \\
\text { трансплантатом и иммуносупрессией. }\end{array}$ \\
\hline $\begin{array}{l}\text { Наиболее часто встречающиеся } \\
\text { осложнения: }\end{array}$ & $\begin{array}{l}\text { Обструкция, реакция отторжения, } \\
\text { инфекция, неопластические процессы, } \\
\text { связанные с иммуносупрессией. }\end{array}$ \\
\hline $\begin{array}{l}\text { Какие осложнения связаны с } \\
\text { иммуносупрессивной терапией? }\end{array}$ & $\begin{array}{ll}\text { Оппортунистические } & \text { инфекции, } \\
\text { неопластические } & \text { процессы, } \\
\text { лекарственные токсикозы. } & \end{array}$ \\
\hline $\begin{array}{l}\text { Наиболее частые инфекции, } \\
\text { возникшие в течение первых месяцев: }\end{array}$ & $\begin{array}{l}\text { Обострение инфекций, существующих в } \\
\text { организме реципиента и донора, и } \\
\text { инфекции, связанные с операцией. }\end{array}$ \\
\hline $\begin{array}{l}\text { Какие инфекции часто наблюдаются в } \\
\text { течение 2-6 месяцев после операции? }\end{array}$ & Оппортунистические инфекции. \\
\hline $\begin{array}{l}\text { Наиболее часто встречающиеся } \\
\text { оппортунистические инфекции: }\end{array}$ & $\begin{array}{lrr}\text { ЦМВ, ЭБВ, } & \text { полиома, } & \text { туберкулёз, } \\
\text { Pneumocystis } & \text { Carinii, } & \text { Candida, } \\
\text { аспергиллёз. } & & \end{array}$ \\
\hline
\end{tabular}




\section{Вопросы Ответы}

Какие осложнения часто наблюдаются Общие инфекционные заболевания. по истечении 6 месяцев после трансплантации?

Как проводится профилактика цитомегаловирусной инфекции?

Как проводится профилактика инфекции, вызываемой вирусом

Эпштейн-Бара?

Как проводится профилактика герпетической инфекции?

Профилактика инфекции, Ко-тримоксазол.

вызываемой Pneumocystis Carinii:

Профилактика инфекции, вызванной Нистатин.

Candida:

Наиболее часто встречающиеся неопластические процессы после трансплантации:

Меры, направленные на уменьшение риска возникновения рака:
Ганцикловир, валганцикловир.

Ганцикловир или валганцикловир.

Ганцикловир или валганцикловир.
Саркома Капоши, рак кожи, лимфопролиферативные заболевания.

- Тщательное предоперационное обследование;

- Избегать длительной иммуносупрессивной терапии;

- Ограниченное употребление АТГ (анти-Т-лимфоцитарный глобулин);

- Избегать инсоляции;

- Применение ингибиторов mTOR. 


\section{ТРАНСПЛАНТАЦИЯ ПОЧЕК}

- Трансплантация почек является единственным эффективным методом лечения терминальной стадии хронической почечной недостаточности и «беспочечного» состояния.

- Клиренс креатинина ниже 20 мл/мин является показанием к пересадке почки.

- В качестве источника донорской почки используются живые и мёртвые доноры (доноры со сердечной и мозговой смертью).

- В отличие от трансплантации печени, после пересадки почки высока вероятность развития реакции отторжения, что требует проведения широкой системы профилактики:

○ Перекрёстная проба на гистосовместимость по группе крови, PRA- и HLAсистемам;

○ Индукция IL-2 блокаторами, ATГ, использование стволовых клеток;

○ Интенсивная иммуносупрессия: преднизолон, антиметаболиты, ингибиторы кальциневрина.

- Изъятие почки от живого донора осуществляют лапароскопическим доступом.

- Донорскую почку пересаживают в подвздошную ямку.

- Обычно формируют 3 анастомоза: соединяют почечную и подвздошную вены, затем - почечную и подвздошную артерии, в последнюю очередь формируют анастомоз между мочеточником и мочевым пузырем.

- Обструкция протока и сосуда, острая и хроническая реакции отторжения, инфекция, дегидратация, тубулярный некроз являются наиболее частыми послеоперационными осложнениями.

- 5-летняя выживаемость после трансплантации почки составляет 80-95\%.

\section{Вопросы и ответы по трансплантации почки}

\section{Bопросы}

Показания к трансплантации почки:

\section{Ответы}

- Терминальная стадия хронической почечной недостаточности;

- «Беспочечное» состояние. 


\begin{tabular}{|c|c|}
\hline Основное показание: & Хроническая почечная недостаточность. \\
\hline $\begin{array}{l}\text { Какая стадия хронической почечной } \\
\text { недостаточности является показанием } \\
\text { к трансплантации почки: }\end{array}$ & $\begin{array}{l}\text { Клиренс креатинина ниже } 20 \text { мл/мин, } \\
\text { требующий диализа. }\end{array}$ \\
\hline $\begin{array}{l}\text { Противопоказания к трансплантации } \\
\text { почки: }\end{array}$ & 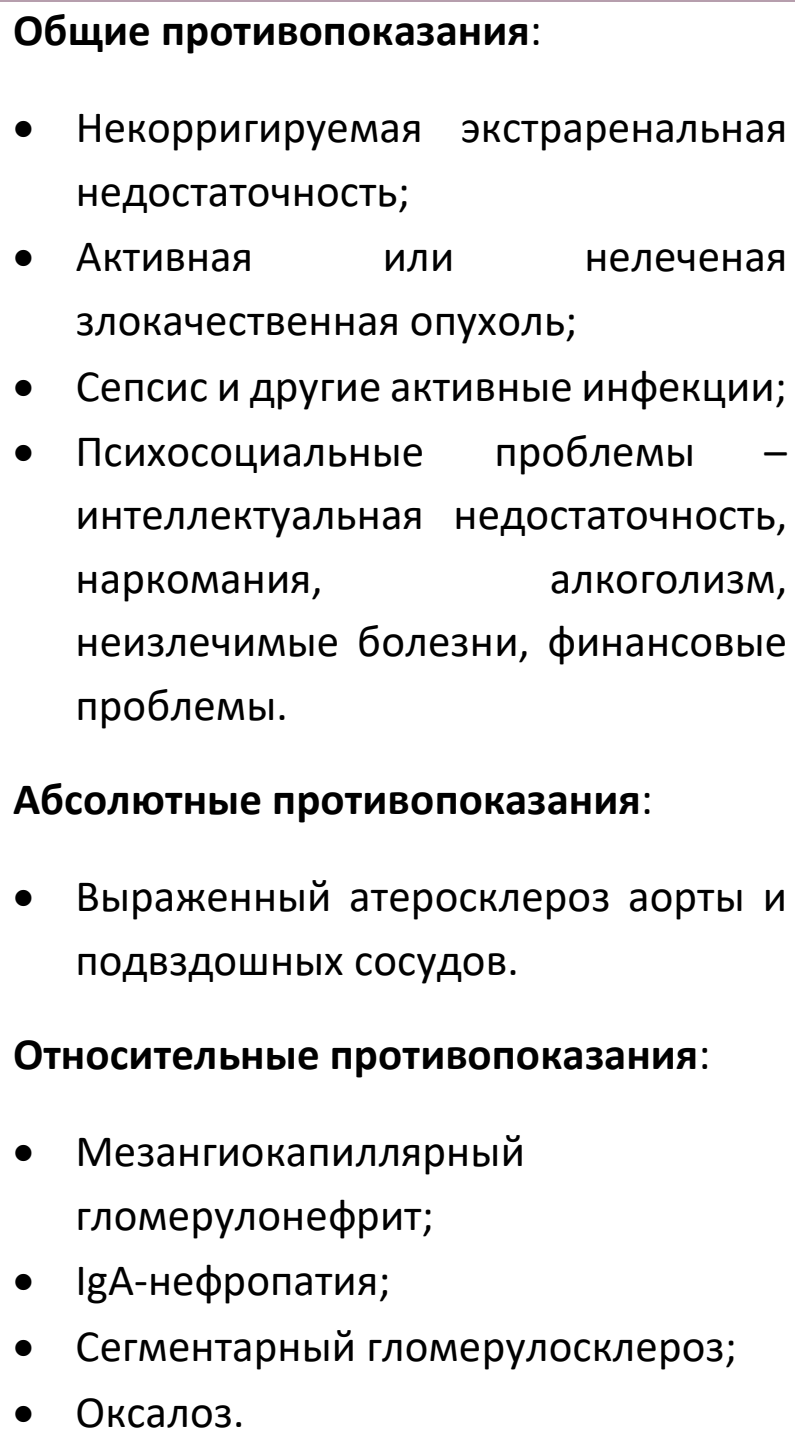 \\
\hline $\begin{array}{l}\text { Какие иммуносовместимые тесты } \\
\text { проводятся? }\end{array}$ & $\begin{array}{l}\text { - Группа крови; } \\
\text { - Перекрёстный тест } \\
\text { лимфоцитарную } \\
\text { гистосовместимость; } \\
\text { - Панель реактивных антител; } \\
\text { - НLA-система. }\end{array}$ \\
\hline
\end{tabular}




\begin{tabular}{|c|c|}
\hline Методы трансплантации почки: & $\begin{array}{l}\text { - От живого донора или от донора со } \\
\text { смертью мозга или сердца; } \\
\text { - Самостоятельно или в сочетании с } \\
\text { поджелудочной железой; } \\
\text { - Открытый или лапароскопический } \\
\text { доступ. }\end{array}$ \\
\hline $\begin{array}{l}\text { Какую почку используют в качестве } \\
\text { трансплантата в первую очередь? }\end{array}$ & $\begin{array}{l}\text { Левая почка (в связи с более длинной } \\
\text { веной). }\end{array}$ \\
\hline $\begin{array}{l}\text { В какую область реципиента } \\
\text { пересаживают почку? }\end{array}$ & В подвздошную ямку. \\
\hline $\begin{array}{l}\text { Почему не производят } \\
\text { ортотопическую пересадку? }\end{array}$ & $\begin{array}{l}\text { Подвздошная ямка более удобна для } \\
\text { биопсии и формирования анастомоза } \\
\text { между мочеточником и мочевым } \\
\text { пузырем. Также сохраняется почка } \\
\text { реципиента. }\end{array}$ \\
\hline Почему больную почку не удаляют? & $\begin{array}{l}\text { Во избежание дополнительной } \\
\text { операционной травмы. }\end{array}$ \\
\hline $\begin{array}{l}\text { В каких случаях больная почка } \\
\text { обязательно должна быть удалена? }\end{array}$ & $\begin{array}{l}\text { - Хронический рецидивирующий } \\
\text { калькулёзный и бескаменный } \\
\text { пиелонефрит. } \\
\text { - Тяжёлая протеинурия; } \\
\text { - Рефрактерная гипертония; } \\
\text { - Большие поликистозные почки, } \\
\text { сопровождающиеся болевым } \\
\text { синдромом, кровотечением, риском } \\
\text { малигнизации; } \\
\text { - Инфекционная нефропатия. }\end{array}$ \\
\hline Осложнения: & $\begin{array}{l}\text { - Дисфункция пересаженной почки; } \\
\text { - Отсутствие или задержка функции } \\
\text { трансплантата; }\end{array}$ \\
\hline
\end{tabular}




\begin{tabular}{|c|c|}
\hline & $\begin{array}{l}\text { - Артериальный или венозный } \\
\text { тромбоз; } \\
\text { - Артериальный стеноз; } \\
\text { - Недостаточность пузырно- } \\
\text { мочеточникового анастомоза; } \\
\text { - Уретральная обструкция; } \\
\text { - Лимфоцеле; } \\
\text { - Реакция отторжения. }\end{array}$ \\
\hline Критерии отторжения трансплантата: & $\begin{array}{l}\text { Повышение уровня } \\
\text { повышение лотинина, } \\
\text { температуры, слабость, гипертония, } \\
\text { отёк нижних конечностей. }\end{array}$ \\
\hline $\begin{array}{l}\text { Что является причиной повышения } \\
\text { уровня креатинина? }\end{array}$ & $\begin{array}{l}\text { Обструкция, отторжение, инфекция, } \\
\text { дегидратация, острый тубулярный } \\
\text { некроз. }\end{array}$ \\
\hline $\begin{array}{l}\text { Диагностическая тактика при } \\
\text { повышении креатинина: }\end{array}$ & $\begin{array}{l}\text { - Определяется наличие гипотензии } \\
\text { - } \text { Кли гиповолемии; } \\
\text { - Узи, допплерография; } \\
\text { - Фуросемидный тест; } \\
\text { - Биопсия. }\end{array}$ \\
\hline $\begin{array}{l}\text { Когда нормализуется функция } \\
\text { пересаженной почки? }\end{array}$ & $\begin{array}{l}\text { После трансплантации от живого } \\
\text { донора через 3-5 дней, от мёртвого } \\
\text { донора - в течение 7-15 дней. }\end{array}$ \\
\hline $\begin{array}{l}\text { Отдалённые результаты пересадки } \\
\text { почки: }\end{array}$ & $\begin{array}{l}\text { 5-летняя выживаемость составляет 80- } \\
\text { 95\%. }\end{array}$ \\
\hline
\end{tabular}




\section{ТРАНСПЛАНТАЦИЯ ПЕЧЕНИ}

- Показаниями к пересадке печени являются терминальная стадия цирроза печени, гепатоцеллюлярный рак, метаболические заболевания, острая печёночная недостаточность, причём цирроз занимает первое место среди этих показаний.

- Внепечёночное распространение гепатоцеллюлярного рака и рефрактерная лёгочная гипертензия и неподдающаяся излечению инфекция служат противопоказаниями к трансплантации печени.

- Источниками донорской печени являются живые и мёртвые (с мозговой и сердечной смертью) доноры. В зависимости от места пересадки различают ортотопическую и гетеротопическую трансплантацию печени. Существуют заместительные и адъювантные методы трансплантации в зависимости от того, удаляется ли печень пациента.

- В настоящее время пересадку печени выполняют в основном от живого донора и от мёртвого донора с мозговой смертью. По общим принципам размер трансплантата должен составлять не менее 0,8\% массы тела реципиента или не менее $40 \%$ (или не более 200\%) стандартного объёма печени.

- При ортотопической пересадке трансплантат помещают на место удалённой печени. Сначала соединяют печёночные, а потом портальные вены, затем артерию. В последнюю очередь формируют анастомозы между жёлчными протоками.

- Наиболее частыми осложнениями являются обструкция жёлчных протоков, тромбозы сосудов, реакция отторжения трансплантата, инфекции.

- После пересадки печени 1-летняя выживаемость составляет 73-86\%, 5-летняя $60-72 \%$.

\section{Вопросы и ответы по трансплантации печени}

Bопросы

Показания к трансплантации печени:

\section{Ответы}

- Цирроз печени;

- Злокачественные опухоли;

- Метаболические заболевания; 


\section{Bonросы}

\section{Ответы}

- Острая печёночная недостаточность.

Наиболее частая нозологическая Ц Цирроз печени (80\%).

причина пересадки печени:

В какой стадии цирроза показана Стадия декомпенсации с
трансплантация? манифестацией осложнений.

Показания к срочной трансплантации: Острая печёночная недостаточность;

- Гепаторенальный синдром.

Корригируем ли гепаторенальный Да.

синдром после трансплантации

печени?

Противопоказания к трансплантации Общие противопоказания:

печени:

- Некорригируемая экстрапечёночная недостаточность;

- Активная или нелеченая злокачественная опухоль;

- Сепсис и другие активные инфекции;

- Психосоциальные проблемы интеллектуальная недостаточность, наркомания, алкоголизм, неизлечимые болезни, финансовые проблемы.

Абсолютные противопоказания:

- Гепатоцеллюлярный рак с внепечёночными метастазами;

- Рефрактерная лёгочная гипертензия.

Относительные противопоказания:

- Гемохроматоз;

- Холангиоцеллюлярный рак. 


\begin{tabular}{|c|c|}
\hline Вопросы & Ответы \\
\hline $\begin{array}{l}\text { Какую пробу на совместимость } \\
\text { проводят? }\end{array}$ & Совместимость по группе крови. \\
\hline $\begin{array}{l}\text { Какой должен быть объём } \\
\text { пересаженной печени? }\end{array}$ & $\begin{array}{l}\text { Не менее 0,8\% от массы тела или } 40 \% \\
\text { стандартного объёма печени. }\end{array}$ \\
\hline $\begin{array}{l}\text { Какие методы трансплантации печени } \\
\text { существуют? }\end{array}$ & $\begin{array}{l}\text { - От живого донора и от мёртвого } \\
\text { донора со смертью мозга, сердца; } \\
\text { - Ортотопическая и гетеротопическая; } \\
\text { замена печени или адъювантная } \\
\text { трансплантация. }\end{array}$ \\
\hline $\begin{array}{l}\text { Посттрансплантационные } \\
\text { осложнения: }\end{array}$ & $\begin{array}{l}\text { - Сосудистые осложнения, } \\
\text { обусловленные артериальными и } \\
\text { венозным тромбозами; } \\
\text { - Стеноз или несостоятельность } \\
\text { анастомозов жёлчных протоков; } \\
\text { - Реакция отторжения (40\%); } \\
\text { - Инфекции; } \\
\text { - Рецидив основного заболевания; } \\
\text { - Медикаментозные токсикозы; } \\
\text { - Синдром малой доли печени. }\end{array}$ \\
\hline Признаки острой реакции отторжения: & $\begin{array}{l}\text { Гипербилирубинемия и повышение } \\
\text { уровня печёночных } \\
\text { (дисфункция трансплантата). }\end{array}$ \\
\hline $\begin{array}{l}\text { Что является “мишенью” при развитии } \\
\text { реакции отторжения? }\end{array}$ & $\begin{array}{l}\text { Процесс начинается с жёлчного } \\
\text { эпителия, } \quad \text { распространяется на } \\
\text { эндотелий сосудов и гепатоциты. }\end{array}$ \\
\hline $\begin{array}{l}\text { Какие исследования нужно проводить } \\
\text { при дисфункции трансплантата? }\end{array}$ & $\begin{array}{l}\text { Уточняется наличие обструкции } \\
\text { инфекции, реакции отторжения. } \\
\text { Проводится УзИ, допплерография, } \\
\text { холангиография. }\end{array}$ \\
\hline
\end{tabular}




\begin{tabular}{|c|c|}
\hline Вопросы & Ответы \\
\hline $\begin{array}{l}\text { Диагностика реакции острого } \\
\text { отторжения: }\end{array}$ & $\begin{array}{l}\text { На основании клинической картины, } \\
\text { результатов биопсии. }\end{array}$ \\
\hline $\begin{array}{l}\text { Признаки хронической реакции } \\
\text { отторжения и метод диагностики: }\end{array}$ & $\begin{array}{l}\text { Проявляется симптомами хронического } \\
\text { заболевания печени. При биопсии } \\
\text { обнаруживается симптом “вымывания" } \\
\text { жёлчных протоков. }\end{array}$ \\
\hline $\begin{array}{l}\text { Отдаленные результаты } \\
\text { трансплантации печении: }\end{array}$ & $\begin{array}{l}\text { - } 1 \text { и 5-летняя выживаемость } \\
\text { пациента составляет соответственно } \\
86 \% \text { и 72\%. } \\
\text { - Приживление пересаженной печени } \\
\text { составляет } 80 \% \\
\text { соответственно. }\end{array}$ \\
\hline
\end{tabular}




\section{ТРАНСПЛАНТАЦИЯ ПОДЖЕЛУДОЧНОЙ ЖЕЛЕЗЫ}

- Показанием к пересадке поджелудочной железы является коррекция дефицита инсулина при тяжёлой форме сахарного диабета, в особенности, при диабетической нефропатии и повторяющихся метаболических кризах (гипо-, гипергликемические комы и др.)

- При трансплантации поджелудочной железы используется 2 способа: пересадка целой железы и клеток островков Лангерганса.

- Принято 2 варианта пересадки поджелудочной железы: пересадка только железы и симультанная (одновременная) пересадка почки и железы.

○ Поджелудочную железу пересаживают гетеротопически в подвздошную ямку: сосуды железы соединяют с подвздошными сосудами, а выводной проток железы (обычно вместе с 12-перстной кишкой) - с мочевым пузырём.

○ Паратопическая пересадка поджелудочной железы более физиологична. Вену поджелудочной железы соединяют с портальной веной, протоковую систему с - двенадцатиперстной кишкой.

- Иммуносупрессивная терапия не отличается от таковой при пересадке почки.

○ В структуре послеоперационных осложнений наиболее часто встречаются панкреатит, венозный тромбоз и реакция отторжения.

○ Реакция отторжения клинически проявляется болью, повышением уровня амилазы, гипергликемией и снижением инсулина. Морфологически отторжение подтверждается биопсией.

○ При одновременной пересадке поджелудочной железы и почки 3-летняя выживаемость составляет 80-85\%.

- Пересадка клеток островков Лангерганса производится при осложнённом сахарном диабете или после тотальной панкреатэктомии.

○ В качестве источников клеток используются изолированные из ткани железы островковые клетки или специально выведенные клетки. Обычно клетки островков помещают в печень через портальную вену.

○ Добиться нормогликемии путём трансплантации островковых клеток крайне затруднительно и является временным эффектом. Однако развитие клеточной технологии вселяет надежду.

- Таким образом, пересадка поджелудочной железы технически сложна, сопровождается осложнениями, однако позволяет нормализовать углеводный 
обмен, избавиться от необходимости инсулинотерапии. В то же время пересадка клеток островков технически проста, безопасна, но пока неэффективна для лечения сахарного диабета.

\section{Вопросы и ответы по трансплантации поджелудочной железы}

\begin{tabular}{|c|c|}
\hline Вопросы & Ответы \\
\hline $\begin{array}{l}\text { Показания к трансплантации } \\
\text { поджелудочной железы: }\end{array}$ & $\begin{array}{l}\text { Осложнения сахарного диабета: } \\
\text { - Диабетическая нефропатия; } \\
\text { - Повторяющиеся метаболические } \\
\text { кризы (гипо- и гипергликемические } \\
\text { комы). }\end{array}$ \\
\hline $\begin{array}{l}\text { Противопоказания к трансплантации } \\
\text { поджелудочной железы: }\end{array}$ & $\begin{array}{l}\text { - общие противопоказания к } \\
\text { пересадке; } \\
\text { • Специфические противопоказания - } \\
\text { гангрена стопы, тяжёлые формы } \\
\text { кардиомиопатии, периферическая } \\
\text { нейропатия. }\end{array}$ \\
\hline $\begin{array}{l}\text { Какие иммунологические тесты } \\
\text { проводятся? }\end{array}$ & $\begin{array}{l}\text { - Группа крови; } \\
\text { - Лимфоцитарные перекрёстные } \\
\text { тесты; } \\
\text { - Панель реактивных антител; } \\
\text { - НLA-система. }\end{array}$ \\
\hline $\begin{array}{l}\text { Варианты трансплантации } \\
\text { поджелудочной железы: }\end{array}$ & $\begin{array}{l}\text { - Изолированная пересадка железы; } \\
\text { - Пересадка почки и поджелудочной } \\
\text { железы; } \\
\text { - Пересадка клеток островков } \\
\text { поджелудочной железы; } \\
\text { - Гетеротопическая или } \\
\text { паратопическая. }\end{array}$ \\
\hline
\end{tabular}




\begin{tabular}{|c|c|}
\hline Вопросы & Ответы \\
\hline $\begin{array}{l}\text { Что такое гетеротопическая } \\
\text { трансплантация? }\end{array}$ & $\begin{array}{l}\text { Поджелудочную железу пересаживают } \\
\text { в подвздошную ямку, последовательно } \\
\text { соединяют сосуды поджелудочной } \\
\text { железы с подвздошными сосудами, 12- } \\
\text { перстную кишку соединяют с мочевым } \\
\text { пузырем. }\end{array}$ \\
\hline $\begin{array}{l}\text { Преимущества гетеротопической } \\
\text { трансплантации: }\end{array}$ & $\begin{array}{l}\text { Определением уровня амилазы в моче } \\
\text { можно получить информацию об } \\
\text { экзокринной функции поджелудочной } \\
\text { железы. }\end{array}$ \\
\hline $\begin{array}{l}\text { Недостатки гетеротопической } \\
\text { трансплантации: }\end{array}$ & $\begin{array}{l}\text { Потеря большого количества } \\
\text { бикарбонатов, ацидоз, гематурия, } \\
\text { инфекции мочевого пузыря, рефлюкс } \\
\text { панкреатит. }\end{array}$ \\
\hline $\begin{array}{l}\text { Что такое паратопическая } \\
\text { трансплантация? }\end{array}$ & $\begin{array}{l}\text { Вены трансплантата соединяют с } \\
\text { воротной веной, проток - } \\
\text { кишечником. }\end{array}$ \\
\hline $\begin{array}{l}\text { Преимущества паратопической } \\
\text { трансплантации: }\end{array}$ & $\begin{array}{l}\text { Является физиологической: гормоны } \\
\text { поступают в портальную систему, } \\
\text { пищеварительные соки - в кишечник. }\end{array}$ \\
\hline $\begin{array}{l}\text { Недостатки паратопической } \\
\text { трансплантации: }\end{array}$ & $\begin{array}{l}\text { Оценка экзокринной } \\
\text { поджелудочной } \\
\text { затруднительна. }\end{array}$ \\
\hline Осложнения: & $\begin{array}{l}\text { - Посттрансплантационный } \\
\text { панкреатит; } \\
\text { - Реакция отторжения; } \\
\text { - Тромбоз вен трансплантата; } \\
\text { - Ацидоз, гематурия, цистит, рефлюкс } \\
\text { панкреатит; } \\
\text { - Несостоятельность анастомозов. }\end{array}$ \\
\hline
\end{tabular}




\begin{tabular}{|c|c|}
\hline Вопросы & Ответы \\
\hline $\begin{array}{l}\text { Признаки реакции отторжения } \\
\text { трансплантата: }\end{array}$ & $\begin{array}{l}\text { Гиперамилаземия, гипергликемия, } \\
\text { снижение уровня С-пептида и инсулина. }\end{array}$ \\
\hline $\begin{array}{l}\text { Чем объясняется эффективность } \\
\text { симультанной (одновременной) } \\
\text { трансплантации почки и } \\
\text { поджелудочной железы? }\end{array}$ & $\begin{array}{l}\text { Возможность раннего выявления } \\
\text { реакции отторжения (повышение } \\
\text { уровня креатинина, биопсия). } \\
\text { Симультанная трансплантация имеет } \\
\text { лучшие отдалённые результаты. }\end{array}$ \\
\hline $\begin{array}{l}\text { Источники островковых клеток } \\
\text { поджелудочной железы: }\end{array}$ & $\begin{array}{l}\text { - Изолированные из ткани железы } \\
\text { островковые клетки; } \\
\text { - Специально выведенные клетки. }\end{array}$ \\
\hline $\begin{array}{l}\text { Куда помещаются островковые } \\
\text { клетки? }\end{array}$ & В портальную вену. \\
\hline $\begin{array}{l}\text { Сколько островковых клеток железы } \\
\text { необходимы для пересадки? }\end{array}$ & 6000 клеток/кг. \\
\hline $\begin{array}{l}\text { Почему неэффективна пересадка } \\
\text { островковых клеток? }\end{array}$ & $\begin{array}{l}\text { В короткие сроки после пересадки } \\
\text { большая часть клеток погибает. }\end{array}$ \\
\hline $\begin{array}{l}\text { Отдалённые результаты и пересадки } \\
\text { поджелудочной железы: }\end{array}$ & $\begin{array}{l}\text { 3-х летняя выживаемость: } \\
\text { - } \quad \text { После симультанной } \\
\text { (одновременной) пересадки почки и } \\
\text { поджелудочной железы - 80-85\%; } \\
\text { - } \text { При последовательной пересадке } \\
\text { почки и поджелудочной железы - } \\
\text { 60-65\%; } \\
\text { - При изолированной пересадке } \\
\text { поджелудочной железы-50-60\%. }\end{array}$ \\
\hline
\end{tabular}




\section{ТРАНСПЛАНТАЦИЯ СЕРДЦА}

- Показаниями к трансплантации сердца являются сердечная недостаточность с объёмом сердечного выброса менее $20 \%$, вероятностью выживания в течение менее 1 года и отсутствие эффекта от консервативных мер. К наиболее распространённым показаниям к трансплантации относятся дилатационная и ишемическая кардиомиопатия.

- В предоперационном периоде в качестве лечения (“моста" к пересадке) применяют аппараты искусственного сердца и инотропную поддержку.

- Заболевания лёгких и лёгочная гипертензия являются специфическими противопоказаниями к пересадке сердца. Эти пациенты нуждаются в одновременной пересадке сердца и лёгких единым блоком.

- Реакция отторжения трансплантата после пересадки сердца встречается наиболее часто и проявляется повышением температуры тела, признаками гипоили гипертензии. С целью диагностики реакции отторжения требуется биопсия.

- 1-летная выживаемость после пересадки сердца составляет 81\%, а 5-летняя $70 \%$.

\section{Вопросы и ответы по трансплантации сердца}

\section{Вопросы Ответы}

Показания к трансплантации сердца: Ишемическая кардиомиопатия;

- Дилатационная кардиомиопатия;

- Врождённые пороки сердца.

Основное показание к трансплантации Дилатационная кардиомиопатия. сердца:

Противопоказания к трансплантации сердца:
- Общие противопоказания к пересадке;

- Специфические противопоказания: лёгочная гипертензия. 


\begin{tabular}{|c|c|}
\hline Вопросы & Ответы \\
\hline Варианты трансплантации сердца: & $\begin{array}{l}\text { Изолированная пересадка, } \\
\text { одновременная пересадка сердца и } \\
\text { лёгких единым комплексом. }\end{array}$ \\
\hline Осложнения: & $\begin{array}{l}\text { - Кровотечение из ушитых ран; } \\
\text { - Реакция отторжения; } \\
\text { - Инфекци (цМВ, Pneumocystis } \\
\text { carinii); } \\
\text { - Психические нарушения; } \\
\text { - Миоинтимальная васкулярная } \\
\quad \text { гиперплазия трансплантата. }\end{array}$ \\
\hline $\begin{array}{l}\text { Признаки реакции отторжения } \\
\text { трансплантата: }\end{array}$ & Гипертемия, гипо-, гипертензия. \\
\hline Отдалённые результаты: & $\begin{array}{l}\text { 1-летняя выживаемость - 81\%, 5-летняя } \\
-70 \% .\end{array}$ \\
\hline
\end{tabular}




\section{ТРАНСПЛАНТАЦИЯ ЛЁГКИХ}

- Показаниями к трансплантации лёгких являются обструктивная и рестриктивная лёгочная недостаточность, лёгочная гипертензия и инфекции, резко снижающие качество жизни и продолжительность.

- Активное курение и, как правило, левожелудочковая недостаточность являются противопоказанием к трансплантации изолированных лёгких.

- Возможна одной доли лёгкого, одного целого лёгкого, двух лёгких, сердечнолёгочного комплекса. При трансплантации от живого донора можно пересаживать часть лёгкого.

- Иммуносупрессивная терапия не отличается от таковой при пересадке почки.

- Наиболее частые послеоперационные специфические осложнения включают первичную дисфункцию трансплантата, острое и хроническое отторжение, бронхиальные, сосудистые и инфекционные осложнения.

- После трансплантации 1-летняя выживаемость составляет 78\%, а 5-летняя - 51\%

\section{Вопросы и ответы по трансплантации лёгких}

\begin{tabular}{|c|c|}
\hline Вопросы & Ответы \\
\hline Показания к трансплантации лёгких: & $\begin{array}{l}\text { - Хронические обструктивные болезни } \\
\text { лёгких - хОБЛ (хронический бронхит, } \\
\text { эмфизема); } \\
\text { - Рестриктивные заболевания } \\
\text { (идиопатический лёгочный фиброз); } \\
\text { - Лёгочная гипертензия; } \\
\text { - Кистозный фиброз, бронхоэктазия. }\end{array}$ \\
\hline $\begin{array}{l}\text { Основное показание к трансплантации } \\
\text { лёгких: }\end{array}$ & ХОБЛ. \\
\hline $\begin{array}{l}\text { Противопоказания к трансплантации } \\
\text { лёгких: }\end{array}$ & 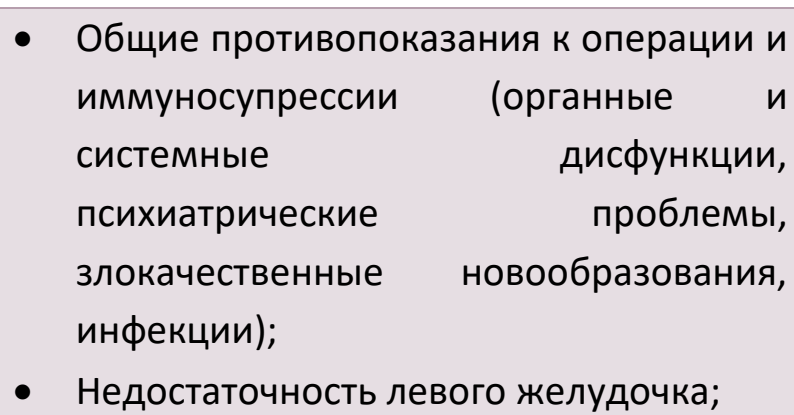 \\
\hline
\end{tabular}




\begin{tabular}{|c|c|}
\hline Вопросы & Ответы \\
\hline & 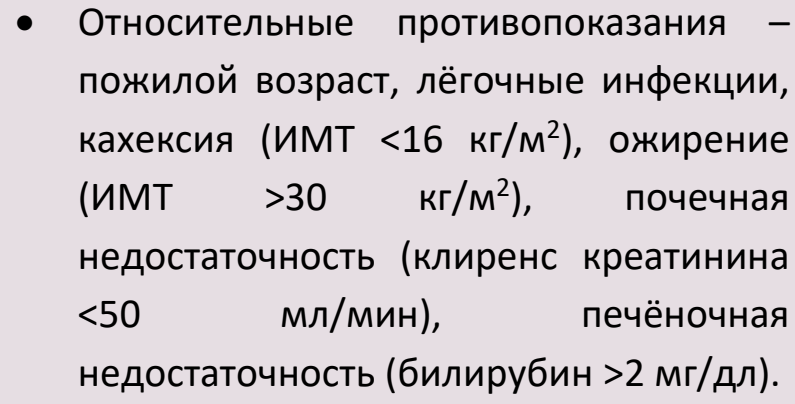 \\
\hline Варианты трансплантации лёгких: & $\begin{array}{l}\text { Трансплантация сердечно-лёгочного } \\
\text { комплекса, 2-х лёгких или одного лёгкого. }\end{array}$ \\
\hline Осложнения: & $\begin{array}{l}\text { - Первичная дисфункция трансплантата; } \\
\text { - Острое и хроническое отторжение; } \\
\text { - Бронхиальные, сосудистые } \\
\text { инфекционные осложнения. }\end{array}$ \\
\hline Признаки реакции острого отторжения: & $\begin{array}{l}\text { - Одышка; } \\
\text { - Высокая температура; } \\
\text { - Лейкоцитоз; } \\
\text { - Снижение объёма форсированного } \\
\text { выдоха и жизненной ёмкости лёгких; } \\
\text { - Снижение давления кислорода в } \\
\text { артериальной крови; } \\
\text { - Инфильтраты при рентгенологическом } \\
\text { исследовании. }\end{array}$ \\
\hline $\begin{array}{l}\text { Признаки реакции хронического } \\
\text { отторжения: }\end{array}$ & Обструктивный бронхиолит. \\
\hline Отдалённые результаты: & $\begin{array}{l}\text { 1-летняя выживаемость - 78\%, 5-летняя } \\
\text { выживаемость-51\%. }\end{array}$ \\
\hline
\end{tabular}




\section{ТРАНСПЛАНТАЦИЯ ТОНКОЙ КИШКИ}

- Показаниями к пересадке тонкой кишки являются необратимая кишечная недостаточность и осложнения, связанные с тотальным парентеральным питанием (прогрессивная холестатическая печёночная недостаточность, тромбоз более 2 магистральных вен, сепсис, дегидратационный синдром и др.)

- В структуре причин кишечной недостаточности лидирующее место занимает “синдром укороченной тонкой кишки".

- Различают изолированную пересадку тонкой кишки и пересадку кишки вместе с другими органами.

- Кишечник очень чувствителен к отторжению, поэтому требуется полноценная иммуносупрессия, для которой характерна высокая частота осложнений.

- Реакция отторжения трансплантата проявляется гипертермией и признаками мальабсорбции (водянистая диарея).

- Для диагностики реакции отторжения используют мукозальную биопсию, что требует формирования илеостомы.

- 1-летняя выживаемость после трансплантации тонкой кишки составляет 78\%, 5летняя $-40 \%$.

\section{Вопросы и ответы по трансплантации тонкой кишки}

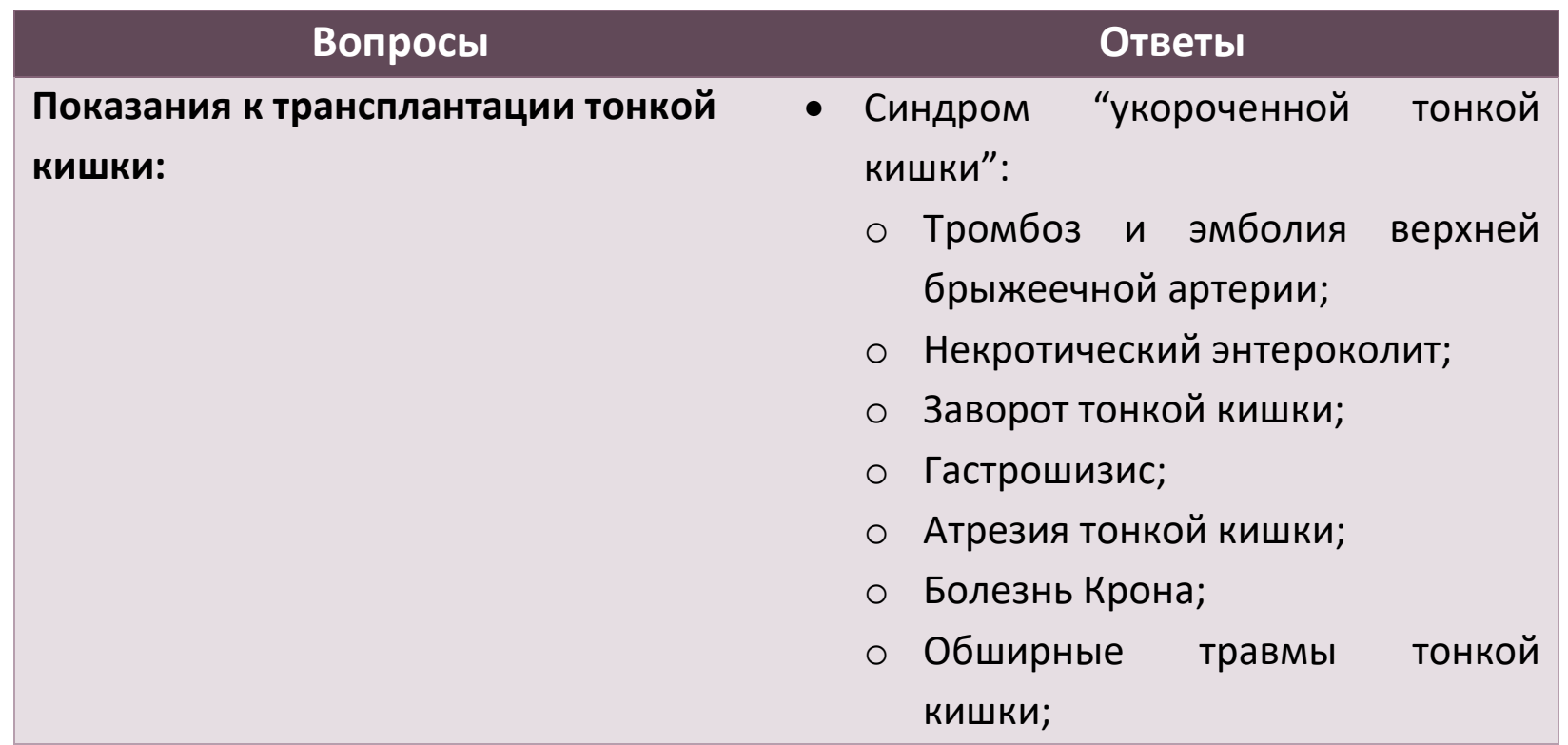




\begin{tabular}{|c|c|}
\hline Вопросы & Ответы \\
\hline & $\begin{array}{l}\text { О Радиационный энтерит. } \\
\text { - Новообразования (десмоидные } \\
\text { опухоли, полипоз); } \\
\text { - Псевдообструкция. }\end{array}$ \\
\hline $\begin{array}{l}\text { Основное показание к трансплантации } \\
\text { тонкой кишки: }\end{array}$ & Синдром “укороченной тонкой кишки". \\
\hline $\begin{array}{l}\text { Противопоказания к трансплантации } \\
\text { тонкой кишки: }\end{array}$ & $\begin{array}{l}\text { Общие противопоказания } \\
\text { трансплантации. }\end{array}$ \\
\hline $\begin{array}{l}\text { Варианты (методы) трансплантации } \\
\text { тонкой кишки: }\end{array}$ & $\begin{array}{l}\text { - Мультивисцеральная } \\
\text { трансплантация; } \\
\text { - Изолированная пересадка тонкой } \\
\text { кишки. }\end{array}$ \\
\hline Осложнения: & $\begin{array}{l}\text { - Реакция отторжения трансплантата; } \\
\text { - Реакция трансплантата на } \\
\text { реципиента; } \\
\text { - Лимфопролиферативные процессы. }\end{array}$ \\
\hline $\begin{array}{l}\text { Признаки реакции отторжения } \\
\text { трансплантата: }\end{array}$ & Водянистая диарея. \\
\hline Отдалённые результаты: & $\begin{array}{l}\text { 1-летняя выживаемость - 78\%, 5-летняя } \\
\text { выживаемость - 40\%. }\end{array}$ \\
\hline
\end{tabular}




\section{СПИСОК ЛИТЕРАТУРЫ}

\section{общая литература}

- Blackbourne LH. Surgical Recall. 4 edition, 2006, LWW, Philadelphia

- Doherty GM. Current Diagnosis and Treatment: Surgery, $13^{\text {th }}$ edition, 2010, Lang International Edition.

- Klingensmith ME, Aziz A, Bharat A, Fox AC, Porembka MR. The Washington Manual of Surgery, $6^{\text {th }}$ edition, 2012, LWW, Philadelphia.

- McNally PR. GI/Liver Secrets Plus. 4 edition. Mosby, Elsevier, 2010

- Medscape, http://www.medscape.com

- Oxford Handbook of Clinical Surgery, 3d edition, 2011, Oxford Press

- Sayek I. Sayek Temel Cerrahi 1-2. 4-cü baskı, 2016, Güneş Tıp Kitabevleri.

- UpToDate, http://www.uptodate.com

\section{Специальная литература}

- Bayramov N.Y. Orqan transplantasiyasında müasir istiqamətlər. Azərbaycan Tibb Universitetinin 80 illik yubileyinə həsr olunmuş beynəlxalq elmi konfransın materialları. Bakı 2010, s.15-18.

- Bradley H Collins, Thomas D Johnston. Renal Transplantation. Emedicine Specialties > Transplantation > Surgery, 2017

- Clinical Practice Guideline Post-Operative Carein the Kidney Transplant Recipient. Renal Association Clinical Practice Guideline - Post-Operative Care - February 2017.

- Haberal M. Doku ve orqan transplantasyonları. Haberel Egitim Vakfı, Ankara

- Karam G. et all. Guidelines on Renal Transplantation. European Association of Urology 2014

- KDIGO Clinical Practice Guideline on the Evaluation and Care of Living Kidney Donor. Transplantation, 2017, Volume 101, Number 8 S

- Vanrenterghem Y, Monbaliu D. Kidney Transplantation. ITP, 2012. 